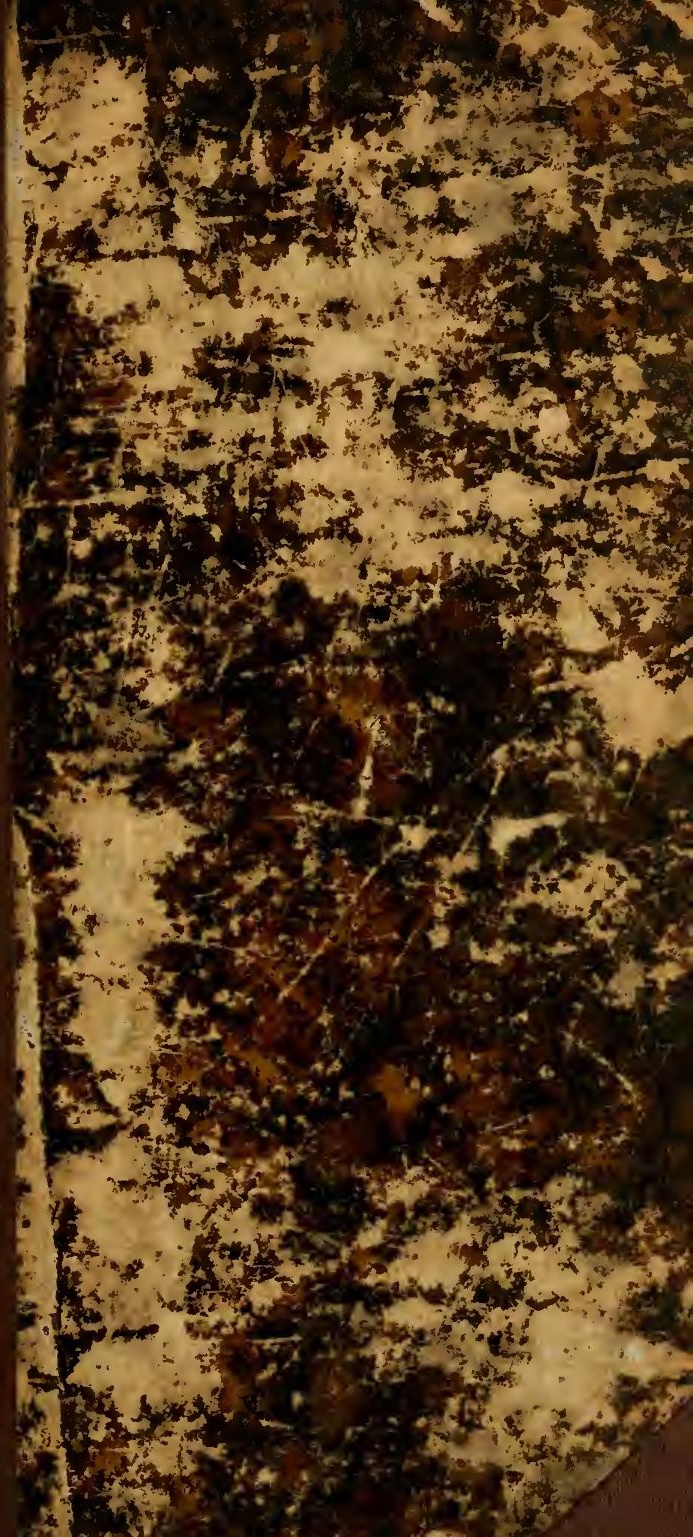




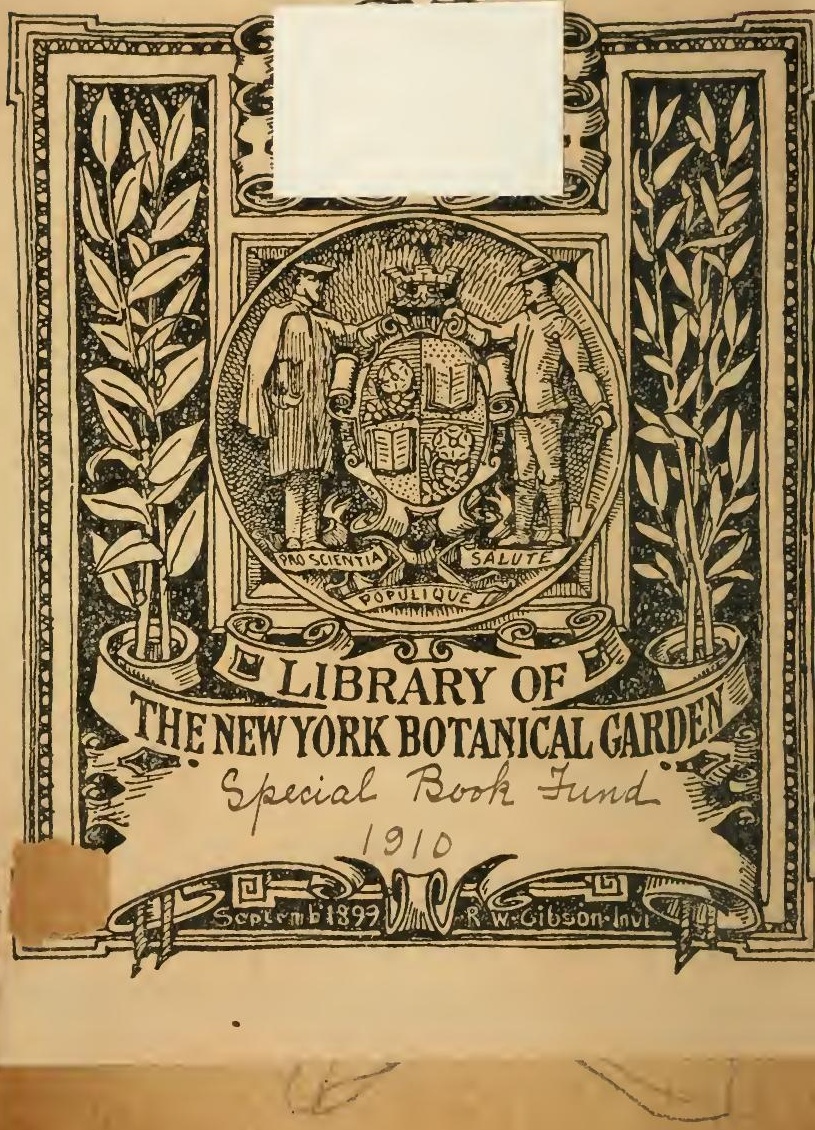




\section{Flora von Halle}

mit näherer Berücksichtignng der Umgegend ron

Weissenfels, Naumburg, Freiburg, Bibra, Nebra, Querfurt, Allstedt, Artern, Eisleben, Hettstedt, Sandersleben, Aschersleben, Stassfurt, Bernbarg, Kōthen, Dessau, Oranienbaum, Bitterfeld und Delitzsch

ron

Dr. August Garcke.

Erter ebsil.

Phanerogamen.

HaI e,

Eduard Inton.

1848. 


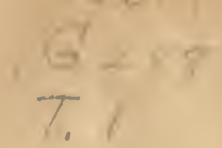

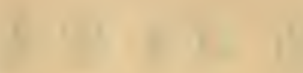

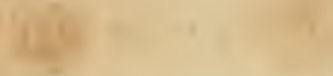


somen repehrten Lehrer

\section{Herrin Professor von Schlechtendal,}

der Med. Chir. und Philos. Dr,, Director des botanischen Gartens z.u IIalle u. s. w.

hochachungsvoll gewidnet

rom

Verfinser. 



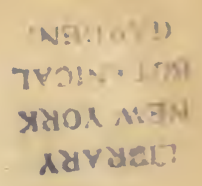

\section{Vo I w o t.}

Bei Ausarbeitung der Flora von Halle hatte der Verfasser, abgesehen run den praktischen Nebenzwecken, drei wissenschaftliche Hauptzwecke vor Augen. Einmal wollte er den Freunden der Pflanzenwelt in dieser Gegend die zahlreichen, seit dem Erscheinen der letzten Flura von Halle anfgefundenen Schätze übergeben; sodam beabsichtigte er eine gleiche Berücksichtigung aller' 'Theile des Gebietes zu liefern und drittens diese Aufzählung der Pflanzen in eine dem jetzigen stande der Wissenschaft angemessene Form zu bringen.

Was deu ersten Punht anlangt, su sind seit dem Erscheinen der letzten Flora von Halle von Curt Siprengel im Jahı'e 1×32, alsu seit 16 Jahren viele und nicht ptwa blos die von Dr. Antun Sprengel in der Vorrede zu seiner Anleitung aufgezählten 6 Pflanzen aufgefundun. Dieses wird am besten zu ersehen sein, wenn der Verfasser die Forschungen beibringt, wie sie sich von den ältesten bis auf die neuesten Zeiten durch die Bemuhungen der einzelıen Floristen herausgestellt haben.

Den Grund zu einer Flora von Halle legte Dr. Car I Schaeffer, zuer'st russischer l,eibarzt, dann praktischer Arzt zu Halle, woselbst er im Jahre 1675 starb. Er schrieb die Deliciae botanicae Hallenses seu Catalogus plantarum indigenarum quae in locis herbosis, pratensibus, montusis, saxosis, clivosis, umbrosis, arenosis, paludosis, uliginusis, nemorosis et sylvestribus circa Hallam Saxonum procrescunt. Hall. 1662. 12. pag. 91 In diesem kurzen Verzeichnisse zählt der Verfasser wildwachsende und in Gärten gebaute Pflanzen in alphabetischer Ordnung blos dem Namen nach ohne Hinzufügung der Autoren und nicht selten unter falscher Benennung auf, so dass dieses Werk nur als der erste, schwache Versuch zu einer Flora von Halle zu betrachten ist.

Ein scheinbar hierher gehöriges Buch ist das specimen Florae Hallensis sive designatio plantarum hortuli V. Joh. Gottf. Olearii quibus instructus fuit anmo 1666. 1667. 1668. certis de causis anicis maxime sic volentibus exhibita atque publicata. Hal. Saxonum 1668. 12. 
31) full. innum. Lis enthält dieses Burh jedoch nur dir. im Garten des Pastor Olearius cultivirten Pllanzen, wie lies ler vullständige 'l'itel anch anzeigt. Dieser Gar. ten wirl ibrigens späterhin unchmals vun Christ "f h h 11 a uth erwähnt, weil in demsellien Myrrhis perennis semine striato subfusco flore albo minor foliis hirsutis Moris. vurkam.

Der zwpite, welcher über die Hallische Flora schrieb, ist Dr. Christoph Kuauth, praktischer. Arzt und Physilius zu Halle, geh. 163ð, gest. 1694. Seine Enu. meratio plantarum circa IIalan Saxomun tet in eius vicind, al trium fere milliarium spatium, sponte provenientium, cum parum synonymiis, lucis natalihus ubi proveniunt, et tempore quo florent, additis characteribus geuprum summornm atgue subilternorum, et indice copioso, in hotanophilorum gratiam methodice cosssignata. Lips. $1687 .{ }^{*}$ ) 8. p. 187. praef. et iusl. innum. ist mit writ gröiserem Fleissw abgefasst, als das II erk seines lorgäingers. Sire enthält schon mit dusnahme pinger run Carl seliaeffer und Juhanu Bauhiu als Arten aufgestellten, von in 11 ath aber richtir als blosse Varietäten trhannten Pflanzen 848 speries, Wurunter sich 4 Equiseta, 2 Lycopolia, 17 Farnkräuter, 13 I aubund Lebermoose und 20 Pilze befinden, welche theils inn ihm selbst aufgefunden, theils ihm ron seinem Vor. yänger als Schriftsteller mod Zeitwenossen Car I S r l a a ffer und dew später zu Magdeburg lebenden prahtischen Arzte Dr. August Schäf $\mathrm{g}$ r angezrigt sind. D:e Pflanzen sind nach Morisun und Rajus in Klassen und Gattungen geordnet, die Arten zwar ohne Diagnusru, aber mit den gebräuchlichsten Synunymen von Caspal und $J o h a n \| B$ ahin, Tabelnaemontanus, Yurisun u, A. versehen, ihnen auch der deut. sche Name beigefügt und die Standurte mit ziemlicher Genaniglieit angezeigt. Obgleich in diesem Werke eine gewisse hritik nicht vermisst wird, su ist doch nicht zu läugnen, dass bei der Bestimmung der Planzen unit namentich bej der Wahl der Synunyma sirh mancher Irrthum gelteud gemarht hat, auch sind die der moch nicht verbesserten Rajischen Methode entnomminen Gat.

") Eine andere Ausgabe vom Jahre liss wirl von banks erwilhu, welche bei gleicher Seitenzahl eine etwas veränderle Vorrede gehabt halen muss, wie dies aus einer Anmerkung in Buxbaum'sVorrede zu seiner Enumeratio plantarum hervorgeht. 
tunrscharaktere nicht immer passend und mit den dahin gezogenen Arten übereinstimmend. - Ihm und seinem Suhne, welcher sich ohne h schrieb, zu Ehren henannte Thumas Coulter die Dipsaceengattung Knautia.

Der dritte hierher gehörige Schriftsteller ist A braham Rehfeldt, dessen Geburts - und 'Tudesjahr d* Verfasser nicht aufzufinden vermochte. Er schrieb als Candidat der Medicin seine Flora von Halle unter dem 'Titel: Hodegus botanicus menstruns, praemissis rudimentis botanicis, plantas, quae potissimum circa Halam Saxumun, vel sponte proveniunt vel studiose nutriuntur, nun solum usitatioribus nominibus enumerans; sed et, quo loco eaedem inveniantur, et quo tempsre iuxta serien mensium flureant, indigitans, plantis offirinalibus peculiariter notatis. In botanophilurum gratian con. signatus ab Abrahamo Rehfeldt. Hal. 171\%. 8. pag. 95. Es wejden hierin mit den Varietäten 1139 theils wildwachsende, theils in Gärten, besunders inı Waisenhausgarten gehaute Pflanzen who Diagnosen, Synonyma und Auturen, aber mit der dentschen Benennung nach den Munaten, in welchen sie blühen, aufgezählt. Wenn srhon das Weglassen der Autoren und der Synonyma ein grusser Uelelstand dieses Buches ist und zu bedeutemlen Verwirrungen und Verwechselungen Anlass gibt, su ist duch mehr zu bedauern, lass der Verfasser die seinem Werhe vorgesetzten, aus Rivini Institutiones entlehnte" Grundsätze sellhst fast ganz unberiicksichtigt gelassen hat, wuher es kommt, dass Pflanzen, welche den verschienlensten Gattungen an:-hören, bei ihm unter demselhen Gattungsnamen vereinigt sind.

Der vierte un die Hallische Flura sehr verdiente Schriftsteller ist $J u h a n n$ Christian Buxbaum. Er "urde zu Merseburg in Jahre 1694*) geboren, studirte in Leeipzig, Jena und Wittenberg und Wurde später run deu beruhmten Ifallischen Medrinaldathe und Professur Friedrich $H$ offmann, welcher auch eine Vurrede zu Buxbaum's Enuneratio geschieben hat, dem als Gésandten narh Cunstantinopel gehenden Grafen Alexander Romanzof empfohien. Nun durchreis'te

*) Aller Bemühungeu ungeachtet ist es dem Verfasser nicht gelungen, den lieburtstag dieses Mannes auszumittelı, da sich in den vorhandenen Kirchenbicheru Merseburgs vom Jahre 1694 B uxb a u m's rame nicht findet und das Kirchenbuch der Domgemeinde jenes Jahres felitt. 
B u $\mathbf{x}$ b a m viele Pruvinzen Griecheulands, Kleinasien und Armenien, lehrte nach Petersburg zuriick, verliess diesen Ort krank und starb an den Fulgen piner furcht. baren Syphilis schun an 17. Juli 1730 zu Wernsdurf an der Geissel zwischen Merseburg und Mücheln grlegen. Der rollstiandige 'l'itel seiner Flura ist: Jo. Christiani Buxbaums Enumeratio plantarum acculatior in ayro Hallensi locisque vicinis crescentium ma cum earmm characteribus et viribus qua variate numquam antea descriptat exhibentur. Cum praefatione Friderici Huffmanni de methodo compendiosa plantarum vires et virtıtes in medend, indagandi. Hal. Magdeb. 1721. 8. pag. 342. praef. innum., mit einem deutschen Register und 2 'Tafeln. Es sind hierin in alphabetischer Ordnnng ausser den einheimischen auch die in grösserer Menge auf dem Felde und in den Gärten der landlente ge. bauten Pflanzen, sowie mehre Ziersträucher aufgenum. men und es werden iberhaupt nit den Varietiiten 1690 Gewächse erwähnt, worunter sich 302 Agamen befinden und zwar 6 Equiseta, 2 Lycopodia, 21 Farnkräuter (mit Ophingloisum in 4 Furmen), 75 Musci, 55 Lichenes, 13. Pilze (mit 4 Ustilagines), 2 Byssi und 6 Confervae. Die Zahl der Varietäten beläult sich auf 400 und darüber. Den einzelnen Arten sind zwar heine Diagno. sen bejgegeben, dageren die betreffenden Synonyma mit den Auturen citirt, bisweilen ist eise kurze Be schreibung der Pflanze geliefert, auch fehlt der deutsche Name in der Regrel nicht und die arzueiliche An. wendung der Pflanzen ist fast ausfiihrlicher, als es der Raum gestattete, auseinandergesetzt. - Nach ihn naunte II alle $r^{\circ}$ die schöne Moosgattung Buxbaumia. welche Gattung er früher selbst schon steinem Vater widmen wullte, aber aus Furcht vor Missverständniss unterlassen hatte.

Der fünfte Hallische Florist ist Friedrich Wil. helm ron T,eysser (in der ersten Auflage der Flora fälschlich L, eyser gedruckt), Preussischer Kriegs • und Domainenrath, Dr. phil. und Präses der Hallischen naturforschenden Gesellschaft, geboren zu Magdeburg am 7. März 1731, gest. an 10. Octoher 1815 . Seine Flora Halensis exhibens plantas circa Halam Salican crescentes secundum systema sexuale Linnaeinum distributas. Hal. Salic. sumptib. aucturis $\mathbf{1 7 6 1}$. enthält in der ersten Auflage bei Weglassung aller Kulturgewächse mit den Zusätzen 1122 Planzen, worunter sich 904 phantrogamische befinden. Von den aufgezählten 218 agamischen 
Gewächsen gehören mit 5 Schachtelhalmen 21 zu den Farn, $63 \mathrm{zu}$ den Lisubmoosen, $86 \mathrm{zu}$ den Algen, wozu fieilich Narchantia mit 2, Jungermannia mit 11, Riccia mit 1, Jichen mit 44, Byssus mit 10, Tremella mit 5, Ulva mit 2, Cunferva mit 8 , Spongia mit 1 und Chara mit 2 Arten gerechnet werden und 48 zu den Pilzen. Die Anordung der Pflanzen nach dem Linné ischen Sexualsysteme, die hier zuerst in Anwendung gebrachte, uft freilich nur kurze Charakteristik der Gattungen und Arteu, die Genauigheit der Standorte zeichnen das Werk vor den früheren rühmlichst aus. Dis zweite Auflage vom Jahre 1783 enthält 1275 Pflanzen mit 1017 phanerogamischen und 255 agamischen Artrn. Obgleich in beiden Auflagen an der richtigen Bestimmung der Pflanzen meist nicht $\mathrm{zu} z$ weifeln ist, so sind duch einige von leysser erwähnte Pllanzen gewiss nie im Gebiete gefunden und ihre Angabe beruht auf einer Verwerhselung, wie Salıia Verbenaca, welche nach Rupp aufgenummen ist, Agrostis capillaris, Stipa juncea, Briza minor mod Br. Eragrostis, Festuca amethystina, Arena sesquitertia, Lonicera nigra nach Buxb., Bupleurum rigidum, Seseli turtuusum, Alisma ranunculoides, Dian. thus arenarius, I,ychnis quadridentata, Sedum Cepaea, Clematis erecta, Marrubium supinum, Prunella laciniata, Iberis rutundifulia, Alyssum eampestre, Brassica 'Turrita, Polygala monspeliaca, Phaseolus lunatus, Lathyrus latifolins, (unter IIypericum pulchrum ist gewiss das rrst später aufgestellte H. elegans zn verstehen), Hieracium chondrilloides, Onopurdon illyricum, Cineraria eordifulia, Senecio alpinus, Aster acris, Achillea odorita, Centaurea alba, splendens, sicula (worunter unstreitig C. solstitialis zu verstehen ist), Orchis globusa und abortiva, Carex globularis, Atriplex hastata; andere sind wenigstens nicht als einheimische Pflanzen zu betrachten, wie Staphylea pinnata, Aconitum Napellus, Nigella damascena u. a. m. Ausser dieser Flora finden sich von ihm in den Abhandlungen der Hallischen naturforschenden Gesellschaft Band 1. S. 362-372 Beobachtungen iber einige neue im Linnéischen Systeme nicht beschriebene Pflanzen der Hallischen Flora. - Nach ihm benannte I,inné die Compositengattung Leyssera.

Einige Beiträge zur Flora von Halle wurilen auch von tlb. Wilh. Roth in dell Acten der Leupoldiner 'Th. 7. S. $198 \mathrm{ff}$. und wiederum verbessert in seinen Bejträgen zur Botanik T'h. 2. S. 135 gegeben. 
Unter dem Titel: Supplementi ad leyssri filoram Halensem fascontus 1. Mal. 1796 gah Juh. Friedr.

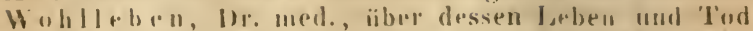
sich Nachrichton in 110 ple e's butanischem 'Taschen. hurlie von 1797 s. 5l-80 finden, pincul 44 Siden um. fassenden Nischerag zu dem phanerogamisthen Theile dev Leyser'schen Flura von Ilalle, worin 119 theils von ilui zonerst aufgefundene, theils ron beysser zwar schun erwilunte, aber nicht als Irten unterschiedene Pilanzen anferaihlt werden. Von dirsen 119 Pflanzen sind 4 ! von ihm zuerst fïr die Ilallische I'lora aufgefundeu, 42 vun Jeysser zwar schun als Varietäten angergeben, aher vou Wuhllehe" zuerst als Arteu aufgefiihrt, 17 dagegen falsch hestimnt (Callitriche all. tumualis, Pua trinervati, Arundu atenaria, Plantagu subulata, Primula araulis, Bupleurum junceum nach Roth, Allium arenarium, Junrus maximus, Alisma na. tans. Velampyrum silvaticum, Erysimum repaudum, Vicia hiennis, Astragalns danicus und arellarius, Medirago roronata, Séenprio abrutunifulius, Carex Lewengluchin), 8 als Arten citirte lïmnen mur als Abart(n an. gesehen werilen (Agrustis gigantea, Pantago dentati, Pimpinella nigra, Inncus stolunifer, Mentha virticillata, Rhinanthus Alertoroluphus, Bidens minima, Betula pendula), 7 waren schmu vor Wohlleben bekaunt (Veronica hybrida L., welehe iibrigens sum tbart yon V. spi. cata ist, Hried Tetralix, I,yhrum Thymifulia = Hys. sopifolia, Sisymbrium Irin, welches $R_{\text {o }}$ th bei Eisleben beubichtet liaben will, aber whue $Z$ weifel anf einem Irrthume leruht, Vicia silvatica, 'Trifolium striatmm und T. alpestre) mol 4 (Iris squalens, Llmus octandra $=$ effusa, Isatis tinctoria narh dem Standurte, Colutea orientalis) sind cultivirte Pflanzen. - Nach der Vurresle beabsichtigte er in einem zweiten 'Theile die nen aufyefundenen agamischen Pllanzen zu bearbeiten, wurde aber durch seinen frühen 'lod diran gehindert.

Varh W" Wissenschaft iiberhanpt sehr verdiente C urt \$ prengel iber die Hallische Flora. Er wurde an 3. August 1766 zu Buldekww, einem bei Anclam gelegeneu pommersehen Durfe geborel, "w sein Vater Predicere "ar. Anfangs zum Theologen bestinmt, beyal, er sich Ostern $\mathbf{1 7 8 5}$ als Stml. theol. zur Friedrichsmuirersitit rach Halle, änderte uber bald seinen Plan und studirte wun Medicin und Naturwissenschaften. Schon im Ortober 1757 wulde er Privatilucent in der medicinischen Fakul. 
tiit, im December 1789 ausserordentlicher mul in April 1895 ordentlicher Professor der Medicin, damals mit 55 'Thlr. Gehalt!! Narh Ju uglians 'Tude prhielt er im Juni 1797 auch die Prufessur der Butanik mit der Direction des botanisihen Gartens, "elches Ant er bis zu seinem 'lode (15. März 1833) brkleidete. Smith nannte nach ihm die Eparideengattung Sprengelia.

s prengel schrieh fluriat haleusis tentamen novmm. Hal. Saxon. 1506. 8. pag. 420. crum Xll tab. aen. Dips. Flora enthält mit den /usätzen 1757 nicht ganz streng nach dem Linneischen Sexualsystem geordnete Pflanzen, wormiter sich 1111 phanerigamische und 676 agamische befinden. Wie L, eys el wullte auch sprenge I nur die einheimischen Pfauzen der Hallischen Gegend heschruben, er ist jeduch hierin nicht consequent yewesen; da er Pllanzen, wie Galanthus nivalis, scilla ammena u. a., welche im Gebiete nicht eimmal vervildern, aufzumehmen kein Berlenhen trug. Die ausführlichere und :-enaure Charahteristik lel" Gattungen und Arten und die zirmlich genaur Angabe der Standorte ist sehr zu luben. Viele Pllanzen sind von ihm zuerst fiir die Hallische Flura angezeigt. Da sprengel die Gegend um Halle mit grussem Eifer durchforschte, su konute es nicht fehlen, lass er für diese Flura immer mphr weve botanische Schöitze auffand und so war es ihm schon narh einem Jahre des Erscheinens der Flora möglich, zu derselben nuter dem 'Titel: Nantissa prima flurae halensis addita nuvarum plantarum centuria. Hal. 1807. 8. pag. 5.). einen Nachtrag folgen zu lassen, in welıhem Berichtigungen und Verbesserungen in den Diagnosen und standurten gegeben nnd eingge neu aufgefundene Biirger der Flora anfgezählt werden; in Ganzen behandelt dieser Nachtrag 55 phanerogamische nnd 95 ayamische Gewiichse. Wie in gleicher thsicht geschriebenen Observationes botanicae in floram halensem. Mantissa secunda Mal. 1811. 8. pag. 31. enthalten ein Supplement vin 124 Pीanzen.

Eiı um dit Erforschung der Hallischen Flura gleichfalls sehr verdienter Schriftsteller ist der jetzt zu Nordhausen lebende Kreisphysikus und Hofrath Dr. Fripdr. Wilh. Wallroth. Di er seine Bildung auf der Klosterschuie zu Rossleben erlangte, so wurde er schon liuh mit einem Theile der Hallischen Flora bekannt nusl unter sprengel's Leitung machte er später solehe Furtschritte, dass er schon nach dreijähriger gründlicher Beschäftigung mit der Butanik sein erstes Werk 
unter dem 'Titel: Annus botanicus sive supplenentum tertium arl Curtii sprengelii fluram halensem. Cum tractatu et iconibus VI Charam genus illustrantibus. Ilal. 181\%. 8. pag. 200. dem botanischen Publikum übergeben konute. Ausser den Diagnosen werden in diesem sehr schätzenswerthen Burhe nust kurze, aber ireffende Beschreibungen der Pflanzen gegeben, den Variptäten eine grösscre Aufuerksankeit gewidmet, die Standorte, welche sich liesonders auf die Wälder bei ludersleben, Kiegelrude und Wendelstein und auf die Berge von Schmon und Bibra beziehen, gewöhnlich etwas genauer bezeichnet. Vun den hierin prwähnten. 277 Arten sind viele fii die Hallische Flora von ihm zuerst aufgefunden.

Ein zweites Werk über die Hallische Flora ron demselben Verfasser erschien unter den 'litel: Schedulae criticae de plantis florae halensis selectis. Corollarium novum ad C. Sprengelii tluram halensem. Accedunt generum quorumiam specierminge ommium definitiones novae, excursus in stirpes difficiliores et icones $V$. 'Tumus 1. Phanerogamia (ein zweiter ist nicht erschienen). Hal. 1822. 8. pag. 516, Es ist jedoch ill diesem sehr ausführlichen supplenente, welches mit den Zusätzen über 442 Pflanzen Beobachtungen mittheilt, die Mallische Flora nicht ausschliesslich herücksichtigt, sondern es werden viele Nutizen über die benachbarten Gegenden von Fraukenhausen, Heeringen und Nordhausen beigebracht. Obgleich das Urtheil De Candolle's über dieses Werk günstig lautet, so verdient doch die Recension eines anderen tüchtigen Butanikers, Hur. n u g's nämlich, welcher dem Buche die grusse Weitschweifigkeit in Behandlung der einzeluen Gattungen und Arten, die oft unnütze Zersplitterung in Varietäten, die Sucht neue Namen für mohaltbare Arten zu bilden (denn von den aufgestellten 82 neuen Arten sind nur 4 angenommen), vollkommene Anerkennuner. An schnierzlichsten berïhit aber den wissenschaftlichen Mann die Heftigkeit und Bitterkeit, mit welcher abweichende Ansichten berühmter Butaniker gebrandmarkt werden; dies sind Flecken, welche unstreitig ein Jeder von einem Werke, welches einen reichen Schatz. selbstständiger Beobachtungen enthält und ein seltenes streten nach Grïndlichkeit zeigt, gern entfernt wünschte. - Nach Wallroth henanuten De Candulle und Roth Gattungen, welche aber in neuerer Zcit wicder eingezogen sind. 
Zehn Jahre nach dem Erscheinen der Schedulae criticae wurde die Flora halensis von Curt Sprengel in der zweiten Auflage alsgegeben. Einige wenige Verbesserungen abgerechnet steht diese Auflage der ersten bei weitem nach, wie dies auch gründliche Beurtlieilungen über dieses Werk öffentlich ausgesprochen haben. Die Charakteristik der Arten ist selten scharf und genau, meist viel zu allgemein gehalten, die Bestimmungen der einzelnen Species oft unzuverlässig, einige schon von Wallroth fïr die Flora angegebene ganz unberïcksichtigt gelassen, die Standurte sehr mangelhaft angegeben, indem bei den seltensten Pflanzen oft gar kein besunderer Fundort citirt, bei sehr verbreiteten nur in Allgemeinen ein weit entlegener namhaft genacht wird, andere werden wieder als ganz gemein hezeichnet, während sie zu den seltensten Pflanzen der Flora gehören, wozu sich die Belege in des Verfassers Flora von Halle in grosser Anzahi finden. Auch ist das Citiren der Abbildungen nach den seltensten und kostbarsten Werkel, besonders der Englischen und Diinischen Flora, welche kaum Gelehrten, "ie viel weniger Anfängern zu Gebote stehen, sehr zu tadeln. Vun jen mit den Zusätzen angeführten 2199 Pflanzen gehören 1173 den Phanerogamen und 1026 dell Agamen an. Da nach Sprengel's Plane nur wirklich einheinische Pflanzen aufgenommen werden sollten, su ist die augegebene Zahl von 1173 Phanerogame nicht richtig, demu es befinden sich darunter 60 Gewächse, welche nicht als "ild angesehen werden können, sondern die theils aus anderen Erdtheilen gekommen jetzt nur das Bürgerrecht erhalten haben, theils mit fremdem Samen aus südlichen Gegenden einmal eingeführt sind, aber den Winter nicht ertragen, theils als Gartenflüchtlinge,-theils als Culturgewächse angesehen werden niiissen und 5 ('Thesium pratense, Bupleurum junceum, Erysimum canescens, Trifolium scabrum, Senecio alpinus) in der Art falsch bestimmte, dass die damit verwechselten schon mitgezählt sind, 14 sind als Arten angegeben, welche jetzt allgemein nur als Varietäten betrachtet werden und umgekehrt sind die 34 als Abarten bezeichneten als gute Arten anerkannt, so dass die Gesammtsumne der damals als einheimisch bekaunten Pflanzen nur 1128 betriige, von welchen 10 (Drosera anglica, Linum tenuifolimn, Muscari racemosum, Silene conoidea, Nepeta pannonica, Geranium phaeum, 'Trifolium spadiceum, Cen- 
taurea montana, Sumchus alpinus, Ireras anthropophora) spaiterlin nicht wieder grelunden sind.

Ein dit Mallische Gegend nicht ausschliesslich berïcksichtigende's Werk ist dir Flura saxonica von H. G. 1. Reichenbach. Dresden und leeipzig 1s44. 8. pag. 503. Es simb in diesem Werke, wie dies hei riner filnora eines grossen Gobietes kaum anders nöglich ist, die Floristen dir rinzeluen Gegenden henutzt und fiir die Hallische Umgegend namentlich die Werke von Wall. ruth und siprengel angrzugen. Der Verfasser der Flora von sichsen ist dadurch freilich in die unangenehne. Nuthwendigkeit rersetzt worden, viele unrichtig gewordene Bestinmumun auf \%umehmen und e's werden sogar Wäldeo reitirt, welehe sohun viele Jahre vor dem Erscheinen der Flora von Sachsen gar nicht mehr existirten! Ueberhaupt ist die Unbekanntsehaft des lerfassers mit der Gegend vun IIalle mol die daraus folgrmle grosse Verstiommelung der Ortsuanen ein bedeutener Mangel des Buches. Su wirt der von Sprengel oft citirte mous serenus, wurunter bekanntlich der Petorsberg zu verstehell ist, fast immer mit he iterel Berg übersetzt, ans dem Trothaer Wurdev werilen in der Regel zwei Standorte 'Irotha und Werthen oder Werden gemacht, ebenso aus dem Lettiner Werder, aus Collenbey wird Collebri, aus Kitten wird Köllme, aus der Stadt Salza wird der Fluss silzke, aus Wanslebeu - Wanderslebeu, aus Bischofsberg - Bischofsrode und so zu nuzähligen anderen Malen, wodurch natürlich das Auffinden einer Pflanze geradezu ummöglich gemacht wird. Ja es ist ohne sich davon zu äherzengen fast unglaublich, dass aus dem Dr. Webe r zul Gera (Weberus Geramus), welcher von Sprengel hal. ed. 2. p. 139 als Entdectier des Ostericum palustre genannt wird, bej Reichenbach sax. p. 270 W. Ge ran us (also Wilhelm aus Gera?) gebildet werden konnte. Der gänzliche Mangel der Synonyma auch der L inueischen Namen in der ersten und der nur schwache Ersatz eines vollständigen Registers in der zweiten, übrigens ganz unveränderten Ausgabe dürfte gleichfalls nicht zu rechtfertigen sein. Dagegen gereicht dem Werke die Anordnung der Pflanzen nach den natürlichen Systeme, verbunden nit einem Schlussel des $\mathrm{J}$ i n néischen Sexualsystems, das Citat einer guteu, meist nicht zu schwer zu erlangen. len Abbildung, nie Aufnahme der in grösserer Menge gebauten Pflanzen zum grossen Vortheile. 
Ueler die erst vor einigen Wuchen unter den 'l'itel: Auleitung zur Kenntniss aller jn der Umgegend von Halle wild wachsenden phanerugamischen Gewächse von Dr. A. Sprengel. Halle 1843. 8. pag. 538. erschienene neneste Floral von Halle ist wenig Gutes zu sagen. Sie ist grösstentheils eine Uebersetzung der zweiten Duflage der Flura halensis seines Vaters mit den larin enthaltenen Fehlern und einigen neu hinzugekommenen anffallenden Versehen, su dass die gegen jenes Werk erhubenen Ausstellungen mejst aurh hipr ilure Anwendun "inden. Wie wenig der Verfasser dieser Anleitung das Gebiet der Flora, über welohe el schrieb, selhst kannte, geht schon faraus hervor, dass el im ganzen Buche die Wilder hei Erdolorn und Brehna citirt und erst während des Drucke's daraut anfmerksam gemacht werden musste, dass an den erwähnten Orten sejt langer Zeit gar keine Wälder mehr existiren. Auf diese Vise finden rinige in der. Vurrede gregebene, fiir jeden Fremolen unverständliche Bemerkungen ihre Erklälung. Da 6 in der Flora halensis ron Curt Sprengel nicht erwähnte Pflamzen (Allium sphaerocephalun 1. und A. fallax $\mathrm{D}$ on, welches sich jedoch schun bei Curt Sprengel mnter dem Namen A. angulosum Jac q. als Synonymon von All. acutangulum Willd. findet, Spergula nodosa L., Erucastrum Jullichii Schim p. u. Sp., Inula nedia M. B., welche der Verfasser aber nicht als Ait anerkemen kann, und Najas major All.) hinzugekommen sind und Anthemis agrestis Wallr. als Art eingezogen ist, so beträgt die Summe der beschriebenen Arten 1177.

Der Verfasser kommt unn zu seiner eigenen Flora von Halle und zwar zunächst zu der Auseinandersetzung des Verhältnisses der einheimisthen und cultivirten Gewächse. Von den 1341 beschriebenen Pflanzen sind 1207 wirklich einheimisch und 134 nicht wild warhsend, sondern 81 davon zum Gehrauche der Menschen in grösserer Menge gebaut oder als Bämme gezogen, 11 ils Ziersträucher ursprünglich in Gärten und Parkanlagen cultivint und jetzt in Hecken verwildert, 7 in Wäldern, Döıfern und an Flussufern angepflanzt, 13 miissen als Gartenflüchtlinge bezeichnet werden und 22 sind theils mit fremdem Samen aus anderen Erdtheilen oder wenigstens aus sudlichen Gegenden eingefürt, theils auf Lehnmauern angepflanzt. Diese Jetzteren werden mit einigen aus den vorhergehenden 3 Abtheilungen von 
mehren Floristen, obwohl mit Lnrecht, als eimheimisch betrachtet. Unter dell 1207 einheinischen Arten brfinden sich 724 ausdaurrude, 276 einjährige, 103 zweijäh. rige, 95 strauch- und baumartige Gewächse, is suwohl ein-als zweijährige und 4, welche theils zweijärig, theils ausdauernd vorkonmen. 90 Arten sind hiervon für die Hallische Gegend in vorliegender Flora zuerst aufgefïhrt. Den Dicotylen gehören von diesen wild. wachsenden Pflanzen, von denen hier immer nur die Rede sein wird, 910 Arten und zwar 468 auslauernde, 240 einjährige, 98 zweijährige, sämmtliche 95 strauch. und baumartige und die 9 ein-, zwei- und mehrjährigren, den Innucotylen dagegen 297, nämlich 256 ausdauernde, 36 einjährige und nur 5 zueijährige an, die letzteren verhalten sich daher zu deu ersteren wie $1: 3,06$.

Sämmtliche aufgezählte Pflanzen gelı̈ren zu $110 \mathrm{Fa}$ milien, von welchen 2 (dmpelideen mit Vitis und Am. pelopsis uul Juglandeen mit Juglans) nur cultivirte Ge"ächse und 44 nur mit je einer Gattung, aber mehren Arten, is dagegen nur mit je einer Art vertreten sind. Die bei weiten zahlreichste Familie bilden die Compusiten mit 15l Arten; sie nehmen daher den achten Theil sämmtlicher Phanerogamen ein; unter den Monocotylen sind die Gramineen an zahlreichsten: sie besitzen nit Ausnahne einiger mit fremdem Samen eingefühten, sowic der cultivirten Arten, welrhe in dieser Familie wegen der hierher gehörigen Getreidearten bc. sunders zahlreich sind, 97 Repräsentanten und verhal. ten sich daher zu sämmtlichen Phanerogamen wie $1: 12,4$.

Was die systematische Anordnung der Pflanzen anlangt, so ist bei derselben nach Kuch's vortrefflicher. Synopsis florae germanicae et helveticae das natürliche System von De Candolle angewandt, da die Vor. theile eines natïrlichen Systems jetzt allgemein aner. kannt sind. Zu diesem Behufe ist dem Burhe eine tahellarische Uebersicht der Familien beigegeben, welche am Schlusse jeder einzelnen Familie die dahin gehörigen Gattungen mit ihrer Stellung in Linnéischen Systeme anzeigt. Auf der anderen Seite ist es eine bekannte Thatsache, dass Viele von dem künstlichen Systeme sich nicht trennen mögen und un beiden Theilen zu genügen, ist die Charakteristik der Gattungen uach dem Linnéischen Sexualsysteme angeordnet, su dass ein doppelter Weg eingeschlagen werden kann, 
um zur richtigen Bestimnung der Gattung zu gelangen. Un aber bei der Bestimmung einer Pflanze nach dem künstlichen Systeme ein sicheres Resultat zu bekommen, ist es durchaus nöthig, dass jede abweichende Gattung und soweit dies möglich auch jede abweichende Art an allen Orten namhaft gemacht ist, an welchen sie wegen ihres abweichenden Charakters gesucht werden kann. Ebenso glaubte der Verfasser bei verwandten, schwer zu unterscheidenden Arten ausser den Diagnosen, bei welchen die constanten Unterscheidnngsmerkmale stets cursiv gedruckt sind, durch tine hurze Beschreibung dem in Bestimmen weniger Geübten zu Hilfe kommen zu müssen. Aus demselben Grunde ist auch fast überall eine naturgetreue, allgemein verbreitete Abbildung citirt und besonder's gern die vortreffliche Abbildung in Dentschlands Flora von Reichenb a $c$ is gewählt.

Eine andere Erleichterung suchte der Verfasser dem Anfäıger dadurch zu verschaffen, dass er dem Gattungs und in schwierigen Fällen auch dem Artenuamen eine Erklärung beifügte oder deu Schriftsteller nannte, bei welchem der jetzige Gattungsmane sich zuerst findet. Denn "enu es auch eilerseits ganz veifehlt wal, wenn Sprengel und die Verfasser der Flora von Würtemberg denjenigen Schriftsteller als Autonität cirtirten, bei welchem der jetzt zur Bezeichmung der Gattung dienende Name zuerst vorkommt, ohne die geringste Rücksicht darauf zu nehmen, in welcher Bedeutung dieser Name ron dem angefürten Schriftsteller gebraucht wird, su ist es doch andererseits wïnschenswerth zu wissen, in welcher Zeit ein Pflanzenname entstanden ist.

In einer deutsch geschriebenen Flora durften auch die deutschen Gattungs - und Artennamen nicht fehlen. Es wäre hierbei num nichts leichter und bequener gewesen, als die von Planer, Panzer, Willdenow u. a. eingeführten deutschen Pflanzennamen anzunehmen, wie dies in den meisten botanischen Handhiichern geschehen ist. Da diese ersonuenen Nanien dem Munde des Volkes aber ganz unbekannt geblieben sind und ron den botanischen Schriftstellern willkürlich verwendet werden, so wäre auch nichts unerspriesslicher, als dieselben beizubehalten. Un dieser Willkür, im Ge. briuche der Pflanzennamen ein Ziel zu setzen, hat in neuerer Zeit E. Meyer nachyewiesen, nach welchen Grundsätzen deutsche Gattungsuamen aufzustellen seien, 
inden el besonders das höhere Alter und die grössere Verbreitung des Namens berïcksichtigte und der Verfasser ist seinen unübertroffenen Forschungen durchaus gefulgt oder hat in einzelnen Fällen denselben Weg eiugeschlagen.

Bei Zusammenstellung der Standorte war der Verfasser bemïht fïr die seltenen und minder häufig vor. kommenden Pflanzen möglichst viele anzugeben. So hat er bei jeder Pflanze zuerst die unnittelbare Ungegegend von Halle berïcksichtigt, ist sodann südlich und östlich nach Merseburg und Schkeuditz bis zum Bie. nitz gegangen, wo nach Petermann's Vorgange die Wiesen nördlich vom Bienitz die Wiesen an Bienitz, die Wiesen nördlich von KI. Dölzig und westlich von Schambert die Wiesen bei Kl. Dölzig und die Wiesen westlich vom Bienitz $z u$ beiden Seiten des Schambert die Schambertwiesen genannt sind, kam darauf südlich wach Weissenfels, Naumburg, Freiburg und südwestlich und westlich nach Laucha, Bibra, Nebra, Wendelstein (mit der Steinklippe), Rossleben, Schmon, Querfurt, Lodersleben, Ziegelrode, Allstedt zur Grenzflora von Artern und nach Eisleben und nordwestlich und nördlich nach Mansfeld, Gerbstedt, Hettstedt, Sandersleben, Aschersleben, Stassfurt, Bernburg und Köthen und end. lich nordöstlich und östlich nach Dessau, Oranienbaum, Bitterfeld und Delitzsch. Diese Reihenfolge der Standorte ist bei jeder seltenen Pflanze beubachtet. Mit der Aufzählung dieser Orte ist zugleich auch der Umfang der Flora angegeben, welche den Raum eines Kreises umfasst, dessen durch den Mittelpunkt Halle gezogener Durchmesser 6 Meilen beträgt, wie diese Grenze von Wallroth bestimmt, von Sprengel in der 2. Auflage der Flora angenommen wurde, während er in der ersten Auflage der Flora die Grenzen enger gesteckt hatte.

Obgleich der Verfasser dies angegebene Gebiet seit einer Reihe von Jahren in botanischer Hinsicht durchforscht und einen Theil desselben schon in früher Ju. gend kennen gelernt hat, so hielt er es doch für seine Pflicht, die innerhalb dieses Kreises wohnenden Butaniker un Mittheilungen für ihre nächste Umgegend anzugehen und er sagt hiermit allen, welche ihn durch Beiträge unterstützten, seinen aufrichtigen Dank, besonders aber fühlt er sich den Herren: Apotheker B ene. ken in Naumburg, Apotheker Hornung in Aschersle. 
ben, welcher schon frïher ein Verzeirhniss der seltenen Pflanzen der Aschersleber Gegend-in der Regensburger butanischen Zeitung Jahrg. 1S32. \$. $273 \mathrm{ff}$. u $296 \mathrm{ff}$. be. kannt gemacht hat, Apothekel li ra se in Oranienbaum, sowie seinem Freunde Karl M üllel, "elcherdie Flora seiner Heimath, Allstedt, durchfurschte, verpflichtet. Auch rohielt er von Hern von Mengersen in Rossleben einige nicht unwichtige Nittheilungen fiir die Rossleber und Ziegelröder Gegend. Ungeachtet dieser schätzenswerthen Beiträge ist einige Male der Fall eingetreten, dass von friiheren hallischen Schriftstellern angezeigte Pflanzen in neuerer Zeit nicht wieler gefunden sind, wb. gleich an ihrem jetzigen Vorhommen "egen der unveränderten I,okalität nicht gezweifelt werden kann. In diesem Falle sind die betreffenden Pflanzen zwar aufgenommen und mit vollständigen Diagnosen versehen, aber es ist dabei hemerkt, dass sie in neuerer Zeit nicht wieder beobachtet sind. Denn der Verfasser hält es fiir keine Schande, eine Pflanze trotz alles Suchens nicht gefunden zu haben, wohl aber für eine arge Gewissenlusigkeit und geralezu für einen Betrug, bei Pflanzen falsche Standorte anzugeben und daher die da. nach Suchenden irıe zu leiten. Diejenigen Gewächse dagegen, welche bei ganz veränderter Lukalität nicht wieder gefunden werden konnten, sind nur dem $\mathrm{Na}$ men nach ohne mitgezählt zu werilen aufgefïhrt.

Vor allen Dingen muss der Florist darauf sehen, dass die ron ihm angezeigten Pflanzen auch wirklich richtig bestimmt sind, weil in einem für den Unterricht und fiir das Selbststudium bestimmten Buche jeder Irrthum um so gefährlicher und nachhaltiger wirkt, je früher er anfgenommen wird. In dieser Hinsicht blieb dem Verfasser bei der grossen Unzuverlässigkeit der $S$ prengel'schen Flora viel zu verbessern übrig und oft konnte er nur durch Zurïckgeben auf die ersten Quel. len und durch Vergleichung von Originalexemplaren zu einem sicheren Resultate gelangen, wobei ihn sein verehrter Lehrer, Heir Professor von Schlechtendal mit seiner Bibliothek, seinem Herbario und seinem Rathe auf das Zuvorkommenste unterstützte.

So wenig der Verfasser die Aufnahme von Gartenpflanzen oder gar Topfgewächsen billigen kann, so glaubt er doch, dass die in grösserer Menge meist zum ökonomischen Gebrauche der Menschen gebauten Pflanzen in einer Flora nicht fehlen diirfen. 
Nuch ist zu erwähnen, dass der Verfasser bei offici. nellen Pflanzen die in der Arzuei gehrauchten Theile derselben mit wenigen Worten angezeigt hat, ohne sich auf weitläufige Erörterungen eingelassen zu haben, da diese in keine Flura gehören; sodaun hat er der Betonung der Namen eine grössere Aufmerksamkeit geschenht, als derselben in den meisten Floren bewiesen ist und endlich ein vollständiges, die Synonyma und deutschen Namen umfassendes Register gegeben.

Gern hütte der Verfasser eine geomostische Uebersicht des Gebietes beigefiigt; da dieselbe wegen des beschränkteu Raumes aher nur kuz und daher unvoll. ständig hätte sein köınen, so verweist er auf die eben erscheinende Gaea excursoria germanica seines Freundes, des Herrn Dr. Giebel.

Schliesslich erlaubt sich der Verfasser darnuf aufmerksan zu machen, dass er zur Ausarbeitung des zweiten Theiles, welcher die agamischen Pflanzen enthalten soll, iibergehen wird, subald die Materialien zum Ab. schlusse gekonmen sein werden. Bis dahin empfiehlt er sich dem Wohlwollen der Freunde seiner Flora.

Halle im Mai 1848. 


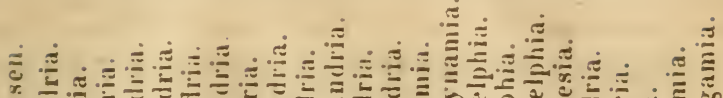

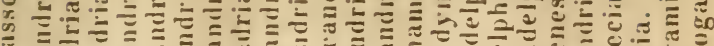

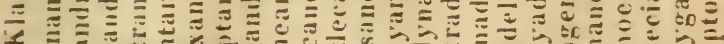

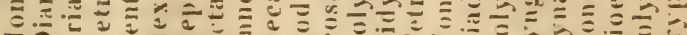

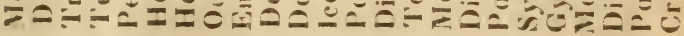

$\therefore$ -

8

$\equiv$

$=2-1$

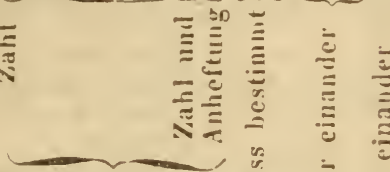

$\leqq$

$\stackrel{\sim}{\sim}$

$\equiv$

:

$\underline{\underline{0}}$

c

$\equiv \stackrel{2}{=}$

c

en

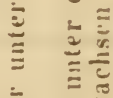

$i_{i} \bar{c}$

: $\cong$

- e

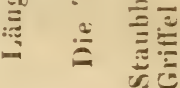

:

s.

t

$-9$

$\therefore \equiv$

$-$

a

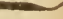

$\therefore \dot{=0} \equiv$

i $\overline{0}$

$\stackrel{2}{=}$ $\geqslant$
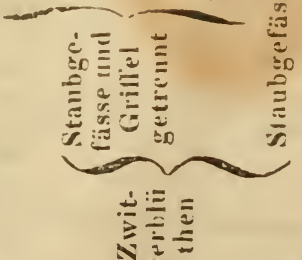

$=$

군

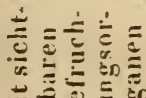

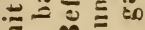

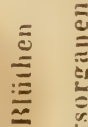

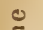

ec

三

T

ב

rarcke, Floria

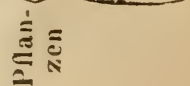


B.

\section{Schliissel zu den Drdnungen der Lin né ' - schen Klassen.}
Classen.
Ordnungen *). 1. Monandria: 1 Staub- $\left\{\begin{array}{l}1 \text { te: } 1 \text { Griffel : Monogynia. } \\ 2 \text { te: } 2-\text { Digynia. }\end{array}\right.$ gefäss

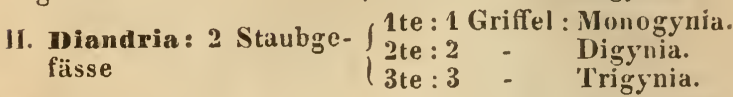

11I. Triandria: 3 Staub- $\left\{\begin{array}{l}1 \text { te }: 1 \text { Griffel : Monogynia. } \\ 2 \text { te }: 2\end{array}\right.$ gefüsse

3te:3 - Trigynia.

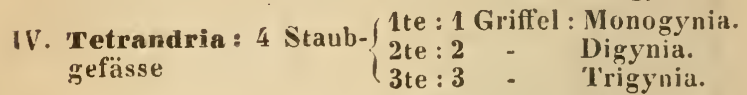

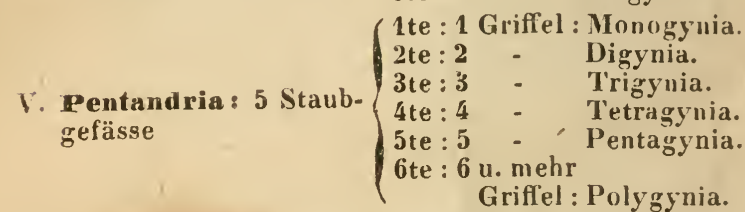

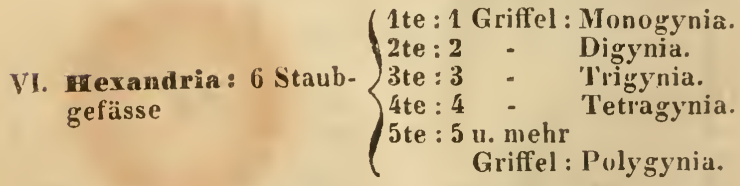

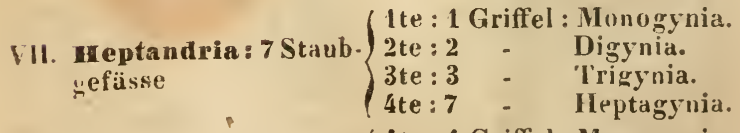

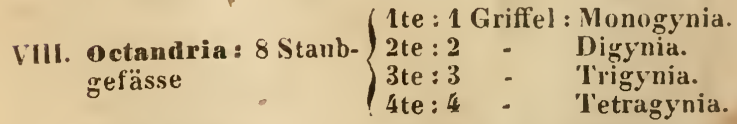

IX. Enneandria: 9 Staub- 1 te $: 1$ Griffel: Monogynia. gefässe

$\begin{cases}2 \text { te:3 } & \text { Trigynia. } \\ 3 \text { te: }: 6 & \text { Hexagynia. }\end{cases}$

-) Von der ersten bis 13. Klasse sind die Ordnungen nach der Zahl der Grifful oder Narben gebildet. 
Classen.

Ordnungen.

X. Decandria : 10 Staub. $\left\{\begin{array}{l}1 \text { te }: 1 \text { Griffel : Monogynia. } \\ 2 \text { te }: 2\end{array}\right.$ gefässe

\{

3te $: 3$ - Trigynia.

4 te $: 5$ Pentagynia.

5te: 10 - Decagynia.

XI. Dodecandria : $12-19$ Staubgefässe

1 te : 1 Griffel : Monogynia.

$\left\{\begin{array}{lll}2 \text { te }: 2 & - & \text { Digynia. } \\ 3 \text { te }: 3 & - & \text { Vrigynia. } \\ 4 \text { te }: 5 & - & \text { Pentagynia. } \\ 5 t e: 12 & - & \text { Dodecagynia. }\end{array}\right.$

XII. Icosandria : 20 und $(1$ te : 1 Griffel : Monogynia. miehl einer scheibe an Kelche eingefüg. te Stanbgefä:se 2te : 2
3te : 3
Digrnia.
4te: 5 - Pentagynia.
5te : Viele Gr.: Polygynia.

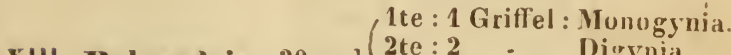

XIII. Polyandria: 20 und mehi dem Fruchtboden eingefiigte Staub. gefässe
4 te: Trigynia.
Tetragynia.
5te:5 Pentagynia.
fite: 6 - llexagynia.
7te : Viele Gr.: Poly'gynia.

XIV. Didynamia : 2 lange (1te: 4 nackte und 2 kurze Staubg- Samen: Gymnospermia. fässe (meist Iippen- 2te : Samen in blüthler) Kapseln:Angiospermia.

XV. Tetradynamia: $4 \operatorname{lan}-\left\{\begin{array}{l}1 \text { te : breites Schöt- } \\ \text { chen u. deutli }\end{array}\right.$ ge und 2 kurze Staub. cher Griffel : Siliculusa. gefässe (Kreuzblüm-\{2te : lange Schoten
ler) zem Griffel : Siliquosia.

XVI. Monadelphia: Staub- $\left\{\begin{array}{c}1 \text { te : } 5 \text { Staubge- } \\ \text { fässe : Pentandria. } \\ \text { fäden in } 1 \text { Bündel vel-o Staubg.: Enneandria. } \\ \text { wachsen }\end{array}\right.$ $1 \mathrm{~A}$. * 
Classen.

Ordnumgen.

XVII. Diadelphia: Staubfäden in 2 - Bündel verwachsen (grössten-) theils Schmetterlingsblïthler)
XVIII. Polyadelphia : Staubfäden in mehr als 2 Bünclel verwachsen
Ite: 5 Stiubgefässe (2 oben, 3 unten) : Peutandria.

2te : 6 Stiubgefässe (3 oben, 3 unten) : Hexandria.

3te : 8 Staubgefässe (4 oben, 4 unten, alle an Grunde rerwachsen) . : Octandria.

4te : 10 Staubgefässe (1 oben, 9 unten in eine den 1 ruchtknoten umgebende, oben oft gespaltene Röhre verwachsen) . :Decimblria.

(1te: 5 Staubfädenbiindel (jedes Bündel 5 Staubbeutel tragend $=25$ Staub. gefässe) . . : Pentandria.

2te : 12 Staubfädenbündel (jedes Bündel 3 Staubbeutel tragend $=36$ Staubgefässe) . . . : Dodecundria Viele Staubgefässe in Bündeln, in Kelche eingefiigt (20 Staubgefässe in Bündelu von ungleicher Staubbeutelzahl) : Icosandria. 4te: Viele Staubgefässe in $3-5-6$ Bïndeln im Fruchthoden eingefïgt : Polyaudria. 
Classen.

Ordnungen.

Ite: Lauter Zwitterbliithen . . . . Polygania aequalis.

XIX. syngenesia: Staub. grefässe fünf; die Staubfäden firei, die Staub. beut. unt. einand. verwachsen (Blunie meist einblätterig; Blüthen mit Ausnahne der sechsten Ordnung meist zu einem Kino. pfe vereinigt. Hieher sänımitliche Cumpo. siten gehörig.) bei der ersten bis viert. Ord. nung blos ein gemeinschaftlicher Kelch 2te: ' Zwitterbliithen in $\mathrm{der}$ Scheibe, fruchtbare "eibliche Blüthen im Strahle (d. h. am Rande) . . . : Polygamia superflua.

3te : Zwitterblïthen in der Scheibe, geschlechts. lose (d. h. ohne Staubgefässe u. Griffel) im Strahle . : Polygamia

4 te : Scheibenblüthen $/$ wit. ter mit undeutlichem Griffel, Randbliithen sind fruchtbare weibliche (d. h. Staubgefüsse fehlen, Griffel vorhanden) . . . I'olygamia necessaria.

Jte : Ein geneinschaftlicher Kelch für alle Blïthchen und ein besunderer für jedes einzelns. 'Zwitter' blüthchen . . . : Polygamia

6te : Einfache Blüthen blos segregata. mit einem Kelche : Monogynia.

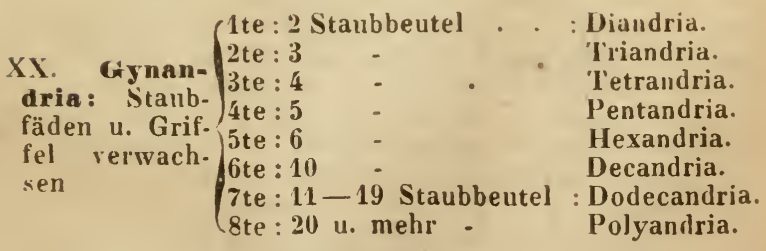


Ordnungen.

\section{Classen. \\ XXI. Monoe- cin: Blüthen getrennten Ge- schlechts auf piner Pflanze}

XXII. Dioecia : Blüthen trennten geschlechts auf zwei Pflanzen

1te : 1 Staubgefäss

2te : 2 Staubgefüsse

3te : 3

4 te $: 4$

5 te $: 5$

6 te $: 6$

7 te : 7

Ste: Mehrals 7 Staubge-

fässe . . . : Polyandria.

9 te : Staubfäden verwach-

sen.... . : Monadelphia.

10te : Staubbeut. verwach.

sen . . . . : Syngenesia.

11te : Staubfäden und Grif-

fel verwachsen . : Gynandria.

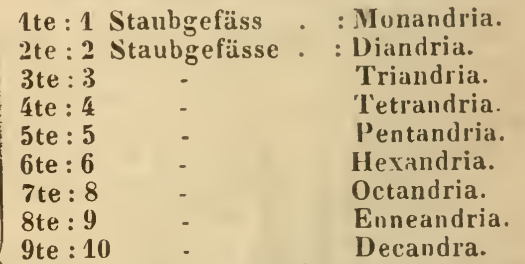

10te : 11-19 Staubgef. : Dodecandria.

11te : Viele Staubgef. . : Polyandria.

12te: Staubfäden in ein

Bïndel verwachsen: Monadelphia.

13te: Staubbeutel verwachsen . . : Syngeresia.

14te : Staubfäden und Grif-

fel verwachsen . Gynandria.

1 te: Zwitterblüthen nebst männlichen und weiblichen Blüthen auf der-

XXIII. Polygamia: Zwitterblüthen und eingeschlechtliche Blüthen in derselben Pflanzenart
Monoecia.
: Monandria.

Tetrandria.

Hexandria.

Heptandria. 'riandric. selben Pflanze

2te: Zwitterblüthen nebst Blüthen bloss einen Geschlechts auf derselben Pflanze : Dinecia.

3 te : Zwitterblüthen auf einer und eingeschlechtliche Bliithen auf zwei anderen Pflanzen vertheilt 


\section{Anordnung der Gattungen nach dem Linné'- schen Geschlechts-Sisteme (systema sexuale).}

1. Classe. Monandria. E i um in n ige. Zwitterblüthen mit 1 freien Staubgefässe.

1. Ordnung. Monogynia. Einweibige. Ein Griffel oder, "o dieser fehlt, eine Narbe.

165 *). Hippúris $\mathbf{L}$. Blumenkrone fehlend. Kérlı aus einem undeutlichen, deu fruchtknoten krönenden Rande bestehend. Griffel der Furche des Staubbeutels anliegend. Steinfrucht einsamig. Blätter quirlständig.

Hierher gehört auch : Alchemilla arvensis S c o p. $(\mathbf{I V}, \mathbf{1})$.

2. Ordnung. Digynia. Zweiwe ibige. 'Zwei Griffel (uder Narben).

Callitriche (XXI, 1), Blitun $(V, 2)$, Festuca Pseuda. myurus (III, 2), Polycnemum (III, 2), Salicornia (II, 1).

II. Classe. Dianałria. 'Z w e i mün n i ge. Zwitterbliithen mit 2 freien, gleichlangen Staubgefässen.

1. Ordnung. Monogynia. Einweibige. Ein Griffel oder eine Narbe.

A. Blüthen unvollständig, unterständig.

435. TRnpia L. Blïthenhülle fehlend. Kólben blattwinkelständig, 2blüthig, anfangs von einer Scheide eingeschlossen. Staubhentel gruss, auf sehr kurzen, schuppenförmigen Staubfüden. Niisse 4 , zuletzt lang-gestielt. Stengel faderiförmig mit borstigen Blättern. Salzwasserpflanze.

389. Salicornia L. Blüthenhïlle fleischig, ungetheilt, nur mit piner Ritze sich öffnend. Blüthen zu dreien in

*) Die Nummern ror den Arten - und Familiennamen bezichen sich auf die Seiten. 
drn Aushöhlungron der Stengelglieder whe Deckblatter. Nuss on der bleibenden Bliithenhïlle eingeschlussen. Sitrugel gecoliplert, blattlus. Sialzuflanze.

437. Lemna L. Bliithen zwitterig uder 2häusig. Bliithenhiblle 1bläterig, zusammengedrickt, uncetheilt wler aII Rande feill-grkerbt. Staubgefisse pinzelı sich entwickelnd. Frucht schlauchförmig. Stengel hlattartig, schuim:uend.

Zu dieser Unterahtheilung gehören die blumrnblattluse Fraxinus excelsior $(11,1)$, einige Arten vou Scirpus (III, 1) und Cyperus fuscus $(I I I, 1)$.

B. Blüthen volistündig, oberständiğ.

163. Circaea L. liel.hsaum 2lappix. Blumenhrone 2hlätterig. Frucht birnförnig, mit hakigen Haaren besetzt, 2fücherig, Fächro Isamig.

C. Blüthen vollstäıdig, unterständig, 1frïchtig, regrlmüssig.

a. Sihciulewand des Fruchtknotens in den grössern Durchmesser desselben.

306. Eigustrum L. Kelch 4zähnig; Blumenkrone trichterförnig mit 4 spaltigem Saume. Frucht eine 2 fii. cherige, 2-4samige Beere.

307. Syringa L. Kelch 4zähnig; Blumenkrone fast präsentirtellerförnig nit 4spaltigem Saume. Frucht eiue -2samige, 2färherige, 2klappige Kapsel. Klappen kahnförmig, die Hälfte der bei ier Reife gespaltenen Scheidewand tragend.

b. Scheidewand des Fruchtknotens in dem klei. "ern Durchmesser desselben.

307. Fráxinus L. Blïthen vielehig. Kelch und Biumenkrune fehlend (uder 4 theilig bei F. Ornus I.). Frucht flach - zusanumengedrückt, gefliigelt, 2fächerig, 1samig. Baum mit unparig gefiederten Blättern.

D. Blïthen vollständig, unterständig, Ifrïchtig, unregelmässig.

378. Utricularia d. Kelch 2blätterig. Blumenkrune maskenförmig, gesporut. Kapsel unregelmässig zerreissend, Ifächerier, vielsamig. Wasserpflanze mit feinzertheilten, hlasentragenden Blättern.

331. Gratiola L. Kelch 5theilig mit 2 Deckblätt. chen. Blnmenkrone 2lippig mit 4 kantiger Röhre. Staub- 
gefässe 4 zweinächtige, wovmn die beiden längeren unfruchtbar. Staubbeutel nit 2 Ritzen aufspringend. Narhe 2lappig. Kapsel 2fächerig, 2klappig; Klappen sich rndlich spaltend.

335. Weronica L. Kelch 4-5theilig. Blumenkrune flappig, Jer wbere Lappen grösser. Staubgefisse 2, ohne unfruchtbare Nebenstaubfäden. Staubbeutel mit 2 Längsritzen anfspringend. Narbe ungetheilt. Kapsel ausgerandet, 2 färcherig.

E. Blüthen rullständig, unterständig, 4 früchtig.

356. Lýcopus L. Kelch kurzröhrig, 5zähnig. Jlumenkrowe triohterförmig, kaum länger als der Kélch, 4spaltig, der obere Lappen breiter, ausgerandet. Staubarefässe auseinanderstehend, 2 vollkwmmene nit 2 fäche. rigen, der lö̈nge nach aufspringenden Staubbeutelı und 2 unfruchthare oiler aush ganz fehlende. Quirlbliithen.

356. Súlvia L. Kelch 2lippig: Oberlippe ganz oder 3zähnig, Unterlippe 2zähnig. Blumenkrone 2lippig: Oberlippe heluförnig, zusammengefaltet, Unterlippe 3lappig. Staubbentel Ifächerig, mit fadenförmigem Mittelliande. staubfäden kurz, ohne Nebenstaubfäden. Quirlblüthen.

V'erbena $(\mathrm{XIV}, 2)$, Lepidium ruderale $(\mathrm{XV}, 1)$.

2. Ordnung Digynia. Zweiweibige. '/wei Griffel. Anthoxanthum ein Gras (III, 2), Salix (XXII, 2).

111. Classe. Troimnd roin. Dreimännige. Zwitterblüthen mit 3 freien, gleichlangen Staubgefuissen.

1. Ordnung. Monogynia. Einweibige. Ein Griffel.

A. Blüthen vollständig, vberständig.

219. Valeriana L. Blüthen zwitterig und 2häusi... lielch ein rerdickter, eingerwllter Rand, welcher sich zur Fruchtzeit zu einem Federkelch (pappus) entwickelt. Blumenkrone trichterförmig, 5spaltig, am Grunde höckerig. Frucht trucken, nicht aufspringend, durch Schwinlen ler scheidewände Ifächerig. Blätter meist fiederspaltig.

221. Valerianella Noench. Blüthen zwitterig. Kelch ein gezühnter, seltener undeutlicher Rand. Blumenkrone trichterförmig, 5spaltig; Frucht trocken, nicht aufspringens, rom Kelche gekrönt, 3fücherig, mit $1-2$ 
leeren Fïchern. Blätter ganz oder gezähnt; Stengel ga. belförnig getheilt.

B. Blïthen vollständigr, unterständig.

170. Montia L. Kelch 2 bläterig, bleibend. IBlumenkrone trichterförmig, mit gespaltener Röhre und einem 5theiligen Samme, an welchem 3 Zipfel kleiner sind. Griftel sehr kurz, sich in 3 Narben theilend. Kapsel Ifächerig, 3klappig, 3samig.

C. Blïthen unvollständig. Blüthenhülle blumenblattartig.

457. Iris $\mathbf{L}$. Blüthenhülle an Grunde röhrig, mit regelmässigenı, 6theiligem Saune: 3 äussere Zipfel auswärts, 3 innere eiuwärts gebogen. Griffel 3kantig, in 3 blumenblattartige, die Staubgefässe bedectende Narben getheilt. Kapsel 3fächerig, 3klappig. Samen ungeflügelt. Blüthen aufrecht.

457. Gladiolus L. Blüthenhülle mit trichterförmiggebogener Röhre, Saum 6theilig, unregelmässig, fast 2lippig. Stanlgefässe aufsteigend. Griffel fadenförmig, mit 3 länglichen, wberhalb verbreiterten, zusammengelegten Narben. Kapsel 3 fächerig, 3klappig. Samen geflü:yelt. Blüthen fast wagrecht in einseitiger Aehre.

D. Blüthen unrollständig; Blüthenhülle kelchartig.

390. Polycnémum L. Blïthenhülle 5blätterig, von 2 Deckblättern gestuitzt. Staubgefüsse meist 3 (seltener 1,2 oder 5), einem unterständigen Ringe eingefiigt. Griffel 2spaltig. Frucht schlauchartig, mit einem aufgewachsenen Deckelchen, 1samig. Same aufrecht mit krustiger Samenhaut.

E. Blüthen unvollständig, balgartig.

a. Aehrchen 2reihig.

483. Cypérus $\mathbf{L}$. Spirre zusammengesetzt. Bälge gekielt, zahlreich, 1 klappig, alle blïthentragend wler die 2 untersten kleiner und leer. Bluthenbursten fehlend. Staubgefässe 3, seltener 1 wder 2. Griffel abfallend, 2 - 3theilig. Nuss 3 kantig, seltener zusammengedrückt.

484. Schoenus C. Aehre einfach, undentlich 2reihig. Bälge $6-9$, $1 \mathrm{klappig}$, nur $2-4$ blïthetragend, die $3-6$ untersten kleiner und leer. Blüthenborsten unter. ständiğ, 1-5 oder fehlend. Stanbgefässe 3, Griffel abfallend oder 3 theilig. Nuss 3 kantig. 
b. Aehrchen von allen Seiten dachziegelig. Die 3 - 4 unterel Bälge kleiner und unfruchtbar.

484. Rhynchóspora Wh $\mathbf{W}$. Aehrchen wenigbliithig. Bälge 1klappig, die $2-3$ oberen blüthentragend. Bliithenborsten $6-10$, unterständig, eingeschlossen. Staubgrefässe 3, Griffel 2thrilig, am Grunde breiter, durch ein Gelenk mit der Nuss verbunden, verhärtend, bleibend und den Schnabel der Nuss bildend.

c. Aehrchen von allen Seiten dachziegelig. Die unteren Bälgre grösser oder gleich gross, 1-2 derselben unfruchtbar.

485. Heleócharis $\mathbf{R}$. B $\mathbf{r}$. Aehrchen reichblïthig. Bälge 1 klappig. Blüthenbursten meist 6 , unterständig, eingeschlossen. Griffelyrund verbreitert, durch ein Gelenk mit der Nuss verbunden, verhärtend, bleibend und die Spitze der Nuss bildend.

486. Scirpus $\mathbf{L}$. Blütheuborsten meist 6 oder fehlend. Griffelgrund nicht verbreitert und mit der Nuss durch kein Gelenk verbunden; in Uebrigen wie Heleocharis.

490. Erióphorum L. Unterständige Blïtheuborsten zuI Fruchtzeit viel länger als die Bälge und als seidige wollige Fäden die Yuss eirhüllend; sonst wie Scirpus.

Nardus (1II, 2).

2. Ordnung. Digynia. Zwe i weibige. Zwei Griffel. Blüthen balgartig. Gräser.

A. Aehrchen alle auf den Zähnen einer Spindel sizzend, keine gestielt.

552. Nardus L. Aehre einseitswendig. Aehl'chen einzeln, 1 blïthig. Balg fehlend. Bälglein 2 spelzig, äussere Spelze fast lederartig, borstenförmig, scharf-gekielt, die inner'e häutige einschliessend. Deckspelzen fehlend. Griffel in eine einfache, feinbehaarte, hervortretende Narbe verlängert.

551. Lolium L. Aehre einfach-zusammengesetzt. Aehrchen einzeln, weclıselständig, mehrbliithig, zusammengedrïckt, die eine Kante der Spindel zukehrend. Balg bei den seitenständigen Aehrchen $1 \mathrm{klappig}$, bei dem endständigen 2klappig. Bälglein 2spaltig, die untere grannenlos oder unter der Spitze begrannt. Griffel sehr kurz.

550. Hordeum L. Aehre 2zeilig. Aehrchen zu dreien 
beisamnen stehend, Ablithig, die mittere zwittrig, un. grestielt, die seitenständi,- en meist mänulich oller geschlechtslos, gestielt. Balg 2hlappig, vor den Bliithen stehend, mit den ïbrigen Klappen eiur 6blätterige Hülle darstellend. Bäglein 2spelzig. Narben sitzend, gewimpert, auf der mutern seite kahl.

550. Ely̆mux c. Aehre einfach-zusammengesetzt; Aehrchen zu 2-4 heisammen stehems, 2-vielbliithig, zwitterig. Im Uebrigen wie hei Hordenm.

549. Triticum L. Aehre einfach-zusammengesetzt. sphrchen einzeln, zusammengedrïckt, die pine fache Seite der Spindel zugekehrt, mehrbliithig. Balg 2hlappig, Klappen gekielt, spitz oder stachelspitzig. Bälglein 2spelzig, untere spelze aus der spitze begrannt oder gramenlos, die ubere mit 2 mehr oder weniger gewimperten kielen.

550. Secale L. Aehre ohne Gipfelährchen. Aehrehen einzeln, llarh - gewölbt, 2hlüthig mit dem Stielchen einer dritten verkümmerten Blüthe. Balg 2klappig, Klappen pfriemlich. Die untere spelze ans der spitze begrannt; dic ubere mit 2 stumpfen und kaum schärflichen Kielen.

B. Aehrchen an den Gelenken einer Aehre wder gegliederten Rispe zu zweien, das eine sitzend, zwitterig, das andere gestielt, mämblich.

512. Andropigon L. Aehren fingerförmig. Aehrchen linealisch, die endständigen $\mathrm{zu} 3$, woron das mittlere sitzend, alle Iblïthig, mit einem 1spelzigen Ansatze zu einer unteren Blüthe. Bälge 2hlappig, die untere Klappe auf dem Rücken ziemlich flach, kiellos, die obere gekielt. Spelzen durchsichtin, 3 , die mittlere (die unterc spelze der '/witterbliithe) hegraunt. Griffel verlängert. Narbe sprengwedelförnig.

C. Achrchen länger oder kürzer gestielt, 1blüthig. oder 1 hlüthig und mit einem Ansatze zu einer zweiten oberen und zu 2 unteren Blïthen.

a. Aehrchen vom Rücken her zusammengedrückt.

512. Pánicum L. Aehrchen Iblüthig mit einer untere॥ Ispelzigen, geschlechtslosen Blïthe. Balg $3 \mathrm{klappig}$, die untere Klappe viel kürzer als die uberen, welche die beiden knorpeligen Spelzen ganz einschliessen. Narben sprengwedelförmig. Hülle fehlend. 
514. Setaria SP. Hülle aus grannenförmigen Bursten zusammengesetzt, welche unter dem Gruncle der Blüthenstielchen eingefügt sind. Das Uebrige wie bei Panicum.

522. Mrilium c. Mehrchen 1bluthig. Balg 2klappirg, bauchig, länger als die knorpelig werdenden, gramenlosen spelzen.

b. Aehrchen von der Seite her zusammengedruckt. Balg fehlend.

518. Leersin sol a nd. Aehrchen Ablithig. Balg fehlend. Die beiden Spelzen pergamentartig, zusanmengedrïckt-gekielt, grammenlus, fast gleich lang, die äussere die innere umfassend. Narben federig, aus der Seite des lehrchens herourkommend. Karyopse von den Spelzen eingeschlossen.

r. Aehrchen von der Seite her zusamnengedrückt; Balg 2klappig; Bliithe am Grunde mit 2 silhuppenförmigen oder spelzigen Ansätzen zu unteren Bliithen.

515. Plhaláris c. Aehrchen 1blüthig; Blüthe mit 2 kleinen, schuppenförmigen, gramenlosen, meist behaarten Blättchen an Grunde. Spelzen knurpelig, grannenlus, glänzend, kleiner als die beiden fast gleich langen Klappen.

315. Anthoxanthum L. Aehrchen 1blüthig, zwitterig, am Grunde mit 2 begrannten Spelzen, welche etwas grösser sind als die grannenlosen Spelzen der Z $\mathbf{W}$ itterblithe und 2 leers, einspelzige Blïthen darstellen. Untere Klappe halb so lang als die ubere. Staubgefässe 2.

d. Aehrchen von der Seite her zusamnengedrückt oder walzenförmig. Balg 2klappig, 1blïthig oder mit dem Ansatze einer zweiten oberen Blïthe.

1. Narbe fadenförmig aus der Spitze des Aehrchens hervortretend. Griffel lang.

515. Alopecurus C. Aehrchen 1blüthig, ohne Ansatz 7ur zweiten Bliithe. Balg 2klappig, Klappen am Grunde verwachsen, gekielt. Bälglein 1spelzig, schlauchförnig, an der einen Seite gespalten, anf dem Rücken begrannt. Dechspelzen fohlend.

517. Phleum L. Aehrchen 1blüthig oder mit den Ansatze einer zweiten Blüthe. Balg 2 klappig, Klappen 
fast gleich gross, gekielt, gestutzt oder zugespitzt, länger als die beiden häutigen, begrannten uder grannenlosen Spelzen. Deckspelzen lanzettlich.

2. Narbe federig, am Grunde des Aehrchens hervortletend. Griffel kurz oder fehlend.

518. Agrostis L. Aehrchen 1 blüthig, ohne Ansatz einer zweiten Blüthe. Balg 2klappig, länger als die Blüthe. Klappen spitz, die untere grösser. Bälglein 2spelzig, häutig, kahl oder am Grunde mit sehr kurzen Haarbüschel, fein oder unbegrannt.

520. Apéra dans. Aehrchen 1 blüthig mit einen Stielchen als Ansatz einer zweiten Blüthe am Grunde der oberen Spelze. Untere Klappe kleiner, sonst alles wie bei Agrostis.

520. Calamagrostis Roth. Aehrchen 1blüthig, mit und ohne behaartes Stielchen, als Ansatz einer zweiten Blïthe am Grunde der uberen Spelze. Spelzen am Grunde mit Haaren umgeben, welche länger als der Querdurchmesser der Spelze sind. Im Uebrigen wie bei Agrostis.

522. Stypa $\mathbf{L}$. Aehrchen 1 blüthig. Balg 2klappig, länger als die Bluthe. Klippen spitz oder aus der Spitze begrannt. Bälglein 2spelzig, Spelzen knorpelig, die untere walzenförmig - zusammengerollt, mit ciner gedrehten, langen Granne. Deckspelzen 3.

D. Aehrchen länger- oder kürzer -, oft sehr kurzgestielt, 2-vielbliithig, seltener die untern geschlechtslos oder männlich, die oberste oft verkümmert.

a. Narben fadenförmig, aus der Spitze des Aehrchens lang hervorragend.

523. Sesleria A rduin. Aehrchen 2-6blüthig. Balg 2klappig. Bälglein 2spelzig, Spelzen häutig, die unteré ungetheilt und stachelspitzig oder begrannt, oder an der Spitze 3-5zähnig; Zühne stachelspitzig oder begrannt.

b. Narben sprengwedelförmig, unter der Spitze der Blïthe hervorragend.

523. Phragmites $\mathbf{r}$ in. Aehrchen vielblüthig; untere Blüthe männlich oder geschlechtslos, nackt, die übrigen zwitterig, mit Haarbüscheln aus der Spindel besetzt. 
c. Narben federig, an Grunde der Blüthe hervorragend.

526. Arrhenathérum P. B. Aehrchen 2bliithig, untere Blïthe männlich, mit langer, gedrehter, geknieter Granne, obere zwitterig, grannenlos oder meist mur kurz begrannt. Griffel fehlend.

525. Holcus $\mathrm{L}$. Aehrchen 2blüthig, untere Blüthe zwitterig, unbegrannt, where männlich, auf den Rücken begramt, Granne gerade, zuletzt zurückgebogen. Griffel sehr kurz.

525. Corynéphŏrus P. F. Aehrchen 2blüthig; Blii. then zwitterig. Untere Spelze an der Spitze ganzran. dig, an Grunde begrannt; Granne oberwärts keulenförmig, in der Mitte von einem bärtigen Ringe umgeben. Griffel sehr kurz.

524. Aira L. Aehrchen 2blüthig, Blïthen zwitterig. Untere spelze an der spitze abgestutzt, 4 zähnig, ant Grunde oder anf dem Rücken begramnt; Granne am Grunde gedreht, gekniet oder fast gerade. Griffel sehr kurz.

527. Avéna $\mathrm{L}$. Aehrchen 2 - bis vielblüthig, Blüthen zwitterig. Untere Spelze an der Spitze 2spaltig oder 2grannig, Granne ruickenständig, gekniet, am liunde gedieht. Griffel fehlend.

530. Triódia R. Hr. Aehrchen 2-bis vielblüthig, Blüthen zwitterig. Klappen bauchig, aile Blüthen un. fassend, die untere grösser. Spelzen am Grunde nit 2 Haurpinseln umgeben, die untere an der Spitze 3zähnig, der mittlert Zahn stachelspitzig, etwas flach.

530. Mélica L. Aehrchen 1-2blïthig mit einer ge. schlechtslusen Blïthe, welche 1 oder mehre unvollkommene einschliesst; die untere Blïthe oder die 2 untern vollkommen, zwitterig, der geschlechtslusen nicht ähn. lich. Klappen die Blüthe umfassend, grannenlos. Spelzen zuletzt knorpelig, unbegrannt.

524. Koeleria P e z. Aehrehen 2-bis vielblüthig. Blüthen zwitterig. Balg zusammengedrückt - gekielt, die Bliithen einschliessend. Untere Spelze an der ungetheilten oder 2spaltigen Spitze stachelspitzig oder be. grannt, Granne burstenförmig, gerade; die obere Spelze 2 kielig, 2spitzig.

538. Dŕctylis $\mathbf{L}$. Aehrchen 3 - bis vielblüthig, gehnäuelt. Blüthen auf dem Rücken zusammengedrückt- 
grehielt, mit cimü̈rts gekrümmter Spitze. Untere Spelze ungleichseitig, an der ungetheilten oder 2spaltigen spitze stachelspitzig oder begramt, auf dem Kiele gewimpert; Granne burstenförmig, gerade.

532. Poa L. Aehrchen 2- !is vielblüthig. Blüthen ei- oder lanzctüörmig, auf dem Rücken zusanmengedrückt-gekielt, gramienlos, mit den Gelenken der Spindel abfällig. Klappen kïrzer als die nächste Blüthe.

531. Eragrostis $\mathbf{P}$. Untere Spelze abfällig, die obern nebst der spindel bleibend. Sonst wie Poa.

537. Glyceria R. Mr. Blüthen länglich, anf dem Rücken halbwalzenförmig, pinwärts fast bauchig, gră. nenlos. In Uebrigen wit bei Poa.

538. Molinia seh rk. Aehrchen 2- his vielbliithig, entfernt, kegelförmig mit eimwärts-hanchigem Grunde, auf dem Rüchen halbwalzenförmig, granneulos uder an der Spitze mit gerader Granne. Klappen kurz, ungleich. Obere spelze gespalten.

531. Moriza c. Aehrchen 2-bis vielblüthig. Blüthen dachiegelig, granuenlus. Untere Spelze eiförnig, stumpf, bauchig-aufgeblasen, am Grunde herzförnig-geöhrt; ubere 2 kielig.

539. Festrica L. Aehrchen 2- bis vielblüthig. Bliithen lanzettlich oder lanzettlich-pfriemlich, auf dem Rücken walzenförmig, begrannt oder unbegrannt. Obere Spelze an Rande fein gewimpert. Griffel oder Narbe all der Spitze des Fruchtknotens.

539. Cynosúrus $\mathbf{L}$. Jedes Aehrchen am Grunde mit einer aus abwechselnd zweizeilig-gefiederten Klappen gebildeten Hïlle gestützt. Sonst wie Festuca.

542. IBachypodium IP. K. Aehrchen vielhliithig. Obere spelze am Kande kammföımig-gewimpert. Im Uebrigen wie Festuca.

543. Bromus L. A ehrchen viclblüthig. Blüthen lanzettlich oder eiförmig-lanzettlich, begrannt oder unbegrannt. Griflel oder Narben der vorderen Seite des Fruchtknotens oberhalb der Mitte eingefiigt."

Hierher einige Juncus-Arten (VI, 1).

3. Ordnung. Trigynia. Dreiweibige. Drei Griffel oder Narben.

Holosteum (X, 3), Alsine media $(X, 3)$, Muntia $($ III, 1), Elatine (VIII, 3), Amarantus (XXI, 5). 
1. Orun. Monogguia.

1V. Classe. 'Teț terblüthen mit 4 freien, glejchlangen Staubgefüssen.

1. Ordnung. Monogynia. Einweibige. Ein Griffel oder Narbe.

A. Blüthen vollständig.

a. Kelch doppelt; der innere zuletzt an die Frucht angewachsen. Blumenkrone Iblatterig, oberständig: die Blüthen auf gemeinschaftlichem Blüthenbodell.

224. Lnautia $\mathbf{C o u} 1 \mathrm{t}$. Blüthenburen rauhharig, whue Siprenblätchen. Aeusserer Kelch nicht gefurcht, 4-vder mehrzähnig; innerer kelch wit $8-16$ pfriemlich-borstenförmigen Zähnfn. Blumenhrone 4spaltig. Hulle vielhütterig.

224. Guccisa Ir ert. I. Hoch. Blüthenbuden spreuhlatterig. Aeusserer Kelch 8furrhig, mit 4spaltigem, krautartigem Saume; innerer Kelch schüsselförmig, neist mit 5 borstenförmigen Zähnen. Blumenhrone 4 spaltig. Hiille vielblätterig.

225. Scabiósa spreublätterig. Acusseler Kelch 8furchig wder 8rippig, mit glockenförmigem wder ralförmigem, trockenliäutigem Saume; inuerer lielch schiisselförmig, meist mit 5 borstenförmigen Zähnen. Blumenkrone jspaltig. Hülle vielblätterig.

223. Dipsacus L. Blüthenboden mit grussen Siprenblättern. Aeusserer Kelch vieljährig; innerer helel. borstenförnig. Blumenkrone 4spaltig. Ilïlle steii-strah. lenförnig, Strahlen länger als die spreublätter.

b. lielch einfach. Blumenhrome 1blätterig, mnterständig.

385. Globalaria L. Blüthen in küpfchen. Bhumenhrone unregelmässig mit $4-5$ theiligem, fast 2lippigem Namme. Kelch röhrenförmig, hipibend. Narbe 2spaltig. Frucht schlauchartig, einsamig, nicht aufspringend.

356. Plantago L. Bïithen in Aehren. Kelch 4theilig. Blimenkrune regelmässig, mit 4theiligen, zurückgeschla enem Saume. Narbe fadentörmig, verlängert. Kapsel rin sum aufspringend, 2 -4fächerig, nehrsanig.

382. Centúnculus $\mathbf{L}$. Bï̈then blattwinkelständig. Kelch 4theilig. Blumenkrone fast hugelförnig, mit

Ga r clie, Flora. 
4theiligem, abstehendem Saume. Narbe kopfförmig. Kapsel ringsum aufspringend, Ifächerig, vielsamig.

c. wie b, nur mit oberständiger Blumenkrone.

212. Aspérula L. Kelchsaum undeutlich, abfallend. Blumenkrone trichter-oder glockenförmig, 3-5spaltig, mit abstehendem Saume. Griffel gespalten. Frucht rundlich, 2 knotig, nit diinnem, trockenem Fruchtgehäuse.

211. Sherardia L. Kelchsaum 4-6zähnig, bleibend. Blumenkione trichterförmig; sunst wie Asperula.

213. Galium L. Blumenkrune flach oder radförmig; sonst wie Asperula.

d. Blumenkrone vielblätterig, oberständig.

207. Cornus $\mathbf{L}$. Kelch 4 zähnig. Blumenkrone 4 blätterig. Steinfrucht 2fächerig. Bliithen in Dolden und Trugdolden.

164. 'rapa L. Kelch 4theilig. Blumenkrone 4blätterig. Narbe kopfförmig. Nuss hart, durch die vergrösserten und verhärteten 'Zipfel des Kelches 4dornig, ifächerig, 1samig. Keimblätter ungleich.

B. Bliithen unvollständig.

a. Unterständig.

463. Fajánthemum Wig $g$. Blüthenhülle blumenkronenartig, tief - 4theilig, nit wagrecht - abstehenden oder zurückgebogenen Zipfeln. Beere 2fächerig, Fächer Isamig.

154. Alchemilla L. Blumenkrone kelchartig, nit 8spaltigem Saume. Zipfel abwechselnd kleiner. Staub. jefässe 1, 2 oder 4, auf einem den Schlund verengen. den Ringe. Nuss von der bleibenden Blithenhülle eingeschtossen.

155. Sanguisórba $\mathbf{L}$. Blüthenhülle kelchartig, farbig, von $2-3$ Deckblättern umgeben; Röhre 4kantig, Salim 4theilig. Staubgefässe auf einem den Schlund verschliessenden Ringe. Nuss von der verhärteten Röhre unıgeben.

416. Parietaria $\mathbf{L}$. Blüthen vielehig. Blüthenhülle gluckenförmig, meist 4 spelzig, bei der Zwitterhlüthe zuletzt verlängert. Staubgefísse vor der Bliuthezeit einwärts-geknickt; Staubfäden elastisch-zurücksprin- 
gend. Narbe kopfartig-pinselförnig. Frucht von der bleibenden Blüthenhiille umgeben.

Hieher Evonymus europaeus $(\mathrm{V}, 1)$, Thesiun intermedium $(V, 1)$; einige rierspaltige Gentianeen $(V, 2)$.

4. Ordnun:- Tetragynia. Vierweibige. 4 Griffel.

81. Tendiola Gme 1. Kelch 4 spaltig, mit 2-3spaltigen Zipfeln. Blumenkrone $2-3$ blätterig. Kapsel 8fächerig; Fächer Isamig.

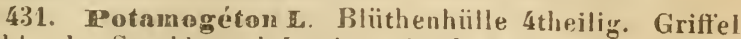
fehlend. Staubbeutel 4, sitzend, dem Grunde der Bliithenhüllzipfel eingefiigt. Steinfriichte 4 , sitzend.

Sagina, Mönchia (X, 5), Cuscuta $(V, 2)$; einige Gentianeen $(\mathrm{V}, 2)$.

V. Classe. Pentana roia. Fünfm blüthen mit 5 freien, gleichlangen staubgefassen.

1. Ordnung. Monogynia. Einwe ibige. Ein Griffel.

I. Blïthen vollständig, 1blätterig, unterständig.

1. Nüsse 4, 1samig oder 2 , jede 2 samig.

a. Nïsse 4 , mit dem Riicken an den bleibenden Grifiel angewachsen.

314. Asperúgo K. Kelch 5spaltig, nach des Bliithe sich vergrösserud, zusammengedriickt mit buchtigen $Z i p$ felı. Blumenkrone trichterförnig, durch 5 gewölbte Schuppen geschlossen. Niisse zusanmengedriickt, mit der schmäleren Seite an den Griffel angewachsen.

315. Echinospérmnm : S $\mathbf{w a r t z}$. Kelch 5theilig. Blumenkroue präsentirtelferförmigy, durch 5 gewölbte Schuppen geschlussen. Nïsse 3eckig, am Rande weichstachelig, klettenartig, mit der Rïckenkante an den Griffel angewachsen.

315. Cynoglossum L. Kelch 5theilig. Blumenkrone trichterförmig, mit 5 gewölbten Schuppen. Niisse plattgedrückt, kurz-weichstachelig, klettenartig, unberandet oder mit einem herrortretenden, aber nicht umgebogenen Rande.

b. Nüsse 4 , einer unterständigen Scheibe eingefügt, am Grunde mit einem gedunsenen, ge. rieften, ausgehöhlten Ringe versehen.

316. Borago L. Kielch 5theilig, ausgebreitet, zur $2 \mathrm{~A}$. 
Fruchtzeit geschlossen. Blumenhrune radlörnigg, mit 5) kurzen, stunufen, ausgerandeten Schuppen.

317. Anchusa L. Kelch 5spaltig, zur Fruchtopit anfrecht. limmentione trichterfömig mit gerader Röhre; Schlund durch 5 gewölbte, stumpfe Schuppen gesrhlussen.

317. Lycopsis L. Kelch 5thrilig, zur Frurhtzeit gesrhlossen. Blumenkrune trichterförmig. mit gekriinumter Röhre; Schlumd lurch 5 stmupfo behuppen geschlussen.

317. Nonmĕa Tred. Keleh 5spaltig, zur Frnehtzeit aufgeblaseli. Blumenkrone trichterförmig mit geraler Röhre. Schlund offen, bärtig oder mit srhwachen, helaalten sichupyen besetzt, aber durch diese laum verengert.

318. Symphytum L. Kelch 5theiliz. Wlumenkrune walzenförmig-gluckig, mit 5 pfriemlichen, hegelförnizgzusammengencigten schmppen.

c. Niisse 4, finer unterständigen Sicheibe eingrfiigt, am Grunde nicht ausgehöhlt.

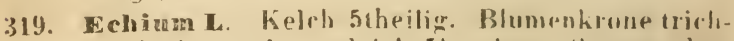
terförmig, gluekig, mit ungleich 5lappigen Siume who Schuppen. Staubgefässe anfstcigenul, das eine kijrk\%.

319. Pulmonaria L. krloh prismatisch-5hantig, 5spaltig. Blumenkrone trichterförnig. Silulund whe Schupper, aber mit 5 Haarbüscheln.

320. Lithospermum E. Kelch 5theilig. Blumenlirune trichterförnig; Schlum durch 5 behaarte Falten etwas verengert. Nüsse steinhart.

321. Iryositis L. Kelch 5theilig. Blumenkruns: trichter-oder präsentirtellerförmig: Schlund durch 5 kahle Schuppen verengert. Nüsse glänzend, glatt.

B. Kapsel ffächerig, mit einem freien mittelpunhtständigen Samenträgrr.

a. Bhumenhrume trichter-uder tellerförmi. Kelch 5spelzig oder 5zähnig.

383. Andrósace $L$. Blumenröhre eiförnig, am Schlunde verengert und mit 5 Höckerchen. Kapsel 5 hlappig, meist bis anf den Grund aufspringend.

383. Primula C. Blumeuröhre walzenförmig, an der Einfügun: der staubgofässe erweitert. Schlund mit oder whe Hösherchen. Kapsel in 5 oft gespaltene Zähue anfspringend. Staubgefässe bald höher, bald tiefes der köhre eingefiigt und daher mit kïrzerem und Jängerem Griffel. 
i. Oidn. Monogynia. V. Cl. Pentandria.

- b. Blumenkrone rad-uder tellerförmig. Kelch 5theilig.

330. Lysimachia L. Blumenkrune radförmig, jtheilig. Staubgefasse am Grunde unter sich verwachsen. Kapsel sklappig.

381. Anagállis L. Blumenkrone radförmig, 5theiligg. Staubgefässe frei. Kapsel ringsum aufspringend.

384. Hottonia L. Blumenkroue tellerförmig, Röhre walzenförmig, Saum flach, 5theilig; Kapsel zerreissend.

C. Kapsel Ifächerig, mit 2 randständigen Samenträgrern.

308. Menyanthes L. Kelrh 5theilig. Blumenkrone trichterförmigr, mit stheiligem, inwendig bärtigem Saume.

D. Kapsel 2-5fächerig.

312. Erythraea Hen. Rich. Kelch 5spaltig. Blumenhroue trichter - wher tellerlörmig mit 5spalticem Saume. Staubbeutel nach dem Verbluihen schraubenförmig-gedreht. Kapsel von den eingebogenen Klappenrïnlern 2fächerig.

313. Convilvulus L. Kelch 5theilig, bleibend; Blumenkrone trichterförmig-gluckig, 5faltig. Griftel ungretheilt, mit 2 Narlen. Kapsel $2-4$ fächerig; Fächer Isamig.

32\%. Datura L. lielch abfallend, bis auf den bleibenden, ringsum abgestutzten Grund. Plumenkrone trichterförmig, 5 faltig. Kapsel 4 fächerig, 4 klappig.

327. Nicotiana L. Kielch gluckig, 5spaltig. bleibend. Blumenhrone trichterförmig, 5faltig. Narbe kopförrmig. Kapsel mit 2 uder méhen Füchern und Klappen: Klappen zultet gespalten.

327. Hyoscýamus $\mathbf{L}$. Kelch krugförnig, 5zähnì̀, bleibend. Blumenkrone trichterförmig, mit ungleichJlappigem Saume. Staubgefässe gekrimmt. Kapsel banchi, in einen Hals verschmälert, mit einem Deckelchen aufspringend.

32S. Verbascun L. Kelch Stheilin, bleibend. Blumenkrone liadförmig, mit mingleich-5lappigen Saume. Staubgefässe ungleich. Stiubbeutel quer oder schief angewachsen. Kapsel 2 fächeriø̈, 2 klappig.

E. Frucht aus 2 Balgkapseln bestehend.

308. Vinca $\mathbf{I}$. Kelch 5theilig. Blumenkrone teller- 
förmig mit schief-abgestutzten Zipfeln und nacktem schlunde. Staubbentel wberhalb des Grillels zusammengreneigt. Narbe scheibenförmig, mit eimer Haarkrune. Fruchitknoten 2, mit einem gemeinschaftlichen Griffel.

F. Frucht eine Beere.

324. Lýcium L. Kelch glockig, 2-5spaltig. Krone trichterförmig, mit 5lappigem Saume. Stauligefässe mit ihren Bärten den Schlund verschliessend. Beere 2färherig, nur an Grunde vom Kirlche umgeben.

326. Atrŏpa L. Kelch 5theilig. Blumenkrone glokhenförmig. Stauhgefässe etwas ungleich, mit ihrem Grunde den Schlund verschliessend, oberwärts auseinander tretend. Beere 2fächerig, am Grunde ron den vergrösserten Kelche umgeben.

326. Phýsalis L. Kelch 5spaltig. Blumenkrone radförmig. Staubgefässe zusammenneigend; Staubbentel der länge nach aufspringend. Beere 2fächerig, von ausgewachsenen, blasenförmigen Kelche ganz umgeben.

324. Solninum K. Kelch 5spaltig. Blumenkrone radförmig. Staubbentel dicht aneinander liegend, an ler Spitze mit 2 Löchern aufspringend. Beere 2 fächerig.

III. Blüthen vollständig, 1blätterig, oberständig.

A. Kapselfrucht.

384. Sumolus L. Kelch 5spaltig, Röhre mit dent Fruchtknoten verwachsen. Blumenkrune kurz-gluckenförmig, mit abstehendem, 5spaltigen Saume. Staubgefässe 10, die 5 fruchtbareu an Grunde der Blunienkrone, die 5 unfruclitbaren höher zwischen den Zipfeln eingefügt. Kapsel halb-oberständig, 5hlappig.

296. Jasióne $\mathbf{L}$. Kelch 5spaltig. Zipfel der Blumen. krone linealisch, zusammenklebend, zuletzt vom Grunde aus sich lösend. Staubfäden pfrienlich. Staubbeutel zusammenklebend. Kapsel vom Kelche gekrönt, 2fächerig, an der spitze aufspringend. Blïthenköpfchen von einer gemeinschaftlichen Hiille ungeben.

297. Phytevima L. Kelch und Blumenkrune wie bei Jasione. Ntaubfäden am Grunde breit, Staubbeutel frei. hapsel 2-3fücherig, durch seitliche Löcher aufspringend. Blüthenstand kopf - oder walzenförmig von einer gemeinschaftlichen Hülle ungeben.

297. Campánula L. Kielchröhre kreiselförnig. Blu- 
menkrone meist glockenförmig, 5lappig oder 5spaltig. Staubgefässe mit verbreitertem Grunde dem Rande einer becherförnigen Scheibe eingefügt. Kapsel kreiselförmig, mit 3-5 Löchern aufspringend.

300. Specularia He is t. Kelchröhre verlängert. Blumenkrone radförnig, 5 spaltig. Staubgefässe häutig, behaart, gleich breit. Kapsel länglich, prisnatisch, mit Seitenritzen aufspringend.

B. Beerenfrucht.

211. Lonicéra L. Kelch 5zähnig. Blumenkrone röhren-oder trichterförmig, mit 5spaltigem, oft rachenförmigem Saume. Becre 2-3fächerig, mehrsamig.

III. Blïthen rollständig, vielblätterig;, unterstäıdig.

a. Blume unregelmässig.

96. Impatiens L. Vollständiger Kelch 5blätterig, das hintere Blatt viel grösser, blumenblattartig, gespornt, die beiden vorderen schr klein, meist fehlend. Blumenkrone 5blätterig, die seitenständigen Blätter paarweise verwachsen. Staubfäden sehr kurz. Staubbeutel zusammenklebend. Kapsel 5klappig. Klappen elastisch aufspringend, zusammenrollend.

52. Viola c. Kelch 5bhätterig, am Grunde mit Anhängseln. Blumenkrone 5blätterig, unteres Blumenblatt gespornt. Staubgefässe meist breit, walzenförmig-zusammengestellt. Kapsel $3 \mathrm{klappig}$, vielsamig.

b. Blume regelmässig.

89. Vitis L. Kelch schwach-5zähnig. Blumenkrone 5blätterig, mützenförnig, an der Spitze zusammenhängend, am Grunde sich ablösend, den Rande einer Scheibe eingefügt. Beere 2:ächerig, 2-4sanig.

89. Ampelópsis Mich. Kelch schwach - 5zähnig. Blumenkrone 5blätterig, von der Spitze nach dem Grunde sich trennend, an der Spitze nicht zusammeuhängend, dem Rande einer Scheibe eingefügt. Beere 2fächerig, 2-4samig.

99. Evónymus L. Kelch flach, 4-5lappig. Blumenkrone 4-5blätterig, mit dem Kelche und den $4-5$ abwechselnden Staubgefïssen dem Rande einer Scheibe eingefïgt. Kapsel 4-5kantig, 4-5fächerig. Samen mit einem breiartigen Mantel.

99. Rhamnus L. Kelch 4-5spaltig, abfallend, mit 
krugförmiger, bleibender Röhre. Blumenkrone 4-5blätterig, nebst den 4-5 vor deu Blumenblättern stehenden Stanhgefässen dem Rande einer Scheibe eingefügt. steinfrucht mit meliren knorpeligen Steinen.

IV. Blïthen vollständig, vielblätterig, oberständig.

176. Hibes L. lielch 5-, selten 4spaltig. Blumenkrone nieist aus 5 benagelten Blumenblätteri bestehend, mit dlen Staubgefässen dem Kelchṣchlunde cingelügt. Beere vielsamig.

207. Hédera d. Kelchsaum undeutlich wler gezïhnt. Blumenkrone aus 5-10 am Grunde breiten Blumenblitttern bestehend, mit den 5-10 Staubgefüssen dem Rande einer Scheilse eingefügt. Griffel 5-10, wder in einen einzigen rerwachsen. Beere 5-lofücherig. Samen krustig.

V. Bluthen unvollständig, unterständig.

a. Staubgefässe 5 .

385. Glaux L. Kelch glorkenförmig, 5spaltig, inwendig gefürbt. Blumenkrone fehlend. Kapsel kugelförmig, šklappig.

b. Staubgefüsse 10 , ron denen 5 ohne Staubbentel sind.

172. Merniaria L. Kelch 5theilig, mit flachen oder ein wenig gewölbten, inwendig etwas gefärbten Zipfeln. Blumenblütter sehr klein oder fehlend. Frucht von Kelche eingrschlussen, häutig, 1simig, nicht aufspringend.

172. Illéebrum L. Kelch 5theilig, mit knorpeligen, von iler situte her znsanmengedrückten, stachelspitzigen, weissen ZZipfeln. Blumenblätter sehr klein, borstenförmig oder fehlend. Kärsel rum Kelche eingeschlussen, lïngsfurrhig, 1samig, am Grunde in 5-10 Lappen aufspringend.

VI. Blüthen unvollständig, oberständig.

407. Thesium L. Blüthenhülle 4-5spaltig, trichterförmig. Stanbgefïsse von einem Ifarbüschel eingeschlossen. Steinfrucht 1samig, von der bleibenden Biiithenhülle umgeben und gekröıt.

Zur Monugynia: Arten von Gentiana $(\mathrm{V}, 2)$ und Pulygonum (VIil, 1). 
2. Ordnung. Diggnia. $Z$ we iw e ibige. Zwei Griffel. I. Blïthen unvollstïndig.

4i8. VImus L. Blüthenhïlle $4-5 z a ̈ h n i g$, gluchenförmig. Fuchtknoten 2 fücherig. Nuss durch Fehlschla. gen lfücherig, ringsun gefliigelt.

394. Beta L. Blüthenhülle 5spaltiy, fleischig werlend, an Grunde mit der Röhre den Fruchtkonten einschliessend. Frurlst an die Blüthenhïlle angewachsen, mit einen wagrechten Samen, dessen ëussere Hant lederartigr ist.

359. Schoberia C. A. Meyer. Blüthenhiille 5theiliør, kelchartig, whne Anhängsel. Schlauchfrucht häutig, plattgedrückt. Samenhaut hrustig. Samenkein schranbenförunig.

391. Chenopodium 5. Plüthenhïlt 5theilig, kelchartig, ohue Anhiangsel. Sihlauchfrucht dünnhäutig, plattgellrückt. Sumpnhant krustig. Samenkeim ringförmig. Samen alle wagrecht.

393. Blitam $\mathbf{E}$. Blüthenhülle $3-5$ theilig, kelchartig, ohne Anhängsel. Samen alle aufrecht oder mit wagrecliten gremischt; soust wie bei Chenopodium.

II. Blüthen vollständig, einblätterig, unterständig.

317. Cynanchum P. R. Kelch 5theilig. Blumenhroue radförmig, 5theilig. Staubgefässe an Grunde in einen 5lappigen Körper verwachsen. Fruchtinoten 2, mit einem einzigen, seitenständigen Samentriger und einer gremeinschaftichen Narbe. Frucht eine doppelte Balgkipsel.

309. Gentióna $\mathrm{L}$. Kelch 4-6litpuig, oder 4-6theilig, aufiecht. Blumenhrone walzen- obler glockenförmig, mit 4-6ipaltigem Saume. Staubgefässe 5, (bei wenigen 4 oder 6 ). Griffel 2 oder 1 ; Narbe 2. Fiuchtknotrn 1, mit 2 gegenständigen Samenträgerı.

313. Cúsenta L. Keloh 4-5spaltig. Blumenkrone glucken- oder kruøförmig, 4-5xpaltig, vertruckuend, unter den staubgefässen mit Schïppchen. Fruchtknoten 1, mit wenigen, den Grunde des Fruchtknotens cingrefügten Eichen. Kapsel ringsum aufspringend. Schma. ristzerpflanze.

III. Blïthen 5blätterig, oberstïndig. Doldengewächse. A. Blüthen in einem Köpfchen oder in einer einfachen Dolde. 
180. Iydrocoityle L. Kielchrand undeutlich. Blumenblätter ungetheilt, eiförmig, spitz. Frucht von des Seite flach-zusammengedriuckt, beiderseits auf dem Mittelfelde mit 2 bogenförnigen Rippen.

182. Fryngium L. Kelchrand 5zähnig. Blumenblätter aufrecht, zusinmmenneigend, länglich-verkehrt-eiförmig, ron der Mitte an in eiu läppchen von ler länge des Blumenblattes cingrknickt. Frucht rerkehrt-eiförmig, schuppig oder höckerig. Früchtchen rippenlos. Fruchtträger getheilt.

181. Astrantia L. Friichtchen mit 5 erhabenen, faltig-gezarkten Rippen. Fruchtträger ungetheilt; sonst wie hei Eryngium.

\section{B. Dolde zusammengesetzt.}

a. Eiweiss vurne flach oder gewölbt. Ilauptrippen 5, fadenfömig, ohne Nebenrippen. Frucht von der Seite her deutlich zusammengedrückt.

1. Blumenblätter ungetheilt. Kelchrand undentlich.

187. Huplenrum L. Blumenhläter an des Spitze abgestutzt, eingerollt. Rippen geflïgelt oder undeutlich. Seitenrippen randbildend. 'Thälchen striemig oder striemenlos.

183. Helosciádium Koch. Blumenblätter sternförmig-ansgebreitet, eiförmig, mit einem kleinen geraden oder einwärts gebogenen Spitzchen. Frucht pilörmigzusammengedrïckt. Seitenrippen randbildend. 'Thälchen Istriemig. Fruchtträger ungetheilt, frei.

182. Apium L. Blumenblätter sternförmig-ausgebreitet, rundlich, mit einem dicht-eingerollten spitz. chen. Frucht kugelig-zusammengedrücht. Seitrnrippen randbildend. Tliälchen 1striemig. Fruchtträger ungetheilt.

183. Petroselínum Mof $\mathbf{m}$. Blumenblätter rund. lich, in ein einwärtsgebugenes luäppchen verschmälert. Frucht eiförmig-zusammengedricht. Seitenrippen randbildend. Thälchen 1striemig. Fruchttäger getheilt.

2. Blumenblätter regelmässig, verkehrt-herzförmig, mit einem kleinell einwärts-gebugenen Läppchen. Kelchrand unmerklich.

184. Aegopódium . Frucht länglich-zusammen- 
grolrükt. Seitenrippen randbildend. 'Thälchen striemenlos. Fruchtträger borstenförmig, an der Spitze getheilt.

184. Carum L. Frucht länglich-zusammengedrückt. Seitenrippen randbildend. Thälchen 1striemig. Stritemen farlenförmig. Fugenfläche eben. Fruchtträger frei, all der Spitze getheilt. Griffel zurïckgebugen.

185. Pimpinélla L. Frucht eiförmigr-zusammengedrückt, 2 knutig. Seitenrippen randbildend. 'Jhälchen 3striemig. Striemen fadenfömig. Fruchträger frei, gespalten. Griffel haarfein, abstehend.

3. Blumenblätter verkehrt herzförmig, mit einem kleinen, einwärtsgebogenen läppchen. Kelch 5zähnig.

* 'I'hälchen 1striemigr.

182. Cicuta C. Frucht hugelig-zusammengedrürkt, 2knotig. Rippen flarh, Seitenrippen randbildend. Striemen die Thälchen ausfüllend, bei der trockenen Frucht ein wenig mehr hervorspringend als die Rippen. Fruchtträger getheilt. Eiweiss im Querdurchschnitte kreisrund.

154. Falcaria Host. Blumenbläter nit herrortretenden Läppchen. Frucht länglich-zusammengedrückt. Seitenrippen randbildend. Striemen fadenförmig. FruchtIräger getheilt. Eiweiss walzenförmig - gewölbt, vorne flach.

\section{- ** Thälchen 3striemig.}

186. Hérula Koch. Frucht eiförmig-zusammen. gedrüclit, fast 2 knotig. Seitenrippen neben den Rande. striemen mit dem vindenartigen Fruchtrehäuse bedeckt. Fruchtträger undeutlich. Griffel abstehend.

187. Sium L. Kelchzähne oft sehr klein. Frucht fast 2 knotig. Seitenrippen randbildend. Striemen oberflächlich. Fruchtträger getheilt. Griffel abstehend.

B. Eiweiss vorne flach uler gewölbt. Hauptrippen 5 , fadenförmig oder geflïgelt, uhne Nebenrippen. Frucht iuf dem Querdurchschnitte kreisrund oder vom Rïrken her zusammengedrückt, aber nicht linsenförmig.

a. Samen nur in den 'Thälchen an das Fruchtgehäuse angewachsen.

194. Ostéricum Ko f $\mathbf{f m}$. Kelch 5zähnig. Blumenblätter benagelt, rundlich-verkehrt-herzförmig, mit ei- 
nem cinwä̀ts gebogenen Jüpprhen. Frucht ın Räcken her zusammengedrïrlit, beiferseits 2llïgelig. Fü̈chtchen mit 3 fadenförmigen Rückenrippen, die 2 seitlichen breit keflïgelt, alle inwendig röhrig. Thälchen istriemig. Fruchttrïger getheilt.

b. Simmen ïberall an das Frurhtgehäuse angewachsen.

aa. Blunenblïter ganz, zugespitzt.

194. Angélica L. Kielchrand undeutlich. Frucht vom Rücken her zusammengedrickt, beiderseits 2flügelig. Die 2 Seitenrippen einen Flügel run doppelter Breite der 3 fadenföranigen Ruchenrippen bildend. Thälchen istriemig. Fruchttrïger getheilt.

bb. Blumenbliater aufrecht, ron der Mitte an in ein Lïppchen von der Länge des Blumenblattes cingehniclit.

181. Sanicula $x$. Kelchzähne blattartig. Frucht fast kugelig, mit hakenförmigen stacheln dicht bedeckt, von xelbst sich nicht von dem undeutlichen Fruchtträger ablösend. Frïchtchen rippenlos, vielstriemig. Blüthen vielehig.

c. Biumenblätter rundlich, ganz, eingerollt.

191. Eoeniculum Hof $\mathrm{fm}$. Kelchrand undeutlich. Blumenläppchen fast 4 eckig, gestutzt. Frucht auf dem Querdurchschnitte fast kleisrund. Rippen stumpf-gekielt. Thälchen 1-, selten 3striemig. Fruchtträger gespalter.

dd. Blumenblätter rundlich, verkehrt-ei-oder herzförmig, mit einem einwärts gebogenen I.̈̈ppchell.

* Thälchen Astriemigr. Kelchrand undeutlich.

193. Levisticum fioch. Rlumenblätter rundlich, cinwärts rekrümmt, in rin lïpprhen verschmälert. Frucht beiderseits 2 fligelig. Seiteullügel der Früthtchen noch einmal so breit als die Rïchenrippen. Fruchtträger gespalten.

193. Selinum I. Blumenblätter verhehrt-herzförnig. Frucht nur wenig zusammengedrïckt; die äusseren zuweilen 2striemigr; sunst wie bei Levisticum.

190. Aethúsa L. Blumeublätter verkehrt-eiförmig; Frucht eiförmig-kugelig. Ruckenrippen der Früchtchen 
"rhaben, dick, scharf-grekielt, Seitenrippen etwas breiter, randbildend.

192. Cnidiun $\mathbb{C}$ uss. Blumeublätter rerkehrt-eiförmig. Frucht anf cim Querdurchschnite kreisrundlich; Rippen der Früchtohen etwas häutig-geflügelt, die seitlichen randbildend.

** Thälıhen Istriemig. Kelchrand gezälnt.

18:3. Oenanthe L. Blummblätter verkehrt-eiförmig. Frucht länglich, walzen- wler kreiselförmig. Seitenrippen randbildend, etwas breiter als die Rückenrippen. Grifiel aufrecht. Fruchtträger: angewachsen, undertlich.

131. Séseli L. Kẹchzähne 3eckig. Blumenblätter verkehrt-eiförmig. Frurht eiföımig oder lïnglich, auf dem Querdurchschnitte hreisundlich. Seitenrippen randbiliend, oft etwas breiter als die Riickenrippen. Thäl. rhen istriemig, selten 2-3strienig. Griffel zurückge. bugen. liruchtträger frei, getheilt.

192. Libanotis Crantz. Kelchzähne pfriemlich, verlängert, abfällig; sonst wit bei Seseli.

\section{*** Thälchen 3strienig.}

193. Silăus $\mathbf{3}$ ess. Blumenblïtter verkehrt-eiförmicr-länglich, mit breitem Grunde sitzend. Frucht auf dem Querdurchschnitte kreisrundlich. Rippen scharf, etwas gefliggelt, fast gleich, die seitlichen randbildend. Griffel zurückgebogen. Fruchtträger getheilt.

C. Eiweiss vorne flach oder gewölbt. Hanptrippen fadenförmig, whe Nebenrippen. Frucht rom Rïcken her flach - oder linsenförnig-zusammeugedrückt, mit einem geflügelten, spitzen oder verdichten Rande umzogen. striemen uberflächlich, 1-2 in jedem Thälchen.

a. Rippen sehr fein; die 3 Rückenrippen gleichweit abstehend; die Seitenrippen entfernt, den verbreiterten Rand berührend oder von diesem bedeckt.

199. Tordylium L. Blumenblütter verkehrt-herzföımig. Striemell fallenförmig. Fruchtrand verdickt.

198. Heracléum L. Blumenblätter verkehrt-herzförmig, die äusseren oft strahlend. Striemen keulenförmig. Fruchtrand aboeflacht. 


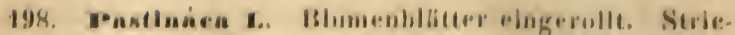

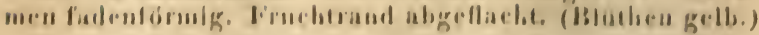

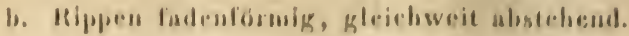

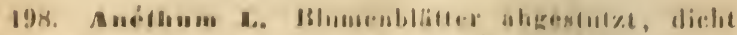

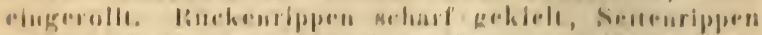

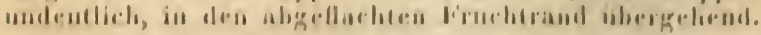

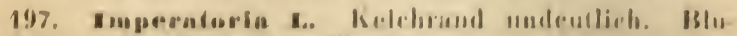

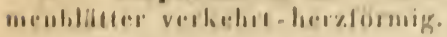

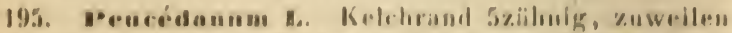

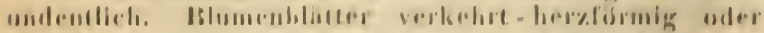

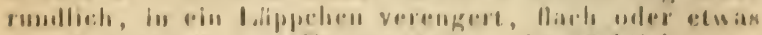

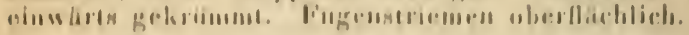

196. 'Thy

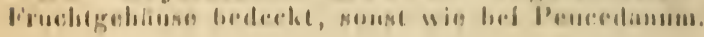

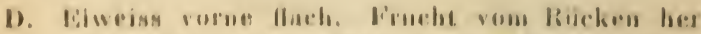

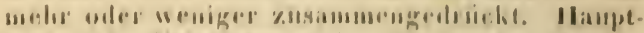

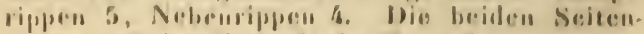

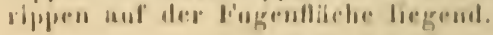

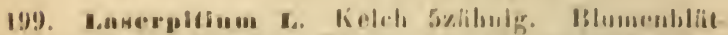

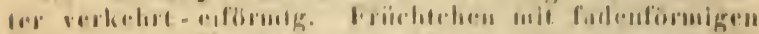

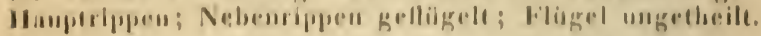

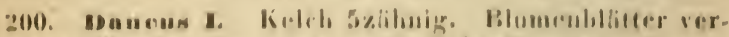

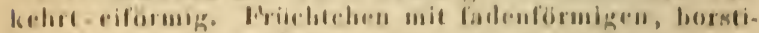

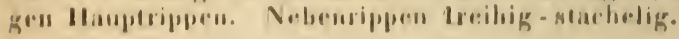

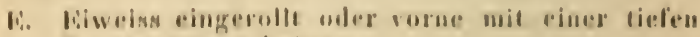
liurshe vingeschuillen.

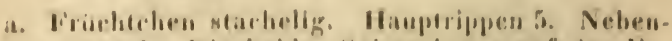

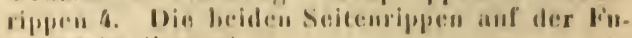

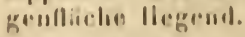

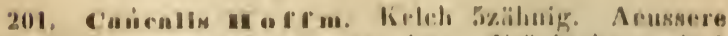

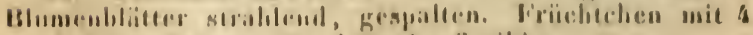

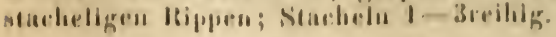

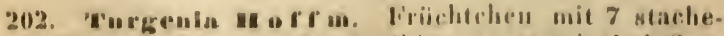
ligun lipplen; Stachelu 2-3reihig; sunst wie bei Canrulis.

202. Tropills a a

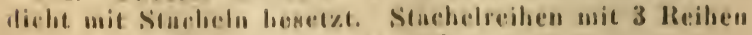
von kleinen Horsten abwecharlad. 
b. Fribchtefen niche stacheligh, aber bisereilen mit kleine foursten tragenden Knijtchen bestrent. leippren plattgeslrijekt, stumpl, niche gekerlst, bistueilos felilend.

203. Anthrincus II of fom. Kelchanol undeutlich.

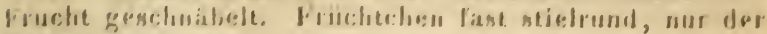
Schoubel solipuig.

203. Scasolix L. Kelchrand undelltheh. Fruche meht

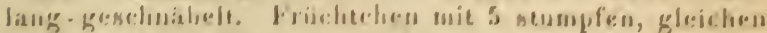

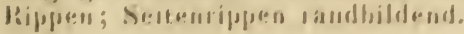

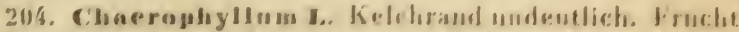

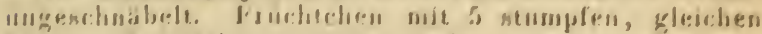
Rippen; Seitenrippen raudbuldend.

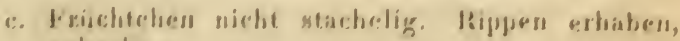
ke:ke:lit.

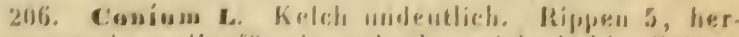
vorteretend, wrllenfiormigg-gekesht, sisht hohl. Seitron rippent latudlifldends.

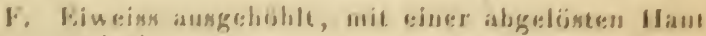
bedseckt.

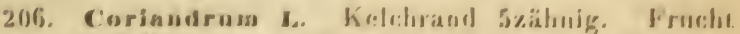

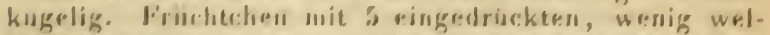

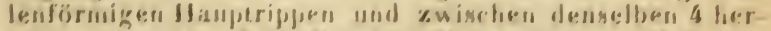

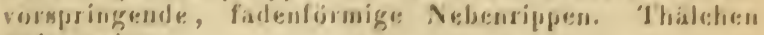
strivatuenlus.

Ilerniaria $(V, 1)$.

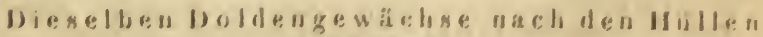
gocos ord $n \in t$.

A. Dolden binfiach,

180. If yodrocotyle L. Hiulls 3-oblitterig.

182. Ergngiom I. Hiille: vieltheilig, dornig.

li. Julden \%usiammengentet\%.

1. Hislle vielblatterig $(3-10)$. Hiblletren virel. blisttrigh $(5-10)$.

15l. Saniculn I. Fruche borstenfiomige, rippranlos. Blintlien vielehigh.

18:. Weloschaldum repens koch. Fructit kugel. fiomig, 2 kustign, gerippt. 
18\%. Sinm L. Frucht 2 knntig, gerippt, Seitenrippen rambildend. Blumen weiss.

186. Berula Foch. Frucht 2 hnatig, gerippt, Seiteurippen nehen dem Rande. Blumen weiss.

187. Hupleurum L. Fircht 2 knotig. gerippt. Blıwen grelb.

192. Libanotis Crantz. Frucht eiförmig, grerippt, steiflıarig.

193. Levisticam Hoch. Furht linsenförmig, eiförmigr, fliigelig-gerippt, Rand hlaffend. Blumen grelblich.

195. Pencedanum Cerv. Ta p. und Oreoselinnm moench. Frucht linseuförnigg, gerippt, ans Rander schmal-geflügelt.

196. Thysselinum II f f m. Frucht linseuförmign, erhaben gerippt, am Rande schmal-geflügelt.

199. Tordylium L. Fruclıt linsenförmig, gerippt, am verdickten Rande runzelig-hnutig.

199. Laserpitium L. Frucht \&lligrelig, Flügelkiel behart.

200. Daucus L. Frucht linsenförmig, Nebenrippen 1reihig-stachelig; fruchttragende Dolde vogelnestartig vertiest.

202. Turgenia Hoffm. Frucht 2 knutig, stachelig. Kelchzähne bursteuförnig.

202. Torilis Anthriscus G e 1. Frucht lünglich, stachelig. Kelch 5zähnig. Zähne 3eckig.

206. Conium L. Frucht eiförmig, 2knotigr, wellenförmig - gerippt.

154. Falcaria Host. Frucht länglich, gerippt.

2. Hülle fehlend oder wenighlätterig $(1-3)$. Hüllchen vielblätterig $(3-8)$.

181. Sanicula L. Frucht fest, kugelig-eiförmig, borstenförmig.

181. Astrantia L. Frucht schlauchartig, Rippen faltig.

182. Cicuta L. Frucht 2 knotig, gerippt. Blumenblätter ausgerandet.

183. Petroselinum Hoffm. Frucht 2 kinotig, gerippt. Blnmenblätter ganzrandig.

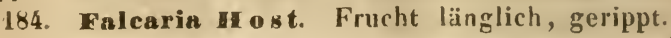


187. Hupleurum L. Frucht aknotig, gerippt. Blumen gelb.

190. Aethusa $\mathbf{L}$. Frucht eiförmig - kugelig, gerippt.

189. Denanthe L. Frucht länglich-eiförmig, erhaben gerippt.

191. Seseli L. Frucht eiförmig-länglich, gerippt. Kelch 5zähnig.

192. Cnidium renosum Koch. Frucht rundlich eiförmig, scharfrippig. Blumen weiss.

193. Silnus $\mathbf{H}$ ss. Frucht länglich, scharfrippig. Blumen gelb.

193. Selinum L. Frucht eiförmig, flïgelig gerippt; Raud klafiend.

194. Ostericum Hof $\mathbf{f m}$. Frucht eiförmig, gerippt; Rand klaffend-geflügelt.

194. Angelica L. Frucht linsenförmig, eiförmig, gerippt; Rand klaffend-geflugelt.

197. Imperatoria L. Frucht linsenförnig, gerippt, an Rande gefliigelt.

195. Peucédanum officinale L. Frucht linsenförmig, gerippt, anı Rande schmal-geflïgelt.

198. Heracléum L. Frucht linsenförmig, gerippt, am Rande breit-geflügelt.

201. Cancalis Hof $\mathbf{f m}$. Fucht länglich, stachelig. Kelch 5zähnig.

202. Torilis helvetica $\mathrm{A}$ m el. Frucht länglich-eiförmig, stachelig. Kelch 5zähnig, Zähne 3eckig.

203. Scandix L. Frucht länglich-linealisch, lang geschnäbelt.

203. Anthriscus silvestris $\mathrm{H}$ o $\mathrm{fm}$. und Cerefolium Hof $\mathrm{fm}$. Frucht länglich oder länglich-linealisch, geschnäbelt, kahl.

204. Anthriscus vulgaris Pers. Frucht eiförmig, geschnäbelt, borstenförmig.

204. Chaerophyllum L. Frucht länglich, ungeschnäbelt, kahl.

206. Coníum L. Frucht eiförmig, 2knotig, wellenförmig - gerippt.

206. Coriandrum L. Frucht kugelförmig, fast glatt.

3. Hülle wenigblätterig. Hüllchen fehlend.

198. Anéthum $\mathbf{L}$. Frucht linsenförnig, geripgt, breitgeflügelt.

Garcbe, Flora. 
4. Hülle und Hüllchen wenigblätterig $(1-3)$.

186. Pimpinella Anisum L. Frucht eiförmig 2knotig.

184. Carum L. Frucht länglich-2knotig, gerippt.

5. Hïlle und Hüllchen fehlend.

152. Apium E. Frucht 2 hnotig, gerippt.

184. Aegopotium $\mathbf{L}$. Frucht länglich, gerippt. Blumell weiss.

191. Foeniculum of of $\mathrm{m}$. Frucht länglich, gerippt. Blumen gelb.

184. Carum L. Frucht länglich, gerippt. Blumen weiss.

185. Pimpinella L. Frucht eiförmig, gerippt.

198. Anéthum $\mathbf{L}$. Frucht linsenförmig, gerippt, breitgeflügelt. Blumenbläter abgestutzt.

198. Fastinaca L. Frucht linsenförmig, gerippt, breit-geflügelt. Blumenbı̈̈tter eingerullt.

6. Nülle fehlend. Hüll'hen wenigblätterig.

197. Imperatoria L. Frucht linsenförmig, gerippt; Rand breit-geflügelt.

3. Ordnung. Trigynia. Dreiweibige. Drei Griffel.

a. Blüthen vollstündig, unterständig.

171. Corrigiola L. Keleh 5theilig. Blumenblätter 5, so lang als die Kelchżiptel. Narben sitzend. Kapsel isamig, nicht aufspringend.

b. Blüthen vollständig, uberständig.

210. visurnum L. Kiplch 5zähnig. Blumenkrone gluckig-radförmig oder röhrig, 5spaltig. Narben sitzend. Fruchtinoten 3fächerig. Beete durch Fehlschlagen ifächerig, 1samig.

209. Sambucus c. Kelch 5zähnig. Blumenkrone. ralförmig, mit 5spaltigem, zuletzt zurückgebugenem Saume. Narben sitzend. Fruchtknoten 3 - 5fächerig. Bure durch Fehischlagen meist 3fächerig, 3samig.

Stellaria media $(\mathbf{X}, \mathbf{3})$.

4. Ordnung. 'Tetragynia. Vierweibig e. Vier Griffel. 59. Parnassia L. Kelch 5 blätterig. Blumenblätter 5, 
vor welchen 5 schmale, oberwälts geschlitzte, drïsen. tragende Nebenblunsenblätter stehen. Kapsel Ifächerig, an der Spitze 4 klappig.

5. Ordnung. Pentagynia. Fünfweibige. Fünf Griffe].

ro. Linum E. Kelch und Blumenkrone 5 blätterig. Kapsel 5klappig, Lofächerig. Fächer 1samig.

58. Drósera L. Kelch tîf - 5spaltig. Blumenblätter 5. Griffel 3-5, oft gespalten. Kapsel Ifächerig, an der Spitze $3-5 k l a p p i g$, mehrsamig.

386. Státice L. (Amreria Willd.). Kelch trichterförmig, mit trockenhäutigem saume. Kapsel 1samig, nicht aufspringend, von kelche umschlossen.

Arten von Cerastium und Spergula $(X, 5)$.

6. Ordnung. Polygynia. Vielwe ibige.

Myosurus (XIII, 7).

V1. Classe. Mexandria. Sechsmännige. Zwitterblüthen mit 6 freien, gleichlangen Staubgefässen.

1. Ordnung. Monogynia. Einweibige. Ein Griffel.

I. Blïthen vollständig.

18. Bérberis L. Kelch 6blätterig, aus 2 dreiglie. derigen Kreisen bestehend. Blumenblïtter 6 , jedes am Grunde 2drüsig. Staubbeutel elastisclı aufspringend. Beere 2-3samig.

168. Peplis $\mathbf{L}$. Kelch glockenförmig, etwas zusanı. mengedrückt, 12zähnig, 6 'Zähne kürzer, zurïcligebugen. Blunsenblätter 6 , schnell abfallend. Kapsel 2 fä. cherig, vielsamig.

II. Blüthenhülle blumenkronartig, oberständig.

460. Leucojum C. Blüthenhülle glockenförnig, bis auf den Grund 6theilig, Zipfel alle gleich, an der Spitze verdickt.

1II. Blüthenhülle blumenkronartign, 6zähnig oder 6spal. tig, unterstïndig.

462. Convallaria L. Blüthenhülle glucken-oder röhrenförmig, 6zäbnig "der fast 6 spaltig. Fruchtknoten 3fächeri: 2 eiig. Beere mit 3 einsamigen Fächeru. 
474. Múncari Tournef. Blüthenhülle hugel-oder walzenförmig, an der Mündung verengert, mit einem sehr kurzen, 6zähnigen Saune. Kapsel 3fächerig, 3 klappig.

IV. Blïthenhülle blumenkronartig, 6blätterig, unterständig.

A. Griffel an der Spitze 3spaltig.

461. Aspáragus L. Blüthenhülle gluckenförmig, all einen gegliederten stielchen. Narben 3, zurïckgebon. gen. Beere 3fücherig, Fücher 2eiig.

B. Griffel ungetheilt oder fehlend. Narbe stumpt uder 3lappig.

a. Staubbeutel aufrecht, mit dem Giunde auf dis Spitze des Staubfadens gestellt.

465. Grigea $\mathbf{S}$ a 1 isb. Bliithenhüllblätter oberwälts abstehend, ohme Honigbehälter. Griffel fadenförmig. Kapsel 3fächerig. Samen fast kugelig.

463. Túlipa L. Blüthenhüllblätter glochenförmig sich zusammenneigend, whne Honigbehälter. Griffel fehlend, Narbe 3lappig. Kapsel 3ficherig. Samen glatt.

b. Staubbeutel aufliegend. Bluithenhïllblätter am Grunde mit einer hongtragenden Jäingsfurche versehen.

464. Lilium L. Blüthenhüllblätter glockenförmig oder zuriickgerullt. Griflel ungetheilt. Narbe 3eckig. Samen grlatt.

c. Stanbbeutel aufliegend. I onigbehälter fehlend.

464. Anthéricum L. Blïthenhüllblätter abstehend, an einem gegliederten Stielchen. Staubfäden pfriemlich. Griffel ungetheilt. Samen kantig.

469. Allium L. Dolde vor der Blïthezeit ron einer Blüthenscheide eingeschlossen. Bluthenhüllblätter glokkenförmig oder abstehend, nit ungegliederten Stielen. Staubgefässe an Grunde mit der Bliitheuhülle verwach. sen. Samen kantig.

465. Ornithógalum L. Blüthenscheide fehlend. Bliithenhillblitter abstehend, mit ungegliederten Stielen. Staubgefässe dem Fruchtboden eingefügt oder nur wrnig mit dem Grunde der Blïthenhuillblätter zusammen- 
hängend. Griffel 3seitig. Samen eiförmig, fast kugelig oder kantig.

469. Scilla $\mathrm{L}$. Bliithenscheide fehlend. Blüthenhiillblätter abstehend, nit ungegliederten Stielen. Staubgefässe dem Grunde der Blüthenhüllblätter eingefïgt. Griffel 3seitig. Samen rundlich.

d. Blüthenhülle kelchartig (durchsichtig oder trokkenhäutig, unterständig.

476. Juncus L. Blüthenhülle 6blätterig, aus 2 dreigliederigen Kreisen bestehend, spelzenartig. Griffel mit 3 fadenförmigen Narben. Kapsel 3klappig, Klappen in der Mitte die Scheidewand tragend, vielsamig.

482. Lúzula DC. Kapsel Ifächerig, 3klappig, Klappen ohne Sclieidewand, 3samig; sonst wie bei Juncus.

440. Ácŏrus $\mathbf{~}$. Blüthenhïlle 6blätterig, bleibend. Narbe stumpf, sitzend. Kapsel 3fächerig, nicht aufspringend. (Blïthen an einem seitenständigen, schwamunig-fleischigen Kolben; Blüthenscheide fehlend).

Lythrum Hyssopifolia (XI, 1).

3. Ordnung. Trigynia. Dreiweibige. Drei Griffel.

475. Cólchicum L. Blüthenhülle 6theilig, trichterförnig, mit verlängerter Röhre. Staubgefässe der Spitze der Röhre eingefügt. Kapsel aufgeblasen, 3fächerig; Fächer an der Spitze sich trennend, nach innen aufspringend.

476. Tofieldia II u ds. Blüthenhülle 6blätterig. Staubbeutel nit 2 Längsritzen aufspringend. Kapseln 3, bis zur Mitte zusammengewachsen, nach innen an der Spitze aufspringend, vielsamig.

430. Triglóchin $\mathbf{C}$. Blüthenhülle 6blätterig, in 2 dreigliedrige Kreise gestellt, kelchartig. Staubfäden sehr kurz. Fruchtknoten 3-6fächerig, zuletzt vom Grunde aus sich ablösend. Narben $3-6$, sitzend, bärtig.

398. Kumex L. Blïthenhülle kelchartig, tief 6theilig, in 2 dreigliederige Kreise gestellt, innere Blithenhüllblätter grösser, zusamminneigend, später vergrössert und die 3kantige Nuss umgebend. Narben federig. Blüthen zwitterig, vielehig oder zweihäusig.

Arten von Polygonum (VIII, 1). 
5. Orduung. Polygynia. Viplweibige. Sechs und mehr Griffel.

42!). Alisma L. Kelch und Blumenkrone 3blätterig. Frucht ans sehr vielen, wenigstens 6 sitzenden, quirlständigen, nicht aufspringenden, 1samigen Früchtchen bestehend.

'riglochin maritimum (VI, 3).

VII. Klasse. Wheptandara. S i e b e n männige. Zwitterbliithen mit 7 freien, gleichlangen Staubgefässen.

1. Ordnung. Monogynia. Einweibige. Ein Griffel.

379. Trientalis L. Kelch tief 6-9-, meist 7sualtig. Blumenhrone mit flachem, 6-9-, meist 7theiligem Rande, dessen 'Zipfel an Grunde durch einen die Staubgefässe tragenden Ring verbunden sind. Kapsel mit 7 Klappen bis auf den Grund aufspringend.

89. Escŭlus L. (nicht Aesculus). Kelch gluckenförmig, 5zähnig, mit der 4-5blätterigen, mregelmässigen Blumenkromp und den Staubgefässen den Rande einer unterständigen sicheibe eingefïgt. Staubgefässe $7-8$, gekrümmt, aufsteigend. Narbe spitz. Kapsel kugelig, stachelig, 3fächerig. Fächer mit 1 grossen Samen.

Calla $(\mathrm{XXI}, 1)$.

VIII. Klasse. Derawatria. A chtmännige. Zwitterblüthen mit 8 freien, gleichlangen Staubgefässen.

1. Ordnung. Monogynia. Ei nwe ibige. Ein Griffel.

A. Blüthen vollständig, 5blätterig.

38. Acer L. Blïthen vielehig. Kelch 5theilig. Blumenkrone 5 blätterig. Staubgefässe 8 , selten 7 uder 9 . Frucht 2 flügelig, in 2 nicht aufspringende, nussartige Frïchtchen sich trennend.

B. Blüthen vollständig, 4blätterig.

160. Epilobium L. Kelch 4 theilig, mit dem freien Theile der Röhre ringsum abspringend. Griffel fadenförmig, mit 4 abstehenden oder in eine Keule verwach. senen Narben. Kapsel linealisch, 4 kantig, 4 fầcherig, vielsamig. Samen mit einem verlängerten, seidenhaarigen Schupfe.

162. Denothéra $\mathbf{L}$. Kelchröhre verlängert. Frucht 
länglich, 4kantig. an Grunde etwas dicker. Samen ohne Schopf; sonst wie Epilobium.

98. Ruta L. Kelch 4-5theilig, bleibend. Blumenblätter 4 , bei der endstärrligen Bliithe 5 , benagelt. Staubgefässe 8 , bei der endständigen Blüthe 10. Honiggrübchen in der unterständigen Scheibe so viel als Staubgefässe. Griffel $4-5$ spaltig. Kapsel $4-5$ fücherig, vielsanig.

C. Blüthen vollständiğ, 1blätterig, unterständig.

302. Callúna 5 a İib. Kelch 4hlätterig, gefärbt. Blumenhrone glockenförmig, 4 spaltig, vertrocknend, vom Kelche überragt. Staubbeutel nit längsritzen aufsprinwend. Kapsel 4fächerig. Sicheillewände an den mittelpunktständigen, sänlenförmigen Samenträger angewachsen, den Nähten gegenstündig.

302. Erica L. Kelch 4 blätterig oder 4theilig; Blumenkrone 4 spaltig, länger als der Kelch. Staubhrutel sich durch ein seitliches luch öffuend. Kapsel ffürherig. Scheidewände in der Nitte der Klappe angewachsen.

D. Blüthen vollständig, 1blätterig, oberständig.

301. Vaccinium L. Kelch 4-5spaltig oder 4-5rähnig, mit dem Fruchtknoten verwarhsen. Blunenkrune: 4-5spaltig, gluckenförmig. Staubgefässe 8-10. Beer lingelig, 4 - 5fücherig, vielsamig.

Ł. Blïthen unvullständigr, unterständig.

407. Daptne $\mathbf{L}$. Blüthenhülle gefärbt, 4spaltig, abfallend. Ntaubgefässe der Köhre eingefügt. Griftel kurz. Narbe 1. Steinfruclit Isanig, mit weichem Fleische.

406. Passerina $\mathbf{L}$. Bliithenhülle 4spaltig, verwelkend und bleibend, später die einfache Nuss nugebend; sonst wie Daphue.

403. Polýgonum t. Blüthenhülle 4-5spaltiøg, oberwärts gefarbt. Staubgelässe $5-8$. Griffel mit $2-3$ Varben. Nuss einsamig, von der bleibenden Blüthenhiille ungeben.

Monotropa $(X, 1)$. Calla $(X X I, 1)$.

2. Ordnung. Digynia. $Z$ we i weibige. Zwei Griffel.

179. Chrysosplenium L. Kelch halboberständig, 4spaltig, inwendig gefärbt, 2 gegenständipe Zipfel klei. ner. Blumenkrone fehlend. Staubgefässe 4 , bis auf den 
Grund getheilt, einer drüsigen, den Fruchtknoten umgrebenden sicheibe eingefügt. Kapsel Ifächerig, 2schnäbelig, vielsamig. (Die Mittelbliithe oft mit 5spaltigem Kelche und $\mathbf{5}$ zweitheiligen Staubgefüsen).

Möhringia $(X, 3)$. Ulmus effusa $(\boldsymbol{V}, 2)$. Arten von $\mathbf{P}(\mathbf{X}$ lygonum (VIII, 1). Scleranthus (X, 2).

3. Ordnung. Trigynia. Dreiwe ibige. Drei Narben. Polygonum (VIII, 1).

4. Ordnung. Tetrandria. Vie rw e i bige. Vier Griffel.

461. Paris L. Blüthenhülle bleibend, wagrecht-abstehend, aus 2 abwechselnden, 4 theiligen Kreisen bestehend, die 4 äusseren Zipfel einen Kelch, die 4 schmäIeren inneren rine Blumenkrone darstellend. Staubbeutel auf der Mitte der Staubfäden. Beere 4 fücherig, Fächer 4-ssamig.

209. Adoxa L. Kelch halboberständig, an der endständigen Blïthe 2lappig, an den seitenständigen 3lappig, I,appen halb su lang als die radförmige, '5spaltige (bei der endständigen Blüthe 4spaltige) Blumenkine. Staubgefässe 8 oder 10. Staubbeutel anfliegend. Beere 4-5färherig, krantartig, saftig, an der Seite die Kelchlappen tragend.

79. Elatine L. Kelch 3 - 4 theilig. Blumenblätter 3 -4. Staubgefässe $3,4,6,8$. Griffel 3-4. Kapsel oberstäıdig, 3 - 4 fächerig, vielsamig.

Myriophyllum (XXI, 6).

IX. Klasse. Emmeandrin. Neunmännige. Zwitterblïthen mit 9 freien, gleichlangen Staubgefässen.

3. Ordung. Hexagynia. Sechsweibige. Sechs Griffel.

430. Tútomus L. Blïthenhiille 6blätterig, gefärbt. Kapseln 6, unterwärts zusammengewachsen, einwärts aufspringend.

X. Klasser. Hecaudroia. Zehnmännige. Zwitterbliithen mit 10 freien, gleichlangen Staubgefässen.

1. Ordnung. Monogynia. Einwe ibige. Ein Griffel.

98. Dictámnus L. Kelch 5theilig, abfallend. Blumenblätter 5, benagelt, etwas ungleich, Staubgefässe 
abwärts geneigt, an Enìe aufsteigend. Fruchtknoten כlappig, auf einem kurzen, dicken Fruchträger sitzend.

305. Monótropa L. Kelchblätter 4-5, flach. Blu. menkıne glockenföınıig, 4-5hlätterig, unterständig, Blumenblätter am Grunde höckerig. Staubgefässe 8 oder 10. Kapsel 4-5fächerig. Srheidewände in der Vitte der Klappe. (Endblüthen in allen Theilen 5zählig, Seitenblüthen 4zählig).

303. Ledum L. Kelch klein, 5zählig, bleibend. Blumenkrone 5blätterig. Staubbeutel an der Spitze mit 2 Löchern aufspringend. Kapsel 5fächerig, bis zur Spitze durch Randtheilung mit 5 Klappen aufspringend. Staubgefässe am Raude der unterständigen, gekerbten Scheibe ringefügt.

303. Pýrola L. Kelch 5spaltig, bleibend. Blumenkrune 5blätterig. Unterständige Drüsen fehlend. Staubbeutel mit 2 Löchern aufspringend. Kapsel 3fächerig, durch Mitteltheilıng mit Lüngsritzen aufspringend.

Samolus, Herniaria und Illecebrun $(V, 1)$. Ruta und Vacciniun (VIII, 1). Erodium und Geranium (XVI, 1).

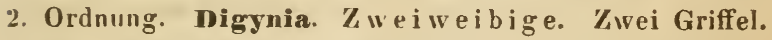

178. Saxifraga L. Kelch 5zähnig oder 5theilig, an den Fruchtknoten angewachsen. Blumenkrone 5blätterig. Kapsel 2fächerig, 2schnäbelig, zwischen den Grif. feln mit einem Loche aufsprin

61. Gypsóphila $L$. Kelch 5zähnig, am Grunde ohne schuppenförmige Deckblätter. Blumenblätter 5, nach dem Grunde allmählig verschmälert, den Schlund nicht verschliessend. Kapsel $1 \mathrm{fächerig,} \mathrm{an} \mathrm{der} \mathrm{Spitze} 4 \mathrm{klap}-$ pig, aufspringend. Samen kugelig-nierenförnıig.

61. Dianthus L. Kelch 5zähnig, an Grunde mit schuppenförmigen Deckblättern. Blunenblätter 5, mit leutlich gesondertem, linienförmigem Nazel, Schlund greschlossen. Kapsel 1fächerig, an der Spitze 4klappig dufspringend. Samen schildförmig.

64. Saponaria L. Kelch 5zähnig, anı Giunde ohne schuppenförmige Deckblätter. Blumenblätter 5, mit deutlich gesonderten, linienförmigem Nagel. Kapsel Ifücherig, an der Spitze 4 klappig aufspringend. Samen kugelig - lierenförnig.

173. Scleranthus L. Kelch 5zähnig, Schlund durch. einen knorpeligen Ring verengert. Blumenkrone fehlend. 
Staubgefässe 10 , lie Iralfte meist unfruchtbar. Fruclit 1samig, im Grunde des verhärteten Kelches.

Chrysosplenium (VIII, 2).

3. Ordnung. Trigynia. Dreiweibige. Drei Griftel.

A. Kelch 1 blätterig.

64. Cucribalus L. Kelch mit 5 grossen Zähnen, zu. letzt aufgeblasen. Blumenblätter 5, allmählig in den Nagel ijbergehend, tief ausgerandet. Beere 1fächerig, nicht aufspringend.

65. Siléne L. Kelch 5zähnig. Blumenblätter 5, lanıbenagelt, Schlund bärtig oder glatt. Kapsel an frumle 3- 4 fücherig, an der Spitze 6zühnig anfspringend, viclsanig.

B. Kelch 5blätterig, selten 4blätterig. Blumenblätter 5 , selten 4 . Kapsel tief gespalten uder auch nur an der spitze gezähnt.

71. Alsine Wahlen b. Blumeublätter ungetheilt oder schwach ausgerandet. Staubgefässp 10, selten weniger, die äusseren am Grunile mit 2 kleinen Driisen gestützt. Kapsel 3kluppig, vielsimig. Samen nierenförmig, flïgellos.

70. Lepigonum Wh henb. Blumenblätter ungetheilt. Staubgefässe 10, zuweilen nur 5 uder 3 . Aeussere Staubgefässe an Grunde mit 2 kleinen Drïsen gestiitzt. Kapsel 3-5klappig. Samen 3eckig oder rundlich, flügellos oder geflügelt.

72. Mochringin L. Blumenblätter ungetheilt uder schwach ausgerandet. Kapsel 1 fächerig, 4-6klappig. Samen nierenförmig, nit einem Anhängsel.

72. Arenaria L. Kapsel an der Spitze 6klappig, Samen nierenförnig, ohne dnhängsel; sonst wie Much. ringia.

73. Holósteum L. Biumenblätter gezähnt. Stauh. gefässe 3-5. Kapsel 1fächerig, an der Spitze 6klappig. Samell schildförmig.

73. Stellaria L. Blumenblätter tief ausgerandet oder 2theilig. Staubgefässe $3,5,8$ uder 10. Kapsel 1 fücherig, 6klappig. Samen nierenförmig.

4. Ordnung. Tetragynia. Vier w e ibige. Vier Griffel.

75. Troenchia $\mathbf{E h h}$. Kelch bblätterig. Blumen- 
๖. Ordn. Pentagynia. XI. Cl, Dodecandria.

blätter 4, ungretheilt. Stanbgefässe bei unserer Art 4. íapsel an der spitze 8klappig.

Adoxa (Vill, 4).

5. Ordnung. Pentagynia. Fü nf we ib ige. Fünf Griffel.

68. Sagina $L$. Kelch 4-5blätterig. Blumenblättel 4-5, ungetheilt. Staubgefässe 4, 5, 10. Kapsel 4-bis 5klappig. Samen nierenförmig, flügellos.

69. Spérgula 4 . Kelch 5bätterig. Blumenblätter 5 , ungetheilt. Staubgefässe 5 oder 10 . Kapsel 5klappig. Samen kreisrund, mit einem Flïgel umzugen.

76. Dralachium Fies. Kelch 5bläterig. Blumen. blätter 5, gespalten. Staub:-efässe 10. Kapsel 5klappig, Klappen gespalten.

76. Cerastium L. ielch 5blätterig. \& Binmenblätter 5, ansgerandet oder respalten. Staulgefässe 10. Kapsel an der Spitze 10klappig. Samen hörnig.

96. Oxălis L. Kelch 5theilig oder 5blätterig. Blumenblätter 5. Staubgefässe am Grunde verwachsen, die 5 änsseren kürzer. Kapsel länglich, 5kantig, an den fianten aufspringend.

173. Sedum L. Kelch 5theilig, fleischig. Blumenbätter 5. Staubgefässe mit 5 schuppenförmigen Drüsen. Fruchtknoten 5, am Grunde zusanmengewachsen.

66. Lychnis $\mathbf{L}$. Kelch krautartig, 5zähnig. Blumenbiatter 5, mit Schuppen am Srhlunde, lenagelt. Kapsel halh - 5fächerig oler 1fächerig, mit 5 wler 10 Zähnen aufspringend. Narben einwärts nit Papillen besetzt, ausserdeul hahl.

67. Agrostemma L. Kelch lederartig, 5zähnig, mit verlängerten Zähnen. Blumenblätter 5, ohne Schuppen am Schlunde, benagelt. Kapsel Ifächerig, nit 5 Zähnen aufspringend. Narben einwärts mit Papillen und überall mit Haaren besetzt.

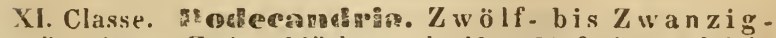
mä nnige. Zwitterblüthen mit $12-20$ freien, gleichlangen Staubgefässen.

1. Ordnung. Monogymia. Ein w e ibige.

410. Asărum L. Blüthenhïlle wherständig, bleibend, glockenförmig, 3spaltig. Staubgefässe einer kurzen, den Fruchthnoten kröıenden scheibe eingefügt. Staub- 
bentel in der Mitte der Staubfiden angewachsen. Narbe strahlig, 6theilig. Kapsel 6ficherig.

170. Portuláca L. Kelch 2spaltig, zuletzt von seinem bleibenden Grunde ringsum abspringend. Blumenblätter $4-5$, frei oder am Grunde verwachsen. Słaubgefässe 8-15. Griffel an der Spitze 3-6theilig. Kap. sel ringsum abspringend.

168. Lythrum $\mathrm{C}$. Kelch röhrig, \&-12zähnig, mit abwechselnden, aufrechten und abstehenden Zähneı. Blumenblätter 4-6, dem Énde der Kelchröhre eingefügt. Kapsel 2fächerig, vielsamig.

2. Ordnung. Digynia. Zwei we ibige. Zwei Griffel.

148. Agrimonia $\mathbf{L}$. Kelch kreiselförmig, mit 5spaltigenı, nach dem Verblïhen aufwärts zusammengentigtenı Saume, an der Röhre mit zahlreichen hakenförmigen, sich später vergrössernden Durnen besetzt. Blımenblätter 5, nebst den 6, 12 oder 15 Staubgefüssen, dem Rande eines den Kelchschlund verengenden Ringes eingefügt. Fruchtknoten 2 fächerig.

3. Ordnung. Trigynia. D reiwe i bige. Drei Griffel.

57. Reséda $\mathbf{L}$. Kelch 4-6theilig. Blumenblätter ganzrandig oder meist unregelmässigzerschlitzt. Staubgefässe 12 und mehr, in $2-3$ Reihen. Griffel $3-6$. Kapsel 3-6kantig, 1fächerig, an der Spitze offen.

5. Ordnung. Dodecagynia. $Z$ w ö If w e i b ige. Zwölf Griffel.

176. Sempervivum $\mathrm{L}$. Kelch 6-12theilig. Blumenblätter 6-12, mit dem Grunde der Staubgefässe in eine 1 blätterige Blumenkrone verwachsen. Kapseln $6-12$, vielsamig, von gezähnten oder geschlitzten Schuppen unigeben.

XII. Classe. Ieosandria. Z Z a nzigmännige. Zwitterblüthen mit 20 und mehr freien, gleichlangen, einer Scheibe (aber nicht dem Kelche, wie es gewöhnlich heisst) eingefügten Staubgefässen.

1. Ordnung. Monogynia. Einweibige. Ein Griffel.

132. Pérsica To u r nef. Kelch röhrenförnig, 5spal. tig. Blumenkrone 5bätterig. Fruchtknoten halbunterständig. Steinfrucht saftig, nicht aufspringend. Stein 
mit Furchen unregelmässig durchzogen und mit Löchern durchbohrt.

132. Prunus L. Stein glatt oder unregelmässig mit Furchen durchzogen, aber ohne Löcher; sonst wie Persica.

Crataegus monogyna (XII, 2).

2. Ordnung. Di-Pentagynia. $\mathrm{Z} w$ e i - bis [F ünfweibige. Zwei bis fünf Griffel.

a. Kelch 5theilig. Blumenblätter 5, einer Scheibe eingefügt. Fruchtknoten mit der Scheibe verwachsen.

156. Crataegus c. Scheibe krugförmig, zu einer falschen Frucht auswachsend. Griffelfuss schmäler als der Querdurchmesser der Frucht. Steinfrucht 1-5steinig. Steine 2- oder durch Fehlschlagen 1samig.

157. Méspilus L. Scheibe becherförmig, zú einer falschen Frucht answachsend. Griffelfuss fast so breit als der Querdurchmesser der Frucht; sonst wie Cra. taegus.

157. Cotoneaster I e dic. Steinfrucht mit $\mathbf{3}-\mathbf{5}$, unter sich zusammenhängenden, dem fleischigen Kelche uur anliegenden, an der Spitze freien Steinen; sonst wie Crataegus.

158. Pyrus L. Scheibe kreisel-oder eiförmig, auswachsend. Griffelfuss trichterförmig-eingedrïckt, schnal. Kernfrucht 2-5fächerig. Fächer mit einel knorpelig papierartigen Haut bekleidet, 2samig.

158. Cydonia Tournef. Kernfrucht $2-5$ fächerig; Fächer mit einer knurpelig-papierartigen Haut bekleidet, vielsamig; sonst wie Pyrus.

159. Sorbus L. Fruchtknoten 5fächerig; Fächer der 1-5samigen Beere ungetheilt. Fächerhaut sehr dünn, weich, nicht knorpelig.

Poterium (XXI, 5).

b. Blïthen vollständig; halbunterständig; Scheibe an der Spitze offen.

136. Spiraea L. Kelch 5spaltig. Blumenblätter 5. Kapseln mehre, 2-6samig.

5. Ordnung. Polygynia. Vielweibige. Sechs und mehr Griffel. 


\section{a. Ohne Hïllkelch.}

148. IRosa L. Kelch bleibend mit 5spaltigenı Saume und krugförmiger, an Schlunde zusammengezogener Röhre. Blumenblätter 5. Fruchthnoten zahlreich, ron der Kelchröhre, welche zuletzt eine falsche, meist gefärbte Beere darstellt, eingeschlossen.

138. Rubus L. Kelch bleibend, 5theilig, ziemlich flach. Fruchthnoten zahlreich, ejnem halbkugeligen oder hegelförmigen Fruchtbuden eingefügt, saftig 1 er. dend und zusammen in eine falsche, abfallende Beere verwachsen.

b. Huillchen 4-5spaltig; Zipfel kleiner als die mit ihnen abwechselnden Kelchlappen.

137. Geum L. Blätter 5. Fruchtboden trocken, walzenförmig. Früchtchen zahılreich, mit bleibendem, kahlem oder behaartem Griffel begrannt.

142. Fragaria L. Blumenblätter 5. Fuchtboden nach der Blithe vergrössert, in eine falsche, fieischigsaftige, abfallende Beere auswachsend. Früchtchen granueulus.

143. Cómarum L. Blumenblätter 5. Fruchtboden nach der Blüthe vergrössert, in eine falsche, fleischigschwammige Beere auswachsend. Früchtchen grannenlos. (Kelch gefärbt).

143. Potentilla L. Blumenblätter 5. Fruchtboden gewölbt oder kegelförmig, saftlos, nicht beerenartig. Früchtchen grannenlos.

XIII. Classe. Pielmännige. Zwitterblüthen mit 20 und mehr freien gleichlangen, dem Fruchtbuden eingefügten Staubgefüssen.

1. Ordnung. Monogynia. Einwe ibige. Ein Griffel.

A. Blumenkrone 4 blätterig.

22. Chelidonium $\mathbf{c}$. Kelch 2blätterig, abfallend. Kapsel schotenförnig, 2 klappig, vom Grunde aus aufspringend. Samen an 2 zwiscisen den Klappen liegen. den Samenträgern angeheftet.

21. Glancium Tournef. Kelch 2 blätterig, abfallend. Kapsel verlängert, schotenförmig, 2 klappig, von der Spitze aus aufspringend. Samen in die zwischen den Klappen liegende, schwanmige, vollständige Scheidewand eingesenkt. 
19. Papaver $\mathbf{L}$. Kelch 2blätterig, abfallend. Narbe strahlenförmig, Strahlen 4-20. Kapsel durch unvoll. stïndige Scheidewände 4-20fächerig, unter der Narbe mit Löchern aufspringend.

18. Actaea L. Kelch 4blätterig, abfallend. Staubbentel an die verbreiterte spitze der staubfäden angewachsen. Frucht beerenartig, Ifächerig.

B. Blumenkrons 5blätterig.

8j. Tilia L. Kelchblätter 5, abfallend, in der Knospeulage hlappenförmig. Fruchtknuten 5fächerig, Fächer zeiig. Frucht uussförmig, durch Fehlschlagen 1fächerig, 1 - 2samig.

51. Helianthemum Tournef. Kelch 5blätterig, die 2 ïussem Blätter kleiner oder fehlend, die 3 inneres in der Knospenlage zusammengerollt. Kapsel Ifächerig oder unvollkonimen 3fücherig, 3klappig.

C. Blumenkrone vielblïtterig.

19. Nymphaea $\mathbb{L}$. Kelch 4blätterig. Blumenblätter whue Hunighehälter, die äussern länger als die Kelchblïter. Narbe vielstrahlig. Samen mit einem Samenmantel.

19. Nuphar $\mathbf{s}$ m. Kelch 5blätterig. Blumenblätter auf dem Rücken mit Honigbehälter, kürzer als die Kelchblätter. Narbe ganzrandig oder vielstrahlig.

3. Ordnung. Trigynia. Dreiweibige. Drei Griffel.

16. Delphinium L. Kelch 5blätterig, unregelmässig, blumenkronartig, das obere Kelchblatt gespornt. Blumenkrone 4blätterig uder verwachsen 1 blätterig, die 2 wheren Blätter mit einem rom Kelchsporne eingeschlossenen, sporuartigen Anhängsel. Kapseln meist 3, selten 1 oder 5, vielsamig.

17. Aconitum C. Kelch 5blätteriğ, unregelmässig, blumenkronartig, das obere lielchblatt helmförmig ge"ölbt. Blumenblätter 5, die 2 uberen kaputzenförmig, lang benagelt, rom Helme eingeschlossen, die 3 anderen hlein, linien- oller schuppenförmig, oft fehlend. Kapselı 3-5, vielsamig.

5. Ordnung. Pentagynia. Fü nfweibige. Fünf Griffel.

16. Aquilegia $L$. Kelch 5blätterig, regelmässig, blumenhrunartig. Blumenblätter 5, trichterförmig, abwärts in einen Spurn verlängert. Kapseln 5, getrennt. 
15. Nigella 4 . Kelch 5blätterig, regelmässig, blu. menkronartig. Blumenblätter klein, undeutlich-2lippig, benagelt, am Grunde des Nagels mit einer beschuppten Honiggrube. Kapseln 5-10, verwachsen.

Hierher Aconitum variegatum (XIII, 3).

7. Ordnung. Polygynia. Vielwe i bige. Viele Griffel. Blüthen regelnüssig. Kapsel einwärts aufspringend.

A. Samen zahlreich.

15. Trollius L. Kelch 5-15blätterig, blumenkronartig. Blumenblätter klein, benagelt, linealisch, am Grunde mit einer unbedeckten Houiggrube. Kapseln zahlreich, lederartig, vielsamig.

15. Caltha L. Kelch 5blüthig, blumenkronartig. Blumenkrone fehlend. Kapseln 5-10, häutig, vielsamig.

B. Samen 1. Früchtchen nussartig, nicht aufspringend.

a. Kelch in der Knospenlage dachziegelig. Blumenkrone $\mathbf{5}$ - bis mehrblätterig.

7. Adónis $\mathbf{C}$. Kelch 5blätterig. Blumenblätter flach oder ausgehöhlt, ohne Nagel und Honiggrube. Früchtchen zahlreich, einem kugelig-eiförmigen Fruchtboden eingefügt.

9. Ranúnculus $\mathbf{L}$. Kelch $3-5$ blätterig. Blumenkrone 5-bıs mehrblätterig. Nagel der Blumenblätter kürzer als die Platte oder sehr kurz, nit einer nackten oder meist beschuppten Honiggrube. Fruchtboden halb. lingelig. Fruchtknoten zahlreich, 1fächerig. Früchtchen nussartig, 1samig, nicht aufspringend.

9. Iyosúrus L. Kelchblätter 5, an Grunde mit einem Anhängsel. Blumenkrone 5bätterig; Nagel fadenförmig, länger als die Platte, mit einer etwas röhren. förmigen Honiggrube. Fruchtboden sehr verlängert, walzenförmig. Staubgefässe nicht zahlreich, meist 5. Fruchtknoten zahlreich, 1fächerig.

b. Kelch in der Knospenlage dachziegelig, blumenhronartig. Blumenkrune fehlend.

5. nemóne $\mathbf{L}$. Kelch 5 - bis mehrblätterig. Blumenkrone fehlend. Friichtchen zahlreich, geschnäbelt oder geschweift, einen verdickten, halbkugeligen oder kegeliörmigen Fruchtboden eingefügt. 
1. Ordn. Gymnospermia. XIV. Cl. Didynamia.

2. Thalictrum L. Kelch 4-5blätterig, fast blumenblattartig. Blumenkrone fehlend. Früchtchen mehre, ungeschweift, kahl, einem kleinen, scheibenförmigen Fruchtbuden eingefügt.

c. Kelch in der Knospenlage klappenartig, oder an Rande einwärts-gefaltet, blumenblattartig.

2. Clématis $\mathbf{L}$. Kelch 4-5blätterig. Blumenkrone fehlend. Frïchtchen zahlreich, federartig-geschweift, einem halbkugreligen Fruchtboden eingefügt.

XIV. Classe. Didymamia. Zwe in ä chtige. Zwitterblüthen mit 4 fieien Staubgefüssen, von welchen 2 Staubfäden länger sind.

1. Ordnung. Cymnospermia. Nacktsamige.

Nüsse oder Steinfrüchte 4, im Grunde des Kelches. Griffel 1, aus der Mitte der 4 Fruchtknuten hervortretend.

1. Staubbeutelfächer mit einer Klappe aufspringend.

363. Galeópsis L. Kelch glortienförmig, 5zähnig. Blumenkrone nit hervorragender Röhre, Oberlippe gewölbt, Unterlippe an Grunde beiderseits mit einem spizzen huhlen 'Zahne, der mittlere 'Zipfel stumpf oder ausgerandet. Staubgefässe unter der Oberlippe gleichlaufend.

11. Staubbeutel mit einer duppelten oder einfachen, beiden Fächern gemeinschaftlichen Iängsritze aufspringend. Fächer gleichlaufend oder auseinan. derfahrend.

A. Blumenröhre an der Einfügung der Staubgefässe mit einem unterbrochenen Haarringe besetzt. Griffel nebst den Staubgefässen eingeschlossen.

369. Irarrubium $\mathbf{L}$. Kelch steif, mit 5-10 gleichen, zuletzt abstehenden 'Zähnen, am schlunde dicht behaart. Blumenröhre etwas kürzer als der Kelch, Oberlippe aufrecht, gespalten, Unterlippe 3spaltig. Nüsse an der flachen, З̉eckigen Spitze abgestutzt.

B. Blumenröhre unterhalb der Einfügung der Staubgefässe mit einem ununterbrochenen Haarringe besetżt. Griffel aus dem Schiunde hervortretend.

a. Staubgefässe genähert, unter der Oberlippe gleichlaufend. Kelch 2lippig.

373. Prunella L. Kelchł̣ röhrenförmig ·glockig, 2lip.

Garcke, Flora.

4 A. 
pig, Oberlippe flach, 3zähnig, zur Fruchtzeit zusanımengedrückt-geschlussen, Unterlippe schmäler, 2zähnig, schlund nackt. Oberlippe der Blumenkrone ausgehöhlt, 'Zipfel der Unterlippe stımpf. Staubfäden an der Spitze gezähnt.

b. Staubgefässe genähert, gleichlaufend. Kelch 5zähnig.

374. Ájuga L. Kelch eiförmig. Schlund nackt. Oberlippe der Blumenkrone flach, sehr kurz, 2lappig, untere 3spaltig, viel grösser.

361. Lamium L. Kelch röhrig-gluckig. Schlund nachit. Oberlippe der Blunienkirone gewölbt, untere nit sehr kleinen, zahnförmigen oder fehlenden Seitenzipfeln, Mittellappen verkehrt-herzförmig.

363. Galeóbdolon H uds. Zipfel der Unterlippe alle spitz; sonst wie Lamium.

365. Stachys L. Kelch röhrenförmig-glockig. Oherlippe der Blumenhrone etwas ausgehöhlt, Zipfel der Unterlippe stumpf, der mittlere am grössten. Staubgefässe nach dem Verblühen zusammengedreht, auswärts gebo. gen. Nïsse uberwärts - abgerundet.

370. Ballóta $\mathbf{c}$. Staubgefässe nach dem Verblühen gerade; sonst wie Stachys.

371. Leonúrus $\mathbf{L}$. Kelch glockenförmig, mit 3 aufrechten und 2 abwärts geschlagenen Zähnen. Schlund nackt. Oberlippe der Blumenkrone etwas ausgehöhlt, Zipfel der Unterlippe stumpf. Nüsse 3eckig, an der Spitze abgestutzt.

c. Blunenröhre olıne Haarring.

a. Staubgefässe genähert, gleichlaufend. Oberlippe der Blumenkrone fehlend, oder eigentlich sehr kurz, 2theilig; die Zipfel auf den Rand der Unterlippe vorgerückt.

376. Teucrium L. Kelch röhrig oder glockenförmig, 5zähnig oder 2lippig. Schlund meist behaart. Unterlippe undeutlich 5lappig, der nittlere Lappen sehr gross; Oberlippe sehr kurz.

b. Staubgefässe genähert, unter der flachen, ausgerandeten Oberlippe gleichlaufend.

360. Népeta $\mathrm{L}$. Kelch röhrenförmig, ungleich 5zäh- 
nig. Schlund nackt. Unterlippe der Blumenkrone tief ausgehöhlt, der mittiere Lappen sehr gross. Staubgefïsse nach dem Verblühen seitwärts gekrünmt.

360. Glechóma L. Kelch röhrenförmig, 5zähnig. Schlund nackt. Unterlippe der Blumenkrone flach, der mittlere Lappen am grössten. Staubbeutel in ein Kreuz gestellt.

361. Melittis L. Kelch weit-glockenförmig, ungleich 2lippig, 3-5́lappig. . Schlund nackt. Unterlippe der Blumenkrune flach, der mittlere Lappen am grössten. Staubbeutel in ein Kreuz gestellt.

c. Staubgefässe genähert, unter der ausgehöhlten oder gewölbten Oberlippe gleichlaufend.

372. Scutellária L. Kelch kurz glockenförmig, 2lippig, Lippen ganzrandig, Oberlippe dectelförnig, die Unterlippe späterhin rerschliessend, bei der Fruchtreife abspringend, hinten mit einer ausgehöhlten schuppe. Oherlippe der Blumenkrone 3spaltig, Unterlippe ungetheilt. Staubgefässe an der Spitze vorwärts gekrünmt.

361. Dracocéphalum $\mathbf{L}$. Kelch röhrenförmig, 2lippig, Lippen genahert. Oberlippe der Blumenkrone gewölbt; Unterlippe 3lappig, der mittlere Lappen am grössten, ausgerandet. Staubgefässe an der Spitze vorwärts gekrümmt.

368. Betónica L. Kelch gleichmässig ózähnig. Schlund nackt oder blos schwach behaart. Unterlippe des Blumenkroue 3lappig, der mittlere Lappen an grössten, stumpf. Nüsse oben stumpf, etwas abgerundet.

371. Chaitúrus Host. Nüsse 3 kantig, an der Spitze abgestutzt, weichhaarig, sonst wie Betonica.

d. Staubแefässe von einander entfernt, oberwärts auseinandertretend, an sich gerade.

353. Fientha L. Kelch röhrenförmig, 5zähnig, Schlund nackt. Blumenkrune trichterförmig, 4lappig; Zipfel aufrecht-abstehend, der ober'e ungetheilt oder ausgerandet. Staubbeutelfächer gleichlaufend.

360. Hyssópus $L$. Kelch röhrenförmig, spitz 5zähnig. Schlund nackt. Oberlippe der Blumenkrone flach, tief ausgerandet, Unterlippe 3lappig, der mittlere Lappen verkehrt-herzförmig. Staubbentelfächer auseinanlerfahrend. 
111. Staubbeutelfächer an ein 3echiges Nittelband $z u$ beiden Seiten angewachsen.

358. Thymus L. Kelch vollkommen 2lippig, Oberlippe kurz 3zähnig, Unterlippe lang 2zähnig. Oberlippe der Blumenkrone gerade, ansgerandet, Unterlippe 3lap. pig. Staubgefässe von einander entfesut, gerade, uberwärts auseinandertretend.

359. Calamintha $\boldsymbol{K}$ oench. Kelch vullkummeu 2lippig, Oberlippe 3zähnig, Unterlippe 2zähnig. Oberlippe der Blumenkrone ;erade, ausgerandet, Unterlippe 3lappig. Staubgefässe von einander entfernt, oberwärts bogenförmig - zusammenneigend.

359. Clinopódium C. Blüthenquirle am Grunde mit Piner aus borstenförnigen Deckblättern bestehendell Hülle gestutzt. Das Uebrige wie bei Calamintha.

358. Saturéja $\mathbf{L}$. Kelch gleichmässig 5 zähnig, 10streifig. Oberlippe der Blumenkrone gerade, ausgerandet, Unterlippe 3lappig. Staubgefässe von einander entfernt, oberwärts bogenförmig-zusammenneigend.

357. Origanum L. Kelch 5zähnig vder schief-gespalten, 10streifig. Oberlippe der Blumenkrone yerade, ausgerandet, Unterlippe 3lappig. Staubgefässe ron einander entfernt, gerade, oberwärts auseinandertretend.

2. Ordnung. Ingiospermia. Bedecktsamige. Samelı in einer Kapsel.

1. Staubbeutelfächer an Grunde mit einem Dörnchen versehen.

A. Fruchitknoten Afächerig, vieleiig. Samenträger wandständig.

348. Lathraea $L$. Kelch gluckenförmig, 4spaltig. Blumentirone 2lippig, nach dem Verblühen sich ganz ablösend, vorne am Grunde des Fruchiknutens eine grössere freie Drüse.

344. Orobánche L. Kelch 2 blätterï, 4 spaltig oder verwachsenblätterig, 5spaltig. Blumenhrone rachenförnig, nach dem Verblühen bis auf den bleibenden Grund ringsumschnitten abfallend.

B. Fruchtknoten 2 fächerig, 4 - bis vieleiig. Frucht 1 - bis vielsanig.

a. Kelch 5zühnigg.

350. Pedicularis L. Kelch röhrig oder aufgeblasen. 
Blumenkrone rachenförmig. Oberlippe der Blumenkrone helmförmig, zusammengedrïckt; Unterlippe 3lappig. Kapsel zusammengedrückt, schief geschnäbelt.

b. Kelch \&zähnig.

351. Nectorólophus Ha 11. Kielch etwas anfgeblasen und zusammengedrïckt. Oberlippe der Blumenkrone helmförmig, zusammengedrückt, lünger als die untere. Samen glatt, mit einem kreisrunden Flügel um. zogen oder flügellos.

332. Euphrásia L. Kelch röhren-oder glockenförmig. Oberlippe der Blumenkrune helmförmig, etwas kiirzer als die untere. Kapsel stumpf, ganz uder ausyerandet. Samen gerippt, Rippen fliigellos.

349. Melampýrum C. Kelch röhrenförmig. Oberlippe der Blumenkrone stumpf-gekielt, am Rande zuriickgeschlagen. Samen glatt, flïgellos.

I1. Staubbeutelfächer an Grunde ohne Spitzchen.

1. Fruchtknoten Ifächerig, Samenträger frei, vieleiig.

344. Limosella $\mathbf{~ L . ~ K e ́ l c h ~ 5 s p a l t i g , ~ s u ~ l a n g ~ a l s ~ d i e ~}$ Blumenröhre. Blumenkrone trichterförmig, 5spaltign, fast regelmässig.

B. Fuchtknoten 2 fächerig.

331. Scrophularia L. Kelch 5spaltig. Blumentrone bauchig oder fast kugelig, 2lippig, mit schmalem, 5lappigen Saume, mntere Lappen zurückgebogen. Staubbeutel quer-aufliegend. Oft findet sich noch ein fünftes unfruchtbares Staubgefäss.

332. Antirrhinum $\mathbf{L}$. Kelch כtheilig, schief. Blumenkrone 2lippig, am Grunde sackartig, ungespornt. Oberlippe 2lappig; Unterlippe 3lappig, mit einen gewölbten, den behaarten Schlund verschliessenden Gau. men. Kapsel an der Spitze mit Löchern aufspringend.

333. Linaria Tournef. Kelch 5theilig. Blumenkrone 2lippig, anı Grunde gespornt. Oberlippe 2spaltig; Unterlippe 3lappig, mit höckerigem, den Schlund nicht ganz verschliessendem Gaumen. Kapsel mit Klappen aufspringend.

332. Digitalis L. Kelch 5theilig. Blumenkrone bauchig, röhrig-glockenförmig; Saum schief, 4spaltig; Oberlippe ausgerandet, Unterlippe 3lappig.

Gratiola (II, 1). 
C. Fruchtknoten 4fächerig. Fächer 1eiig.

378. Verbéna L. Kelch 5zähnig, ein Zahn kürzer. Blumenkrone tellerförmig, mit 5lappigem, fast 2lippigem Saume. Frucht in 4 Nüsse zerfallend. Staubgefässe $4 \mathrm{zweim}$ üchtige, von denen 2 oft unfruchtbar sind. Aehren wechselbliithig.

$X V$. Classe. Tetradynamin. Viermächtige. Z/witterblïthen mit 6 freien Staubgefässen, von denen 4 längere Staubfäden haben.

1. Ordnung. Siliculosa. Schö tchenfrü chtige. längendurchmesser der Frucht dem Querdurchmesser gleich oder nicht viel grösser.

I. Schötchen kugelförnig, hart, nicht aufspringend.

A. Schötchen aus einem einzigen Gelenke bestehend.

49. Neslen Desv. Schötchen kugelförmig, mit bleibendem Griffel, Ifächerig, 1samig. Keimblätter flach.

B. Schötchen 2gliederig, die Glieder bei der Reife sich quer trennend.

49. Rapistrum $\mathbf{B}$ o e rh. Das untere Glied stielför. mig, 1- bis mehrsamig, das obere eiförmig oler rundlich, 1samig, in den Griffel zugespitzt. Nabelstrang sehr kurz. Keimblätter gefaltet.

II. Schötchen von der Seite zusammengedrückt, mit hervorragender oder geflügelter Mittelrippe der Klappen.

1. Schötchen nicht aufspringend oder zuletzt in 2, dip Samen jedoch nicht austreuende Klappen sich trennend.

49. Isătis L. Schötchen länglich, hängend, wegen der durchbohrten Scheidewand Ifächerig, 1samig. Keimblätter krumm, ein wenig rinnenförmig.

45. Biscutella L. Schötchen flach, am Grunde und an der Spitze ausgerandet, brillenförnig, 2fächerig, Fücher 1sanig, Klappen kreisrund, nach dem Abspringen den Samen nicht ausstreuend. Keimblätter an. einanderliegend.

48. Senebiéra Pers. Schötchen an Grunde und an der Spitze ansgerandet, fast $2 \mathrm{knotig}$, ohne geflïgel- 
ten Rand, 2fächerig, Fächer 1sanig. Keimblätter aufeinanderliegend, in der Mitte zurückgeknickt.

B. Schötchen aufspringend und die Samen ausstreuend.

44. Teesdálea R. H r. Staubgefässe an Grunde mit einen blattartigen Anhängsel. Schötchen rundlich. Klappen kahnförmig, an der Mittelrippe geflügelt. Fächer 2samig. Keimblätter aneinanderliegend.

46. Lepidium L. Blumenblätter gleichgross. Staub. gefässe ohne Anhängsel. Schötchen rundlich oder eiförnig. Kilappen kahnförmig, an der Spitze meist etwas geflügelt. Fächer 1samig. Keimblätter anfeinanderliegend.

45. Ibéris L. Aeussere Blumenblätter yrösser als die inneren. Staubgefässe ohne Anlıängsel. Fächel 1samig; sonst wie T'eesdalea.

43. Thlaspi $\mathbf{C}$. Blumenblätter gleichgruss. Staubgefässe ohne Anhängsel. Schötchen an der Spitze ausgerandet. Fächer 2- bis mehrsamig. Klappen besonders an der Spitze geflügelt; Keiniblätter aneinander. liegend.

47. Hutchinsia $\mathbf{R}$. B r. Blumenblätter gleichgross. Staubgefässe whne Anhäıgsel. Sichötchen länglich oder rundlich. Klappen flïgellos. Fächer 2samig. Keinblätter bei unserer Art schräg-seitenwurzelig.

47. Capsella $\mathbf{m}$ d. Blumenblätter gleichgross. Staubgefüsse ohne Anhängsel. Schötchen verkehrt-herzkeilförnig, an der Spitze ganz oder schwach ausgerandet. Klappen flïgellus. Fächer vielsanig.

111. Schötchen fast kugelig, mit einer Scheidewand vun der Breite des schötchens selbst uder das Schötchen von Rïcken her mehr oder weniger zusammengedrückt, aufspringend.

40. Alýsum L. Staubgefässe mit einem platten Anhängsel oder an Grunde gezähnt. Schötchen kreisrundlich oder eiförnig. Fächer 1-4sanig. lieimblätter alleinanderliegend.

41. Farsetia R. B r. Fächer der Schötchen 6 - bis mehrsamig; sonst wie Alyssun.

42. Camelina Crantz. Staubgefüsse ohne Anhängsel. Schötchen birnförmig, Klappen an der Spitze nit einem den Griffel umfassenden Fortsatze. Griffel bei 
der Fruchtreife sich vou der Scheidewand ablösend und mit einem der Klappen abspringend. lieimblätter aneimanderliegend.

41. Iraba C. Staubgrefässe ohne Anhängsel. Schötchen länglich oder elliptisch, zusamméngedriickt, mit flachen oder etwas gewölhten Klappen. Fächer vielsamig. Nabelstränge frei. Keimblätter aneinanderliegend.

42. Cochlearia L. Staubrefässe ohne Anhängsel. Schötchen rundlich oder elliptisch, durch die sehr gewölbten Klappen gedunsen oder fast kugelig. Griflel auf der Scheidew and bleibend. Keimblätter aneinander. liegend.

Hierher Arten von Nasturtium $(\mathrm{XV}, 2)$.

2. Ordnung. Siliquosa. Schotenfrïchtige. I aingendurchmesser der Frucht viel grösser als der Querdurchmesser.

A. Schote nicht aufspringend.

50. Kiphanus L. Schote walzen - oder perlschnurförmig, nicht aufspringend, aber zuweilen an der Stelle der Einschüirung zerbrechend, undeutlich 2fächerig (da die dïnne Scheidewand später vun den Samen an die Wand angedrïclit wird). Keimblätter rinnenförnig. gefaltet.

B. Schote in 2 Klappen anfspringend.

a. Klappen nerrenlos oder nur am Grunde mit einem schwachen Nerren versehen.

32. Dentaria L. Schote linealisch, mit flachen Klappen. Samen in jeden Fache 1reihig. Keimblätter am Rande beiderscits zusammengefaltet.

30. Caramine c. Schote linealisch, mit flachen Klappen. Samen in jedem Fache 1reihig. Keimblätter flach.

25. Nasturtium Ix. H r. Schote linealisch, elliptisch oder kughelig, mit gewölbten oder flachen Klappen. Samen in jerlem Fache 2reihig oder unregelmässig gereihet. Keimblätter aneinanderliegend.

b. Klappen $1-3-5$ mervig. Das Würzelchen auf der Seite der Keimblïtter.

28. Turritis L. Schote linealisch, mit gewölbten, von einem starken Längsnerven durchzogenen Klappen. 
Samen in jedem Fache 2reihig. Keimblätter aneinanderliegend.

25. Cheiranthus DC. Schote linealisch, 4 kantig, mit einem auf der Mitte der Klappen vurragenden Nerven. Samen in jedem Fache 1 reihig. Narbe 2lappig, mit zurïckgekrummten Lappen. Keimblätter aneinanderliegend.

27. Barbarnea IR. H r. Schote fast stielrund oder zusammengedrïckt-4kantig, mit einem auf der Mitte der Klappen vorragenden Nerven. Samen in jedem Fache 1reihig. Narbe stumpf, zuweilen etwas ansgerandet. Keimblätter aneinanderliegend.

28. Árabis c. Schote linealisch, mit flachen oder schwach-gewölbten Klappen. Mittelnerv deutlich oder verschwindend, seitemuerven mehre, deutlich. Samen in jedem Fache 1reilig. Narbeu stumpf, zuweilen schwach ausgerandet. Keimblätter aneinanderliegend.

c. Klappen 1-3-5nervig. Das Würzclehen auf den Räicken der flachen Keimblätter.

34. Erýmimum L. Schote linealisch, 4kantig, mit einem deutlichen Mittelnerv. Samen in jeden Fache 1reihig. Keimblätter aufeinanderliegend.

32. Sisýmbrium L. Schote linealisch. Klappen ge"ölbt, 3nervig. Samen in jeden Fache Treihig. Keimhlätter aufeinanderliegend.

d. Klappen 1-3-5nervig. Das Wïrzelchen auf dem Rïchen der tief-rimnigen oder rinnig - gefalteten Keimblätter.

40. Diplotaxis I) C. Schote linealisch oder lanzettlich-linienförmig. Klappen gewölbt, Inervig. Samen in jedem Fache 2reihig, eiförmig oder länglieh, etwas zusanımengedrïckt.

40. Erucastrum Schimp. u. Spenn. Schote linealisch. Klappen gewölbt, Lnervig. Samen in jedem 'ache 1reihig, länglich oder eiförmig, etwas zusammengedrückt.

36. Brássica L. Schote linealisch oder länglich. hlaupen gewölbt, 1nervig. Samen in jedem Fache 2reihig, kugelig.

39. Sinapis L. Schote linealisch oder länglich, mit einem verschmälerten Schnabel. Klappen gewölbt, mit 
$3-5$ starken Nerren. Samen in jedem Fache 1reihig, liugelig.

XV1. Classe. Monadelphia. Ei i b r ü de r i ge. Zwit. terbliithen, deren Staubfäden in ein Bündel verwachsen sind.

1. Ordnung. Pentandria. Fiü $\mathrm{f} m$ ännige. Fünf verwachsene Staubfäden.

Erodium (XVI, 3), Bryonia, Cucumis und Cucurtita (XXI, 9), Linum (V, 5), Radiola (IV, 4), Lysimachia $(\mathrm{V}, 1)$.

2. Ordnung. Decandria. 'Zehnmännige. Zehn velwachsene Staubfäden.

90. Geranium L. Kelch und Blumenkrone 5bätterig. Staubgefässe 10 , alle fruchtbar; 5 Hunigdiüsen an Grunde der 5 grösseren Staubfäden. Griffel bei der Keife sich bogenförmig aufwärts ablösend.

95. Erodium L'Herit. Kelch und Blumenkrone 5blätterig. Staubgefässe 10, die des äusseren Kreises breiter und ohne Staubbentel, die des inneren frucht- bar, an Grunde mit Honigdrüsen. Griffel bei der Reife schraubenförmig zusammengedreht.

Oxalis $(X, 5)$.

5. Ordnung. Polyandria. Vielmännige. Viele velwachsene Staubfäden.

84. Lavatéra $\mathrm{c}$. Kelch doppelt, der äussere 3 6lappig, der innere 5spaltig. Früchtchen nierenförmig, zahlreich, in einen Kreis gestellt, einsamig, sich einzeln absondernd.

84. Althaea C. Kelch doppelt, der äussere 6-9spal. tig, der innere 5spaltig. Früchtchen wie bei Lavatera.

81. Malva L. Kelch doppelt, der äussere 3 blätterig, der innere 5spaltig. Früchtchen wie bei Lavatera.

Zur Monadelphia gehören ferner: Pulygala (XVII, 3), Sarothamnus, Genista, Cytisus, Onunis, Anthyllis und Ulex (XVII, 4).

XVII. Classe. Eiadelphia. Zw e i brii d e r i g e. Zwitterblïthen, deren Staubfäden in 2 Bündel verwach. sen sind. 
2. Ordnung. Hexandria. Sechsmännige. Sechs Staubgefässe.

24. Fumaria L. Kelch 2 blätterig. Blumenblätter 4 , das obere gespornt. Schötchen rundlich, nussartig, nicht aufspringend, Isamig. Samen ohne Anhängsel.

22. Corýdalis DC. Kelch 2 blätterig wder fehlend. Blumenblätter 4 , das obere gespornt. Staubgefässe in 2 Bündel verwachsen. Schute 2 klappig, zusammengedrückt, vielsamig. Samen mit einem duhängsel.

3. Ordnung. Octandria. A chtmän॥ige. Acht Staub. gefässe.

59. Polýgala c. Kelchblätter 5, bleibend, die 2 inneren sehr gross, flügelförmig, blumenblattartig. Blumenblätter $3-5$, mit den Staubfäden verwachsen. Staubgefässe in 1 oder 2 Bundel verwachsen. Kapsel zusam. mengedrückt. Samıen an Grunde mit einem gezähnten Mantel umgeben.

4. Ordnung. Decandria. Zehn männige. Zehn Staub. gefässe (Schmetterlingsbliithler).

1. Staubgefässe einbrüderig.

A. Flügel der Blume von Grunde aufwärts runzelig - grefaltet.

100. Ulex L. Kelch bis auf den Grund 2theilig oder 2lippig, mit 2 Deckblättern. Blumenkrone kaum länger als der Kelch. Schiffchen stumpf. Hiilse angeschwollen, wenigsanig, nur wenig aus dem. Kelche hervorragend.

100. Sarothámnus $\mathbf{W}$ im m. Kelch 2lippig, am Rande trockenhäutig; Oberlippe 2-, Unterlippe 3zähnig. Schiffchen stumpf. Griffel einwärts zusanımenuerollt, oberwärts verbreitert, an der innelen Seite flach. Narbe klein, kupfförmig.

101. Cenista L. Kelch 2lippig. Schitfchen stumpf. Griffel pfriemlich, aufsteigend. Narbe schief, einwärts abschiissig.

111. Cýtisus L. Kelch 2lippig. Schiffchen stumpf. Griffel ptriemlich, aufsteigend. Narbe auswärts ab. schüssigg.

B. Flügel der Blume nicht gefaltet.

102. Onónis L. Kelch 5spaltig, bleibend, zur Frucht- 
zeit offen. Schiffchen pfriemlich-geschnäbelt. Hülse aufgeblasen.

1102. Anthyllis L. Kelch 5zähnig, zur Fruchtzeit geschlossen, banchig, bleibend, trockenhäutig, die kıgelförmige Hülse einschliessend. Schiffchen stumpf oder hurz zugespitzt.

II. Staubgefässe 2brïderig. Hülse nicht in Glieder zerfallend. Griffel kahl.

A. Schiffchen geschuäbeit.

114. Lotus L. Kelch 5spaltig oder 5zähnig. Flügel oben zusammenueigend. Girffel allmählig verschmälert. Hiilse stielrund oder zusammengedrückt, ungeflïgelt, mit zusanmengedrehten Klappen aufspringend.

115. Tetragonólobus scop. Kelch 5spaltig oder 5zähnig. Flügel oben zusammenneigend. Griffel oberwärts verdickt. Hülse mit 4 gefliigelten Kanten aufspringend.

B. Schiffchen ungeschnäbelt, einfach-spirz oder stumpf.

a. Staubfadenbündel mit der Blumenkrone verwachsen.

107. Trifolium L. Kelch 5spaltig oder 5zähnig. Blumenkrone verwelkend, bleibend. Schiffchen stumpf. Staubfäden oberwärts etwas verbreitert. Hülse eiförmig, seltener länglich, wenigsamig, rom Kelche oder der Blumenkrone bedeckt, kaum aufspringend.

b. Staubfadenbündel mit der Blumenkrone nicht verwachsen.

1. Hülse durch eine vollständige oder unvollständige längenscheidew and 2 fächerig oder halh - 2fächerig.

117. Astrágalus L. Kielch 5zähnig. Schiffchen stumpf, ohne Stachelspitze. Hülse an der unteren Naht eingedrückt.

116. oxy'tropis DC. Kelch 5zähnig. Schiffchen unterhalb des stumpfen Endes in eine gerade, grannenartige Spitze auslaufend. Hülse an der oberen Naht eingedrückt.

2. Hiilse 1fächerig.

105. Melilótus Tournef. Kelch 5zähnig. Schiff- 
chen stumpf. Fruchtknoten gerade. Hülse kurz, fast kugelig oder läuglich, 1-3samig.

105. Trigonélla L. Kelch 5spaltig oder 5zähnig. Schiffchen stumpf. Fruchtknoten gerade. Hülse linealisch, zusammengedrückt, 6 - bis vielsamig.

103. Medicágo $L$. Kelch 5spaltig oder 5zähnig. Schiffchen stumpf. Fruchtknoten auf wärts gekrümmt, der Fahne anliegend. Hülse sichel- oder schneckenförmig gewunden, 1 - bis vielsamig.

120. Onóbrychis Tournef. Kelch 5spaltig. Schiffchen schief abgeschnitten, länger als die Flügel. Hülse knochenhart, rerkehrt-eiförmig, auf der unteren Naht flügelartig - bekielt, glatt oder kammförmig - gezähnt, grubig - netzartig, 1samig.

III. Staubgefässe 2brüderig. Griffel behaart.

A. Griffel an der oberen (imneren) Seite behaart.

124. Errum L. Kelch 5spaltig, Lappen ungleich, lang, zugespitzt. Griffel fadenförmig, oberwärts rinısunı gleichmässig behaart. Hülse zusammengedrückt, 2- bis vielsamig. Samen kugelig oder eiförnig.

128. Láthyrus L. Kelch 5zähnig oder 5spaltig, Lappen meist ungleich. Griffel oberwärts flach, von gleicher Breite oder nach oben verbreitert, anf der inneren Seite in einer Längslinie von der Narbe abwärts behaart, auf der äusseren' Seite kahl. Hülse zusammengedriickt, 2- bis vielsamig. Blätter mit und ohne Wickelranken. (Hierher gehört auch Orobus L.)

127. Pisum L. Kelch 5spaltig. Gıiffel 3 kantig und von der Seite her zusammengedrüclit, am Grunde oberseits gekielt, unterseits rinniy, an der Spitze bärtig. Hülse Ifächerig, vielsamig.

B. Griffel rom Grunde an gewimpert.

116. Colútea L. Kelch 5zähnig, die oberen Zähne küızer. rahne ausgebreitet, 2schwielig. Giriffel an der Spitze hakenförmig, in der Biegung die Narbe tragend. Hülse aufgeblasen, in einen Stiel ver'schmälert, zuletzt trockenhäutig.

C. Griffel überall weichhaarig und unterhalb der Spitze auf der äusseren Seite bärtig.

121. Vicia L. Kelch 5zähnig oder 5spaltig, die oberen Zühne kürzer. Griffel fadenförmig, an der Spitze 
auf der äusseren Seite bärtig, übrigens kahl oder ringsum mit kürzeren Haaren besetzt. Hülse zusammengedrückt, 2 - his vielsamig.

132. Phaséolus L. Kelch 2lippig, Oberlippe 2-, Unterlippe 3zähnig. Griffel, Staubgefässe und sichiftchen schraubenförmig-gedreht. Hülse durch zellige Hervorragungen der Klappen fast querfächerig.

IV. Hülse quer in Glieder zerfallend.

119. Ornithopus $\mathrm{C}$. Kielch verlängert-röhrenförmig, 5zähnig, die bejden oberen 'Zähne am Grunde verwach. sen. S'chiflchen abgerundet - stumpf, ungeschübelt. Staubgefässe nach oben verbreitert. Gliederhülse verlängert, meist sichelförmig-gekrünmt, zusammengedrückt, an der Gelenken beiderseits zusammengezugen. Samen rundlich.

120. Hippocrépis L. Kelch kurz-gluckenförmig, 5zähnig, fast 2lippig. Schiftchen zugespitzt-geschnä. belt. Gliederhülse verlängert, zusammengedriickt, an der oberen Naht buchtig-ausgeschnitten und gelappt. Samen gekrümut.

118. Coronilla c. Kelch kurz-glockenförmig, 5zähnig, fast 2lippig. Schiffchen zugespitzt - geschnäbelt. Gliederhülse verlängert, gerade oder gekrümmt, walzenförmig oder 4 kantig, oft geflïgelt, an den Gliedern zusammengezogen. Samen fast walzenförmig.

XVIII. Classe. Polyadelplnia. Vielbriiderige. Zwitterblüthel, deren Staubfäden in 3 vder nehre Bün. del verwachsen sind.

1. Ordnung. Polyandria. Vielmännige. Viele Staubgefässe in 3, 5 vder 6 Bündeln.

Sả. Hypericum L. Kelch 5blätterig oder 5theilig. Blumenblätter 5. Griffel 3. Kapsel 3fächerig. (Blumen gelb, an Rande oft schwarz punktirt.)

XIX. Classe. Syngemesin. Staubbeutelverwach. sung (daher von Richard Synanthereae genannt).

1. Ordnung. Polygamia aequalis. Gleichfö rmige Vielehe. Alle Blïthen sind zwitterig.

I. Zungenblüthige. Blüthen alle zungenförmig.

A. Federkelch (pappus) aus gefiederten Strahlen gebildet (plumosus). 
a. Blüthenboden spreublätterig.

277. Hypochoeris $\mathbf{L}$. Hauptkelch dachziegelig. Blüthenboden nit abfallenden Spreublättern besetzt. Federkelch 2reihig, die äusseren Strahlen kürzer und nur rauh, die inneren gefiedert.

278. Achyróphorus scop. Hauptkelch dachziegelig. Blüthenboden mit abfallenden Spreublättern besetzt. Federkelch 1reihig, alle strahlen gefiedert.

b. Blüthenboden ohne Spreublätter. Hauptkelch einfach, aus 8-12 gleichlangen und gleichgestalteten Blättchen bestehend.

274. Tragopógon L. Federchen (plumulae) der Federkelchstrahleı ineinander gewebt. Achänen geschuäbelt.

c. Blüthenbolien ohne Sprenblätter. Hauptkelch dachziegelig.

1. Federchen der Federkelchstrahlen ineinander gewebt.

275. Scorzonéra L. Achänen allmählig verschmälert, an Grunde mit einer den Nabel ungebenden, sehr kurzen Schwiele.

277. Podospérmum D C. Achänen nicht verschmälert, an Grunde mit einer den Nabel umgebenden, verlängerten Schwiele, welche dicker ist als die Achäne selbst.

2. Federchen der Federkelchstrahlen frei.

271. Thrincia oth. Federkelch der randständi. gen Achänen kurz, krunenförmig, Achänen des Mittelfeldes weit länger, fiellerhaarig.

273. Picris L. Federkelch gleichförmig, abfällig, die Strahlen an Grunde in einen Ring verwachser, die inneren an Grunde breiter, deutlicher gefiedert als die äusseren, schmäleren.

272. Leóntodion $\mathbf{L}$. Federkelch gleichförmig, bleibend, fiederhaa:ig. dchänen nach oben verschmälert.

273. Helminthia Juss. Hauptkelch doppelt, der innere Sblätterič, der äussere jblätterig. Federkelch gleichförnig, beibend. Achänen an Her Spitze abgerundet-stumpf, mit verlängertem, fadenförnigen Schnabel. 
B. Federkelch aus haar - oder borstenförnigen Strahlen gebildet. Blïthenbuden utine spreublätter.

a. Federkelch aus Spreublättern oder flachen Haaren gebildet.

271. Cichorium L. Hauptkelch doppelt, der äussere sblätterig, abstehend, der innere sblätterig. Blïthen an Grunde verwachsen. Blïthenboden nackt oder et. was wabenartig. Federkelch krunenförmig, kürzer als die Achäne.

b. Achänen gleichgestaltet, geschnäbelt; Schnabel an Grunde mit Schuppen wder mit einem Ringe ungeben.

2811. Chondrilla L. Köpfchen $7-12$ blüthig, in 2 Reihen. Hauptkelch meist sblätterig, mit einem aus wenigen kurzen Blättchen bestehenden Ausseukelche. Achänen an der. Spitze weichstachelig, am Grunde des Schuabels mit knurpeligen Schüpprhen besetzt.

279. Taráxacum J us. Köpfchen reichblüthig, vielleihig. Hauptkelch doppelt, der äusserc anliegend, abstehend oder zurückgebogen, die Blättchen des inneren Ireihig, aufrecht. Achänen etwas zusammengedrückt, oberwärts knorpelig-weichstachelig, lang geschnäbelt.

c. Achänen gleichgestaltet, geschnäbelt, aber whne Schuppen oder Ring am Grunde des Schnabels oder schnabellos.

281. Lactuca L. Köpfchen armblüthig, 1-2reihig. Hauptkelch dachziegelig, meist 8blätterig, die äusseren Blättchen kürzer. Achänen stark zusammengedrückt, in einen fadenförmigen Schnabel zugespitzt.

283. Sonchus L. Köpfchen eiförmig wder am Grunde bauchig, reichblüthig, Blïthen vielreihig. Hauptkelch dachziegelig. Achänen zusammengedrückt, an der Spitze gestutzt oder ein wenig verschmiilert, nicht geschnäbelt. liederkelch haarförmig, am Grunde ohne hiönchen.

280. Trenanthes $\mathbf{L}$. Köpfchen walzenförmig, 3 - bis 5blüthig. Blüthe 1reihig. Hauptkelch meist 8blätterig, durch die äusseren, kürzeren Blättchen dachziegelig. Ichänen zusammengedrückt, ungeschnäbelt.

285. Crepis L. Hauptkelch 'mit einem Aussenkelche, einreihig, selten fast dachziegelig. Köpfehen vielblü- 
thig. Achänen walzenförmig oder etwas zusammengedrückt, an der Spitze sihmüler oder etwas geschnäbelt. Federkelch mehrieihi, weich, nicht zerbrechlich. Strahlen haarförmig, meist schneeweiss.

288. Hieracium L. Hauptkelch dachzieyelig, selten yur 2reihig, Köpfchen vielblüthig. Achänen walzenförmig oder walzenföınig - kantig, an der Spitze schwach herandet, ungeschnäbrlt. Federkelch 1reihig, steif, zerbrechlich. Strahlen haarförmig, schmutzig-weiss.

C. Achänen an der Spitze kronenförmig oder undeutlich berandet, whne Federkelch. Blüthenboden ohne Spreublätter.

270. Arnóseris Gärtn. Hauptkelch vielblätterig, mit kurzem Aussenkelche, zur Fruchtzeit wulstig, kugelig-zusammeuschliessend. Arhänen abfällig, mit 10 abwechselnd mehr hervortetenden Streifen und mit sliantigem, sehr kurzem Krönchen endigend.

270. Lámpsana L. Haupthelch mit 8-12 anfrechtél Blättern und kïrzerem Aussenkelche, zur Frucht. zẹt unverändert. Achänen abfällig, zusammengedrückt, uit 20 gleichen Rippen und undeutlichen Rande.

II. Röhrenblüthige. Blïthen alle röhrig.

A. Blïthenboden ohne Spreublätter.

226. Eupatorium L. Köpfchen armblithig. Blüthen röhrig - trichterförmig. Hauptkel h dachziegelig.' Schenkel des Griffels fadenförmig, verlängert. Federkelch haarföımig.

228. Linósyris DC. Hauptkelch dachziegelig. Schenkel des Griffels lanzettlich, verschmälert-spitz. Achänen zusammengedrückt, ungeschnäbelt. Federkelch haarförmig.

B. Blïthenboden tief - wabenartig.

263. Onopórdon L. Hauptkelch dachziegelig, mit lanzettlichen, zugespitzten nder dornigen Blättchen. Achänen zusammengedrückt, 4kantig, querrunzelig. Federkelch abfällig; Strahlen am Grunde in einen Ring verwachsen.

C. Blüthenboden spreublätterig oder spreublätte. rig - borstig. 
i. Strahlen des abfälligen Federkelches am Grunde in eimen Ring verwachsen, ästig. Aeste feclerig.

265. Carlima L. Hauptkeloh dachziegelig, äussere Blättchen fast blattartig, ahstehend, gezähnt-dorniy, die inneren verlängert, unbewehrt, strahlend, trocken. hältig, gefärbt.

b. Strahlen des Federkelches fiederhaarig oder haarförmig, in einen Ring verwachsen und mit diesem abfallend.

262. Carduns L. Hauptkelch dachziegelig, mit lauzettlichen oder linealischen, zugespitzten oder durnigen Blättchen. Achänen länglich-zusammingedrückt, kähl. Federkelch haarförmi... Staubgefässe frei.

256. Cirsium Tournef. Hauptkelch dachziegelig, mit dornigen Blättchen. Achäıen länglich-zusanmengedrückt, kahl, häutig. Federkelch fiederharig. Staubgefässe frei.

262. Silybum Gärtn. Hauptkelch dachziegelig, äussere Blätchen dicht angedrückt, blattartig, alle zurespitzt. Achänen zusammengedrückt, kahl. Federkelch fast fiederhaarig. Staubgefässe lbrïlerig.

c. Strahlen des Federkelches haarförmig, an einen auf der Frucht befindlichen Kinopf angewachsen und mit diesem abfalleud.

266. Jurinea Cass. Hauptkelch dachziegelig, kuyelförnig. Achänen 4 kantig.

1. Strahlen des Federkelches haarförmigg, nicht ablallend.

266. Serratula L. Hauptkelch dachziegelig, die äusseren Blättchen hïrzer, stachelspitzig, die inneren länger, etwas truckenhäutig. Achänen länglich, zusammengedrückt. Federkelch haarförnig, mehrreihig, die äussere Reihe der llaare küizer, besonders abfallend.

e. Fellerkelch ans haarförmigen Borstchen gebildet.

263. Lappa Tournef. Köpfchen kugelförmig. Blätchen des Hauptkelches dachziegelig, am Grunde anliegend, oberwärts pfriemlich, mit hakenförmiger Stachelspitzte. Achänen länglich, zusanmengedrückt, querrunzelig. 
Arten von Artemisia, Bidens ohne Strahlenblütherl. Helichrysum. Arten von Centaurea.

2. Ordnung. Polygamia superflua. Ueberfliissige Vielehe. Die randständigen Bluthen weiblich, zungen-oder röhrenförmig. die des Mittelfeldes zwitterig, fruchtbar, immer röhrenförmig.

1. Federkelch haarförmig. Bluthenboden ohne spreublätter. Die randständigen Blüthen nicht zungenförmig (un bei Petasites ein wenig zungenförnig).

1. Hauptkelch einfach, mit einem schwachen Aussenkiplche.

227. Petasites Gürtn. Köpfchen 2häusig. Randständige Blïthen weiblich, in den männlichen Köpfehen 1reihig, in den weiblichen mehrreihig.

B. Hauptkelch dachziegelig; die äusseren Blittrhen allmählig kïrzer.

236. Filágo L. Blättchen des Hauptkelches krautartig oder nur an Randle truckenhäutig. Federkelch sitzend, an den Randblüthen fehlend.

239. Helichrýsum örtn. Hauptkelch trockenhäutig. Weibliche Blüthen 1reihig, wenige.

237. Gnaphalium L. Hanptkelch trockenhäutig. Weibliche Blüthen mehrreihig. Köpfchen bei einige॥ 2häusig.

Zu dieser Abtheilung: Arten von Inula und Senecio.

II. Federkelch haarförmig. Blïthenboden ohne Spreublätter. Randblüthen zungenförmig.

A. Hauptkelch dachziegelig. Blättchen vielreihig.

a. Staubbeutel geschwänzt.

234. Pulicaria G̈̈rtn. Federkelch haarförmig, die äussere Haarreihe kurz, in ein Krönchen verwachsen.

232. Inйla L. Ferlerkelch haarförmig, gleichgestaltet.

b. Staubbeutel ungeschwänzt.

231. Erígeron $\mathbf{c}$. Federkelch gleichgestaltet. Weih. liche Blüthen mehrreihig.

228. Aster L. Federhelch gleichgestaltet. Weibliche Blüthen 1reihig. Randblüthen verschiedenfarbig, fruchtbar. 
231. Solidágo L. Kandblüthen gleichfarbig. Im lebrigen wie bei Aster.

B. Haupthelch gleich, aus 1 -3reihigen und gleich. langen Blättchen gebildet oder die äussesen $+\mathrm{i}$ nen Aussenkelch bildend.

d. Federkelch verschieden gestaltet.

230. stenactis Cass. Federkelch der Randblizthen uinfarh, aus kurzen Burstchen bestehend, der des Nittelfeldes doppelt, der äussere aus kurzen Borstrhen, der innere aus verlängerten llaaren gebildet.

b. Federkelch gleichgestaltet, haarförmig, an den randständigen dchänen bisweilen fehlend. Weibliche Bliithen 1reihig.

248. Arnica L. Sihenkel des Griffels uberwärts verdickt, mit einer kegelförmigen spitze endigend.

249. Senecio L. Schenkel des Griffels kopfföruig, abgestutzt-stumpf. Hauptlielch walzenlörmig, einfach wler mit einem Aussenkelche.

c. Federkelch gleichgestaltet, haarförmig. Weibliche Blïthen mehrieihig.

226. Tussilágo L. Hauptkelch mit einem schwachen Anssenkelche.

III. Federkelch nicht haarfürnig. Blüthenboden ohme Spreublätter.

A. Hauptkelch aus 2reihigen, gleichlangen Blättchen gebildet.

230. Bellis L. Randblüthen zungenförmig. Federkelch fehlend.

B. Hauptkelch dachziegelig, vielreihig.

a. Achänen schnabellos. Randblụthen fadenförmig oder fehlend.

242. Tanacétum L, Achänen kantig-gerillt, die uberständige Scheibe von der Breite der Achänen.

239. Artemisia L. Achänen verkehrt-eiförmig, fliigellos, die uberständige Scheibe hlein.

b. Achänen schnabellos. Randblijthen zungenförmig oder glockenförmig-röhrig, den Bluthen des Mittelfeldes gleichgestaltet.

246. Matricaria L. Achänen flïgellos. Blüthenboden kegel-walzenförmig, lıwhl. 
246. Chrysánthemum L. Achänen flügellos. Blüthenboden gewölbt uder halbkugelig, mit Mark ausgefüllt.

IV. Federkelch nicht haarförmig. Bliithenboden mit Spreublätterı.

A. Hauptkelch Ireihig, einfach.

233. Galinsóga Ruiz u. Pavon. Federkelch sprenartig; Spreuen federig - fransig.

B. Hauptkelch vielreihig, dachziegelig. Griffel an der Spitze nicht verdickt, Schenkel fadenförmig - zurïckgekrïmmt.

243. Achilléa L. Ranłblüthen zungenförmig, mit rundlich-eiförnigem Saume, die Blüthen des Mittelfeldes mit flach-zusanımengedrückter, 2flügeliger Röhre. Staubbeutel ungeschwänzt.

244. Anthemis L. Randblüthen zungenförmig, nit länglichenı Saume, die Blüthen des Mittelfeldes mit flach-zusammengedrückter, 2flügeliger Röhre. Achänen flïgellos. Staubbeutel ungeschwänzt.

3. Ordnung. Polygamia frustranea. Fruchtlost Vielehe. Randblüthen weiblich, aber durch Fehlschlagen des Griffels und der Narbe geschlechtslos, die Blüthen des Mittelfeldes zwitterig und fruchtbar.

a. Blüthenboden spreuig - borstenförmig.

266. Centauréa L. Hauptkelch dachziegelig. Röhre der Randblüthen in einen trichterförnigen Saum verlängert. Achänen mit einem seitenständigen Nabel. Federkelch haarförnigg.

b. Blüthenboden spreublätterig, jede Blüthe mit einem einzelnen Spreublättchen.

236. Helianthus $\mathbf{L}$. Haupthelch dachziegelig. Randblüthen zungenförmig, Scheibenblüthen röhrenförmig. Kelch aus 2 uder 4 abfälligen Schuppen bestehend.

235. Bidens L. Hauptkelch 2reihig, die äusseren Blätter abstehend. Randblüthen zungenförmig oder wie die Scheibenblüthen röhrenförnig. Federkelch aus 2 oder 4 bleibenden, rückwärts stacheligen, starren Borsten bestehend.

Hierher Arten von Anthenis (2. Ordn.). 
4. Ordnung. Polygamia necessaria. Noth we ndige Vielehe. Randblithen weiblich und fruchthar, Scheibenblüthen zwitterig, aber unfruchtbar.

25.5. Calendula L. Hauptkelch 2reihig, Blättchen qleichlang. Achänen verschieden gestaltet.

Hierher auch 'Tussilago (2. Ordn.).

i. Ordnung. Polygamia segreguta. A bgesonderte Vielehe. Köpfchen 1-bis mehrhlüthig, in einen gemeinschaftlichen Kopf zusammengestellt.

256. Echínops L. Köpfchen 1tliithig, in einen gemeinschaftlichen, kugelförmigen Kopf zusammengesteḷt.

(j. Ordnung. Monogynia. Ei n w e ibigge. Blüthen einzeln, ohne gemeinschaftliche Hiille, jerle besonder's gestielt, mit besonderem Kelche.

Hierher Impatiens und Viola $(\mathrm{V}, 1)$.

XX. Classe. Crymandria. W e i b e rmännige. Stanh. fäden und Griffel verwachsen.

1. Ordnung. Monandria. Einnännige. Ein entwickelter Staubbeutel.

I. Staubleutel ganz angewachsen.

A. Lippe gespornt. Fruchtknoten gewunden.

a. Fächer des Staubheutels gleichlaufend, unterwärts aneinanderliegend.

440. Orchis L. Fächer des Staubbeutels am Grunde. Jurch eiı 2 fächeriges Beutelchen verbunden. Stiele der staubmassen auf 2 getrennten Haltern ruhend. Lippe abstehend, nicht gewunden.

447. Anacamptis Rich. Fächer des Staubbeutels durch ein 1 fächeriges Beutelchen verbunden. Stiele der Stanbmassen auf einem gemeinschaftlichen Halter ruhend. Lippe abstehend, nicht gewunden.

448. Himantoglossum spreng. Staubbeutel wie bei Anacamptis, aber die Lippe zusammengedreht.

447. Gymnadenia R. Br. Fächer des Staubbeutels an Grunde ohne Beutelchen. Jippe abstehend.

h. Fächer des Staubbeutels unterwärts durch pine Bucht des ausgeschnittenen Schuabelchens getrennt.

449. Platanthéra Rich. Sporn lang, fadenförnig. 
B. Lippe spornlos, ununterbrochen.

450. Ophrys $\mathbf{L}$. Blüthenhülle und Jippe abstehend. Beutelchen 2, getrennt. Staubmassen gestielt, gelappt.

451. Herminium R. B r. Blüthenhülle gluckenförmig. 'Zipfel mnd Lippe aufrecht. Lippe am Grunde sackförmig-höckerig. Beutelchen fehlt.

\section{Staubbeutel frei.}

A. Lippe suorulos, 2gliederig.

451. Cephalanthéra Rich. Zipfel der Bliithenhülle aufrecht, etwas zusammenneigend. Lippe 2gliederig, unteres Glied sachföruig-hohl. Fruchtknoten stiellos, gew unden.

452. Epipactis Re ich. Blüthen glockenförmig, etwas abstehend. Iippe 2yliederig, unteres Glied sickförmig-hohl. Fruchtknoten gestielt, nicht gewunden.

B. Lippe spurnlos, nicht gegliedert.

45.5. Corallorrhiza Hal1. Lippe an Grunde mit den seitenständigen Zipfeln der Bliithenhïlle verbunden und daselbst einen hurzen, angewachsenen spurn darstellend.

456 Sturmia Kchb. Blüthenhülle abstehtnd. Süule des Staubhentels verlängrert, halb - walzenförmig. Staubheutel endständig, abfällig.

454. Neottia L. Blüthenhiille glockenförmig, fast helmartig. Staubbeutel endständig, sitzend, bleibend. Finchtknuten nicht gedreht.

454. Listéra R. B r. Blütheuhülle helmartig. Befruchtungssäule hinten mit einem eiförmigen Furtsatze endigend, ler den bleibenden Staubbeutel an Grunde oder an der Spitze trägt. Fruchtknoten nicht gedreht.

455. Spiranthes Rich. Blüthenhiille rachenförmig. Jippe eingeschlossen. Staubbeutel sitzend. Fruchtkno. ten gedreht.

454. Goodyéra R. B r. Blüthenhülle rachenförnig. Lippe eingeschlossen. Staubbeutel gestielt. Fruchtinoten gedreht.

2. Ordnung. Diandria. Zwe imännigre. Zuvei entwickelte Staubheutel.

456. Cypripéaium L. Blüthenhülle abstehend, mit 
bisurhig - aufgeblasener I,ippe. Befruchtungssänle an der spitze 3spaltig.

5. Ordnung. Mexandria. Sechsmïnnige. Sechs staubbeutel rings um den Griffel.

410. Aristolochia $L$. Blüthenhïlle blumenblattartig, röhrenförmig; Röhre anı Grunde bauchig, an der Spitze iı eine॥ zungenförmigen fortsatz verbreitert.

XXI. Classe. Monoecin. Einh ïusige. Männliche und weibliche Blïthen auf einer Pflanze.

1. Ordnung. Monandria. Einmännige. Ein Staubgefäss.

411. Euphorbia L. Besondere Blüthenhülle glockenförmig, $y$ - 10zähnig; 4-5 lähne von einer fleischigen und honigtragenden scheihe beleckt. Männliche Blüthen zu 10-20, an Grunde der besonderen Blüthenhülle, nackt, Imäınig. Weiblirhe Blüthen einzelı auf einem Stielchen, mit undeutlicher Blïthenhïlle versehen. Fruchtknoten 1. Griffel 3spaltig.

439. Arum $\mathbf{L}$. Kulben an der spitze nackt, in der Mitte mit mäunlichen, am Grunde mit weiblichen Blüthen ringsum besetzt, von eine kilppenförmigen Blïthenscheide umliillt. Frucht eine Beere.

439. Calla L. Kolben überall mit Blüthen bedectit. Blüthensiheide flach. Frucht eine Beere.

436. Najas $\mathbf{L}$. Blüthenscheide der männlichen Blïthe Iblätterig, an der Spitze 2-3zähnig, den Staubbeutel eng-einschliessend. Staubbentel (bei $\mathbf{N}$. major) 4 fächerig, Steinfrucht saftlos, Isimig.

166. Callitriche $L$. Blïthen eingeschlechtlich oder zwitterig. Blüthen in den Blattwinkeln von 2 kleinen, blumenblattartigen Deckhlätterı gestützt. Griflel 2. Steinfrucht saftlıs, in 4 Früchtchen sich trennend.

435. Zannichellia L. Männliche und woibliche Blïthen in derselben Blïthenscheide. Blüthenhiille der männlichen Blïthe fehlend, die der weiblichen Blüthe glockenförmig. Griffel bleibend. Narbe schief-schildförni... Fruchtchen nussartig, mehre, jedes auf einen fadenförmigen Fruchtträger sitzend.

2. Ordnung. Diandria. Zweimännige. Zwei Staubgefässe.

427. Pinus $L$. Blüthen nackt, in zapfenförmigen 
tehren; Deckblätter schuppenförmig, verholzend. Staubfäden schuppenförmig-ausgebreitet. Samen geflügelt.

3. Ordnung. Triandria. Dreimä un ige. Drei Staubgefüsse.

437. Typha L. Männliche und weibliche Blüthen gedrängt an einer walzenförmigen Aehre; männliche Blüthen endständig. Fruchthnıten mit Borsten umgeben. Frucht ron bleibenden Griffel gekrönt.

438. Sparganium L. Aehren kugelförmig; oberste Köpfchen mänulich, untere weiblich. Blüthenhülle mehrblütterigr, spreuartig. Steiufrucht trocken, sitzend.

491. Carex L. Blüthen 1 -, seltener 2häusig, von einen schuppenförmigen Deckblatte (Balg) gestiitzt, in mehrblüthigen Aehrchen. Griffel 1. Narben 2 oder 3. Bliithenhülle eine falsche Frucht bildend.

511. Zea L. Näınliche Blïthen endständig, traubig-rispig; weibliche Blïthen blattwinhelständig, mit Scheiden eingehiillt. Aehrchen 2 blïthig, das eine daron geschlechtslus. Karyupsen lundlich-nierenförmig, in dicht genäherten Reihen einer gemeinschaftlichen Achse eingefügt.

4. Ordnung. Tetrandria. Viermännige. Vier Staubgefässe.

a. Blüthen unvollständig. Vünnliche und weibliche Blüthen mit einer Blïthenhülle.

415. Urtica L. Blüthen 1- und 2häusig. Männliche Blüthenhülle 4theilig; Staubqefässe elastisch zuriickspringend; weibliche Blüthenhiille 2theilig. Narbe sizzend, kopfig - pinselförmig. Frucht uussartig.

417. Morus L. Mäınliche Blüthenhïlle 4theilig, weibtiche 4 blätterig. Narben 2, fadenförmig. Falsche Frucht aus den fleischig gewordenen Blïthenhüllen gebildet.

b. Blüthen unvollständig, in Kätzchen. Weibliliche und männliche Blïthenhüllen fehlend.

427. Alnus Tournef. Blüthen in zapfenförmigen Kätzchen. Männliche Blüthen 3, auf dem Stielchen der Kätzchenschuppe sitzend, 4spaltig. Weibliche Bliithenhülle fehlend. Narben 2, fadenförmig. Nuss zusammengedrüickt, 2 fächerig. 
5. Ordnung. Pentandria - Polyandria. I ü n f-Viel III ï 11 ige. Fünf his viele Staubgefüsse.

a. Blüthen vollstïndig, nicht kützchentragend.

164. Myriophýllum L. Männliche Blüthe mit 4lap. pigem Kelche und 4 sehr hinfälligen Blumenblättern. Staubgefässe 8. Weibliche Bliithe mit oberständigem, 4zähnigem Kelche. Blumenblätter sehr klein. Narben 4, zuttig. Steinfrucht saftlıs, bei der Reife in 4 Steine zerfallend.

430. Sagittaria L. Kelch 3theilig. Blumenkrone 3blätterig. Staubgefüsse zahlreich. Friichtchen zahlreich, auf rinem kugelförmigen Fruchtboden.

155. Potérium L. Blïthen vielehig, gedrängt, in eiförmigen Köpfrhen. Blüthenhülle röhrenförmì, nit ausgebreitetem, 4theiligem Saunı". Staubgefässe 20-30. Fruchtknoten 2-3. Griffel fadenförmig. Narbe pinsel. förmig. Nüsse $2-3$, von der bleibenden, verhärteten Blïthenhiille eingeschlossen.

b. Blüthen vollständig, die männlichen in Kätzchen.

418. Juglans L. Blïthenhülle der nuänlichen Blïthen 2-6theilig. Staubgefüsse zahlreich, sehr kurz. Weibliche Blüthen 1-3, an der Spitze der Aestchen. Kelch 4zähnig, abfällig. Blumenblätter 4, krautartig. Narben 2. Steinfrucht fleischig, mit 2 - 4 klappiger Nussschale.

c. Blüthen unvollständig, nicht in Kätzchen.

388. Amarántus L. Blïthenhïlle 3-5theilig. Stauhgefässe $3-5$. Griffel 3. Kalısel 1 samig, ringsum aufspringend.

395. Atrīplex L. Blütien 1 häusig, steltener vielehig. Männliche oder 'Zwitterblüthen mit 5 blütteriger Blïthen. hülle und $3-5$ Staubgefässen. Weibliche Blïthen mit 2theiliger oder 2lappiger Blïthenhiille. Hantfrucht zu sammengedrückt. Samen aufrecht, nit krustiger Sa-ı menhaut.

395. Hálimus wa I $\mathbf{x}$. Blüthen 1 häusig. Blïthenhülle der männlichen Blüthen 5blïtterig, dite der weiblichen Blüthen 2spaltig oder 2theilig. Staubgefüsse 4-5. Hautfucht zusammengedrückt. Samen aufrecht, mit dünnhäutiger Samenhaut.

167. Ceratophýllum L. Blüthenhülle der männlichen Bliithen vielblätterig, nit linealischen, an Ende 
abgestutzten und 2 dornigen Blättern. Staubbeutel zahlreich, sitzend, auf jeder Seite in ein Dörnchen auslaufend. Blüthenhïlle der "eiblichen Blüthen fehlend. Nuss mit eimen Durn endigend.

295. Xanthium L. Hauptkelch bei der männlichen Bluthe vielblätterig. Blïthenhiille 5zähnig. Hanptkelch hei des "eiblichen Blüthe 1blïtterig, 2facherig, 2blïthig. Bliithenhülle bei der weiblichen Blïthe fehlend. Falsche Frucht aus dem erhärteten Hauptkelche gebildet.

d. Blüthen unvollständig, die männlichen in Kätzchen. Staubrefässe der Blüthenhülle eingefügt.

419. Fagus $\mathbf{L}$. Männliche Blïthen in kugelförmigen, gestielten, seitenstänligen Kätzchen. Schuppen klein, abfallend. Blüthenhülle 5-6spaltig. Staubgetässe zahlreich. Weibliche Blüthen zwei auf gemeinschaftlichem Stiele, in einer 4spaltigen, aus Deckblättern gebildeten Hülle. Nabben 3. Frïchte 1-2samig, voll deı erhälteten, zı einem Fruchtbecher verwachse"en Deckblättern eingeschlossen.

419. Quercus L. Männliche Blüthen in Kätzchen. Bluthenhiille sitzend, 5-9blüthig. Stanbgefässe 5-9. Weibliche Blüthen in den Winkeln abfälliger Deckblätter. Blüthenhülle sehr klein, an Grunde von sehr kleinen Deckschuppen unıgeben, die später in den die 1samige Frucht unterwärts umfassenden Fruchtbecher zusaunuenwachsen.

e. Blïtheı unrollständig, die männlichen oder die männlichen und weiblichen in Kätzchen. Staubgefässe den Kätzchenschuppen eingefïgt.

420. Córylus 4 . Männliche Blüthen in Kätzchen. schuppen verkehrt-eiförmig, an der spitze mit 2 Anhängseln versehen. Staubgefässe 8. Weibliche Bliithen in knuspenförmigen Aehren, Schuppen dachziegelig, nur die obersten fruchthar und lblïthig. Nuss von einer 2spaltigen, eingeschuittenen, bleibenden Hülle umgeben.

420. Carpinus L. Männliche und weibliche Bliithen in Kätzchen. Männliche Blüthen mit eiförmigen Schuppen. Staubgefässe 6-12. Schuppen der weiblichen Blïthen locker, zu 3 beisammen stehend, 2blüthig, die äusseren abfälig, die inneren 2spaltip oder gelappt, bleibend, bei der Frucht sehr vergrössert. Nuss von 
einem blattartigen, halbirten Fruchthecher umgeben. mit der bleibenden Blüthenhïlle gekrönt.

426. Métula L. Männliche und weibliche Blüthen in Kützchen. Schuppen der männlichen Blïthen gestielt, tblïthig, unter der Spitze mit 2 Anhängseln. Blüthenhülle 3 blätterig. Stanbbentelfächer durch den 2spaltigen Staubfaden getrennt. Schuppen der weiblichen Bliithen länglich, zuletzt 3lappig, abfallend, 2-3blüthig. Nuss geflügelt.

9. Ordnung. Monadelphia. Einbrüderige. Staubfäden, zuweilen auch die Staubbeutel untereinandes verwachsen.

169. Cucurbita L. Kelch 5zähniğ, auf der Spitze einer fleischigen Sicheibe. BInnenkrune 5spaltig. Staubbeutel in eine Röhre verwachsen. Weibliche Blüthen mit 3 verwachsenen Staubfäden ohne Staubbeutel. Griffel 3spaltig. Fucht beerenartig. Samen mit einem gedunsenell Rande umzogen.

169. Cúcumis L. Nünnliche Blüthen nit zusammenneigenden Stanbbeuteln. Frucht beerenartig, vielsamig. Samen mit spitzem Rande. Im Uebrigen wie bei Cucurbita.

169. Bryonia L. Kelrh 5zähnig. Blumenkrone 5theilig. Staubbeutel frei. Griffel 3spaltig. Frucht beerenartig, kugelförmig, 3-6samig. Samen nit stumpfem, nicht gedunsenem Rande.

Pinus (XXI, 2).

XXII. Classe. Dioecia. $Z w$ wihäusige. Nännliche Blïthen auf der einen, weibliche auf der anderen Pflanze.

1. Ordnung. Monandria. Einmännige. Männliche Blïthen mit einenı Staubgefässe.

Najas (XXI, 1), Salix purpurea (XXI1, 2).

2. Ordnung. Diandria. Zweimännigg. Männliche Bliithen nit 2 staubgefüssen.

420. Salix L. Bliithen in Kätzchen. Deckblätter schuppenförmig. Blüthenhïlle fehlend. Staubgefüsse 1, 2 oder mehre, Griffel 1. Narben 2. Kapsel 2klappig. Samen mit einem Haarbüschel.

Lemna und Fraxinus $(11,1)$. 
3. Ordunng. Triandria. Dreimännige. Männliche Bliithen mit 3 Staubgefüssen.

laleriana divica (III, 1), Salix amygdalina (XXII, 2), Carex dioica und Daralliana (XXI, 3).

4. Ordnung. Tetrandria. Vi e rmänni ge. Männliche Blüthell mit 4 staubgefässen.

208. Viscum L. Blumenkrone der männlichen Blüthe 4 theilig, mit fehlendem Kelche. Staubbeutel mit den Blumenblättern verschmolzen. Weibliche Blumenkrone 4blätterig. Kelch, in einem oberständigen Rande bestehend. Griffel fehlend. Narbe stumpf, sitzend. Frucht eine einsamige Beere.

395. Spinacia L. Blïtheñhülle der männlichen Blij. the 4theilig, die der weiblichen Blïthe 2-3spaltig, bleibend. Griffel 4. Fruchtgehänse mit der verhärte. ten Blüthenhülle verwachsen.

Urtica dioica und Morus nigra' ${ }^{\prime}$ XXI, 4).

5. Ordnung. Fentandria. F'ü n fmännige. Männliche Blüthen mit 5 Staubgefässen.

416. Cánnabis $\mathbf{L}$. Blüthen nackt. Männliche Blüthe von einem krugförmigen, 5theiligen Deckblättchen gestïtzt. Deckblättchen der weiblichen Bluthe kruøförmig, mit seitlichem Längenspalte. Griffel 2. Frucht vom bleibenden Deckblättchen eingeschlosseu.

417. Húmulus L. Männliche Blüthen cinzeln, gestielt, mit 5theiliger Blüthenhülle. Weibliche Blïthen in zapfenförmigen Aehren. Statt der Blüthenhïlle ein krugförmiges Deckblättchen in der Achsel grosser Deckschuppen.

427. Juniperus L. Männliche Blüthen in Kätzchen. Blüthen nackt. Schildförmig ausgebreitete Staubfäden mit 4-7 Staubbeutelfächern. Weibliche Blüthen in der Achsel der Deckschuppen. Eichen nackt, zu 3 in der Achsel einer Deckschuppe. Falsche Beere aus fleischigen Deckschuppen gebildet.

Ribes alpinum und Rhannus catharticus (V, 1), Atriplex (XXI, 5), Salix pentandra (XXII, 2), Spinacia (XXII, 4).

6. Ordnung. Hexandria. Sechsmännige. Männ. liche Blüthen mit 6 Staubgefässen.

Rumex $(11,3)$. 
7. Ordnung. Octandria. A chtmäunige. Mänuliche Blïthen mit 8 Staubgefüssen.

424. Pópulus $\mathbf{c}$. Blüthen in Kätzchen. Statt der Blïthenderke eine becherförmige, kleine Scheibe in der Achsel einer Deckschuppe.

Acer $(\mathrm{VIII}, 1)$.

8. Ordnung. Enneandria. Neunmännige. Männliche Blüthen mit 9 Staubgefässen.

414. Mrercuriális C. Blüthen 1-oder 2häusig. Blüthenhülle 3̈theiliı. Staubgelässe 9-12. Griffel kurz. Narben 2, verlängert. Kapsel 2knotig; Fächer 1samig.

429. Hydrócharis L. Kelchsaum 3theilig. Blumen. krune 3 blätterị. In der münnlichen Blüthe 9 Staubgefüsse und 3 fehlschlagende Griffel, in der weiblichen 3 fadenförmige Nebenstaubfäden, 3 fleischige Honigschuppen, 6 Griffel und eine 2theilige Narbe.

9. Ordunng. Decandria. $Z$ e h n männige. Männliche Blüthen mit 10 Staubgefässen.

Silene Otites und $\mathbf{S}$. inflata $(\mathrm{X}, 3)$, Iychnis vespertina und L. diurna $(\mathbf{X}, \mathbf{5})$.

10. Ordnung. Dodecandria. Eilf - Neunzehn Staubgefässe.

428. Stratiotes $\mathbf{L}$. Kelch 3theilig. Blumenkrone 3blätterig. Ausgebildete Staubgefässe 12 . Nebenstaubfäden $20-30$. Griffel 6,2 spaltig. Beere 6seitig, 6fằcherig, vielsamig.

Mercurialis (XXII, 8).

11. Ordnung. Polyandria. Viele Staubgefüsse aut dem Blüthenbuden befestigt.

Stratiotes (XXII, 10), Pupulus nigra (XXII, 7).

13. Ordnung. Syngenesia. Staubbeutel verwachsen.

Gnaphaliun dioicum (XIX, 2).

XXIIl. Classe. Polygamia. Viel e hig e. Pflanzen, welche $Z$ witterblüthen und zugleich männliche oder weibliche Blüthen tragen.

(Die hierher gehörigen Gattungen sind nach dem Baue der $\mathbf{Z}$ witterblüthen leichter in den vorhergehenden Klas. 
sen aufzufinden und werden hier nur dem Nanıen nach ohne Charakteristik erwähnt.)

1. Ordnung. Monoecia. Zwitterblüthen und Bliithen beiden Geschlechts auf derselben Pflanze.

a. Zwitterblüthen mit 2 Staubgefässen. Fraxinus (11, 1).

b. Zwitterblüthen mit 4 Staubgefässen. Parietaria $(\mathbf{I V}, \mathbf{1})$, Morus (XXI, 4).

c. Zwitterblüthen nit $\mathbf{5}$ Staubgefüssen.

Ulmus und Blitum ( $(, 2)$, Atriplex (XXI, 5).

d. Zwitterblüthen mit 7 Staubgefüssen. kisculus $(\mathrm{VII}, 1)$.

e. Zwitterblüthen mit 8 Staubgefässen.

Acer (VIII, 1).

f. Zwitterblüthen mit 10 Staubgefässen.

Silene Otites und $\mathbf{S}$. inflata $(\mathbf{X}, \mathbf{3})$, Lychnis vespertina und L. diurna $(X, 5)$.

g. Zwitterblüthen mit 20-30 kelchständigen Staub. gefässen.

Poterium (XXI, 5).

2. Ordnung. Dioecia. Zwitterblüthen und Blüthen blos eines Geschlechts auf derselben Pflanze.

a. 1 Staubgefäss.

Zannichellia (XXI, 1).

b. 2 Staubgefässe.

Fraxinus $(\mathrm{II}, 1)$.

c. 3 Staubgefässe.

Valeriana dioica $(111,1)$.

d. 4-5 Staubgefässe.

Rhamnus catharticus $(\mathrm{V}, \mathbf{1})$. 
Schlïssel zur natiirlichen Anordnung der P'llanzen nach De Candolle.

1. Abtheilung. Plantae vasculares s. Cotyleae. Gefässpfianzen oder Pflanzen mit keimblättern $d$. h. Pflanzen mit Zellgewebe und Gefüssen, deren Samenkeim ein uder mehre Keimblätter besitzt.

1. Klasse. Exogenae s. Dicotyleae. Pflanzen, bei welchen die Gefässe in cuncentrischen kivisen stehen und der Samenkeim gegenständige oder quirlständige Kémblättev hat.

1. Mit doppelter Bliithendecked. h. deren Kelch und Blume deutlich unterschieden sind.

1. Unterklasse. Thalamiflorae. Fruchtbodenblüthige. Blumenblütter getrennt, auf dem Fruchtbodell eingefïgt.

1. Unterklasse. Calyciflorae. Kelchblüthige. Blumenblätter getrennt oder verwachsen, einer dem Kelchigunde angewachsenen scheibe eingefuigt.

3. Unterklasse. Corolliflorae. Kronenblit thige. Blumenblätter zu ciner unterständigen oder nicht auf dem Kelche befestigten Blume verwachsen.

B. Mit e inf a cher BI üthendecke, deren Kelch und Blumenblätter nur eine einzige Hülle bilden.

4. Unterklasse. Monochlamydeae. Einhüllblii thige. Blumenblätter entweder fehlend oder mit dem helche verwachsen.

2. Klasse. Endogeneae s. Monocotyleae. Pflanzen, bei welchen die Gefüsse bündelweise stelien und deren Samenkein mit wechselständigen Keimblättern versehen ist.

5. Unterklasse. Phanerogamae. Phanerogamische. Pflanzen mit sichtbaren Befruchtungsorganen.

6. Unterklasse. Cryptogamae. Kryptoga uis is he. Pflanzen mit verburgenen Befruchtungsorganel.

II. Abtheilung. Plantae cellulares s. Acotyleae. Zellenpflanzen oder Pflanzen ohie Keimblätter $d$. $h$. nur aus Zellgewebe zusammengesetzte, gefässlose Pflanzen, deren Samenkeim ohne Keimblätter ist.

7. Unterklasse. Foliosae. B e b lätterte. Pflanzen mit blattähnlichen Ausbreitungen.

8. Unterklasse. Aphyllae. Blattlose. Pflanzen whue blattartige Ausbreitungen. 


\section{Tabellarische Uebersicht derjenigen Familien des natürlichen Sistems, welche im Gebiete vorkommen.}

1. Classe. Ringfaserige phanerogamische Gefässpflanzen. Dicotylen *).

x. Unterabtheilung. Bliithen vollständig, vielblätterig, unterständig.

A. Fruchtknoten mehre, getrennt, jeder einen Griffel tragend; wder mehre in eine lappige Frucht mehr oder weniger zusammengewachsen und jeder Lappen einen Griffel tragend; oder ein einziger Fruchtknoten mit einem einzigen seitenständigen Samenträger.

18. Herberideen $\mathbf{v}$ ent. Kraut-oder strauchartige Pflanzen mit abwechselnden oder büschelförmigen, einfachen, oft ästig - dornigen oder zusammengesetzten Blättern. Blüthen in 'Trauben oder Kispen. Kelchblättw 3, 4 oder 6 in 2 Kreise gestellt, abfallend, aussen oft ron einem schuppenförnigen Hüllkelche gestiitzt. Blumenblätter unterständig, so viel als Kelchblätter und ihnen gegenüber, selten doppelt so viel, jedes am Grunde nit 2 hleinen Driisen oder Nebenblättchen. Staubgefässe in gleicher Anzahl mit den Blumenblättern und diesen gegenüberstehend. Staublıcutel seitlich angewachsen, mit 2 Klappen anfsspringend. Fruchtknoten einfächerig. Frucht eine Beere oder eine Kapsel. Samen 1-3, am Grunde des Faches auf einer Seite. Samenkeim gerade, in der Achse des Eiweisses. - Hierher gehört die Gattung Berberis (VI, 1).

*) Sehr passend ist von Buttmann vorgeschlagen und jetzt vielfach angenommen, statt der längeren, von $\approx o \tau v \lambda \eta \delta^{0} \omega \dot{\omega} \nu$, kleiner Nabel, abgeleiteten Namen Cotyledonen, Monocotyledoneu u. s. w. die kürzeren, von zot $\dot{v} \lambda$, Nabel, herkommenden Wörter Cotylen, Monocotylen u. s. w. zu gebrauchen.

Garcke, Flera.

6 A. 
1. Kanunculaceen $\mathbf{J}$ uss. Kräuter, in Gebiete nie Sträucher mit scharfem, oft giftigem Safte und meist ab. wechselnilen, ganzen oder gewöhnlich getheilten Blättern, deren Blattstiele an Grunde in cine halbstengelunfassende Scheide erweitert sind, whe Nebenblätter. Kelch 3-6bläterig, regelmässig uder unregelmässig, uft blumenartig, in der Knospenlage gleich den Blumenblättern dachziegelförmig. Blumenblätter 5 odel mehr in einem oder mehren Kreisen; bei einigen Gattungen verkleinert mid nelitarienartig, oder auch firh. lend. Stanbyetässe frei, zahlreich. Stanbbentel an die Staubfäden angewachsen, mit lïngsritzen aufspringend. Fruchthuoten meist zahlreich, oft alle rerwachsen, selten einzeln, stets einfächerig, ein - oder mehresig. Frucht muss , berien - oder kapselartig. Samenkeim sehr klein, rom Eiweisse eingeschlossen. - Clematis, Thalictrum, Anemone, Idunis, Myusurus, Rammeulus, Caltha, 'Trollius (XIII, 7), Nigella, Aquilegia (XIII, 5), Delphinium, Aconitum (XIII, 3), Actaea (XIII, 1).

173. Crassulaceen DC. Saftige Kränter oder Stauden mit fleischigen, gegenständigen oder zerstreuten Blättern whne Nebenblätter. Bliithen meist endstïndig. Keloh frei, bleibeud, meist 5spaltig, 5theilig wder 5blätterig, bei der Kuospung deckend. Blumenbläter regelniässig, 3-20blätterig, mit den Staubgetässen und den schuppenförmigen Nebenblumenblättern in Grunde des Kelches pingefiigt, zuweilen am Grunde zu einer Röhre verwachsen, bei der Knospung gedreht. Staubgefïsse so viel als Blumenblïtter, oder doppelt so viel. Fruchtinoten am Grunde mit einer unterstïndigen Schuppe. Kapseln balgartig, an der Naht aufspringend. Samen sehr hein. Samenheim umgekehrt, in der Achse des Eiweisses. - Sedum (X, 5), Sempervivum (XI, 5).

136. Kzosaceen ass. Kirüuter, Stauden oder Strüucher mit abvechseluden, einfachen vder zusammenge. setzten Blättern unl Nebenblättern, welche oft mit dem Blattstiple verwachsen sind. Kelch 5 -, selten 4spaltig, mit einer verschicden gestalleten Rühre, oft mit einer 5. orler 4spaltigen Hülle versehen, deren Glieder mit den Kelchblätterı abwechseln. Blumenbläter 5, keleh. ständig. Staubgefässe zahlreich, 12 bis 100 und mehr, frei, mit 2fücherigen Staubbeuteln, dem Kelche vor den Blumenblättern eingefiigt, in der Knospenlage einwärts çekrümmt. Fruchtknoten zahlreich, einfächerig, meist eineiig, oft rom Kelche eingeschlossen, aber licht mit 
ihm rerwachsen. Griffel seitenständig. Samenheim umgekehrt, gerade, ohne Eiweiss. - Spiraea (XII, 2), Geum, Rubus, Fragaria, Comarum, Potentilla, Agrimolia, Rosa (X1I, 3).

100. Papilionaceen $\mathbf{L}$. Kräuter, Sträucher oder Bäume mit abwechselnden, einfachen oder meist zusammengesetzten, oft gefiederten Blättern und Nebenblättern, "elche meist mit den Blattstielen verwachsen sind, Bluitlen meist $Z$ Zwitter, in Büscheln, 'Trauben, Aehren oder Köpfchen; Blüthenstielchen gegliedert und gewöhnlich nut Deckblättchen versehen. Kelch 5zähnig oder 2lippig, die Oberlippe mit 2, die Unterlippe mit 3 'Zähne॥. Blumenlirone unregelmässig, sclimctterlingsförmig, dem Grunde des Kelches eingefügt, 5blätterig, und zual sind die beiden untrren Blumenblätter meist mit einauder verwachsen und bilden das Schiffichen (carina), das oberste, gewöhnlich aufrecht stehend und vor dem Aufbrechen-der Blüthe die 4 übrigen bedekkend, heisst die Fahne (vexillum), die beiden seitlichen werden die Fliigel (alite) genannt. Zuweilen sind sänmtliche Blumenblätter mit einander verwachsen. Staulgef üsse 10 , cines firei und 9 zusammengewuachsen (diarlelphisch) oder alle in ein Bïndel zusammengenvachsen (munadelphisch), vor den Blumenblättern eingefügt. Fruchtionoten mit einem seitenständigen Samenträger. Frucht eiue llülse (legumen). Samen eiweisslus, seltener mit spärlichem Eiweisse. Samenkeim auf die Ritze der Samenblätter zurückgelegt. - Hierher gehören sämntliche Pflanzen aus der Diadelphia Decandria (XVII, 4).

B. Fruchtknoten einer, mit wandständigen, an den Rändern der Klappen gelegenen Samenträgern.

19. Papaveraceen DC. Kräuter nit wässerigem, milchigtm uder gefärbtem, giftigen! Safte und abwechselıden, getheilten Blätter'n ohne Nebenblätter. Bluithen zwitterig, einzeln, langgestielt. Kelch 2blïtterig, ahfallend. Blumenkrone 4 blätterig, regclmässig oder die beiden gegenständigen grösser und fast 3lappig, in der Knospenlage meist unregelmässig zusammengefaltet. Staubgefässe unterständig, zahlreich, selten nur 4, frei. Frucht 1 fächerig oder mit unvollständigen Fächern. Samenträger zwischen den Klappen oder auf den Wänden der Fächer. Samenkein sehr klein, gerade, am Grunde des Eiweisses. - Papaver, Glaucium, Chelidonium (XIII, 1). 
22. Fumariaceen DC. Kräuter mit wässerigem, meist bitterem Safte und meist abwechselnden, vieltheiligen, zuweilen mit Ranken versehenen Blättern. Blii. then zwitterig, meist in gipfelständigen Aehren. Kelch zblätlerig, klein, abfallend. Blumenblätter 4, unregelmäissig, 2lippig, gespornt. Staubgrelässe unterständig, 6, in 2 Bündel zusanmengewachsen, mit je 3 Staubbeuteln, wovon der mittlere 2fächerig, der äussere Ifächerig. Fruchtinoten fä̈herig, 1- oder mehreiig. Samenträger zwischen den Klappen. Samenkein an Grunde des Eiweisses. Frucht eine 2 klappige, vielsamige Schote whue Scheidewand, oder ein 1samiges, nicht aufspringendes, kugellörmiges Schötchen. - Corydalis, fumilia (XVII, 2).

25. Crucireren Juss. Kräuter oder Stauden mit wässerigem Safte, abwechselnden, einfachen, ganzen oder getheilten Blättern ohme Nebenblätter. Blïthen zwitterig, in 'Trauben oder Rispen. Kelch 4blätteri", abfallend. Blumenblätter 4, mit einem Nagel versehen und in ein Kreuz gestellt, meist gleichformig, selten fehlend. Slaubgefässe 6, unterständig, viermüchtig, die 4 längeren den Samenträgern, die 2 kürzeren den Klappen gegenüber. Fruchtknten frei, meist vollkommen 2fächerig, 2 - bis mehreig, mit 2 nackten, zwischenklappigen, der Scheidewand anliegenden Samenträgern. Frucht eine Schote (siliqua) odr' ein Sichötchen (sili. cula), meist mit abspringenden Klappen und bleibender Scheidewand; seltener nicht aufspringend. Samen eiweisslos. Samenkein gekrïmmt. - Hierher gehören alle Pflanzen aus der 15 . Klasse.

19. Nymphaeaceen DC. Wasserpflanzen mit grossen schwimmenden Blïthen und Blättern und mit dickem, fleischigem, im Schlanme kriechendem Wurzelstocke, aus welchen die langen, wal\%enförmigen, krautartigen Blüthen - und Blattstiele hervorgehen. Blätter schild-oder herzkreisförnig, ganzrandig, lederartig. Kelch 4-bis fblätterig, kraut- oder blumenartig. Blumenkrone regclmässig, mit zahlreichen, freicn, allmählig in die Staubgefässe iibergehenden Blumenblüttcrn. Staubgefässe xahlreich, unterständig oder der fleischigen Scheibe eingefiigt, welche den Fruchtinoten überzieht. Fruchtknoten mehrfächerig, Fächer vieleiig, Eichen an den Wänden der Fächer. Samenkeim ausserhalb des Eiweisses, in bleibenden Keinsacke eingeschlossen. Nymphaea und Nuphar (XIII, 1). 
57. Kesedaceen I) C. Kräuter oder stauden mit abwechselnden, getheilten oder ungetheilten Blättern, an deren Girunde sich 2 drüsenartige Körper befinden. Blïthen in 'I'rauben, zwitterig. Kelch 4-6theilig, bleibend. Blumen/irone unregelmässig, mit 4-6 mit den Kelchabschnitten abwechselnden Blumenblättern. Staub. gefäisse 10-24, mit dem Iruchtknoten einem Iruchtirciger (carpophorum) cingefiigt, welcher nach eines Seite in eine drüsige Scheibe (discus) erweitert ist. Fruchtknoten 1fächerig, an der Spitze offen, 3-6lappig, Lappen in einen kurzen, kegelförmigen Griffel endigend. Samenträger $3-6$, an den Nähten vieleiig, oder 4-6, getrennt, Ifächerig, an Grunde often, jeder nit 1 Griflel versehen. Fächer 1-2eiig. Frucht. häutig, an der Spitze offen. Samenkeim gekriimmt, fast eiweisslos. - Reseda (XI, 3).

C. Fruchtknoten piner, nit wandständiger, auf der Mitte der Klappe befindlichen Samenträgern.

52. Violnrieen I) C. Kräuter mit meist abwechselnden, selten gegenständigen Blättern, deren Stiele am Grunde mit 2 Nebenbliittern versehen sind. Blüthen zwitterig, einzeln, an langen, von 2 Deckblättern begleiteten Blüthenstielen, oder in 'Trauben. Kelch und Blumenkrone 5blätterig, unregelmässig. Staubgefässe 5, auf unterständiger Siheibe. Staubbeutel dem Fruchtknuten dicht anliegend, nach innen sich öfnend; Staubfäden über die Staubbeutel verlängert. Fruchtknoten Ifächerig, 3klappig. Santentrüger in der Mitte der Klappen. Griffel 1, mil schräiger Narbe. Sanınkein aufrecht, in der Achse des Eiweisses. - Viola $(V, 1)$.

58. Drosernceen I) C. Kräutel zum 'Theil mit dicht besetzten, Irüsentragenden, rothen Haaren, abwechselnden Blättern, welche gleich den wurzelständigen Bluthenstielen in der Jugend schneckenförmig eingerollt sind. Blüthen zwitterig, in fast einseitigen Aehren. Kelch 5blätterig, bleibend, frei uder am Grunde ein wenig mit dem Fruchtknoten verwachsen, in der Knospenlage dachziegelig. Blumenkrone 5blätterig, regelmässig. Staubgefässe 5 oder mehre, frei, mit endständigen Staubbeuteln. Fruchtknoten 1-3fïcherig, frei. Samenträger wandständig. Griffel melıre, oft 2theilig, oder mehre sitzende Narben. Samenkein aufrecht, in der Achse des Eineisses. - Drusera $(V, 5)$ und Parnassia $(\mathrm{V}, 4)$. 
51. Cistineen Du n I. Kräuter oder Sträıcher mit meist ungetheilten, gegenständigen oder abwechselnden Blättern, mit oder whne Nebenblätter. Blüthen \%witterig, einzeln oder in einseitigen 'l'raubell, schnell verwelkend. Kelch 5blätterig, bleibend, die 2 änsseren Blätter meist kleiner oder fehlend, die 3 innelen gleich, in der Knospenlage zusammengedreht. Blumenkrone oblätterig, hinfällig, in der Kinospenlage zusammengeIreht, aber in einer den Kelchblättern entgegengesetz. ten Richtung. Staubgefässe unterstïndig. zahlreich. Griffel und Narbe einfach, abfallend. Fruchtinoten frei, selten 3 - und mehrfächerig. Kapsel entweder 1 fächerig, vielsamig, mit in der Nitte der Klappen befindlichen Samen, wder durch halbirte Scheidewände 3, veltener $\mathbf{6}$ - Iofächeriy, die Scheidewände auf der Mitte der Klappen, die Samenträger am inneren Rande dieser Scheidewände. Samenkeim gehrümmt, in dem mehligeu Eiweisse. - Helianthemum (XIII, 1).

D. Fruchtknoten einer, 1fächerig uder unterwärts mehrfächerig. Der Samenträger in der Mitte der Frucht, frei oder an die unvollständigen Zwischenwände angewachsen, aber duch oberwärts frei.

61. Sileneen DC. Kräuter orler Halbsträucher mit gegenständigen Blättern vhne Nehenblätter. Kelch einblätterig, röhriğ, an der spitze 5-6zähnig. Blumenblätter so viel als Kelchzähne, mit den in doppelter uder gleicher Anzahl als diese vorhandenen Staubgefüssen auf einem mehr oder weniger bemerlilichen Fruchtträger unter dem Fruchtknoten befestigt. Fruchtknnten frei, Ifächerig, höchstens am Grunde undeutlich mehrfächerig, oder 2-5fächerig, vun unten bis zur Mitte reichend, Fächer vieleiig, Samenträ̀er mittelpunhtständig. Griffel 2-5, getrennt. Frucht eine mit 4, 6, 8 oder 10 Zähnen aufsuringende Kapsel, selten fleischig und nicht anfspringend. Samentein um das Eiweiss gekrümmt. - Gypsophila, Dianthus, Saponaria (X, 2), Cucubalus und Silene $(X, 3)$, Lychnis und Agrostem. $\operatorname{ma}(X, 5)$.

68. Alsineen DC. Kräuter mit gegenständigen Blättern, whne Nebenblätter (mit Ausnalime von spergula und Lepigunum, welche truckenhäntige Nebenblätter hahen). Kelch 4 -5blïttcrig oder tief $4-5$ theilig. Blnmenblätter so viel als Kelchabschnitte. Staubgefässe 10 
oder zueniger, anf einem aus Driisen gebildeten, kelchstïndigen und mehr oder weniger deutlichen Ringe befestigt. Fruchtknoten frei, Ifächerig, Fücher vieleiig, Samenträger mittelpunktständig, frei. Griffel 2 bis 5, getrenut. Kapsel mit läıgeren uder kürzeren Zähnen oder Klappen anfspringent. Samrnkein um das Eiweiss gekrïnnt. - Alsine, Lapigunmm, Murehringia, Arenaria. Ifolosteum und Stellaria $(X, 3)$, Moenchia $(X, 4)$, Sagina, spergula, Malachiun und Cerastium $(X, 1)$.

171. Parouychieen st. Hil. Kränter mit gegenstïnligen Blättern und trockenliäntigen Nebenbliitlern. Blüthen klein, blattwinkel - oder gipfelständig, mit wder whne Deckblätter. Kelch 5theilis, seltener 3-4theilig, in rer Krospenlage dachziegelig, bleibend. Blumenbläter so vicl als liplehzipfel, "ff klein und Nebenstinhfüden ähnlich, dem Kelche eingefïgt. Slanbefusse su viel als Keichzipfel, mit den bl:ımenllätlern abwechselnd, oder weuiger, auf einer "ft schwachen, unterständigen Scheibe befestigt. Fruchtkunten frei, Ifärherig; Eichen zahlreich, an einem freien, nittelpunktstïndigen Samenträger, oder nur eines, an einer im Grunde des Fruchtkmotens befestigten Nabelschuur. Griffel 2-3, getrent oder unterwärts zusammengewarhsen. Samenkein an der Seite des Hiweisses. Hentiaria und lliecebrum $(\mathrm{V}, 1)$, Corrigiola $(\mathrm{V}, 3)$.

170. Portulaceen uss. Siftige Krüuter mit abwechselnileu witer gegenständigen, fleischigen, sitzenden orler kuzgestielten Blättern und truckenhäutigen oder fehlenden Nebenblättern. Kelch 2-5theilig, zuweilen unten an den Fruchtknoten angewachsen, in der Knospenlage dachaiegelig. Bumenblitter $3-6$, getrennt oder in eine hurze Röhre zusammengewachsen, oft ganz fehlend. Staubgefüsse ungleich, so viel als Blumenblätter oder weniger und ihnen gevoniiber, oder zahlreich, und in Grumde des Kelches. Fruchtkunten meist frei, oder nach unten an den Kelch gewachsen, lfächerig mit 3 oder mehren Eichen an einem freiel, mittelpunktstänıligen Samenträger. Griffel 1 oder fehlend. Samenkeim um das Eiweiss gekrïmmt. - Montia $(\mathrm{III}, 1)$, Portulaca $(\mathrm{XI}, 1)$.

132. Amygdaleen J uss. Bäume oder Strü̈cher nit abwechselnden, einfachen, yesägten, am Grunde: drüsenrandigen Blättern und abfallenden, kleinen Nebenblättern. Blüthen zwitterig, einzeln in Blattwiukeln, 
oder in Büscheln oder 'Trauben. Kelch 5lappig, abfallend, inwendig mit einer Ilonigstheibe überzogen. Blumenblätter 5. Staubgefässe 20, frei, gleich den Blumenblätlern dem Rande der Scheibe cingefiigt, in der Knuspenlage einwïrts gekrïmut. Fruchtknuten frei, If iicherig, mit 2 hängenden Eichen und einem einnarbigen Griffel. Steinfrucht mit 1, selten 2 Samen. Samenkein yerade, eiweisslos. - Persica und Prunus (XII, 1).

E. Fruchtkunten einer, mehrfächerig. Kelch in der Kinuspenlage klappig.

99. Thamneen R. H r. Strüucher oder kleine Bäume mit abwechselnden oder büschelföımiłen, selten gegenständigen Blättern und kleinen, zuweilen dornigen Nebenblättern. Bliithen zwitterig wder 2hïusig, einzeln "der in Büscheln, blattwinkel-, selten gipfelständig. Kelch an den Fruchthnoten angewachsen, 4-5lappig, Lappen abfillig. Blumenhlätter in gleicher Anzahl mit den Kelchzipfeln und mit ihnen abwechselnd, im Schlunde eingefingt. Staubgefässe so viel als Blumenblätter und ilmen gegenständig. Frurhtkuoten von einer drïsigen Scheibe unzogen, 2-4fächerig. Fächer 1eiig. Griffel 1, zuweilen bis auf den Grund getheilt. Narben 2-4. Samenkeim aufrecht, im Eiweisse. - Rhamnus $(\mathrm{V}, 1)$.

168. Lythrarieen $\mathbf{J}$ uss. Kräuter oder Stauden mit gegenstiindigen, ganzrandigen Blättern whne Nebenblätter. Blüthen zwitterig, einzeln in Blattwinkeln oder in gipfelständigen Aehren uder Tranten. Kelch röhrenförmig, gezühnt, Kelchzähne bleibend, in der. Knospenlage hlappig uder auseinander stehend; zuweilen noch ein äusserer. Kreis von kleineren, kegelförnigen, mit den Kelchzähnen abwechselnden Blättchen. Blumenblätter dem ubersten Rande der Kelchröhre eingrfïgt und mit den Kelchzähnen abwechselnd. Staubgefässe in der Röhre befestigt. Fruchtknoten frei, 2- 4 fächerig, vieleiig. Samenträger mittelpunktständig. - Griffel und Narbe einfach. Kapsel häutig, 2-4fächerig uder durch Schwindeu der Srheidewände 1 fächerig. Samenkeim aufrecht, eiweisslus. - Lythrum (XI, 1) und Peplis (VI, 1).

85. Tiliaceen Jus. Bäume mit abwechselnden, ganzrandigen Blïttern und abfallenden Nebenblättern. Bliithen zwitterig, in blattwinkelständigen Trauben. Kelch 4-5blätterig, abfallend. Blumenblätter so viel 
als Kelchblätter und mit diesen abwechselnd. Staubgefüsse unterständig, zahlreich, frei oder vielbrüderig. Staubbeutel 2 fächerig, mit Längsritzen aufspringend. Fruchtknoten 4-10fächerig, Fächer 2- bis mehreiig. Samenträger nittelpunktständig. Sanenkein gerade, in der Achse des Eiweisses. - In den Achseln der Blätter entwickeln sich die Knospen, bei welchen man fruchtbare und unfruchtbare unterscheiden kann. Die unfruchtbaren beginnen mit 2 seitlichen, sichuppenähnlichen Vorblättern und sind mit der Knospe, welche sie bergen, zum Ueberwinter'n bestinnt. Die fruchtbaren kommen dagegen in demselben Jahre, in welchem sie entstanden, zum Blïhen. Während nämlich die Hauptknospe mit dem einen Vorblatte derselben zum Ueberwintern bestimmt ist, und dieses als Knospenschuppe verharrt, entfaltet sich das andere Vurblatt, sı wie sein Achselproduct (der Blüthenzweig) un ein Jahr frïher; jenes wird zur flügelartigen Bractee, beide verwachsen unter sich eine Strecke weit. Zur Zeit der Fruchtreife gliedern sie sich $a b$ und hinterlassen eine 3seitige Narbe, welche am Zweige den überwinternden Vurblatte gegenübersteht. Der Bluithenzweig ist also rin frühzeitig zur Entwickelnng gekommener Seitentrieb der überwinternden Hauptknospe und stammt nicht mit ihr von derselben Achse ab, sondern ist ein Seitenproduct der Arhse dieser Knospe selbst. Die unfruchtbaren Knospen besitzen als schützende Decke nur die beiden schuppesı̈hnlichen Vorblätter; die fruchtbaren bringen ausser dem einen ïberwinternden Vorblatte noch 2 andere Kinospenschuppen hinzu. - Tilia (XIII, 1).

81. Malvaceen R. Br. Kräuter oder Stauden mit abwechselnden, ganzen oder gelappten Blättern und Ne. henblättern. Blüthen $\mathrm{zwitterig,} \mathrm{blattwinkel-,} \mathrm{selten}$ gipfelständig. Kelch 3-5spaltig, meist bleibend, an! Grunde gewöhnlich von einem aus verwachsenen, nur an der Spitze freien uder aus ganz freiell Deckblättern gebildeten Aussenkilche umgeben. Blumenblätter so viel als Zipfel des inneren Kielches, nit diesen abwechselnd, in der Knospeulage schraubenförmig - zusammengedreht. Staubgefäisse monadelphisch, in eine Röhre zusammengewachsen. Staubbentel 1fächerig, mit einer Querritze aufspringend. Fruchtknoten mehr-oder vielfächerig, bisweilen gelappt. Fächer 1-bis mehreiig. Samenträger mittelpunktständig. Frucht bald rielkörnig, mit freien oder durch Randtheilung sich ablösen- 
Jfu Körnern, hald hapselartig und durch Mitteltheilumg aufspringend. Eiweiss fohlend oder gering. Sanenleim gerade, mit zusanmengefalteten Keimblättern. Mialia, Althaea, Lavatera (XY1, 5).

F. Fruchthnoten einer, mehrfächerig. Kelch in der Knospenlage dachziegelig. Unterstïndige Drüsen wier Scheibe fehlend.

90. Geraniaceen DC. Kräuter mit mejst gegenständigen unteren, abwechselnden und den Blüthenstimen gegenständigen oberen, gewöhulich haulförmig - gelappten Blättern nit oder ohne Nehenblätter. Kelch 5hlätteri, bleibend. Blumenblätter 5 , nit den Kelchblättern abwech. selud. Staubgefässe unterstänrig, nuch cinmal su viel als Blumenblätter, am Grunde meist einbrïderig. Fruchtknoten 5, verwa'hsen, gedunsen, jeder mit 2 häıgenden Eichen, bei der Reife 1samig. Griffel 5, zu einem langen, schnabelförmigen Körper verwachsen, jeder am Ende des Schnabels in eine Narhe auslaufend. Klappen vom Grunde bis zur Spitze mit dem zirkel-oder schraubenfürmig-zusammengerollten Griffel von einer stehen. bleibenden Mittelsäule abspringend. Samen eiweisslus. Samenkein gekrïmmt, mit zusammengerollten wder gefalteten Keimblättern. - Geranium und Erodiun (XVI, 3).

80. Lineen C. Kräuter mit eiufachen, sitzenden, schmalen, abwechselnden Blättern whne Nebenblätter. Kelch 4-5blätterig, bleibenl. Blumenkrone 4-5blätterig, regelmässig, in der Knospenlage zusammengerollt. Staubgefässe $4-5$, mit den Blımenblättern wechselnd, an Grunde in pinen Ring zusanmengewachsen, mit 4-5 dazwischen gestellten, verkünmerten, unfruchtbaren, zahnförmigen Nebenstanbfäilen. Fruchtknoten durch $4-5$ vollständige, aus einer doppelten Haut gebildete, und eben so viele unvollständige Scheidezvïncle 8-10fächerig, Fächer mit 1,..am mittelpunktständigen Samenträger hängenilen Eichen. Griffel 4-5. Samen ciweisslos. Sanıenkeim gerade, mit flachen, elliptischen Keimblättern. - Linum (V,5), Radiola (IV, 4).

96. Oxalideen D C. Sanerschmeckende Krüuter mit zusammengesetzten, meist fingerig-getheilten Blättern ohne uder mit sehr kleinen Nebenblättern. Blüthen b]attwinkelständig. Kelch 5theilig, bleibenl. Blunenkrone regelnässig, 5blätterig, bisweilen am Grunde zusammenhängend, in der Kuospenlage zusammengerullt. Staubgefässe 10, von denen 5 grösser, 5 kleiner sind, 
am cirunde oft einbrïlerig. Fruchtknoten 5kantig, 5fiirherig. Fächer mehreiig, samenträger mittelpunhtständig. Griffel 5. Kapsel 5- oder 10klappig, 5fächerig. Samen von cincm fleischigen, elastisch-auf'springenden Mantel umgeben. Samenkeim gerade, im Eiweisse. Oxalis $(X, 5)$.

96. Balsamineen A. Kich. Kräuter mit saftigem, durchscheinendem Stengel und einfachen, abwechselnden Blättern ohne Nebenblätter. Blüthen zwitterig, in ver. kïrzten, blattwinkelständigen, oft armblïthigen 'Trau. ben. Der vollstänlige Kelch 5́blätterig, mmregelmäissig, las hintere Kelchblatt gespornt, "eit grösser als die seitlichen, die beider vorderen meist fehlend. Blumenlivone unregelmässig, Blumeublätter 5, mit den Kelchhlättern abweshselnd, das vordere am grössten, jedes ler beiden hinteren mit seinem spitlichen verwachsen. Staubgefässe 5, den Fruchtknoten dicht umgebend, oberwärts mehr oder weniger zusammengewachsen. Frucht. hnoten 5fächerig, vieleiig. Samenträger mittelpunktstündig. Narbe sitzend. Griffel fehlend. Kapsel $5 \mathrm{klap}$ pig, elastisch aufspringend. Samen eiveisslos. Samenkeim gerade. - Impatiens $(V, 1)$.

85. Hypexicineen DC. Kräuter, Sträucher oder Bäume nit harzigem Safte und einfachen, gegenstän. digen, selten abuechselulen, oft durchscheinend-punktirten Blättern ohne Nebenblätter. Blïthen zwitterig, blattwinkel - oder gipfelständig. Kelch $4-5$ theilig, blei. hend. Blumenkrone regelmässig, $4-5$ bläterig, in der linospenlage zusammengerollt. Staubgefïss zahlreich, viellriiderig, in 3 bis 5 Biindel zusammengewuchsen. Fruchtknoten vieleiig, mehrfächerig, die Eichen im inneren Winkel der Fächer wder durch verkürzte Schei. dewände, Ifticherig, die Eichen an Rande der Klappen. Griffel 3 oder 5, frei, selten zusammengewachsen. Frucht eine Kaysel oder Beere. Sanien eiweisslos. Samenkein gerade. - Hypericum (XVIII).

79. Elatineen $\mathbf{C}$ a b essè des. Wasser. oder sumpfliebende Kräuter mit gegenständigen oder quirlförmigen Blättern whne Vebeublätter. Blüthen meist zwitterig, einzelu, blattwinkelständig. Kelch 3-5theilig. Blumenblätter so viel als Kelchabschnitte und mit ihnen wechselnd. Staubgefässe so vicl oder doppelt so viel als Blumenbliitter, firei, unterständig. Fruchtknoten frei, 3-5fächerig. Fächer mehreiig. Griffel so viel als Fächer. Kapsel mit Klappen aufspringend, die 
Scheidewände mit der Achse verbunden. Samen eiweissIns. Samenkeim gerade oder gekrümms. - Elatine (VIII, 4).

303. Pyrolaceen Lind 1. (mit Ausschluss der Monotrupeen). Kiäuter mit meist wurzelständigen, lederartigen, glänzenden, blejbenden Blättern oline Neben. blätter und mit kriechendem Wurzelstuck. Blïthen in endständigen 'Trauben oder Dolden wder einzeln an der Spitze des wurzelständigen Blüthenstielchens. Kelch 5spaltig, bleibend. Blumenblätter 5, regelmässig. Staubgefässe 10, frei, unterständig, Staubbeutel ohne Anhängsel, 2fächerig, Fächer an Grunde nit einem Luch aufspringend. Fruchtknoten 4-5fächerig, veleig. Griffel 1. Narbe Slappig. Kapsel mit Ritzen fachspaltiy aufspringend, die Scheidewände nit den Klappen und der Achse verbunden. Samen sehr klein, kugelförmig, in einer röhrenförmigen, netzartigen Samenhaut eingeschlossen. Samenkeim in der Mitte des Eiw eisses. - Pyrula (X, 1).

G. Fruchtknoten einer, mehrfächerig, auf einer unterständigen Scheibe sitzend oder von unterständigen Drüsen umgebell. Kelch in der Kuospenlage dachziegelig.

88. Acerineen DC. Bäume mit gegenständigen Blättern whne Nebenblätter. Blüthen zwitterig wder 2häusig. Kelch meist 5theilig, selten 4-9theilig, am Grunde mit einer driisigen Scheibe bedeckt. Blumenblätter su viel als Kelchzipfel und mit ihnen wechselnd, am Rande der Scheibe, selten fehlend. Staubgefässe 8 , selten 5-12. Fruchtknoten 2-3fiigelig, 2-3fïcherig, Fächer 2eiig. Griffel 1. Narbe 2. Frucht in $2-3$ geflügelte Nïsse zerfallend. Samen eiweisslus. Samenkeim gekrïmt, mit zusammengerullten Keimblättern. - Acer (VIII, 1).

89. Hippocastaneen $\mathbf{D C}$. Bäume mit gegenständigen, 5zähligen oder gefingerten Blättern ohne Nebellblätter. Blüthen in endständigen Rispen mit gegliederten Blüthenstielen. Kelch einblätterig, 5zähnig. Blumenkrone unregelmässig. Blumenblätter $4-5$, lang. benavelt, an Rande einel unterständigen Sclieibe. Stanbgefässe $7-8$, frei, ungleich, der Scheibe eingefügt. Fruchtknoten 3fächerig, Fächer mit 2 aufrechten Eichen. Kapsel kugelig oder birnförmig, 1-3samig. Samen nit einem breiten Nabel, eiweisslos. Samenkeim ge- 
krünmt. Keimblätter zusammengewachsen, mit einer Spalte an Grunde, aus welcher das Federchen heraustritt. - Esculus (VII, 1).

89. Ampelideen $\mathrm{K}$ un b. Fonp 1. und Kunt. Windende, rebenartige Sträucher mit angeschwollenen Stengelknuten und mit Wickelranken, welche den Blättern gegenüberstehen. Blätter unten gegenständig, oben abwechselnd, einfach orter getheilt, mit Nebenblättern. Kelch fehlend oder 4-5zähnig, am Rande einer unterständigen Scheibe. Blumenblätter $4-5$, mit den Kelchzähnen abwechselnd vider eben so viel Blüthenhuillblätter, in der Knospenlage hlappenartig. Staubgefäisse so viel als Blumenblätter, vor ihnen stehend und mit schuppenförnigen, fleischigen Nebenstaubfäden abwechselnd. Fruchtknoten frei, 2 fächerig: Fächer nit 2 aufrechten Eichen. Griffel und Narbe einfach. Frucht eine Beere. Samenkein gerade, mit Eiweiss. - Ampelopsis und Vitis $(\mathrm{V}, 1)$.

99. Celastrineen R. B r. Sträuchel vd॰r Bäume mit abwerhselnden wder gegenständigen, einfachen oder zusammengesetzten Blättern mit oder whe Nebenblät. ter. Blïthen meist zwitterig in blattwinkelständigen Büschelı oder endständigen, langgestielten 'Tranben. Kelch 4-5spaltig, an seinem Grunde eine fleischige, unterstiindige Scheibe. Blumenblätter 4-5. Staubgefässe ebcn so viel, mit den Blumenblättern abwechselnd und mit diesen dem Rande der Scheibe eingefügt. Fruchtknoten 2-4fächerig, Fächer 1 - oder mehreiig. Samenkeim gerade, nit und ohne Eiweiss. - Eronymus $(\mathrm{V}, 1)$.

98. Rutaceen Juss. Kräuter oder Sträucher mit gegenständigen oder abwechselnden, oft durchscheinend. punktirten Blättern whne Nebenblätter. Blïthen zwitterig. Kelch 4-5theilig. Blumenblätter von gleicher Zahl der Kelchzipfel und mit ihnen abwechselnd, oder doppelt so viel. Staubgefässe so viel als Kelchzipfel uder doppelt so viel, auf einer unterständigen Scheibe stehend. Fruchtknoten 3-5lappig. Fächer mit 2-4 Eichen an mittelpunktständige: Samenträger. Griffel 1, aus der Mitte der Fächer hervorgehend. Narbe einfach. Kapselfächer innen an den Nähten oberwärts aufspringend. Samen mit fleischigem Eiweisse. Samenkeim gekrïmmt oder gerade. - $\operatorname{Ruta}($ VIII, 1), Dictamnus $(\mathrm{X}, \mathrm{1})$.

305. Monotropeen Nutt. Den Orobancheen ähn- 
liche, auf Baunwureln schmarotzende, fleischige, blattlose, mit Schuppen belleidete, nicht griine Kräuter. Bliithen in endstiudigen, meist nickenden Aehren. Kelch sblätterig, bleibend, an cien seitenständigen Blüthen meist von unregelmässigen Schuppen ersetzt. Blumen. krune 5blätterig, unterständig, vertrochnend, bleibend. staubgefïsse firei, doppelt so viel als Blumenblätter, wovun bei der einheimischen Art jo in den Einschnitten cler driisenartigen Antiängsel am Grunde des Fruchibodens stehen und mit den Blumenblättern abwechseln, während die ïbrigen 5 mit den Anhängseln abwechseln. Stanbbeutel Ifücherig, durch eine Querspalte in 2 Klappen aufspringend. Finchthnuten frei, halb 5fächerig. Kapsel 5klappig; Klappen in der Nitte mit einer unvoll. ständigen, am Grunde einem 5kantigen Säulchen angefiigten scheidewand. Griflel 1; Narlue gross, trichterförmig. Simen zahlreich, fast hugeltörmig, von einer röhrenförnigen, "uetzartigen Samenlant eingeschlossen, viel hleiner als die Samenhaut. - Monotropa $(X, 1)$.

11. Unterabtheilıng. Blüthen vollständig, vielblätterig, oberständig.

1. Fuchtkuoten einfächerig. Frucht saftig.

176. Grossularicen $\mathbf{b C}$. Sitrauchartige, zuweilen mit Stacheln versehene. Gewächse mit abwechselnden, handförnig-gelappten Bläıtern ohne Nebenblätter. Blüthen meist zwitterig, in blattwinkel- und endständigen 'Trauben. Kelch mehr oder weniger mit dem Fruchtknoten verwachsen, mit einem 4-5spaltigen, abwelkenden saume. Blumenblätter $4-5$, den Schlunde des Kelches eingefügt mul mit dessen I appen, sowie mit den 4 - 5 freien Staubgefässen abwechselnd. Staubbeutel 2 fächerig, der lï̈nge nach einwärts anfspringend. Fruchtknoten einfücherig, mit viclen an den beiden wand. umd gegenständigen Samenträgern befestigten Eichen. Griffel 2, selten $3-4$, am Grunde mehr oder weniger rerwachsen, mit einfacher Narbe. Frucht eine mit dem bleibenden, verwelkenden Krlche gekrönte, vielsamige Beere. Samen an einem langen Nabelstrange, mit hornartigem Eiweisse. Samenkeim sehr klein, an der Spitze des Samens. - Ribes $(\mathbf{V}, \mathbf{1})$.

208. Loranthaceen $\mathbf{D}$ on. Kleine, sehr verästelte, auf Baumen und Sträuchern schmarotzende, holzige Gewächse mit meist gegenständigen, ungetheilten, ledes- 
artigen Blättern ohne Nebenblätter. Blüthen getrennten Geschlechts oder zwitterig, blattwinkel-oder endstïndig, einzeln oder in Trauben. Kelch mit dem Fruchtknoten verwachsen, aus hleinen Zähnen oder blus aus rinem etwas hervortretenden Rande gebildet. Blumenkrone 4-8theilig oder 4-8blätterig, in der. Knuspen. lage klappenartig, zuweilen fehlend. Slaubgefässe so viel als Blumenblïtler und diesen gegenständig, frei oder mit den Staubbeuteln anf den Blumenblätern sitzend. Fruchthnoten Ifächerig, mit einem aufrechten Eichen. Griffel verlängest, mit hopfförmiger Narbe oder sehr kurz und mit scheibenförmiger Narbe. Frucht pine einsamige Beere. Eiweiss fleischig. Samenkein ungehehrt. - Viscum (XXII, 4).

B. Fruchtkmoten $1-2-4$ fächerig. Staubgefässe so viel als Blumenblätter, oder doppelt so viel. Frucht bei den einheimischen Arten trochen, vielsamig.

178. Saxifrageen ent. Unsere Arten krautartig, mit einfache⿰, abuphselnden, selten gegenständigen Blätterı, meivt whne Nebenblätter. Blüthen zivitterig, einzeln oder in 'Trauben und Rispen. Kelch 4-5lappig, bleibend, meist mehr oder weniger mit dem Fruchtknoten verwachsen. Blumenblätter $4-5$, grleich den Staubgefüssen dem Kelche eingefïgt, mit den Kelchlappen abwechselnu, in der Knospenlage dachziegelig, selten fehlend. Staubgefässe frei, in gleicher odeo" doppelter Anzahl mit den Blumenblättern. Fruchthnoten vicleiig, 2schnuilelig, 1-2fücherig, die Sr.heidewände durch die einwärts gelogenen Klappen yebildet; die Samenträger bei dem 2tächerigen fruchtknoten mittelpunktständig, bei dem Ifächerigen an Rande der Klappen. Narbe an der Spitze der Schnäbel des Fruchtknotens schief - aufgewachsell. Frucht eine am inneren Rande der Schüibel aufspringende Kapsel. Samenkeim in der Mitte des Eiweisses: - Saxifraga $(X, 2)$, Chry. sosplenium (VIII, 2).

159. Onagrarieen $\mathbf{J} \mathbf{s}$ s. Kräuter oder Halbstrüucher mit meist gegenständigen, einfachen, ganzrandigen oder gezähnten Blättern ohne Nebenblätter. Blï. then zwitterig, blattwintiel - oder gipfelständig. Kelch uit dem Fruchtknoten rerwaclisen, oft ïber denselben verlängert, mit meist 4-, selten 2theiligem, in der Knospenilage klappenartigem Saume. BInmenblätter von 
gleicher 'Zahl der Kelchbläter und mit diesen abwechselnd, nebst den Staubgefüssen dem Kelche eingefügt, in der Knospenlage zusammengedreht. Staubgefässe in sleicher oder duppelter Anzahl mit den Blumenblättern oder nur halb so viel. Iruchthnoten 2-4fächerig, Fä. gher 1 - bis vieleiig. Samenträger mittelpunktständig. Griffel 1, fadenfö:mig, mit kopförmıger uder gespal. tener Narbe. Samenkeim gerade, eiweisslos..- Epi. lobium und Oenothera $(V 111,1)$, Circaea (II, 1), Trapa (IV, 1).

C. Fruchtknoten 2-4fächerig. Staubgefässe su vicl als Blumenblätter, uder doppelt su viel. Frucht in 2-4samige Frichtchen sich trennemi.

150. Umbelliferen Juss. Ein - und 2jährige oder ausdanernde Kräuter mit hohlem oder von eimem Marke angefüllten, walzenförmigem, kantigem oder gefurch. ten stengel, meist abwechselnden, mehr udel weniger getheilten Blättern, deren Stiele am Grunde scheilenartig sind. Bliithen zwitterig, in einfachen oder zusammengesetzten Dolden (umbellae simplices v. cumpusitae), welche an Grunde gewöhnlich nit einer aus Deckblättern gebildeten Hiille (involucrunı) ungeben sind. Steht diese Hülle am Grunde der aus der Spitze des Stengels nder der Zweige unmittelbar hervorgehenden Blüthenstiele (Strahlen, radii), so heisst sie die geneinschaftliche Hülle (involucrum universale), bildet sie dagegen die Deckblätter vun den kleinen Döldchen (umbellulae), welche an der Spitze dieser Blüthenstiele stehen, so wird sie besondere Hülle (involucrum partiale, Hüllchen, involucelluni) genannt. Kelchröhre an den Fruchtknoten angewachsen, mit 5zähnigen oder ungetheiltem Saume. Blumenblätter 5, ganzrandig, ausgerandet uder 2 lappig, gewöhnlich an der Spitze mit einwärts gebogenen Läppchen; die üusseren Blumenblätter länger (strahlend), alle dem Kelche eingefiigt und mit den Kelchlappen abwechselnd. Staubgefässe 5, hinfällig, mit den Blumenblättern abwechselnd und gleich diesen in der Knospenlage ein wärts gerollt. Fruclitknoten 2fächerig, jedes Fach mit einem hängenden Eichen; sehr selten Ifächerig. Griffel 2, jeder am Grunde in eine oberständige Scheibe emveitert, welche die Spitze des Fruchtknotens bedeckt und Stempelpolster (Griffelfuss, stylopodium) genannt wird. Die Frucht besteht aus 2 von unten nach oben sich trennenden, an der Spitze einer 2spaltigen oder 2theiligen Achse hängenden Halb- 
frïchtchen (mericarpia); diese Halbfrichtchen sind mit dem Fruchtgehäuse verwachsen, oder selten frei. Samenkeim sehr klein, in der Spitze des grossen Eiweisses.

Die prwähnten Halbfrüchtchen besitzen eine Fugenfläche (planum comnissurale), mit welchel sie sich vor der Reife mehr uder weniger berïhren und eine der Fugenfläche entgegengesetzte, meist gewölbte Fläche, welche der Rücken (dorsum) genannt wird. Dieser hat bei jeilem Halbfrüchtchen 5 mehr oder weniger deutliche Iängstiefen vder Kippen (costise, juga), welche Hauptrippen (juga primaria) heissen. Die mittelste dieser Hawptrippen bildet den Kiel (carina) und führt den $\mathrm{Na}$ men Kielrippe (jugum carinale), während die ïbrigen zu briden Seiten des kieles liegen. Dir 2 äussersten bilden gewöhnlich den Rand; zuweilen liegen sie jedoch rur dem Rande und sogil anf der rugenseite. sie " ̈̈brigen, zwischen Kiel und Rand liegenden, Mittelrippen (juga intermedia) heissen. Bisweilen finden sich noch 4 Nebenrippen (juga secundaria) zur Seite der Hauptrippen, mit welchen sie abwechseln. Die zwischen den Hauptrippen liegenden, rinnenartigen Vertiefungen werden Thälchen (valleculae) genannt. Unter der Oberfläche dieser 'I'hälchen liegen ölführende, wenig vorspringende Kanälchen (Stritmen, vittae), "Ielche newöhnlich erst durch einen Querschnitt sichtbar werden. Die Berührungs. ouler Fugenfläche ist nach der Gestalt des Eiweisses entweder eben, wie bei den meisten Doldenfrüchten, welche dann flachfugige, geradsamige (orthuspermae) genannt werden, witer durh Einwärtsbiegung der Seitenränder der Iänge nach vertieft (vertieftugige, gefurchtsamige, campyluspernae), uder endlich durch Einwärtsbiegung der Spitze und des Grundes längs dem Querdurchmesser ausgehöhlt (gekrümmtfugige, huhlsamige, coelospermae). - Die hierher gehörigen Duldengewächse strhen bei I,inné in der 5. Klasse 2. Oidnung.

164. Halorageen $R$. B r. Krantartige Wasserpflanzen mit quirlförmig gestellten, gefiederten Blätteru ohne Nebenblätter. Blïthen sehr klein, einhäusiğ, blatt"inkelständig uder in endständigen tehren. Kelclıröhre an dcn Fruchthnoten angewachsen, mit einem 3-4thei. ligem Saume. Blumenblätter s" viel als Kelichlappen und mit ihnen abwechselnd, den Rande des Kelches

f a reke, Flora. $7 \mathrm{~A}$. 
eingefügt. Staubgefässe in gleicher oder doppelter $\Lambda \mathrm{n}$. zahl mit den Blumenblättern. Fruchtknoten 1-4fäche. rig, Fächer eineiig. Samentrïger mittelpunktständig. Griffel fehlend. Narhen so viel ials Fürher des Frucht. knitens, sitzend, warzen - oder pinselförmig. Frucht bei der einheimischen Gattung in 4 Theilfrichte zerfallend. Samenkeim iufrecht, im Mittelpunkte des Eiweisses. - Myriophyllum (XXI, 5).

D. Fruchtknoten 2- bis vielfächerig, Fächer mit pinem Eichen. Frucht sich nicht trennend. Staub. gefässe von gleirher oder duppelter ' $/$ ahl der Blumenhlätter.

207. Araliaceen Juss. Bämme oder hletternde Sträucher mit abwerhseluden, gestielten Blättern whne Nebenblätter. Bliithen meist zwitterig, in Dulden oder Köpfchen. Kelch ganzrandig oder 4-5zähnig, mit dem Fruchthnoten verwachsen. Blumrnblïtter 5-10, init breitem Grunde anf dem Rande puner oberständigen Scheibe sitzend, in der Knospenlage Klappenartig. staubgefässe gewöhnlich 5 , oder in gleicher $/ / a h l$ nit den Blumenblättern und mit ihren abwechselnd. Frucht. knoten 2- bis mrhıfächerig; Fächer mit einem hängenden Eichen. Griffel 1 oder mehre. Frucht cine Beere mit 2-10 Fächern. Samen hängend. Samenkein aufrecht, im Mittelpunkt des Eiweisses. - Hedera $(V, 1)$.

207. Corneen DC. - Bäıme oder sträucher mit gegenständigen, ganzrandigen Blätter oline Nebenblätter. Blithen zuitterig, selten 2 häusig, in Dulden oder 'Trugdolden. Kelch 4 zähini., mit den Fruchthnoten verivachsen. Blumenblätter 4, nit breitem Grunde, anf dem Rande einer uberständigen Scheibe sitzend. in der Knospenlage klappenartig. Stanbyefässe 4, mit den Blumen. blättern abuechselnd. Griffel 1, mit kupfförmiger Narhe. Irucht eine Stcinbcerc. Steinchen 2fächerig. Samen hängend. Samenkẹn anfrecht, im Mittelpunkte des Eiweisses. - Cornus (IV, 1).

E. Fruchtknoten 2- bis mehrfächerig. Staubgefässe 4 mal su viel als Blumenblätter oder mehr.

156. Pomaceen Lind 1. Sträucher uder Bäume mit abwechselnden uder büschelförmigen Blättern und Nebenhlättern. Blüthen zwitterig. Kelch 5spaltig nder 5zühni r, vertrucknend, in der Knospenlage dach ziegelig, die Köhre mit dem Fruchtknoten verwachsen. Blumen- 
hlätter 5, mit den Staubgefüssen dem Kelchschlunde eingefügt. Staubgefässe 20 , frei, in der Knospenlage einwälts gekrïmmit. Fruchtknoten 2-5fächerig, Fächel mit 2 oder mehren, anfrechten Eichen. Samenträger mittelpunktständig. Griffel so viel als Fächer des Fruchtknutens. Frucht fleischig, beeren-, apfeloder steinfruchtartig, nit dem bleibenden Kelche gekrönt und eine Kapsel enthaltend, deren Fächer 1- bis 2 klappig sind. Klappen aus einer sehr zarten, weichen, kaum sichtbaren, wder einer papier-, knorpel-uder knochenartigen IIaut bestehend. Samenkeim aufrecht, eiweisslos. - Crataegus, Cutoneaster, Mespilus, Cyduuia, Pyrus und Sorbus (XII, 2).

II. Unterabtheilung. Blüthen vollständig, einblätterig, wberständiğ.

A. Staubgefässe auf dem Ende des Fruchtknotens vor den Blumenblaittern eingefügt.

169. Cucurbitaceen Iuss. Krüuter mit kletterudem Stengel, wässerigem Safte und spiraligen Ranken. Blätter alswerhselnd, saftig und gleich dem Stengel oft mit kurzen. stejfen Haaren bedecht. Blïthen 1-oder 2häusig, selten zwitterig, einzelı oder in Büscheln, blattwinkelständig. Kelch 5zähnig, röhrig, oberstäudig. Blumenkrune 5zähnig, regelmässig, am Grunde mit den Kelche verwachsen und wie dieser abfällig. Staubge. fässe 5, 1-3brïderig, mit freien oder unter sich verwachsenen Staubbuteln, selten piit freien 'Trägern. Staubbentel verschieden gedreht oder gebogen. Griffel 1, Narben 3-5, lick, 2lappig. Fruchtkmoten 3-5fächerig. Samenträger Wandständig, an den äusseren Winkein der Färher. Frucht fleischig, beerenartig, mit mehren oder vielen Samen. Samenkeim gerade, eiweisslıs. - Cururbita, Cucumis und Bryonia (XXI, 9).

296. Campanulaceen Jus $\mathbf{s}$. Kräuter oder Stauden, gewöhnlich rinen bittern Milchsaft führend, mit abwechselnden Blättern ohne Nebenblätter. Blüthen zwitterig, in den Blattwinkeln oder in endständigen Büscheln, Aeh. ren oder Trauben, mit Deckblättern versehen. Kelch wherständig, 5 spaltig, bleibend, auf dem Rande einer becherförnigen Scheibe stehend. Blumenkrone reoplmässig, selten unregelmässig, veruelkend. Staubgefässe 5, meist am Grunde verbreitert, vor der Blumenkrone dem Rande der Scheibe eingefiigt und mit den Kron- 
zipfelu ahwechselnd. Staubheutel 2fächerig, zuweilen ain Grunde in eine Röhre zusammenklebend. FruchtLnoten 2-8fächerig, Jächer vieleig, Samenträger mittelpunhtstänlig. Griffel 1, Narbe $2-8$ spaltig, nackt. Fruchl eine 2 - 8fächerige kapsel. Samenhein anfrecht, in der Vitte des Eiweisses. - Jasione, Phytemma, Campanula und specularia $(V, 1)$.

301. Vaccinieen DC. Kleine, gerbestuffhaltige, stranchartige Gewächse mit abwechseluden, einfarhen, ganzrandigen, lederartigen Blättern ohne Nebenblätter. Bliithen zwitterig, einzeln in Blattwinkeln oder in eniständigen 'Trauben, mit Deckblättern versehen. lielch halbuberstäudig, 4-5zähnig oder ganzrandig. Blumen. hrune glorkenförnig, 4-5lappiy, regelmässig, abfäl. lig. Staubgefüsse nit den Kronlappen abwechselnd wder doppelt su viel, am Rande einer getierblen Schcibe stehend, mit der Blumenkrone nicht verwachsen. Stauh. beutel 2fücherig und auf dem Rüchen meist 2hörnig. Fruchtkuoten 4-5färherig, Fächer mehreig. Samen. träger mittelpunktständig. Griffel und Narbe einfarh. Frucht eine Beere. Samenteim in der Nitte des Hi"leisses. - Vaccinium (VII, 1).

B. Staubgefässe in der Röhre der Blumenkrone oder zwischen den Zipfeln des Saumes ein. gefiigt.

226. Compositen dans. (Synanthereen Rich.) Eine der natïrlichsten und $z$ ahlreichsten Familien. Kíäu. ter oder Stauden mitomeist abwechselnden Blättern ohne Nebenblätter. Blüthen (flosculi Li nn.) meist klein, zwitterig oder getrennten Geschlechts, in grösserel oder geringerer Zahl auf einem gemeinsihaftlichen, nackten wder mit Spreublätchen (paleae) versehenen Blïthenboden (receptaculum commune oder rachis Lessing, clinanthium Cassin.) in ein Köpfchen (capitulum, flos communis I., Blüthenkorb, calathidium Cassin.) dicht zusammengedrängt und von einer vielblätterigen Hiille (involucrum, periclinium Cassin., calyx communis I,inn.) umgeben. Bisweilen hat jedes einzelne Bliith. chen noch einen besonderen Hüllhelch. Der Kelclı (ca. lyx proprius) jerles einzelnen Blüthchens besteht aus eincer auf lem Rande des Fruchtinotens befestigten Röhre, deren freier Samm in Borsten, Haare, Schuppen, Federchen (daher Federkelch, Samenkrone, pap. pus genannt) tief getheilt, zuweilen häutig nnd unge- 
theilt, selten undeųtlich ist. Blumenkrone einblitteriğ, dem Rande des Fruchtknotens eingefiigt; Saum entweder re „elmässig, 5spaltig, in ler Knuspenlage klappenartig, oder muregelmässig 2lippig und zungenförınig. Staubgefässe 5, der Blumenröhre eingefïgt und mit den Zipfeln derselben abwechselnd. Staubfäden frei. Staubbeutel linienförnig, in eine den Griffel umgebende Röhrc zusammengewachsen, nach innen aufspringend, an der Spitze stets mít einen, an Grunde oft mit 2 Anhängseln versehen. Fruchtknoten Ifächerig mit 1 aufrechten Eichen. Griffel 1, an Grunde von einer Honiggrube umgeben; Narben 2. Frucht eine trockene Schliessfirucht (achaenium, nicht achenium, denu das Wort kominit roul (e priv. und zciew, klaffen), nicht aufspringend, eiwrisslus. Samenkeim aufrecht. - Hierher gehören sämutliche Pflanzen aus der 19. Klasse bei I, in

295. Ambrosiaceen Link. Klettenartige Kräuter mit abwechselnden, gelappten oder getheilten Blättern. Bliithen getrénnten Geschlechts, die männlichen an den Zweigen in len endständigen Köpfchen und von einer vielblätterigen oder vieltheiligen Hülle unigeben. Blumenkrone trichterförmig - röhrig, mit 5zähnigem, in der Kunspenlage klappenartigem Saume. Staubgefässe 5, dem Grunde der Blumenkrone eingefügt und mit dessen Saumlappen abwechselnd, frei oder mit verwachsenen 'Jrägern. Staubbeutel fiei. Griffel 1, fadenförmig, mit einer dicken, ungetheilten Narbe. Fruchtkuoten des männlichen Blïthe sehr klein, frei, unfruchtbar. Weibliche Blüthen blumenblattlos, einzeln oder mehre in ein figenes, zuletzt nussartiges und knöchernes Hüllchen eingeschlussen. Griffel 1. Narben 2. Fruchtknoten Ificherig, leiig. Frucht cine truckene, von der verhïrteten Hiille umgebene Schliessfrucht. Samenkein gerade, eiweisslos. - Xanthiun (XXI, 5).

211. Stellaten L. (Rubiaceen DC.) Kräuter (bei den nicht einheimischen Arten auch Strüuchel und Bäume) init quirlförmigen oder gegenständigen, einfachen, ungetheilten Blättern; die gegenständigen mit Nebenblättern, die quirlförmigen ohne dieselben. Blüthen zwitterig, selten getrennten Geschlechts. Kelch oberständig, mit 4-6lappigem oder undeutlichem und bei der Fruchtreife verschwindendem Saume. Blumenkrone einblätterig, 4-6spaltig, denı Fruchtknoten eingefügt, in der Knospenlage klappenartig. Staubgefässe zwischen den Zipfeln der Blumenkrone eingefügt, in gleicher Zahl 
mit den Kronabschnitten und mit ihnen abwechselnd. Fruchthoten 1, oft ans 2 verwachsenen bestehend, Ifücherig; Fücher mit einem aufrechten Lichen. Griflel einfach, oft 2spaltig. Narben 2. Iriichtchen 2, trucken uler beerenartig, zuletzt sich theilend. Samenkeim aufrecht, in der Mitte des hurnartigen Eiweisses. - Sherardia, Asperula und Galium $(I V, 1)$.

20S. Caprifoliaceen $\mathbf{J}$ us. Sträncher, selten Bäuwe und Kräuter nit gegenständigen, einfachen wile gretheilten Blüttern, selten mit Nebenblättern. Blüthen zwitterig, einzeln oder paarweise in Blattwinkeln oder in endständigen Trugdolden und Ebensträussen. Kelch uberständig, mit $2-5$ spaltigem vder fast ungetheiltem Saume. Blumenkrone uberstäudig, mit 4-5spaltigem. in der Knospenlage dachziegeligem Saume. Staubge. fässe der Kromrölire eingefugt und mit deren Lappen abwechselnd, in gleicher oder duppelter Zahl mit den Kronabschnitten, oder 4, didynamisch. Fruchthnoten 2-5/ächerig; Fächer mit 1 oder mehren hängenden Eichen. Griffel 1 oder mehre, zuweilen fehlend. Narbe ungetheilt, zuweilen 3-5lappig. Frucht cinc Beere, zuweilen trocken, Ifacherig, zuweilen aus 2 verwachsenen Fruchthnoten gebildet und von 2 Kelchen gekrönt. Samenkeim gerade, in der Mitte des fleischigen. Liweisses. - Aduxa (VIII, 4), Sambucus und Viburmum $(V, 3)$, Lonicera $(V, 1)$.

219. Valerianeen DC. Kräuter oder Stauden mit gregenständigen Blättern ohne Nebenblätter. Bliithe॥ zwitterig oder vielehig, selten 2häusig, in kopfförmigeu Kuäueln, 'Trugdulden oder Rispen. Kelch oberständig. mit einem nach innen eingerullten und bei der Fruchtreife einen Federkelch bildenden, oder gezähnten, oder endlich undentlichen saume. Blumenkrune oberständig, am Grunde zuweilen höckerig oder gespurut, mit einem 3-5spaltigen, etwas ungleichen wder unregelnıässigen, in der Knospenlage dachziegeligen Saume. Staubgefässe der Krunenröhre einıefiigt, fïei, 4 uder weniger. Staubbentel frei. Fruchthnoten mit 3 Fächern, wovun nur eins fruchtbar ist und eiı hängendes Eichen einschliesst. Griffel 1 mit mngetheilter oifer 3 spaltiger Narbe. Frucht trocken, nicht aufspringend, lederartig oder häutig. Samen eiweisslus. Samenkein aufrecht. - Valeriana und Valerianella $(I I I, 1)$.

223. Dipsaceen I C. Kräuter ader Stauden mit ge. genständigen Blättern uhne Nebenblätter. Bliithen klein, 
zwitterig, in verschiedener Anzahl anf einem gemeinschaftlichen, "ackten wder durch die Deckblättrhen der einzelnen Blïthen spreublätterig erscheinenden Blüthenbuden in ein dichtes Köpfchen vereinigt, welches am Grunde vul einer vielblätterigen, ans unfruchtbaren Deckblättern bestehenden Hülle (involucrum oder calyx conumunis l,inn.) umgeben ist. Kelch doppelt, bleibend, der innere endlich mit dem Fruchtinoten verwachsend. Blumenkioue dem Rande des inneren Kelches eingefügt, röhrig, mit 4-5spaltigem, in der Knospenlage dachzicgeligem Samme. Stauhgefässe 4, frei, ler Krunröhre eingefügt. Stauhbeutel frei. Griffel und Narbe einfach. Fruchtknoten l/ächcrig, mit einem hänyenden Eichen. Frucht häutig odel fast nussartiy, nicht anfspringend. mit dem Rande des innern Kelches gekrönt und vom iinsseren eng eingeschlossen. Samen mit Eiweiss. Sampoleim aufereht. - Dipsacus, Knantia, Succisa und scabiosa (IV, 1).

I. Unterabtheilung. Blüthen vullständig, einblätterig, unterständig.

A. Fruchtknoten 4 uder 2 , auf einer unterständigen Nicheibe sitzend. Griffel 1, vermittelst der Scheibe mit dem Fruchthnoten zusammenhän. gend.

314. Toragineen Desv. Ḱräuter (bei den ausländischen Arteı auch Sträucher und Bäıme) gewöhnlich mit steifen Haareı besetzt md mit abwechselnden Blät. tern whe Nebenblätter. Blüthen zwitterig, blattwinkel-oder enilständig, in Aehren, Köpfchen, Trauben oder Kispen. Kelch getheilt oder gezähnt, bleibend. Blumenlirone mit 5theiligen Saume, regelmäissi. oder unglcich, der Schlund oft durch 5 hohle Höckerchen geschlosien. Staubgefässe 5, der Blunenkrone eingefügt und mit ihren Zipfeln abwechselnd. Fruchtknoten Pntweder 4, frei, auf einer unterständigen, fleischigen Scheibe (gynubasis), einfächerig, eineiig, oder 2 , zweifächerig, zweieiig, oder selten mur 1 ungetheilter Fruchtknoten, bei der Reife in 4 'Theilfruchtchen zerfallend. Griffel 1, aus der Mitte der Fruchtknoten hervortretend. Theilfrüchtchen vom Kelche eingeschlossen. Samenheim geralle, eiveisilıs, mit blattföımigen Keimhlätterı. - Asperugo, Echinuspermum, Cynoglıssun, Borago, Anchusa, Lycupsis, Nonnea, Synuhytum, Echium, Pulmonaria, Lithospernum und Myosotis $(V, 1)$. 
353. Labiaten I us. Eine der natiulichsten Familien. Kräuter, seiten Sträucher mit mejst 4 kantigem Stengel und gegenständigen, einfachen liattern ohne Nebenblätter. Blüthen zwitterig, einzeln oder quirl. förmig in den Blattwinkeln uder in endständigen Köpfchen wder Aehren. Kelch röhrig, bleibend. Blumen. lrone unregelmäissig, meist rachenjürmig. Staubge/ässe 4, ziveimaichtig, oder 2. Fruchtlinoten 4, frei, eineiig, einer unterständigen, fleischigen Scheibe (gynobasis) eingefügt. Griffel 1, aus der Nitte der Fruchtknoten hervortretend. Die Frucht aus 4 , von dem Kelche eingeschlossenen 'Theilfrüchtchen bestehend. Samenkeim aufrecht, ejweisslos. - Hierher Lycopus und Salria (II, 1) und sänmtliche Pflanzen aus der Didynamia Gymnospermia (XIV, 1).

B. Fruchtknoten einer, 1fächerig, 1eiig.

386. Plumbagineen Juss. Kräuter mit abwech. seluden, gauzrandigen, am Grunde den Stengel mit ihrer Scheide ungebenden Blättern. Blïthen $\mathrm{zwitterig,}$ in Köpfchen. Kelch rölırig, mit 5zähnigem Saume, gefaltet, bleibend. Blumenhrone einblätterig, regelmässig 5theilig viler 5blätterig. Staubgefiisse 5, bei der einblätterigen Blumenkrone unterstiindig, bei der 5blätteriyen den Blumenblattnägeln eingefïgt; in der linospen. lage gerale. Fruchtinuten frei, lfächerig; Fächer mit einem an der Spitze einer langen Nabelschnur hängenden Eichen. Griffel oder Narhen 5. Kapsel bei der einheimischen Gattung nicht aufspringend. Samenkeim gerade, im fleischigen Eiweisse. - Statice (Armeria) ( $\mathrm{V}, 5)$.

385. GIobularieen DC. Strüucher oder ausdauernde Kräuter mit wurzelständigen odel abwechselnden Blättern whne Nebenblätter. Blïthen zwitterig, anf einen mit Spreublättchen besetzten Blüthenboden in ein kugeliges Köpfchel dicht zusammengedrängt, welches von einer gemeinschaftlichen Fïlle umgeben wird. Kelch 5theilig, in der Knospenlage dachzicgelig; bleibende Blumenkrone röhrig, mit 2lippigem Saume; Oberlippe kleiner, 2spaltig, Unterlippe 3spaltig. Staubgefäisse 4, der Kronröhre eingefiigt und mit den Kronabschnitten abwechselnd; das fünfte Staubgefäss fehlend. Fruchtknoten frei, Ifächerig; Fächer mit einem hängenden Eichen. Griffel einfach, mit einfacher, selten mit gespaltener Narbe. Frucht schlauchartig, nicht aufsprin- 
gend. Samenkein gerade, im fleischigen Eiweisse. Glubularia $(I V, 1)$.

C. Fruchthnoten einer, Ifächerig, mehrsamig. Samenträger mittelpunktständig, frei.

386. Plantagineen J uss. Kräuter oder Stauden mit unterirdischem oder sehr hurzem uberirdischem Stengel und oft gegenständigen, meist ungetheilten Blättern whe Nebenbliitter. Bliithen zwitteriy oder (bei Littorella) getrennten Geschlechts, in dichten Aehreu mit Deckb ättchen versehen. Kelch 4theilig, bleibend. Blumenkrone 4spaltig, regelmüissig, trockenhïiutig. Staubgefässe 4, mit den kironabschnitten abwechselnd, der Blumenröhre oder (bei Littorella) dem Blüthenboden ringefügt, hei der Kinospung einwärts gebogen. FruchtLnuten frei, Ifächerig, mit einem aufrechten Eichen, wder 2-4färherig, mit 1 oder mehren an den Winkeln eines 2-4fliigeligen, mittelpunktstänligen Samenträgers befestigten Eichen. Griffel 1. Narbe lang, fadenförmig. Frucht nuss - oder kapselartig. Samenkeim gerade, in der Mitte des dicht-fleischigen Eiweisses. Plantag" (IV, 1).

379. Primulaceen vent. Kräuter oder Stauden mit meist gegenständigen uder quirlförmigen Blättern. Blüthen zwitterig, blattwinkel- oder endständig, einzeln oder in Aehren oder Ebensträussen Kelch 4כzähnig oder 4-5theilig, bleibend. Blumenkrone re. gelmaiissig. 5-, selten 4spaltig. Staubgafässe 5, selten 4 , der Binmenkrone eingefügt und ihren Abichnitten gegenïberstehend (hei Samolus und Lysimarhia finden sich noch 5 nit den Kronabsrhnitten abwechselnde Nebenstaubfäden). Fruchtknoten frei, 1fächerig, mit vielen an einem freien, mittelpunhtständigen, walscnföro. migen Samentrïger sitzenden Eichen. Griffel und Narbe einfach. Frucht eine Kapsel. Samen schildförmig Samenkein gerade, in einem fleischigen Eiweisse. 'Trientalis (VII, 1), Lysihachia, Anagallis, Andrusace, Hottonia, Samolus, Glaux und Primula $(V, 1)$, Centunculus $(I V, 1)$.

378. Lentibularieen Rich. (Utricularieen Link). Wasser-oder Sumpfpflanzen nit einfachen oder vielfach fein-zertheilten, blasentragenden Blättern und einem meist einfachen, an der Spitze ein-oder mehrblïthigen Schafte. Blüthen zwitterig. Kelch getheilt, bleibend. Blumenkrone unregelmässig, 2lippig, gespornt. 
Staulgefässe 2, dem Grmule der Blumenkrume eingefiigt. Frnchtkonten frei, lfärherig, mit vielen an einem freien, mittelpunktstindigen, walzenförmigen Samenträger hefindlichen Eirhen. Griffel 1. Narbe 2lap. pig. Kapsel kugelig, unregelmässig anfspringend oder 2hlappig. Samenkeim eiweisslos, mit undeutlichen lieimblättern. - Utricularia $(11,1)$.

D. Fruchtknoten einer, llächerig, mit waudständigen, oder zfächerig und danu mit mittelpunkt. stäıdigen Samenträgern. Staubgefässe 2, oder 4 zweimächtige. Blumenkrone unregelmässigr vder ungleich.

344. Orobancheen J uss. Krantartige, einfache, selten etwas verzweigte, auf den Murzeln anderer Pflauzen schmarutzende Gewächse mit gelben oder braunen, niemals griinen, schuppenförmigen, rertrucknenden Stengelblättern. Blïthen zwitterig, endstänlig, einzeln oder in Aehren, mit Deckblättern versehen. Kelch I-2blät. terig, röhrıg, 4-5theilig, hleibend. Blumenkirone miregclmässig, 2lippig. Staulıgefässe 4, zweimächtig, des Blumenkrone enugefïgt. Blumenlirone 1, frei, Ifächerig, mit vielen Eir:lıen an 2 uder 4 " andständigen Samenträgern. Griffel 1. Narhe 2lippig. Frucht eine Ifächerige, 2 klajpige, vom Grunde der verwolliten Blumenlirone umoebene Kapsel. Samen zahlreich, sehr. klein. Samenkeim rerkehrt, in einem fleischigen li.iweisse. - Orobanche und Lathrapa (XIV, 2).

331. Antirrhineen I uss. (Personaten DC. mit Ausschluss der Verbasceen, Scrophularieen R. B. zum 'Theil). Kïater oder stauden mit meist gegenstindigen Blättron ohne Nebenblätter. Bliithen einzeln in Blattwinkeln, "der in Aehre", Trauben und Rispen. kelch getheilt, bleibend. Blumenkrone muregelmässig "der ungleich, abfallend, in der Knospenlage dachzipgelig. Staubgefässe 4 , zweimächtin, zuweilen mit dem Ansatze eines funften oder mur 2, der Blumenkrone ein. gefügt. Staubbeutel am Grunde nicht stachelspitzig. Fruchtknoten frei, 2fächerig, viefeiig; Samenträger in der Mitte der Scheidewände. Griffe! 1. Nirbe ungetheilt oder 2lappig. Frurht eine mit Klappen oder Jöchern aufspringenle, 2fächerige Kapsel. Samenheím gerale, in einem fleischigen Eiweisse. - Gratiola und Veronica (II.1), Digitalis, Antirhinum, Jinaria und Limosella (XIV, 2). 
349. Hhinanthaceen DC. Staulbeutel am Girunde mit 2 Stachelspitzen, sunst ganz wie bri den Antirrhiнeen. - Mrlampyrum, Pedicularis, Alectorulophus und Euphrasia (XIV, 2).

378. Verbenaceen $\mathbf{J}$ ss. Kräutej (die ausländischen Arten gewöhulich strauch - oder baumartig) mit meist gergenständigen Blätter" ohue Nebenblätter. Blüthen zwitterig, meist in Aehren, seltener rinzeln in Blattwinkeln. Kelch röhrig, bleihend. Blumenkrone röhrig, an Rande unregelmässig wder ungleich, abfallend. Staubgefässe 2 voler 4 zweimächtige, der Blumenkron eingefügt. Fruchtinuten frei, 2-4fächerig; Fächer mit 1 oder 2 anfiechten Eichell. Griffel 1, gipfelständig. Steinfrucht $2-4$ ficherig, meist in 4 Niissclien zerfallend. Samenkeim gerade, eiweisslus. Verbena (XIV, 2$)$.

E. Fruchtknoten einer, 2fächerig. Staubgefässe 8 . Blume unregeluässig.

59. Polygaleen J us. Kiräuter oder sträurher mit meist abwechselnden, einfachen, ganzrandigen Blättern ohne Nebenblätter. Blüthen zwitterig, einzelı oder in endständigen, selten in blattwinkelständigen 'Trauben, mit Dechblüttern. Kelch 5blätterig, in der Knospenlage dachziegelig; die 3 äusseren Blätter klein, grün, dic 2 inneren (Fliigrl, alae, genannt) grösser, blumenblattartig. Blumenkrune unregelmässig, 3-5bätterig, mit der staubfadenröhre mehr oder weniger verwachsen; die beiden seitlichen Blunenblätter sehr klein oder gewöhnlich fehlend, das obere eine liahne (vexillum) bildend, die beiden unteren in ein Schiffchen (carina) verwachsen. Staubgefässe 8, unten cinbriiderig, an der spitze in 2 gegenständige, gleichförmige Biundel verwachsen (zueibriiderig). Staubbeutel 8, 1fächerig; Fächer an der Spitze mit einem Luche aufspringend. Fruchtknoten 1-2fürherig; Scheidewand auf der Mitte der Klappen befestigt; Fächer mit einem hän:enden, an Grunde oft von einer lockeren Samenhaut unschlossenen Eichen. Samenkein in der Mitte des fleischigen fiiweisses. - Polygala (XVII, 3) (Diall. Octandria).

F. Fruchtknoten einer, 2fächerig. Stanbgefässe 2. Blume regelmässig.

306. Oleaceen $L_{i n d}$. (Oleïneen $L_{A} i n k$, Lilaccen V ent). Sträucher vder Bäume nit meist gẹenständi- 
gen, einfachen, selten gefiederten Blättern ohne Nebenhlïter. Blüthen zwitterig, selten durch Fehlschlagen eingeschlechtlich, end-oder blattwinkelständig in Trauben oder Rispen. Kelch gezähnt oder getheilt. Blumenkrone regclmässig, 4spaltig, oder aus 4 einzelnen Blumenbättern bestehend, welche paarweise mit je 1 Staubgefässe zusammenhängen, in der linospenlage klappenartig. Zuweilen fehlen Kelch und Blumenkrone gänzlich. Stauboefässe 2, der Blumenkrone eingefügt, oder zwischen den Blumenblättern stehend. Fruchtinuten 2 fücherig; Fächer mit 2 nebeneinanderhängenden Eichen. Frucht eine Kapsel, Beere oder Steinbeere. Samen. keim aufrecht, eiweisshaltig. - Ligustrum, Syringa und Fraxiuus (11, 1),

G. Fruchtknoten einer, 2- bis vielfächerig, mit mittelpunktständigen Samenträgern, oder 2 einfächerige, deren jeder mit einem Griffel und einem Samenträger an der inneren Naht versehen ist. Staubgefässe 4,5 und mehre.

313. Convolvulaceen J uss. Kraut - oder stiudenartige, meist "indende, mit cinem scharfen Safte versehene Gewächse, mit abwechselnden, bei Cuscuta foh. lenden, gelappten oder eingeschnittenen Blättern ohne Nebenblätter. Blüthen zwitterig, blattwinkel - oder endständig. Kelch 5spaltig, bleibend. Blumenkrone re. gelmässig, abfallend, mit 5lappigem, meist der Länge nach gefalteten Saume. Staubgefässe 5, den Grundt der Blumenkrone eingefügt und mit ihren Iappen abwechselnd. Fruchtknoten frei, auf einer unterständigen Scheibe stehend, 2-4fächerig, selten 1fächerig. Fücher mit wenigen, aufrechten Eichen." Griffel 1, zuweilen getheilt. Kapsel 2-4fächerig, zuweilen ifächerig; Klappen durch Trennung vom Rande der unvoll. kummenen, durch Kanten oder Fliigel des Nittelsäulchens gebildeten Scheidewände aufspringend, oder gar nicht anfspringend. Samen am Grunde der Centralwin. kel des Mittelsäulchens, mit eineu weichen Eiweisse. Samenkeim gekriimnt mit gerunzelten, bei Cuscuta fehlenden Keimblättern. - Convolvulus ( $V, 1)$, Cuscuta $(\mathrm{V}, 2)$.

328. Verbasceen $\mathbf{H}$ a rt 1. (Scrophularieen R. B r. zum 'Theil, Personaten DC. zum Theil). Kräuter oder Stauden nit gegenständigen oder abwechselnden, einfachen Blättern ohne Nebenblätter. Bliithen zwitterig, 
in Aehren oder Trauben, oder einzeln in Blattwinkeln. Kelch 5theilig. Blumenkrone 5theilig, ungleich oder unregelmaissig, radförmig oder 2lippig, in der Knospenlane dachziegelig. Staubgefässe 5, "der 4 zweinächtige und oft mit einem unvollständigen uberen. Staubbeutel auf der verdicliten Spitze des Stambfadcns quer oder schief sitzend, Ifächerig. Fruchtknoten frei, 2fächerig, vieleiig. Samenträger dick, in der Mitte der Scheidewand. Griffel und Narbe einfach. Frucht eine 2fächerige, meist 2 hlappige, vielsamige Kapsel. Sumenkeim g’krümnt, in einem fleischigen Eiweisse. - Verbascum $(V, 1)$, scrophularia $(X I V, 2)$.

324. Solaneen J us. Die einheimischen Arten krautartig mit abwechselnden oder am uberen 'Theile des Stengels gegenständigen Blättern ohne Nebenblätter. Blüthen zwitterig, einzeln in den Blattwinkelı oder in endständigen Aehren. Kelch meist 5theilig, bleibend. Blumenkrone meist 5theilig, regelmässig oder ungleich, abfallend, in der Knospenlage ¿faltet. Staubgefâsse 5, der Blumenröhre eingefügt, und mit ihren Zipfeln abwechselnd. Staubbeutel anf der nicht verdicliten Spitze des Staubfadens sitzend, 2fächeriz, gewöhnlich der Länge njich, bei Solamm aber durch Löcher an der Spitze aufspringend. Fruchtknoten frei, 2färherig, vieleiigr. Samenträgrr dick, in der Mitte der Srheidewand. Griffel einfach. Narbe stumpf, selten 2lappig. Frucht eine 2-4färherige, vielsamige Kapsel, deren Scheidewände mit den Klappenändern rerbunden sind, odel eine vielsamige Beere. Samenkeim gekrümmt, in einem fleischigen Eiweisse. - Lycium, Solanum, Physalis, Atropa, Hyoscyanus, Nicotiana und Datura $(V, 1)$.

318. Gentianeen J uss. Die einheimischen Arten krantartiy mit abwechselnden uder gegenständigen, ge"öhnlich sitzenden, einfachen Blättern ohne Nebenblätter. Bliithen zwitterig, blattwinkel-oder endständig, einzeln oder in Büscheln. Kelch einblätterig, getheilt, bleibend. Blumenkrone 4-8spaltig, regelmässis, verwelkend, in der Knospenlage dachzieoelig oder spiralig. yedreht. Staubgefässe del' Blumenröhre eingefügt, sil viel als Kronlappen und mit ihnen abwechselnd. Fruchtknoten frei, 1-2fächerig. Griffel 2, ganz oder zum 'Theil rerwachsen. Narben 1-2. Frucht eine vielsamige, 1-2fächerige Kapsel. Samen bei der 1fächerigelı an den einwärts gebogenen Rändern der Frucht, bei der 2 fächerigen an den mittelpunktständigen Sa. 
mentrïgern sitzend. Simenkeim gerade, in der Mitte eines fleischigen Eimeisses. - Menyanthes und Erythraea $(V, 1)$, Gentiana $(V, 2)$.

308. Apocyncen 18. Tor. Kraut-viler strauchartige Pflanzen mit gegeuständigen, einfachen, ganzrandigen Blïttern whe Nebenblätter. Blüthen zwitterig, "inzeln in den Blattwinkrln. Kelith 5theilig, bleibend. Jlumenkrone reselmäissig, 5theilig, in der Knospenlage schief sedreht, abfallend. Staubgefässe. 5, frei, dev Blumenkrune eingefugt und mit ihren Kipteln abuech. selnd, uhue Anhangsel. Staubbeutel nit 2 längsritzen anfspringend, den hörnigen Blumenstaub unnittelbar an die Narbe abgebend. Fruchtinuten 1-2, vieleig. Griffel 1-2, mit miner gemeinschaftlichen Narbe. Frucht eine liapsel oder Balgkapsel, eine Beere uder steinbeere. Samenkeim aufrecht, eiweisshaltig. - Vinca $(\mathrm{V}, 1)$.

307. Asclepindeen R. F r. Aufrechte (bei den ausländischen dren gewöhnlich windende) Kräuter- oder Sträucher mit meint gegruständigen, einfarhen, ganzrandigen Blättern ohue Nebeublatter. Blüthen zwitterig, meist in blattwinkelständigen Rispen. Krlch 5theilig. bleibend. Blumenkrone regelmässig, 5theilig, in der Kinospenlage dachziegelig, selten klappenartig, abtallend. Staubgefässe 5, dem Grunde der Blumenkrone eingefügt und mit ihre⿰ Zipfelı abwechseind, oft zu einer Röhre verwachsen, "lach aussen mit Anhängseln versehen. Staubbeutel 2- oder 4fächerig. Blumenstaub in wachsartige Massen zusammengedriingt, welche an die 5 Driisen der grossen 5kantigen Narbe angehefiet sind. Fruchtknuten 2. Griffel 2, mit einel gemein. schaftlichen Narbe. Frucht 2 Balgkapselı; Samenträger llahtstïndig, später frei. Samen dachziegelartig, ïbereinander hängend. Samenkeim anfrecht, in einenı dünnen Eiveisse. - Cynanchum $(\mathrm{V}, 2)$.

302. Ericineen Desv. Strüucher mit einfachen, abwechseluden, gegenständigen uder quirlförmigen, meist nadelförmigen Blätterı ohıe Nebenblätter. Blüthe॥ zwitterig. Bliithenstielchen oft mit Deckblättchen versehen. Kelch $4-5$ spaltig wder getheilt, bleibend. Blumenkrone 4-5spaltig wder getheilt, in der Knospenlage dachziegelig. Staubgeficse su viel als Kronzipfel und nit ihnen abwechselnd, oder duppelt so viel, einer unterständigen, gekerbten Scheibe ein:efiigt, frei oder selten anı Grunde mit der Blumentivue verwachsen. 
Staubheutel mit und whne Anhängsel. Fruchtknoten frei, der Srheibe eingefügt, 4-5fächerig; Fächer nit 1 oder mehren Eichen. Samenträger mittelpunktstän. dig. Griffel und Narbe einfach. Fucht eine Kapsel oder Beere. Samen ungeflügelt. Samenkeim in der Mitte des Eiweisses. - Calluna und Érica (VIII, 1), Ledum $(X, 1)$.

V. Cnterabtheilung. Blüthen unvullständig; Blïthenhülle einfach viler fehlend.

A. Blüthen oberständig, nicht in Kätzchen.

410. Aristolochieen $\mathrm{I}$ us. Austumernde, oft windende Kräuter mit abwecliselnden, einfachen, gestielten Blittern, gewöhmlich mit Nebenblättern. Blüthen zwitterig, blattwinkelständig. Blüthenhïlle regelmässig, 3spaltig, uder unregelmässig mit schief abgestutztem Saume. Ziplel in der Kmospenlage klappenartig. Stanb. scf cisse 6-12, frri, alif der Spitze des Fruchthnotens, oder mit einer oberstïndigen Scheibe verwachsen, welche Griffel unl Narbe trägt. Staubfäden sehr kurz oder fehlend. Fruchtkuten 3-6fücherig, vieleiig. Samenträger mittelpunktstänlig. Samenkeim sehr klein, am Grunde des knorpeligen Eiweisses. - Aristoluchia (XX, 5), Asarmin $(\mathrm{X} 1,1)$.

165. Hippurideen Link (Halurageen DC. zum 'Theil). In II asser lebende Kräuter mit quirlförmigen, einfachen Bläıtern whot Nebenblätter. Blithen zwitterigg, blattwinkelständig. Blüthenhülle an den Fruchtknoten angewarhsen, mit ganzrandigen oder undeutlich 2lappigen Saume. Staubofässe 1, frei, dem Rande der Élithentiille am Grunde des vorderen Lappens cinøefiigt. Staubfaden hurz. Staublieutel mit 2 Längsritzen aufspringend. Fruchtknuten Ifärherig, mit einem hängenden Eiclen. Grifiel fiulenförmig, in der Rinne Jes staubbentels liegend. Steinfmcht Isamig, mit dünnem Flejsche " d dicher, knorpeliger Frurlithiille, vou Kelrhsaume gehrönt. Samenkeim aufrecht, im Eiweisse. - Hippuris $(I, 1)$.

407. Santalaceen R. B r. Die einheimischen Arten hrautartig mit abwechselnden ofer zerstreuten, ungetheilten Blättern whne Nebenblätter. Blüthen zwitterig, in Trauben weler Risper. Blüthenhülle 3-5spaltig, in. "e"l hlumenblattartig gefiirbt, in der Knospenlage klap. penartig. Staul,ofiisse 3-5, am Grunde der Zipfel eingef iigt und ihnen gegenständig. Fuchtknoten 1 fäche. 
rig, mit 2-4 hängenden Eichen. Samenträger mittelpunktstïndig. Griflel 1. Frucht nuss - oder steinfruchtartig, einsamig. Samenkeim in ler Mitte des fleischigen Eiweisses. Wïrzelchen den Nabel zugekehrt. Thesium $(\mathrm{V}, 1)$.

B. Blüthen unterständig, nicht in Kätzchen. Frucht in mehre Fiüchtchen zerfallend, wder in solche elastisch aufspringend.

166. Callitrichineen $\mathrm{L}$ in $\mathrm{k}$ (Halorageen D C. $7 u m$ 'Theil). Kleine, krautartige Wasserpflanzen mit gegenständigen, einfuchen Blättern ohne Nebenblätter. Blüthen sehr klein, zwitterig uder häufiger getrennten Geschlechts, blattwinhelständig. Kelch und Blumenkione fehlen, statt deren sind 2 lilcine. blumenblattartige, gesenstiindige, durchscheinende Dechlbiatter vorhanden. Staubgefiiss 1; staubbeutel nierenförmig, Ifächerig, mit eine: Quernaht aufspringend. Grittel 2, pfriemenförmig. Varbe ungetheilt. Fruchthuoten 4fächerig, 4samig. Frucht trocken, iuletzt in 4 nicht aufspringende Theilfriichtchen zerjallend. Samenkeim verhehrt, im Mittelpuntite des fleischigen Eiweisses. - Callitriche (XXI, 1).

411. Euphorbinceen J uss. Kräuter (bri den aus. läudischen auch sträucher und Bäume) mit meist giftigem, milcharti_em safte und abwechseluden, pinfachen Blättern, „ewöhnlich whne Nebenblätter. Blïthen 1. uder 2 häusig, blattwinkel- oder endstäıdig, mit Deckblättein, welche oft eine Hiille bilden. Bliithenhiille gespalten oder fehlend. Blumenblätter bei den einheimischen Arten fehlend. Staub Zahl, in der Mitte der Bliithe, oder Whter einem Griffelrudimente, frei oder verwachsen. Griffel oder Narben getheilt. Fruchthnoten frei, sitzend oder gestielt, 3 (selten 2- oder mehr-) fächerig; Fächer um den mittelpunktständigen Samenträger in einell Kreis gestellt, mit 1 oder 2 hängenden Eichen. Früchtchen su viel als Fächer, von der Achse abspringend. Samenkeim gerade, in dor Nitte des fleischigen Eiweisses. Wïrzelchen dem Nabel zugekeirt. - Euphurbia (XXI, 1) und Mercuriais (XXII, 8).

C. Blüthen unterständig, nicht in Kätzchen (nur bei Morus in Kätzchen). Frucht nicht aufspringent und nicht in Frïchtchen zerfallend. Blätter mit Nebenblättern.

398. Polygoncen J us. Kräuter oder selten Sitaude'n 
den mit abwechselnden Blättern und Nebenblättern, welche in eine den Stengel einschliessende Scheide ('Tute, uchrea, genannt) zusammengenvachsen sind. Blüthen meist zwitterig, belten getrennten Geschlechts, in Aeh. ren viler Trauben. Blüthenhülle 3 - btheilig, in der Knospenlage dachziegelig. Staubgefässe $4-9$, dem Grunde der Bluthenhiille eingefiigt. Fruchtknoten frei, Ifücherig. mit einem anfrechten kichen. Griflel 1-3. Frucht nicht aufspringend, nussartiy, nacht oder mit den bleibenden imeren Abschnitten der Blïthenhiille verwachsen. Samenkeim gekrümmt oder gerade, seitwärts oder in der Mitte des mehligen Eiweisses. Rumex (VI, 3) und Polygonum (VIII, 1).

154. Sanguisorbeen Lind 1. Kränter mit abwechselnden Blättern und Nebenblättern, welche an den Blatt. stiel anı ewachsen sind. Blüthen zwitterig "der getremnten Gesihlechts, hlattwinkel-oder endstïndig, in Köpfchen oder Aehren. Bliithenhille mit 3-5spaltigem Saume. Zipfel in der Konspenlage klappenartig, zu"eilen durch äussere, heinere in doppelter Anzahl vor. handen. Röhre mit einem Ringe geschlnssen. Staubgefïsse 4, oder mehr und weniger, vor dem Ringe ein. gefïgt. Fruchtknoten 1-4, jeder mit einen hängenden oder aufsteigenden Eichen. Griffel spitlich, von der Spitze (scheinbar ron dem Grunde) des Fruchtknotens ausgehend. Narbe kopf - orler pinselförmig, "der gebartet. Frucht von der oft rerhärteten Blüthenhïlle eingeschlossen. Samen eiweisslus. - Alchemillia, Sanguisorba $(\mathbf{I V}, 1)$ un! Poterium (XXI, 5).

415. Urticeen J uss. Bäume, Sträncher und Kïäıter mit abwechscluden oder gegenständigen Blättern und fireien, bleibenden oder als fullenden Nebcnbliittern. Bliithen 1-odev 2 häusig, oder vielehig, stitten zwitterig, in hlattwinkelstimbigen Rispen, Aehren wder Kätzchen, selten einzelı. Blüthenhülle 4theilig, selten $3-6$ theilig, Zipfel in der Knospenlage dachziegelig, oder bei den weiblichen Blüthen ungetheilt. Stanhgefässe n:eist 4-5, frei, dem Grunde der Bhiithenhiiille pingefügt und ihren Abschnitten gegenübersteheud. hei der Knospung einwärts gebogen und zur Blüthezeit sich elästisch aufrichtend. Fruclithnoten frei, 1-2fächerig; Fächer mit einem Eichen. Griffel 1-2. Frucht eine Nuss oder Steinfrucht, zuweilen eine falsche Frucht, durch fleischig gewordene und zusammongewarhsene Blütlienhïllen oder durch einen fleischigen, gemeinschaftlichen

Ga a c ke, Flora.

$8 \mathrm{~s}$. 
Fruchtboden gebildet. Samenkein gerade, gekrümmt oder spiralig gewunden. - Urtica und Morus (XXI, 4), Parietaria (IV, 1), Cannabis, Hunulus (XXII, 5), UI. mus $(\mathbf{V}, 2)$.

D. Blüthen unterständig, nicht in Kützchen. Frucht nicht aufspringend und nicht in Früchtchen zer. fallend. Blätter ohne Nebenblätter.

406. Thymelaeen J uss. Sträucher oder Kräuter nit abwechselnden, ungetheilten Blättern whne Nebenblätter. Blüthen zwitterig, blattwinkel - oder endstäl. dig, in Aehren oder Büscheln. Bliithenhülle gefärbt, röhrig, mit 4-, seltener 5spaltigen Saune, in der linnspenlage dachziegelig. Staubgefässe $2-4-8$, den Schlunde oder der Röhre eingefïgt. Staubbeutel 2 fiichc. rig, mit 2 Länosritzen aufspringend. Fruchtknoten frei, Ifacherig, mit einem hängenden Eichen. Griffel und Varbe einfach. Frucht tror:hen oder beerenartig. Samen mit spärlichem. fleischigem Eiweisse oder tiweisslus. Samenkeim gestiurzt. - Passerina und Daphne (VIII, 1).

173. Sclerantheen $\mathbf{L}$ ink. Kleine Kräuter mit ge. genständigen, an Grunde zusammengewachsenen Blätteru vhne Nebenblüttrr. Blüthen zwitterig, in endständigen Büscheln oder 'Trugdolden. Bliithenhiille bleibend, verhärtend, mit der von ihr eingeschlossenen reifen Schlauchfrucht abfillend, Röhre der Bliithenhiille olockenförmig, Schlund mit einem drüsigen Ringe geschlossen, Saum 4-5spaltig, in der Knospenlage dachziegelig. Staubgefüsse so viel als Zipfel der Bliithenhiille, vor dem Kinge eingefügt; zuweilen besteht die Hälfte derselben aus Nebenstaubfäden. Fruchtinoten Ifächerig, mit 2 an der Spitze eines Nabelstranges befindlichen Hichen, wovon das eine oft fehlschlägt. Griffel 2. Samenkeim um das mehlige Eiweiss gekrümmt. - Scleranthus $(X, 2)$.

389. Chenopodeen $\mathbf{v}$ ent. Kïäter oder Stauden mit neist abwerhselnden, öfter fleischigen Blättern ohne Nebenblätter. Blüthen zwitterig oder vielehig, in hlatt. winkelständigen Knäueln wder in endständigen Aehren und Rispen. Blüthenhülle 5 theilig, in der Knospenlage dachziegelig. Staubgefässe ani Grunde der Blüthenhïlle pingefiigt, von gleicher oder geringerer Zahl der Zipfel und ihnen ge.peniibcr. Fruchtknoten frei oder mit dem Grunde der Bliithenhülle verwachsen, Ifäche- 
rig, mit einem auf dem Grunde des Fruchtknotens sizzenden Eichen. Griffel gcwöhnlich 2-4spaltig, selten einfach. Narbe ungetheilt. Frucht trocken, nicht aufspringend, zuweilen eine aus der fleischig gewordenen Blüthenhuille entstandene falsche Beere. Samenkeim kreisförnig, den mehligen Eiweisskörper umschliessend, oder schraubenförnig gewunden, zur Seite des mehligen Eiweisses oder eiweisslos. - Salicoruia (II, 1), Polycnemum (III, 1), Schoberia, Chenopodiunı, Blitum und Beta $(\boldsymbol{V}, 2)$, Halimns und Atriplex (XXI, 5), Spinacia (XXI1, 4).

388. Amarantaceen Juss. Kränter mit abwechselıden, einfachen Blättelı ohne Nebenblätter. Blüthen zwitterig oder getrennten Geschlechts, in Aehren oder Köpfchen, nit Deckblattern versehen. Bliithenhiille 3-5theilig, trockenhäutio, in der Knospenlage dachziegelig. Staubsefässe $3-5$, unterständis, bci der männtichen Bliithe in der Mitte der Blithe, frei oder in eine Röhre zusammengewachsen. Fruchtknoten Ifächerig, mit 1 vder mehren am Grunde des Faches befestigten Eichen. Griffel 1. Narbe 1 oder niehre. Frucht schlauchartig oder kapselartig und ringsum aufspriıgend. Samenkeiı $1 \mathrm{~m}$ das mehlige Eiweiss gekrümmt oder ringförmig. - Amarantus (XXI, 5).

167. Ceratophylleen ray. Krautartige, ästige Wasserpflanzen mit quirlföruig gestellten, 2-3mal oabelförmig getheilten Blcittern ohne Nebenblätter. Blüthen einhäusig, blattwinkelstündig. Blüthenhülle aus $10-12$ breit-linealischen, abgestutzten, mit 2 Dörnchen besetzten Blättchen bestehend. Staubbentel 12-16, sehr kurz gestielt, dicht zusammenstehend, etwas länger als die Bliithenhiille und in ihrer Mitte sitzend, verkehrt,-eiförmig, an der Spitze halbnındförmig ausgeschnitten, auf jeder Seite in ein Dörnchen auslaufend, 2fächerig; Fücher durch unvollständige Scheide. wände halb getheilt. Weibliche Blüthen einzeln in jeder Blüthenhülle, frei. Fruchtknoten frei, llächerig, mit einen hängenden Eichen. Griffel 1, pfriemenförmig. Narbe einfach. Frucht eine 1fächerige, eiweiss. lose Nuss. Samenkeim aufrecht, mit 4 quirlförmigen Keimblätteru, wovon 2 abwechselnd breiter sind. Ceratuphyllum (XXI, 5).

E. Die männlichen Blüthen immer in Kätzchen.

418. Juglandeen DC. Büume nit abwechselnden, 8 A. * 
unparrig gofiederten blätern ohme Vebenhlatter. Blüthen einhinssor. Blüthenhiille 2 - btheslig. Staubgefässe mehre. Dtinbliden sehr kurz, Staubbeutel 2ficherig, der Linge nach anfspringend. Weilliche Blïtlen einrelu oder zu 2-3 an der Spitze der lestchen, mit doppeller Bliillicndeche. Kelch uberständig, abtällig. Blumenblätce 4, hrantartig, hei ausländischen fehlens. fruchthuolen leächerion, mit einem aufrechten Eichen. Varlien 2, lanzellich, verlängert, oder nur I und schildföımig, 4lappig. Steinfrucht fleischig, mit $2-4$ hisp. piger Dussschale. Samcon eiweisslos. Samenheim mit Ileischigen, 2spaltigen, faltig gewundencell liemblattern, - Juglans (XXI, 5).

419. Cupuliferen R ich. ((quercineen Juss.). Bänme: coler strabcher mit eintarhen, abwechselnden Blät. irrn und bald abfallenden Vebenblattern. - Bluthen eill. häusig: mämbliche in "alzenförmi; en oder rundlichen, als sihuppenförmigen Dechblättern zusammengesetzlch Natzchen. Blisthenhiille 4-6ipaltig uder fehlend. Staubarfisse 5-20 und mehr, der Bluthenhialle oder dem Derhblatte eingefiger. Sianbbrutel alucherig, 2ritzın. "reilliche bliallen cinzelu, gehüuft oder in Achren. Blii-

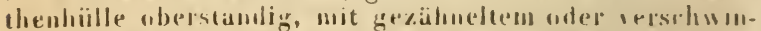

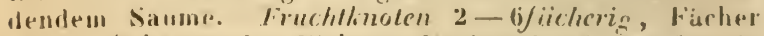
mit 1-2 hängenden Eichen. Narben 2-6, asm Cirunde oft verwachsen. Dechbläter nach der Blichezoit lost. wachsend, das fruchigehäuse ganz berleckend orler nur am Grumle umfassmol und mut ihu verwachsend. Sie bilden so eine scheinbare fruchthille (Becher, cupula). Fincht (Nuss) hoochenhart oder lederartig, meist durch fiplifschlagen Isamig. Samenheim gross, gerarte, ei"risulos. - Fagus, Quercus, Curylus, Carpinus (XXI, 5).

426. Betulineen Rich. (Imentareen Juss. zum

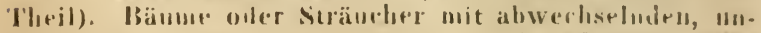
anethejlen libittern und hleinto, bald abfillenden Ne. benblütern. Blühen cinhäusig, in blattwinkelstindi-

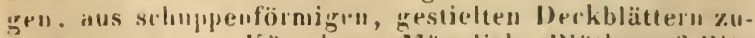
sammengesetzten Kützclien. Männliche Blüthen: :3 Bluliruhiillen, ganz wler 4theilig, in Wink+1 des Werhhlates. jede mit 2-4 stabbrefiissen. Neibliche Bliithrn: Blüthenhiilte fehleus. Fychtinolen zinter jeder schuppe 2-3, firi, 2 fiicherio. Iächer mit cinem hiein-

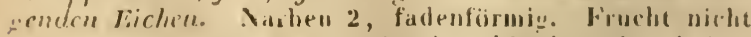
antspringend, zusammengedrückt, häntig ober ledesartig. must gefhigelt, lurch Fehlschlagen Afacherig. 
Samen hängend, eiweisslus. Samenkeim gerade, mit flachen Keimblätterm. - Betula (XXI, 5) umi Ilnus (XXI, 4).

420. Salicineen reich. (Imentaceen Juss. zum Theil). Baume oder Sträncher mit abwechselnden, ungetheilten Blättern und abfallenden viler bleibenden Ne. benblättern. Blüthen 2hänsig, in blattwinkel-oder endständigen Kätzchen, "elche aus schuppenförmigen Deckblättern grebildet sind. Anstatt der Blïthenhulle hefindet sich eine driisen - oder liecherförmige, fleischige Scheibe in den Winkeln der Deckbläter. Mänuliche Blïthe : Sraub:efässe 2-24, frei oder einbriderig. Weibliche Blüthe: Fruchtinoten 1, im Winlicl des Deckblattes, Jrei, lficherig, mit viclen an 2 "wadständigen Samentrigern hänzenden Eichen. Griffel 1. Narben 2, oft gespalten. Kapsel 2 klappig. Samen nit langen llaren lesetzt, eiweisslus. Samenkeim anfecht, mit etwas fachen Keimblättern. - Salix (XXII, 2) und Popuulus (XXII, 7).

427. Coniferen J ин. Bäume wder Strüucher mit harzigem, terpentinartigem Safte und meist quirlförmig gestelltel Aesten. Blätter 2reihi wler zerstrent, meist nadelförmig Nadeln oft hüschelförmig Zu 2-5 vereinigt und vou einem trockenhäntigen Blattscheidchen umgeben, einnervic wier parallel-nervig. Bluthen 1 2häusig, an den Enden der Kweige, selten einzeln oder תи $2-3$, häufiger in Kätzchen, von denen dic veiblichen in Zapfen oder in falsche Beeren iibergchen. Vämuliche Bliithen: Staubgefüsse 1 oder mphre, mit dem Staubfalen zusammengewachsen, oder viele der länge nach an eine Achse gostellt, die Staubfäden und besonders das Mittelband (connectivum) in schuppen- oder schildförnige Flichen verbreitert, welche an der unteren Seite die Staubbutel tragen; letztere zu 2 nebeneinander liegend, oder zu mehren kreisförmig gelagert wder an untren Rande angeheftet. Weibliche Bliithen: 1 oder 2 nackte Eichen, anf einem schuppenförmigen, Hach ausgebreiteten simentrüger, im linkel cines schuppenförmigen, verholzenden Dechblattes. Samenkeim verkehrt, in der Nitte des fleischigen Eiveisses, mit 2 uder mehren qưirlförmig gestellten Keimblättern. - Pinus (XXI, 2) und Juniperus (XXII, 5). 
II. Classe. Zerstreutfaserige phanerogamische (iefïsspflanzen. Nonocotylen.

1. Fruchtknoten mehre, getrennt, oder am Grunde zusammengewachsen oder völlig zusammengewachsen und erst bei der Reife oberwärts aus. einandertretend oder von der mittelpunktstän. digen Achse sich trennend; jeder griffeltragend oder mit einer sitzenden Narbe endigend. Bliithenhülle unter'ständig.

429. Alismaceen J uss. Ausdiuernde Wasserpflanzen mit langgestielten, einscheidenden Blättern. Blüthen zwitterig oder getreunten Geschlechts, langgestielt, in Quirlen oder einfachen Dulden. Kolch 3blïtterig, hrautartig. Zlumenkrone 3blätterig, regelmässig. Staubgefüsse unterständig, frei, 6 oder zahlreich. Fruchtlinoten 3-6 oder mehr, wberständig, jeder mit 1 Griffel und 1-2 an der inneren Naht befindlichen Eichen. Narbe einfach. Frucht trocken, nicht aufspringend. Samenkeim gekrümmt, eiweisslos. - Alisma (VI, 6) und Sagittaria (XXI, 5).

430. Butomeen Rich. Ausdauernde Wasserpflanzen mit ganzrandigen, einscheidenden Blättern. Blïtheu zwitterig, in Dolden auf wurzelständigen Stielen. Bliithenhiille aus 2 dreigliederigen Blattkreison (bei ansländischen aus 3 grïmen Kelchblättern und 3 gefärbten Blımenblättern) bestehend. Staubgefässe unterständig, frei, 9 oder mehr. Fruchtknoten 3, 6 oder mehr, getrennt oder an Grunde unter sich verwachsen, jeder mit einer einfachen Narbe. Eichen zahlreich, die ganze innere Wand des Fruchtknotens bekleidend. Frucht frei oder rerwachsen. Samen mittelst kleiner Gefässbuindel befestigt, ohne Eiweiss. Samenkeim gerade. - Butomus $(I X, 3)$.

430. Juncagineen R ich. Ausdauernde, krautartige sumpfpflanzen mit schmal-linealischen, einscheidenden Blättern. Blüthen klein, zwitterig, in Achren oder 'Trauben. Blïthenhiille 6blätterig, belchartig oder etwas gefïrbt. Stanbgefüsse 6, unterständig. Fruchthnoten 3 wler 6, jeder mit einem freien Griffel, oder einer schief aufgewachsenen Narbe, 1-2eiig, am Grunde zusammenhängend oder zu einer ganzen, trockenen Frucht zusammengewachsen, bei der Reife abcr in 3 oder 6 Friichtchen sich ablüsend. Samenkeim gerade, eiweisslus, mit einer seitlichen Spalte, aus welchen 
das Federchen (plumula) bein Keimen hervortritt. 'Iriglochin (VI, 3).

475. Colchicaceen DC. Ausdauernde, krantartige Pflanzen mit zwiebeltragender oder faseriger Wurzel und einfachen, ganzrandigen, einscheidenden Blättern. Blüthen zwitterig, selten vielehig, einzeln aus der Zwie. bel kommend oder in Aehren oder Trauben an der Spitze des Stengels oder der Aeste stehend. Bliithenhiille 6theilig oder 6bliitterig, gefärbt, zuweilen am Grunde röhrig. Staubgefässe 6 , selten 9, dem Blüthenboden odes der Blüthenhülle eingefügt. Staubbeutel nach aussen gewendet. Fruchtknoten 1 oder 3, frei oder an Grunde init der Blïthenhïlle verwachsen, mit zahlreichen, an den inneren Fachwinkel befestigten Eichen. Griffel 1 oder 3, oder fehlend. Narbe 1 oder 3. Frucht nach innen aufspringend, entweder aus 3 getrenuten, ifäıherigen Balgkapseln bestehend, oder eine aus verwachseuen Balgkapseln zusammengesetzte, 3klappige Kapsel bildend, wobei die Ränder der Klappen sich nach innen umbiegen und 3 Fächer darstellen, die sich bei der Reife wieder trennen. Samenkein walzenförmig, in dem fleischigen Eiweisse. - Colchicum und 'T'ufieldia $(\mathrm{Vl}, 3)$.

431. Potameen Juss. Krautartige Wasserpflanzen mit zum 'Theil schwimmenden Blättern. Blüthen klein, zwitterig oder getrennten Geschlechts. Blüthenhülle 4theilig oder fehlend. Staubgefässe frei, 1, 2 oder 4. Fruchtknoten 4 uder mehre, getrennt, eineiig, mit 1 Griffel oder mit einer sitzenden Narbe. Früchtrhen nicht aufspringend, nuss - oder steinfuchtartig. Samen eiweisslos. Samenkein gekrümmt oder eingerollt. Potamogeton (IV, 4), Ruppia (II, 1) und Zannichellia (XXI, 1).

B. Fruchtknoten einer, unterständig.

440. Orchideen uss. Krautartige (nur in der heissen 'Zune auch strauchartige), meist ausdauernde, zuweilen auf Stämmen und Wurzeln anderer Gewächse schmarotzende Pflanzen mit biischelförmiger oder aus 2 ungetheilten oder handförmig getheilten Knollen gebildeter Wurzel. Der Stengel ist einfach nit abwech. selnden, ganzrandigen, einscheidenden Blättern; zuwrilen sind anstatt der Blätter blattscheidenartige, entfärbte Schuppen vorhanden. Blüthen zwitterig, an der Spitze des Stengels in Aehren uder 'Iraube⿰, selten 
einzeln; jede von einem Deckblatte gestützt. Bliithenhiilie auf der Spitze des Fruchthnotens stehenl, blı. menblattartigr, muregehmässig, meist rachenförmig, aus 2 dreibläterigen lireisen bestehend, "nvon die $3 \mathbf{A b}$ schnitte des änsseren mnd 2 des inneren Kreises die Oberlippe (gewöhnlich IIelm, galea, genannt). der dritte Abschnitt des inneren Kreises aber die Unterlippe (Iippchen, Jabellum) bilden. Dieses Lippchen verlängert sich zuweilen in einen spornartigen, huhlen Fortsat\% (calcar). Der ron ilem Blüthenstielchen oder von dessen Spitze gebildete Fruchtknoten ist oft schraubenförmi. gedreht, wudurch die Stellıng der Bliithenhülle verändert erscheint (flures resupinati), Ificherig, mit zahlreichen, an dem wandstïndigen Sanenträger befertigten Eichen. Staubgefäste oberständig, 3 , von denen aber nur das obere einen Staubbentel trägt. (Nur in der Gattung Cypripedium entwicheln sich die beilen unteren Stanbgeffisse und das wbere bleibt whne Staubbeutel.) Die mit dcm Griffel verwaclssenen Staubfäden bilden in der Mitle der Bliithenhiille ein Säulchen (columna, Narbenträger gynustemium), "elches auf seiner vorde. ren und oberen seite die Narbe in Gestalt eines fench. ten, driisigen Gribchens mit einem vortretenden Spitzchen oder Pliattchen (rostellum) und an seiner Spitze den 2färherigen Staubbeutel trägt. Die Fächer des Staubbentels sind durch unvollstïndige Scheilewände oft in 2 oiler 4 Säckchen getheilt, welche entwpler getrennt und seitwiilts an den verlängerten Griftel angeheftet, oder unter sich verwachsen sind und einen unbeweglichen und bleibenlen, oder einen beweglichen, deckelförnigen und ahfallenden staubbeutel hilden. Der Biüthenstaub (pullen) besteht aus wachsartigen oder hörnigen Klünpchen, deren Kömer entweder leicht trennbar sint oder elastisch zusamnenhängen. Die Kapsel springt der Läıge nach in 3 Klappen auf. Namen zahlreich, klein, feilspänartig. Der Samenkein am Grunde eines lleischigen Eiweisses. - Hierher gehören sämmtliche Gattungen aus der Gynandria Munandria und Diandria (XX, 1 u. 2).

428. Hydrocharideen DC. Wasserpflanzen mit schwimmenden, seltener aus dem Wasser hervorragen. den, ganzrandigen oder feingesägten Blättern. Blüthen bei den einheimische'l Arten 2häusig, von einer 1 - oder 2blätterigen Blïthenscheide eingeschlossen. Kelch 3blätterig, krautartig. Blumenkrone 3blätterig, regelmässig. 
Niangefässe frei, 3 , mit den Blumenblättern abwechselud, uder mehre. Fuchtknoten 2 - bis mehrfächerig, vieleiig. Samenträger an der äusseren Wand viler an de" Scheidewänden der Fächer. Griffel hei der einheimischen Art 6, zwrispaltig. Frucht nipht aufspringend, fleischic, immen breiartig. Samenkeim gerade, walzenförmig, eineissliss. - Stratiotes (XXII, 10) und $\mathrm{Hy}$ drucharis (XXll, 8).

457. Irideen $J$ us. Ausdauernde Pflanzen mit meist knolligem Wurzelstucke und walzenföınigem voler zusammengellrüchtem Stengel. Blätter abwechselnd, schwertförmìn oder linealisch. Blüthen zwitterig, gewöhnlich endständic in Aehren, 'Trauben oder Kispen, run einer 2blätterigen Blüthenscheide eingeschlossen. Bliithenhiille blumenblattartig, 6theilig. Ahschnitte in 2 Kreise gestellt, wovon der innere mist klejuer. Staubgefässe 3, dem Grunde der äusseren Abschnitte der Bluthenhülle oder dem Fruchtknuten ringefügt. Staubbeutel nach aussen aufspringend. Fruchtkuwten 3fächerig, mit vielen 2reihigen kichen. Simenträger mittelpunktständig. Narben 3, einfach uder geschlitzt, oft blumenhattartig. Kapsel 3klappig. Klappen dip Scheidewand tragend. Samenkeim walzenförnig, in pinem fleischige'll Eiwegisse. Gladiolus und lris (1II, 1).

461). Amuryllideen R. B r. Ausdauernde Pflanzen mit meist zwiebeltragendem Wurzelstocke und ganzranligen, einscheidenten Blättern. Blïthen zwitteri:-, einzelı uder in eiufachen Döldchen, vur ilırem dufbliihen vun eimpr truckenen Blïtlenscheide einureschlossen. Bliithenhiille blumenblattartig, 6spaltig. Stanlgefiisse b, dem Frurhtinuten oder der Blüthenhülle pingefügt. Staubbeutel nach innen anfspringend. Fruchtinoten 3fächerig, 1-bis vieleiig. Griffel 1, Narbe 3lappig. Frucht eine 3fächerige, 3klappige Kapsel (Klappen die scheidewand tragend) oder pine wenigsamige Bepre. Samenkeim walzenföımig, in einem fleischigen Eiweisst. - Leucujun (VI, 1).

C. Fruchtknuten einer, wherständig.

463. Liliaceen D C. Ausdaueinde Pflanzen mit meist zwiebeltracentem Wurzelstucke und flachen, zuweilen röhrigen oder rinnigen, ganzrandigen Blätterı. Blïthen zwitterig, eimzeln an der Spitze oder in Aehren, 'Irauben und Dolden, vor ihrem Aufbliihen zuweilen von Blüthenscheiden eingeschlossen. Bliithenhiille blu- 
menblattartig, 6spaltig oder 6llitterig. Staubgefässe 6, dem Blithenboden oder der Blüthenhülle eingefïgt. Staubbeutel nach inuen gewendet. Fruchtknoteu frei, 3 fächerig, Fächer mit zahlreichen Eichen, welche an den inneren Winkel der Fächer in 2 Reihen angefiït sind. Griffel 1. Narben 3 oder 1, 3eckig. Fruch eine 3 fächerige Kapsel. Scheidewände in der Mitte der Fächer. Samenkein in einem fleischigen Eiweisse. 'Tulipa, Lilium, Authericum, Ornithugalum, Gagea, Scilla, Allium, Muscari $(V I, 1)$.

461. Asparageen Juss. Ausdauernde Krïuter mit kriechenden Wurzelstuche und flachen, ganzrandigen, zerstreuten oder quirlständigen, zuweilen einscheidenden Blüttern. Blüthen bei den einheimischen Arten zwitterig. Bliithenhiille blumenblattartig, 4-6-8spaltig oder 6bliitlerig. Staubgefïsse in gleicher Anzahl mit den Abschnitten uder Blättern der Blüthenhülle, und dieser oder dem Blüthenbuden eingefïgt. Staubbeutel nach innen gewendet. Fruchtknoten firei, $3-$, seltener 2- oder 4 fächerig, Fächer mit 1 oder vielen dem inneren Winkel angehefteten Eichen. Griffel 1 oder mehre. Frucht eine 3 , selten eine Ifücherige Beere; Fücher 1samig. Samenkeim in fleischigen Eiweisse. - Asparagus, Convallaria (VI, 1), Majanthemum (IV, 1), Pa. ris (VIII, 4).

476. Juncaceen $\mathbf{B}$ a r t 1. (Junceen R. B r.). Krautartige meist ausdauernde, den Halbgräsern ähnlıche Pflanzen, mit einfachem, nacktem Schafte oder beblättertem Halme und abwechselnd - zweizeiligen, linealischen oder borstenförnigen, oft einscheidenden Blättern. Die kleinen, unausehnlichen, zwitterigen Bliithen bilden eine büschelförmig zusammengedrängte Aeh. re, einen ausgebreiteten Ebenstrauss uder eine Trug. dolde, welche bald an der spitze, bald an der Seite des Halmes stehen. Da die Seitenblüthen über die Gipfelblüthe hinansragen, so "ird dieser Blüthenstand gleich jenem der Halbgräser gewöhnlich Spirre (anthela) genannt. Dic Aeste des Bliithenstandes und die Zweige sind an ihrem Grunde nit 2 scheinbar gegeniiberstehenden, scheidenförmigen Blittern besetzt, vou denen das ïnssere (Deckblatt, involucrum, genaunt) grösser ist, in eine blatt-oder pfriemenförnige Spitze ausläuft und, besonders wenn es am Grunde der unteren 'Zweige steht, die Blüthen vor ihrer Entwickelung einschliesst; das innere, kleinere, etwas höher stehende ('Tute, ochrea, 
genannt) hüllt den unteren Theil des 'Zweiges scheiden. förnig ein. Bliithenhiille aus 6 , in 2 Kreise gestcllten, spclzenfü:"migen, am Rande trockenhäutigen Blättern bestchend. Staubgefässe 6 , seltener 3 , den Blättern der Blüthenhïlle gegenüberstehend. Staubfäden pfriemlich, steif. Staubbeutel '2fächerig. Fruchtknoten 1-3fächerig, meist vieleiig. Griffel 1. Narben 3, fadenförmig, behaart. Frucht eine 3klappige, vielsamige Kapsel, deren Klappen in ihrer Mitte die Scheidewände tragen; oder die Kapsel ist wegell der fehlenden Scheidewände 1fächerjg, 1samig. Sanıenkein fast walzenförmig, in einen fleischigen Eiweisse. - Juncus und Luzula (IV, 6).

439. Aroideen Juss. Ansdauernde Pflanzen mit meist knolligem Wurzelstocke und wurzelständigen oder abwechselnden, einscheidenden Blättern. Bliithen auf cinem Aleischigen Kolben (spadix) sitzend, oft von einem scheidenförmigen Deckblatte (Blïthenscheide, spatha) umgeben, einhäusig oline Bliithendecke, oder zwitterig und mit einer 4-6blätterigen, schuppenförmigen Bliithenhliille. Staubgefïsse bei den einhäusigen Blüthen sehr kurz, zwischen oder über dem Fruchtknoten; bei den '/wittern den eben so langen Blüthenhüllblättern gegenïberstehend. Fruchthnoten frei, $1-3$ fächerig, vieleiig. Narbe sitzend oder auf einem Griffel. Frucht trocken oder beerenartig, nicht aufspringend. Samen 1 uder mehre. Sanenkiein gerade, walzenförnig, in der Nitte des Eiweisses. - Arum, Calla (XXI, 1) und Acorus (VI, 1).

437. Typhaceen Juss. Ausdauernde, knotenlose Wasserpflanzen mit kriechendem Wurzelstucke und abwechselnden, schnalen, einscheidenden Blättern. Blïthen cinhäusig, in walzen - oder kugelförmige Achren oder Kolben dicht zusammengedrängt: die oberen Aehren männlich, die unteren weiblich. Blüthenhülle ans 3 oder mehren Schuppen oder Borsten bestehend. Staub„efässe einfach, oder an der Spitze kurz 2-3spaltig und auf jeder Spitze einen Staubbentel tragend. Fruchtknoten frei, mit einem hängenden Eichen. Griffel und Narbe einfach. Frucht trocken, nicht aufspringend. Samenkein gerade, in der Mitte des Eineisses. Typha und Sparganium (XXI, 3).

436. Najadeen Link. Unter dem Wasser lebende Kräıter mit meist gegenständigen, einscheidenden Blättern. Blüthen sehr klein, getrennten Geschlechts, zer- 
streut. Bliithenliille fehlend. Staubgrefüsse 1-3. Staubfälen fehlend. Staubbeutel sitzend, mehrlächerig, vun einer Hiille ungeben, weiche zur Blüthezeit zerreisst und sich zurückschlägt. Fruchthnoten Ifächerig, Leiig. Narbe 1, sitzend oder 2-3, fadelförmig. Frucht nuss. vider fast steinfruchtartig. Samentieim gerade oder gehrümmt, eiveisslos. - Najas (XXI, 1).

437. Lemnaceen $\mathbf{L}$ in $k$. Schwimmende Wasserpflanzen mit blattartig ausgebreitetem, linsenförmigern, of $t$ geglicdertem Stengel olme Blïtter. (Ihre hatförmigen, an dem freien Ende mit dem sugenannten Mützchen (calyptra) versehenen Wurzeln entspringen aus der Untertläche und hängen frei in $\mathbf{W}$ asser.) Blüthen zwitterigr uder 2häusig, am Rande des Stengels. Bivithenhiille einblätterig, zusammengedruckt, ungetheilt wier an Rande feingekerbt. Stanb entwickelnd. Staubberutel 2fächerig. Fruchtknoten frei, nit 2-6 aufrechten Eichen. Griffel kurz. Narbe stumpf. Frucht schlauchföınig. Samen ein eisslus. Samenkein gekrümmt, verkehrt. - Lenına (11, 1).

483. Cyperaceen Juss. Grasartige Gewächse mit 3kantigem, zusammengedruckten oller rundlichem Stengel (Halm, culmus) und schmalen, grasartigen, ganz. randigen, auf einer un:. etheilten Scheide sitzenden oder gänzlich fehlenden Blättern. Diese Blattscheide vertritt die Stelle des Blattstieles und umfasst einen 'Theil des Ifalmes; sie ist un ihrer inneren Fläche mit einer ge. glätteten Haut ïberzugen, welche zuweilen ïber den Rand ler Srcheide hervorragt und wie bei dell ächten Gräsern an Grunde des Blattes ein Blatthäutchen (li. gula) bildet. Blïthen zwitterig odel getrenten Geschlechts, in Aehren, welche einzeln oder mehrfach am Halme stehen. Jede Aehre (spica) ist am Grunde von Deckblättern (bracteae) begleitet und besteht aus dicht zusanımeıgedrängten, darhziegelförmig sich deckeuden, balgartigen Blïthen (flores glumacei), welche an Grmnde mit einem schuppentörmigen, spelzenartigen Deck. blätchen (bractrola wder gewöhnlich Balg, gluma, genaunt) versehen sind. Dieser Balg ist 1. oder seltener 2 klappig, die innere Klappe (bei Cyperus) an die Spindel angewachsen uder (bei Carex) in einen kleinen krugförmigen Schlauch (urceolus) ungewandelt. Die Blüthenhülle aus 6 oder mehr, selten aus weniger unterständigen Borsten (setae hypogynae nach R. Br.) oder (bei Étophorum) aus vielen Fäden bestehend, oder 
gauz fehlend. Staubgefässe 3 , mit aufrechten, an der Spitze ungetheilten Stanhbeutelı. Griffel 1. Narbe 2 -3. Nuss 3kantig oder zusanmengedrüickt, nackt orter mit den bleibenden Borsten der Blüthenhiille nmgeben oder (bei Carex) von einen krugföruigen Schlauche eingeschlossen und nit denselben abfallend. $S a$ menkeim sehr klein, am Grunde des mehligen Eiweisses. - Cyperus, Schoenus, Rhynchospora, Heleocharis, scirpus und Eriuphurum (111, 1), Carex (XXI, 3).

511. Gramineen I uss. Einjährige oder ausdauerude kraut-, selten standenartige und nur in del heissen Zome baumartige Gewächse, entweder mit blus faseriyer Wurzel oder mit hriechendem, gegliedertem Wurzelstocke und meist einfachem, farlenförmigem, hohlem Stengel (Halm, culnus, genannt), "elcher mit harten, mit Mark ausgefiilten, oft hervorragenden linoten (nodi) versehen ist. Wie einfachen, abwechselnden Blätter stehen auf den die Stelle des Blattstieles vertretenden, an der cinen Seite der Lïnge nach gespaltenen Blattscheiden, deren innere Haut als Blatthäutehen (ligula) übrr dell Rand der Scheide hinausgeht. Die Bliithen (vin L,inné flosculi, Blüthchen, genaunt) sind meist zwitterig, seltenes getrennten Geschlerhtes, balgartig, in eill- wer vielblühigen Aehrchen (spiculap), welrhe an der spitze des Halmes oder der Aeste zu einfachen oder zusammengesetzten Aehren (spitap), 'l'rauben (racemi) uder Rispen (paniculae) whue gemeinschaftliche Hiille verbunden sind. Jedes Aehrchen hat an seinem Grunde meist 2 zueizeilig grestellte (scheiubar gegenïberstehende), unfruchtbare, 1 oder mehre Blüthen ein. schliessende Blattrhen (Klappen, Valrar, genannt), welrhe den Balg (gluma, nach I, inne Kelchbalg, gluma (alycina) bilden; zuweilen fehlt jeduch die eine, selten beide Klappen. Ueber diesen infruchtbaren Klappen stehen 2 oder eigentlich 3 an der Spitze oder auf dem Rüchen oft mit piner Granne (arista) versehene Blätt(hen (Spelzen, paleae), ron welchen die 2 inneren mit ilıren Rande verwachsen; sie bilden das Bülglein*)

$\left.{ }^{*}\right)$ Diese Theile der Graşblüthe haben die verschiedenen Schrifsteller versclifeden benannt. So heissen die äussersten, gewöhnlich Klappen genannten Deckblättchen auch Kelch-oder Deckspelzen, Hüllspelzen, Spelzschuppen, Blüthenscheiden u. s. w., ralvae ealycinae, glumae, bracteae, valvulae, spathae etc. und der vom Verf. mit dem Janen Balg bezeichnete Theil ist ron Anderen perigonium 
(glumella, nach I,inné Blumenkrone, corolla) und sind fruchtbar d. h. sie schliessen $2-3$ sehr kleine und zarte, pine innere Blüthenhülle andeutende Schïppchen (squamulae oder Deckspelzen, Iodiculae, von Li in é nectarinn genannt) und die Befruchtungsorgane ein. Staubgefässe gewöhnlich 3, nit den Deckspelzen abwechselnd, seltener 2-6. Staubbeutel an beiden Enden gespalten. Fruchtknoten frei, 1eiig. Griffel 2, selten 1. Narben lang, fadenförmig, federartig und pinselförnig oder gewöhnlich sprengwedelig (aspergilliformis) genannt). Frucht nackt oder von den bleibenden Spelzen umschlossen. Samenkeim ausserhalb des mehligen Eiweisses an dessen Grunde liegend. - Die in Gebiete vorkommenden Gräser gehören in die 3. Klasse 2. Ordnung, nur Nardus stricta (III, 1) und Anthoxanthum odoratum (II, 2).

externum ( $\mathrm{K}$ o el e r), tegmen (P. B e a u r.), lepicena (R i ch a $\mathrm{d}$ ) etc. benannt worden. Ebenso verschieden sind die Benennungen für Spelzen, Bälglein und Deckspelzen. 
Erklärung der Abkïrzungen von Autorennamen und der gebranchten Zeichen.

\begin{tabular}{|c|c|c|c|}
\hline $\begin{array}{l}\text { A dans. } \\
\text { Afz. } \\
\text { Mit. }\end{array}$ & $\begin{array}{l}\text { Adanson. } \\
\text { Afzelius. } \\
\text { Aitun. }\end{array}$ & $\begin{array}{l}\text { Crtz. } \\
\text { Curt. }\end{array}$ & $\begin{array}{l}\text { Crantz. } \\
\text { Curtis. }\end{array}$ \\
\hline $\begin{array}{l}\text { Alex. Br. si } \\
\text { All. } \\
\text { Andrz. } \\
\text { Ard. }\end{array}$ & $\begin{array}{l}\text { iehe Braun. } \\
\text { Allioni. } \\
\text { Andrzeiowsky. } \\
\text { Arduino. }\end{array}$ & $\begin{array}{l}\text { DC. } \\
\text { Desf. } \\
\text { Desr. } \\
\text { Desv. } \\
\text { Don }\end{array}$ & $\begin{array}{l}\text { De Candolle. } \\
\text { Desfontaines. } \\
\text { Desroussaux. } \\
\text { Desvaux. } \\
\text { Don. }\end{array}$ \\
\hline $\begin{array}{l}\text { Babingt. } \\
\text { Balb. }\end{array}$ & $\begin{array}{l}\text { Babington. } \\
\text { Balbis. }\end{array}$ & $\begin{array}{l}\text { Drej. } \\
\text { Duby }\end{array}$ & $\begin{array}{l}\text { Drejer. } \\
\text { Duby. }\end{array}$ \\
\hline $\begin{array}{l}\text { Balding. } \\
\text { Bartl. }\end{array}$ & $\begin{array}{l}\text { Baldinger. } \\
\text { Bartling. }\end{array}$ & Whrh. & Ehrhart. \\
\hline $\begin{array}{l}\text { Bast. } \\
\text { C. Bauh. } \\
\text { J. Bauh. } \\
\text { Baunig. }\end{array}$ & $\begin{array}{l}\text { Bastard. } \\
\text { Caspar Bauhin. } \\
\text { Johann Bauhin. } \\
\text { Baumgarten. }\end{array}$ & $\begin{array}{l}\text { Fl. Wett. } \\
\text { Fr. }\end{array}$ & $\begin{array}{l}\text { Flora der Wet. } \\
\text { terau. } \\
\text { Fries. }\end{array}$ \\
\hline 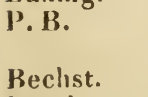 & $\begin{array}{l}\text { Palisot de Beau- } \\
\text { vois. } \\
\text { Bechstein. }\end{array}$ & $\begin{array}{l}\text { Gaertn. } \\
\text { Gaud. } \\
\text { Gniel. }\end{array}$ & $\begin{array}{l}\text { Gaertner. } \\
\text { Gaudin. } \\
\text { Guelin. }\end{array}$ \\
\hline $\begin{array}{l}\text { Benth. } \\
\text { Bernh. } \\
\text { Bertol. } \\
\text { Bess. } \\
\text { II. B. }\end{array}$ & $\begin{array}{l}\text { Bentham. } \\
\text { Bernhardi. } \\
\text { Bertoluni. } \\
\text { Besser. } \\
\text { Marschal von } \\
\text { Bieberstein. }\end{array}$ & $\begin{array}{l}\text { Haenk. } \\
\text { Hall. } \\
\text { Hartm. } \\
\text { Haw. } \\
\text { Hayn. }\end{array}$ & $\begin{array}{l}\text { Haenke. } \\
\text { Haller. } \\
\text { Hartmann. } \\
\text { Haworth. } \\
\text { Havne. }\end{array}$ \\
\hline BI. u. Fing. & $\begin{aligned} & \text { B } \text { Bluf } \\
& \text {. }\end{aligned}$ & & $\begin{array}{l}\text { Hegetschweiler } \\
\text { liHeritier. }\end{array}$ \\
\hline $\begin{array}{l}\text { Buenngh. } \\
\text { Boerh. } \\
\text { Borkh. } \\
\text { Alex. Br. } \\
\text { K. Br. } \\
\text { Britt. } \\
\text { Brot. }\end{array}$ & $\begin{array}{l}\text { Benninghansen. } \\
\text { Boerhaave. } \\
\text { Borkhausen. } \\
\text { AlexanderBraun. } \\
\text { Rubert Brown. } \\
\text { Brittinger. } \\
\text { Brutero. }\end{array}$ & $\begin{array}{l}\text { St. Hil. } \\
\text { Hoffin. } \\
\text { Hoff'msg. } \\
\text { Horneni. } \\
\text { Hunb. Bpl }\end{array}$ & $\begin{array}{l}\text { Saint Hilaire. } \\
\text { Hoffmann. } \\
\text { Hoffmannsegg. } \\
\text { Hornemann. } \\
\text { Kth. Hunboldt, } \\
\text { Bonpland und } \\
\text { Kunth. }\end{array}$ \\
\hline Cass. & & $\begin{array}{l}\text { Jacq. } \\
\text { Juss. }\end{array}$ & $\begin{array}{l}\text { Jacquin. } \\
\text { Jussieu. }\end{array}$ \\
\hline & & Koel. & Koeler. \\
\hline $\begin{array}{l}\text { Clairv. } \\
\text { Coult. }\end{array}$ & $\begin{array}{l}\text { Clairville. } \\
\text { Coulter. }\end{array}$ & $\begin{array}{l}\text { Lani. } \\
\text { L'Herit. }\end{array}$ & $\begin{array}{l}\text { La } \\
\text { ehe }\end{array}$ \\
\hline
\end{tabular}




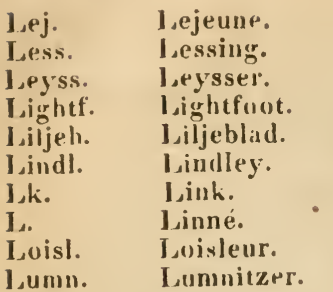

F. B. siehe Bipberstein.

Med.

Mer.

M. II. K.

Michx.

Mik.

Mill.

Medicus.

Merat.

Muq. 'Tind. Moquin-'Tasidun

Murr.

Rees

Nestl.

Nutt.

Mertens u.Kuch

Michaux.

Mikan.

Miller.

ED. B. siehe Beaurois.

Pall. Pallas.

Pers. Persuon.

Peterm. Petermann.

Poir.

Poiret.

Pull.

Pollich.

R. Br. siehe Brown.

Rebent. Rebentisch.

Rehb. Reichenbach.

Retz.

Kich.

Retzius.

Roem. u. Schult. Roemer u. Sichultes.

Ruz. Ruzier.

St. Hil. siehe Hilaire.

Salisb. Salisbury.

Schkr. Schkuhr.

Schlecht. Schlechtendal.

sichleich. Sichleicher.

Schrad. Schrader.

Schreb. Schreber.
Schübl. u. Nart. Schübler .

Martens.

Schumol. Schumarher.

Schweig. 11. Kört. Schweigger u. Körte.

Scop. Scopoli.

Sibth. Sibthorp.

Sni. Smith.

Schimp. u. Sp. Schimper u.

Spr.

sprengel.

Sternb. Sternherg.

Ster. Steren.

St. Sturm:

Sutt. Suttun.

Sw. Swartz.

Tenur. 'Tenore.

'Ihuill. 'Thuillier.

Vent. Ventenat.

Vill. Villars.

Vis. Visiani.

Wahlberg Wahlberg.

Whlbg. Wahlenberg.

W. K. Waldstein IIKitaibel.

Wallr. Wallioth.

Weig. Weigel.

IVib. Wibel.

Wigg. Wiggers.

Wickstr. Wickstruen.

Willd. Willdenuw.

W imm. u. Grab. Wimmer u. Grabuwshi.

Wither. Withering. Wulf. Wulfen.

$\odot=$ eine 1 jährige Pflanze. $\odot=$ eine 2 jührige Pflanze. $4=$ eine ausdauernde (pe. renuirende) Pflanze.

$\hbar_{2}=$ baun - oder strauch. artige liewächse.

' = Fuss.

$"$ = Zull. 


\section{Gefässpflanzen.}

Pflanzen mit Gefässen.

\section{Classe. Phanerogamische Exo- genen, Dicotylen.}

Gefässbündel im Stengel in einen Kreis gestellt und 7.11 einem Holzringe zusammenlaufend, wodurch Rinde und Mark geschieden wird. Hei strauch - und baumartigen Pflanzen der Stamm aus mehren concentrischen, von der Rinde umzogenen Holzlagen gebildet. Samenkeim mit zwei gegenständigen Keimblättern, seltner mit mehren in einen Quirl gestellten, sehr selten (bei Schmarotzerpflanzen) nit fehlenden Keimblättern.

I Unterclasse. Thalamifloren. Fruchtbodenbliithige.

Blumenblätter mehre, getrennt und nebst den Staubgefässen auf dem Fruchtboden und nicht auf dem Kelche eingefügt.

I. Familie. Ranunculaceen Juss. Ha hnenfussgew ächse.

1. Gruppe. Clematideen DC. Waldlebengewächse. Kelch blumenartig, in der Knospenlage klappig oder eingefaltetklappig; Blumenkrone fehlend oder kleiner als der Kelch ; Früchtchen nicht aufspringend, einsamig, mit dem fortwachsenden, meist bärtig-gefiederten Griffel gekrönt.

Garcke, Flora. 
1. Clématis I. Waldrebe (von rinuuctis Ranke, weil mehre Arten ranken).

1. Cl. Vitálba L., gemeine W. Reichenb. *) Abb. 4667. Stengel letternd; Blätter rankend, gefiedert, Blättchen herz-, seltener eiförmig, zugespitzt, ganzrandig oder entfernt gezähnt; Kelchblätter länglich, auf beiden Seiten filzig; Fruchtschweife lang, bärtig. t. Hügel und Waldründer, besonders auf Kalkbuden wirklich einheimiseh, in Hecken und Zäunen öf. ters nur verwildert. 'Züune bei Diemnitz und Granau, Abhänge zwischen dem Kurgs und Bennstedt, an den sozenannten Weinbergen bei Uiilrenberge, bei Weissenfels, hänfig in der Gegend von Naumburg und Freibrrg \%. B. Pfortenbery, INeinberge hei Rossbach; bei Alfstedt im Rimbache und an den wiisten Bergen; Züune bei Sandersleben. Juni. Juli. Blüthen aussen gelbgrün, innen und am Rande weiss. Der Stengel klettert bis 20' hoch an Bäumen hinauf.

2. Gruppe. Anemoneen DC. Windrëschengewächse. Kelch meist gefärbt, in der Knospenlage dachziegelförmig, Blumenblätter fehlend oder flachblätterig ohne Schuppe oder IIonigdrüse; Früchtchen nicht aufspringend, einsamig.

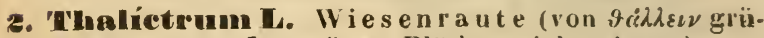
nen, wegen der grïnen Blüthen vieler Arten).

A. Tripterium DC. Frïchtehen glatt, nicht gerieft, ge. stielt, 3 kantigy-geflügelt.

2. Th. aquilegifolium $L_{.,}$A k e le iblät terige W. Abb. 4635. Stengel schwach-gerillt; Blätter $2-3$ fach gefiedert. Verästelungen des Blattstieles mit deutlichen, bleibenden Nebenblättern, Blättchen herzförmig-rund. lich, stumpf, 3lappig, Jappen ungetheilt oder gekerbt; Rispe fast ebensträussig; Frïchtchen 3kantig-gefliigelt, glatt. 1 . Wiesen; diese fül das Gebiet äusserst seltene Pflanze wird von Knauth bis Spreng. auf der grossen Wiese bei Passendorf angegeben und von letzterem bemerkt, dass sie wegen der Heuernte nur sehr selten zur Blüthe komme. Der Verf. fand sie bisher noch nicht. Mai. Juni. Blüthen blassgrün, Staubfäden lila. Höhe $1-\mathbf{3}$.

B. Euthalictrum DC. Früchtchen längsfurchig, sitzend.

*) Bei Weglassung des Namens beziehen sich die Abbildunger atets auf Reichenbach's Deutschlands Flora. 
a. Rispe dem Umfange "ach pyramidenförnig; Blüthen gleichmässig zer streut. Staubgefasse niederhängeud.

3. Th. flexuosum Bernh., bogigstengelige W. Abb. 4628. Stengel wenigstens in der Jugend am Grunde beblïttert, oft gebugen; Blättchen rundlich-verkehrteiförmiu, 3spaltiğ, 5-9zähnig; Oehrchen der Blattscheiden schmal, abgerundet, etwas gezähnt, zuletzt öfter umgeschlagen; Blüthen der abstehend ausgebrei. teten Rispe iberhängend; Friichtchen 10rippig; Riickenrippe 3 fach. 24. Hügel, sonnige Plätze, Acherränder und Wiesen. Bei Halle nicht selten z. B. auf dem Vogelsberge und den Kalkbergen bei Bennstedt rechts von der Chaussee, auf Wiesen bei Lettin; auf Aeckern bei Merseburg, Weissenfels, zwischen Etzdorf und Opphansen, bei Russleben und sonst verbreitet. Juni. Jul. Th. Jacquinianum $\mathrm{K}$ och.

Die hier beschriebene Pflanze stimmt auf das Genaueste mit der citirten Abbildung bei $\mathbf{R} \mathbf{c h}$ h. überein. Del Stengel ist $1-4^{\prime}$ hoch, glänzend, meist nur schwach gestreift, stets unbereift; die Blattstielscheiden scharf gestreift; die Verzweigungen des Blattstiels bei den vorliegenden Exemplaren stets ohne Nebenbliittchen; die Blättchen sehr zahlreich, meist 3spaltig und 5-9., selten nur dreizähnig, grün, unterseits blässer; die Hauptäste alle gebogen, oft geschlängelt; die Früchtchen grösstentheils (Orippig, nur sehr selten mit 9 oder 11 Rippen, die etwas mehr hervortretenden Rückenrippen inumer dreifach.

Hierher gehört unstreitig Th. collinum Wallr. sched. p. 259 und Th. minus bei Spreng. hal. ed. 2 p. 244. Das wahre 'Thalictrum mimus L. hat der Ver'fasser noch nicht im Gebiete gefunden. Zwal wird dasselbe von Wallr. sched. p. 255 unter dem Namen 'Th. nıontanum Wallr. sehr genau beschrieben und an den Weinbergen bei Bennstedt angegeben; der Verfasser fand aber daselbst nur Th. flexuusum Bernh. Die von $R c h b$. flor. saxon. p. 406 für Th. miıus L. citirten, aus Walli. ann. bot. p. 73 entlehnten Standorte "bei Nietleben, Bennstedt, Wansleben, Rossleben u. s."w. " verdienen un so weniger Beachtung, als Wallr. selbst in den sched. keinen Bezug darauf nimmit und Th. nıaius L., welches Rchb. sax. p. 407 gleichfalls nach Wallr. ann. bot. p. 72 am Bischofsberge angibt, von letztereu in den sched. p. 261 ausdrücklich zu Th. elatum Murr. gezogen wird; Rchb. hat also die beiden Werke vun W a lir. nicht einnal mit einander verglichen. 
b. Rispe last ehenstrïussig; Blüthen an der spitze der Aeste und Aestchen gedrängt; Früclite daselbst in dicliten Büscheln.

1. Blattstiele $3 z$ ählig-zusammengesetzt.

4. Th. angustifolium Jacq., s chm a l blät trig e W. Abb. 4636 u. 4637 . Wurzel faserig; Stengel gefurcht; Blättchen der untersten Blätter länglich-keilförmig oder linealisch, ungetheilt oder 3spaltig, die der oberen linealisch, ungetheilt, oberseits glänzend, unterseits bleicher und weichhaarig; Oehrchen der oberen Blattscheiden eiförmig, zugespitzt; Verzweigungen des Blattstiels ohne Vebenbliitchen; Rispe fast ebensträus. sig; Blüthen an der Spitze der Aestchen gehäuft, nebst den Staubgefässen aufrecht; Friichtchen eilänglich, an der Spitze etwas gekrümt. +. Feuchte Wiesen, in Gebiischen, selten. In der Aue von Döllnitz und Burgliebenau bis Modelwitz, bei Kl. Dölzig, an Bienitz, bei Dessau zerstreut, bei Oranienbaum im Bräunick; fehlt ausserdem in Gebiete. Jun. Jul. 'Th. nigricans G a u d. Th. Bauhinianum $\mathbf{~}$ a $11 \mathrm{r}$. Th. angustifolium L. zum 'Theil. Höhe 2-3'. Aendert ab:

a) stenophyllum W. u. Grab. Die Blättchen del unteren Blätter linealisch, zugespitzt, die der oberen fast fadenförmig.

b) heterophtyllum W. u. Grab. Die Blättchen des unterєn Bläter länglich, die der oberen linealisch.

c) I a s e pitifolium Willd. Die Blättchen aller Blätter länglich, die der unteren Blätter zum Theil bı eit-elliptisch, die der oberen etwas schmäler.

2. Blattstiele fiederig-zusammengesetzt.

5. Th. flarum L., go elbe W., Abb. 4639 u. 4639. Wurzel liriechend; Stengel grefurcht; Blättchen verliehrt ei-keilförmig, 3spaltig, seltener ungetheilt, unterseits mattgrün, die der oberen Blätter limealisch; Oehrchen der Blattscheiden länglich-eiförmig, länger als die Breite der Scheide; die unteren Verzweigungen des Btattsticls mit Vebenblïtlchen; Rispe fast ebensträussig; Blïthen an der Spitze der Aeste gehäuft und nebst den Stauhgefässen aufrecht; Früchtchen kugelförmig, stumpfkantig, gerade. 24. Feuchte Wiesen; sparsam zwischen Kröllwitz und der Kreuzschäferei und an den Pulver. weiden, häufiger zwischen Corbetha und der Merseburyer Chaussee, sehr häufig in der Aue bei Döllnitz, Burg Liebenau, KI. Dölzig, Wallendorf; Ostrau nordwestlich von Dürenberge, zwischen Weissenfels und Markwerben, in der Aue bei Naumburg, zwischen der Stein- 
Wippe und Memleben, in Riethe bei Allstedt, und aut den nassen Wiesen ron Benndorf nach Bitterfeld und Dessau ধu häufig. Jun. Jul. 'Th. nigricans Jacq. 'Thalictr. - - (anonymun) W allr. sched. 1. 263. Blïthen weisslich, Staubbeutel gelb. Höhe $1-3$ '.

3. Anemóne ta. Wi ud rös chen (ron üncuos, Wind, wegen der standorte und der frïhen Blüthezeit).

1. Hepatica $\mathrm{koch}$. Hüllblätter $3 z a ̈ h l i g$, sitzend, ungetheilt, kleiner als die Bliithen, denselben sehr genähert, einem Kelche ähnlich.

6. A. Hepática L., Märzblüm chen, L, e b e r blume. Abb. 4642. Blïtter 3lappig, Lappen ganzrandig, breit eirund; Blüthen auf nacktem, einbliithigem, fast handhuhem, feinzuttig behaartem Schafte; Friichtchen ungeschweift. 24. Schattige Walder und Haine, zwischen Gebüsch. Fehlt bei Halle (nach Spreng. in Mittelholze, wo sie der Verfasser nicht fand), Wälder und Gebüsche von Weissenfels bis Naumburg und Freiburg häufig, Schmonsche Berge, bei Allstedt besonders häufig im Hagen, bei Eisleben in den tiefer gelegenen Theilen des Katharinenhölzchens und der Hüneburg; Wälder bei Sander'sleben häufig. März. April. Hepatica triloba llC. Blume blau, selten roth oder weiss; in Gärten häufig gefüllt.

B. Pulsatilla $\mathrm{K} 0 \mathrm{ch}$. Hülblätter 3zählig, sitzend, gefingert-vieltheilig, am Grunde in eine Scheide verwachsen; Früchtchen lang, bältig-geschweift.

7. A. Pulsatilla L., ge me ine $\mathbf{K u h}$ - vder $\mathbf{K} \ddot{u}$ heschelle, oder yewöhnlich Küchenschelle genannt. Abb. 4657. Wurzelblätter 3 fach - fiederspaltig, zur Blüthezeit noch unentwichelt, Zipfel linealisch, verschmälert-spitz; Bliithen aufrecht; Kelchblätter noch einmal so lang als die Staubgefässe, am Grunde glockenförmig, von der Mitte an nur schwach auswairts gebogen; Früchtchen rauhhaarig, vielmal kürzer als die langen, zottigen Schweife. 4. Sunnige Hügel und Berge. Felsen zwischen Giebichenstein und Trotha, Ochsenberg hinter Kröllwitz, Hügel zwischen der Irrenanstalt und der Heide, Abhänge des Rockenholzes, trockene Abhänge des Bienitz, bei Naumburg und Freiburg sehr häufig, zwischen Hornburg und Rothenschirnbach unweit Eisleben; fehlt bei Aschersleben; bei Dessau zerstreut, bei Oranienbaum im Nichrim. April. Pulsa- 
tilla vulgaris Mill. Blume violett, zuletzt bleicher. Höhe $1 / 2-1$.

Unterscheidet sich von der folgenden, sehr nahestehenden Art durch die aufrechten, etwas grösseren, heller gefärhten Blüthen, durch die abstehenilen, an der Spitze nicht zurïckgeschlagenen Kelchblätter und durch die schmälern, mehr eingeschnittenen 'Zipfel der Blätter.

8. A. pratensix L., $s \mathrm{chwal} z \mathrm{e} \mathrm{Kuh}$ - oder $\mathrm{K} \ddot{\mathrm{u}}$ chenschelle. Abb. 4655. Wurzelblätter 2-3fach fiederspaltig, meist mit den Bliithen gleichzeitig, Zipfel linealisch; Bliuthen niederhängend; Kelchblütter immer glockenförmig-zusammenschiessend, an der Spitze nach aussen zuriickgerollt, wenig lïnger als die Staubgefüsse; Frïchtchen rauhharig, vielmal kürzer als die langen, selbzottigen Schweife. 24. Sandige 'lriften, trockene Hiigel, Heiden; nicht gar häufig. 'Irockene Hïgel der Dölauer Heide, z. B. am südlichen Rande zwischen Nietleben und der Fasanerie, auf lem Bischofsberge, einzeln auf dem Kellerberge, an einem Alhange des $\mathrm{R}_{0}$ rkenhulzes, in Mittelholze; bei Naumburg in den Wrinhergen von Eulau, bei Gosek und Leislingen; seltener hei Aschersleben; bei Dessau und Oranienbaum häufig z. B. im Nichrim, auf dem Kakauer Gottesacker. April. Mai. Pulsatilla pratensis Mill. Blume schwarzviolett. Höhe ' ' und darüber. OFF. Pulsatillae nigricantis rad. et herba.

1. vernalis L. kommt nur auf der Grenze des Gebiets in Heiden zwischen Sprottau und Gruhna nördlich von Eilenburg vor.

C. Anemone $\mathrm{K} 0 . \mathrm{ch}$. Hüllblätter $3 z a ̈ h l i g$, gestielt, den oft fehlenden Wurzelblättern gleich gestaltet; Früchtchen ungeschweift.

9. A. silvestris L., Wald-W. Abb. 4651. Wurzelbliitter 5theilig, weichhaarig, Zipf'el fast rautenförmig. 3spaltig, ungleich-gesägt; Blüthen einzeln; Kelchblätter neist zu 5, eiförmig, unterseits seidenhaarig; Friichtchen silberhaarig-wollig; Griffel kahl, sehr kur:.. 24. Sonnige, trockene Anhöhen der Laubwälder selten. Bei Halle mit Sicherheit nur in Mittelholye (auf dem Bischofsberge der Heide nach Leys er und S p r e ng.); häıfiger auf Kalk, z. B. südlicher Rand der neuen Giehle. bei Freiburg, bewaldete Anhöhen zwischen Freiburg und Laucha, Berge bei Bibra, Steinklippe bei Wangen; fehlt in nördlichen und östlichen Gebiete ganz. April. Mai. Blume weiss. Höhe $1 / 2-1$ '. 
10. A. nemorosa L., B us ch-W. Abb. 4644. Hüllblätter 3zïhlig, gestielt, Blattstiel fast halb so lang als das Blatt; Blättchen eingeschnitten-gesägt, das mittlere 3spaltig, am Grunde keilförmig, die seitenständigen 2spaltig, am Grunde schief-eiförmig; Blüthen einzeln; Kelchbliitter meist zu 6, länglich, stımpf, auf beiden Seiten kahl; Früchtchen weichhaarig, so lang als der kurze, gekrümmte Griffel. 24. Liabbwälder, Gebüsche, Waldwiesen gemein. März-Mai. Blume weiss, aussen röthlich, selten ganz rosenroth. Höhe 6-9".

11. A. ranunculoides $L_{0}$, hahnenfussartiges W. Abb. 4643. Hiillbläitter 3zählig, gestielt, Blattstiel vielmal kiirzer als das Blatt; Blättchen eingeschnittengesägt, das mittlere 3spaltig, an Grunde keilförmig, die seitenständigen 2spaltig, an Grunde etwas schief; Blüthen meist zu 2; Kelchblätter meist zu 5, eiförmig, seicht ausuerandet, unterseits weichhaarig; Früchtchen weichhaarig, in den gekrümmten, fast eben so langen Griffel zugespitzt. 4. Laubwälder, Hecken, Waldwiesen gemein. April. Mai. Blumen goldgelb. Höhe $1 / 2-1^{\prime}$.

Die Blüthen sind in den trockenen Wäldern um Halle fast immer einzelı, jedoch fehlen die Hüllblättchen für die zweite Blüthe nie; in den nassen Laubwäldern der Aue bei Schkeuditz sind die Blüthen wenigstens zu zweien, sehr oft aber zu dreien und vieren vorhanden.

4. Aelónis I. Ado $\mathrm{n}$ is (von Mdonis, welcher in eine rothe Blume verwandelt wurde.)

\section{a. Wurzel einjährig.}

12. A. Autumnalis L., Herbst-A. Abb. 4621 . Stengel ästim; Blätter gefiedert, vielfach-zertheilt; Kelch kahl, abstehend, vou den halbkugelföımig-zusammenneigenden Blumenblätern entfernt; Früchtchen zahnlos, in den geraden Schnabel anslaufend. $\odot$. Anf Aeckem verwildert. Obgleich diese Pflanze schon von Knauth enum. p. 119 und von Buxb. p. 6 unter der Saat bei Passendorf und Gimritz angegeben wird, so kann der Verf. doch nur der Meinung W allr. sched. p. 276 beitreten, dass sie ein Flüchtling aus den Gärten sei. Juni-September. Blume dunkel blutroth, am Grunde schwarz. Höhe 1'.

13. A. aestivalis $\mathrm{c}$., So $\mathrm{m} \mathrm{mer}-\mathrm{A}$. Abb. 4619. Stengel einfach oder ästig; Blätter gefiedert; Kelch kahl, den ausgebreiteten Blumenblättern angedrückt; Friichtchen oberwärts mit einem gleichfarbigen, etwas schief 
aufstrebenden Schnabel und am inneren Rande mit einem spitzen Zahne versehen. $\odot$. Unter ler Saat nicht selten, z. B. zwischen IIalle und Nietleben, bei Bennstedt und sonst hiiufig. Mai - Juli. A. miniata J a c q. Blumen weiss, Sblätrig, mennigroth, einfarbig oder am Grunde mit schwarzem Flecke. Höhe $1-1 \frac{1}{2}{ }^{\prime}$. Mendert ab:

h) citrina $H$ off $m$. Blumen strohgelb.

14. A. flamea Jacq., brennendrother $\mathrm{A}$. Abb. 4620 . Stengel ästig; Blätter gefiedert; Kelch weichhaarig, den ausgebrejteten Blumenblättern angedrückt; Frielitchen oberwäits abgerundet, mit cinem auf'strebenden, an der Spitze brandigen Schnabel versehen. $\odot$. Kalkhaltige Aecker, weit seltener als die vorige Art; einzeln zwischen Passendorf und Zscherben, zwischen Merseburg und Dürrenberge, häufiger auf Kalk an Vugelsberge bei Bennstedt; bei Naumburg und Freiburg verbreitet, ehensw zwischen Querfurt und Schmon, Querfurt und Lodersleben; selten bej Allstedt anf der Trift; fehlt im östlichen und nordöstlichen Gebiete. Juni Aug. A. anomala Wallr. Blume 3-, 6- oder 8blätterig, mennigruth, einfarbig oder an Grunde mit schwarzem Flecke. Höhe 1-11/2'.

b. Wurzel ausdauernd.

15. A. vernalis L., F rühling $\mathrm{s}-\mathrm{A}$. Abb. 4622. Stengel am Grunde schuppenförmig, uben beblättert, einfach oder ästig; Blätter gefiedert; Kelch weichhaarig; Frïchtchen fast kugelig-verkehrt-eiförmig, runzelig, weichhaarig, mit eincm hakenförmigen Schnabel. 4. Sonnige, unfruchtbare Hügel, besonders anf Kalkboden; sehr häufig auf den Vugelsberge und den Bergen zwischen Bennstedt und Köln:e, bei Lettin, zwischen Lieskau und Benkendorf, frehlt sidlich von Halle bis Weissenfels; bei Nammburg und Freiburg verbreitet, Steinklippe bei Wendelstein, Galgenberg bei Querfurt; bei Einzingen unweit Allstedt, Berge bei Obcriesdorf unweit Eisleben: bei Aschersleben, Sandersleben und Bernburg häufig; fehlt im östlichen und nordöstlichen Gebiete. April. Mai. Blume 12. bis 20blätterig, hellgelb. Höhe $1 / 2-3 / 4 "$.

3. Gruppe. Ranuneuleen DG. Aechle Hahnenfussgewächse. Kelch und Blumenkrone in der Knospenlage dachziegelförmig; Blumenblätter am Grunde auf der inneren Seite mit einem drüsenartigen Schüppchen oder mit einem röhrenförmigen Honiggrübchen. 
5. Myosúrts L. Mäuses chwanz (von uv̌s, dite Maus und oréc, der Schwanz).

16. Ir. minimus L., $k l e i$ is te M. Abb. 4569 . Blättes sänmitlich wurzelständig, büschelartig, schmal-linealisch; Schaft aufrecht, blattlus, einblüthig, zur Blüthezeit so lang als die Blätter. (.) Sand - und Lehmäcker, Lehmmauern gemein. Mai. Jumi. Blume gelbgrün. Höhe nur 2-4'. Der Fruchtbuden bildet mit den dicht an einander sitzenden kleinen Füchtchen eine oft 2" lange Aehre. Aendert mit 5 - 10 Staubgefässen ab.

6. Tanúnculas I. II a h n e $\mathrm{f}$ us (von rana, Frusch, wegen der in Wasser wachsenden Arten).

A. Batrachium DC. Blıme weiss, am Grunde gelb, ohne Schuppe des Honiggrübchens; Früchtchen querrunzelig.

17. R. aquátilis $\mathrm{L} ., \mathrm{W}$ a s s e $\mathrm{r}-\mathrm{H}$. Abb. 4576 . Untergetauchte Bliitter borstenfürmig-vielspaltig, gesticlt, Zipfel nach allen Seiten abstchend, schwimmende nierenförnig, gelappt vder gespalten; Blumenblätter breit, verkehrt-eirund, Staubgefiisse 20 und mehr, länger als das Köpfchen des Fruefitknotens; Früchtchen etwas ge. dunsen, quer-runzelig, steifhaarig oder kahl, mit einem kurzen Spitzchen; Fruchiboden behart, fast kugelförmig. 千. Stehende Gewässer gemein. Juni Aug. K. heterophyllus Wigg. Die untergetauchten Blätter fallen ausserhalb des Wassers sogleich in einen Pinsel zusammen. Aendert ab:

a) peltatus DC; schwimmende Blätter herzförnigrundlich, entweder bis über die Mitte 3 spaltig, nit 2theiligen, seitenständigen Lappen, oder meist 5lappig, mit 2 -3kerbigen Lappen, so in Lachen zwischen Burg Liebenall und Wallendorf.

b) truncatus Koch; schwimmende Blätter an Grunde abgestutzt, nicht herzförmig, sonst wie vorige Abart, so in Teichen bei Kl. Liebenau.

c) quinquelobus Koch; schwimmende Blätter 5lappig, mit ungekerbten Lappen, so in einem Teiche in Rödgen westlich von Brehna.

d) capillaceus 'Thuill. Blätter sämmtlich untergetaucht und rielspaltig; dirse Abart kommt mit grösseren und kleineren Blïthen vor; sehr häufig.

e) succuleutus Koch: schwimmende Blätter fehlend oder vorhanden, der Stengel verkürzt, oft nur 2-4" hoch, dicht beblättert, Blattıipfel dicker, saf- 
tig, etwas fleischig, so an überschwemmt gewesenen Stellen z. B. all den 'leichen bei Dieskau.

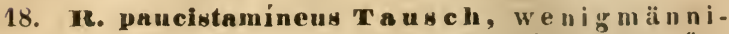
ger H. Liitter siimmtlich untergetaucht, lorstenfürmig-viclspaltig, gestielt, Zipfel nach allen Sciten abstehend; Blumenblätter verkehrt-eiförmig-länglich; Staubnefässe wenige, ungefüilı 8-12, länger als das Köpfchen des Fruchtinotens; Früchtchen etwas gedunsen, quer-runzelig, meist ein wenig steifhaarig, nit einem kurzen Spitzchen; Frurhtboiten behaart, fast kugelförmig. 24. Gräben und 'leiche; Teiche bei Röglitz und bei Kötschau, Gräben am Bifnitz und bei Dölzig. Mai-Auщ. Blumen viel kleiner als bei R. aquatilis I.

19. IR. divaricatus schranck, spreizblätteriger H. Abb. 4575. Lliitter siimmtlich untergetaucht, borstenförmig-vielspaltig, Zipfel in cine krcisrunde Flïche starr ausgebrcilct; Blumenblätter verkehrt-eiförmig; Staubgefüisse zahlrcich, länger als das Köpfchen des Fruchiknotens; Friichtchen etwas gedunsen, querrunzelig, unberandet, steifhadrig, nit einem kurzen Spitzchen. 2i. Stehende Gewässer, z. B. in einem Sunipfe bei Zaschwitz unweit Wettin, in den Lachen der alten Saale und der Aue zwischen Naumburg und Rossbach und sonst im Gebiete. Juni-Aug. R. circinatus Sibth. $R$. rigislus $\mathbf{H}$ of $\mathrm{fm}$. R. stagnatilis Wallr. Blume 5blätterig, hleiner als bei R. aquatilis I. Die untergetauchten, dunkelgrïnen Blätter bleiben ausserhalb des Wassers steif-kreisrund ausgebreitet.

20. Fe. fluitans $L$ am., f I uthender H. Abb. 4577. Blïtter sïmmtlich unter.ctaucht, borstenförmig - vielspaltig. Zipfel schr lang, glcichlaufend, fluthend, Blumenblätter 9-12, länglich-keilförmig; Staubgefïisse kür. zer als das Köpfclicn des Fruchknotens; Früchtchen etwas gedunsen, querrunzelig, unberandet, kahl, mit einem| kurzen Spitzchen. 24. Flüsse. Elster zwischen Döllnitzi und Burgliebenau, kleine Saale bei Kösen, Mulde zwischen Bitterfeld und Pouch, bei Dessau häıfig; blüht an vielen stellen nur sehr selten, z. B. in der Salzke in der Nähe des salzigen Sees. JuniAug. R. fluviatilis Wigg. R. peucedanifolius All. R. pantothrix $\gamma$. DC. Blume gross.

B. Ranunculus. Blumen hell-oder goldgelb; das Honiggrübchen mit einer fleischigen, aufwärts ge. richteten Schuppe bedeckt. 
a. Blitter ungetheilt. Wurzel faserig.

21. R. Flámmula L., b rennender H. Abb. 4595. Stengel aufsteigend oder niederliegend und wurzelnd, vielblüthig; Bï̈ttel elliptisch oder linealisch-lanzettlich, ganzrandig oder gesägt; Frïchtchen verkehrteiförnig, slatt, sthwarh beraudet, mit einem kurzen, stumpfen Spitzchen endigend. 24. Feuchte Wiesen, Sümpfe und Gräben gemein. Juni-Herbst. Blume klein, hellgelb. Höhe $1 / 2-1 \frac{1}{2}$.

22. R. Lingua L., gros s e r H. Abb. 4597. Stengel steif-aufiecht, vielblüthig, am Grunde quirlartig wurzelıd, röhrenförnig; Blätter lang - lanzettlich, zugespitzt; Früichtchen verkehrt-eiförnig, zusammengedrückt, berandet, glatt, mit breitem, kurz-sichelför. mig-gekrimmtem Schnabel. 24. Tiefe Sümpfe und Teiche zerstreut. Teiche zwischen Bruckdorf und Dieskau gleich an der Chaussee, an den Teichen bei Zörbig und in den 'Iorfstichen an der Fuhne häufig $z$. B. bei Löhersdurf, Göttnitz, Möst u. s. w.; in Lachen zwischen Markwerben und Uechteritz westlich von Weissenfels, auf Wiesen zwischen Thalwinkel und Burgscheidungen, in dem Aschersleber See, bei Dessau und Oranienbaum häıfig z. B. am Schrotmühlenbache. Juli. Aug. Blume gross, guldgelb. Höhe $12-4^{\prime}$. Stengel, Blätter und Kelche sind gewöhnlich kahl, selten durch angedrückte Haare rauh.

h. Blätter ungetheilt oller etwas lappig: Wurzel vielknollig, aus verdickten lasern zusainmengesetzt.

23. R. Ficária L., Feigwurzel-H., Schar. bock. Abb. 4572. Wurzel faserig, mit keulenförmigen Knollen untermischt; Stengel beblättert; Blätter rundlich-her fürmig, dic unteren geschweift, die oberen eckig, kahl, glänzend, in den Blattwinkeln oft zwiebelntragend; Blïthenstiele einblïthig; Kelch neist 3blätterig. 24. Schattige, feuchte Orte, Wiesen, im Gebüsch gemein. April. Mai. Ficaria ranunculoides $M$ ö n ch. F. verna Huds. Die Zahl der Kelchblätter ändert sehr ab und man kann an ein und demselben Exemplare Kelche mit 3, 4 und 5 Blättern wahrnehmen. - Die Wurzelknöllchen treten zuweilen aus der Erde und werden vom Winde muhergestreut, was Veranlassung zu der Sirge vom Brotregen gegeben hat.

c. Blätter getheilt oder zusammengesetzt. Wurzel vielknollig.

24. I. illýricus L., illyrischer II. Abb. 4587. Wurzelknollen länglich - walzenförmig; Stengel aufrecht, 
wenigbliithig, nebst den Blätern scidenarlig-sillsergliinzend, die ersten Wurzelblätter einfarlı, linealiss-li-lanzettlich, die folgenden $3 z$ ählig, Blättchen linealischlanzettlich, ungetheilt udur 2 - 3theilig; Bliithenstiele rund; Kelch zurïckgeschlagen. 4. Grasige llügel sehr selten. Schweizerling bei Wettin; auf der Grenze des Gebietes auf Hiigeln beï Hecklingen, Lödeburg und Stassfurt weit häufiger, aber selten blïhend. Maj. Rilume gross, fast goldgelb. Stengel 1' hoch.

1. Blätter zusammengesetzt oder tief-gelippt und gespalten: Wurzel faserig (hei $R$. bulbosus ist der Grund des Stengels knollenartig verdickt); Früchtchen glatt.

1. Bläthenstiele uichtgefurcht.

25. R. auricǒmus C., gold gelber H. Abb. 4599. Stengel anfrecht, vielblïthig; Wurzelblätter rundlich. nierentörmig, gekerbt, ungetheilt wder 3 - und mehrspaltig, Stengelblätter fingerig-getheilt; Blattsticle am Grunde scheidenartig; Friichtchen bauchig, schmal berandet, wcichhaarig, Schnabel völlig hakenförmigr. 21. Feuchte Wälder, Haine und Gebüsche gemein. April. Mai. R. cassubicus St. R. polymorphus All. Blume guldgelb. Höhe $6-18^{\prime \prime}$.

26. Fe. acris L., s $\mathrm{ch}$ arfer $\mathrm{H}$. Abb. 4606. Stengel aufrecht, vielbluthig; Wurzelblätter handfölmig-getheilt, in der Mitte meist schwarzbraun gefleclit, Zipfel fast rautenförmig, eingeschnitten-spitz-gezähnt, die oberen Stengelblätter fast sitzend, 3theilig, nit linealischen Zipfeln; Blattstiele weichhaarig, mit anliegenden oder aufrechteu Haaren; Früchtchen linsenförmig-zusammengedrückt, berandet; Schnabel etwas gekrümmt, vielmal kiirzer als das Friichtchen; Fruchtboden kahl. 24. Wiesen, Grasplätze, Wälder gemein. Nai. Juni und in Herbste wieder. Blume guldgelb. Höhe 1-3'.

27. Re. Ianuginōsus $\mathrm{C}$., Wolliger H. Abb. 4609. Stengel aufrecht, vielbliithig, nebst den Blattsticlen mit langen, weit abstehenden, weichen Haaren besetit; Wurzelblätter' handförmig-getheilt, 'Zipfel breit-verkehrteiförnig, 3spaltig - eingeschnitten, spitz-gezähnt; die oberen Stengelblätter 3theilig, mit länglich-lanzettlichen Zipfeln; Frïchtchen linsenförmig-zusamniengedrückt, berandet, Schnabel am Grunde breit, an der Spitze eingerollt, fast halb so lang als das Friichtchen; Fruchtboden kahl. $i$. Fenchte Stellen schattiger Laubwälder. Fehlt in der Nähe von Halle und Merseburg; Wälder bei Schkeuditz häufig, Büsche am rechten Saalufer 
Schellsitz gegenüber unweit Naumburg, Mühlthal zwi. schen Ziegelrude und Kossleben, in allen Laubwäldern bei Allstedt; bpi Eisleben im Helftaer Holze häufig, Wälder bei Freckleben unweit Sandersleben; quellige Abhänge des Muldenthales zwischen Rösa und Pouch östlich von Bitterfeld. Mai. Juni. Blume goldgelb. Hö he $1-3^{\prime}$.

\section{Blüthenstiele gefurcht.}

25. R. polyánthemos L.. vielblüthiger H. Abb. 4607. Stengel aufrecht, L - bis vielblïthig, unten abstehend-, oben angedriicht - bchaart; Wurzelblättes handförmig - getheilt, Zipfel 3theilig, eingeschnitten, Zipfelchen linealisch; Kelch rauhhaarig, den Blumenbliitlern anliegcnd; Früchtchen linsenförmig - zusammengedrückt, berandet, Schnabel liurz-hakenfürnig; Fruchiboden lorstig. 24. Wiesen, Waldränder zerstreut. Bischufs. berg in der Hejde, Mittelholz, Wiesen ron Kl. Dölzig, bei Naumburg zerstreut, südlicher Rand der alten Giehle bei Freiburg, Berge bei Bibra, bei Aschersleben und Dessau nicht selten. Mai-Juli. Blume goldgelb. Höhe $1-2$ '.

29. R. repens L., kriechender H. Abb. 4610. Stengel aufsteigend, mehıbliithig, mit kriechenden Ausliufern; Wurelblätter 3zählig wder duppelt 3zählig, Blättchen 3spaltig, eingeschnitten - gezähnt; Kelch loclier absichend; Frïchtchen liusenförmig-zusamnengedrückt, berandet, fein-cingestochen-puntitirt; Schnabel mur schwach gekrümnt; Fruchtboden behaart. 4. Feuchte Stellen in Gebüschen, Gräben, Wiesen überall genein. Nai - Juli. Blume goldgelb. Höhe $1 / 2-1 \frac{1}{2}$ '.

30. R. bulbōsus L., knolliger H. Ahb. 4611. Stengel anfrecht, niehrblüthig, am Grunde knollenfürmig; Wurzelblätter 3zählig oder doppelt 3zählig. Blättchen 3spaltig, eingeschnitten-gezähnt; Kelch zurïclige. schlagen; Friichtchen linsenförmig - zusammengedrückt, herandet, glatt; Schnabel schwach-hakenförmig; Fruchtboden behaart. 24. Brachfelder, 'Triften, Raiue, Wegund Ackerränder überall gemein. April - Juni. Blume goldgelb. Höhe $1 / 2-1$ '.

e. Blätter getheilt; Wurzel faserig; Trüchtches runzelig, hückerig oder di) ruig.

1. Fruchtkēpfchen ruudlich.s

31. R. Philonotis Eh h., blasser II. Abb. 4617. Stengel aufrecht, vielblüthig, am Grunde nicht knollen- 
fürmig; Wurzelblätter 3zählig oder doppelt 3zählig, Blättchen 3spaltig, eingeschnitten-gezähnt; Ḱclch zuriickgeschlagen; Friichtchen linsenförmig - zusammengedrückt, berandet, vor dem Rande höckerig. $\odot$. Feuchte, lehmige Aecker unter der Saat, Wiesen; Aecker zwischen Kröllwitz und der Heide, zwischen der Irrenanstalt, Nietleben und der Heide, Aecker an den Sümpfen bei Liestan, Wiesen zwischen Burgliebenau und Collenbey; fehlt bei Naumburg; sumpfige Stellen bei Ro. thenburg, Köthen und Dessau, lehmige Aecker an der Benndorfer Mühle. Mai-August. R. hirsutus Curt. R. sardous Crantz. Blume blass-dottergelb. Höhe $3 / 4-11 / 2^{\circ}$.

Unterscheidet sich ron dem nahestehenden $R$. bulbosus durch den Mangel der Knollen, durch eine einjährige Wurzel, durch die höckerigen Frïchte und durch ein helleres Grün der Blätter. Uebrigens findet sich die Pflanze mit einreihigen oder auf der ganzen Oberfläche der Früchte verbreiteten Höckern und sowohl rauhhaarig als fast kahl.

32. R. arvensis L., A cker-H. Abb. 4614. Stengel aufrecht, vielblüthig; Wurzelblätter ganzrandig oder 3spaltig, gezähnt, Stengelblätter 3zählig, Blättchen gestielt, 3- bis vielspaltig, Zipfel heilförmig, vorne gezähnt, die oberen linealisch; Kelch abstehend; Friichtchen nur $\mathbf{4}$ bis $\mathbf{6}$, gross, flach-zusammengedriickt, geschniibelt, auf beiden Seiten mit starken, hakigen Stacheln besetzt. $\odot$. Aecker hüufig z. B. bei Passendurf, vor Nietleben u. s. w. Mai-Juli. Blume hlejn, blass. citronengelb. Höhe $1-2$. A endert ab:

b) tuberculatus DC. Früchtchen auf beiden Seiten mit stumpfen Knötchen und am Rande mit stumpfen Zähnen besetzt. Die Abart mit wehrlosen Früchtchen ist noch nicht im Gebiete beobachtet worden.

2. Fruchtköpfchen Iänglich - walzcuförmig.

33. R. sceleratus L., Gif $t: H$. Abb. 4598. Stengel aufrecht, vielblüthig; Blätter etwas fleischig, glän. zend, die unteren handförmig - getheilt. eingeschnitten. gekerbt, dir oberen 3spaltir, mit liuealischen 'Zipfeln; Kelche zurückgeschlagen; Friichtchen selir Klein, unbekielt, an Rande nit einer eingrgrabenen Linie umzo. gen, in der Mitte auf beiden Seiten fein-muzelig. $\odot$. Gräben, Sümṕfe, 'Teiche, Flüsse und Bäche häutiğ z. B. an der Saale bei Giehichenstein, Grähen bei Dölau u. s. w. Juni - Herbst. Blumenblätter sehr hlein, kaum länger 
als der Kelch, blass citronengelb. Höhe $1 / 2-3^{\prime}$. Sehr giftig.

4. Gruppe. Helleb ore en DC. Niess ur $\mathrm{zgewa} \mathrm{chse}$. Kelch und Blumenkrone in der Knospenlage dachziegelig; Blumenkrone unregelmässig, verkümmert oder fehlend; Früchtchen balgartig.

8. Caltha L. Butter-, Dotter-oder Schmalz * blume.

34. C. palustris L., Sump f - B. Abb. 4712. Wurzel büschelig; Stengel aufsteigend, röhrenförmig; Blätter gestielt, herzförmig - kreisrund oder nierenförmig, feingekerbt, am Grunde des BIattstiels mit einer grossen, häutigen Scheide. 7. Sunpfige Wiesen, Gräben und Teiche gemein. April-Juni. Blume goldgelb. Höhe $1 / 2-1 \frac{1}{2}$.

\section{Tróllius T. Trollblume.}

35. T. europaeus L., e u ropä is ch e 'T. Abb. 4713 . Stengel aufrerht, einblïthig; Blätter handförmig, 5 - bis 7theilig, Zipfel rautenförmig, 3spaltig, eingeschnitten; Kelchblätter $10-15$, blumenkronartig, fast in eine Kugel zusammenschliessend; Blumenblätter so lang, als die Staubgefüsse oder etwas kürzer. 4. Feuchte Wiesen stellenweise. Vor und hinter den Sebenschen Busche, vor Gutenberg selten, auf einer Wiese bei Göhren an der Merseburg - Leipziger Chaussee, bei Kl. Dölzig und am Bienitz, Wiesen bei Rippah zwischen Weissenfels und Lützen, fehlt bei Naumburg, auf einer Wiese zwischen dem Scheierholze und dem Gehren und im Sandthale hinter Lodersleben, Wiesen bei Kreisfeld unweit Eisleben, Wiesen bei Sandersleben und Dessau, im Walde bei Löbersdorf an der Fuhne, in Bruche zwi. schen Sandersdorf und Bitterfeld, an der Benndurfer Wassernühle nördlich ron Delitzsch. Mai - Juli. Kelch. blätter hellgelb; Blunienblättchen dottergelb. Höhe $1-1 \frac{1}{2}$.

9. Nigélla L. Schwarzhümmel (von nigellus, schwarz, wegen der Farbe der Samen).

36. N. arvensis L., Feld-S ch. Abb. 4735. Stengel kahl, vom Grunde an ästig, Aeste abstehend; Blätter 2-3fach fiedertheilig; Bluithenhülle fehlend; Kelchblätter rundlich, mit einer Spitze; Blumenblätter klein, 2 lippig; Staubleutel stachelspitzig; Kapseln vom Grunde bis zur Mitte zusammengewachsen, glatt; Samen höckerig-punktirt. $\odot$. Aecker unter der Saat, auf Kalk. 
und J.ehmboden stellenweise. Vor der Gersdorfer wüsten Feldmark hinter Kiöllwitz selten; häufiger auf dem Vugelsberge bei Bennstedt, zwischen Seeburg und Erdeburn, zwischen Kötschau und Dürrenberge, Wein. berge bei Weissenfels, bei Naumburg häıfig, zwischen Gerbstedt und Zabenstedt, Schiessberg bei Sandersleben. Juli - Sept. Kelchblätter weiss oder hellblau, unterseits griingestreift und netzartig. Höhe $4-8$ ".

37. N. sativa L., ge b a te r S ch. Abb. 4736 . Stenuel weichbeharit, einfach wler mit wenigen aufrechten Aesten: Blïtter 3farh-fiedertheilig; Blüthenhülle fehlend; Kelchblätter rundlich, mit einer Spitze; Blumenblüter klein, 2lippig; Staubbeutel ohne Stachelspitze; Kapseln vw! Grunde bis zur Spitze zusammengewachsen, driisig-rauh; Samen querrunzelig. $\odot$. Wird in Ihüringen in grosser Menge gebauet, in Gebiete nur hier und da unter der Saat und unbeständig, so auf Gemüseäckern bei Grochlitz und Schellsitz unweit Naumburg, früher anch bei Röglitz und Lauchstedt ge. funden. Juni. Juli. Kelchblättel bläulich- Ieiss, mit yrüner Spitze. Höhe 8-12". OFF. Sem. Nigellae s. Nelauthii.

10. (1) A scheinlich nicht ron aquila, Adler, ab, sondern ist aus denı ursprünglich deutschen Namen Acoleia (im 12. Jahuh.) gebildet).

35. A. vulgaris C., gemeiner A. Abb. 4729. Stenvel anfrecht, oberwärts ästig; Blätter doppelt 3zählig, unterseits biäulich-grün, Blättchen 3lippig. geterbt, '/ipfel eiförmix, abgerundet; Blüthenstiele meist weichhaarig; Kelchblätter länglich-eiförmig; Sporn der Blumenhlätter an der Spitze hakenförmig. - - Wälder und Gebiische, besonders auf Kalkboden zerstreut. Einzelı in dem Wäldchen vor Gutenberg, "eit häufiger unter den Weinbergen bei Naumburg, im Schaafhulze bei Nismitz unweit Freiburg und am Hahn bei Laucha; selten in Rimbache bei Allstedt; in Nichrim bei Ora. nienbaum. Juni. Höhe $1-2$ '. Blume nickend, violett. hlau, seltener roth.

11. Belphinium T. Rit te r purn (der Nane soll sich auf die Aehnlichkeit der Knospen mit einen Delphine beziehen).

39. D. Consólida L., Feld-R. Abh. 4669. Stengel aufrecht, mit abstehenden Aesten; Blätter 3theilig, mit 
getheilten, schmal-linealischen Abschnitten; 'Trauhe 11 ("nigblüthig; Blüthenstielchen länger als die Deckblättchen; Blumenblätter verwachsen; Kapseln einzeln, kahl. $\odot$. Aecker ïberall gemein. Juni-Sept. Blume azurblau. Höhe $\mathbf{1}^{\prime}$.

12. Aconitum L. Sturmhut, Eisenhut (Name ron exóon, Fels, wegen des Standortes vieler Arten).

40. A. variegatum L., b un ter $S t$. Abb. 4682 - 4684 . Stengel pinfach, uberwärts abstehend ästig; Blätter handförmig , 5-7theilig, mit rautenförmigen, fiederspaltigen Zipfeln; 'Tranbe am Grunde ästig, endlich rispig; Ilelm kegelförmig; Honigbehälter auf cinem geraden Nagel anfrecht oder schief genejgt; Sporn halicnförmig; $5 \alpha$ men scharf-3kantig, auf dem Riiicken gefliigelt-querfal1ig. 24. Schattige Lanbwälder, Quellen und Bäche sehr selten. An der siidlichen seite des Mlittelholyes selten; im Gebïsch am rothen Brunnen und Sandbrunurn im Srheierholze hinter Ludersleben häufig; im Bornthale in der Nähe des Brunnenhauses bei Allstedt sparsam: sonst weiter nicht im Gebiete. Ju'i-Sept. I. Bernhardianum Wallr. A. Cammarum Jacq. Blume violett, blan, weiss und bunt geschecht. Höhe $3-5$ '.

Diese Pflanze wird zuerst ron kna $\mathrm{k}$ th enum. p. is erwähnt und zwar unter dem falschen Namen Aconitum coeruleum s. Napellus C. B. in dem l'etersbergischen Mittelholze wachsend, darauf von $k e h f$. hod bot. p. 93 unter Napellus, von Buxb. enum. p. 233 mnter Napellus verus flore coeruleo Parck. an dem erwähnten Stand. orte angegeben, ron Iseyss. hal. p. 130 aber daselbst vergeblich gesucht. Ehensu hat sie Wallr. sched. p. 252 an diesem Orte nicht gefunden und bemerkt, dass sie weder von $S p r e n g e l$, noch sonst Jemand durt bewhachtet sei, während doch Spreng. hal. ed. 1. p. 155 ausdrücklich sagt, dass er sie im Nittelholze 2 Mal gefunden labe, späterhin aber verschwunden sei und daher fl. hal. ed. 2. nicht wieder erwähnt wird. Erst vom Hrn. Prof. v. Schlechtendal und vom Verf. ist sie in Nittelholze wieder aufgefunden.

41. A. Lycóctonum L., II o If s - S t. Abb. 4679-4681. Blätter handförnig, tief 5-7spaltig, Zipfel 2-3spaltig, pingeschnitten - gezähnt; Blüthenstand traubig; Helm walzig-kegelförmigr; Honigbehälter aufrecht. Sporn faden. förmig, kreisförmig-zusammengerollt; Samen anf allen Seiten faltig-runzelig, stark-3liantig. 24. In Berguäl.

is a r cke, Flora. 
dern, besonders in den Thälern zerstreut. Fohlt um Halle und Merseburg; Sperlingsholz hintes Naumburg, Schuaf - und Mühlholz bei Freiburg, Mïhlthal zwischen hiegelrode und Rossleben, Burn- und Molkenbrunnen. thal hei Allstedt, tief gelegene. Stellen der Hiineburg bei Eisleben. Juni. Juli. Blume schwefelgelb. Höhe 1-4'. A. Thelyphonum Rehb.

5. Gruppe. Paeoniaceen DC. Päoniengewät hse. Keleh und Blumenkrone in ter Knospenlage lachziegelig; staubgefisse zahlreich; Staubbeutel nach innen aufspringend; Früchtchen mehrsamig.

13. Actaéa C. Christuphskiaut (nach Actïon, dem "yythologischen Jüger, benannt).

42. A. spicata L., ährentragendes Chr. Abb. 4739. Stengel aufrecht, kahl, am Grunde ohne Blätter, mit einigen Scheiden besetzt; Blätter 3zühlig-doppelt. gefiedert, Blättchen eiförmig oder länglich, eingeschnitten-gesägt; 'l'raube ei- oder walzenförnig; Blumenblätter so lang als die Stanbgefüsse; Beeren glänzend. schwarz. 24. Feurhte, schattige Laubuälder und Haine; stellenweise. Lupholz bei Schuchwitz, Brenau bei Wettin, Wall bei leislingen himer Weissenfels, Wälder bei Naumburg ziemlich verbreitet, Schlag - und Marienberge bei Freiburg, Steinklippe nach Wangen zu; Hule bei Voigtstedt unweit Allstedt. Mai. Juni. Blunie gelblich . weiss. Höhe $1-\mathbf{2}^{\prime}$.

\section{Familie. Berberideen Vent. Saut-} dorngewächse.

14. Bérberis I. Sauerdorn; Berberize (der jetzt lateinische Name stammt aus dem Arabischen).

43. H. vulgaris L., geme iner S. Abb. 4486. Dornen 3theilig; Blätter verkehrt-eiföımig, wimperartig gesägt, büschelstäıdig; Traube vielblüthig, niederhängend; Blumenblätter ganzrandig oder schwach-ausyerandet; Berren länglich - walzenförmi, scharlachroth. ち. In Gebüschen selten, häufiger in Hecken angepflanzt. Kroppenthal zwischen Schönburg nnd Wetau. Spechtsar bei Naumburg. Mai. Juni. Blume gelb. Ein $4-8^{\prime}$ hoher Strauch nit gelblichem Holze und schwarz-punctirter Rinde. OFF. Baccar Berberum. Die Pflanze soll nach Ruellius aus Mauritanien stammen. 


\section{Familie. Nymphaeaceen DC. See-} rosengewächse.

15. Nymphaéa L. Smith. Se e rose, Se elilie (von $\nu \dot{v} u \prime \eta \eta$, Nymphe, wegen des Standortes).

44. N. alba L., we is se S. Abb. 117. Blütter rundlich, tief-herzförmig, ganzrandig, schwinmend, mit walzenförmigen Stielen; Kelch 4blättrig; Fruchtknoten bis gegen die Spitze mit Staubgefüssen besetzt; Narben gelb, 12-20strahlig, Strahlen aufsteigend. 24. Stehende und langsam fliessende Gewässer stellenweise. Steinlache zwischen dem Ammendorfer Chaussechause und der Saale, zwische'n Osendorf und Collenbey, Zö. schen an Wege nach Wesmar, Merseburger Schlossgarten (hineingesetzt), 'Torfstiche an der Fuhne sehr hüufig z. B. bei Löbersdorf, Möst u. s. w., Petersrude bei Bitterfeld, zwischen der Rösaer Fähre und der Ziegelscheune östlich von Bitterfeld, Dessan häufig. Juni-Aug. Blume weiss. OFF. Rad. N. alb. Aendert mit um die Hälfte kleineren Bliitlien ab: $\mathbf{N}$. alba var. ninor DC.

16. Nuphar Smith. Numme I, N ixblnme.

45. N. Iuteum smith, gelbe M. Abb. 113. Blätter eiförmig, auf $1 / 3$ herzförnig - eingeschnitten, ganzrandig, schwinınıend; Kelch 5blättrig; Narbe flach, tiefgenabelt, ganzrandig oder an Rande wenig gekerbt, 10-20strahlig, Stralilen vor dem Rande verschwindend. 4. Stehende und langsam fliessende Gewässer, häufiger als die vorhergehende; bei Halle sehr verbreitet z B. vor Passendorf, zwischen Osendorf und Collenbey, 'Zöschen, in der Elster bei Ammendorf, Osterfeld unweit Naumburg, fehlt in 'Thüringen, so weit es zum Gebiete gehört, mit Ausnahme der Lache an der Unstrutbrücke bei Nebra; im östlichen und nordöstlichen Gebiete sehr häufig. Juni-Aug. Blume gelb. Nymphara lutea $L$. Aendert mit kleineren Bluthen und mit seidenartig-weichhaarigen Blatt- und Blüthenstielen ab. OFF. Rad. Nymph. Inteae.

IV. Familie. Papaveraceen DC. Mohngewächse.

17. Papáver L. Mohn (von papare, essen, weil dic Römer den Mohn unter Speisen nischten). 
\&. Kapseln steifhaarig.

46. P. Argemōne L., S a n d-M. Abb. 4473. Stengel aufrecht, beblättert, mehrbliithig, nebst den Blii. thenstielen mit anliegenden, steifen Haaren besetzt; Blätter fiederspa!tig; Staulfäden oberwärts verbreitert: Kapseln verlängert-keulenfürmig, vun zerstreuten, aufrechten Borsten steifhaarig; Blunienblätter einander nicht deckend; Narben 4-5strahlig. $\odot$. Aecker, Sandfelder lı̈ufig. Mai - Juli. Blume dunkelroth. Höhe $1 / 2-1^{\prime}$. Aendert ab, obwohl sehr selten:

b) glabrım Koch, der obere Theil des Stengeis "lebst Blïttern und Kapseln kahl.

47. P. hýbridum L., B astard-M. Abb. 4476. Stengel aufrecht, beblättert, mehrbluthig, webst den Bliithenstielen mit anliegenden, steifen Haaren besetzt; Staubfïden oberwärts verbreitert; Blumenblätter an Grunde sich deckend; Kapsel rundlich, mit gebogenen, weit abstchenden Borsten besetzt; Narben 6-8strahlig. $\odot$. Aecher, sandige Raine sehr selten. Zwischen Pfizenburg und Wansleben, an der Eisenbahn in der Aue bei Naumburg. Nach S p reng. bei Granau, wo es der Verf. nicht fand. Mai-Juli. Blume ziegelroth. Höhe 1-2'.

b. Kapseln kahl.

45. P. Thoeas L., Klatschrose. Abb. 4479. Stell. gel anfreclit, beblättert, mehrblüthig, nebst den Blï. thenstielen mit wagrecht-abstehenden IJaren besetzt; Blätter fiederspaltig; Staubfiiden pfriemenförmig; Blumenblätter sehr breit, sich deckend; Kapseln Kurz-verkehrt-cifürmig, an Grunde abgerundet, lahl; Narben 8-12strahlig, Stralilen mit ihrem Rande einander dekkend. $\odot$. Aecker gemein. Mai-Juli. Blume scharlachroth, am Grunde bisweilen schwarz. Höhe 1-2'.

49. P. alubium L., $\mathrm{z}$ we if el haftel M. Abb. 4477. Stengel aufrecht, beblättert, mehrbliithig, unterwärts mit abstehenden, oberwärts mit angedrichten Haaren besetzt, Blüthenstiele angedrïrkt-belaart; Blätter doppelt-fiederspaltig; Staubgefüsse pfriemenfürmig; Blımenblätter fast hreisrund, sich gar nicht wder nur wenig deckend; Kapsel lïnglich, verkchrt-ciförmig, am Grunde verschmcilert, kahl; Narben 7-9strahlig; Strahlen deutlich von cinander gesondert. $\odot$. Sandiuge Aecher, nicht hünfig. Im Bade Wittekind, sparsam zwischen den Donnersberge und dem Schwalchloche hinter Kröltwitz, hänfiger zwischen Brehna und Serbitz und Serbitz 
und Zaasch, ebensu zwischen Schortan und Branderode siidlich ron Merseburg, Weinberge an der Henne und an den Saalhäusern unweit Naumburg, einzeln an Schiessberge bei Sanderslpben. Mai - Juli. Blıme hellscharlachroth, am Grunde bisweilen schwar'z. Höhe 1-2'.

50. P. somniferum L., schlafbringende. M. Abb. 4481 1. 82. Stengel aufrecht. beblättert, kahl, neergrün; Blätter länglich, ungleich-gezähnt, die unteren buchtig, am Grunde verschmälert, die oberen ganzrau. dig, mit herzförnigem Grunde stengelumfassend; Staub. gefiisse obcrüirts verbreitert; Kapsel kugelfürmig oder. ciförmig-lïnglich, kahl, unter der Narbe in Löchern aufspringend oder geschlussen bleibend, Narben vielstrahlig. $\odot$. Nur hier und da anf Feldern gebaut z. B. I ei Oberthau, hänfiger bei Ascherslebel. Juli. Ang. Blunie gross. Höhe $2-5^{\prime}$. Aendert ab:

a) officinale $\mathrm{Gmel}$. Blumenblätter weiss, an Grunde violett.

b) som nif,erum Gmel. Blumeublätter heller oder dunkler rosenruth, an Grunde viulett. OFF. Capita et Semina Papar. albi et coerulei.

Pap. trilobum Wallr. Abb. 4480. welches nur der Autur zwischen Osterhausen und Rothenschirmbach gefunden hat, war schon zu Sprengel's Zeit (cf. hal. ed. 2. p. 235) durt verschwunden.

18. Claucium Tounef. Hornmohn (vou ¡'hce\%ós, meergrün, wegen der blaugrünen Jiarbe der Pflanze).

3. C. Inteum scop., gelber H. Abb. 4465. Stengel fast kahl; Wurzelblätter gestielt, Stengelblätter mit tief-herzförnizem Grunde stengelumifassenil, lappig-fieJersopaltig; Blïthen kurz gestielt; Frucht linütig-rauh, nur nach der Spitze hin kurz burstig. (-) duf Kalkboilen an alten Burgen sehr selten. Sichlossberg in Wallbeck unweit Hettstedt, alte Burg bei Aschersleben, Vizzenburg unweit Nebra. Jun. Jul. Chelidoniun Glaucium L. Blumenblätter gruss, fast 3eckig, citronengelb, Früchte bis 8 ' lang. Höhe $1-2$ '.

52. G. corniculatum Curt., rother H. Abb. 4470 11. 71. Stengel und Blïtter behaart; Wurzelblätter gestielt, Stengelblätter mit abgestutztem Grunde sitzend, fiederspaltig; Bliithen gestielt; Frucht borstig-steifhaarig. $\odot$. Aecker unl unbebaute Weinberge sehr selten, nur in Weinbergen zwischen Seeburg und Wansleben 
und auf Aeckern bei Aseleben an süsseu See. Jun. Jul. Blumenblätter kleiner als bei voriger Art, breitrundlich, hochroth, an Grunde mit einem schwaryen Flecke. Höhe 4-18". G. phoeniceun Gärtn. Chelidoniun corniculatum I. Zuweilen ist der schwarze fleck der Blumenblätter von einem weissen Samme umzogen: G. triculor $B$ ernh. Dies ist die gewöhnliche foru in Gebiete, dorh keineswegs beständig und der Verf. hat Blumenblätter ler sonst ganz übereinstimmenden Pflanzen mit und ohne weissen Samm gefunden.

19. Chelialóniom I. Schellwurz, Schell.

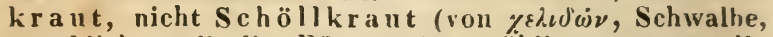
angeblich weil die Pflanze in Frihlinge, wenn die Schwalben kommen, ausschläıt und zur Zeit, wo sie wegriehen, abwelkt).

53. Ch. maius L., grösseres Sch. Abb. 4466. Stengel ästig, lang hehaart; Blätter fiederspaltig, unterseits meergrïn, Zipfel runllich, burhtig, gezähnt: Blüthen duldig; Kelch fast kahl; Staubfäden uberwärts breiter; Blumenblätter länglich, ungetheilt. 24. Schutt, Felsen, Mauern, Zäune, gemein. Mii-Herbst. Blume gelb. Höhe $1-3^{\prime}$. OFF. Rad. et $\mathbf{H b}$. Chelidonii maioris.

Die Ahart $\mathrm{Ch}$. la c iniatum Mill. mit länger gestielten, bis ïber die Mitte fiederspaltigen Blättchen, länglichen, eingeschnitten-gekerbten Zipfeln und eingeschnitten-gekerbten Blumenblittern ist früher zwischen Seeburg und Eisleben beubachtet, in neuerer Keit jedoch dort nicht wieder gefunden worden.

\section{Familie. Fumariaceen DC. Erdrauch- yewächse.}

20. Corýdalis DC. Hohlwurz, Spornchen (ron yo@vocilis, Lesche, wegen der Gestalt der Blunen).

a. Deckhlitter ganzrandig.

54. C. cava schweigg. u. Kijrt., geme ine $H$. Abb. 4463. Wurzelstock knullig, hohl, auf allen Seiten mit Fasern besetzt; Stengel an unteren 'Theile ohne Schuppcn; Blïtter doppelt-3zählig, eingeschnitton; Fruchttraube aufrecht; Bliithenstielchen 3 mal kürzer als die längliche, zusammengedrückte Kapsel. 24. Haiıe, Gebüsche, Wald - und Wiesenränder nicht selten z. B. in Wörmlitzer Hölzchen, auf der Rabeninsel, in Zorgs und sonst häufig. April. Mai. C. tuberosạ DC. Fuma- 
ria cava Mill. F. bulbosa \& L. Blume trübpurpurı oder weiss. Höhe $1 / 2-1$ '.

55. C. fabácea Pers., bohnenartige H. Abb. 4461). Wurzelstock knulliv, nicht ausgehöhlt, an untersten Ende mit Fasern besetzt; Stengel an unteren Theile mit ciner rinnenförmigen Schuppe; Blätter doppelt - 3zählig, eingeschnitten; Fruchtraulie nicht verliingert, weniglliithig, gedrungen, iiber/hangend; Blïthenstiele 3 mal kürzer als die eiförmig-längliche Kipsel 4. Haine, Gebüsche nicht gerade selten: Wörmlitzer Hölzchen häufig, 'Trothaische Werder seltener, Ränder des Mit. telholzes, Gemeindeholz bei Zöschen, Zöschener Holz zwischen Röglitz und Zöschen, Gebiische bei Beuditz unweit Weissenfels, Gebüsche zwischen Leislingen und Schönburg, Wälder bei Schönburg, Ahhang des Berges zwischeu Almerich und Schulpforte, Mühlthal bei Ziegelrode, Wäldchen an der Lindenschlucht zwischen Sepburg und Neehausen, alte Burg und Westerberge bei Aschersleben, Wïlder bei Freckleben unweit Sandersleben. April. Mai. Fumaria fabacea Retz. F. intermedia Eh rh. F. bulbosa $\beta$. L. Blume trïbpurpurn. Höhe $4-6^{\prime \prime}$.

Der Krupf an Grunde der Blumenkrone vor dem Blütheustielichen ist ebensu unbedeutend, wie die kaum bemerkbare Anschwellung dieses Theils bei C. pumila Host und kann daher nicht als Unterscheidungsmerkmal dienen, wie öfter irrthümlicher Weise angegeben. wird.

h. leckbätter fingerig - getheilt.

56. C. pumila Fost, $\mathrm{Z}$ we r g-H. Abb. 4461. Wurzelstock kuollig, nicht ausgchöhl, an untersten Eude mit Fasern besetat; Stengel an unteren Theile mit cinernierenförmigen Schuppe; Blätter doppelt-3zählig, eingeschnitten; Fruchttraube meist venigbliithig, gedrungen, iiberhangend; Deckblätter länger als die Blïthenstielchen, diese 3 mal kïrzer als die kurzen, breit-lanzettlichen Kapseln; sporn gerade oder nur wenig gekrïmmt. 2. Haine, Gebiische, nicht gar selten, aber inmer verwechselt. Sebener Busch, Bischufsberg in der Heide, Lindberg, Zorgs, Ränder des Nittelholzes, Frenzelholz bei Lieskau, Wäldchen an der Lindenschlucht zwisichen Seeburg und Nechausen, Westerberge bei Aschersleben, Wälder bei Freckleben, Lehholz bei Sandersleben; fehlt bei Naumburg und Freiburg und im östlichen Gebiete. März. April. C. Lobelii $\mathbf{T}$ a u s ch. Blume trïbpurpurn. Höhe $4-6^{\prime \prime}$.

Diese Pflanze haben Sprengel, Wallroth und 
Kollb. irrthimlicher Weise fiir C. digitata P'ers. ge halten, welche in Gebicte nicht rorkummt.

81. Fuméxin I. Eidrauch (von funus, Rauch, wegen der graucn Farbe des lirautes).

57. F. officinalis L., gebräll chlicher E. Abb. 4454. Blätter doppelt-gefiedert, mit länglichen und li"ealischen Zipfeln; Fruchttraube locker; Kelchbliitter 3 mal kiirzer ais die Blume, breiter als das Bliithenstielchen; Schütchen rundlich, breiler als lang, an der Spitze abgestutzt und ctwas ausgerandet. $\odot$. Necker und Schutt iiberall gemeiu. Mai-Herbst. Bume purpurroth, an ler Spitıe schwärz ich-ruth. Höhe $1 / 2-1$ OFF. Hb. Fumariae. Aendert ab:

b) minur Kuch; Bliithen um die Hälfte kleiner. F. media autur.

F. tenuifolia Fries, welche Koch synopsis p. 1018 als Abart zu F. off. ritirt, gehört nach brieflichen Mittheilungen von Prof. Fries an Prof. Kunze zu F. Wirtgeni $\mathrm{K}$ oc $\mathrm{h}$.

58. F. Wirtgeni Koch, Wirtgen's E. Blätter einfach uder dopp+It gefiedert, mit lanzettlichen Zipfeln; Kelchbliitter ei-lanzettlich, zugespitzt, gezühnt, fast 3 mal kiir: $: e r$ als die Blume, breiter als das Bliithenstielchen; Schötchen kugelig, so breit als lang, stumpf, nicht ansgerandet, in der Jugend spitzig; Blithenstielchen dïnı, fast 4 mal so lang als das Dechblätchen. $\odot$. Bebauter Boden selten, Weinberge von Weissenfels und gewiss weiter verbreitet. Juni-Septbr. Blume fleischroth, kleiner als bei der vorigen. In der gauzen Tracht und in der Färbunur mit F. officinalis, in Gestalt der Schötche॥ mit F. Vaillantii übereinstimmend.

59. F. Vaillantif Loisl., Vaillant's E. Abb. 4452. Blätter einfach- oder doppelt-gefiedert, mit lanzettlichen ouler linealischen Zipfeln; Kelchblätter sehr klein, kaum mil unheiunffnetem Auge zu er\%ennen, schmäler als das Bliithenstielchen, Schötchen kugelig, so breit als lang, stumpf, in der Jugend spitzig. $\odot$. Bebauter Buden, besonders auf Kalk nicht selten. Vor Giebichenstein, zwischen Halle und Nietleben, besonders häufig in Weinbergen bei Bennstedt, Rollsdorf und Seeburg, Rauschens Hölzchen bei Mersehurg, Weinberge bei Weissenfels und Naumburgr, Mittelhiitte und Hutberg bei Eisleben, Westerberge bei Aschersleben. Juni - Sept. Blume blass rosenroth oder weisslich, an der Spitze dunkler, kleiner als bei $F$. off. Höhe $1 / 2-3 / 1$. 
Fum. spicata L. Abb. 4450 mit endständigen, dicht kupfartigen Tranben und eiförnigen, flachgedriickten Schötchen wurde im Jahre 1847 auf Schntt bei Zöschen an der Merseburg-Leipzigre Chaussee in mehren Exemplaren gefunden. Der Verf. muss sich jedoch erst von der Beständinkeit dieser seltenen Pflanze in Gebiete überzeugen, ehe er sie der Flura einverleibt.

VI. Familie. Cruciferen Juss. Kreuzb) 1 ii mler.

1. Unterordnung. Siliquosen. S ch ot en f r ü chtige. schote linealisch oder linealisch-lanzettlich, $2 \mathrm{klap-}$ pig, aufspringend.

1. Gruppe. Arabideen DC. Gänsekressegewächse. Keimblätter der Scheidewand parallel, dem Würzelchen anliegeud.

22. Cheiránthus BC. Lack (keineswegs vun zeio, Hand, und ¿ ¿vos, Blume, wie oft falsch angegeben wird, souder"n von dem arabischen Pflanzennamen cheiri oder keiri und $\left.u^{\prime} y^{\prime}\right)$ oc, also die Blume oder Pflanze Cheiri.)

60. C. Cheiri L., Guldlack. Abb. 4347. Blättej lanzettlich, spitz, ganzrandiy, mit einfachen, zerstreuten, anliegenden Haaren besetzt, die unteren beiderseits 1-2zähnig, Zühne spitz; Schoten zusammengedrïclit. 7. Alte Mauern sehr selten, nur an der Moritzburg in Halle, wohl einheimisch. Mai. Juni. Blume sattgelb. Höhe $1-1 \frac{1}{2}{ }^{\prime}$. Linné wannte die cultivirte, nieist urangegelb blïhende Pflanze Ch. Cheiri, die wilde $\mathrm{Ch}$. fruticulosus.

23. Nagtúntiuna R. Mrr. Brunuenkresse (angeblich von nasus, Nase, und sternutare, niesen, weil das P'ulver ron einigen Arten Niesen erregt).

a Carlamiuum 1)(. Blumenhlatter weiss.

61. N. officinale R. B r., ge bräuchliche B. Abb. 4359. Stengel in Wasser niederliegend, aus den Blattachseln uurzelnd; Blätter gefiedert, die unteren 3zählig, die wberen $3-7$ pararig, Bliittchen geschweift, die seitenstündigen elliptisch, das endstiindige eiförmig, am Grunde fast herzfürmig: Schuten linealisch, gedunsen, so lang als das Bliithenstielchen. 24. Quellen, Bäche, Gräben stellenweise. 'I'eich in Radewell, Schmöl'- 
leubach zwischen Teutschenthal und Steuden und zwi. schen Eisdorf und Kochstedt, hinter Priester all Fuss. wege nach Iöhejïn, Quellen am Bienitz, Nue bei Naumbury und hänfiger in einer Quelle bei liösen; Bibra zahlreich, zwischen Erdeborn und dem salzizen See; Aschersleben stellenweise; Dessau hänfig. Juni - Sept. sisymbrium Nasturtium J. Höhe $1 / 2-2$ '. OFF. Hb. Nasturtii aquatici. Aendert ab:

a) mic.lophyllum But"ningh. (Abh. 436(1). Die ganze Pflanze kleiner, Blättıhen kurzgestielt, klej"1P, Blïthe"\| grösser, so an feuchten Orten ansserhalb des Wassers.

b) sifolium Rchb. (Abb. 4361). Stengel bis $8^{\prime}$ lang. Blättchen aus herzförmigem Grunde lanzettlich zugespitzt, so in tipferen Wasser z. B. Lobesbach zwischen Benndorf und Paupitzsch.

h. Irachyluhos DC. Blumenblatter gelh.

62. N. amphibium R. Br., ortwe chselnde $\mathbf{B}$. Abb. 4363. Stengel am Grunde wurzelnd, of ausliufertreibend, im Wasser aufgeblasen-röhrig; Blätter lïnglich oder lanzettlich, am Grunde mit wnd ohne Oehrchen; Schötchen elliptisch oder fast kugelig, 2-3 mal jiirzer als das Bliithensticlchen. 4. Gräben, Sïnıfe, Flïsse gemein z. B. Griben bei Passendorf, Reide hei Osendurf u. s. w. Mai - Juli. Sisymbriun anıhibium L. S. Roripa Sicop. Nast. aquaticum und $N$. riparium Wạ llr. Höhe $2-3$. Aenclert ab:

a) Iiparium Tausch. Stengel aufrecht, härter, weniger röhrig; Blätter ungetheilt oder die untersten kammartic oder leierförmig eingeschuitten.

b) aquaticum' I' a us ch. Stengel am Grunde kriechend. ausläufertreibend, weit-röhrig, leicht zusammendrückbar, die untersten Blätter leierförnigg oder fiederspaltig.

c) $s$ n b m ersum Taush. Stengrl wie bei voriger Abart, aber mehr oder minder schwimmend, die untergetauchten Blätter kammartig-fiederspaltig, mit haarfeinen Abschnitten, die über dem Wasser kammartig eingeschnitten und ungetheilt.

63. N. vilvestre R. I r., Wald-B. Abb. 4368. Stengel sehr ästig, ausgebreitet; Jilitter siimmtlich tieffiederspaltig oder' gefiedert; Zipfel länglich-Ianzettlich, gezähnt oder wieder fiederspaltig, die der wberen Blätter oft linealisch; Blumenblïtter lïnger als der Kelch; Schötchen linealisch, so lang, etwas lüinger oder kïirzer 
als das Bliithensticlchen. 24. Gräben, Aecker, feuchte Gras-und Sandplätze gremein. Jun. Aug. Sisymbriun silvestre $L$. Höhe $1 / 2-1 \frac{1}{2}$

64. N. palustre IC., Sum p f-13. Abb. 4362. Untere Blätter leierföımig, wbere tict-fiederspaltig, mit länglichen, gezähnten Zipfeln; Jlumenblïtter nur so lang als der Kelch; Schötchen länglich, gedunsen, stiel. rund, fast su lang als das Blïthenstielchen (.). Grähen, überschwenmit gewesene Plätze, etwas seltener als vurige z. B. Gräben vor Reidebur., und Bischdorf, rul Gutenberg. Juni-sept. N. terrestle R. B s. Si. symbrium palustre I, eyss. Höhe $1 / 2-2^{\prime}$.

N. a nceps DC, we!ches spr. hal. ed. 2. p. 299 als Abart vou $\mathbf{N}$. amphihium $\mathrm{R}$. Br. ohne besonderen Standort anfïhrt, hat der Verf. in Gebiete noch nicht beobachtet, eben su wenig $N$. terrestre 'Tauseh, welche beide vielleicht norh gefunden "erden könnten; dagegen ist das Vurkummen von N. pyreuaicum $\mathbf{R}$. Br. (DC?), welches Wallr. bei Wettin angibt, zu bezweifeln.

24. Hsrbaraea H. Hr. Winterkresse (nach der heiligen Barbara benannt; hiess früher Herba sanctae Barbarae).

65. H. Vulgaris M. H r., geme ine W. Abb. 4356. Untere Blätter leierförmig, Endlappen sehr gross, meist rundlich, am Grunde etwas herzförnig, Seitenläppchen 2-4paarig, obere Blätter ungethrilt, verkehrt-eiförmig, gezähnt; Jlumenbliitter ziemlich doppelt so lang als der Kelch; 'Traube während des Aufblïhens gedrungren, Schoten aufrecht-abstehend. (.). Feuchter, besonilers sandiger Buden, Aerker, weit seltener als die beiden folgenden Arten. Mit Sicherheit nur bei Riickmarsdorf. Mai - Jul. Erysinum Barbarea I. Rlume goldgelb. Höhe $1-2^{\prime}$.

Was Spr. hal. ed. 2 p. 294 als B. vulg. anführt, ist $B$. stricta.

66. 13. arcuata Hehb., krummschotige W. Abb. 4357. Untere Blätter leierförmig, Endlappen sehr gross, rundlich oder eifömig, am Grunde etwas herzförmig, Seitenläppchen 2 - 4 paariø, obere Blätter ungetheilt, verkehrt-eiföımig, gezühnt; Blumenblätter ziemlich doppelt so lang als der Kelch; Traube während des Aufblïhens zienlich locker; Schoten bogenförmigaufsteigend. (-). Feuchte Orte, Wiesen, Wälder zer- 
streut, Wiesen zwischen Zöschen und Wesmar und auf den benachbarten Auenwiesen häufig. Mai. Juni. B/ıme goldyelb. Höhe $2-3^{\prime}$.

67. H. stricta Andrz., steife W. Abb. 4355. Untere Blätter leierförmig. Endlappen sehr gross, länglich-piförmig, seiteuläppchen 2-3paarig, meist hlein, mittlere Blätter am Grunde leierförmig-eingeschnitten, "bere ungetheilt, verkehrt-eiförmig, geschweift-gezähnt; filumenbliitter nur 1/3 liinger als der Kelch; Schoten an die Bliithenspindel angedriickt, aufrecht. ¿. Feuchte, schattige Wälder und Gebïsche, steinige Flussufer, zienlich verbreitet. Gehïsch an Schwalchloche hinter Kröllwitz, Saale vur Bölberă, zwischen der Elster und Luppe liei Schkenditz; Aue an der Saale bei Naumburg. Mai - Jul. Blume klein, etwas heller goldgelb. Höhe $2-3^{\prime}$.

Die Seitenläppchen sind bei B. vulg. und B. arcunta heineswegs immer 4 paarig, wie Koch synops. p. 39 angibt und das oberste Paar derselben ist anch bei $B$. stricta oft su breit als der Querdurchmesser des Endlappens; auch hat der Verf. die Schoten bei B. arcuata, welche nach Koch a. a. O. ,, bei der Reife zienulich gerade" sein sollen, immer weit bogenförnig - abstehend gefunden.

25. Turpitis I. 'Thu r m kraut (von turris, Thurm).

68. T. glabra L., kahles Th. Abb. 4346. Stengel aufrecht, kahl; Wurzelblättel schrotsägeförmig, gezühnt oder ganzrandig, von 3gabeligen Haren ranh, Stengelhlätter kahl, nit tief-herz-pfeilförnigen Grumb stenoelumfassend; Srhoten steif-aufrecht. 6 mal länger als das Bliithenstielchen. $\odot$. Somnige Inhöhen, lichte Wälder, Dämme häufig z. B. Saale zwischen dem Schwalchloche und I,ttin, Tannenberg bei Gutenberg, Mittelholz u. s. w. Jun. Jul. Blıme gelblich-weiss. Höhe $2-4^{\prime}$.

\section{Areabis I. Gänsekresse.}

a. Stengelhlätter am Grunde herzförmig-stengelumfassend.

69. A. brassicaefirmis w a Il r., kwhlartige G. Abb. 4333. Bliitter lialil, ganzrandig, die wurzelständigen länglich orler länglich-rund, in den langen Blattstiel verschmälert, die stengelstündigen länulich. lanzettlich, mit tief-her z-pfeilformigem Grunde sten- 
gelumfassend; Schoten auf abstehendem, 6-8 mal hïrzeren Stielchen fast aufrecht; Klappen etwas gewölbt, mit starkem Mittelnerr. 4. Kalkfelsen, meist im Gesträuch sehr selten. Oberer 'Theil des Mühlholzes bei Freiburge sparsam, häufiger bej Naumburg an Pfur. tenberge, Kösen nach dem Mordthale zu. Mai. Juni. Brassica alpina L. Pflanze bläulich-grün, Blume weiss. IIöhe 1'.

Diese seltene Pflanze wird zuerst von Buxb. en. 1. 43 unter dem Namen Brassica alpina perenuis 'T'o u r nef. in Bergwaildern bei Schmon angegelien, von Leys., Wohll., spr. ed. 1 und II a IIr. all. bot. gauz weggelassen, esst von 11 a $11 \mathrm{r}$. siched. p. $3(0)$ als sehr selten hei Schmon und Bibra elwähnt, welche standorte von R chb. sax. p. 374 hieraus entnommen sind, obgleich sie an denselben schon seit vielen Jahren vergeblich gesucht wird.

70. A. auriculäta Lam., öhrolientragende G. Abb. 4334. Stengel aufrecht, diiun und schlank nebst den Bliittern von ästigen IÏ̈̈rchen rauh; II urzelblätter längliłh, in den Blattstiel verschmälert, meist ganzrandig, Stengell,lïter eiförmig-länglich, entfernt rezähnt, mit tiff-herz-pfeilfürmigem Grunde sitzend; 'raube zuletzt verlängert, geschlängelt; Scholen ziemlich entfernt, etwas abstehend, linealisch, zusammengredriickt, fast 3nervig, mit hervorragendem Nittelnerv, nicht dicker als das 6 mal kürzere Bliithensticlchen. Sunnige, truckene halkberge sehr selten. Oherer Rind des Mühlholzes hei Freiburg. auf der Ebene des l'furtenberges üher Schulpforte und nach der Wiudliiche zu, Saalberge bei Naumburg, hier ïberall nicht selten; dagegen jst sipan dem ron W all r.. S pr. und in Folgre dessen von Rchb. sax. $\mu$ 3i.j angegelonen Standurte "Nteinhrüche hei Ludersleben", wohl gänzlich resschwunden. April. Mai. A. patula Wallr. Blume kleis, weiss. Höhe $1 / 3-3 / 4$.

71. A. hirsuta scop., rauhhaarige G. Abh. 4342. Stengel aufrecht, unterwärts von abstchenden, cinfachen IÍaren rawhhaarig; Blätter länglich, gezähnelt, meist von ästigen Haaren ranh, diß wurzelständigen in den Blattstiel verschmälert; die stengclständigcn aufrecht, etwas ahstehend, mit abgestut:t-gcülurtem oder her fürmigem Grunde sitzend, die Oehrchch v'om Stengel abstelicnd; Schoten aufrecht, schmal-linealisch, zusam- 
mengedrïckt, mit schwachen Lüngsnerven und starkem Vittelnerv; Samen fast unpunktirt, an der Suitze gelliiselt. (-) n. 24. Wälder, Hiigel, Abhänge, Wiesen, Kaine häufig z. 13. Lindberg, 'lannenberg bei Gutenherg, Mittelholz und sonst nicht selten. 'Turritis hirsuta I. BInme weiss. Höhe $1 / 2-2$ '.

A. Gerardi Bess. (A. planisiliqua Pers.) Abb. 4343, bei welcher die Oehichen des Blattgrundes gerade nach unten gerichtet und abwärts dem Stengel angedrückt und die Sumen netzartig punktirt sind, ist gewiss auch innerhalb der Grenzen des Gebiets.

2. Stengelblitter burz gestielt, wederpfeil- noch herzförmì.

72. A. Halleri L., II all e r's - G. Abb. 4326 . Stengel aufsteigend, von unten ästig; Blätter ganzrandig oder etwas gezühnt, die zuurzelstiindigen herzförmig. rundlich oder eifürmig, mit oder ohne Seitenläppchen an Stiel, die unteren stengelstïndigen eifürmig, die oberen lanzettlich; Schoten abstehend, gedunsen, init schwachem Mittelnerv, 2 bis 3 mal länger als das Blüthen. stielchen. 4. Feuchte, schattige Orte, Ufer, Bäche sehr selten, nur an den Ufern der Mulde, besonders bei Muldenstein zwischen Bitterfeld und Jessnitz. Mai - Juli. Blune weiss. Höhe $1 / 2-1^{\prime}$.

37. Cardamine K. Schaumkaut (Name ron

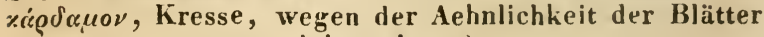
einiger Arten).

a. Blattstiel am Grunde pfeilförmig-geöhrt.

73. C. impritiens L., Spring-S ch. Abh. 4302. Blätter sämmtlich vielpaarig-gefiedert, Blättchen der unteren Blätter eiförmig, $3-5$ spaltig, kurz gestielt, die der oberen länglich.lanzettlich, oft an hinteren Rande gezähnt, sitzend; Jlumenllïtter länglich, wenig länger als der Kelch; Srhuten webst den $4-5$ nial kürzeren Blüthenstielchen aufrecht. ๑. Feuchte, schattige Wälder, bewaldete Anhöhen, selten, nur in Wäldern zwischen Leislingen, Schönhurg und Nammburg häufiger, Pfortenberg einzeln, Dessau häufiger; nach $\mathrm{Spr}$. auch bei Pouch am Mulitenufer. Mai-Jul. Blumenblätter weiss, sehr klein, sehr oft fehlend. Höhe $1-1 \frac{1}{2}$.

b. Blittstiel uicht geöhrt.

74. C. silvatica Lk., Wa! $\mathbf{L}-\mathrm{S}$ ch. Abb. 4303. Blätter sämmtlich gefiedert, Blättchen der unteren Blätter 
rundlich oder länglich-rundlich, etwas geschweift oder gezähnt, kurzgestielt, das Endblättchen grösser, die der uberen Blätter länglich vder linealisch; Blumenblätter doppelt so lang als der Kclch, länglich-verkehrt-eiförmig; Schoten auf den etwas abstehenden Blüthenstielchen ziemlich aufrecht; Griflel so lanu als die Breite der Schute. $\odot$. Wüller, besonders an Bächen selten, nnr in Wäldern bei Burg Liebenau und Schkeuditz. April-Jun. Blume sehr klein, weiss. Höhe $1 / 2-1 \frac{1}{2}$. Aendert mit stärkerer und geringerer Behaarung ab.

Diese Pflanze wird von Spr. hal. ed. 2 p. 292 unter dem Namen C. hirsuta I. angegeben, welche in Gebiete nicht vorkommit.

75. C. pratensis L., Wiesen-Sch. Abb. 4308. Stengel stielrund, oberwärts schwach-gefurcht, huhl; Blätter sämutlich gefiedert, Blättchen der unteren Blätter rundlich, geschweift oder geziihnt, kurz-gestielt, das Endblättctien grösser, rundlich-nierenförmig, die der oberen linealisch, ganzrandig; Blumenllïtler verkehrt.eiförmig, 3 mal so lang als der Kelch und 2 mal liinger als die Staubgefiisse; Schoten und ihre Stiele aufrecht; Griffel kurz. 24. Wiesen und feuchte Wälder iiberall gemein. April. Mai. Blume blass-rosenroth, seltener weiss. Staubbeutel gelb. Höhe meist 1', Aendert ab:

b) dentata Rchb. Stengel höher, Blättchen der unteren Stengelblätter breiter, eckig-gezühnt.

76. C. amara L., bitteres Sch. Abb. 4305. Sten. gel kantig-yefurcht, markig; Blätter sämmtlich gefiedert, Blättchen der unteren Blätter rundlich-eiförnig, die der oberon länglich, alle eckig-gezïhnt, das Endblätchen grösser; Blumenblätter verkehrt-eiförmig, 3 mal so lang als der Kelch und wenig liinger als die Staubgefässe, Schoten und ihre Stiele aufrecht, Griffel lang. 24. Feuchte Stellen der Wälder, Quellen, Gräben, weit seltener als vorige. Rabeninsel, Gemeindeholz bei Zöschen, Bienitz, Wiesen an der Klause bei Merseburg, besonders häufig auf den Pfortenwiesen und an der kleinen Saale bei Naumburg, Kroppenthal zwischen Schönburg und Wetau, Wald zwischen Möhlau und Sollnitz nördlich von Raguhn. April. Mai. Blume weiss, Staubbeutel violett. Höhe 1'. A endert ab:

b) hirta W. u. Grab. Stengel kurzhaarig, Blüthenstielchen kahl: 
Ist der Brumnenkresse (Nast. off.) nicht unälınlich: diese unterscheidet sich aber ausser den Gattungsmerhmalen durch pinen röhrigen, ans den Blattwinkeln wurreluden Stengel, dirch die kleinen Blunien mit gelben Staubbeuteln und die gedunsenen Schoten.

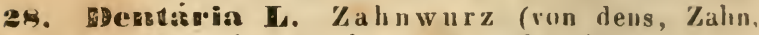 wegen der gezähnten Wurzelstöcke).}

77. D. bulbifera L., z. wi e beltragende \%. . Ibl. 4318. Wurzelstock weit kriechend, schuppenförmig-gezähnt; Stengel schlank, kahl; Blättrr werhselständig.

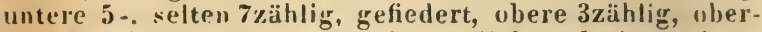
ste ungeth-ilt, alle länglich-lanzettlich und ringeschnitten-gesägt; Blattwinkel zwiebeltragend; die selten reifemlen Silotrn schmial lanzettlich. 24 Bergwälder sehr selten; nur an einer Stelle des Mühlholzes b-i Freiburg, wenn man von der Zeddenbacher Mïhle hinauf. geht. Mai. Blume blassroth oder weiss. Höhe 1-2'. Dir Zwielerlknospron in den Blattwinheln fallen nach dep Blithe ab und hilden newe Pflamzen.

$\because$ Fruppe. Sisymliriecn DC. Raulensenfgewächs". Wiirzelehen den thachen, gleichlaufenden Keimblättern aufliegent).

\section{Siś́mbrium L. Raukensenf.}

A. Velarum DC. Schoten an den Stengel angedricht, pfriemenförmig-zugespitzt. Blume gelb, klein.

7.. S. officinale scop., ge bräuchlicher R. Abb. 4f(1). Stengel steif, ästig; Blätter schrotsägenförniig fiederspaltig, Zipfel 2 - 3parig, länglich, gezïhnt, del "ndständige sehr gruss, spiessförnig; Blïthensticlchr" kanm so lang als der Kelch, zur Fruchtzrit rerdicht; schoten an die Spindel angedriicht, weichhaurig. $\odot$. Wey, Nanern, Sichthanfen überall gempin. Mai Herbst. Erysimum officinale L. Höhe $1-2$ '.

B. Irio DC. Schoten stielrund; Blumen gelb.

i. Blitter eiufach gefiedert.

79. s. austríacum Iacq., österreichis che r R Abb. 4410 und 4411 . Stengel aufrecht, sehr ästig nclist den schrotsägenförmig-fiederspaltigen Bliittern kahl oder nur spärlich mit borstigen Haaren besetzt, Zipfel aus hreiterem Grunde 3erkig-spitz, eingeschnitten-gezälıt ")der ganzrandig, ler endständige grösser, an den wheren Blättern verschmülert; Schoten kahl, genähert, anf 
dem dicken, aufstrebenden, zuweilen gewundenen, 5 8 mal kiirzeren Bliithenstielchen etwas abstehend; Griffel 2 mal so lang als die Breite der Schote. ๑. Felsen, alte Mautern sehr selten. Möchte bei Eisleben, Winmelburg und Bibra, an welchen Orten es Spr. hal. ed. 2 p. 295 und daher auch $\mathrm{Rch}$ b. sax. p. 385 angeben, vergeblich gesucht werden; es jst aber an der Rudelsburg, Saaleck und anf Manern in Eckartsberge vorhanden. Mai. Juni. S. eckartsbergense Willd. S. multisiliquosum $\mathrm{H}$ of $\mathrm{fm}$. Höhe 1-2'.

80. S. Loeselii L., Lö s e l's - R. Abb. 4409. Stengel aufrecht, sehr ästig, nebst den unteren Blïttern mit steifen, riickwärts stehenden Haaren besetzt; Blätte. schrutsügenförnig-fiederspaltig, Zipfel eingeschnittengezähnt, an den unteren Blättern länglich, die endstän. digen zusammenfliessend, an den oberen lanzettlich, die endständigen sehr gross, spiessförmig; Schoten kahl oder behairt, aufstrebend, 2-3 mal lïnger als die diinnen, abstehenden Bliithenstielchen; Griffel kürzer als die Breite der Schote. (-). Schutthaufen, alte Manern, Wege selten. Burg in Giebichenstein und Petersberg zahlreich; sparsam an Mauern besonders an Schlosse in Merseburg, Dölkan bei Merseburg, Felsen bei Wendelstein, Schluss bei Seeburg; sehr verbreitet in und un Eisleben, auf Mauern in Aschersleben und dem 'schlosse in Bernburg. Mai-Herbst. Höhe 1-3'.

h. Blatter dreifach gefiedert.

81. S. Sóphia L., f e inblätterige R. Abb. 4405 . Stengel weichhaarig oder fast kahl; Zipfel aller Blätter linealisch; Blüthenstirlchen $2-3$ mal so lang als der Kelch; Blumenblätter kürzer als der Kelch; Schoten aufwärts gebogen, anderthalb mal so lang als die diinnen, abstehenden Blithenstielchen. $\odot$. Sandfelder, Wege, Nauern, schutt überall gemein. Nai - Herbst. Blume sehr klein. Höhe 1- $3^{\prime}$. OFF. Sophia Chirurgorum.

C. Alliaria DC. Blätter ungetheilt; Schoten stielrund; Samen länglich, mit Längsstreifen; Blumen weiss.

82. S. Alliária scop., Lau chhederich, Läuchel. Abb. 4379. Stengel steif aufrecht; untere Blätter nierenförmg, grob -geschweift - gekerbt, lang gestielt, obere herzeiförmig, kürzer gestielt, zugespitzt; Blüthenstielchen etwa so lang als der Kelch. Schoten ab. stehend, vielmal liinger als die fast wagrecht abstehen.

Garcke, Flora. 
den, dicken Bliithenstielchen. (.). Gebüsche, IIecken, Waldränder, feuchte, schattige Stellen gemein. Mai. Juni. Erysimum Alliaria L. Alliaria oflicinalis Andız. IIöhe 1-3'. OFF. Hb. Alliariae. Die Pflanze riecht besonders beim Reiben stark nach Knoblauch.

D. Arabidopsis DC. Blätter ungetheilt; Schoten linealisch, zusammengedrückt; Samen nicht gestreift; Blumen weiss.

S3. ฐ. Thalińnum Gaud., Thal's $R$. Abb. $438 \%$. Stengel fadenförnig-vielästig, fast blattlos; Wur aclbliitter rosettenartig, lïnglich-lanzettlich, in den Blattstiel verschmälert, entferut-gezähnelt, zuweilen am Grunde buchtig gezähnelt, Stengelblätter sitzend, linealisch-länglich, alle mit 2-3gabeligen Haaren besetzt; Schoten auf dem fast gleichlangen, dïnnen, abstehenden Bliithenstielchen anfstrebend. $\odot$. Brachäcker, bebauter Boden häufig $z$. B. an Donnersberge hinter Kröllwitz, vor Seeben u. s. w. April. Mai und Herbst. Arabis Thaliana I. Conringia Thaliana $\mathbb{R} \mathbf{c h b}$. Höhe $1 / 4-1$ '.

Hesperis matronalis L. ist zwar einige Male an Freckleber Holze bei Sandersleben gefunden worden, jedoch auch dort nur verwildert und unbeständig.

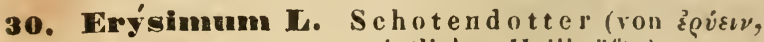
retten, wegen vermeintlicher Heilhräfte).

A. Erysimastrum DC. Stengelblätter länglich oder linealisch, am Gruude nicht herzförnig. Blumen gelb.

84. E. cheiranthoides C., lackartiger Sch. Abb. 4383. Stengel steif aufrecht, von 2spaltigen, angedrückten Haaren scharf; Blätter länglich-lanzettlich, nach beiden Enden verschmälert, geschweift - gezähnelt, mit 2-3spaltigen, kurzen Haaren bestreut und etwas lauh; Bliithenstielchen $2-3$ mal liinger als der Kelch, zur Fruchtzeit halb so lang als die scharf-4kantigen, spärlich mit Haaren besetzten, fast kahlen, aufrecht-ab. stehenden Schoten; Griffel kurz. $\odot$. Flussufer, Züune, Schutthaufen, sparsaner auf Aeckern, nicht selteı z. B. Saale zwischen dem schwalchloche und Lettin 1 . s. w. Juni - Herbst. Cheiranthus silcestris Lam. Blume duttergelb. Höhe 1-2. Aendert ab:

b) dentatum Koch. Blàtter fast buchtig - gezähut. 
85. E. strictum Fl. der Wetterau, straffer $S \mathrm{ch}$. Abb. 4388. Stengel steif anfrecht, von 2spaltigen, angedriicliten Haaren scharf; Blätter länglich-lanzettlich, geschweift-gezähnelt, mit $3-4$ spaltigen, kurzen Haaren fein bestreut und etwas rauh; Bliithenstielchen fast so lang als der Kelch; zur Fruchtzeit aufwärts gokrümmt, 6 mal kiir:er als dic aufiechten 4 kantigen, ein wenig zusammengedriickten, weichhaarigen, gleichfarbigen Scho. ten; Griffel verlängert. $\odot$. Manern, steinige Orte, zwischen Weidengebiisch sehr selten. Der Verf. hat es nur zwischen lönnern und Rothenburg gefunden; von Schwabe fl. anh. wird es nuch bei Alslehen, Bernburg, Sandersleben und Dessau angegeben. Juni. Juli. E. hieracifolium I. fl. suecc., nicht der Lin né ische"l Sammlung. k. virgatum DC. Blume citronengelb. Höhe $2-4^{\prime}$.

Dem E. cheiranthoides sehr ähnlich, unterscheidet sich aher durch die $2-3$ mal längeren, mit dem Stengel gleichlaufenden Schuten, während sie bei jenem fast wagrecht abstehen und aufsteigen, durch die kürzeren Bliithenstielchen, durch den längeren Griffel und durch das hellere Gelb der doppelt so grossen Blumenblätter.

86. E. crepidifolium $\mathrm{Rchb}$, grundfestblät . teriger Sch. Abb. 4355. Stengel sperrig-ästig, von 2 spaltigen, angedrückten Haaren scharf; Blätter lanzettlich, buchtig - oder geschweift-gezähnt oder fast ganzrandig, an der Spitze zurückgebogen, mit einfachen und 3spaltigen kurzen Hairen bestreut und etwas rauh; Bliithenstielchen 2-3 mal liiirzer als der Kelch, zur Fruchtzeit fast wagrecht abstehend, $6-8$ mal hiirzer als die aufsteigcnden, stumpf-4kantigen, vom Rüclien esu wenig zusammengedrürliten gleichfarbigen, angedrücht behaalten Schoten; Griffel kurz. (-). Sonnige Abhänge, be: sonders auf buntem Saudstein, selten; fehlt in der Näht von Halle, Merseburg, Weissenfels, Naumburg und Freiburg; auf lialhfelsen hej steinbach in der Nähe von Bibra, Steinhlippe hei Wendelstein, sehr häufig bei Wettin, Kloschwitz, Rothenhurg, zwischen Könnerı und 'Trebnitz und 'Trebnitz und Aistehen; ebenso verbreitet in den Kirseh- und Weinhergen zwischen Seeburg und Wormsleben und bei Eisleben. Mai. Juni. E. hieracifolium der Linnéischen Sammlung und DC: Blume hellschwefelgelb, geruchlos. Höhe 1-2'.

Hierher gehört auch das zuerst ron Wallr. sched. p. 363 falsch bestimmte Erys. pallens Pel's, welches von Spr. hal. ed. 2. p. 295 als $E$. canescens Rotl auf. 
genommen wurde und in Folge dessen wiederum von R ch b. sax.p. 384 unter E. diffusmm E h r h. erwähnt wird.

Erys. repandum L., welches von Wohll. suppl. p. 27 in Badendorfer Holze bei Höhmstedt, darauf von S p r. hal. ed. 1. p. 187 und anf beider Autorität hin von W allr. sched. p. 363 erwähnt wird, ist niemals innerhalb der Grenzen des Gebietes aufgefunden. Die dort vorkommende Pflanze gehört zu E. crepidifolium $\mathrm{Rchb}$., wie das Spr. hal. ed. 2. p. 296 richtig erkannt hat. Dagegen ist Erys. odoratum Ehrh. einige Male bei Naumburg in der Iue in der Nähe der Saale unweit Rossbach und an der Grossjenaer Fähre gefunden worden, aber daselbst unbeständig, wie dies bei mehren in Gebiete hin und wieder vorkonmenden, nicht wirklich einheimischen Pflanzen der Fall ist.

B. Conringia DC. Stengelblätter anı Grunde herzförnig, stengelumfassend. Blume weiss oder gelblich - weiss.

87. E. orientale R. Fr., morgenländischer Sch. Abb. 4382. Stengel anfrecht, nebst den Blïttern kahl; Blïtter meergrïn, panzrandig, stumpf, unterste verkehrt-piförmig, in den Blattstipl verschnialert, obere länglich-eiförnig, am Grunde her:förmig-stengelumfassend; Bliitlicnstielchen so lang als der Kelch, zur Fruchtzeit vielmal kiir:er als die abstehenden stumpf4kantigen Schoten; Klappen Inervig; Griffel kurz. $\odot$. Aecker besonders auf Lehm-und Kalkboden, selten; unter dem Vogelsberge bei Bennstedt sparsan; häufiger in den Weinbergen an der Chaussee zwischen Langen. bogen und Rollsdorf und in Weinbergen von Rollsdurf bis Seeburg, bei Naunburg und Bihra nicht selten, bei Freiburg zwischen der Probstei und denı Rödel unweit Willsdorf, bei Alsleben und Bernburg. Mai - Jul. E. perfoliatum Crantz. Brassica orientalis L. Höhe $1-1 \frac{1}{2}$.

3. Gruppe. Brassice en DC. Kohlgewä chse. Keimblätter gleichlaufend, eine Längsrinne bildend, in welcher das Würzelchen liegt.

\section{Brássiea L. Koh l.}

88. H. olerácen I., G a rte n-K. Abb. 4433. Blätter kahl, meergrün, untere gestielt, leierföımig, obere sitzend, länglich, Trauben locker. schon vor dem Auf: bliihen verlängert; Kelch aufrecht, geschlossen; Staub- 
gefässe sïmmtlich aufrecht; Fruchtstiele nebst den dicken Schoten abstehend. (.). Wird in vielen Spielarten gebaut. Mai. Jun. Blume weissgelb, seltener weiss. Die gewöhnlichsten Abarten sind:

a) a céphăla DC., Winter-oder Blattkohl, nit verlängertem, stielrundem Stengel und ausgebreiteten, keine Köpfchen bildenden Blättern, und zwar. 1) mit flachen, buchtig-fiederspaltigen Blättern als grïner oder röthlicher Blattkohl (B. aceph. vulgaris DC.) und 2) mit gespitzten, flachen, nicht wellenförmigen oder uur schwach wellenförmigen Blättern als G r ü nkohl (B. aceph. quercifolia DC.), 3) mit krausen, fiederspaltigen Blättern und länglichen, pingeschnittenen Lappen als BraunkohI oder krauser Winterkohl (B. aceph. crispa).

b) gemmifera DC: Rosenkohl. Stengel 2-3' hoch, mit halhgeschlossenem Endköpfchen und zahl. reichen, geschlussenen Seitenköpfchen, aus welchen im Frïhjahre des zweiten Jahres die Blüthenstände hervortreten: Blätter blasig.

c) sabaúda L., Welschkohl, Wirsing, Sa. voyerkohl. Ntengel etwas vellängert, stielıund: Bläter ungetheilt oder wenig geschlitzt, blasig uder kraus, zu einem luckeren, l'undlichen oder länglichen Köpfchen verbunden.

d) capitata L., Kopfkohl, gewöhnlich Kraut genannt. Stengel kurz, stielrund; Blätter gewölbt, meist völlig glatt, vor der Blüthe zu einem festen Kopfe verbunden, entweder weiss (W eisskraut, woraus das Sauerkraut bereitet wird), oder roth (Rothkraut, als Gemïse benutzt).

(e) gon Stengelyrund über dem Boden zu einer weiss fleischigen, kugelförmigen Masse verdickt. Diese Abart wird auch Obererdkuhlrabi, gewöhnlich Oberkohlrabi genannt in Gegensatze zur Kohlrïbs (13. Napus var. napubrassica), bei welcher der Wury.lhals in der Erde zu einer Rübe anschwillt.

f) botrytis L.. Blumenkohl, Käsekohl. Blätter ungetheilt oder eingeschnitten; wbere Blätter und Blïthenstiele verdicken sich zu einer weissgelben, küseartigen Masse, in welcher die oft fehlschlagenden Blüthen verborgen sind. Ist der Stengel niedrig, der Blüthenstand gedrängt, gestutzt oder gewölbt, so heisst diese Form gemeiner 
Blumfnkoh I (B. botr. cauliflora), ist der Stengel höhrr und erheben sich aus den oberen Blattwin. keln wielerum fleisehige '/weige, so fïlıt sie den Namen Brokholi orler Spargelkuhl (B. botr. asparagoides).

89. T. Kapa L., Rüben-K., Rübsen. Abb. 4434 rund 4437. Wurzelblätter grasgriin, leierförmig-fiederspaltig, heiderseits rauh, Stengelhlätter meergrün, untere leierförmig, obere cifürmig. mit tief-her fürmigcm Grunde stenoclum/assend, zusespitzt; Tranbe während des Aufliihens flach. die :eüffneten. Bliithen iiber die noch nicht auf gebliiheten cmporragend; Krlch zuletzt wargerecht-abstehend; kïrzere Staubgefässe abstehendaufstrebent. () und $\odot$. Wird hesonders in 3 Abarten gebaut. Die wille Pflanze, die Brassica eampestris $I_{\text {.., }}$ ist einjährig oder ïherwintert aus spät ansgelaufenem Samen, erstere blüht Jul. Aug., letztere April. Mai. Blume gelb. Nendert ab:

a) annua Knch, einjähriger oder Sommer Rübsen. Wurzel diimn, einjährig; Stengel, Scchoten und Samen kleiner als bei den fulgenden Abarten. Häıfír als Oelpflanze gebaut. Jul. Aug. Hierher gehört auch B. campestris bei Spr. mant. 2 p. 14 und hal. ed. 2. p. 297, welche zwar häufig in Gebiete verwildert, aber nicht einheimisch ist.

b) ol e if era DC. Wi nter-Kübsen. Wurzel dünn, zweijährig; Schoten und Samen grösser. Gleichfalls als Oelpflanze gebaut. Blïht im zweiten Jahre mit der ersten Form.

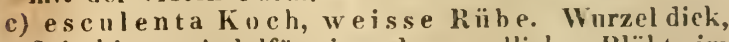
fleischig, spindelförmig oder rundlich. Blïht im zweiten Jahre im April und Mai.

90. B. Napus L., $R$ a p s. K., Kaps. Abb. 4435. Blätter meergrün, untere leierförmig - fiederspaltig, obere lïnglich, mit verhreitertem, her fürminem Grunde halb. stengclum/assend; Traube locker. schon waihrend des Aufbliilicns verliinscrt, die souffneten Bliithen tiefer stehend als die noch nicht aufocluiheten; Kelch zuletzt halboffen; kürzere Staubgefässe abstehend-aufstrebend. (.) und $\odot$. Wird besonders in 3 Abarten gebaut:

a) nleifera DC. Winter-Raps. Wurzel diinn, zweijährig. Als Qelpflanze gebaut. April. Maj.

b) annuakoch. Sum mer-Raps. Wurzel dünn, einjährig, gleichfalls als Oelpflanze gebaut. Juli. Aug. 
c) esculenta DC. Kohlrübe, Steckrübe, Erdkohlrabi. Wurzel fleischig, sehr lick, kugelig, essbar. Mai. B. uleracea \% napobrassica $L$.

91. T. nigra Koch, schwarzer K. Abb. 4427. Blïtcr sïmmtlich gestielt, untere leierförmig, gezähnt, mit grossem, grlapptem Endzipfel, obere lanzettlich, ganzrandig; Kelch wagrecht-abstehend; Bliithensticle und Schoten der Spindel angedriicht. $\odot$. Kiesige Flussufer sehr selten, un bei Naumburg in der Nälie der Saale auf Kies und im Weidengebüsch in der Aue daselbst; unter der saat und an Ackerrändern, wo sie Spr. ohne besunderen Standort angibt, hat sie der Verfasser nie gefunden. Jun. Jul. Sinapis nigra L. Blume gelb. Höhe $2-4^{\prime}$. OFF. Sem. Sinapeos nigrae.

\section{Sinápås $\mathbf{H}$. S e $n \mathrm{f}$.}

92. S. arvensis L., Acker-S.: von Volke He derich genannt. Abb. 4425 . Stengel riickwiilts steifhaarig; Blätter ungleich gezähnt, untere fast leier/örmig oder cifürmig, an Grunde geöhrt, obere ciförmig odeslänglich; Kelch wagrecht-abstehend; Blïthenstielchen zur Fruchtzeit verdickt, 5-7 mal kiirzer als die wal. zenförmigen, wulstigen, kahlen oder rïckwärts behaar. ten Schoten, Klappen 3nervig, Schnabel etwa so lang als die Schoten. Aecker, Schutt überall gemein. Juni - Aug. Blume hochgelb. Höhe 1-2'. Aendert ab:

b) Schkuhriana Rchb. Schoten lang gestreckt, in einen dünnen, zugespitzten Schnabel endigend.

Von dem äholichen Raphanus Raphanistrum L., welcher bei den Landleuten ebenfalls den Namen Hederich führt, durch den wagrecht-abstehenden Kelch und die dunkelgelberen Blumenblätter. sogleich zu unterscheiden.

93. s. alba L., we is ser S. Abb. 4424. Stengel rückwärts steifhaarig; lilïtter gefiedert, Fiedern ungleich - grob-gezähnt, obere grösser, zusammenfliessend; Kelch wagrecht-abstehend; Blitthenstielchen auch zur Fruchtzeit diinn, 2 mal kiirzer, als die walzenförmigen, wulstigen, weissborstigen Schoten; Klappen 5nervig, schnabel etwa so lang als die schote. $\odot$. Wird im Gebiete selten gebaut und verwildert noch weit seltener; an hänfigsten in der Gegend von Aschersleben. Jun. Jul. Blume gelb. Höhe 1-2'. Die Samen liefern den Senf. OFF. Sem. Sinapeos albae s. Erucae. 
33. Erucrístrum Sellimp. und Spenner. I undsra ue (von Eruca, Rauke, dem alten Namen

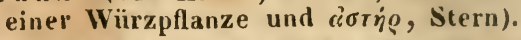

94. N. Pollichii sch im p. u. Sp., Pollich's H. Abb. 4428. Stengel steifhaarig; Blätter tief-fiederspaltig, Kipfel länglich, "ngleich - stumpf - gezähnt, am Grunde durch eine eiförmige Bucht gesondert; untere Bliithen der Traube mit Deckbliittern; Kelchblätter anfrecht-abstehend; Schoten abstehend, $3-4$ mal länger als das Stielchen. $\odot$ und $\odot$. Ackerränder, Brachfelder sehr selten, nur aut Aeckern am Vogelsberge bei Bennstedt sparsam, häufiger zwischen Bennstedt und Kölme: und in den Weinbergen bei Kölme. Mai - Herbst. Sisymbrium Erucastrum Poll. Erucast. inodorum $\mathbf{R} \mathrm{ch}$. Blume gelblich weiss. Höhe $1-1 \frac{1}{2}$.

34. Diplotáxis DC. Rampe, Rempe (von $\delta$ $\pi \lambda_{0} s$, doppelt, und $r a ́ s ı s$. Anordnung, wegen der 2 reihigen Samen).

95. D. tenuifolia DC., dünnblätterige R. Abb. 4420. Stengel ästig, beblättert, an Grunde halbstrauchartig; Blätter völlig kahl, buchtig-gezähnt, einfachund doppelt-fiederspaltig oder ungetheilt, Zipfel linealisch, entfernt-gezähnt: Blüthenstiele doppelt so lang als die Blume, zur Fruchtzeit abstehend, nach der Spitze verdickt, etwa halb so lang als die fast aufrechten Schnten. 24. Unbebauter Buden sehr selten, anı Eisenbahndanme in der Aue bei Naumburg häufiger, sehr sparsam an Schlossgarten in Merseburg. Juni Herbst. Sisymbrium tenuifolium L. Blume citrunengelb, abgeblüht lederbraun. Höhe $1-2$ '.

II. Unterordnung. Latisepten DC. Bre itwa ndige.

Schötchen 2 klappig, aufspringend; Scheidewand breiter oder so breit als der Querdurchmesser des Schötchens, sehr selten und nur an sehr gedunsenen ein we. nig schnïler.

4. Gruppe. Alyssineen D C. Schildkrautgewächse. Würzelchen den flachen Keimblättern anliegend.

35. Alýssume T. Schildkraut (von $\alpha$ priv. und $\lambda \dot{v} \sigma \sigma \alpha$, Wuth, wegen vormaliger Anwendung gegen die Hundswuth).

96. A. montanum $\mathrm{C}_{\text {., }} \mathrm{B}$ er g-Sch. Abb. 4274. Stengel niederliegend oder aufsteigend, zuletzt am Grunde etwas strauchartig; Blätter grau, lanzettlich, untere 
spatelförnig; 'Traube endständig; Kelch zur Fruchtzeit cibfallend; lännere Staubfäden bis zur Hälfte gefliigelt, kurzere nur an Grunde mit geflügeltem Anhängsel; Griffel liinger als die Hailfte des kaum ausugerandeten, rundlich-elliptischen oder rundlichen schötchens. 4. Felsen und Hïgel besonders auf Purphyr, Kalk und Saudstein, selten. Zwischen Lehmanns Garten und Giebichenstein sparsam, häufiger zwischen Mücheln und Wettin, auf Bertrams Berge bei Wettin, an einem Berge bei Kluschwitz Stengels Hölzchen gegenüber, Berge bei Rothenburar; bei Naumbury auf Sandstein zerstreut z. B. zwischen der Henne und Gruss. Jena; an Felsen bei Wendelstein; ausserdem nicht in Gebiete. Mai. Juni. Blume guldgelb. Höhe $1 / 3-3 / 4$.

97. A. calýcinum L., kelchfrüchtigges Sch. Abb. 4269. Stengel aufsteigend, klautartig; Blättel grau, lanzettlich, an Grunde verschmülert, unterste verkehrt-eiförmig; 'Iraube endständig; Kelch zur Fruchtzeit bleihend; längere Staubfüden whut Anhängsel, kïrzere auf beiden Seiten mit einem burstenförmig*" '/ahne; schötchen kreislund, ausgerandet, vielmal so lang als der Griffel. $\odot$. Aecker, Dümme, sandige Hügel, Weinberge, Mauren hiufig. Mai. Juni und Herbst. Blume blass-schwefelgelb, "ach dem Bliihen "eiss verbleichend. Höhe $1 / 2-1^{\prime}$. - Hierher gehört auch $A$. campestre bei Leyss, Spr. ed. I und solsw abe fl. anh.

36. Farsétia 1B. Ir. Farsetie (nach dem Venetianel Philip Farseti benannt).

98. F. incāna R. T r., grau e F. Abb. 4284. Stengel krautartig. anfrecht oder aufteigend nebst den Blättern und Schötchen graufilzig; Blätter lanzettlich, untere in den Blattstiel verschmälert; Kelch zur Fruchtzeit abfallend, Blumenblätter 2spaltig; längere Stanb. gefässe geflïgelt. kürzere über dem Grunde gezähnt; Sichötchen elliptisch, flach gewölbt, etwa $4 \mathrm{mal}$ su lang als der Griffel. (.) Felsen, Hügel, Wege, Ackerränder hänfig z. B am Galgenberge, Felsen bei Kröllwitz u. s. w. Juni - Herbst. Alyssum incanum L. Berterua incana DC. Myopteron incanum Spr. Blume weiss. Höhe $1-1 \frac{1}{2}$.

37. Draba T. Hungerblume.

a. Stengel beblättert; Blumenhlätter ganzrandlig, weiss.

99. D. muralis L., Mauer-H. Abb. 4235. Wurzelblätter rosettenartig, länglich, in einen kurzen Stiel 
verschmälert. meist ganzrandir, Stensellliitter sitzend, halbstengelumfassend. rundlich-eiförmig, gęähnt; IB̈üthenstielchen wagrecht-abstehend, fast doppelt so lang als die länglichen, kahlen Schötchen. $\odot$. Felsen, $A b$ häne sehr selten; am Felsen des Imtspartens in Giebichenstein und iu den Gärten vol dem Dorfe, am $\mathbf{A b}$. hange rechts von der Strasse von Naumburg nach Almerich. Mai. Höhe $1 / 2-1$ '.

b. Stengel blattlus; Blumeublitter gespalten, weiss, sehr klein.

100. D. verna L., Frühlings-H. Abb. 4234. Wurzelblätter rosettenartig, lanzettlich, am Grunde verschmälert, ganzrandig, Stengelhliitter Jelilend; Bliithenstielchen aufrecht-abstehend, $2-3$ mal länger als die lïnglichen, seltener rundlichen Schötchen. $\odot$. Sonnige, dürre Anhöhen, 'Iriften, Sandfelder, Grasplätze ïberall gemein. März - Nai. Erophila vulgaris DC. Höhe $2-4^{\prime \prime}$. Aendert ab:

b) spathulata L, an s. Schötchen rundlich, an denselben Orten, aber weit seltener.

38. Cochleária L. Löffelkraut (von cochlear, Löffel, wegen der Aehnlichkeit der Blätter).

101. C. Armorńcia L., Meerrettig. Abb. 4262. Wurzel fleischig, dick, walzenförnig, über fusslang; Stengel aufrecht nebst den Blätern kahl; Wurzelblätte• länglich, herzförnig oder eiförmig-länglich, gekerbt. untere Stengelblätter kammartig-fiederspaltig. obere eiförmin-lanzettlich. gekerbt-gesägt, oberste linealisch, fast ganzrandig; Schötchen elliptisch "der rundlich. 4. Flussufer, Bïche, Grüben stellenweise: an dem Graben unterhalb Rauschens Hölzchen bei Merseburg, bei Naumburg in der Aue an feuchten Aeckem und Giäben ziemlich verhreitet. an Unstrutufer von Vemleben bis nach Rossleben, bei Eislobell an Gräben zwischen dem Wiesenlamse und Oberriesdorf selten, bei Aschers. leben und Dessau zerstreut; wird auch häufig gebant. Jun. Jul. C. rusticana Lam. Armoracia rusticana Fl. d. Wett. Blume weiss; Höhe $2-4^{\prime}$. OFF. Rald. Armoraciae.

5. Gruppe. Camelineen DC. Keimblätter gleichlaufend, flach, dem Würzelchen aufliegend.

39. Camelina Crantz. Leindottel (die Ableitung ist zweifelhaft; es soll von \%ruci, an Boden. daher klein, und hivov, I,ein, herkommen, dann müsste es jeduch Chamélina heissen).

102. C. gativa Crantz, gebauter L. Abb. 4292 
u. 4293. Mittleve Sten@elblïtter länglich-lanzettlich, canzrandig oder geziilinclt, an Grunde pfeilförmig; Schötchen birnförnig. $\odot$. Arcker, Raine häufig; auch als Oelpflanze unter dem Namen Dötter gebant. Jun. Jul. Myagrum sutivum L. Blume blassgelb. Höhe $1-$ 2'. Aendert ab:

a) pilosa DC. Die ganze Pflanze hehaart, graugrün; diese Abart ist, wenn die Schötchen kleiner und die Klappenfortsätze länger als der halbe Griffel sind, C. micrucarpa Andrz.

b) gl i b l'ata DC. Die ganze Pflanze fast kahl, grasgriü.

103. C. dentata Pers., gezähnter L. Abb. 4294. Mittleve .itengelbliitter linealisch-lïnglich, buchtig-scziihnt oder fiederspaltig, in der Mitte schmiiler. am Grunde wieder breiter, pfeilförmig; Schötchen kugreligbirnförmig. $\odot$. Nur unter Lein, nicht häufigz. B. zwischen Kaasch und Rödgen östlich von Brehna. Jun. Jul. Nyagrum dentatum Willd. M. sativum $\gamma$. L. Blıme blassgellı. Höhe $1-2^{\prime}$.. Schötchen und Samen doppelt su gross als bei voriger Art.

III. Unterordnung. Angustisepten Koch. S chm alwandige.

Schötchen 2hlappig, aufsuringend; Scheidewand schmäler als der Querdurchmesser des Schötchens, an beiden Enden verschmälert.

6. Gruppe. Thlaspideen DC. Pfennigkrautgewächse. Keimblätter aneinanderliegend, Würzelehen auf der Spalte der Keimblätter.

40. Thlaspi C. Pf e $\mathbf{n} n \mathbf{i g k} \mathbf{r}$ a u t (von $\vartheta \lambda_{\dot{c}} \dot{\mathrm{C}}(\omega$, ich - quetsche, wegen der platten Schötchen).

104. T. arvense $\mathbf{C}$., F e I d-P f. Abb. 4181. Stengel oberwärts ästig; Stengelblätter sitzend, länglich, meist buchtiw-gezïhnt, am Grunde pfeilförmig; Schötchen fast kreisıun, tief-ausgerandet, mit sehr kurzem Griffel, breit geflugelt; Fächer vielsanig, Samen bogenfürmig. runzelig. $\odot$. Felder, Schutt, Mauern, Wege überall gemein. Mai-Herbst. Blume weiss. Höhe $1 / 2-1^{\prime}$. Die Pflanze riecht wie Knoblauch.

105. T. perfolintum L., durchwachsenes $P$ f. Abb. 4153. Stengel einfach oder vom Grunde aus ästig; Stcngelblätter sitzend, elliptisch oder herzförmig-elliptisch, ganzrandig, am Grunde tief-pleilförmig; Schöt. 
chen rundlich-verkehrt-herzförmig, breit ausgerandet, mit sehr kurzem Griffel; Fiarher 4samig, Samen olatt. $\odot$. Aecker, Weinberge, sonnige Hügel, besonders auf Kalk, stellenweise; fehlt in der unmittelbaren Nähe von Halle und westwäts bis fast nach Querfurt und Eisleben; findet sich aber in den Wejubergen von Röglitz, an steinigen Anhöhen bei Dürrenberge; häufig bei Naumburg, Freiburg, Querfurt, Allstedt, bei Eisleben an ler Hüneburg, im Stadtgraben. April. Mai. Blume weiss. Höhe $1 / 2$, .

106. T. alpestre L., Alpen-Pf. Abb. 4184. Wurzel mehroüpfï, Stämmchen kurz, rasenartig zusammengedrüngt; Stengel meist einfach; Stengrlblättel eiförmig. sitzend, stengrelumfassend; Staubfäden su lang als die Blunenblïtter; Schötchen 3eckig-verkehrt-herzförmig, an Grunde verschnülert; Griffel so lang als die Bucht der Ausrandun, ; Flüzelsaun vorne so breit als die Klappe, Fïcher 4-Ssamig. Samen glatt. 24. Thä. ler, Triften. Der Verfasser hat es an dem von $\mathrm{Spr}$. hal. ed. 2 p. 289 angegebenen standurte ,Bergtriften bei Hornburg und Sittchenbach " bisher vergeblich gesucht; es findet sich nur an den Grenzen des Gebietes auf hoch gelegenen 'Triften des Mullenthales bei Eilenliurg und erstreclit sich von da bis in den Park von Schönwölkaı östlich vun Delitzsch; bei Dessau nach Schw abe fl. anh. häufig. April. Mai. T. caerulescens Presl. T. montanum Pull. Blume klein. weiss. Staub. beutel anfänglich gelb, bald purpurroth, endlich schwarz. Höhe 4-9".

107. T. montannm C., Berg.Pf. Abb. 4187. Wurzcl mehrköpfig, Stämmchen verlängert, auslüuferartig; Stengcl einfach; Stengelblätter läıglich - helzförmig, sizzend, halbstengelumfassend; Stuuhfäden länger als die Blumenblätter; Schötchen rundlich-verkehrt-herzförmig, am Grunde aligerunlet, vom Griffel deutlich iiberraot; Flügelsaum breiter als die Klappe; Fächer 2samig, Samen glatt. 24. Felsen und Hügel, besonders auf Kalkboden, sehr selten, nur im Mordibale und an der Rudelsburg bei Nammburg, am Schlifter und den Schlagbergen bei Freiburg, aber daselbst hüufig. April. Mai. Blume weiss, Staubbeutel gelb. Höhe $6-9 "$.

41. Teesidilea R. Br. Teesdale e (nach dem Engländer Robert Teesdale benannt).

108. T. nudicaulls R. Br., kahlstengelige T'. Abb. 4189. Stengel blattlos, Nebenstengel bisweilen mit 
einigen Blättern; Wurzelblätter rosettenartig, leierförmig-fiederspaltig; Blumenblätter ungleich, äussere länger; Schötcheı verkehrt-eiförmig, schwach geflügelt. $\odot$. Sandfelder, Heidewälder zerstreut; Domersberg hinter Kröllwitz zahlreich, Südseite des Bienitz, fehlt bei Merseburg, Weissenfels und Naumburg: bei Meinweh unweit Osterfeld, unbewaldeter Theil der Wüste bei Allstedt sparsam, am Wege und im Walde zwischen Pouch und Crina östlich ron Bitterfeld, Abhänge zwischen Benndorf und Paupitzsch. April-Jun. T. Iberis DC. Iberis nudicaulis 1. Blume klein, weiss. Höhe $3-8 "$ ".

42. Ibéris L. Bauernsenf, Schleifenblume (von lberia, einer spanischen Landschaft).

109. I. amāra L., b it terer B. Abb. 4197. Blätter länglich, stumpf, in den Blattstiel verschmälert, beiderseits nit $2-3$ grossen, länglichen, stumpfen Zähnen; Blüthenstanil zuletzt traubig; Schötchen fast kreisrund, schmal ausgerandet, 2spitzig; Spitzchen kürzer als der Griffel. $\odot$. Nur anf Saalkies in der due bei Naum. burg; nach Spr. hal. ed. 2 p. 286 unter Santen bei Rossbach und Branderode, wo sie der Verf. vergeblich gesucht hat. Juni - Aug. Blume weiss. Höhe $1 / 2-1^{\prime}$.

43. Hiscutélla L. Brillenschote (ron bis, zweimal, doppelt und scutella, Schale, Napf, eigentlich Doppelschale).

110. B. laevigata L., glattfrï chtige B. Abb. 4203. Stengel aufrecht, "enig beblättert, oberwärts ästig; Wurzelblätter länglich, in den Blattstiel ver. schmälert, gezähnt oder ganzrandig, Stengelblätter länglich, mit abgeruniletem, halbstengelumfassendem Grunde sitzend: Schötchen am Grunde und der Spitze ausgerandet, kahl und glatt. 24. Felsen, Kalkhügel seh" selten; "Iur am Felsen zwischen Kröllwitz und der Kreuzschäferei, auf breiten Grasrainen zwischen dem Kröllwitz-Lettiner Wege und dem Schwalchloche, auf Bertrams Berge und dem Schweizerling bei Wettin. Diese zum Theil schon von Leyss. hal. p. 160 und Spr. ed. 1 p. 186 angegebenen Standorte waren W a IIr. (sched. p. 338) merkwürdiger Weise unbehannt. MaiJul. Blume gelb. Höhe $1-1 \frac{1}{2}{ }^{\prime}$. Aendert ab:

b) ambigua DC. Blätter und untere Theile des Stengels steifhaarig.

7. Gruppe. L epidinee n DC. Keimblätter aufeinander liegend, Würzelchen auf dem Rücken des einen Keimblattes. 
44. Tepidium T. Pfefferkraut, Kresse (von

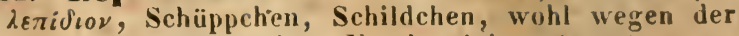
schuppenförmigen Frucht einiger Arten).

a. Schötchen mit langem Griffel.

111. L. Draba C., stengelumfassendes P'f. Abb. 4211. Stengel aufsteigend, uberwälts ästig; Blätter länglich, geschweift-gezähnt, wurzelständige in den Blattstiel verschmälert, stengelständige mit pfeilförmigem Grunde stengelumfassend; Schötchen her: fürmig, fliigellos, mit aufgedunsenen Klappen. 2. Triften, Aecker, Wewe, Schutt sehr selten, mit Sicherheit nur bei Schaafstedt an der hiegrelschenne. Jun. Jul. Cochlearia Draba L. Cardaria Draba Desv. Blume weiss. Höhe 1-11/2'.

Diese schon von Knauth p. 23 und Leyss. p. 121 und 159, aber nicht von $13 \mathrm{u} \times \mathrm{b}$, wie Wa $11 \mathrm{r}$. sched. p. 341 fälschlich meint, angegebene Pflanze muss früher im Gebiete häufiger gewesen sein. Spr. hat sie zuerst bei Pfitzenburg rechts vom Dorfe, wenn man den Fusssteig nach Wansleben geht, gefunden, späterhin dort aber vergeblich gesucht. Der Verfasser hat die erwähnte Stelle uft besucht, aber weder dort, noch an dem anderen von $\mathbf{S} p \mathrm{r}$. angegebenen Standurte, Ackerraine un Alsleben und Poplitz" die Pflanze gefunden. Schwabe führt sie fl. anh. bei Alsleben in Ackerfurchen als sehr selten an.

\section{b. Schötchen mit kurzem Griffel.}

112. L. campestre K. Br., F'eld-Pf. Abb. 4214. Stengel aufrecht, oberwärts ästig, nebst den Blättern grau-weichhaarig; Wurzelblätter lïnglich, in den Blattstiel verschmälert, am Grunde buchtig-gezähnt, Stengelbätter gezähnelt, am Grunde pfeilförnig, stengelumfassend; Schötchen schuppenfürmig-punlitirt, ringsum brcit-scfiigclt. ๑. Felder, Triften, Acherränder stellenweise wnd meist gesellschaftich, zwischen Lieskau und dem Dölauer Kirchholze, sparsam in Chansseegraben zwischen Bennstedt und der Eimnehmerwohmun!, einzeln auf Rainen zwischen Kölwe und Müllerdorf, Aecker zwischen dem Walde und Kl. Dölzig, an der Naumburgei Chaussee unter den Weinbergen bei Frei. burg, häufig bei Russbach nnweit Naumburg, selten hei Aschersleben; bei Sandersleben und Bernburg zerstreut. Juni. Juli. Thlapsi campestre I. Blune weiss. Höhe $1 / 2-1^{\prime}$. 
113. L. ruderale L., S c hut t - P f. Abb. 4215. Stengel abstehend-vielüstig; untere Blätter gestielt, gefiedert oder doppelt-gefiedert, obere sitzend, linealisch; Schötchen auf abstehenden Sticlen elliptisch-rundlich, ausgerandet, an der Spitze schmal gefliigelt. (-). Zäune, Wege, Mauern, Schutt ïberall gemein. Juni Sept. Blüthen 2männig, ohne Blumenblätter. Höhe $1 / 2-1$. Uebelriechend.

114. L. sativum L., Gartenkresse. Abb. 4212. Stengel schlank, ästig; untere Blätter gestielt, unregelmüssig - eingeschnitten, gelappt, gefiedert oder dop. pelt-gefiedert, obere sitzend, linealisch; Schütchen auf aufiechten Stielen elliptisch-rundlich, ausgerandet, gcfliiøclt. $\odot$. Häufig in Gärten ztm Küchengebrauche gebaut und oft auf Schnte verwildert. Juni. Juli. Blune "eiss. Blätter grangrun bereift. Höhe $1-2$ '.

45. Hutehínsia B. IB re. Hutchinsie (nach Miss Hutchins benamut).

115. H. petraea R. Br., Ste in-1I. Abb. 4190. Stengel ästig, beblättert; Blätter gefiedert; Blumenblätter etwas länger als der Kelch; Schötchen auf abstehenden Stielchen rundlich-elliptisch; Narbe fast sitzend. $\odot$. Sonnige Hügel, besonders auf Kalk selten; südöstliche Berge von Kölme, Berge zwischen St. Ulrich und Mücheln, an den Schlagbergen und den Steinbrïchen über dem Mühlholze bei Freiburg, alte Burg bei Aschersleben, hier iiberall häufig. In den von S pr. angegebeneu Standorten bei Bibra, Gerbstedt und Alslebell hat sie der Verfasser nicht gefundell. April. Mai. Lepidium perraeum l. Eime zarte, leicht zu übersehende Pflanze von $2-4$ "IIöhe.

46. Capsélla Mredikus. 'I äschel kraut, H i l' te $n$ täschel.

116. C. Bursa pastoris Mönch, ge me ines ' $\mathbf{m}$ '. Abb. 4229. Stengel aufrecht, beblättert, einfach oder ästig; Wurzelblätter schrotsägenförmig - fiederspaltig, mit 3eckigen, spitzen. etwas gezähnten Zipfeln, Stengelblätter ganzrandig; Schötchen 3eckig-verkehrt-her-fürmig. $\odot$. Aecker, Wege, Schutt überall gemein. Härz Uctob. Ihlaspi Bursa pastoris I. Aendert ab:

a) integrifolia Schlcht. Alle Blätter ganz, Blumen regelmässig. 
b) sinuata K och. Blätter buchtig - gezïhnt, Blumen regelmässig.

c) p innat if ida S ch l cht. Blätter fiederspaltig, Blnmen regelmässig.

d) coronopif o Iia DC. Blätter fiederspaltig, Zipfel vorne eingeschnitten, Blumen regelmässig.

e) a petala Schlcht. Bluthen blumenblattlos, mit 10 Staubfüden.

117. C. procumbens ries, liegendes 'T. Abl. 4221. Stengel aufsteigend, fadenförmig; Blätter gestielt, tief-fiederspaltig, Zipfel ganzrandig, lanzettlich oder elliptisch, der endständige grösser, ubere stengelblätter linealisch, ungetheilt; Schötchen verkehrt-ciförmig oder elliptisch. $\odot$. Salzhaltige 'Triften sehr selten; zwischen Stassfurt und Bernburg zwischen den Artemisien äusserst selten; häufiger auf der Grenze auf salzhaltigem Boden bei Hecklingen unweit Stassfurt und zwischen Artern und Kahstedt gleichfalls in ler Nähe von Artemisia rupestris und A. laciniata. Mai und öfters wieder im Sept. Ein sehr zartes Pflänzchen von 2-4" Höhe.

8. Gruppe. Brachycarpeen DC. Kurzfrüchtler. Schötchen nicht aufspringend oder, wenn die Klappen abspringen, die Samen nicht ausstreuend. Keimblätter zurückgeknickt.

47. Semebiéra Pers. Senebiere (nach dem Genfer Yotaniker Senebier benannt).

118. s. Corónŏpus $\mathbf{P}$ ir., $\mathrm{k}$ a a he ufussartige

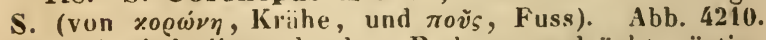
Stengel niederliegend, dem Boden angedrückt, ästig; Blätter tief-fiederspaltig, nit linealischen oder keilförmig-linealischen, ganzrandigen oder vorne eingeschnittenen Fiederchen; Schötchen fast nierenförnıg, an Grunde und an der Spitze zusammengedriickt, netzförmig-runzelig, an Rande strahlenförmig-gestreift, mit dem pyramidenförnigen Griffel gekrönt. $\odot$. Wege, Gräben, Triften, in Dörferm, oft vom Grase bedeckt, nicht gerade selten, bei Halle z. B. am Wege zwischen Halle und der Nietleber Windmühle, an Wege von Trotha nach Sennewitz, ebenso von 'Trotlia nach Seben sehr häufig, Gräben bei Kötsclıan, Wege in der Aue bei Naumburg häufig, ebenso bei Allstedt, Eisleben und Sandersleten ziemlich verbreitet. Juli. Aug. Cochlearia Coronopus L. Coronopus Ruellii All. Blume klein, weiss. Stengel 3-10" lang. 


\section{Unterordnung. Nucamentaceen DC. Nuss-} früchtler.

Schötchen nicht aufspringend, durch Schwinden der Scheidewand zuweilen 1 fächerig.

9. Gruppe. Is atideen Desv. Waidgewächse. Keimblätter aufeinander liegend, flach; Würzelchen auf dem Rücken des einen Keimblattes.

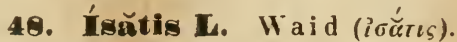

119. I. tinctoria $\mathrm{L} ., \mathrm{F}$ ärbe r - W. Abb. 4177. Stengel aufrecht, oberwärts sehr ästig; Wurzelblätter gestielt, länglich-lanzettlich, in den Blattstiel verschmälert, Stengelblätter pfeilförmig, stengelumfassend; Schötchen länglich, sehr stumpf oder ausgerandet, nach dem Grunde verschmälert. (.). Hügel, Ackerraine sehr sel. ten; am Pfortenberge hinter Naumburg einzeln, häufiger auf der Grenze bei Eckartsberge an Ackerranderu in der Nähe der Weimarischen Strasse. Nach Spr. und $R c h b$. auch an Ackerrändern bei Freiburg, wo sie seit vielen Jahren vergeblich gesucht wird. Mai. Juni. Blume gelb. Blätter bläulich-grïn. Höhe $1-\mathbf{3}^{\prime}$.

49. Néslea Desv. Neslee (nach dem französischen Botaniker De Nesle genannt).

120. N. paniculata Desv., rispige N. Abb. 4291. Stengel aufrecht, einfach oder wberuärts ästig. nebst den Blättern kurz behaart; Blätter lanzettlich, wurzelständige gestielt, stengelständige nit tief - pfeilförmigem Grunde sitzend; schötchen klein, kugelförmig, 1samig. $\odot$. Aecker häufig $z$. B. vor Nietleben, $z$ wischen der Irrenanstalt und der Heide, zwischen Seeben und Gutenberg, oft in grosser Menge beisammen z. B. zwischen Bitterfeld und dem Bruche. Vai-Juli. Myagrum paniculatum L. Blume goldgelb. Höhe : $-1: 2$.

\section{Unterordnung. Lomentaceen DC. Glieder- $\mathrm{h}$ ü I s i ge.}

Schoten und Schötchen der Quere nach in 1samige Glieder sich trennend.

10. Gruppe. Raphaneen DC. Rettich gewächse. Keimblätter um das Würzelchen riunenförmig gefaltet.

50. Hapistrum Boerhave. DC. Winds bock (von rapum, Rübe).

121. R. perenne Il., mehrjähriger W. Abb. Garche, Flora. 
4170. Stengel aufrecht, sparrig - ästig, unterwärts nebst den Blättern steifharig; Wurrelblätter schrotsägenförmì - fiederspaltig, mit länglichen, tief - gezähuten, '/ipfeli, untere Stengelblättèr eingeschnitten, ungleich gezühnt, obere lanzettlich; Schoten nebst den Blüthenstielchen der Spindel angedrückt, von einem kurz-kegelförmigen Griftel gekrönt. \%. IIüg(t), Aecker, Raine, Wege besonders auf Kalk, zerstreut; Ackerraine zwischen Gutenberg und dem Mittelholze einzeln, sandige Aecker bei Dürrenberge selten, häufiger bei Weissenfels, Markwerben, Naumburg und Freiburg; ziemlich verbreitet an Bergen zwischen Langenbogen und Rollsdorf, sehr häufig in den Weinbergen zwischen Seeburg und Wansleben und an Chausseegrabien zwischen Seeburg und Eisleben; auf Aeckern bei Sandersleben so häufig, dass ein ganzes Feld, die W inds bö cke" davon seinen Namen führt. Juni. Juli. Myagrum pereme L. Blume citronengelb. Höhe 1-3'.

51. Fŕphanus H. Rettich (die Schreibart Rettig ist neu und grundlos; das lateinische Wort stamint

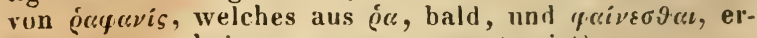
scheinen, zusammengesetzt ist).

222. F. Raphanistrum L., Acker-R, H e de rich. Abb. 4172. Stengel aufrecht, ästig, steifhaarig; Wur. zelblätter leierförmig, mit grossen, rundlichen, stumpf gezähntem Endlappen und länglichen Seitenlappen, obere Stengelblätter lanzettlich; Kelchblätter aufrecht; Schoten perlschnurförmig, bei der Reife gerieft, endlich in einzelne Glieder zerfallend, länger als der Griffel. $\odot$. Aecker, Raine überall gemein. Juni-Aug. Raphanistrum arvense $\mathrm{Rchb}$. Blume blassgelb mit violetten oder dunkelgelben Adern, sehr selten weiss. Höhe $1-2^{\prime}$.

123. R. sativus L., Garten-R. Abb. 4175 . Stengel aufrecht, ästig, etwas steifhaarig; Blitter leierförmig, mit herzförmigen, stumpf-gezühnten End- und Seitenlappen; Schoten walienförmig, wenig oder gar nicht eingeschniirt, zugespitzt, bei der Reife nicht in Glieder zerfallend, wenig läıger als das Stielchen. (-) Aus Asien stammend, jetzt häufig in mehren Abarten gebaut und bisweilen verwildert $z$. B. Aecker $z$ wischen Schkeuditz und der Eisenbahn. Mai. Jun. Blume blassviolett uder weiss, geadert. Höhe $2-4^{\prime}$. Aendert ab:

a) niger DC. mit grusser, fleischiger, aussen grauschwarzer Wurzel. 
b) Radiola DC., Radieschen, mit kleinerer, fleischiger, runder oder länglicher, aussen röthlicher oder weisser Wurzel.

\section{Familie. Cistineen Dunal. C istro-} s engewächse.

52. Heliánthemum Tournef. WC. Sonnengünsel, sonnenröschen (von y̆hios, Sonne, und $\varkappa \nu \vartheta \varepsilon u \circ \nu$, Blume).

a. Die 3 grösseren Kelchblatter den 3 Fruchtklappen entgegengesetzt.

124. H. Fumána Mill., dünnblätteriger S. Abb. 4531. Stengel halbstrauchig, niederliegend, mit aufstrebenden Aesten; Blätter zerstreut, linealisch, stachelspitzig, schwach-gewimpert, ohne Nebenblicter; Blüthenstiele seitenständig, einzeln, die fruchttragenden zurückgekrümmt; Griffel 3 mal so laner als der Frucht. knoten. Ђ. Sonnige Hïgel und Berge besonders auf Gyps, weit seltener auf Muschelkalk, mit Sicherheit nur an der Vitzenburg unweit Nebra. In der Südseite der Berge bei Kölme äusserst sparsam, wenn überhaupt nuch vorhanden; frijher auch am Sperenberge bei Sandersleben, aber seit der Bepflanzung dieses Berges gänzlich verschwunden. Jun. Jul. Blumenblätter goldyelb. Strauch $4-8$ " lang.

b. Die 3 grösseren Kelchblätter mit den 3 Fruchtklappen abwechselnd.

125. H. oelándicum Wahlenb., öl andischer S. Abb. 4533. Stengel halbstrauchig, niederliegend, mit aufstrebenden Aesten; Blätter gegeniiberstehend, linealisch-lïnglich oder eiförmig, mit büscheligen Наaren am Rande oder auf beiden Seiten bestreut oder unterseits filzig, ohne Nebenblätter; Griffel so lang als der Fruchtknoten. †. Sonnige Berge, Ackerraine stets auf Kalk, selten; auf einem breiten Raine zwischen Bennstedt und Kölme, einzeln an den Bergen bei Kölme, sehr häufig am Pfortenberge, überhaupt an Kalkbergen bei Naumburg, bei Freiburg besonders am südlichen Rande der neuen Giehle. Mai. Juni. Blume gelb. Höhe 4-6". Von dieser Art findet sich in Gebiete nur die Abart:

b) tom entosum Koch. Blätter unterseits grau oder schneeweiss-filzig, übrigens unbehaart oder kurzhaarig. Cistus canus Jacq. C. vinealis Willd. C. marifolius $\mathbf{S}$ m. 
126. H. vulgare 4 ärtn., geme iner $\mathrm{S}$. Abb. 4547. Stengel halbstrauchig, mit aufstrebenden Aesten; Blait. ter gegeniiberstehend, clliptisch, lïnglich oder linealischlänglich, gewimpert, mit Nebenblätlern; Blüthenstielchen zur Fruchtzeit gewunden-herabzebogen; Griffet 2 -3 mal so lang als der Fruchtinoten. h. Haiden, 'Triften, Waldränder, sonnige Grasplätze häufig z. 13. auf dem Bischofsherge, an lindberge, Mittelholze u. s. w. Mai-Aug. Cistus Helianthemum L. Blume gelb, grüsser als bei den vorigen Arten. Höhe 6-9". Aendert ab:

a) tumentosum Kuch. Blätter unterseits grauoder weiss - filzig, oberseits mit einfachen oder sternförmigen Härchen bestreut. H. vulgare DC. und $\mathrm{Gaud}$.

b) hirsutum Koch. Blätter unterseits mit zerstreıten Häıchen bestetzt und deshalb grün.

\section{Familie. Violarieen DC. Veilchen- gewächse.}

53. Viola I. Veilohen (ist das Diminutiv von iov, Veilchen).

A. Nominium Gingins. Mittlere Blumenblätter seitlich abstehend, nicht aufwärts gerichtet, am Giunde meist bärtig, das unpaarige inmer bart. lus; Griffel fast gerade; spätere Blïthen blumenblattlos.

a. Tarbe in ein schiefes Scheihchen ausgehreitet; fruchttragende Bliithenstiele aufrecht.

127. V. palustrix L., Sumpf-V. Abb. 4491. Stengellos; Bliitter nieren-herzförmig, kahl; Blattstiel.ungefliigelt: Nebenbliitter piförmig, zugespitzt, kurz - fransig-gezähnelt oder ganzrandig, frci; fruchttragende Blïthenstiele aufrecht mit hängendes Kapsel. 24. Feuch. ter Torfboden besonders jn nassen Muose zerstrent; auf einer Wiese zwischen Dölau und der Heide sparsam, häufig in den Sümpfen der Heide nach Dölau zu "nd den Sünpfen bei Liestall, sumpfige Wiesen bei Osterfeld nach Meiıweh zu; sumpfige Stellen der Wuste lınks von der Querfurt-Arterschen Chaussee, 'Turfstecherei bei 'Törten südlich vou Dessau, T'urfwiesen zwischen Puuch und Crina östlich von Bitterfeld. Mai. Juni. Blınıe blass-lila. Höhe $3-6 "$ ". 
128. V. uliginosn $5 \mathrm{ch} \times \mathrm{xd}, \mathrm{M}$ o o $\mathrm{r}-\mathrm{V}$. Abb. 4492. Stengellos; Blätter her zförmig, kahl; Blattstiel gefliigelt; Nebenblaitter lanzettlich, drüsig - gezähnelt, bis zur Mitte an den Blattstiel angenvachsen; fruchtragende Blüthenstiele aufrecht mit hängender Kapsel. 4 . Sumpfige Moorwiesen sehr selten. Von Wallr. sched. p. 97 an quelligen Stellen der Wiesen bei Wiehe angegeben, also nur auf der Grenze des Gebietes, da der Standort bei Benndorf, wo sie Wallr. a. a. O. gefunden zu haben glaubte, sich nicht bestätigt hat. Die von Spr. ed. 2. p. $12 i$ angegebenen Fundurte , sumpfige Quellen hinter Schkeuditz, bei Zöschen und Zweynien" wagt der Verfasser nicht aufzunehmen, da er mit vielen Freunden seit mehren Jahren durt stets vergeblich gesucht hat. April. Mai. Blume gross, blass-lila. Höhe 4-6".

b. Narbe in ein herahgehogrues Schnähelchen verschmälert; fruchttragend: Blüthensticle nierlergestreckt.

129. V. hirta C., rauhhaariges V. Abb. 4493. Stengellos; Auslïufér fehlend, nur die seitenständigen Stämmchen zuletzt öfter iı kurze dusläufer verwandelt; Blätter herz - eiförmig, gekerht-gesägt, nebst den Blattstielen kurzharig; untere Nebenbliitter eiförmig, obere lanzettlich, nebst den Fransen am Rande kalil; Fransen kürzer als der Querdurchmesser des Nebenblattes; Kelchblätter stumpf; Kapseln weichharig. 4. Wiesen, Raine, Gebüsche überall häufig. April. Mai. Blume blass - lila, geruchlos. Aendert ab:

b) parvula Opitz. Blätter am Rande gewinpert, sonst nebst den Blattstielen fast kahl.

130. V. odorata L., wohlriechendes V. Abb. 4498. Stengellos, Ausliiufer lang, kriechend; Blätter breit-eiförmig, tief - herztörnig, an den Sommerausläufern nieren-herzförnig, alle fein behaart; Nebenblïtter ei-lanzettförnig, spitz, com Rande nebst den Fransen kahl, an der Spitze fein-wimperig. Fransen viel kürzer als der Querdurchmesser des Nebenblattes; lielchblätter stunpf; Kapseln weichhaarig. 4. Waldränder, Gebüsche, Zäune, Wiesen überall häufig. März. April. Blume wohlriechend, dunkel violett, sedten mosa oder weiss (V. alba der Autor., nicht Besser). Mit letzterer Farbe z. B. im Walde bei Kl. Liebenau, aber unstreitig mit Gartenerde dorthin gekommen, in Obstgärten häufig.

c. Narbe in ein herahgebogenes Schnähelchen verschmälert; fruchttragende B̉lüthenstiele unverïndert.

131. V. silvestris $I_{\mathrm{a} \mathrm{m}}, \mathrm{W}$ a l $\mathrm{d}-\mathrm{V}$. Abb. 4503. Sten- 
grel niederliegend und aufsteigend, kahl oder etwas weichhaarig; Blïtter tief-herzförmig, nach der Spitze schmäler, oberseits schwach behaart; Blattstiel ungeflügelt; Ncbenblätter lanzettlich, fein wimperig-gesägt, mehrmal kiirzer als der Blattsticl; Kelchblätter lanzettlich-zugespitzt; Sporn verlängert, nicht ausgerandet, mit der Bhume gleichfarbig; Kapsel kahl, länglich, zugespitzt. 24. Wälder, Haine häufig. April. Mai. Blume violett. Höhe bis $8^{\prime \prime}$. Eine schöne Abart hiervon ist:

b) Kiviniana Rchb. Abb. 4502 . Kelchblätter an Grunde mit ausgerandeten, 3kerbigen Anhängseln; Sporn walzenförmig, ansgerandet, weiss. Blume grösser, hellblau. Schattige Laubwälder weit seltener als V. silvestris, Brenau bei Wettin, zwischen Leislingen und Schönburg, Wälder bei Naumburg, zwischen Freiburg und Pödelist.

132. V. canina L., Hunds-V. Ahb. 4501. Stengel niederliegend und aufstcigend, kahl oder sparsan kurzhehaart: Blätter her_förmig-lïnglich, ganz kahl; Blattstiel ungeflïgelt; Nebenblëittcr länglich-lanzettlich, gefranst-gesägt, mehrmal kiirzer als der Blattstiel; Kelchblätter länglich-lanzettlich, zugespitzt; Sporn unterseits nit einer Furche, meist doppelt so lang als die Anhängsel des Kelchs; Kapsel abgestutzt-stumpf, mit kurzem Spitzchen. 24. Wiesen, Raine, Triften, Wälder gemein. Blume gesättigt blau, mit gelblich-weissem Sporne. Aendert ab:

a) sabulosa Kchb. Sehr klein, oft nur 1-2" hoch, Blätter besonders in der Jugend kürzer herzförmig, Sporn gelblich, daher V. flavicornis $\mathrm{S} \mathrm{m}$. V. calcarea $\mathbf{R} \mathbf{c h b}$. auf dürrem Sandboden und sonnigen Kalkbergen.

b) ericetorum Schrad., grösser und ästiger, Blätter länglicher.

c) Iucorum Rchb. Stengel aufsteigend, fast aufrecht, $1 / 2-1^{\prime}$ hoch, Blätter länger gestielt.

d) montana Fries. Stengel aufsteigend oder aufrecht, bis $1 \frac{1}{2}$ hoch, Blätter und Blüthen sehr gross, mit der vơrigen Abart in schattigen Laubwäldern.

Die V. sabulosa oder calcarea $\mathrm{R} \mathrm{ch}$ b. ist in der Jugend wegen der fast herz-nierenförmigen Blätter der V. arenaria DC. täuschend ähnlich und gewiss oft mit ihr verwechselt worden. Von Wallr. sched. p. 98 (und ebenso ron $\mathrm{Rchb}$. sax. p. 395) wird diese letztere Art an Kalkbergen bei Kölme, Nietleben, Bennstedt 
angegeben, wo der Verfasser nur die Abart von V. canina fand, wie die aboestutzten Kapseln und die später erscheinenden lïnglichen, nicht herzförnigen Blätter beweisen. Ebensowenig wie diese ist die von Wallr. sched. p. 99 erwähnte $V$. lancifolia $T$ hore, wenn darunter etwas anderes als $V$. lactea $S \mathrm{~m}$. verstanden werden soll, wie dies aus der Diagnose und den Standorte hervorzugehen scheint, von Verfasser in Gebiete bewbachtet worden.

133. V. recta Gcke., a ufrechtes V. Stengel aufiecht; Bliitter aus ei- oder herzförmigem Grunde lanzettlich; Blattstiele geflügelt; Nehenblätter lanzettlich, gezähnt, obere blattartig; Kelchblätter spitz; Kapsel zugrespitzt. 4. Haine, Gebüsche, Wiesen Mai. Juni. Aendert ab:

a) persicifolia Schkuhr. Abb. 4508. Stengel stark, nebst den eilanzettlichen Blättern in der Jugend anliegend behaart, Nebenblätter fast sichelförmig, mittlere su lang oder länger als der ziem. lich breit geflügelte Blattstiel, obere den Blattstiel weit überragend, ganzrandig oder am Grunde mit 1 bis 3 grossen Zähnen, Klumenblätter breit-verkehrt-eirund, Spurn etwas länger als die Kelchanhängsel. Blume gross, blassblau, am Grunde weiss. Höhe $1 / 2-1 \frac{1}{4}{ }^{1}$. V. elatior Fries.

b) I a ctea Sm. Abb. 4507. Stengel nebst den eioder keil-lanzettlichen Blättern kahl, Nebenblätter lanzettlich, mittlere meist halb so lang als der oberwärts etwas breiter gefliigelte Blattstiel, obere so lang oder länger als der Blattstiel, gezähnt vder ganzrandig, Blumenblätter verkehrt-eirund; Sporn etwas länger als die Kelchanhängsel. Blume kleiner, milchblau oder hellblau, an Grunde weiss. Höhe $3-8 "$ ".

c) stricta Horn. Abb. 4505. Stengel nelist den herzeiförmigen Blättern $k a h l$; Nebenblätter lanzettlich, gezähnt, nittlere halb so lang als der oberwärts schwach geflïgelte Rlattstiel, obere etwas länger als der Blattstiel; Blumenblätter länglich oder verkehrt-eirund; Sporn. ungefähr doppelt so lang als die Kelchanhängsel. Blume mittelgross, hellulau; Stengel oft bis $1^{\prime}$ hoch. V. Ruppii All. V. nemoralis $K$ iitz.

Die Abart a. liebt Gebüsche und Haine z. B. Pulverweiden, grosse Wiese und Busch bei Passendorf, 
zwischen Mucheln und Wettin; b. konmt anf Wiesen vor \%. B. grosse Wiese bei Passendorf, zwischen Lieskau und Zorgs, Wettin u. s. W.; c. an feuchten Stellen in Wäldern selten z. B. in Bienitz.

Sind die Blätter am Grunde herzförmig und die mittleren Nebenblätter halb so lang als der Blattstiel. su ist dies $V$. stagnina $K$ ita $\mathrm{ib}$., sind sie dagegen am Grunde ei- oder keilförmig und die mittleren Nebenblätter länger als der Blattstiel, so wird diese Form V. pratensis M. K. genannt Dass diese angegebenen Merkmale der $V$. staunina Kit. und V. pratensis M. K. (oder $V$. riphaea $K$ rock.) nicht beständig sind, ist hinlänglich nirhgewirsen und man kann sich bei vorurtheilsfreier Prüfung in der Natur sehr leicht daron überzeugen. Ebensowenig abel wie die angegebenen Formen glaubt der Verfasser V. lactea $S$ m. und V. persicifolia schkuhr specifisch tremmen zu dürfen, da die letztere gewiss nur die Waldform der ersteren ist. Im deutlichsten wird der Uebergang beider Furmen an Stellen bemerkt, wo feuchte Wiesen an Gebïsche grenzen. Die Formen in den Gebüschen und am Rande derselben sind weit grösser und behaart und bilden die V. persirifolia Schk., je weiter sie sich von den Gebüschen entfernen, nehmen sie an Grösse und Behaarung ab, werden endlich ganz kahl und erscheinen als $V$. lactea $S$ m. Specifische Unterschiede rernag der Verfasser auch von $V$. stricta II orn. nicht anzugeben.

134. T. mirabilis L., Wund e r-V. Abb. 4504. Stenocl cufvecht, einveihig-behacurt; Blattstiele an Kiele liehaart; Blätter breit-herzförmig, kurz-zugespitzt, klein gekerbt, jung tutenförmig - zusammengerullt, untere fast nierenförmig; Nebenblätter lanzettlich, zugespitzt, ganzrandig, obere mit kurzen Bursten gewimpert; Kelchblätter lanzettlich; wurzelständige liliithen mit Blumenbliittern, stengelstïndi@e blumenblattlos. 4. Bergige Laubwälder zerstreut, in Zorgs, sehr häufig an den Schlaghergen und fast allen Bergwäldern bei Freiburg und Naumburg, in Helftaer Holze und der IIinehurg bei Fisleben, in Walde bei Freckltben unweıt Sandersleben, in einem Wäldchen bei Kluschwitz links vom Wege nach Rumpin nördlich von Wettin. April. Mai. Blume blass - lila, wohlriechend. Höhe 3-9".

Den Namen "wunderbares V." bekam diese Art von Linné deshalb, weil die ersten, langgestielten, wurzelständigen, mit Blumenblättern versehenen Blüthen 
meist unfruchtbar sind, während die spätern, aus den Blattwinkeln kommenden, kurzgestielten, blumenblattlisen Blüthen stets Früchte tragen. Die Eigenschaft, nach "elcher die ersten blumentragenden Blïthen unfruchtbar, die späteren blumenblattlosen fiuchtbar sind, theilt sie übrigens mit mehren Arten dieser Abtheilung, sie tritt nur bei ihr deutlicher hervor.

D. Grameionium $\mathrm{Rehb}$. Die 4 oberen Blumenblätter aufwärts gerichtet; Griffel aufstrebend; Narbe gross, krugfö̈mig.

135. V. tricolor L., dre ifarbiges V., Stief. in üt erchen. Abb. 4517 . Stengel aufsteigend oder aufrecht, ästig; Blätter gekerbt; untere herz-eiförmig, obere länglich oder lanzettlich; Nebenblätter gross, blattartig, leierförmig - fiederspaltig, mittlere Zipfel verliingert, meist gekerbt. $\odot$. Aecker, Raine gemein. Mai - Octub. Aenilert ab nach der Farbe:

a) arveusis Murr. Blume su lang oder kürzer als der Kelch, weisslich-gelb, dip beiden oberen Blumenblätter hisweilen nit einem viuletten Flecke.

b) vulgaris Koch. Obere Blumenblätter violett, seitliche weisslich oder an der Spitze violett, unteres gelb; diese Abart weit seltener. OFF. Hb. Jaceae.

\section{Familie. Resedaceen DC. Wa a ge-} wäch s e.

54. Reséda K. Wa u (von resedare, wieder beruhigen, wegen vermeintlicher Wirkungen).

a. Kelch 6theilig.

136. R. Iuten L., ge l b e I. W. Abb. 4446. Stengcl ausgebreitet, schr ästig; Blätter in Unrisse 3eckig, mittlere stengelstïndige doppelt-fiederspaltig; obere 3 spaltí. Staubfiden 15-20; Blumenblätter 6 ; Frucht in der Mitte bauchig. We. Wege, steinige Hügel, Weinberge zerstreut; Weinberge bei Bennstedt und Rollsdorf häufig, Anhöhen bei Kötschau, Guttesacker bei Teuditz, Weinberge bei Weissenfels und Naumburg gemein, auch am Pfortenberge nach der Windlücke zu. Juni Aug. Blume grünlich blassgelb. Höhe $1-1 \frac{1}{2}$.

$$
\text { b. Kelch 4theilig. }
$$

137. R. Lutéola L., Fär ber-W. Abb. 4442. Sten- 
gel aufrecht, einfach oder nur oberwärts ästig; Blätter lang-lanzettlich, ganzrandig, am Grunde meist 1zaihnig; Staubfäden $\mathbf{3 0}$ und mehr; Blumenblätter $3-5$; Frucht 3spaltig. (-). Dämme, Wege, Acherränder, Schutt zerstreut; an Wegen pinzeln z. B. an der Chaussee zwischen Beidersee und Domnitz, bei Röglitz, sehr häufig an den Saalufern und Abhängen bei Diirrenberge, bei Naumburg, Sandersleben, Bernburg zerstreut. Juni Aug. Blume blassgelb. Höhe $2-3^{\prime}$. Liefert gelben Färbestuff und deshalb bisweilen in grösserer Menge gebaut.

\section{Familie. Droseraceen DC. Sonnen- thangew ächse.}

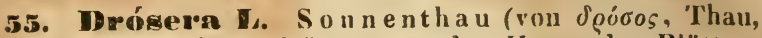
wegen der rothen, drüsentragenden Haare der Blätter; hiess früher Kos solis).

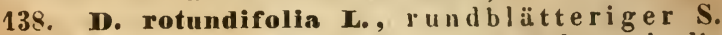
Abb. 4522. Schaft aufrecht, $3-4 \mathrm{mal}$ so lang als die Blätter; Blättcr kreisrund, langgestielt, auf der oberen Seite mit purpurrothen Drüsenhaaren besetzt; Narben keulenförmig, ungetheilt; Samen mit lockerer Samenhaut. 4. Feuchte, turfige Wiesen, fehlt im grössten Theile des Gebietes. Ziemlich häufig in den Sümpfen bei Lieskau, seltener auf 'Torfmoren an der Benudorfer Mïhle, an der Fuhne bei Löbersdorf. Juli. Aug. Blume klein, weiss. Höhe 4-8".

139. D. longifolia L., langb/ütteriger S. Abb. 4524. Schaft aufrecht, doppelt so lang als die Blätter; Bliitter linealisch-keilförmig, mit purpurrothen Drüsenhaaren besetzt; Narben ungetheilt; Samen mit lockerer Samenhaut. 24. Wird von Spr. und Wallr. ans breiten Saale in Lndersleber Forste angegeben; der Verfusser sah die Pflanze an diesem Standorte noch nicht, obgleich er die Richtigkeit desselben keineswegs bezweifelt. Juli. Aug. D. anglica $\mathrm{Huds}$. Blume weiss. Höhe 6-8".

D. intermedia II ayne wird vun Spr. hal. ed.1. p. 101 unter diesem Namen in Torfsumpfen bei Lieskau, Dölau und Benndorf als selten angegeben, von $W$ allr. sched. p. 128 unter dem falschen Namen D. lungifulia I. in Sümpfen bei Dölau als zerstreut vorkommend citirt und zuletzt von Spr. hal. ed. 2. p. 146 gleichfalls unter dem unrichtigen Namen D. longifolia I. aufgezählt und dabei erwähnt, dass er sie zuletzt im Jahrc 1814 in 
dem damals noch nicht ausgetrockneten Blutigelteiche in der Heide und ausserdem im Sumpfe bei Benudorf gefunden habe. Es erscheint daher mindestens sehr unpassend, wenn $\mathrm{Kchb}$, in der 1844 erschienenen flor. sax. p. 398 den zuerst erwähnten Standort auch jetzt nuch als z uverlässig citirt; aber auch der andere Ort ist sehr unsicher, da diese Pflanze vom Dr. P e t e rm. weder in der flor. lips., nuch in analytischen Pflanzschl. angegeben wird, und da sie auch der Verfasser bei Benndorf nicht gefunden hat, so kann sie für unser Gebiet nicht wieder aufgezählt werden.

56. Parnássia I. Herzblatt (nach dem Parnass benannt; hiess früher Gramen Parnassi).

140. P. palustris L., S um p f - H. S t urm Heft 13. Wurzelblätter herzförmig, kurzspitzig, lang gestielt, das einzige Stengelblatt sitzend, stengelumfassend; Blumenblätter mit kurzem Nagel; Nebenkronblätter mit 9-13 drüsentragenden Borsten. 24. Nasse, etwas schwammige Wiesen nicht gerade selten $z$. B. auf Wiesen und an einem Sumpfe vor Nietleben, vor dem Sebenschen Busche, Wiesen am Bienitz und auf den Schambertwiesen, Gröbitzer Wiese bei Naumburg, bei Bibra häufig, bei Allstedt selten, nur auf einer Wiese bei Wolferstedt am Wege nach Mittelhausen und bei Katharinenrieth, bei Eisleben und Aschersleben verbreitet. Juli. Aug. Blume weiss, längsstreifig, Nebenkronblätter gelbgrüin. Höhe $1 / 2-3 / 41$. OFF. Hb. et Flores Parnassiae s. Hepaticae albae.

\section{Familie. Polygaleen Juss. Kreuz-} blumengewächse.

57. Polýgala L. Kreuzblume (von todv́s, viel, und ycilc, Milch, weil viele Arten gute Futterkräuter sind).

141. P. vulgaris L., ge ne ine K. Rchb.pl. crit. I. Abb. 52.53. Stengel grundständig, einfach, meist in Büscheln; Blätter schmal-lanzettlich, unterste kleiner, elliptisch; Traube endständig, vielblüthig; Blumenkrone mit vielspaltigen Anhängsel; flügelartige Kelchblätter elliptisch oder eiförmig, 3nervig, so lang als die Blume, länger und so breit als die verkehrt - herzförnige Kapsel, Nerven derflügelartigen Kelchblätter an der Spitze mit einer schiefen Ader verbunden, Seitennerven nach aussen mit verästelten Verzweigungen; Deckblïtter alle halb so lang 
als das Bliithensticlchen. 4. Trockene Wiesen, grasige Waldplätze gemein. Mai. Juni. Blume blau, rosenruth, selten weiss. Höhe $1 / 2-3 / 4$. Aendert ab:

b) ox ptera R c h b. Fliigelartige Kelchblätter schnı̈ler als die Kapsel, spitzig.

142. P. comosa s chk., s c hopfförmige K. K chb. pl. crit. 1. Abb. 54-56. Stengel grundständig, einfach, meist in Büscheln; Bliitter schmal-lanzettlich, unterste kleiner, elliptisch; 'Traube endständig, vielblüthig; Blumenkrone mit vielspaltigem Anhängrel; flügelartige Kelchblätter elliptisch, 3nervig, so lang als die Blume, länger und so breit als die verkehrt-herzförnige Kapsel; Nerven der flïgelartigen Kelchblätter an der Spitze mit einpr schiefen Ader lerbunden, Seitennerven nach aussen nit verästelten Verzweigungen; dic noch uncntwickelten Bliithen von den schopfartigen, obersten Dechblïttern iiberragt. 4. Anhöhen, Waldränder, Wiesen etwas seltener als vo. rige; Vogeisberg bei Bennstedt, an Rande des Mittelholzes, bei Röglitz, Wiesen bei Kl. Dölzig und an Bienitz, auf allen Bergwiesen bei Naumburg und sonst ziemlich verbreitet. Mai. Juni. Blume fast immer blass rosenroth. Höhe $1 / 2-3 / 4$.

143. P. amara L., bittere K. Stengel grundständig, einfach, zuwpilen in Büscheln; unterste Blïtter gross, verkchrt-ciförmig, cine Rosette bildend, stengelständige länglich - keilförnig; Traube endständig, vielblüthig; Blumenkrune mit vielspaltigen Anhängsel; flügelartige Kelchblätter länglich - verkehrt - eiförmig, 3nervig, Nerven an der Spitze kaum ineinanderfliessend, Seitennerven nach aussen aderig, Adern spärlich-ästig, nicht netzartig verbunden; seitenständige Deckblätter so) lang als das Blüthenstielchen. 24. Sumpfige Wiesen und an Waldrändern auf Muschelkalk. Mai. Juni. Hierron kommt im Gebiete nur die Abart ror:

b) a ustríaca Koch. Kchb. pl. crit. I. Abb. 40.41. Blïthen sehr klein, flïgelartige Kelchblätter oft kürzer als die liapsel; ist liese abgerundet, so

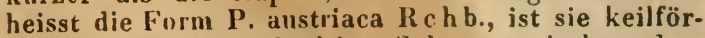
mig: P. uliginosa $\mathrm{Kchb}$. Selten; zwischen den Bienitz und dem Schambert rinzeln, häufig an den Quellen wwischen dem Bienitz und Rücknarsdorf; an schattigen feuchten Plätzen in der Giehle bei Freiburg, in Rödel und zwischen Wilsdorf und Rossbach nördlich von Naumburg, nach Schwabe flor. anh. bei Dessaı und Mosigkau. Blume bläulich oder sattblau. Höhe $4-6 "$. 
Nach Spr. hal. ed. 2. p. 312 soll auch die eigentliche P. anara Jacq. auf Salzwiesen bei Schladebach und Kötschau vorkommen, welche Angabe jedoch einer Bestätigung bedarf.

\section{Familie. Sileneen DC. (Gattungen von Curyophylleen bei Juss.) Taubenkropf- gewächse.}

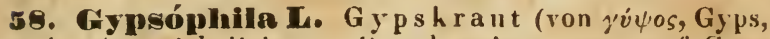
und yickw, ich liebe, weil mehre Arten gern auf Gyps " achsen).

144. G. muralis L., Ma ue $\mathbf{r}-\mathrm{G}$. Abb. 4997 und 4998. Stengel autrecht, fadenförmiy, fast gabelspaltig, mit rispigen Aesten, an Grunde etwas rauh; Blätter linealisch. an beiden Enden verschmälert; Blïthen zerstreut; Blumenblätter ab_estutzt oder ausgerandet, fein gekerbt; Kelch hreiselförnigr, 5zähnig, Zähne ahgerun. det-stumpf. $\odot$. Sandige, feuchte Aecker, 'Triften, Mauern lıäufig z. B. zwischen Kröllwitz und der Heide, Aecker vor Seben, zwischen Hohenthurm und handsberg und sonst verbreitet. Jul. Ang. Blume hellroth, mit dunkleren Adern. Höhe $2-6^{\prime \prime}$ Aendert ab:

b) serótǐna Hayne. Blumenblätter ausgerandet, Blätter breiter, dichlich, etwas fleischi⿺r, su auf feuchtem Buden.

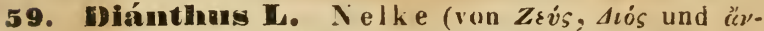
$\vartheta \circ \varsigma$, Blume, eigentlich Zeusblume).

A. Kohlrauschia Kunth. Blïthen in endständigen Köpf. chen.

145. D. prólifer L., s prossende N. Abb. 5009. Stengel aufrecht, $k a h l$; Blätter linealisch, untere stumpf, ubere spitz; Blüthen koptartig-gehäuft; die 6 Hiillschup. pen durchscheinend-hüutig, rauschend, elliptisch, die 2 äusseren un die Hälfte kürzer, stachelspitzig, die inwersten sehr stumpf, länger als der Kelch; Kelchschuppen wie die Hïllschnppen, den Kelch einwickelnd; Platte der Blumeublätter schwach ausgerandet, bartlos. $\odot$. Truckene, sunnige Hïgel stellenweise; Berge zwischen der Schasfrichterei und dem Galgenberge, Bertrams Berg bei II ettin, bei Naumburg an Abhängen der Hohlwege am Spechtsar, hei Grochlitz und am Krop. penthale zwischen Sichönburg und Wetau, bei Sanders. 
lehen und Bernburg. Juli-Sept. Blıme rosenroth. Höhe $1 / 2-1$. D. diminutus L. Abb. 5008 ist die ein. blüthige Form.

B. Armeriastrum Ser. Blüthen büschelig.

146. D. Arméria L., $\mathrm{rau}$ he $\mathbf{N}$. Abb. 5011. Stengel aufrecht nebst den Blättern weichhaarig; Blätter linealisch-lanzettlich, untere stumpf, obere spitz, ihre Scheiden so lang als dic Breite des Blattes; Bliithen biischelig; Kelchschuppen und Deckblätter lanzettlich-pfriemlich, krautig, ungefähr so lang als die Kelchröhre, rauhhaarig; Platte der Blumenblätter eilänglich, etwas bärtig. -.. Truckene, sonnige Gebüsche, Waldwiesen, Hïgel nicht häufig; hei Halle sehr selten, in der Heide sehr sparsam, im Bieuitz etwas häufiger, in den Wäldern bei Naumburg zerstreut z. B. über der Henne und im Sperlingsholze; einzeln an $\mathrm{der}^{\circ}$ Steinklippe bei Wendelstein, an kahlen Berge bei Landgrafrode und in den Wäldern bei Allstedt. Juli. Aug. Blume hellkarminroth, mit dunkleren Punkten. Höhe $1-2$ '.

147. D. Carthusianōrum C., Ka r thä u s e r - N. Abb. 5019. Stengel aufrecht, kahl; Blätter sämmtlich Jinealisch, ihre Scheiden 4 mal länger als die B̈reite des Blattes; Bliithen in cin endstïndiges, meist 6bliithiges, biischeliges Köpfchen geh ̈̈uft; Kelchschuppen lederartig, braun, trockenhäutig, verkehrt-eiförmig. sehr stumpf, begranut, Granne pfriemlich, so lang als die halbe Kelchröhre, Deckblätter fast gleich gestaltet; Platte der Blumenblätter so lang als ihr Nagel, bärtig 24. Trokkene, begraste Hügel und Triften sehr häufig z. B. Berge vor Giebichenstein und Trotha, bei Kröllwitz, Anhöhen vor der Heide u. s. w. Juli-Sept. Blume blutroth; Höhe $1 / 2-1 \frac{1}{2}$. Verkümnerte Exemplare auch 1bliithig.

148. D. Seguierii vill., Seguier's- N. Abb. 5023. Stengel aufrecht, einfach oder oberwärts 2spaltig, kahl; Blätter linealisch-lanzettlich, verschmälert zugespitzt, meist 5nervig, ihre Scheiden so lang als die Breite des Blattes; Bliitlicn zu zueien oder biischelig; Kelchschuppen eiförmig, brgrannt, Granne krautig, meist nicht länger als die halbe Kelchröhre; Deckblätter lanzettlich, Jang zugespitzt; Platte der Blumenblätter so lang als ihr Nagel, bartlos. 2. Wälder und Wald. ränder sehr selten; nur in Wäldern bei Lingenau und Dessau. Juni-Aug. Blume hell liarminroth oder pur- 
purroth, an Schlunde mit einem Ringe ron dunkelrothen Flecken. Höhe $1 / 2-1^{\prime}$. Aendert ab:

b) silvaticus Hoppe. Kelchschuppen aufrecht und meist angedrückt.

C. Caryophyllum Ser. Blüthen einzeln oder rispig. a. Blumenblätter gezähnt.

149. D. deltoides L., d e I t a b l umige $N$., B l u t s tröpfchen. Abb. 5040 und 5041 Stengel anfsteigend, weichhaarig, mit einblüthigen Aesten; Blätter linealischlanzettlich, untere stunpf, an Rande rauh, ihre Scheiden kurzer als die Breite des Blattes; Kelchschuppen meist $\mathrm{zu} 2$, elliptisch, begrannt, mit der pfiemlichen Granne um die Hiilfte kiirzer als die Kelchrïhre; Deckblätter von den Kelchschuppen entfernt, oft blattartig. 4. Trockene Wiesen, Triften, Waldränder häufig z. B. Bischofsberg in der Heide, sehr häufig bei Burg Ltebenau; ebenso zwischen der Benndorfer Muhle und Pan. pitzsch und sonst verbreitet. Juni-Sept. Blume purpurroth, mit weissen Punkten und einem dunkleren Ringe, selten ganz weiss. Höhe $1 / 2-1 \frac{1}{2} 2^{\prime}$. Aendert ab:

b) g la ucus L. Blätter meergrïn.

Hierher gehört unstreitig auch Caryophyllus silvestris humilis fl. unicu C. B. bei $B u x b$. en. p. 60 und Dianthus arenarius bei Leyss. hal. p. 78 und p. 104, welcher in asperis ad Brehna angegeben wird.

b. Blumenblätter fiederspaltig-eingeschnitten.

150. D. superbus L., Pracht-N. Abh 5032. Stengel aufrecht, oft einzeln, $k a h l$, an der Spitze ästig, 2 - mehrblüthig, Blüthen zerstreut; Blätter grasgrün, linealisch-lanzettlich, zugespitzt, untere stumpflich, am Grunde meist in eine ziemlich lange Scheide verwachsen; Kelchschuppen eiförmig, kurz begrannt, $3-4$ mal kiirzer als die Kelchröhre; Deckblätter verkehrt-eiförmig, stachelspitzig, etwa halb so lang als die Kelchschuppen; Blumenblätter vielfach tief-zerschlitzt, mit einem ganzen, liinglichen Mittelfelde. () und 4 . Bergwälder, trockene Wiesen nicht gar selten; Zorgs, Mittelholz, Bergholz, Wiese zwischen Göhren und Rodien an der Merseburg - Leipziger Chaussee, Bienitz, Wälder bei Naumbury genein, Theilholz bei Allstedt häufig, Katharinenholz bei Eisleben. Juli-Sept. Rlıme fleischfarben oder weisslich, mit purpurrothen Härchen anf dem Mittelfelde, wohlriechend. Höhe 1-2". 
60. Soponápin I. Se if enkraut (von sapo, Seife, weil der Wurzelstock von S. off. mit Wasser einen seifenartigen Schaum gibt).

151. S. Vnccíria L., Ku h-S. Abb. 4991. Wuriel senkrecht; Stengel aufrerht, kahl, oberwärts istig; Blätter lanzettlich, an Grunde ei-vder herzförmig, verwachsen; Blüthen lucker ebensträussig; Kclch röhrig. zur Fruchtzeit pyramidenförmig, 5fiigelig, kahl, Blumenbliitter fein gekerbt, am Schlunde ohne Anhiingsel. $\odot$. Im Getreide, besonders auf Lehm - und Kalkbwden stellenweise; einzeln auf Aeckern zwischen I,ettin und Dölau, zwischen Holleben und Schaafstedt, bei Merseburg, Kriegsdnrf, Kl. Dölzig, Weissenfels, häufig hei Naumburg auf thonigen Boden, ebenso auf halkhaltigen Aeckern zwischen (Juerfurt und I,odersleben, seltener auf Aeckern an Peinholze bei Allstedt, fohlt bei Ascher.leben, selten bei Bernburg. Jun. Jul. Gypsophila lac. caria $S$ m. Varcaria pyramidata Fl. der Wett. Blume fleischfarben. Höhe $1-2$ '.

152. 5. officinalis L., gebräuchliches $\mathbf{S}$. Abb. 4995. Wurzelstock weit kriechend; Stengel anfsteigend, fast kahl, oberwärts ästig; Blätter länglich-lanzettlich; Blüthen büschelig-ebensträussig, Kelch walzenfürmig, ohne Fliigel, kahl; Blumenbliitter abgestutzt, fein gekerbt, am Schlunde mit 2 spitzigen Zähnen. 24. Hecken, Gebüsche, Flussufer besunders anf sandigem Buden nicht selten z. B. am Schwalchloche hinter Kröllwit\%, in der Saale bei Wörmlitz. Juli-Sept. Blume hellfleischfarben. Höhe $1-1 \frac{1}{2}{ }^{\prime}$. OFF. Rad. Saponariae.

61. Cucúbalus T. H ühnerbiss (Pflanzennamen bei Plinius).

153. C. bacciferus L., be erentragender $H$. tbb. 5122. Stengel schwach, kletternd, fein-behaart, mit weit abstehenden Aesten; Blätter kurzgestielt, länglich-eiförmig, spitz, fein-behaart, anı Rande wimperartig gesägt; Blïthen end- und blattwinkelständig; Kelch bauchig-glockig; Blumenblätter 2spaltig; Beere kugelig, schwarzglänzend. 7. Zwischen Weidengebuisch an Flüssen und Bächen sehr zerstrent; zwischen Döllnitz und Collenbey, bei Naumburg in der Aue sehr selten, häufiger an der krummen Hufe; an einem Wäldchen zwischen Rathmannsdorf und Neundorf nördlich von Giisten, in Thiergarten bei Dessau. Juli-Sept. Silene baccifera Roth. Lychnanthus scandens Gmel. Blume grünlich weiss. Höhe $3-4^{\prime}$. 
62. Siléme L. Taubenkropf (vielleicht von Silen, dem Begleiter des Bacchus).

a. Blumenblätter ohne Schuppen.

154. S. Otites Sm., Ohrlöffel- $\mathrm{T}$. Abb. 5094. Stengel steif aufrecht, oben wenig beblättert, unten nebst den Blättern kurz behaart, in der Mitte klebrig; Wurzelblätter verliehrt-eirund, spatelförmig, Stengelblätter klein. linealisch; Aeste der Rispe gegenüberste. hend, quirlin-traubig; Kelch röhrrig-glockig, liahl, stumpfzähnigr; Bilumenblïtter linealisch, ungetheilt. -1. 'Trokkrne, sunnige Hügel und Anhöhen stellenweise; bei IIalle sehr häufig z. B Felsen bei Kröllwitz, Anhöhen am Schwalchloche und ror der Heide, bei Schkeuditz an der Eisenbahnrestauration, trockene Anhöhen bei Dürrenberge, sandige Ackerrändej zwischen Eulau und Gosek und an der Henne. Mai - Aug. Cucubalus Otites L. Blume klein, grünlich. Höhe $1-2 \%$ Die Pflanze ist zweihäusigoder vielehig.

155. S. inflata Sm., a uf geblasener. 'T. Abb. 5120. Stengel aufsteigend, kahl, oben gabelästig; Blätter elliptisch oder lanzettlich, zugespitzt; Blüthen gabel- und •ndständig; Kelch eiförmig, aufgeblasen, vielstreifig, netzin-ader.ig; liahl, mit eiförmigen, spitzen Zähnen; Blumenbliitter gespalien, am Grunde 2höckerig. 24. Weye, Raine, Irïgel, Wald - und Wiesenründer gemein z. B. Anhöhen zwischen der Irrenanstalt und der-Heide, bei Kröllıitz, Röglitz u. s. w. Juni-Aug. Cucubalus Behen L. Blume weiss. Höhe $3 / 4-11 / 2^{\prime}$. Die Pflanze ist $z$ weihäusig oder vielehig.

b. Blumenblätter mit Schuppen.

156. S. nutans L., $n$ ick en de r. T. Abb. 5108. Stengel aufrecht, weichharrig, oberwärts drüsig-klebrig; Blätter gewimpert, untere lanzettlich oder elliptisch, in den Blattstiel verschmälert, obere sitzend; Rispe einseitswuendig, zur Pliithezeit einwürts-geknickt-iiberhängend; Aeste gegeniiberstehond, 3gabelig-getheilt, 3-7bliithig; Kelch löhrenförmig, etwas keulenförmig, mit spitzen Zähnen. 24. 'Trockene Hügel, Waldränder, Raine gemein z. B. Heide, Mittelholz u. s. w. Juni. Juli. Blume weiss, unterseits bisweilen mit bleigrauen oder grünen Streifen. Höhe $1-2^{\prime}$.

157. S. noctiflóra L., nächtlichblühender $T$. Abb. 5063. Stengęl aufrecht, einfach oder oberwärts

Garcke, Flora. 
gabelspaltig, nebst den IJlithensticlen und Kolchen klebrig-zottig; untere Blätter spatelföruig-verkehrt-eilörmig, obere sitzend, länglich.lanzettlich; Kiclch etwas bauchig - röhrenförmig, 10streifig, im reifen '/ustande walzenförmig-elliptisch, mit langen, linealisch-pfiricmlichen Ziihnen; Blumenblatter tief 2spaltig. ○. Aecker häufig z. B. vor Sehen, vor Nietlehen. bei Passendorf u. s. w. Juli-Sept. Blume weiss oder blass fleisch. roth. Höhe $1 / 2-1^{\prime}$.

158. S. Arméria L., Garten-T. Abb. 5079. V̈üllig lahl; Stengel anfrecht; uberwïrts ästig, obere Gelenle chwas lilebrig; Blatter breit eiförmig, etwas herzförmig, spitz; Rispe endständig, biischelig-gedrungen, reichbliithig; Kelch lang keulenförnig, 10streifig, mit eiförmigen, stumpfen Zïhnen; Blmmenblätes ausgerandet. $\odot$. Aecker, Schutt, im Gebiete nur selten verwildert. Aecker bei Gertitz unweit Delitzsch ziemlich häufig; nach Schwab e fl. anh. auch bei Bernburg und Dessau; früher sull sie llach Leyss. und Spr. ed. 1 auch in Mittelholze gewesen sein. Juli. Aug. Blume kirschroth, seltener rusenroth oder "iss. Höhe 1',

S. conoidea L., welche ron Leyss. und Spr. ed. 1 bei Schlettau als nicht selten rorkommend ange. geben wird, war schon vor dem Jahre 1832 nach Spr. hal. ed. 2 fast verschwunden und dürfte jetzt vergeblich gesucht werden. Ebenso ist das Vorkunmen von s. conica L. bei Sandersleben nach Schwabefl. anh. zu bezweifeln.

63. Týelnmis DC. Lichtnelke (von ib́xvos, Leuchte, wegen des Farbenglanzes der Bljithen.

a. Blüthen zwitterig.

159. L. Viscrixia L., kl e b rige I. Abb. 5131. Stengel kahl, oberwiirts unter den Gelcnlien stark klebrig; Blätter lanzettlich, kahl, am Grunde gewimpert; Blüthen in traubenförmiger Rispe, fast quirlständig; 13lumenbliitter ungetheilt, mit Nebenkrune. 24. Trockene Wie. sen, begraste Abhänge gemein z. B. Heide, Mittelholz u. s. w. Blume hellivith. Höhe $1-1 \frac{1}{2}{ }^{\prime}$. Wird of in Gärten mit gefïllten Blumen unter dem Nanten Pech. uelke gezugen.

160. L. Flos cuculi L.. Kukuks-L. Abb. 5129. Slengel etwas rauh, nicht klebrig; Blätter kahl, untere 
spatelförmig, obere linealisch-lanzettlich; Blüthen rispenförmig; Blumenblätter bis iiber die Mitte 4spaltig, Lipfel linealisch, auseinanderstehend; Kelche gluchenförnig, 10streifig. 2. Wiesen, feuchte Gebüsche überall häufig $z$. B. auf Wiesen vor Nietleben, hei Dölau u. s. w. Mai - Juli. Blume fleischroth, selten weiss. Höhe $1-2$ '.

b. Blüthen 2häusig.

161. L. vespertina s ibth., A b e nd-J. Abb. 5125. Stengel unterwärts zottig, oberwärts drïsig-rauh, gabelspaltig; obcre Bläticr ei-lanzettlich, verschmälert zugespitzt nebst den Bliithenstielen und Kelchen driisigliur-haaris; Blumemblätter bis zur Hälfte 2spaltig, mit Nebenkrune; Kapsel ei-kegelförmig, mit vorgestreckten Zälınen. -.. Arker - und Waldräıder, Gehïsclıe, Väune lıäufig \%. 13. in Gebüsch an der Saale an Schwalchloche hinter Kröllwitz, im Lindholze, Zurgs, in Zäuneu bej Ermlitz u. s. w. Juni-Herbst. I. dioica $\beta$. I. I. pratensis spr. hal. ed. 1. Blume weiss, sehr selten fleisch. $10 \mathrm{th}$, am Aliend geöffnet und wohlriechend. Höhe $1-3^{\prime}$.

162. L. diurna sibth., 'T'ag-I. Abb. 5126. Stengel nebst den I:liittern, Bliithensticlen und Jiclchen zot. tig, mit driisenlosen IIaaren; obere Blätter eiförmig, plötzlich - zugespitzt; Blumenblätter bis zur Hälfte 2spaltig, mit Nebenkrome; Kapscl rundlich-eiförmig, mit zuriicligcrollten Zïhnen. 24. Feuchte Laubwälder, nasse Waldwiesen nicht so häıfig als vorige Art; inı Busche bei Passenduf. Wörmlitzer Hölzchen, Rabeninsel, bei Naumburg häufig, bei Allstedt selten, nur im Bornthale und in der Hube nuweit Voigtstedt. häufig bei Dessau. $\mathbf{M a i}$ - Juli. I. dinica c. L. I. silvestris Hoppe. Blume geruchlos, am lage geöfnet, schön purpurruth, sehr selten weiss. Höhe $1-2$ '.

64. Agrostémma I. Rade (von èyoós, Acher, und orżuน, Krone, eigentlich Ackerkrone).

163. A. Githágo L., $K\|r\|$ - oder Acker-R. Abb. 5132. Stengel aufiecht, neb.t den linealischen, langzugespitztell Blättern und Kelchen mit sehr langen, auf. rechten Hairen bedeckt; Kelchzipfel länger als die Kelchröhre und die alogestutzten Blumenbläter. $\odot$. Unter dem Getreide gemein. Juni. Juli. Githag" segetum Desf. Blume purpurroth, gestreift, sehr selter: weiss. Höhe $2-3^{\prime}$. 


\section{Familie. Alsineen DC. (Fattungen} von Caryophylleen bei Juss.) Alsinecngewächse.

65. Sagina L. Sagine (zwar von sagina, Mast, stanmend, aber sehr unpassend mit Mastkraut ühersetzt, da diese kleinen Gewächse nichts mästen und der Name Mastkraut für Spargula arvensis gebraucht wurde. Ein deutscher Volksname fehlt).

a. Kelchblatter 4 , deutlich länger als die 4 Blumenblitter.

164. S. procumbens $L_{\text {. }}$ nied erliegende $s$. Abb. 4959. Stengel niederliegend, an Grunde wurzelnd; Aeste aufsteigend; Bliittcr linealisch, stachelspitzig, nicht gevimpert; Blïthentheile 4zählig, alle Kclchblïtter stumpf und ohne Stachelspilzchen; Bliithenstiele nach dem Verbliihen hakenförmig - herabgekriimmt, zur Fruchtreife wieder aufrecht $\odot$. Feuchte, grasize Stellen, Triften, Aecker, Sandplätze gemein. Mai-Sept. Blumeublätter klein, stunipf, weiss, 3 bis 4 mal länger als der Kelch. Höhe 1-2".

165. S. apétala L., b $\mid$ umen $I$ ose S. Abb. 4956 und 4958. Stengel aufrecht, rom Grunde an ästig, seitenständige Aeste aufstrebend; Blïtter linealisch, begrannt, am Grunde gewimpert; Blüthentheile 4zählig; Kelchblätter stumpf, die 2 üusseren sehr lint - stachelspitzig; Stachelspitzchen einwärts gekrïmnt; Bliithentsticle stets aufrecht. $\odot$. Aecker, w enig begraste P'lätze stellenweise; bẹi Halle selten, auf Aeckern am Dölauer Kirchholze unweit Lieskau, auf schwach begrasten Hiigeln am rechten Saalufer zwischen Trothit und Lettin, auf Atckern an Bienitz, bei Naumburg auf bebautem Boden häufig. Nai. Juni. Blumenblätter verkehrt-herzförnig (nicht lanzettlich), weiss, sehr klein und bald verschwiudend. Höhe $2-4^{\prime \prime}$. Aendert ab:

b) ciliāta Fries. Blüthenstiele nach dem Verblühen an der Spitze hakenförmig - herabgekrümmt, zur Fruchtreife wieder aufrecht; sind die Blätter am Grunde mit sehr wenigen Wimpern versehen, so heisst diese Form S. depressa Schultz; besonders auf thonigen Brachäckern mit Sandunterlage am Bienitz, bei Naumbury am Buchholze und bei Flem. ningen; die S. depressa bei Naumburg im Hennell. holze und den angrenzenden Aeckern liäufig. 
Nach Beneken's sorgfältigen Beobachtungen ist S. ciliata Fries nicht specifisch von $\mathbf{S}$. apetala $L$. verschieden. Vyl. Botanische Zeitung Jahrg. 1845 S. 721.

b. Kelchblätter 5, fast oder nur halb so lang als die 5 weissen Blumenblatter.

166. S. nodōsa Tor rey u. Gray. 1838 (nicht E. Meyer. 1539), knotige S. Abb. 4965. Stengel ausgebreitet wder nufstrebend; unterc Blätter linealisch-fadenförmig, kurz-stachelspitzig, ohere kurz, in Winkel einen Blätterbüschel tragend; Blüthentheile 5theilig; Bliithenstiele stets aufrerht; 13lumenbliitter doppelt so lang als der Kelch. 4. Sunpfige, meist torfige Wiesen, feuchter Sandbuden stellenweise; "estliche Seite des salzigen Sees, feuchte Wiesen bei Kl. Dölzigg, bei Stassfurt, bei Dessau und Oranienbaum häufig, am 'Torfstiche an der Benndurfer Mühle. Juli. Aug. Spergula nodusa L. Höhe 3-6". Findet sich kahl und mit drüsenharigen Stengeln, Blïthenstielen und Kelchen; diese letztere Form ist spergula glandulosa Bess.

66. Spérougala L. Sperk oder Spark (nach Linné von spargere, ausstreuen).

167. S. arvensis $\mathrm{L}$., Feld-S. Rchb. pl. crit. VI. Abb. 704. Stengel aufrecht oder aufsteigend, ästig; Blïtter linealisch-pfriemlich, quirlförmig-gebüschelt, oberseits gewölbt, unterscits mit einer Furche durchzogen; Blïthenstiele nach dem Verblühen zurïckgeschlagen; Samen kugelig-linsenförmig, fein punktirt udes fein warzig, sehr schmal gefligelt. $\odot$. Sindfelder gemein. Juni. Juli. Blume "eiss. Höhe $1 \frac{1}{2}-1$ '. Staubgefässe 11), zuweilen nur 5-7. Aendert ab:

a) satira buenuingh. Samen schwarz, von sehr femen Punhten rauh, whne weissliche wiler bräunliche Wärzchen. Kraut hellyrïn.

b) vulgaris Buenningh. Rehb pl. crit. VI, 705. Same゙ nit weissliche», zuletzt bräunlichen Wälzchen besetzt. Krant dunkelgrün.

c) maxima Weihe. Kchb. pl. crit. VI, 706. Wie die vornge Furm, aber nit weit grösserem, oft 2 3 'huhen Stengel und 3 mal grösserem Samen, besonders auf Leinäckern und zuweilen gebaut.

168. S. pentándra L., fü $\mathrm{n} \mathrm{fmänn}$ iger S. St. Heft 12. Stengel aufrecht, ästig; Blïtter linealisch-pfriemlich, quirlförmig - gebüschelt, fast. stiellos, unterseits ohne Furche; Blüthenstiele nach dem Verblühen zurïcligeschla. 
gen ; Samen Rach-zusammengedriickt, mit einem breiten, strahlig-gerieften Fliigelrande umgeben, in der Mitte glatt, an Rande nebeu dem Fliigel gekrönt. ○. Trokkene. saudige IIügel, Nadelwälder zerstreut; sunnige IIiigel hei Kröllwitz häufig z. B. am Ochsenberıe, siidlicher Rand der Heide in Jer Nähe der Fasanerie, seltener im Bienitz; fehlt bei Merseburg, Weissenfels und Naumburg; an Hahn bei Bihra, sandige Aecker bei Dessau. April. Mai. Blume weiss. Höhe 3-6". Al. sine marginata Schreb. Arenaria media Poll.

68. Tepigonam WVahloero. Schuppen-

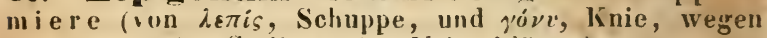
ler Stellung der Nebenblätter).

169. C. rubrum wahlbg., rothe $s \mathrm{ch}$. Flura v. Thüring. II, 13. Stengel niederliegend, anfsteigend, ästig, oberwärts meist driisig-behaart; Blätter linealisch-fadenförmig, stachelspitzig, etwas fleischig, auf beiden Seiten flach; Aeste trabig; Kelchblätter lanzettlich, stumpf, nerrenlus, an Rande hüutig; Kapseln so lang als der Kelch; Samen fast 3eckier, feinrunzelig, ungefliigelt. $\odot$. Sandiger Buden, Triften, Wege, Mauern sehr häufig z. B. zwischen der Irrenanstalt und der Heide, zuischen Kröllwitz und der Hride u. s. w. Mai - Sept. Arenaria rubra var. c. campestris $L_{\text {. A Asine }}$ rubria IV a hle ubg. Blumenblätter so lang als der Kelch, rosenruth. Höhe $3-6$ ".

170. L. medium Wahlbg., mittle re Sch. Stengel niederliegend, anfsteigend, ästig meist kahl; Blätter linealisch fadenförmig, stumpflich. fleischig, auf beiden Seiten gewölbt; A Pste traubig; Bliithen-tiele und Kelche drüsig - behaart; Kelchblätter lanzettlich, stumpf, nervenlos, im Rande hüutig; Kapsel wenig lïnger als der Kelch; Samen verkehrt - eiförmig, zusammengedrückt, sehr schwach runzelig, alle ungefliigelt oder nur die untersten weissgefliigelt. $\odot$. Salinen, salzige 'Triften, am Rande salziger Lachen zerstreut; Salzwiesen bei Dieskau, zwischen der Passendurfer Windmühle und Zscherben, sehr häıfig an den Dömeken zwischen P'fitzenburg und Wansleben, an Rande des salzigen Sees bei kirdeborn und bei Rollsdorf, anf feuchtem Salzborlen bei Seeburg zwischen dem Schlosse und den Weinbergen, an der Salzke zwischen Langenbogen und Rollsdurf, an den Seelöchern bei Zabenstedt unweit Gerbstedt; ebenso häufig bei Kötschau und Teuditz, bei Stassfurt. Juli-Sept. Are- 
naria rubra rar. $\beta$. marina J. Arenaria marina Roth. Spergularia salina Presl. Blumenblätter kürzer als der Kelch, blassroth. Höhe $4-\mathcal{S}^{\prime \prime}$.

171. L. marginātum Koch, flïgelsa mige S ch. Stengel niederlitgend, anfsteigend, ästig, kahl; Blïter linealisch-fadenförmiug stumpflich, fleischig, halbwalzenförmig; Aeste traubig; Bluthenstiele und Kelche drüsig-behaart; Kelchblïtter lanzettlich, stumpf, nervenlos, am Rande häntig; Kapsel fast doppelt so lang als cler Kelch; Samen rundlirh-verkehrt-eiförmigr, zusammengedrüiclit, sehr schwach-runzelig, alle weiss gefliigelt. $\odot$. Salinen, an Rande salziger Lachen mul Seen mit ver vorigen drt, aber weit seltener, Dömekrn zwische॥ Pfitzenburg unil Wansleben, salziger See bei Erdeborn und Rollsdurf, Salzke zwischen langenbogen und Rolls. dorf, fenchter Salzhoden bei serburg zwischen dem Schlosse und den Weimbergen, bei Stassfurt und auf der Grenze des Gebietes an den Salinen bei Arterni. JuliSept. 1. narinum W a h $\mathrm{lbg}$. Alsine marina Wah. lenbg. Arenaria media I. mit Ausschiuss der Syn. Blumenblätter kürzer als der Kelch, weiss oder blass ruseirwth. Höhe $1 / 2-1$ '.

68. A Isine Wa I I e bg. Als ine; ein deutscher Vulksname fehlt (von ǔhros, Hain, wegen der Standorte).

172. A. verna $\mathbf{H}$ artl., Frühlings-A. Abb. 4927. Stämnchen rasenförnig; blühende Stengel aufstrebend oder anfrecht, 1 - vielblüthig; Blätter linealisch-pfrienlich, 3nervig; Blumenbliitter oberhalb des kur:en Nagels beinalie her:fürmig, liinger als die hüutig-berandeten, ei-lanzetıförmigen, spitzen Kelchblütter. 4. Sunnige, steinige Hügel, besonders an Halden des Kupferschiefers, nur im Mannsfeldischen; anf einer Halde am Waldrande des Bärloches bei Helfta, bei Eisleben sehr verbreitet $z$. B. an Neustädter Schiessplatze, an der Chaussee nach Wimmelburg, zwischen Wulferode und dem Bischofsröder Holze, zwischen Helbra und Jeimharh, zwischen Kloster Mannsfeld und I,eimbach, an mehren Orten bei Hettstedt z. B. zwischen Hettstedt und Meisberg, bei Welbsleben und in dieser ganzen Gegend häufig; ganz vereinzelt an der Steinklippe bei Wendelstein. Mai. Juni und im Herbste wieder. Arenaria rerna I. A. cespitosa Ehrh. Sabu. lina cespitosa Rchb. Blume weiss. Höhe 2-4", 
173. A, tenuifolin Wahlenbg., s c hma I b l ät terige A. Abb. 4916 und 4917 . Stengel aufrecht, gabelspaltig; Blätter linealisch-pfrienlich, 3nervig; Blïthen büschelig; Blüthenstiele zur Fruchtzeit aufrecht, mehrmals lïnger als der Kelch; Blumenblïter verlichrt. eiförmig, liirzer als die lanzettlich-pfriemlichen, 3nervigen, am Rande hïutigen Kelchbliitter; Kapsel elliptisch-kegelförmig, meist länger als der Kelch. $\odot$. Sandige Aecker, trockene, sonnige Sandhïgel. Mai. Juni. Arenaria temuifolia L. Blune weiss. Höhe 24". I III Gebiete findet sich nur die Abart:

b) viscosa Schreb. Stengel klebrig, oberwärts nebst den Blättern und Kelchen mit drüsentragenden, abstehenden IIaaren besetzt. Zerstreut; Felsen an Schwalchloche hinter Kröllwitz, auf kurzbegrastem, sandigem Boden zwischen der Fasanerie und Niftleben selir selten, sandige Abhänge des Rockènholzes, Aecker zwischen Dölan und Lieskan, Siidseite des Bienitz, Salflhügel am Walde zwischen Eulau und Gosek, am Buchholze bei Naumburg, auf ler Grenze bei Hecklingen unweit Stassfurt. Die Kapsel ist oft an denselben Exemplaren länger, so lang, oder kürzer als der Kelch. - Von Alsine verna ist diese Art durch den Mangel nicht bliihender Stengel sogleich zu unterscheiden.

69. Roelnringia I. Möhringie (nach dem ostfriesländischen Leibarzte Möhring bellannt).

174. Mr. trinérvia Cla irv., dreinervige M. Abb. 490). Stenofel und Aeste aufstrebend; Blätter eiförmig, spitz, 3-5nervig, auf platten, gewimperten Stiele; Kelchbläter spitz, 3nervig, mit stärkeren Mitteluerve, am Rande gewimpert, viel längel als die B'umenblät-. ter. $\odot$. Schattige Orte der Laubwälder, Gebiische, Zäune häufig z. B. in der Heide, Gebüsche zwischen Radewell und der stillen Elster u. s. w. Mai. Juni. Arenaria trinervia L. Blume weiss. Höhe $1 / 2-1$.

70. Arenária L. Sandkraut (von arena. Sand, weil diese Kräuter besonders auf Sandboden gedeihen).

175. A. serpyllifólia L., que ndelblät teriges s. Abb. 4941. Stengel anfrecht, sehr ästig; Blätter eiförısig, zugespitzt, sitzend; Blüthen einzeln in Blattwinkelı; Kelchblätter lanzettlich, zugespitzt, 3nervig, anderthalb mal so lang als die länglichen Blumenblät- 
ter, am Rande breit trockenhäutig. (-). Aecker, Triftell, diirre Iliigel besonders anf Sandboden überall gemein. Juli. Aug. Blume weiss. Höhe 2-4". Aendert $a b$ :

b) viscida Loisl. Stengel hleiner, aufrecht oder aufstrebend, uberwärts nebst den Blättern driisigbehaart.

a1. Holósteum L. Spure, Schachtk ohl (von

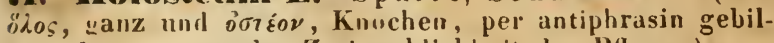
det, wegen der Zerbrechlichheit der Pflanze).

176. H. umbellätum $\mathbf{L}$., doldenblii thige $S p$. Alb. 4901. Stengel kahl oder oberwärts drüsig - behaart; Blätter sitzend, eiförmig, stumpflich, unterste Jänglich; Bliithenstiele endständig, ungleich lang, in Dolden, nach dem Verblühen zurückgeschlagen und nach ausgestreu. tem Samen wieder aufiecht; Blune und Kapsel länger als die breit-trockenhäutigen Kelchblätter. $\odot$. Aecker, Sandfelder, Wege, begraste Hügel hänfig z. B. an Galgenberge, auf Aeckern hinter Lehmanus Garten bei Giebichenstein n. s. w. März-Mai. Blume weiss, selten röthlich. Höhe $2-8^{\prime \prime}$. Kraut bläulichgrïn.

z2. Stelláxia L. Vogelkrant (von stella, Stern, wegen der Aehnlichkeit der Blumen mit Stermen).

a. Stengel stielrund.

177. S. némŏrum L.,-Ha in-V. Abb. 4906. Stengel schlaff, aufsteigend, oberwäirts zottig, sticlrund; Bläiter her-fürmig, zngespitzt, untere gestielt, gabelständige sitzend; Rispe gubelspaltig; Blumenblätter tief -2spaltig, duppelt su lang als die lanzettlichen Kelchblätter; Kapsel länger als der an Grunde abgerundete Kelch. 21. Feuchte, schattige Laubwälder und Gebüsche selten; in der Aue hei Burg Liebenau und häıfiger im Walde bei Schkeudit\% besonders zwischen der Elster und Luppe, in feuchten Wäldern bei Dessau häufig. Mai, Juni. Blume weiss. Höhe $1-2^{\prime}$.

178. S. media Vill., g e meines V., Mäusedarm. Abb. 4904 und 4905 . Stengel aufsteigend, einzeilig behaart; Eliitter eiförmig, kurz-zugespitzt, gestielt, obere sitzend; Blüthen gabel. und endstandig, 3 5männig; Blumenblätter so lang oder kürzer als der Kelch, 2theilig; Kapsel länglich, länger als der an Grunde abgerundete Kelch. $\odot$. Bebauter Boden, Schntthaufen, líege, das gemeinste Unkraut. März-Oct. 
Alsine media L. Blume weiss. Stengel vun $3^{\prime \prime}$ bis $2^{\prime}$ lang. Aendert ab:

b) neglecta Weihe, grösser, Blüthen 10 mäınig, so auf fettem, feuchtem Boden unter Bäumen, an quelligen Orten.

\section{b. Stengel kantig.}

179. S. Holósten $K$, grossblumiges V. Abb. 4908. Stengel aufsteigend, Skantig; Blätter sitzemi, lanzettlich, lang-zugespitzt, am Rande und auf dem Kiele scharf; Ebenstrauss gahelästig; Deckbliitter lirutartig; Blumenblätter halb 2spaltig, doppelt su lang als die nervenlosen Kelchblätter; Kapsel kugelig, so lang als der am Grunde abgerundete Keich: 24. Laubwälder, Gebuische, Hecken uberall häufig. April. Mai. Blıme weiss, ziemlich gross. Wöhe $1 / 2-1$ '.

180. S. glauca Wither., meergrünes V. Abb. 4909. Stengel aufrecht, schwach, 4 kantig, nebst den sitzenden, linealisch-lanzettlichen, spitzen Blättern ganz kahl und glatt; Ebenstrauss gabelästig; Deckblätter trokkenhäutig, am Rande kahl; Blumenblätter 2theilig, länger als die 3nervigen Kelchblätter; Kapsel länglirh-eiförmig, so lang als der am Grunde abgerundete Kelch. 4. Feuchte Wiesen, Gräben, sumpfige Grasplätze zerstreut; zwischen Döllnitz und Burg Liebenan. Gräben zwischen Wesmar und Oberthau. Juni. Juli. S. graminea $\beta$. L. S. palustris Retz. Blume weiss. Höhe 816". Aendert ab mit meergrünen und grasgrünen Blättern, mit grösseren Blumen und sulchen, welche nur halb su lang als rler Kelch sind, mit 1-2- und 6-9. blüthigem Stengel. Die Abart nit grasgrinen Blättern, kleineren Blumen und 1-2bliithigem, sehr schlaffen Stengel billet die St. Dilleniana Mönch. Abb. 4910.

181. s. graminea $\mathbf{L}$., grasblätterige V. Abb. 4911. Stengrel ausgebreitet, niederliegend, 4 rckig, nebst den sitzenden, schmal-lanzcttichen, am Grunde etwas gevvimperten Blïttern kahl; Ehenstrauss gabelästig, knickhogig; Deckblïtter trockenhïutig, am Rande gewimpert; Blumenblïtter 2theilig, so lan. als die 3nervigen Kelchblätter; Kapsel länglich, länger als der am Grunde abgerundete Keich. 7. Wiesen, Grasplïtze, Ackerränder, Züune gemein. Nai-Juli. Blume weiss. Stengel $1 / 2-1 \frac{1}{2}$, lang. Aendert ab mit grösseren und kleineren Blüthen. Nach der Benbachtung von schumnel hat die Pflanze entwickelte Griffel bei verkiimmerten oder unfruchtbaren Staubgefüssen und kleineren 
Blïthen oder entwickelte Staubgefässe bei verkümmertem Griffel und grösseren Blüthen.

182. S. uliginosa Murray, $\mathrm{Sump}$ f - V. Abb. 3669 . Stengel ausgebreitet, nielerliegend, 4eckig nebst den sitzenden, liinglich-lanzettlichen, spitzen, am Grunde etwas gew imperlen Blättern kahl; Rispe gabelästig; Deckblïter trockenliuiutig, am Rande kahl; Blumenblätter tief 2theilig, kürzer als die 3nervigen Kelchblätter; Kapsel länglich - verkehrt - eiförmig, kürzer oder so lang als der an Grunde kurz trichterförmige Kelch. $\odot$. Gräben, Quellen, Bäche, sumpfiger Boden in Wäldern zerstreut; Gräben zwischen Döllnitz und Collenbey, am Klapperborn im Ziegelröder Forste, sumpfige Wiesen bei Bibra, quellige Abhänge des Muldenthales zwischen Rösa und Pouch östlich von Bitterfeld, an der Benndorfer Mühle. Juni. Juli. S. graminea $\gamma$.J. S. Alsine Keichard. S. Dilleniana Le ers. Lurbrea aquatica St. Hil. Blume klein, weiss. Stengel $1 / 2-1^{\prime}$ lang. Aendert ab mit längeren, bis 2 langen Stengeln, grösseren und klpineren, dunkelgıünen Blättern und fehlenden Blumenblättern. Nie Deckblätter sind meist trokkenhäutig, zuweilen aber auch krautartig (St. bracteatı Richt. Abb. 3668), ja krautartige und trockenhäutige finden sich, wiewohl selten, auf einem Stengel beisanımien.

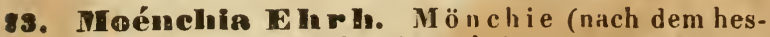 sischell Botaniker Mönch benaunt).}

183. I. erecta Flor. d. Wett., a afrech te $M$. Abb. 4953. Stengel einfach, steif aufrecht oder mit grundständigen, aufsteigenden Seitenästen, 1-2blüthig ; Blätter lanzettlich, untere an Grunde verschmälert; Blumenblätter un ein Drittel kürzer als die breit trokkenhäutigen Kelchblätter; Blüthen 4 nännig. $\odot$. Triften, trockewe Hïgel, Sandplätze selten, nur in Thüringen häutiger; fehlt bei Halle, Merseburg, Weisseu. fels, Naunburs und Freiburg; bei Bibra an der südwestlichen Seite des Holzrandes Namens Hahn und auf sandigen 'Triften am Wege von Bibra nach Wendelstein; einzeln auf dem Orlasberge an der Ziegelscheune zwischen Memlehen und Bibra, an sandigen Aeckern bei Nebra, Reinstorf und Steigra (nach $\mathbf{S}$ pr.), häufig auf den unbewaldeten Stellen der Wüste hei Allstedt, seltener an Bergen zwischen dem Stuckbache und dem Rödgen zwischen Leimbach und Hettstedt. April. Mai. 
M. quaternella Ehrh. Sagrima erecta I. Blume weiss, Kraut bläulichgrïn, kahl. Höhe $1-4 "$.

\section{Maldichium wies. We ichling (von us-} ג(exós, weich).

184. M. aquaticum ries, Wasser-W. Ibb. 4967. Stengel gestreikt und kletternd, am Grunde oft wurzelnd; Blätter herz-eiförmiz, zugespitzt, sitzend, minterste und die der nichtbluhenden Stengel gestielt; Rispe gabelspaltig, driisig -behaart: lleckblätter krautig; Blumenblätter 2theilig, länger als der Kelch; Kapsel wenig länger als del Kelch. 24. Schattige, fenchte Orte, Gräben, Ufer, zwischen Gebïsch häufig z. B. Gebüsch am Schwalchloche hinter Kröllwitz, zwischen Radewell und Oseulorf u. s. It Jum-Aug. Cerastium aquaticum L. Blume weiss. Stengel $1-3$ ' lang.

Hat den Wuchs von Stellaria nemorum L, ist aber üppiger und ausgehreiteter, die helchblätter sind eiförnig, nervenlos, am Rande kaum etwas trockenhäıtig nebst den Blïthenstielen und dem oberen Theile des Ntengels drisig-hehaart, die Fruchtstiele $2-4$ mal länger als die Kapsel, wagrecht - abstehend, nit abuärts geneigter Frucht; ausserdem ist es durch die fiinf Narben soglejch von St. nemorum zu unterscheiden.

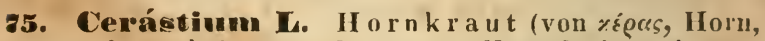
wegen der gekrümmten Spitze der Kapsel viteler Arten).

a. Ein-oder zweijahrige Arten, deren Blumenblatter kürzer oder su ling als der kelch sind.

1. Deckhlätter säm tlich krautartig.

185. C. glomerātum Thuill., geknäucl tes H. Abb. 4970 . Stengel anfiecht oder anfsteigend, behaart; Blätter meist rundlich-eiförnic, seltener länglich, untere in den Blattstiel verschmälert; Blüthen geknäuelt; Deckblätter siimmtlich krautartig und nebst den Kelchblättern ïberall bchaart; fruchttragende Blïthenstielchen und die Blumenbätter ctwa so long als der Kclch. $\odot$. Feuchte Stellen schattiger Lisubwälder, feuchte lehmige Aecker keineswegs gemein, wip ans der bezeichnung Ifes Standortes bei sipr. ,auf feuchten teckern" geschlossel werden nuss; im Wangener Grunde bei KI. Wangen unweit Nebra, an tief gelegenen, schattigen Stellen des Waldes zwischen Memleben und Gr. Wangelı; im Scheierholze bei Lodersleben il der Nähe des jothen Brunnens. Mai-Auı. C. ovale P'ers. C. vul- 
gatum des Lin né ischen Herbar. und Sm. C. viscosum Fries. Blume weiss, Kraut blass - oder fast gelbgrün. Höhe $3-6^{\prime \prime}$. Die Pflanze ändert ab nit drïsentragenden und drüsenlosen Haaren (C. eglandu. losum Koch) und fehlenden Blımenblättern (C. apetaIum $\mathrm{Dum}$ o r t).

186. C. brachypétalum Desp., kle in bumigres H. Abb. 4971 . Stengel anfrecht oder aufsteigend, behaart; Blättes länglich-eiförmig, untere in den Blattstiel verschmälert; nur dip wheren Aestchen der Rispe einander genähert; Deckblïtter sümmtlich krautartig und nebst den Kelchbliittern iiberail mit abstehenden Haaren besetzt; firuchtr.agende Bliithenstielchen 2-3 mal so lang als der Kelch; Blumenblätter su lang oder kürzer als der Kelrh. $\odot$. Im Grase trockener Hügel und Abhänge, in Weinbergen selten, bei Naumburg in den Weinbergen am Spechtsar zerstreut und häufiger in den Weinbergen an der Henne; an der Steinklippe bei Wendelstein selten, auf der Hïneburg bei Eisleben sparsam. - Bei Aschersleben findet sich die Pflanze nicht, wie Rchb. sax. ed. 1. u. 2. p. 437 angibt, wohl aber am Falkenstein, welchel nicht erwähnt ist. Mai. Juni. C. viscosum $P_{0}$ ll. C. strigosum Fries. Blume weiss. Höhe $4-8 "$. Aendert ah wip die vorige und die fulyenden Arten mit und whe Drïsenhare. - Von der vorhergehenden A't ausser den angegebenen Merkmalen durch das graugrïne Kraut und die längeren, grauen Haare sugleich zu unterscheiden.

2. Alle Deckbiatter oder nur lie oberen am Rande trockenhäutig.

157. C. semidecándrum L., fü $\mathrm{fmänniges} H$. Abb. 4968. Stengel aufrecht oder aufsteigend; Blätter länglich oder eiförmig, untere in den Blattstiel verschmälert; obere Aestrhen der Rispe einander genähert; alle Deckbliitter gleich den an der Spitze ausgebissengezähnclten Kelchblättern halb trockenhïutig; Frucht. stiele zuriickgeschlagen, 2-3 mal so lang als der Kelch; Blumenblätter ausgerandet, gezähnelt oder kurz geschlitzt, so lang oder etwas länger als der Kelch; Samen glatt, nur an Rande fein punktirt. $\odot$. Sonnige Hügel, trockene Triften, sandigre Aecker häufig z. B. am Galgenberge, Berge bei Kröllwitz u. s. w. MäızMai. C. viscidum Link. C. viscosum Pers. C. pellucidum Chaub. Biıme klein, weiss. Höhe 1-3". Aendert ab mit und ohne Drüsenhare. 
188. C. glutinōsum Fies, klebriges H. Abb. 4969. Stengel aufrecht oder aufsteigend; Blätter länglich oder eiförmig, untere in den Blattstiel verschmälert; obere Mestche'n der Rispe einander genähert; unterc Decliblïter krautarlig, obcre glcich den an der Spitie ganzrandigen Kclchblïllorn am Rande trockenliciutig, an der Spitze kahl, mit cinem mehr oder weniger auslaufenden, krautartigen streifen; Fruthtstiele wagrecht-abstehend, $2-3$ mal so lang als der Kelch; Blumenbläter 2spaltig, etwa so lang als der kieleh; Samen schwach punktivt. $\odot$. Trockene Wejopuplatze, Raine, Brachärker, smmige llügel; zwischen IIalle und Seben, zwischen Kröllwitz und der lleide, beswnders häufig an der Steinhlippe bei Wendelstein und gewiss weiter verbreitet. April. Mai. C. punilum M. u. K. C. semidecandrum Pers. Blıne weiss. Höhe $3-8^{\prime \prime}$. Aendert ab mit hellgrimer Farbe und schmal-häutig. berandeten unteren Deckblättern C. putnilum a. Koch, C. Grenieri $\beta$. pallens F. W. Schultz und b) mit dunkelgriiner Farbe, krautartigen unteren und sehr schmal berandeten oberen Deckblättern C. pumilum $\beta$. Ko ch, C. obscurum Chaubard.

Die deutschen Botaniker haben auf die Merkmale, welche Fries Novit. ed. 2. p. 132 sq. und Mant. 2. p. 36 sq. fiir sein C. glutinosum besonders hervorhebt, nämlich die walzenförmigen, anf wagrechten endlich aufrechten sticlen stehenden Kapseln, welche doppelt su lang sind als der Kelch und die klebrigen, wicht blos driisig-behaarten stengel entweder gar kein Gewicht gelegt uder nur ein unbedentendes und in der That sind die aus verschiedenen Gegenden Dentschlands vorliegenden Exemplare weit weniger hebrig mol hei gleicher Höhe in allen Theilen weit schwächer und schmächtigr als die schwedischen. Die wagrecht-abstehenden Fruchtstiple möchte der Verf. (gegen Fries) nicht fiir ein entscheidendes Kemmeirhen des C. gluti. nosum halten, da diese auch bei C. semidecandrunı vor. kommen, dagegen sind die unteren Dechblätter bei C. glutinosum an deutschen und schwedischen Exemplaren stets krautartig.

189. C. triviāe L ink, ge me in es II. Abb. 4972. Stengel anfsteigend, seitenständige an den unteren Gelenken wurzelnd; Blätter länglich, unterste in den Blattstiel rerschmälert; oberste. Aeste der Rispe einander genähert; Deckllïiter nebst den ganzrandigen Kelcíbliit- 
tern am Rande, trockenhäutig, an der Spitze kahl; Fruchtstiele 2-3 mal so lang als der Kelch; Blumenblättel 2spaltig, ungefähr so lang als der Kelch; Samen sehr deutlich warzig - punktist. (i) und $\odot$. Felder, Triften, Wegränder überall gemein. Nii - Octub. C. rulgatum Wahlenbg. C. viscosum des Linné ischen Herhars narh Sm. Blume weiss. Höhe 4-12". Aendert ab mit und ohne Drüsenhaare. b. Ausilauernde Arten, deren Blumenblatter doppelt so lang sind als
der Kelch.

190. C. arvense $\mathbf{L}$. , A c ker - H. Abb. 4980. Stämmchen nicdcrgestreckt, am Grunde wurzelnd; Stengel anfsteigend, die nirht bliihenden dicht rasenförmig, die blïhenden aufrecht; Blätter linealisch-lanzettlich oder linealisch; Deckbliittcr breit-trockenhüutig-berandet; Bliithensticle kurz- und weich - behaart, nach dem Verbliihen aufrecht, mit nickendem Kelche; Blumenblätter doppelt so lang als der Kelch. 24. Wegräinder, Triften, sandige Raine überall gemein. April. Mai. Blume weiss. Höhe 4-8". Aendert mit schmäleren und hreiteren, aufrechten, abstehenden und zurückgeschlagenen Blättern und drïsig - behaarten uder drüsenlusen Blïthenstielen ab. Ferner:

b) strictum Haenke. Stengel und Blätter kahl, letztere nur am Grunde gewimpert.

XIV. Familie. Elatineen Cambessedes.

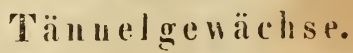

96. Elatíne L. Tännel (von żhictr, Tanne).

a. Blätter gegenüherstehend.

191. E. Kydropīper L. (mit Ausschluss des Syn. Vaill ants und der Variet. $\beta_{0}$ ), p fefferfüuth tiger T. Dreves und Hayne t. 71. Stengel niedergestreckt; Blätter gegeniiberstehend, länglich-elliptisch, hürzer als der Blattstiel; Blüthen in den Blattwinkelu sitzend oder sehr kurz gestielt; Kelch 4theilig; Blume 4blätterig. 8männig; Samen halbkreisförmig gehrümmt. $\odot$. Veberschweminte Stellen, am Rande der 'Teiche und Flïsse. Wird von $\leqslant p$ r. hal. ed. 2 p. 183 an den Ufern der Saale in der Nähe der Salinen als selten angegeben; der Verfasser hat sie dort nicht gefunden; an den Ufern der Elbe bei Dessau nach Schwabe fl. anl. JuniAug. Blume rosenroth oder weiss. Stengel 1-4"lang. 


\section{h. Blätter yuirlständig.}

192. E. Alsinnstrum L., quirliger' 'T'. Dietrich Flor. Regni Bor. VIII. Abb.574. Stengel bei der Landform aufrecht, bei der Wasserfurn schwimmend oder aufsteigend, dick, röhrenförmig, ästig: Blätler quirlständig, sitzend, länglich-eiförnig. die mntergetauchten linealisch-lanzettlich, viel kleiner; Bliithen in den Blattwinkeln fast sitzend; Kelch 4theilin; Blume 4blätterin, 8männig; Samen fast gerade. $\odot$. Teiche, Sïmpfe sphr selten; wird von Spr. a. a. O. an ausgetrockneten Siimpfen bei Oberthau, Ermlitz und Wallendorf als sehr selten angezeigt, "॥ sie der Verfasser nicht aufzufinden vermuchte; sie finlet sich aber sehr häufig in Rathsteiche bei Allstedt, seltener in den 'I'eiche del Wiiste zwischen dem Winkelschen 'T'eiche und dem Allstedter Theilholze, ebenfalls sehr häufig an nördlichen Ende des Pötnitzer Sees östlich ron Dessall. Juli. Mug. B Blıme grünlich-Weiss. Höhe des Stengels auf den Lande kaum 1", im IVasser dagegen $1 / 2-1$.

\section{Familic. Lineen DC. Leinge-}

wälise.

87. Giveran I. I, ein (von den celtischen Wurte Jlin, der Faden, stammend).

193. L. cathárticum L., Purgi r-I. Abb. 5165. Stengel aufsteigend, fallenförmig, oberwärts gabelästig; Bliitter kahl, am Rande etwas rauh, untere schmal. verkehrt-eiförmig, obere lanzettlich, alle gegenïberstehend; Kelchbliitter elliptisch, zugespitzt, driisig-getvimpert. Wiesen, 'Triften, Grasplätze hänfig z. B. vur dem Sebenschen Busche, auf dem Bischofsberge in der Hej. de u. s. w. Juni - Ang. Cathartolinum pratense $R \mathrm{ch}$ b. Blume weiss. Höhe $2-8^{\prime \prime}$.

194. L. usitatissimum $\mathrm{L}$., ge m e in er L. Abb. 5154. Stengel einzelı, aufrecht, zwweilen ästig; Bliitter kahl, srhmal-lanzettlich, wechselstïndig; Kelchblïtter eiförmig, zugespitzt, fein gewimpert, driisenlos, fast so lang als die Kapsel. $\odot$. Wird auf Aeckern gehaut, ubsleiclı in grössteu Theile des Gebietes selten; am häufigsten bei Aschersleben. Juni. Juli. Blune blau. Höhe 1 2'. Aendert ab:

a) vulgare Sehübl. und Mart: Höher; Blätter, Bliithen und die nicht aufspringenden Kapseln klei- 
nel; Samien dunkler; von den Landleuten S chliesslein, Dreschle in genannt.

b) crepitans Schübl. u. Mart. Abb. 5155. Niedriger und ästiger; Blätter, Blüthen und die elastisch aufspringenden Kapseln grösser; Samen bleicher, früher reifend. Springlein, Klanglein genannt.

L. tenuifolium L. Abb. 5165, mit schmal-linealischen, an Rande wimperig-rauhen Blättern und drüsiggewimperten Kelchblättern, welche die Kapsel nur wenig überragen, wird von Wallr. sched. p. 127 an trokkenen Hiigeln bei Querfurt links von der Windmühle als selten angeführt und von s'pr. hal. ed.2. p. 147 und Rchb. sax. p. 449 aufgenummen. Da diese Pflanze aber seit einer Rejhe ron Jahren von vielen Botanikern dort vergeblich gesucht wurde, su wagt es der Verfasser bei dem Mangel eines zuverlässigen Standortes nicht, sie aufzunehnen.

88. Hadiola danel. Zwerg-Leini (von radiolus, eill kleiner Strahl, wegen der strahlförmig gestellten Friuchtchen).

195. R. linoídes Omel., tausendkörniger Z Z. Abb. 5152. Stengel fadenförmig, aufrecht, gabelspaltigvielästig; Blätter gegenüberstehend, eiförnig; Blüthen klein, einzeln, fast linäuelartig beisammenstehend. $\odot$. Feuchte, sandige Plätze und Triften, Fahrgleise stellenweise; in alten Fahrgleisen der'Triften vor der Heide au Wege nach Kröllwitz nicht selten, feuchte, sandige Stellen am Bienitz, ïber der Henne bei Naumburg, an der Sprödaer Heide östlich von Delitzsch. Juli. Aug. R. Millegrana $\mathbf{S m}$. Iinum Radiola l.. Blume weiss. Ein sehr zartes, 1-2" hohes Pflänzchen.

XVI. Familie. Malvaceen R. Br. Malvengewächse.

79. Malva L. Käsepappel, Malve (aus dem Griechischen $\mu c \lambda \dot{c} \gamma \eta$ gebildet, von $\mu c \lambda \dot{c} \sigma \sigma \varepsilon \iota \nu$, erweichen, wegen der Wirkungen).

A. Bismalra Medik. Stengelblätter handförmig-ge. theilt; Blüthenstiele einzeln, einblüthig oder doch armblüthig.

196. M. Alcēa L., spitzblätterige M., Sig. lia reke, Flora. 
marswurz. Abb. 4842. Stengel aufrecht, durch angedriickte Sternhaare graugrün; liuzelblätter herzförmigrundlich, gelappt, Stengelbliitter handförmig-5theilig, mit 3spaltigen oder fiederspaltigen, cingeschnitten - geziihnten Zipfeln; Bliithensticle blattwinkelständig, einzeln nebst elem Kelche mit angedriichten sternhaaren besetzt; Iruchtklappen kahl, fein-quer-runzelig, anf dem Riicken gekielt, an Rande abgerundet. H. Truckene II ugel, Z̈iune, Wegränder, Raine zerstreut; Wiesen am Schwalchluche und an der Gersdorfer wiisten Feldmark hinter Kröllwitz, am Lindberge, bei Röglitz, Waldründer bei Namburg zerstreut, In den wisten Bergen und an Waldrünlern bei Allstedt, bei Eisleben, an Dämmen bei Sandersleben und Dessau. Juli-Sept. Blume rosenroth, geruchlos. Höhe $2-4^{\prime}$.

197. M. moschāta L., M us chus-K. Abb. 4841. Stengel aufrecht, von abstehenden, meist cinfachen IIaaren rauh; Wurzelblätter herzförmig-rundlich, Stengelblïtter 5theilig, mit eingeschnittenen, fiederspaltigen oder doppelt-ficderspaltigen Zipfcln; Bliuthenstiele blattwinkelständig, einzelı nebst dem Kelche mit abstehenden, meist einfachen Haaren besetzt; Fruchtklappen dicht rauhharig, gliatt, am Rande abyerundet. 2 . Ackerränder, schutt sehr selten, nur bei Naumburg unter den Rossbacher Weinbergen und am Eisenbahndamme in der Aue; nach Sp r. hal. ed. 2. p. 308 auf den Irothaer Werder, wo sie der Verfasser vergeblich gesucht hat. Juli-Sept. Blume rosenroth. Höhe $1-1 \frac{1}{2} \%$ Das Kraut riecht getrocknet nach Moschus.

Diese Art ist der vorhergehenden sehr ähnlich, aber durch die abstehenden Haare der Stengel, Blattstiele und Kelche, die sehr feiı zerschlitzten Stengelblätter, die schnäleren, kleineren Blumenblätter und die dicht rauhhaarigen Früchte bestinınt zu unterscheiden.

B. Fasciculatae DC. Stengelblätter gelappt; Bliithenstiele in den Blattwinkeln büschelförmig beisammenstehend.

198. Mr. silvestris L., wilde K., Rosspappel. Abb. 4840. Stengel niederlipgend, aufsteigend oder aufrecht, rauhhaarig; Blätter helzförmig-rundlich, 57lappig, kerbig-gesägt; Blatt- und Bliithenstiele rauhhaarig; Bliithenstiele gehäuft, vor dem Aufbluhen kürzer, nach dem Aufbliihen verlängert, aufrecht; Blumenbliitter 3 mal liinger als der Kelch, tief ausgerandet, am Stengel dicht bärtig; Fruchtklappen kahl, beraudet, 
netzförnig-runzeliz. (-). Wege, Zäune, Schutthaufen, Mauern gemein z. B. in Giebichenstein, Kröllwitz u. s. w. Juli-Sept. Blume hell-purpurroth, mit dunkleren Streifen. Höhe $1-3^{\prime}$. OFF. Flores Malvae.

M. mauritiana L., mauretanische K., Abb. 4839, welche in Gärten gezogen und sich, wiewohl sel. ten, auf Schutt verwildert findet, hat stärkere, steif aufrechte, fast kahle Stengel, dunklere, fast blutrothe, breitere, weniger tief ausgerandete Blumenblätter, nur auf der oberen Fläche weichhaarige Blattstiele und kahle Bliithenstiele, welche kaum die Länge der entfalteten Blüthe haben. $\odot$. Stammt aus der Barbarei und Südeuropa. Juli - sept.

199. M. vulgaris Fres, geme in e K. Abb. 4836 . Stengel niederliegend oder aufsteigend, rauhhaarig; Blätter herzförmig-kreisrund, seicht 5-7lappig, gekerbt; Blatt - und Blüthenstiele rauhharig; Bliithenstiele gefurcht, nach dem Verlliihen abwüirts-gehogen, mit aufrechten Kelche; Blumenblätter $2-3$ mal so lang als der Kelch, tief-ausgerandet; Fruchtklappen auf dem Riicken abgerundet, olatt oder schwach-runzelig, kahl oder weichhaarig. $\odot$. Wege, Mauern, Schutt, in Dörfern überall gemein. Juni - Sept. M. rutundifolia der meisten Autoren. Blume hell- rosenroth oder fast weiss. Stengel $1-1 \frac{1}{2}$ ' lang. OFF. Hb. et Flores Malvae vulgaris.

200. Mr. boreālis Wallmann, nördliche K. Abb. 4835. Stengel niederliegend oder aufsteigend rauhhaarig; Blätter herzförnig - kreisrund, seicht 5-7lappig, gezühnt; Blatt- und Blüthenstiple rauhhaarig; Bliithenstiele gehïuft, nach dem Verbliihen abwärts-gebogen, mit aufrechtem Kelche; Blumenblätter so lang als der Kelch, schwach ausgerandet; Fruchtklappen scharf-berandet, grubig-runzelig, fein - behaart. $\odot$. Ackerränder, Wege, in Dörfern stellenweise; Aekker an der Nietleber Windmühle häufig, zwischen Passendorf und der Windmühle einzeln, häufiger zwischen der Passendorfer Windmühle und Zscherben, zwischen den Dömeken und Wansleben, in Wesmar an der Elster, selten zwischen Liederstedt und Vitzenburg bei Nebra, gleichfalls selten auf der Grenze des Gebietes zwischen Voigtstedt und Kahstedt westlich von Allstedt, bei Aschersleben nach Neundorf zu und zwischen Rathmannsdorf und Hohenerxleben. Jun.-Sept. M. rotundifolia L. nach Fries. M. pusilla Wither. Blu- 
me hell-rosenroth oder fast " $e$ iss, sehr klein; Stengel $4-12 "$ lang.

Der M. vulgaris Fries im Wuchse ganz ähnlich, aber durch die kleineren, den Kelch kaum ein wenig ïberragenden Blumenblätter und die netzförmig-runzeligen Früchte bestinınıt unterschieden.

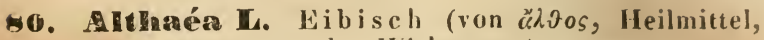
wegen der Wirkungen).

201. A. officinalis L., gebräuchlicher E. Abb. 4849. Stengel aufrecht, filzig-zuttig; Blätter gestielt, ungleich zahnartig-gelierbt, auf beiden Seiten dichtsammetartig-filzig, untere herzförmig, 5lappig, obere länglich-eiförnig, 3lappig; Blüthenstiele blattwinkelständig, reichblüthig, kürzer als das Blatt; der äussere Kelch 9spaltigr. 24. Gräben, feuchte Wiesen, besonders auf salzhaltigem Boden zerstrent; salzhaltige Wiesen bei Dieskau sehr häufig, Grähen zwischen Halle und Reideburgr. Gräben zwischen Kötschau und Schladebach, bei 'Teuditz, Dürrenberge, Weissenfels, fehlt bei Naumburg und Freiburg; in Riede bei Allstedt häufig, an Gräben bei Sandersleben, Stassfurt und Radegast, bei Mosigkau und Gruss Kühnau unweit Dessau. Juli. Aug, Blume röthlich-weiss. Höhe $2-4^{\prime}$. OFF. Rad. Hb. et Flores Althaeae.

81. Lavotéa I. Lavatere (nach den Züricher Arzte Lavater benamint).

202. L. thuringiaca L., thüringische L. Abb. 4854. Stengel aufrecht nebst den Kelchen, Blatt- und Blüthenstielen sternhaarig-filzig; Blätter dünn-filzig, untere echig-gelappt, obere 3lappig, der mittlere Lappen länger, stumpf, Blïthenstiele blattwinhelständig, pinzeln, länger als der Blattstiel; der äussere Kelch 3spaltig; Blunenblätter 2lappig. 24. Wege, Raine, unbebaute Hügel, Kirchhöfe zerstreut, fehlt im östlichen und nordöstlichen Gebiete; Gebüsche an der Saale zwischen dem Schwalchloche und Lettin, Kirchhof in Gutenberg, bei Kötschau, Teuditz und Weissenfels, in der Aue bei Naumburg. Wiesen zwischen Laucha und Burgscheidungen, am Schlosse in Querfurt, Hagen bei Fisperstedt, Helmedamm von hatharinenrieth lis Kalbsrieth unweit Allstedt, bei Ascherslehen lıäufig, im Pregel hei Sandersleben. Juli. Ang. Blume gross, blassrosenroth. Ilöhe $2-4^{\prime}$. 
XVIl. Familie. Tiliaceen. Lindenge-

wächse.

82. Tilia L. Linde.

203. T. grandifolia $\mathbf{E h h}$., grossblätterige L., S o m m e r-1. Abb. 5139. Blätter schief - rundlich herzförmig, zugespitzt, unterseits kur zhaarig, beiderseits grün, in den Achseln der Adern bärtig, Blattstiele weichhaarig; Ebensträusse 2 - 3blïthig; Lappen der Narbe aufrecht; Kapsel holzig, mit 5 starken Kanten. ち. In Wäldern seltener z. B. im Sperlingsholze bei Naumburg einzeln, häufiger am Pfortenberge, bei Bibra, Steinbach, Winkel, weit häufiger in Anlagen angepflanzt. Schlägt friiher aus als die folgende Art und blüht unter allen diten an frïhesten, von Mitte bis Ende Juni. 'T. platyphyllos $\mathbf{S} \mathrm{cop}$. 'T. enropaea $\beta . \delta . \varepsilon$. L. 'I. pauciflora Hay ne. Blume blassgelb oder weiss, wie bei der folgenden. Aendert ab mit 4-7blithigen Ebensträussen und ausserdem:

b) o хуса́rpa Rchb. Kapseln kngelförmig Jsseitig, nicht birnförnig.

204. T. parvifolia $\mathbf{E} \mathbf{r}$ h., kle inblätterige L., Winter- L. Abb, 5137. Bliitter schief-rundlich-herzförmig, zugespitzt, auf beiden Seiten kahl, unterseits meergrün und in den Achseln der Adern bärtig; Blattstiele kahl; Ebensträusse 5-7blüthig; Lappen der Narbe zuletzt wagrecht-auseinanderfahrend; Kapsel dünnschalig, papierartig, mit 4-5 undeutlichen Kanten. \$. In Laubwäldern und oft in Dörfern, Alleen angepflanzt, nicht selten. Blüht 14 'I'age später als vorige. Juli. T. ulnifolia S c op. 'T. eurupaea $\%$. L. Aendert ab mit etwas grösseren Blüthen und Blättern und blasseren Haaren in den Achseln der Adern: T. vulgaris Hayne. T. intermedia DC. Abb. 5138. OFF. Flores Tiliae.

\section{Familie. Hypericineen DC. Hart- h engewächse.}

83. Hysericunan. Hartheu, Johanniskraut (von die Heide überragend, in Betreff des Standortes).

a. Kelchhlätter ganzrandig, am Rande drüsenlos (nur bei H. humifusum L. bisweilen am Rande mit drüsigen Zähnen besetat).

205. H. perforātum L., durchlö chertes H. Abb. 
5177. Stengel aufrecht, 2 kantig; Blätter eiförmig-länglich, durchscheinend punktirt; Kelchblätter lanzettlich, sehr spitz, ganzrandig, doppelt so lang als der Fruchtknoten; Stanbgefässe 50-60. 24. Raine, Ackerründer, Gebüsche, Hecken überall genıein. Juli. Aug. Blume gelb. Höhe 1-2'.

206. H. quadrángulum L., vierkantiges H. Abb. 5178. Stengel aufrecht, schuach-4kantig; Blätter eiförnig, zerstreut - und gross - durchscheinend - punktirt; Kelchblätter elliptisch, stumpf, ganzrandig, ungeführ so lang als der Fruchtknoten. 24. Waldwiesen, Gräben zerstieut; bei Halle selten; feuchte Wiesen bei Osendurf, häufiger bei Naumburg, in Sandthale des lodersleber Forstes, bei I,ingenau und Dessau. Juli. Aug. H. dubium I, e e rs. H. delphinense Vill. Blume gelb. Höhe 1-2'.

Am unteren 'Theile des Stengels verschwinden zuweilen die Streifen und es erscheint dann 2 kantig, ist dann aber durch die durchscheinenden, sehr grossen, aber nur wenigen oder ganz fehlenden Punkte der Blätter und durch die kürzeren Kelchblätter von den ähn. lichen H. perforatum L. zı unterscheiden.

207. H. tetráptěrum Fies, vierflügeliges $H$. Abb. 5179. Stengel aufrecht, gefliigelt-4kantig; Blätter eiförmig, dicht-durchscheinend-punktirt; Kelchblätter lanzettlich, zugespitzt, ganzrandig, ungeführ so lang als der Fruchtknoten. 24. Feuchte Wiesen, Gräben, Teiche sehr häufig z. B. Gräben vor und in Bischdorf und Reideburg, Teiche bei Dieskau u. s. w. Juli. Aug. H. quadrangulare $\mathrm{Sm}$. und fast aller Autoren. Blume hellgelb, kleiner. Höhe 1-2'.

208. H. humifüsum L., niederliegendes H. Abb. 5176. Stengel niederliegend, fadenförmig, fast 2 kantig; Blätter eiförmig - länglich, durchscheinendpunktirt; Kelchblätter länglich, stumpf, kurz-stachelspitzig, ganzrandig oder mit einigen feinen Zähnen besetzt, doppelt so lang als der Fruchtknoten; Staubgefüsse $15-20$. 24. Sandfelder, Brachäcker, feuchte 'Iriften, Heiden nicht selten z. B. Aecker an der Heide in der Nähe des Kröllwitzer Weges, sandige Aecker an Dölauer Kirchholze, Aecker zwischen dem Zorgs und Lieskau u. s. w. Juni-Sept. Blume gelb. Stengel 2-6" lang. Aendert ab:

a) glandulosum Wallr. Kelchblätter am Rande drüsig-gesägt und

b) pumilum Klett u. Richt., niedriger, nur $1-2^{\prime \prime}$ 
hoch, aufrecht, armblüthig, zuweilen nur mit 4 Kelchblättern und 4 Blumenblättern. H. humifusun ק. Liottardi Vill.

b. Kelchblitter am Rande drüsig-gesägt oder gefranst.

209. H. élegans steph., zierliches H. Abb. 5190. Stengel aufrecht, fast 2 kantig, kahl; Blätter aus herzförnigen Grunde lanzettlich oder eiförmig, durchscheinend-punktirt, an Rande zurückgerollt und mit schwarzen Drïsen besetzt; Kclchblc̈tter lanzettlich, spitz, kurz-gefranst, an rer Spitze feindriisig; Samen fein punktirt. 24. Sonnige Kalk - und Sandsteinfelsen sehr selten; am Vogelsberge und in den Weinbergen rechts von der Chaussee hinter Bennstedt ziemlich selten; an der Steinklippe bei Wendelstein sehr häufig, am Frevel bei Allstedt sparsam. Juni. Juli. Blıme blassgelb. Höhe $1 / 2-1^{\prime}$. Den Namen H. Kohlianum fl. hal. ed. 1. hat Spr. selbst wieder zurïckgenomulen.

Hierher gehört unstreitig auch das zuerst von $\mathrm{K} n$ a $u t^{\mathrm{t}} \mathrm{h}$ en. p. 61, dann von $R$ ehf. hod. p. 78 und $B u x b$. en. p. 163 erwähnte Hyp. ninus erectum C. B., welches nach den beiden ersten Autoren an hegrasten Hügeln des Petersberges, nach $B u x b$. aber an sonnigen Bergen bei Bennstedt wuchs; es wird gewöhnlich zu H. pulchrunı L. gezogen.

210. H. pulchrum L., s chönes H. Abb. 5185. Stengel aufrecht, stielrund, kahl; Blätter aus herzförmigem Grunde eiförmig, abgerundet-stumpf, sitzend, unterseits graugrïn, durchscheinend-punktirt; Kelchblïtcr verkehrt-ciförmig, sehr stumpf, driisig-genvimpert, mit sitzenden oder sehr kur -oestielten Driisen; Samen sehr fein punktirt. 4. Heidewälder sehr selten; nur auf der Grenze des Gebietes bei Osterfeld an dem ersten Heidenteiche und daselbst durch Unackern sehr gefährdet. Juni. Aug. Rlume blassgelb. Höhe $1-2 \%$.

211. H. montanum L., Berg-H. Abb. 5187. Stengel aufrecht, stielrund, kahl, wenig beblättert; Blätter sitzend, aus herzförmigem Grunde eiförmig oder länglich-eiförmig, an Rande schwarz-punktirt, nur die oberen durchscheinend, unterseits etwas rauh; Kelchblätter lanzettlich, spitz, driisig-gewvimpert, Driisen kugelförmig, gestielt; Bliithen fast kopfartig-gedrängt, Samen fein-punktirt. 2. Wälder; Heide, Lindberg, Zorgs, Mittelholz und sonst nicht selten. Juni-Aug. Blume blassgelb. Höhe 1-2'. 
212. K. hirsutum L., $r$ a uha ariges H. Abb. 5159. Stengel aufrecht, stielrund nelst den kur acestiel. tcn, eiföınigen oder lüıglichen, durchscheinend-punktirten lilittern weichbehaart; Kelchbliitter lanzettlich, spitz, driisig-scuvimpert, Driisen kur z-nestielt; Bliithen in langrestrechter Rispe; Samen sammetartig. 24. Trokkelle Laubwälder: bei Halle nicht häufig; im 'Zorgs und Mittelholze sparsam; im Bienitz; weit verbreiteter bei Naumburg und Allstedt z. B. im Rathsholze und Hagen; bei Eislehen an der Hüneburg. Juli. Aug. Blume blasigelb. Höhe '2'.

XIX. Familie. Acerineen DC. A horngew ïchse.

\section{Acen L. Ahorn.}

213. A. Pseudoplátanus $\mathbf{L}$., w e isser $\mathbf{A}$ h $0 \mathrm{rn}$. Abb. 4829. Blätter handförmig-5lappig, unterseits graugriin, Iappen zugespitzt, ungleich-gekerbt-gesägt; Trauben hiingend, verlängert, unterste Bliithenstiele mehrblïthig; Fruchtknoten zottig; Fliigel etwas abstehend; Stanbgefässe der männlichen Blüthen doppelt so lang als die Blume. $\hbar$. Bergwälder sehr zerstreut, bei Naumburg, Eisleben, häufiger angepflanzt. so bei Dürrenberge, Weissenfels u. s. w. Mai. Juni. Blume klein, grün. Ein Baum von $60-80^{\prime}$ Höhe.

214. A. platanoĩdes L., spitzblät teriger A. Abb. 4828. Blätter handförmig-buchtig-gelappt, mit scharf -zugespitzten, 3-5zïhnigen Lappen; Libensträusse aufrecht; Fruchtknoten kahl; Flïgel wagrecht-ausgespreizt; Staubgefässe der männlichen Blïthen von der Länge des Kelches. t. Wälder ziemlich selten; Pfortenberg bei Naunburg häufig, bei Eisleben im Bischofslöder Holze und an buschigen Bergen bei Wolferode. April. Mai. Blume gelbgrïn. Ein Baum von $60-80^{\circ}$ Höhe.

215. A. campestre L., Feld-A., Mas shold er. Abb. 4825. Bliitter her fürmig-5lappig, Lappen ganzrandig, lïnglich, der miltlere stumpf-3lappig; Ebensträusse aufrecht; Kelch und Blumenblätter linealisch, zottig, von den Stanbgrefässen der nünnlichen Blüthe nicht uberragt; Flïgel wagrecht-ausgespreitzt. ち. Wälder, Gebüsche, Zäune weit häufiger als die vorhergehenden Arten. Mai. Blume grün. Ein meist 8- 
$10^{\prime}$ hoher Strauch, aber anch als Baum ron $20-30^{\prime}$ Höhe mit glatter und korkiger Rinde vorkommend. Aendert ab mit ganz kahlen und unterseits weichhaa. rigen Blättern. kahlen und weichhaarigen, bleineren und grösseren Früchten.

\section{Familie. Hippocaslaneen DC. Ross- kastaniengeü̈chse.}

85. Riscŭlus L. Rosskastanie (von edere, essen; Plinius bezeichnet hiermit die speise eiche, Quercus Es. culus, welche essbare Früchte trägt).

216. E. Hippocństanum L., gemeine R. Blätter 7 oder 5 fingerig, mit verkehrt - ei - keilförnigen, sehr kurz zugespitzten, gezähnelten Blättchen; Bliithen sblätterig, 7noüunig; Kapsel igelstachelig. Ђ. Stanımt aus den nördlichen Theilen Ostindiens und ist jetzt überall an Alleen und Wegen angepflanzt. Mai. Juni. Blume weiss mit rothen oder gelben Flecken. Bamm $60-80$ ' hoch. Die erste europäische Rosshastanie erzog Clusius $\mathbf{1 5 7 5}$ zu Wien.

XXI. Familie. Ampelideen $\mathrm{Humb.,}$ Bonpl. 11. Kunth. Rebengewächse.

86. Anupelópsis Michaux. Zaunrebe, rom Volke wild e r We in genannt (von «̈uredos, Weinstock und öwıs, Gesicht, Aussehen).

217. A. hederácea Mchx., epheuartige $Z$. Blätter 3-5zählig, kahl, mit kurz-gestielten, eiförmigen oder lünglichen, zugespitzten, stachelspitzig •gesägten, oherseits dunkelgrünen, unterseits weisslich. grïnen Blättchen. ち. Zierstrauch aus Nordamerika; wird häıfig an Mauern, in Zäunen angepflanzt. Juli. Aug. Hedera quinquefolia $L$. Cissus quinquefolia Pers. Vitis hederacea Willd. Blume grünlich, Beeren schwarzblau. Klettert an Bäumen und Mauern zu einel Höhe von $40^{\prime}$ hinauf.

87. Vitis L. Weinrebe.

218. v. vinífera L., e dl e W. Blätter herzförmig, meist buchtig-5lappig, grobgezähnt, kahl oder filzig. 万. Eine aus dem Süden stammende, jetzt an sonnigen 
Bergen in sehr vielen Abarten im Grossen gebaute Nutzplanze; an Bergen bei Röglitz, Weissenfels, besonders häufig bei Naumburg, Freiburg, Rollsdorf, Höhnstedt, Seeburg, Unterriesdorf. Juni. Juli. Blumen gelblich-grün; Beeren dunkelblau oder grün. Aen. dert $a b$ :

b) silvestris Gmel. (als Art). Ranken weniger zahlreich; Blätter kleiner, Blüthen unvollständig2 häusig.

c) lacinios a $\mathrm{L}_{\text {. }}$ Blätter 5theilig, mit tiefeingeschnittenen, vielspaltigen Blättchen.

\section{Familie. Geraniaceen DC. Kra-}

\section{nich schnabe $l$ gew ächse.}

88. Ceránium L. Kranichschnabel (von yégovos, Kranich, wegen der langen Fruchtschnäbel. Der Name Storchschnabel muss der Gatttung Pelargonium bleiben).

a. Mehrjährige Arten, deren BInmenhlätter len Kelch weit ïberragen; Fruchtklappen gliatt, weder runzelig, noch faltig, übrigens kahl oder behaart.

219. G. pratense L., Wi e s e $\mathrm{n}-\mathrm{K}$. Abb. 4883. Stengel aufrecht, oberwuirts driisig-behaart; Blätter handförmig - 7theilig; Blüthenstiele 2blüthig; Bliithensticlchen driisig-zottig, nach dem Verbliihen herabgeschlagen, zur Fruchtreife wieder aufrecht; Kelch lang-begrannt; Blumenblätte' breit-verkehrt-eiförmig, über dem $\mathrm{Na}$ gel kahl und nur am Rande bärtig-gewimpert; Staub. „efiisse am Grunde kreisförmig-enveitert; Fruchtklappen glatt und nebst dem Schnabel mit wagrecht-abstehenden Drüsenhaaren hesetzt: Sameu sehr fein punktirt. 24. Wiesen, Grassplätze, Chausseegräben sehr häufig; fehlt aber im nordöstlichen Gebiete fast ganz. Juli. Aug. Blume sehr gross, blau. Höhe 1-2'.

220. G. silváticum $\mathbf{L}$., $W$ ald $-K$. Abb. 4882. Stengel aufrecht, oberwöirts driisig-behaart; Blätter handförmig-7spaltig; Blüthenstiele 2bliithig, Bliithenstielchen driisig-zottig, nach dem Verbliihen aufrecht; Kelch meist kurz begrannt; Blumenblätter verkehrt-eiförmig, iiber dem Nagel und am Rande bärtig; Staubgefüsse lanzetlich; Fruchthlappen glatt und nebst dem Schnabel mit wagrecht-abstehenden Drüsenhaaren besetzt; Samen sehr fein punktirt. 24. Besonders in Gebirgs- 
gregenden, weit sparsamer auf Waldwiesen der Ebene, sehr selten; nur auf der Grenze des Gebietes bei Oranienbaum nach Sehwabe fl. anh. Juni. Juli. Blume gross, violett, ins Röthliche spielend. Höhe 1-2'.

Diese Pflanze, von Spr. hal. ed. 2. p. 301 in der Heide und bei Gutenberg als selten angegeben, wird daselbst seit 14 Jahren vergeblich gesucht und der Ver. fasser muss nach der ganzen Beschaffenheit der Gegend die Richtigkeit der Bestimnung sehr bezweif $\ln ; \mathbf{R} \mathbf{c h}$ b. hätte deshalb sax. ed. 1. u. 2. p. 429 die von Spr. angegebenen Standorte nicht wieder aufnehmen sullen. Wie diese Pflanze wird auch G. phaeum I., von Spr. a. a. O. im Schiessgraben und in Schiitzens Zwinger angezeigt, bei jetzt veränderter Lokalität vergeblich gesucht, welches ïbrigens nie einheimisch war, sundern nur als Gartenpflanze gezogen wurde und höchstens noch innerhalb des Gartens an den Mauern verwilderte.

Als Hauptunterschied dieser beiden sehr nahestehenden Arten werden von K o c h (Syn. und Taschenbuch), von $\mathrm{R} c h \mathrm{~b}$. sax. und von vielen Anderen die nach dem Verblühen aufrechten Blïthenstielchen bei $G$. silvaticum L. angegeben, welche bei $G$. pratense L. nach dem Verblühen zuriickgeschlagen sein sollen. Der Ver. fasser fand bei $G$. pratense die Blüthenstielchen unmittelbar nach dem Verbliihen zwar oft zuriickgeschlagen, bei der Fruchtreife aber fast immer aufrecht, so dass es nach diesen Merkmale im fruchtreifen Zustande nicht von G. silvaticum zu unterscheiden ist. Es ist auch in der That schwer scharfe Unterschiede für diese Arten zu geben, welche übrigens Niemand verwechselı wird, der sie in der Natur zu beubachten Gelegenheit hatte. Die Tiefe der Blattheilung und die Gestalt der Zipfel, so wie die Granne der Kelchblätter ist sehr veränder. lich, dagegen sind die breit-verkehrt-eiförmigen, grösseren, an Grunde mit kurzem Nagel versehenen, azur. blauen Blumenblätter und die am Grunde kreisförmig. erweiterten Staubgefässe bei G. pratense beständig.

221. G. palustre L., Sum p f-K. Abb. 4892. Stengel ansgebreitet, obervüirts von rückwärts - gekehrten driisenlosen Haaren rauh; Blätter handförmig $-5-7$ spaltig ; Blüthenstiele 2 blüthig; Bliithenstielchen mit riickwärts-gekehrten, driisenlosen Haaren besetzt, nach dem Verbliihen niedergebogen; Kelch lang - begrannt; Blumenblätter verkehrt-eiförnig; Staubgefässe lanzettlich; Fruchtklappen glatt mit abstehenden, drüsenlosen Haaren bestreut; 
Fruchtschnäbel fast kahı; Samen fein längsstreifig. = Feuchte Wiesen und Wilder, unter Gebiisch, an RuplIen etwas seltener als G. pratense; Seben, Gutenberg, Wiesen an Bienitz, bei Naumburg zerstreut \%. B. in den Waldern ibes der Henne, in Kroppenthale zwi. schen Sehönburg und Wetau, in den Wäldern heil andgrafinde, Allstedt, Eisleben, Dessau und Oranienbaum häufig. Juli. Ang. Blume gross, purpurroth. Höhe $1-3^{\prime}$.

222. G. sanguineum L., b lutrother K. Ibb. 4894. Stenoel ausgebreitet, vom Grunde an mit langen, wangecht - abstehenden, driisenlosen II 1 aren besetzt; Blïtter in Unrisse nierenförmig, tief theilig mit 3 - und mehrspaltigen linealischen Lipfeln; Bliithenstiele meist 1bliitlig, selten 2blïthig, von langen, wasrecht-abste. henden, driisenlosen Haaren rauh, nach dem Verbliiheñ etwas abucirts gencigt; Kelch kurz-begrannt: Blumenblätter verkehrt-eifö̀rnig, ausgerandet; Fruchtklappen glatt, mit zerstreuten, drüsenlosen Haaren, Fruchtschnäbel nur an der Spitze behaart; Samen sehr fein punktirt. 24. Sonnige Hügel, trockene Waldwiesen zwischen Gebiisch häufig z. B. auf dem Bıschofsberge in der Heide, in Mittelholze, am westlichen Rande des Bienitz u. s. w. Juni - Aug. Blume gross, blutroth. Höhe $1 / 2-1 / 2$,

223. G. pyrenáicum L., pyrenä is eher $K$. Abb. 4881. Stengel anfrecht, weichhaarig und etwas zottio; Blätter im Unurisse nierenförmig, 7-9spaltig, Zipfel der unteren vorn eingeschnitten, stumpf-gekerbt; Blüthenstiele 2blïthig, l:liithensticlchen fein driisig-weichhaarig, nach dem Verbliihen abwiirts sencig; Kelch nur stachelspitzig; Blımenblätter verkehrt-herzö̈rmig, 2spaltig, oberhalb des Stengels beiderseits dicht-bärtig; Fruchtklappen glatt, angedrücht - weichhaarig. drüsenlos; Samen glatt. 24. Grasplätze. Juli- Herbst. Blume weit kleiner als bei allen vorhergehenden. Höhe $3 / 4-11 / 2^{\prime}$.

Diese Pflanze gibt Spr. fl. hal. ed. 2. p. 302 in pomoeriis, cultis, ad sepes an. Soll hierunter der bot anische Garte" in Halle verstanden werden, so ist der Standort richtig, denn durt wächst sie in grosser Anzahl, obwohl, wie viele andere, nur verwildert. Einheinisch ist sie im Gebiete sicherlich nicht und wenn sie im Zwinger zwischen dem Neu - und Georgenthore bei Naumburg gefunden wird, so beweist dies nur, dass 
sie in der unmittelbaren Nähe ron Gärten, in welchen sie als Gartenpflanze steht, bisweilen verwildert und nur aus diesem Grunde hat sie der Verfasser aufgenommen. - Ein ähnliches Verhältniss findet bei G. rotundifolium L. statt.

b. Einjährige Arten, deren Blumenblätter meist klein sind. 1. Fruchtklapen glatt, aber dabei behart; Samenglatt.

224. G. pusillum L., nied!iger K. Abb. 4877. Stengel ausgebreitet, mit kurzen Driisenhaaren besetzt, ohne längere Haare dazwischen; Blätter in Umrisse fast kreislund, 5-9theilig; Blüthenstiele 2blüthig; Blüthenstielchen nach dem Verblühen abwärts geneigt; Blu. menblätter länglich-verkehrí-herzförmig, so lang als der kurz-begrannte Kelch oder ein wenig länger; FruchtKlappen slatt, angedriickt weichhaarig; Samen glatt. $\odot$. Wege, Zäune, Schutt, Aecker überall gemein. Mai - Aug. G. rotundifolium Pollich. Fries. - Nach Ko ch sollen stets nur 5 Staubfäden Staubbeutel tragen. Blume klein, blass - violett oder bläulich-roth. Höhe $1 / 4-3 / 41$.

2. Fruchtklappen glatt, aber dabeibehart; Samen grubig-punktirt.

225. G. dissectum L., s chlitzblätteriger K. Abb. 4876 . Stengel ausgebreitet, kurz-behaart; Blätter 5 - 7 theilig, mit 3 - vielspaltigen, linealischen Zipfeln; Blüthenstiele 2blüthig; Blüthenstielchen nach dem Verblühen abwärts-geneigt; Blnmenblätter verkehrt-herzförmig, über dem Nagel bärtig, so lang als der begrannte Kelch; Fruchtklappen glatt und nebst dem Schnabcl mit abstehenden Driisenhaaren besetzt; Samen grubig-punktirt. $\odot$. Aecker, Schutt nicht häufig; bei Halle selten: aut Aeckern hinter den Nietleber Gärten links von der Chaussee, Aecker zwischen Lieskau und Kölme, häufiger auf Aeckern am Bienitz, bei Naumburg und Dessau verbreitet. Mai-Juli. Blume klein, purpurroth. Höhe $1 / 4-3 / 4$.

226. G. columbinum L., 'I' a ube n-K. Abb. 4875. Stengel ausgebreitet nebst den Blüthenstielen mit kurzen abwärts angedrücliten Haaren sparsam besetzt; Blätter 5-7theilig, mit 3-vielspaltigen linealischen Zipfeln; Blüthenstiele 2blüthig, lang; Bluthenstielchen nach dem Verblïhen abwästs-geneigt; Blumenblätter veshehrt-herzförnig, am Grunde bärtig, so lang als der lang-begrannte Kelch; Fruchtilappen kahl; Frucht- 
schniibel mit sehr kuzen, vorwuirts gerichteten, driisenlosen Haaren besetzt; Samen grubig-punktirt. ○. Hügel, Felsen, Berge zwischen Gebüsch zerstreut; fehlt in der unmittelbalen Nähe von Halle; am Schweizerling bei Wettın, Steinklippe bei Wendelstein, Berge bei Bibra und Schnou. Juni. Juli. Blume rusenroth, ein wenig vrösser als bri der vurigen. Stengel $1 / 2$ ' huch, oft aber bis $1 \frac{1}{2}{ }^{\prime}$ hoch kletternd.

227. G. rotundifolium L., rundblätteriger K. Abb. 4878. Stengel ausgebreitet, weich behaart; Blätter nierenförnig-kreisrund, untere 7spaltig, mit vorn eingeschnitten - gekerbten Zipfeln; Bliithenstiele 2bliithig; Blïthenstielchen nach dem Verbliihen abwärts - geneigt; Blumenblätter länglich-keilförmig, ganzrandig, über dem Nagel nicht bärtig, ein wenig länger als der kurz-begrannte Kelch; Fruchtklappen slatt, ab. stehend-weichhaarig; Samen @rubig-punlitirt. $\odot$. Aecker. Juni - Herbst. G. viscidulum Fries. Blume fleisch - oder rosenruth. Hölıe $1 / 4-3 / 4^{\prime}$.

Diese seltene Pflanze wird zuerst ron Leysser hal. ed.1.p. 129 und ed. 2. p. 169 auf Aeckern als häufig angegeben, obgleich der Verfasser die Richtigkeit der Bestimmung nach der Diagnose der 2. Aufl. (petalis subintegris) in $\mathbf{Z}$ weifel ziehen möchte. Dasselbe gilt von Sprengel, welcher sie nach der ersten duflage p. 194 noch häufig, nach der zweiten nur stellenwe is e gefunden haben will, whne jedoch einen besonderen Standort anzugeben. Der Verf. hat sie mit Ausnahme des botanischen Gartens zuHalle, in welchem sie jährlich verwildert erscheint, im Gebiete vergeblich gesucht und ist nur vom Dr. Petermann auf Feldern bei Delitzsch einnal gefunden worden. Die Richtigkeit der Standorte: Bernburg und Sandersleben im Drängel nach Schwab. fl. anh. wird von Hampe vielleicht nicht mit Unrecht bezweifelt.

3. Fruchtklappen runzelig; Samen glatt.

228. G. molle L., we i cher K. Abb. 4879. Stengel ausgebreitet, von kiirzeren Haaren weich und von läingeren zugleich zottig; Blätter in Unrisse nierenförmig, 7 -9spaItig, mit vorn breiteren, eingeschnittenen und stumpf-gekerbten Zipfeln; Blïthenstiele 2blüthig; Blüthenstielchen nach dem Verblühen abwärts geneigt; Blumenblätter verkehrt - herzförmig, länger als der kurz stachelspitzige Kelch, am Grunde fein gewimpert; Frucht- 
klappen querrunzelig, kahl; Samen glatt. $\odot$. Wege, Ackerränder, Grasplätze ziemlich häufig, obwohl seltener als G. pusillum L. z. B. Wiesenränder unter dem Felsen bei Kröllwıtz, am Schwalchloche hinter Kröllwitz, Grasplätze an der Rollsdorfer Mühle u. s. w. Mai - Herbst. Blume hlein, purpurroth. Höhe $1 / 4-1$ '.

Unterscheidet sich ron dem in der Trioht selir ähnlichen G. pusillum I. durch die doppelte Behaarung der stengel und die runzeligen Fruchthlappen, "elctie bei jenem glatt sind.

229. G. lúcidum L., glänzende $\mathrm{l}$ K. Abb. 4872. Stengel aufrecht, fast : anz kahl; Blätter im Umrisse nierenförmig, 5-7spaltig, eingeschnitten-stumpf - gekerbt; Blüthenstiele 2bliithig; Bliithenstielchen nach dem Verblïheı abwärts geneigt; Blumenblätter verkehrt-eiförniig, ganzrandig, länger als der querrunze. lige, pyranidenförmige Kelch; Fruchtklappen netzigrunzelig und klcin-gekerbt-gestreift, oberwärts weichhaarig; Samen glatt. $\odot$. Felsen sehr selten, nur am Felsen des Amtigartens in Giebichenstein und an der südlichen Seite des Petersherges. Mai-Aug. Blume purpurroth. Der stengel meist roth angelaufen, leicht zerbrechlich, $1 / 2-\mathbf{t}^{\prime}$ hoch.

230. G. Robertin̄num L., Ruprech tskraut. Abb. 4871. Stengel aufrecht, abstehend behaart; Blätter 3. oder 5ziihlig, Bliittchen gestielt, 3spaltig, fiederspaltig eingeschnitten; Blïthenstiele 2bliithig; Blüthenstielchen nach dem Verbliihen etwas abwärts geneigt; Blumenblätter verkehrt-eiförmig, ganzrandig, länger als der begrannte Kelch; Fruchtklappen netzig - runzelig; $\mathbf{S} \alpha$ men glatt. $\odot$. Feuchte Stellen der Gebiische und Wälder, schattige, steinige Orte, alte Mauern nicht selten z. B. an Felsen in Giebichenstein, im Sebener Busche, im Wörmlitzer Hölzchen u. s. w. Juni-Herbst. Blume rosenroth, mit 3 weisslichen Streifen, grösser als

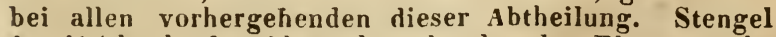
1-1 1/2' hoch, fast blutroth und nebst den Blättern sehr widerlich riechend.

89. Eródium L'T erit. ReiherschnabeI (von ẻpwơiós, Reiher).

231. F. cicutárium L'Ferit., schierlingsblätteriger $R$. Abb. 4864. Stengel niederliegend, vom Grunde an ästig, nebst den Blatt. und Blüthen- 
stielen rauhbarig; Blätter gefiedert, mit tief-eingeschnitten - fiederspaltigen Blättchen; die 5 fruchtbaren Staubgefässe an Grunde verhreitert, ohne Zühnchen; Blüthenstiele vielblüthig; Blumfublättel ungleich. $\odot$. Bebauter Boden, Aecher, sandige Stellen, 'Iriften iiberall gemein. April - Merbst. Geranium cicutarium L. Blume purpurroth; Stengel $1 / 2-1$ ' lang. Aendert ab:

a) immaculatum Koch. Blunen ungefleckt.

b) maculatum Koch. Die 2 grösseren Blumenblätter an Grunde mit einen gelblichen, dicht schwarz-punktirten Flecke versehen.

XXIII. Fanilie. Balsamineen A. Richard. Bals am in en $\underline{\text { e wäch se. }}$.

90. Emmátedens. Springkraut (von impatiens, ungeduldig, weil die Kapsel zur Fruchtzeit bei leiser Berührungr aufspringt).

232. I. Nohi tángere L., gemeines $S p$. Sturm Ileft 5. Stengel sattig, durchscheinend, an den Gelenken angeschwollen; Blätter gestielt, eiförmig, grob-gezähnt; Blüthenstiele 3-4blüthig, kürzer als das Blatt; Blüthen hängend. Sporn an der Spitze zuruckgebogen. $\odot$. Feuchte Waldstellen, schattige Quellen und Grüben zerstreut; feuchte Abhänge zwischen Schkeuditz und Wehlitz, Weidengebusch an der Saale hei Naumburg sehr selten, häufig in Gräben in der Gottsche zwischen Paupitzsch und Niemegk, quellige Abhänge des Mul. denthales zwischen Rösa und Pouch östlich von Bitterfeld und im Bruche zwischen Sandersdorf und Bitterfeld, bei Dessau häıfig, bei Oranienbaum im Nichrim. Juli. Aug. Blume citronengelb, inwendig roth - punktirt. Höhe 1-2'.

\section{Familie. Oxalideen DC. Sauer- kle gewächse.}

91. Ǵxฉ̆liss L. Sauerklee (von ợv́s, sauer, und ċis, Salz, weil Sauerkleesalz daraus bereitet wird).

233. D. Acetosélla L., ge en e in er S. Abb. 4898. Wurzelstock kriechend, gezähnt; Stcngel fehlend; Blätter 3zählig, mit verkehrt.herzförmigen, feinbehaarten

Blätt- 
Blättchen; Blïthenstiele 1blüthig, länger als die Blätter, ïber der Mitte mit 2 Deckblättchen; Blumenblätter länglich-verkehrt-eiförnig, schwach-ausgerandet. 4. schattige, feuchte Laubwälder; fehlt bei Halle und Merseburg, hïufig im Walde zwischen Leislingen und Schönbury, im Kroppenthale zwischen Schönburg und Wptau, Wälder bei Judersleben, Ziegelrode, Allstedt und Eisleben nicht selten, quellige Abhänge des Muldenthales $z$ wischen Rösa und Pouch östlich ron Bitterfeld häufig. April. Mai. Blume weiss oder röthlich weiss, mit purpurrothen Adern und einem gelben Flecke am Grunde. Höhe 3-6". Die Blumenklone ist meist 4 mal länger als der Kelrh, die inneren staubgefüsse 2 mal so lang als der Kelch. Aendert ab:

b) parviflora $\mathrm{L}$, ej. Blumenkrone nur doppelt so lang als der Kelch, 5 Stanbgefüsse von der Länge des Kelches, die iibrigen 5 ganz rerkümmert. OFF. IIb. Acetusellate s. Lugulae.

234. O. stricta L., ste ifer S. Abb. 4895. Wurzel Ausliufer treibend; Stengel cinzelı, aufrecht, sparsam. feinbehart; Blätter 3zählig, mit verkehrtherzförmigen Blättchen; Blattsticle am Grunde ohne Nebenbliitter; Blïthenstiele $2-5$ blüthig, ungeführ so lang als das Blatt; fruchttragende Bliithenstielchen aufrecht-abstehend. $\odot$, die lVurzelläufer $\odot$. Bebauter Boden, IIiesen, Schutt häufig z. B. Wiesen zwischen Dölau und der Heide u. s. w. Juni-Octob. Blume gelb. Höhe $1 / 2-1^{\prime}$. O. corniculata St. Hierher gehört auch 0 . corniculata bei Leyss. ed. 2. p. 111.

235. O. corniculata L., gehörnter S. Abb. 4896. Hurzel ohne, Ausläufer; Stengel mehre, ausgebreitet, an Grunde wurzelud, weichhaarig; Blätter 3zählig, mit verkehrt-herzförmigen Blättchell; Blattstiele am Grunde mit 2 kleinen, aneervachsenen Nebenblättern beset $=t$; Blïthenstiele $2-5$ bliithig, kürzer als das Blatt, fruchttragende Blïthenstielchen zurückgeschlagen. $\odot$. Fetter, bebauter Boren, Schutthanfen; im Gebiete sehr selten und gewöhnlich unbeständig, so an Wegen und auf Srhutt bei Naumburg, häufiger in Gärten auf fettem Boden. Juni-Octob. Blume gelb. Stengel $1 / 4$ - 1' lang.

Diese Pflanze hann kaum als einheimisch betrach. tet werden, wie dies spreng. hal. ed. 1. p. 138 schon richtig erkannte.

Garcke, Flora. 


\section{Familie. Rutaceen Juss. Ranten- ge wächse.}

A. Wahre Rutaceen. Die Innenhaut der Kapsel trennt sich nicht vom Fleische.

92. Ruta I. Rate (die Abstamnung ist zweifelhaft).

236. R. gravéolens $L$. var. $\jmath^{\prime}$, gemeine $R$. Abb. 4814. Stengel aufrecht, einfach oiler oberwarts ästig; Blätter gestielt, doppelt oder fast 3 fach-gefiedert, in Unrisse fast 3eckig. mit verkehrt-eiförmigen Blättchen; Blumenblätter ganzrandig oder wenig gezähnelt, plötzlich in den Nagel vorgezogen; Lappen der Kapsel stumpf. 2. Steinige Hügel, Weinberge sehr selten, aber unstreitig einheimisch; nur an den Marienbergen bei Freiburg selten, häufiger über den Weinbergen in der Nähe von Wilsdurf, auf Saudsteinfelsen unterhalb der Weinberge bei Gross Jena. Juni-Aug. Blume gelb. Höhe $1-1 \frac{1}{2}$. OFF. Herba Rutae.

B. Diosmeen Adr. Juss. Fächerhaut der Kapsel elastisch abspringend.

93. Dictámnus T. Diptam (von Dicte, einen Berge auf Kreta, wo Origanum Dictamnus wuchs).

237. D. Fraxinélla Pers., eschenblätteriger D. Abb. 4819. Wurzelstock holzig. Weiss; Stengel aufrecht; Blätter unpaarig-gefiedert, mit eiförmigen oder lanzettlichen, am Kande feingesägten, unterseits durchscheinend-punktirten Blättchen; Blüthen in verlängerter Kispe, drüsig. 24. Bewachsene, sunnige Kalkfelsen, Wälderzerstreut; bei Halle sehr häufig z. B. Heide, Lindberg, Frenzelhulz bei Lieskau, Mittelhulz u. s. w., fehlt bei Merseburg und Weissenfels; an Pfortenberge bei Naumburg, Berge bei Bibra, beiAllstert $z$. B. im Raths. holze in der Nähe der Pulvertannen, bei Sandersleben, fehlt in östlichen und nordöstlichen Gebiete. Mai. Juni. Dictamnus albus L. Blume röthlich-weiss mit purpurrothen Adern. Höhe 2-3'. OFF. Kad. Dictamni albi. - Der ätherisch-ölichte Duft soll sich Nachts bei Annäherung einer Flamme entzünden.

II. Unterclasse. Calycifloren. Kel ch blü thig e.

Kelchblätter sind mehr oder weniger unter sich ver. 
wachsen und Blumenblätter und Staubgefässe einer dem Kelchgrunde angewachsenen Scheibe eingefügt, oder der an den Fruchtknoten angewachsene Kelch trägt die Blumenblätter und Staubgefässe oder die einblätterige Blumenkrone.

\section{Familie. Celastrineen R. B r. Ce- lastergewächse.}

94. Wvónymus I. P faffen käppehen (von $\varepsilon v^{3}$,

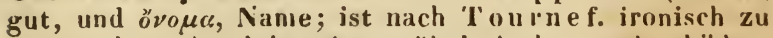
verstehen, da einige Arten übel riechen und schädlich sind).

238. E. europaeus L., e u $r$ op ä is ches $P$ f., $S$ p in de lbaum. Abb. 5134. Aeste 4kantig, glatt; Blätter länglich oder elliptisch-lanzettlich, fein-gesägt, kahl: Blumenblätter länglich; Kapseln meist 4lappig, stumpfkantig, glatt, ungeflügelt; der Mantel den ganzen Samen einhüllend. Ђ. Waldıänder, Gebüsche, Hecken häufig z. B. Gebüsche an der Saale hinter Kröllwitz häufirg, Gebiische zivischen Osendorf und Radewell u. s. w. Mai. Juni. Blume grünich-weiss; Kapseln rosenroth; Samennantel safrangelb; Samen weiss. Strauch von $6-10^{\prime}$ I Öhe.

XXVII. Familic. Rhamneen R. B r. Kreuzdorngewächse.

95. Thannuars L. Kreuzdorn (aus dem celtischen Worte ram, ästiger Busch, gebildet).

239. R. cathartica $L$, g e m e iner K. Flor. v. Thüring. II, 24. Zuveiळe glatt oder weichhaarig, dornig; Dornen end- und gabelständig; Blätter rundlich-eiförmig, fein gesiigt, an Grunde fast herzförmig; blattstiele $2-3$ mal so lang als die abfallenden Nebenblätter; Blüthen unvollständig-2häusig, die männlichen nit verkümmerten Fruchtknoten, die weiblichen mit verkümmerten Staubgefässen; Steinfrucht 4 kernig, auf dem napförmigen Kelche sitzend, schwarz. ћ. Laubwälder, Gebüsche, Zäune hüufig z. B. Gebüsche an der Saale zwischen Kı̈llwitz und Lettin. Mai. Juni. Blume grün. Ein 6-8' hoher Strauch. OFF. Baccae Spinae cervinae.

240. R. Frángula L., Faul ba um, auch Pulverh o lz genannt. Ha y n Arzng. V, 44. Zweige unbedornt; 
Blätter elliptisch, zugespitzt, granzrandig; Blüthen zwitterig, 5männig; Blüthenstiple und Kelch kahl oder angedrückt-weichhaarig; Narbe ungetheilt. t. Wälder, Gebüsche, besonders an feuchten Stellen häufig z. P. in der Heide. Mai. Juni. Frangula vulgaris Kchb. Blume grünlich - weiss. Fricht zuerst roth, dann schwarz. Ein 6-8' hoher Strauch. OFF. Cortex et baccae Frangulae s. Alni nigrae. - Das Hulz liefert eine zur Bereitung des Schî̉esspulver's geschätzte Kohle.

\section{Familie. Papilionaceen I. Schmetterlingsblü hler.}

1. Gruppe. Loteen DC. Il ornkleegewächse. Hülse Ifächerig, oder mit Einwärtsbiegung einer der Nähte 2fächerig. Keimblatt ziemlich flach, uber die Erde hervortretend.

1. Unteruprup. Genisteen. dinstergewatise. Staubgefasse Ibrïderig. I lägel der Blumenhrone am uberen Rande faltig - runzeliy.

96. Ulex L. Gaspeldoin, Heckensame.

241. U. europaeus L., europäischer G. Aufrecht, ästig; Blätter linealisch, in eine stechende Stachelspitze zugespitzt, die bliithenständigen sol lang als der Blüthenstiel, die unter dem kielche befindlichen Deckblättchen viel breitel" als der Bliithenstiel; Blüthen in werigbliithigen Trauben, Kelch und die 4-5samige Hülse zottig. †. Sandige, unfruchtbare Heiden sehr selten, nur bei Dessau in der Mosigkaner Heide in der Nähe des Scharewaldschen Thurhauses, aber dort häı. fig; von $S \mathrm{chw}$ a b e zuerst gefunden. Mai. Juni. Blume gelb. Ein $3-5^{\prime}$ hoher Strauch.

97. Sarothémuns vV i m mero. P f r i e m e n (von Ga@oss, Besen, und $\vartheta$ áuvos. Strauch, wegen des Gebrauchs zu Besen).

242. s. vulgaris wimm., ge me in e Pf. Hayne Arzneigew. IX, 10. Stengel anfrecht, nebst den grïnen, ruthenförmigen Aesten scharfkantig; Blätter 3 zählig oder einfach, mit verkehrt-eiförmigen, weichbehaarten Blättchen; Blüthen blattwinkelständig; Hülsen zusammengedrückt, an beiden Nähten zottig-gewimpert. Ђ. Lichte Wälder, Waldränder, besonders auf Heide. ind Sandboden zerstreut; bei Halle nicht selten 7. B. in der ILeide besonders zwischen Dölau nnd Lieskau; 
fehlt bei Merseburg; bei Weissenfels und Naumburg sehr selten, wohl nur zwischen Gosek und Eulau am Rande der'Tannen; sandige Wälder bei Dessau häufig. Mai. Juni. Spartium scoparium L. Blume gross, gelb. Höhe 2-4'.

98. Gúcuista I. Ginst oder Ginster (vom celtischen Worte gen, kleiner Busch).

243. C. pilosa L., beha harter G. Stengel niederliegend oder aufstrebend, gefurcht, höckerig, dornenlos; Blätter länglich-lanzettlich, unterseits nebst den Aesten, Blüthenstielen, Kelchen, der Fahne, Hiilse und dem Schiffchen scidenharris; Bliithenstiele scitcnstïndig, rinzeln oder mehre vun einem Blätterbiischel ungeben, so lang als der Kelch. $\hbar$. Dürrer Heideboden seh. zerstreut; bei Halle häufig z. B. zwischen Kröllwitz und den Donnersherge, unfruchthare Hügel vor der Heide u. s. w., bei Dessau und Oranienbaum häufig. Mai. Juni. Blume gelh. Iöhe $4-8$ ".

244. G. tinctória L., F är b e r - G. Stengel aufrecht, tiefgefurcht, dornenlos, kahl, uberwärts weichhaarig; Blätter länglich oder elliptisch, am Rande weichhaarig; Nebenblätter pfriemlich, sehr klein; Blüthen in endständigen Trauben; Blmmenkrone und Hiilsen Kahl; Schiffchen so lang als die Fahne. h. Trockene Wiesen, Triften, Wälder häufig z. B. Heide, Mittelholz u. s. w. Jun. Jul. Blume gelb. Höhe $1-2$ '.

245. A. germanica L., deutscher G. Sturm Heft 12. Stengcl dornig, unterwärts blattlos, oberwärts istig; Aestchen beblättert, zottig, blïthentragende dornenlos; Rlätter lanzettlich oder elliptisch, weichhaarig; Blüthen in endständigen Trauben; Blumenkrone kahl; Schiffchen mit behaartem Kiele, länger als die Fahne; Hiilsen behaart. ち. Trockene Wälder nicht so häufig als die vorhergehende Art; in der Heide selten, häufiger in Mittelholze, Bergholze, Bienitz, Wälder bei Freiburg, Katharinenholz bei Eisleben, bej Allstedt. Mai. Juni. Blume gelb. Höhe 1-2'.

90. Cýtisus I. Geisskle e (die Abstammung ist zweifelhaft).

246. C. sagittalis Koch, geflügelter G. Stengel niederliegend, gegliedert, breit geflügelt; Aeste aufsteigend; Blätter einfach, eilanzettlich, behaart; Blüthen in endständigen, kopfförnigen Trauben; Fahne 
kahl, wenig länger als die Flïgel und das Schiffchen: Hülsen behaart. \%. Nadelwälder sehr selten, nur in der Mosigkauer Heide und bei Dessan, aher laselbst häıfig. Mai. Juni. Genista sagittalis J. Blume gelb. Höhe der Aeste $1 / 2-3 / t^{\prime}$.

2. Untergruppe. Anthyllideen. Wundkleegewächse. Stauhgefasse lhrüderig; die Flïgel der Blumenikrone nichit runzelig-gefaltet.

100. Dnónis X. Hauhechel (von ǒvos, Esel, als dessen Futter).

247. O. spinosa L., dornige H. Sturm Heft 72. Stengel aufrecht oder aufstrebend, von 1-2reihigen Haaren zottig und zerstrent-driisenharig; Aeste dornig, Dornen meist zu 2; Blätter einfach vder 3zählig, mit länglichen odler eiförmig-länglichen, gezähnelten, ziemlich kahlen Blättchen; Bluthen einzeln, blattwin. kelständig; Blïthenstiele kürzel als del Kelch; Hiilscn ciförmig, aufrecht, so lang oder liinger als der Kelch; Samen höckerig-rauh. 24. Wege, sandige Triften, unbebaute Felder gemein. Juni. Juli. Blume rosenroth. Höhe $1-2^{\prime}$.

248. O. repens L., $k r$ iechende H. Sturm Heft 72. Stengel liegend, am Grunde wurzelnd. ringsum zuttig, mit aufstrebenden meist in einen Dorn auslau. fenden Aesten; Blätter meist einfach. mit eiförmigen, drïsig-behaarten, gezähnelten Blättchen; Bliithen einzeln, blattwinkelständig; Blïthenstiele kürzer als der Kelch; Hiilsen eiförmig, aufrecht, kürzer als der Kelch; Samen dicht höckerig-rauh. 24. Sandige Triften, trok. kene Wiesen, Wege verbreitet, obwohl etwas seltenel als vorige z. B. zwischen Dölau und Lieskaı. sandige Triften bei Nietleben u. s. w. Juni. Juli. O. procurrens Wallr. O. hircina Sp r. hal. ed. 1. p. 202. Blume rosenroth. Stengel $1-2$ ' lang. Aendert ab:

b) mitis Gmel., ganz durnenlos.

101. Anitiýllia K. Wundkle (Pflanzenname bei Dioscorides ( $\left.\dot{\nu} \vartheta \dot{v} \lambda \lambda_{\iota} \nu \nu\right)$, aus $\ddot{\varkappa} \nu \vartheta \varsigma \varsigma$, Blume, gebildet).

249. A. Vulnerária L., gemeiner W. Sturm. Heft 49. Stengel mehre, liegend oder aufsteigend; unterste Blätter langgestielt, länglich-eiförmig, einfach "der am Blattstiele noch eiı Paar Seitenblätchen. Stengelblätter dentlich gefiedert; Blüthen in einem endständigen, kugeligen Köjfchen mit fingerig - getheilten Deck- 
blättern; Kelch bauchig, behaart, Kelchzähne viel kürzer als die Röhre; Fahne halb so lang als ihr Nagel. 4. Trockene Wiesen, Triften, Grasplätze häufig z. B. anı Donnersberge hinter Kröllwitz, an Rande des Mittelholzes, Wiesen zwischen Göhren und Rodden und bei KI. Dölzig und sunst verbreitet. Mai. Juni. Blume gelb. Stengel $1 / 2-1$ ' langr.

3. Untergruppe. Trifolieen. Kleegewa chse. Staubgefisse 2hrülterig; Blatter 3zählig; Hülse Ifacherig.

102. Mealicáğ L. S chneckenklee.

a. Hülsen welırlos.

250. M. sativa L., Luz e rne. Flora v. Thüring. II. 20. Stengel aufrecht, üstig; Blättchen ansgerandet, stachelspitzig, an der Spitze gezühnt, lie der unteren Blätter länglich-verkehrt-eiförnig, die der wberen li. nealisch-keilig; Nebenblätter ei-lanzettlich, pfriemlich. zugespitzt, die unteren gezähnt; Trauben reichblüthig, länglich; Hiilsen wehrlos, schncckenförmign-gewuunden, mit 2 - 3 Windungen, im Mittelpunkte offen, schwach. netzig-aderig, anoedriickt-weichhaarig. 24. Wird in Grossen gebaut unil verwildert oft an Grasplätzen und Ackerrändern. Juni - Sept. Blıme bläulich oder vio. lett. Höhe $1-2$ '.

251. M. falcata L., sich e Iförmiger S ch. Sten. gel niederliegend uder aufsteigend, ästig; Blättchen stachelspitzig, an der Spitze gezähnt, die der unteren Blätter länglich-, die der oberen linealisch-keilig; Nebenblätter ei-lanzettlich, pfriemlich-zugespitzt, die unteren gezähnt; Trauben reichblüthig, liurz, oft fast kugelförmig; Hiilsen wchrlos, sichelförmig-gebogen oder mit einer einzigen Windung, netzig-aderig, ab. stehend. oder driisig-behart. 24. Trockene Wiesen und Grasplätze, Raine nicht selten z. B. an Felsen zwischen Giebichenstein und Trotha. bei Röglitz, auf Grasplätzen an der Saale zwischen Merseburg und Menschau und sonst häufig. Juni-Sept. Blume gelb. Höhe 1-11/.'. Aendert ab :

b) media Pers. Blume anfangs gelb, dann grasgrïn, zuletzt bläulich oder violett.

Ob M. sativa und falcata wirklich zwei gute Arten sind, müssen weitere Beobachtungen lehren.

252. M. Iupulina L., Hop fen-S ch. Stengel ausgebreitet, mehr oder weniger behart; Blätchen verkehrt-eiförmig, schwach ausgerandet, so lang oder 
länger als die Blïthenstiele; Nebenblätter eiförnig, zugespitzt, meist ganzrindig; Aehren reichbliithig, nedrungen; Hiilsen wehrlos, nievenförmig, ptwas gedunsen, die hurze spitze gewunden, im Mittelpunkte ge. schlossen, der Länge nach brigenförmig-aderig, kahl oder angedrückt-weichhaarig. $\odot$. Wiesen, Feller, 'Triften, Wegränder ïberall in Menge. Blume gelb. Stengel $1 / 2-1$ ' lang. Aendert $a b$ :

b) Willdenowii Bönningh. Hülsen mit geglie. derten, abstehenten Drüsenharen besetzt.

\section{h. Hülsen dornig.}

253. M. minima L., kleinster S ch. Stengel nie. derliegend oder aufsteigend, 4 kantig nebst den Blättchen. Blatt- und Blüthenstielen weichhaarig; Blättchen verkehrt-eiförnig, vorne gezühnelt, so lang oder kïrzer als die 1-2blüthigen Bliithenstiele; Nebenbliitter lanzettlich - lïnglich oder eiförmig, zugespitzt, am Grunde kurz-gezihneli, die oberen fast ganzrandig; Hiilsen dornig, schneckenförmig, fast kugelförnig, mit 5 lockeren, aderlosen Windungen, der Rand 2zeilig-dornentragend, Dornen abstehend, pfriemlich, an der Spitze hakenförmig, auf beiden Seiten durch eine Furche ausgehöhlt. $\odot$. Sandfelder, trockene Hïgel zerstreut; bei Halle häufig z. B. an Galgenberge, am Felsen zwisrhen Kröllwitz und der Kreuzschäferei sehr häufig; am uberen Rande von Rauschen's Hölzchen bei Merseburg, unbebaute Hügel bei Keuschberg; bei Naunburg verbreitet z. B. an kiesigen Hügeln bei Grochlitz, vor den Georgenthore und an Rande des Möllerschen Berges an der Saalseite; bei Sandersleben und Bernburg. Mai. Juni. M. polymorpha $\mu$. minima I. Blume gelb. Stenyel $1 / 2-3 / 4$ ' lang. Aendert ab:

b) mollissima Spreng. Stengel und Blätter von driisenlosen Haaren grauzuttig. M. graeca Hor. ne 11 , so an dem Weinhergshäuschen bei Röglitz.

254. II denticulate Willd., gezähnter Sch. Stengel niederliegend, efurcht - 4 kantig, nebst den Blättchen, Blatt. und Blüthenstielen kahl; Blättchen verkehrt - eiförnig, stunıf - gezähnelt, nngefähr so lang als die 4- bblïthigen Blïthenstiele; Nebenblütter mit zahlreichen, pfriemlich-borstenförmigen Zïhnen, fast fiederspaltig; Hïlsen dornig, schneckenförmig, mit 2 bis 4 Windungen, auf der Oberflïche netzförmig; der Rand 2zeilig - dornentragend, Dornen auseinanderfahrend, pfriemlich, an der Spitze hakenförmig, halb so 
lang als der Durchmesser der Hülse, anf beiden Seiten pingedrücht. $\odot$. Bebauter Boden unter dem Getreide selten; bei Halie sehr verbreitet $z$. B. Ackerraine unter der Irrenanstalt, Iecker an der Nietleber Windmühle, Aecher zwischen dem Galgenherge und der Magdeburger Chaussee, an der Götsche zwischen Trotha und der Lerche, zwischen Corbetha und der Verseburger Chaussee, zuischen Collenbey und Meuschau; bei Naumburg zerstreut z. K. auf den Spechtsar, häufiger auf Aeckerı zwischen der Weichau unil der Schönburg; scheint ausserdem in Gebiete zu fehlen. Mai. Juni. Blume gelb. Stengel $1 / 2-1 \frac{1}{2}$ ' lang.

Diese hier beschriebene Art ist keineswegs M. apiculata Willd., wie WaIIr. meint.

103. Troigonélla L. B o ckshorn (von togis, drei, und yevis, Winkel, wegen des Ireieckigen dussehens der Blume).

255. T. Foenum graecum L., Bockshorn, griechisches Heu Hayne Arzmeig. VII, 4l. Stengel aufrecht, wenig ästig; Blättchen länglich-keilförmig, vorne gezähnelt; Bliithen pinzeln oder zu zweien in den Blattwinkeln sitzend; Hülsen linealisch, etwas sichelförnig, längsaderig - gestreift, durch den verschnälerten Griffel geschnäbelt. $\odot$. Wird in Grossen gebaut, ohwohl im Gebiete nicht häufirg. Mai. Juni. Blume gellhlich - weiss. Höhe $1-1 \frac{1}{2}{ }^{\prime}$. OFF. Sem. Foeni graeci.

104. Melilótus To urmef. In m. St e inklet (von $\mu \dot{\varepsilon} \lambda_{\iota}$, Honig, und $\lambda \omega \tau o ́ s$, Lotus, wegell des Huniggehaltes der Blımen).

256. .r. dentata Pexs., g g z zähnter St. Sturm Heft 15. Stengel meist aufsteigend; Blättchen länglichlanzettlich, stumpf, nit ungleichen, kurz-stachelspitzigen Sägezähnen; Nebenbliitter aus verbreitertem, eingeschnitten-gezähntem Grunde pfriemlich; 'Trauben gedrungen, zuletzt verlängert: Blüthenstielchen halb so lang als der Kelch; Flüge! kürzer als die Fahne, länger als das Schiffchen; Hiilsen eiförmig, netzförmig-runzelig, an der Naht zusanınıngedrückt, kahl. (.). Salzhaltige Wiesen, feuchte Gräben, Wegränder stellenweise; einzeln im Chausseegraben an Krukenberg's Garten, bei Nietleben und auf Wiesen hinter Pfitzenburg, hänfig auf Salzwiesen bei Dieskau, sehr hänfig auf Wiesen am salzigen See zwischen Wansleben, Amsdorf bis 
Ober-Röblingen, ebenso zwischen Kölme und Langen. bogen; an Gräben und anf Wiesen un die Saline von Kötschau; fehlt bei Weissenfels, Naumburg und Freiburg; häufig auf der Grenze des Gebiets an der Saline bei Artern; bei Eisleben zwischen dem Wiesenhause und Oberriesdorf, an den Seelöchern bei '/abenstedt unweit Gerbstedt, bei Aschersleben, Stassfurt und Leau; fehlt in ganzen nordöstlichen Gebiete. Juli - Sept. Trifolium dentatum W. K. T. Kochianum H a y ne. Blume citronengelb. Hülsen schwarz. Höhe $1 / 2-1 \frac{1}{2} 2^{\prime}$.

257. M. macrorriza Pers., langwurzeliger St. Stengcl aufrecht; Blättchen geschäift-gesägt, etwas gestutzt, an den unteren Blättern verkehrt-eiförmig, an den oberen länglich-linealisch; Nebenblïtter pfriemlich-borstenförmig, ganzrandig; Trauben riem. lich lucker, zuletzt verlängert; Bluthenstielchen halb so lang als der Kelch; Flügel und das Schiffchen so lang als die Fahne; Hiilsen eiförmig, kurz-zugespitzt, netzförmig-runzelig, an der Naht zusammengedrückt, kurz-weichhaarig. $\odot$. Ufer, Gräben, Wiesen, Wei. dengebiische nicht gar selten, abel lange übersehen. Hospitalgarten, Gebiische am Schwalchloche und beson. ders häufig an der Saale zwischen dem Schwalchloche und Iettin, feuchte Wiesen bei Passendorf, Rabenirsel, Wiesenränder zwischen Merseburg und Meuschau, Wiese dicht bei Zöschen nach Göhren zu; häufig in Weidengebüsch an der Saale zwischen Rossbach und der Gruss Jenaer Fähe, in Weinbergen zwischen Russbach und Kl. Jena, Waldränder bei Lodersleben, bei Rathmannsdorf unweit Giisten, hei Delitzsch. Juli - Sept. M. officinalis $\mathbf{W}$ illd. 'Trif. Melilotus officinalis $\gamma$. L. Blume sattgelb, Fahne nit einigen feinen, braunen Streifen. Hülsen schwarz. Höhe 3-4'. OFF. Summitates Meliloti. Aendert ab:

b) palustris W. K. Blättchen mit sehr kleinen, kurzen Zähnen, die obersten fast ganzrandig; die Streifen der Fahne kaum bemerkbar.

258. M. officinalis Desr., gebräuchlicher St. Sturm Heft 15. Stengel niederliegend oder anfstejgend; Blättchen gesägt, stumpf, an den unteren Blättern verkehrt-eiförnıig, an den oberen lanzettlich; Neben. blätter pfriemlich-borstenfürmig, ganzrandig; Trauben locker, verlängert; Blüthenstielchen kürzer als der Kelch; Fliigel so lang als die Fahne, länger als das Schiffehen; Hülsen eiförnig, stumpf, stachclspitzig, querrunzclig- 
faltig, etwas netzförnig, an der Naht stumpf-gekielt, kahl. (.) Wege, Raine, Ackerrinder, trockene Wiesen nicht selten, obgleich einzelner als vorige Art $z$. B. zwischen Halle und Nietleben, bei Röglitz, Schkeuditz, sehr häufig bei Naumburg u.s. w. Juli-Sept. M. officinalis Desf. M. Petitpierreana $\mathrm{Rch}$ b. M. arvensis Wa $11 \mathrm{r}$. Trifolium Melilotus officinalis var. c. L. Blume blassgelb, selten weiss. Hülsen hellbraun.' Höhe 1-2'. UFF. Summitates Meliloti.

Spreng. hat diese Pflanze ganz unerwähnt gelas. sen, was un so auffallender ist, da sie schon von W allr. sched. p. 391 unter dem Namen M. arvensis W allr. mit wuter Diagnose und Beschreibung angegebeu wird. Von Spreng. scheint zwischen dieser und der vurigen Art kein Unterschied gemacht zu sein, da die nicht genaue Diagnose mehr auf M. macrorrhiza Pers. passt, während die Angabe des Vorkommens (inter segetes) sich nur auf M. ofticinalis Desr. beziehen kann.

259. M. alba Desr., we isser St. Flora v. Thüring. II, 16. StengPl aufrecht; Blättchen gezähnt, stumpf, an den unteren Blättern verkehrt-eiförmig, an den oberen länglich-lanzettlich; Nebenblätter pfriemlich-borstenförmig, ganzrandig; 'Trauben locker, zuletzt verlängert; Blüthenstielchen halb so lang als der Kelch; Fliigel su lang als das Sohiflchen, kürzer als die Fahue; IIiilsen eiförmig, stumpf, stachelspitzig, netzförmig runzelig, an der Naht stumpf-gekielt, kahl. (.). Wege, Raine, Mallern nicht selten. Acherränder zwischen Halle und Nietleben, in der Nähe der 'T'eiche bei Dieskau, hänfig an der saale hinter Kröllwitz, besunders nach Lettin zu und am Chausseegraben zwischen Langenbogen und Rollsilorf Juli - Sept. M. vulgaris Will Tr. Trifolium Melilotus officinalis \&. L. Blume weiss. Hülsen schwarzbraun. Höhe $1-4^{\prime}$.

105. Trifóliunan K. Kle e (von tres, drei, und folium, Blatt, wegen der dreitheiligen Blätter).

A. Die einzelnen Blïthen sitzend, in ein rundliches oder längliches Köpfchen zusammengestellt.

a. Kelchschlund inwendig mit einer schwieligen Linie oder einem Haarkranze hesetzt.

1. Kelchröhre weichharigoder zottig.

260. T. pratense L., Wi esen-K. Sturm Heft 15. Stengel aufsteigend; Blättchen eiförmig, an den oberen 
Blättern elliptisch oder länglich, fast ganzrandig, etwas weichhaarig; Nebenbliitter eifürmig, plötzlich in cine Granne ïbcrgehend; Köpfchen lugelförnig, zuletzt eiförmig, meist zu zweien, am Grunde von Blïttern umhiillt; Kelch 10nevvio, weichhaarig, kïrzer als die Hälfte der Blumenkrone; Zühne fast fadenförmig, gewimpert, zur Fruchtzeit aufrecht, die 4 wberen so lang als ihre Röhre. (.). Wiesen und Grasplätze und ausserdem in Grossen gebaut, überall häıfig. Juni-Sept. Blume purpurroth, selten weiss. Höhe $1 / 2-11$. Aendert $a b$ :

b) hete rophyllum I, ej. Blättchen der Wurzelblïtter eingedrïckt, fast verkehrt.herzförmig. Ausserdeu wird die Pflanze durch Kultur auf fettem Boden grösser, ästiger, die Stengel bisweilen hohl und die Köpfchen erheben sich auf freien Stielen, das ist ' $\mathrm{T}$. sutirum $\mathrm{R} \mathrm{e} \mathrm{h}$.

261. T. alpestre L., Wald-K. Sturm Heft 15. Stengel aufrecht, einfich, behaart; Blätchen länglich. lanzettlich, schr fein-gezähnelt; Nebenblïtter lanzettlich-pfriemlich; Köpfchen kugelförmig, meist zu zweien, am Grunde von Bliitlern umhiillt; Kelch 20nervig, zottig; Zühne fadenförmig, gewimpert, zur Fruchtzeit aufrecht, die 4 oberen so lang oder kürzer als ihre Röhre, der unterste verlängert. 24. 'Trockene Wälder, Bergabhänge häufig z. B. in der Ileide, im Mittelholze u. s. w. Juni - Aıg. Blume purpurroth. Ilöhe $1 / 2-1$ '.

Obgleich diese Art sunst gewöhnlich mit zwei Köpf. chen gefunden wird, so erscheint sie doch im Gebiete, besonders in den Wäldern um Halle meist nur einköpfig.

262. T. arvense L., A cker-K. Sturm Heft 16. Stengel aufrecht, ästi chen linealisch-länglich, schr schwach-gezähnelt; $\mathrm{Ne}$ benblätter eiförmig-zugespitzt; Köpfchen einzeln, sehr zottig, zuletzt vailzenfürmig, am Grunde ohne Hiille; Kelch 10nervig, Zähne pfriemlich-borstenförmig, etwas abstehend, liinger als ihre Rühre und als die Blume. $\odot$. Aecker, besonders Sandfelder, dürre Hiigel überall gemein. Juli - Sept. Blume weisslich, danu fleischfarben. Höhe $1 / 4-11$. Aendert ab:

b) Brittingeri Weitenweber. Stengel schlanker mit weniger abstehenden Aesten; untere Nebenblätter schmäler mit längerer, pfriemlicher Spitze; Kelchzähne $1 / 3$ länger.

263. T. striātum L., g estreifter K. Sturm Heft 
16. Stengel aufrecht, meist ästig, nebst den Blättern und Kelchen zottig; Blättchen an der Spitze kleingesägt, verkehrt-eiförmig, an den unteren Blättern velkehrt-herzförmig; Nebenbläiter eifürmig, haarspitzig : Köpfchen eiförmig, zuletzt fast walzenförmig, am Grunde umhiillt; Kelchzähne lanzettlich-pfriemlich, stachelspitzig, abstehend, gerade, Kelchröhre zur Fruchtzeit bauchig-aufgeblasen. $\odot$. Trockene, sonnige Hügel. Bei Halle sehr häufig z. B. Galgenberg, Felsen unmittelbar hinter Kröllwitz, Felsen zwischen Kröllwitz und der Kreuzschäferei, sparsamer an Rainen zwischen der lirenanstalt und der Heide und an Bergen bei Granau; häufig an eimem Abhange an der Reide bei Osendorf und auf Wiesen bei Burgliebenau nach Collenbey hin, bei Diirrenberge, bei Eisleben im Katharinenholze am Wege nach Kreisfeld, bei Aschersleben und Sandersleben, sparsam an Abhängen des Muldenthales zwischen Punch und Bitterfeld. Juni. Juli. Blume rosenroth. Höhe $1 / 4-3 / 4$.

Trif. scabrum wird zuerst von Leyser hal. ed. 1. p. 138 an trockenen Stellen beim Weinberge in der Nähe von Giebichenstein als zerstrent vorkommend erwähnt, welcher jedoch ohne $Z$ weifel das bei ihm feh. lende ' $\boldsymbol{T}$. striatun gemeint hat. Anders verhält es sich mit Sprengel, welcher in beiden Auflagen T. scabrum an der von Leysser bezeichneten Stelle. wo sich jetzt das Bad Wittekind befindet, anführt und ausserdem nuch ' $T$ '. striatum an anderen und zwar zuverlässigen Standorten angibt. Der Verfasser hat an jentr Stelle weder T. scabrum, noch '1. striatum gefunden und glaubt den schon von Rchb. sax. $t$ d. 1. u. 2. p. 286 erhobenen Zweifel an der richtigen Bestimmung dieser Pflanze theilen zu dürfen.

2. Kelchröhrekahl.

264. T. medium L., mittle rer K. Sturn Heft 15. Stengel anfsteigend, ästig, meist hin und her gebogen; Blättchen elliptisch, sehr fein gezähnelt oder fast ganzrandig, oberseits kahl; Nohenhlätter lanzettlich, verschmälert; Köpfchen liugelfürmig, einzeln, am Grunde whne Hïlle; Kelch 10nervig, lahl, kïlzer als die Hälfte der Blumenkrone: 'Zähne fadenförmig, gewinuert, zur Fruchtzeit aufrecht, die 4 uberen so lang als ihre Röhre. 4. Wälder, Waldränder, truchene Wiesen. Bei Halle ziemlich sparsam, mur in der Abbatissine und in Berg. holze (frïher auch in Mittelholze), häufiger in der Bré- 
nau bei Wettin und auf den Auenwiesen zwischen Schkenditz nach Mudelwitz, an Bienitz, bei Naumburg und Freiburg in allen trockenen Wäldern, in Walde zwischen Memleben und Bibra, in Katharinenholze bei Eisleben; sparsam auf Wiesen zwischen Niemegk und Pouch östlich von Bitterfeld. Juni-Ang. 'T. flexuo. sum Jacq. Bhume purpurroth. Höhe $1-1 \frac{1}{2} \%$ 。

265. T. rubens L., rother K. Sturm Heft 15. Stengel aufrecht, einfach, kahl; Blättchen länglich-lanzettlich, mit kurz-stachelspitzigen Sägezähnen; Nebenblätter lanzettlich, zugespitzt, entfernt-kleingesägt; Köpfchen lïnglich-walzenförmig, meist zu zweien, am Grunde oft behüllt; Kelch 20nervig, kahl; Zähne pfriemlich, gewimpert, die 4 wheren 2 wder 3 mal kürzer als ihre Röhre, der unterste verlängert. 24. Gebirgswälder selten. Fehlt bei Halle und Nerseburg; bei Naumburg und Freiburg zwar verbreitet, aber meist nur einzeln vorkonmend, so in Mordthale und bei Russbach, bei Allstedt in den wïsten Bergen ziemlich häufig, im Hagen dagegen sehr sparsanı; im Katharinenhulze bei Eisleben links vom Wege nach Kreisfeld sparsam; im lan. gen Hulze zwischen Hettstedt und Sandersleben. Juni. Juli. Blume purpuroth. Höhe $1-2$ '.

Diese Pflanze wird zuerst von Ley's sel ed. 1. p. 137 erwähnt, worunter aber uustreitig das von ihm aus. gelassene, an den angefühten Standorten wachsende Trif. alpestre L. zu verstehen ist, wie auch aus der Diagnose selbst hervorgeht, da 'I'. rubens kahle, 'I'. alpestre aber $z$ ottige Kelche besitzt, welche I, eyss. füi seine Pflanze ausdrücklich angibt. Sprengel führt diese Pflanze hal. ed. 1. p. 208 whne $t$ an und fiigt zu dell schon von Leyss. angegebenen Standorte, den Mittelholze, noch zwei andere hinzu, nämlich Hornburg und den Langenberg bei Möncherode, so dass hiernach der Glaube Raum gewinnt, er habe die Pflanze selbst gefunden, obgleich er sie mit zottigen Kelchen beschreibt. In der 2. Aufl. p. 316 sagt er jedoch, dass unter ' $T$. rubens bei $I$, eys s. mu 'T. medium $z$ u verste. hen sei (hiergegen spricht aber die Beschreibung; denn I. medium hat kahle Kelche und aufsteigende, meist gebogene, nicht aufrechte Stengel, wir Leyss. ausdrücklich angibt) und dass er 'T. rubens nur anf Leys. ser's Autorität aufgenommen habe, "iewohl es von ihm nie gefunden sei. Sprengel hat also gegen den von ihm in der Vorrede zur ersten Auflage p. 5 ausge- 
sprochenen Grundsatz gehandelt, keine Pflanze aufzu. nehmen, welche er nicht selbst gefunden habe, oder die von zuverlässigen Freunden aufgefundenen wenigstens mit einem $†$ zu bezeichnen; ein fall, welcher leider einige Nale wiederkehrt.

h, Kelchschlund inwentig kilhl und atren; lä̈cken des Kelches mit den 2 oberen Zilhnen nach den Verhlïhen sehr vergrössert, aufgehlatsell, hautig, nit einem Adernetze geziert.

266. T. fragiferum L., Erdbeer-K. Stur m Heft 16. Stengel kricchend, kalıl; Blattchen elliptisch uder breit-verkehrt-eiförmig, mit stachelspitzigen Sägezähnen; Nebenblätter lanzettlich - pfriemlich; Köpfchen langgestielt, kugelförmig, am Grunde von einer vieltheiligen Hiille umgeben; Fruchticlch au/geblasen, häutig, net:aderig, behaart. 4. Finssufer, feuchte, besonders salzhaltige Wiesen häufig z. B. an der Saale bei Giebichenstein, an Wege von Wesmar nach Oberthan, am Bienitz, besonders auf Salzwiesen bei Kötschau, 'Teuditz, Dïrrenberge und an salzigen See zwischen Wansleben und Ober - Röblingen. Juni - Sept. Blume fleischroth. Stengel 3-6" lang.

B. Die einzelnen Blüthen länger vder kürzer gestielt. a. Kelchschlund inwendig kahl; Kelchzälne gleichlang oder die 2 ohereu länger.

267. T. montanum L., Berg-K. Sturm Heft 15. Stengel fast aufrecht, behaart; Blättchen länglich-lanzettlich, scharf - fein - gesägt, unterseits behaart, am Rande mit dichten, verdickten Adern; Nebenblätter eiförmig, zugespitzt; Köpfchen gestielt, kugelförnig, zuletzt eiförnig, am Grunde ohne Hülle; Blüthen kurzgestielt, nach dem Verblühen herabgebogen; Kelch halb so lang als die Blume, etwas zottig, Zähne fast gleichlang, lanzettlich - pfrienılich, gerade. 24. Trockene Wiesen, Triften und Wälder häufig. Mai-Juli. Blume weiss. Höhe $1 / 2-1^{\prime}$.

268. T. parvifōrum Ehrh., kle in blïth iger $K$. Sturm Heft 15. Stengel meist ansgebreitet - ästig; Blättchen scharf-gesägt, an Rande nit etwas verdickten Adern, die untersten verkehrt-eiförmig, die oberen lanzettlich; Nebenblätter häutig, eiförmig, haarspitzig; Köpfchen meist kurz-gestielt, kugelförmig, am Grunde whe Hülle; Blïthen sehr kurz-gestielt, nach dem Verblühen herabgebogen; Kelch ein wenig länger als die Blume, schwach-behart, gestreift, zur Fruchtzeit 
auf der immeren Seite lis auf den Grund gespa ten; Zäh. ne lanzettliph, aufw ïrts gehogen, die 2 oberen länger. $\odot$. Summge Felsen und schwach begraste llïgel schi selten; nur bei Ilalle: Galgenberg, Felsen bei lírölwitz, an der Bergschenke bis nach der Kreuzschäferei hin, an Wege zwischen del Irrenanstalt und der Heide. Nai. 'I. strictum S c hre b. Blume weiss. Stengel 1-4". Wallroth erwähnt ann. bot. p. 90, dass er diese Pflanze auch bei Granau in Huhlwege rechts vom Nietleber Gottesacker jährlich sehr häufig gefunden habe, welchen Standort Spreng. hal. ed. 2. p. 315 und Koch synopsis p. 191 aufgenommen haben. Der Verfasser hat dort stets vergeblich gesucht und während er diese P'flanze in manchen Jahren in grosser Anzahl an den von ihm zum 'Theil zuerst aufgefumienen Standorten gesehen hat, fand er bei Granan auch nicht ein einziges Exemplar, obwohl er 'T. striatum, welches "lach Wallr. a. a. O. p. 91 ebendaselbst vorkommen soll. nicht vergeblich suchte.

269. T. repens L., kriechender K. Sturm lleft 15. Stengel niederliegend, wurzelnd; Blättchen keiligverkehrt-herzförmig, scharf-gesägt; Nebcnbliitler trokkenhäutig, breit-lanzettlich, plötzlich in eine Haarspitze übergehend; Köpfchen lang-gestielt, kngelförmig, am Grunde ohat Hiille; Blüthenstielchen nach dem Ver. blühen herabgehogen, die inneren so lang als die Kelch. röhre; Kelch halb so lang als dic Blume, kahl; Zühne lanzettlich, dip 2 oberen länger. 24. Wiesen, 'Triften, Raine, Wege iberall gemein und ausserdem oft im Grossen gebaut. Mai-Herbst. Blume weiss oder röthlich-weiss. Stengel 4-9" lang.

270. T. hýbridum L., Bastard-K. Stu i m Heft 15. Stengel aufsteigend, ganz kahl, röhrig; Blättchen der unteren Blätter verkehrt-ei - oder herzförmig, die der oberen elliptisch, stumpf, fein-gesägt; Nebenblätter länglich-lanzettlich, allmählich fein-zıgespitzt; Köpfchen lang - gestielt, kugelförmig, dichtbliithig, am Grunde ohne Hülle; Blüthenstielchen nach dem Verblühen herabgebogen, die inneren zuletzt 2 oder. 3 mal so lang als die Kelchröhre; Kelch kaum halb so lang als die Blume, kahl; Zühne pfriemlich, die 2 oberen länger. 4. Feuchte Wiesen und Grasplätze nicht selten z. B. auf der grossen Wiese bei Passendorf, auf Wiesen am Görz, oft in Chausseegräben u. s. w. Mai-Septbr. Blume weiss, danu rosenroth, so dass das Köpfchen in der Jitte weiss und am Grunde rusenıth ist. Höhe $1-1 \frac{1}{2}$. 
^. Kelchschlunil inwendig kahl; die 2 oberen Kelchzähme bemerklich kürzer.

271. T. agrárium L., Gold-K. Sturm Heft 16. Stengel aufrecht; Blättchen länglich-lanzettlich, feingezähnt, alle sitzcnd; Nebenblätter läinglich-lanzettlich, am Grunde nicht brciter; Köpfchen gestielt, kugelig oder eiförmig; Blüthen zuletzt herabgebogen; Kelch kahl, die 2 uberen Zähne kürzer; Fahne lüffelförmig, gefurcht, Fliigel weit auseinandertretend; Griffel ungefuihr so lang als dic Hiilse. 24. Truckene Wälder und Waldränder zerstreut. Fehlt bei Halle und Merseburg; am Bienitz, in Wäldern und an Waldrändern bei Naunıburg und Freiburı häufig, auch zwischen Rossleben und Ziegelrode und im Katharinenholze bei Eisleben nicht selten. Juni. Juli. 'I'. aureum Poll. 'I'. campestre Gmel. Blume goldgelh, nach dem Verblühen braungelb. Höhe 1'. - Der Linné ische Name 'T. agrarium, Ackerklee, ist nicht passend, da die Pflanze wohl gar nicht auf Aeckern vorkonmt und ist nur der Priorität wegen beibehalten.

272. T. procumbens L., niederliegender K. Sturm Heft 15 und 16 Stengel aufrecht oder nieder. liegend; Blättchen verkehrt-eiförmig, fein-gezähnt, das mittlere länger gestielt; Nebenblätter eiförmig; Köpfchen gestielt, kugel- oder eiförmig, 30-40bliithig; Blüthen zulptzt herabgebogen; Kelch kahl, die 2 oberen Zähne kürzer; Fahne löffelförmig, gefurcht, Fliigel weit auseinandertretend; Griffel 4 mal kiir zer als dic Hiilse. $\odot$. Aecker, Triften, Wege überall häufig. Juni - Sept. Aendert ab :

a) maius Kuch. Stengel aufrecht, mit abstehenden Aesten; Köpfchen grösser, gesättigter gelb; Blï. thenstiele ungefähr so lang als die Blätter. T. campestre $\mathrm{Schi}$ eb. 'T. agrarium $\mathrm{Gmel}$.

b) minus Koch. Stengel meist niederliegend; Köpfchen kleiner, schwefelgell; Blüthenstiele oft doppelt sn lang als die Blätter. 'T. procumbens Schreb. 'T. pseudoprocumbens $\mathbf{G} \mathbf{m e l}$.

273. T. filiforme L., f a d e n förmiger K. S turm Heft 16. Stengel ausgebreitet vder aufrecht; Blättchen keilförmig, ausgekerbt, fein-gezähnt; Nebenbliitter eiförmig; Köpfchen gestielt, locker, 10-20bliithig; Blüthen zuletzt herabgebogen; Kelch kahl, Zähne an der Spitze ein wenig behaart, die 2 oberen kürzer; Fahne gefaltet, fast glatt; Fliigel gerade vorgestreckt; Griffel

G a r cke, Flora. 
4 mal kiirzer als die Hiilsc. $\odot$. Wiesen, 'l'riften, feuchte Plätze häufig z. B. Wiesen bei Seben, Wiesenränder an Schwalchloche hinter Kröllwitz u. s. w. Mai Sept. 'I'. procumbens I'oII. 'T. nimus Sim. Blume blassgelb. Stengel 3-12" lang.

Das mittlere Blättchen ist gewöhnlich längel ge. stielt, als die seitlichen, duch ist dies nicht beständic und es erscheinen zuweilen alle 3 Blätchen mit gleich langen stielen.

'I. spadiceum L. Sturm Heft 16. wirl zuerst von Leyss. hal. ed. 1. p. 135 auf truckenen, sumigen Bergwiesen als zerstreut vorkommend angegeben, darauf von Spreng. hal. ed. 1. p. 210 an gleichen Orten als selten, in der mantissi prima p. 11 dagcgen am westlichen Rande der Lude bei Holzweissig als sehr häufig wachsend angezeigt mol zuletzt in der 2. Aufl. der Flora p. 315 auf den e inzigen Ort ,Dounersberg hinter Kröllwitz" beschränht. Der Verfasser hat es an dieser letzten Stelle, wie in ganzen Gebiete bisher vergeblich gesucht.

106. Hotus I. Hornkle e (Pflanzenname bei Dioscorid. und Theoph.)

274. L. corniculatus $L_{0}$, gemeiner H. Flora v. Thüring. II, 23. Stengel ausgebreitet, aufsteigend; Blättchen länglich-verkehrt-eiförmig uder keilförmig; Nebenblätter meist schief - breit - eiförnig; Köpfchen meist 5 blüthig, lang - gestielt; Kelchzähne aus 3eckigem Grunde pfriemlich, fast gleich, vor dem Aufliihen zusammenschliessend; Schiffchen fast rautenförmig, rechtwinkelig-aufstcigend; Hülsen linealisch, stielrund, gerade. 24. Mai - Sept. Blume gelb. Aendert ab:

a) vulgaris Koch. Kahl oder spärlich behaart; Stengel nicht röhrenförmig: Kelchzähne aufrecht oder aufrecht-abstehend, kahl oder mit anliegenden Haaren besetzt.

b) ciliatus Koch. Wie voriger, aber die Blättchen und Kelche durch lange Haare gewimpert.

c) villosus 'Thuill. Ueberall zottig, graugrün.

Diese drei Formen kommen auf truckenem, magerem Boden, auf Triften, Rainen nnd Grasplätzen vor.

() tenuifulius Rehb. (als Art). Stengel schlank, weitästig, kahl oder fast kahl; Blättchen und $\mathrm{Ne}$ benblättel linealisch oder länglich-lanzettlich, Flügel schmäler als bei den drei vorhergehenden For. 
men. L. corniculatus $\gamma$. tenuifolius L., L. tenuis Kit. (als Art). Auf fetten Grasplätzen, salzhaltigen Wiesen z. B. bei Kölme, Kötschau und Schladebach.

275. L. uliginosus $\mathbf{S} \mathbf{c h} \mathbf{k} \mathbf{h}$, Sumpf - H. Stengel stärker, ziemlich aufrecht, kahl oder spärlich behaart, meist röhreıförmig; Nebenblätter rundlich - herzförmig; Köpfchen meist 10-12blüthig, langgestielt; Kelchziilıne uus 3eckigem Grunde pfriemlich, fast gleich, vor dem Anfbliihen zuriickgebogen; Schiffchen aus eiförmigem Grunde allmählig in einen Schnabel verschmä. lert. 4. Feuchte Plätze, Gräben, sumpfige Wiesen z. B. an einer quelligen Stelle zwischen dem Donnersberge und der saale hinter Kröllwitz, in Siimpfen rechts vom Kröllwitz.Lettiner Wege und sonst nicht selten. Juni. Juli. L. maior S m.

Nach den Beobachtungen von $\mathrm{Koch}$, Wimmer u. A. scheint L. uliginosus Schk. von L. corniculatus L. wirklich specifisch verschiedeu zu sein.

108. Tetragnnólobus Scop. Spargelbohne

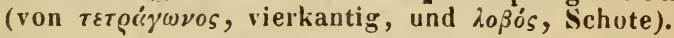

276. T. siliquosus Roth, schotentragende Sp. Stengel niederliegend oder aufsteigend, weichhaarig; Blättchen verkehrt-ei-keilförmig; Nebenblätter schief-eiförmig; Blüthen einzeln; Blüthenstiele 2 oder 3 mal so lang als das Blatt; Flïgel der 4tekigen Hülsen gerade, 4, nual schmäler als die Hülse. 4. Feuchte Wiesen, 'Triften, Gräben zerstreut. Bei Halle sehr verbreitet z. B. an Gräben zwischen Halle und Nietleben, auf Wiesen zwischen Dölau und der Heide, auf Wiesen und am Chausseegraben vur Bennstedt, seltener zwischen Halle und Ammendorf; auf Wiesen bei KI. Dölzig, am Bienitz und an den Quellen am Bienitz, bei Kötschau und Teuditz, auf Wiesen bei Gross Jena unweit Nammburg, an Hupfberg im Riethe bei Rossleben und bei Kurz-Gehmven in Riethe unweit Allstedt, einzeln bei Aschersleben und an den seelöchern bei Zabenstedt unweit Gerbstedt. Mai. Juni. Jotus siliquosus L. Blume gruss, hellgelh, mit dunkleren Flecken. S tengel 4-12" lang. Aendert ab:

b) Lotus maritimus L. Die ganze Pflanze ist kahler, die Blätter sind dicker, fleischig. so an salzigen Stellen \%. B. auf der Wiese zwischen Dölau und der Heide sparsam, häufig auf Salzwiesen bei Kötschau und Teuditz. 
4. Tntergruppe. Galeggen DC. Geisrautengewächse. Stauhgefisse 2hrüderig; Blatter muparig-gefieclert; Hülse Ificherig, ohne eingerlriickte Naht.

\section{Colítea I. B lasenstrauch (Pflanzenname bei Theophrast).}

277. C. arborescens $L_{.0}$ b a u martiger B I. Blättchen elliptisch-verkehrt-eiförmig, schwach ausgerandet oder gestutzt; Hörker der Fahne abgekïrzt; Hiilsen geschlossen. $\hbar$. Als Zierstrauch in Anlagen angepflanzt und oft in Gebüschen und Hecken verwildert $z$. B. an den Teichen bei Dieskau. Juni. Juli. Blıne gelb. Strauch $10-15^{\prime}$ hoch.

278. C. cruenta Ait., rother Bl. Blättchen verkehrt-eiförmig, schwach ausuerandet uder gestutzt; Höcker der Fahne stumpf, sehr klein; Hïlsen an der Spitze klaffend. $\hbar_{2}$. In den Weinbergen von Rollsdorf und Höhnstedt angepflanzt und verwildert. Mai. Juni. Blume pomeranzenfarben. Strauch kleiner als der vorige.

Das Weglassen der Ga le ga officinalis L. hätte Spreng. von Wallr. nicht zum Vorwurf gemacht werden sollen, da diese Pflanze im Gebiete kaum einmal rerwildert und dann stets unbeständig ist, also noch viel -weniger $z u$ den einheimischen Arten gerechnet werden kann.

5. Untergruppe. Astragaleen DC. Bärenschotengewächse. Staubgefisse 2hrüılerig; Blätter unparig-gefiedert; Hülse durch die untere (niclit samentragende) eínwärtsgebogene Niaht 2fäeherig oder halb 'fächerig, ouler al der oberen Naht eingedrückt.

109. Dxýtropis DC. Fahnwicke (ron óśs s, spitz, und төо́ль⿻, Schiffskiel, wegen der Gestalt des Schiffchens).

279. D. pilosa DC., b e ha arte F. Stu rm Heft 49. Stengel aufrecht, zottig; Blättchen der unteren Blätter länglich, der oberen lanzettlich, zugespitzt, zottig; Blïthenstiele blattwinkelständig, länger als das Blatt; Aehren eiförmig-länglich; Hülsen aufrecht, linealisch, 2fächerig, zottig. 24. Sonnige Hügel, steinige Abhänge, hesonders auf dem bunten Sandstein, selten. Abhänge des Saalthales zwischen Wettin und Dobis, Weinberge zwischen Rollsdorf und Seeburg und Seeburg und Wormsleben häufig, Plesnitzer Berge bei Laucha; nach Sch wabe auch bei Sandersleben, Bernburg und Alsleben. Juni. Juli. Plume ochergelb. Höhe $1 / 2-1^{\prime}$. 


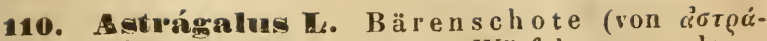
ycelos, Sprungbein des Fusses, Würfel, wegen del eckigen Samen).

280. A. Hypoglóttis L., Wi esen-B. Stengel ausgebreitet, anliegend-behaart; Blätter 9-12paarig, mit lanzettlichen, abstehend-kurzhaarigen Blättchen; Nebenblätter länglich, nit einander verwachsen, dem Blatte gegenüberstehend; Aehren kupf-oder eiförmig; Blüthenstiele länıer als das Blatt; Fruchtknoten und die aufrechten, rundlich-eiförmigen, rauhhaarigen Hiilsen deutlich gestielt. 4. Triften, trockene Wiesen, sonnige Berge zerstreut. Bei Halle häufig z. B. Berge bei Granau, Chausseegrähen vil' Bennstedt, Wiesen zwischen Dölau und der Heide; sonnige Berge bei Weissenfels, fehlt bei Naumbury; zwischen Schaafsee und Schraplau, zwischen Steudten und Schaafstedt; 'Triften an der Chaussee zwischell lem Vulkstedter Grunde hinter Eisleben und Siersleben; zwischen Iettstedt und Gerbstedt und Gerbstedt und Ihlewitz, bei Sandersleben am Tannenküppchen in Pregel und nach Ober Wiederstedt zu. Mai. Juni. A. danicus Retz. A. microphyllus Willd. Oxytropis montana Spreng. hal. ed. 1. tab. 8 und As. tragal. arenarius bei s ple $n$ g. hal. ed. 1. p. 206. Blume violett. Stengel $3-9 "$ lang.

281. A. Cicer L., kicherartige B. Sturm Heft 49. Stengel ausgebreitet, ästig, anliegend-behaart; Blätter 8-12paarig, wit länglich-lanzettlichen oder eiförmigen Blättchen; Nebenblätter lanzettlich, dem Blattstiele nicht anhängend, die oberen mit einander verwachsen und ihrem Blatte gegenüberstehend; Athren kropf-oder eiförnig; Blïthenstiele kürzer oder länger als das Blatt; Fruchtknoten fast sitzend; Hiilsen aufrecht, rundlich, aufgeblasen, in dem Kelche beinahe sitzend, rauhhaarig 4. Wegränder, Raine, sonnige Anhöhen, 'Triften nicht gar selten. Chausseegräben vor und hinter Nietleben, Wiesenränder unter den Vugelsherge und an der Rollsdorfer Mühle; häufig auf Wiesen gleich hinter Pfitzenburg am Wege nach Wansleben; Ackerrane bei Röglitz und Weissenfels nicht selten, ebenso in Weinbergen und auf hochgelegenen Wiesen hei Naumburg u. s. w. Juni. Juli. A. microphyllus S c hübl. und Mart. und del anderen deutschen Autoren mit Ausnahme von Willd. Blume gelolichweiss; Hülse bei der Reife schwarz. Stengel 1-2' lang.

282. A. glycyphýllos L.,; süssholzblätterige 
13. Stengel niederliegend, langästig, fust hahl; Blïtter 5-6paarig, mit grossen, fiförmigen Blättchen; Nebenblätter frei, eiförmig, stachelspitzig uder zugespitzt; Aehren eiförmig-länglich; Blüthenstiele länger als dis Blatt; IIiilsen linealisch, fast 3 kantig, etwas gelogen, kahl, zuletzt aufrecht-zusammenneigend. 24. IVälder, Gebiische, Wiesenränder häufig z. ł. am 'Tanneuberge bei Gutenberg, im Mittelholze I. s. w. Juni. Juli. Blume gelblichweiss. Stengel $3-4^{\prime}$ lang.

283. A. exscōpus L., st engellose B. Hayne Arzneigew. VI, 12. Stengellos, schr zottig; Blätter $12-$ 20paarig, mit eiförmigen Blättchen; Nebenblätter an den Blattstiel angewachsen; 1:liithen auf der Wurzel gehïu/t; der gemeinschaftliche Blithenstiel sehr kurz; Bliithenstielchen ungefähr so lang als die Kelchröhre; Kelchzähne fast so lang als die Röhre, pfriemlich; Hiilsen eiförmig, zugespitzt-stachelspitzig, zottig. 24. Trockene Hiigel, unbebaute Kirsch- und Weinberge selten und meist nur an einer kleinen Stelle, aber diselbst in der Regel zahlreich. Berge zwischen Müllerdorf und Krimpe sparsam, zwischen Wettin und Dobis häufiger, ebenso zwischen Seeburg und Wansleben; fehlt bei Weissenfels, Naunburg und Freiburg; an der Steinklippe bei Wendelstein häıfig, Vitzenburg unweit Nebra, auf der Grenze des Gebietes unweit Stassfurt bei Hecklingen auf Lehmboden; am Radeberge bei Mukrena unweit Alsleben. - Wird ausserdem nuch bei Ruthenburg. Könnern, Hettstedt und Sandersleben angegeben. Mai. Blume schwefelgelb. Die Blüthenstiele nebst den Blüthen nur 1-2" hoch, von den 6-10" langen Blättern weit überragt.

2. Gruppe. Hedysareen DC. Süsskleegewächse. IIülse in Fächer oder flieder quer abgetheilt und oft in Glieder zerfallend.

1. Untergruppe. Coronille en DC. Kronwickengewä chse. Blüthen doldenförmig.

111. Coronilla L. Kronwicke (von corona, Krone, wegen der Stellung der Blïthen).

284. C. vaginalis $L$ am., scheiden b] ät terige $K$. R chb. pl. crit. I. Ahb. 65. Halbstrauchig, gestreckt: Blätter 3-4paarig, Blättchen blüılich - grïn, verkehrt eiförmig, das unterste Paar vom Grunde des Blattstieles entfernt; Nebenblätter eiförmig - zusammengewachsen, von der Grösse der Blättchen, dem Blatte gegen. 
ïberstehend; Dolden 6-10bliithig; Blüthenstielchen so lang als die Kelchröhre, die unteren Kelchzähne sehr klein, wenig bemerklich; Hülsen scharf-4kantig. 24. Sunnige, truckene Berge des Muschelkalks sehr selten; nur an Schlifter bei Freiburg. Mai-Juli. C. minima Jacq. Blume gelb, später grün werdend. Stengel 4g" lang.

Diese Pflanze wird von Spreng. hal. ed. 2. p. 329 an sonnigen Bergen bei Freiburg irrthünlicher Weise als C. montana angegeben. - Bei Schmon und Laucha welche Orte von S preng. hierbei noch citirt werden, hat der Verfasser bis jetzt weder $C$. vaginalis, nuch $C$. montana finden können.

285. C. montana soop., B e r g-K. Rehb. pl. crit. 1. Abb. 6x. Stengel kriutartig, aufrecht, meist einfach; Blätter meist 5 paarig, Blättchen eiförmig oder verkehrteiförnig, stachelspitzig, das unterste Paar an Grunde des Blattstieles stehend; Nebenblïtter klein, fadenför. mig, die unteren in ein einziges, ausgerandetes, dem Blatte gegenüberstehendes zusammengewachsen, die oberen getrennt; Dolden 15-20bliithig; Blüthenstielchen 3 mal kürzer als die Kelchröhre; Hülsen zusammengedriiekt, schwach-4kantig. 24. Kalkberge sehr selten, mur an Geiersberge in Mordthale hinter Nanmburg. Juni. Juli. C. coronata L. Blume gelb. Stengel 1-11/2'.

286. C. varia L., bunte K. Sturm Heft 49 . Sten. gel krautartig. niederliegend; Blätter meist 10paarig, Blättchen länglich odel verkehrt-riförmig, stumpf, kurzstachelspitzig; Ncbenbliitter lanzettlich, nicht zusammengeruachsen; Dolden 15-20bliithig; Blïthenstielchen 2-3 mal länger als die Kelchröhre; Hülsen schwach4kantig. 24. Sunnige Hügel, Raine, Wiesen- und Akkerräıder häufig z. B. Galgenberg, Gebüsche an der Saale hinter Kröllwitz, Bischofsberg in der Heide, Mittelholz u. s. w. Juni-Aug. Blume weiss, mit rother Fahne; die Spitze des Schiffchens schwarz-purpurroth. Stengel 1-1/2/ lang.

112. Orníthø̆pas I. Klauenschote (ron ǒ Vugel, und noг̃, Fuss, wegen der Schoten su benannt).

287. D. perpusillus $\mathbf{L}$., $\mathrm{k} l$ e ine $K$. Stengel niederliegend uder anfrecht, wie die ganze Pflanze weichhaarig; Blätter 7-12paarig. Blättchen klein, elliptisch: Bliithenstiele $1-5$ blüthig, unter den Blüthen ein sitzendes, gefiedertes Blatt tragend; Hülsen zu zweien oder 
dreien, schwach aufwärts - gebogen. $\odot$. Sandfelder, Sandbuden in Kiefer- und Fichtenwäldern, dürre Anhöhen selten. Sandige Stellen am Bienitz, bein Werlbusch unweit Delitzsch, kurz begraste Abhänge zwischen der Benndorfer Mühle und Panpitzsch, häufiger in Wäldern westlich von Crina bei Bitterfeld und besunders bei Dessau und Oranienbaum. Mai - Juli. Blume klein, Fahne weisslich, ruth gestreift, Flügel weisslich oder blassioth, Schiffichen gelblich. Stengel $2-12$ "lang.

Diese Pflanze, welche jetzt im ganzen südlichen, westlichen und nördlichen Gebiete fehlt, scheint frühes häufiger gewesen zu sein, da sie von $K n a u t h$ bis Sprengel auf sandigen Aeckern ohne bestimmten Stand. ort angegeben wird. Bei Halle hat der Verfasser bis jetzt vergeblich darnach gesucht.

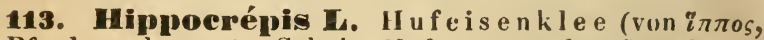

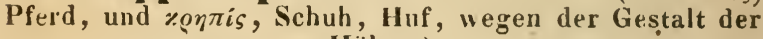
Hülsen).

288. H. comosa L., s cho p f förm iger H. Stengel krautartig, niederliegend oder aufsteigend, ästig; Blätter 5-7paarig, Blättchen länglich oder verkehrt-eiförmig; Dolde 4-8blïthig, Hülsen bogenförmig, Glieder gekrümmt, mit eingedrückten, kahlen Gelenken. 24. Trockene, unbebaute Kalkberge zerstreut. Vuyelsberg und Weinberge bei Bennstrdt bis nach Kölme hin, bei Weissenfels am Kruge, bei Naumburg, Freiburg und Bibra sehr häufig, Abhänge des Buchenberges bei Rossleben, Schmonsche Berge, selten $z w$ ischen Querfurt und Lodersleben, Kalkberge bei Bernbury und Sandersleben z. B. anı Katharinenhölzchen bei Ober - Wiederstedt. Mai - Juli. Blume dottergelb. Stengel 3-9" lang.

2. Untergruppe. Fuhedysareen Dr. A e clite Süsskleegew ä̉ c lı e. Blütheı traubenfürmigg.

114. Dnóbryelnis Tour me It. Esparsette (ron

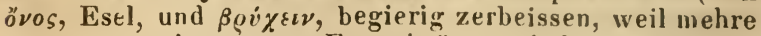
Arten gute Futterkräuter sind).

289. O. sativa $\mathrm{C}$ am., gebaute H. Stu r.m Heft 19. Stengel aufsteigend; Blätter 8-12paarig, Blättchen linealisch-länglich, stachelspitzig; 'Irauben zuletzt seh. verlängert; Blüthenstiel doppelt so lang als das Blatt; Flügel sehr klein, kürzer als der Kelch, Schiffrhen ungefähr so lang als die Fahne; Hülsen kroisundlich, am vorderen Rande gehielt, auf dem Mittelf netzförmig, am Rande und auf dem Mittelfelde dornig. 
gezähnt. 4. Hïgel, Abhänge, besonders auf Kalkboien; ausserdem oft als Futterkraut im Grossen gebaut. Kalkberge bei Bennstedt, Kölme, Weinberge bei Rollsdorf, Auhöhen bei Röglitz, Kötschau und sunst nicht gerade selten. Mai-Juli. Hedysarum Onobrychis I. Blume rosenroth mit dunkleren Linien durchzogen. Höhe $1-2$ '.

3. Gruppe. Vicieen Bronn. Iülse Ifächerig oder durch weiche, aus lockerem, schäumigem Zellgewebe gebildete Querwände in unvollständige Fächer getheilt; Blätter abgebrochen gefiedert.

\section{Vieia E. Wicke (Pflanzenname bei Plinius).}

a. Blüthenstitle der Trauben verlangert (wih) $8-12$ mal läger als tine Blüthe), re!cbhlüthis.

290. V. dumetorum C., He cke $\mathbf{-}-\mathrm{W}$. Sturm Heft 31. Stengel kahl; Blätter 4-5paarig; Blättchen gross, eiförmig, stumpf, kurz - starhelspitziğ; Nebenbliitter mit viclen, verlïngert-haarspitzigen Ziihnen, das cine halbmondförmig; Trauben 6-12blüthig; Blïthenstielchen halb so lang als der Kelch; Hülsen länglich, im Kelche lang-gestielt. 24. Bewachsene Bergabhänge, schattige IVälder stellenweise. Fehlt in der Nähe von Halle; in verschlossenen Holze an der Luppe südlich von Schkeuditz, im Bienitz selten, bei Niumburg ziemlich hüufig z. B. im Buchholze, im Gebüsche Schellsitz gegenüber, in den Wäldern bei Bibra zerstleut, im Peinholze und in Hagen bei Allstedt nicht selten, in Hagen bei Esperstedt zerstlent, in Welfsholze bei Hettetedt sehr sparsam. Juli. Ang. Blume ruth-violett, mit dunkleren Adern. Stengel weithin kletternd, 4-6' lang.

Diese Ait ist keineswegs Bastard von V. Cracca und V. sepium, wie Kittel Tascheubuch der Flora Deutschl. p. 1166 meint. - Sreng. gibt in der mant. secund. p. 15 auch die Strinklippe bei Wangen und die Hünebnrg bei Eisleben als Standurte für diese Pflanze an, erwähnt sie jedoch in der 2. Aufl. seiner Flora nicht wieder. Dessenungrachtet führt Rchb. sax. p. 294 diese beiden Standorte als zuverlässig wieder an, obgleich der zweite wenigstens ganz bestimmt falsch ist.

291. V. Cracea L., Vugel-W. Sturm Heft 31. Stengel schlaff, angediückt-weichhaarig; Blätter $10-$ 12 paarig, Blättchen länglich-linealisch vder lanzettlich, kurz-zugespitzt, beiderseits weichhaarig; Nebenblätter ganzrandig, halbspiessförmig, die obersten linealisch - 
lanzetlich; Trauben reichbliithig, gedrungen; Bliithen. stielchon so lang als die Kelchröhre; Plaste der Fahne so lang als ihr Nagel; die 2 wheren Kelchzähne aus breitem Grunde plötzlich pfriemlich, sehr kurz; Hiilsen schnal länglich-linealisch, ihr Stiel kürzer als dor helch. 4. Wiesen, Zäune, Aecker, Wege häufig. Juni-Aug. Blume röthlich-violett. Höhe 1-4'.

292. W. tenuifolia Roth, feinblätterige W. Sturm Heft 31. Stengel aufrecht, meist kahl; Blätter 10 -12paarig, Blättchen länglich-linealisch, stachelspitzig, unterseits mit etwas abstehenden Haaren be. setzt, wberseits kahl oder spärlich behaart; Nebenbliitter ganzrandig, fadenförmig-linealisch, die unteren halb. spiessförmig; Trauben reichblüthig, etwas locker; Blüchenstielchen kurzer als der Kelch; Platte der Fahne doppelt so lang als ihr. $\mathbf{V a g e l ;}$ die 2 uberen Kelchzähne aus breiterem Grunde plötzlich pfriemlich, sehr kurz; Hïlsen schmal länglich-lineilisch, ihr Stiel kürzer als der Kelch. 24. Gehüsche,-Bergwiesen, Anhöhen, hochgelegene Aecker nicht selten z. B. Lindberg, Zorgs, Tannenberg bei Gutenberg, Mittelholz u. s. w. JuniAng. Blunie viulett, die Flügel meist blpicher. Höhe $2-4^{\prime}$.

lst der vorigen Art sehr ähnlich und unterscheidet sich $n n r$ durch die lange Platte der Fahne und die längeren Blätchen, deren Rand geradlinig ist, während er bei den kürzereı Blättcheu der V. Cracea eine krum. me Linie beschreil,t.

h. Blüthenstiele sehr kurz, kürzer als eine Blüthe, 1-6hlïthig.

293. V. sepium L., Za un-W. Sturm Heft 31. Stengwl meist kahl; Blätter 4-6paaric, mit einer getheilten Wickelranke endigend, Blüttchen breit-eiförmig oder eiförmig. lïnglich, stumpf, stachelspitzig; Traubeu biattwinkelständig. $3-5$ blïthig, sehr kurz; Kelchzïhne ius breitem Grunde pfriemlich, ungleich lang, die 2 oberen zusammenneigend, $2-3$ mal kiirzer als ihre Röhre; Fahne kahl; IÏ̈lsen linealiseh-länglich, kahl. 24. Hecken, Zäune, Wege, Wiesen, Grasplätze überall gemein. April-Juni. Blume schmutzig-violett, sehr selten gelblich-wriss (V. sepium $\beta$. wchroleuca Bast.). Höhe $1-2{ }^{\prime}$. Die Blättchen sind an Grunde meist breit -eiföming und nach der Spitze verschmälert; die Pflanze ändert aber ab:

b) nıntana Fröhlich. Blättchen weit schmäler, eiförmig-länglich oder ei-lanzettlich. 
294. V. sativa L., S a t - W. Stur m Heft 31. Mehr oder weniger weichhaarig; Blätter 4-7paarig, mit einer getheilten Wickelranke endigend; Bliittchen der unteren Blïtter breit-verkehrt-eiförmig, tiefer ausgerandet, die der oberen liinglich-verkehrt-eifürmig oder länglich, ausgerandet-gestutzt, alle stachelspitzig; Blüthen blattwinkelstäılig, einzelı oder zu zweien, hurz-gestiels; Kelchiähne lanzettlich - pfriemlich, gleichlang, gerade hervorgestleckt, ungefähr so lang als ihre Röhre; Hiilsen aufrecht, länglich, mehr uder minder dicht kurzbehaart; Samen zusammengedrückt - kugelförmig. $\odot$. Wird iiberall auf Aeckern gebaut und verwildert. Juni. Juli. Fahne blan, Flügel purpurroth, Schiffchen weisslich; Hülsen uelbbraun; Samen meist braun, mit einigen scliwarzen Punkten. Höhe $1-1 \frac{1}{2}$.

295. V. angustifolia Roth, sch ma l b lät erige W. Sturm Heft 31 und 32 . Meist kahl; Blätter 45paarig, nit einer getheilten Wirkelranke endigend, blättchen der unteren lilitter verkehrt-eiförmig, ausge. randet-gestutzt, die der oberen lanzettlich - linealisch oder linealisch, stumpf oder gestutzt; Bliithen blattwin. kelständig, einzelı oder zu zu eien, kurzgestielt; Kelchzähne lauzettlich-linealisch, gleichlang, gerade hervorgestreckt. ungefälur so lang als ihre Röhre; Hiilsen abstehend, linealisch, im reifen Zustande kahl; Samen kugelföınıig. $\odot$. Mai. Juni. Fahne und Flügel vio. lett-purpurroth. Hülsen schwarz. Samen meist schwarz, seltener hellbraun uder braungeflectit. Stengel bis 1' hoch. Die Pflanze ist zarter und schmächtiger als die vorige, mit welcher sie grusse Aehnlichkeit hat. Sie ändert in den schon angegebenen Formen ab:

a) Blätchen der oberen Blätter lanzettlich-linealisch: V. segetalis 'Thuill. (als .trt), V. angustifolia For. ster, V. sativa $\beta$. Ser. bei DC. Auf Aeckern unter der Saat.

b) Blättchen der oberen Blätter linealisch : V.Bobartii Forster (als Art), V. angustifolia $S$ m. und Roth, V. sativa $\delta$. Ser. bei DC. Diese Furm kommt be. sonders auf sandigen Aeckern und in. Nadelwaldungen vor.

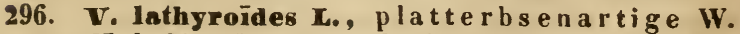
Sturm Heft 31. Stengel aufsteigend, nebst den Blärtern und Kelchen weichhaarig; Blätter 2-3paarig, mit einfacher Stachelspitze oder ungetheilter Wickelranke, Blättchen der untersten Blätter schmal-verkehrt-herz- 
förmig, die der oberen verkehrt-eiförmig - länglich oder länglich, etwas ausgerandet oder stumpf; Bliithen blattwinkelstäudig, rinzcln, fast sitzend; lielchziilne pfriemlich; fast gleichlano, gerade, beinahe so lang als ihre Röhre; IIiilsen linealisch, kahl; Samen würfelförmig, etwas zusaumengedrürkt, körnig-ranh. ○. Kurzgrasige Hügel, sandige Felder zerstreut. Felsen ummittelbar an den Gärten vor Giebichenstein, Felsen hei 'Trothis, am Donnersberge hinter Kröllwitz, schwejzerling bei Wettin, bei Naumburg seltener z. B. an bewaldeten Hügeln hei Gusek. April-Juni. Blume klein, hellviolett. Hiilse bei der Reife schwärzlich. Stengel $3^{\prime \prime}$ hoch, späterhin ausugebreitet und bis $3 / 4$ lang.

297. V. Faba L., Buffbuhue. Sturm Heft 32. Stengel aufrecht, stark; Blïtler rankenlos, in cine einfache Stachelspitze anslaufend, die unteren 1paarig, die oberen 2 -3parirg, Blättchen gross, elliptisch oder länglich, stumıf, stachelspitzig; Blüthen in sehr kurzen, 2-4hliithigen, hlattwinkelständigen 'lrauben; Kelchzähne lanzettlich - pfriemlich, unzleich lang, die 3 unteren viel liin.er als die 2 oberen; Hülsen fast walzenförmig, lederartig, weich behaart. $\odot$. Wird öfter gebaut; stammt aus Asien. Juni. Juli. Blume gross, weiss, jeder Fliigel mit einem grussen, schwarzen Flecke. Höhe 2-4'. Eine kleine Abart mit bläılirhen Blmmen ist die sugenannte Pferde-oder Saubohne.

116. Frvatan (emend.). Erve (ein aus ŏ verstïmmelter Pflanzenname bei Plinius).

a. Blätchen der Blätter eiförmig oder eifürnig-linglich. (Vicia L.)

298. E. pixiforme Peterm., erbsenaltige E. Sturm Meft 31. Kahl; Blälter 3-5paarig, in eine getheilte Wickelranke auslanfend, Blättehen sehr gross, breit-eiförmiž, star-helspitzig, alas minterste Paar dicht am Stengel, dic srossen, hulbp/eilförminen, gezïhnten Nebenbliitter verdeckend; 'Trauten 10-15bliithig, kürzer als ihr Blatt; Hülsen länglich. Inealisch, Nabel die IIälfte des Samens ungebent. 4. I situbwälder besonders Waldhügel zerstreut. Fehlt bei Halle, Merseburg, Schkeuditz und Weissenfels; findet sich aber in der Brenau bei Wettin, in den Wäldern bei Naumburg nicht selten, im Hackenholze bei Branderode, an südlichen Rande der alten Giehle bei Freiburg, an buschigen Bergen zwischen Balgstedt und Laucha; an den Schmonschen Bergen häufig, im IIagen bei Esperstedt nicht 
selten, bei Allstedt in den wïsten Bergen und im Rathsholze ziemlich häufig, an der llüneburg bei Eisleben, in den Wäldern bei Freckleben unweit Sandersleben. Juni. Juli. Vicia pisiformis I.. Blume gelblich-weiss. Stengel hochkletternd, bis $6^{\prime}$ lang.

299. E. silvaticum Peterm., Wald-E. Sturm Heft 31. Kahl; Blïtcr 7-9paarig, in pine getheilte Wickelranke auslaufend; Blättchen eiförnig oder eiförmig - länglich, starhelspitzig; Nclerblïtter halbmondförmign, cingeschnitten-vielziihnig, Kähne borstenförmigr haarspitzig; 'Trauben $8-15$ bliithig, länger als ihr Blatt, Hülsen länglich-limealisch; Nabel ₹/3 des Samens umgebend. 24. Iaubwälder, bewaldete Bergabhänge zerstreut. Fehlt bei Halle, Nerseliurg, Schkeuditz und Weissenfels; bej Naumburg nur hier und da z. I3. inı Buchholze; buschige lierge zwischen Balgstedt und I aucha, Wälder bei Memleben und liodersleben, IIineburg bei Eislehen, Welfsholz bei Hettstedt. Juli. Ang. Vicia silvatica L. Blume weisslich, mit riolett-gestreifter Fahne. Stengel hochkletternd, bis $6^{\prime}$ lang.

300. F. cassúbicum Peterm., $k$ assubische E. Sturm Ileft 31. Stengel anfrecht, weichhaarig oder zottig; isliitter 9-13paarig, in pine pinfache oder 3theilige Wickelranke auslaufend; Blättchen eiförniglänglich oder breit-linzettlich, stumpf, meist stachelspitzig, nebst den Blattstielen behaart; Nebcubliitter halb-pfeilförmig, ganzrandig; 'Trauben 6-10blïthig, kürzer als das Blatt; Hülsen länglich - rautenförmig; Nabel nur $1 / 3$ des Samens umgebend. 4. Trockene Laubwälder, bewaldete Hiigel zerstreut. Dölamer Heide, besonders an der süllichen Seite; fehlt bei Merseburg und Schkeuditz; hei Weissenfels und Naumburg nur in den Wäldern zwischen Schönburg und Wetau, aber daselbst häufig, Steinklippe bei Wendelstein; fehlt bei Aschersleben. Juni. Juli. Vicia cassubica I. V. multiflora Poll. Blume violett-roth. Höhe 1-2'.

h. Blättchen der Blätter linealisch, sehr selımal.

301. E. hirsutum L., behaartfrüchtige E. Sturm Ileft 32. Bliitter meist fiparrig, in eine ge. theilte Wichelranke auslaufend. Blättrhen linealisch, stumpf oder gestutzt, lurz-stachelspitzig; Nebenblitter halb-pfeilförmig, lanzettlich oder 2-3theilig: Bliithensticle 2-6bliithig, ungefïhr so lang als das Blatt; Kelchzähne sı lang als ihre Röhre; Hiilsen länglich, 
2samig, weichhaarig. $\odot$. Aecker, Züune, Gebüsche, besonders auf Sandboden häufig z. B. Dölauer Heide, Aecker an Dölauer Kirchholze u. s. w. Juni. Juli. Blu. me sehr klein, bläulich- "eiss. Stengel sehr zart und dünn, $1 / 2-2$ ' hoch kletternd.

302. E. tetraspérmum L., viprsamige E.; heisst mit der vorigen beim Volke Zitterlinse. Sturm Ileft 32. Blätter 3-4paarig, in eine getheilte Wickel. ranke auslanfend, Blättchen linealisch, stumpf, kurz. stachelspitzig; Nebenblätter halb-pfeilförmig, Blitthenstiele 1-2bliithig, ohne begrannte Spitze, unge/iihr so lang als das Blatt; Kelchzähne kürzer als ihre Röhre, Hiilsen linealisch, 4-, seltcn 3-oder 5samig, kahl. $\odot$. Sandfelder, Gebüsche, Waldränder wie die vorige und ebenso hä̈fig. Juni. Juli. Blume sehr klein, blass. violett und blau gestreift. Stengel schlaff, meist niederliegend, $1 / 2-2^{\prime}$ lang.

303. E. grácile DC., schlanke E. Stengel aufrecht, etwas straff, von Grunde an ästig; Blïtter 34paarig, in eine einfache oder getheilte Wickelranke auslaufend, Blättchen linealisch, spitz; Nebenblätter halb-pfeilförmig; 13liithenstiele 1-4, in eine begrannte Spitze auslaufend, zuletzt doppelt so lang als das Blatt; Kelchzähne kürzer als ihre Röhre; Hïlsen linealisch, mcist 6samig, kahl. $\odot$. Sehr selten, nur auf sandigen Feldern an der Benndorfer Mühle, aber daselbst zahl. reich. Juni. Juli. Vicia gracilis Lo isl. Blume grösser als bei den beiden vorigen. Höhe $3 / 4-1$ '.

Der vorigen Art sehr ähnlich, besonders wenn die Blïthenstiele bei $\mathbf{E}$. tetraspermum länger als das Blatt sind, "as bisweilen vorkonmet ist indessen durch die nicht stumpfen, sondern spitzen oder zugespitzten Blättchen, besonder's der oberen Blätter, durch die fast doppeit so grossen Blïthen, die begrannten Blüthenstiele, die meist 6samigen, seltener 5-8samigen Hiilsen und den um die Hälfte kürzeren, nicht länglich-linealischen Nabel des Samens hinlänglich nnterschieden, Weshalb das hlosse Citat dieser Pflanze zu E. tetraspermum bei Spreng. hal. ed. 2. p. 325 sehr unpassend erscheint. Wallr. hat (ann. bot. p. 85) diese seltene Pflanze für das Gebiet zuerst angezeigt.

304. E. monanthos L., e inblumige. E. Sturm Heft 32. Stengel schlank; Blätter meist 7paarig, in eine getheilte Wickelranke auslaufend; Blättchen li- 
nealisch, stumpf oder gestutzt, stachelspitzig; Neben. blätter ungleichförmig, das eine linealisch, ganzrandig, sitzend, das andere halbmondförmig, borstenförmig-gezähnt, gestielt; Bliithenstiele 1bliithig, mngefähr so lang oder etwas länger als das Blatt; Kelchzähne länger aly hre Köhre; Hülsen breit-länglich, meist 3samig, kahl. ○. Aecker, Ackerränder, sehr selten und meist unbeständig. An der Salzke bei Kölme an Fusswege nach Langenbogen. Juni - Juli. Viria articulata.Willd. Blune weit grösser als bei den 3 vorhergehenden Arten; Fahne lilafarben, nit violetten Adern, Flïgel ind Schiffchen weiss. Stengel 1-2' lang.

Zuerst ist diese seltene Pflanze von $\mathrm{L}$ eys ser (cf. hal. ed. 2. p. 185) auf Waldwiesen in der Heide, dann von Wallroth (ann. but. p. 86) in Gebiischen zwischen lettin und der Heide und unter Saaten hinter 'Trotha und später von Sprengel (hal. ed. 2. p. 323) unter Saaten und in Gebiischen um Trotha und Lettin gefunden worden. In Jahre 1829 wurde sie auch von Richter auf Aeckern bei Werlitzsch nördlich von Schkeuditz in grosser Anzahl anfgefunden. Von Schwabe wird sie bei Dessau, Oranienbaum, Bernburg und Sandersleben angegeben.

117. Plsum I. Erbse (soll von den celtischen Worte pis, Erbse, stammen).

305. F. sativum L., S ch o ten-E. Blätter 2-3paarig, in eine ästige Wickelranke auslaufend, Blättchen eiförmig, ganzrandig, am Rande wellenförmig; Nebenblätter eiförmig, fast halbherzförmig, an Grunde gekerbt oder gezähnt; Blüthenstiele 2 - vder mehrblüthig; Samen kugelförmig. $\odot$. Auf Aeckern häufig gebaut. Mai - Juli. Die ganze Blume weiss oder die Fahne weiss und die Flü䒑el rosenroth, in welchem Falle auch die Nebenblätter gefärht sind; Samen hellgelb, seltener blass - grünlich oder blass - bläulich. Höhe 1-2`.

306. P. arvense L., A cker-E. Sturm Heft 4. Blätter 2 - 3parig, in eine ästige Wickelranke auslaufend, Blättchen piföımig, feingeherbt; Nebenblätter eiförmig, fast halbherzförmig, anı Grunde gekerbt oder gezähnt; Blüthenstiele 1-2blüthig; Samen kantig-ein. gedriickt. $\odot$. Auf Aeckern öfter gebaut und hin und iieder verwildert. Mai-Juli. Fahne blass-violett, Flügel purpurroth. Schiffchen weiss; Samen graugrün, mit braune'n Punkten. Höhe $1-2^{\prime}$. 
118. Cátlny rus I. Platterbse (Pflanzenname bei 'Theophrast).

a. Bläter felılend; Blattstiele rankenförmig orler blattartig.

307. L. Áphaca L., nebenblättrige P. Kahl; Stengel 4 kantig ungefligelt; Blattsticle faclenförmig, in eine Wickelranke auslaufend, ohne Bliittchen; Nel,cnblätter sehr gross, eiförmig, am Grunde spiessförmig; Blüthenstiele 1 blüthig; Samen glatt. $\odot$. Aecker sehr selten, nur bei Naumburg, aber dolt zien ich häufig, besonders anf thoni em Boden, so zwischen Naunburg und der Kroppenmühle bei Wetau und noch häıfiger zwischen Gross-Jena und Freiburg, hin und wieder auch in den Weinbergen bei Naumburg. Juni. Blune gelb. Stengel $1 / 2-1^{\prime}$ hoch.

Wird von Wallr. sched. p. 386 auch unter Saaten unweit Bibra am Wege nach Kösen und von Schw a be fl. anh. bei Sandersleben angegeben, an welchen Stellen diese Pflanze in neverer Zeit nicht wieder beubachtet worden ist.

308. L. Nissólia L., blattlose P. Meist kahl; Stengel kantig, ungefliigelt; Blattstiele lilattfürmig, lanzettlich, oline Wickelranke und ohne Blïttchen; Vebcnblätter sehr Klcin, pfiriemenförmig, an Grunde halbspressförmig; Blüthenstiele 1-2blüthig: Samen knötig-rauh. $\odot$. Acker- und Wiesenränder sehr selten, nur an Wiesenrändern an Wege von Burg Liebenau nach Collenbey und auf Wiesen zwischen Zöschen und der Ziegrelscheune. Nai - Juli. Blume purpurroth. Höhe $1-1 \frac{1}{2}$.

Die Blïthenstiple sind keinesweges immer 1 blüthig,

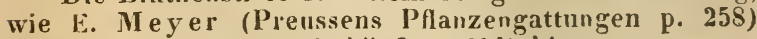
behauptet, sondern weit häufiger 2blüthig.

h. Blattstiele blättertragend, in eine Wickelranke auslaufend.

1. Stengel ungeflügelt.

309. L. Lens Peterm., I, inse. Sturm Heft 32. Stengel kantig; obere Blïtter in eine Wickelranke auslaufend, meist 6paario ; Nebenblätter lanzettlich, ganzrandig; Bliithenstiele $\hat{\mathbf{1}}-2$ bliithig, ungefähr so lang als das Blatt: Hiilsen elliptisch-rautenförmig, 2samig, kahl. $\odot$. Auf Aeckern häufig gebaut und unter der Saat oft verwildert. Juni - Juli. Errum Lens L. Blume weisslich, oft mit violettem Anfluge. Höhe $1 / 2-1^{\prime}$.

310. L. tuberosus L., Erdnuss. Wurzelstock fadenförnig, an den Gelenken mit haselnussgrossen Knol- 
Knollen; Stengel 4kantig; Blätter 1paarig, in eine Wickelranke auslaufend; Nebenblätter halbpfeilförmig, linealisch; Bliithenstiele reichblüthig, länger als das Blatt; die oberen Kelchziihne kurz-3eckig; Hülsen linealisch-länglich, netzföınıig-aderig, kahl; Samen schwach-knötig. 24. Auf Aeckern in Getreide häufig, z. B. zwischen Halle und Nietleben, hei Röglitz u.s. w. Juli. Ang. Blume purpurroth. Stengel niederliegend, $1-3^{\prime}$ ling.

311. L. pratensis L., Wiesen-P Weichharig; Stengel aufsteigenl, kletternd, scharf-4kantig; Blïtter Ipcoction, in eine Wickeiranke auslaufend; Nebenblätter pfeilförmig, breit-lanzettlich, fein-zugespitzt; Bliithensticle reichbliathig, länger als das Blatt; Kelchzähne siimmtlich lanzettlich-pfriemlich; Hulsen linealisch länglich, schief - aderig, kahl oder schwach behart; Samen glatt. 24. Wiesen, Hecken, Gräben genein. Juni. Juli. Blume gelb. stengel $1-3^{\prime}$ hoch.

\section{Stengel geflügelt.}

312. L. sativus L., essbare P. Stengel schmal. gefliigelt; Blätter 1pacario; Nehenblätter halb-pfeilförmigr; bliithenstiele lbliithi, hiirzer als das Blatt, mit kleinen Deckblättchen; Hiilsen elliptisch - länglich, flachzusammengedrückt, netzförnig - aderig, am oberen Rande answü̈rts - ockrïmmt, 2flii..elig; Samen kantig. Wirl hin und wieder auf Aeckern gebaut. Mai. Juni. Blunie bläulich, röthlich'vder "eiss. Stengel $3 / 4-$ $11 / 2^{\prime}$ lang.

313. L. silvestris $L_{0}, \mathrm{II}$ ald-P. Stengel hreit-gefliigelt, liligel doppelt so lreit als die der rilattstiele; Blictter 1paarig, Jiliitchen lanzettlich oder linealisch. lanzettlich, zugespitzt; Nebenblätter halb-pfeilförmig, linealisch-pfriemlich; Elïthensticle reichblïthigo, länger als das Blatt; Hülsen länglich-linealisch; Nabel die Hälfte des Samens umgrebend. 24. Wälder selten. Fehlt bei Halle, Merseburg, Weissenfels; findet sich in den Waldungen über der Henne bei Naumburg, an buschigen Kalkhergen bei Bibra, im Walde Namens Hahn bei Thalwinkel, in Ludersleber Walde. Juli. Aug. Fahue auf dem Rücken röthlich-grün, inwendig am Grunde purpurroth und von da allmühlig fleischfarben, nit dunkleren Adern, Flügel an der vorderen Hälfte purpurroth, Schiffchen blass-grün, mit purpurrother Spitze. Stengel $3-6^{\prime}$ lang.

Garcke, Flora. 
Spreng. gibt in der 2. Aufl. der Flora gar keinen Standort für diese Art an, da an dem angeführten nur l. platyphyllus Retz. wächst.

314. L. platyphýllos Fetzins, flach blat te ri gre P. Stengel breit-geflügelt. Flï.. el rlev Islatlsticle fast chen so breit als die des Stengels; Blätler 1 parrio, Bilïtlchen länglich-lanzetllich, stumpf, mit auf gesetzter Stachclspitze; Nebenhlätter halb-pfeilförmig, linealisch pfrienlich; I:liithensticle rechbliuthiz, länger ils das Blatt; I Iülsen länglich-linealisch; Nabel die Hälfte des Samens umgebend. 24. Gebusche selten. Gebiische an der Sasle zwischen dem Schwalchloche und Jettin (an welchem Orte sipreng. die rorhergehende Art anzeigt); häufiger in Gebüschen in der Aur bei Burgliebenau und Dölnitz, einzeln an Wiesengräben zwischen Rasuitz. und Zöschen. Juli. Ang. Blume etwas grösser als hei briger Art, rosemroth, mit schmutzig-gelbem Schittchen. Höhe $3-6$ ' lang.

Hierher gehört Lath. latifolius bei $K$ n a uth, B uxb., Le yss. ed. 1 u. 2 uml spreng. ell. 1., Lath. intermedius IV allr. (sched. p. 386) und bei Spreng. ed. 2. p. 321 .

315. L. palustris L., S u mp f - P. Stengel breit - geflügelt; Blattsticle flïgellos, schmal - berandet; Jiciuter 2-3paarig, Blättrhen länglich - lanzettlich, stumpf, kurzstachelspitzig; Nebenblätter halb-pfeilförnig, liwealischlanzettlich; Ditithensticle reichbliithig, länษer als das Blatt; Hïlsen länglich - linealisch; Nabel den vierten Theil des Samens ungebend. 4. Sumpfige Wiesen stellenweise. Weidengebïsch zwischen der Reide und Döll. nitz sparsam, häufiger bei Burgliebenau und auf sumpfigen Wiesen zwischen dem Schambert und Kl. Dölzig, bei Zaschwitz unweit Wettin; fehlt bei Weissenfels, Naumburg und Freiburg; Wiesen zwişchen Reinsdorf und Bebra, Wiesen zwischen der Steinklippe und Memleben, auf der Grenze des Gebiets bei Herklingen unweit. Stassfurt. Juli. Aug. Blume blau. Höhe $1-3^{\prime}$.

c. Blattstiele sille Wickulranke. (Orobus L.*))

316. L. vernus exhl., Fr ühlings-P. Sturm Sleft 7. Stengel hantig, ungefliigelt; Bliitter 2-3paarig,

*) Dass Orobus ron Lathyrus nicht generisch rerschieden ist, scheint jetzt allgemeiner anerkannt zu sein. - Von den nachfolgenden Arten stehen Latlyrus vernus und L. montanus hier nach 
in eine einfache Spitze auslaufend, Blättchen eiförmig oder eifürmig-länglich, lang-zugespitzt, kurz-gewimpert, unterseits glänzend; Blüthenstiele 4-6bliithig, ungefähr so lang als das Blatt. 21. Schattige, etwas feuchte Iaubwälder zerstrent. Fehlt bei Halle; Wälder der Aue nicht selten z. B. zwischen Schkeuditz und Kl. Dölzig, zwischen Dölkau und dem Zöschener Holze, in allen Wäldern bei Naumburg, Freiburg, Schmon, Eisleben und Freckleben. April. Mai. Orobus vernus L. Blume purpurioth, später blau werdend und zuletzt ins Blaugräne iibergehend. Höhe $3 / 4-1$ '.

317. L. montanus TB ernh., Berg-P. Sturm Heft 21. Hurzelstuck weit kriechend, an den Geleutien knollenförmig; Stenœel oeflïgelt; Blätter 2-3pactrig, Blättchen lïnglich-lanzettlich, stachelspitzig, unterseits blaugriin, glanzlos; Blüthenstiele 4-6blithig, meist länger als das Blatt. 24. 'Trochene Jaubwälder zerstreut. Dölaner Heide, besonders am nördlichen Rande, Frenzelholz bei l,ieskau, an Krug bei Weissenfels, fchlt bei Naumburg: alte Giehle zwischen Freiburg und Pödelist häufig, Katharinenholz bei Eisleben. April. Mai. L. macrorrhizus W W mm. Orobus tuberosus L. Blume purpurroth, zuletzt schmutzig-blau. Höhe $1 / 2-1$. Aendert ab mit breiteren fast $4^{\prime \prime}$ breiten Blättchen und

b) tenuifulius Roth. Blättchen sehr schmal, linealisch, nur $1 / 2$ " breit.

318. L. niger wimm., s chwarze P. Stensel kantig, ungefliigclt; Blüller 2-öpaurig, Bläuchen ciförmig -lïnglich, stunıpf, stachelspitzig, unterseits blia grün, glanzlos. Blüthenstiele 4-Sblüthig, meist !äıger als das Blatt. 24. 'T'rockene Laubwälder häufís z. B. Dölauer IIeide, Frenzelholz bei Lieskau u. s. w. Juni. Juli. Orobus niger J. Blume purpuroth, zuletzt blau. Itöhe $1-3^{\prime}$. Die Blättchen sind schmäler und breiter und werden beim Trockuen schwarz.

dem Vorgange Kittel's (rgl. Taschenbuch der Flora Deutschlands 2. Aufl. S. 1181) unter der Autorität Bernhardi's. Der Verfasser war früher der Meinung $\mathrm{K}$ o ch's (cf. Syn. et. 2. p. 218), dass zuerst Wimmer in der 2. Aufl. der Flora ron Schlesien S. 166 die Gattungen Lathyrus und Orobus vereinigt habe. Da jedoch $K$ ittel a. a. 0. den Wimmerschen Namen L. macrorrhizus als Synon. zu L. montanus Bernh. citirt, so verdient dieser letzlere als der ältere den Vorzug und es wäre wünschenswerth zu erfahren, wann und wo Bernhardi jene beiden Lathyr. aufgestellt hat. 
4. Gruppe. Phas e oleen Bronn. Hulsen 1ficherig, Blätter 37.îhlig.

119. Rrvaséolas I. Schminkhohne.

319. Ph. multiforus Willd., vielblumigre Sch. H a y e Arzneigew. Xl, 45. Stengel windend, fast kahl; Blättchen +iföruig, zugespitzt; Traubcn gestirlt, reichbliithig, lïnger als das Blatt; Hiilsen hängend, etwas sichelförmig, rauh. $\odot$. Soll aus Sïdanerika stanmen; wird jetzt häufig gebaut. Juni-Aug. Stengel klettert 8-12' huch. Aendert ab:

a) coccineus I, a m., Feuerbohne. Blume scharlachroth, Samen gefärbt und

b) albus L, am. Blmmen und samen weiss.

320. Ph. vulgaris L., gemeine Sch. Hayne Arzneigew. Xl, 46. Fast hahl; Blättchen eiförmig, zugespitzt; Trauben gesticlt, armblüthig, liirz:er als das Blatt; Hiilsen hängend, ziemlich gerade, glatt. $\odot$. Sull aus Ostindien stammen; wirl jetzt häıfig gebaut. Juni - Aug. Blume wejss uder röthlich. Der Stengel hlettert meist 8-12' huch; es gibt aber auch eine nicht windende, niedere Ahart mit $1-2$ ' hohen Stengel, dies ist Ph. nanis L., Zwergbuhne. II a y " Arzueigew. $\mathrm{XI}, 47$.

\section{Familie. Amygdaleen Juss. Man- delgewächs e.}

120. Pércien 'E'munef. Pfirsiche (der Name bezieht sich wie bei der folgenden Prunus Armeniaca auf das Vaterland lieser Bäume; die Römer nannten die Pfirsichen und Aprikusen mala persica et armeniaca, persische und armenische Aepfel).

321. P. vulgaris Mill., gemeine Pf. Hayne Arzneigew. IV, 38. Blätier lanzettlich, scharf doppelt oder einfach gesägt; Blithenstiele kurz, den halben Querdurchmesser des Blattes nicht erreichend; Früchte meist filzig, seltener lahl. Ђ. Wird in mehren Abalten in Gärten gezugen. April. Mai. Auygdalus Persica L. Blüthen hellusenroth. Frucht weiss-, gelb- oder roth; fleischig. Der Baum stammt aus Asien.

121. Prumua L. Pflaume, Kirsche und Aprikose (Pflanzenname bei 'Theophrast). 
A. Aprikose. Steinfrucht sammetartig.

322. P. Armeniaca L., A p rikose. Blätter breit eifürmign, zugespitzt, doppelt - gesägt, kahl; Blattstiel drüsig; Bliithen seitenständig, cinzeln oder zu zucien, kurz - gestielt; Bliithenstielchen cingeschlossen. ち. In Gärten häufig gezogen. März. April. Blume weiss, mit röthlichem Anfluge. Der Baum stamnt aus Armenien.

B. Pflaumen. Steinfrucht kahl, mit einem bläulichen Reife.

323. P. spinōsa L., S c hl e he n-Pfl. H a y ne Arzneigew. IV, 44 . Blätter elliptisch oder verlehrt-eiförmigr, gesägt; Zwejge in Durnen endigend, in der Jugend weichhaarig; Bliithenknospen liliithig, einzeln, zu zweien wder zui dreien; Isliithenstiele liahl; Friichte kugelförmig. cufrecht. ち. Waldränder, steinige Orte, Hecken, Züune überall gemein z. B. Gebüsche an der Saale hinter Kröllwitz. April. Mai. Ein 6-10' hoher strauch. Die Blïthen, welche gewöhnlich vor den Blättern erscheinen, sind weiss. Eine seltene Abart mit gleichzeitigen Blüthen ist $P$. spinosa $\beta$. coactanea $\mathbf{W}$. u. Grab. P. fruticans Weihe.

324. P. insititia L., Kriechen, Haferschlehe. Gu imp. t. 65. Blätter elliptisch, gesägt, unterseits weichhaarig; Zweige sammetartig, meist dornenlus; Bliithenknospen meist 2 hlitthis; Bliithenstiele sehr fein-weichhaarig; Friichte kugelförmig, nickend. 施. Steinige Orte, Gebüsche nur sehr selten wirklich wild $z$. B. Gebüsrhe an der Saale hinter Kröllwitz, altegiehle bei Freiburg. April. Nai. Blwmenblätter rundlich. schneeweiss; Frürhte dunkelıiulett. Ein Straurh oder Bam viा 10-2u Hhe.

Wirl in Gärten in vielen Abarten mit ruthen, gelben und grünen Frïchten unter verschiedenen Namen gezugen, "nter welchen die Mirabelle, Reine-Claude, Aprikusenpflaume die vorzüglichsten sind.

325. P. doméstica L., $Z$ wetsche, ge mejne Pfla ume. Blätter elliptisch, deutlich-gekerbt-gesägt, weichharier; Zwcige liahl, meist dorneulos; Blithenknospen mcist 2liithig; Jilithensticle wcichhaari: Friichte länglich. hiingend. $\hbar$. Wird in vielen Abarten gezogen. April. Blumenblätter länglich - eiförmig, grïnlich - weiss. Ist die Stammart der cultivirten Pflaumen mit länglichen Früchten. 
Ausser diesen werden theils als selbstständige Ar. ten, theils als Abarten folgende funterschieden und im Gebiete hin und wieder gezogen:

a) Pr.cerasífera Ehrh., Kirschpflaume, mit kleinen, rothen, kugelförmigen, hängenden Frïchten.

h) Pr. vinaria Bechst., Weinschlehe, mit kleinen, röthlich - marmorirten, blau - bereiften, früh reifenden, siissen Frïchten.

c) Pr. Brignola L., Brignole, mit fast kugelförmigen, rothen oder gelben, roth gefleckten Frïcliten.

d) Pr. Cereola L., gelber Spilling, mit kleinen, gelben, länglich - eiförmigen, etwas zusammengedriickten Friichten.

e) Pr. $d$ a mascena L., $d$ a m a szener $Z$ we t $\mathrm{s}$.he, mit eiförmig - ellipsoidischen, hängenden Früchten und zusammengedrïckten, beiderseits spitzen Steinen.

c. Kirschen. Steinfrucht kahl, unbereift; Blüthen - büschelförmig, aus einer Knospe.

326. P. avium L., Vogelkirsche. Wurzel ohne Ausläufer; Blätter elliptisch, zugespitzt, ctwas runzelig. unterscits weichhactig, an der Spitze des Blattstiels mit 2 Drüsen; Schuppen der Blüthenknospen blattlos. †. Wälder, häufig in mehren Abarten in Obstgärten gezogen. April. Mai. Die bekanntesten Abarten sind:

b) juliana DC. (als Art), Weichkirsche. Frucht ei-herzförnig, gross, mit weichem Fleische. Hierzu gehören nach Sichler die rothe Glanzherzkis ische, die rothe Molkenkirsche, die gelbe Herzkirsche und die kleine Früh. kirsche.

c) Durácina DC. (als Art) Knorpelkirsche. Frucht herzförmig, schwar'z, gelblich - roth oder weissgelb, mit hartem, dem Steine anhängendem Fleische.

327. T. Cérasus L., Sa ue rkirsche, Weichsel. Hayne Arzneigew. IV, 42. Wurzel mit Auslüufern; Bliitter flach, kahl, glainzend, etwas lederartig, elliptisch, sïmmtlich zugespitzt; Blattstiele drüsenlos; die inneren Schuppen der Bliithenknospen hlättertragend; Blumenblätter rundlich. ち. Stammt ans Asien, wird jetzt überall angepflanzt und verwildert. April. Mai. Die bemerkenswerthesten Abarten sind: 
a) arida Ehrh., Glaskirsche, mit längeren Blüthenstielen und nicht ruth färbendem Safte.

h) austera Ehrh., Morelle, mit kürzeren Blïthenstielen und ruthem Safte.

c) Aproniana Schïbl. und Mart., Siissweichsel, wird als Bastard von P. avium und P. Cerasus angesehen.

d) semperflorens Ehrh., Allerheiligenkirsche. Bei dieser Abart verlingert sich der mit Blättern umgebene Blïthenstanl und dic Kweige tragen den ganzen Summer iiber Blïthen und Früchte.

328. P. Chamaecérasus J a $\mathbf{c}$., $\mathrm{Z}$ w e r $\mathrm{g}-\mathrm{K}$ i r s $\mathrm{c}$ h $\mathrm{e}$. Guimp. t. 61. Wuzel nit Ausläufern; lilïter flach, kahl, glänzcnd, etwas !ederartig, die uberen länglich uder lanzettlich, zugespitzt, die der seitenständigen Knospen verkehrt-ciförmig, rundlich, stumpflich; Blattstiele drüsenlos; die inneren Schuppen der Bliithenknos. pen blättertragend; \lumenblätter länglich-verkehrt-eiförmig uder verkehrt-eiförnig. ち. Am Rande trockener Laubuälder, an sonnigen, unfruchtbaren Hiigeln selten. Bei Halle häufig: Lindberg, Lorgs, Mittelholz; im übrigen Gebiete nur an Rande der Giehle in des Nähe der Weinberge bei Freiburg. April. Mai. Blumen und Früchte klein. Ein $1-4^{\prime}$ hoher Strauch.

Weshalb sprengel die drei ersten, schon von Wallr. sched. p. 210 erwähnten Standorte nicht aufgenommen hat, ist unbegreiflich, da dieser Strauch dolt weit lıäufiger vorkomnt, als bei Freiburg. Dies wird ihm von Wallr. auch mit Recht zum Vorwurf gemacht, doch kann der Verf. letzterem nicht beistimmen, wenn er späterhin diese Kirsche für P. Cerasus var. semperflorens ausgibt.

D. Traubenkirsehen. Sieinfrucht kahl, unbereift; Blïthen traubenförnig, nach den Blättern erscheinenil.

329. P. Padus L., Traubenkirsche; rom Volke auch Faulbaum genanut. Hayne Arzneigew. IV, 40. Blätter elliptisch, fist doppelt gesägt, etwas runzelig, abfallend; Blattstiele an der Spitze mit 2 Drïsen; Bliithen in iiber/ïingenden Tranben; Blumenblätter ganzrandig oder gezähnelt; Früchte kugelig, klein, schwarz. $\hbar_{2}$ Fenchte Wälder, Gebüsche, Bäche häıfig z. B. Wörmlitzer Hölzchen, Gemeindeholz bei Zöschen u. s. w. Mai. Ein 10-30' hoher Strauch oder Baum. OFF. cortex et folia Pruni Padi. 
P. Mahāleb L., welche in Süddeutschland einhei. misch unl'in Gebiete bisweilen in Parkanlagen angepflanzt ist, liefert die bekannten Weichselröhre.

XXX. Familie. Rosuceen Juss. Rosenye withise.

1. Gruppe. Spirae aceen D C. Ge is bartgewä $\mathrm{chse}$. Früchtchen $2-4$ eiig, bei der Reife kapselartig, einwärts aufspringend.

122. Spiraen L. G e isbart (Pflanzenname bei

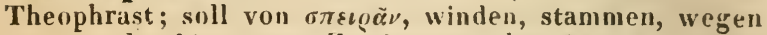
der biegsamen 'Zweige mancher Arten).

a. Blüthen 2häusig; Früclıte zuräckgehogen; Nehenblitter follend.

330. Sp. Aruncus L., Ge is b a r t. Stengel anfrecht, kantig; lilïter mehrfach-zusammengesetzi gefiedert; Blättchen gruss, eiförmig, lang-zugespitzt, ungleichgesägt; Bliithen 2hïusig, in langen, fadenförmigen, zahlreiclien Aehren, welche zuxammen eine grosse Rispe bilden. 24. Feuchte Stellen der Wälder, Bäche, Quellen sehr selten, nur an Lothariusberge im Lodersleber Forste und bei Bibra in der Aue und in Thale nach Burgscheidungen zu. Juni. Juli. Blume hlein, gelblich. weiss. Höhe $4-6^{\prime}$.

b. Blüthen zwitteriog; Nehenblitter an den Blattstiel angewachsen.

331. Sp. Ulmária L., Sumpt'- G. Sturm Ifeft 18. Stengel aufrecht, kantig; Blätter unterbrochen-gefiedert; Blättchen gross, eiförmig, ungetheilt, das end. stündige grösser, handförmig $3-5$ spaltig, alle ungleich resägt; Bliithen zwitterig, in ebensträussiger Rispe: Kapselı kahl, zusammengewunden. - ;. Kach - und Flussufer häufig z B. Rabeninsel, Gebüsch an der stillen Elster bei Osendorf u.s. w. Juni. Juli. Blume weiss. Höhe 3-6'. Aendert ab:

a) denudata Hayne. Blättchen beiderseits grïn.

b) glauca Schultz. Blättchen unterseits aschgrau oder weissfilzig.

332. Sp. Filipéndula L., knollentragender G. Sturm Heft 18. Wurzelfasern an ihrem Ende zu länglichen Knollen verdickt; Stengel aufrecht, rundlich; Blïtter unterbrochen - gefiedert; Blïttchen klein, länџlich, fiederspaltig - eingeschnitten, mit gesägten Läppchen; Bliithen zwitterig, in ebensträussiger Rispe; Kapseln weichhaarig, gerade, an einandergedricht. 7. Truh- 
hene Wiesen, Anhöhen. Waldränder häufig z. B. Donnersberg, Heide, Lindholz, Frenzelholz bei Lieskau, Mittelhulz u. s. w. Juni. Juli. Blume "eiss, selten röthlich. doppelt su gross als bei den vorhergehenden Arten. Höhe 1-2'.

2. Gruppe. Dryadeen Vent. Dryadengewächse.

123. Cevam L. Nellienwulz (ein hei griechischen Schriftstellern vorkommender Pflanzenname).

333. C. urbanum L., Nelkenwurz. Ha y ne Arzneiw. IV, 33. Stengel aufrecht; Wurzplblätter unterbruchen - leierförmig - gefiedert, Stengelblätter 3zählig; Blïthen aufrecht; Blumenblätter verkehrt - eiförmig, ohne. Nagel; Kelch nach dem Verbliihen zuriickgeschlagen; Fruchthöpfchen ungestielt; das obere Glied der kahlen Granne iter frïchtchen an Grunile sehr fein-behaart, 6 mal kürzer als das untere. 4. Feuchte Wälder, Gebüsche. Zäıse, Bäche gemein. Juni-Aur Blume guldgelb. Höhe $3 / 4-1 \frac{1}{2}{ }^{\prime}$. OFF. Rad. Caryophyllatae.

334. Ot. intermedium Eh h., mit l e re $N$. Hayne Arzneigew. IV, 34. Stengel aufiecht; Wurzelblätter unterbruchen - leierförmig - gefiedert, Stengelblätter 3zähliy: Blüthen aufrecht oder nickend; Blumenblatter rundlich, an Grunde keilförmig, mit hurzem Nagrel; Kelch nach dem Verbliihen wagrecht-abstehend; Frnchtköpfchen ungestielt; Früchtchen am Grunde zuttig, 4 mal kiurzer als das untere. 4. Feuchte Wälder und Gebüsche sehr selten. Wälder zwischen Schkeuditz und dem Bienitz sehr spar. sam. Juni - Aug. Blumenblätter goldyelb, meist grösser als bei voriger Art.

Kommt nur in Gesellschaft der heiden anderen Arten vor, von denen es vielleicht Bastard ist und könnte daher nuch an anderen Orten, an welchen G. urbanum und G. rivale zugleich wachsen $z$. B. in Bruche zwischen Sandersdorf und Bitterfeld u. s. w., gefunden werdell.

335. A. rivale L., Ba ch-N. Ha yne Arzneigew. IV, 34. Stengel aufrecht; Wurzelblätter unterbrochenleierförmig - gefiedert, Stengelblätter 3zählig; Blüthen nickend; Blumenblätter breit-vertehrt-eiförmig, mit langem Nagel; Kelch stets aifrecht, su lang als die Blumenblätter; Fruchtköpfchen lang - gestielt; das obere Glied der Granne der Früchtchen mit dem unteren fast 
gleichlang, bis unter die Spitze behaart. 7 . Fruchte Wälder, Gebüsche, Gräben, Bäiche selten, nur im östlichen und nordöstlichen Gehiete. Aue bei Burg Liebenau selten, Wälder zwischen Srhkeuditz mul Ki. Dölzig häıfig, im Bruche zwisehen Sanderstlorf und Bitterfeld, Wiesen bei Alten und Kochstedt unweit Dessall. Mai - Juni. Blumenblätter gelb, mit röthlichen Adern, aussen mit einem ruthbraunen Anfluge. Höhe 1-112:

124. Terbang (soll rom celtischen Worte rub, roth, stammen und we. gen der rothen Früchte einiger Arten so benannt sein).

a. Uniruchtbarer Stengel $k$ ahl; Blätter 3-5zählig.

1. Bit titerunterseits griun oder etwas grat.

336. R. plicatus weihe u. N., faltige B. Weih. t I. Unfruchtbarer Stengel liahl, kantig, mit zerstrenten, zuriickgekrïmmten Starheln bestzt; Blätter an unfruchtbaren Stengel 5zählig; Blïttchen eiförmig-r'undlich, zugespitzt, liings den Verven gefaltet, oherseits kahl, unterseits grün, fein-behaart oder sammethaarig; Fispe cinfach, luckerblüthig, meist wenig stachelig, Kelch zur Frucl.tzeit zurückgeschlagen. Ђ. Waldränder, Gebüsche nicht selten z. B. am Frenzelholze hei Lieskan, im Zorgs, am Rand des Bergholzes, am Bienitz 11. s. w. Juni. Juli. R. fruticosus L. nach Fries. Blune weiss. Frucht glänzent - schwarz. Der blühende Stengel ziemlich aufrecht. Andert ab:

b) fastigiatus Weihe u. N. (als Art), gipfelbliithige B. Weihe t. II. Unfruchtbarer Stengel weniger stachelig, Blätter flach; Frïchte dunkelblutroth. R. suberectus Anders.

c) nitidus Weihe u. N. (als Ait), glänzende B. Weihe t. IV. Blättchen oberseits glänzend, meist etwas kleiner, Blume meist blass-rusenroth. R.

*) $0 \mathrm{~b}$ die hier angenommenen, zum Theil von Weihe aufgestellten Arten wirklich als solche betrachtet werden können, ist nicht eher mit Bestimmtheit zu sagen, bis Culturversuche, welche am besten mit Aussaat der Samen in den botanischen Gärten anzustellen sind, ein sicheres Resultat geliefert haben. Es unterliegt jedoch keinem Zweifel, dass auch in Deutschland weit mehr gute Arten gefunden werden, als Linne kannte, wenn auch Weihe in Aufstellung derselben zu weit gegangen ist. - Beim Einsammeln dieser Arten darf der unfruchtbare Stengel mit cinigen Blättern nicht unbeachtet bleiben. 
corylifolius Hayne, so in der Dölauer Heide, am Lindberge u. s. w.

337. R. affinis Weihe u. N., verwandte B. Weihe t. HI. Unfruchtlarer Stengel kahl, kantig, mit meist grekrïmmten Stacheln besetzt, Blätter an unfruchthiren Stengel 5zählig, Blätchen herz-eiförmig, zugespitzt, nü am Grunde etwas wellenförmig, sonst flach, oberseits fast kahl, unterseits griin, fein-behaalt; Rispe zusammengesetzt, stachelig, an den Verzweigungen meist beblättert. Kelch zur Fiuchtzeit angedrïckt. ち. Waldränder, Zäıne z. B. am Rande des Bergholzes. Juni. Juli. Blume weiss. Frucht blauschwarz.

2. Bläter unterseits weiss-filzig.

338. R. fruticosus we ih e u. N., Bus ch-B. Weihe t. VII. Unfruchtbarer. Stengel kahl, kantig, mit zerstreuten, fast geraden Stacheln besetzt; Blätter am unfiuchtbaren Stengel 5zählig, Blïttchen länglich-eiförmig, das endständige schwarh herzförnig, zugespitzt, flach, oberseits kahl, unterseits orau-oder weiss-filzio; Rispe zusammengesetzt, lïnolich und meist schmal, stachelig; Kelch zur Fruchtzeit zurückgeschlagen. $\hbar$. Trockene Wälder besonders im Zorgs. Juni. Juli. R. candicans Weihe. Blume weiss. Frïchte schwarz.

b. Uufruchtharer Stengel hehart; Blätter 3-5zählig.

339. R. vulgaris weihe u. N., gemeine $B$. Weihe t. XIV. Unfruchtbarer Stengel beharet, 5kantig, mit schwach-gekrümmten Stacheln besetzt; Blätter am unfruchtbaren Stengel 5zählig, Blättchen eiförmig, zugespitzt, oberseits kahl, unterseits grau-filzig; Rispe weit ausgebreitet, Stiele derselben zottig und mit grösseren oder kleineren Stacheln besetzt. $\hbar$. Waldränder nicht gerade selten $z$. B. am Frenzelholze, am Bergholze. Juni. Juli. Blume weiss. Früchte schwarz. Aendert ab:

a) viridis Wimm.: unfruchtbarer Stengel schwach behaart und unterwärts fast kahl, mit dünneren Stacheln besetzt; Blätter grün, unterseits weichhaarig; diese Form ist weit seltener als die folgende.

b) mollis Weihe: unfruchtbarer Stengel behaart, oft zottig, aber ohne Drüsenhaare; Blätter unterseits meist grau-filzig; dies ist die gewöhnliche Form. 
c. Unfruchtharer Stengel drüsenhaarig; Blatter 3-juählig.

340. R. corylifolius sm., haselblüterige B. We ihe t. XI,V. Unfruchtbarer Stengel rundich, schwach. 5kantig, zerstrcut-clriisenhaarig, mit gerarten Sitacheln; Bläter all unfruchtharen Stengel 5zahligr, Blättchen sehr breit, weich, änsseres oder beide äussere Paare sitzend; Rispe "enighlüthig, lower; Keloh zur Fruchtzeit abstehend. 4. Ifechen, läume, Wüller. Am Bienitz. Blume ziemlich gruss, weiss oder rosenroth. Frucht bäulich-schwarz. Die Blätter sind den Hasel. blättern (von Coryl. Aielland) ähulich. Aendert ab:

a) vulgaris Weihe: unfruchtbarer Stengel behaart, mit wenigeren stacheln besetzt; Blätter oberseits etwas hehaart, unterseits weichhaarig.

b) tomeutosus Weihe: unfruchtbarer Stengel wie bei der vorigen Abart; Blätter unterseits weisslichfilzig

c) fer" $x_{\text {W }}$ ihe: Stacheln am unfimchtharen Stengel und an den Blattstiele'n weit hräftiger und nebst den Drüsenharen zahlrejcher.

d. Unfuchtharer Stengel ber eif t; Blätter 3zählig.

341. R. caésius L., bläuliche B., Kratzbeere. Weihe t. XINI. Unfruchtbarer Stengel dïnn, stielrund, blïulich-bercift, mit feiuen Stacheln und Borsten besetzt; Bliitter 3ziihlig (die unteren selten 5zählig), Blättch€n eiförmig oder rautenförmig, die seitenstänılgen sitzend; Rispe wenigbtüthig; Blumenblätter länglich, ausgerandet. ち. Aecher, Gebüsche, Wälder gemein. Juni-Aug. Früchte schwarz, bläulich-bereift. Aendert ab:

a) umbrusus Wall : : unfruchtharer Stengel kahl, schlauk und dïnu; Blätter Bzählig, Blättchen unterseits schwarh- weichhiarig, die Seitenhlättchen "ft 2lappig. R. catesius e. aquaticus We ihe. Diese Abart kommt auch mit zerschlitzten Blätchen und blattartig auslaufenten, oft gefiederten Kelchzipfeln vor.

b) arve $u$ is $W$ a $\| 1 \%$ : unfruchtbarer Stengel kahl, dichter bestachelt; Blättchen unterseits fast sammetartig; so auf Aechern. R..caesius $\beta$. agrestis Weihe.

c) pseudo-caesius Weihe: unfruchtharer Stengel ziemlich dünı, feill-behaart, mit wenigen zurickgekrünmten Stacheln besetzt; Blätter 3zählig, Blätt- 
chen unterseits weiss - filzig, das mittlere fast 3lappig, so besmoders in Wälilern.

d) pse ud u-idaeus We ihe: untruchtbarer Stengel dicker, liahl, dicht bereift, mit blauen Stacheln; Blätter 3- oder 5zählig, oberseits runzelig, unterseits grünfilzig, so in Heckel.

e. lirüchte ruth.

342. R. Idaeus L., Himbeere. We ihe t. XLVII. Stengel aufrecht, stiplrund; Blitter 7 zïhlig-gefiedert, obere 3 zïhlig, mnterseits weiss filsig; Rispe wenigblïthig; Blumenbliitter verkehrt-eiförmig, aufrecht; Kelch abstehend. 万. Wälder, Grbusche z. B. in Ite Dölaner Heide, im Bienitz u. s. w. Mai. Juni. Blume "eiss. Frucht mit kurzen, feinen Haile" bedecht, roth uder in cultirirten Znstande bisweilen " eiss oder gelb. OFF. baccae Rubi Idaei.

343. R. saxátilis L., Felsen-B. We ihe t. IX. Unfruchtbarer Stengel niedergestrecht, ausläuferaltig, fruchttragender tast krautartig, anfrecht, ganz einfach; bliitter auch am unfruchtl,aren Stengel 3 iihlig, beiderseits griin; Rispe nn 3-6hluthig, Blumenblïtter linealisch-liinglich: Keloh abstehend-aufreaht $\hbar$. Hochliegenile, nieist truchene $\mathrm{l}$, ubwälder, heineswegs inmer anf Kalk, wie von Einigen angegeben wird. Zerstreut; fehlt bei Halle; findet sich im Bienitz, bei Nammburg verbreitet z. B. im Burhhulze, am lothariusberge im Lodersleber Forste, im Bornthale bei Allstedt ziemlich häufig. Mai. Juni. Blune hlein. Frucht roth, aus 3 oder 4 ziemlich grossen Beerchen bestehend, deren Steinschaalen in getruckneten Zustande immer höckerig-runzelig sind. Fruthttragender Stengel nur $1 / 4-1$ ' hoch. - Auf kalkhaligem, truckenem Boilen fehlen die auslänferartigen unfiuchtharen Stengel uft ganz, so in Wäldern zwischen Keugfeld und Branderode und am Schlifter bei Freiburg.

Ausser den aufgezäliten Arten wird von Wallr. (sched. p. 229) noch Rubus hyhridus Vill., wurunter aber nach Weihe (cf. Rub. german. p. 97) R. glandulosus Bell. oder R. Bellardi Weihe zu verstehen ist, für das Gebiet angegeben mol zwar in der Dölauter Heide und im Ludersleber Forste als sehr selten vorkommend. Der Verfasser fand ihn bisher nuch nicht. Von Sprengel wird in der 2. Aufl. der Flura S. 224 noch R. Schlechtendalii W e i h. erwähnt, welchen R chb. sax. p. 336 aufgenommen hat. Diese Angabe verdient 
jedoch wenig Beichtung, da Sprengel a. a. O. die Weiheschen Arten mit der grössten Willkuhr gedeu. tet hat.

125. Frogánia I. Erdbeere (von fragrare, duften, wegen des Wuhlgeruches der Frïchte).

344. F. vesca $\mathbf{L}$., ge ne ine E. Hay ne Arzneigew. IV, 26. Blätter 3zählig; Haare ans Schafte und an den Blattstielen wagrecht-abstehend, an den seitenstiindigen oder an allen Biiithenstielen anfrecht oder angedriickt; Kelch bei der Fruchtreife weit abstehend oder zuriicligekriimmt; Staubgefässe kaum so lang als das Fruchtknotenköpfchen. 24. Wälder, Gebüsche, Hügel, Wiesen gemein. Mai. Juni. Blume rein-" Neiss, wie bei der fulgenden. Schaft $1-4$ " huch.

345. F. elatior $\mathbf{E} \mathrm{h} \mathbf{h} ., \mathrm{h}$ o he E. H a y ne Arzneigew. IV, 27. Blätter 3zählig; Haare der Blattstiele, Schafte und siimmtlichen Bliithenstiele wagrecht-abste. hend; Kelch bei der Fruchtreife weit abstehend oder zuriickgekriimmt; Staubgefässe an der fruchtbaren Pflanze so lang als das Fruchtknotenköpfchen, an der unfruchtbaren doppelt so lang. 24. Bergwälder sehr selten. Der Verfasser hat sie nur in Hackenhulze bei Branderode zwischen Merseburg und Freiburg gefunden; von IV allr. Wird sie auch bei Lodersleben angegeben. Mai. Juni. Schaft his $1^{\prime}$ hoch und weit zottiger, als an den beiden anderen Arten; Frucht grösser, weisslich-roth.

346. F. collina $\mathrm{W} \mathbf{x h}$. If ï gel - E., Ki nackelbee re. Hay Haare an Schafte und an den Battstielen wagrecht-abstehend, an den seitenstiindigen wder an allen bliitlienstielen aufrecht oder angedriickt; Kelch an die Irucht angedriickt; Staubgefisse der unfouchtbisen Pfinze doppelt so lang als das Fruchtinutenköpfchen. $\frac{1}{4}$ Sunnige, trucktne Stellen, Hiigel, hesunders Kalkberge, Wiesen. In Hügeln bei Grinau, am lindberge, Zurgs, an den Bergen bei Bennstelt, in Mittelhulze und Petersberge, an Hügelı und auf Wiesen bei Röglitz, am Bienitz, bei Naumburg und Freiburg häufig, an der Steinhlippe bei Wendelstein, an den Bergen bei Bibra und Schmon, bei Allstedt besonders in den wïsten Bergen, bei Eisleben und an sonnigen Bergen überhaupt nicht selten. Mai. Juni. Blume gelblich-weiss. Frucht härter als bei den vorigen Arten.

Dicse Pflanze ist im Gebiete keineswegs selten, 
aber lange übersehen worden. Zuerst gibt sie $\mathbf{B}$ uxb. enum. p. 116 unter dem Namen Fiagaria fructu albo C. B. an unfruchtbaren Bergen bei Querfurt an; sie ist darauf merkwürdiger Weise ron Leysser, Wohlleben und Sprengel hal. ed. 1. ganz übersehen und wird erst wieder von IV allr. ann. bot. p. 70 für das Gebiet angegeben.

126. Cónnaruma L. Blut a uge (Pflanzenname bei Apul.).

347. C. palustre L., Sump f - B. Wurzet kriechend; Stengel autsteigend; Blätter unpaarig-gefirdert, mit $\mathbf{5}$ oder 7 scharf-gesägten, oberseits dunkelgrïmen, nnterseits bläulich-grïnen Blättchen. 4. Simpfige Torfwiesen sehr zerstreut. In Walde zwischen Ziegelrode und Schmon, hänfiger im nordöstlichen Gebiete z. B. an der Bennilurfer Bühle selten, anf dell Turfwiesen bei Crina östlich von Bitterfeld, hei Dessau in der 'Torfsterherei bei Möst und auf den Wiesen bei Alten. Juni. Juli. Blume dunkel-purpurroth, weit hleiner als die inwendig dunkel-rothbraunen Kelchblätter. Stengel $1-3^{\prime}$ lang.

Sprengel will nach der 2. Aufl. der Flura S. 226 diese Pflanze anch bei Schkeuditz gefunden haben.

127. Fố tign, wegen vermeintlicher Heilkräfte der $P$. Anserina).

A. Potentillae genuinae. Früchtchen kahl.

a. Acephalae. Die einfache Wuzel treibt einen einfachen oder getheilten Stengel, aber nicht zugleich Bätterbiischel.

348. P. supina L., niederliegender G. Sturm Heft 91. Strugel meist niederliegend oder aufsteigend, gabelästig; Blätter gefiedert, Blättchen länglich, eingeschnitten-gesägt, die nberen herablaufend; Blüthen einzeln; Bliithenstiele nach dem Ferbliihen zuriiclgchriimmt. $\odot$. Flussufer, 'T'eiche, laarhen, in Dörferı an feuchten stellen zerstreut. An der Saale zwischen Kröllwitz und deu Vorwerk Gimritz, an den Lachen in kröllwitz. anf ïberschwemmiten Aeckern in der Aue bei Naumburg häufig, bei Aschersleben in den Teichen nach Hecklingen zu, im Schackenthaler Busche hel Sandersleben. Juni-Octob. Blume klein, gelb. Stengel $1 / 2-1^{\prime}$ lang. 
b. Multicipites. Die ausdauernde, holzige, vielköpfige Winzel treibt blühende Stengel und zugleich Blätterbïschel.

\section{Hlätter gefiedert.}

349. P. rupestris L., Fe Isen-G. Sturm Heft 91. Stengel aufrecht, oherwärts gabelspaltig; mintere Bliitter gefiedert, obere 3 ziihlig, Bliittchen cifürmig-rundlich, eingeschnitten - gesügt, "richhrarig; Nebenhlätter ungetheilt; Blumenhlätter verkehrt-eiförmig, länger als der Kelch. 24. 'Trurkent Wälder, sumuige, diirre Plätze selten. Findet sich in dél Dölnuev Heide und hei se. ben gar nicht mehr und im Mittelholze nur äısserst selten; häufiger in lel tbbatissine bei Kitten und besonders in Krosigker Holze hinter dem Petersberge; fohlt bei Merseburg, Weissenfels, Naumburg umit Fieiburg bis Lodersleben mol Lamlgraforde hin; hei Allstelt nu. an einem Wege in ter Nähe der Lelıngruben ru der südlichen, dem Theilholze zugewandten, Seite des Hagens; fehlt dann wieder bei Eisleben, Aschersleben, Sandersleben und erscheint erst am hohen Ufor der Torfstecherei bei Viöst und an dürren, freien Plätzen an der Gottsche bei "Zörkeritz zwischen Bitterfeld und Delitzsch wieder. Mai. Juni. Blume weiss, einer Erdbeere ähnlich. Höhe 1'.

350. P. Anserina L., gemeiner G. Sturn IIeft 4. Stengel rankenartig, kriechend; Elïtler nnterbrochengeficdert, vielpaarig, Blättchen länglich, scharf-u*sä̀t; stengelständige Nêbenblätter scheidenförmig, vielspaltig; Blumenblïtter rumdlich verkehrt-eiförmig, duppelt so lang als der Kelch. 24. 'Triften, Srhutt, Wege, Gräben, Pfiitzen überall gemein. Mai-Juli mod im Herbste. Blume gelb. Stengel $1 / 2-1 \frac{1}{2}$ lang. Die Blätter sind oberseits grün, unterseits "eiss-seidenharig: sie ändern aber ab:

a) viridis Koch: Blätter spärlich behaart; beiderseits yrïn;

b) serícea Koch: Blätter beiderseits seidenhaarig, weiss-glänzend.

h. Blätter gefingert; Blumen gelh.

351. P. argéntea $L_{0}$, silberweisser G. Sturm Heft 17. Stengel anfstcigend, filzig, an der Spitze ebensträussig; Blätter 5zähliug, Blüttchen aus ganzrandigem, verschnïlertem Grunde verkehrt-eiförmig, tief-eingeschnitten-gesägt oder fiederspaltig: am Rande umge- 
rollt, unterseits weiss - oder grau-filzig; Bliithenstielchen auch nach dem Verbliihen gerade; Früchtchen runzelig, unberandet. 24. Trockene, sonnige Plätze, WValdränder, Raine, Mauern überall gemein. Juni. Juli. Blume gelb. Höhe $3 / 4-11$. Aendert ab nit uberseits grasgriinen oder grauen und oft glänzenden, unterseits weissfilzigen oder auch oberseits weissfilzigen, nur mit dünnerenı Filze ïberzogenen Blättesn.

352. P. reptans L., kriechender G. Sturu Heft 91. Stcngel rankenfürmig, gestreckt, einfach, an den Gelenlien wur:elnd; Blätter 5zïhlig, mit einigen eingemischten 3zïhligen, Blättchen länglich - verkehrt eiförmig, fast vom Grunde an gesägt, kahl oder unterseits angedrückt - behaart; Blïthen einzeln; Blïthentheile 5zählig; Frïchtchen körnig-rauh. 24. Wege, Gräben, Ackerründer, feuchte Triften, in Dörfern gemein. Juni-Aug. Blume goldgelb. Stengel 1-2'lang.

353. P. Tormentilla sibth., B lut w u r z - G., A r mentillwurzel. Sturm Heft 34. Stengel niederliegend oder aufrecht, obernüirts ästig; nicht wurizelnd, weichhaarig; Blätter 3zïhlig, sitzend oder die unteren

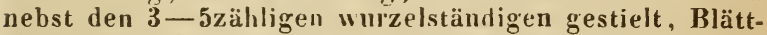
chen länglich-lanzettlich, eingeschnitten-gesägt, am Grunde ganzrandig, an den unteren Blättern verkehrt eiförmig; Nebenblätter 3 - vielspaltig : Bliithentheile meist 4zählig; Erüchtchen schwach-runzelig. 4. 'Trockene Wälder, Wiesen, Triften, Heiden häufig z. B. am Dunnersberge hinter Kıöllwitz, in der Dölawer Heide u. s. w. Juni. Juli. 'Tormentilla erecta I. Blume klein, dottergelb. Stengel $1 / 2-1^{\prime}$ lang. OFF, rad. Tormentillae.

354. P. procumbens sibth., gestreckter G. Sturn Heft 92. Stengel rankenförmig, gestreckt, oberwärts ästig, fruchttragende an den Gelenken vurrzelnd; Blätter gestielt, 3zählig oder die untersten 5zählig, Blättchen verkehrt - eiföınig, eingeschnitten - gesägt, unter der Mitte keilförmig unıl ganzrandig; Nebenblätter ganz oder 2-3zähnig; Bliithentheile meist 4zïhlig, Früchtchen fein-runzelig. 24. Schattige, trockene Wälder sehr selten, mit Sicherheit nur bei Laue nordöstlich von Delitzsch. Juni. Juli. P. nemoralis Nestl. Tormentilla reptans I. Blume goldgelb. Stengel $1 / 2-$ $1 \frac{1}{2} 2^{\prime}$ lang. Die Stengel treiben gegen Herbst an den Gelenken Wurzelfasern und ein Büschel Blätter und theilen sich hieranf in viele Stöcke, was bei P. 'Turmentilla Sibth. nie der Fall ist.

Garcke, Flora. 
Diese seltene Pflanze wird zuerst von Sprengel mant. 1. p. 8 unter dem Linnéischen Namen 'Tormentilla reptans mit der Bemerkung erwähnt, dass sie nach Schwägrichen in rauhen II äldern vorkomme, ohne einen bestimmten Standort beizufïgen. Ëbenso verführt Spreng. in des 2. Aufl. der Flora, wenn er sagt, lass sie in Wälern seltener vorkomme, alsu wiederum heinen Fundort angibt. Da die Wälder in der Nähe von Halle aber ganz audere Bodenrerhältnisse besitzen, als diejenigen sind, welche diese Pflanze liebt, st muss der Verfasser das Vorkommen derselben durrhaus bezweifeln und ist $\mathrm{zu}$ dem Glauben geneigt, lass sie von sprengel immer verwechselt ist, wie dies bri einigen Pflanzen nachgewiesen werden kann. - Rchb., welcher hierbei merkwürdigrer Weise das keineswers seltene 5blätterige Vurkommen der Blüthentheile bei der $\mathrm{L}, \mathrm{i}$ un é ischen Gattung 'Tormentilla bezweifelt, fïhrt in der flor. sax. p. 333 in Fulge der Sprengel'schen Angabe Halle als $\mathrm{zuverlässigen} \mathrm{Standurt} \mathrm{für} \mathrm{P.} \mathrm{pro-}$ cumbens an!!

355. Perna L., Frühlings - G. Sturm Heft 17. Stc̈immchen gestreckt, of wurzclnd; Stengel aufsteigend, nebst den Blattstielen von aufrechten, etwas abstehenden Haaren spärlich behaart; untere Blätter 5- und 7zählig, Blättchen länglich - verkehrt-eiförmig oder verkehrt-eiförmig, bald kahl, bald am Rande vder unterseits, bald ober- und unterseits einfach behaart, tiefgesägt; unterste Nebenblätter schmal-linealisch; Nïsschen schwach - runzelig. 24. Wälder, Waldränder, trukkene Abhänge häufig, obwohl seltener als die Abart b. Im Mittelhulze, am Sichweizerling bei Wettin, bei Dïrrenberge, bei Naumburg häufig u. s. w. April. Mai. Blume gelb. Höhe $3-6^{\prime \prime}$. Aendert ab:

b) cinérea Chaix (als Art). S t. Heft 92. Stengel nebst den Blattstielen und Blättern mit aufrechten, etwas abstehenden Haaren besetzt und zugleich ron Sternharen grau-filzig; so besonders an Porphyrfelsen unıl auf Nuschelkalk. Bei Halle weit häufirger als die Hauptart, an anderen Orten des Gebietes selten, so bei Naumburg. - Eine hierher grehörige Form mit 3zähligen und untermischten $4-5$ zähligen Blüttern ist $P$. suhacaulis Wulf., St. Heft 92, so an IVeinbergen zwischen Rullsdorf und Seebur:.

356. F. opāca L., glanzloser G. Sturm lieft 17. 
Stämmchen gestreckt, oft wurzelnd; Stengel aufsteigend und nebst den Blattstielen rauhhaarig, Haare verlïngert, wagrecht - abstehend; Blätter 5 - und 7zählig, Blättchen länglich-keilförmig, tief - gesägt, gestutzt; Nüsschen runzelig. 4. Waldränder, sonnige Raine und Anhöhen etwas seltener als rorige Art. 'Waldränder des Mittelholzes, Raine zwischen Bennstedt und Kölme, an Kauschens Hölzchen bei Merseburg, an sonnigen Waldrändern bei Naumburg, Freiburg und Allstedt verbreitet. Mai. Juni. Blume gelb, etwas kleiner als bei P. verna. Der $3-6$ " hohe Stengel ist meist roth angelaufen.

B. Fragariastrum DC. Frïchtchen auf der ganzen Oberfläche oder wenigstens am Nabel nit Haaren besetzt. Blume weiss.

357. P. alba L., weisser G. Sturm Heft 4. Stämmchen kriechend, Stengel schwach, aufsteigend, Wurzelblätter lang - gestielt, 5zïhlig, Blättchen lünglich-lanzettlich, nur an der Spitze gesägt, fast ganzrandig, oberseits kahl, unterseits und am Rande seidenhaarig; Früchtchen an Nabel behaart. 24. Trockene Waldränder nicht gerade selten. Am Donnersberge hinter Kröllwitz, an den Rändern der Heide, im Busche bei Seben, am 'Tannenberge bei Gutenberg, im Nittelholze, am Rande des Bienitz und auf den benachbarten Wiesen, bei Naumburg, Freiburg, Allstedt, Eisleben verbreitet. Mai. Juni. Blume gross, wriss. Höhe 3-9".

358. P. Fragariastrum Ehrh., erd bee rblät te riger. G. Sturm Heft 92. Stämmchen niederliegend, oft wurzelnd und lange Ausläufer treibend; Stengel schwach, niederliegend; meist 2blïthig; Wurzelblätter lang-gestielt, 3ziilılig, i:lïttchen rundlich-ciförmig, uberseits zirmlich hahl, unterseits zottig, die jingeren seidenhaarig, das mittlere bis zur Hailfte, die seiten. stündigen un der ïusseren Scite fast vom Grunde an gesügt, das stcngelstiindige 1,latt 3zühlig; Früchtche॥ an dem Nabel behaart. " 7. Buschige Hiigel, Waldränder sehr selten. Luphulz bei Schochwitz; bei Naum. burg in Sperlingsholze und im Walde zwischen Rossbach und Nismitz. April. Mai. P. Fragaria Sm. Fragaria sterilis L. Blune wciss, so lang, etwas kürzer oder länger als der Kelch. Höhe 2- 4".

Diese: Pflanze, welche ganz die 'Tracht der gemeinen Walderdbeere (Frag. vesc.) hat, kummt auch ohne Ausläufer ror. 
Die Standorte bej Seben und Lettin nach Wallr. und vor der Breihahnschenke nach Spreug. mant. 1. p. 9, welche von Spreng. selbst in der 2. Aufl. der Flora als unsicher nicht wieder citirt werden, hätten von $\mathrm{Rchb}$. fl. sax. p. 329 nicht nachgeschrieben werden sollen. Was die Fundorte bei Lodersleben und Rossleben nach Wallr. ann. bot. p. 71 und in Hazen bei Esperstedt nach S prengel hal. ed. 2. p. 228 anlangt, so weiss der Verfasser nicht anzugeben, ab sie noch jetzt Giltigkeit haben.

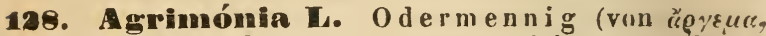
Fleck im Auge, der Staar, gegen welchen die P'flanze oft angewandt wurde).

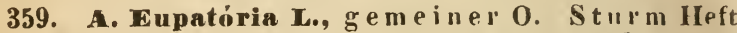
59. Stengel aufrecht odes aufsteigend, ranhhaarig; Blätter unterbrochen - gefiedert, Blättchen längl ch-lanzettlich, gesägt, unterseits grau-kurzhaarig, das unpaarige gestielt, die dazwischen gestellten kleineren eiförmig, gesägt; Aehren verlängert; Fruchtkelche verkehrt-kegelfürmig, der ganzen Liinge nach sefurcht, am Grunde mit weit abstehenden, weichen stacheln. 4. Buschige Hügel, Wegränder, truckene Wiesen, Grasplätze, Gebüsche nicht selten z. B. am Berge zwi. schen Nietleben und der Dölaurr Heide, an lindberge u. s. w. Juni - Aug. Blume goldgelb. Höhe 1-3'.

360. A. odorata it., wohlriechender 0 . Stengel aufrecht, nehst der Unterseite der Blätter und der Kelchröhre mit langen Haaren und zugleich mit zahlreichen, kleinen, weisslichen Drüsen bedeckt; Blätter unterbrochen-gefiedert, Blättchen länglich-lanzettlich, gesägt, das unpaarige gestielt, die dazwischen gestellten kleinesen eiförmig, gezähnt; Aehren verlängert; Fruchtkelche halblingelig - glockenförmig, nuт bis zu* Mitte schvach-gefurcht, mit zurïckgeschlagenen, äusseren Stacheln. 24. Bisher nur auf der Grenze des Gebietes: an Waldrändern bei Leutzsch östlich vom Bienitz beobachtet. Von Wallr. wird sie auch bei BayerNaumburg angegeben. Juni - Aug. A. procēra W allr. Blume goldgelb. Höhe $1-3^{\prime}$. Alle Theile duften angenehm.

129. Hoga I. Ros e (ein bei vielen rönischen Schriftstellern varkommender Pflanzenname, welcher von dem celtischen Worte rhos, roth, abgeleitet sein soll). 
a. Pimpinellifoliae. Der Stiel des in Mittelpunkte des Kelches stehenden Fruchtknotens kürzer als die Hälfte desselben oder fehlend. Nebenblätter fast gleichgestaltet. Blïthen einzeln, deckblattlos, oder mit einem einzigen Dechblatte gestützt. Die jungen Stämme mit sehr vielen, ungleich grossen Stacheln besetzt.

361. R. Lutea Mil1., gelb e R. Guimp. t. 84. Stacheln der diesjährigen Wurzeltriebe gerade, gedrungen, an den $Z$ weigen zerstreut, etwas gekrümnt; Blättchen 5-9, rundlich oder elliptisch, meist doppelt-gesägt, beiderseits lebhaft grün; Nebenblätter gleichgestaltet, linealisch - keilförmig, an den Rändern zurückgebogen, mit abstehenden, zugespitzten Oehrchen; Kelchzipfel mit Anhäingseln, kürzer als die Blume, an den platt-kugeligen Friichten weit abstehend oder zurïckge. bogen; Staubbeutel am Grunde spiessförnig. ち. Diese schon von Leyss. ed. 1. p. 91 in Zäunen und Gebiischen bei Passendorf und Schlettau als selten angegehene Rose ist daselbst nur verwildert. Juni. R. Eglanteria L. mit Ausschluss der Synonyme. Blume dottergelb; Frichte gelb-scharlachruth. Ein 4-6' hoher Strauch.

362. R. pimpinellifolia DC., $\mathrm{s}$ te in pe t e r l e in blä t terige R. Guimp. t. 86 . Stacheln ungleich, pfriemlich und borstenförmig, gerade, an den diesjährigen Wurzeltrieben gedrungen, an den Zweigen zerstreut; Blättchen 5-9, rundlich oder eiförmig, meist einfach gesägt; Nebenblätter linealisch-keilförnig, mit etwas abstehenden, zugespitzten Oehrchen, die der blïthenständigen Blätter breiter; Kelchzipfel ungetheilt, halb so lang als die Blume, linealisch-zugespitzt, an den platt-kugelförmigen, lederartigen Friichten zusammen. neigend. $\hbar$. Sonnige Hügel sehr selten. Wirklich einheimisch wuhl nur an den Schmonschen und Grockstedter Bergen, sunst öfters in Hecken rerwildert.

Bisher hat der Verfasser nur die Form mit liahlen Bliithensticlen beobachtet, welche die $R$. pimpinellifolia L. ist.

b. Cinnamomeae. Die Fruchtkmoten in Mittelpunkte der Kelche, doppelt so lang als ihr Stiel; Blüthen in 3-6blüthigen Ebensträussen an der Spitze der Aestchen, sämmtlich mit einem Deckblatte gestützt; die Nebenblätter an den blüthenständigen Blättern breiter als die der übrigen. 
363. R. cinnamómen L., Zimmetruse. Guimp. t. 85. Stacheln der diesjährigen Stämme gerade, gedrungen, ungleich, die grösseren pfriemlich, die kleineren borstenförmig, drüsenlos, die der Kweige nur zu zweien am Grunde der Blattstiele, etwas melı gekrümmt; Blättchen 5 oder 7 , eiförnig - länglich, einfach-gesägt, unterseits aschgrau oder blaugriin, weichhaarig; Nebenblïtter der nicht bliihenden Zuveige linealisch-länglich, rinnenförmig, an den blïthenständigen Blättern oberwärts verbreitert, mit etwas abstehenden, eiförmigen, zugespitzten Oehrchen; Kelchzipfel ganzrandig, mit lanzettlicher Spitze, so lang als die Blume; Friichte kugelförmig, markig, mit dem bleibenden, zusammenschliessenden Kclche gekrönt. †. In Hecken, Zäunen. Gebïschen verwildert $z$. B. in Ilecken an den Teichen bei Dieskan, in Zäurien bei Gutenbery, bei Schortau zwischen Merseburg und Freiburg, bei Opphausen und sonst nicht selten. Mai. Juni. Stengel und Aeste gew öhnlich zimmetbraun. Blume rosenroth. Friichte roth. Höhe $4-6^{\prime}$.

364. I. turbinata At., kreiselfriichtige R. Stacheln der diesjährigen Stämme gedrungen, ungleich, die grösseren aus verbreitertem Grunde pfrienılich, fast sichelförmig, die kleineren burstenförmig, mit drïsentragenden Bursten untermischt, sämntlich inı Alter verschwindend; Zweige wchrlos; Blättchen 5-7, eiförmig, runzelig, grob-einfach-gesägt; Nebcnblätter der bliithenständigen Blätter elliptisch-verbreitert, die der ïbrigen länglich, ziemlich flach, mit gerade hervorgestreckten, eiförmigen, zugespitzten Oehrchen; Kelchzipfel so lang als die Blume, mit werigen, oft sehr kleinen Anhängseln; Friichte elliptisch uder länglich, mit dem schr abstehenden Kelche gekrönt. $\hbar$. Sonnige Berge. Im Gebiete nur verwildert $z$. B. in Hecken bei Nietleben und Granau, in Westewitz südlich vom Petersberge, an den Westerbergen bei Aschersleben und sunst öfters. Juni. R. campanulata Ehrh. R. francofurtana Vï nchh.

c. Caninae. Die im Mittelpunkte des Kelches stehenden Fruchtknoten so lang als ihr Stiel; sonst wie die vorige Abtheilung.

365. R. canina L., Hunds-R. Stul'm Heft 18. Stacheln derb, sichelförmig, am Grunde verbreitert, zusammengedriickt, ziemlich gleich, an den Stänmen zerstreut, an den Zweigen meist $\mathrm{zu}$ zweien am Grunde der Blattstiele; Blättchen 5 oder 7, elliptisch oder ei- 
förmig, scharf - gesägt, die oberen Sügezühne zusam. menneigend; Nobenblätter der blüthenständigen Blätter elliptisch, verbreitert, die der übrigen länglich, ziemlich flach, mit gerade herrorgestreckten, eiförmigen, zugespitzten Oehrchen; Kelchzipfel fiederspaltig, ziem.. lich so lang als die Blume, zurückgeschlagen, zuletzt von der elliptischen oder rundlichen, meist knorpeligen Frucht abfallend. †. Zäune, Hecken, Gebüsche, Waldränder. Juni. Höhe 4-9'. Dieser vielgestaltige Strauch kommt im Gebiete in folgenden Fornen vor:

a) vulgaris Koch: Blattstiele, Blättchen, Bliithensticle und Kelchröhre kahl; Blattstiele öfters mit entfernten Drüsen bestreut und zuweilen am Grunde etwas hehaart. Blume rosenroth; dies ist die häufigste Form.

h) dunıtorun Thuill. (als Art): Blattstiele iiberall behaart; Blättchen unterseits auf den Hauptadern oder auf der ganzen Fläche fein-behaart; Bliithenstiele lahl; Blumenblätter rosenruth uler fleischroth; hierher gehört R.. collina DC., nicht J a c q., R. corymbifera B o rkh.; so besonilers an Waldründern z. B. an der Dölauer Heide.

c) collina Koch: Bliithensticle, oft auch die Kelchröhre driisig - steifhaarig; Blätter und Blattstiele kahl oder fein-behaart; Blumen rosenroth oder fleischroth, zuweilen weiss.

1) Jacquiniana (Flor. Frib.). Sturm Heft 34. Blattstiele und die cinfach - gesägten Blättchen unterseits weichhaarig oder schwach-zottig; Blï. thenstiele und Kelche am Grunde drüsig-borstenförmig. R. collina Jacq. u. Rau. An Hügeln, Feldwegen selten; bei Döllnitz, auf dem Gottesackes vun 'T'euditz.

2) trachyphýlla Rau (als Art): Blattstiele drüsig; 13lüitchen fast 3 fach-gesägt, beiderseits kahl, unterseits anf den Nerven oft drüsig; an Waldrändern selten. Am Waldrande Kl. Dölzig gegenïber in der Nähe des Schkeuditz - Dölziger Weges.

3) a lba L.: Stacheln schwächer; Blättchen eiför. mìr-rundlich, unterseits bläulich-grün, nebst den Blattstielen behaart; Blüthenstiele und Kelchzipfel drüsig-steifhaarig; Kelchröhre kahl oder steifhaarig; Blumenbläter weiss oder blass-fleischfarben; in Hecken bisweilen verwildert; in gefüllten Zustande oft in Gärten als Zierstrauch. - 
Ob diese Rose wirklich eine Abart von R. canina L. ist, wie dies Koch syn. p. 252 ganz bestimnt behauptet, vermag der Verfasser uicht zit entscheiden.

d) sepium Koch: Blattsticle und Blïtchen unterseits oder aurh beiderseits mit klebrigen Driisen bestrcut; Bliithenstiele und Kelchröhre kahl. Bei dieser Form ist die nur schwach-knorpelige Frucht oft mit dem bleibenden Kelche gekrönt, so an Bergen in Wettin. OFF. fructus et semen Cynosbati.

366. R. Tubiginosa C., W e i n rose. S turm Heft 18. Stacheln derl, sichelförmig, am Grunde wenig zusammengedriickt, an den Stänmen zerstreut, ungleich; Blïtchen 5 oder 7, elliptisch, unterseits driisig, am Rande fein-driisig - gesägt, Sägezähne etwoas abstehend; Nebenblätter der blïthenständigen Blätter elliptisch, etwas verbreitert, die der ïbrigen länglich, ziemlich flach, mit gerade hervorgestreckten, eiförmigen, zugespitzten Oehrchen; Kelchzipfel fiederspaltig, fast 80 lang als die Blume, weit abstehend, oft etwas zurückgeschlagen, zuletzt ron den rumlichen, fleischig-knorpeligen Fiüchten abfallend. ち. Hügel, truckene Waldränder, Wege, Raine häufir z. B. an Berge bei Granau, auf breiten Rainen zwischen Nietleben und Bennstedt u.s. w. Juni. R. Eglanteria Mill. R. suarifolia Lightf. Blume lebhaft purpurroth, bald grösser, bald kleiner. Ein 2-5' hoher Strauch.

Durch die kleineren, zuweilen fast rundlichen, unterseits drüsentragenden, nach Wein oder Obstfrüchten duftenden Blätter, dunkler-rosenrothen Blütlen und ungleichen Stacheln von den Abarten der R. canina unterschieden. Die Blüthenstiele sind entweder kahl oder mit drüsentragenden borstenförnigen Stacheln besetzt; die Blumen zuweilen einzeln.

367. R. tomentosa Sm., filzige R. Sturm Heft 18. Stacheln derb, lang, fast gerade, am Grunde wenig zusammengedriickt, an den Stämnen zerstreut, ungleich; Blättchen flliptisch oder eiförmig, doppelt-gesägt, graugriin, fein-behaart; Nebenblätter der blüthenständigen Blätter elliptisch, verbreitert, die übrigen länglich, ziemlich flach, mit gerade hervorgestreckten, eiförmigen, zugespitzten Oehrchen; Kelchzipfel fiederspaltig, so lang als dis nicht driisig-gewimpcrten Blumenblätter, an den rundlichen, knorpeligen, meist stacheligen Frïchten zurïckgeschlagen, bleibend oder 
sehr spät abfallend. ち. Wald- und Wiesenränder, Wege, Grbüsche häufig z. B. in der Dölaner Heide, in der Aue zwischen Burg Liebenan und Wallendorf, in Berowäldern bei Naumburg und Bibra nirht selten. Juni. R. Ilarginata Wallr. nach Koch. Blumenblätter rosenroth. Ein 4-7' hoher strauch.

Durch die langen, schlanken, meist wagrecht-abstehenden, fast geraden Stacheln und die aschgraue, weder abwischbare, nuch von Haaren herrühende Farbe der Blättchen run allen Arten unterschieden. Die Blättchen sind iibrigens unterseits bald drüsenlos, sehr weich anzufülen, bald dicht-drüsig und daher rauh anzufühlen, selten ziemlich kahl. Die Früchte sind entweder kugelig (R. nullissima Willd.) oder eiförmig (R. hispida $B$ urkh., R. villusa Pull.).

368. R. pomífera Kermann, A p f el-R. Stacheln derb, aus verbreitertem, zusammengedriicktem Grunde pfriemlich. gerade, an den diesjährigen Stämnen zerstreut, ungleich; Blättchen länglich-lanzettlich, doppelt-gesägt, graugrün; Nehenblätter der blüthenständigen Blitter elliptisch - verbreitert, die der ïbrigen länglich, zimmlich flach, mit gerade hervorgestreckten, eiförmigen Oehrchen; Kelchzipfel fiederspaltig, so lang als die driisig-gewimperten Blumenblätter, bleibend, an den grossen, kugeligen, nickeuden, sehr stacheligen Frichten aufrecht - zusamniengeneigt. ち. An Weinberge bei KI. Godula bei Diirrenberge. Juni. Blume rosenroth.

d. Rosae nobiles. Fruchtknuten sämmtlich sitzend; Nebenblätter gleichgestaltet, an den blüthenständigen Blättern kaum breiter.

369. R. gállica C. Cindl., französische R. Stacheln der diesjährigen Stämme gedrungen, ungleich, die grösseren aus breiterem Grunde pfriemlich, schwach sichelförmig, die kleineren burstenförmig, die Blïthenstiele und Kelche mit driisentragenden Borsten besetzt; Blättchen elliptisch oder rundlich, einfach gesägt, etwas steif-lederartig, unterseits stark aderig und etwas rauh; Nebenbliitter schmal-linealisch-länglich, flach, mit auseinanderfahrenden, ei-lanzettlichen, spitzen Oehrchen; Kelchzipfel fiederspaltig, kürzer als die Blumenblätter, an den aufrechten, fast kugeligen, knorpeligen Früchten zurïckgebogen und zuletzt abfallend. 24. Waldränder, Aecker. Juni. Blume gross, purpurroth. Hiervon findet sich in Gebiete nur die Abart: 
h) pumila L. fil. Sturn Heft 34. Stengel nu $1 / 2-1^{\prime}$ hoch, nebst den Kelchen und Blüthoustielen mit zahlreichen, röthlichen Drüsenbursten besetzt; Blätter kleiner, rundlich oder rundlich-eiförmig. Nicht häufig. An der südseite der Pröse bei Werlitzsch nördlich von Schkeuditz, in der Nähe der Wälder von KI. Dölzig, bei Naumburg in den Weinbergen zerstrent $z$. B über der Henne, an sumpfigen Waldplätzen in der Nähe von Wilsdorf siidlich vun Freiburg, auf Aeckern am Fusse der Berge bei Bibra, besonders nach Steinbach zu, in den w üsten Bergen bei Allstedt. R. austriaca Crantz.

Die Abart mit höherem, bis $5^{\prime}$ huhem Stengel nnd grösseren, ei-läıglichen Blättchen (R. gallica der Autor.) wird oft als Zierstrauch in Gärten gezogen.

\section{Familie. Sanguisorbeen Lindl. Wiesenknopf gewächse.}

130. Alchemilla L. Sin a u (Pflanzenname bei Plinius; vielleicht " $r$ gen der vermeintlichen Kräfte in der Alchemie su benannt. Der deutsche Name Sinau ist aus dem veralteten $\sin$ oder sint $d$. h. immer, und Au, Owe d. h. Wasser, zusammengesetzt, also eigentlich Immerfencht, weil sich 'Thau- und Regentropfen auf den jungen, tutenförmigen Blättern sanimeln und lange halten).

370. A. vulgaris L., gemeiner S. Sturn Heft 2 . Stengel aufsteigend; Wurzelblätter langgestielt, nierenförmir , 7-9lappig, meist beiderseits grün, Lappen fast halbkreisförmig, ringsum gesägt. $1 / 3$ der ganzen Blattlïnge einnelimend; Blüthen in endständigen Ebensträussei, meist 4 mämnig. 24. Schattige Wälder, feuchte Wiesen zerstreut. In Walde zwischen Döllnitz und Burg Liebenau, in Wäldern bei Schkeuditz zwischen der Elster und Luppe; bei Naumburg zerstreut und einzeln; bei Nebra im Wangener Grunde, in der Aue bei Bibra häıfig, im Mühlthale bei Zliegelrode und auf Waldtriften bei Ludersleben, $b+i$ Eislehen in Katharinenholze einzeln und häufiger auf Wiesen im Bischofsröder Forste, in Błnche zuischen Sandersdorf und Bitterfeld. Mai - Juli. Blume hlein, gelblich-grïn. Höhe $1 / 2-1^{\prime}$. Aendert áb: die ganze Pflanze kahl oder dicht weichhaarig, die Lappen der Blätter kürzer oder etwas länger und die Blätter am Grunde weniger herz- 
förmig und abgestutzt. Dies ist A. truncata T'a usch. Eime bemerkenswerthere Form ist:

b) A. II $1 \mathrm{ntana}$ W ill d. enum. A. vulgaris $\gamma^{\prime}$ hybrida Willd. sper. A. alpina $\beta$. hybrida L. Blätter oberund besmolers unterseits seidenartig-zottig, so auf Waldtriften bei liegelrode, selten.

371. A. arvensis scop., Feld-S. Stengel fadenförni., niederliegend, aufsteigend oder aufrecht, meist ästig, Bliitter handförmig - .sspaltig, am Grunde keilförmien, 'Zipfel virne eingeschnitten, 3-5zählig; Blïthen in den Blattwinkeln gekwänelt, einmännig. $\odot$. Aecker häufig, z. B. Aecker an Dunnersherge hinter Kröllwitz, ebenso am Dölauer Kirchholze, zwischen der Dieskaner Mïhle und Döllnitz. Mai - Merhst. A. Aphanes I.e ers. Aphanes arvensis I. Blüthen klein, gelblich - grüı. IIöhe $2-4^{\prime \prime}$.

131. Sanguisórba T. Wi esenknupf (von sanguis, Blut, und sorbere, saugen, weil die Pfanze friiher zum Blutstillen gebraucht wurde).

372. S. officinalis L., gemeiner W. Hayne, Arzneigew. VIII, 22. Stengel aufrecht, ästig; Blätter unpaarig-gefiedert; Blättchen kurz-gestielt, herzförmig-länglich, gelierbt-gesägt, am Grunde ohne Nebenblätter: Blïthen in eiförmig-läıglichen, dınkelruthbraunen Köpfrhen; Staubgefässe ungefähr so lang als die Kelchzipfel. 24. Fenchte Wiesen häufig, z. B. auf Wiesen an den Pulverweiden, auf der grossen Wiese hei Passendorf, sehr häıfig im Görz bei Wörnlitz, auf der Wiese zwischen Dölau unıl der llejde u. s. w. Juni - Aug. Höhe 2-5'. Aendert ab:

b) auriculata Scop. Blättchen am Grunde mit Nebenblättchen.

132. Potérium I. Biberuelle*) (ein bei griechischen Schriftstellern rorkommender Pflanzenname).

373. P. Sanguisórba L., wiesenknop fähnliche B. Hay

*) Der deutsche Name Bibernelle, welchen ursprünglich die Gattungen Sauguisorba und Poterium führten, kann nicht auf die Gattung Pimpinella übertragen werden, sondern muss der Gattung Poterium mit um so grösserem Rechte bleiben, als noch jetzt in manchen Gegenden wie in der Provinz Sachsen Poterium Sanguisorba L. unter dem Namen Bibernelle oder Pimpinelle nicht selten zuin 
steigend; Blätter unpaarig-grefiedert, Blättchen der untere॥ Blätter eiförmig - rundlich, am Grunle herzförmin oder abgestutzt, mit viel kleinerem Findzahne, die der obren länglich, schärfer gesägt; Blüthen in kugelförnigen, anfangs grïuen, später röthlichen Köpfchen, die muteren männlich, die oberen weiblich, dir mittleren öfter zwitterig; Kelche zur Fruchtzeit knöchern. verhärtet, 4 kantig, mit stumpfen Kanten. 24. Irockeme, somnige Berge; besunders auf Kalk wicht gerade selten. Bei Bennstedt, Kölma, Rollsdorf und Seeburg hänfig, an Abhängen des Apolluberges bei Westewitz, bei Röglitz einzeln, an sonnigen Anhöhen bei Dürrenberge, Keuschberg und Weissenfels häufin, bei Eisleben an den Abhängen des Katharinenholzes links vom Wege nach Kreisfeld sparsam. Juni. Juli. Höhe $1-1 \frac{1}{2}$ '. Aendert ab mit kahlem, unterwärts kurzhaarigem Stengel: P. guestphalicum B o enningh. und mit unterseits bläulich-grünen Blättchen: P. glaucescens Kchb.

\section{Familie. Pomaceen Lindl. Apfel- gew ächse.}

133. Crataegus C. W e is sd o r n (Pflanzenname bei Theophrast, von \%outüó, stark, fest, abstammend, wegen des festen Holzes).

374. C. Oxyacnintha $X_{\text {., g }}$ eme iner W. Gui mp. t. 72. Blätter verkehrt-eiförmig, 3-5lappig, eingeschnitten und gesägt, am Grunde keilförmig, unterseits weit bleicher, nebst den Aestchen und Bliithenstielen kahl; Kelchzipfel aus eiförmigem Grunde zugespitzt; Griffel 1-3; Früchte eiförmig, 1-3steinig. t. Hecken, 'Zäune, Waldgebuische gemein z. B. Lindberg, Zurgs, Mittelholz u. s. w. Mai. Juni Mespilus Oxyacantha Gärtn. Blume weiss. Ein 6-15' hoher Strauch.

Die Theilung und Gestalt der Blätter ist sehr veränderlich: bisweilen haben die Blätter nur 3 kurze, stumpfe Lappen oder sind auch ganzrandig (M. oxyacanthoides 'I'huill.), bisweilen tief 5spaltig und stark gesägt (Crat. Oxyacantha apiifolia Med.).

375. C. monógyna Jacq., eingriffeliger W.

Küchengebrauche gebaut wird. Für Pimpinella ist der schon bei Tabernaemontanus vorkommende und jetzt noch vom Volke gebrauchse Name Stein peterlein anzuwenden. 
G u im p. t. 73. Hlätter verkehıt - eiförmig, tief $3-5 \mathrm{spal-}$ tig, eingeschnitten und gesägt, am Grunde keilförnig, unterseits bläulich-grïn; Aestchen kahl: liliithenstiele zotlig; Kelchzipfel lanzettlich, zugespitzt; Griffel 1; Früchte fast kugrelförmig, 1steinig. h. Hecken, 'Zäune, Waldränder, seltener als die vorige Art. Lindholz, Korgs, an Bienitz, häıfig bei Nammburg an Waldrändern. Blibhet 14 'Tage suäter als C. Oxyacantha. Blume kleiner, weiss. Aendert in Gestalt der Blätter wie die vorhergehende Art ab.

Nach Moret ti ist Crat. monogyna Ja $q$. die ächte C. Oxyacantha I. der Spec. plant. und der I innéischen Sammiung. - llass die Abbildungen dieser beiden Sträucher bei Jacquin mit den von ihm gegebenen Diagnosen nirht ibereinstimmen, ist bekannt.

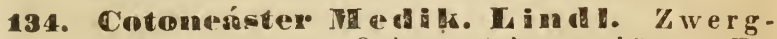
mispel (ron cotwneum, Quitte und der angehängten Endumg aster, mit ler Bedeutung ähulich, wegen der filzigen Blätter und Früchte).

376. C. vulgaris Lind1., g e me in e '/. Flora v. Thüring. II, 15. Blätter eiförmiır uder rundlich-eiförmig, ganzrandig, unterseits tilzig: Blïthenhüichel 2-3bliithig; Kelche und die iiberhäigenden Frïchte kahl. ち. Steinige Iügel, Kalkberge stellenweise. Am Felsen zwischen kröllwitz und der Kreuzschäferei und auf dem Kellerberge in der Hejle sparsam, etwas häufiger am Schweizerling bei Wettin, fehlt bei Merseburg und Weissenfels; an den Kalhbergen bei Naumburg und Freiburg, schmon und Grockstelt sehr häıfig, fehlt im iibrigen fiebiete. April. Mai. Mespilus Cotoneaster 1. Blume klein, weisslich-roth; Fruchte roth, mit 3 Steinen. Ein $2-5$ ' hoher Strauch.

135. Méspoilua T. (mit Ausschluss von Arten). Mis pel ( 'Theophrast; die von 'Théis gegebene, von Don 11. A. aufgenommene Erklärung diestes Namens ist unwahrscheinlich).

377. M. germanica L., de uts che M. Guimp. t. 69. Blätter lünglich-linzettlich, ganzrandig, nur an der Spitze schwach-gesägt, unterseits filzig, Blïthen endständig, einzeln; Kelchzipfel länger als die Blumenblätter. $\hbar$. Wälder und Waldränder zienılich selten und meist nur einzeln vorkommend; wirklich einheinisch wohl nur in der Brenau bei Wettin, am Bienilz 
und an Waldründern bei Naumburg, z. B. am Sperlingsholze und über den Almericher Weinbergen, sonst häufig in Obstgärten angepflanzt, so bei IIalle, wn dieser Baum ganz bestimnt nicht wild ist. Mai. Blume weiss. Iföhe $6-18^{\prime}$.

136. Cyulónia Toumuef: Quite (nach dem Stammorte Cydın, jetzt Canea, einer Stadt auf Kreta, bellannt).

378. C. vulgaris Pers., ğemeine $Q$. II ayne Alzneigew. IV, 47. Blätter eiförmiı́, ganzrandig. unterseits nebst ren Kelchen filzig; Blüthen enlständig, einzeln; Kelchzipfel eiförnig, driisig-grzähnelt, Bımenblätter an Grunde bïrtig. ち. In Obstgäiten gebaut und öfters in Läunen verwildert; aus den siiden und Sïdosten von Europa stammend. Mai. Pyrus Cydonia L. Blume weiss, mit röthlichen Anfluge. Frucht gross, apfelartig, citronengelh. - Aendert mit birnförmigen, länglichen oder fast kugeligren Früchten ab.

137. HPyms 耳. B irn- und A p f e l b a u m (Pflanzenname bei Plinius).

379. Pyrus communis L., gemeiner Birnb. Guimp. t. 75. Picitter eiförmig, ungefähr so lang als der Blattsticl, kleingesägt, in Alter nebst den Zweigen und Knospen kahl; Blüthenstiele ebensträussig; Griffel frei. h. Wälder, Felsen und in vielen Abarten gebaut. April. Mai. Blume weiss. Ein 20-60' hoher Baum, aber wild fast nur als Stranch vorkommend. Aendert ab:

a) glabra Koch: Ueberzug der Blätter diunn, bald nach ihrer Entwichelung verschwindend.

b) tomentosa $\mathrm{K}$ och: Filz der Blätter dicht, fast bis in den Herbst bleibend. P. Pollveria Lej., nicht I. P. communis $\%$. dasyphylla 'T'a us ch.

380. H. Falus L., gemeiner Apfelb. Hayne Arzneigew. IV, 46. Blaiter eiförnig, kur/-zugespitzt, kahl oder unterseits filzig; lilattstiele halb so lang als das Blatt; Blïthenstiele ebensträussig; Griffel bis zur Mitte zusammengewachsen. t. In IVäldern einzeln und in vielen Abarten gezogen. Mai. Blumenblätter weiss, mit ruthem Anfluge. Höhe bis $3 \theta^{\prime}$. Aendert ab:

a) P. acerba Merat: Griffel kahl oder an Grunde wollig; Blätter und Fruchtknoten kahl.

b) P. Malus $\beta$. mitis Wallr.: Blätter unterseits und Fruchtknoten wollig. 


\section{Sorbag L. Eberesche (Pflanzenuame bei} Plinius).

381. S. aucupária L., grime ine E., Quitschbeere. Bliitter unpaurig-gefiedert, in del Jugend zottim, in Alter kahl oder unterseits ein wenig filzig; Blättchen länglich, spitz - gesägt; Knospen filzig; Frïchte hugelfürmig. ち. Wälder mud. Gebïsche, nicht selten. Mai. Juni. Pyrus aucuparia Gärtn. Blume weiss. Frucht roth.

382. S. domestica L., $\mathrm{z}$ a h m e E. Sturm Ieft 34 . blütter unpuarig-:efiedert, in der Jugend zottig, im Alter kahl; Blättchen eiförmig oder eiförniø-länglich, spitz-grsägt; Knospen kuhl, klebrigr; Iriiclite Lirnförmig. . Bisher nur in len Weinbergen hei lireiburg einzeln gefunden z. B. nach Scheiplitz hin und in den Weinbergen bei Russbach unweit Naumburg. Nach Wallı. " ar dieser Baum früher auch im Wendelsteiner Furste. Mai. Pyrus Sorbus Gärtn. Blume weiss.

383. S. torminalis Crantz, Els e be e re. Guimp. t. $\times 0$. Llïtter in Unfanye breit-eiförmig, gclappt, im Alter lahl: Lappen ungleich-gesü̈t, zugespitzt, dic unteren grösscr, abstehend; Fruchte länglich-eiförmig. ち. Bergwälder zerstrent. Fehlt bei llalle, Merseburg und Weissenfels; bei Naumburg häufig z. B. an Pfurten. berge, im Buchholze. in den laasen, in den Wallungen ron Rossbach nach Freiburg zu; an der Steinhlippe bei Wangen und Wendelstein, an den sibmonschen Bereren, im lodersleber Furste, be्i Allstedt in Rathshulze und einzeln auf der Wüste zwischen dem Rathsteiche und lem Kirschluche, an bewaldeten Anhöhen bei Wulferode und im Katharinenhulze bei Eisleben, in Wäldern bei sandersleben; fehlt im östlichen und nordöstlichen Gebiete. Mai. Cratapgus torminalis I. Blu. me weiss. Frucht lederbraun und weiss punktirt. Wird bis 80 ' huch, konmut jedoch im Gebiete weit häufiger als Strauch vor.

\section{Fanilie. Oncogrurieen Juss.}

Nachtkerzengewächse.

1. Gruppe. Onagreen DC. Aechte Nachtlerzengewä chse. Kelchröhre länger als der Fruchtknoten; der freie Theil mit dem Saume abfallig. 
139. Fublóbium T. Schotenweiderich (den Namen Epilubim bildete $\mathbf{C o n r}$. Gesner aus cov żлi $\lambda \hat{\beta} \beta o v$, Veilchen iiber der Schote, die Stellung der Blume auf dem schon zur Bliithezeit verlängerten Fruchtknoten andentend, im Gegensatz zur Viola matronalis, jetzt Hesperis matronalis, welche die Schote ïber der Blume trägt).

A. Chamaenerion Tausch. Blätter zerstrent. Blumen ausgebreitet. Sitaubgefässe am Grunde zusam. menfliessend, dann abwärts geneigt.

384. E. angustifolium L., s chmalblätte riger Sch. Sturm Heft 81 . Wurzel liriechend; Stengel glatt; Blätter zerstreut, lanzettlich, seltell elliptischlanzettlich, ganzrandig oder drïsig-schwach-gezähnelt, aderig; Blumenblätter verkehrt-eiföımig; Griffel zuletzt abwärts gebugeu. 24. Freie, ausgehauene Waldstellen, Waldräuder nicht selten $z$ B. in der Dölauer Heide u. s. w. Juli. Aug. Blume gross, purpurroth. Höhe $2-4^{\prime}$.

B. Lysimachion T aus ch. Untere Blätter gegenständig, obere wechselständig. Blumen trichterförmig. Staubgefässe aufrecht.

a. Stengel nicht mit erhabenen linien belegt und nicht aweizeilig behaart.

385. E. hirsutum L., r a uh ha ariger Se h. Sturm Heft 81. Wurzel ausliinfertreibend; Stengel stielrund, sehr ästig, run einfachen längeren und kürzeren drüsentragenden Haaren zuttig; liliitler stengelumfassend, mit blattartigem Grunde cin wenig herablanfend, Ianzettlich - länglich, haarspitzig, wezähnelt - kleingesägt, Sägezähne eiuwärts gebogen; Blumenhliatter verkehrt herzförnig, doppelt so lang als die Kelchabschnitte; Narbe weit abstehend. 24. Gräben, Ufer, fenchte Gebüsche nicht gerade selten. Grüleen zwischen Bruckdorf und Dieskau, Gräben unter dem Vugelsberge hei Bennstedt, ebensu bei Röglitz und Kötschau, in Wejdengebüsch an der Saale hei Naumburg, an der kleinen Saale zwischen Almerich und Schulpforte, an Bächen bei Bibra hïufin, bei Sandersleben nicht selten. Juni. Juli. Blume gross, purpurroth. Höhe 3-4.

Der Stengel ist zuweilen nur mit kurzen Haaren besetıt, die Blätter oberseits kahl, unterseits nur auf den Nerven behaart oder der obere Theíl des Stengels, 
die Blüthenstiele und Kelche sind dicht wollig-zottig, diese letztere Form ist E. intermedium Merat.

386. E. parviflorum sch reber, $k \mathrm{l}$ e inblumi. ger Sch. Sturm Heft 81. Wurzel ohne Ausläufer : Stengel stielrund, meist einfach, von einfachen Haaren zuttig oder weichharig; Bliitter sitzend, nicht stengelumfassend und nicht herablaufend, lanzettlich, spitz, gezähnelt, meist $4 \mathrm{mal}$ so lang als breit, die unteren hurz-gestielt; Blumenblätter verkehrt-herzförnig bis 2spaltig; Narben zu Anfang der Blüthezeit zusammenhängend, später aufrecht-abstehend. Z4. Gräben, 'Teiche, in Weidengebüschen häufig $z$. B. Gärten zwischen llalle und Bölberg, zwischen Halle und Nietleben u.s. w. Juni. Jnli. E. hirsutum $\beta$. L. E. pubescens Roth. E. molle $\mathrm{L}$, nm. Blume hellviolett bis weiss. Höhe $1 / 2-2^{\prime}$.

357. E. montanum L., Berg-Sch. Sturm Heft 72. Wurzel olıne Auslïufer; Stengel stielrund, mit sehr kurzen, angedrïrkten Härchen besetzt; Blïtter ciför. mig oder eiförmig - liingtich, ungleich-gesägt-gezähnt, 2., selten 3mal so lang als breit, am Rande und auf den Nerven weichharig, die unteren, zuweilen auch alle kurz - gestielı; Blımenblätter verkehrt-eiförmig, 2spaltig, lünger als der Kelch; Narben abstehend. 4 . Wälder, Gebüsche nicht selten z. B. Wörmlitzer Hölz. rhen, Sebener Busch, Mittelholz und sonst häufig. Juni - Aug. Blume rosenroth. Iöhe 1-3'. Aendert ab:

b) verticillatum Koch. Sturm Heft 72 . Blätter $\mathrm{zu} 3$, quirlförmig.

c) I a nce latum Koch. Sturm Heft 72. Blitter eiförmig - länglich, stmmpfer, länger gestielt. E. nitidum Host.

d) collinum Gmel. Klein, dje Blätter wohl innal kleiner, die meisten wechselständig. Alle 3 Abarten kommen an gleichen Orten, wie die Mauptart vor, aber weit seltener.

385. E. palustre C., Sumpf - S ch. Sturn Heft 81. Wurzel mit fadenförmigen Ausläufern; Sitengel stielrund, kurz-behaart; Eliiticr lanzettlich oder linealisch-lanzettlich, ganzrandig oder schwach-gezähnelt, mit keilförmigem Grunde sitzend, die unteren gegenständig; Blumenblätter verkehrt-eiförmig, ausgerandel, etwas länger als der Kelch; Narben in eine Keulc ver. wachsen. f1. Sumpfige Wiesen, Gräben nicht gemein, Gräben bei Nistleben, Wiesen am Bienitz, in der Aue bei Naumburg und auf der Gröbizer Hiest, in dem

Garcke, Flora. 
fördlichen und nordöstlichen Gebiete häıfiger. Juli. Aug. Blume fleischfarben oder weiss. Höhe $1 / 2-1^{\prime}$.

Der stengel ist unter der Einfugungsstelle der Blaitter oft mit 2 grauen Haarstreifen bestzt, whe jedoch erhabene Iinien zu bilden.

h. Stengel mit '2 oder 4 erhithenen Linien belegt.

389. E. tetragōnum L., vi e rkantige r S c h. Sturm Heft 81. Wmrzel sprosscnd; Stengel aufrecht, meist sehr ästig und hahl, mit 2 orler 4 herablanfenden erhabenen Linien; Blätter lanzettlich, vom Grunde bis zur spitze allmählig verschmälert, fast 4 mal so lang als breit, zahnartig-gesägt, die mitlleren mit hlattartigem Grunde am Stengel herablaufend-angewachsen, die unteren kurz-gestielt orler tast sitzend; Blumenblätter verkehrt-eiförmig, tief 2 spaltig, so lang oder wenig länger als der Kelch; Narben in eine Keule verwach. sen. 4. Gräben, Bäche, Quellen nicht häufig. Gräben zwischen Halle und Reideburg, ebensn bei Dieskau und Kl. Dölzig; bei Delitzsch in der Nähe des Schiessstandes. Juni-Aug. Chamaenerion obscurum Schreb. Blume klein, rosenroth. Höhe 2-4'.

390. E. róseum schreb., rosenrother Sch. Sturm Heft 81. Wurzel faserig, ohne Ausläufer und. olme Sprossen; Stengel ästig, leirhblüthig, mit 2 oder 4 erhabenen, herablaufenden Linien, oberwärts weichhaurig; Blitter zicmlich lang-gesticlt, länglich, ah beiden Enden spitz, kaum 3mal so lang als breit, dicht ungleich-zahnartig-yesägt, an Ranile und auf den Nerven weichhaarig, die unteren gegenuberstehend; Blumenblütter verkehrt-eiförmig, 2spaltin, so lang als der Kelch; Narben in eine Kenle verwachsen od+r zuletzt etwas abstehend. 24. Grähen, Bäche, feuchte Stellen nicht gemein. Gräben am Fahrwege vur Seben, an einem Bache zwischen Wansleben und dem salzigen See, bei Naumburg und Aschersleben häufig, im nurdöstlichen Gebiete sehr selten. Juli. Aug. Blume klein, blass-rosenroth oder weiss, mit dunkelrothen Streifen. Höhe $1 / 2-2^{\prime}$.

140. Denothéna I. Nachtlierze (ein von Dioscorides für Epilubium angustifolium I. gebrauchter Pflan-

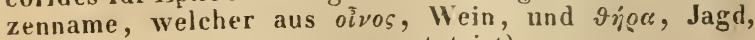
zusammengesetzt ist).

391. oen. biennis L., $z$ we ijährige N. Sturm Heft 5. Stenuel aufrecht, krautartig, meist einfach, 
kurz - weichhaarig und mit längeren auf Warzen sitzen: den Haaren bestrent; B! aittel gezähnelt, etwas geschweift, länglich oder ei-lanzettlich; Blüthen einzeln, pine zuletzt schr verlängerte, beblätterte Aehre bildend; Blumenblätter länger als die Staubgefässe. halb so lang als die Kelchröhre. (.). Stammt ans Virginien, seit 1614 in Eurwpa verwildert; auf Sandfeldern, Schutt, an Ufern nicht selten z. B. Gräben in Nietleben, oft in grosser Anzahl beisamnen, so am Luberbache bei der Benndurfer Vühle. Juni-Aug. Blume gross, gelb. Höhe $2-3^{\prime}$. Die Pflanze wird in Gebiete auch gebaut und die Wurzel davon unter dem Namen Rapontica als Salat genossen.

2. Gruppe. Circaeeen DC. Il exenkrautgewăchse. Kelchröhre den Fruchtinoten nicht überragent, mit 2 - oder 4 spaltigem, abfallenden Situme.

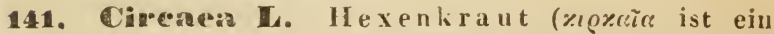
von Dioscorides gebranchter P'llanzenname, welcher mit der Zauberin Circe nicht im '/usammenhange zu stehen braucht, wie dies fast ïberall angegeben wird).

392. C. Iutetiana L., gemeines H. Sturm Heft 23. Stengel aufsteigend oder aufrecht, oft weichhaarig; Blätter eiförmig, an. Grunde etwas herzförmig, geschweift-gezähnelt; Blattstiele rundlich, rinnenförmig; am Grunde der 13liithensticlchen licine Deckbliitlchen; Bhumenblätter so lang als der Kelch; Friichte verkehrt-eiförmig, mit widerhakigen Stacheln besetzt. 4. Schattige, feuchte Laubwälder zerstreut. Auf der Rabeninsel bei Böllberg, sehr lıäufig in den Wäldern der Aue z. B. bei IIesmar, im Gemeindeholze bei Zö. schen und bei Schkpulitz; selten bei Allstedt, nur in der Hube unweit Voigtstedt, bei Eisleben sehr selten, nur in Helftaer Holze an dem ron Bischofsrode kom. menden Bache; häufig im Walde bei Löberslorf an der Fuhne und im nurdöstlichen Gebiete überhaupt nicht selten. Juli. Ang. Blume weiss orler röthlich-weiss. Höhe $3 / 4-11 /$ ¿ $^{\prime}$.

393. C. alpina L., Alpen-H. Sturm Heft 23. Stengel aufrecht, ästig, kahl: Blätter eiförmig odel breit-eiförmig, am Grunde herzförmig, geschweift-gezähnt, hellgrïn, fast durchsichtig; Blattstiele flach, hä̉utig-geflügelt; am Grunde der Bliithensticlchen kleine, borstenfürmise Decliblättchen; Blüthenspindel kahl oder wenig behaart; Blumenblätter kürzer als der Kelch; Friichte länglich-lieulcnförmig. 24. Feuchte, schattige 
raubwälder sehr selten, nur im Nichrim bei Oranienbaum und anf der Grenze des Gebietes zwischen Crina und Däben. Juni-Aug. Blume weiss oder röthlich. Höhe 3-8". Aendert ab :

b) intermedia lih rh.: Blattstiele rundlich, rimenförmig; Blüthenspindel druisig - behaart; Blumenbläter so lang als der Kelch; Früchté fast hugelig eifürmig. Höhe $1 / 2-1 \frac{1}{2}$ '。

Kleine Exemplare von C. intermedia Ehrh. mit wenig behaarter Blüthenspindel und etwas kleineren Blumenblätern sind kam, besonders ohne die gewöhn. lich vor der Reife abfallenden Früchte, von C. alpina I. zu unterscheiden, daher der Verfasser der Ansicht neutrer Beobachter ist, welche die C. intermedia für eine iippige Abart der $\mathbf{C}$ alpina halten. Von Einigen wird sic als Abart der C. lutetiana I. angesehen, von der sie jedoch durch die stets vorhandenen Decliblättchen bestimmt unterschieden ist.

3. Gruppe. Trapeen E. II eyer. Wassernussgewächse. Kelchröhre angewachsen, mit bleibendem Saume. Frucht nussartig, knöchern.

142. '㹂agrs kannt, da die angegebenen Ableitungen sehr unwahrscheinlich sind; nach L obel gab es einen Volksnamen Trapas).

394. T. natans L., schwinmende W. Sturm Heft 30. Wurzel im Schlamme kriechend; Stengel lang; untergetauchte Blätter haarförmig-grefiedert, schwimmende rautenförmig, gezähnt, gestielt; Blattstiele in der Mitte aufgeblasen; Blüthen einzeln, blattwinkelstänliš; Frïchte 4lurnig. $\odot$. Stehende Gewässer sehr selten, nur in dem Gross-Kïhuauer See bei Dessau und in den Seen bei Riesegk umweit Oranienbaum, aber an beiden Orten häufig. Juni. Juli. Blume weiss. Früchte schwarz-yrau, essbar.

\section{Familie. Halorageen R. B r. Me er-} beerengew ächse.

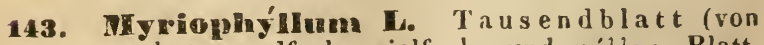
uvgior, zehntausendfach, vielfarh, und qiddov, Blatt, wegen der feiuzertheilten Blätter).

395. N. verticillatum L., quirlblüthiges $T$. 
Blätter quirlförmig, tief-fiederspaltig, mit haarfeinen Zipfeln; Blürhen in blattwinkelständigen und ährenförmigen Quirlen: Deckblälter sämmtlich kammförmig fiederspaltig. 4. Gräben und stehende Gewässer sehr zerstreut. Auf der Wiese hinter der Steinmühle nach Spreng., an Rande der Lachen in der Aue bei Naum. burg nicht selten, in Aschersleber See und bei Dessau häufig. Juli. Aug. Stengel $1 / 2-3 / 4$ ' hoch. Aendert ab:

a) pinnatifidum Wall $x$. Deekblätter so lang als die ïbrigen Blätter, vielmal grösser als die Blïthen; die Fiedern ziemlich entfernt von einander, so in langsam fliessenden Gewässern.

b) pinnatum Wallr. Deckblätter hleiner als die ïbrigen Blätter, 3 mal länger als die Blïthen; die Fiedern einander genähert, so in wasserreichen Gräben.

c) pectinatum DC. Deckblättes ungeführ so lang als die Blïthen, die Fiedern fast sich berührend, so am Rande stehender Lachen und an ausgetrockneten Gräben.

396. Mr. spicatum L., ährenblüthiges T. Blätter quirlförmig, fiederspaltig, mit haarfeinen Zipfeln; Blüthen in ährenförnigen Quirlen, die jungen Aehren aufrecht; die unteren Deckblïtter eingeschnitten, so lang oder etwas länger als die Blïthen, die iibrigen gan:randig und kürzer als die Blüthen. 4. Stehende Gewässer, Grïben, auch in Flüssen häutig z. B. im 'Teiche an der Strafanstalt, sehr häufig in Lachen am salzigen See u. s. w. Juli. Aug. Stengel unter dem Wasser oft $3-6^{\prime}$ lang.

\section{XXXV.Familie. Hippurideen Link. Tann- wedelgewächse.}

144. Hippuris T. T'a nnwed el (ein bei griechischen Schriftstellern vorkonmender Pflanzenname von

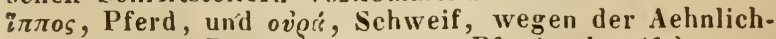
keit der Pflanze mit einem Pferdeschweife).

397. H. vulgaris L., g e me iner T. Sturm Heft 44. Wurzelstock verlängert; Stengel aufrecht, der blüthentragende Theil ausserhalb des Wassers; Blätter Jinealisch, zu 8-12 in Wirteln; Blüthen blattwinkelständig, sitzend, sehr klein; Früchte länglich. 24. Gräben und stehende Gewässer nicht gerade selten. In La- 
chen auf Jer grossen Wiese zuischen IIalle und Pas. sendorl, jn Gräben unl Toichen unmittelbal vor Bennstedt, an den Knappendorfer 'T'eichen bei Schknpau, ju sumpfigen Stellen und an 'Peichen bei Dailkan und Kweymen, in Gräben bei Kl. Dölzi und Dürrenberge, sehr häufig in Jachrn zwischen dem salzigen und siissen See bei Seeburg. Juli. Aug. Bliithen griin. Stengel 1-3' lang. In sehr tiefem wer reissembem Wasser fluthet der Stenge!, bleiht untergetaucht und wird zuweilen ästig, treibt aher lieine Bliithen, so im salzigen See.

\section{Familie. Callitricheen Link. \\ Wassersterngewäe hse.}

145. Callitriche $\mathrm{C}$. Wasserstern (ein ron Pli-

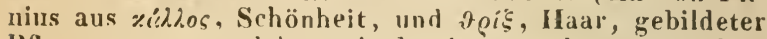
Pflanzennime, welcher mit der jetzt so, benanuten Gattung nichts gemein hat).

398. C. stagnalis s cop., Sumpf - IV. Abb. 4747. Blätter sümmtlich verkehrt-eiförmig; Dechblätter sichelförmig, an der Spitze gegen pinduder gebngen, bald kürzer, bald länger als die Frucht; Griffel bleihend, zuletzt zuruckgekrïmnt; Frucht kreisrund, breit ausgerandet, mit scharfkantigen, fliigelig - gekielten Rändern. 24. Bäche, kleine Flüsse, Gräben und Pfützen nicht selten. Nai - Octub. Die Länge des Stengels ist bei dieser Art wie bei den folgenden sehr veränderlich, oft nur 2", oft bis $10^{\prime \prime}$ lang.

399. C. vernalis Kiitz., Frühlings.W. Abb. 4746. Untere Blätter der Acste linealisch, obere verkehrt-eiförnig; Deckblätter etwas gebogen, kaum ein wenig länger als die spitz-gekielte Firucht; Griffel anfrechit, bald verschwindend. 24. Stehende und fliessende Gew üsser häufig. Nai-Octob. Lendert $a b$ :

b) minima Hoppe: die Pflanze viel heiner; alle Blïtter schmal-linealisch, abgestutzt oder auch ausgekerbt.

400. C. platycárpa Iítz., bre itfrüchtiger W. Abb. 4i48. Untere lilätter der Aeste lincalisch, of an der Spitze buchtig ausgerandet, wbere verkehrt-eiförmig; Deckblütter sichelförmig, an der Spit:e ziemlich gerade, so lang oder länger als die kreisrunde, schmal- 
ausgerandete, flügelig-gekielte Frucht; Griffel bleibend, zuletzt zuriickgekriimmt. 24. An gleichen Orten wie die vorhergehenden Arten, aber etwas seltener. MaiOctub.

401. C. hamulata Kiitz., hakenförmiger W. Abb. 4749. Untere Blätter der Aeste linealisch, obere verkehrt-eiförmig; Deckblätter kreis-sichelförmig, an der Spitze hakenförmig; Griffel bleibend, auseinander fahrend; Frucht kreisrund-elliptisch, sehr schwach-ausgerandet, mit scharfen, sehr schmal-geflügelten Kanten. 24. Verbreitung und Blüthezeit wie bei der vorigen Art.

\section{Familie. Cerctophylleen Gray. Igellockgewächse.}

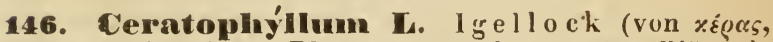
Hor", und wivd $20 \nu$, Blatt, wegen der starren Blätter).

402. C. demersum L., rauher I. Blätter quirlständig, durch einfarhe oder wiederholte Gabeltheilung in 2 oder 4 linealische, fadenförmige Zipfel getheilt; Friichte eiförmig, ungeflïgelt, am Grunde mit 2 zuriickgehriimmten Dornen, an der Spitze mit cinem der Frucht an Lïnge glcichkommenden oder sie ïhertreffenden Sta. chel. 24. Stehende und langsam fliessende Gewässer gemein. Juli. Aug. Wie die folgende Art untergetaucht; die Blätter sind dick, starr, dunkelgrün, leicht zerbrechlich, besunders wenn die Pflanze im Salzwasser wächst, wie in salzigen See bei Rollsdorf.

403. C. submersum L., glatter I. Blätter quirlständig, durch 3 fache Gabeltheilung in 5 bis 8 borsten. förmige Zipfel getheilt; Fröichte eiförmig. ungefliigelt, am Grunde ohne Dornen, an der Spitze mit einem Sta. chel, welcher mehrmal lïnger ist als die Frucht. 24. In Teichen sehr selten. Mit Sicherheit nur auf der Grenze des Gehietes im Teiche bei Leutzsch zahlreich und im Gross-Kühnaner Sז e bei Dessau. Juli. Aug. Die Blätter sind lebhaft grün und haben haarfeine Zipfel. Trägt wie die vorhergehende Art selten Früchte.

Sprengel gibt für diese änsserst seltene Art gar keinen Standort an. 
XXXVIII. Familie. Mythrarieen Juss. Weilerich gewächse.

17. Lythruma. We iderich (von $\lambda \dot{v} \vartheta \rho o \nu$, Purpursaft, wegen der Farbe der Blumen).

404. L. Salicaria L., ge me iner W. H a yne Arzneigew. III, 39. Stengel aufrecht, oberwärts ästig; Bliit. ter her z-lansettförmig, untere gegenüberstehend oder quirlförmig; Bliithen 12männig, quirlförmig und Aehren bildend; Kelche am Grunde ohne Deckblättchen, die Zähne desselben abwechselnd länger. 24. Gräben, Ufer, feuchte Gebiische, nasse Wiesen genein. Juli-Sept. Blume purpurroth. Höhe 2-4'. Aendert ab:

a) vu I g a re Pete I'm. : die pfriemlichen inneren Kelchzähne doppelt so lang als die äusseren; Griffel kürzer als der Kelch.

b) Iongistylum Koch: Griffel sehr lang, weit aus dem Kelche hervorragend, so an Gräben unmittelbar hinter den Nietleber Gärten, in der Nähe von Alsleben zwischen Mukrena und Trebnitz. - Die Blätter sind an beiden Formen mehr oder weniger kurzhaarig.

405. L. Hyssopifolia L., ysopblät teriger W. Stengel aufrecht, einfach oder wenigästig, Bliitter lanzettlich-linealisch oder lïnglich, am Grunde abgerundet, die untersten gegenüberstehend, die übrigen abwech. selnd; Bliithen 6nı̈nnig, einzeln in den Blattwinkeln vom Grunde des Stengels an; Kelch am Grunde mit 2 kleinen pfriemlichen Deckblättern, die Zähne desselben abwechselnd länger. $\odot$. Feuchte, sandige Triften und Aecker, Gräben zerstreut. Bei Halle nicht selten z. B. auf feuchten Aeckern zwischen. Dölau und der Heide, ebenso am Dölauer Kirchholze bei Lieskau, auf feuchten Aeckern bei Röglitz, am Bienitz, bei KI. Dölzig und bei Diirrenberge, auf überschwemmten Aeckern in der Aue bei Naumburg und bei Bibra, bei Aschersleben unter den Westerbergen, auf Wiesen bei Alten unweit Dessau. Juli - Sept. Blume klein, violett.roth. Höhe 4-9".

148. Peplis L. Bachburgel (Pflanzenname bei Dioscorides).

406. P. Portula L., ge meine B. Sturm Heft 1. Stengel niederliegend, vielästig, nit w urzelnden Aesten; 
Blätter gegenüberstehend, verkehrt-eiförmig, gestielt; Blüthen einzeln in den Blattwinkeln, fast sitzend; Kapsel kugelförmig. $\odot$. Ueberschwemmt gewesene Stellen, feuchte, schwach begraste Triften, Gräben, 'Teichränder nicht gar selten. In feuchten, wenig begrasten Stellen zwischen Kröllwitz und der Heide und Kröllwitz und Lettin, in der Aue bei Döllnitz, an iiberschwemmten Plätz'n an der Saale bei Naumhurg, auf 'T'riften hei Bibra, stellenweise bei Aschersleber, häufig bei Dessau. Juli-Sept. Blume sehr klein, bald abfallend, röthlich - weiss. Der meist roth angelaufene Stengel ist $3-8$ " lang.

\section{Familic. Cucurbitaceen Juss. Kürbisgewächse.}

149. Cucúrbita L. K ü $\mathrm{r}$ b is (Pflanzenname bei Plinius).

407. C. Pepo L., gemeiner $\mathbf{K}$. Stengel steifhaarig, kletternd; Blätter herzförnig, undeutlich 5lappig, rauh; Wickelranken ästigr; Früchte rundlich oder läng. lich, glatt. $\odot$. Culturpflanze aus Nittelasien. Juni Aug. Blume gross, gelt. Frucht gelb und grïn gestreift, essbar.

150. Crícrasais L. Gurke (Pflanzenname bei Plinius).

408. C. sativus L., gemeine G. Stengel steifhaarig, kletternd; Blätter herzförmig, 5eckig, mit spitzen Zipfeln; Wichelranken einfach; Früchte länglich, mehr oder" " eniger höckerig. $\odot$. Wird häufig gebaut; stammıt ans Isien. Mai - Aug. Blume gelb.

151. Sryóngar C. Zaunrïbe (Pflanzennane bei Dioscorides; soll von $\beta$ girev, sprossen, lierkommen, wegen des schinellen Wachsthunis).

409. F. alba L., schwarzbeerige Z. Sturn Heft 80. Stengel kletterud; Blätter herzförmig, 5lappig, gezähnt, schwielig-rauh; Blüthen traubenförmig, einhäusig; Kelch der weiblichen Blüthen so lang als die Blumenkrone; Narben kah!. 2. Zäune, Hecken, Gebüsche nicht gerade häufig. Zäune in Döllnitz, hällfiger bei Naumburg, Zäune in Nemleben an der Unstrut. Juni-Aug. Blunie grünlich-gelb. Beeren erbsengross, schwarz. Stengel $8-10^{\prime}$ hoch kletternd. 
Bryonia dioica $L$, führt Knauth enum. p. 2 miter dem Namen Bryonia aspera sive alba bacris ruhris C. B. an, aber schon Buxb. enmm. p. 44 zweifelt wwhl nicht mit Lnrecht an dem Vorkommen dieser P'flanze im Gebiete.

\section{Familie. Portulaceen Juss. Portu-} lakgewächse.

152. Portulíca L. Portulak (Pflanzenname bei Palladius, aber nicht bei Varro, wie öfter angegeben wird).

410. P. olerńcea L., gg eme in e r P. Stengel nebst den Aesten niedergestrerlit; Blätter länglich-keilförmig, fleischig; Bliithen gipfelständig oder einzeln, zu zweien und dreien in den Blattwinkeln sitzend; Kelchzipfil stumpf-gekiclt. $\odot$. Sandiger Boilen, Felsen ziemlich selten. An Felsen an der Saale Kröliwitz gegenüber, am Felsen an der Schönburg, auf Schutt un Naumburg. Juni - Sept. Die nur Mittags bei Sonnenschein sich öffnenden Bliithen sind gelb, wie bei der folgenden Art. Stengel $3-8$ " lang.

411. F. sativa Haw., gebauter P. Stengel aufrecht, mit aufstrebenden Aesten; Blätter verkehit -eiförmig, fleischig; Bliithen gipfelständig wder einzeln und zu mehren in den Blattwinkeln sitzend; Kelchzipfel auf dem Riicken gefliigelt - zusammengedriiclt. $\odot$. Wird zun hïr-hengebranche oft gebant. Juni-Sept. P oleracea $\beta$. L. Ist viel grösser und fleischiger als die vorhergehende Art.

153. MIOngin E. Montie (nach Joseph Monti, einst Prufessur der Botanik zu Bolugua, benannt).

412. Mr. minor Gme l., kleine M. Sturm Heft 11. Stengel sehr ästig, aufsteigend, nebst den gegeniiberstehenden, sportelförmigen Blättern fleischig unil kahl; Bliithen in kleinen, 2-5blüthigen Trauben; Samen kiötig-rauh, fast glanzlos. $\odot$. Feuchte Aecker selten und leicht zu vibersehen. Aecker zwischen Kröllwitz und der Heide links vom liege nach Dölan, weit seltener anf feuchten Stellen der decher, welche von der Heide und dem Kröllwitz-Dölaner Wage eingeschlossen werden, auf feuchten, sandigen Aeckern zwischen dem Bienitz und den Quellen, auf den Kuch- 
stedter. Wiesen hinter der Brachmeierei bei Dessan, auf der Hutıng an der Briickmiihle bei Oranienbaum. Mai. Blume klein, weiss.

Montia rivularis Gmel. wird schon ron Buxb. enum. p. 51 und von J,eyss. hal. ed 2. p. 31 unter dem Namen Cameraria aquatioa et maior Dill. an Bächen bei Bitterfeld erwähnt, und obgleich Sprengel hal. ed. 2. p. 61 ihr Vorhandensein im Gebiete läugnet, so könnte sie doch wieder aufgefundell werden.

\section{Familie. Paronychieen St. Hil. Pa-} ronychiengewächse.

1. Gruppe. Telephieen DC. Telephiengewähse. Blätter wechsel-, seltener gegenüberstehend. Blumenblätter von der Grösse der Kelchblätter.

154. Corrigioln L. Strandling (ron corrigia, Riemen, soll wegen der niederliegenden Stengel sis benannt sein).

413. C. littoralis L., ge meiner St. Stengel fadenförmig, mit zahlieichen, nach allen Seiten hin niedergestreckten, " enig verzweigten Aesten; Blätter abwechselnd, linealisch-keilförmigr; Blüthen gestielt, in kuaulartigen Wicheln; Blumenblätter so lang als der Kelch. $\odot$. Sandine, fenchte Plätze und Wege. Diese für das Gebiet sehr seltene Pflanze sull nach $B$ uxb. enum. p. 266 ind nach Wallr. sched. p. 126, obgleich von Beiden kein bestimmtes Citat angegeben wird, von Knauth an sandigen Aeckern bei ller Heide gefunden sein. $B$ u $x$ b. suchte sie daselhst vergeblich. Erst $\mathbf{W}$ a $11 \mathrm{l}$. (a. a. O.) fand sie an sandigen Stellen vor der Heide rechts vom Heidchause (Fasamerie) und ausserdem bei Bennstedt und Amsdorf. Spreug. (hal. ed. 2. p. 144) führt sie an kiesigen Orten bei Nietleben, Bennstedt, Lieskau und Wansleben als selten an. Der Verfassep findet sie weder in rer enum. plant. von Knauth angezeigt, noch hat er sie an len angeführten Orten geselıen, und vermag sie nur an der nordöstlichen Grenze des Gebietes bei Dessau und Oranienbaum anzugeben, woselbst sie selır häufig ist z. B. beim Kochstedter Thurhause und an der alten Leipziger Strasse bei Des. sau und in der unmittelbaren Näe von Oranienbaum am kalten Hause, anf Sandstellen bei der Kolonie Gnadicke, am Wege nach Dessau u. s. w. Juli. Ang. Blu- 
me sehr hlein, weiss, meist geschlosien, hugelförmig. Kelchblättchen grün mit röthlichem Saume. Stengel 3 -9" lang.

2. Gruppe. Ille cebreen D C. Knorpelkráutgewächse. Blätter gegenüberstehend (bei Ilerniaria in den Wicheln stets eines fehlschlagend). Blumenblätter fehlend oder schr klein, pfriemlich und Staubfäden ohue Staul,beutel ähnlich, einern nebenständigen Ringe eingefügt.

155. Hernix́åa I. 'Tausendkorn (von hernia, Bruch, wegen ehemaliger Anwendung).

414. H. glabra K., kahles T. Hayne Arzneigew. IV, 37. Stengel niedergestreckt, nach allen Seiten hin ausgebreitet; Blätter Klein, elliptisch oder länglich, an Grunde verschmälert, kahl; Blüthen meist zu 10 in blattwinkelständigen Käueln; Kelch kahl. 2. Sandige Brachäcker, Heiden, Triften gemein z. B. an Felsen zwischen Giebichenstein und T'rotha, am Felsen an der Bergschenke bei kröllwitz u. s. w. Juli-Oetob. Blumen sehr klein, gelbgrün. Stengel 2-6" lang. Aen. dert $a b$ :

b) puberula Peterm.: Stengel mit anliegenden, weichen Haaren bedeckt.

Die von Spreng. hal. ed. 2. p. 144 irrthümlicher Weise als Abart zur vorigen angeführte Hern. hirsuta $I_{\text {. }}$. kommt nicht im Gebiete vor.

156. Huéceloneara I. Knorpelkraut (von ille. cebra, Lockspeise, Augenweide, wegen der zierlichen Gestalt der Pflanze).

415. I. verticillatum C., quirlblüthiges K. Stengel niederliegend, narh allen Seiten hin ausgebreitet; Blätter klein, gegenüberstehend, verkehrt - eitörnig, sehr kurz gestielt, kahl; Blïthen sitzend, in blattwin. kelständigen Knäueln von silberweissen, knorpelartigen Deckblättchen begleitet. 24. Feuchte sandplätze sehr selten. Der Verfasser fand es nur bei Oranienbaum, aber daselbst häıfig z. B. aı der Briickmiihle, an der Kolonie Gnadicke, an Wege nach Dessau. - Von Spreng. wird es auf feuchtem Sandhoden bei Sollnitz unweit Raguhn angegeben, angeblich von Schwabe gefunden, welcher diesen Standurt in der fl. anh. aber nicht erwähnt; nach erhaltenen Exemplaren einzeln bei Wallendorf. Juli. Aug. Die sehr kleinen Blumen sind schneeweiss. Stengel $2-9$ " lang. 


\section{Familie. Sclerantheen Link. K na I- elgewächse.}

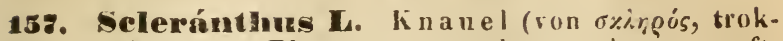
ken, und ๕̌v lusen Kelche).

416. S. annuus L., e injähriger K. Wurzel einjiilurig; Stengel aufrecht oder niederliegend; Blätter gegeniiberstehend, schmal - linealisc!; Bluthen meist 10 männig; Kclch:ipfel breit - pfriemlich - lanzettlich, ziemiich spitz, grün, mit einem sehr schmalen, weisslichen Rande, so lang als die lielrhröhre, zur linuchtzeit et. was abstehend. $\odot$. Sandfelder, etwas feuchte Arcker uberall häufig. Juni-Octub. Blume grünlich. IÖht $3-8^{\prime \prime}$.

417. \$. perennis L., a usdaue $r n d e r$ K. Wurzel ausdancrnd; Stengel anfsteigend; Blätter gegenüberstehend, linealisch-pfriemlich; Blïthen Lllü̈unig; Kelchzipf $c l$ linealisch-länglich, abgerundet-stumpf, grün, mil cinem breiten, weissen Randc, zur Iruclitieit an der spitze zusammengeneigt und fast geschlossen. 24. Sonnige Hügrel, trochene Felsen, sandige Abhänge, seltener als vorige Art. Bei llalle houfig z. B. Berge bej 'Trutha, Kröllwitz u.s.w., a'ls Bienitz, fehlt bei Naum. burg, bei Bibra auf sandigen Iriften sehr hänfig, bei Dessau hänfig, bei Delitzsch und an den Anhöhen zwischen der Benndorfer Mïhle und Paupitzsch nicht selten. Mai - Octub. Blume grünlich. Stengel $2-6$ " hoch.

\section{Familie. Crassulaceen DC. Dick- b lat tgewäclise.}

158. Seduma Le. Fet thenne (wder fette Henne) (Pflanzenname bei Plinius).

a. Blitter heiderseits flach, hreit.

418. s. maximum out., gross e F. Sturm lfeft 83. Wurzel knullenförmig; Stengel aufsteigend; Blïtter dickfleischigr, flach, länglich oder eiförmig, stumpf, ungleich-gesägt, gegeniiberstehend uder zu 3 quirlförmig, die unteren mit breitem Grunde sitzend, die oberen am Grunde kurz-herzfürmig, etwas stengelumfassend; Trugdolden endstündig, dichtblüthig; Blumenblätter abstehend, crade, an der Spitze rinnenförmig-eingedrïclit, 
mit einem hleinen, zusammengedrückten Hörnelien endigend; die inneren Staubgefiisse dem Grumle der IBlumenblätter eingefiigt. 4. [F'lsen, sonnige Auhöhen, truckene, sandige Stellen der Wälder nicht selten. Dölauer Heide, Mittelholz, Weimherge bei Röglitz, im Bienitz und ausserdem auf Mauern in den Dörtern häil fig angepflanzt. Blïht Mitte August. S. T'elephium $\delta$. u. $\varepsilon$. L. Blume grünlich. oder weisslich-gelb. Höhte $3 / 4-11 / 2$ '. UFF. rad. et herb. 'Telephii s. Crassulae maioris s. Fabariae.

419. 5. purpurascens Koch, purpurrothe $F$. Sturm Heft 83. Wurzel knollenförinig; Stengel anfrecht; Blïter flach, verkehrt-eiförmig, länglich oder lanzettich, vom Grunde bis zur Nitte fast ginzrandig. nach der spitze zı ungleich gezähnt-gesägt, die mutcren lilrz-gestielt, gegenüberstelend uder zu 3 quillförmig, die oberen mit abgerundetem Grunde sitzend; 'Trug. dolden endständig, dichtblüthig; Blumenblätter über der Mitte zurïckgekrümmt-abstehend, an der Spitze flach, ein wenig rintenförmig und fast whue Hörnchen; die inneren staubgefässe $1 / 6$ ïber dem Grunde der Blunen blätter eingefuigt. 24. Auf I,ehmmaneru angepflonzt, whgleich selten z. B. in Raguhn. Blïht Ende Juli. S'. Telephim $\beta$. purpureum I. S. Telephium $5 \mathrm{~m}$. Blume purpurroth. Höhe $3 / 4-11 / 2^{\prime}$.

Die specifische Verschiedenheit beiler Arten ist wach den Beobachtungen von $\mathbf{W}$ im mer (vgl. Flura v. Schlesien 2. Anfl. S. 89), welcher vullständige Lebergänge bemerkt haben will, sehr zweifelhaft und es sind daher neue Untersuchungen daruber anzustellen.

b. Blätter lincalisch, stielrumb uder eiförnič.

420. S. album L., weissbliihende F Floravon Thüring. II, 14. Stïmmchen liviechend; blïthentragende Stengel aus anfsteigendem Grunde aufrecht, die nicht blühenden Stenvel locker beblättert; 1;lätter linealisch, stumpf, fast walzenförmig, oberseits etwas flach, abstehend; im Grunde gleich; Trugdolde fast gleich hoch, liahl; Blumenbläter lanzettlich, stumplich, 3 mal su lang als der Kelch. 4. Felsen, Maurn, Dächer, zerstreut. Nanern in Ostrau und Nerseburg, Stadtmauer in Nammburg und Freiburg, auch am Schlifter bei Freiburg, Stadtmaner in Allstedt häufig. Juli. Aug. Blume weiss wder röthlich-weiss. Höhe $1 / 2$.

421. S. acre L., scharfe F., Mauerpfeffer. H a ${ }^{2}$ e Arzneigew. I, 15 . Stiommchen kriechend, die 
nichtblïhenden Stengel 6zeilig beblättert; Blätter fleischig, klein, cijürmig, anf dem Riicken gewöllt, mit stumpfem Grunde sitiend; Trugdolde kahl; Blumenbläter lanzettlich, spitz, doppelt so lang als der Kelch. 7. Sonnige Hügel, Felsen, Sandfeldel gemein, z. B. Felsen bei Giebichenstrin, bei kröllwitz u. s. w. Juni. Juli. Hlume gelb. Höhe $2-6 "$.

422. S. sexangulare L., se chsreihige F. Hayne Irzneigew. 1, 16. Stïmmchen livicchend, die nichtblïhenden Stengel 6zeilig beblättert; Lliitter sticlvund, linealisch, stumpf, mit cinem unter die Anheftungsstelle heralgezogenen stumpfen Anliängsel; Trugdolde hahl; Blumenbläter lanzettlich, spitz, doppelt solang als der Kelch. fo Sandfelder, trockene, sandige Abhänge weit seltener als vorige Art. In einem Wäldchen zwischen der Gersdorfer wïsten Feldmark und Lettin, am $\mathrm{Ab}$ hange der Dölauer Ileide zwischen der Fasinerie und Nietleben, an srasigen Plätzen der Weinberge bei Naumburg häufig, bei Dessau häufig. Juli, blüht 14 Tage später als vorhergehende Art. Blume gelb: Höhe $3-6^{\prime \prime}$.

Die r̈chte Linnóische, dem $\mathrm{S}$. acre sehr nahe stehende Pflanze hat eine wenigblüthige (mit nm $1-2$ Blüthen versehene) 'I'rugdalde, während diese bei s. buloniense Lois l. 5- loblüthig ist. Nur dieseletztese Form konmt in Gebiete vor.

423. S. reflexum L. (erweitert), $z$ ur ü ckg e k r ümm te F. Stïmnchen kriechend; stengel derb, aus aufsteigendem Grunde aufrecht; Blättcr lincalisch-pfriemlich, kurz stachelspitzig, am Grunde unter der Anheftungs. stelle mit eincm kur zen, stumpflichen Anhïnssel versehen; Trugdolde kahl; Blumenblätter limzettlich, abstehend; doppelt so lang als der Kelch. 24. Juli. Aug. Blume gelb. Stengel $1 / 2-1$ ' hoch. Aendert ab:

a) viride Koch, S. reflexum l. Rehb. pl. crit. 111. Abb. 459. Blätter lebhaft grün. Diese Form wird oft in Gärten unter lem Nimen T ripmad am cultivit und bisweilen auf Mauern gepflanzt.

b) rupestre L. Sturm Heft 12. Blätter bläulich. grün oder hechtblau, so an Porphyrfelsen, an sonnigen, dürren Hügeln nicht selten z. B. am Donnersberge hinter Kröllwitz, an sonnigen Aphängen zwischen dem Bienitz und Rückmarsdorf, bei Naum. burg häufig u. s. w. 
159. Sempervivmm C. II auslauch, uft II a us laub genannt (Von semper, immer, und virese, leben, wegen der langen Daner dieser Gewähse).

424. S. tectorum L., D a c h. H. Hayne Arzneigew. V1, 14. Blätter der Rosetten länglich-verkehrt-eiförmigr; stachelspitzig, wrasgrün, kahi, am Rande überall grewimpert; Blumenblïtcr lanzettlich, zugespitzt, dopjelt so lang als der Kelch, nebst den Kelch=ipfelu slervformig ausgelreilet 4. Fast in allen Dïrfern auf Jehnmanern uni Daichern angepflanzt. Juli. Ang. Blumenblätter rusenroth. Höhe $1 / 2-1$ '.

425. s. noboliferum sims, spossender 11. R chb. pl. crit. IX. Abb. 1131. Blittel del Rosetten velkehrt-eiförmig oder länglich-keilförmig, spit\%, die stengelständigen länglich, zugespitzt, die ohersten eiförnig, alle nebst dem Kelche oler-und unterseits kiahl, am Rande gewimpert; Jlumenbliilter anfiecht, slockenförmig, doppelt so lang als der kelch. 24. Auf lehmmauern angepflanzt, aber weit seltener als die vorhergehende Alt z. B. in Kö̈tschau, Altraustïrlt, Naumburg, Ober-Schmon u s.w. Juli. Ang. Blume gelblich-griin. Höhe $3-6 "$. Die Blattrustten der Seitentriehe sind anfangs durch ein dünnes Stielchen mit der IIauptrusette verbunden, lösen sich aber bald ab und wurzeln, während diese Nebenwosetten bri der vorhergahenden Art mit des Hauptrosette durch einen dicken Stiel rorbundell sind mul sich nicht ablösen.

Diese hier beschriebene Pflanze ist $\$$. hirtum bei Spreng. hal. ed. 2. p. 212, aber nicht Lin., wofür sie sprengel ausgibt.

\section{Familie. Grossularieen DC. Sta- chelbeerengewächse.}

160. Ribes L. Stachel-und Juhannisbeere (Name arabischen Ursprungs).

A. Grossularia. Stachelbeere. Stachelig; Blüthenstiele 1 - 3 bliithig.

426. Tr. Grossularia L., St a che l be e re. Sturm Heft 4. Decklliitter der Aeste aus einem unoctheilter oder Stheiligen Stachel bestehend; Blätter 3lappig, eingeschnitten-gekerbt; Blizthenstiels 1-3bliithig, mit $2-3$ Deckblätcinen; Kelch glochenförnig, mit lïnglichen, zurückgebogenen Zijfeln; Blumenbläter ver- 
kehrt-eiförmig. †. Züune, Gräben, Felsen, Mauerı, Gebüsche und Wälder nicht gerade selten $z$. B. im Bergholze, Bienitz, bei Freiburg u. s. w. und sehr häufig in Gärten cultivirt. April. Mai. Blume meist griinlich-gelb, selten brauniuth. Ein 2-5' hoher Strauch. Aendert $a b$ :

a) glauduloso-setosum íoch. Fruchtkuoten und Beeren mit drisentragenden Borsten. Dies ist das ächte R. Grossularia $\mathbf{L}$.

b) pubescens linch. Sturm Heft 44. Fruchtknuten nit kurzeu, weichen, Irüsenlosell Haaren, die Beeren zuletzt kahl. R. Uva crispa $L$.

c) glabrum Kuch. Fruchthouten, Blätter, Blattstiele, Blüthenstiele, Deckblïttchen und Kelche lahl, der Rand der Blätter, Blattstiele, Deckblättrhen und Kelchaipfel gewimpert. R. reclinatum I. Diese Abalt wirl in Gärten cultivirt.

B. Ribesiá. Johannisbeere. Stachellos; Blüthen in vielblüthigen 'Irauben.

427. R. alpinum L., Alpen-J. Sturm Heft 51. Stachellos; . Blïtter. 3lappig, eingeschnitten-gezähnt, unterseits nicht punktirt; Trauben anfrecht, drusig-behaart, nit lanzettlichen, das Blüthenstielchen überragenden Derkblättrhen; Kelch flich, kahl, mit eiförmigen Zipfeln; Blumenblätter spatelförmig. ち. Felsen, IIälder zerstreut. 'Zorgs, Badeudorfer Holz zwischen seeburg und Neehausen, in Wäldern bei Naumburg und Freiburg häufig, bei Allstedt ini Hagen und Theilhulze. nicht selten, Wei Eisleben in Helftaer Hulze. Mai. Juni. Der $3-8^{\prime}$ hohe Strauch ist oft zweihäısig, die mäunliche 'Traube mit $20-30$ gelblich-grünen, die weibliche mit $3-5$ dunkler-grïnen $B 1:$ then. Beere roth.

428. R. nigrum R., schwarze J. Hayne Arzneigew. 111, 25. Stachellos; Blïtter spitz, fast 5lappig, grob eingeschnitten-gezähnt, unterscits driisig-punlitirt; Trauben liängend, weichhaarig, mit pfriemlichen Decliblcittchen, welche vielma! kïrzer als die Blïthenstielche⿰ sind; Kelch glockenförmig, weichhaarig, drïsigpunktirt, mit länglichen, zurückgekrümmten Zipfeln; Blumenblätter länglich. ち. Bäche, feuchte Wälder selten. Bärhe unmittelbar bei Bibra häufig, Thäler zwischen Bibra unal Burgscheidungen, bei Benndorf; ron Spreng. auch bei Döllnitz, Schkeuditz und Holzweissig angegeben; wird in Gärten öfter cultivirt. April. Mai.

Garcke, Flora. 
Blume grünlich, inwendig blass-röthlich, Beeren schwarz, nebst den Blättern mit einem wanzenahulichen Geruche. Ein 4-5' hoher Strauch.

429. R. rubrum L., lothe J. Stulu Heft 4. Stachellos; Blïtler stumpf, fast 5 lappig, grob eingeschnitten-gezähnt, muterscits nicht punlitirt; Tranfen hïnsend, fast kahl, mit ciförmicn Decliblättern, welche. vielmal kiirzer als die Blïthenstielchen sind; Kelch beckenförmig, hish, am Rande nicht gewimpert, mit spatelförmigen Kipfeln; Blumenblätter spatelformig. ち. Fenchte Wälder, Hecken zerstreut $\%$. B. in Bienitz, bei Naumburg stellenweise, weit häufiger in Giarten gezogen. April. Mai. Blume einfach gelblich-grïn. Beeren roth, bei den cultivirten Gartensträuchern anch weiss. Höhe $4-5$ '. OFF. baccae Ribium rubrorum.

\section{Familie. Saxifrageen Vent. Stein- brechgewächse.}

161. Saxifirama T. Steinb rech (ron saxum, Stein, und frangere, brechen, ingeblich wegen vormaliger Anwendung in dieser Krankheit).

430. 5. granulata L., knollentragender St. Sturm Heft 6. Wurzcl mit körnigen Knüllchen besetzt; Stengel aufrecht, einfach, oberwärts ästig - ebeustrüussig, armblüthig; Wurzclblïtter gesticlt, nierenförmi, lappiggekerbt, mit rinnenförmigen lilattstielen, mittlese und obere Stengelblätter sitzend, keilförnig, 3-5spaltig; Blumenblïtter länglich-verkehrt-eiłörnig, doppelt so lang als der Kelch. 24. Waldränder, zrasige Hïgel, Wiesen, Raine gemein $z$. B. am Filsen vol' lirotha, bei Kröllwitz n. s. w. Mai. Juni. Blume gross, weiss. Höhe $1 / 2-1^{\prime}$.

431. S. tridactylites L., dreifingeriger St. Sturm Heft 33. Wurzel einfach; Sttogel aufrecht, meist ästig, driisig behaart, Wurzellicitter verlichrt-eioder spatelfürmig, ungetheilt oder meist 3lappior oder. 3spaltig, mit flachem Blattstiele, die stengelstïndigen handförmig-3spaltig; Bliithensticle 16liithig, mit zwei Dechblätchen, vielnal länger als die Frucht; Blumenblätter wenig länger als der Kelch. $\odot$. Felsen, steinige Orte, Mauern, Sandfelder weit seltener als vorige Ait. Schwalchloch hinter Kröllwitz, Felsen bei Giul. ritz unweit Wettin sparsam, Jehmmauern in Ermlitz. 
und Wehlitz, grasige Abhänge ganz in der Nähe von Kl. Dölzig, Felsen zwischen dem Bienitz und den Quellen, bei Naumburg ziemlich verbreitet z. B. auf Sandsteinfelsen nach der Schönburg zu, ïber der Henne, am Pfortenberge, vor dem Buchholze, bei Freihurg am Schlifter und an den Steinbrüchen über dem Mühlholze, bei Querfurt am Schlosse, bei Allstedt im Hagen an Wege nach den Lehmgruben sehr sparsam, bei Bernburg, auf Mauern in Delitzsch nicht selten. April. Mai. Blume klein, weiss. Stengel $2-6^{\prime \prime}$ hoch. Aendert ab:

b) exilis Poll.: Stengel klein, oft nur 1" hoch; Blätter sämmtlich ungetheilt, so in grosser Menge zwischen Wansleben und Amsdorf in der Nähe der Tannenpflanzung.

162. Chrysosplérniam I. Milzkraut (von xœvós, Gold, und $\sigma \pi \lambda \tilde{\eta} \nu$, Milz, in Bezug auf die goldgrelbe Farbe der Blüthe und den vormaligen Gebrauch dieser Pflanzen).

432. Chr. alternifolium L., we chselblät teri ges M. Sturm Heft 12. Stengel 3kantig, 1-3blätterig; 1:lätter wechsclständig, nierenförmig, tief gekerbt, meist mit schwach ausgerandeten Kerben. 4. Feuchte, schattige Stellen, besonders an Quellen, Bächen, Brumnen in Wäldern zerstreut Quellige Abhänge zwischen Schkeuditz und Wehlitz, bei Naumburg stellenweise z. B. auf der Gröbitzer Wiese, bei Landgrafrode in Bornthale in der Nähe des Brunnens, am rothen Brunnen und an lem benachbarten Bache im Lo. dersleber Forste, bei Oranienbaum an kalten Hause, in Schenkenberger Busche bei Delitzsch. März. April. Eine zarte, saftreiche, leicht zerbrechliche Pflanze von $3-6 "$ Höhe, mit goldgelben Blüthen und Deckblättern.

433. Chr. oppositifolium L., g eg e nblätteriges M. Sturm Heft 4 . Stengel 4 kantig, am Grunde niederliegend und wurzelnd, armblüthig; Blätter gegeniiberstehend, halbkreisrund, geschweift - gekerbt, an Grunde abgestutzt. 24. Bellässerte schattige Stellen, besonders an Waldbächen, viel seltener als die vorige Art. Quellige Abhänge zwischen Schkeuditz und Wehlitz sehr sparsam, bei Naumburg auf der Gröbitzer Wiese unweit Giekau und im Mordthale, bei Freiburg in Schaafholze über Nismitz. April-Juni. Kleiner und zarter als vorhergehende Art, nur 2-4" hoch; 
Blüthen kleiner, grünlich-gelb. Nach Linne sollte jede erste Blume bei beiden Arten 5lappig sein und 10 Stanbgefässe haben, "eshalb von ihm diese Gattmng zur zehuten Klasse gerechnet wurde; es fiuden sich jedoch grösstentheils 4lappige, mit 8 Stanbgefässen verselirne: Bhumen und nur üusserst selten das von linne angegebene Verhältuiss, daher von den Neuern meist in die achte Klasse gestellt.

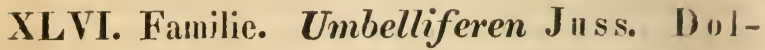 denge wächse.}

\section{Ordnung. Orthospermeen DC. Geradsa- $\mathrm{mige}$.}

Eiweiss, auf der Fugenseite nicht ausgehöhlt, oft flach.

1. Gruppe. II ydrocotyleen spreng. Wassernabelgewächse. Frucht vou der Seite deutlich zusamnengedrücht; Dolde unvollkommen.

163. Hydrocótyle L. Wassernabel (von $u^{\prime}(1)$, Wasser, und \%ot $\gamma_{\eta} \eta$, Nabel, wegen des Vurhummens der Pflanze und der Gestalt der Blätter).

434. H. vulgaris $\mathbf{L}$, ge meiner W. Stengel fadenförmig, kriechend, aus den Gelenken Bliithen treibend und wurzelnd; Blätter langgestielt, schildförmig, kreisrund, doppelt-gekerbt, 7-9nervig; Blattstiele all der Spitze behaart; Dolden kopfförmig, $3-5$ blïthig; Frucht breiter als hoch. 24. 'Torfhaltiger Boden sehr selten. Sümpfe bei Lieskau zahlreich, fehlt im granzen östlichen, siidlichen und westlichen Gebiete; findet sich im Aschersleber See häufig, ebenso bei Dessau häufig, bei Oranienbaum an der Brückmühle und in Göttertsbruch, auf 'Iurfwiesen zwischen Pouch und Crina östlich von Bitterfeld und im nordöstlichen Gebiete ïberhaupt nicht selten. Juli. Aug. Blumen sehr klein, weisslich oder röthlich. lendert ab :

b) Schkuhriana $\mathbf{R c h b . : ~ d i e ~ K e r b e n ~ d e r ~ B l a ̈ t t e r ~}$ sehr stumpf.

$\therefore$ Gruppe. Saniculeen Koch. S nnikelgewächse. Fruclut in Querdurchschnitte fast kreisrund; Dolden büschel- oder kopfförmig, einfaclı oder etwas und zwar unregelınässig zusammengesetzt, oder kopfförmige Döldehen. 
164. Sanicula L. Sanikel (ein bei Plinius vorkommender Pflanzenname, welcher von sanase, heilen, herkommen soll, wegen ehemaliger Anwendung).

435. S. europaea C., e u r o pä is ch er $\mathbf{S}$. Stengel aufrecht, mit 1-2 sitzenden Blättern; Wurzelblätter handförmig - getheilt, mit keilförnigen, 3spaltigen, eingeschnitten - gesägten Zipfeln; Döldchen kopfförmig, die zwitterigen Blüthen sitzend, die männlichen sẹhr kurzgestielt; Früchte mit langen hakenförmigen Stacheln besetzt. 24. Schattige Bergwälder stellenweise. Im Lehriannschen Wäldchen bei Gutenberg suarsam, häufiger im Nittel - und Bergholze, im Wä!dchen über der Herrenmühle bei Weissenfels, in Wäldern bei Naumburg, Freiburg, Allstedt und Eisleben häufig, ebensn häufig bei Qualendorf in Mühlenbusch beim Fasanen. teiche südwestlich von Dessau, bei Oranienbaum im Nichrim, an quelligen Abhängen des Muldenthales zwischen Pouch und Rösa östlich von Bitterfeld. Mai. Juni. Blume klein, röthlich-weiss. Höhe $3 / t-1 \frac{1}{\varkappa^{2}}$.

165. A đtrántia C. Strenze oder Astränze

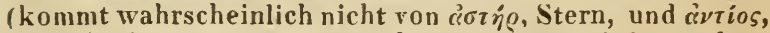
ähnlich, her, wie gewöhnlich angegeben wird, sondern der zuerst bei 0 tto Brunfels vorkommende, von Conr. Ge sner weiter eingeführte lateinische Name ist Umbildung des ursprïnglich deutschen Wortes Astränze).

436. A. major L., grosse St. Sturm Heft 29. Stengel aufrecht, einfach oder oberwärts ästig; Wurzelblätter handförmig-5theilig, mit länglich-verkehrteiförmioen, spitzen, fast 3spaltigen, ungleich-spitzeingeschnitten-gesägten Zipfeln; Hüllblättchen ganzrandig oder an der Spitze gezähnelt, so lang oder etwas länger als die Döldchen; Kelchzähne ei-lanzettlich, mit einer Stachelspitze endigend. 2i. Schattige Thäler der Laubwälder sehr selten. Bei Bibra in schattigen feuchten Waldungen über Sickels Ruhe hinaus und nach der Buchnühle hin jn der Nähe der Bäche, im Bornthale bei Landgrafrode häufig, im Sandthale bei Lo. dersleben selten. Die von $\mathrm{S}$ preng. hal. ed. 2. p. 127 angerebenen Standorte ,Gebirgswälder an der Unstrut bei Wendelstein und Zingst" vermag der Verfasser nicht zu verbïrgen. Blüht stets erst im Aug., nicht schon im Juni und Juli, wie Spreng. angibt. Hüllblättchen weisslich, mit 3 grïnen Streifen und grüner Spitze. Blume weiss oder blass roth, die männlichen Blïthen 
sind länger gestielt als die Zwitterblïthen. Die Fruchtrippen sind schuppig - gekerbt. Wïhe $1-2$ '.

166. Erýngium L. Männertreue (Pflanzenname bei Diuscurides).

437. F. campestre L., Feld-M. Hayne IIzneigew. II, 1. Stengel ausgebreitet-ästig, mit 3-und oberwärts 2 theiligen Aesten; Blätter starr, netzaderig, 3zählig - doppeltfiederspaltig, mit verlängerten, in einen Dorn auslaufenden Zähnen, die wurzelständigen gestielt, die stengelständigen stengelumfassend, mit lappig-gezähnten Oehrchen; IIüllchen Iänger als die rundlichen Köpfchen; Kelch längel als die Blumenblätter. 24. Dürre unfruchtbare Anhöhen, truckene 'Triften, Wegränder, häufig z. B. am Schwalchloche hinter Kröllwitz, Wegränder zwischen der Nerseburger Chaussee und dem Waisenhausgarten u. s. w. Juni. Juli. Blume weiss oder graugriin. Höhe $1 / 2-1 \frac{1}{2}$.

3. Gruppe. Ammineen hoch. Ammeigew ă chse. Frucht von der Seite deutlich zusammengedrückt; Früchtchen mit $\mathbf{5}$ gleichen Rippen olne Nebenrippen. Eiweiss stielrund oder höckerig-gewölbt, zuweılen eben. Dolden vollkommen.

162. Cicúta I. Wütherig, Wasserschierling (Pflanzenname bei Plinius).

438. C. virosa L., g i f tig e r W. H a y ne Arzneigew. 1, 37. Wurzelstock dick, kurz, fleischig, mit zahlreichen, fadenförmigen Wurzelfasern, innen durch Querwände fächerig, hohl; Stengel aufrecht, wie die ganze Pflanze kahl; Blätter 3 fach gefiedert, mit linealischIanzettlichen, spitzen, scharf-gesägten Blättchen; Dolden meist vielstrahlig; Hülle fehlend oder ein 3lappiges Blatt; Hïllchen vielblätterig, linealisch; Frucht breiter als lang. 24. Gräben, Sümpfe, T'eiche sehr zerstreut. In Gräben im Riethe bei Rossleben und Bottendorf häufig, bei Dessau und Oranienbaum häufig, kleine Lachen zwischen der Benndorfer Miihle und Paupitzsch und an den Teichen bei Paupitzsch, in Lachen bei Bitterfeld. Juli. Ang. Blume weiss. Höhe $3-4^{\prime}$. Aendert mit schmäleren und breiteren Blättern ab. Sehr giftig. 168. Ápium L. Sellerie (Pflanzenname bei Pli-

439. A. gravéolens L., gemeiner S. Hayne Arzneigew. VII, 24. Wurzel dick, spindelförmig-ästig 
Stengel sehr ästig, gefurcht, kahl; Blätter gläızend, unpaarig gefiedert, die wurzelständigen mit 5 rundlichen, 3lappigen, eingeschnitten-gezähnten Blättchen gefiedert, die stengelständigen 3zählig, mit am Grunde keilförnigen Blättchen; Dolden vielstrahlig, klein, fast sizzend; Hïlle fehlend. $\odot$. Gräben und feuchte Stellen der salzigen Wiesen stellenweise. Bei Halle nicht selten z. B. an den Teichen bei Dieskan häufig, am Chausseegraben in Bennstedt, an der Mühle bei Kölme, an Gräben zwischen Wansleben und dem salzigen See, salzhaltige Wiesen bei Kötschau und Teuditz; fehlt bei Naumburg; Seelöcher bei Zabenstedt unweit Gerbstedt, Salzwiesen bei Stassfurt und Leau; ansserdem häufig als Gemüsepflanze gebaut. Juli. Sept. Blume klein, weiss. Höhe $1-3^{\prime}$. Die Wurzel wird beim Anbau sehr stark und knollenförmig und hat nebst len Blättern einen starken Geruch.

169. Pernoselínum Moffm. Petersilje (ron

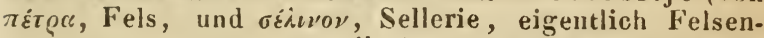
sellerie).

440. P. sativum Hoffm., gemeine P. Hayne Arzneigew. VII, 23. Wurzel spindelförmig; Stengel aufrecht, vom Grunde an ästig, kantig; Blätter glänzend, die unteren 3 fach gefiedert, mit eiförmig-keiligen, 3spaltigen, gezähnten Blättchen, die oberen 3zählig, mit linealisch-lanzettlichen, ganzen oder 3spaltigen Blättchen; Dolden vielstrahlig; Hülle 1-2blätterig; Hüllchen $6-8$ blätterig, mit pfriemlichen Blättchen. $\odot$.' Wird in Gemüsegärten überall gebaut und verwildert hin und wieder an Schutthaufen. Juni. Juli. Blume grünlich-gelb. Höhe $2-\mathbf{3}^{\prime}$. Aendert ab :

b) crispa DC., die Blättchen der unteren Blätter breiter und kraus. Apinm crispum Mill.

OFF. rad. herb. et semen Petroselini.

Das Kraut hat einen eigenthümlich starken Geruch und unterscheidet sich schon dadurch von dem sehr ähn. lichen Hundschierling (Aethusà Cynapium).

170. Helosciádium Ko Ch. S cheiberich (ron

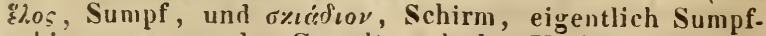
schirm, wegen der Gestalt und des Vorkommens der Pflanze).

441. H. repens Koch, $\mathrm{kriechender} \mathrm{S.} \mathrm{Stengel}$ kriechend, wurzelnd, kahl; Blätter gefiedert, mit rund- 
lich-eiförmigen, ungleich-gezähnt-gesägten oder gelappten Blättchen; Dolde den Blättern gegenüberstehend, kürzer als der Blattstiel; Hülle 2-5blätterig, nit lan. zettlichen Blättchen; Hüllchen 6- und mehrblätterig, fast so lang als das Döldchen; Frïchte zusammengedrïcktkugelförmig. 24. Sumpfige Stellen, nasse Wiesen sehr selten, иแr an der Grenze des Gebietes im Aschersleber See, aber daselbst häufig; nach $\mathbf{S}$ chwabe fl. anh. auch in Torfsümpfen bei schierau. Aug. Sept. Sium repens L. Blume weiss. Die Pflanze kriecht und ist nur $4-6$ " hoch.

171. Falcária IIost. Sichelmör e (von falx, Sichel, wegen der Gestalt der Blätter).

442. F. Rivini Most, Rivin's S. Stengel sehr ästig, stielrund, zart-gerillt; Wurzelblätter einfach und 3zählig; das mittlere Blättchen tief 3spaltig, die seiten. ständigen answärts 2-3spaltig, die Zipfel linealischlanzettlich, gleichförmig - genühert-gesägt, mit dornigstachelspitzigen Sägezähnen; Dolden lang gestielt; Hülle und Hüllchen 6-8blätteriz, mit linealisch - borstenförmigen Blättchen. @. Acher - und Wegränder häufig z. B. an der Gersdorfer wüsten Feldmark hinter Kröllwitz, all Chausseegraben bei Nietleben und Benustedt u. s. w. Juli. Aug. Sium Falcaria L. Critanus agrestis Bess. Blume klein, weiss. Stengel 1-2' hoch. Aendert mit breiteren und schmäleren Blättchen ab.

172. pgopóalionm I. Gersch oder Giersch (ron

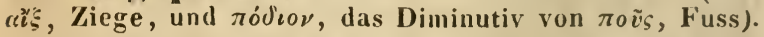

443. Aeg. Podagraria L., g e m e in er G. Wurzel weit kriechend; Stengel aufrecht, oberwärts ästig, tief gefurcht, wie die ganze Pflanze kahl; Wurzelblätter und untere Stengelblätter doppelt :3zählig, langgestielt, mit eiförnig - länglichen oder länglich - lanzettlichen, zugespitzten, eiufach. und duppelt-gesägten Blättchen, obere Stengelblätter einfach 3zählig; Dulden gross, flach; Hïlle und Hiillchen fehlend. 24 . Schattige Hekken, Zäune, Grasgärten, Bäche, Gräben überall gemein. Juni - Aug. Sison Podagtaria Spreng. Blume weiss. Höhe $2-3$ '.

173. Cartana L. K ü m m el (stammt nach Plinius von der Isandschaft Carien ab).

444. Co Carvi L., gemeiner K. Hayne Arzneigew. VII, 19. Wurzel spindelförnig; Stengel anf- 
recht, ästig, kantig; Blätter doppelt gefiedert, Blättchen fiederspaltig-vieltheilig, mit linealischen Kipfeln, die untersten Paare an den gemrinschaftichen Blattstiel kreuzweise gestellt; Hülle und Hiillchen meist fehlend oder aus 3 borstenförmigen Blättchen bestehend. (.). Wiesen, Wege, Ackerraine nicht selten und noch häufiger im Grossen gebaut. Mai. Juni. Blume weiss oder röthlich. Iöhe $1-2^{\prime}$. OFF. sem. Carri.

Früher fand sich auch Carum Bulbocastanm K o ch im Gebiete, welches von Knauth, B $\mathbf{n} x$ b. mnd Le ys s. bei Saasdorf und Eisleben angegeben wird.

174. Pimpinélla I. Steinpeterlein (1bstammung zweifelhaft).

A. Tragoselinum Tournef. Früchte kahl; Hurzel ausdauerind.

445. P. magna IL., grosser St. Hayne Arz. neigew. VII, 21.. Kahl uder etwas weichhaarig; Stengel bebliittert, kcintig-gefurcht; Blätter gefiedert, Bliittchen kur zgesticlt, spitz, gozähut, ungetheilt, gelappt oder geschlitzt; Hiille und Hüllchen fehlend; Griffel länger als der Fruchtlnoten; Früchte länglich-eiförmig, kahl. 4. Waldränder, Gebüsch, Wiesen zerstreut. Bei Halle im Sebener Busche, bei Naumburg und Allstedt ver. breitet, bei Dessan stellenweise. Juni-Aug. Blume weiss. Höhe 2-3'. Aendert ab:

b) I a ciuiata Wallr. Blättchen handförnig-fitderspaltig, mit lanzettlichen, vingeschnitten-gesägten Zipfelu. P. orientalis G ou an.

c) dissecta $\mathrm{Retz}$. Blättchen handförmig - doppelt fiederspaltig, mit linealisch-lanzettlichen Zipfeln.

446. P. Saxifraga C., gemeiner St. Hayne Arzneigew. VII, 20. Stengel stielrund, zart-gerill, oberwairts fast blattlos, kahl oder weichhaarig; Blätter gefiedert, Blïtchèn sitzend, eiförnig, stunıpf, „ezähnt, gelappt uder geschlitzt; Hülle und Hüllchen fehlend; Bliithenstiele lahl; Griffel zur Blüthezeit hürzer als ler Fruchtknoten; Früchte eiförmig, kahl. 24. Hügel, 'Triften, Raine, Wiesen ïberall gemein. Juli-Sept. Blume weiss. Höhe $1 / 2-11 / 2$. Aendert ab:

a) maior Wallr. Blättchen an den grundständigen Blättern eiförmig, an den Stengelblättern oft zerschlitzt.

b) dissectifolia Wallr. Blättchen aller Bläter zerschlitzt. 
c) poterifolia Wallr. Schuächer; Blättchén rundlich-eiförnig, zahnartig-gekerbt; so auf dürrem sande. Alle 3 Abarten sind bald kihl, hald weichharrig.

Pimp. nigra Willd. wird öfter fïr das Gebiet angezeigt und zwar zuerst von spreng. fl. hal. ed. 1. p. 99 als eigene Art auf Waldwiesen bei Gutenberg und Wörmlitz wachsend, darauf ron Wallr. ann. bot. p. 50 ebenfalls als selbstständige Art bei Halle, Lodersleben und Ziegelrude, sodann ron demselben Verfasser in den sched. p. 124 als Abart von P. Saxifraga B. maior Wallr. und zuletzt von Spreng. hal. ed. 2. p. 129 auch als Varietät ron P. Saxifraga angegeben. Allein die ron den erwähnten Autoren beschriebene Pflanze scheint nicht die ächte Willden"w'sche zu sein, welche sich durch die dicht-zeichhaarigen Bliithenstiele und durch die blaue Fïrbung der durchschnittenen Wurzel von P. Saxifraga leicht unterscheidet und bisher vergeblich im Gebiete gesucht ist.

B. Anisum Adans. Frïchte weichhaarig; Wurzel jährig.

447. P. Anisum L., An is. Ha y ne Arzneigew. VII, 22. Stengel stielrund, zart-gevillt, kurz-weichhaarig; Wurzelblïter ungetheilt, herzförmig-rundlich, eingeschnitten-gresägt, die mittleren St-ngelblätter gefiedert, mit keilförnigen, zuweilen eingeschnitten - gezähnten Blättchen, die obersten 3 spaltig vder ungetheilt; Hülle und Hüllchen meist fehlend, oder aus $1-3$ linealischen, sehr kleinen Blättchen bestehend; Friichte eiförmig, angedriickt-2veichhaarig. $\odot$. Wird in Thüringen und bei Aschersleben im Grossen gebaut; stammt aus Aegypten. Juli. Aug. Anisum vulgare Gärtı. Blume weiss. Höhe 1-1 $1 \frac{1}{2}$. Die ganze Pflanze hat einen durchdringenden Geruch. OFF. sem. Anisi vulgaris.

195. Bérula Koe K. B erle (ein aus dem Französischen stammender, schon bei 'Tabernaemontanus vor. kommender Pflanzenname).

448. H. angustifolia $\mathrm{Koch}, \mathrm{s} c h \mathrm{~m}$ a l b lät terige B. Hayne Arzıeigew. 1, 39. Stengel ästig, rundlich, kahl, gestreift; Blätter gefiedert, mit eiförmigr-länglichen, eingeschnitten-gesägten Rlättchen; Dolden kurz gestielt, den Blättern gegenüberstehend; Hülle unil Hüllchen vielblätterig, mit linealischen, oft fiederspal- 
tigen Blättrhen. 24. Grüben, Bäche, 'Teiche, Quellen häufig z. B. in Gräben zwischen Halle und Nietleben, bei Dieskau, Bennstedt, an salzigen See, bei Kl. Dölzig, am Bienitz, bei Kötschau u. s.w. Juli. Aug. Sium angustifolium L. Blume veiss. Höhe 1-2'.

176. Simm I. Merk (ein bei griechischen Schriftstellern vorkommender Pflanzenname).

449. S. Iatifolium L., bre it b lit teriger H. Ha y ne Arzneigew. I, 38. Wurzel faserig, anslänfertreibend; Stengel aufrecht, kantig-gefurcht; Blätter gefiedert; Blättchen scharf - yesägt, lanzettlich, an Grunde anf der inneren Seite schmäler, die untergetauchten doppelt-fiederspaltig oder vielfach-zerschlitzt; Hiille und Hiillchen vielblätterig, oft gesägt oder eingeschnitten. 2. Stehende Gewässer, Gräben, 'Teiche gemein z. B. an der Saale bei Gimritz, in Gräbell bei Dieskau u. s. w. Juli. Aug. Blume weiss. Höhe $3-4^{\prime}$. Aendert ab:

b) I o ngifoliu m M r t. u. Ko ch.: Blättchen länger, linealisch - lanzettlich.

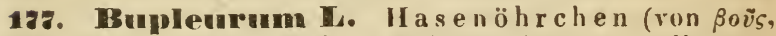
Ochse, und $\pi \lambda \varepsilon v \rho \dot{c}$, Seite, nach Beckmann soll es su benannt sein, weil das Kraut die Ochsen platzen macht).

a. Blitter nicht durchwachsen; Früchte köruig-rauh.

450. R. tenuissimum $\mathrm{K}$., fe ines $\mathrm{II}$. R $\mathrm{ch}$ b. pl. crit. II. Abb. 298. Stengel aufrecht, meist vom Grunde aus mit abstehenden Aesten; Blïtter linealisch-lanzettlich, zugespitzt; endständige Dolden 3 strahlig, seitenständige unvollständig, alle ron einer Hiille umgeben; Hüllchen Iinealisch.lanzettlich, zur Blïthezeit die 3-5blïthigen Döldchen iberrageud; Friichtchen 5rippig, zivischen den Rippen körnig-weichstachelig, die Rippen liörnig-gekríuselt. $\odot$. Salzhaltige Wiesen, an den Salinen, an begrasten Wegen stellenweise. Wegränder in der Nähe des nordöstlichen Raniles der Dölauer Heide selten, salzhaltige Wiesen zwischen Wansleben, Amsdorf und Röblingen häufig, an den Salinen von Kötschau nicht selten; fehlt bei Naumburg und Freiburg; an der Grenze des Gebietes auf salzhaltigen Wiesen hei Artern, ebenso bei Stassfurt und Leau. Juli. Aug. Blume sehr klein, gelb. Höhe 3-9".

B. junceum L., welches Spreng. hal. ed. 2. p. 128 an salzigen Stellen bei Diirrenberge, Schladebach und Kötschau angibt, ist gewiss dort nie gefunden worden. 
Der Verfasser hat an dem zuletzt erwähnten Orte nur B. tenuissinum beobachtet, an den beiden ersten aber gar kein Bupleurum bemerkt. Ebensowenig wie dieses, ist wohl jemals in Gebiete das zuerst von hin anth enum. p. 83 aufgezählte Bupl. latifolium ' $\mathrm{l}$ a b. $=$ Bupl. folio rigido $\mathrm{C}$. $\mathbf{B}$. = $\mathrm{B}$. rigidum $\mathrm{L}$. gefunden worden. Dass später von Rehfeldt hod. bot. p. 68 dieses 13. latifulium angegeben wird, ist weniger zu verwunderu. als dass auch $B \backsim x$ b. enum. p. 47 und sogar L, yss. hal. ed. 1. p. 48 und ed. 2. p. 68 dasselbe nit den Formen von B. falcatum verwechseln komnten. Sprengel hat dieses Verhältniss hal. ed. 1. p. 89 richtig erkannt.

h. Blitter nicht durchwachsen; Thälchen der Früchte nicht körnig.

451. H. falcatum L., s i ch elfö rmiges H. Stengel aufrecht, oberwärts üstig; blïtter 5-7ncrvig, zwvischen den Verven aderig, die unteren elliptisch oder liinglich, in den Blattstipl verschmülert, dic oberen lanzettlich, an beiden Enden spitz, sitzend; Dolden 610strahlig; Hiillchen lanzettlich, haurspitzig; Früchte glatt, mit sehr schmal-geflügelten Rippen und 3streifigen, flachen 'Thülchen. 4. Hügel, Gebüsche, Waldränder nicht gerade selten $z$. B. am 'I'annenberge bei Gutenberg, im Bergholze, an Kalkbergen bei Bennstedt, in Weinbergen bei Rollsdurf; bei Weissenfels, Naumburg und Freiburg auf Kalkboden sehr verbreitet, an der Hüneburg bei Eisleben u. s. w. Juli-Octub. Blume gelb. Höhe $2-3^{\prime}$.

452. F. Iongifolium L., la ngblatteriges II. Stengel aufrecht, uberwärts etwas ästig; Blïtter eifür. mig oder eiförmig-läıglich, aderig, die unteren in den Blattsticl verschmälert, die mittleren und oberen sitzend, mit tief-herzfürmigem Grunde stengclumfassend; Dolden 5 -8strahlig, mit 3-5blätteriger Hülle; Hüllchen 5bläterig, elliptisch oder rundlich, kurz-zugespitzt, so lang als die Döluchen; Früchte glatt, mit scharfen Rippen und 3streifigen 'Thülchen. 24. Auf kalkhaltigem Boden in Bergwäldern, auf IIïgeln und in Gebüschen sehr selten. Auf Hügeln unter Gebüsch bei Weissenfels, an Bergabhängen zwischen Rossbach und Wilsdorf und im Schaafholze über Nismitz bei Freiburg. Juli. Aug. Blume gelblich. Höhe $1-\mathbf{3}^{\prime}$.

An den von Rchb. fl. sax. ed. 1 u. 2. p. 267 erwähnten, aus Wallr. ann. bot. p. 53 und Spreng. hal.ed. 2. p. 128 entlehnten Standorten bei Wendelstein, Rossle- 
bell, Bottendorf und bei Schmon, Karlsdorf und Scheidungen hat der Verfasser stets vergeblich gesucht.

c. Blattchen durchwachsen.

453. B. rotundifolium $\mathbf{L}_{\text {, }}$ rundblätteriges $H$. Ha y ne Arzneigew. VII, 1. Stengel anfrecht, oberwärts mit abstehenden Aesten: Blätter eiförmig, die untersten an Grunde etwas verschmälert, die mittleren und oberen durchwachsen und sfengelumfassend; Dolden 57strahlig, whne Hülle; Hällchen 3-5blätterig, eiförmig, zugespitzt, nach dem Verblühen aufrecht-zusammengeneigt, doppelt so lang als die Dölichen; Früchte mit wulstigen Rippen und streifenlosen Thälchen. $\odot$. Aecker unter der Saat stellenweise. Aecker zwischen Lieskau, Bennstedt und Kölme sparsan, häufiger auf Aeckern unmittelhar bei Pfitzenburg am Wege nach Wansleben und in Weinbergen zwischen Seeburg und Wormsleben, Aecker bei Weissenfels, bei Naumburg sehr verbreitet, bei Eisleben sparsan z. B. auf Aeckern zwischen Helftá und dem Walde und am Hutberge; fehlt bei AschersTeben: auf Aeckern und am 'Tannenküppchen bei Sandersleben, anf Aeckern bei Bernburg sparsam; fehlt im östlichen und nordöstlichen Gebirte. Juni. Juli. B. perfoliatum Lam. Blume gelb. Höhe $1 / 2-1 \frac{1}{2}$.

4. Gruppe. Seselineen $\mathrm{K} 0 \mathrm{eh}$. Seselgewä $\mathrm{chse}$. Frucht in Querdurehschnitte kreisrunl oder fast kreisrund; Früchtehen mit J Rippen, die seitenständigen gleich breit oder ein wenig breiter. Eiweiss auf der Fugenseite flach oder fist stielrund. Dolde vollkommen.

178. Denánthe T. Pf erdesa at (Pflanzenname bei Dioscorides, aus oivos, Wein, und ๕้̋vos, Blume, zusammengesetzt).

454. Oen. fistulosa L., röhrige Pf. Wurzel bii. schelförmig, mit riiben- oder fadenförmigen Fasern; Stengel ausläufertreibend; Wurzelblätter meist doppeltgefiedert, mit flachen, 3 - vielspaltigen Blättchen, Stengelblïtter einfach - gefiedert, liirzer als der röhrenförmige Blattstiel, mit linealisch-stielrunden, einfachen und 3spaltigen Blättchen; Hauptdolde 2-3strahlig, fruchtbar, die übrigen 3 - istrahlig, unfruchtbar; Hülle fehlend oder 1 blätterig ; Früchte hreiselförnig, mit verwachsenen Rippen. 24. Gräben, Teiche, sumpfige Wiesell häufig z. B. an Gräben bei Dieskau, zwischen Döllnitz und Burgliebenau, zwischen Wesmar und Oberthau 
und, in der Ane iberhaupt nicht selten, Cräben vor Beuchlitz u. s. w. Juni. Juli. Blïthen weiss, die änsseren strahlenförmig. Höhe $1-2^{\prime}$. Aemlert ab:

b) 'I aberua montani Gmel.: Wurzelbläter fast 3 fach-gefiedert, mit fein-zertheilten Blättchen.

455. oen. Phellándrium Lam., fenchels a mige l'f., Pferdekümmel. I a y ne Arzneigew. I, 40. Wurzel spindelförmig, mit fädenförmigen, am Grunde des Stengels mit quirlförmigcn Fasern; stengel ausläufertreibend, mit abstehenden testen; Stengelblïter doppclt-lis 3fach-sefiedcrt, nit ausgespreizten, eiförmigen. fiederspaltig-eingeschnittenen Blätchen, die untergetauchten vielspaltig, mit haarförnigen Zipfeln; Dul. den den Blätern gegenüberstehend, vielstrahlig, ohne IIille; Früchte eiförmig-länglich. 24. Gräben, Siinnfe, stehende Gewässer zerstreut. lachen an der Sasle zwischen Kröllwitz und Gimritz, häufier in der Ane z.. B. bei Wesmar W. s. W., bei Allstedt in der Entenpfütze und im Winkelschen Teiche; bei Ischersleben und Dessau häufig. Juli. Ang. Phellandrium aquaticum L. Bliithen "leiss, die äusseren "enig strahlenförmig. IJ̈he 2-5'. OFF. sem. Phellandrii s. Foeniculi aquatiri.

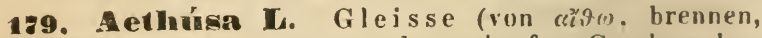
glänzen, entweder wegen des scharfen Geschmackes uder wegen des Glanzes der Blätter; der deutsche Name Gleisse bedeutet die Glänzende, weil sie durch den Glanz vou der nicht glänenden Petersilje sugleich zu unterscheiden ist).

456. A eth. Cynápium L., Hundsg le is s e, H unds. petersilje. Hayne Arzneigew. 1, 35. Stengel anfrecht, stielrund, gestreift; Blätter unterseits glänzend, doppelt- bis 3fach-gefiedert, mit fiederspaltigen, eingeschnittenen oder gesägten Blättchen; Hülle fehlend, Hüllchen 3blätterig, linealisch, zurïckgeschlagen, länger als die Döldchen. $\odot$. Aerher, Schutthanfen, Wegränder häufig z. B. Aecker zwischen llalle und Reidehurg, bei Dieskau, bei l'fitzenburg am Wege nach Wansleben u.s.w. Juni-Herbst. Blume weiss. Höhe $1 / 2$ 2'. Aendert ab:

b) a grestis Wallr.: Stengel nur 2-5" hoch, gleich den Aesten kantig; sind die Blattzipfel zugleich stumpf, so heisst diese Furm teth. segretalis Boen. n ing h. 


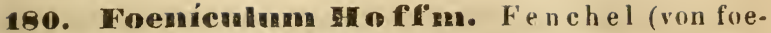
num, Heu, wunit auch das deutsche Wort Fenchel zusammenhängen s(oll).

457. F. officinale ll., gebräuchlicher F. Hay u Arzneigew. VII, 18. Stengel an Grunde stielruna, fein-gerillt; Blattscheiden lang, an der Spitze mit einem miitzenförmigen Oehrchen, Blätter 3-und mehrfach-gefiedert, mit verlängerten, linealisch-pfriemlichen, 2-3sualtigen Zipfeln; Doliten 10-20strahlig Hülle und Hüllchen fehlend; Früchte rund. $\odot$. Wird bisweilen angebaut. Juli. Aug. Anethm Foeniculnm Is. Blume gelb. Höhe $3-6^{\prime}$. OFF, sem. Foeniculi.

181. Séseli F. Sesel (der Name bezeichnet bei Griechen und Römern mehre Duldengewächse).

45S. s. Hippomaráthrum L., P'ferde-S. Stengel stielrund, oberwärts ästig; Blätter 3fach-gefiedert, in Umrisse länglich - eiförnig, mit linealischen Zipfeln; Blattscheiden angedrückt, die oberen blattlos; Dolden 9 - 12 strahlig, Strahlen kantig, einwärts nebst den jüngeren Früchten weichhaarig; Hülle fehlend, Hiillchen zuscimmengewuchsen - Llütterig, beckenfürmig, gezïhnt. 4 Sonnige Hügel, besonders auf Kalkboden, stellenweise. Vugelsberg und Vieinberge bei Bennstedt bis nach Kölme unil bei Rollsdorf und Seeburg häufig, am Kande der neuen Gieh!e bei Freiburg sehr häufig, Kalkberge bei harsiorf und Reinsdorf im Unstruthale, bei Mllstedt an der Louisenstrasse sehr selten, häufiger zwischen Nienstedt und Wolferstedt im Mühlthale, am Gal. genberge bei Querfurt nicht selten, am Schiessberge bei Sandersleben, an der alten Burg bei Aschersleben, fehlt im östlichen und nordöstlichen Gebiete. Juli. Aug. Blume weiss oder röthlich. Höhe $1-1 \frac{1}{2} 2^{2}$.

459. \$. coloratum $\mathbf{E h h . , ~ s t a r r e r . ~ S t e n g e l ~}$ gefurcht, oberwärts ästig; Wurzel - und untere Stengel. blätter 3fach-gefiedert, im Umrisse länglich -eiförmig, mit linealischen Zipfeln; Blattscheiden ihrer ganzen Länge nach den Stengel oder die teste unifassend; Blattstiele rinnenförnig; Hauptdolde 20-30strahlig, Strahlen kantig, fast gleich, auf der inneren Seite nebst den jüngeren Früchten weichhaarig; Hülle fehlend, Hiillchen lanzettlich, zugespitzt, breit-häutig-berandet, läinger. als das Düldchcn. @. Sunnige Hügel, Bergwiesen, freit Waldstellen stelleuweise. Bei Gutenberg in der Nähe des 'Tannenberges, Kirchhof zu 'Teicha, bei Naunı- 
burg an Ausgange des Mordthales nach Flemmingen zII, bei Bibra, im Walde zwischen Memleten und Gruss. Wangen, bei Allstedt in der Nähe ron Einzingen auf einem Raine nach Bayer-Naumlurg zu, bei Sanderslebeu und Bernburg selten. Juli. Aug. S. anmum $L_{\text {. }}$. Blume weiss wder röthlich. Höhe 1-2'. Auf mage. rem, trackenem Buden bleiht die Pflanze oft sehr hlein, so dass sie bisweilen mur 1-2" hoch wird, so anf dem Orlasberge zwischen Bibra und Nemlehen und auf sal\%. haltigen 'Triften zwischen Irtern und Kahstedt.

18z. Libanótis Crantz. II irschwurz (ron $\lambda i$ -

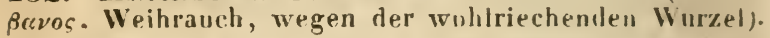

460. L. montana 11., Berg-II. Stengel kantigr, gefurcht, ästig, hahl; Blätter doppelt-bis 3 farh-gefiedert, Blättchen fiederspaltig-eingeschnitten mit lanzettlichen, stachelspitzigen Zipfeln, die untersten Paaste der Blättchen an der Mittelrippe hreuzständig; Hülle und IIüllchen vielblätterig ; Frïchte kurz - hehaart. (-). Buschige Hïgel und Berge sphr selten. Nur an den alten Veinbergen bei Märtendorf nud bei Bibra an huschigen Kalkbergen und nach Burkersrode zu. Juli. Aug. Athamanta libauntis I. Blume "eiss oder röthlich. Stengel 3-4' hoch.

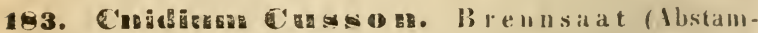

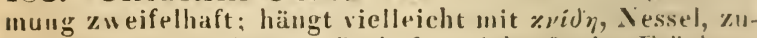
sanmen, "rgen der gew iirzhaften schärfe der Friichte).

461. C. renosum koch, a derige B. Stengel kahl, unterwärts schwach-gerillt, wberwärts gefurcht, einfach uder oberwärts mit einfachen Aesten; Blätter doppelt gefiedert, mit linealischen wher linealisch-lanzettlichen, kurz-bespitzten, ungetheilten oiler 2 - nnd 3spaltigen Zipfeln; Blattscheiden verlängert, die wheren dem stengel straff-auliegend; Hälle fehlend oder wenig blätterig; Hïllchen vielblätterig, pfriemlich, hahl, so lang als das Döldchen. (.), nach Fries 24. Sumpfige Wiesen, besunders an feuchten Gehüschen und Waldrändern, sehr zerstreut. Feuchte Gebiische in der Nähe der Sümpfe bei Lieskau, zwischen der Reide und Döllnitz sparsam, zwischen Osendorf und Collenbey häufiger, fehlt im ganzen südlichen und westlichen Gehiete, bei Dessan häufig. Juli. Aug. Selinum silrestre L. Sieseli venosum 11 of $\mathrm{fm}$. Blume weiss. Höhe $1-2^{\prime}$. Aendert mit schmäleren und breiteren Blattzipfeln ab.

luf der sunpfigen Wiese hinter dem Donncrsherge bei 
bei Kröllwitz, wo sie Spreng. hal. ed. 2. p. 130 angibt, hat der Verfasser stets vergeblich gesucht.

\section{Silnus Bess. Silau (Pflanzenname bei Pli- nius).}

462. S. pratensis Bess., Wiesen-S. Hayne Arzueigew. VII, 5. Stengel kantig, gefurrht, ästig; Wurzelblätter 3- und 4 fach-gefiedert, seitenständine Blättchen 2-5theilig, endständige 3-7theilig, mit linealischen, stachelspitzigen Zipfeln, wbere Stengelblätter einfach-gefiedert; Hïlle tehlend oder 1-2blätterig, Hüllchen vielblätterig, linealisch-lanzettlich, häutig-berandet. \%. lieuchte Wiesen, Gräben fast im ganzen Gebiete häufig. Bei Halle, Merseburg, Weissenfels, Nanmburg u. s. w. auf allen Wiesen sehr verbreitet, nur östlich von Bitterfeld seltener, bei Dessau aber wieder hänfig. Juni-Ang. Pencedanum Silaus L. Blume blassgelb. Höhe $2-3^{\prime}$. Aendert mit breiteren, weniger getheilten und schmäleren, mehr getheilten Blättchen ab.

5. Gruppe. A ngeliceen Koch. B rustwurzgewächse. Frucht auf beiden seiten zweiflügelig. Die Flügel nicht aufeinanderliegend. Jedes Früchtchen mit 5 geflügelten Rippen oder à fadenförmigen Rückenrippen. Eiweiss auf der Fugenseite ziemlich flach. Dolde vollkommen.

185. ILevísticum Koeh. Ljebstö ckel ( $\lambda_{\imath} \beta v \sigma \tau \imath$ $x \dot{v} \nu$ ist ein Pflanzenname bei griechischen Schriftstellern).

463. L. officinale Koch, gebräuchlicher L. Hayne dizneigew. VII, 6. Stengel gestreift, kahl, ästig; Blätter glänzend, einfach - oder duppelt - gefiedert, mit breit-rerkehrt - eiförmigen, spärlich eingeschnitten-gezähnten Blättchen; Hülle und Hüllchen vielblätterig, lanzettlich, häıtig-berandet. 24. Hin und wieder als Arzneipflanze in den Gärten der Landleute gebaut und dann biswejlen verwildert. Juli. Ang. Ligusticum Leristicum L. Blume blassgelb. Höhe 4-6'. OFF. rad. herb. et sem. Levistici.

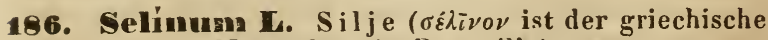
Name für die Petersilje).

464. s. Carvifolia $\mathbf{L}$, kümmelblätterige $s$. Stengel gefurcht, scharf-kantig, ästig; Wurzelblätter 3fach-gefiedert, Blättchen tief-fiederspaltig oder ein-

Garcke, Flora. 
geschnitten, mit linealisch-lanzettlichen, kurz-stachelspitzigen Zipfeln; Blattscheiden schmal; Dolden gedrungen, etwas gewölbt; Hülle fehlend, Hiillchen vielblätterig, linealisch-pfrienlich, häutig - berandet, kürzer als das Döldchen; Griffel fast so lang als die Frucht. 24. Fenchte Wirsen, freie Waldstellen, zwischen Gebiisch häufì z. B. in Görz bei Wörmlitz, in Gebüschen an der stillen Elster bei Osendorf u. s. W., nur bei Aschersleben seltener. Juli. Aug. Angelica Carrifolia Spr. Mylinum Carvifolia Gaud. Blume weiss. Höhe $2-3^{\prime}$.

188. Dstéricum IT of m. Mut terwurz (Pflan. zenname bei Tragus und C. Bauhin).

465. O. palustre Bess., S umpf - M. Rehb. pl. crit. V. Abb. 588. Stengel gefurcht, wenigblätterig, kahl; Blätter 2- bis vielfach-gefiedert; Blättchen eiföomig, zugespitzt, am Grunde öfters schwach-herzförmig, ungleich-gekerbt-gesägt, unterseits auf den Nerien etwas rauh; Hülle fehlend oder 1 blätterig, Hüllchen vielblätterig, lanzettlich - $p$ friemlich. 24. Sumpfwiesen sehr selten, nur auf Wiesen zwischen der Dieskauer Miihle, Osendorf und Döllnitz, aber daselbst zahlreich. Juli. Aug. O. pratense II of $\mathrm{m}$. Inperatoria palustris Bess. Angelica pratensis M. B. Blıme weiss. Hö. he $2-4^{\prime}$.

188. Angélica C. Brustwurz (ron angelus, Engel, wegen der vermeintlichen vortrefflichen Heilkräfte der Pflanze).

466. A. silvestris L., Wald - B. H a yne Arzneigew. VII, 9. Stengel gefurcht, ästig; Blätter 3fach-gefiedert, Blättchen eiförmigy viler lanzettlich, geschärft-gesägt, nicht herablaufend, das endständige ganz oder 3spaltig, die seitenständigen fast sitzend, am Grunde ungleich und bisweilen 2spaltig; Blattscheiden sehr gross, bauchig - anfgeblasen; Hülle felilend oder 1-3blätterig, kurz, Hüllchen vielblätterig, linealisch, fast bortenförmig, su lang oder länger als das Döldchen. 24. Bäche, Gräben, Wiesen, Wälder häntig z. B. Wiesen an der Dieskauer Mühle, bei Osendorf u. s. w. Juli. Aug. Selinum silvestre Crantz. Blume weiss. Höhe $3-6^{\prime}$. Aendert ab: Blättchen kahl oder unterseits auf den Nerven scharf, rundlich oder länglich-lanzettlich, ziemlich gleichmässig gesägr orler doppelt-eingeschnittengesägt oder endlich eingeschnitten - gelappt. 
6. Gruppe. Peucedaneen DC. Haarstranggewächse. Frucht sehr plattgedrückt, mit eınem verbreiterten, einfach - gefügelten, flachen oder gewölbten und verdickten Bande ungeben. Früchtchen mit $\mathbf{5}$ Hauptrippen, die seitenständigen dem verbreiterten Rande anliegend oder in denselben versehmelzend; Nebenrippen fehlend; Eiweiss vorne flach; Dolden vollkommen.

189. Pescédanuma I. Ha arstrang (Planzenname bei Dioscorides, von $\pi \varepsilon v \nLeftarrow \varepsilon d^{\prime}\left(\nu^{\prime} s\right.$, bitter, herbe, wegen des Geschmackes).

467. P. officinale L., ge bräuchlicher II. H a y. n e Arzneigew. VII, 4. Stengel stielrund, gerillt; Bliitler 5 mal drcifach-zusammengeset $=t$, Blätlchen linealisch, anr Grunde und an der Spitze verschmälert, die endständigen 3zählig; Hiille fehlend oder 3blïtterig und abfullend, Hüllchen vielblätterig, borstenförmig, bleibeud; Strahlen der Dulde kahl; Blüthenstielchen 2-3mal so lang als die Frucht. 24. Wiesen, freie Waldstellen, Bergabhänge stellenweise. Wiesen an der Gersdorfer wiisten Feldmark nicht selten, sehr häufig in der Aue z. B. Zwischen Döllnitz und Collenbey, zwischen Burg Liebenau und Wallendorf, zwischen Wesmar und Zïschen, bei Naumburg und Freiburg verbreitet z. B. in den Weinbergen bei Eulau, an der Menne und bei Russbach, am siddichen Rande der neuen Giehle bei Freiburg, bei Allstedt sehr selten, nur am Frevel, fehlt bei Aschersleben: auf feuchten Wiesen bei Qualendorf und Radegast. Juli. Aug. Blume gelb. Höhe 4-6'. Kommt auf Wiesen wegen der Heuernte nur selten zur Blüthe und fast nie zur Fruchtreife.

468. P. Cervaria Lap., sta rrer H. Stengel stiel. rund, gerillt, oberwärts gefurcht; Verästelungen des Blattstieles abstehend; Blätter 3fach-gefiedert, Blättchen meergriin, eiförmig, fast dörnig-gesägt, die unteren an der hintelen seite des Grundes gelappt, die oberen zusammenflirssend; Hïlle vielllätterig, bleibend, Hüllchen reichblätterig. so lang als die Döldchen; Strahlen der Dulde innen rauh; Striemen der Beriihrungsfliche gleichlaufend. 24. Bergwälder, trorkene Wiesen, Hügel und Raine stellenweise. Bei Halle ziemlich verbreitet z. B. in der Dölauer Heide, am Tannenberge bei Gutenberg, im Mittelholze, Frenzelholze bei Lieskau, auf Wiesen bei Kl. Dölzig häufig, hei Weissenfels und Naumburg häufig, seltener bei Allstedt, nur in Hagen, im Hornfelde an buschigen Ackerrainen, im 
'Thale zwischen Nienstedt und Wolferstedt, bei Kisleben, Aschersleben und Sandersleben. Juli. Aur. Athamanta Cervaria L. Selinum Cervaria Crantz. Blume " eiss. Höhe $2-4^{\prime}$.

469. P. Oreoselínum M $\mathrm{I}$ n ch, Berg-H. G r und heil. Hayne Arzneigew. VIl, 3. Stengel stielmund, gerillt; Verästelungen des Blattstieles zuriickgeschlagenspreizend; Bliitter 3fach gefiedert, Blïttchen glïnzend, eiförmig, eingeschnitten - oder fastfiederspaltig-geziihnt, mit kur z zugespitzten Zähnen; Hülle vielhlätterig, bleibend, Hülchen reichblitterig, kaum halb so lang als die Blüthenstiele; Strahlen der Dolde innen rauh; Striemen der Beriilwungsfiiche bogenförmig, dem Rande gencihert. 24. Trockene und fouchte Wiesen, grasige Anhöhen, Waldränder stellenweise. Abhänge der Völauer Heide zwischen der Fasanerie und Nietleben. Wiesen an der Geridorfer "üsten Feldwark hinter Kröllwitz häufig, 'lamuenherg bei Gutenberg, Ränder des Mittelholzes, Wiesen am Bienitz, fehlt bei Weissenfels und in der Nähe von Aschessleben; bei Dessau hänfig, im Bruche zwischen Sandersdorf und Bitterfehl, bei Benndorf, auf dem Kirchhofe von Beerendurf bei Delitzsch. Juli. Aug. Athamanta Oreuselinum I. Oreoselinmm legitimum M. B. Blume weiss. Höhe $1-3^{\prime}$.

Peucedannm alsaticum L. gribt Zenker und nach ihm Rchb. sax. ed. 1 u. 2. p. 271 bei Allstedt all, an dessen Vorkommen jedoch zu zweifeln ist.

190. Thysgelimum Mofrm. Oelsenich (der lateinische Name ist aus Plinius (lib. 25. cap. 11) entlehnt, bei dem aber in verschiedenen ifandschriften bald 'Tiselium, bald 'Thryselium, bald Rhysseliun, in neueren Ausgaben 'Thysselium steht; der deutsche Name ist alt und dunkel, aber wahrscheinlich slarischer Herkunft).

470. Th. palustre Hof fm., Sumpf-Oel. Stengel gefurcht; Blätter 3fach gefiedert mit eincm oberseits tief-rinnigen Blattstiele, Blättchen tief-fiederspaltig, mit linealisch-lanzettlichen, zugespitzten, am Rande etwas rawhen Zipfeln; Hïlle und Hïllchen vielblätterig. pfriemlich-lanzettlich, häutig-berandet; Strahlen der Dulde innen weichhaarig; Striemen der Berïhrungsfläclie gleichlaufend. (.). Sumpfige Wiesen, feuchte Wälder sehr zerstreut. In der Nähe von Halle nur in Schilfe an den Teichen bei Dieskau, auf sumpfigen 
Wiesen bei Kl. Dölzig; fehlt im ganzen südlichen Gebiete; einzelı auf der Wüste links von der QuerfurtArterschen Chaussee; bei Dessau und Oranienbaum häufig; im Bruche zwischen Sandersdorf und Bitterfeld. Juli. Aug. Selinum palustre L. Peucedanum silvestre DC. Blume weiss. Höhe $3-4^{\prime}$. Aendert mit breiteren und schmäleren Blattzipfeln ab.

191. Imperatória L. Me isterwurz (von imperator, Oberfeldherr, wegen der ansgezeichneten arzneilichen Wirkungen).

471. I. Ostrutium L., gemeine M. Hayne Arzneigew. VII, 15. Stengel gestreift, kahl; Blätter doppelt-3zählig, Blättchen breit - eiförmig, doppelt-gesägt, die seitenständigen 2spaltig, die endständigen 3spaltig; Blattscheiden häintig, aufgeblasen; Hülle fehlend, Hüllchen sehr klein, wenighlätterig, hinfällig. Sir. Steinige, besonders quellige Orte in Gebirgsinäldern. Diese seltene Pflanze wiril zuerst von lin i uth enum. p. 84 unter tem Namen Imperatoria maior C. B. im Brehnischen Inulze angegeben, darauf von Rehf. hod. bot. p. 54 unter gleirhem Namen und an gleichen Standurte citirt und rier Jahre später von B u $x$ b. enum. p. 167 gleichfalls unter demselben Namen und an demselben Standurte erwähnt. Auch Leyss. gibt hal. ed. 1. p. 51 denselben Standort an und fügt in der 2. Aufl. S. 72 die Wälder um den Petersberg und Löbejün als Fundurte hinzu. Spreng. fand nach der 1. Aufl. der Flura S. 96 diese Pflanze in Bergwäldern bei Löbejiin, Harnburg und Ebersrode, Wallr. nach ann. but. p. 42 in Wälde'rn bei Löbejïn und Lodersleben und nach der 2 Aufl. de Flura von spreng. S. 139 sull sie in Bergwäldern bej Löbejuï, in Winkelschen Forste hinter Gatterstedt und bei Brehna vorkommen. Der Verfasser fanil diese äusserst seltene Pflanze nie im Gebiete. Da seit einer Reihe ron Jahren die Wälder bei Löbejün nnd Brehna gänzlich ausgerudet sind, so hann natiirlicher ll eise diese Pflan:e dort nicht mehr vorkummen und jene Orte hätten von Rehb. six. p. 373 als zurerlässige Standurte nicht nachgeschrieben werden sollen. Es hliehe daher als einziger möglicher standort der Winkelsithe Forst hinter Gatterstedt, wo der Verfasser lisher aber auch vergeblich gesucht hat. Juli. Aug. Blume weiss. Höhe $1-3^{\prime}$. OFF. rad. Imperatoriae albae s. Ostrutii. 


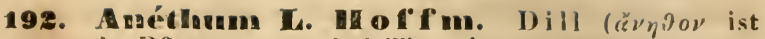
cin Pflanzenname bei 'Theophr. und Diose.).

472. A. gravéolens L., gem e iner. I). II a y Arzneigew. VII, 17. Stengel stielrund, gestleift, hahl; Blätter duppelt-bis 3 fach-gefiedert, mit linealisch-fadenförmigen, verlängerten, oberseits etwas rinnigen Zipfeln; Blattscheiden weissberandet, kurz, an der spitze beillerseits Oehichen hildend; Hïlle und Ilïll. chen fehlend; Frucht elliptisch, von einem verbreiterten, flachen Rande ungreben. $\odot$. In Südenropa einheimisch; im Gebiete häufig zun Küchengebrauche gebaut ınd nicht selten an Schutt, Wegen und Zäunen verwildert. Juli. Ang. Blıne gelb. Der bläulich-bereifte, weiss und dunkelgrïn gestreifte Stengel ist $2-4^{\prime}$ hoch.

193. Pastimáca L. Pastinak (Pflanzenname bei Plinius).

473. P. sativa L., gemeiner P. Hayne Arzneigew. VII, 16. Stengel kantig-gefurcht; Blätter gefiedert , oberseits glänzend, unterseits w eichhaarig, Blättchen eiförmig-länglich wler länglich, stımpf, gekerbtgesägt; lie seitenständigen an Gruncle gelappt nud 3zähnig, das endständige 3lappig; Hïlle und Hïllchen fehlend oder 1 - 2blätterig, hinfällig. C. Wiesen, Gräben, Wege, Zäune gemein und zum Küchengebrauch anch in Gärten gebaut. Juli. Ang. Blume gelb. Höhe 1-3'.

194. Keraclémm I. Bärenklau (Pflanzenname bei Dioscorides, nach Hercules benannt, gleichsam die herculische Pflanze; den Namen oqovfódıov, kleines Wirbelbein, erhielt sie vun den aufgetriebenen Stellen an Stengel, wo die Blattscheiden sitzen).

474. H. Sphondýlium L., ge mojne R. II a yn Arzneigew. V11, 10. Stengel gefurcht, mehr oder monder steifhaarig; Blätter rauhharig, gefiedert oder tief. fiederspaltig, mit gelappten oder handförmig - gुetheilten Fiedern; Dolden flach; Hïlle fehlend oder mit 1-6 kurzen, linealischen Blättchen; IJïllıen vielblätterig, borstenförmig; Fruchtknoten dicht-weichharig; Frïchte eiförnig-kreisrundlich, stumpf, ausgerandet, zuletzt kahl. @. Wiesen, Wälder, Gebüsche gemein. Juni-Herbst. Randbliithen strahlend, "eiss und oft mit 2 grinen Punkten an Grunde oder rosenroth. Höhe $2-5{ }^{\prime}$. Aendert ab:

b) elegans Jacq.: Blattfiedern schmäler, verlängert.

Das ächte H. angustifoliun L. $=$ H. sibiricun I. hat der Verfasser noch nicht im Gebiete gefuncen. 
195. Tordýlium L. Zi rme t (Pflanzenname bei Diuscorides).

475. T. maximum L., grösster Z. Stengel feingestreift, rückwärts steif behaart; Blätter gefiedert, Blättchen stumpf-gekerbt, die der unteren Blätter eiförmig, die der oberen lanzettlich, das endständiue verlängert und schmäler; Hiille und Hüllchen mehrblätterig; Früchtchen auf dem Mittelfelde borstig-steifhaarig, 4striemig. $\odot$. Zäune, Hecken sehr selten. Wird von Spreng. hal. ed. 2. p. 132 auf dem Bischofsberge in der Dölauer Heide angegeben, wo es seit vielen Jahren vergeblich gesucht wird. Viel wahrscheinlicher sind die von W all r. ann. bot. p. 40 angegrebenen Standorte: Yäune bei Rossleben und Bayer-Naumburg, da die Pflanze zwischen beiden Orten bei Allstedt an Zäunen der Gärten von der Louisenstrasse an nach der Schlangengasse und ron da nach der Peinholzgasse herunter ziemlich häufig volkommt. Juli. Aug. Blume weiss. Höhe 2-4'.

7. Gruppe. Thapsieen Koch. Scharfdoldengewä chse. Frucht zusammengedrückt oder im Querschnitte fast kreisrund; Früchtchen mit $\mathbf{5}$ fädenförmigen, bisweilen steifhaarigen Hauptrippen; die seitenständigen auf der Berührungsfläche liegend; Nebenrippen 4, die inneren fadenförmig, die äusseren geflügelt, oder sämmtlich geflügelt; Flügel ganzraudig; die Frucht daher 4 - oder sflügelig. Eiweiss vorne platt.

196. Lasenvitium L. Laserkraut (Laserpitium ist bei den römischen Schriftstellern ein Doldengew üchs Nordafrika's, welches den Saft Laser liefert und gleichbedeutend mit Silphium; der Name hat also mit der jetzt so benannten Gattung nichts gemein. Den Trivialnamen pruthenicum, preussisch, erhielt die Pflanze, weil sie zuerst aus Preussen durch Breyn gellauer bekannt wurde).

476. L. Iatifolium L., breitblätteriges L. Stengel stielrund, sehr fein-gerillt, kahl; Wurzel-und untere Stengelblätter 3zählig-doppelt-gefiedert, Blättchen eiförmig-gesïgt, am Grunde her_förmig, sümmtlich ungetheitt oder die endständigen der Wurzelblätter 3spaltig; Blattscheiden gedunsen; Hülle vielblätterig, lanzettlich-pfriemlich, häntig-berandet, Hüllchen borstenförmig, kurz; Strahlen der Dolde innen rauh; Griffel lang. 24. Wälder besonders auf Kalkboden, stellenweise. Mittelhol\%, Brenau bei Wettin, früher auch im 
Bienitz, hei Naumburg, Freiburg und Schmon häufig, bei Sandersleben spirsam. Juli. Aug. Blume weiss. Höhe 2-5'.

477. L. pruthénicum L., preussisches L. Stengel kantig-gefurcht, untervü̈rts rauhhaarig; Blätter doppelt-gefiedert, am Rande und an den Blattstielen rauhhaarig, Bliittchen fiederspaltig, mil lanzettlichen Zipfeln; Hïlle und Hüllchen vielblïtterig, lanzettlich, häutiq - berandet, gewimpert; Strahlen der Dulde innen weichhaarig; Griffel zuriickgekrümmt; Früchte eiförnig, Hauptrippen spärlich steifhaarig. 24. Trockene Wälder und Wiesen nicht gerale selten. Mittelholz, Bergholz, Bienitz, Wiesen lıei K'. Dölzig, häufig bei Naunburg, Freiburg, Mücheln, dllstedt u.s. w. Juli. Aug. Blume weiss, getrocknet oft gelblich. Höhe 1-3'.

8. Gruppe. Daucine en Koch. Mörengewächse. Frucht plattgedrückt-linsenförmig oder fast kugelig; Früchtchen mi 5 fadenförmigen Hauptrippen, die seitenständigen auf der Berührungsfläche liegend; Nebenrippen 4, melır hervortretend, mit freien oder in einen Flügel verwachsenen Stacheln. Eiweiss flach oder fast halbstielrund, vorne ziemlich platt.

197. TDaucus I. Mör re (Pflanzenname bei Dioscorides; der deutsche Name stammit von mör, mürbe).

478. D. Carota L., gemeine M. Hayne Arzneigew. VII, 2. Wurzel spindelförmig; Stengel steifhaarig; Blätter duppelt bis 3 fach gefiedert, Blïttchen fiederspaltig, mit lanzettlichen, haarspitzigen Zipfeln; Hülle vielblätterig, meist so lang als die Dolde, dreioder fiederspaltig. Hüllchen vielblätterig, häntig - berandet, gewimpert; blïhende Dolde flich, fruchttragende in der Mitte vertieft, Stacheln so lang als der Querdurchmesser der läıglich-eiförmigen Frucht. (). Wiesen, Triften gemein und in Grussen auf Aeckern gebaut. Juni-Herbst. Blume weiss. Höhe 1-2\%

In der Mitte der Dolde steht oft eine purpurrothe oder schwarzrothe, unfruchtbare, fleischig gewordene Bliithe, dies ist D. mauritanicus bei Leyss. hal. ed. 2. p. 65 oder Caucalis carnosa Roth.

Orlaya grandiflora Hoffm. oder Caucalis grand if 1 or a L. wird zuerst von Buxb. enum. p. 99 unter dem Namen Echinophura flore magno Riv. mit der Bemerkung angegeben, dass er sie nur einmal auf sandigen Aeckern bei Querfurt gefunden habe. Darauf hat 
sie nur noch Wallr. beobachtet, welcher sie nach sched. p. 110 unter Wintergetrcile auf sandigen Aeckern zwischen Querfurt und Schmou sammelte, welchen standurt neuerdings $\mathrm{Rchb}$. sax. p. 276 wieder aufgenommen hat. Da jeduch schon Spreng. in der 2. Aufl. der Flora sie wuerwähnt lässt und sie auch in newerer Zeit uinht wieder aufgefunden ist, su kanı der Verfasser diese Pflanze bei dem Mangel eines sicheren Stanilortes nicht wieder aufnehmen.

II. Ordnung. Campylospermen Koch. Gefurchtsamige.

Eiweiss an Rande eingebogen, eingerollt oder auf der inneren Fläche mit einer Längsfurche.

9. Gruppe. Gá calincen koch. II a ftdoldengewä $\mathrm{ehse}$. Frucht zusammengedrücht oder fast stielrund; Früchtchen mit 5 fadenförmigen, borstigen oder stacheligen IIauptrippen; die 3 mittleren auf dem Rücken, die 2 seitlichen auf der Berührungsfläche liegend ; Nebenrippen 4, mehr hervortretend, stachelig, oder durch die das ganze Thälehen bedeckenden Stacheln verwischt; Eiweiss einwärts gerollt oder am Rande einwärts gebogen.

198. Caúcalis Ioffm. Haftolde (Pflanzen. name bei Hippocrates und 'Iheophrast).

479. C. daucoìdes $L_{.}, \mathrm{m}$ ör $\mathrm{r} n \mathrm{f}$ ö r m i ge H. St u rm Heft S1. Stengel gefurcht, wherwärts ästig, Blätter doppelt-bis 3fach-getiedert, Blätchen fiederspaltig, mit linealischen, spitzen Zipfelchen; Dolden lingostielt, Döldchen wenigblïthig, den Blättern geyenüberstehend; Hiille fehlend wder Iblätterig, Hïllchen Janzettlich, breithäutig berandet; Frucht mit starken, an der Spitze hakenformigen Stacheln besetzt, welche so lang oder länger als der Querdurchmesser der Früchtchen sind. $\odot$. Aecker. unter Sommergetreide besonders auf Kalkbuden, stellenweise und oft unheständig. Aecker zwischen Nietleben und Benustedt, sehr häufig auf Aeckern und an Weiubergen bei Bennstedt, in Weinbergen bei Weissenfels, bei Naumburg und Freiburg verbreitet, sehr selten und unbeständig bei Allstedt und ebenso bei Eisleben auf Aeckern nach Helfta zu, bei Sandersleben an Kalkbergen über dem Pregel. Juni. Juli. Blume veiss. Höhe $1 / 2-1$ '. 
199. Turgénin Flofin. T'urgenia (lit)mmt keineswegs von turgere, strotzen, her, wegen der dikken Friichte, wie sellust $D$ un und Andere angeben, sulldern ist von Hof $\mathrm{fm}$. "ach dem Dr. Alexander 'Turgeneff, einst Direktor der Kanzelei heim Fürsten Gal. litzin benannt, ef. Ho f $\mathrm{m}$. genera plant. unbellif. p. 59).

480. T. Iatifolia Hoffm., b te it b lät terige 'I'. Stengel oberwärts kurz-borstiz, abstehend-ästig; Blätter gefiedert mit linealisch-länglichen, eingeschnitten-gezähnten Blättchen; Dulden 2 - 3strahlig, Dölılchen meist 5 blüthig; Hïlle $2-5$ blätterig, Hüllchen 5-7blätterig, häutig-berandet; Stacheln der Rippen auf der Berührungsfläche so lang oder kürzer als der Querdurchmesser der Fuge. $\odot$. Aecker, unter Getreide, beson. ders auf Kalkbuden, sehr selten. Nur hei Bibra am Fusse der Kalkberge und am Wege nach Memleben hin zienlich zahlreich und einzeln auf Aeckern bei KI. Jena. - Bei Schleberode und Freiburg, wo Spreng. hal. pll. 2, p. 133 und in Folge dessen auch $R \mathrm{chb}$. sax. p. 263 diese Pflanze angeben, hat der Verfasser vergeblich gesucht. Juli. Ang. Cancalis latıfolia L. Syst. nat. Tordylium latifolium I. Spec. plant. Blume weiss, weisslich-violett oder etwas röthlich. Höhe $1 / 2-1 \frac{1}{2}$ '.

200. Tórilis dans. Klettenkprbel (ein von A d anson zuerst gebrauchter Name, welcher, wie vielc andere von ihm gebildete Wörter, ohne bestimmte Be. deutung ist).

481. T. Anthriscus $G$ me l., gemeiner K. II a yne Arzueigew. 1, 36. Stengel nebst den abstehenden desten ron aluärts angedriicliten Haaren rauh; Blütter dop. pelt gefiedert, ron angedrückten Haaren scharf, Blätchen länglich, einguschnitten - gesägt; Dolden lang-gestielt; Hiille reichbläterig, den strahlen angedrückt, Hiillchen pfriemlich, so lang als das Döldchen; Stacheln der Friichte einwärts-gekriimmt, an der Spitze einfach, nicht widerhakig. (-). Züune, Hecken, Gebüsch, Schutt überall gemein. Juni. Juli. Tordylium Anthriscus I. Blıme weiss oder röthlich-weiss. Höhe 2-4'.

482. T. helvetica me I., s c hweizerischer. K. Stengel hin und her gebogen nebst den gespreizten Aesten von abivärts angedrückten Haaren rauh; unterste Blätter doppelt-gefiedert, obere gefiedert und 3zählig, Blättchen eingesclınitten-gesägt, das endständige del 
oberen Blätter oft verlängert; Hïlle tblätteriø odes fehlend; Stacheln der Friichte widerhakig. @. Aecker, Wegränder, besonders an Kalkbergen, stellenweise. Grasire Stellen des Gartens an der Weintraube, Weinberge hei Rullsdorf, bei Naumburg an Kalkbergen und Wegrändern häufig z. B. am We $e_{e}$ nach Almerich, bei Freiburg sparsamer z. B. an der neuen Giehle und an Kalkbergen in der Nähe der Querfurter Chaussee, bei Allstedt an Zäunen der Gärten von der Louisenstrasse nach der Sichlangengasse, bei Querfurt am Galgenberye und nach $\mathbf{S c h}$ wabe bei sandersleben und Bernburg. Juli. Ang. Caucalis helvetica J a c q. Scandix infesta L. Blume weiss. Der meist graugrïne Stengel ist im Gebiete gewöhnlich $1 \frac{1}{2}-3^{\prime}$ hoch.

10. Gruppe. Scandicineen Koch. Nadelkerbelgewächse. Frucht länglich, von der Seite her bemerklich zusammengedrückt oder zusammengezogen, öfters geschnäbelt; Früchtchen mit $\mathbf{5}$ fadenförmigen, gleichartigen oder nur an der Spitze bemerklichen Hauptrippen, ron welchen die seitlichen die Ränder bilden, so dass die Nebenrippen fehlen. Eiweiss vorne mit einer tiefen Furche ausgehöhlt oder am Rande einwärts gerollt.

\section{Seantix I. Nadelkerbel (Pflanzenname bei Dioscorides).}

483. S. Pecten Veneris $\mathbf{L}$., $k$ a $\mathrm{mm}$ fö $\mathrm{rmig}$ e $\mathrm{r}$. Stengel etwas rauh, meist ästig; Blätter 3fach gefiedert, mit fiederspaltigen Läppchen; obere Blattscheiden häutig, am Rande gewimpert; Dolden 1-3strahlig, an Grunde meist mit einem Blatte; Hülle fehlend, Hüllchen meist 5 blätterig, lanzettlich, ganzrandiy oder an der Spitze 2-3spaltig, länger als die sehr kurzen Blïthenstiele; Schnabel der Frucht sehr lang, vom Riicken her zusammengellrückt, 2reihig - steifhaarig. $\odot$. Felder unter der Saat nicht gerade selten, aber oft unbeständig. Bei Halle ziemlich häufig besonders auf Aeckern zwischen Niptleben und Bennstedt und zwischen Bennstedt und Kölnıe, bei Röglitz, Kl. Dölzig. Aecker am Bienitz u. s. w. Mai. Juni. Blume weiss. Stengel meist 6" hoch.

202. Anthríscus Ur of an. Kerbel (Pflanzen. name bei Plinius).

484. A. silvestris Hoffm., Wald-K. Hayne Arzneigew. I, 33. Stengel unterwärts rauhhaarig, oberwärts kahl; Blätter kahl odes unterseits auf den llauptnerven borstlich-haarig, doppelt bis 3 fach gefiedert, 
glänzend, Blättchen im Umrisse eiförmig - länglich, fiederspaltig mit linealisch-lanzettlichen Zipfeln; Iiille fehlend oder 1-2blätterig, Hüllchen 5blïtterig, ziemlich lang-gewimpert; Frucht glänzend, länglich, glatt oder ierstreut-knötig, 5mal lïnger als der Schmabel. 4. Wald - und Wiesenränder, Zäune, Heckell, Mauern nicht selten z. B. in Weidengebüsch an dem Pulverweiden, auf dem 'Trothaischen Werder, im Passendurfer Busche, in 'Zäunen bei Gutenberg 11. s. w. Mai. Juni. Chaero. phyllum silvestre L. Blume weiss. Höhe 3-4'.

485. A. Cerefolium Hof $\mathrm{fm}$., Gartenkerbel. Hayne Arzneigew. VII, 14. Stengel über den Gelenken weichhaarig; Blätter 3 fach gefiedert, kahl, unterseits auf den Nerven zerstreut - behaart, Blättchen im Umrisse rundlich-eiförmig, tief-fiederspaltig mit stumpfen, kurzstachelspitzigen Zipfelı; Dolden kurz gestielt oder sitzend, 3-5strahlig, Strahlen der Dolde weichhaarig; Hülle meist fehlend, Hüllchen 1-4blätterig; Friichte linealisch, glatt, doppelt so lang als der Sclmalyel. $\odot$. Stammt ans südeuropa und "ird jetzt häufig in Gärten gebaut, findet sich nicht selten auf Schutt und in 'ä̈llnen verwildert. Nai. Juni. Sciandix Cerefolium I. Cerefolium sati um Bess. Blume wriss. Höhe 1-2'. Die Blätter habe॥ einen aromatischen, anisartigen Geruch und Geschmack.

486. A. vulgaris Pers., g e meiner K. Stengel kahl, mit abstehenden Aesten; Blätter 3fach gefiedert, kahl, unterseits auf den Nerven zerstreut-haarig, Blättchen in Uarisse piförmig, fiederspaltig, mit länglichen, stumpfen, kurz - stachelspitzigen Zipfeln; Dolden kurzgestielt, Strahlen der Dolde kahl: IFïlle fehlend, Hiillchen 2-4blättrig, einseitig; Friichte eiförmig, mit einü̈̈rts gehrïmmlen, pfriemlichen Stachech besetzt, sehr kurz geschmäbelt; Narben fast sitzend. $\odot$. An Wegen in Dörfer'n, an Zäunen, Félsen und Schutt nicht gerade selten. An Chausseegraben in 'Truthit häufig, etwas seltener an den Felsen ror' Trotha, an der Bergschenke bei Kröllwitz zahlreich, auf dem Kellerberge in der Dölauer Ileide, an Mauern in Wesmar und Kl. Dölzing u. s. w. Mai. Juni. Scandix Anthriscus L. Torilis Anthriscus Gärtn. Blume weiss. Höhe $1 / 2-1 \frac{1}{2}$.

203. Chaerophýllum L. Kälberkropf (Pflan-

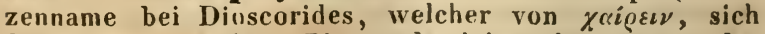
freuen, und quid.ov, Blatt, abzuleiten ist, wegen der schönen Blätter). 
487. Ch. témulum L., be täubender K. Hayne Arzneigew. I, 34. Stengel unter den Gelenken aufgeschwollen, am Grunde steifhaarig, oberwärts kurzhaarig; Blätter doppelt gefiedert, beiderseits kurzhaarig, Blaittchen im Umrisse eifürmig - länglich, lappig - fiederspaltig, mit stumpfen, kurz-stachelspitzigen, etwas gekerbten Zipfcln; Hülle fehlend order 1-2blitterig, linealisch länglich, Hiillchen vielhlätterig, einseitig, mit eiförmig-lanzettlichen, haarspitzigen, gevimperten Blïtchen; Blumenblïtter liahl; Griffel zuriickgcbogen. (.). Herken, Zäune, Gebusch, schuthaufen, Wegründer iiberall ge. mein. Mai. Juni. Myrrhis temula spreng. Blumenblätter weiss, tief 2spaltig. Der meist dunkelroth gefleckte Stengel ist $1-3^{\prime}$ hoch.

488. Ch. bulbosum C., knolligger K. Hayne Arzneigew. 1, 32. Stengel unter den Gelenken aufgeschwollen, am Grunde steifborstig, oberwärts kahl; Blätter 3- bis 4fach-gefiedert, an den Nercen untes. seits mit zerstrellen, langen llaaren besetzt, Blïtchen tief-fiederspaltig, mit linealisch-lanzettlichen, spitzcn, an den oberen blïttern schr schmal-linealischen Zipfeln; Hiille fehlend oder Iblätterig. Hïllchen 4-bblätterig, rinseitig, mit lanzettlishen, haarspitzigen, kahlen lilitt. chen: Llumenblïter liahl; Griffel zuriüligebogen. (.) Zwischen Gebüsch, an Wildründern, Zäunen, Flussufern hänfig z. B. in Gebüsch an her Saale hinter rem Schwalchloche zwischen Kröllwitz und Lettin, auf der Rabeninsel, auf dem Truthaischen Werder, in Frenzelholze bei Lirskau, im Hagen bei Esperstedt u. s. w. Juni. Juli. Myrhis bulbusa Spreng. Blume weiss. Der nur unten roth gefleckte Stengel ist $4-6^{\prime}$ hoch. Wurzel kugelig onler länglich-kugelig, mit spmdelförmigem Ende.

489. Ch. hirsutum L., rauhha r iger K. Stengel unter den Gelenken fast gleich dick, meist rauhharig; Blätter doppelt - 3zühlig, Blättchen 2-3spaltig oder fiederspaltig, eingeschnitten-gesägt; Hïlle fehlend, Hiillchen vielblätterig, fast so lang als die Blüthenstielchen, mit breit-lanzettlichen, zugespitzten, am Rande gewimperten Blïtchen; Blumenblïtter genvimpert; Griffel aufiecht, $1 / 3$ si) lang als die Frucht. 4 . Fenchte Stel. len und Bäche in Bergwäldern. Wird von $S p r e n g$. an Bergwäldern bei Schmon und Lodersleben als seiten vorkonmend angegeben. Der Verfasser hat es noch nicht im Gebiete gefunden, bezweifelt aber das Vor- 
kommen dieser Pflanze, wenigstens an dem zuletzt erwähnten Standorte keineswegs. Juli. Ang. Ch. Cicutaria Vill. Nyrrhis hirsuta Spreng. Blume weiss oder rosenroth. Höhe $1-3^{\prime}$.

11. Gruppe. Smyrneen DC. Maceronengewächse. Frucht gedunsen, oft von der Seite her zusaminengedrückt oder zusammengezogen; Früchtchen mehr oder weniger deutlich Jrippig, die seitlichen Rippen randbildend oder ror dem Rande gelegen. Eiweiss einwärts-gerollt oder auf der inneren Seite gefurcht.

204. Conium I. Schierling (das Wort *úveเov wird schon von Dioscorides für den Schierling gebraucht).

490. C. maculatum L., g efleckter Sch. H a y e Arzneigew. 1, 31. Stengel rundlich, zart-gerillt, bläulich-bereift, am Grunde roth gefleckt, kahl; untere Blätter 3fach-gefiedert, mit stielrunden, hohlen Blattstielen, Blättchen in Umrisse eiförmig - länglich. tief fiederspaltig, ganz kahl, mit eingeschuitten-\%ezähnten Zipfeln; Strahlen der Dolde innen schürflich; Hïlle vielblätterig, Hüllchen 3-4błätterig, einseitig, lanzettlich, zugespitzt, kürzer als das Döldichen. (-). Schutt, Hecken, Wege, Mauern nicht gerade hälfig nnd oft unbeständig. Ist in Hecken bei Zöschen, in der Aue bei Naumburg, am Schlosse zu Mannsfeld hin und wieder gefunden worden, häufiger in nordöstlichen Gebiete. Juli. Aug. Blume weiss. Ilöhe $3-6^{\prime}$.

\section{Ordnung. Coelospermen Koch. Hohl-}

\section{s a $\mathrm{mi} \mathrm{g}$ e.}

Eiweiss ausgehöhlt, halbkngelig oder sackartig.

12. Gruppe. Coriandreen koch. Koriandergewäehse. Frucht kugelig oder durch 2 last kuglige Früchtchen 2knotig; Früchtchen mit $j$ oft etwas welligen Ilauptrippen, wovon die äusseren vor dem scharfkantigen Rande stehen und ausserdem mit 4 etwas hervorragenden, ungeflügelten Nebenrippen.

305. Coxiándrum L. Koriander (Pflanzenname bei Plinius; von *óoı, Wanze, abgeleitet, Iegen des wanzenartigen Geruches der Blätter).

491. C. sativum $\mathbf{L}$., g e bauter $K$. Hayne Arzneigew. VII, 13. Stengel rundlich, gestreift, kahl; Wurzelblätter bald abfallend, gefiedert, mit rundlichen, ein- 
geschnitten - gesägten Blättchen, untere Stengelblätter doppelt - gefiedert, mit fiederspaltig - eingeschnittenen Blättchen, obere Stengelblätter fein-zertheilt; Dolden 3 -5strahlig. $\odot$. Wird in Thüringen und in der Gegend von Aschersleben im Grossen gebaut; stammt aus Südeuropa. Juni-Aug. Blume wejss, die Randblïthen strahlend. Höhe 1-2'. Das Kraut hat einen unangenehmer, wanzenartigen Geruch. OFF. sem. Coriandri.

XLVIII. Familie. Araliaceen. Araliengewächse.

206. Hédera L. E pheu (Pflanzenname bei Plinius).

492. H. Helix L., geme ine I. Hayne Arzneigew. IV, 14. Stengel mit wurzelartigen Fasern kletternd; Blätter lederartig, kahl, glänzend, eckig-5lappig, die obersten und die der blïhenden Aestchen ganzrandig, eiförnig, zugespitzt; Doiden einfach, weichhaarig. ち. Wälder, Felsen, Mauern häufig, aber in Wäldern meist nicht blïhend, sondern mr auf dem Boden rankend oder an alten Büumen hinaufkletternd; nit Blïthen wird sie nur an Felsen gefunden z. B. an Felsen in den Gärten vor Giebichenstein und besonders im Anitsgarten u. s. w. Juli-Octob. Blume grùn, Früchte schwarz. Der Stamm klettert an Mauern bis $60^{\prime}$ hoch.

XLIX. Familie. Corneen DC. Cornellengewächse.

207. Comums C. Cornelle (ein bei Plinius vorkunmender Pflanzenname, welcher von cornu, Horn, abgeleitet sein soll, "egen des harten Hulzes).

493. C. sanguínea $\mathbf{L}$, r o the C. Flora v. Thüring. II, 18. Aeste aufrecht; Blätter eiförnig. zugespitzt, beiderseits grün und kurzhaarig; Trugdolde flach; Hiille fehlend; Haare der Aeste und Blüthenstiele angedrückt. Ђ. Wälder, Gebüsche, Hecken häufig z. B. Wälder um Gutenberg, zwischen Dölkau und Horburg und oft in Hecken und Zäunen. Mai. Juni. Blume weiss. Steinfrucht schwarz, weiss punktirt, fast kugulig. Zweige in Herbste und Winter blutroth. Ein 10-18' hoher Strauch.

494. C. mas L., gelbe C., Cornelkirsche. 
Flora v. 'Thiiring. I, 1. Aeste kahl, nur in der Jugend angedrückt-behaart; Blätter kurz-gestielt, eiförmig oder elliptisch, lang-zugespitzt; die cinfache Bliithendolde vor den Blïllern hervorbrechend und bliiliend, et. wa so lang als die 4lulitterige Hiille. ち. Trockene Hugel, besonders auf Muschelkalk, wirklich einleinisch wohl nur in 'Thïringen z. B. am Pfortenberge hei Naumburg, am Schlayherge, Schlifter und in Miihlholye bei Freiburg, in Hagen bei Allstedt, ausserlen häufig in Anlagen, Gärten, Zäunen und Hecken angepflanzt. April. Mai. Blume grelb. Steinfrucht hängwıd, elliptisch, glän. zend-kirschroth. Ein $8-20$ hoher strauch oder Banum.

Männliche Cornelle, Cornus silvestris mas, heisst dieser Baum hei C. Bauhin in Gegensatz zur we iblichen Cornelle, Cornus femina C. B., welche L,inné später C. sanguinea nannte, während er für jene den ältern Namen Cornus mas oder mascula beibehielt.

Die jungen, stärkeren, gerade gewachsenen 'I'riebe wurden früher von den Bewohnern des in der Nähe von Jena liegenden Dorfes Ziegenhayn brann gebrannt und unter dem Namen der Z $/$ jegenhayner Stöcke weithin versandt.

\section{Familie. Loranthaceen Don. Riemen- b lumengewächse.}

208. Viscum M. Mistel (ron riscus, Vogelleim, wegen der hebrigen Beschaffenheit der Beeren).

495. V. album L., Weisser M. Haye Arzneigew. IV, 24. Stengel gahelspaltig, sehr ästig, deste stielrund; Blätter gegenüberstehend, lanzettlich-spatelförmig, lederartig; Blïthen endstïndig, sitzend, meist 5zählig, geknäuelt. ち. Auf Aesten verschiedener Bäume schmarotzend, besonders auf Pappeln, Linden, Birken, Birn - und Aepfelbäumen und Nadelhölzern nicht gerade selten z. B. in der Dölauer Heide. März. April. Blume gelb. Beeren durchscheinend-weiss. Ein grünlich-gelber Strauch von 1-2'Höhe. Aus den Beeren bereitete man fiüher den Vugelleim.

\section{L1. Familie. Caprifoliaceen Juss. Geiss -} hlattgewächse.

1. Gruppe. Sambuceen H. B. u. K. Holundergewächse. Blumenkrone radförmig. Griffel oder Narben $\mathbf{3}-\mathbf{5}$. 
209. Adóxa T. Bis a mkraut (vou reprirat. und Sósc, Ruhm, eigentlich die Unberühmte, Unbeachtete).

496. A. Moschatellina $\mathbf{L}_{\text {., g }}$ ew e ines B. Flora v. 'Thüring. II, 17. Wurzelstock schuppenförmig, weiss; W urzelblätter lang - gestielt, 3zählig-gefiedert, 2 gegenüberstehende Stengelblätter, Blättchen 3theilig, eincreschnitten; Blüthenstiel endständig, ein fast würfelförmiges 5 blüthiges Köpfchen tragend; endständige Blüthe 4zählig, seitenständige meist 5zählig. 24. Schattige Wälder, besunders in lockerer Lauberde, Erlengehïsche, Hecken nicht yerade selten, aber leicht zu übersehen. Lindberg, Zorgs, Zöschener Holz zwischen Röglitz und Zöschen. Brenau bei Wettin, bei Weissenfels an Abhängen zwischen Beuditz und Leislingen, bei Naumburg an buschigen, waldigen Abhängen der Schellsitzer Fähre gegenüber und in Hecken nach der Schön. hurg hin, an der Steinklippe bei Wendelstein, im Mühl. thale zwischen Ziegelrode und Rossleben, in Bornthale แแ⿺ im Molkenbrumnenthale bei Allstedt, an rothen Brumnen in Scheierholze bei Lodersleben, bei Eisleben in Helftaer Holze am Bache sparsam und häufiger in Küchenberge bei Holzzelle, bei Aschersleben häufig, hei Sandersleben in Walde in der Nähe von Unterwie. ierstedt, bei Oranienbaum nicht selten z. B. im Nichrim, bei Delitzsch in Schenkenberger Busche und im Poe. tongange nach Gertitz hin. März. April. Blume grün. Ein 3-4" huhes, nach Bisam duftendes Pfäızchen.

210. Sambúcus H. Holunder (von $\sigma \alpha \mu \beta i x \eta$, sambuca, ein musikalisches Instrument, welches aus Holunderholz verfertigt wurde; schon Plinius gebraucht den Nanien Sambucus).

497. S. Ébulus L., Z w e rg-H., Eppich. Hayne Arzneigew. IV, 15. Stengel krantartig, kleinwarzig; Blätter g $\mu$ fiedert, mit 5-9 fiförmig-lanzettlichen oder lanzettlichen, dicht-gesägten Blättchen; Nebenblätter l,lattartig, eiförmig, gesägt; IIauptäste des Ebenstrausses 3zïhlig; Staubbentel purpurroth. 24. Waldränder, zwischen Gebüsch an Bergabhängen, breite Ackerraine, in Hecken. Wird von Spreng. in Zäınen und Hecken bei Reideburg, Radewell und Döllnitz angegeben, wo dieser Strauch aber nur angepflanzt ist; häufiger ist er an Aclierainen bei Hettstedt, ob aber auch durt wirkfich wild, rermag der Verfasser nicht mit Bestimmtheit zu sagen. Juli. Aug. Blumen weiss, aussen röthlich. Beeren schwarz. Ein nur $2-6^{\prime}$ hoher Strauch. 
498. \$. nigra L., schwarzer H., Flieder. Hay ne Arzneigew. IV, 16. Strauch-oder baumartig; Mark der Aeste schneeweiss; Blätter gefiedert, mit $3-7 \mathrm{ei}$ förmigen, dicht-gesägten, lang-zugespitzten Blättchen: Vebenbliitter warzenförmig oder fehlend; Ilauptiiste der Trugdolde 5zïhlig; Staubbeutel gelb. h. In Wäldern und viel häufiger in Dörfern, Hecken, 'Jïunen angepflanzt. Juni. Juli. Blume weiss, Beeren schwarz. IIöht? $10-30$. OFF. flores et baccae Sambuci. Aendert ab:

b) virescens Kuch: Beeren grïn.

c) leucocarpa Koch: Beeren weiss.

499. s. racemosa C., Trauben-II. Guimp. t. 35. Strauch-, selten bammartig; Mark der Aeste gelb oder gelbbraun; Blätter gefiedert, nit eiförmig-länglichen, gesägten, zugespitzten Blättchen; Ncbenbliitter warzenförmig; Rispe eiförmig; Staubbentel gelb. t. Bercwäl. der. Wird von Sprengel im Wendelsteiner und Lodersleber Forste und in der Kl. Eichstedter Wiiste angegeben, zu welchen Standorten der Verfasser die Bergwälder in der Nähe von Bornstedt unweit Eisleben fïgt. April. Mai. Blume gelblich-wejss. Beeren scharlachroth. Höhe $6-12^{\prime}$.

211. Vibúrmum L. Schlinge (ein von Plinins gebrauchter Pflanzenname, welehel wohl mit vimen, Gerte, verwandt ist, wegen der biegsamen Zweige von $V$. Lautana).

500. V. Lantána L., wollige Sch. Guimp. t. 31 . bic̈itler eiförmig, gezühnelt-gesïgt, an Grunde fust herz. förmig, unterseits runzelig-aderig und nebst den Aestchen von einem sternförmigen Flaune filzi⿺尢丶, oberseits von sternförmigen, zerstreuten Härchen flaumig; Ebensträusse endständig, gestielt. ち. Bergwälder, Gebiische, fast nur auf Kalk stellenweise. Fehlt bei Halle (denn air Tannenberge bei Gutenberg, welchen Standort spreng. hal. ed. 2. y. 145 angibt, ist dieser Strauch, wie mehre andere, nur angepflanzt), ist aber wirklich wild und häufig an Kalkbergen bei Naumbnrg, Freiburg, im Hackenholze bei Branderode, in den Schnon. schen Bergen, im Hagen bei Esperstedt, sehr sparsam an der Steinklippe bei Wendelstein. Mai. Blume weiss. Früchte eiförmig, etwas zusammengedrückt, grün, dann hochroth, endlich schwarz. .

501. v. Ópulus L., gemeine Sch., Schneeball. Sturm Heft 27. Blätter 3- oder 5lappig, mit zugespitz- 
ten, gezähnten Lappen; Blattstiele oberwärts mit mehren sitzenden und am Grunde mit 2 gestielten Drusen versehen; Ebensträusse endständig, ¿estielt, Randblüthen grösser, strahleul, geschlechtsios. ち. Wälder, feuchte Gebüsche und Hecken, Flussufer gemein z. B. auf der Kabeninsel, im Wörmlitzer Hölzchen, im Gebïsch an der stillen Elster zwischen Radewell und Osendorf u. s. w. Mai. Juni. Blume weiss. Früchte länğlich-rund, scharlachroth. Ein 6-12' hoher Strauch. Aendert $a b$ :

b) roseum L.: 'I'rugdolden kugelig, alle Blüthen sehr gross und geschlechtslos. Diese Abart wird häufig in Gärten gezogen.

2. Gruppe. Lonicereen R. Br. Lonitzerengewächse. Blumenkrone röhrig oder glockıg, oft unregelmässig. Griffel fadenförmig.

212. Honicéra T. Lunitzere (nach den Frankfurter Arzte Adam Lonitzer benant; der Trivialname ist aus $\xi i \lambda o \nu, ~ H o l z$, und $\partial \sigma \tau \varepsilon \nu \nu$, Bein, zusammengesetzt).

502. L. Xylósteum L., go emeine L. Guimp. t. 9. Stengel aufrecht; Blätter eiförmig oder rundlich-elliptisch, weich behart; Blüthenstiele 2blüthig, zottig, ungefähr so lang als die Blïthen; Fruchtknoten am Grunde

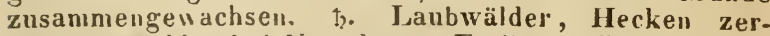
streut. Wälder bei Naumburg, Freiburg, Lodersleben, Schmon, Eisleben. Mai. Juni. Blume weichhaarig, in der Knospe blass - röthlich, nach der Entfaltung weiss und zuletzt gelblich. Beeren scharlachroth, unten verwachsen. Ein $4-S^{\prime}$ hoher Strauch.

L. Periclymenum L. scheint im Gebiete gant zu fehlen; von s chw abe wird dieser Strauch zwar bei Oranienbaum angegeben, ob aber auch dort wirklich wild? - L. C ap rifulium L., Je länger, je lieber, wird oft in Gärten an Lauben angepflanzt.

\section{Familie. Stellaten I. Sternblüthler.}

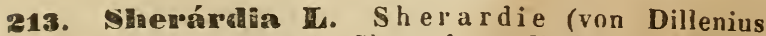
zum Andenken an Wilh. Sherard, englischen Konsul in Sniyrna und eifrigen Reförderer der Naturwissenschaften, genannt).

503. Sh. arvensis L., Acker-Sh. Stengel liegend oder etwas aufsteigend, ästig, glatt nder schärflich; 
Blätter meist 6ständig, lanzettlich, die unteren elliptisch, oberseits nul an Ramle scharf; Blüthen in einem endständigen Köpfchen, welches vun gewöhnlich 8 am Grunde verwachsenen Dechblättern umgeben ist; Frucht mit den Kelchzähnen gekrönt. $\odot$ und $\odot$. Aecher häıfig z. B. vor Nietleben, vor Seben u. s. "W. JuniOctub. Blume lilafarben. Stengel 3 -S" lang.

214. Aspérula I. M e i e $r$ (von asper, rauh, wegen der rauhen Blätter und Frichte mehrer Arten; del Trivialname cynanchica ist von yvvig'\% , Halsentziindung, abgeleitet, weil die Pflanze dagegen angewendet wurde).

504. A. tinctoria L., färbender M. Wurzel hrie. chend; Stengel aufrecht, meist einzeln; Blïtter lincalisch, kahl, am Rande etwas rauh, die unteren 6stäldig, die oberen 4ständig, ungleich-lang; Ebenstriusse endständig; Deckblätter oval, spitz, ohne Stachelspitze; Blume kahl, Röhre so lang als der Saum; Füuchte glatt. 24. Waldränder, buschige Hiigel stellenweise. Bei Halle häufig z. B. Bischufsberg in der Dölauer Heide, Frenzelholz bei Lieskau, Mittelhulz, Bergholz, Krosigker Holz nordwestlich rom Petersberge; Westseite des Bienitz, fehlt in der Nïhe von Weissenfels und Naumburg; an suidlichen Rande der neuen Giehle und an Waldrändern an Rörlel bei Freiburg, im Hacken. holze bei Branderode, an der Steinklippe bei Wendelstein, Waldründer bei Frechleben unweit Sandersleben, in nördlichen und "urdöstlichen Gebiete selten, bei Oranienhaum im Nichrim. Juni. Juli. Blnme Weiss. Höhe $1-1 \frac{1}{2}$ '.

5115. A. cynánchica L., Hüg el-M. Wurzel spindelförmig, reichstengelig; Stengel ausgebreitet, aufstrebend, sehr ästig; Blïtter linealisch, 4stïndig, kahl, an Kande etwas rauh, die oberen ungleich-lang; Eben. sträusse endständig; Deckblïtter lanzettlich, stachelspitzig; Blumenkrone aussen lörnig-rauh, Köhre su lanı als der Saum; Früchte körnig-rauh. 4. Truckene Wegränder, Raine, freie Waldstellen, sonnige Bergab. hänge in ganzen Gebiete mit Ausnahme der Niederungen häufig. Juni. Juli. Blume fleischroth, inwendig weiss. Stengel 4-12" lang.

506. A. odorata L., Waldmeier oder Wald mei. x ter. Stengel aufrecht oder aufsteigend; Blc̈tter breit. lanzettlich, kahl, an Kande und Kiele rauh, die unte- 
fen 6ständig, die oberen Sständig; Ebensträusse endständig, gestielt; Friichte mit halienförmigen Borsten besetzt. 4. Schattige Wälder, Haine, buschige Abhänge stellenweise. Fehlt in ler Nähe ion Halle, da sie sich an den vun Sprenge! angegebenen Orten bei Seben und am Petersberge nicht mehr findet; bei Naumburg zerstreut, etwas häufiger nur in 'Morithale nach der Kuhlenstrasse hin. bei Allstelt in Winkelschen Theilholze, in den Wälern bei Eisleben zerstreut, bei Holzzelle im Kürhenberge einzeln, an quelligen Abhängen des Muldeuthales zwischen Puuch und Rösa östlich von Bitterfeld häufig, ju Zschepener Busche östlich von Delitzsch. Mai. Juni. Blume weiss. Das trockene Kraut riecht wie Ruchgras (Anthoxanthum odoratum L.). Höhe 4-8".

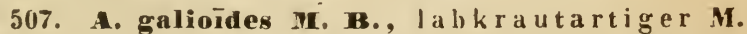
Stengel aufrecht.oder aufsteigend. stielrund, schwachkantig, kahl oder am Grunde weichhaarig, oberwärts rispig-ebenstrüussig; Blätter starr, linealisch, stachelspitzig, am Rande umgerollt und rauh, die stengelständigen meist 8ständig; Blımenkrone kuız-glockenförmig, Röhre kürzer als der Saum; Früchte glatt. 4 . Sonnige IIügel, trockene Berge. an Rande hochgelegener Wälder stellenweise. Bei Halle nicht selten z. B. am Kande des I,indberges, an Zurgs, am Wege zwischen Seben und Gutenherg, in Weinbergen bei Röglitz, sel. ten im Bienitz, häufiger zwischen Dïrremberge und Godula und in den Weinbergen von Weissenfels, bei Naumburg und Freiburg verbreitet, an der Steinklippe bei Wendelstein, an den Weinbergen bei Bernburg. Juni. Juli. Galium glaucum J. G. campanulatum Vill. Blume weiss. Höhe $1-2^{\prime}$.

215. Grílume I. Jabkraut (der von Dioscorides

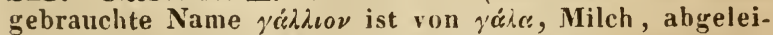
tet und bezieht sich, wie der deutsche Name Labkraut, auf die Eigenschaft dieser Pflanze, die Milch zum Gejinnen zu bringen).

A. Cruciata Tournef. Blüthenstand blattwinkelständig. Blüthen vielehig; die endständige Blüthe an den Verästelungen zwitterig, fruchtbar, die. seitenständigen männlich, unfruchtbar. Blïthenstiele und Blätter nach der Blüthezeit bugenförmig - zurückgekrünmt.

508. G. Cruciata scop., kreuzblätteriges J, 
Sturm Heft 7. Stengel von wagrecht-abstehenden Haaren rauhhaarig; Bliitter 4 ständig, elliptisch-lïnglich oder eiförmig, meist 3nervig, zur Fruchtzeit herabgeschlagen; Bliithenstiele seitenstïndig, ästig, deckblätterig, steifhaarig oder kahl, bei der Fruchtreife abwärts-gehrümmt; Früchte kahl, unter den Blättern verborgen. 4. Laubwälder, zwischen Gebüsch, an Hecken und Zäunen häufig. April. Mai. G. cruciatum Sm. Valantia Cruciata L. Blume gelb. Höhe $1 / 2-2^{\prime}$. Aendert $a b$ :

b) laevipes Koch: Blüthenstiele und Bluithenstielchen kahl. V. Cruciata Willd.

B. Vaillantioides. Blüthenstand blattwinkelständig. Blüthen vielehig, die endständige Blüthe an den Verästelungen $z$ wtterig, fruchtbar, die seitenständi„en männlich, unfruchtbar. Blätter nicht abwärts gekrümmt.

509. G. saccharatum All., iiberzuckertes L. Stengel schwach, niederliegend, rückwärts stachelig. rauh; Blätter meist 6ständig, linealisch-lanzettlich, stachelspitzig, 1nervig, am Rande aufuäirts-stacheligrauh; Bliithenstiele seitenständig, 3lliithig, nach dem Ferbliihen herabgebogen, 1 friichtig, Blüthenstielchen kürzer als die grosse, dicht-warzige Frucht. $\odot$. Auf Feldern unter der Saat, besonders auf Kartoffeläckern, sehr selten und oft unbeständig. Aecker zwischen Halle und Nietleben sehr sparsan, etwas häufiger zwischen dem Zorgs und Bennstedt, bei Kölme, zwischen dem Bienitz und KI. Dölzig sehr selten. Früher auch einmal bei Lieskau und Merseburg gefunden. Die Richtigkeit les ron $\mathrm{Sch}$ wa be fl. anh. angegebenen Standortes bei Bernburg wird ron $H$ a $\mathrm{mp}$ e in Zweifel gezogen. Juli. Aug. G. verrucosum $\mathbf{S}$ n. Valantia Aparine $\mathbf{L}$. Blume weisslich. Stengel 4-8" lang.

c. Aparine. Blüthenstand blattwinkelständig oder zuletzt rispig. Bliithen zwitterig. Stengel von abwärts gekrümmten, ziemlich breiten Stacheln rauh.

510. G. tricorne with., dreihörniges L. Stengel ziemlich dick, gestreckt, rïckwärts stachelig-rauh; Blätter meist 8ständig, linealisch-lanzettlich, stachelspitzig, 1nervig, am Rande riichwärts stachelig-rauh; Bliithensticle seitenständig, meist 3bliithig, 1-3früchtig; Bï̈thenstielchen nach dem Verbliihen zuriickgekriimmt, länger als die warzig-körnige Frucht. 
Aecker auf Kalk - und Jehmboden, besonders unter Kartuffeln, stellenweist. Bei Halle nicht gerade selten z. B. auf Aeckern zwischen Halle und Nietleben und nach Bennstedt zu häufig, ebenso zwischen Beuchlitz und Schaafstedt, auf Aeckern bei Kl. Liebenau, bei Möritzsch und Kl. Dölzig, bei Naumburg zerstreut, bei Eisleben selten z. B. zwischen Helfta und dem Walde, bei Sandersleben, Bernburg und Dessau hin und wieder. Juli - Herbst. G. Valantia Wigg. Valantia Aparine Poll. Blume weisslich oder gelblich-weiss. Stengel $1 / 2-1$ ' lang.

511. G. Aparíne L., kletterndes J., Kleber. Stengel niederliegend oder kletternd, 4 kantig, rückwärts stachelig-rauh; Blätter 6- und 8ständig; linealisch-lanzettlich, stachelspitzig, 1nervig, am Rande und an dem Kiele riickwäirts stachelig-rauh; Blïthenstiele blattwinkelständig, zuletzt fast rispig; Bliithenstielchen nach dem Verbliihen gerade; Früchte hakenförmig - steifhaarig oder glatt; $\mathrm{der}$ Durchmesser der Blume kleiner als der der entwickelten Frucht. $\odot$. Aecker, Zäune, Hecken, Gebüsche, Wälder überall gemein. Juni Herbst. Blune weiss uder grünlich. Der an den Gelenhen meist borstig-kurzhaarige oder ganz behaarte Stengel klettert 2-4' hoch. Aendert ab:

b) Vaillantii DC.: kleiner, Frïchte um die Hälfte kleiner, hakentörmig-steifhaarig; Stengel an den Gelenken meist glatt. G. infestum W. K. G. agreste o. echinospermum Wallr.

c) spurium L.: Frïchte unbehaart, sonst wie die vorige Abart. G. agreste $\beta$. leiospernum Wallr.

512. G. uliginosum L., M $\mathbf{~} \mathbf{r}$ a $\mathbf{~ t}$ - L. Stengel schwach. aufsteigend, 4 kantig, rückwärts stachelig rauh; Blcitter meist 6ständig, linealisch-lanzettlich, stachelspitzig, 1nervig, am Rande und oft auch am Kiele riichuairts stachelig-rauh; Blüthenstiele blattwinkelständig, zuletzt fast rispig, Bliithenstielchen nach dem Verbliihen gerade; Früchte kahl, feinkörnig; der Durchmesser der Blume grösser als der der entwickelten Frucht. 4. Sumpfige, torfhaltige Wiesen, Gräben stellenweise. 'Torfhaltige Wiesen unter dem Tannenberge bei Gutenberg, sumpfige Wiesen vor Bennstedt, ebenso am Bienitz, bei Naumburg auf der Gröbitzer Wiese, bei Eisleben nach $\mathrm{Rchb}$. fl. sax. p. 135, aher wo?, in Aschers. leber See, bei Dessau häufig, im Bruche zwischen Sandersdorf und Bitterfeld, im Torfstiche an der Benndor. 
fer Mühle, bei Katharinenrieth unweit Allstedt. JuniAng., aber nicht schon Mai. Blume weiss. Stengel meist 6-9" hoch.

513. C. parisiense L., parisisches I. Stengel schwach, aufsteigend, sehr ästig, rückwärts stacheligrauh; Bliitter meist 6ständig, linealisch-lanzettlich, stachelspitzig, 1nervig, am Rande aufwoirts stachelig-rouh; Bliithenstiele blattwinkelstïndig, zuletzt fast rispig, nebst den Bliithenstielchen gerade; Früchte körnig-rauh oder steifhaarig; der Iurchmesser dor Blume viel kleiner als der der entwickelten Frucht. $\odot$. Aeckes. Juni - Aug. Blume grünlich-gelblich, aussen röthlich. Der selır zarte Stengel 4-8" ling. Vou dieser Art findet sich in Gebiete nur die Form:

b) anglicum Huds.: Früchte kahl, dicht körnig. rauh. G. gracile $\mathbf{W}$ allr. Stellenweise. Sandige Aecker am Dölauer Kirchholze bei Lieskau, Aecker am Zurgs, Aecker sïdwestlirh von Merseburg, bei Naumburg an Buchholze nach Flemmingen zu, bei Freiburg zerstrent, bei Aschersleben besonders auf Esparsettäckern, bei Dessau zerstreut.

514. G. palustre L., S u m p f - I. Stengel schwach, ausgebreitet, 4kautig, meist rückwärts rauh: Blïtter 4ständig, seltener 6ständig, linealisch-länglich, abgerundet-stumpf, ohne Stachelspitze, 1nervig, arm Rande viickwärts rauh; Rispe ausgebreitet; Bliithenstielchen nach dem Vcrbliihen gerade, wagrecht-abstehend; Früchte kahl und glatt. 24. Sumpfige Wiesen, nasse Wälder, Gräben, Bäche ziemlich häufig z. B. Gräben und Wiesen vor Nietleben, häufiger vor Bennstedt, ebenso auf sumpfigen Wiesen bei Gutenberg u. s. w. Mai-Juli. Blune weiss. Höhe $1 / 2-1^{\prime}$. Aendert ab mit glatten, oft $2-3^{\prime}$ hohem Stengel und glatten, meist 6ständigen Blättern, so besonders in der Aue zwischen Döllnitz. und Burg Liebenau und bei Zaschwitz unweit Wettin und sonst öfters.

D. Platygalium Dr. Blüthenstand endständig, rispig; Blüthen zwitterig; Blüthenstiele nach dem Verblühen gerade. Blätter 3nervig.

515. Gt. boreale L., nördliches L. Stengel anfrecht, steif, 4 kantig, kahl wder weichhaarie, oberwiirts rispig: Bliitter 4stäuliu, lanzettlich, 3nervig, ohne Stachelspitze, am Rande aufwärts stachelig-rauh; Blütheıstielchen filzig-kurzhaurig oder kahl, nach dem Ver- 
blïhen aufrecht - ahstehend; Frïchte filzig-steifhairiz nder kahl. 4. Wiesen, freie Waldstellen, Hriden, sonnige Berge nicht gerade selten. Wiesen an der Saale zwischen der Gersslurfer wüsten Feldmark und Lettin, im Frenzcholze bei Lieskall, bei Bennstedt, am Bie. nitz, bei Naumburg an Waldrändern und auf freien Waldstellen verbreitet, an südlichen Rande drr weuen rifhle hei Freiburg, im Hackenholze bei Branderoile, in der Grgend von Hettstedt selten, bei Dessan häufig, in Bruche zwischen Sandersdorf und Bitterfelı, Wiesen an der Benndorfer Vühle. Juli. Aug. Blume weiss.

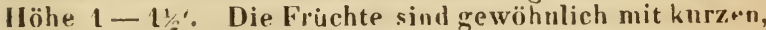
nufrechten, an der Spitze hakenförmigen Bursten dicht besetzt; die Pflanze ändert aber ah:

b) intermedium Koch: Früchte mit sehr kurzen. angedrückten Borsten besetzt.

(1) hyssupifolium $H$ offm.: Frürhte ganz kahl. G. Inbioides Pullich., nicht $L_{\text {.., }}$ sn an Bienitz.

G. rotundifulium L. soll zwar einmal bei Mersebury gefunden sein, duch verdient dieser Standurt kaum Erwähnung, dis es dort gauz unheständig ist, wie es nach der dortigen Beschaffenheit des Bodens nirht anders sein kann; dagegen ist es schon ansserhalb der Grenzen des Gebietes in einem Fichtenwäldchen bei Weissenborn unweit Osterfeld nicht gerade selten.

E. Eugalium DC. Blïthenstand endständıg, rispig oder quirlig: Blïthen zwitterig: Blüthenstielchen uach den Verblühen gerade; Blätter Inervig. Stengel kahl oder rauhhaarig, aber whne rückwärts gekrïmute Stachelchen.

516. G. verum L., ächtes L. Flora v. Thüring. II, 14. Stengel aufrecht oder aufstrehend, steif, fast walzenförmi⿺r, 4rippig, weichhaarig; Blätter 8-12stänlig, schmal-linealisch, fast fadenförmig, stachelspitzig, am Rande umgerollt, unterseits kurz-weichhaarig; Aeste der Rispe abstehend-dichtblüthig; B̈liithensticle nach dem Verbliihen fast wagrecht-abstehend; Blumenblïtter stumpflich, sehr kurz bespitzt; Früchte kahl und glatt. 4. Wiesen, Triften, Ackerraine, Wegränder iberall häufig. Juni-Herbst. Blume dottergelh. Höhe 1-2'. Aendert ab:

b) verosimile R.u. Sch.: Blätter wberseits rauh.

517. G. Mollugo L., ge meines L. Flora v. Thülingen II, 14. Stengel aufrecht oder gestreckt, 4 kantig, 
kahl oder kurzhaarig; I3lätler meist 8ständig, lanzettlich ocler verlichrt-eiförmig-lanzellich, stachelspitzig, am Rande aufuärts stachelig-rauls; Aeste der ausge. spreizten Rispe reichblüthig; Bliithensticlchen nach dem Ferbliilien ansgespreizt; Blumenblaitler hoarspitzig; Friichte kahl, etwas runzelig. 4. Wiesen, Raine, Wegräuder, zwischen Gebüsch gemein. Mai - Aug. Blume weiss. Höhe $1-3$ '. Aendert ab:

b) ochruleucum Wo If: Bliitheu gelblich- weiss, so an Frenzelholze bei Lieskau. Diese Abart stinımt in der ganzen 'Tracht mit G. Mollugn überein und kanu daher nicht zu G. verum gezogen werden, wie dies $W$ olf $u$. A. gethan haben; nach Anderen soll sie ein Bastard von G. verum und G. Mollugo sein.

518. G. silvaticum L., W a Id-I. Stengel aufrecht, fast stielrund, stumpf-4rippig, an den Quirlen knotig, kahl oder kurzhaarig; Blïtler meist 8ständig, liinglichlanzettlich, stumpf, stachelspitzig, am Rande stacheligrauh, unterseits meergriin; Rispe weitschneifig; Bliithenstielchen haarfein, vor der Bliithezeit nickend, nach dem I erbliihen anfrecht-abstchcnd; Blumenhlätter kurzbespitzt; Früchte kahl, etwas runzelig. 24. Wälder häufig. Juni. Juli. Blume weiss. Blätter bläulich-grün. Höhe $1-4^{\prime}$.

519. G. saxátile L., F elscu-L. Stengel niederliegend, 4 kantig, kahl, die blithentragenden aufstrebend; Blïter meist 6ständig, stachelspitzig, Inervig, an Rande aufwärts stachelig-rauh oder glatt, die untcren verkehrt-eiförmig, die oberen lanzettlich, vorne breiter; Blïthen ebenstrüussig-rispig; Bliithenstielchen aufrecht-abstchend; Blumenblätter spitz; Friichte dichtliörnig-rauh. 24. Wird von Spre ng. auf Bergwiesen bei Annerode und Möllendorf unweit Mannsfeld angegeben. Juli - Aug. G. hercynicum We ig. Blume weiss. Stengel 4-10" hoch.

520. G. silvestre Pol1., H eide-I. Stengel niederliegend oder aufsteigend, 4kantig; Bliitter meist 8ständig, linealisch-lanzettlich, vorne breiter, zugespitzt, stachelspitzig, Inervig, am Rande rückwärts stacheligrauh, die unteren verkehrt-eiförmig-lanzettlich; Blüthen ebenstrüussig-rispig; Bliithenstielchen aufrecht-abstehend; Blumenblätter spitz; Iriichte mit wenigen schwachen Knötchen besetzt. 24. 'Irockene Wälder nicht selten z. B. Dölauer Heide, Zorgs, Tannenberg bei 
Gutenberg, Nittelholz, Bienitz u. s. w. Juni Aug. Blume weiss. Der sehr dünne, schwache Stengel ist 4-12" lang. Aendert ab:

a) glabrum Koch: Stengel und Blätter kahl. Diese Abart ist im Gebiete selten; sie wird von Wallr. ann. hot. p. 22 untel dem Namen G. pusillum glabınm Wallr. an Steinbrüchen bei Schirmbach, Hornburg, Gr. Osterhansen und Eislehen angegeben; in den sched. p. 53 wird sie G. multicaule $\alpha$. polyphyllum Wa lli. genannt.

b) hirtum M. u. K.: Stengel nebst den Blättern rom Grunde bis zur Mitte uder höher hinauf kurzhaarig. G. scabrum Pers. G. Bocconi DC. G. multicaule $\jmath^{\prime}$ eriophyllum Wallr., dies ist die gewöhnliche Furm.

\section{Familie. Valerianeen DC. Bal- dri angewächse.}

216. Valeriana L. Bald rian (soll nach Einigen von valere, gelten, werth sein, herkommen, wegen der vielfachen Anwendung der V. officinalis in der Arznei, nach Anderen dem Valerius zu Ehren benannt sein).

a. Blüthen zwitterig, gleichartig.

521. V. officinalis L., gebräuchlicher B. Hayne Arzneigew. III, 32. Wurzel einstcngelig, ausläufertreibend, Auslëufer kurz, unter der Erde liegend, nur eine Endknospe bildend; Stengel schwach gefurcht; Blïtter sämmtlich gefiedert, 7-11paarig, Blättchen lanzettlich, gezähnt-gesägt uder ganzrandig. 24. Wälder, bewaldete Bergabhänge, Wiesen, Gräben, Ufer häıfig z. B. auf Wiesen unter dem Tannenberge bei Gutenberg, im Mittelholze, in der Aue bei Dieskau, Döllwitz u. s. w. Juni. Juli. Blume fleischroth. Höhe 1-3'. OFF. rad. Valerianae minoris. Aendert ab:

a) ma i or Koch: Stengel höher; Blätter sämmtlich gezähnt.

b) minor Koch: Stengel ganzrandig oder die unteren wenig gesügt. $V$. angustifulia $T$ a us ch.

Nach brieflichen Mittheilungen rom Hofr. Koch an Prof. v. S chlechtendal unterscheidet ersterer die beiden hier aufgeführten Varietäten als Arten.

Die leicht abbrechbaren, weiss aussehenden, mit Blattrudimenten versehenen Ausläıfer kommen an den 
blühenden und an den der Blithe nahestehenden Stengeln zwischen den Wurzelfasern hervor, löspn sich späterhin von dem stengel ab und die Pflanze erscheint lann ohne Auslänfer, welches wohl der Grund ist, dass so oft angegeben wird, der gebräuchliche Baldrian habe gar keine stolonen. Uebrigens scheinen die Ausläufer bei den im fenchten Buden wachsenden Pflanzen den Zusammenhang mit der Mutterpflanze schneller aufzugeben, als bei den an trockenen Stellen rorkommen. den. Bei jungen, niclit blühenden Exemplaren befinden sich unter den Blättern nur einige wenige dickliche Wurzelfasern, zwischen denen in der Mitte ein dickerer Ausläufer etwa $1 \frac{1}{2}-2 \mathrm{Zoll}$ tief herabgeht, an seinem unteren Ende etwas anschwillt und wite an dem uberen Ende eine Anzahl dicherer Wurzelfasern und oft auch neue Ausläufer hat. Dieses Wachsthum wird bei $V$. sambucifolia Mik. nicht bemerkt. Vgl. hierüber die Abhandlung vom Prof. v. Schlechtendal in der botanischen Zeitung Jahrg. 1847. S. 609 ff.

522. V. sambucifolia Mik., holund e rblät te riger B. Wurzel einstengelig, ausliuufertreibend, Ausläufer sehr lang, meist iiber der Erde liegend, an den Knoten mehre Knospen lildend; Stengel gefurcht, unterwärts behaart; Blïtter sämmtlich gefiedert, 4-5paarig, Blättchen lanzettlich oder länglich, gezähnt-gesägt. 4 . Flussufer sehr selten, nur am Loberbache zwischen der Benndarfer Mïhle und Paupitzsch. Juni. Juli. Blune fleischroth. Höhe $2-4^{\prime}$. Hierher gehört gewiss $V$. procurrens $\mathbf{W}$ allr. und nicht $\mathrm{zu}$ V. otficinalis $I$.

Die bei dieser ganzen Gattung noch zu wenig beruicksichtigte Frucht scheint ebenfalls gute Unterschiede darzubieten. Sie hat bei V. sambucifolia zwar dieselben 3 Rücken- und 1 Bauchstreifen, wie bei V. officinalis, ist aber oberwärts schmaler, der trichterförmige Theil des Kelchrandes doppelt so gross und ausgebreitet, mit der oberen Mündung breiter als der grösste Querdurchmesser der Frucht, der Federkelch ist länger und langhaariger.

523. V. exaltata Mik., hoher B. Wurzel vielstengelig, ohne Auslïufer; Stengel tief-gefurcht; Blaitter sämmtlich gefiedert, 7-11paarig, Blättchen lanzettlich, gezähnt-gesägt. 4 . Feuchte Wälder. Besonders in der Aue, z. B. zwischen Döllnitz und Burg Liebenau, bei Röglitz, zwischen Schkeuditz und Kl. Dölzig, einzeln bei Merseburg̣ unter Rauschens Hölz- 
chen und geviss weiter verbreitet. Juli. Aug., blüht später als V. officinalis. Bimme fleischroth. Stengel bis $6^{\prime}$ hoch. V. altissima Hurnem. V. multiceps W a $11 \mathrm{r}$.

b. Blüthen zweihäusig; Blunenkrome umd Staubfideri ar den weiblichen Blüthen kleiner als an den Zwitterbläthen.

524. v. dioica $\mathbf{X}$., $k$ le in er B. H a yn e Arzneigew. III, 31. Wurzel ausläufertreilend; die untersten Wurzelblätter rundlich-eiförmig vier elliptisch, die der nichtbliihenden Wurzellöpfe lang-gesticlt, eiförmig, spitz. lich, die unteren Stengelblätter leierfürmig-fieuerspaltig, die oberen meist 3 paarig mit linealischen Zipfeln; Ebensträusse endständig. 24. Sumpfige, besonders torfige Wiesen, zwischen Gebüsch häıfig z. B. an Gräbrn und in Grbüsche vor der Broihanschenke unweit Ammendorf, sehr häufig auf Wiesen vor und hinter Gutenlierg, bei Zöschell, am Birnitz, bei Naumburg anf der Gröbitzer Wiese und auf Wiesen bei Schulpforte u. s. ". Mai. Juni. Blume fleischroth. Höhe $1 / 2-1$ '. Findet sich, obgleich selten, mit ungetheilten Stengelblïterm.

217. Valerianélla Po II. Rapünzchen (Diminutiv ron Valeriana).

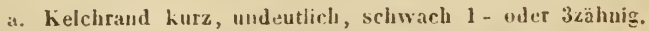

525. V. olitoria Mönch, gemeines R. Rchb. pl. crit. 1. Abb. 121. Stengel aufrecht, gabelüstig; Blätter linealisch - zungenförmig oder spatelförmig - länglich, die oberen an Grunde bisweilen mit einigen Zähnen; Frïchte rundlich-ciförmig, zusammengedriickt, leiderscits zicmlich piatt, auf dem Rande mit einer Furche durchzogen, an den Sciten 2rippig, die eine Rippe sehr diun; Kelchrand schwach-3zähnig. $\odot$. Feliler, Hecken, Zäıne, Grasplätze häufig. April. Mai. Valeriana Locusta olitwria L. V. olitoria Willd. Fedia olituria Vahl. Blume weiss, in das Bläuliche oder Röthliche spielend, wie bei den folgenden Arten. Höhe meist 4-6". Die Früchte sind gewöhnlich liahl; die Pflanze ändert aber ab:

b) Iasiocarpa Koch: Früchte weichharig.

526. V. carinata Loisl., gekieltes R. Kchb. pl. crit. 1. Abb. 123. Stengel aufrecht, gabelästig; Blätter verkehrt-eiförmig oder länglich-spatelförnig, meist ganzrandig; Friichte länglich, fast 4seitig, auf der hinteren Fläche tief-rinnenförmig, auf der vorderen 
ziemlich platt, in einen beiderseits hervorspringenden Rand verbreitert, in der Mitte und auf den Seitenflächen schwach-1rippigr; Kclchrand sclinucach-1zïlnigig Aecker. Weinbergeselten. Bei Wettin einzelı, häufiger in Weinbergen bei Naumburg. Von $\mathbf{S c h}$ wab. fl. anh. auch an Weinbergen und auf deckern bei Bermburg und Sandersleben angegeben. April. Mai. Stengel meist (j" hoch.

b. Kelchrand deutlich, krautig, schief-ahgestuszt, gozähnt, der hintere \%atıı grösser.

527. V. Morisonii DC., Morison's R. Rehb. pl. crit. I. Abb. 124. Stengel aufrecht, gabelästig; Blätter länglich-spatelförmig, die oberen am Grunde meist mit einigen Zühne'n; Friichte ci-kegelförmig, hinten etwas gewölbt, schwach-3rippig, vorne ziemlich platt, mit einem lünglichen, zwischen den erhabenen Rüindern cingedriickten Mittelfelde; Kelchsaum halb so breit als die Frucht, schief-abgestutzt, spitz, gezähnelt. $\odot$. Aecker nicht selten z. B. Aecker zwischen Halle und Nietleben, vor Seben, zwischen der Dieskauer Mühle und Döllnitz u. s. w. Juni-Ang. Höhe bis 1'. Mendert ab:

a) leiocarpa DC.: Frïchte kahl. Valeriana Locusta $\delta$. dentata L. Fedia dentata Vahl.

b) lasiocarpa Kuch: Früchte mit kurzen, an der Spitze gekrümmten Haaren besetzt. V. mixta Dufresne, V. dentata Poll. Fedia Morisonii Spreng.

528. V. Auricula DC. , ge öhrtes $R . \quad R$ chb. pl. crit. I. Abb. 128. 129. Stengel aufrecht, gabelästig; Blätter länglich, ganzrandig oder an Grunde mit einigen Zähnen; Friichte aufgctrieben, fast kugelig-eiförmig, schwach.5rippig, vorne mit ciner Iurclie durchzogen; Kelchrand $1 / 3$ so breit als dic Frucht, in einen hinteren länglichen Zahn auslaufend, die vorderen 'Zähnchen sehr klein. $\odot$. Aecker unter der Saat, etwas seltener als die vorhergehende Ait, aber wohl nirgends fehlend. Aecker zwischen Halle und Nietleben, zwischen Beuchlitz und Schaafstedt, bei Naumbnrg zerstreut, bei Eisleben auf Aeckern nach Erreburn zu, bei Aschersleben nicht selten, bei Möst und Schierau südlich von Dessau, zwischen Könnern und Trebnitz. Juni. Juli. Höhe $1 / 2-1^{\prime}$. bie. Früchte sind gewöhnlich kuhl, die Pflanze ändert aber ab:

b) lasiocarpa Koch: Früchte weichharig. 
c) tridentata $\mathbf{K o c h}$ : vordere Zühnchen des Kelch. randes etwas grösser und deutlicher. V. dentata DC. Fedia tridentata $\mathrm{R} \mathrm{chb.}$

Die Wurzeln dieser und der vorhergehenden Art riechen wie die der Valeriana officinalis, obgleich etwas schwächer.

V. eriocarpa Desv. wird von R chb.sax. ed. 1 u. 2. p. 129 bei Rossleben und Lauchstedt angegeben. Der erste Standort ist unstreitig aus II allr. ann. bot. p. 6 entlehnt, wi Valerianella eriocarpa als Synon. zu Fedia Morisonii Spreng. citirt wird. In den sched. p. 23 wird dagegen Fedia Morisunii Spleng. gans eingezogen und als Synon. zu Fedia dentata Gärtn. gebracht, wozu auch Valerianella dentata DC. gehören soll. Wallr. will also Valerianella eriocarpa llesv. nicht im Gebiete gefunden haben und Rchb. hätte bei Vergleichung beider Werke ron Wallr. obigen Fehler leicht vermeiden können.

\section{Familie. Dipsaceen DC. Karden- gewä chse.}

218. Dipsacus I. Karde (von $\delta \iota \psi \alpha \dot{s} \omega$, ich dürste, weil sich Regen in den Achseln der verwachsenen Blätter, besonders bei D. Fullonum ansammelt).

529. D. silrestris L., wilde K. Stengel aufrecht, stachelig; Blïtter sitzend, gekerbt-gesägt, am Rande liahl oder zerstreut-stachelig, die untersten an Grunde verschmälert, die stengelständigen breit-zusanmengewachsen, meist ungetheilt; Hüllblättchen linealischpfriemlich, bogenfoirmig - aufstrebend; Spreublättchen biegsam, länglich - verkehrt - eiförnig, mit gerader Spitze, länger als die Blüthen. (-). Unbebaute Stellen, Wegund Waldründer, Gräben. Auf der Rabeniusel, häufig in der Aue z. B. bei Dieskau, zwischen Döllnitz und Collenbey, zwischen Wesmar und Zöschen, bei Wal. lendorf; an Acker - und Wiesenrändern zwischen Weissenfels und Uechteritz, bei Naumburg zerstreut z. B. an Rande der Weinberge bei der Henne, häufig am unteren Rande der Steinklippe zwischen Kl. Wangen und Wendelstein, auf der Fohlenwiese bei Allstedt. Juli. Aug. Blume blass-lila. Staubbeutel bläulich. Höhe $3-6^{\prime}$. Aendert $a b$ :

b) pinnatifidus Koch: mittlere Stengelblätter fiederspaltig. 
530. D. Fullonum Mill., W e betiotrde. Stengel aufrecht, stachelig; blïtler sitzend, eingeschnitten-gekerbt, die stengelständigen breit-verwachven, ungetheilt; Hüllblättchen wagerecht - abstehend, an der Spitze ttwas abwärts-gebogen; Spreubliittchen steif, länglich, mil zuriicligelirimmter Spitze, so lang als die Blïtlen. (.). Wird für die Tuchfabrihen gebaut. Juli. Ang. Blume lila oder blass roth. Ilöhe $4-6^{\prime}$.

531. D. pilosus L., beh a a te K. Stengel aufrecht. stachelig und nebst den Iesten steifhilarig; filiitler gestielt, an der Spitze des Blatlsticles geröhrrt: Hüllblättchen abwärts gerichtet, fast su lang als die Blïthen; Sprcublïtchen verhehrt-eiförmig, bitessam, borstig-ge? wimpert, mit gerarler Spitze, Wruig länger als die Blüthen. (.) Géliüsche, Zäume, Wene, feuchte II älder. Bei Ermlitz, zwischen sihhenditz mol Wehlitz, an Zäunen bei Göhren, in Gräben am Spechtsal bei Naum. burg, auf der Fohlewire bei Allstedt u. s. W. Juli. Aug. Blume weisslich. Staubbentel dushelviolett oder schwärzlich. Hähe $2-4^{\prime}$.

219. Kmantin Coult. Kuautie (uach dem Hal. lisch $n$ Arzte Christoph Knauch, Verfiuser einer Flura ion Halle, und seinem Sohue Chr. Kuanth, benamut).

532. K. arvensis Coult, Arkel-k. II ayuc Arzneigew. V, 35 . Stengal von sehr kwzen Hailen etwas grau und von längeren steifharig; Wnrelblätter meist ungetheilt, ganzrandig uder eingeschnitten, stengelblätter fiederspaltig, mit lanzettichen Kipfeln und einem grösseren zugespitzt・n mnd etwas gesägten lindzipfel; Randblumen strahlend, länger als die Hiillblätrer. 4. Truckene Wiesen, Waldränder, Arkerraine hänfig. Juli. Ang. Scabiusa arrensis L. Blume ptirsichblithig, fleischroth, selbst "eiss. Höhe 1-2'. Aemdert ab:

b) integrifolia Klett u. R.: alle Blättrr ungotheilt, lauzettlich, ganzrandig wder etwas gesägt.

c) canpestris Bess.: Raudblumen uicht strahlend.

220. Succísa M. u. K. A b biss (voll succider. uuten abschweiden, wegen des scheiuhar abgeschnittencu Hurzelstuckes).

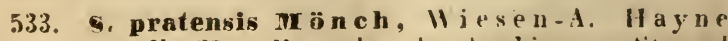
Arzneigew. V, 37. Wurzelstock ahgebisnen; Stengel anfrecht, kahl; Wurzelblattr eiförnig-länglich, in d+n Blattstiel verschmälert, Steıgelhlätter länglich-lanzett- 
!ich, ganzrandig oder entfernt-gezähnt; Blüthenköpfchen halbkugelig, später kugelig; der äussere Kelch rauhhaarig, mit 4spaltigen Saume und eiförnigen, stachelspitzigen Zipfeln, der innere Kelch i॥ 5 schwärzliche Bursten endend. 24. Feuchte Wiesen, zwischen Gehüsch häufig. Juli - Sept. Scabiusa Succisa l. Blunıen meist blau. Höhe $1-2$ '

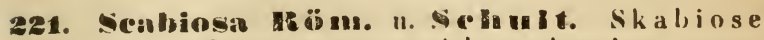
(von scabies, Krätze, gegen welrhe mehre Arten ange"andt wurden).

534. S. Columbaria L., ' l a u ben-Sk. Reh h. pl. crit. IV, Aluh. 535. Stengel einfach uder ästig, halil; Blätter an den nichtblühewden Wurzelköpfen Iänglich, stumpf, aı Grunde ierschmulert, gekerbt, ganzrandig uder leiertörmig, die untersten stengelständigen leiev/ür. mig, die iilrigen bis zur Mittelrippe fiedertheilig, mit linealischen an den untern Blättern fiedersualtig-gesägten, an de"ll obersten ganzraniligen Zipfeln; Randblüthen strahlend; Frürhte 8furchig; Borsten des inneren Kelches 3-4mal lïnger als der.Surm des äusseren Kelches, braunschwarz. (-) und 2 . Trockene Anhöhen, Wiesenräuder nicht häufig. Wiesenränder zwischen Kl. Dölzig und dem Bienitz und zwischen dem Bienitz und den Quellen, bei Naumburg zerstrent z. B. an Ahhängen des Pfurtenberges, bei Bibra stellenweisf, häufiges in nordöstlichen Gebiete. Juni-Herbst. Blume blau, bläulich-roth oder selten weiss. Höhe 1-2'. Aendert ab:

b) ochruleuca I.: Blumen gelblich-weiss; weit häufiger als die Hauptart.

Diese hier als Abart angeführte S. ochruleuca $L_{\text {. }}$. ist von S. Columbaria L. nach IVim mer's Beobachtungen ausser der Blïthenfarbe auch wicht im mindesten verschieden.

535. S. suavéolens Desf., " "hlriechendes. $\mathbf{R ~ c h b . ~ p l . ~ c r i t . ~ I . ~ A b b . ~ 7 6 . ~ S t e n g e l ~ n i e d e r l i e g e n d ~ o d e r ~}$ aufsteigend, fein behart; Blätlel der nichtblïhenden Wurzelköpfe und die untersten Stengelblätter länglich oder lanzettlich, ungetheilt, ganzrandig, die iibrigen Stengelbluitter fiedertheilig, mit linealischen, ganzrandigen Zipfeln; Früchte 8 furchig; Borsten des inneren Kelches ungefähr doppelt so lang als der hlein-gelierbte Saum des äusseren Kelches, weissgelh. 4 . 'I'rockene Anhöhen, Wegränder besonders auf Kalh häufig: Uonnersherg hinter Kröllwitz. am Chausseegraben zwischen Nietlehen und Bennstedt häufig, bej Röglitz, KI. Dölzig, anı Bie-

Garcke, Flora. 
nitz, bei Dürrenberge, bei Naumburg anf Kalkhïgelı und in den Weinbergen häufig, ebensu bei Bibra unal Allstedt, am Schiessberge bei Sandersleben, seltener in nordöstlichen Gebiete. Juli-Herbst. S. canescens W. K. Asterocephalus suaveolens Wallr. Blume blau, wohlriechend. Höhe bis 1'.

\section{V. Familie. \\ Compositen Alans. \\ $\left(S_{y-1}\right.$}

\section{nanthereen Rich.) Vereiubiithle.}

1. Ordumng. Corymbiferen. Vaill. Babensträussige.

Bliithen alle röhrig oder die randständigen zungenförmig. Griflel an der Spitze nicht verdickt und da. selbst uhue Haarkianz.

\section{Unterordnung. Eupatoriaceen Lessing.}

Griffel der Zwitterblïthen walzenförnig, zweispaltig, die Schenhel verlängert, fast stielrund oder etwas keulenförmig, uberseits ion femen Papillen weichharig; an den männlichen Bliithen ganz oder kurz zwrispaltig, schenhel lirulenförmig; Staubbeutel uhne Anhängsel.

1. Gruppe. Eupatorieen. Blüthen sämmtlich zwitterig.

222. Eupatóriogra L. Kunigundenkraut (der Name bezeichnet eine von Diose. nach Mithridates Eupatur hellannte Pflanze).

536. E. cannábinum L., hanfartiges K. Hayne Arzneigew. VIII, 44 Stengel steif-aufrecht; Blatter mestielt, 3 - oder 5theilig, mit lanzettlichen, gesägten Zipfelu, von denen der mittlere grösser ist; Köpfchen in dichten Ebenstränssen. \% Feuchte Wiesen, Gräben, Quellen, Bäche meist hänfigg. Bei Halle verbreitet z. B. in den Teichen bei Dieskan, an Gräben der sumpfigen Wiesen unter dem Tannenberge bei Gutenberg, an Bienitz, fehlt bei Naumburg. im nurdöstlichen Gebiete häufig, hei Bennlorf, an Luberbache bei Delitzsch. Juli-Ang. Blume hell-rosenroth. Höhe $3-6 "$.

2. Gruppe. Tussilagine en Cassin. Blüthen vielehig.

223. Wussilágo L. Huflattich (Pflanzenname bei Plinius; von tnssis, Husten, abgeleitet, weil die Pflanze nach Dioscorides und Plinius gegen Husten angew endet "urde). 
537. T. Fárfara L., gemeiner H. Hayne Arzneigew. II, 16. Schaft einköpfig, mit Deckblättern besetzt; die er'st nach den Blüthen erscheinenden Blätter eckig-herzförmig, gezähnt, unterseits weich behaart. 4. Gräbel, Aecker, Wrgränder, gern auf 'Thonboden, nicht selten z. 13. im Sebener Busche, auf feuchten Aeckern vor der Broibinschenke $11 . \mathbf{s}$. w. Mäız. April. Blüthen gelb, die randstänligell schmal-zungeoförmig. Schaft $4-8$ " hoch. OFF. herb. et rad. Farfarae s. Tussilaginis s. Ungulae caballinae.

224. Petacites didu. Neunkraft, Pest -

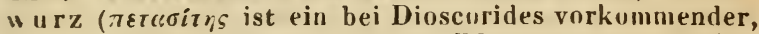
von лв́т dieser Pflanze wegen ler grussen, schirmförmigen Blätter beigelegt ist).

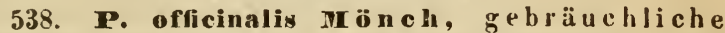
N. Hay"le Arzneigew. 11, 17. Schaft aufrecht. mit Schuppen besetzt, viele Blüthenköpfe in einem länglichen Blüthenstrausse tragend; Blätter nach den Blüthen erscheinend, sehr gross, lierzförmig, ungleich-gezähnt, unterseits "ullig-grau, Zipfel am Grunde abgerundet: weibliche Bliithen fadenförmig; Narben der Zwitterblüthen kurz, eiförmig. 4. Gräbell, truchte Wiesen, Bäcle nicht gerade selten. Gräben vor Seben links rom Fahrwege, an der Göttsche zwischen Sennewitz und Teiche, zwischen Zappendorf und Müllerdorf, in Gräben zwischen Horbury und Kötzschlitz, am Schambert in der Näle des Bienitz, in Gräben bei Uechtritz nach Markrölitz zu, in Gräben bei Unterriesdorf bei Eisleben u.s. w. März. April. P. vulgaris Desf. Blume purpurfarben. Höhe $1-2$ '. Aendert ab:

a) Zwitterpflanze: Blüthenstrauss eiförmig, mit grösseren Köpfohen Tussilagu Petasites L.

b) Weibliche Pflanze: Bliithenstrauss länglich, mit halb su grossen Köpfchen 'Tussilago hybrida L.

Petasites spurius Rchb. wächst schon ausserhalb der Grenze des Gebietes an Ien Ufern der Bude in der Gegend viı Stassfurt und an den Ufern der Elbe bei Dessau.

II. Unterordnung. Asteroideen Less. Sternblumengew ä chs e.

Griffel der 'Zwitterblüthen walzenförmig, 2spaltig, Schenkel linealisch, ausweudig fast flach, oberwärts w eichharig. 
3. Gruppe. Asterineen Nees. Staubbeutel am Grunde ohne Anhăngsel.

235. Limósyris DC: Leinkraut (ein aus den beiden Pflanzenbenennungen hivov, Jein, und ǒovots, Pflanzenname hei Dioscorides, zusammengesetzter Name, welches auf die Aehnlichkeit der Blätter dieser Pflanze mit Leinblättern deutet).

539. L. vulgaris Cass., gemeines L. Flora v. Thiiring. II, 21. Stengel anfiecht, diun, dicht mit linealischen, kahlen Blättern besetzt; Köpfchen fast kreisförmig, in Ehenstrüussen; Blättchen des Hauptkelches locker. sparrig-absteliend. 24. 'T'rockene Abhänge stellenweise. Bischufsberg in ter Dölatier Heide, Mittel. holz, Weinberge zivischen Rollsdorf und Seeburg, einzeln an buschigen Alhängen auf der rechten Seite der Saale zwische'" Wettin und Dubis, trockene Abhänge bei Weissenfels, am Pfortenberge bei Naumburg liäufig, bei Freiburg an Rande der neuen Giehle, an der Stein. hlippe bei Wendelstein, feh!t hei Aschersleben; hei Bernhurg nach Schwabe. Juli-Sept. Chrysucoma Linosyris L. Blume gelb. Höle messt $1^{\prime}$.

226. Asten. Aster (Pflanzenname bei Dioscorides

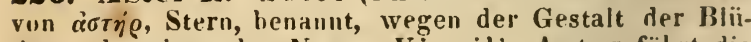
then; den deutschen Namen Virgil's Aster führt die Pflanze deshalb, weil sie Virgil Georg. IV, 271 zuerst erwähnt).

541). A. Amellus L., Virgil's A. Stengel aufrecht, hehaart, ebensträussig, mit abstehenden, mehrköpfigen, selten einhöpfigen Aesten; Elïtter kurz-steifhaarig, die unteren elliptisch oder verkehrt-eiförmig-spatelig, die oberen länglich-lanzettlich, etwas gesägt oder ganzrandig; Blättchen des Hauptkelches abgerundet-stumpf, etwas abstehend. 74. 'Truckene Abhänge, sonnige Hiigel, Waldränder, gern auf Kalkboden, sehr zerstreut. Bej Halle jetzt nur im Mittelholze (da er an Vogelsherge bei Bennstedt seit vielen Jahren verschwunden ist), bei Naumburg auf Kalkbergen häufig z. B. am Pfortenberge, in Sperlingshulze, bej Freiburg an Schlifter. Aug. Sept. Strahlblumen blau-violett, Scheibenblumen gelb. Höhe 1'.

541. A. Tripolium L., Str and-A. Stengel einfach oder ästig, hahl; Aeste ebensträussig; Blätter ziemlich fleischig, kahl und glatt, linealisch-lanzettlich, 
ganzrandig oder am Rande fein-gesägt; die inneren Blättchen des angedriickt-dachziegeligen Hauptkelches länger, stumpt: ‘. Salzhaltige Wiesen, an Salinen stellenweise. Bei Halle verbreitet $z$. B. an den Teichen bei Dieskau, an salzhaltigen Stellen zwischen Kölne und Langenbogen bis nach Rollsdorf, sehr häu. fig am salzigen See, ebenso am süssen See zwischen Seeburg und Wormsleben, um die Salinen von' Kötschau und Teuditz häufig, fehlt bei Naumburg; auf der Grenze des Gebietes zwischen Artern und Kahstedt, an den Seelöchern bei Zabenstedt unweit Gerbstedt, bei Stassfurt und Leau. Juli-Sept. A. pannonicus Jacq. Tripolium vulgare Nees. Strahlblumen blau, Scheibenblumen gelb. Stengel $1 / 2-3^{\prime}$. Die Kelchblättchen sind an der Spitze bald purpurroth, bald ganz grün.

542. A. salignus willd., we id eublät terige A. Stengel aufrecht, fast kahl, rispig, mit ebensträussigen Aesten und Aestchen; untere Blätter anı Grunde verschmälert, obere mit breiterem Grunde sitzend, lanzettlich, oberseits am Rande hin rauh, ganzrandig oder in der Mitte mit wenigen, abstehenden Sägezähnen versehen; Blüthenstiele mit weuigen, linealischen, anfrechten Blättern; Hauptkelch angedriickt -dachziegelig, die Blättchen nur mit der äussersten Spitze etwas abstehend. 24. Flussufer, unter Weidengebüsch zerstreut. An der Saale unmittelbar an der Fähre bei Kröllwitz, einzeln an der Saale bei Lettin, an der Saale zwischen Wettin und Trebitz, ron Schkeuditz bis Wehlitz, an der Saale an der krummen Hufe bei Naumburg und an der Saale bei Kösen in der Nähe der alten Brücke, an der Saale bei Alsleben, an der Wipper bei Sandersleben. Aug. Sept. A. salicifolius Scholler. Strahlblumen erst weiss, zuletzt blasslila, Scheibenblumen erst gelb, dann rothbräunlich. Höhe bis 4'.

543. A. leucánthemus $D$ esf., weiss blüthige A. Stengel aufrecht, rispig, Aeste traubenförmig, Aestchen 1 köpfig, die oberen an den Aesten $2-4 \mathrm{köpfig}$; Stenoelblätter sitzerd, lang, lanzettlich-linealisch, verschmälert-zugespitzt. oberseits im Unfange rauh, ganzrandig oder in der Mitte beiderseits mit $2-3$ kleinen, entferntstehenden Sägezähnen versehen; Blätter der Blüthenstiele linealisch, abstehend; Hauptkelch anoedriickt. dachziegelig, die Blättchen nur mit der äussersten Spitze etwas abstehend. 24. Stammit ans Nordamerika, jetzt an Flussufern hin und wieder verwildert; im Gebiete 
äusserst selten, nur an der kleinen Saale bei Almerich unweit Naumburg. Aug. Sept. A. dracunculoides Willd. Strahlblumen weiss, zuletzt blassiüthlich. Die Köpfchen sind kleiner als bei der vorhergehenden Art.

227. Hellis I. Massliebe (Pflanzenname bei Plinius; kommt vun bellıs, schön, niedlich, her, wegen der Blïthen; der deutsche Name Massliebe soll nach A delung so viel als Matten d. h. Wiesen liebend bedeuten; wahrscheinlicher ist jeduch die von De l'Ecluse gegebene Erklärung, nach welcher Massliebe für Madeliebe d. h. Mädchenliebe steht).

543. B. perennis L., a us da ue rn de M., Gänseb lüm chen. Florar. Thüring. I, (i. Wurzel kriechend: Schaft einköpfig; Blätter grundständig, verkehrt-eiförmig -spatelig, gekerbt; Blättchen des Hauptkelches sehr stumpf. 2. Grasplätze, Wiesen, Triften ïberall gemein. Blüht fast das ganze Jahr hindurch. Strahlblumen weiss, zuweilen röthlich, Scheibenblumen gelb. Schaft 2-6" hoch. In Gärten werden Spielarten mit pothen Blüthen gezogen, welche unter dem Namen von rausendschönche n bekannt sind.

228. Stenáctis Cossin. Stenaktis (von $\sigma \tau \varepsilon$ ris, sclimal, und $\alpha \%$ is, Strahl, eigentlich Schmalstrahl, wegen der schmalen Randblüthen; ein deutscher Volhsname fehlt).

544. St. bellidifiora 1 ex. I raun, mas lie benblïthige St. Stengel aufrecht, etwas behaart, an der Spitze ebensträussig; untere Blätter verkehrteiförnıig, grob-gesägt, in den Blattstiel verschmälert, obere lanzettlich, entfernt - gesügt oder ganzrandig; Blättchen des Hauptkelches rauhharig. 24. Stanmt ursprünglich aus Nordameriki, jetzt an feuchten Zïunen, Hecken, auf Grasplätzen, ja selbst an Waldrändern verwildert, ubgleich nur stellenweise vorkommend, so an grasigen Stelien des Waisenhausgartens, an südlichen Rande der neuen Giehle bei Freiburg, von Spreng. auch bei Zscherben und Beuchlitz angegeben. Juni - Aug. St. annua Nees. Aster anmus L. Puli. caria bellidiflora Wallr. Strahlblumen sehr schmal, weiss oder mit bläulichem Anfluge, Scheibenblumen gelb. Höhe 1-2'. Die Blüthenköpfe sind denen der Massliebe (Bellis perennis) sehr ähnlich. 
329. Erigerou L. Dïr rwulz (ein ron Dioscorides gebrauchter Pflanzenname, welcher aus $\eta^{3} \varrho \iota$, früh, und $\gamma \dot{\varepsilon} \varrho \omega \nu$, Greis, zusammengesetzt ist und eigentlich Frïhreis bedeutet, wegen des bald sichtbaren grauen Federkelches).

545. E. canadensis $L$., can a dis che D. Flora v. 'Thüring. I, 8. Stengel steif - aufrecht, mit aufrecht abstehenden Aesten, rispig; Rispe länolich, sehr viele, kleine Köpfe tragend; Aeste und Aestchen traubenförmig; Blätter linealisch-lanzettlich, beiderseits verschmälert, kurzhaarig, borstig-oewimpert, die untersten entfernt-gesägt. $\odot$. Staninit aus Canada, jetzt an unbebauten Stellen, kiesigen Ufern sehr gemein. Juli. Aug. Strahlblumen schmutzig-weiss, den Kelch kaum iiberragend. Höhe $1-3^{\prime}$.

546. E. acris L., scharfe D. Stengel aufrecht oder aufsteigend, trauhenförmig, zuletzt fast ebensträussig; Aeste 1-3höpfig; Blütter entfernt, abstehend, linealisch-lanzettlich, rauhhaarig, die unteren in den Blattstiel verschmälelt, die wheren sitzend; Strahlbliithen aufrecht, so lang als die Scheibenbliithen oder ein wenig liinger. (.) und 4 . Sandige, dürre Plätze, Wegränder, Hügel nicht selten. Juli. Aug. Strahlblumen blass-fleischfarben wder blass-lila. Höhe $1 / 2-1$. Aendert ab mit flachen und wellenförmigen Blättern und weisslichen und braunrothen Federkelchen.

230, Solidỉxo $\mathbf{L}$. Goldruthe (dieser zuerst von Tragus gebrauchte Name kummt ron solidare, befestigen, zuheilen, her, wegen der zusammenziehenden Wirkung bei Wunden).

547. s. Virga aurea L., geme ine G. Il ayne Arzneigew. VIII, 12. Stengel aufrecht, an der Spitze rispig - traubenförnig oder einfach - traubenförmig, 'Trauben aufrecht; Wurzelblätter elliptisch, gesägt, Stengelblätter eiförmig oder lanzettlich, zugespitzt, in den geflügelten Blattstiel herablaufend, nehır oder "eniger weichlıarig, am Rande scharf. 4. Trockene Wälder, Hügel häufig. Juli. Aug. Strahlblumen goldgelb. Stengel $1 / 2-3^{\prime}$ hoch. Aendert mit schmäleren und breiteren Blättern ab.

4. Gruppe. Inuleen Cassin. Randblüthen weiblich, Scheibenblüthen zwitterig. Staubbeutel am Grunde mit pfriemlichen Anhängseln. Federkelch mit getrennten Strahlen. 
230. Ímula L. Alant (Pflanzenname bei Columella;

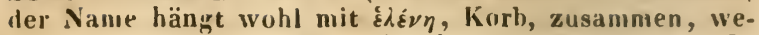
gen der Gestalt des Hauptkelches bei I. Helenium I. oder Ėंevıov bei 'Theophrast):

a. Achänen kahı.

548. I. germanica L., deutscher A. Stengel aufrecht, zottig; Blätter län̈lich-lanzettlich oder länglich, spitz, entfernt-gezähnelt, aderig, oberseits kahl, unterseits behaart, am Rande rauh, die stengelständigen am Grunde herzörmig: Ebenstrauss zusammengesetzt, geknïuelt, viellü̈pfio; Blättchen des fast walzenförmigen Hauptkelches auf dem Rïcken weichhaarig, StrahlUliithen nur wenig liinger als die Scheibenblitthen; Achänen kahl. 4. Trockene Abhänge. Weinberge stellenweise. In Gebüsche zwischen Kröllwitz und der Gersdorfer wüsten Feldmark, zwisihen dem Zorgs und Bennstedt, an und in Weinbergen von Röglitz, an Weinbergsrändern bei Russbach unweit Naumburg, an der Steiuklippe bei Wendelstein. Juli. Aug. Blumen gelb. Höhe 1-2'. Aendert ab:

b) media M. B.: Blätter auch unterseits fast kahl; Ehenstrauss meist arnblüthig; Strahlblüthen ungefähr doppelt so lang als die Scheibenblutthen, so an der Gersdorfer wüsten Feldmark hinter Kröllwitz.

Die hier als Abart angeführte 1. media M. B. ist gewiss nicht specifisch von I. germanica $L$. verschieden. Zwar finden sich bei der zuerst genannten die Blätter und die Blättchen des Hauptkelches grösstentheils kahl, die Ebensträusse fast einfach und bisweilen trägt der Stengel sugar nur wenige $(2-3)$ Blüthenköpfchen, allein alle diese Merkmale können auch bei I. germanica beobachtet werden. Dennach würden die längeren Strahlblïthen Lei I. media M. B. als einziger Unterschied bleiben. Der Verfasser hat jeduch Exemplare mit zusammengesetzten Ebensträussen im Gebiete gesammelt, an denen die äusseren Aeste nur kleinere. aber zahlreichere Blüthenköpfchen mit wenig verlängerten Strahlblüthen trugen, während die in der Mitte stehenden zwar gı̈̈ssere, aber weit wenigere Bliithenköpfchen mit langen Strahlbliithen hatten, deren Hauptkelche bauchig und nicht walzenförmig, wie bei je. nen, waren.

549. I. salicinn L., weid e n b lät terig er A. Stengel aufrecht, fast kahl, 1. bis mehrköpfig, fast eben- 
sträussig; Blätter lanzettlich, zugespitzt, entfernt-gezähnelt oder ganzrandig, aderig, kahl, an Rande rauh, die oberen her-fürmig-stengelumfassend; Elättchen des Hauptkelches kahl, gevvimpert, die inneren an der Spitze etwas ungebogen; Achiinen kahl. 4. Feuchte und truckene Wiesen, Gräben, zwischen Gebüsch, Waldränder nicht selten. Zwischen Gebüsch an Schwalchluche hinter Kröllwitz, Wiesen zwischen Pfitzenburg und Wansleben, bei Kil. Dölzig, bei Naumburg in der tue und auf trorkenen Wiesen häufig II. s. W. Juli. Aug. Strahlbliithen viel länger als die Scheibenblüthen, gelb, Bliithenköpfchen zienlich grioss. Stengel 1-2'.

550. I. hirta L., la uhhaaliger A. Stengel aufrecht oder aufsteigend, mit wagrecht-abstehenden Haaren, 1 köpfig; Blïtter länglich uder lanzettlich, vorne verschmälert-zngespitzt, ganzrandig wder etwas gezäh"elt, adrrig, raulhwarier; Blättchen des Hauptkelches linealisch-lanzettlich, zugespitzt, steifhaarig, länger als die Scheibenbliithen, aber 1 eit kürzer als die Strahlbluthen; Achänen kahl. 24. Sonnige Hügel zwischen Gebüsch, gern auf Kalkhoden, stellenweise. Bei Halle verbreitet $z$. B. auf dem Bischofsberge in der Dölauer Heide, in Mittelholze u. s. w., in Bienitz sehr sparsam, bei Wrissenfels, Nammburg, Freiburg und Bibra auf kalhhaltigen Bergen und an Waldrändern häufig, an der Steinklippe bei Wendelstein und an Buchberge bei Rossleben, an den Schmonschen Bergen. Mai. Juni. Höhe 1'.

h. Acbanen rauhliarig.

551. I. Conýza DC., sparrige $\mathbf{A}$. Stengel aufrecht, dünn - filzì, uberwärts rispig-ästig, Aeste ebensträussig, reichbliithig; Blätter elliptisch oder elliptischlanzettlich, spitzlich, oberseits weichharig, unterseits dïn-filzig, die unteren in den Blattstiel verschmälert, die wberen sitzend; Blättchen des Hanptkelches abstehend-zuruickgebogen;'Strahlbliithen 3spaltig, kaum zungenförmir, so lang als der. IIauptkelch. (-). Dürre Bergabhänge, truckene, steinige Waldplätze, Waldränder stellenweise. Bei Halle selten, nur in denı Wäldchen am Beuchlitzer Weinberge, am Felsen in Wettin, bei Weissenfels über den Eulauer Weinbergen häufig, hei Naumburg und Freiburg sehr verbreitet, an dur Steinklippe bei Wendelstrin, an den Schmonschen Bergen, in der Lindenschlucht zwischen Seeburg und Neehausen, an der Hüneburg bei Eisleben, an den Wester- 
bergen hei Aschersleben, am Scheuberge hei Hettstedt, am Sperenberge bei Sandersleben. Juli. Aug. Conyza squarrosa I. Strahlblumen röthlich, Scheibenblumen gelb. Stengel $2-4$ '.

552. I. Hritúnice L., Wiesen-A. Stengel aufrecht, zottig-wollig, 2 - bis vielköpfig; Blätter lanzettlich, ganzrandig viter gezähnelt, unterseits zottig vder kurzhaarig, die unteren in den Blattstiel verschmälert, die oberen mit her förmigem Grunde stengelumfassend; Blättchen des Haupthelches linealisch.lanzettlich, zugespitzt, die iusseren so lang als die inneren und die Scheibenbliithen ein wenig iiberragend, aber weit kiirzer als die Strahlenbliithen; Achänen liurzharig. 4. Feuchte Wiesen, Gräben, Bäche, in Dörfern gemein z. B. an Gräben rur und in Reideburg, bei Dieskin, Röglitz u. s. w. Juli. Aug. Blume guldgelb. Höhe $3 / 4-11 / 2^{\prime}$.

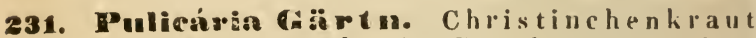
(von pulex, Floh, welche die P. vulgaris vertreibell sullte).

553. P. vulgaris Girtn., gemeines Chr. Sterlgel aufsteigend oder aufrecht, meist graufilzig, rispigebensträussig; Blïtter länglich-lanzettlich, wellenförmig, mit abgerundetem Grunde sitzend, fast stengelumfassend, die jüngeren zottig; Bluthenköpfchen seiten- und endständig, fust kugelig; Strahlbliithen wenig länger als die Scheibenbliithen; der ünssere Federkelch in kleine Borsten zerschlitzt. $\odot$. Ueberschwemmte Plätze, Pfützen. 'Teiche, Anger nicht allgemein verbreitet. Bei Halle häufig z. B. an der Saale zwischen Giebichenstein und 'Trutha, an Lachen zwischen Halle und Passendorf und nach Nietleben zu, an Gräbe" und Ackerrändern vor Reideburg, in Schkopau in der Nähe der'Teiche, bei Naunburg seltener, uur auf Holzplätzen und an der Saale z. B. bei Schellșitz. Juli. Aug. Inula Pulicaria L. Blumen schmutzig-gelb. Höhe $1 / 4-1$. Hat einen widrigen Geruch.

554. P. dysentérica ärtn., Ruhr-Chr. Hayne Arzneigew. VI, 46 . Stengel aufrecht, zottig, ebensträussig; Blätter länglich, mit breiterem, tief-herzförmigem Grunde stengelumfassend, geschweift, undeutlich-gezähnt, unterseits graufilzig; Blïthenköpfchen endständig; Strahlblüthen weit länger als die Scheibenblïthen; der äussere Federkelch kronförmig, klein-ge- 
kerbt. 4. Feuchte Wiesen, Gräben stellenweise. Bei Halle häufig z. B. Gräben zwischen Halle und Rejdeburg und in Réideburg, an den 'Teichen bei Dieskau und an der Reide zwischen der Dieskauer Mühle und Osendorf, an Gräben bej Röglitz, an Gräben zwischen Wallendorf und Zöschen, bei Kl. Dölzig, am Bienitz, bei Kötschan und Teuditz, fehlt bei Naumburg und Freiburg; bei Sandersleben häufig. Juli. Aug. Inula dysenterica L. Blumen goldgelb. Höhe 1-2'. Die Blïthenköpfchen sind mehr als doppelt so gruss, als an voriger Art.

III. Unterordnung. Senecioideen $\mathrm{L}$ ess. B a I dgreisgew i ch se.

Griffel der Zwitterhlüthen walzenförmig, Schenkel linealisch, an der Spitze pinselförmig und gestutzt, uder über dem Pinsel mit einem kurzen Kegel oder pinen verlängerten, schmalen, rauhhaarigen Anhängsel versehen.

5. Gruppe. Helenieen Cassin. Ileleniengewächse. Staubbeutel ohne Anhängsel. Federkelch aus mehren Spreublüttchen bestehend.

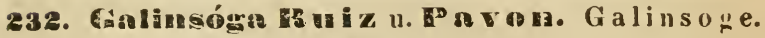

555. G. parviflora Cavanilles, $k \mathrm{l}$ in blumige G. Stengel aufrecht, hahl, nach oben 3gabelig-verästelt; Blätter gegenüberstehend, kurz-gestielt, herzpiförnicg, gezähnt-gesägt, ziemlich kahl. $\odot$. Stammt aus Peru; an Zäunen, Mauern, Wegell und auf Aeckern verwildert, obgleich im Gebiete weit seltener, als in anderen Gegenden. Einzeln an Zäunen bei Merseburg gefundeu. Juli. Aug. Wiburgia Aemella Roth. Strahlhlumen weiss, kleiner, Scheibenblunien gelb. Höhe 1'. Die Blïthenköpfchen sind kaum erbsengruss.

6. Gruppe. Heliantheen Lessing. Sonnenrosengewä chs e. Staubbeutel ohne Anhängsel, schwärzlich; Federkelch fehlend, begrannt oder kronenförmig.

233. Widens I. Wa s serdost (aus bis, zweimal, und dens, Zahn, eigentlich Zweizahn, wegen des gewöhnlich mit 2 Borsten versehenen Federkelches).

556. H. tripartita L., dreitheiliger W. Flora v. Thüring. II, 24. Stengel aufrecht, ästig; Blätter gestielt, meist 3theilig oder fiederspaltig.5theilig, nit lan- 
zettlichen, gesägten Zipfeln; äussere Blättchen des Hauptkelches länger als die aufrechten Bliitlienköpfchen; Achïnen braun-grau, verkehrt-eifürmig, aus Rande rückwärts stachelig. $\odot$. Griben, sumpfige stellen, Ufer überall hänfig. Juli-Ilerbst. Blüthen gelb, Strahlblüthen fehlend. Höhe $1 / 2-31$. Aendert mit un. getheilten, Ianzettlichen |Blättern ab.

Die Mhart mit Strahlhiiithen ist im Gebicte noch nicht beubaclitet.

557. H. cernua L., nickender W. Stur m II eft 1. Stengel aufrecht, einfach ude' ästig; Bliitter ungetheilt, lanzettlich, gesägt, am Grunde ctwas zusammengewach. sen; äusserp Blättchen des Hanptkelches länger als die nickenden Blüthenköpfchen; Achïincn schwarz braun, verkehrt-cifürnig - keilig, am Rande riickwärts starhelig. ○. Gräben, Sïmpfe, 'riche, iiberschwennite Plätze seltener als vorhergehende. An der Saale zwischen Halle und Giebichensteia sparsam, häufiger in Radewell, bei Naunburg selten, häufig bei Bibra nach Saubach zu, bei Allstedt in Kipthe und an Rathsteiche. Aug. Herbst. Blüthen gelb, meist mit Strahlblizthen. Höhe $1 / 2-3^{\prime}$. Aendert ab:

a) discoidea: Blïthenköpfe whne Strahlbliithen.

b) radiata: Blïthenköpfe mit urussen, guldgelben Strahlbliitlien. Cureopsis Bidens 1.

c) minima: Ntengel nur 1-4." hoch, meist ein. löpfig. B. minima I.

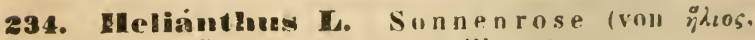

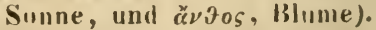

558. Yr. annuus L., einjährige S. Stengel steift. aufrecht; Blätter 3nervig, alle herzförmig, gesägt; Blïthenstiele verdickt; Bliithenköpfe nickend, scheibenför. mig, sehr gruss. $\odot$. Stammt aus Peru, wird theils als 'Zierpflanze in Girten, theils als Oelpflanze auf Feldern gebaut. Juli-Sept. Blume gelb. Scheibenblüthe oft $1^{\prime}$ im Durchmesser. Höhe bis $6^{\prime}$.

7. Grnppe. Gnaphalieen. Ruhrkrautgewãchse. Staubbeutel mí Anhängel.

235. Fuńx I. Schimmelhraut (wahrscheinlich von filum, Faden, wegen der schlauken. fast fadenförmigen Stengel einiger Arten).

559. F. Germanica L., deutsches Sch. Sturu Heft 12. Filzig-wollig; Stengel aufsteigend, gabel- 
spaltig; Blätter lanzettlich, stumpflich, Wellenförmig; klüthenköpfchen in gabel- und endständigren Knäueln; Blätchen des Hauptlielches mit kahler Stachelspitze. $\odot$. Aecher, trockene Hügel, Wegränder stellenweise. An Ilügelı zwischen Kröllwitz und der Dölauer Heide sehr häufig, einzeln an Rande der Dölauer Heide in der Nähe del Fasanerie, bei Röglitz, am Fahrwege zwische" sichkopau und Merseburg rinzeln, bei Kl. Dölzig, fehlt bri Naumburg, sprusam an Bergen zwischen Leinbach und Rittrode, bej Dessalı häutig. Juli. Aug. Blume gelblich-weiss, wie bei der folgenden. Höhe $1 / 2-1$ '. Die ganze P'flanze ist I:It einem schmuzig-gelben Filze iiberzugen.

560. F. arvensis L., A clier-S :h. Sturm Ileft 35. Dicht-wolligr ; Stengel aufrerht. rispig, mit aufrechten, fast einfachen, ziemlich ïhrenfürmigen Aesten; Bläter lanzettlich: Blürhenköpfchen in end- und sei. tenständigen Kı̈̈ueln ; lilïltchen des IIauptkelches stumpf. lich, ohne Stachelspitze, an der Spitze zuletzt kahl. (). 'Truckene Felder, I'ritten, sandige Aecker läufig z. K. Aecker hinter Króllwitz, or der Dölautp Heide u. s. w. Juli, Aus. F. arvensis und montana 1. der Fl. suec. und des llerbar. F. montana W a h I enb. Höhe $1 / 2-3 / 4^{\prime}$.

561. F. minima ries, kleinstes Sch. Sturm Heft 38. Filzig, etwas wollig; Stengel aufrecht, diinn, mit gabelspaltigen Aesten; Blätter linealisch-lanzettlich, aufrecht und angedrückt; Knäuel gabel-, seiten-und endständig, länger als die Blätter; Blättchen des Hauptkelches stumpfiich, an der Spitze kahl. ๑. Aecker, Sandfelder, trockene Hügel häufig z. B. Aecker und Hügel vor der Dölauer Heide u. s. w. Juli. Aug. F. arvensis $W$ ahlenb. F. muntana L. gehört nach Fries zu. F. ariensis I. Stengel zart, 4-8" hoch.

F. gallica l." wiri von Wallr. ann. bot. p. 102 an kiesigen Aechern hinter Kröllwitz und Lettin angegeben, welche Standurte sowuhl von Koch (synops. ed. 2. p. 398), als alich vol Rehb. (sax. ed. 1 u. 2. 1. 155) erwähnt werden. Schon Splenge I hat jedoch diese Pflanze unerwähnt gelassen und da sie auch in neutrer Zeit nit: gefuuden ist, so kann sie für das Gebiet nicht wieder aufgenummen werden.

236. Cunghosiliaara L. Ruhrkraut (dieser schon von Dioscurides und Plinius gebrauchte Name kummt vull yoúfalov, Wulle, her, wegen der filzigen Stengel und Blätter). 
A. Gnaphalion. Köpfchen ejuhäısig. Randblüthen weiblich, die Bliithen des Mittelfeldes zwitterig. Fe. derkelch aller fadenlörmig, oder an der Spitze nur wenig verdickt.

562. G. silvaticum L., Wald-R. Stengel steif-aufrecht, einfach, ruthenförmig, ïhrenförmi:"; Wurelblätter lanzettlich, Stengellilitter allmählig lileiner; die uberen linealisch, sämmtlich spitz, nach dem Grunde verschmälert; unterseits weiss-filzig, oberseits zuletzt kahl "Ierdend; die ïnssersten lilittchen des Hanptlielches 3 mal liurzer als clas Köpfchen. 4. Wälder, Hei. den, trockens 'Iriften häufir \%. B. am Donuersherge hintel Kröllwitz, Bischufahég in der Dölaner Heide, Mittelholz u. s. w. duli. Augr. G. rectum sm. Blune gelblich- " Heiss. Höhe $A^{\prime}$ und dirüber.

563. G. uliginosum L., Sinmpf-R. Stengel vom Grunde an iistis, ansgebreilet, selturner aufrecht, weisswollig; Blätter linealisch - lanzettlich, nach dem Grunde verschmälert. graulich-behaurt; süpjechen knanelartigchäuft, lebliillevt; Arhäırn hahl. $\cup$. Fenchte decker, iiberschwenmt gewesene Plätze, 'leirhe, Pfützen gemein z. B. an der Saale zwischen Halle mol Giebichenstein, sehr häufig an schwalchloche hinter Kröllwitz u. s.w. Juli-Ilerbst. Blume gelb-weiss. Höhe 6-9".

564. Gr. Inteo-album L., gelblich-weisses $R$. Sturm Heft 38 . Stengcl cinfuch oder oberwärts ästigebensträussig; Blätter s'hnal-lanzettlich, beiderseits weisswollig, halbstengelumfasiend. die meren vorne breiter, stumpf, die wheren nach der Spitze verschnälert; Köpfchen s ehnäuelt, blattlos: Achänt” fein-gekörnelt. $\odot$. Sundfelder, 'I'riften, Heiden stellenw eise. Vor den Dunnersberge hei Kröllwitz, Areker an der Dölaner Heide zwischen Nietleben und der Fasanerie, fenchte Aecker in der Nähe ler Sümpfe hei Lieskau, sehr sparsall bei Westewitz südlich vom Petersberge, "w es finst Kuhl fand, in der Aue bei Naumburg in der Nähe der Saale, inı westlichen Gebiete etwas ver. breiteter z. B. in Wendelsteiner Furste an II ege ion Ziegelrode nach Wendelstein; anf unbewaldeten Stellen der Wïste bei Allatedt in der Nähe der Stange, in Peinholze und im Mühlthale zwisclien Wulfersteit und Nienstedt unweit Allstedt, bei Aschersleben hänfig $z$. B. an der alten Burg, bei Dessan und Oranienbaum hin und wieder, in Werlbusche bei Delitzsch. Juli. Aug. 
Haptkelch gelb-silberfarben.

Blume trüb-röthlich. Höhe $2-8$ ".

B. Antennaria Gărtn. Köpfchen zweihänsig, die zwitterigen mit einem an der Spitze verdickten Federkelche.

565. G. dioicum L., $\mathrm{z}$ we ihäusiges R., Kaz zenpfötchen. Hayne Arzueigew. V, 6. Mit gestreckten, wurzelnden Anslïufern; Stengel einfach; Wurzelhlätter verkehrt-eiförmig-spatelir, wherseits kahl, unter'seits srhneewriss-filzig, stengelblätter linealisch. lanzettlich, an den Stengel angedrickt; Ebenstranss endständig - ardrunge"l; Blättchen des weihlichen Haupthelches grlürbt, stumpf, die der inuersten Reihe spitz. 4. Waldwiesen, Triften; Heiden gemein z. B. auf dem Bischofsherge in der Dölautr Heide, besonders auf Heideboden zwischen dem Lindberge und der Dölaner Heide u. s. w. M i. Juni. Antennaria dioica l)C. Gärtn. Hauptelch rosemroth oder schneeweiss, Blume weiss oder purpumoth. Höhe $3-9 "$.

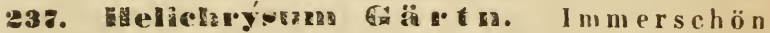
( der Name kik\%veno hommt schun bei Theophrast und

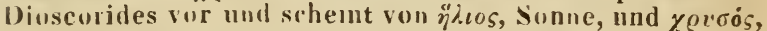
Guld, hergeleitet werden zu müssen).

566. H. arenarium DC., S and-I. II a yne Arzneigew. V, 5. Krautartig, anfsteigend; Blätter filzig, die wurzelständigen rerkehrt-piförmig-lanzettlich, die stengelständigen linealisch-lanzettlich; Ebensträusse zusammenresetzt. 24. Somnige, sundige Anhöhen, Sandfelder, Waldränder häufiq z. B. bei Kröllwitz, an einigen Orten seltener z. B. bei Allstedt, wo es nur auf der 'Trift und in Wiihlthale zwischen Wolferstedt und Nienstedt vorkummt. Juli. Aug. Gnaphalium arenarium L. Hauptkelch schön citronengelb. Höhe $1 / 2-1^{\prime}$.

8. Gruppe. Anthemideen. Rindsaugengewächse. Staubbeutel ohne Anhängsel, gelb. Federkelch fehlend oder kronenförmig.

238. Artenaisin E. Beifuss (diese zuerst von Dioscorides erwähnte Pflanze hat ihren Namen von Artemis, der Schutzö̈ttin der Gebährenden; der 'Trivial. name (i)' ivfiov wird schun von 'Theophrast für den Wermuth gebraucht. Der dentsrhe Nime Beifuss bedeutet si) viel als Neben-oder Hilfsfuss; schon Plinins sagt: Artemisiam alligatam qui habet viator, negatur lassitudinem sentire). 
A. Absinthium Tournef. Blithenboden zuttig; Rarf. blüthen weiblich.

567. A. Absinthium L., We in uth-B. II ayne Arzneigew. I1. I1. Stengel aufrecht, uberwärts rispig;

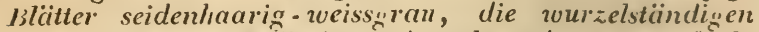
3 fach-, die stengelstïndinen doppelt. oder nur einfachofiedert; mit lanzettlichen. stumpten 'Zipfelchen, die blüthenständigen Blätter ungethejitt; Jlatlsticle ohne Ochrchen; Blüthenhöpfchen tast kugeli;-, graulich-be. haart, nickend; Blättchen des Ilaupthelches grau, die inneren sehr' stumpf, au Rande truchmohäutig, die äusseren linealiseh, "ur an der Spitzo trockenhäutig, su lang als die inneren; Bliithenboden zottig., 4. W'einberge, 'Züune, in Dörtern zwal' nur i erwildert, aber jetzt fast eingebiirgert. Wrinberge zwischen Rollsdorf und Seeburg, in Kötsrhau, hei Dürrenberge und oft anf Kirchhöfen angepflanzt. Juli-Sept. Absinthimm $\mathbf{\text { III. }}$ gare Gärtn. Blumen gelb. Höhe 2-4'. UFF. herba s. summitates Absinhii. Die Pflanze hat einen starhell, widerlich-aromatischen Geruch.

568. A. rupestris L., Fels+n-B. Nichtblühende Stengel liegend, histhentragende aufstlebend, einfachtraubenförmig oder oberwärts ästig - rispiğ, lispe schnal, ruthenförmig; Bliitter kahl, doppelt-gefiedert, nit linealisch-lanyettlichen Ziptelchen, die unteren gestielt, nut fiederspaltig-gezähnten Blattstielen, die stengelständigen sitzend, die oberen und bliithenständigen sümmtlich-einfach, kammförmig-fiederspaltig; Blïthenköpfchen fast kugelig, nichend; die inneren Blättchen des Haupthelchés eiföınig, an Kande häutig, angedrücht, die ̈̈usseren abstehend, linealisih, ganz oder eingeschnitten und krautartig; Blithenboden zottig. 4. Salzhaltige 'Triften sehr selten, "ur auf salzhaltigen Triften zwischen Stassfurt und Beruburg und auf ier Grenze des Gebietes zwischen Artern und Kahstedt. Sept. Blüthenköpfchen erbsengross, alsu grösser als an allen Beifussarten. Hölıe $3-6^{\prime \prime}$.

B. Abrotanum Tournef. Blüthenbuden nackt. RandLlüthen weiblich.

a. Blätter vielspaltig, am Grunde des Blattsticles whne Oehrcben.

569. A. Iaciniata willd., gुeschlitzter B. Nirhtblühende Stengel rasenförmig, blüthentragende aufstrebend, ganz einfach, nit einer einfachen l'rauhe endigend, oder mit aufrechten, traubenförmigen Aesten; Blät- 
ter zuletzt kahl, doppelt-fiederspaltig, mit gezähnten, stachelspitzigen Zipfelchen, alle gestielt, Blattstiel am Grunde ohne Oelirchen, die bliithenständigen oberen Blätter ganzrandig; Blüthenköpfehen fast kugelig, nikkend; Blättchen des Hauptkelches sämmtlich eiförmig, stumpf, am Rande trockenhäutig, die äusseren kürzer; Bliithenboden kahl. 24. Salzhaltige Triften äusserst selten, nur auf salzhaltigen 'Triften zwischen Stassfurt und Bernburg und auf der Grenze des Gebictes auf salzhaltigen Triften zwischen Artern und Kahstedt mit der vorhergehenden Art, aber noch weit seltener. Juli. Aug. A. Mertensiana Wallr. Blume gelb. Höhe $3-6 "$ ". Bei Aschersleben wächst diese seltene Pflanze nicht, wie $R$ chb. sax. ed. 1 u. 2. p. 152 angibt, soudern nur an dem angeführten Standorte.

b. Blätter vielspaltig, am Grunde des Blattstieles mit Oelirchen,

570. A. pontica L., p o n t ischer B. Hayne Arzneigew. II, 10. Wurzel kriechend; Stengel aufiecht, oberwärts rispig, fast ruthenförmig; Blätter unterseits weisslich-filzig, oberseits kahl oder grau, doppelt gefiedert, nit linealischen, genäherten, ganzen oder etwas gezähnten Zipfelchen, die unteren stengelständigen am Blattstiele mit Oehrchen, die oberen sitzend, die blüthenständigen ganz; Bliithenköpfchen fast kugelig, graulichbehaart, nickend; Blättchen des Hauptkelches verkehrteiförnig, sehr stumpf, am Rande trockenhäutig, die äusseren krautartig, kürzer, lanzettlich; Blïthenboden kahl. 24. Waldränder, Bergabhänge stellenweise. Am oberen Rande des Lindbergs, an Zorgs, an Bergab. hängen zwischen Bennstedt und dem Zorgs, an Abhängen zwischen Langenbogen und Rollsdorf in der Nähe der Salzke, bei Naumburg auf Ackerrainen zwischen dem Jakobsthore und Grochlitz, bei Allstedt nur am Eingange in die Schlangengasse links auf einem Hügel. Juli. Aug. Blume gelb. Höhe $2-3$ '.

571. A. campestris L., Feld-B. Ha yn e Arzneigew. II, 9. Nichtbliihende Stengel rasenartig, blüthentragende aufstrebend, rispig; Blätter seidenhaarig-grau oder kahl, doppelt - bis 3fach-gefiedert, nit linealischen, stachelspitzigen Zipfelchen, die unteren stengelständigen am Blattsticle mil Oehrchen oder fiederspaltig-gezähnt, die oberen sitzend, einfach-gefiedert, die oberen blüthenständigen unjetheilt; Bliithenköpfchen eiförmig, kahl, aufrecht oder nickend; Blättchen des Hauptkelches eiförmig, am Rande trockenhäutig, die äusseren 
kürzer, die inneren eiförmig-länglich. 4. Trockene Hügel, Felsen, Raine, Mauern häufig z. B. am Felsen zwischen Giebichenstein und 'Trotha, selbst auf der Stadtmauer in Halle u. s. w. Juli. Nug. Blume gelb mit röthlichem Anfluge: Der meist ruth angelaufene Stengel ist $1-2^{\prime}$ hoch. Aendert mit grösseren und kleineren Blüthenköpfen ab und:

b) stricea Fries.: Blätter seidenhaarig-grau, mit bleibendem Ueberzuge.

572. A. vulgaris L., gemeiner B. H a y ne Arz. neigew 11, 12. Stengel aufrecht, ästig, zuletzt rispig; Blätter unterseits weissfilzig, fiederspaltig, mit lanzettlichen, zugespitzten, meist eingeschnittenen oder gesägten Zipfeln, die stengelständigen am Grunde mit Ochrchen, die obersten linealisch-lanzettlich, zugespitzt; Blüthenköpfchen eiförmig oder länglich, nickend oder aufrecht, fast sitzend, filzig; Bliithenhoden kahil. 24. Unbebaute Stellen, Mauern, Zäune, Wege, in Dörfer'n nicht selten z. B. in Reideburg, Bischdorf u. s. w. Aug. Sept. Blume gelb. Der röthlich oder grau angelaufene Stengel ist $3-6^{\prime}$ hoch. OFF. herba et summitates Artemisiae rubrae et albae.

C. Seriphida Bess. Blüthen sämmtlich zwitterig.

573. A. maritima L., Ne erstrand-B. Nichtbliihende Stengel rasenartig, blüthentragende aufstrebend oder aufrecht, Blätter schneeweiss-filzig oder zuletzt kahl werdend, $2-3$ fach-geñedert, mit linealischen, stumpfen Zipfelchen, die unteren stengelständigen am Blattstiele mit Oehrchen, die oberen sitzend, die obersten blüthenständigen ungetheilt; Bliithenköpfchen länglich, filzig; Blättchen des Hauptkelches länglich-linealisch, die inneren trockenhäutig, die äusseren kürzer, krautartig; Bliithen sämmtlich zwitterig. 24. An Salinen auf schwachbegrastem Boden. Sept. Octob. Hiervon findet sich im Gebiete nur die Abart:

b) salina Willd.: Blüthenköpfchen nickend, sehr selten. An Bergen zwischen Langenbogen und Rollsdorf, an Bergen unmittelbar am Wirthshause bei Rollsdorf, auf der Grenze des Gebietes an den Salinen bei Artern; soll nach Schwabe fl. anh. auch bei Stassfurt vorkommen. Blume gelblich. Höhe $1-2^{\prime}$.

239. Tramaxétum $\mathbf{L}$. R e infar n (ein zu Dodonaeus Yeit gebildeter Pflanzenname zweifelhafter Ableitung). 
574. T. vulgare L., gemeiner R. Hayne Arzneigew. II, 6. Stengel aufrecht; Blätter doppelt - fiederspaltig, mit länglich-lanzettlich, fiederspaltigen Zipfeln und gesägten Zipfelchen; Blättchen des Hauptkelches angedrückt, eiförmig. 24. Wiesenränder, Flussufer, Wege, Raine häufig, z. B. zwischen Gebüsch am Schwalchloche hinter Kröllwitz, oft an Chaussegräben z. B. bei Anıniendorf, Schkopau u. s. w. Juli. Ang. Blumen goldgelb. Höhe $2-4^{\prime}$. Die ziemlich grossen Blüthenköpfchen des Ebenstrausses stehen dicht beisammen. Aendert besonder's in Gärten mit wellenförmig-krausen Blättern ab.

240. Acliilléa F. Ga rbe (diese schon von Dioscorides erwähnte Pflanze erhielt ihren Namen von Achilles, welcher die A. magna L. zuerst arzneilich gehraucht haben soll; der gleichfalls schon ron Dioscorides ge-

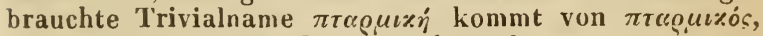
zum Niesen nöthigend).

1. I'tarmica Tournef. Strahl meist 10blüthig.

575. A. Ptármica L., B e r tra $11-\mathrm{G}$. S t u r m Heft 10. Stengel aufrecht; 13lätter kahl, lanzettlich-line-。 alisch, verschmälert - spitz, aus beiderseits eingeschnittengezähntem Grunde bis zur.Mitte klein- und dicht., iiber der Mitte tiefer- und entfernter-gesägt, Säigezähne stachelspitzig, fein-gesägt, fast angedriickt; Ebenstrauss zusammengesetzt; Strahlblüthen zungenförnig, die Zunge derselben so lang als der Hauptkelch. 24. Wälder, sumpfige Wiesen, Ufer, zwischen Gebüsch häufig z. B. in der Dölauer Heide, Mittelholz u. s. w. Juli. Aug. Ptarmica vulgaris DC. Blume weiss. Höhe 1-2'.

B. Millefolium Tournef. Strahl 5blüthig.

576. Arillefolium L., S c ha a f g a r be. Hayne Arzneigew. IX, 45. Stengel aufrecht, etwas zottig; Blätter wollig-zottig oder fast kahl, die stengelständigen im. Umrisse lanzettlich oder fast linealisch, doppelt-fiedcr. spaltig, Fiederchen 2-3spaltig oder oeficdert-5spaltig, mit zugespitzten, stachelspitzigen Zipfelchen; Blattspindel ungezähnt oder nur an der Spitze des Blattes etwas gezähnt; Ebenstrauss doppelt-zusammengesetzt; Strahlblüthen zungenförmig, die Zunge derselben halb so lang oder kaum halb so lang als der Hauptkelch. 4. Wiesen, Weg- und Ackerränder, Raine, Triften, iiberall gemein. Juni-Octob. Blume weiss. Höhe $1 / 2,1 \frac{1}{2}$. Aendert ab: 
b) L anata Ko ch (nicht Spreng.): Stengel, Blätter und Ebenstrauss wollig-zottig.

c) polyphylla Schleich.: wie die gewöhnliche Form, aber weniger wollig, Strahlblüthen schnutzigweiss.

d) s etacea W. K. : wollig-zottig, Blattzipfel sehr schmal, borstenförmig, so am Lindberge, Zorgs, an Weinbergen bei Röglitz u. s. w.

577. A. nobilis L., edle G. Stengel aufsteigend, weichhaarig; Blätter wollig - weichharig oder fast kahl, die slengelständigen im Umrisse eiförmig, doppelt-fiederspaltig, Fiederchen schwach-fiederspaltig-gezähnt, die grösseren nit 5-7 kurzen, stachelspitzigen Zähnen; Blattspindel schmal, von der Spitze bis zur Mitte des Blattes gezähnt; Ebenstrauss doppelt-zusanınengesetzt; Strahlblüthen zungenförmig, die Zunge derselben halb so lang als der Hauptkelch. 24. Sunnige Hügel, buschige Bergabhänge, Raine, Wegränder stellenweise. Lindberg, auf unbebanten Aeckern und Rainen suidich vom Petersberge, häufiger an buschigen Abhängen zwischen Gutenberg und dem Bergholze, bei Naumburg auf Aeckern über der Henue, an den Laasen und bei Wilsdorf, auf Aeckern an südlichen Rande der neuen Giehle bei Freiburg, auf Mauern in Barnstedt, an Ackerrainen zwischen Barnstedt und Göhrendorf und zwischen Barnstedt und Reinsdorf häufig, bei Querfurt, bei Allstedt auf der Stadtmauer und in Rathsholze häufig, bei Eisleben und Aschersleben. Juli. Aug. Blume weiss oder gelblich-weiss. Höhe $1 / 2-1^{\prime}$.

21. Anthemis E. Rinds a uge (ein von Dioscorides gebrauchter Pflinzenname, welcher von $\dot{\iota} \nu \vartheta \varepsilon i \nu$, blühen, abgeleitet ist und sich auf die zahlreichen Blüthen dieser Gattung bezieht).

a. Spreublittchen lanzettlich, in eine starre stachelspitze zusammengezogen.

578. A. tinctoria L., Fä r b e r-R. Flora v. Thüring. 1, 6. Stengel steif-aufrecht; Blätter weichhaarig, doppelt-fiederspaltig, nit länglichen, fiederspaltig-eingeschnittenen 'Zipfeln; Blattspindel gezähnt; Blïthenboden fast halbkugelig; Spreublätchen lanzettlich, in eine starre Stachelspitze zugespitzt; Achänen 4eckig-zusammengedrückt, schmal - geflügelt, beiderseits 5 streifig, mit einem geschärften Rande endigend; die Zunge der Randbliithen kaum halb so lang als der Querdurchmesser des 
Miltelfeldes. 4. Trockene, sonnige Hügel, Wegränder, Mauern stellenweise. Kalkberge bei Bennstedt bis nach Kölme häufig, einzeln auf Matern in Dölau, bei Naum. burg häufig, einzeln zwischen Querfurt und Lodersleben, bei Eisleben an der Hïneburg, an Bergen bei Sandersleben. Juli. Aug. Blume gelb. Höhe $1-1 \frac{1}{2} 2^{\prime}$. Die Blumen werden zum Gelbfärben gebracht.

579. A. arvensis L., A c kel-R. Hayne Arzneigew. 1, 5. Stengel aufsteigend oder aufrecht, mit abstehenden Aesten; Blätter wollig-weichhaarig, doppelt-fiederspaltig, mit linealisch-lanzettlichen, ungetheilten oder 2 - 3fach-gezähnten, stachelspitzigen Zipfeln; Bliithenboden verlängert-kegelförmig, innen markig; Spreublättchen lanzettlich, in eine starre Stachelspitze zulgespitzt; Achänen stumpf, $4 \mathrm{kantig}$, gleichmässig-gefurcht, die äusseren mit einem wulstigen, faltig-runzeligen Ringe, die inneren nit einem spitzen Rande endigend. $\odot$. Aecker ïberall geniein. Juni-Herbst. Strahlblumen weiss, Scheibenblumen gelb. Höhe $3 / 4-1{ }^{\prime} / \mathrm{s}^{\prime}$. Die Pflanze mit jüngeren Achänen ist $A$. arvensis Wall $\mathrm{r}$. und mit ausgebildeten Achänen A. agrestis Wall $r$.

h. Spreublätter linealisch - borstenförmig, spitz.

580. Cótula L., stinkendes R., Hundshamille. Ha yne Arzneigew. I, 6. Stengel aufsteigend oder aufrecht, mit abstehenden Aesten; Blätter ziemlich kahl, doppelt-fiederspaltig, mit linealischen, ungetheilten oder 2-3zähnigen, kurz-stachelspitzigen Zipfeln; Bliithenboden verlängert-kegelförmig, innen markig; Sprenblättchen linealisch-borstenförmig; Achänen beinahe walzenförmig, knötig-gerieft, mit etwas gewölbter, deutlich berandeter Scheibe. $\odot$. Flussufer, Accker, Schutt, in Dörfern stellenweise, fehlt in der Nähe von Halle, bei Naunburg in der Aue auf Saalkies, auf Aek. kern über der Henne und in der Nähe der Strasse nach Freiburg, häufig auf Aeckern bei Landgrafrude und Allstedt, in Wolferode bei Eisleben, Aecker zwischen Leim. bach und dem Amte, fehlt bei Aschersleben, Aecker bei Dessau nicht selten. Juni-Herbst. Maruta Cotula DC. Strahlblumen weiss, Scheibenblumen gelb. Höhe $1 / 2-11 / 2$.

lst der vorigen Art sehr ähnlich, unterscheidet sich aber von ihr ansser den linealisch-borstenförmigen Spreublättchen, welche am untern Theile des Fruchtbodens neist fehlen, während sie bei $A$. arrensis auch am Grunde desselben vorhanden sind, noch durch die hellgrünere Farbe der Blätter und besonders durch den 
sehr widrigen Geruch der etwas geriebenen Blüthenköpfe.

Anthemis nobilis L., edle oder römische Kamille, welche im Siiden einheimisch ist, wird hin und wieder in Gärten zum arzneilichen Gebrauche gebaut.

242. Matricária I. K a mille (von mater, Mutter, wegen der Wirkung dieser Pflanze auf den uterus; der

Name kunmt zuerst bei Matth. Sylv. vor).

581. Mr. Chamomilla L., ächte K. Hayne Arzneigew. I, 3. Stengel aufrecht, kahl, mit ausgebreiteten Aesten; Blätter doppelt-fiederspaltig, mit linealischfadenförmigen, zuweilen gespaltenen Zipfeln; Blüthenboden walzig-kegelförmig, ohne Spreublätter, innen hohl; Achänen klein, linealisch, seicht-gebogen, an der Spitze abgestutzt, mit einem etwas hervorstehenden, stumpfen Kande endigend. $\odot$. Aecker, Wege, in Gebiete meist häufig z. B. auf Aeckern zwischen Halle und Nietleben, an Wege und auf Aeckern vor Ammendorf, seltener bei Allstedt, daselbst nur auf der Grenze nach Kahstedt zu, auch bei Eisleben wenig verbreitet. Mai - Aug. Strahlblumen weiss, Scheibenblumen gelb. Höhe $1 / 2-1$. Blätter heligrün nebst den etwas geriebenen Bluthenköpfen stark riechend. OFF. flores Chamomillae vulgaris.

Ist durch den hohlen Blïthenboden sogleich von den sehr ähnlichen Anthemis - und Chrysanthemum-Arten zu unterscheiden.

243. Chrysánthemum $\mathbf{~}$. W u ch e rb lum e (Pflanzenname bei Dioscorides, aus $\chi \varrho v \sigma o s$, Gold, und $\varkappa \nu \vartheta \varepsilon$ uov, Blume zusammengesetzt; der Trivialname Leucanthemum bedeutet die weisse Blume, von $\lambda \varepsilon v x o$ s, weiss, und $\ddot{\nu} \vartheta \imath \mu \circ \nu$, Blume).

a. Strahlblüthen weiss.

582. Chr. Ceucánthemum L., we is s e W., grosse Massliebe. Sturm Heft 2. Stengel aufrecht, meist einblüthig; untere Blätter lang-gestielt, verkehrt-eiförmig-spatelig, gekerbt, obere sitzend, linealisch-länglich, gesägt. 4. Wiesen, Acker - und Waldränder gemein. Juni. Juli. Leucanthemum vulgare DC. Blüthenköpfe gross, gelb, mit zahlreichen, weissen Strahlblüthen. Höhe 1-2'. Aendert mit kahlen und behaarten, ast- 
losen und ästigen Stengeln und mit tief - eingeschnittenen, fast fiederspaltigen Blättern $a b$ und ausserdem:

a) vulgare Peterm.: Achänen sänımtlich ohne Federkelch.

b) auriculatum Peterm.: Achänen der Randblüthen mit einem häutigen, einseitigen, ohıförmigen, kleinen Federkelche, welcher am Rücken der Zungenblïthe nicht sichtbar ist, die Achänen der scheibenständigen Blïthen ohne Federkelch.

c) a ffine Peterm.: Achänen der Randblïthen mit einem häutigen, gæzähnt-gespaltenen, grösseren Federkelche, welcher an Rücken der Zungenblüthe mit einer breiten Bucht ausgeschnitten ist, die Achänen der scheibenständigen Blïthen ohne Federkelch.

d) coronulatum Peterm.: Achänen der Randblüthen mit einem häutigen, gezähnt-gespaltenen, grösseren und weiteren Federkelche, welcher an Rücken der Zungenblüthe durch eine breite Bucht ausgeschnitten ist, die Achänen der scheibenständigen Blüthen mit einen häutigen, kronenförmigen, ganzen, aber ungleichen Federkelche.

583. Chr. corymbosum L., e bensträus sige W. Fast kahl; Stengel aufrecht, kantig, oberwärts ebensträussig; Blätter gefiedert, weichhaarig, Fiedern der. unteren und bisweilen auch der oberen Blätter fiederspaltig, mit scharf-gesägten Zipfeln und stachelspitzigen Zähnen; Zungenblüthen linealisch-länglich; Achänen sämmtlich mit häutigem, kronenförmigem, längerem Federkelche. 24. 'Truckene Wälder, Hügel zwischen Gebüsch nicht selten z. B. Dölauer Heide, Mittelholz, Bergholz, Weinberge bei Röglitz, in Bienitz u. s. w. Juni. Juli. Pyrethrum corymbosun Willd. Höhe $1 \frac{1}{2}-3^{\prime}$. Aendert mit mehr oder minder tief eingeschnittenen und behaarteren und kahleren Blättern ab.

584. Chr. Parthénium Pers., Mut terkraut - W. H a yne Arzneigew. VI, 20. Stengel aufrecht, gestreift, oberwärts ebensträussig; Blätter weichhaarig, gefiedert, Fïedern elliptisch-länglich, stumpf, fiederspaltig, die obersten zusammenfliessend, Zipfel etwas gezähnt, sehr kurz-bespitzt; Achänen mit einem geschärften, sehr kurzen Rande endigend. 24. An Wegen, Mauern, auf Schutt, in Dörfern verwildert; stammit aus Südeuropa. Juni - Aug. Matricaria Partheniun L. Pyrethrum Partheniun S m. Strahlblüthen weiss, Scheibenblüthen gelb. Höhe 1-2'. OFF. herba et flores Matricariae. 
585. Chr. inodorum L., geruchlose W. II ayne Alzneigew. 1, 4. Stengel aufrecht, oberwärts ästig, kahl; Blïtter 2-3fach-fiederspaltig, mit linealischen. fadenförmigen, verlïngerten Zipfeln; Strahlblüthen abstehend; Blïthenboden halbkugelig, innen markig; Blättchen des Hauptkelches an der Spitze weisslich-trockenhäutig. ○. Aecker unter der Saat, Wege häufig z. B. zwischen Kröllwitz und der Dölauer Heide, sehr häufig auf Aeckern am Dölauer Kirchholze bei Lieskau u. s. w. Juli-Octub. Matricaria inodora L. fl. suec. Tripleuro. spermum inodorum C. H. Sehultz bip. Strahlblumen weiss, Scheibenblumen gelb. Höhe $3 / 4-2{ }^{\prime}$. Das dunkelgrïne Kraut ist nebst den selbst geriebenen Blüthenköpfchen geruchlos und unterscheidet sich schon dalurch voll der ähul chen ächten Kanille (Matric. Chamonilla L.).

\section{h. Strahblïthen gelh.}

586. Chr. segetum L., S a a t - W. Stengel aufrecht, mit wenig abstehenden Aesten; Blütter kahl, gezïhnt, vorne verbreitert, 3spaltig - eingeschnitten, die oberen mit her fürmigem Grunde stcngelumfassend; Achänen mit einem undeutlichen Rande endigend. $\odot$. Aecker inter der Saat stellenweise, an vielen Urten ein lästiges Unkraut, an anderen gar nicht. Bei Halle auf Aeckern zwischen der Irrenanstalt und der Dölauer Heide und zwischen Dölau und der Heide sehr häufig, bei Merseburg weit seltener, fehlt bei Weissenfels, Freiburg und Naumburg, obgleich es Rchb. dort angibt, bei Dessan häufig, ebenso bei Laue und Benndorf nördlich von Delitzsch. Juli. Aug. Höhe 1-2'.

'9. Gruppe. Senceioneen. Ba ldgreisgewächse. Federkelch behaart; sonst alles wie bei den Anthemideen.

244. Arišea C. Wolverlei (der in Rupp's fl.jen. zuerst gedruckte Name Arnica ist von Christ. Schroeder wahrscheinlich aus der früheren Benennung dieser Pflanze Doronicum gebildet; der deutsche Name Wolverlei heisst eigentlich Wohl verleihend, weyen der viel-

fachen arzneilichen Anwendung dieser Pflanze).

587. A. montana L., B e r g - WW. II a y n e Arzneigew. VI, 47. Wurzelstock fast Wagrecht, abgebissen; Stengel aufrecht, nur 1-3 Blüthenköpfe tragend; Wurzelblätter länglich - verkehrt - eiförnig, fast ganzrandig, כrnervig, Stengelblätter gegenüberstehend; Blüthenstiele 
und Hauptkelch zottig oder drïsig - weichhaarig. 4. fienchte Wiesen besonders auf Torlboden, selten; nur im nordöstlichen Gebiete, aber daselbst hüufiger. Auf der grossen Bruchwiese und in den Fichten zwischen Sandersdorf und Bitterfeld, anf Torfwiesen zwischen Pouch und Crina östlich von Bitterfeld, in der Lingenauer Heide und bei 'Törten unweit Dessau, hei Oranienbaum auf der Lugwiese, im Nichrim und sonst häufig. Juni. Juli. Blumen urangegelb. Höhe $1-2^{\prime}$. OFF. rad. herb. et flores Arnicae.

245. Senécio E. Baldgreis (der zuerst von Plinius gehrauchte Name ist aus senex, Greis, gebildet und bezieht sich wie der schon bei Taberuaemontanus vorkommende, sehr passende deutsche Name Bald. greis auf das frïhe Abblühen vieler Arten).

A. Cincraria L. Auseenkelch fehlend oder doch nur durch einige Schüppchen angedeutet.

588. s. spathulaefolius DC., spatelblät te lo i ger B. R chb. pl. crit. II. Abb. 240. Stengel aufrecht, Ebenstrauss endständig, einfach; Blätter mit gegliederten, kurzen Haaren spärlich bestrent und zugleich oberseits spinnwebig-flockig, unterseits weiss-wollig, die untersten eifürmig, am Grunde fast abgeschnitten, gekerbt uder gezühnelt, die folgenden eifürmig-länglich. in den breit- „efliigelten, leilfürmigen Blattstiel zusammengezogen, die oberen sitzend, lanzettlich und linealisch; Hauptkelch wollig; Fruchtknoten dicht - und kurzsteifhaarig; Federlielch während der Bliithezeit ungefïhr. so lang als dic Blume. 21. Bergwälder, freie Waldstellen besonders auf Kalkboden, selten, nur in 'Ihüringen, aber daselbst häufig. Kei Naumburg in den I,aasen, ïber ler Henne, bei Märtendorf und Rossbach, bei Freiburg in Bergwäldern verbreitet, Abhänge des Sandthales in Isodersleber Forste, im Walde bei KI. Wangen am Eingange in den Wangener Grund. Mai. Cineraria spathulaefolia $\mathrm{G} \mathrm{mel}$. C. integrifolia bei IV allr. sched. p. 474. Blume hochgelb. Höhe 1/1/2-4'. Einige von Rchb. sax. ed. 1 u. 2. p. 147 zu S. campestris citirte Standorte gehören unstreitig zu dieser Art.

589. S. campestris DC., Feld-B. R chb. pl. crit. I1. Abb. 251-255. Stengel anfrecht; Ebenstrauss endständig, einfach; Blätter fast kahl, spinnwebig-wollig, die vuur:elständigen eiförmig oder rundlich, in den kurzen Blattsticl zusammengezogen, gauzrandig oder etwas 
gekerbt, die unteren stengelständigen länglich, nach dem Grunde verschmälert, die obersten lanzettlich; Hauptkelch fast kahl, am Grunde etwas wollig; Fruchtlinoten dicht - und kurz-steifhaarig; Federkelch wailırend der Blithezeit ungefälur so lang als die lilume. 4. Kalkberge sehr selten. Mit Sirherheit nur am Vogelsberge bei Bennstedt und auf der Grenze des Gebietes bei Hecklingen unweit Stassfurt. Mai. Juni. Cineraria campestris Retz. Blume hellgelb. Höhe $1 / 4-3 / 4^{\prime}$.

Bei Hornburg und Farnstedt, welche Standorte Spreng. hal. ed. 2. p. 355 angibt, hat der Verfasser vergeblicb gesucht.

590. S. palustris D C., Sum $\mathrm{p} \mathbf{f}-\mathbf{B}$. Zottig; Stengel aufrecht, oberwärts ästig, ebensträussig; Jlcitter lanzettlich, halbstengelumfassend, die unteren buchtig. oezïhnt; Federkelch während der Blüthezeit kürzer. zur Fruchtzeit um die Hälfte länger als die Blume. $\odot$. Sumpfige Stellen, an Ufern tiefer Gewässer, iı Torfuräbereien sehr selten. Ist in neuerer Zeit an dem von Spreng. hal. ed. 2. p. 356 angegebenen Standorte "Fischteiche bei Bruckdorf und Dieskau" nicht wieder gefunden und auch am süssen See (nicht salzigen See, wie Spreng. schreibt) weit seltener geworden; seh. häufig auf der Grenze des Gebietes im Aschersleber See, an Teiche bei Markranstedt. Von Schwabe fl. anh. wird sie bei Radegast und Oranienbaum als häufig angegeben. Juni. Juli. Cineraria palustris L. Blume hellgelb. Höhe $1 / 2-2$ '

B. Senecio L. Aussenkelch mehr oder minder vollkommell.

a. Blüthen sänmtlieh röhrenförnig.

591. S. Vulgaris L., gemeiner B., Kreuzkraut. H a yne Arzneigew. VIII, 10. Stengel aufrecht, meist ästig; Blätter kahl oder spinnwebig-wollig, fiederspaltig, die unteren in den Blattstiel verschmälert, die oberen mit geöhreltem Grunde stengelumfassend; Schuppen des Aussenkelches meist 10, angedrïckt, viel kurzer als der Hauptkelch, mit langer schwarzer Spitze; die randständioen Zungenbliithen fchlend; Achänen spärlich anliegend-seidenhaarig. $\odot$. Aecker, Wege, Schutthaufen überall gemein. Blüht fast das ganze Jahr hindurch. Blume gelb. Höhe $1 / 2-1^{\prime}$.

b. Randbüthen zungenförmig, zurückgerollt, gelh.

592. S. viscosus L., klebriger B. Stengel auf- 
recht, sehr ästig; Blätter tief - fiederspaltig, gezähnt, nebst dem Stengel, den Blüthenstielen und dem Hauptkelche klebrig-driisig-behaart, Blittzipfel nach denı Grunde des Blattes hin allmählig kleiner werdend; Aussenkelch aus wenigen, linealisch - fadenförmigen Blättchen bestehend, halb so lanı als der Hauptkelch; Zungenbliithen zuriïckgerollt; Achänen kahl. $\odot$. Sandfelder, Wegränder, ausgehauene Waldplätze, trockene Hïgel, dürre Berge häufig z. B. am Felsen zwischen Halle und Giebichenstein, am Galgenberge, am Felsen bei Kíröllwitz u.s. w. Juni - Octob. Blume gelb. Höhe $1 / 2-1 \frac{1}{2}$.

593. S. silvaticus L., Wald-B. Stengel schlank, gerade, aufrecht, nehr oder minder behaart; Blätter spinnwebig - wejchhaarig, tief - fiederspaltig, mit linealischen, gezähnten, oft fast fiederspaltigen Zipfeln, nebst den Blüthenstielen und dem Hauptkelche driisenlos; Ebenstrauss weitschweifig, gleichhoch; Haupthelch kahl oder weichhaarig; Aussenkelch sehr kurz, angedrückt, meist ungefärbt; Zungenbliithen zuriickgerollt; Achïnen srau-weichhaario. $\odot$. Auf Sandboden in Wäldern nicht gerade selten, obgleich weniger verbreitet als die beiden vorhergehenden Arten z. B. in der Dölauer Heide, im Bienitz u. s. w. Juli. Aug. Blune gelb. Höhe $1 / 2-1 \frac{1}{2} 1$.

c. Randhlüthen zungenförmig, flach - abstehend; Blatter getheilt.

594. 's. erucifolius $L_{.,}$raukenblätteriger B. R chb. pl. crit. IV, 516. Wurzelstock kriechend; Stengel aufrecht, etwas grau-filzig; Hlïtter fiederspaltig, die unteren gestielt, die übrigen sitzend, Fiedern linealisch, gezähnt und fiederspaltio, am Grunde mit lileinen, ganzrandigen Oehrchen, Blattspindel ganzrandig; Ebenstrauss vielköpfig, gedrängt; Aussenkelch mehrblätterig, angedüickt, halb so lang als der Hauptkelch; Strahlblüthen abstehend; Achainen durch kurze Behcıarung rauh, sümmtlich mit glcichförmigem Federkelche. 24. Zwischen Gebiisch an Waldrändern, an fruchten Orten selten. In Lehmannschen Hölzchen bei Gutenberg, wo er von Spre ng. hal. ed. 2. p. 358 angegeben wird, hat ihn der Verfasser nie gefunden, wohl aber in Schilfe am süssen See bei Wormsleben, frïher auch in Gebüsche an den Sümpfell bei Lieskau, sehr hänfig bei Naumburg, bei Vitzenburg unweit Nebra. Juli. Aug. S. tenuifolius Jacq. u. S mith. Blume blassgelb. Höhe $2-\mathbf{4}^{\prime}$. 
Die Blattzipfel sind meist am Rande etwas zurüclgebogen und schmäler als an der folgenden Art.

595. S. Jacobrea L., Jakob's-B. Wurzelstock abyebissen, mit kurzen Ausläufern; Stengel aufrecht. ästig, deste des Ebenstrausses aufrecht; Wurzel-und untere Stengelblätter gestielt, länglich-verkehrt-eiförmig, am Grunde verschmälert, lejerförmig oder fiederspaltig, die iibrigen stengelstündigen mit vieltheiligen Oehrchen stengelumfassend, fiedertheilig, Fiedern gezïhnt oder fast fiederspaltio, vorne breiter 2-3zähnig oder 2 spaltig, mit weit-abstehenden Zipfelchen, 'Blattspindel ganzrandig; Aussentelch meist 2blätterig, sehr kurz, angedrückt; Strahlblïthen abstehend; Achüinen des Mittelfeldes kurzhaarig-scharf, die des Randes kahl und nit wenig-behaartem, hinfälligem Federkelche. (-). Truckene und feuchte Wirsen, Wegränder, Raine, Waldplätze gemein. Juli. Aug. Blume goldgelb. Höhe $1-3^{\prime}$.

596. S. aquaticus H uds., Was ser-B. Wurzelstock ohne Ausläufer; Stengel aufrecht, ästig, Aeste des Ebenstrausses aufrecht - abstehend, locker; Wurzel und untere Stengelblätter gestielt, länglich - eiförnig, am Grunde verschmälert, ganzrandig, gezähnt oder etwas leierförnig, die iibrigen stengelständigen mit getheilten Oehrchen halbstengclumfassend, am Grunde eingeschnitten oder leierförmig, die seitenständigen Fiedern länglich oder linealisch, schief aus der Mittelrippe ausgehend, die endständige eiförmig-länglich, gezähnt oder fast gelappt, die oberen Blätter fiederspaltig oder ungetheilt, gezähnt; Aussenkelrh meist 2blätterig, angedriickt, sehr kurz; Strahlbliithen abstehend; Achänen der Scheibenblüthen schwach - weichhaarig, die der Strahlblüthen kahl, mit wenig behaarten, hinfälligem Federkelche. (.). Feuchte Wiesen stellenweise. Bei Döllnitz häufig, ebenso im Walde bei Schkeuditz zwischen der Elster und Luppe, bei Weissenfels; fehlt bei Nanmburg und Freiburg; an der Mulde bei Bitterfeld. Juli. Aug. Blume goldgelb. Höhe $1 / 2-2^{\prime}$.

Ist der vorigen Art in der ganzen Tracht sehr ähnlich, aber gewöhnlich etwas niedriger, meist kahl, nur selten etwas spinnwebig - wollig und mit grösseren Bliithenköpfchen versehen.

Senecio alpinus Scop. wird von Spreng. ed. 2. p. 357 an Bergwäldern bei Schmon und Lodersleben als selten angegreben und schon in der ersten Auflage 
der Flora S. 239 unter dem angeblich Linn é ischen Namen Cineraria cordifolia an diesen Standorten angezeigt (Linné hat übrigens nie eine Cineraria cordifolia beschrieben und die in suppl. p. 375 angeführte Pflanze dieses Namens steht ausdrücklich unter Jacquin'scher Autorität). Schon $R \mathrm{chb}$. sax. ed. 1 u. 2. p. 149 zweifelt mit Recht an der Richtiglieit dieser Angabe. Was Sprengel aber unter Senecio alpinus Seop. verstanden hat, ist schwer zu sagen. da sco. poli unter diesen Namen drei verschiedene Cinerarien beschrieb; wahischeinlich ist es jedoch, dass Sprengel hielmit den bei ihn fehlenden, bei I, sdersleben "achsenden Seneciu spathulaefolius DC. gemeint hat.

d. Randblüthen zungenförmig, flach abstebend; Blätter ungetheilt, gesä̀t oder ganzrandiy.

597. S. nemorensis L., H a in - B. R chb. pl. crit. III. Abb. 467. Wurzelstuck wenig kriechend; Stengel aufrecht, fast kahı; Blätter beiderseits oder nur unterseits etwas feinhaarig, ungleich-gezähnt-gesägt, mit verdickten, gerade hervorgestreckten, gewimperten Spit:chen der Zähne, die unteren Blätter breit-rundlichciförmig, die oberen ei-lanzettlich -oder lanzettlich, alle in einen breit-geflïgelten Stiel verschmälert, am Grunde des Blattes wieder ohrförmig verbreitert, halbstengelumfassend; Ebenstrauss vielköpfig; Strahlblüthen 5, selten 6-7; Aussenkelch 3-5blätterig, so lung als der kurz-walzenförmige, aus 10-12 Blättchen bestehende Hauptkelch; Achänen kahl. 24. Bergwälder selten. An buschigen Abhängen zwischen der Schönburg und Naum. hurg, an Kalkbergen bei Bibra. Anfangs Juli; blüht 3 Wuchen früher als die folgende Art. \$. germanicus Wallr. Blüthen gelb, wohlriechend. Der nur selten roth angelaufene Stengel ist bis $4^{\prime}$ hoch.

598. S. Fuchsii Gme1., Fuchs'sche B. Rchb. pl. crit. 1II. Abb. 466 . Wurzelstock wenig kriechend; Stengel aufrecht, kahì; Blïtter kahl, ungleich-gezähntgesägt, mit verdickten, gerade hervorgestreckten, meist ungewimperten Spitzchen der Züihne, die untersten Bläiter eiförmig, die oberen schmal-lanzettlich, alle in einen schmal-gefliigelten, am Grunde kaum verbreiterten Stiel verschmälert; Ebenstrauss vielköpfig; Strahlblüthen 5; Aussenkelch 3-5blätterig, so lang als der länglich - walzenförmige, meist aus 8 Blättchen bestehende Hauptkelch; Achänen kahl. 24. In Wäldern, besonders an Waldbächen selten. Im Lodersleber Forste 
in der Nähe des rothen Brunnens und auf der Grenze des Gebietes in Walde bej Annerode unweit Mannsfeld. Juli. Aug. S. salicifolius W allr. sched. p. 478. S. saracenicus Wallr. in Linnaea 14. p. 645. Blüthen gelb, geruchlos. Der meist roth angelaufene, schlanke Stengel ist bis $5^{\prime}$, hoch.

599. S. saracenicus L., $\mathrm{s}$ a ra ce $\mathrm{n}$ is $\mathrm{ch}$ e r B. R $\mathrm{chb}$. pl. crit. III. Abb. 468. Wurzelstock weit kriechend; Stengel aufrecht, kahl, bis zum Ebenstrausse reich- und grossblätterig; Blätter kahl, länglich-lanzettlich, spitz, am Grunde keilförmig und ungezähnt, die untersten in den geflïgelten Blattstiel verschmälert, die oberen mit breitem Grunde sitzend, alle ungleich-gezähnt-gesägt, mit vorwärts gekriimmten Spitzchen der Sägezähne; Ebenstrauss vielköpfig; Strahlblüthen 7-8; Aussenkelch meist 5blätterig, so lang oder kürzer als der kurz-walzenförmige, aus 10-12 Blättchen bestehende Hauptkelch; Achünen kahl. 24. Flussufer sehr selten. Wird von Spreng. hal. ed. 2. p. 355 im Weidengebüsch an der Saale un Schkopau und Wörmlitz angegeben. Der Verfasser fand daselbst keinen Senecio und kann daher die richtige Bestimmung dieser vielfach verwechselten Art nicht verbiirgen. Mit Sicherheit ist diese Pflanze nur an der Elbe bei Dessau, besonders im Vockeroder Forste anzuzeigen. Juli. Aug. S. fluviatilis Wa IIr. Blume gelb. Höhe bis $6^{\prime}$.

Schon Linné gibt als charakteristisches Merkmal für diese Art den weit kriechenden Wurzelstock an. Nach Koch Synops. ed. 2. p. 430 soll zwar S. nemorensis und Fuchsii keinen kriechenden Wurzelstock haben, allein er fehlt bei beiden Arten in der Regel nicht, nur treibt er weit kürzere Ausläufer und fehlt in seltenen Fällen bei S. Fuchsii, wenı diese Pflanze auf diirrem, magerenı Boden "ächst.

600. S. paludosus L., Sumpf-B. Stengel steif aufrecht; Blätter sitzend, vcrlängcrt-lanzettlich, verschmälert-spitz, scharf-sägezähnig, kahl oder unterseits filzig; Ebenstrauss vielköpfig; Strahlbliithen meist 13; Aussenkelch meist 10blätterig, halb so lang als der Hauptkelch; Achänen etwas weichhaarig oder kahl. 2. Sumpfige Wiesen, Gräben, Bäche stellenweise. Einzeln im Görz bei Wörmlitz, in Weidengebüsch bei Döllnitz und Burg Liebenau, in Walde bei Wesmar, fehlt im ganzen südlichen Gebiete, findet sich am Lossgraben zwischen Russleben und Wiehe, bei Hecklingen unweit 
Stassfurt, an der Mulde bei Döbern und Löbnitz östlich von Bitterfeld. Juli. Aug. Blume gelb. Höhe $3-6^{\prime}$.

\section{Ordnung. Cynareen Lessing.}

Griffel der Zwitterblüthen oben in einen Knoten verdickt, am Knoten oft kurzhaarig.

10. Gruppe. Calendulaceen Cass. Ringelblumengewä chs e. Stralılblüthen weiblich, fruchtbar, Scheibenblüthen zwitterig oder männlich, 5spaltig, unfruchtbar; Blüthenboden nackit.

246. Caléndihla L. Ringelblume (von Calendae, der erste Monatstag, angeblich wegen der langen Blüthezeit).

601. C. arvensis $\mathrm{C}$. , A cker-R. Stengel ausgebreitet; Blätter länglich-lanzettlich, etwas gezähnelt, die unteren am Grunde rerschmälert, liurz-gestielt, die mittleren und oberen mit abgerundetem Grunde halbstengelumfassend, spitz; Blättchen des Hauptkelches linealisch-länglich-zugespitzt; Achänen am Rande ganz, auf dem Rücken weichstachelig, die 3 bis 5 äussersten linealisch, mit aufrechtem Schnabel, wenigc kahnförmig, die inneren linealisch, in einen Ring gekrümmt. $\odot$. 'Schutt, Wege, Mauern. Ist nicht als einheimische Pflanze anzusehen, da sie nur in der Nähe der Städte, Dörfer und Gärten auf Schutt und lockeren Boden gefunden wird, so bei Merseburg, Dürrenberge, Naumburg, Schulpforte und sonst nicht gerade häufig. Juli - Octob. Blume hellgelb. Höhe bis 8 ".

602. C. officinalis L., gebräuchliche R. Stengel aufsteigend oder aufrecht; Blätter verkehrt-eiförmig-länglich, vorne verbreitert, entfernt klein-gezähnelt, die unteren in einen langen Blattstiel verschmälert, die oberen keilförmig - länglich, sitzend; Blättchen des Hauptkelches pfriemlich-lanzettlich; Achänen eingekrünmt-stachelig, die meisten kahnförmi@, geflïgelt, auf dem Rücken gefurcht, wenige von den inneren länglich, pfriemlich. $\odot$. Sehr häufig in Gärten angepflanzt und auf Schutthaufen, ausgeworfener Gartenerde, in Dörfern nicht selten und zwar seit langer Zeit verwildert, denn schon Buxb. (énum. p. 50) zeigt diese Pflanze auf Aeckern bei Diemnitz an. Juni-Septbr. Rlume goldgelb. Höhe bis 1/2'. Die Blüthenköpfe sind fast doppelt so gross, als bei der vorhergehenden Art. 
11. Gruppe. Eehinopsideen Cass. Kugeldistelgewä chse. Blüthenköpfehen ungestielt, einblüthig, zahłreich, in kugelförmigen Knäueln auf einem gemeinschaftlicheı Boden beisammen stehend.

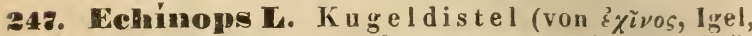
und ö้ thenkupf bezeichnend).

603. E. sphacrocéphalus $\mathbf{L}$., rundköpfige $K$. Stengel aufrecht, ästig; Blätter fiederspaltig, uberseits von etwas klebrigen Haaren weichhaarig, unterseits wollig-filzig und grau, mit länglich-eiförmigew, buchtigen, dornig - gezähnten Zipfeln; Hauptkelch an Grunde burstenförmig, Borsten länger als die halbe Länge desselben, die äusseren Blättchen desselben drüsig-haarig. 4. An alten Burgen, unstreitig nur verwildert. Binzeln an Wirthshause bei Rollsdorf, häufigger am sichlusse bei Seeburg und am Schlosse in Wallbeck unweit Hettstedt. Juli. Aug. Blumen weisslich, Staubbeutel blan. Höhe $2-\jmath^{\prime}$.

12. Gruppe. Carduineen Cass. Distelgewächse. Blüthenköpfehen reichblüthig; alle Blüthen rőhrenfërmig, meist zwitterig; Blättchen des Ilauptkelches oft dornig. Achäneu kahl, mit haarförmigem oder gefiedertem Federkelche.

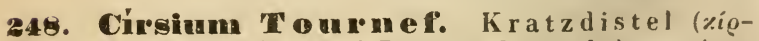
Glov ist eine Distelart bei Dioscorides und hat seinen

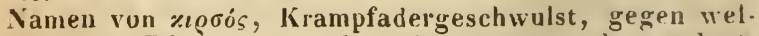
che diese Pflanzen von den Alten angewandt wurden).

d. Epitraehys DC. Blätter unterseits dornig-kurzhaarig. Blüthen purpurn.

604. C. Ianceolatum Scop., I anzettliche K. Stengel aufrecht, mit abstehenden Aesten; Blätter herablaufend, oberseits mit steifen Stacheln, unterseits mit diinner, spinmuebiger Wotle besetzt, tief - fieder'spaltig, die Seitenzipfel 2spaltig, mit lanzettlichen oder eiförmigen, in einen starken Dorn endenden Zipfelchen; Bliithenköpfchen einzeln, eiförmig, spinnw ebig - wollig; Blättchen des Hauptkelches lanzettlich, nit der pfriemlichen, in einen Dorn endigenden Spitze abstehend. (.). Wegränder, Triften, Schutthaufen, wüste Plätze gemein. Juni - Sept. Carduus lanceolatus L. Cnicus lanceolatus Willd. Höhe 2-4'.

605. C. exióphorum Scop., wollköpfige K. Stengel aufrecht, üstig; Bläitter stengelumfassend, nicht 
herablaufend, oberseits dornig-sleifluario, unterseits filzig, tief-fiederspaltig, die Seitenzipfel 2 spaltig, mit lauzettlichen, in einen starken Dorn endenden Zipfelchen; Blïthenköpfe enneln, kugelförmig, spinnwebig wollig; Blättchen des Hauptkelches lanzettlich, vorne breiter, stachelspitzig, abstehend. (-). Unfruchtbare Berge sehr selten. Dürfte jetzt hei Seben, wo es noch Spreng. angibt, vergeblich gresucht werden; es wächst aber bei Eisleben an der Hïneburg, und zwar im Kessel sparsanı, weit häufiger in der Nähe der Diebeshöhle nach Wolferode zu. Vun Schwabe auch an Bergen bei Sandersleben und Bernburg angegeben. Juli-Sept. Carduus eriophorus L. Cnicus eriophorus Roth. Blume dunkel-purpurroth. Höhe $3-5^{\prime}$. Ist durch die grussen, kugrlförmigen Blüthenköpfe sehr ausgezeichnet.

B. Chamacleon DC. Blätter oberseits nicht durnig kurzhaarig; Blättchen des Hauptkelches mit einem einfachen Dorn oder fast wchrlus. Blüthen zwitterig.

\section{a. Blatter gïnalich herablaufend.}

(iv6. C. palustre $\$$ cop., $\mathrm{Sump}$ - $\mathrm{K}$. Stengral steif aufrecht, uberwärts ästig; Blätler am Stengel tief-herablaufend, zerstreut - behaart, tief-fiederspaltig, mit 2spaltigen, stachelspitzigen Zipfeln; Aeste an der Spitze vielköpfig, Bliithentüpf chen traubenfürmig - geknäuelt; Blättchen des Hauptkelches dornig - stachelspitzig. (.) Nasse Wiesen, sumpfige Stellèn häufig z. B. bei Dieskau, Gutenberg u. s. W., seltener bei Naumburn, nur an einer quelligen Stelle über der Henne, bei Bibra an Wiesenründern über Sickel's Ruhe hinaus häufig. Juli. Ang. Carduus palustris L. Cnicus palustris IVilld. Blume purpurroth. Sitengel $3-5$ '. Aendert ab:

b) Chailleti Gaud., nicht Koch: Blätter am obe. ren 'Theile des Stengels wenig herablaufend, daher der Stengel daselbst ziemlich nacht, so am Bienitz.

h. Blatter nicht herablaufend.

607. C. oleraceum scop., kuhlartige K., Wie. senkuhl. Stengel aufrecht, kantig; Blätter kahl oder mit zerstreuten Hörchen besetzt, ungleich dornig-gewimpert, stengelumfassend, die unteren fiederspaltig, mit lanzettlichen, zugespitzten, gezähnten Zipfeln, die oberen ungetheilt, gezähnt; Bliuthenköpfchen endstäindig, gehäuft, von grossen, breiten, eiförmigen oder läng. Garcke, Flora. 
lichen, gelblichen Deckblättern umhiillt; Blättchen des Hauptkelches linealisch - pfriemlich, mit verlängerter, abstehender Stachelspitze. 24. Gräben, feuchte Wiese॥ gemein z. B. auf Wiesen zwischen Halle und Nietleben, bei Bennstedt, vor dem Sebenschen Busche u. s. w. Juli. Ang. Cnicus oleraceus L. Carduus acanthifolius Lam. Blumen gelblich-weiss. Höhe 2-5'. Aendert mit ungetheilten unteren und fiederspaltigen uberen Bıättern ab.

608. C. acaule All., stengellose K. Sturm Heft 24. Wurzelfasern fadenförmig; Stengel fehlend oder sehr kurz; Bliitter grundständig, kahı, lanzettlich buchtig - fiederspaltig, Zipjel eiförmig, fast 3spaltig, mit kleinzähnigen, dornig-gewimperten, stachelspitzigen Zipfelchen; das Bliithenköpfchen cinzeln oder $2-3$ auf der Wurzel sitzend; Blättchen des Hauptkelches angedrücht, kurz - stachelspitzig, die äusseren eiförnig, die innersten lanzettlich-linealisch. 24. Trochene Wiesen, 'Triften, Rain', Hügel nicht gerade selten z. B. auf Wiesen zwischen Halle und Nietleben, bei Passendorf u. s. w. Juli. Aug. Carduus acaulis I. Cnicus acaulis Willd. Blume purpurroth. Aendert ab:

b) caulescens Pers.: Stengel hand-bis fusshoch, 1-4köpfig, vom Grunde bis zur Spitze beblättert. Cnicus dubius Willd., su besonders an Waldrändern.

609. C. bulbosum DC., knollentragende K. Flora v. Thüring. II, 24. Wurzelfasem in der Mitte verdickt; Stengel spinnwebig - wollig, aufrecht, von der Mitte an blattlos, 1-3küpfig; Blätter uberseits zerstreut-behaart, unterseits efwas spinnwebig-wollig, dornig-gewimpert, tief : fiederspaltig, Fiedern mit $2-3$ lanzettlichen Zipfeln; Blüthenstiele verlängert; Blättchen des Haupthelches angedrückt, kurz - stachelspitzig, die unteren lanzettlich, die oberen länglich-linealisch. 4. Wiesen stellenweise. Bei Halle nicht splten z. B. auf Wiesen vor dem sebenschen Busche, Wiesen vor Nietleben und vor Bennstedt, bei Grosskugel, bei KI. Dölzig, an Bienitz, bei Kalbsrieth und Katharinenrieth unweit Allstedt, auf Wiesen bei Kochstedt und Mosigkau unweit Dessau, bei Benndorf und Roitzsch unweit Delitzsch. Juli. Ang. C. tuberosum All. Carduns tuberosus Poll. C. tuberosus var. $\beta$. I. Blumen purpurroth. Höhe 2-4'. 
C. Breea Less. Blätter oberseits nicht dornig-kurzhaarig; Blättchen des Hauptkelches mit einen einfachen Dorn. Blüthenköpfchen zweihäusig.

610. C. arvense Scop., F eld-K. Flora v. Thiiring. II, 20. Wurzel kriechend; Stengel aufrecht, fast kahl, blattreich, ästig, die unteren Aeste kurz, beblättest, blïthenlos; Blätter sitzend, nur die unteren we. nig herablaufend, länglich-lanzettlich, dornig-gewinpert, ungetheilt oder fiederspaltig - buchtig, stachelspitzig, unterseits meist kahl, fast blïulich-grïn; Bliithenköpf: chen ziemlich klein, zweihüusig, eifürmig, rispig-ebenstrïussig; Blättchen des Hauptkelches angedriickt, stachelspitzig. 24. Auf Aeckern unter Getreide, wïsten Plätzen, schutt ïberall gemein. Juli. Ang. Serratula

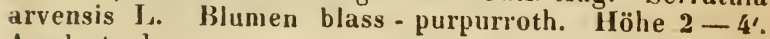
Aendert ab:

a) horridum Wimm. u. Grab.: alle Blätter wel. lenförmig, fiederspaltig, sehr dornig, häufig.

b) mite Koch: Stengelblätter buchtig, Astblätter ungetheilt oder gezähnt, feiner-und kleiner-dornig, nicht selten.

c) vestitum Koch: Blätter unterseits schneeweissfilzig, selten, auf Aeckern bei Weissenfels.

Die Abart mit sämmitlich flachen, ganzrandigen oder etwas gezähnten Blättern (Cirsium setusum M. B.) hat der Verfasser noch nicht in Gebiete beobachtet.

D. Wirkliche oder muthmassliche Bastarde. (Bei Zusammensetzung der folgenden Beneunungen hat Na e g eli stets den Namen derjenigen Pflanze, welche den Blüthenstaub abgibt, voran-, und den Namen derjenigen, welche den Samen bildet, nachgestellt.)

611. C. bulboso-oleraceum Naeg. Wurzelfasern fadenförmig; Stengel unten dicht-, oben wenig - beblättert; Blätter kahl oder weichhaarig (aber nicht spinnwebig-2uollig), gelappt oder buchtig-fiederspaltig, Fiedern länglich oder lïnglich-lanzettlich, gezühnt, seltener 2spaltig; Bliithenköpfchen ziemlich lang gestielt, einzeln, mit 1 oder 2 linealisch-lanzettlichen oder linealischen Deckblättern gestiitzt; Blättchen des Hauptkelches länglich, kurz - stachelspitzig. 24. Feuchte Wiesen stellenweise. Wiesen vor dem Sebenschen Busche, Wiesen zwischen Halle und Nietleben, bei Bennstedt, Wiesen bei KI. Dölzig und an Bienitz und an diesen 
Standorten ïberall nicht selten, fehlt bei Weissenfcls und Nammburg; in der Nähe von Kalbsrieth uml Katharinenrieth unweit Allstedt seltener, muf Wiesen zwischen Roitzsch und Brehna nach Wallr., überall nur in Gesellschaft vou C. oleracem und C. hulbusum vorkommend. Juli. Aug. Blumen weiss-gelb. Höhe 2-5'. Aendert mit einfichem, an der Spitze 2-5köpfigem wder ästigem, vielköpfigem Stengel und tief - fiederspaltigen oder nur gezähuten Blättern ab. - Stimnt in Wurzel - und Blattform und in der Bliithenfarbe mehr mit C. olerareum, in der Gestalt der Blïthenköpfe und dem ganzen Blüthenstande mchr mit C. bulbusum überein.

Hierher gehört C. bulbusum $\beta$. pallens W allr. scherl. p. 445 . C. rigens bei Spreng. hal. ed. 2. p. 342 , aber nicht Wallr., wie Spreng. fälschlich angibt. C. Iachenalii Koch (zum 'Theil).

612. C. oleraceo-bulbosum Naeg. Wurzelfasern etwas verdickt; Stengel unten dicht-, oben wenig-beblättert; Blïtler oberseits weichhaarig, unterscits spinnwebig-wollig, buchtig - fiederspaltig, Ficdern eifürmiglänglich, 2 -3spaltig; Bliithenköpfchen ziemlich gehäifit, hur $\approx$-gestielt, mit lanzettlichen, nicht gelblich-gefürbten Deckblättern; Blättchen des Hauptkelches lanzettlich, stachelspitzig. 24. Auf feuchten Wiesen bei Kl. Dölzig und am Bienitz. Juli. Aug. Blumen weiss-gelblich. Höhe 2-5'. Aendert mit einfachem, wenigliöpfigem oder ästigem, vielköpfigem Stengel, gelappten oder tief - fiederspaltigen Blättern und deckblattlosen Blïthenköpfchen al. - In Wurzel- und Blattform mehr mit C. bulbosum, in den Blïthenköpfchen mehr mit C. ole. raceum übereinstimmend und in Form des Blüthenstandes zwischen beiden stehend.

613. C. oleraceo-acaule Naeg. Wurzelfasern dïnn; Stengel meist niedrig, ganz beblättert; Blätter fast sitzend, buchtig-gelappt, mit ciförmigen, kurz. 2 - 3spaltigen Fiedern; Bliithentöpfchen einzeln oder etwas gehäuft, kurz-oder ctwas länger-gesticlt, mit lanzettlichen, nicht gelblich - gefärhten, dornig - gezähnten Deckblättern; Blättchen des Hauptkelches länglich. lanzettlich, oberwiirts abstehend. 2. Auf feuchten Wie. sen bei KI. Wölzig und am Bienitz selten, bei Naumhurg in der Aue hin und wieder, auf der Grenze des Gebictes auf Wiesen an der Katze unweit Kösen, auf Wiesen hei Rossleben nach Wallr. Juli. Aug. Blumen gelblich-weiss. Aendert ab mit niedrigem, 2-5köpfi- 
genı und höherem, 2-3' hohem, 6-15köpfigem Stengel. - Die Blätter stimmen mit C. acaule, die Blïthenköpfchen mit C. oleraceum überein, der Blüthenstand und die Deckblätter stehen zwischen beiden in der Mitte.

Hierher gehört C. rigens Wallr. sched. p. 446, aber nicht bei Spreng. C. decoloratum Koch und C. Lachenalii Koch (zum Theil). Cnicus acauli-oleracens Schiede. - Spreng. fïhrt (hal. ed. 2. p. 342) C. rigens $W$ allr. auf feuchten Wiesen rol dem Sebenschen Busche mit der Bemerkung an, dass es ein Bastard von C. acaule und C. oleraceum sei, in deren Ge. sellschaft es wachse. Dies ist jedoch unrichtig; denn die vor dem. Sebener Busche wachsende Pflanze gehört zu C. bulbosu-oleraceum $\mathbf{N}$ a eg. und wäclist zwischen C. bulbusum und C. oleraceum, aber nicht in Gesellschaft vun C. acaule, es ist daher diese Pflanze mit Unrecht C. rigens Wallr. genaunt. Diese falsche Benennung hat wohl auch Veranlassung gegeben, dass Koch (Taschenbuch p. 294) zu C. decoloratum Koch und ebenso $\mathrm{Kchb}$. (sax. ed. 1 u. 2. p. 181) zu C. rigens A i t. Halle als Standort citiren, da doch diese Pflanze in der Nähe ron Halle nicht wächst.

614. C. bulboso-acaule Naeg. Wurzelfasern nur wenig verdickt; Stengel beblättert; Blätter ohne Oehr. chen, behaart (aber nicht spinnwebig-wollig), gelappt oder buchtig - fiederspaltig, mit ciförmigen, $2-3$ theiligen, kurzen Fiedern; Bliithenköpfchen 1-4, ohne Deckblätter; Blüthenstiele spinnwebig - wollig, fast ganz nackt oder mit einzelıen, entfernten kleinen Blättchen besetzt; Blättchen des Hauptkelches länglich, stumpflich, plötzlich kurz - stachelspitzig. 4. Auf feuchten Wiesen an Bienitz. Juli. Aug. C. mediun All. C. Zizianum Koch. Cnicus acauli - tuberosus Schiede. Blumen purpurroth. - Dic Blätter gleichen denen von C. acaule, die Blüthenköpfchen denen von C. bulbosum.

615. C. palustri-bulbosum Na eg. Wurzelfasem etwas verdickt; Stengel unten dichter-, oben entfernter-beblättert; Bliitter am Stengel kaum halb herablaufend, etwas dornig, buchtig-fiederspaltig, oberseits weichharig, unterseits behnart oder spinnwebig - wollig, 'Zipfel länglich, 2-3spaltig, mit lanzettlichen Zipfelchen; Bliithenköpfchen ctwa 6-15, klein, länglich, fast einzeln, ohne Deckblätter, mit ziemlich langen, nackten Stielen; Blättchen des Hauptkclches läng- 
lich, stumpflich, angedrückt, auf dcm Rücken wenig klcbrig. 24. Sumpfige feuchte Wiesen selten. An Bipnitz. Wiesen an der Benndorfer Mühle. Juli. Aug. C. semidecurrens Richt. C. Kocheanum Löhr. Cnicus palustri-tuberosus Schiede. Blumen purpurroth. Wirzel, Verästelung und Blätter gleichen denen von C. bulbusun, die wenig grösseren Blüthenköpfchen denen von C. palustre.

219. Silybum Gärtm. Mariendistel ( $\sigma i \lambda v \beta \circ \varsigma$ ist ein Pflanzenname bei Dinscorides für ein distelartiges Gewächs).

616. S. marianum Girtn., geme ine M. Hay" e Arzneigew. VII, 31. Stengel aufrecht, dick, ästig; Wurzelblitter länglich, buchtig-eckig, gezähnt, dornig, Stengelhlïtter stengelumfassend, fiederspaltig, alle glănzend, kahl, weiss geadert; Blüthenköpfe endständig, einzeln, gross. $\odot$. Zierpflanze aus Südeuropa; inı Gebiete nur selten verwildert und meist unbeständig, so am Galgenherge bei Querfurt. Juli. Aug. Cardıus marianus L. Blıne purpurroth. Höhe $3-5$ '.

250. Cárduus L. Distel (Pflanzenname bei Plinius).

A. Ilomalolepidoti. Blättchen des Hauptkelches angedrückt oder zurückgekıünmt, aber nicht zurückgebrochen.

617. C. acanthoides L., St a c hel-D. R c hb. pl. crit. X. Abb. 1319. Stengel einfach oder ästig, dorniggeflügelt; Blätter herablaufend, $k a h l$ oder unterseits auf den Adern zottig, tief-fiederspaltig, nit 3lappigen, gezähnten und stachelig - gewinuperten Fiedern; Bliithenköpfchen meist cinzeln, rundlich; Blithensticle kurz, gekrïusclt, dornig. (-). Wege, Zäune, Raine und Schutthaufen sehr geniein. Juli. Aug. C. polyacanthos S c hreb. C. crispus Huds. Blumen purpurroth, fleischfarben oder weiss. Höhe $1-3^{\prime}$.

618. C. crispus $\mathbf{C}$., krause D. Stengel ästig, Aeste geflügelt - dornig; Blcitter herablaufend, oberseits zerstreut-behaart, unterseits wollig-filzig und auf den Adern etwas zottig, länglich, buchtig-fiederspaltig, Fiedern eiförmig, 3lappig und gezähnt. der mittlere Isappen grösser; Bliithenköpfchen rundlich, gehïuft oder einzeln; Bliithenstiele kurz, domig oder an der Spitze nackt; Blättchen des Hauptkelches pfrienlich-lanzett- 
lich. (-). Wiesen, Flussufer, besonders in feuchten Wäldern und Weidengebüsch, nicht selten z. B. im Gebüsche an der Saale zwischen Kröllwitz und Lettin, zwischen Gebüsch in der Nähe der Teiche bei Dieskau 11. S. W. Juli. Aug. Blumen purpurroth. Höhe 2-5'.

B. Clastolepidotus. Blättchen des Hauptkelches oberhalb des Grundes ein wenig zusammengeschnürt und zurïckgebrochen.

619. C. nutans L., nickende D. Stengel aufrecht, ästig; Blätter herablaufend, oberseits ziemlich kahl, unterseits auf den Adern zottig, tief-fiederspaltig; Fiedern eiförmig. fist 3spaltig und gezähnt, dorıig-gewimpert, stark stachelspitzig; Bliithenköpfe rundlich, einzeln, nickend; die mittleven Blïttchen des Ilauptkelches ïber dem eiförmigen Grunde eingeschniirt, in einen starken Dorn zugespitzt, zuriickgeknickt-abstehend. (.). Wege und Ackerränder, trockene Triften, Schutthaufen genein. Juli. Aug. Blume purpurroth. Höhe 1-3'. Die Blïthenköpfe sind weit grösser als an den beiden vorhergehenden Arten.

Carduus defloratus L. wird von Zenker bei Allstedt angegeben, welchen Standort $R$ ch b. sax. ed. 1 u. 2. p. 184 wieder aufgenommen hat. Bisher hat der Verfasser dort vergeblich danach gesucht.

251. Dnopóxion L. Krebsdistel (von övos, Esel, und $\pi 0 \varrho \delta \dot{\eta}$, Blähung, nach Plinins von der Wirkung dieser Pflanze auf die Esel).

620. O. Acanthium L., geme ine K. Hayne Arzneigew. VI, 34. Stengel aufrecht, ästig, ttwas wollig, durch die herablaufenden Blätter meist sehr breit geflügelt; Blätter elliptisch-länglich, buchtig, spinnwebig-wollig, stachelspitzig; Blättchen des Hauptkelches aus eiförmigem Grunde linealisch-pfriemlich, die unteren weit abstehend. (.). Wege, unbebaute Orte, Mauern, Schutt gemein. Juli. Aug. Blume purpurroth. Höhe $2-5^{\prime}$. Aendert ab:

b) Schultesi Britt.: niedrig, nur 3-6" hoch; Stengel und Blïtter stark weiss-wollig, so an sandigen Stellen zwischen Nietleben und der Dölauer Heide.

252. Lappa Tournef. Klette (Pflanzenname bei Virgil und Plinius). 
621. L. major G̈̈rn., grössere K. Hay゙ne Arzneigew. 11, 35. Stengel aufrecht, ästig; Blüthenstand ebensträussig; Blätter sehr gross, gestielt, am Grunde rundlich, schwach-herzförmig; ljliittchen des Hauptkclches siimmtlich griin, meist pfricmlich, am Grunde anliegend, dann abstehend, die abstehende, fast regelnässig-3kantige Stachelspitze an den mittleren Blättchen länger als der anliegende 'Theil des Blättchens; Achänen länglich-linealisch-keilförnig. (-). 'I'rif. ten, schattige Wälder, Gebüsche, Zäune nicht selten z. B. im Gebüsch an der Saale hinter Kröllwitz, auf dem Trothaischen Werder, besonders in den Wäldern der Aue bei Kl. Liebenau u. s. w. Juli. Aug. Arctium Lappa L., diese und die folgende mitbegriffen. Blumen bei allen drei Arten purpurroth. Wird bis $6^{\prime}$ hoch. OFF. rad. Bardanae.

622. L. minor DC., kle ine re K. Stengel aufrecht, ästig; Blïthenstand traubenförmig; Blätter gross, ge. stielt, am Grunde schwach-herzförnig; Hauptkelch meist etwas spinmucbig-zottig, Blättchen desselben pfriemlich, der verschnialerte abstehende Theil kürzer als der anliegende breitere, dic inneren Jlättchen an der Spitze purpurroth oder purpurbraun gefärbt; Achänen keilig - verkehrt-eiförmig. (.). Wege, Schutthaufen, wïste Plätze häufig. Juli. Aug. Arctium minus Schk. Höhe 2-4'. - Die Blüthenköpfe sind un die Hälfte kleines als bei der vorigen Art.

623. L. tomentosa Lam., filzige K. Hayne Arzneigrew. II, 36. Stengel aufrecht, ästigr; Blüthenstand ebensträussig; Blätter breit-eiförmig, anı Grunde tief - herzförmig, unterseits fein-yranfilzig: Hauptkelch stark spinnwebig-zuollig, die änsseren Blättchen desselben pfriemlich, die verschnälerte, abstehende Stachelspitze an den mittleren ungefähr so lang als der breite anliegende Theil, die inneren Bliittchen linealisch-lanzetllich, stumpflich, mit einem aufgesetzten geraden Stachelspitzchen, gefürbt, fast strahlend; Achänen länglich-verkehrt-eiförmig. (-). Mit der vorigen Art. Juli. Ang. Aretium tomentosum Schk. A. Bardana Willd. Höhe 2-4'.

13. Gruppe. Carlineen Cass. Eberwurzgewächse. Blüthenköpfchen reichblüthig; Blüthen zwitterig; Federkelch Ireihig, ästig, abfallend. 
253. Carlína L. Éberwurz (eigentlich Carolina, angeblich weil eine Art zur Zeit Karls des Grossen gegen die Pest empfohlen wurde; der Name wird zuerst von 'Tournef. gebraucht).

624. C. acaulis L., stengellose E. IIayne Arzneigew. X, 45. Stengellos oder stengelig sich erhebend; Stengel stets 1 köpfig; Blätter kahl oder unterseits etwas spinnwebig - wollig, tief - fiederspaltig, mit eckig gelappten, stacheligen Zipfeln; die strahilenden Bliittchen des Hauptkelches vom Grunde bis iiber die Mitke linealisch, an der Spitze lanzettlich, die längeren Fasern der Spreublättchen stumpf - keulenförmig. 24, nicht -), wie Koch und alle Anderen angeben. An Kalkbergen, Acker- und Wegrändern selten, nur in 'Thüringen, aber daselbst verbreitet; so auf allen Kalkhïgeln bei Naumburg, Freiburg und Bibra, an Kalkbergen bei Karsforf im Unstrutthale, einzeln auf Kalk zwischen Querfurt und Ludersleben. Juli. Aug. C. caulescens Lam. C. subacaulis DC. C. alpina J acq. Strahlen des Hauptkelches weiss. Blüthenhöpfe auf der Wurzel sitzend oder mit verlängertem, bis $1^{\prime}$ hohem Stengel.

Dass die stengellose Pflanze, welche mit der ebenso häufigen stengeltreibenden Form an den genanuten Standorten zugleich vorkommt, wirklich zu einer Art gehört, lässt sich wohl nicht bezweifeln. Anders verhält es sich aber mit der Frage, ob C. simplex W. K. pine gute, ron C. acaulis L. hinreichend unterschiedene Art sei und dies möchte der Verfasser nach den vurlie. genden, zahlreichen Exemplaren von C. acaulis fast verneinen.

625. C. vulgaris L., gemeine E. Stengel aufrecht, 2. bis mehrliöpfig, fast ebensträussig; Blätter lünglichlanzettlich, buchtig - gezähnt, dornig, unter'seits mehr nder weniger filzig - wollig; dip änsseren Blättchen des Hauptkelches doppelt-fiederspaltig - dorniy, die inneren lanzettlich, verschmälert-stachelspitzig, die strahlenden linealisch-lanzettlich, an Grunde ein wenig breiter, his zur Mitte gevimpert; Deckblätter kiirzer als das Bliithenköpfchen. $\odot$. . Dürre und unbebaute Plätze, Kalkberge, Ackerraine, Waldränder nicht gerade selten; sehr häufig an den Kalkbergen bei Bennstedt, an Bergen bei Schkopan, an Bienitz und im Gebiete fast nirgends fehlend. Juli. Aug. Strahlen des Hauptkelches strohgelb. Höhe $1 / 2-1 \frac{1}{2}$. 
14. Gruppe. Serratuleen Cass. Schartengewit hse. Blüthenköpfchen reichblüthig; Blüthen zwitterig; Federkelch mehrreihig, fiederhaarig oder haarförmig, bleibend, die innerste Reihe längér als die übrigen.

254. Serrátula I. S $\mathrm{c}$ h a r te (ein bei Plinius für pine nicht genau bekannte Pflanze vorkommender Name, wrlcher von serra, Süge, abgeleitet ist, wahrscheinlich wegen der gesägten Blätter).

626. S. tinctoria L., F ï r be r-Sch. Stur m Heft 3. Stengel aufrecht, oberwärts ästig-ebensträussig; Blätter etwas l'auh, geschärft-gesägt, ungetheilt, leierförmig oder fiederspaltig; Blüttchen des Hauptkelches dicht - dachziegelig, an den Spitzen purpurroth. 4. Wiesen zwischen. Gebiisch, Wälder häıfig z. B. an Donnersberge hinter Kröllwitz, in ler Dölauer Heide u. s. I. Juli. Aug. Blumen purpurroth. Höhe $1 \frac{1}{2}-3$ '. Die Blüthen sind suwuhl zwitterig, als getrennten Geschlechts.

255. Jurimea Cass. Jurinie (nach dem französischen Butaniker André Jurine, Sohn des berühnteren Zoologen Luuis Jurine, benannt).

62\%. J. cyanoides $\mathrm{ch}$ b., $k$ or n b I um e nartig e J. Flora v. Thuiring. II, 24. Stengel aufsteigend, einfach uder wenig ästig, 1- oder armköptig, Köpfchen endständig, einzeln, fast kugelförmig ; Blätter unterseits weiss-filzig, fiederspaltig, mit linealischen, ganzrandigell Zipfeln; Blättchen des Hauptkelches lanzettlichpfriemlich, filzig-grau; Achänen glatt, schwach-grubig. 24. Sandfelder und trockene Hïgel sehr selten, nur an der Gersdurfer wïsten Feldmark hinter Kröllwitz und bei Dessau auf den Sandbergen hinter dem Akenschen Thorhause. Juli. Aug. Carduus cyanoides ce. nınoclonos I. C. mollis Poll. Nerratula Pollichii Koch. Acarna cyanoides Wibel. Blume purpurroth. Stengel meist $1^{\prime}$ hoch.

15. Gruppe. Centaurieen Less. Blüthenköpfchen reichblüthig; Blüthen zwitterig, die randständigen meist geschlechtslos; Federkelch mehrreihíg, fiederhaarig oder haarförmig, bleibend, die vorletzte Reihe der Strahlen desselben länger als die übrigen, oder der Federkelch fehlend.

256. Centauréa L. Flockenblume (der Name soll sich nach Virgil auf die erste arzweiliche Anwendung einer Art durch den Centauren Chiron beziehen). 
A. Jacea Juss. Blättchen des Hauptkelches dornenlos, an der Spitze trockenhäıtig, ungetheilt odes fransig-getheilt, die letzte Franse mit den übrigen gleichartig.

62S. C. Jácea L., gemeine F. Sturm Heft 4. Stengel aufsteigend oder aufrecht, ästig; Blätter lanzettlich, ungetheilt oder die unteren entfernt-buchtig oder fiederspaltig; Anhängsel der Blättchen des Hauptkelches trockenhäutig, gewölbt, kreisrundlich oder eiförnıig, ungetheilt, zerrissen uder die unteren kammförmig-gefranst; Federkelch fehlend. F. Wiesen, Triften, Raine, Wege gemein. Juni-Octuh. Blumen pfirsichblïthig, bisweilen mit weisslichen Rantblüthen. Stengel 2-3' huch. Aendert vielfach ab: Stengel aufrecht, hoch, mehrköpfig, ästig oder niedriy, bisweilen nur einige Zoll huch und einköpfiı, die Blätter sind breit oder schmal, ganzrandig oder buchtig und fiederspaltig, kahl oder spinnwebì-wollig, Blüthesköpfe bisweilen whne Randblumen, die Staubfüden sind behaart oder unbehaart; ferner:

a) genuina $K u c h$ : die Anhängsel aller Blättcheu des Hauptkelches löffelförmig - ausgehöhlt, ganzrandig oder gezähnelt, oder durch einen oder den anderen Riss unregelmässig gespalten.

b) vulgaris Koch: die Anhängsel der untersten 1-3 Blätchen des Hauptkelches gefranst, soust wie bei der vorigen Abart.

c) decípiens Reich.: Anhängsel der meisten äusseren Blättchen des Hauptkelches gefranst, die darauf folgenden unregelmässig zerrissen-gef 'anst, nur an den uberen Blättchen ungetheilt.

d) pratensis 'Thuill.: Anhängsel des Blättchen des Hauptkelches verlängert, entfernter gefranst, öfters zurückgekrümmt.

629. C. phrýgia L., phrygische F. Stengel aufrecht, einfach vder etwas ästig; Blätter länglich, zugespitzt, meist rauh, ganzrandig oder mit stachelspitzigen Zühnchen, die untersten gestielt, die oberen sitzend, etwas geöhrt; Blïttchen des Hauptkelches an der Spitze mit einem lang - pfiriemlichen, zuriickgekriimmten, stark fiederig-gefiansten. Anhiingsel; Federkelch 3mal länger als die Achïne. 4. Bergwiesen, Wälder sehr selten; einzeln in Bienitz, in Sandthale und an den benachbarten Bergen im Luderslebel Furste sparsan. Juli. Ang. Blumen purpurroth. Höhe $1-2$ ' 
B. Cranus. Blättchen des Hauptkelches an der Spitze trockenhäutig, fransig-gespalten, die Endfranse breiter und stärker als die anderen, oft einen weicheren oder starren Durn bildend.

630. C. Cýanus $\mathbf{L}$. K o I n - F., Kornblume. Hayne Arzneigew. VII, 32. Stengel aufrecht, ästig, nebst den Blättern flockig-filzig; Bliitter schmal, lincalischlanzettlich, die unterstcn am Grunde gezähnt, die wurzelständigen verkehrt-eiförmig-lanzettlich, ungetheilt oder 3spaltig; Blättchen des Hauptkelches schwarz-oder bräunlich-berandet, gesïgt-fransig; Federkelch ungefähr so lang als die Achäne. @. Auf Feldern unter der Saat uberall gemein; ist mit dem. Getreide eingeführt. Juni. Juli. Scheibenblunen violett, Stahlblumen azurblau, selten dunliplroth, fleischroth oder weiss. Höhe 1-2'. OFF. flor'es Cyani.

631. C. Scabiosa L., s cabiosenartige F. Hayne Arzneigew. VII , 33. Stengel stark, aufrecht, ästig; Blätter etwas flockig - wollig, scharf oder kahl, fieder. spaltig oder doppelt-fiederspaltig, Zipfel lanzettlich, ganzrandig oder gezïhnt, mit einem schwieligen Punlite endigend; dic Anhüingsel der Blättchen des rundlichen Hauptkelches schworz, 3eckig, spitz, gefranst, schmä ler als die nervenlosen Blätchen und diese nicht verdeckend; Federkelch ungeführ so lang als die Achäne. 4. Weinberge, Hügel, trockene Raine, Wege zerstreut und meist einzeln. Breite Arkerraute zwischen Dölau und Lettin sparsam, häufiger an den Kalkbergen bei Bennstedt, Weinberge hei Röglitz, Hügel bei Ermlitz, bei Naumburg an Weinbergen zerstreut, bei Freiburg am südlichen Rande Her neuen Giehle, an Hügeln bei Eisleben, Bernburg und Sandersleben. Juli. Aug. Blume meist dunkelroth. Höhe $2-4^{\prime}$. Aendert vielfach ab: die Blattzipfel sind bald hreiter, bald viel schmä. ler, seltener sind die Blätter ganzrandir, lanzettlich oder die unteren nur am Grunde fiederspaltig, die Blïthenköpfe dagegen bald spinnwebig-wollig, bald kahl und die endständigen Fransen der Anhängsel des Hauptkelches bald kurz, bald in einen Dorn vorgezogen.

632. C. maculosa $\mathbf{L}$ m., gefleckte F. Stengel steif - aufrecht, oberwärts rispig und fast ebcnstrüussig ; Blätter lauh, etwas wollig, die wurzelständigen meist doppelt-gefiedert, die stengelständigen einfach-gefiedert mit linealischen Zipfeln, die astständigen oft ungetheilt und linealisch; Anhüingsel des rundlich-eiför- 
migen Hauptkelches mit einem äeckigen, schwarzen, beiderseits etwas hinabziehenden Flecke bezeichnet, dic 5nervi, "en Blättchen nicht verdeckend, gefranst; Feder kelch halb so lang als die Achäne. (-). Sunnige Anhöhen, Raine, Wege, Mauern häufig z. B. auf allen alten Mauern in der. Stadt, an Wegrändern zwischen Kröllwitz und der Dölauer Heide u. s. w. Juli - Sept. C. paniculata Jac q. und der meisten Autoren. Blume blass-purpurroth. Höhe $1-3^{\prime}$. A Aendert mit grössereı und kleineren Blüthenhöpfen ab.

Centaurea moutana l. wird von Spreng. hal. ed. 2. p. 345 an bewaldeten Kalkbergen bei Bennstedt und sichmon als selten angegeben. Da aber seit einer Reihe von Jahren an beiden Orten vergeblich darnach gesucht ist, so wagt es der Verfasser nicht, diese Pflanze wieder aufzunchmen.

c. Calcitrapa (Name von chausse - trapes, Fussangelu, "1egen der Aehnlichheit des Kelches). Blättchen des Hauptkelches am Kande nicht gefranst, aber an der Spitze in einen 3 theiligen oder "zefieder. ten Dorn auslaufend.

633. C. Calcitrapa E., distelartige F. Sturm Heft 4. Stengel aufrecht, behaart, mit sperigen Aesten; Blätter tief-fiederspaltig, nit linealischen, gezähnten Zipfelu, die unteren gestiglt, die uberen sitzend, die obersten ungetheilt; Islïttchen des sanz kahlen Hauptkelches fast handfürmig-dornig, der mittlere Durn stark, länger als das Köpfrhen, die seitenständigen Köpfchen einzeln, fast sitzend; Federkelch fehlend. *. 'Truchene Anhöhen, Wegränder, wïste Plätze sehr zerstreut. Bei Halle häufig z. B. am Felsen zivischen Giebichenstein und 'Trotha, hei Kröllwitz u. s. w., einzeln zwischen 'zscherben und 'Teutschenthal; fehlt dann im ganzen südlichen und westlichen Gebiete; erscheint vereinzelt wieder bej Sanderslebell und Köthen; bei Paupitzsch und Delitzsch, besonders an den Windmühlen häufig. Juli. Aug. Blume blass - purpurroth. Höhe $1 / 2-1 \frac{1}{2}$.

634. C. solstitialis L., Sonnenwe nde-F. Stengel aufrecht, mit abstehenden Aesten; Blätter grau-filzig, linealisch - lanzettlich, herablautend, ganzrandig, die wurzelständigen leierförmig; Blättchen des wolligen Hauptkelches handförmig - dornig, der mittlere Dorn stark, länger als das Köpfchen, endständige Köpfchen 
einzcln. (-). Auf und an Aeckern selten und stets unbeständig, nur mit fremdem Samen eingeführt. So ist sie in neuerer 'Zeit bei Naumburg, Allstedt an der Chaussee nach Querfurt, bei Aschersleben besonders auf Esparsettäckern und sonst hin und wieder gefunden worden. Juli. Aug. Blunı citrunengelb. Höhe $1-3^{\prime}$.

III. Ordnung. Cichoraccen Juss. Z Zungenblithler (Semiflosculosae L.).

Griffel nicht gegliedert; Blïthen sämmtlich zungenförmig und zwitterig; Schenkel des Griffels fadenförmig, zurïckgerollt, kurz - weichhaarig.

16. Gruppe. Lampsancen Less. Milchengewächse. Federkelch fehlend oder an dessen Stelle ein hervorspringender Rand.

257. Lámpsana L. (nicht Lapsana). Milche (2cru-

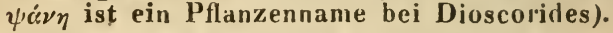

635. L. communis L., geme in e M. Flora $v$. Thüring. I, 8. Stengel aufrecht, rispig - ästig; Blätter eckig gezähnt, die unteren leierförmiğ, Seitenzipfel eiförnig, Endzipfel sehr gross; Blüthenköpfe klein, wenigblüthig. $\odot$. Aecker, Raine, Gräben, Zäune, $\mathrm{z}$ wischen Gebüsch haufig. Juli. Aug. Blume gelb. Höhe $1 / 2-4^{\prime}$. Aendert mit drusig - rauhhaarigem Stengel und kurz-behaarten Blättern ab.

258. Armóseris Gä r th. Lanı $\mathrm{kraut}$ (von

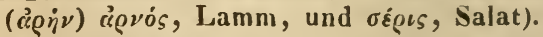

636. A. pusilla G birtn., kleines L. Schaft blattlos, 1-3köpfig, Bliithenstiele uberwärts keulenförmig verdickt, röhriyr; Blïthenköpfe klein; Blätter sämnitlich grundständi, verkehrt - eiförmig - länglich, gezähnt. $\odot$. Sandige, truckene Aecker stellenweise. Sandige Aecker zwischen der lrrenanstalt und der Dölaner Heide häufig, etwas seltener zwischen Dölau und der Heide, sandige Aecker am Bienitz, fehlt in ganzen siidlichen Gebiete; auf Aeckern bei Bibra häufig; fehlt dann wieder im westlichen und nordwestlichen Gebiete; bei Dessau hänfig, Aecker zwischen Pouch und Crina östlich von Bitterfeld, auf sandigen Aeckern an der Benn. dorfer Mühle hänfig. Juli. Ang. Hyoseris minima 1 . Lapsana pusilla Willd. Blume gelb. Der am Grunde roth gefärbte Schaft ist $4-8^{\prime \prime}$ hoch. 
17. Gruppe. Cichorieen C. 11. Schultz. Wegwartengewä chse. Federkelch kurz, aus verbreiterten, stumpfen, freien oder mehr oder weniger verwachsenen und eine hrone bildenden Borsten zusammengesetzt.

259. Cichórium L. W e guarte (Pflanzenname bei Dịoscuricles).

637. C. Intybus $t$, g e me ine W. Hayne Arzneigew. II, 24. Stengel aufrecht, rauh; untere Blätter schrotsägenförmig, unterseits am Kiele steifhaarig-rauh, die oberen länglich, ungetheilt, die blüthenständigen aus breiterem, etwas stengelumfassendem Grunde lanzettlich; Blüthenköpfe zn 2 oder mehren gehäuft, theils sitzend, theils gestielt; Fedlerkelch vielmal kürzer als die Achäne. 24. Wege, Triften, Raine überall gemein. Juli. Ang. Blume blau. Höhe 1-4'. OFF. rad. Cichorii.

Cichorium Endivia L., welches den Endiviensalat liefert, wird bisweilen in Gärten gebaut.

18. Gruppe. Le ontodonteen C. II. Schultz. Löwell$\mathrm{z}$ a h $\mathrm{n}$ ge $\mathrm{w}$ ă $\mathrm{e}$ h se. Federkelch aller $\Lambda$ chänen fiederlaarig, mit freien Haaren oder Strahlen; oder der Federkelch der randständigen Achänen kronenförmig. Blüthenboden kahl odler mit bleibenden feinen Füserchen.

260. Whrincia Toth. Zinnensat (von $y \circ \%$ xós, Kranz, wegen des Federkelches der Randachänen).

638. Thr. hirta IRoth, kurzha arige Z. Rchb. pl. crit. VIII. Abb. 990-992. Wurzelstock nit starken Wurzelfasern besetzt, dann abgebissen; Blätter sämmtlich grundständig, lanzettlich, meist durch 2gabelige Haare kurzhaarig, ganzrandig, gezähnt oder buchtig gezähnt; Schäfte blattlos; Blättehen des Hauptkelches schwarz-berandet; Achänen an der Spitze in einen rauheil, kurzen Schnabel zusammengezogen. 4. Triften, Wiesen stellenweise. An den Teichen bei Dieskau, Wiesen zwischen der Dieskauer Mühle und Osendorf, bei Benustedt, Kölme, an den Dömeken zwischen Pfitzenburg und Wausleben, hei Röglitz, Wiesen bei KI. Dölzig und am Bienitz, bei Kötschau und Schladebach, fehlt bei Naumburg und Freiburg, bei Aschersleben häufig, bei Dessau hinter der Brachmeierei häufig, bei Paupitzsch und Benndorf. Juli. Aug. Blumen gelb, unterseits nit schwarzblauen Streife. Höhe 2-8". Aendert ab : 
a) naior Peterm.: Schäfte bis fusshoch; Blüthen. köpfe gross; Zunge cier Randblumen wenigstens 5 mal so lang als breit; Blättchen des Hauptkelches bald kahl, bald kurzburstig-behaart.

b) media l'eterm.: Schäfte zienlich steif, vielfurchig; Bliithenköpfe etwas kleiner; Zungre der Randblumen rtwa 3mal so lang als breit; Blättchen des Hauptkelches bald kahl, bald kurzborstig-behaart. 'Thr. hirta $R \mathrm{chb}$.

c) I, eysserj Wallr.: Schüfte sehr dünn, klein, etwa 5-7furchig; Blüthenköpfe sehr klein; Blättchen des Haujthelches bald kahi, bald kurzhorstig-behaart.

d) crlabriuscula Peterm.: Blätter fast kahl, am Rande ganz whe Haare, ohes - und unterseits nur mit zerstreuten Haaren besetzt.

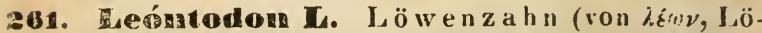
we, und ojons, Zahu, wegen der zahnartig eingeschnit. tenen Blätter).

1. Oporina bon. Strahlen des Federkelehes fast greich, sämmtich fielerhanrig, an den breiteren Grunde aber hlos klein - esägt.

639. L. antumnalis $\mathbf{L}$., H e rbst - I. Wurzelstrock abgebissen, überall faserig; schaft 1 - bis mehrtiöpfig, blattlos; Bliithensticle allmähliw verdickt, oberwairts schuppenförmig, wor dem Aufbliihen aufrecht; Plätter sämmtlich grundständig, mejst buchtig-oder fiederspal. tig-gezähut, kahl oder mit cinfachen Haaren besetzt. 4. Wiesen, Raine, 'lriften geme.in. Juli - Herbst. Apargia autumalis Willd. Oporina autumalis Don. Blume gelb. Höhe $1 / 2-2^{\prime}$. Aendert mit einköpfigem Sirhafte und ungetheilten Blättern ab und ferner:

b) pratensis Koch: Blättchen des Hauptkelches und die Blïthenstiele uberwärts dicht braun-zuttigrauhhaarig. Apargia pratensis link, und wenu der Schaft zugleich nur ein Köpfchen trägt: Apargia Taraxaci S' $m$. Hieracium 'Taraxaci L., so zient. lich selten z. B. bei Kötschau.

B. Dens Lecuis. Strahlen des Federkelches ungleich, die inneren fiederharig, an dem breiteren Grunde klein-gesägt; die äusseren kurz und bloss rauh.

641). L. Hastilis L., spiess förmiger L. Wurzelstock 
stock abyebissen, an Grunde mit starken Fasern besetzt; Schaft 1köpfig, blattlos oder mit 1-2 Schuppen besetzt, an der Spitze dicker; Blätter sämmtlich grundständig, länglich-lanzettlich, in den Blattstiel verschmälert, gezühnt oder fiederspaltig, kahl oder mit 2-3gabeligen kur:en Haaren besetzt. 2. Wiesen, Triften, Grasulätze gemein $z$. B. auf Wiesen vor dem Sebenschen Busche, bei Dieskau u. s. w. Juni - Herbst. Blume gelb. Höhe $1 / 2-1^{\prime}$. Aendert ab:

a) $v u l g a r i s ~ K o c h$ : Blätter, Schaft und Hauptkelch oder nur die Blätter durch 2-3gabelige Haare dicht kurzhaarig. L. hispida L. Apargia hispida Host u. Willd. Hicracium incanum Polli ch.

b) hastils L.: Blätter, Schaft und Hauptkelch kahl oder mit wenigen Harren besetzt. I. danubiale Jacq. Apargia hastilis Host. Diese Form ist sehr selten.

262. Pieris I. Bitterich (Pflanzenname bei Theophrast, von $\pi$ \% $\rho^{\prime} s$, bitter, abgeleitet).

641. P. hieracioides L., habichtskraut ähnlicher B. Stengel aufrecht, ästig, nebst den Blättern von borstigen, an der Spitze widerhakigen Haaren steifhaarig; Blätter läıglich-lanzettlich, gezähnt oder etwas buchtig, die nittleren mit abgestutztem oder spiessförnigem Grunde etwas stengelumifassend; Blüthenköpfchen an dem Stengel und den Aesten endständig, ebensträussig; die äusseren Blättchen des Hauptkelches abstehend, auf denı Rücken steifhaarig, anı Grunde kahl; Achänen fein-querrunzelig, nit fiederhaarigem, abfälligem Federkelche, dessen Strahlen an Grunde in einen Ring verwachsen sind. (.). Wiesen, Raine, Wegränder meist sehr häufig, so bei Halle, Schkenditz, Kötschau, Naumburg, dagegen an einigen Orten des nördlichen Gebietes selır selten z. B. bei Sandersleben. Juli. Aug. Blume gelb. Höhe $1-3^{\prime}$.

263. Helminthia Jus s. Wu rm k r a t (vnn Ėhuı's, Wurm; das Wort ist von Juss. aus dem bei Vaill. zuerst rorkommenden Pflanzennamen Helninthotheca (Wurmbüchse) gebildet, weil der bauchige Kelch die wurmähnlichen Samen gleichsam wie eine Büchse einschliesst).

642. H. echioides G̈̈rtn., natterkopfartiges W. Stengel steif-aufrecht, ästig, steif-behaart; BlätGarcke, Flora. 
ter geschweift, gezähnt, die unteren verkehrt-eiförmig, die stengelständigen länglich-lanzettlich; Blithenstiele 1köpfig; die äusseren Blättchen des Ilaupthelches eiherzformig, zugespitzt. $\odot$. Archer, Wegränder sthr selten und unlieständig, ist mit fremdem Samen cinge führt. Nur an der Chaussee von Allstedt nach (Querfurt, daselhst aber schun seit einizen Jahren beubaclitet. Juli. Aug. Picris echioides I. Blume gelb. Höhe 1-2'.

19. Gruppe. Scorzonereen C. II. Scliuliz. Sclirarzwurzgewàchse. Federkelch aller Achänen fielerhaarig. Ficderlaare der Stralılen ineinander greifend, oder der Federkelch der randstāndigen Achãuen spreuıg, Spreublattichen einlach, oder der Federkelch aller Achānen einfarh, die Stralılen klein-gesăgt-rauh und am Grunde inwendig zotlig.

261. Tragogógon L. II a ferwurz (ein bei Dios-

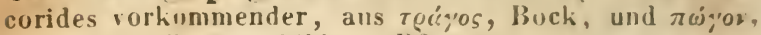
Bart, gebildeter P'flanzennarıe).

643. T. major Jacq., grusse H. Stengel aufrecht, ästig; Blättel steif, linealisch-lanzettlich, langzugespitzt; Bliithenstiele besunders zur Fruchtzrit oberwärts lieulenförmig verdickt; Haupthelch 8-12blïterig, fast doppelt sil lang als die Blüthen; Blithenliöfchen oberseits konkav; die randständigen Achünen stachelschuppig, scharfiantig. (.). Sunnige Auhöhen, Weinberge, Wegränder, Mauern, gern auf Kalk, stellenweise. In Kalkbergen bei Bennstedt häufig, nu Chausseegraben von Bennstedt bis nach Rollsturf, an Bergen bei Wettin, an Weinbergen und auf Mauern bei Köglitz, Weissenfels und Naumburg häufig, bei Eisleben an der Landwehr und nach Helfta $z u$, an Weinbergen hei Reruburg. Juni. Juli. Blume blassgelb. Höhe 1-3'.

644. T. porrifolius L., la u chblätterige H. Stengel anfrecht, ästigr; Blätter steif, linealisch-lanzettlich, lang-zugespitzt; Bliithenstiele besonders zur. Fuchtzeit obenviirts keulenförmig verdickt; Hauptkelch Sblätterig, fast doppelt so lang als die Blüthen; Bliithentöpfchen obcruärts gan: flach; die randständigen Achänen fein schuppenförmig-knötig. @. Hırd als Geniisepfanze hin und wieder gebaut. Sie wird zwar schon vun K $n$ a th enum. p. 143, von $13 u x b$. enum. p. 322, von Rupp. jen. ed. Hall. p. 20 (welcher sie jeduch gleich. falls als Gartenpflanze kennt), von Leyss. hal. ed. 1 y. 145 und ed. 2. p. 190 auf bebautem Buden und auf Waldwiesen bei Gutenberg und im Rocken- und Mittel. 
holze angegeben und ron S preng. (zuletzt hal. ed. 2. p. 372), welcher, "ie Leyss., heine Culturpflanzeu aufzunehmen pflegte, gleichfalls auf Waldwiesen bei Gutenberg citirt, inciessen ist sie unstreitig auch damals nur rerwildert gewesen. Der Verfasser hat durt stets relgeblich danach gesucht. Juni. Juli. Blume purpurblau. Höhe $\mathbf{2}-\mathbf{4}^{\prime}$.

645. T. pratensis L., Wiesen-H. Stengel aufrecht, istigr; Blätter linealisch, lang-zugespitzt; Bliithenstiele gleich dick, "ur unter den Köpfichen ein $\amalg$ enig verdickt; Hauptkelch meist 8blätterig; Blättchen iiher dem Grunde quer-eingedrückt; Achänen körnigscharf. @. Wiesen, Gräben, Wrgränder häufig z. B. IViesen bei Seben, Gutenberg, Dieskau u. s.w. Mai Juli. Höhe 1-2'. Aendert ab :

a) vulgaris Kitt.: Randblüthen so lang oder kürzer als der Hanptkelch.

b) tortilis Meyer: Blätter wellenförmig und an der Spitze zusammengerullt.

c) orientalis I.o: Randblüthen meist länger als der Hauptkelch.

Der Verfasser hat viele Exemplare von $T$. pratensis L. und T'. orientalis 1. untersucht und gefunden, class die Form und die Länge der Achäıen keine bestimmten Unterschirde abgeben können, da sie zu veränderlich sind. Auch die Farbe und die Länge der Randblïthen gewähren keinen Anhaltspunkt; denn wenı sie auch bei 'T. pratensis gewöhnlich blassgelb und kürzer als der llauptkelch sind und bei ' $T$. orientalis meist goldgelb und etwas länger als der Hauptkelch gefunden werden, su gibt es doch eine Menge Zwischenformen, bei denen die Randblüthen ganz hlassgelb und su lang oder anch etwas länger als der Hauptkelch erscheinen. Ebensı ist die Grösse der Blïthenköpfe sehr. veränderlich und so scheinen sich keine festen Unterschiede darzubieten oder sollte das von $\mathrm{W}$ immer angegebene Merkmal, wonach sich die Bliithenköpfe bei T. pratensis zwischen 9 und 10 Uhr Vornittags schliessen, während sie sich hei 'T. mientulis erst um Mittag schliessen sollen, constant sein?

265. Scorzonéra T.S Shwarzwurz.

646. S. humilis L., niedrige Sch. Wurzelschopf schuppig; Stengel wollig, einfach, meist 1 köpfig; Blätter länglich-lanzettlich ider linealisch-lanzettlich, die 
2 - 3 stengelständigen linealisch; Hauptkelch halb sn lang als die Blüthen, neist wollig, die äusseren Blättchen eiförmig-lanzettlich, zugespitzt, an der spitze selbst stumpf; Achïncn gerieft, glatt. 24. Wiesen, Wälder nicht häufig. Im Rande der Dölauer Heide zwischen Nietleben und der Fasanerie sparsam; weit häufiger auf Wiesen bei Kl. Dölzig und am Bienitz, in Lodersleber furste, bei Dessau hinter der Brachmeierei. Mai. Juni. S. lanata S chrank. S. plantaginea Schleich. S. angustifolia Wigg. Blume gelb. Höhe $1 / 2-1^{\prime}$.

647. S. hispanica L., spanische Sch. Wurzel. schopf schuppig; Stengel etwas wollig oder fast kahl, obcrucirts aistig, Aeste 1 köpfig; Blätter ganzrandig oder gezähnt; Hauptkelch halb so lang als die Bliithen, kahl, die äusseren Blättrhen 3eckig-eiförmig, die inneren eiförmig-lanzettlich, alle spitz, die randstündigen Achiinen fein-weichstachelig. (-). Grasplütze, sonnige Hügel sehr zerstreut. Auf Hügeln bei Weissenfels, bei Naumburg verbreitet $z$. B. am Pfortenberge, an den Bergen bei Bibra, bei Rathmannsdorf nördlich ron Aschersleben, ist, so unwahrscheinlich es jetzt auch klingt, ohne Zweifel nur verwilderte Culturpflanze, denn noch in jetziger, wie in Buxbaum's (cf. hal. p. 297) Zeit wird sie ihrer Wurzeln wegen bisweilen in Gebiete gebaut. Juni. Juli. Blume gelb. Höhe $2-4$ '. Aendert $a b$ :

a) latifolia Koch : Blätter eiförmig-länglich oder länglich - lanzettlich.

b) glastifolia Wallr.: Blätter lang-lanzettlich.

c) asphodeloides Wallr.: Blätter schnal, linealisch.

Unter dem Namen Scorzonera, welcher aus Scor. zon nera d. h. schwarze Viper, Schlange, zusammengesetzt sein soll, erhielt Matthioli die erste Scorzonerenwurzel als ein berühntes Gegengift gegen Schlangenbiss aus Spanien. Seit dieser Zeit wird diese Pflanze in-Italien und Deutschland gebaut und ist überall nur verwildert, wie dies aus den Schriften gewissenhafter Floristen zu ersehen ist und Thal's Behauptung, sie sei an den meisten Orten Deutschlands einheimisch, erscheint demnach als ungegründet. Den Namen Scorzonera möchte der Verfasser jedoch eher von dem italiärischen Scorza, Rinde, Schale, und nera, schwarz, 
ableiten und den deutschen Namen Schwarzwurz für eine alte Uebersetzung halten.

648. S. purpurea L., purpurblüthige $S c h$. Wurzelschopf fadenförmig; Stengel heblättert, $1 \mathrm{höpfig} \mathrm{oder}$ an der Spitze ästig und 2-4köpfig; Blätter linealisch oder linealisch-lanzettlich; die äusseren Blättchen des Hauptkelches eiförnig-lanzettlich; Achänen gerieft, mit glatten Riefen. 24. Trockene, knrzbegıaste Hügel, gern auf Kalk, sehr zerstreut. Im und am Mittelholze, bei Naumburg an Pfortenberge nach der Kohlenstrasse zu, am sudlichen Rande der neuen Giehle bei Freiburg, an der Steinklippe hei Wendelstein, nach $S c h w a b e$ tl. anh. auch an Kalkbergen bei Bernburg und Sandersleben. Mai. Juni. Blume rosenroth. Höhe $1 / 2-1 \frac{1}{2}$.

266. Podospérmum DC. Stiels a me (aus nov̀s,

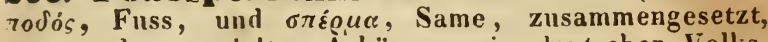
wegen der gestielten Ichänen; ein deutscher Volksname fehlt).

649. P. laciniatum DC., schlitzblät teriger St. Wurzel einfach, einköpfig; Stengel aufrecht oder aufstrebend, ästig, mit stielrunden Aesten; Blätter fiederspaltig, mit linealischen, zugespitzten Seitenzipfeln und lanzettlichem, verlängerten Endzipfel; Blättchen des Hauptkelches dachziegelig; die randständigen Blüthen so lang oder etwas länger als der Hauptkelch; Achänen mit einem dicken, fast aufgeblasenen Stielchen versehen. (-) Raine, Acker - und Wegränder, Weinberge, Iauern nicht gerade selten. In Wegen zwischen Passendorf und der Windmühle häufig, an Kalkbergen bei Bennstedt, bei Wettin an Bertram's Berge, an schwarzen Bär und bei Günthersdorf in der Nähe der Merseburg - Leipziger Chaussee. Wegränder bei Kötschau und Teuditz, bei Naumburg an Ackerrändern häufig, an Wegrändern zwischen Kl. Wangen und Wendelstein, an Wegen bei Hettstedt, Sandersleben und Bernburg. Mai - Juli. Scorzonera laciniata I. S. octangularis Willd.

20. Cruppe. H pochoerideen Less. Ferkelkrautgewächse. Federkelch fiederhaarig; Blüthenboden mit abfālligen Spreublättern.

268. Hypochoeris I. Ferkelkraut (Pflanzenname bei 'Theophrast). 
(5)1). H. glabra L., kahles F. Schaft blattlos, üstig, lahl; Blätter sünmtlich grundständig, buchtiggezähnt; Bliithen so lang als der Ilauptlielch; die mittleren Achänen lang-geschnäbelt, die randständigen schuabellos, oder alle geschnäbelt. $\odot$. Sandfelder, unter dem Getreide, sandige, grasige Abhänge nicht gerade selten $z$. B. auf Aeckern am südlichen Rande der Dölaner Heide, Aecker bei Kl. Dölzig, am Bienitz u. s. w. Juli. Ang. Blune gelb. Höhe $1 / 2-1$ '. Aendert mit kahlen und am Rande kürz-borstigen oder zugleich auch beiderseits mit zerstreuten kleinen Borsten besetzten Blättern ab. Die Form mit lauter geschnähelten Achänen heisst H. Balbisii Koch, nicht l, ois l.

651. H. radicata L., I ang w rzeliges F. Schaft blattlos, ̈̈stig, kahl; Blätter sänmtlich grundständig, buchtig-gezähnt oder buchtig-fiederspaltig; Bliithen länger als der Hauptkelch; Achänen sämntlich lang-geschnäbelt. 24. Wiesen, Triften, Raine, Ackerränder, Schutt gemein $z$. R. an Donnersberge hinter Kröllwitz, an Rainen bei Nietleben und vor der Dölauer Heide u. s. w. Juli. Any. Achyrophorus radicatus Scop. Blume gelb. Höhe $1-2$.

265. Achyróphorus S e op. Hach elk opf (von

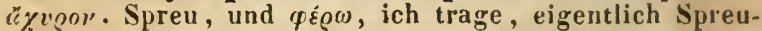
träger, wegen des Blüthenbodens).

652. A. maculatus Scop., gefle ck te r H. H a yne Arzneigew. VI, 43. Schaft rauhhaarig, 1-3höpfig, meist 1 blätterig; Blätter verkehrt-eiförmig - länglich, buchtig, gezühnt oder fast ganzrandig; Blättchen des Hauptkelches am Rande ganz, die mittleren an des Spitze filzig - herandet; Randblüthen weit länger als der Hauptkelch. 4. Waldtriften, grasige Abhänge stellenweise. Bei Halle nur in Mittelholze, aber daselbst häufigr, fehlt östlich und südlich bis Naumburgr, daselbst in den Laasen unweit Almerich und bei Rossbach, am siidlichen Raude der newen Giehle bei Freiburg, an Kalkbergen bei Bibra häıfig, im Sandthale des Lodersleber Forstes, am Frevel bei Allstert, bei Dessau auf den Sandbergen hintel dem Akenschen Thorhause. Juni. Juli. Hypochneris maculata L. Blïthentöpfe gross, gelb. Höhe $2-4^{\prime}$. Die Blätter sind meist braun ge. fleckt. 
21. Gruppe. Chondrilleen. Krümlingsgewächse. Federkelch haarförmig, die Strahlen fein, am Grunde nicht breiter. Blüthenboden nackt. Achänen geschnäbelt, Schnabel am Grunde mit einem hervorragenden Krönchen oder mit schuppenförmigen Weichstacheln umgeben.

269. 'Taráxacum Juss. Kuhblume (die AbJeitung des Wortes ist unsicher).

653. T. officinale wigg., gebräuchliche $K$. H a y e Arzneigew. II, 4. Schaft 1 köpfig; Blätter länglich-odes lineilisch-lanzettlich, fiederspaltig-schrotsägenförmig uder ungetheilt, gezähnt oder ganzrandig; Achänen linealisch-verkehrt-eiförmig, gerieft, an der Spitze schuppig - weichstachelig, der ungefärbte Theil des Schnabels längel als die Achäne mit dem gefärbten Theile vom schuabel. 4 . Feuchte und trockene Wiesen, Triften, Ilege gemem. Mai - Herbst. Blume gelb. OFF. rad. et fulia Taraxaci. Eine sehr vielgestaltige Pflanze, sie ändert ab:

a) genuinum Kuch: Blättchen des Hauptkelches sämmtlich linealisch, die äusseren abwäits gebogen: 'T'. Dens Leonis Desf. u. D C. Leontodon Taraxacum I. und der meisten Autwren. Blume meist goldgelb; dies die gewöhnlichste Form.

h) glaucescens Kuch: Blättchen des Hauptkelches sämmtlich linealisch oder die äusserell, wag. recht-abstehenden lanzettlich, die inneren oft an der Spitze schwielig oder gehörnt. Das Kraut oft etwas meergrïn. T. officinale b. corniculatum $\mathbf{K}$ o c h u. Ziz. Leuntodon corniculatus Kit. I. glaucesceus M. B. Blumen oft hell- wder schwefelgelb; sil an dïrren, sandigen Stellen.

() tar axacoides Koch: äussere Blättchen des Hauptkelches eiförmig, zugespitzt, angedrückt, die imneren an der Spitze gehörnt. Leontudon taraxacuides II oppe. L. laevigatus Willd. I. D C., su an trockenen Stellen.

d) lividum Koch: äussere Blättchen des Hauptkelches eiförmig, zugespitzt, angedrückt, die inneren an der Npitze nicht gehörnt. T. palustre DC. 'T'. Jancenlatum Poir. Leontodon palustre S m. L. lividus W. 11. K. Aendert in der Blattform sehr ab: die Abart mit lanzettlichen, buchtig-schrotsägenförmigen Blättern ist L. erectus $H$ oppe, die mit schmal-lanzettlichen, gezähnten oder nur gezähnel- 
ten Blättern ist L. salinus Pullich., so auf Salzwiesen bei Nietleben, Dölau, Kölme, Dieskan, Döl. kall, Gross und Kíl. Dölziğ u. s. w.

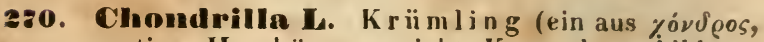
graupenartige Harzkörner, nicht Knorpel, gebildeter Pflanzenname bei Diuscorides).

634. Ch. juncea L., binsenartiger K. Wurzelblätter schrutsägenförmig, die uberen stengelständigen Blätter linealisch-lanzettlich und linealisch; Aeste ruthenförnig; die seitenständigen Blüthenköpfchen einzeln, zu zweien oder zu dreien; Achäne mit 5 lanzettlichen Zühıen endigend. ๑. Truckene Abhäuge, Raine, Wegränder, sandige Aecker nicht gerade hänfig. An Wegränderu zwischen Halle und Giebichenstein, einzeln an der Gersdurfer wïsten Feldmark hinter Kröllwitz, zwischen Ermlitz und Wehlitz, bei Schkeuditz, am Bienitz, an Sandsteinfelsen an der Henne bei Naumburg, an Abhängen zwischen Isangenbogen und Rullsdurf. Juli. Aug. Blune goldgelb, Strahlblumen meist safrangelb, unterseits mit schwefelgelben Streifen. Höhe $1-4^{\circ}$. Aendert ab:

b) glabra Kitt.: mittlere und obere Stengelblätter linealisch-lanzettlich, an Rande nicht stacheligsteithaarig.

c) acanthophylla Borkh.: Stengel unterseits und der Rand der Blätter doruig-steifhaarig; mittlere und obere Stengelblätter linealisch-lanzettlich.

d) Iatifolia M. B.: die ganze Pflanze weit grösser und stärker; mittlere und obere Stengelblätter länglich-lanzettlich, fast elliptisch, ziemlich breit, an Rande und unterseits auf dem Mittelnerven stachelig-steifharig. C. rigens $\mathrm{Rchb}$.

22. Gruppe. Lactuceen. Lattichgewä chse. Federkelch haarförmig, Strahlen am Grunde nicht breiter; Blüthenboden nackt; Achänen flach - zusammengedrücht, schnabellos oder mit einem an der Spitze nicht gekrönten Schnabel endigend.

271. Premanthes L. Hasenlattich (von rep-

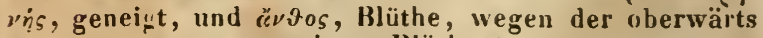
geneigten Bliithen).

655. P. purpurea L., purpurrother H. Stengel aufrecht, einfach oder oberwärts ästig, kahl; Blätter mit herzförnigem Grunde stengelumfassend, kahl, un- 
terseits meergrün, die unteren eiförmig oder länglich, in den geflügelten Blattstiel zusammengezugen, gezähnt, die oberen lanzettlich, zugespitzt, ganzrandig; Blïthenstand rispig. - S. Schattige Bergwälder sehr selten, nur bei Naumburg im Mordthale nach Flemmingen zu sparsam. Juli. Aug. Blume purpur-oder bläulich-ruth. Höhe $2-5^{\prime}$.

232. Lnctúce I. Lattich (der schon bei römischen Schriftstellern vorkommende Name Lactuca scheint aus I actiduca zusammengezogen $\mathrm{zu}$ sein, da alle Iatticharten Milchsaft enthalten).

A. Lactucae genuinae. Achänen beiderseits mit mehreı erhabenen Riefen. Blïthen gelb.

656. L. sativa L., Garten. L. Ha y VII, 30. Stengel aufrecht, walzenförnig; Blätter auf der Mittelrippe unterseits stachelig vder glatt, mit herzförnigem Grunde stengelumfassend, gezähnelt, ungetheilt oder schrotsägenförmig - fiederspaltig; Rispe verbreitert, ebensträussig, Aach; Achänen braun, beiderseits j̇riefig, Schnabel weiss, so lang oder länger als lie Achänc. $\odot$. Wird in Gärten und anf Feldern unter dem Namen Kupfsalat hänfig gebaut. Juni Aug. Höhe $2-3$ '.

657. L. virosa L., Gift - L. H ay ne Arzneigew. I, 47. Stengel aufrecht, walzenföımig; Blätter auf der Mittelrippe unterseits stachelig, oval-länglich, stunıf, pfeilförnig, an Kande mit stachelspitzigen Zähnen, ungetheilt oder buchtig, die oberen zugespitzt; Rispe abstehend; Achänen schwarz, beiderseits 5riefig, ziemlich breit-bcrandet, an der Spitze kahl; Schnabel weiss, so lang als die Achäne. (.). An Ackerrändern bei Kötschau selten. Juni - Aug. Höhe 2-5'. Hat einen widrigen Geruch. OFF. herb. Lactucae virosae.

658. L. Scariola L., wilder L. Hayne Arzneigew. I, 46. Stengel aufrecht, walzenförnig; Blätter auf der Mittelrippe unterseits stachelig, oval-länglich, spitz, pfeilförmig, am Rande mit stachelspitzigen $Z a ̈ h$ nen, fiederspaltig - schrotsägenförnig, seltener ungetheilt; Rispe pyramidenförmig, Aeste traubig; Achänen bräunlich-@rau, beiderseits 5riefig, schmal-Zcrandet, an der Spitze kurz-borstenförmig-behaart; Schnabel weiss, so lang als die Achäne. (.) Wege, Hügel, wüste Plätze, Schutt häufig z. B. am Pfännerholzplatz 
sehr häutig, bei Röglitz, Kötschau u. s. w. Juli. Aug. Hölıe 2-4'.

659. L. saligna L., we i d e $\mathrm{b} /$ ät te riger I. Stenyel aufrecht, walzenförm;g; Blïtter auf der Nittelrippe unterseits stachelig uder glatt, linealisch, zugespitzt, yanzrandig, die untersten schrutsägrnförmig - fiederspaltig ; Aeste ruthenförmig, traubig - ährig; Achïnen braun, beiderseits 5 riefig, Schnabel weiss, doppelt so lang als die Achäne. (.). Raine, Acker- und Wegränder, be sonders an salzhaltigen Orten, selten. Im Chansseegraben bei Rollsdurf nach Laugenbogen zu, an Abhän. gen am salzigen See zwischen Wansleben und Rullsdurf, am Wege zwischen Markrannstert und liitzen, bei Kötschau und Dürenberge, am Galgenberge bei Querfurt, auf salzigem Bolleu bei Stassfurt. Juli. Aug. Iöhe $1-2$ '.

660. L. muralis resenius, Mau er - I. Stell. gel aufrecht, walzenförmig; Bliitter gestielt, leierförmig - fiederspaltig, mit eifürmigen, winkeligen, gezilhnten Zipfeln und groussen Endlappen; Blattstiele pfeilförmix - stengelumfassend; Bliithenstand locker - rispig; Blättchen des Hauptkelches an der Spitze gewöhnlich vöthlich. $\odot$. Wälder, Schutt im Gebiete meist häufig, nur bei Halle sehr sparsam. Einzelı auf der Raben. insel, ebensu in Bienitz, dagegen in den Wärdern hei Naumburg, Freiburg, Allstedt, Eisleben, Sandersleben, Dessau häıfig. Juli. Aug. Prenanthes muralis L. Myrelis muralis Rehb. Cicerbita muralis Wallr. Hö. he $1-3^{\prime}$.

661. L. stricta W. K., ste ifer I. Stengel auflecht, etwas hin und her gebugen, walzenförmig; Blätter unterseits glatt, die wurzelständigen und untersten stengelständigen schrotsägig-leierförmig, grzähnt, die obcren schrotsägenförmig-fiederspaltis, an Grunde pfeilförmig; Rispe ebensträussig, Achänen schuar , beiderseits 5ritfig, Schnabel schwarz, halb so lang als die Achïine. ๑.' Wälder, Hügel zwischen Gebüsch stellenweise. In Lehnann'schen Hölzchen bei Gutenberg, an Zäunen bei Röglitz und Dürrenberge, im Gebiisch bei Schellsitz unweit Naumburg, im Hackenholze bei Branderode, an ler Steinklippe bei Wendelstein, im Hagen bei Esperstedt, lei Rathmanmsdorf nöıdlich von Aschersleben. Juli. Aug. L. quercina IV illd., Foch, wahrscheinlich auch I,in. Höhe $3-6$ '. 
13. Cyanoseris. Achänen auf der Mitte mit einer Riefe. Bliithen blau.

662. L. perennis L., a us d a u e rnde r I. Stengel aufrecht, walzenförnig; Blätter kihl, fiederspaltig, mit linealisch-lanzettlichen, an vorderen Rande gezähnten Zipfeln; Ebenstrauss lucker, endständig; Achäncn beiderscits 1riefis. etwa so lang als der weisse Schnabel. 4. Steinige Hugel, Felsen sehr selten, nur an der Rudelsburur und unter dem Gradirwerke bei Kösen. Mai. Juni. Höhe 1-2'. Die Blüthenköpfchen sind grösser als an allen vurhergehenden.

Mulgedium alpinum Less. wder Sonchus al. pinus L. wird zuerst von Rupp (cf. jen. ed. Hall. p. 205) an den Schmonschen Bergen und in Büschen zwischen Schmon und Wenlelsteio angegeben und dem B u x b a u m (cf. hal. p. 3107) von dort mitgetheilt. Darauf zeigen diese Pflanze an demselben siandurte Leyss., Wallr. und Spreng. auch noch in der 2. Aufl. d. Flora s. 369 an. Nach Wallı. sched. p. 434 fand sie sich daselbst mur sehr selten und spätprhin erklärt dieser Sichriftsteller jenen Standort geradezu fiir zweifelhaft. Auch in nellerer Zeit wurde sie daselbst stets vergeblich gesucht und kann daher nicht wieder aufgenommen werden.

283. Sonchus K. Saudistel (Pflanzenname bei Diuscorides).

663. S. oleraceus L., kuhlartige S. Hayne Arzneigew. 1,48. Stengel ästig, glatt; Aeste doldentranbig-ebcnsträussig; Blätter meist glanzlos, seltener glänzend, länglich, schrotsägenförmig-fiederspaltig, mit grösserem Endlappen wder auch ungetheilt, die stengelständigen am Grunde herzförmig, nit zugespitzten Oehrchen; Irauptkelch kahl; Achänen quer-runzelig, beiderseits unif dem Mittelfelde 3riefig. $\odot$. Aecker, Schuthaufen, iberall auf bebautem und unhebautem Boden. JuniHerbst. S. oleraceus L. mit Ausschluss der Varietäten $\%$ und $\delta$. S. laevis Vill. Hieracium oleraceum Scop. Blume gelb. Höhe $1-2$ '. Aendert ab:

a) integrifulius Wallr.: Blätter ungetheilt, nicht schrotsägenförnig.

b) runcinatus Knch: Blätter schrotsägenförmigfiederspaltig. der Endlappen grösser, 3eckig.

c) lacerus Wa!lr.: Blätter fiederspaltig, mit glei- 
chen Zipfeln, die Seitenzipfel gezähnt oder buchtig, der Endlappen ebenfalls buchtig.

664. S. asper Vill., rauhe S. Stengel aistig, meist kahl; Aeste doldentraubig-ebensträussig; Blätter meist glänzend, oval-länglich, ungetheilt oder etwas schrotsägenförmig, die stengelständigen am Grunde herzförmig, mit abgerundeten Oehrchen; Hauptkelch kahl; Achiincn glatt, berandet, beiderseits auf dem Mittelfelde 3riefir. $\odot$. Auf bebautem Boden, Schutt häufig, ubschon etwas seltener als vorige Art, z. B. auf Aeckern zwischen Halle und Nietleben, Jecker an der Gersdorfer wüsten Feldmark hınter Kröllwitz u. s. w. Juni - Octub. $s$. oleraceus var. $\gamma$. und $\delta$. S. fallax Wallr. Blume gelb. Höhe $1-2^{\prime}$. Die ganze Pflanze ist steifer und stacheliger als die vurhergehende.

665. S. arvensis L., Fel d-S. Wurzelstock kricchend; Stengel cinfach, glatt, an der Spitze meist ebensträussig; Blätter lanzettlich, schrotsägenförmig - fiederspaltig, nit breit-linealischen oder lanzettlich-linealischen, oft zugespitzten und etwas geschweift-gezähnten Zipfeln, die stengelständigen Blätter an Grunde herzförmig, die obersten ungetheilt; Hauptkelch nebst den Blüthenstielen oelb-driisenhaarig; Achänen nit querrunzeligen Kiefen. 4. Auf Aeckern gemein. Juli. Aug. Blüthenköpfe gross, mit gelben Blüthen. Höhe $2-5 \%$. Aendert mit lauter ungetheilten Blätter'n und $1-2 \mathrm{köpfigem} \mathrm{Stengel} \mathrm{ab.}$

666. S. palustris L., Sump f - S. Wurzel ohne Ausläufer, Stengel steif-aufrecht, einfach, an der Spitze cbenstriuussig, nebst dem Hauptkelche und den Blüthenstielen schwarz-driisenhaarig; Blätter schrotsägenförmigfiederspaltig mit lauter lanzettlichen, zugespitzten Zipfeln, die Stengelblätter an Grunde pfeilförmig, die oheren ungetheilt; Achänen mit querrunzeligen Kiefen. 4. Flussufer, Sümpfe sehr selten. Mit Sichrrheit nur an der Eine hei Aschersleben im Krähengeschrei und unter der alten Burg. Juli. Aug. Blume gelb. Höhe $4-6^{\prime}$.

Von Spreng. (hal. ed. 2. p. 368) wird diese Pflanze auf sumpfigen, salzigen Wiesen bei Dirskau und Gröbzig, von S chw a b e fl. anh. auf Sumpfwiesen bei Gröbzig, Werdershausen, Jeau und Sandersleben angegeben, an welchen Orten der Verfasser bisher vergeblich dar. nach gesucht hat. 
73. Gruppe. Crepideen. Grundfestengewä chse. Federkelch haarformig, Sirahlen haarfein oder pfriemlich-borstlich, sher am Grunde nicht spreuig-verbreitert; Achänen stielrund oder kantig, zuweilen ein wenig zusammengedrückt, geschnäbelt oder ungeschnäbelt.,

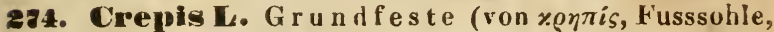
Untergrund, bezeichnet wie der deutsche Name die Eigenschaft einiger Arten, besonders der C. tectorum L., sandigen Grund $z u$ befestigen).

A. Barkhausia II önch. Achänen sämmtlich oder zum 'Theil mehr oder minder geschnäbelt. (Die unhaltbare Gattung Barkhausia ist nach Guttl. B arkhausen, dem Verfasser einer Beschreibung mehrer P'flanzen des Fürstenthums Lippe, benannt und darf daher nicht Borkhausia, etwa nach M. Balth. Borkhausen, geschrieben werden.)

667. C. foetida L., stinkende G. Stengel aufrecht, beblättert, ästig, nebst den Blättern rauhharig; Blätter schrotsägenförmig-fiederspaltig, die obersten lanzettlich, am Grunde tief eingeschnitten; Blüthenstiele vor dem Aufblühen nickend; Hauptkelch iiberall grau und zottig, mit einfachen und drüsentragenden Haaren; Schnäibel der randständigen Achüinen kiirzer als der Hauptkelch, die innersten länger als derselbe; Federkelch schneeweiss. $\odot$. Weinberge, wüste Plätze, Wegund Ackerränder stellenweise. Kalkberge bei Bennstedt und Kölme, Weinberge bei Rollsdorf und am salzigeu See, auf Bertram's Berge bei Wettin, Aecker bei Hohennölsen, auf Kalkbergen bei Naumburg häufig, bei Allstedt an der Chaussee nach Querfurt sparsam, bei Eisleben am Hutberge, an Kalkbergen bei Sandersleben und Bernburg selten. Juni-Aug. Blumen gelb, die Strahlblumen unterseits roth. Höhe 1'. Das Kraut und besonders die Blüthen haben einen widrigen Geruch. Aendert mit mehr oder weniger ästigrem und astlosem, meist kleinerem, $1 \mathrm{köpfigem} \mathrm{Stengel} \mathrm{ab.}$

B. Achänen an der Spitze etwas schmäler, walzenförmig oder in einen kurzen Schnabel ausgehend, 10-13riefig. Federkelch schneeweiss, biegsam.

.. Schaft unheblättert, an der Spitze vielküpfig.

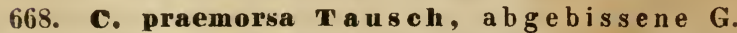
Sturm Heft 39. Wurzelstock abgebissen, mit dünnen 
Wurzelfasern besetzt; Schaft blattlos, traubig, die unteren Blüthenstiele 2-3köpfig, die uberen 1 köpfig; Blätter sämmtlich wurzelständig, oval-länglich, an Grunde verschmälert, entfernt-kleingezähnelt, kurzhaarig-rauh. 4. Wälder, Wiesen selten. Bei Halle sehr sparsam, nur einzeln in der Abbatissina bei Kitten, auf Wiesen bei Gross - und Kl.-Döiziğ, bei Naumburg verbreitet z. B. im Sperlingsholze, in den Laasen, in den Wal. dungen bei Wetau, in den Wäldern vun Rossbach nach Freiburg, in der nenen Giehle zwischen Ebersrode und Freiburg, im Ludersleber Forste. Mai. Juni. Hieraciunı praemorsunı L. Intybus praemorsus Fries. Blume gelb. Höhe $3 / 4-1^{1} / z^{\prime}$.

Nach R chb. sax. ed. 1 u. 2. p. 171 soll diese Pflanze auch bei Sandersleben auf den Sicheuberge angeblich nach Schwabe wachsen, während in der fl. anh. vou Schwabe dieser Standort für C. succisaefolia Ta us ch angegeben wird.

\section{b. Stengel heblättert, an der Spitze ehenstriussig.}

669. C. biennis L., $z$ w e i jährige G. Stengel aufrecht, gefurcht, beblättert, an der Spitze ebensträussig; Blätter gezähnt oder schrotsägenförmig-fiederspaltig, Alach, die stengelständigen sitzend, mit kur z-geöhrtemgezähntem Grunde etwas stengelumfassend, die obersten ganzrandig; Blättchen des Hauptkelches sämntlieh läng. lich-linealisch, stumpflich, grau-behaart, die äusseren abstehend, die inneren auf den Rücken steifhaarig oder kahl, auf der inneren Seite seidenhaarig; Achänen an der Spitze schnäler, 13riefig. (-). Wiesen, Raine, Wege überall häufig z. B. auf Wiesen zwischen Halle und Nietleben, in den Chausseegräben um Halle u. s. w. Mai, Juni und öfters in Herbst wieder. Blumen gelb. Höhe 2-4'. Aendert mit steifhaarigen, oft fast kahlen Stengeln und Blättern ab und ferner:

a) runcinata Kuch: Blätter ziemlich gleichmässig schrotsägenförmig, nit abwärts allmählig kleiner werdenden Zipfeln.

b) Iacera Wimm. u. Grab.: Blätter ungleich fiederspaltig oder geschlitzt fiederspaltig.

c) dentata Koch: Blätter verlängert, linealischlänglich, die unteren gezähnt, die oberen ganzrandig.

670. C. tectorum C., Dach-G. Stengel aufrecht, beblättert, an der Spitze ebensträussig; Wurzelblätter lanzettlich, buchtig - gezähnt, seltener schrotsägenförmig- 
fiederspaltig, den Boden anliegend; Stengelblätter sizzend, linealisch, pfeilförmig, mit weit abstehenden oder aufwärts gebogenen Oehrchen, am Rande zuriickgerollt; Blättchen des Hauptkelches lanzettlich, verschmälert-zugespitzt, nebst den Blüthenstielen grau-behaart, die äusseren linealisch, etwas abstehend, die inneren auf der inneren Seite angedrïckt-behaart; Achänen kastanienbraun, 10riefig, an der Spitze verschmälert-zusammengezogen, fast etwas geschnäbelt, an der Spitze scharf. $\odot$. Auf Mauern, Schutt, sandigen Aeckern nicht selten z. B. auf Mauern in Giebichenstein, Aeckern hinter Kröllwitz u.s. w. Mai, Juni und im Herbste oft wieder. Blumen gelb. Narben braun. Höhe 1-2'.

671. C. virens $W$ il1., grii n e G. Stengel aufrecht, beblättert, an der Suitze ebenstrüussig; Wurzelblätter lanzettlich, gezähnt uder schrotsägenförnig-fiederspaltig, die mittleren und oberen Stengelbliitter linealisch, flach, am Grunde pfeilförmig, mit abwärts gerichteten, oft eingeschnittenen oder gezähnten Oehrchen; Blätchen des Hauptkelches linealisch, angedriickt, die inneren auf der inneren Seite kahl; Achänen hell-oder grau-braun, linealisch-länglich, 10riefig, an der Spitze ein wenig schnäler, glatt. $\odot$. Triften, Weg- und Ackerränder, Weideplätze, lichte Waldstellen häufig z. B. bei Dieskau, Dölau, Gutenberg u. s. w. Juli-Herbst. Blume gelb, mit röthlichen Streifen. Narben gelb. C. virens und C. pinnatifida Willd. C. polymorpha Wallr. Höhe $1 / 2-1^{\prime}$. Aendert in Grösse und 'Zertheilung der Blätter vielfach $a b$ und ferner:

b) agrestis II. K.: Blüthenköpfe doppelt so gross als bei der gewöhnlichen Furm.

Nach Abmähung oder Abweidung des Hauptsten. grels erscheinen im Herbste nicht selten viele aufsteigende, höhere, sehr verästelte Stengel, diese Form ist C. diffusa DC.

c. Achänen 10riefig; Federkelch ziemlich steif, zerbrechlich, gelblich - weiss.

672. C. paludosa M önch., Su in p f - G. Stengel aufrecht, beblättert, an der Spitze ebensträussig; Blätter kahl, die unteren länglich, spitz, schrotsägenförmiggezähnt; am Grunde verschmälert, die oberen eiförmig. lanzettlich, am Grunde herzförmig, stengelumfassend, gezähnt, an der Spitze ganzrandig, lang-zuoespitzt, sehr spitz; Blättchen des Hauptkelches lanzettlich, verschmä- 
lert-spitz, driisig-bchaart, die äusseren 3mal kürzer; Achänen 10riefig, unter der Spitze zusammengezogen. 4. Nasse Wiesen, Sümpfe zerstreut. Auf Wiesen bei Seeben und Gutenberg sehr häufig, Wiesen zwischen der Dieskaner Mühle und Döllnitz, feuchte Wiesen an Bienitz, auf der Gröbitzer Wiese bei Naumburg, bei Bibra verbreitet, im Bruche zwischen Sandersdorf und Bitterfeld. Juni. Juli. Hieracium paludosum L. Blumen gelb. Ilöhe $1-2^{\prime}$.

0. Achänen 20riefig; Federkelch schneeweiss.

673. C. succisaefolia Tausch, abbissblät te . rige G. Sturm Heft 39. Stengel aufrecht, beblättert, an der Spitze ebensträussig, mit ästigen Blattstielen; bliitter lïnglich, schwach-geziihnt, kahl oder mit einfachen IIaren bestreut, die wurzelständigen am Grunde verschmälert, gestielt. stumpf, die stengelstïndigen stencelumfassend, das unterste iiber dem Grunde zusammcn-

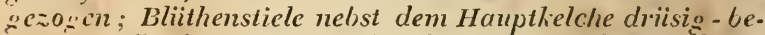
haart; Blättchen des Hauptkelches lanzettlich, verschnälert-spitz, die äusseren nur $1 / 3$ so lang. 24. Feuchte Wiesen, Wälder stellenweise. Anf feuchten Wiesen bei Gross und Kil. Dölzig häufig, bei Naumburg nicht sel. ten z. B. in den Laasen, in den Wäldern über der Henne und bei Märtendorf, in der Hermannsecke des Lodersleber Forstes, auf der Grenze des Gebietes bei Hechlingen unweit Stassfurt. Juli. Aug. Hieracium succisaefulium L, Blume goldgelb. Höhe 2-3'. Aendert ab:

a) mollis Koch: Stengel und Blätter beiderseits hurzhaarig, mit drüsenlosen oder an den obersten Blättern drüsigen Haaren. Hieraciun molle Jacq. H. croaticum W. K.

b) integrifolia Koch: Stengel und Blätter kahl. Hieracium integrifolium Huppe. C. hieracioides W. K.

255. Hiexacium *) $\mathbf{L}$. Hab ichtskra $u$ t (ein aus ígors, Habicht, gebildeter Pflanzenname bei Dioscorides).

A. Piloselloidea $\mathrm{koch}$. Stengel schaftartig. Strahlen des Federkelches sehr fein, einreihig und gleich lang, nur ein oder der andere kurze eingemischt.

*) Da dic in dieser Gattung aufgestellten Bastardformen noch vielfache Intersuchungen nöthig machen, so sind sie hier nicht aufgenommen. 
a. Stengel hlattlos oder lbläterig, 4köpfig oder in eine Gabel gespalten und 2küpfig, mit fast autrechten, langgestielten seitlichen höpfchen.

674. H. Pilosella L., ge mie ines H. Hay ne Arzueigew. III, 42. Schafi blattlos, 1 köpfig, am Grunde mit hingestreckten, beblätterten, nicht blühenden oder blïthentragenden und dann aufsteigenden, $1-3 \mathrm{köpfigen}$ Ausläufern versehen; Blätter etwas ins Meergrïne spielend, verkehıt - eiförmig-lanzettlich oder lanzettlich, burstig behaart, unterseits stärker oder schwächer weissoder grau - filzig; Hauptkclch kur z-walzenförmig. 4. Sandplätze, 'Triften, Heiden, Anhöhen überall gemein. Mai - Herbst. Blumen schwefelgelb; die Randblumen an der Unterseite röthlich gestreift. Schaft $3-12$ ". Aendert ab :

a) VuIgale $M I$ on n. : Ausläufer verlängert und dünn; B!ätter unterseits filzig; Hauptkelch drüsig - behaart; Blüthenköpfchen kleiner.

c) robustius $K$ uch: Auslänfer verlängert und dikker als an der vorigen Form; Blätter unterseits "eiss - filzig: Hauptkelch von einfachen Haaren rauhhaarig, ist überhaupt an allen 'Theilen grösser und behalarter.

c) incanum l'etern.: Blätter beidesseits, doch unterseits stärker filzig.

675. H. bifurcum M. H., gabeli g es H. Stengel mcist 1 blättcrig, gabelig, 2 köpfig oder wiedcrlıolt gabclig und 3 - nnd mehrlöpfig, Blüthenstiele verlängert, aufrecht; Ausläufer liegend, verlängert, nicht blühend oder blïthentragend und dann aufstrebend, $1 \mathrm{köpfig} \mathrm{oder}$ gabelig-mehrliöpfig; Blätter ins Meergrüne spielend, verkehrt-eiförnig-lanzettlich, unteiseits durch den zerstreuten fein-sternförmigen Flaum etwas grau; Hauptkelch am Grunde etwas bauchig. 4. Bergwiesen, Nauern, Wegränder sehr selten, nur bei Nammburg an der Leipziger Strasse in der Nähe ron Wetau und schon ausserhalb des Gebietes nach Stösen zu. Mai-Juli. Blume schwefelgelb, auch die randständigen meist gleichfarbigr. Höhe bis $1^{\prime}$.

b. Stengel an der Spitze 2-5köpfig, mit ehensträussig-zusamnengestellten Köpfchen.

676. H. Auricula L., A u rikel-H. Schafi blutllos oder 1blätteri§, an der Spitze 2-5küpfig, Hliithenstiele cbcnstränssig, nach dem Verbliihen aufstrcbend; Ausläufer licsend, verlïngert, nicht blühend wier sehr selten aufstrebend und blüthentragend und gabelig - 2 - bis

Garcke, Flora. 
mehrköpfig; Blätter bläulich-grün, spatelförmigr-lanzettlich oder danzettlich, am Gruncle gewimpert, sonst meist liahl oder besonders unterseits zerstrent-burstigbehaart; Ilauptkelch aussen mit kurzen Drusenhäıchen besetzt und an Rande etwas grautilzig. 4. Waldwiesen, Iriften, begraste Ackerraine zerstreut. Fehlt bei Halle; auf Wiesen zwischen dem Walde und KI. Dölzig und am Bienitz, bei Naumburg stellem eise z. B. in den Wäldern iber der Henne und an der Strasse nach Markrölitz auf der Höhe, im Sandthale des l,odersleber Forstes und unnittelbar vor dem Walde, bei Allstedt auf unbewaldeten Stellen dev Wiiste nach Iandgrafrude hin, häufig bei Dessau, bei Raguhn und zwischen Puuch und Crina östlich von Bitterfeld, an der Bennslorfer Niihle sparsan. Juni - Octub. II. dubium S m. Ind so auch bei Spreng. ed. 2. p. 364 (wo die Pflanze fülschlich unter Linnéischer Antorität steht). II. Iactucella Wallr. Blume gleichfarbig gelb. Die Bliithenköpfe kleiner als bei den vorhergehemilen Arten. Sichaft $4-$ 12 " hwch. - Findet sich zuweilen mit blithentragenden Auslüufern und 8-12bliithigem Schafte, in welchem Falle die Blïthen lang-gestielt sind, während sie bei der gewöhnlichen, meist 4 köpfigen Form nur sehr kurz erscheimen. Kräftigere, reichblüthigere Furmen sind besonders zwischen Pouch und Crina östlich von Bitterfeld zul beobarhten.

$\therefore$ Stengel an der Spitze ehpnstriussig-vielkäpfig, 20-100küpfig; 1ilätter mehr oder wroiger hlaulich-grïi, an liande oder üholall horstie steifharig nud unturseits od.p anf beiden flichen mit sternfürmigem Flaume hestreut, selten gailz kahl.

677. Y. pracaltum Koch (Villars nit Zusätzen), hohes H. Stcngel hahl oder mit zerstruten, steifen, den Durchmrsser des Stengels übertreffenden Bursten und mit foinsternigen Flamme besetzt, unterveiirts 1 - oder wenigbliitlerig, an Grumle mit onler whne beblätterte, bliithentragende oder nicht blühende Ansläufer; Elbenstrauss vicllöpfig, gleichlioch, loclier; Blïthenstiele und Hanptielch loclierer oder dichter sternhaarigr-grauflau. mig und behaart, Blüthenstiele nach dem Verblühen geratle; Pliitler blïulich-griin lanzettlich oder verkehrt-eiförmig-lanzettlich, liabl, am Rande oder auf der gaizen Fläche mit starren Bursten besetzt. 24. Iügel, Mauern, Weinberge, Wiesen stellenweise. Weinberge bei Kölme, Rullsilorf his narh Seeburg hin, Wiesen zivischen Burgr Liebenau und Collenbey und bei Gross und Kl. Dölzig, in den Weinbergen bei Weissen- 
fels und Naumburg nicht selten, ebenso an Kalkbergen bei Freiburg, aut Mauern bei Aschersleben, in den Weinbergen bei Bernburg. Juni. Juli. Blume gelh. Höhe 1-3'. Aendert ab:

a) florentinum Willd.: Ausläufer fehlend uder die blüthentragenden Nebenstengel darstellend; Stengel kahl, Blätter nur an Rande und nnterseits anf des Mittelrippe nit Bursten besetzt. H. praealtum Vill.; ist zugleich der Stengel behaart und sind die Bliithenstiele und Hauptielche mit schwarzen Driisenhaden besetzt, so heisst diese Furm H. ubscurum $\mathrm{Kchb}$.

b) 13 a uhini schult. : Ausläufer verlängert, fadenförmig; das Uebri.te wie bei der vorigen Abart. H. Auricula Willı.

c) fallax DC.: Ausläufer fehlend ocier blüthentragende Nebenstengel darstellend; Blätter oberseits iberall nit steifen Borsten besetzt; Stengel ziemlich liahl. H. eymusum Pollich.

d) decipiens Koch: Ausläufrr verlängert, nicht blühend; das Uebrige wie bei der vurigen Abart. H. f allax inch bei DC. H. collinum, vulgare und calodon 'T'aus $\mathrm{ch}$.

(e) hirsutum Koch: Stengel überall und die Blätter unterseits mit fein-sternharigem Flaume bedeckt; Iusläufer aufstrebend, stengelförmig, blïthentrayend. H. fallax Willd. und zwar ist es H. cymigerum R $\mathrm{ch}$ b. bei weniger rauhhaurigen Stengeln und Blättern und H. Zizianum Ta $\mathbf{T}$ sch bei sehr rauhhaariogen Stengeln und Blättern.

Diese Abart ist dem H. echioides W. K. sehr ähnlich und unterscheidet sich von ihm nur durch die wenigen und nicht allmählig an Grösse abnehmenden Stengelblätter und die kleineren, nicht so dichtfilzigen Köpfchen.

f) setosum Koch: Ausläufer niederliegend, nicht blïhend; das Uebrige wie bei der vorhergehenden Abart. H. piloselloides Wallr., nicht Vill.

678. H. echioides W. H. Stengel reichblätterig, 10 - 20blätterio , von feinsternigem Flanme dicht-filzig und borstig - behaart, Bursten steif, länger als der Durchmesser des Stengels; Blätter allmählig nach oben an Grösse abnelımend, bläulich-grün, lanzettlich, unterseits feinsternförmig-flaumig, beiderscits von starken, 
verliingerten Borsten steifhaarig, Ebenstrauss vielliüplï, "leichlioch, locker, weiss-filzig und behaart; Ausläufer frhlend oder aufstrebend, stengelförmig und blii. thentragend. 24. Grasige stellen an Bergen. JuniAug. Blume gelb. Höhe $1-2^{\prime}$. Hierron nur die lbart

b) setigerum $\mathrm{Tausch}$ : Borsten des stengels und der Blätter abstehend; sehr selten, mur bei Naumburg vor del Laasen nach Almerich zu sowohl in den Weinbergen, als im Walde selbst.

Hierher soll nach Meyer chlor. hanor. II. Rothianum Wallr. gehören, welches vom Antor in der Dölauer Heide ind am Felsen bei Kröllwitz angegeben wird, woselbst es in neuerer 'Zeit aber nicht wieder gefunden ist; auch II. cymusum bei Sp re ng. hal. ed. 2. p. 365 ist hierher zu rechnen.

679. H. Vestleri ill. Stengel an Grunde $3-$ 6blätterig, mit fein-sternförmigem Flaume bestreut und borstig - lurzharig, Borsten so lang oder kürzer als der Durchmesser des Stengels; Llätter länglich-lanzettlich und lïnolich, beiderseits fein-sternfürmig-flanmig und mit liurzen Jiorsten leselzt, die äusseren stumpf, die inneren spitz; Ebenstranss sedrungen, vielliupfio, graulich und von drüsigen Haaren oder Bursten raul. haarig; Blïthenstielchen büschelig. 24. Hïgel, Abhängr selten. Abhänge bei Rückmarslorf, Ileissenfels, bei Naumburg in Weinbergen und anf hochgelegenen Wiesen nicht selten. Juni. Juli. Hierher vielleicht H. $\because$. mosum I., viplleicht auch zu H. prapaltum var. c. (ï. fallax DC.) geliörig. Blumen gelb. Höhe 1-2'.

680. H. pratense Tasch, Wiesen-H. Sturm Heft 39. Stenoel untervürts venigbiätterig $(1-5$ blätterio), von verlängerten, wagrecht-abstehenden, schlanlien Haaren rauhhaarig, oberwärts nebst dem Ebenstrauss von drüsentragenden Haaren und Borsten schwarzbehaart; Ebenstrauss viclliöfig, ecdrungen; Blithenstielchen zur 13liithezeit selinciuelt; Bliitter orasgriin oder nur etwas blüulich - grün, länglich-lanzettlich, von schlanken Haaren rauhhaarig, aher ohne den fein-sternförmigen Flaum oder unterseits spärlich damit bestreut. 4. Wiesen, trockene Wälder, Raine selten. Bei Rüclimarsdurf, von Wallr. und Spreng. auch anf Waldtriften bei Bibra, Rossleben, Judersleben, Freiburg angegeben und gewiss weiter verbreitet. Juni - Aug. Iöhe $1-3 \prime$. H. collinum Gochn. H. cymusun Willd. H. dubium L. H. Auricnla bei Spleng. hal. ed. 2. p. 
365 (wo diese Pflanze fälschlich unter Linnrischer Autorität steht).

B. Pulmonarioidea Koch. Blätter gras - oder bläulich grün, die der nicht blühenden Wurzelköpfe überwinternd und noch zur Bliithezeit vorhanden. Haare der Blätter gezühnelt, nicht drüsentrágend.

681. H. vulgatum Koch, gemeines H. Stengel einen Ebenstrauss tragend, vom Grunde an beblättert, an der Spitze nebst den Dliithenstielen und dem Hauptkelche von sternförmigem Flaume graulich und von schuar:en, driisentragenden Haaren kurzhaarig; Blät. ter grasgriin, unterseits und am Rande rauhhaarig, ciförmig-lanzettlich oder eiförmig, nach dem Grunde verschmailert, gezähnt, die Zähne des Grundes tiefer und vorwärts gewandt, die Stengelblätter 3 oder mehre, die Wurzel - und unteren Stengelblätter gestielt, die oberen fast sitzenr. 4. 'Trockene Wälder häufig z. B. Dölauer Heide, Frenzelholz bei Lieskau, Mittelholz u. s. w. Juni. Juli. H. vulgatum Fries Nov. fl. suec. ed. 2. p. 258, nicht Nov. mant. 2. p. 48 . H. nurorum $\%$ L. H. silvaticum Lam. und Smith. Blume gelb. Höhe $1-3^{\prime}$.

692. H. Schmidtii a $\mathrm{usch}$, Schmidt's H. Slengel einen Ebenstrauss tragend, meist Iblätterig, an der Spitze nebst den Bliithensticlen und dem Hauptliclche graulich und mit am Grunde schwarzen, meist driisen. tragenden Haaren besetzt; Blätter bläulich-griin, am Grunde und unterseits rauhhaarig, eiförnig-lanzettlich, nach den Grunde verschmälert, gezähnt, die Zähne des Grundes tiefer und vorwärts gerichtet, die Wurzel. blätter gestielt, das Stengelblatt fast sitzend. 24. In Felsspalten selten. Einzeln an Felsen vor Giebichenstein und zwischen Giebichenstein und 'Trotha, weit häufiger in Felsspalten bei Kröllwitz, bei Wettin auf Bertrams Berge und an Schweizerling und wohl schon ausserhalb der Grenze bei Naumburg auf einem halkhiigel an der Saale der Katze gegenüber. Juni-Aug. Blume gelb. Höhe bis 1'.

683. H. murorum L. (zun 'I'heil), M a u e r-H. Sturm Heft 39 . Stengel einen Ebenstrauss tragend, 1-2blätterig, an der Spitze nebst den Aesten und dem Hauptkelche graulich und von schwarzen, driisentragenlen Haaren kurzhaarig; Blätter grasgriin, unterseits und am Rande rauhhaarig, die vuurielstïndigen ei-, fast 
her-fümig, gezühnt, dic ticferen Zähne des Grundes riichuairts gerichtet; das Stengellilatt kurz-gestielt oder sitzend: Blättchen des Hanpthelehes verschmälert, die äliseren stumpflich, die inneren spitz. 24. Manern, Hügel, truckene Wüldes, Gebüsche gemein. JuniAug., blïht früher als H. vulgatum. Blume gelb. Höhe 1-2'. Aendert mit am Grunde abgerundeten, ganzrandigen Blättern ab und:

b) silvaticum I.: Blätter am Grunde eingeschnitten-gezähnt, Zähne sückwärts gerichtet, so in Wäldern.

c. Accipitrina Koch. Die Pflanze hat im Herbste keine Wurzelblätter, sondern Knospen auf der Wurzel, die sich im nächsten Jahre zu Stengeln erheben, aber niemals Wurzelblätter treiben. Haare der Blätter nicht drüsentragend.

684. H. boreale ries, nördliches H. Stengel steif - aufrecht, blattreich, rauhhaarig oder kahl, oberwiirts iistig, Aeste fast ebcnstrïussig ; Blïthenstiele nebst. dem Hauptkelche graulich und oft etwas kurzhaarig; Bliitter eiförmig-lanzettlich oder lanzettlich, gezähnt. die unteren in den kurzen Blattstiel verschmälert, die obcren fast sitzend, eiförmig, die zunrzelstiindigen feh. lond; Blätchicn des Hauptleches angedrückt, gleichfarbig, getrocknet schwarzoriin. 24. Waldränder, Gebüsche häufig. Aug. - Octuh. H. silvestre 'I'ausch. H. sabaudum der meisten älteren Autoren, aber nicht Lin. Blume gelb. Höhe $2-6^{\prime}$. Aendert mit grobund feil-gezähnten Blättern und fast kahlen und rauhhaarigen Stengeln ab.

685. H. rigidum artm., starres H. Stengel steif-aufrecht, blattreich, rauhhaarig oder kihl, olerwärts ästig, mit fast elonsträussigen Aesten; Blüthenstiele nebst dem Hauptkelche graulich und oft etwas hurzhanrig; Blätter eiförmig-länglich, lanzettlich oder linealisch-lanzettlich, gezähut, die unteren in den kurzen Blattstiel verschmïlert, die oberen fast sitzend, die uurzelständi,cu fehlend; Blättchen des Hauptkelches angedrücht, ali Rande bleich, getroclinet nichit dnnliler. werdend. ㄱ. Wälder nicht selten, aber wie vigle andere dieser Gattung übersehen. Im Lindberge, Frenzelholze bei Lieskan, Zorgs, Mittelholze, im Bienjtz, in schattigen Waldern bei Namburg häufig z. B. im Buchholze, ïber der Henne. Juni. Juli. Fänght $1 / 2$ Mo. 
nat früher an zu blühen als die vorhergehende Art. H. aftine ' $\mathrm{I}$ 'aus ch. H. laevigatum Koch. Blnme gelb. Höhe $2-5^{\prime}$. Aendert mit kahlem und rauhharigem Stengel ab und ferner:

b) coronopifolium Koch: Blätter schmal-lanzettlich, an jeder Seite des Randes mit $2-3$ verlängerten Zähnen.

c) glaudulosum Ko ch: Bliithenstiele und Hauptkelch mit Drüsenharen besetzt. II. lanceolatum Vill. und Ta us ch.

686. H. umbellatum L., doldiges H. Stengel steif-aufrecht, vielköpfig, rauhhaarig wder kahl, oberwälts ästig, die oberstcin Aeste fast doldig; Blüthen. stiele graulich - flaumig; Blätter lanzettlich oder linealisch, gezähıt oder ginzrandig, die unteren in den kurzen Blattstiel verschnälert, die uberen fast sitzend, die wurzelständigen fehlend; Blätchen des Hauptliclches an der Spitze zuriick, chriimmt. 4. Wiesen, trockene 'Triften, Wälder z. B. an Felsen bei Kröllwitz und vor dem Donnersberge, am Felsell zwischen Giebichenstein und 'Trotha u. s. w. Juli. Aug. Blume gelb. Höhe 1-4'. Aendert ab:

b) coronopifolium B e rnh.: Blätter linealisch. lanzettlich, auf jeder Seite des Randes mit 2-3 verlängerten Zähnen besetzt.

c) angustifulium Koch: Blätter äusserst schmallinealisch, kaum 1 Linic breit.

Nach Abmähen des Hauptstengels kommen in Herbste oft niedrige, dünue Seitenstengel, welche nur venige breite, eiförmige Blätter und wenige, oft nur pin Blüthenköpf(chen haben, so am Donnersberge hinter Kröllwitz, zwischen der Dölaner Heide und Vietleben und sonst nicht selten.

\section{LV1. Familie. Ambrosiaceen Link. Am-} brosiengewächse.

2a6. Xanthium K. Spitzklette (ein hei Dios. corides vorkommender, aus $\xi_{c} \nu_{\vartheta} \dot{o} \varsigma$, gelb, gebildeter Pflanzenname, weil die Pflanze zum Blondfärben der Haare angewendet wurde).

687. X. strumarium L., gemeine Sp. Stengel infrecht, einfach oder wherwärts kurzästig, wehilos; Blätter herzförmig, 3lappig, etwas kurzhaarig - scharf; 
Blïthenköpfche॥ end - oder blattwinkelständig, die weib. lichen Bliithen unten, die männlichen darüher an der Spitze stehend; Früchte weichhaarig, an der Spitze in 2 gerade, etwas zusammenneigende Schnäbel endigend mit an der Spitze hakigen Weichstacheln besetzt. $\odot$. Schutt, wüste Plätze, Wege sehr vereinzelt und oft unbeständig. In Weinbergen am salzigen see bei Rollsdorf sparsam, bei Naumburg hin und wieder auf Schutt, häufig und beständig anı Felsen bei Vitzenbur und von da bis Nebra hin, und sonst einmal hei Stassfurt und Delitzsch gefunden. Juli-Octob. Blüthen grün. Höhe $1-4^{\prime}$.

\section{Familie. Campanulaceen Juss. Glockenblumengewächse.}

2ar. Jasióne' L. Jasione ( $\mathrm{ein}$ ans v̌cers, Heilung, gebildeter Pflanzenname bei 'Theophrast).

688. J. montana L., B e r g - J. S tu r m Heft 9. Wurzel einf $\alpha c h$, vielstengelig; Stengel aufsteigend, einfach oder ästig, an der Spitze einen rundlichen, an Grunde von einer vielblätterigen Hülle ungebenen Blïthenkopf tragend; Blätter linealisch, etwas wellenförmig. -). Sonnige Hügel, Raine, Sandfelder häufig z. B. am Donnersberge hinter Kröllwitz, auf Hügeln vor der Dölauer Heide u. s. w. Juni. Juli. Blume blau. Höhe $1 / 2-1 \frac{1}{2}$. Aendert mit kahlen und rauhhaarigen Stengeln und Blättern ab.

689. J. perennis $\mathbf{L}$ a m., a us d a u e rnde J. Wurzel ausläufertrcibend; Stengel aufrecht, einfach, kahl, an der Spitze einen zicmich grossen, rundlichen, am Grunde von einer vielblätterigen Hülle ungebenen Blüthenkopf tragend; Blätter linealisch, flach. 24. Waldtriften. Wird zuerst von Wallr. sched. p.93 auf Waldtriften bei Russleben und später von S p reng. hal. ed. 2. p. 119 auf Waldtriften im Winkelsehen Forste und der Wüste zwischen Lodersleben und Allstedt angegeben. Zwar ist diese überhaupt seltene Pflanze in neuerer Zeit daselbst nicht wieder beobachtet worden, aber die Lokalität ist besonder's an dem zuletzt erwähnten Standorte für das Vorkommen derselben günstig, so dass der Verfasser sie nicht wegzulassen wagt. JuniAug. Blume blau. Höhe $1 \frac{1 / 2}{2} 3^{\prime}$. 
258. Phyteuman L. Teufelskrallen (Pflanichname bei Dioscorides).

690. Ph. orbiculare L., rundköpfige T. Stellgel einfach, an der Spitze mit eiuem Bliithenköpfchen; Blïtter gelierbt-gesiigt, die der unteren unfruchtbaren Büschel und oft auch die untersten stengelständigen lang - gestielt, herz-eiförmig oder eiförmirn-lanzettlich, die oberen stengelständigen linealisch; Blïthenküpfchcn kugelig, oder nach dem Verbliihen oval, am Grunde mit mehren Deckblättern umhïllt, von denen die äusseren aus einem eifürmigen Grunde lanzettlich zugespitzt und etwas gesägt sind. 4. Wiesen, Waldtriften, Kalkherge zerstreut. Anı Vogelsberge bei Bennstedt, im Mittelholze, auf Wiesen bei Kl Liebenaı, zwischen Göhren und Rodden, bei Kl. Dölzig, am Bienitz und an den Quellen zwischen dem Bienitz und Rïckmarsdorf; fehlt bei Naumburg; findet sich wieder im Sandthale des Lodersleber Furstes, auf der Grenze des Gebietes bei Hecklingen unweit Stassfurt, auf den Kochstedter Wiesen bei Dessau, im Bruche zwischen Sandersdorf und Bitterfeld, auf den Wiesen an der Benndorfer Mïhle. Juni - Aug. Rapunculus orbicularis Scop. Blumen dunkelblan. Höhe $1 / 2-1 \frac{1}{2}$ '.

691. Ph. spicatum L., ährige 'T'. Stengel einfach, an der Spitze nit einer Blüthenähre; Dlïtter doppelt. gckerlut - gesägt, die unteren gestielt, eiförmig, am Grunde herzförnig, die obersten linealisch; Bliithenährc länglich, am Grunde mit sehr wenioen linealischen oder pfriemlichen Deckblüttern besetzt. 24. In allen Wäldern häıfig. Mai. Juni. Rapunculus spicatus Scop. Blume weisslich oder weiss-gelblich, an der Spitze grünlich. Höhe 1-2'.

279. Compánala L. G lock enblume (Pflanzenname bei Matthioli; der Trivialname Tracheliun konmit von $\tau \varrho \dot{\alpha} \chi \eta \lambda . o s$, Hals, weil die Pflanze früher gegen Halskrankheiten angewendet wurde).

A. Blüthen gestielt, an den reichblüthigen Stengeln traubig oder rispig.

a. Kapsel überhängend, am Grunde aufspringend.

692. C. rotundifolia L., rundblätterige G. Stengel am Grunde aufstrebend, dann aufrecht, an der Spitze rispig-vielbliithig; Blätter ganzrandig oder gesägt, die grundständigen und die der nichtbliihenden 
Wuraellüp/e cifürmis, am Grunde her jurmig, plützlich in den langen l.lattstiel iilscr..eliend, zur Bliithezrit meist schon verschwunden, Stengelblätter meist ganzrandig, die unteren lanzettlich, die übrigen linealiseh; blume cifurmig-oder fast hreiselfürmig-glockig; Kelchzipfel fällich-pfrienlich. 4. Grasplätze, Kaine, Witsen, llïgel häufig z. B. an Felsen an der Bergschenke bei Kröllwitz, Grasplätze vor der Dölaner Ileide us. s. w. Juni - Iferbst. Blune hlan. Höhe $1 / 2-1{ }^{\prime}$. Aendert ab:

b) hirta M. n. K.: der untere Theil der Pflanze durch steifliche Härchen hurzhhaarig.

c) velutina DC.: die ganze Planze durch kurze, dichte Iärchen grau.

693. C. bononiensis L., bolugneser G. Rehh. pl. crit. H. Abb. 221. Stengel aufrecht. watzenförmig, an der Spitze eine einfache oder rispig-zusammengesetzte Traube tragend; Blïtter grekerbt-gesägt, nnterseits weich-filzig-gran, die unteren her-fürmig, langgestielt, die oberen éiförmigr, zugespitzt, sitzend; Blumen gluckig-trichterförmig; Kelchzipfel lanzettlich. 4. Trockene Wiesen, trockene, grasige Raine in Weinbergen, sonnige Hügel sehr zerstreut. Auf der Wiese un der Gersdurfer wüsten Feldmark hinter Kröllwitz, wo sie zu Sprengel's Zeit rerschwunden war, auf grasigen Rainen innerhalb und ausserhalb der Weinberge bei Röglitz, an der Steinklippe bei Wendelstein, an den Westerbergen bei Aschersleben. Juli. Aug. C. 'Thaliana Wall r. C. ruthenica M. B. Blume blau. Höhe 1-2'.

694. C. rapunculoides $L ., \mathrm{k} v \mathrm{iech}$ ende $\mathrm{G}$. R $\mathrm{chb}$. pl. crit. VI. Abb. 700 u. 701. Wurzel hriechend: Stengel aufrecht, stumpfkantig; Blätter liurz-rauhhaarig, ungleich-gesägt, dic unteren fast her a ürmig, lang-gestielt, die wheren länglich uder lanzettlich; Traube endständig, einseitswendig, Blüthenstiele 1bliithig; Kelchzipfel lanzettlich. 24. Aecker, Zäune, Hecken gemein. Juli. Aug. Blumen blau, grösser als an der vorigen Art. Höhe $1-2^{\prime}$. Aendert ab:

b) trachelioĩdes Kchb.: 'Traube sehr lang; Blumen grösser und meist heller-blau, su in den Weinbergen vor Röglitz.

695. C. Trachelium L., nesselhlätterige G. Slengel aufrecht, scharf-kantig, meist behaart; Blatter „rob-doppelt-scsigot, steifhaarig, die unteren lang-gestielt, herzförmig oder herz-cifürmig, die oberen läng. 
lich, seltener herz-eiförmig, sitzend oder kurz-gestielt; Blüthenstiele blattrinkelständig, 1-3blüthig, in eine 'T'raube' zusammengestellt; Kelchzipfel eiförnig-lanzettlich. 4. Wälder, Gebüsche. Bei Halle, Freiburg, Lodersleben, Allstedt u. s. w. Juli. Aug. Blume gruss, blau. Iöhe $2-3^{\prime}$. Aendert ab:

b) urticaefolia Schmidt: Kelch borstig-behaart.

c) cordata Peterm.: alle Stengelblätter herz-eiförmig.

b) Kapsel aufrecht, in der Nitte oler ohen aufspringenil.

696. C. patula L., a us gebreite te G. Stengel aufrecht, kantig; Blätter gekerbt, die vuurielstïndigen lïnglich-verkehrt-eifürmio, in den Blattstiel verschmälert-herablanfend, die stengelständigen linealisch-lanzettlich, sitzend; Rispe etwas ahstehend, jast ebenstrïussig, mit ungetheilten und eimblüthigen, oder getheilten und mehrbluithigen Aesten; Blüthen aufrecht; Kelchzipfel pfriemlich. (.). Wiesen, Grasplätze, Waldränder häufiğ z. B. in der Dölauer Heide, im Mittelholze u. s. w. Mai-Juli. Blume blau. Höhe 1-2'. Aendert mit kahlen und behaarten stengelı, Blättern und Kelchröhren $a b$ und ferner:

b) punctata Wa IIr.: Kelch drüsig-punktirt.

c) flaccida Wallr.: Aeste diinn, fadenförmig; Blune um die Hälfte kleiner. C. neglecta R. und Schult.

697. C. Fapunculus L., Rapunze l-G. Wurzel spindelförmig, etwas fleisshig; Stengel meist einfach, steif-aufrerht, gefurcht: Blätter gekerlot, dic zourzelstïndigen länglich-verkehrt-eifürmig, in den Blattsticl verschmälert herablaufend, die stengelständigen linealisch-lanzettlich; Bliithen in verlïngerter, schmaler, zicmlich reichliitliger Rispe, Bliithensticle schon am Grunde „etheilt; Kelchzipfel pfriemlich. $\odot$. Gras. plätze, Ackerraine, Hïgel selten. An breiten Acker. rainen zivischen Döllnitz und Burg Liebenau, in dell Weinbergen von Röglitz und Weissenfels, bisweilen in Hecken und Zäunen verwildert, so an 'Zäunen dem grunen Hofe gegeniiber. Mai-Juli. Blumen blass-blau. Höhe $1-3^{\prime}$. Aendert mit kahlen und rauhhaarigen Stengelı und Blättern und aufrechten und zurückgeschlagenen Kelchzipfeln ab.

695. C. persicifolia L., pfirsichblätterige G. Stengel aufrecht, meist einfach; Blätter entfernt-klein- 
gekerbt, die vurrzelständigen länglich-verkehrt-eifürmis, in den Blattstiel verschmälert-herablaufend, die steigelständigen linealisch-lanzettlich, sitzend; Bliillen in. armblitthigen Trauben; Bliithenstiele ungetheilt; Kelch. zipfel lanzettlich, zugespitzt. 4. 'Truckene Wälder, grasige Hügel häufig z. B. in der Dölaner Heide, in Mittelholze, Bienitz u. s. w. Juni. Juli. Blume gross und weit, blau, seltener weiss. Höhe $1-3{ }^{\prime}$. Die Pflanze ist meist völlig kahl, ändert aber mit graulichkurzhaarigen Stengeln und Blättern ab.

B. Blüthen sitzend, in Aehren oder Köpfchen zusammengestellt.

699. C. glomerata L., geknäuelte G. Rchb. pl. crit. VI. Abb. $752-755$. Stengel anfrecht, stielrund; Blätter klein gekerbt, die wurzclständigen eiförmi oder ciformig-lanzettlich, am Grunde abscrundet oder her:förmig, die mittleren stengelständigen kurz-gestielt, eiförmig oder länglich, die obersten mit herzförnigem, stengelumfassendem Grunde sitzend; Bliithen sitzend in end- und seitenstïndiøen Köpfchen. 24. 'Trockene Berg. abhänge, grasige Plätze, 'Triften stellenweise. In Vugelsberge bei Bennstedt, an Triften zwischen Pfitcen. burg und Wansleben, an Bergen an der Saale bei Brach. witz, auf Rainen östlich von Gutenberg, an der Chaussee bei Gross-Kugel, bei Röglitz, auf Wiesen zwischen Göhren und Rodden, pbenso bei Kl. Dölzig und am Bienitz, bei Nammburg an Kalkhügeln häufig, an Kalkbergen bei Bottendorf, bei Allstedt am Frevel, bei Dessau stellenweise. Mai. Juni. Blume blau. Höhe $3 / 4-1 / 2 '$. Die Pflanze ist meist kurzhaarig oder grau. flaumig, selten kahl.

C. Cervicaria L. kommit erst ausserhalb des Gebietes bei Kl. Helmsdorf unweit Osterfeld vor; sie ist zwar friiher anch bei Hettstedt gesammelt, indessen ist dem Verfasser der Standort nicht genan bekannt, und daher nicht aufgenommen.

280. Speculárin Heist. Frauenspiegel (der Name ist aus der früheren Benennung dieser Pflanze Speculum Veneris gebildet).

700. Sp. Spéculum Alph. BC., ächter F. Stengel aufrecht, ästig, spreizend, die unteren Aeste rerJängert, aufstrebend; Blätter länglich, die unteren verkchrt-eiförmig; Blüthen einzeln; Kelch kahl oder fein- 
haarig, mit abstehenden, endlich zurückgeschlagenen, linealischen Zipfelı, welche so lang oder etwas kürzer als die Blume sind; Kapsel linealisch-länglich, prismatisch. $\odot$. Auf Aeckern nnter der Saat sehr selten. Einzeln und unbeständig auf Aeckern bei Kl. Dölzig und an Bienitz, weit häufiger und beständig auf Aeckern bei Naumburg, besunders auf der rechten Seite der Saale. Juni. Juli. Campanula Speculum L. Prismatucarpus Speculum L'Herit. Blume viulett, in der Mitte weiss, selten ganz weiss. Höhe $1 / 2-3 / 4$.

\section{Familie. I'accineen DC. Heidel- beergenächse.}

281. Vacenturum. He i d elbecre (ejn bei Virgil vorkommender Pflanzenname, welcher eigentlich Bacci. nium, Beerenstrauch, heisst, von bacca, Beere).

A. Yỵrtillus. Blätter abfüllig; Blumenkrone kuggelig; sitaubbeutel anf dem Kucken 2hörnig.

701. T. Mryrtillus L., geme ine H. Hayne . Irz. neigew. 11, 7. Stengel anfrecht, nebst den Aesten scharfFantig; Blätter abfüllig, eiförmig, flach, klein-gesägt, beiderseits grün; Blïthenstiele Lblüthig, einzeln, blattwinkelständig, übrhänuend; Blumen hugelig. t. In Wäldern häıfig. Mai. Juni. Blume grünlich, röthlich ïberlaufen; Beeren schwarz, blau-bereift. Stengel bis ' hoch. OFF. baccae Myrtilli.

B. Vitis Idaea (der durch Missverständniss dieser Pllanze beigelegte Name bedeutet Rebe ron Ida; sie kommit aber auf dem Ida nicht ror). Blätter imnmergrün; Blumenkrone glockenförmig; Staubbentel auf den Riicken wehrlos.

702. V. Vitis idaea L., rothe H., Preussel. beere. Hayne Arzneigew. IV, 19. Stengel und deste stielrund; Bläitter immergrïn, verliehrt-eiförmig, stunıf, sehr schwach-gekerbt, am Rande zurückgerolit, unter: seits dunkel punktirt; Blïthen glockig, in endständiger, dichter, überhängender 'Traube; Staubbentel wehrjos, Griffel länger als die Blume. t. Hochgelegene Wälder sehr selten. Bei Naunburg hin und wieder z. B. in Buchholze, vielleicht auch einzeln im Loderslebel. Forste, welchen Standort Spreng. angibt, selten bei 
Oranienbaun, häufiger bei Gräfenhainchen. Mai-Juli. Blume röthlich - weiss oder weiss. Beeren roth.

C. Oxyeoccos (von o’kis, sauer, und xixyos, Keru, Beere, eigentlich Sauerbeere). Blätter immergrïn, Blumenkrone radförmig; Staubbeutel anf den Rücken wehrlos.

703. V. oxycóccos L., Mo o sbeere. II ayne Arz. neigew. IV, 18 Stengel hriechend, mit fadenfüirmigen, liegenden Aesten; Blïtter immergriïn, eiförrnig, ziemlich spitz, ganzrandig, unterscits aschgrau; Blüthen endständig, lang - gestielt, nickend, radförmig, zurückge. schlagen. $\hbar_{2}$. Auf 'Torfmouren sehr selten. Nur auf Torfmooren bei schieran und 'Törten sïdlich von Des. san und an der Luchwiese bei der Briichmïhle unweit Oranienbaum. Mai. Juni. Oxyencens palustris Pers. Schollera Oxycoccos Roth. Blumen und Beeren ruth.

\section{Familie. Ericineen Desv. Heide- krantgewächse.}

1. Gruppe. Ericeen DC. Frucht kapselig. Blumenkrone verwelkend.

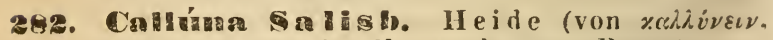
reinigen, wegen der Verwendung zu Besen).

704. C. vuigaris Salisb., gemeine H. Hayne Arzneigew. IV, 17. Blätter 4reihig - dachziegelig, linealisch, stumpf, am Grunde pfeilförmig; Blüthen in ziemlich einseitigen 'Jrauben; Kelch länger als die Blume; Staubbeutel am Grunde mit 2 flachen, gezähnten Anhängseln. Ђ. In Wäldern gemein. Aug. - Ilerbst. Lirica vulgaris L. Blumen blass-rosenroth, seltener "eiss (mit dieser letzteren Farbe z. B. in der Dölauer Heide). Ein aufsteigender, kleiner, $1-3^{\prime}$ hoher strauch.

283. Errien He Heide (von żoziหzu, hrechen, wegen der Brüchigkeit mehrer Arten; der Name kommt schon bei 'itheophrast vor).

705. E. Tétralix L., S $\mathrm{s} m p$ f - H. Blätter' 3 - odel' 4ständig, linealisch, am Rande abgerundet, steifhaarig gewimpert; Blüthen endständig, kupfig - duldig; Blumenkrone länglich-krugförnig; Staubbeutel am Grunde des Rückens gehörnt. ち. Auf 'Torfmuoren sehr' selten; nur in der 'Torfstecherei bei Möst süllich ron Dessau, 
aber daselbst häufig. Juli. Aug. Blume fleischfarben. Ein aufsteigendel $1 / 2-1 \frac{1}{2}$ ' hoher Strauch.

Andromeda polifolia I. ist schon ausserhalb der Grenze auf 'l'orfboden an rothen Hause zwischen Dïben und Eilenburg.

2. Gruppe. thodoreen DC. Frucht kapselig. Blumenkrone abfüllig.

284. Meduran. Purst (Pflanzenname bei Dioseorides).

71)6. L. palustre L., Sumpf-P. Hayne Arznejgew. 111, 21. Blätter limpalisch, am Ramle ungrerollt, unterseits nebst dell jünger'n Aestehen ustbraun-filzig; Blüthen in einfachen Dulden. t. Torfig-sumpfige stellen sehr selten. Im lurfstirhe bei Crina östlich ron Bitterfeld und an einigen Turfsinupfen in der Dübenter Heide: bei Pouch, "rlohen Standort s preng. angibt. hat jedoch der Verfasser rergeblich gesucht, dagegen ist es nach vorliegenden Lixemplaren in lodersleber Furste gefunden vorden. Misi. Juni. Blame weiss, selten rosenroth. Ein 2-4' huher strauch, weleher hier vom Volke Muttenkraut genannt wird. Die Blitter hahen einen unangenehmen, stark-narkutisclien Geruch. OFF. herba Ledi palustris.

\section{Familie. Pyrolaceen Lindl. Win- tergrüugew ächse.}

285. Wintergrän (der bei Otto Brunfeis zuerst rorhommende Name ist Dinimutiv von pyrus, Birnbaum, wegen der Aehnlichkeit der Blätter mit denen des Birnbilums).

707. P. rotmadifolia L., rundblätteriges $\mathbb{W}$. Hayne Arzneigtw. IV, 21. Bläter kreisrundlich oder rundlich-eiförmigr, stumıf, am Grunde abgerundet; Blïthen in verlängerter, luckerer, allseitiger 'raube; Staubgcfässe aufwärts gekrümmt; Griffel abwärts geneigt, an der Spitze Logenförmig; Blumenblätter verhehrt-eifürmig; Kelchzipfel lanzettlich, zugespitzt, an der spitze zurïckgekrunmt, halb so lang als die Blıme. 2l. In schattigen Wädern stellenweise. In der Ileide nach Dölau zu selten, bei Burg Liebenau häufig, ım Bienitz selten, bei Naumburg stelienweise, an Pfur. tenberge einzeln, hïufiger vor den Laasen in einer 
waldigen, buschigen Schlucht, an den Bergen bei Bibra sparsam, im Lodersleber Forste, bei Eisleben im Bischofsiöder Forste, bei Lingenau und Oranienbaum. Juni. Juli. Blume weiss, oft etwas röthlich. Schaft $6-12^{\prime \prime}$.

70S. P. chlorantha $\mathbf{s}$ artz, gr iinblit higes W: Hayne Arzneigew. IV, 22. Blätter verkehrt-eiförmig oder rundlich-eiförnig, vorne abgestutzt oder abgerundet, in den Blattstiel verschmälert; Blüthen in lockerer, mehr oder weniger verkürzter, allseitiger 'Traube; Staubgefässe aufwärts-gekrünmt; Griffel abwärts-geneigt, an der Spitze bogenförmig; Blumenblätter verkehrt-eiförmig; Kelchzipfcl eiförmig, kurz-zugespitzt, so breit als lang, an die Blume und Kapsel angedrïckt, 4mal lürzer als die Blume. 24. In Laub-und Nadelwäldern sehr selten. Im Walde zwischen Wendelstein und Ziegelroile, besonders an der sogenannten Platzpliitze, in Rathsholze bei Allstedt sehr sparsam, nach spreng. auch in Nadelwäldern bei Pouch und Crina östlich rou Bitterfeld. Juni. Juli. P. virens Schweigg. u. Körte. $\mathrm{P}$. media $\mathrm{H}$ ayne, nicht $\mathrm{S}$ w. Blume grinlich-weiss. Schaft $6 "$ hoch.

709. P. media $\$$ wartz, mittleres $\mathbf{W}$. Blätter kleisförmig oder rundlich-eiförmig, stumpf; Blüthen in etwas verlängerter, lockerer, allseitiger 'Traube; Staubscfässe gleichförmig-zusammenschliessend; Griflel schief, nicht gekrïmmt, der King an der. Spitze des Griffels breitcr als die Narbe. 4. Schattige Wälder. Wiild ron Spreng. hal. ed. 2. p. 194 in schattigen $\mathrm{Na}$ delwäldern bei Pouch als selten angegeben; der Verfasser hat sie im Gebiete noch nicht gefunden. Juni. Juli. Blume weiss. Höhe $4-8^{\prime \prime}$.

710. P. minor L., kleines W. Sturm Heft 13. Bläter länglich-kreisrundlich, abgerundet oder spitzlich; Blïthen in dichten, allseitigen T'rauben; Slaubgcfässe von allen Seiten gleichförmig gegen den geraden und senkrechten Griffel geneigl; Narbe 5kerbig, noch cinmal so breit als der Griffel. 24. Huchoelegene Wälder nicht gerade selten. In der Dölaner Heide spar. sam, in Bienitz selten, bei Naumburg, Ludersleben, Allstedt, Eisleben hänfig und sonst ziemlich verbreitet. Juni. Juli. Blume hell-rosemroth. Schaft $4-8^{\prime \prime}$ hoch.

711. F. secunda L., einseitsblïthiges W. sturm Heft 13. Blätter eiförmig oder eiförmig-länglich, spitz, klein-gesügt; Bliillien in zienlich dichten, 
cinscitswendigen Trauben; Blumenblätter ovah.länglich; Griftel hervirragend, ein wenig aufwärts gebogen. In Laub- und Nadelwäldern stellenweise. Jn der Dölauer Heide sparsam, in Bienitz selten, bei Naumburg häufig z. B. in Buchholze und nach dem Nordthale zu, im Loderslelin Forste stellnwweise: bei Eisleben im Bischufsröder Holze, bei Lingenau häufig. Juni. Juli. Blunı grïulich-weiss. Höhe 4-6".

712. W. Wniflora L., e inblüthiges W. Srhaft cinbliithig; Blätter rundlich uder eiförmig, in den Blattstiel kurz-zugespitzt; Narbe gross, 5herbig. 4 . In Wäldern gern in feuchten Moose, sehr selten. In einem Nadelwäldchen zwischen Lodersleben und Ziegelrode; run Schwabe in Wäldern bei Dessau und Oranienbaum als zerstreut vorkominend, bei Lingenau als häufig angegeben. Juni. Juli. Muneses grandiflora Sa lisb. Blumenblätter ganz flach ausugebreitet, gross,

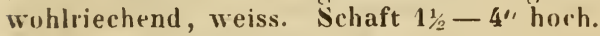

713. P. umbellatum L., duldenblüthiges W. Blätter lanzettlich-keilförmig, gesägt; Bliithen in endstïndigen, 3-6hliithigen Dolden; Staubgefässe au Grunde plattgedrückt, Givfel gerade, anfrecht, sehr kurz. 4. In Berg - und Ileidewälderu sehr selten. Mit Sicherheit nur zwischen Solluitz und Oranienbaun. Jnni. Juli. Chimaphila umbellata Nutt. Blume rosenroth oder weiss - röthlich. Schaft 3-6" huch.

Diese seltene Pflanze wird von Spreng. hal. ed. 2. p. 195 im Lodersleber und Winkelschen Forste als sehr selten und bei Bitterfeld und Sandersdorf angegeben, an welchen Orten ler Verfasser sie noch nicht gefun. den hat.

\section{Familie. Monotropeen $\mathrm{N}$ utt. Ohn- blat ge ewächse.}

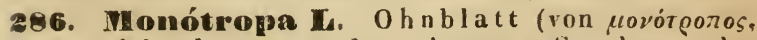
einsam lebend, wegen des einsamen Standurtes der Pflanze unter Fichten, daher Hypopitys von izo, unter, und ritus, Fichte, und unter Buchen, daher Hypophegea von qryós, Buche).

714. M. Mypópitys L., gemeines 0 . Rchb. $\mu l$. crit. V. Ahb. 674 und 675. Wurzelstock dickfleischig; Schaft blattlus, mit weissgelben Schuppen besetzt, an der Spitze eine vielblüthige, mit Deckblättern besetzte, 
oft nickende Traube tragend; Kelchblätter oberwärts breiter, gezähnelt; Blumenblätter gewimpert; Griffel mit einer grossen, trichterförmigen, honiggelben Narbe. 4. In schattigen Laub - und Nadelwaldungen auf Baumwurzeln schmarotzend, nicht gerade selten. In der Dölauer Heide, sparsam, im Bienitz, in den Wäldern bei Naumburg, Wendelstein, Ziegelrode, Lodersleben häufig, bei Allstedt in Rathsholze und in Theilholze, bei Lingenau und Oranienbaum häufig. Juli. Aug. Die ganze Pflanze blassgelb. Höhe $6-10^{\prime \prime}$. Aendert ab:

a) glabra Ko ch: die ganze Pflanze kahl; der Fruchtknoten nit kleinen, erhabenen Punkten besetzt. M. Hypophegea Wallr. Hypopitys glabra Bernh. und DC.; diese etwas seltene Form liebt Buchenwälder.

b) hirsuta Koch: Schaft zwischen den Blïthen weichhaarig; Deckblätter gewimpert; Kelchblätter innen an Kande, Blumenblätter auf beiden Seiten und am Rande nebst den Staubgefässen und am Stengel ranhliaarig. M. Hypopitys Wallr. Hypopitys multiflora Scop.; dies ist die gewöhnliche Form.

III. Unterclasse. Corollifloren. Kr on enblü thige.

Kelch frei, einblätterig. Blumenkrone einblätterig, unterständig. Staubgefässe der Blumenkrone eingefügt. Fruchtknoten frei.

\section{Familie. Oleaceen Lindl. Oel- b a umg ew äc lise.}

1. Gruppe. $0 \mathrm{l}$ eïneen. Aechte $0 \mathrm{clbaumgewächse.} \mathrm{Frucht}$ fleischig.

287. Ligustrum I. Hartriegel (Pflanzenname bei Virgil, von ligare, binden, wegen der Benutzung der Pflanze zu Flechtwerk).

715. L. vulgare L., gemoiner H. Hayne Arzneigew. V, 24. Blätter meist gegenständig oder zu 3, wirtelig, länglich - lanzettlich, kahl, ganzrandig; Blüthen in endständigen, gedrungenen Rispen. \$. Wälder, Waldränder nicht selten $z$. B. auf dem Bischofsberge in der Dölauel Heide, in Frenzelholze bei Lieskau, im Mittelholze, Bergholze, Krosigker Holze u. s. w., 
an welchen Orten dieser Strauch unstreitig wild ist, ausserdem aber öfters zu Verzäunungen und Hecken angepflanzt. Juni. Juli. B!ume weiss. Beeren erbsengross, schwarz. Ein 6-10' hoher Strauch.

2. Gruppe. Lilaceen Vent. Fliedergewächse. Frucht trocken.

288. Syrinaza T. Flieder (Pflanzenname bei Dodonaeus; von $\sigma \dot{v} \varrho y^{\prime} \xi$, Rohrpfeife, wegen des ehemaligen Gehrauches dazu).

716. S. Vulgaris L., ge me in er F. S t r s Heft 2. Blätter gegenständig, herz - piförmig, zuџespitzt, ganzrandig; Blüthen in endständigen, gedrungenen Rispen. Ђ. Stammit nach der gewöhnlichen Ansicht aus Persien und Lngarn, ist jetzt aber sehr häufig in Zäunen und Gärten angepflanzt und verwildert. April. Mai. Blume blau, röthlich oder weiss, wohlriechend. Ein oft baumartiger Strauch von $10-20$ ' Höhe.

389. Fráximers I. Esche (Pflanzenname bei Virgil; von ı $\varrho \iota_{\xi} \iota \varsigma$, Unzäunung, weil dieser Baum in Südeuropa häufig in Hecken gepflanzt wird).

717. F. excelsior L., ge meine E. Stur m Heft 44. Blätter unpaarig-gefiedert, mit $3-6$ Blättchenpaaren; Blättchen sitzend, länglich-lanzettlich, zugespitzt, gesägt; Blïthen vor den Klättern entwickelt, nur aus Staubgefässen und Stempeln bestehend; Früchte keil. förmig-lanzettlich, an der Spitze lang-geflügelt und daselbst schief-ausgerandet. $\hbar$. In Wäldern, Dörfern, an Flussuferm nicht selten angepflanzt. April. Mai. Blüthen whne Kelch und Blumenkrone. Ein Baum von $80-120^{\prime}$ Höhe. Aendert besonders in Anlagen mit goldgelber Rinde, herabhängenden Aesten und gekräuselten Blättern ab,

\section{Familie. Asclepiadeen R. Br. Sei- denpflanzengew äc hse.}

290. Cynanchum L. S chwalbenwurz (von

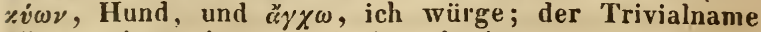
Vincetoxicum ist aus vincire, besiegen, und $\tau_{0} \xi_{\llcorner} x_{0}^{\prime} \nu$, Gift, zusammengesetzt, wegen vermeintlicher Wirkungen dieser Pflanze).

718. C. Vincetóxicum R. B r., ge me iner $\mathrm{Sch}$. Hayne Arzneigew. VI, 30. Stengel aufrecht; Blätter 
gegenständig, herz - eiförmig, zugespitzt, am Kande und aut den Nerven weichhaarig; Bluthen in blattwiukel. ständigen, gestielten Duldeu; Blunenkrune ralförmig, tief-5spaltig, mit eiförnigen Zipfelı; Staubgelasse in einen Cylinder verwachsen, welcher die beiden stempel bedeckt. 4. Trockene Wälder, Gebüsch, felsen nicht selten, z. B. am Felsen bei Kröllwitz, in der Dölaues Heide, Frenzelholze, Mittelholze u. s. ". Juni. Juli. Asclepias Vincetoxicum L. Blumenkrome innen weiss, aussen gelblich - weiss, an Grunde grünlich. Höhe 1-2'.

\section{Familie. Apocyneen R. Br. Hunds - gif tgewächse.}

291. Vinea L. Singrün (Pflanzenname bei Plinius, von vincire, binden, wegen der zähen Stengel).

719. W. minor L., kleines S. Stengel hingestrectit, kriechend, die blïthentragenden Aeste aufrecht; Blätter gegenständig, lanzettlich-elliptisch, völlig kahl, die oberen an beiden Enden spitz; Blïthen blattwinhelständig, einzeln, gestiplt; Blumenkrone präsentirtellerförmig, 5spaltig, mit schief-abgestutzten Zipfeln; Stauh. beutel über dem Stempel zusammenneigend. 7. Wälder, Haine, schattige Hecken, Felsen stellenweise. Am Felsen der Gärten vor Giebichenstein (auch in Schimelzers Garten), bei Burg Liehenau, Weissenfels, häufig bei Naumburg, bei Freiburg verbreitet z. B. in der neuen Giehle und in Mühlholze, bei Allstedt in dent wiisten Bergen und am nordwestlichen Rande des Rathsholzes häufig, bei Lisleben im Bischufsröder Holze. April. Mai. Blume hellblan, selten weiss.

\section{Familie. Gentianeen Juss. G en - zi a nengew äclıse.}

1. Gruppe. Menyantheen. Biberkleegewächse. Fruchtknoten auf eine unterständige Scheibe gestellt oder mit Drüsen umgeben. Blätter wechselständig.

292. Nenyanthes L. B i he rklee (cin im Mittelalter gebildeter Name zweifelhafter Abstammun, ; am wahrscheinlichsten ist die Ableitung von $\mu \eta v v \varepsilon \varepsilon$, anzeigen, und ăsıos, Blume, eigentlich die Pflanze, welche (schöne) Blüthen anzeigt. Aus Biberklee wurde auch Fieberklee). 
720. M. trifoliata L., dreiblätteriger B. Hay ne Arzneigew. III, 14. Wurzelsturk kriechend; Blätter grundständig, lanぬ -gestielt, 3fingerig, Blättchen velkehrt-eiförmig, stimpf uder spitzlich, ganzrandig oder schwach ausgeschweitt; Blattstiele am Grunde scheidenförmig; IBlïthen in einer zienılich dichten 'Traube. 4. Sumpfige Wiesen stellenweise. Sumpfwiesen untes dem 'Tannenberge bei Gutenberg, Wiesen zwischen Phitzenburg und Wansleben, in Torfsticlien an der Fuhne z. B. bei Iöbersdurf häufig, Wiesen bei Kl. Dölzig und an den Quellen zwischen len Bipnitz und Riickmarsdorf, bei Osterfeld nach 'l'euchern hin hüufig, fehlt bei Weissenfels und Naunburg; bei Bibra nicht selten, Wiesen unter der Steinhlippe zwischen KI. Wangen und Wendelstein, Wiesen zwischen Opphausen und Nemsdurf, bei Wurmsleben an der nördlichen Seite des süssen Sees, bei Aschersleben sparsam, bei Oranienbaum nicht selten, in Bruche zwischen sindersulorf und Bitterfeld. Mai. Juni. Blume weisslich-fleischfarben, mit "eissen l'arte; Stambbeutel violett. Schaft $1 / 2-1 '$ huch. OFF. herba 'Trifulii fibrini s. aquatici s. paIudusi.

2. Gruppe. Gentianeae verae. Aechle Genziancngewächse. Die unterständige Scheibe fehlend; Blätter gegenstăndig.

293. Lentinma $\mathbf{L}$. Genziane (nach dem illyrischen Könige Gentius benaunt, "elcher die Heilkrüfte ler Gentiana lutea L. entdeckt haben sull; der 'Trivialname P'neumonanthe kummt von $\pi v \varepsilon \dot{v} \mu \omega \nu$, I sunge, und « Lungenkrankheiten).

A. Coelanthe Froel. Blumenkrone mit kurzer Röhre und sadförmigem Saume oder röhrig-glockig. Schluud nacht. Stengel stets einfich.

721. C. cruciata L., kreuz fö rmigrer G. Bläitler lanzettlich, 3nervig, am Grunde scheidenförmig-verbunden, die unteren Scheiden verlïngert, oberwïrts erweitert; Bliithen quirlfürmig; Kelch röhrig-glockig, 4zäbrig, Blumenkrone 4spaltig, im Schlunde nackt, mit fast eulenförmiger Röhre; Staubbeutel frei. 24. Trokkeue Wiesen, sunnige Hügel stellenweise. Fehlt in der Nähe von Halle; einzeln auf Wiesen bei Möritzsch, KI. Liebenal und Kl. Dölzig, häufiger an Kruge bei lleissenfels und besonders bei Naumburg z. B. zwi- 
schen Almerich und Schulpforte, bei Freiburg an südlichen Rande der ncuen Giehle und an trockenen $\mathrm{Ab}$. hängen des Mühlholzes nach Balgstedt zu, an Bergen bei Bibra, im Hagen bei Esperstedt, in den wiisten Bergen bei Allstedt, an der alten Burg bei Aschersleben. Juli-Sept. Blume innen schön azurblau, aussen violett. Höhe $1 / 2-1 \frac{1}{2}$.

722. G. Pneumonanthe L., g e me in er G. S turm Heft 30. Stengel 1-bis mehrblüthig; Blïthen einzeln oder zu zweien an der Spitze des Stengels oder in den oberen Blattwinkeln; Blïtter lanzettlich-linealisch, stumpf, die untersten schr klein, schuppenförmig; Kelch röhrig, mit 5 verlängerten, linealischen Zähnen; Blumenkrone 5spaltig, im Schlunde nackt, mit keulenförmig-glockiger Röhre; Staubbeutel verwachsen; Narben linealisch. 24. Sumpfige, besonders torfhaltige Wiesen stellenweise. An der Fuhne z. B. bei Löberitz häufig, auf sumpfigen Wiesen bei Möritzsch, ebenso zwischen Göhren und Kodden, bei KI. Liebenau, KI. Dölzig und an den Quellen zwischen dem Bienitz und Rückmarsdorf, bei Osterfeld nach Meinweh zu, fehlt bei Naum. burg, Bibra und scheint im ganzen westlichen Gebiete nicht zu wachsell, dagegen im nordöstlichen Gebiete häufig, so bei Dessau, Oranienbaum, an der Benndorfer Mühle. Juli - Herbst. Blume inwendig dunkel azurblau, mit 5 grïnpunktirten Streifen. Höhe $1 / 2-1^{\prime}$. Aendert $\mathrm{ab}$ :

b) elliptica Kl. u. Richt.: Blätter breit elliptisch länglich oder elliptisch - lanzettlich.

723. A. acaulis L., stengellose G. Sturm Heft 4. Stengel 1bliithig; Wur ielbläitter rosettenartig, lanzettlich oder elliptisch; Kelch keulenförnig - röhrig, mit lanzettlichen, zugespitzten, an dic Blumenkronröhre angedriickten Zähnen; Blumenkrone im Schlunde nackt, mit. keulenförmig - glockiger Röhre; Staubbeutel verwachsen; Narben halbkreisförrmig, gezähnelt. 24. Triften, Bergabhänge sehr selten, nur bei Freiburg iiber dem Mühlholze, und daselbst äusserst selten. Juni. Juli. Blume gross, azurblau. Höhe 2-4".

B. Endotricha Froel. Schlund der Blumenkrone inwendig bärtig.

724. G. campestris L., Fel/-G. Blättel eiförniglanzettlich, spitz, die wurzelständigen verkehrt - eiförmig, gestielt; Kelchzähne ungleich, die 2 äusseren breit - 
elliptisch; Blumenkrone 4spaltig, im Schlunde bärtig, mit stumpfen Zipfeln; Narbe gespalten, ihre Lappen nach der Blïthe abstehend, fast zurïckgerollt. $\odot$. Hochgelegene Wiesen selor selten, nur im Sandthale des Lodersleber Forstes und bei Allstedt auf der Wuste und an Kloster Naundorf. Aug. Sept. Blume bläulich. violett. Höhe 4-10".

725. G. germanica willd., de uts che G. Sturm Heft 23. Blätter sitzend, eiförmig, aus breiterem Grunde verschmälert, spitz, die wurzelständigen verkehrt - ej. förmig, gestielt; Kelch mit 5 linealischen, lanzettlichen, fast gleichen Zähnen; Blumenkrone mit 5 spitzlichen, linealisch - länglichen Zipfeln, im Schlunde bärtig; Narbe gespalten, ihre Lappen nach der Blüthe aufrecht-ab. stehend. $\odot$. Wiesen, Triften, Waldränder nicht gerade selten. Am Vugelsberge bei Bennstedt, auf Abhängen vor dem Mittelholze, Triften zwischen Pfitzen. burg und Wansleben; häufig in Wäldern bei Müicheln, Naunburg und Freiburg, bei Allstedt in den wüsten Bergen, bei Eisleben an Rande des Bunstedter Waldes und sonst verbreitet. Aug. - Octob. G. Amarella Pollich., nicht Lin. Blume violett. Höhe 4-12".

Hierher gehört auch die in Gebiete nicht vorkommende G. Amarella L. bei Spreng. ed. 2. p. 110, welche sich durch schmälere Blätter und weit kleinere Blüthen unterscheidet.

C. Crossopetalum Froel. Blunenkrone mit gefransten 'Zipfeln. Schlund nackt.

725. G. ciliata L., gefranste G. Sturm Heft 23. Stengel aufrecht, meist einfach, etwas geschlängelt, kantig; Blätter linealisch-lanzettlich; Blüthen endständig; Blumenkrone 4spaltig, im Schlunde nackt, mit gesägten, in der Mitte eingeschnitlen-gefransten Zipfeln. 4, nicht $\odot$, wie Koch u. A. angeben. Schwach begraste Abhänge der Kalkberge selten. Fehlt bei Halle, Mlerseburg und Weissenfels, nicht selten bei Naumburg, sparsam bei Freiburg an Schlifter, sehr häufig in den Schmonschen Bergen, an Kalkbergen bei Reinsdorf am Wege nach Barnstedt, an Kalkbergen zwischen Rossleben und Buttendorf, ist jetzt aber an Buchberge, wo sie einst Wallr. fand, verschwunden, an den wüsten Bergen und an den Pulvertannen bei Allstedt, auf der Grenze des Gebietes bei Annerude unweit Mannsfeld, bei Aschersleben schon ausserhalb der Grenze in der Feld. 
mark Paderborn, bei Sandersleben fruher an Schiessberge. Aug. Sept. Blume schön blall. Höhe 4-12".

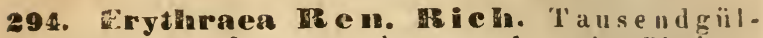
d e n k r a u t (von ż $v \vartheta \varrho o s$, roth, wegen der ruthen Blüthen).

726. E. Centaurium Pers., ge meines' $T$. H a yne Arzneigew. 1, 29. Stengel einfach, 4kantig; Blïtter oval-länglich, meist 5nervig, die grundständigen meist rosettenaitig; Ebenstrauss endständig. gebüschelt, nach den Verbliihen zienılich luclier, immer gleich hoch, die gabelständigen Bliithen sitzend: Blumenkrone mit ovalen Zipfeln. (-). Triften, freie Waldstellen häıfig z. B. am Donnersberge hinter Kröllwitz, anf dem Bischofsberge in der Dölauer Heide, in Mittelhulze u. s. w. Juli. Aug. Gentiana Centaurium I. Chironia Centaurium Schnidt. Blume pficsichblüthig, selten weiss. Höhe $1 / 2-1^{\prime}$. OFF. herba et flures s. summitates Centaurii minoris.

727. E. pulchella Fies, niedliches T. Hayne Arzneigew. I, 30. Stengel scharf 4 kantig, vom Grunde oder von der Mitle an wiederholt.gabclig; Blätter eiförmig oder eiförmig - länglich, meist 5 nervig, die grundständigen meist nur gegenständig; Blïtlen end-und blattwinkelständig, anch die gabelständigen deutlich-gesticlt; Blumenkrone mit lanzettlichenZipfeln. (-). Fenchte Wiesen, Atcker, Triften häufig z. B. auf Aeckern vor Seeben, auf Wiesen und Aeckern zwischen Halle und Nietleben, sehr häufig' auf salzhaltigen 'Triften zwischeu Kölme und Langeubugen und am salzigen See bei Rollsdorf II. s. w. Juli - Sept. E. inaperta Schlecht. E. ramosissima Pers. Gentiana Centaurium $\beta$. L. Chironia Gerardi Sch midt. Blumen pfirsichblüthig. Höhe $2-6^{\prime \prime}$. Aendert mit ganz niedrigen, $1-3$ blüthigen Stengeln ab.

728. E. linariacolia Pers., s chmalb lätteri. ges 'I. Reh b. pl. crit. I. Abb. 185-189. Stengel etwas zusammengedrückt, ungleich 4 kantig; Blätter linealisch oder linealisch-länglich, meist 3nervig; Ebenstrauss zuerst gleichhoch, später in aufrechte, rispigverläingerte Aeste mit entfernt gestellten, meist 3zähligcn Bliithen sich entwickelnd; Blumenkrone mit ovalen Zipfeln. $\odot$. Salzhaltige 'Iriften selten. Auf salzhaltigen Wiesen bei Röblingen, ebenso auf der Grenze des Gebietes zwischen Artern und Kihstedt sparsam, häufiger an gleichen Orten zwischen Stassfurt und Bernburg. 
Aug. Sept. E. littoralis Fries. H. compressa Hayne. Ł. angustifolia $W$ a $/ 1 \mathrm{r}$. Blume pfirsichblüthig. Höhe $3-8^{\prime \prime}$.

\section{L.XVI. Familie. Convolvulaceen Juss. W in - dengewächse.}

1. Gruppe. Genuinae Link. Aechte Windengewächse. Pflanzen mit Blättern und Samenlappen.

295. Convólvulus L. Winde (ein vun Plinius aus convolvere, zusammenwinden, gebildeter Pflanzenname).

729 C. sepium L., Zaun-W. Stengel windend; Blätter pfeilförmig, mit abgestutzten, oft gezähnten Oehrchen; Bliithenstiele 4 kuntig, lblüthig, länger als ler Blattstiel; Kelch von 2 grosscn her-fürmigen Deckblättcrn eingeschlossen. 4. Hecken, Züune, Gebüsche, Flussufer gemein z. B. in Weidengebüsche an Schwalchloche hinter Kröllwitz, zwischen Gebiisch an der Saale in Wörmlitzer Hölzchen u. s. w. Juli-Herbst. Blume gross, weiss. Stengel 5-10' lang.

730. C. arrensis L., Acker.W. Sturm Heft 1. Sten_el windend; Blätter pfeilförmign, nit spitzen oder stumpfen Oehrchen; Blüthenstiele meist 1 blüthig; Kelch nicht eingchiillt, dic Deckbliitter klein und von der Bliithe entfernt. 4. Lecher. Schutt, Wegränder überall gemein. Juni, Juli und oft im Herbst wieder. Blume "eiss oder rusenroth, aussen mit $\mathbf{5}$ rothen Streifen. Stengel 1-2' lang. Aendert ab:

b) villosus Lej.: Stengel, Blätter nnd Blattstiele mehr oder minder stark kurzhaarig.

Conrolrulus Soldanella $\mathrm{L}$. will Wallr. nach ann. bot. p. 32 einmal und zwar ohne Blüthe am ehemaligen Kölnier See gefunden haben.

2. Gruppe. Cuscutinae Link. Seidengewächse. Pflanzen ohne Blätter und Samenlappen. Samenkeim spiralich gedreht.

296. Cuscuta H. S eịde (Flachsseide) (Name zweifelhafter Abstammung, vielleicht arabischen Ursprungs).

731. C. europaea L., puropäische S. Rehb. pl. crit. V. Abb. 690. Stengel üstig; Kelchzipfel eiförmig, spitzlich; Röhre dcr Blumenkrone walzenförmig, 
so lang als der Saum; die unter den Staubgefüssen befindlichen kleinen Schuppen aufrecht, der Röhre der Blumenkrone angedriickt; Narben fadenförmig. $\odot$. Auf Nesseln, Hopfen, Hanf und Weiden schmarotzend. Juli. Aug. C. maior DC. C. vulgaris P e rs. Bliithen in Knäueln; Blumen röthlich. Blumenröhre offen. Sten. gel $6-8^{\prime}$ weit kletternd.

732. C. Epithymum L., Quendel-S. R c hb. pl. crit. V. Abb. 691. Stengel ästig; Kelchzipfel zugespitzt; Röhre der Blumenkrone walzenförmig, so lang als der Saum; dic unter den Stauhgefärsen befindlichen Schuppen gegen einander geneigt; Narben fadenförmig. $\odot$. Auf Heide, Quendel, Ginst schmarotzend, etwas seltener als vorige Art; häufig an den Bergen bei Rollsdorf. Juli. Ang. C. europaea $\gamma$. Epithymum I. C. minor DC. Blitithen halb so gruss als bei voriger Art. röthlich; Blumenröhre geschlossen; Schuppen in der Röhre etwas grösser. Der viel feinere Stengel ist $1-2$ lang.

733. C. Epilinum weihe, Lein-S. Rehb. pl. crit. V. Abb. 692. Stengel ganz einfach; Kelchzipfel stumpf; Röhre der Blumenkrone fast kuyelig, $2 \mathrm{mal}$ so lang als der Saum; die unter den Staubgefässen befind. lichen Schuppen aufrecht, der Röhre der Blumenkrone angedriickt. $\odot$. Auf Lein schmarotzend und demselben selir schädlich, aber im Gebirte zur Freude der Leinbauer nur änsserst selten. Juli. Aug. C. maior Koch u.Ziz. C. vulgaris Presl. Blüthen weiss, grösser als an den beiden vurhergehenden Arten. Stengel $1-2^{\prime}$ lang.

Cuscutina hassiaca Pfeiff. wurde im Jahre 1845 an der Magdeburger Eisenbahn Krausen's Garten gegenüber gefunden, war aber schon im folgenden Jahre wieder verschwunden.

XLVII. Familie. Boragineen Desv. B or agen $\underline{\text { gewä ch se. }}$.

1. Gruppe. Gynoglosseen Endl. Il undszungengewā chse. Nüsse 4, dem Grunde des Griffels angewachsen.

297. Asperúgo L. S c hlang enäugle in (ein von Plinius aus asper, rauh, gebildeter Pflanzenname).

734. A. procumbens L., li e gend es Sch. Stengel niederliegend, meist ausgebreitet-ästig, durch riick- 
wärts gerichtete Stacheln sehr rauh; Blätter länglich, in den Blattstiel verschmälert, alle stachelig-gewimpert; Blüthen blattwinkelständig, Blüthenstiele anfangs aufrecht, zur Fruchtzeit zurückgebogen; Kelch nach der Blüthezeit sehr vergrössert, flach-zusammengedrückt, buchtig.gezähnt. $\odot$. Schutt, Wege, besonders an alten Mauern und Ruinen, stellenweise. An den Pulverweiden einzeln, an Felsen bei Giebichenstein und auf der benachbarten Maner des Amtsgartens häufiger, an Zäunen zwischen der Maille und der Chaussee, an alten Millern auf dem Petersberge, bei Naumburg an Spechtsar zerstreut, an Schlosse bei Wendelstein sparsam, am Schlosse in Querfurt in der Nähe der Schäferei, bei Eisleben am Schlosse und an Züunen in der Nähe der Fellwäsche, bei Aschersleben zerstreut. Mai. Juni. Blume klein, röthlich-blau. Stengel $\frac{1}{2}-2^{\prime}$ lang.

298. Echinospérmum swartz. I gels a me

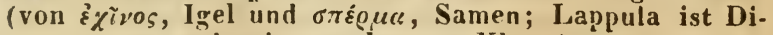
minutiv von Lappa, Klette).

735. E. Láppula Lehm., klettenartiger I. Sturm Heft 43. Stengel anfrecht, oberwärts ästig; Blätter länglich-lanzettlich, angedrückt, behaart-gewimpert; Blumenkrone meist länger als der Kelch; Blüthensticle auch nach dem Verblühen aufrecht; Nüsse an Rande mit 2 Reihen widerhakiger Stacheln, auf dem Mittelfelde und den Seiten mit Knötchen besetzt. $\odot$. Mauern, Schutt, Weinberge nicht gerade selten. Auf der Stadtmauer in Halle, auf Mauern in Giebichenstein, in Weinbergen zwischen Rollsdorf und Seeburg, auf Lehmmauern in Röglitz, Zöschen, Schkeuditz u. s. w. Juli. Aug. Myosotis Lappula L. Cynuglossum Lappula Scop. Lappula Myosotis Mönch. Blmmen klein, blau, einem Vergissmeinnicht ganz ähnlich. Höhe $1 / 2-1 '$. Die Blätter sind gewöhnlich weisslich-grau behaart, die Pflanze ändert aber ab:

b) squarrosum Rchb.: Blätter dunkelgrün, steifer behaart; Aeste sparrig-ausgespreitzt.

209. Cymoglóssum I. Hundszunge (ein aus $x \dot{v} \omega \nu$, Hund, und $\gamma \lambda \omega \sigma \sigma \alpha$, Zunge, gebildeter Pflanzenname bei Dioscorides).

736. C. officinale L., ge br äuchliche H. Hayne Alzneigew. I, 26. Stengel aufrecht; Blïtter von feinem, weichem Fïlie graulich, spitz, die unteren elliptisch in 
den Blattstiel verschmälert, die oheren aus fast herzförnigem, halbstengelumfassendem Grurde lanzcttlich: 'Traube whne Deckblätter; Staubgefässe eingeschlossen; Viisse vorne flach, mit einem zicmlich diclicn, hervor. tretenden Rande umgeben. $\odot$. Wegränder, Itiigel, unbebauete Plätze meist nicht selten. An Wegrändern zwischen Halle und Nietlebell, an Bergen bei Siranau und Bennstedt, an Ifegränderu zwischen Etzdorf und 'Teutschenthal häufig, sehr häutig an Ibhängen am salzigen See zwischen Wansleben und Rollsdorf, bei 'Tellditz, seltener bei Weissenfels, bei Naumburg verbreitet I. s. W. Mai. Juli. Blume braunroth. Höhe $1-3^{\prime}$. Die Blüthen haben einen widrigen Geruch.

737. C. montanum Lam., Berg-H. Stengel aufrecht; Blïtter zerstreut-behaart, spitz, oberscits fas? lahl, gliinzend, interseits etwas ranh, die unteren elliptisch, in den Blattstiel verschmälert, die mittleren fast spatelförmig, die oberen aus fast herzförmigem, halbstengelumfassendem Grunde länglich; 'Praube ohne Deckblätter; Staubgefüsse pingeschiossen; Niisse ohne hervortrctenden Rand. (-). In Bergwäldern. Wird von spreng. hal. ed. 2. p. 105 an Lindberge, Nomnenberge bei Bornstedt, im Geistholze bei Bisthofsrode angegeben; ob aber die Bestimmung richtig ist, vermag der Verfasser nicht anzugeben, da er diese Pflanze in Grbiete niemals gefunden hat. Sie bliiht im Juni, Juli. C. silvaticum II a enke. C. ufficinale $\gamma$. L. C. Diuscuridis Vill. Blume roth - violett. Höhe $1-2^{\prime}$.

Omphaludes scorpioides Lehm. ist früher im Walde bei Freckleben unweit Sandersleben gefunden und wird von $\mathbb{W}$ allr. auch bei Ostrau angegeben, ist aber an beiden Orten in néuerer Zeit wicht wieder heobachtet worden.

2. Gruppe. Anchuseen Endl. 0 ehsenzungengewä chsce. Nüsse 4, der unterständigen Scheibe eingefügt, am Grunde mit einem gedunsenen, gerieften Ringe versehen und innerhalb des Ringes ausgehöhlt. Griffel frei.

300. Horgero $\mathbf{H}$. B o rage (Boretzsch) (vielleicht ein orientalischer, die Rauhheit der Pflanze hezeichnender Name).

738. T. officinalis L., ge b $r$ ï u chli che B. Hay ne Arzneigew. III, 3s. Stengel aufrecht, ästig, borstig; Blätter steifhanrig, die unteren elliptisch, stumpf, nach dem Grunde verschmälert, die uberen eiförnig - länglich, 
stengelumfassend; Bluthen langgestielt, nickend. $\odot$. stammt aus dem Oriente, jetzt häufig in Gürten gehaut und bisweilen aut Schutt, ausgewirfener Gartenerde verwildert. Juni. Iuli Blume radförmig, schön blau, selten weis; staubbeutel schwarz. Höhe $1-2$ '.

301. Anchasa L. Ochsenzunge (Pflanzenname bei Dioscorides; von " $\gamma \chi \omega$, ich würze, wegen der Wirkungen; der dentsche Name Ochsenzunge ist Uebersetzung des älteren und verdrängten Buglossum).

739. A. officinalis L., gabräuchliche O. Haynt Arzneigew. I, 25. Stengel aufrecht oder aufsteigend, oberwärts ästign, mit abstehenden, langen, steifen Haaren besetzt; Blätter lanzettlich, steifharig; Deckl.lätter riförmig - lanzettlich; Kelch 5spaltig, mit ziemlich spitzen Zipfeln und nebst den Rispenästen mit abstehenden Haaren besetzt; Deckklappen am Schlunde der Blumenkrune eiförmig, sanmetartig. $\odot$, bisweilen 4. Unbebaute Orte, Ackerränder, unfruchtbare Abhänge, nicht gerade selten z. B. an Ackerrandern in der Nähe der Gersdurfer wüsten Feldmark zwische⿰ Kröllwitz und Isettin, häufiger an Ahhängen in der Nähe der Rejde zwischen Osenrorf und Döllnitz, bei Ermlitz u. s. I. Mai - Sept. Blume ganz violett oder nit azurhlauen Streifen oder ganz azurblau. Höhe $1-3$ '. Aendert mit mehr oder minder starker Behaarung, mit schmäleren und breiteren Blättern, mit dichteren und lockereru Aehren ab.

302. Lycopai̊ L. L, i e bä u g el (Pflanzenname bei Diosc. : von líxos, Wolf, und ôv'ıs, Gestalt, Aussehen).

740. L. arvensis L., Acker-I. Stengel aufrecht, pinfach oder ästig, nebst den Blättern steifhaarig; Blätter lanzettlirh, ausgeschweift-gezähnt, die unteren in den Blattstiel verschmälert, die oberen halbstengelumfassend; 'Traube mit Dechblättern besetzt; Röhre der Blumenkrone in der Mitte gekrünmt; Deckklappen an Schlunde der Blumenkrone dicht-zottig. $\odot$. Aecker gemein z. B. anf Aeckern an der Irrenanstalt, bei DöIau, I..ttin u. s. w Juni-Merbst. Anchusi arrensis M. B. Blume blan, mit Neisser Röhre. Höhe 1/2-1'.

303. Dómaca Botaniker Nonuc benannt).

741. N. pulla C., \& raune $\mathbb{C}$. Stengel aufrecht 
oder etwas aufsteigend, einfach oder ästig; Blätter lanzettlich, ganzrandig, mit kurzen Driisenhärchen dicht besetzt und zugleich angedriicht-steifhiarig, die blüthenständigen eiförmig-länglich; Kelch 5 hantig, zur Fruchtzeit erweitert, fast aufgeblasen; Samm der Blumenkrone so lang als die Röhre. (-). Aecker, Wegränder stellenweise. Auf Aeckern zwischen Seben und Gutenberg und zwischen Gutenberg und dem Petersberge, einzeln bei 'Zöschen, zwischen Schkopan und Merseburg, bei Weissenfels und Naumburg, häutig zwischen Langenbogen und Rullsdorf und besonders am Chausseegraben zwischen Seeburg und Eisleben, einzeln an der Hüneburg bei Eisleben, häufig bei Aschersleben, stellenweise bei Bernburg und Sandersleben. Mai-Juli. Lycopsis pulla L. Blume dumkel-purpurbraun, mit weisslicher Röhre. Höhe $1 / 2-1$ '.

304. Sýmplnytumn T. W all wurz (Pflanzenname bei Dioscorides; von $\sigma v \mu q v \varepsilon \iota \nu$, zusammenwachsen, wegen der ehemaligen Anwendung der Wurzel zur Heilung vou Winden).

742. S. officinale $\mathrm{L}$., g e bräuchliche W., B $\in$ in well. Sturm Heft 17. Wurzel spinclelförmig, ästig; Stengel aufrecht, ästig, ziemlich steifhuarig; Wurzelblätter gestielt, länglich-eiförmig, Stengelblätter am Grunde und all der Spitze verschmälert, au Stengel sehr weit herablanfend, die oberen und die blüthen. ständigen sitzend, Janzettlich; Blumenkrune kurz-5zähnig, mit zurückgekrümmten Zähnen; Staubbeutel doppelt so lang als die Staubfäden. 24. Nasse Wiesen, Gräben, Ufer gemein z. B. auf Wiesen bei Seben, Gutenberg, Nietleben u. s. w. Mai. Juni. Blume weiss, in Gebiete nur sehr selten roth oder violett. Höhe 1-3'. OFF. rad. Comsolidae maioris s. Symphyti. Aendert mit längerem und hïrzerem Griffel, slockigem Kelche und mit an der Spitze zurïckgekrümmten und abstehenden Kelchzipfeln ab. Die Furm mit abstehendem Kelche und ruthen oder violetten Blüthen heisst S. patens Sibth., die mit weissen Bliithen und langem Griffel S. bohemicum S $\mathrm{chm}$.

3. Gruppe. Lithospermeen. S teins a mengewă chse. Nüsse 4 oder \%, der unterständigen Scheibe eingefügt, anı Grunde nicht ausgehöhlt, sondern mit einem flachen oder etwas gewölbten Hofe angeheftet. Griffel frei. 
305. Eehium I. Natterko p (Pflanzenname bei

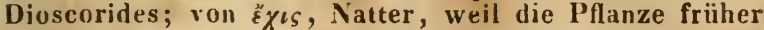
gegen den Biss der Natter angewendet wurde).

743. E. vulgare L., geme iner N. Hayne Arzneigew. I, 27. Borstig - steifhaarig; Stengel krautig, meist aufrecht; Blätter lanzettlich, die grundständigen rosettenartig; Rispe schmal, verlängert, aus genäherten, an der Spitze ungetheilten Achren bestehend; Röhre der Blumenkrone kürzer als der Kelch; Griffel an der Spitze 2spaltig; Staubyefüsse abwärtsgeneigt, spreitzend, dell Saume der Blumenkrone anliegend. (-). Trockene Aecker, Brachen, unbebaute Orte häufig z. B. am Schwalchluche hinter Kröllwitz, zwischen Nietleben und Bennstedt, bei Röglitz, Ermlitz u. s. w. JuniSept. Blume blan, selten weiss oder roth. Höhe 1-3'.

306. Pulmonaria L. L ungenk ra ut (der Name ist ron Bauhin aus pulmo, Lunge, gebildet, wegen der ehemaligen Anwendung der Pflanze bei Lungenkrankheiten).

744. P. officinalis L., g e brä uchliches L. Rch b. pl. crit. VI. Abb. 699. Stengel aufrecht, mit abstehenden Bursten und unternischten kïrzeren Drüsenhaaren besetzt; äussere Blätter der nichtbliihcuden Wurzelliöpfe heräörmig, gestielt, mit schmal-gefliigeltem Blattstiele, Stengelblätter eiförmi - elliptisch oder breit - elliptisch, die oberen sitzend; die Rölıre der Blume invendig unterhalb des Ilaarringes im Schlunde behaart. 24. In Wäldern häufig z. B. in Lindberge, Zorgs, Mittelholze u. s. w. März - Mai. Blume zueist ruth, dann violett. Blätter zuweilen weisslich oder hellgrün gefleckt. Höhe $1 / 2-1^{\prime}$. Aendert, wie die fulgende, mit kürzerem und längerem Griffel ab.

745. P. azurea Besser, azurblaues I. Rchb. pl. crit. Vl. Abb. 694. Stengel ziemlich steifhaarig, ohne Drüsenhaare; Blätter der nichtbliihenden Wurzelköpfe lanzetlich, an Grunde in den geflugelten Blattstiel verschmälert, Stengelblätter aufrecht, sitzend, schmal. lanzettlich, etwas herablaufend; die Röhre der Blume invendig unterhalb des Haarringes im Schlunde kahl. 4- Truckene, hochgelegene Wälder nicht gerade selten. In der Dölauer Heide, im Mittelholze, in der Abbatissine, im Bienitz zienılich häufig, bei Naumburg nicht selten z. B. uiber der Henne, nach Eulau hin, im Walde nach Janisrode zu, in der alten Giehle bei Frei- 
burg u. s. W. April. Mai. P'. augustifolia schra $n$ h. Bessera azurea Schult. Bhume azurblau. Höhs 6-9".

llierher gehört auch P'. allgustifolia $\mathrm{L}$. Lei sp re $\mathrm{r} g$. hal. ell. 2. p. 101, welche im Gehiete nicht vorkmmmt. Zwar soll sie nach Rohb. sax. ed. 1 U. 2. 1. 211 be sammburg Wachsell, Indessen ist dieser tiandort solir zn hezweifeln.

307. Cithospenumm L. Ste insame (ein ans lífos, Stein, und бтвция, Same, gebildeter Pllunzen. name bei Diuscurides).

746. L. officinale L., g e b r äuchlicher St. Hay. ne Arzneigew. V1, 29. Stengel aufreclit, selır iistion; Blätter lanzettlich, spit\%, durch sehr kurze, a川 Grundle in Knötchen verlickte Haare sehr rauh; Röhre der BSIImenkrone iom Kelihe üherragt, länger als der Suum; Viisse glatt. 24. An steingen Orten, unter Gebüsch, in II äldein nicht allgemein verbreitet. In Gebüsch an der Saale zwischen Kröllwitz und der Gersdurfer wiisten Feldmark, anf dem Bischufsberge in del Dölantel ileide, in Frenzelholze bei Lieshau, in Mittelholze, an Weinbergen vor Röglitz, fehlt in der Nälse von Weissenfels und Naumburg; bei Freiburg am Rande der alten Giehle und an Bergen zwischen Balgstedt und Laucha, an den Schmonschen und Grochstedter Bergen, an Kalkbergen bei Bernburg und Sandersleben. Mai Juli. Blume klein, grünlich-Weiss; Nüsse weisslich, stark glänzend. Höhe $1-2$ '.

747. L. purpureo-coeruleum L., p urpurb la u e St. Nichthliihende Stengel hriechend, bliithentragende aufrecht, an der Spitze 2-3spaltig; Blätter lanzettlich, spitz, nach dem Grunde verschmälert, ron angedruchten, hurzen Haaren rauh; Röhre der Blumenkrune den Kelch ein wenig uberragent, so lang als der Saunı; Viisse glatt. 24. Bergwälder, besunders an Kalkbergen unter Gebüsch, stellenweise. Im Zurgrs, Nittelhulze; fehlt in östlichen und süllichen Gebiete bis Weissenfels: hei Naumburg hänfigr z. B3. an P'furtenberge, bei Freiburg am südlichen Rande der neuen Giehle und am wheren Rande des Nühlhulzes, an den Bergen bei Bibra, an den Schmonschen und Grorkstedter Bergen, bei Eisleben an der Hüneburg, im Freckleber Holze un. weit Sandersleben. April. Mai. Blume zuerst roth, dann blau. Nüsse weisslich, etwas glänzend.

i43. C. arvense L., $A$ cher-St. Stengel aufrecht, 
iII der Spitze ästig, einfach oder am Grunde mit Nebenstengeln verseheu; Blätter lanzettlich, ziemlich spitz, von angedrückten, kurzen Harren rauh, die untere॥ länglich-lanzettlich, stumpf, in den Blattstiel verschmälert; Röhre der Bhnnenkivue weit länger als der Saum; Niisse runzelig-rauh. (). Auf Aeckerm überall gemein. April - Juli. Blume lilein, weiss, selten bläulich. Nïsse fast glanzlos. Höhe $1 / 2-1 \frac{1}{2}$.

308. Myosótis I. Vergissmeinuicht (ein ans uṽs, Mans, und ov̀s, Ohr, webildeter Pflanz'nname bei Dioscorides).

a. Kelch angedrückt-behaurt.

749. IT. palustris With., Sumpf- V. St urm IIeft 42. Wurzelstuck schief, kriechend; Stengel kantig, der Gefiiss - und Iastliundellireis desselben nahe am Unifange liegend, nur mit ciner diinnen Haut bedeckt; Blätter länglich-Ianzettlich, spitzlich; 'I'rauben blattlos, meist gestielt; Kelch 5 zahnig. mit angedriichten, gera. den Iliirchen beset $t$, nach dem Verblühen utfen. 4. Gräben, Bäche, Sümpfe, Wälder gemein. Mai-Aug. M. scorpioides W ill I. M. scorpinides $\beta$. palustris I. Blumen hellblau, seltener fleischroth oder weiss. Höhe $1 / 2-1 \frac{1}{2}$ '. Aendert mit grösseren und kleineren Blumen, mit längerem und ganz lurzem Griffel ab, so dass derselbe nicht als Unterscheidungsmerkmal benutzt werden kann; ferner :

a) vulgaris: Stengel abstehend-behaart. M. palustris Rchb.

b) strigulusa $\mathrm{Rchb}$.: Stengel angedrückt-behaart.

c) I axifl l ra R chb.: 'Irauben sehr verlängert, locker, die Blïthenstielchen sehr lang.

d) repens Don: Kelch tipf-5spaltig.

750. M. crespitosa Schultz (fl. starg.), rasen artiges $V$. Sturn Heft 42. Wurzel absteigend, überall faserig, Stengel stielrund, der Gefäss - und Bastbiindelkreis desselben tiefer im Inneren liegend und mit ciner dicken, fleischigen Haut bedeckt; Blätter länglich oder länglich-lanzettlich, stumpf oder spitzlich; Trauben fast immer stiellos und meist zwischen dell unte. ren 2-6 Blïtheu nuch Blätter tragend; Kelch 5spaltig, mit angedriickten, geraden Härchen besetzt, nach dem Verblühen offen. $\odot$. Gräben, feuchte Stellen, besunders auf lehmigen, feuchten Wiesen, nicht gerade selten. An den Teichen bei Dieskau, in der Aue bei Burg

Garcke, Flora. 
Liebenau, bei Naumburg in den Sümpfen der Ane häufig u. s. w. Juni - Aug. N. lingulata Rnem. u. Schult. Blume klein, hellblau. Der Griffel ist meist sehr kurz. Höhe $1 / 2-1 \frac{1}{2}$.

1. Kelchhaare abstehend, die miteren meist an der spitze zurüch"nekrümmt.

751. I. silvatica Hoffm., Wald-V. Sturm Heft 42. Stengel aufrecht, kantig, von abstehenden Haaren rauh; Blätter länglich, plötzlich zugespitzt; Bliithenstielchen nach dem Verbliihen so lang oder läinger als drr Kelch; Kelch tief-5spaltig, abstehend-behaart, Ilaare an Grunde des Kelches spreizend, hakenfürmig-gekriimmt, Zipfel des Fruchtkelches aufrecht-zusammenschliessend; Saum der Blume ganz flach. (.). In feuchten Wälderu schr zerstreut. In den Waldungen der Aue hin und wieder, bei Naumburg nur am buschigen Abhange der Schellsitzer Fähre gegenüber, aber daselbst häufig; bei Dessau und Oranienbaum verbreitet. Mai - Juli. M. arvensis $\beta$. silvatica Pers. M. scorpioides silvatica Eh $\mathrm{rh}$. Blunen lebhaft hellblau, rosenroth oder weiss (M. silvatica $\gamma$. lactea B o e nning h), etwas angenthm riechend. Iöhe $1 / 2-1 \frac{1}{2}$.

752. M. intermedia Link, mittleres $V$. S tur Heft 42. Stengel aufrecht, kantig, von abstehenden Haaren rauh; Blättel länglich, stumpflich; Bliithenstielchen nach dem Verbliihen 2-3mal so lang als der. Kelch; Kclch tief.5spaltig, nach dem Verbliihen ge. schlossen, abstehend-behaart, Haarc an Grunde des Kelches spreizend, hakenförmig-gekriimmt; Saum der Blume vertieft. $\odot$. Wälder, Waldränder, Felder gemein. Juni - Aug. M. scorpioides r. arvensis L. Blume hellblau, kleiner als an der vorigen Art. Höhe $1 / 2^{\prime}$, in Wäldern oft $\mathbf{2}^{\prime}$.

Ist der vorigen Art sehr ähnlich und oft mit ihr verwechselt worden, was der Verfasser auch von $S p r e n$. yel annehmen möchte, da sich an den von ihm hal. ed. 2. p. 102 für M. silvatica $H$ of $\mathrm{fm}$. angegebenen Standorten, nämlich in schattigen Wäldern um den Petersberg, nur M. intermedia l,ink. und zwar in grosser Anzahl findet. Letztere unterscheidet sich jedoch durch die etwas stärker behaarten, mehr graulichen Blätter, welche bei M. silvatica $H$ of $\mathrm{m}$. griin sind, durch die kleineren Blumen mit concavem Saume und durch die längeren, zur Fruchtzeit geschlossenen Kelche, welche abel durch das Pressen gewöhnlich geöffnet werden 
und daher im trockenen Zustande oft zu Verwechselungen Veranlassung geben.

753. M. hispida s chlechtend., $s$ te if hariges V. Sturm Heft 42. Stengel dünn, etwas schlaff, meist vom Grunde an ästig, unten von abstehenden, oberwärts von anแedrïckten Haaren rauh; Bliithenstielchen nach dem Verbliihen wagrecht-abstehend, so lang als der Kelch; Kelch 5spaltig, nach dem Verbliihen offen, abstehend-behaurt, Haare an Grunde des Kelches spreizend, hakenförmig-gelriimmt; 'Traube gestielt; Röhre der Blumenkrone eingeschlossen. $\odot$. Sonnige Hügel, truckene Felder, Wegränder nicht selten z. B. am Donnersberge hinter Kröllwitz, auf dem Bischufsberge in der Dölauer Heide; an Abhängen an der Chaussee unmittelbar hinter Ammendurf sehr häufig, an Abhängen bei Röglitz, in Bienitz, auf Triften bei Kötschau u. s.w. Nai. Juni. N. collina Reich. M. arvensis Link. Blume klein, sattblau. Höhe $1 / 4-1$ '.

75\%. M. versicolor ers., buntblumiges $V$. Sturm Heft 42. Stengel aufrecht, ästig, unten von abstehenden, oberwärts von angedrïckten Haaren rauh; Bliithenstielchen nach dem $V$ erbliihen liinger als der Kelch; Kelch tief-5spaltig, nach dem Verbliihen geschlossen, behaart, Haare ail Grunde des Kelches spreizend, hakenförmig - gekriimmt; Traube gestielt; Rühre der Blumenkrone zuletzt doppelt so lang als der Kelch. $\odot$. Aecker, 'Iriften, Raine, besonders an etwas feuch. ten Orten, zwar nicht selten, aber meist nur wenige Pflanzen beisimmen, so am Donnersberge hinter Kröllwitz, an nördlichen Rande der Dölauer Heide, an Bergen bei Gutenberg, am Bienitz u. s. w. Mai. Juni. M. scorpioides collina Ehrh. Blume anfangs schwefelgelb, dann bläulich, zuletzt dunkler blau. Höhe $1 / 4-1$.

755. M. stricta Link, steifes V. Sturm Heft 42. Bliithenstielchen nach dem Verbliihen weit kiirzer als der Kelch, oft kaum bemerkbar; Kelch tief-5spal. tig, nach dem Verbliihen geschlossen, behaart, Haare an Grunde des Kelches spreizend, hakenförmig-gekviimmt; Traube stiellıs, an Grunde beblättert; Röhre der Blumenkrone im Kelche eingeschlossen. $\odot$. Aecker, Hügel, sandige Plätze gemein, oft ganze Felder bedeckend, so zwischen Kröllwitz und der Dölauer Heide u. s. w. April. Mai. Juli. Aug. M. arenaria Sch ra. de r. M. arvensis $R \in \mathrm{hb}$. Blume klein, blau. Höhe bis $12^{\prime}$, oft nur $1^{\prime \prime}$ hoch. Die Wurzel treibt bald nur 
einen Stengel, bald ist sie vielstengelig, die stengel sind steif-aufrecht, oder im Bogen aufsteigenl und fast vom Grunde an wit beinahe sitzenden I3lüthen besetz.t.

756. M. sparsifiora Mikan, zerstieutbliithiges $\mathrm{V}$. Sturm Heft 42. Stengel schlaff, mit zurüch. gekrümiten, steifen Haaren besetzt; die zuteren Fruchtstielchen viclmal länger als der Kelch, zuriickgeschla. gen; Kelch tief-5spaltig, behaart, IIaare am Grumle des Kelches spreizend, liakenförmig-gcliriommt; 'Iraube sehr locker, wenigblüthıg, am Grunde beblättert. $\odot$. Feuchte, schattige II älder, Gebüsche, Brge sehr zerstreut. Unter Gebüsch an der Siale zwischen dem Schwalchluche und Lettin hänfig, weit sparsamer aul dem 'Trothaischen Werder, an den Rändern des Bergholzes unil am nördlichen Abhange des Petersberges; in ejnem Walde zwischen Kloschwitz und Rumpin nördlich rou Wettin, bei Eisleben auf der Hiineburg sparsam, bei Aschersleben an der alten Burg mod an den Westerbergen häufig, in Frechleber Holze bei Sauders. leben, bei Dessau häufig, bei Oranienbaum im Nichrin. Mai. Juni. Blumen klèin, hellblau. Höhe $1 / 4-3 / 4$ ', bis. weilen bis 2' lang und dann sehr weitästig.

Nach Kehb. sax. ell. 1 u. 2. p. 213 wächst diess: Pflanze auch bei Nammburg, wo jeduch stets vergeblich danach gesucht ist.

\section{Familie. Solaneen Juss. N a cht - schat tengew äclise. \\ 309. Lycium L. 'T e ufe lsz w irn (Pflanzenname bei Dioscoricies).}

757. L. bárbarum L., g e me iner 'T. Aeste dünm, ruthenföımig, herabgebogen; Blätter gestielt, länglich oder lanzettlich, an Grunde rerschmälert, kahl, ganzrandig; der Saum der Blume so lan” als die Röhre; Kelch klein, ungleich-3spaltig; Staubgefüsse ïber den Grunde mit einem filzig-zottigen Ringe umgeben. $\hbar$. Zierstrauch aus der Barbarei, jetzt an Zäunen und Wegen sehr häufig angepflanzt und verwildert. Juni-Ang. Blume hellpurpurroth oder hellviolett. Beere oval oder länglich, mennigroth.

310. Dolansina I. Nach ts ch a t te n (Pflanzenname bei Plinius, von solari, trösten, lindern, wegen der Heilkräfte einiger Arten). 
758. s. nigrum L., s chwal'zer $\mathbf{~}$. H a y neigew. 11, 40. Stengel krautartig; Kanten der Aeste hervortretend. knötig; Blätter eiförmig, buchtig-gezähnt und nebst dem Stenget mit einwiirts-gekriimmtaufrechten Hacren besetzt; Blüthen in einfachen Tranben; Blüthenstielchen zur Fruchtzeit an der Spitze ver. dickt, herabgebogen. $\odot$. Schutt, Mauerı, Wege, Aecker gemein. Juli-Herbst. Blumen weiss oder bleichviolett, wie bei den beiden folgenden. Beeren schwarz. Höhe 1-3'. Nebst den beidenfolgenden Arten $\mathrm{g}$ if $\mathrm{t}$ ig.

759. s. miniatum Eerh., mennigrother $\mathbb{N}$. $\mathrm{K}$ chb. pl. crit. X. Abb. 1327. Stengel krautartig; Kanten Jer Aeste hervortretend, knötig; Blïter eiförmig, buchtig-gezähnt und nebst dem Stengel abstehond-zottig; 'raube einfach; Blüthenstielchen zur Fruchtzeit an der Spitze vesdickt, herabgebugen. $\odot$. Schntt, Wege, unbebaute Orte häufig z. 13. auf Schutt an der Stadtmaner, anf Schwalchloche hinter Kröllwitz, bei Dieskau, in Weinbergen bei Rollsiurf, bei Naumburg häufig u. s. w. Juli-Herbst. Beeren roth.

760. s. villosum Lam., zottiger $\mathrm{N}$. Hayne Arzneigew. II, 41. Stengel krautartig; Kanten del deste sehr schwach. mit wenigen Küitchen besetzt; Blïtter eiförmig, buchtig-gezähnt und nebst dem Stengel fast filzig-zottig; Traube einfach; Blïthenstielchen zur Fruchtzeit an der Spitze verdickt, herabgebogen. $\odot$. Standort und Blüthezeit wie bei der vorhergehenden Art, aber etwas seltenel als dieselbe z. B. bei Röglitz, Wesmar, zwischen Kölme und Langenbogen. Beeren gelb, zuletzt bräunlich

Da der Verfasser keine Uebergänge an den drei vorhergehenden Pflanzen gesehen hat und dieselben sich bei der Verpflanzung in Gürten bisher als constant gezeigt haben, so sind sie als Arten und nicht als Varietätell angenommen.

761 S. Dulcamára L., Bittersüss-N. Hayne Arzneigew. II, 39. Stengel strauchartig, geschlängelt, zuweilen windend, kantig, kahl: Blätter herz-eiförmig, die oberen am Grunde meist spiessförmig; Blüthen ebensträussig, Ebensträusse den Blatte meist gegenïberstehend; die einzelnen Fruchtstielchen nur wenig herabgebogen. $\hbar$. Feuchte Hecken und Gebïsche, Bäche, Flussufer häufig z. B. an einer quelligen Stelle vor den Donnersberge bei Kröllwitz, an den Teichen bei Dieskau u. s. w. Juni - Ang. Blumen violett, an Grunde 
jedes Zipfels mit 2 grïnen Flecken, sehr selten weisslich. Beeren roth. Der Stengel klettert bis $10^{\prime}$ hoch. OFF. stipites Dulcamarie.

762. S. tuberosum L., knollentragender $\mathbf{N}$., Kartoffel. Stengel krantartig; Blïter umpaarig-gefiedert, Blättchen ungleich, abwechselnd sehr kloin; Blüthenstielchen gegliedert; Blïthenkrone 5winkelig. 4, die Knollen aber nur einjährig. Wird iberall gebaut. Juli. Aug. Blume weiss uder violett.

311. Phýsalis C. Judenkirsche (Pflanzenname

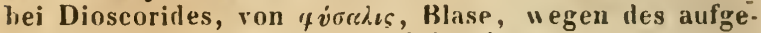
blasenen Fruchtkelches).

763. Ph. Alkekengi L., gemeine J. Hayne Arzneigew. VI, 4. Stengel aufrecht, krautartig, meist vom Grunde an ästig; Blättes meist zu zweien beisammen stehend, lang gestielt, eiförmig, ganzrandig oder etwas ausgeschweift; Blüthen blattwinkelständig, einzeln, gestielt. 4. Weinberıe, bewachsene, sonnize Hügel besonders auf Kalk, stellenweise. An Kalkber. gen bei Bennstedt und Kölme, in Weinbergen bei Laugenbogen, Rollsdorf und Seeburg häufig, ebenso in den Weinbergen von Röglitz und Kösen, am Geiersberge im Nordthale hinter Naumburg, in den Weinbergen am Schaafholze bei Nismitz unweit Freihurg, bej Illstedt, im Lagen an der Lehmgrube, seltener hei Aschersleben und Bernburg. Juni. Juli. Blıme schmutzig - weiss. Beere scharlachroth, von dem aufgeblasen sarkförmigen, netzig-geaderten, mennigrothen Kelche umgeben. Höhe $1-2^{2}$. OFF. baccae Alkekengi s. Halicacabi.

312. Átropa I. 'Tollkirsche (ein von Linné aus dem "priv. und $\tau \varrho \varepsilon \varepsilon t \tau \iota \nu$ wenden, gebildeter Nane, welcher eigentlich die Unabwendbare bedeutet, wegen der tödtlichen W'irkungen dieser Pflanze).

764. A. Belladonna L., geme ine 'l'. Sturm Heft 3. Stengel aufrecht, ästig; Blätter eiförmig, in den Blattstiel herablaufend, zu zwejen beisanmen stehend, von denen das eine kleiner ist; Blüthen blattwinkelständig, einzeln, gestielt. 24. Schattige Orte in Bergwäldern sehr selten; nur im Mordthale hinter Naum. burg. Juni. Juli. Blume violett-hraun. Bepre schwarz glänzend, von der Grösse einer Kirsche. Höhe $2-4^{\prime}$ : Sehr giftig. OFF. rad. et herba Belladonnae s. Solani lethalis rel furiosi. 
313. Ifyoseýnmus L. Bilsenkraut (ein von Dioscorides aus $\dot{v} \varsigma$, Schwein, und $x$ vauos, Bohne, uebildeter Pflanzennane, welcher eigentlich Schweinsbuhne heisst).

765. H. niger L., schwarzes B. Hayne Arz. neigew. 1, 28. Stengel aufrecht, nebst den Blätterı klebrig-zottig; Blätter eiföınig-länglich, fiederspaltigbuchtig, die untersten gestielt, die stengelstäudigen halbtsengelumfassend; Blüthen in den Winkeln der oberen Blätter fast sitzend. $\odot$ und $\odot$. Bebanter und unbebauter Borlen, Schutt häufig z. B. zwischen Halle und Nietleben, bei Giebichenstein, 'Trutha u. s. w. Juni-Aug. Blume schnutzig-blassgelb mit violetten Adern, innen mpist schwarzbraun. Höhe 1-2'. Gif. tig. OFF. herba Hyoscyami. Aendert ab:

b) agrestis Kit.: einjährig, niedrig, die Blätter weniger buchtig.

314. Nicotiana I. Tabak (nach Jean Nicot benannt, welcher zuerst Samen nach Paris brachte).

766. N. Tabacum L., virginischer T. Hayne Arzneigew. XII, 41. Blätter länglich-lanzcttlich, zuge. spitzt, die unteren am Stengel verschmïlert-herablaufand; Röhre der Blumenkrone bauchig-aufgehlasen, Saum 5theilig, mit zienlich lang zugespitzten Zipfeln. $\odot$. Wird mit den folgenden Arten in der Gegend von Allstedt und Dessau viel gebaut. Juli. Ang. Blıme ro. senroth. Höhe bis $5^{\prime}$. OFF. herba Nicotianae. Aendert mit breiteren und sohmäleren Blättern ab.

767. N. latissima Mill., breitbläteriger 'T. Blätter breit - eiförmig - lanzettlich, aus geröhrtem Grunde am Stengel herablaufend; Röhre der Blumenkrone bauchig-aufgeblasen; Saum 5spaltig mit kurz-zugespitzten Zipfeln. $\odot$. Stammt nit der vorhergehenden und fol. genden Art aus Amerika. Juli. Aug. N. macrophylla Spreng. Blume rosenroth. Der Stengel ist höher und weit dicker als bei der vorigen Art.

768. N. rustica L., B a u ern-'T. Blätter gestielt, eiförnig; Röhre der Blumenkrone walzenförmig, länger als der Kelch, Zipfel des Saumes rundlıch-stumpf.

Standort und Blüthezeit wie bei den vorhergehenden. Blume grünlich-gelb. Stengel nur $2-3^{\prime}$ hoch.

315. Datúra L. Stechapfel fein bei Garcias ab Orto zuerst vorkommender Pflanzenname arabischen Ursprungs). 
769. D. Stramonium L., ge me iner St. II ayne Arzneigew.IV,7. Strngel aufrecht, ästig, kahl; Blätter gestielt, eiförmig, kahl, ungleich-buchtig-gezühnt; Blüthen einzeln in den Gabelspalten und an der Spitze; Kapsel aufrecht, weichstachelig. $\odot$. Bebauter und unbehautor Boden, Weinberge, Wege. In der Nïhe von Halle fast gar uicht; einzeln bei Langenbogen, häufiger in den Weinbergen am salzigen See bei Rollsdorf und besonders auf Aeckern bei Seeburg und in Dorfe selbst, auf der Teufelsbrïcke am salzigen See, an Felsen bei Wettin, auf Schutthaufen bei Zörbig, an Bergen bei Rög. litz, Ermlitz, Kötschau, Dürrenberg häufig; auf Aeckern bei Naumburg, Lauchi und Bibra einzeln, bei Allstedt hinter den Schlosse selten, bei Freckleben unweit Sandersleben, bei Dessau stellenweise. Juli-Aug. Stramonium foetidum Gärtn. Blume weiss. Höhe $1 / 2-3^{\prime}$. Sehr giftig. OFF. herbi et semina Daturae s. Stramonii. Hat einen widrig - narkotischen Geruch.

\section{Familie. Verbasceen Bartl. Woll- kraut gew ächse.}

316. Verbascum L. Wollkraut, Königskerze (soll nach Tournef. eigentlich Barbascum heissen, von barba, Bart, wegen der bärtigen Staubfäden).

A. Blätter wollig von Blatt zu Blatt herablaufend; Blume gelb; Wolle der Staubfäden weiss.

770. V. thapsiforme sch rad., grossblumiges W. Hayne Arzneigew. XII, 39. Blätter kleingekerbt, beider'seits mit gelblichem Filze dicht besetzt; alle von Blatt zu lilatt herablanfend; 'Traube meist einzeln; Blüthenstielchen zur Bliithezeit kürzer als der Kelch; Blume flach ausgebrcitet, radförmig; Staub/äiden weisswollig, die 2 lïngeren kahl oder oberwärts spärlich-lie. haart, 11/2 bis $2 \mathrm{mal}$ so lang, als ilir Staubbeutel. (-). Hügel, steinige, unbebaute Stellen häufig z. B. am Felsen zwischen Halle und Giebichenstein. Juli. Aug. V. Thapsus M e y er chl. hanov. Blume gelb, weit grösser als an der fulgenden Art. Höhe bis $7 \%$ OFF. herba et flores Verbasci.

771. V. Schraderi Meyer, Schrader's W. II a y n e Arzneigew. XII, 38. Blätter kleingekerbt, beiderseits mit gelblichem Filze dicht besetzt, alle von Ijlatt zu Blatt herablaufend; Traube meist einzeln; 
Blüthenstielchen zur Bliithezeit kürzer als der lielch: Blume trichterförmig; Staubfäden weiss-wollig, die 2 längercn kahl oder "berwärts spärlich-behaart, 4 mal so lang als ihr Staubbeutel. (.). Unbebaute, steinige Orte sehr selten. In IIalle auf Mauern äusserst selten (auf einer Vauer in Prof. Blanc's Garten), hei Naumburg auf steinigen, freien Plätzen des Sperlingsholzes nach dem Vurdthale zu. Juli. Aug. V. Thapsus L. nach Fries und S m. V. Thapsus S chrad. Die Blume ist kleiner und meist dunkelel gelh als bei der vorhergehenden Art. Höhe 1 - 4'. OFF. herba et flores Verbasci.

B. Blättel nur kurz - oder halbherablaufend.

752. V. phlomoides L., "ind b l umenähnliches II. H a yn Alzneigew. XII, 40. l:liitter kleingekerbt, bejderseits mit gelblichem lilze dicht besetzt, liurzocler halbherablaufend; Traube meist sinzeln; Blïthen. stiele zur Bliithezeit kürzer als der Kelch; Blume rad. förmig; Staubfïden weisswollig. die 2 lüngeren kahl "der oberseits spärlich-behaart, $1 \frac{1}{2}$ bis 2 mal so lang als ilır Staubbcutel. (.). Hügel, wüste Plätze sehr selten. Bisher nur bei Wettin und Delitzsch beobachtet. Juli. Aug. V.rugulosum Willd. Blume gelb, so gross als bei $\mathbf{V}$. thapsiforme Schrad., welchen es in der ganzen Tracht sehr ähnlich ist und sich wur durch die hurz herablaufenden Blätter von ihm unterseheidet. OFF. herba et flures Verbasci. Aendert mit lockereb und dichter Traube und in der Blattform vielfach ab.

c. Blätter nicht herablaufend; Blïthen büschelig. a. Blume geth. Wolle der staubfaden weiss.

773. W. Lychnitis L., lichtnelkenartiges W. Stengel oberwärts, nebst den aufrecht - abstehenden, pyramideuförmig - rispigen Aesten scharfkantig; Hlïtter gekerbt. oberseits zicmlich kahl, unterseits stcubig-filzig, graulich, die unteren elliptisch-länglich, in den Blattstiel versshmälert, die höheren kurz-gestielt, die oberen sitzend, eiförmig-zugespitzt; Staubfüden weiss wollig. (-). Hügel, Wegründer, unbebaute Orte häufig z. B. auf Hïgeln zwischen Gutenberg und dem Mittelholze. in Mittelholze, an Hügeln bei Röglitz, Ermlitz, sehr häufig am Saalufer bei Dürrenberge und sonst nicht selten. Juli. Aug. Höhe 2-5'. Aendert ab:

b) album Mill.: Blumen weiss, so an der Steinklippe bei Wendelstein. 
h. Blume gelh. Wolle der Staubfiden purpur-violett.

774. V. nigrum L., schwarzes W. Strngel oberwärts scharfkantig; Blätter gekerbt, oberseits ziemlich hahl, untersejts fein-filzig, die unteren stengelständigen länglich-eiförnig, am Grunde her fürmig, lang-gestielt, die oberen eiförnig-länglich, fist sitzend; Traubc lang; Bliithenstielchen doppelt su lang als der Kelch; Wolle der Staubfïden purpur-violett. (-). Wege, Waldründer, Hügel nicht häufig. Im Sebener Busche sehr spassan, (in der Dölaner Heide und dem Mittelhulze nach spreng ( ) , wo es der Verfasser nicht fand), bei Naumburg aII Wäldern, in der Aue und an Wewen verbreitet, bei Allstedt an der Fuhlenwiese, bei Aschersleben und Des. sau nicht gerade selten; zwischen Zörbig nnd Radegast. Juli - Ang. Höhe 1-3'.

D. Blätter nicht herablaufend. Blüthen einzeln oder zu zweien.

775. V. phoeniceum L., violettes W. Blätter unter'seits weichhaarig, die wurzelständigen gesticlt, eifürmig oder länglich, gekerbt, die mittleren und oberen stengelständigen viel kleiner, kleingekerbt, sitzend; Traubc drïsig-behaart; Bliithenstielchen einzeln, viel länger als die Deckblätter; Stauhbeutel sämmtlich gleich, nicht herablaufend. (.). 'Iruckene Hügel sehr selten. An Hügeln zwischen Wettin und Dösel, an der Stein. hlippe beı Wendelstein häufig, bei Gross Kühnau unweit Dessau und am Thorhanse zwischen Dessau und Aken häufig. Blume dumkel-violett. Staubfäden mit violetter Wulle. Höhe $1-3^{\prime}$.

776. V. Blattaria L., Motten-W. Blätter kahl, die unteren verkehrt-eiförmig-länglich, am Grunde verschmailert, buchtig, die stengelständigen länglich, spitz, gekerbt, sitzend, die oberen fast herzförnig, zugespitzt, hallstengelumfassend; Traube driisig - behaart; Blüthenstielchen einzeln, 1 $\frac{1}{2}-2$ mal so lang als die Deckblätter; Staubbeutel sämmtlich gleich. $\odot$. Wege, Weinberge einzelı, unbeständig und meist nur verwildert. su vor dem Wirthshause in Kollsdurf, wo es mur ein Flüchtling aus deu benachbarten Garten ist, in Weinbergen bei Naumburg. Juni. Juli. Blume gelb. Staubfäden mit violetter Wolle. Höhe $2-3$ '.

Spreng. gibt diese Pflanze auf dem Trothaischen Werder an (woraus Rehb. sax. ed. 1 und 2. p. 231 gar 
zwei Standorte, Trotha und Werthen, gemacht hat), wo sie der Verfasser nie gesehen.

317. Seroplnulá ria L. B raun u uz (ein hei Matth. Sylvat. zuerst vorkommender, aus scrophula, Scropheln, gebildeter Pflanzenname, "elrhel eigentlich Scrophelkraut bedeutet, wegen itr frïheren arzueilichen Anwendung).

777. S. nodosa L., knutige B. Hayne Arzneigew. V, 35. Stengel scharf-4kantig, nelst den Blattstielen ungefliigelt; Blätter eiförmig - länglich od r herzeiförmig, kahl, doppelt-gesiigt, die unteren Sägeziihne länger und spitzer; Rispe endstündig ; Kelchzipfel eiförmig, stumpf, sehr schmal-häntig-berandet; Ansatz des fiinften staubfartens quer-lïglich, schwarh-ausgerindet. 2!. Feuchte Wäller, Gräben, Bäche häıfig. Juni-Aug. Blume ulivenfarben, auf den Rücken hraun. Höhe 2-4'.

778. S. Ehrharti stev., Ehrhart's B. Hayne Arzneigew. V, 36. Stengel und blattsticle breit-gefliigelt; Blïtter eiförmig-länglich, eiförmig oder fast herzförmig, kahl, scharf-:esï̈t, die unteren Sägezälne lileiner; Rispe endständigr; Kelchzipfel rundlich, sehr stumpf, breit-häutig-berandet; Ansatz des fünften Staubfartens 2spaltig, mit ausuespreizten Zipfeln. 24. Flüsse, Bäche, Gräben etwas seltener als die vorhergehende Art. An Wiesengräben unter dem Tannenberge bei Gutenberg, in Wäldern zwischen Schkenditz und KJ. Dölzig, an Schambert in der Nihe Hes Bienitz, bei Naumburg an der kleinen Saale und im Kroppenthale an der Wetau, an Bächen bei Bibra häutig II. s. w. Juni-Sept. S. iquatica aller Aut, aber nicht Lin. Blume auf den Rïcke purpurbraun. Höhe $2-4^{\prime}$.

\section{Familie. Antirrhineen J uss. L öwen-} maulgew ächse.

315. Curatioln I. Guadenkraut (dol deutsche Name Gnadenkraut oder Gottesgnade, wovon der zuerst bei Dudonaeus vorkmmmende lateinische Na. me Gratiola nur Uebersetzung ist. wurde dieser Pflanze

wegen ilırer vielfachen Heilkräfte beigelegt).

779. G. officinalis L., g e b r ̈̈uchliches G. Hay. ne Arzneigew. III, 13. Wurzelstuck kriechend, mit anliegenden, stumpfen, meist braunen Schuppen besetzt; 
Blätter gegenständig, sitzend, lanzettlich, 3nervi,-, klein gesägt, an Grunde ganzrandig; I3lüthenstiele blattwinkelständig, 1blüthig. 24. Sumpfige, feuchte Wiesen sehr zerstreut. In der Elsteraue zwischen der Broihanschenke und Ammendorf, anf Wiesen bei Burg Liebenau häıfig, auf der Grenze des Gebietes zwischen Stassfurt und Hecklingen, auf feuchten Wiesen bei 'Törten und Dessau nicht selten. Juli. Aur. Blume weiss oder róthlich, mit gelblicher Röhre. Höhe $1 / 2-1$ '. Giftig. OFF. herba Gratiolae s. Gratiae Dei.

319. Higitalis I. Fingerhut (der lateinische Na. me wurde erst aus denı Dentschen von Fuchs iibersetzt).

780. D. grandiflora Lam., grosshlïthiger F. Sturm Heft 11. Blätter länglich-lanzettlich, gresägt, gewimpert, weichharig, die unteren in den Blattstiel verschmälert, die oberen mit eiförmigem Grunde halbstengelunfassend; Blïthen in einseitsilendiger Traube; Blithenstielrhen nebst dem Stengel uberwärts drüsighehaart; Blume erw ètert-gluckenförmign, drüsig - weichhaarig; Kelchzipfel lanzettlich, spitz f. Bergwälder, Schluchten zerstreut. In der Dölauel Heide, in Mittelholze, bei Naumburg an Pfortenberge und in deu Weinbergsschluchten zwischen Kösen und den Saaliausern, bei Sandersleben und Dessau. Juni. Juli. D. wchroleuca Ja c q. Blume trüb-schwefelgell, inwendig mit einem undeutlichen braunen Adernetze. Höhe $2-4$. lendert ab:

a) acutiflora $K$ o $\mathrm{ch}$ : die Zipfel der Unterlippe spitz. D. grandifloria Re ichenb.

b) obtusiflora Koch: die Zipfel der Unterlippe stumpf. D. cochroleuca Re iche $n$ b.

329. Antirrónimun T. I, öw en maul (ein bei Diuscurides vorkommender, aus cuvi, ühulich, unil ois, Nase, gebildeter Pflanzenname, weliher eigentlich nhsenähnlich heisst, wegen der Gestalt der Blumen und Früchte dieser Pflanzen).

781. A. majus L., grusses L. Stengel aufrecht, meist einfach; Blätter lanzettlich, kahl, die unteren gegenständig, die oberen. " echselständig; Blüthen traubenförnig; Kelchzipfel eiförnig, stumpf, vicl kiirzer als die Blume. 2. Auf Mauern, Dächern oft in Menge verwillert; ansserden häufig in Gürten angepflanzt. Juni - Aug. Blume purpurroth, fleischfarben oder weiss, 
der Gaumen meist gelb. Der dıïig - hebrige Stengel ist $1-2^{\prime}$ hoch.

7x2. A. Oróntium L., Feld-L. Sturı Heft 27. Stengel aufrecht, neist ästig; Blätter lanzettlich, lie unteren gegenständig, die oberen wechselständig; Blüthen sehr kurz-gestıelt, ähreuförnig, entfernt; Relchzipfel lanzettlich, lïnger als dic Blume. $\odot$. Aecker, schutt nicht gerade selten. Auf Aeckern zivischen Kröllwitz und dem Donnersberge, häufig auf Aeckern nördlich rum Mittelholze, bei Naumburg zerstreut, und sonst verbreitet. Juli - Herbst. Blume blassruth, seltener weiss. Höhe $1 / 2-1^{\prime}$.

321. Linaria 'Tour mef. Frauenflachs (ein bei M. Sylvat. zuerst rurkommender Pllanzenname, welcher aus linunı, lein, gebildet ist, wegen der leinartigen Blätter mehrer Arten).

A. Cymbalaria Chavannes. Stengel kripchend oder niederliegend; Blätter breit, rundlich, ei- oder spiessfölmig, alle deutlich gentielt; Bluthen langgestielt, einzeln in den Blattwinkelu

783. L. Cymbalaria Mil1. epheublitteriger F. Sturm lieft 70. Stengel fartenformig, herabhälgend; Bliitter herzförmig-rundlich, cclitø-5lappio, kuhl; Blüthen einzeln, blattwinkelständıg. 24. Alte Mauern, Weinberge selten und ursprünglich nicht einheimisch, verbreitet sich jedoch immer mehr, so auf Mauern in Zöschen an der Verseburg-Leipziger Chaussee, häıfiger an der hleinen Saale in Schulpforte in einem Bassin und hesonders in li einbergen, so an steinmeister entlang bis zur Höhe bei Almerich, bei Oranienbaum an chinesischen Hause. Juni - Aug. Antirrhinum Cymbalaria 1. Cymbalaria muralis Fl. der IIett. Blume hellviolett, der Gaumen weiss und dessen beide hervorragende Höckerchen duttergelb. Stengel 1-2' lang.

78f. L. Elatine Jrill., spiessblätteriger $F$. Sturm Heft 70 . Stengel fadenförmig, zottig, hingestrecht; Blïtter zerstreut, zottig, breit-spiessförmig, die unteren eiförmig; Sporn der Blumenkrone gerade; Bliithensticle kahl. $\odot$. Aecher, besonders auf Lehmund Sandboden. Auf Aeckern $z$ wischen Halle und Nietleben häufig, bei Kölnıe, Bennstedt, anı Zorgs, bei Gruss Kugel, zwischen 'Passendorf und Zscherben, zwischen Doberstan und Kühna östlich von Landsberg, 
auf Aeckern bei KI. Dölzig, bei Kötschau, 'Teuditz, bei Naumburg auf überschwemnit gewesenen Aeckern bei Schellsitz und an der Siidseite des Buchholzes, bei Aschersleben, Bermburg und Dessau. Juli - Octub. Antirrhinum Elatine I. Blume weisslich, Oberlippe in. wendig violett, Unterlippe schwefelgelb. Stengel $4-$ 12 " lang.

785. L. spuria mill., e ihlätteriger F. Sturm Heft 70. Stengel fallenförmigr, zottig hingestrecht; Bliitler zerstreut, rundlich-eiförmig, ganzrandig; Sporn der Blumenkrune bugenförmig; Bliithensticle zottig. $\odot$. Aecker, besunders auf Lehm. nnd Kalkboden, etwas seltener als die. vorige Art. Auf Aeckern zwischen Halle und Nietleben hänfig, bei Kl. Dölzig, Kötschau nach Schladebach hin, hei Teuditz, auf dell Saaldäm. men bei Diirrenberge, bei Nammburg auf überschwenmt gewesenen Aeckern bei Sichellsitz und auf Aeckern an del Siidseite des Buchholzes, auf Aeckern bei Aschers. leben, Sandersleben unrl Bernburg. Juli-Sept. Antirrhinum spurium L. Blıme am Grunde weisslich, mit dunkel-violetter Oberlippe und gelber Unterlippe. Stengel 4-12" lang.

B. Chaenorhinum DC. Blüthen einzeln in den Blattwinkeln, beblätterte, sehr lockere 'l'rauben bildend; Blätter lanzettlich oder elliptisch.

786. L. minor Desf., kleiner F. Sturn Heft 70. Stengel aufrerht, meist ausgebreitet - üstig, nebst den Bliitiern, Blithensticlen und Kelchen dicht driisig. bchaart; Blätter lanzettlich, stumpf, in den Blattstiel verschmälert, die unteren gegenständig, die oberen wechselständig, linealisch; Bliithen einzeln, blattwinkelständig, fast traubenfürnig; Bliithensticle $3 \mathrm{mal}$ so lang als $\mathrm{der}$ Kelch, Zipfel der Oberlippe spreizend. $\odot$. Aecker, bebauter Buden verbreitet. Auf Aeckern zwischen Passendoif und Beuchlitz, zwischen Holleben und Schaafstedt, bei KI. Dölzig und am Bienitz, häufig bei Naumbury und sonst nicht gerade selten. Juli Herbst. Antiohinum minus L. Blume hellviolett, mit gelblich-weissen Lippen. Höhe 3-9".

C. Linariastrum DC. Stengel nebst den Aesten mit piner dichteren Traube oiler Aehre endigend. Blätter linealisch oder lanzettlich-linealisch.

787. L. arvensis Desf., Acker-F. Sturm Heft 
70. Stengel aufrecht, einfach oder ästig, nebst den Blättern liahl; Blätter linealisch, an Grunde und an der Spitze verschmälert, die unteren :u 4 quirlständig; Traube gestielt, anfanos kopfförmig, später verlängert; Bliuthensticle nelst dem Kelche driisig-behaart; Kelchzipfel linealisch, stumpflich; Sameı flach, mit einem breiten, kreisrunden Flügel umgeben, glatt. $\odot$. Auf Aeckern zerstreut. Auf Aeckern an Dölauer Kirchholze, zwischen 'Tutha und Lettin, bei Gutenberg nach dem Petersberge zu, am 'zurgs, zwischen Doberstau und Kühna östlich von Landsberg, zwischen Wehlitz und Ermlitz, am Bienitz, bei Naumburg auf Aeckern in der Nähe ron Schelisitz und Goseck und hin und wieder auf dïrren Plätzen und sandigen Aeckern. Juli. Aug. Antirrhinum arvense $\varkappa$. L. Blume klein, hellblau mit dunkleren Streifen, der Gaumen weisslich mit einem schwachen, viuletten Adernetze. Höhe $1 / 2-1$.

788. L. Vulgaris Mill, geme iner. Fturm Heft 15. Sten@el aufrecht, nebst den Blättern kahl; Blïtter dicht stehend, lanzettlich-linealisch, spitz, 3nervig; Bliithenspindel und Bliithenstielchen driisig-weichhaarig; Traube sedrungen; Kelchzipfel läglich-lanzettlich, 3nervig, spitz, kürzer als die Kapsel; Samen flach, mit einen kreisrunden Fliigel umgeben, in der Mitte knötig - rauh. 4. Wege, Kaine, Sandfelder häufig z. B. auf Aeckern an der Reille vor Reideburg, am Saalufer zwischen Kröllwitz und I.ettin u. s. w. JuliSept. Antirrhinm Linaria L. Blume gross, blassgelb, Gaumen safranfarben. Höhe $1-2^{\prime}$. Aendert ab mit gleichnässig 5spaltiger Blume: Peloria L., sehr selten, nur einmal im Weidengebüsch an der Saale bei Ross. bach unweit Naumburg in mehren Exemplaren gefunden.

321. Veronica L. Ehrenpreiss (dieser von Fuchs zuerst gebrauchte Pflanzenname ist zu Ehren der heiligen Veronica benannt, deren Name aus rera una īcon zusammengesetzt ist, daher Verunica und nicht Veró. nica; alle anderen Ableitungen sind unrichtig).

A. Chamaedrys. 'Trauben blattwinkelständig. Wurzel ausdauernd.

a. Kelah 4 theilig.

1. Blitter kahl.

789. V. scutellata L., s childfrï htiger F. Stur m Heft 5s. Niengel aufsteigend, schwach, fädenförmig, nebst den Blättern hahl; Blätter sitzend, lanzettlich. 
linealisch, spitz, entfernt-schwach-gezihnelt; 'Traube blattwinkelständig; Blüthenstielchen nach des Verblü. hen weit abstehend; Kapsel zusammengedrückt, ausgerandet-2lappig, breiter als lang. 4. Grühen, sümpfe, Teiche, feuchte stellen auf Wiesen häufig z. B. all sumpfigen Stellen zwischen Kröllwitz und der Dölauer Heide, ebenso bej Gutenberg, auf feuchten Wiesen zwi. schen Burg liebenau und Wallendorf u. s. W. JuniSept. Blume weisslich, röthlich-oder blau-gestreift. Ilöhe $3-12$ ".

790. V. Anagallic L., Wasser-E. Hayne Aiz. neigew. IV, 1. Stengel aufrecht, ziemlich dick, nebst den Blättern hahl; Blïtler etwas fleischig, sitzend, lanzcttlich oder eiförmig, spilz, sehr schwach gesägt; 'Traube blattwinkelständig; Blüthenstielchen nach deu Verblühen weit abstehend; Kapsel lireisrund oder liinglich, nur " wenig ausgerandet. 4. Stehende Gewässer, Grähen, Teiche, ïberschwemmte Stellen nicht selten z. B. bej Gutenberg, Dieskau, zwischen Dölnitz und Burg Jipbenau u. s. w. Mai - Aug. Blume hellblau, mit dunleren Adern. Höhe $1 / 2-1 \frac{1}{2}$. OFF. lierba re. cens Anagallidis.

791. W. Heccabunga L., B ach bungen-E. H a $y$. ne Arzneigew. IV, 2. Stengel niederliegend oder aufsteigend, wurzelnd, rundlich, nebst den glänzenden, fleischigen Blättern kahl; Blätter gestielt, elliptisch udel länglich, stumpf, gekerbt-gesägt; T'raube blattwinkol. ständig; Blüthenstielchen nach dem Verbliihen abstehend; Kapsel rundlich, gedunsen schwach ausgerandet. 4. Quellen, Bäche, stenende Gewässer häufig. MaiAug. Blume blaı nit dunkleren Arern. Höhe 1-2'. OFF. herba recens Beccabungae.

2. blätter beh is art.

792. V. Chamaedrys L., G a ma $\|$ d e r - E. II a y $\| \mathrm{e}$ Arzneigew. IV, 4. Stengel aufsteigend uder anfrecht, zucireihig-behaart; Blïiter fast sitzend, eiförmig, eingeschnitten - gekerbt-gesägt; 'Iraube blattwiukelständig; Blüthenstielchen nach dem Verblulien anfstrebend, länger als die 3eckig-verkehrt-her:fürmige, getvimperte Kapsel. 4. Wälder, trockene Wiesen, Raine, Zäune gemein. April. Mai. Blune lebhaft blau uder hellblan mit dunkleren Adern. Höhe $1 / 2-1 \frac{1}{2}{ }^{\prime}$. Aendert ab:

h) pilosa Schmidt: Stengel ringsum behaurt, aber die Haare in den 2 gegenständigen Längsteihen dichter und länger. 
793. V. montana L., Berg-E. Sturm Heft 58. Stengel an Grunde kriechend, ringsum behaart; Blätter lang-gestielt, eiförmig, eingeschnitten-gekerbt-yesägt, schwach - behaart; Traube blattwinkelständig, zuenigbliithig; Blüthenstielchen nach dem Verblühen abstehend; Kapsei breiter als lang, am Grunde und an der Spitze ausgerandet, flach, liahl, am Rande fein-gekerbt, gevimpert. 24. Schattige, feuchte Laubwälder sehr selten. Im Walde zwischen Döllnitz und Burg Liebenau, auf der Grenze im Walde bei Jeutzsch, von Wallr. und Spreng. auch im Wendelsteiner Forste, im Mühlthale zwischen Ziegelrode und Rossleben und in der Kl. Eichstedter Wüste und an Bienitz angegeben, an welchem letzten Orte sie ganz bestinumt niclit wächst. Mai. Juni. Blume weisslich-blau, nit dunkleren Aderu.

794. V. officinalis L., gebräuchlicher E. Hayne Arzneigew. IV, 3 . Siengel an Grunde niederlie. gend, dann aufstrebend, nebst den Blättern rauhhaarig; Blätter kurz-gestielt, rerkehrt-eiförmig - elliptisch oder länglich, gesägt; Traube blattwinkelständig; reichbliithig, ycdrungen; Bliithenstielchen nach dem Verbliihen aufrecht, livizer als die 3cchig-verkehrt-her-fömige, stumpf-ausgerandete Kapsel. 24. Höher gelegene Wälder, 'Triften gemein z. B. am Donnersberge hinter Kröll. witz, in der Dölauer Heide u. s. w. Juni-Ang. Blune hellblau, mit dunkleren Streifen. Höhe $1 / 2-1 \%$ OFF. herba Veronicae.

\section{h. Kelch 5theilig, das hinitere Läppchen kleiner.}

795. T. prostrata L., gestreckter. E. Sturm Heft 58. Nichtbliihende Stengel nieder.,estrecht, blühende aufsteigend, behant; Blätter hurz-gestielt, länglich oder linealisch-lanzettlich, gekerbt-gesägt, an Grunde etwas eingeschnitten oder fast ganzrandig; 'T'raube blattwinkelständig; Blüthenstselchen ungeführ so lang als die verkehrt-eiförmige, schwach-ausgerandete Kapsel; Kelph 5spaltig. 4. Sounige Abhänge, Hügel, Raine zerstreut. Am Lindberge $z$ wischen Schhopau und Merseburgr, auf Rainen bei Kötschau, Dürrenberge, Weissenfels und Naumburg, bei Eisleben verbreitet z. B. an Wege nach Bischufsrode und ins Katharinenholze, bei Dessau häufig, bei Delitzsch an den Windnïhlen und an heiligen Brumnen. Mai. Juni. Blume hellblau, sel. tener "eiss oder röthlich. Höhe $4-8$ ".

Garcke, Flora. 


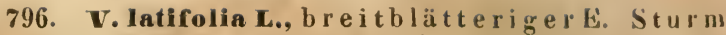
lleft 5S. Stengel sämmtlich aufrecht oder aus boge?förmigem Grunde aufstrebend; Blïtler sitzend, ans fast herzförmigem Grunde eiförmiğ oder länglich, ringeschnitten-gesägt oder fiederspaltig; Iraube blattwinkelständig; Bliithenstielchen aufrecht, ungefähr so lang als die verkehrt-eiförmige, spitz-ausgerandete Kapsel; Kelch 5spaltig. 24. Waldränder, trockene, sonnige Anhöhen, trockene Wiesen zerstreut. Auf der Wiese am Donnersberge hinter Kröllwitz, auf dem Bischufsberge in der Dölauer Heide, an Mittelholze, in den Weinbergen von Röglitz, zwischen KJ. Liebenaı und Kötzschlitz, an Bienitz, bei Dürrmberge, an südlichen Rande der neuen Giehle bei Freibury, an den Bergen bei Bibra, Schmon und Gruckstedt, hei Bernbnrg, fehlt in nordöstlichen Gebiete. Juni. Juli. V. Pseuduchamaedrys Jacq. Blume gross, schön blau, mit dunkleren Adern. Höhe $\mathbf{1}^{\prime}$. Aendert ab:

a) maior Koch: Blätter breit-eiförmig, mit herzförmigem Grunde stengelumfassend. $V$. latifulia maior Schrad.

b) minor Koch: B!ätter schmäler, länglich, mit ejförmigem Grunde sitzend. V. latifolia minor $\mathbf{S} \mathrm{ch}$ rad. V. Teucrium Vahl. Ob hierher auch V. T'eucrium L. gehöre, ist noch ungewiss.

B. Pseudo-Lrsimachium. Trauben endstïndig oder oft mehre seitenständige Nebentrauben; Röhre der Blumenkrone " alzenförmig, länger als ihr (Querdurchmesser; Wurzel ausdauernd.

797. T. spuria L., unächter E. Stengel steif-aufrecht; Blätter gegenständig vder in 3 -4blätterigen Qnirlen, länglich-lanzettlich oder lanzettlich, spitz. einfach-oder fast doppelt-gesäyt; Trauben endständig, fast rispig-verlängert, zicmlich locker; Decliblätter linealisch-lanzetlich, so lang oder liür zer als die Bliithensticlchen; Kapsel rundlich, iusgerumdet, gedunsen. 4. In Bergwäldern sehr selten, nur bei Halle. In Lindberge häufig, sparsam auf dem Bischufsberge in der Dölaner Heide, an mehren Stellen des Mittelholzes. Ende Juni-Aug. Blume blau. Höhe 2-4'. Die Blïthenstielchen sind bald so lang als die. Dechblätter, bald 2- bis 3mal länger. Die Pflanze ändert ferner ab.

b) Iaxiflua L, j.: Blätter lanzettlich, lang-zugespitzt, Sägezähne: genühert. 
c) foliosa W. K.: Blätter elliptisch-lancettlich, meist ungleich-gesägt.

798. V. longifolia L., lang blät teriger E. Stengel steif-aufrecht: Blätter gegenständig oder in 3- bis 4blätterigen Quirlen, aus abgerundetem odel herzförmigen Grunde lanzettlich, zugespitzt, bis zur Spitze geschärft-doppelt-gesägt; Trauben endständig, verlängert, ährenförmig, sehr gedrungen; Deckblätter linealisch-pfriemlich, ungefïh so lang als der Kelch; Kapsel rundlich, gedunsen, ausgerandet. 2. Feuchte Wiesen, Gräben, zwischen Gebüsch nicht selten z. B. auf der grossen Wiese, auf der Rabeninsel, auf Wiesen au der Saale bej Lettin, in der Aue häufig z. B. zwischen Burg Liebenau und Wallendorf. Juli. Aug. Blume blau. Höhe 2-4'. Aendert ab:

a) vulgaris Koch: Blätter an Grunde tief herzförmig. V. longifolia Schrad.

b) maritima Schrad.: Blätter am Grunde abgerundet oder ein wenig keilförmig.

c) media Schrad.: Blätter an Grunde keilförmig.

d) glabra Schrad.: Blätter gänzlich kahl.

799. V. spicata L., äh rentragender E. Stengel aufsteigend, meist einfach; Bliitter gegenständig, eiför. mig oder lanzettlich, sekerbt-gesägt, an der Spitze ganzrandig, die unteren stumpf; Traube endständig, meist einzeln, verlängert ährenförmig, sehr dichtblüthig; Deckblätter lanzettlich-pfriemlich; Kapsel rundlich, ausgerandet, gedunsen. 24. Trockene, grasige Anhöhen, 'Iriften, Raine zerstreut. An Donnersberge hinter Kröll. witz, auf dem Bischofsherge in der Dölauer Heide, an grasigen Ahhöhen bẹi Röglitz, bei Merseburg, am Bienitz, bei Dürrenberge, Naumburg, an der Steinklippe hei Wendelstein, selteh hei Allstedt, nur an sonnigen Stellen hintrr dem Hagen und an kahlen Berge bei l,andgrafrode sparsan, fehlt bei Aschersleben, bej Dessau hüufig, bei Benndorf und Paupitzsch. Juli. Aug. Blume dunkel blau, selten roth oder weiss. Höhe $1 / 2-1^{\prime}$. Aendert $a b$ :

a) rnlgaris koch: Fast gekränselt-oder drüsigweichharig, die unteren Blätter länglich, am Grunde keilförmig. V. spicata der Autur., und " Ienn die Haare driisig sind: V. Clusii Schott, und diese Form mit kishlem, gewinpertem Kelche: V. squamosa Presl. 
b) Iatifolia Koch: Fast gekräuselt - oder drüsig. weichhaarig, die unteren Blätter eiförmin oder auch fast herzförmig, nicht in den Blattstiel verschmälert. V. hybrida L. $V$. australis Schrad.

c) lancifolia $K u c h$ : Fast gekräuselt - weichhaarig, Blätter lanzettljch, geschärfter-gesägt. V. alternifolia Lej. fl. spa. V. media Lej. rev.

c. Veronicastrum. Die Trauben an dem Stengel und len Aesten endständig; Röhre der Blumenkrone sehr kurz. Wie Stengelblätter gehen bei den meisten allmählig in Deckblätter über.

\section{a. Samen flach, schildfürmig.}

800. V. serpyllifolia L., quend e I b I ät teriger k. Sturm Heft 5s. Stengel autsteigend; Hätler kahl, ejförnig uder länglich, schwach-gekerbt uder ganzranlig, die untersten hleiner, rundlich, die oberen blüthenständigen lanzettlich, ganzrandig; Traubt verlängert, lockerblüthig; Bliithenstielchen aufrecht, so lang oder lïnuer als der Kelch; Kapsel zusammengedrückt, rundlich, verliehrt-herzförmig; stumpf ausgerandet, breiter als lang; Griffel ïber die Ausrandung der Kapsel weit hervoriagend. 24. Grasplätze, lichte Waldstellen, Ackerraine, feuchte Plätze gemein. Mai-Herbst. Blume weisslich mit bläulichen Adern. Der kahle oder etwas weichharige Stenuel ist $4-8^{\prime \prime}$ hoch. Eine grössere

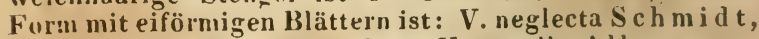
eine hleinere mit fast runden: V. tenella $A l l$.

801. V. arvensis L., Feld-E. Sturm Heft 58. Stengel aufsteigend oder aufrecht; Blätter herz-eiförmig, ganzrandig oder gekerbt, die nberen blïthenständigen lanzettlich, ganzrandig; Hliithen in ziemlich luckeren, ährenförmigen Trauben; Blïthesstielchen aufrecht, kiirzer als der.Kelch; Kapsel gewimpert, zusammenuedrïcht, verkehrt-her:förmig; Griffel meist ein wenig länger als die Ausrandung der Kapsel. ๑. Felder, Grasplätze, I'riften, Raine uberall gemein. April-Herbst. Blume blau. Höhe 4-9".

802. V. verna $L$., Frihlings-E. Sturm Heft 13. Stengel steif -aufrecht; unterste Blätter eiförmig, ganzrandig, die mittleven finger - oder fiedertheilig, die blüthenständigen ungetheilt-lanzettlich; Blüthen in zienslich lockeren ährenförmigen 'Trauben; Bliithenstielchen cufrecht, livir:zer als der Kelch; Kopsel schwach-gewim- 
pert, zusammengedruckt, verkchrt-her:förmig; Griffel so lang als die Ausrandung der Kapsel. $\odot$. Sonnige, besonders sandige Anhöhen, sandige Aecker, Grasplätze nicht allgemein verbreitet. Am Oclisenberge hinter Kröll. witz, in der Dölauer Heide auf dem Bischofsberwe und häufiges an Bergen zwischen Nietleben und der Fasanerie, auf dem Schweizerling bei Wettin, auf Graspläzzen am Fahrwege ron Schkopau nach Merseburg sparsam, auf sandigen Aeckern bei Kl. Dölzig und an und im Bienitz häufig, bei Naumburg in trocknen, sandigen Wäldern über der Heune, an der Steinklippe bei Wendelstein, an den Steinbrüchen bei Lodersleben sparsam, bei Aschersleben zerstreut, bei Dessau häıfig, ebenso bei Oranienbaum in lichten Waldungen. April. Mai. Blume sehr klein, blau, mit dunkleren Adern. Derdrüsig-behaarte Stengel ist nur 2-4" hoch.

h. Samen vertieft, heckenfürmig.

803. V. triphyllos L., dre iblätteriger E. Sturm Heft 8. Stengel aufrecht oder aufsteigend; unterste Blätter eiförnig, ungetheilt, die iibrigen fingerförmiö3 -oder 5thcilig; Blïthen in lockeren Trauben; Blitthenstielchen aufrecht-abstehend, länger als der Kclch; Kapsel rundlich-verkehrt-herzförmig, nur am Grunde gedunsen. $\odot$. Aecker, Mauern überall gemein. März - Mai. Blume hellblau. Der meist ästige, drïsig-behaarte, oft roth angelaufene Stengel ist $3-6$ " hoch.

804. V. praecox Al., frühzeitiger E. Sturm Heft 58. Stengel aufsteigend wder meist aufrecht, nebst den Blättern drüsig-behaart; untere Blätter herz-eiförmig, tiefer gekerbt. stumpf, die bliithenstäindigen lanzettlich; Blüthen in lockeren Trauben; Blïthensticlchen aufrecht, so lang odcr länger als der Kelch; Kapsel oval-verkehrt-herzförmig, gedunsen. $\odot$. Trockene Aecker, Mauern zerstreut. Auf Gartenmauern vor Giebichenstein, sparsam auf Aeckern vor Nietleben, sehr häufig auf hochgelegenen Aeckern am Lindberge zwischen Nietleben und.Bennstedt und in Weinbergen und auf Aeckern zwischen Rollsdorf und Seeburg, auf Aeckern zwischen Seben und Gutenberg, auf Apckern zwischen Merseburg und Weissenfels, bei Naumburg und Freiburg verbreitet, bei Eisleben sparsam, so am Helftaer Holze, an Hutberge und auf Aeckern nach Helbra zu, bei Aschersleben, Sandersleben, Bernburg und Dessau zerstreut. April. Mai. V. romana Scop. Blume dunkelblau. Der meist ästige, roth angelaufene Stengel ist $4-9 "$ " hoch. 
D. Alsinoides. Die Deckblätter fehlend; die bliithenständigen Blätter den unteren gleicligestaltet; Blüthenstiele lang, blattwinkelständig, einzeln, nach dem Verbliihen zurückgekriimmt; Wurzel einjährig.

805. V. Fuxbaumii Tenore, $B$ ux b a u m s - L. St $\mathrm{t}$ rm Heft 56. Stengel niederliegend, meist vom Grunde ästig; Blätter eiförmig, fast herzförmig, tief - gekerbtgesägt; Bliithenstiele blattwinkelständig, einzelı, nach dem Verblïhen nur an der Spitze zurïckgekrïmmt, die oberen länger als die Blaitter; Kelchzipfel eiförmiglanzettlich, spitz: Kapsel breiter als lang, von erhabenen Adern netzformig, stumpf-ausgerandet, mit abstehend. ausgespreiztcn Lappen, die Fächer 7-8samig; Griffel etwas länger als die Ausrandung der Kapsel. $\odot$. Aekker, bebauter Buden sehr selten. Auf Aecliern zwischen Dölau und der Heide, Aecker bei Gross und KI. Dölzig, Delitzsch. April. Nai. V. persica Po ir. V. Tuurnefortii $\mathrm{Gm}$ el. V. filifurmis DC.. nicht $\mathrm{S} \mathrm{m}$. V. hospita Koch. Blume schön blau, grösser als alle in dieser ganzen Abtheilung. Stengel bis fuss!ang.

Sprengel gibt in der 2. Autl. der Flora für diese äusserst seltene P'lanze gar keinen besunderen Standurt an, wahrscheinlich weil sie im botanischen Garten zu Halle jährlich verwildert erscheint.

806. V. agrestis L., Acker-E. Sturm Heft 58. Stengel niederliegend, meist vom Grunde an ästig; Blätter eiförmig viler länglich - eiförmig, anı Grunde fast herzförmig. gekerbt - gesägt; Bliithenstiele blattwinkelständig, einzeln, ungeführ so lang als das Blat, nach dem Verbliihen zurückgekrünmt; Kelchzipfel elliptisch, stumpf; Kapsel auf den Sciten nur mit zerstreuten Driisenhaaren beset-t, ïbrigens daselbst ohne andere Haare, am Rande drïsig-gewimpert, die Lappen der Kapsel gedunsen, an Rande etwas zusammen. gedrückt, die Fächer 3-5samig; Griflel so lang oder kiirzer als die Ausrandung der Kapsel. $\odot$. Aecker, bebauter Boden. Obgleich Spreng. hal. ed. 2. p. 11 diese Pflanze ganz alluemein in Obstgärten und auf Aeckern ohne besonderen Standort angibt, so ist sie in Gebiete doch nur äusserst sparsam. In der Nähe ron Halle fehlt sie gänzlich und findet sich erst auf Aeckern bei Röglitz und Ermlitz, anf Aeckern bei Dölkau unnittelbar an den Gärten, auf Aeckern am Bahnhofe bei Schkeuditz häufig, auf Aeckern bei Zaasch 
östlich von Brehna sehr sparsam, bei Dessau und Oranienbaun etwas verbreiteter. April. Mai und im Herbst wieder. V. pulchella Bast. und Guss. V. didyma Tenore nach Koch. Blume hellblau und der untere Lappen weiss, oder die Blume röthlich und weiss oder ganz weiss. Stengel 4-9" lang.

807. V. polita ries, geglät te ter E. S t u r m Heft 58. Stengel niederliegend, meist vom Grunde an ästig ; Blätter rundlich-eiförmig, tief - gesägt-gekerbt; Bliithenstiele blattwinkelständig, einzeln, etwa so lang als das Blatt, nach dem Verblühen zurückgekrümmt; Kelchzipfel eiförmig, spitz; Kapsel auf den Seiten mit kurzen, driisenlosen Haaren dicht bedeclit, am Rande kurz - drüsig-gewimpert, schwach-ausgerandet, mit kugelig - aufgetriebenen Lappen. die Fächer etwa 10samig; Griffel deutlich länger als die Ausrandung der Kapsel. $\odot$. Aecker, Schutt, Mauern ïberall ganz gemein. März - Herbst. Blume lebhaft blau. Blätter gläızend griin. Stengel $3-8^{\prime \prime}$ lang.

808. T. opaca Fies, glanzloser E. Sturm Heft 58. Stengel niederliegend, meist vom Grunde an ästig; Blätter rundlich-eiförmig, am Grunde etwas herzförmig, gekerbt-gesägt; Bliithensticle blattwinkelständig, einzeln, ctwa so lang als das Blatt, nach dem Verblïhen zurückgekrümmt; Kelchzipfel spatelförmig, stumpf; Kapsel breiter als lang, auf den Seiten mit kurzen, driisenlosen Haaren dicht bedeckt, an Rande länger drüsig-gewimpert, ticf-ausgerandet, die Lappen derselben gedunsen, nur an Rande zusammengedrücktgekielt, die Fïcher 3-5samig; Griffel fast su lang oder kürzer als die Ausrandung der Kapsel. $\odot$. Aecker, bebauter Boden selten. Auf Aeckern zwischen Röglitz und Oberthau, auf Aeckern bei Möritzsch; häufiger auf Aeckern bei Aschersleben und gewiss weiter verbreitet. März - Mai und in Herbste wieder. Blume dunkelblau. Die ganze Pflanze ist zottig-behaart. Stengel 3 - $8^{\prime \prime}$ lang. Die Stauhgefässe sind bei dieser Art dem Schlunde eingefügt, während sie bei der vorhergehenden tief an Grunde der Blumenröhre stehen.

809. V. hederaefolia L., e pheublätteriger E. Sturm Heft 56. Stengel niederliegend, vom Grunde an ästig; Blätter herzförmig-rundlich, gekerbt, fast 5. oder nur 3lappig; Blüthenstiele blattwinkelständig, einzeln, etwa so lang als das Blatt, nach den Verblü. hen zurïckgekrümmt; Kelchzipfel am Grunde herzför- 
mig; Kapsel sehr gedunsen, kaum ein wenigr ausgerandet, fast kuoglförmig-4lappig, kahl, in jedem Fache nur $1-2$ grosse Samen. $\odot$. Aeclirr, Wege, Schutt ïherall gemein. Närz - Mai und bisweilen in Herbste wieder. Blume hellblau, kleiner ais der gewimperte Kelch. Stengel bis g" lang.

322. Himosélla L. Schlammling (von linıs, Schlanın, wegen des Vorkommens in Sïmpfen; der Name findet sich zuerst bei Lindern).

810. L. aquatica L., geme iner Sch. Sturm Heft 30. Wurzelstock fadenförmige Ausläufer treibend; Blätter sänmtlich grundständig, spatelförmig - linealisch, stumpf, lang - gestielt, meist länger als der 1blïthige Schaft; Kelch meist 5zähnig; Blumenkrone röhrenförmig-glockig; Kapsel länger als der Kelıh. $\odot$. Ueberschwemnte Plätze, Pfïtzen, 'Teiche nicht gerade selten, aber leicht zu ïbersehen. An der Saale bei Giebichenstein, auf nassen Wegen in der Dölauer Heide, bei Naumburg besonders in der Aue, auch nach Freiburg hin an iiberschwemmten, kurz - begrasten Plätzen, bei Aschersleben unter den Westerbergen, bei Dessau au überschwemmten Stellen häufig. Juli-Sept Röhr* der Blumenkrone grïlich, Saum röthlich-weiss. Die ganze Pflanze ist nur $1 / 2-2^{\prime \prime}$ hoch.

\section{Familie. Orobuncheen Juss. S o m-} u erw ur z ge

323. Drobrnche F. Sommerwurz (ein aus

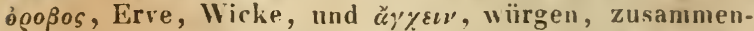
gesetzter, ursprünglich für Flachsseide (Cuscuta Épilinum) gebrauchter Name bei Diuscurides).

A. Osproleon Wallr. Kelch 2 blätterig, mit einem ein. zigen Deckblatte gestiitzt; Blättchen des Kelches zuweilen vorne zusammengewachsen. (M ehr. nervig heissen die Kelchblätchen, wenn sie ausser einem oder 2 stärkeren Nerven noch einige hindurchziehende, zartere haben.)

811. O. maior L., nach Fries, grössere S. Kelch. blättchen mchrnervig, eiförmig, fast gleichförmig - 2spaltig, Zipfel lanzettlich, etwas kürzer als die Röhre der Blumenkrone; Blumenkrune röhrenfürmig-glockig, auf dem Riicken bogenförmig, Lippen ausgefressen-gezäh- 
uélt, die obere undeutlich-2lappig mit gerade vorgestreckten Lappen, die unteren etwas abstehend, 3lappig, lappen läıglich-lund, fast gleich; Staubgef ässe unter ler Mitte der Rölıre cingefiigt, vom Grunde bis zur Mitte zottig-behaart, wben schwach-drüsig; Griffel an der Spitze sparsam drüsig - behaart. 4 . Sehr selten. An Abhäugen des Buchberges bei Rossleben auf Centaurea Scabiosa schmarotzend. Juli. Ang. Blume gelblich, vorue gelbbraun, mit schwachem röthlichem Schimmer. Narbe erst wachsgelb, dann goldgelb. Stengel 1-2' hoch, sehr dick, mit langer, dichter Aehre. llierher gehört nach Wi m m e r (S. Ergänzungsband zur Flnra von Schles. S. 30) O. stigmatodes Wi nı m., wahrscheinlich auch 0 . elatior Suttun.

812. O. Epithymum DC., Quendel-S. Kelchblättchen metirnervig, lanzettlich, pfriemlich-zugespitzt, länger als die Röhre der Blumenkrune, ungetheilt oder durch einen spreizenden Zahn 2spaltig; Blumenkrone glockenförmig, auf dem Rïcken sanjt gebogen, auswendio, so wie die Oberlippe inuendig von Haaren, die auf einem sehr kleinen Knötchen sitzen, drïsig-behaart, Lippen ungleich, spitz-gezähnt, anı Rande gekräuselt, Oberlippe an der Spitze ein wenig aufwärts gebogen, 2lappig. die Iappen ausgebreitet, der mittlere Zipfel der Unterlippe doppelt so lang als die seitenständigen; Staubgefässe oleich iiber dem Grunde der Blumenkrone cingefiigt, unterwärts zerstreut-behaart, an der Spitze nebst dem Griffel drüsig-behaart; Narbenscheibe feinsammetartiug ohne hervortretenden Rand. 2. Sehr selten. An Pfortenberge bei Naumburg auf Thymus Serpyllum schmarotzend. Juni. Juli. O. rubra Smith. O. sparsiflora W allr. Blume gelblich, purpurroth überlaufen, Haare rustbraun. Narbe dunkelroth. Höhe $5-12^{\prime \prime}$.

812. O. Galii Duby, Labkraut-S. Kelchblättchen mehrnervig, ziemlich gleichförnig-2spaltig, halb so lang als die Rölue der Blunienkrone, vorne zusammenstussend oder zusammengewachsen; Blumenkrone aus allmählig erweitertem Grunde olockenförmig, auf dem Rïcken gekriimmt, Lippen ungleich-gezähnelt, Oberlippe helmartig, mit vorwürts „erichteten, (nicht abstehenden) Seiten, Zipfel der Unterlippe eifö:mig, fast gleich, vorwärts gerichtet, nicht halb so lang als die Röhre; Staubgefässe über dem Grunde der Blumenkrone eingefïgt, dicht-behaart, oberwärts nebst dem 
Griffel drüsig-behaart; Narhenscheibe fein-sammetartig, whe hervortietenden Rand. 24. Eimmal im Ge. büsch an der Saale in der Nähe der Gersdorfer wïsten Feldmark hinter Kröllwitz gefunden, häufiger auf dem P'ortenberge bei Naumburg, bei Aschersleben und gewiss weiter verbreitet, gewöhnlich auf Galium Mollugo schṇarutzend. Juni. Jnli. O. caryophyllacea S m. 0 . vulgaris DC., nach $K o c h$ auch $O$. caryophyllacea, stro. biligena, laxiflora und vulgaris bei $\mathrm{kchb}$. Blune weiss. lich, mit röthlichem uder bläulichem Anfluge. Narbe dunkel-purpurroth. Aehre lockerblïthig. Höhe $1 / 2-I^{\prime}$.

814. O. rubens Wall r., röthliche $\mathrm{S}$. Rchb. pl. crit. VIl. Abb. 901. 902. Kelchblïttchen mehrnervigr, breit-eiförnig, pfriemlich-zugespitzt, hinten und rorme nit einem Zahne versehell und nugleich-2spaltig, etwa so lang als die halbe Röhre der Blunentroue, vorne zusamuenstossend wder zusammengewachsen; Blumenkrone aus, sekriimmtem Grunde röhrenförmig-glockig, auf dem Riicken gerade, an der Spitze helmartig-abschiissig, Lippen ungleich-gezähnt, die ubere 2 lappig, mit abstehenden Lappen, Zipfel der Unterlippe eiförmig, zienılich gleich, die seitenständigen abstehend; Staul. grefässe in der Biegung der Blumenkrone eingefiigt, vom Grunde bis zur Mitte dicht behaart; Narbenscheibe fein. sammetartig, ohne hervortretenden Rand. 24. Nirht gerade selten. Einzeln in Gebusche an der Saale hinter Kröllwitz und in Krosigker Holze nordwestlich vom Petersberge, in den Weinbergen bei Röglitz, bei Naumburg sehr häufig z. B. an der Schönburg, an Pfortenberge, bei Guseck, an den Bergen bej Bibra, an der Steinklippe bei Wendelstein; gewöhnlich auf Medicago schmarotzend. Mai. Juni. O. elatior $K$ o $\mathrm{ch}$ und $\mathrm{Ziz}$. O. Medicaginis Schultz. O. Bnekii Dietrich (aber nicht $\mathbf{O}$. Buekiana $K($ () $\mathrm{c})$. Blume gelblich oder bräuılich. Narbe wachsgelb. Höhe $1 / 2-11 / 4$.

815. O. Ioricata Rchb., gepanzerte S. Rchb. pl. crit. V1I. Abb. 917. Kelchblëttchen 3-5nervig, 2theilig, so lang als die Röhre der Blumenkrune; Blumenkrone röhrenförmig-glockig, auf dem Rïcken gerade, an des Spitze vorwärts gelirïnnit, Lippen stunipf-gezähnelt, die oberen 2lappig, mit abstehenden Iappen; Staubgefässe unter der Mitte der Röhre eingefiigt, kahl, an Grunde spärlich-behaart. 24. Sehr selten, nur an den Westerbergen bei Aschersleben auf Artemisia campestris schmarotzend. Juni. O. Artemisiae campestris 
Gaud. O. elatior Schleirh. - Unterscheidet sich durch die schmilen $3-5$ mervigen, tief - gretheilten Kelchblätchen, welche su lang uder länger sind als die Blumenkronröhre, durch die 7-8 Linien lange, vom Grundé bis zur Unterlippe gerade, nur auf dem Rücken der Oberlippe ein wenig gekrümmte Blmmenkrone, die 2lap. pige, abstehende lippe und die spärlich-behaarten, hoch oberhalb des Drittels der Röhre eingefügten Staubgefässe.

816. O. minor sutt., kleine S. Kelchblïtlchen mehrnervig, aus eiförmigem Grumde plötzlich schmalpfrienlich oder in 2 pfriemliche Zipfel gespalten, so lang oder läuger als die Röhre der Blumeukinne; Blu. mcnkrone röhrenfürmig. sanft-geliriimmt, Lippen stumpfwezihnelt, aderig, wellenförmig. die obere 2 lappig, vurwärts gerichtet, Lappen der Unterlippe rundlich, fast gleich; Staubgefäisse unter der Mitle der Röhre eingeiigt, liahl, unterviirts mit zerstreuten Haaren besetzt. $\odot$. Sehr selten. Nur in den Weiubergen am Kroppenthale zivischen Schönburg und Wetau und bei Goseck, fruher von Wallr. auch an Buchberge in Ziegelroder For'ste gefunden; auf 'Trifulium pratense und 'T'. medium schmarotzend. Juni. Narbe purpurroth oder lila, stark ausgerandet. Höhe $1 / 2-1$ '.

B. Trionychon Wallr. Kelch 1blätterig, ringsum geschlossen, mit 3 Deckblättern gestiutzt.

817. O. coerulea Vill., blaue S. Rchb. pl. crit. VII. Abb. 928. Stengel einfach; Kelch 1blätterig, 5zähnig, der hintere 'Zahn sehr Klein, die übrigen lanzettlich; Blumenkrone röhrenförmig, vorwärts gekrümmt, Röhre in der Mitte verengert, Zipfel der Lippen spitz, flach; Staubbeutel kahl oder an Grunde mit wenigen Härchen besetzt. 24. Sehr selten, meist auf Achillea Yillefolium, seltener auf Salvia officinalis schmarotzend. In der Gegend von Naumburg zwischen Eulau und Guserk. Juni. Juli. O. purpurea Jacq. Blume amethystfarben, Narbe weisslich.gelb. Höhe $1 / 2-1 \frac{1}{4}{ }^{\prime}$.

818. O. arenaria $\mathbf{R}$ orkh $\mathrm{h}$ u e $\mathrm{n}, \mathrm{S}$ and $-\mathrm{S}$. R $\mathrm{chb}$. pl. crit. VII. Abb. 929-931. Stcnocl einfach; Kelch tblätterig, 5zähnig, der hintere Zahn sehr klein, die ïbrigen pfriemlich; Blumenkrune röhrenförmig, fast gerade, Röhre in der Mitte verengert, Schlund etwas aufgeblasen; Zipfel der I.ippen stumpf, an Rande zu- 
rückgebogen; Naht der Staubbeutel wollig-behaart. 4. Auf Artenisia campestris schmarotzend, besonders allf Sand- und Kalkboden. An Bergen bei Rollsdorf unmittelbar an Wirthshause, in Weinbergen zwischen Seeburg und Wormsleben, bei Naumburg häufig z. B. in Weinbergen an Kroppenthale zwischen Schönburg und Wetau, zwischen Eulau und Goseck, auf den Pfortenberge, an der Steinklippe bei Wendelstein. Juni. Juli. Blume amethystfarben. Narbe weisslich-gelb. Höhe $1 / 2-11 / 4$.

Zu dieser Art gehören höchst wahrscheinlich auch die von $\mathrm{Schwabe}$ fl. anh. fïr 0 . cuerulea angegebenen Standorte bei Bermbuig und Schackenthal.

819. O. ramosa L., ästige S. Rehb. pl. crit. VII. Abb. 933 - 934. Stengel ästig; Kelch 1blätterig, 4zähnig, Zühne eiförmig-3eckig, pfriemlich-zugespitzt; Staubbeutel kahl. $\odot$. Sehr selten, nur bei Wiehe, Donndorf, Rossleben auf Hanf schmarutzend. Juni. Aug. Blume nur halb uder ein Drittel so gross als an den beiden vorhergehenden, weiss oder blänlich. Narbe gelb. lich - weiss. Höhe $1 / 2-1^{\prime}$.

324. Latinraen L. S chuppenwurz (diese Pflanze erhielt ihren ans $\lambda \alpha \vartheta$ paัos, verburgen, gebildeten Namen von Linné, weil sie die stengel und die schuppenförmigen Blätter unter der Erde und nur die Bliithenschäfte ïber derselben entwickelt).

820. L. Squamaria L., ge ne ine Sch. Wurzelstock dickschuppig; Blättel fehlend; Schaft einfach, mit Schuppen besetzt; Blüthen in dirhter, einseitswendiger, nickender Aehre; Oberlippe der Blumenkrone heImförmig, Unterlippe 3lappig. 24. In fenchten Gebüschen und Wäldern auf Baumwurzeln, besunders auf Haselwurzeln schmarutzend, stellenweise. Fehlt bei Halle und Mersebury; findet sich abel zwischen Weissenfels und Beuditz und bis nach Leislingen hin häufig, ebenso in Walde unmittelbar hinter Leislingen am Wege nach der Srhönburg, bei Naumburg häufig z. B. am Pfortenberge, im Mïhlthale zwischen Russleben und Zipgelrude, bei Allstedt, Eisleben, Aschersleben, San. dersleben, Lingenau, Dessau, Oranienbaum und Delitzsch nicht selten. März-Mai. Die gauze Pflanze weiss oder röthlich überlaufen. Höhe $1 / 2-1^{\prime}$. 


\section{Familie. Rhinanthaceen DC. Rüs -} selblumeng e wäclise.

325. Melampýrum L. Wachtelweizen (ein aus $\mu \varepsilon \dot{k}$ ces, schwarz, und $\pi v \varrho o ́ s$, Weizen, gebildeter Pflanzenname bei Theophrast, wegen der schwärzlichen, dem Weizen ähnlichen Samenkörner).

a. Aehren kurz, 4kantig, dicht -dachziegelig.

821. Mr. cristatum L., $\mathrm{k}$ a m mäh riger W. Blätter sitzend, lan «ettlich-linealisch oder eiförmig-lanzettlich; Aehren 4 kantig, dicht-dachziegelig, Deckblätter herzförmig, aufwärts-zusammengeschlagen, zurückgekrümmt, kammartig-gezühnt, mit ganzrandiger, oft verlängerter Spitze. $\odot$. Laubwälder, trockene Wiesen zerstreut. In der Dölauer Heide, in Mittelholze, sehr häufig auf Wiesen zwischen Collenbey und Burg Liebenau, bei Kl. Dölzig und an den Quellen zwischen dem Bienitz und Rïckmarsdorf, bei Naumburg in allen Wäldern nicht selten, bei Freiburg z. B. am südlichen Rande der neuen Giehle, bei Ziegelrude, Allstedt, Eisleben. Juni. Juli. Blume weisslich, vorne blassgelb, mit dottergelber Unterlippe, seltener röthlich, mit gelblicher Unterlippe. Höhe $1 / 2-1$.

b. Aehren locker, nicht 4kantig.

822. M. arvense L., F e l d - W. Blätter sitzend oder kurzgestielt, aus eiförmigem Grunde lanzettlich und lang zugespitzt; Aehren locker, allseitswendig; Deckblc̈itter eiförmig, lanzettlich-zugespitzt, pfriemlich-gezähnt, unterseits 2reihig-schwarz-punktirt; Kelch weichhaarig, fast so lang als die Röhre der Blumenkrone, Zähne aus eiförmigem Grunde verlängert, borstlich - zugespitzt. $\odot$. Aecher, in Gebiete meist nicht selten. Juni. Juli. Blume purpurroth, in der Mitte mit weissem Ringe, an Grunde der Unterlippe ein gelber Fleck; Deckblätter purpurroth. Höhe $1 / 2-1$ '

823. N. nemorosum L., b lauer W. Sturm Heft 29. Blätter deutlich gestielt, eiförmig-lanzettlich; Aehrenl lucker, einseitswendig; obere Deckblätter tief-herzförmig, gezähnt; Kelch zottig-rauhhaarig, ungefähr so lang als die Blumenkrone, Zähne lanzettlich-pfriemlich, abstehend. $\odot$. Wälder, Haine häufig z. B. in der Dölaner' Heide, am 'Tannenberge bei Gutenberg, in Mittelholze u. s. w. Juli. Aug. Deckblätter violett? 
blau, die obersten blïthenlos; Blume goldgelb, mit rostbrauner Röhre. Höhe $1 / 2-1 \frac{1}{2}$.

824. M. pratense L., W i e se n-W. Blätter kurzgestielt, linealisch-lanzettlich - langzugespitzt ; Aehren locker, einseitswendig; Deckblätter lanzettlich, die oberen am Grunde beiderseits 1-2zähnig, Kelch kahl, 3 mal kiirzer als die Jilume; Blïthen wagerecht-abstehend. $\odot$. Wälder, besunders an freien Waldplätzen, Heiden gemein. Juni. Juli. M. vulgatum Pers. M. commutatum 'T'ans sh. Blıme hellgelb odel weiss und vorne gelb. Decliblätter grün. Höhe $1 / 2-11$. - Ungeachtét des 'Trivialnamens M. pratense kommt die Pflanze duch nie auf Wiesen, sondern nur in Wäldernvor.

326. Pedieularis L. Muorkönig (ein aus pediculus, Laus, gebildeter Pflinzenname bei Columella; daher die deutsche Uebersetzung $L a ̈$ us ekraut).

825. P. silvatica L., Wa ld - M. H a y n e Arzneigew. Vill, 34. WHurzel einen aufrechten, kurzen Stengel und einige niedergestreckte oder aufsteigende Nebcinstengel treibend; Blätter gefiedert, nit fust fiederspaltigen, kleinlappigen Fiedern; Kelch 5zähnig, Zähne uberwäits blattartig und ge;ähnt: Blïthen an Hauptstengel rom Grunde an traubenförnig, Oberlippe an des Spitze ab. gestntzt, die Ecken in pinen 3eckig - pfriemlichen Zahn verlängert. (-), wahrscheinlich nicht 24 . Feuchte Wälder und Wiesen stellenweise. Auf einer nassen Wiese zwischen Dölau und der Heide, auf Wiesen bei Kl. Dölzig, fehlt bei Naumburg, nur bei Osterfeld selten, an sumpfigen Stellen des Ziegelroder und Lodersleber Forstes, fehlt bei Aschersleben, bei Dessau häufig. Mai - Juli. Blume hell-rosenroth. Ilöhe bis 6".

826. P. palustris L., Sumpf - M. Hayne Airzneigew. Vill, 33. Stengcl aufiecht, vom Grunde an ästig; Blätter gefiedert, mit länglichen, fast fiederspaltigen, kleinlappigen Fiedern; Kelch 2lappig, mit eingeschnitten-gezähuten, krausen Lappen; Blüthen traubenförmig; Oberlippe an der Spitze abgestutzt, die Fcken in ein pfriemliches Zähurhen verlängert. (-), nicht 4. Sümpfe, "lasse VTiesen seltener als die vorige Art. Fehlt in der Nähe ron Halle gänzlich, findet sich auf sumpfigen Wiesen bei Kl. Dölzig, an den Quellen zwischen dem Bienitz und Rückmarsiorf, bei Naumburg auf der Wiese zwischen Giekan und Gröbitz und auf den Wie- 
sen bei Schulpforte, häufig bei Dessau und Oranienbaun. Mai. Juli. Blume hellroth. Höhe $1 / 2-1 \frac{1}{2}$ '

327. Alectorólophus III all. K I a p per (ein aus ả $\varepsilon_{x} \tau \omega \varrho$, Hahn, und hóy os, Kamm, Schopf, gebildeter Pflanzenname bei Dodonaeus).

827. A. minor wimm. u. rab., kleine K. Rehb. pl. crit. Vill. Abb. 973. 974. Stengel aufrecht, einfach wder ästig; Blätter länglich-lanzettlich; Deckllïtter grïn oder bräunlich, die oberen eingeschnittengesägt, mit zugespitzten Zähnen; Kelch kahl, zusanmengedrückt, breit eiförmig; Blumenkrone klein, rorne an der Oberlippe mit 2 äusserst kurzen Zähnen. $\odot$. Feuchte Wiesen gemein z. B. auf der Wiese am Donnersberge hinter Kröllwitz, bei Dölau vor und hinter dem Sebenschen Busche, bei Gutenberg u. s. w. Mai. Juni. A. parviflorus $\mathbf{W}$ a $\| \mathrm{s}$. Rhinanthus Crista galli «. I. Blume dunkelgelb, Zahn der Oberlippe weisslich oder violett. Höhe $1 / 2-1$ '.

828. A. maior Pe ch b., glössere K. Rchb. pl. crit. VIIl. Abb. 975. Stengel aufrecht, einfach oder ästig; Blätter länglich-lanzettlich; Deckllätter bleich, weisslich-griinlich, die oberen eingeschnitten-gesägt, mit pfriemlichen, haarspitzigen Zähnen; Kelch kahl oder weichharig; Blumenkrone gross, vorne an der Oberlippe mit 2 deutlichen eifürmigen Zähnen. $\odot$. Feuchte Wiesen etwas seltener als rorige Art. Vor und hinter dem Sebenschen Busche, Wiesen bei Gutenberg, feuchte Wiesen bei Kl. Dölzig, Kötschau, bei Naumburg scltener, nur im Kroppenthale zwischen Schönburg und Wetau und daselbst nur sparsam, häufiger auf Wiesen zwischen Balgstedt und Laucha, zwischen der Steinklippe und Nemleben und bei Bibra, ebenso bei Dessau und an der Benndorfer Mühle. Mai. Juni. A. grandiflorus Wallr. Rhinanthus Crista galli $\beta$. I. Blume hellgelb. Der of schwasz-punktirte Stengel ist $1-1 \frac{1}{2}$ ' huch. Aendert ab:

b) hirsutus All. R chb.pl. crit. VIII. Abb.976. Kelch zotíg. A. grandiflorus $\beta$. pubens Wa II r. Rhinanthus Alecturoluphus Poll. R. Crista galli $\gamma$. L. R. villosus Pers. Diese Form auf Aeckern unter der Saat, so hei Weissenfels, bei Naumburg häufig, daselbst zuweilen auch auf hochgelegenen Wiesen, bei Griss Wangen und in jener Gegend unter dem Getreide nicht gerade selten. 
Dass A. hirsutus $\Lambda$ II. und A. maiol R $\mathrm{ch}$ b. zu einer Art gehören, ist "ohl kaum zu bezweifeln. Der gejingste Werth ist der Breite der Samenflügel beizulegen, da diese sehr veränderlich ist.

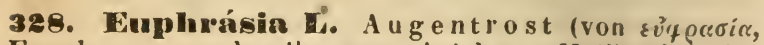
Freude, wegen der ihr zugeschriebenen Heilkräfte; der Name findet sich zuerst bei Matth. Sylvat.).

A. Euphrasium. Das untere Staubbeutelfach der kir. zeren Staubgefüsse mit einem längeren Dörnchen bewehrt, die übrigen Fächer sehr feill- und kurzstachelspitzig.

829. F. officinalis L., ge bräuchlicher A. Blït. ter ciförmig, beiderseits meist 5zïhnig, die unteren $Z$ Zühne genähert, an den wberen Blätteın kïrzer-ode. Jänger-stachelspitzig ; Oberlippe der Blume 2lappig, mit abstchenden, 2 - 3zähnigen Lappen, Unterlippe 3spalijg, mit tief-ausperandeten Zipfeln. ○. Wiesen, 'Triften, Waldplätze gemein. Juli. Aug. Aendert ab:

a) pratensis Fries (Hayne Arzneigew. 1X, 7): oberwärts von abstehenden Haaren drüsig-behaart; Zähne der oberen Blätter stachelspitzig; Blume meist ziemlich gross, weiss, mit einem citrongelben Flecke am Grunde der Unterlippe und auf der Oberlippe mit 6, anf der Unterlippe mit 9 violetten Streifen. E. pratensis Rchb. E. Rostkuviana Hayne, so auf feuchtem Boden, auf Wiesen.

b) nemorosa Pers. (Hayne Arzneigew. IX, 8): von gekräuselten, angedriickten, drusenlosen Haaren weichhaarig, die oberen Blätter tief-gesägt, mit längeren, haarspitzigen 'Zähnen, Blumen meist kleiner als an roriger Abart, die Oberlippe oder bisweilen die ganze Blume violett. E. stricta Host. E. officinalis Hayne, so auf trucknerem Boden, auf Triften.

\section{B. Odontites D u b. Die Staubbentelfücher gleichmässig- stachelspitzig.}

830. E. Odontites L., roth hlumiger A. Blïtter aus breitcrem Grunde lanzettlich-linealisch allmählig verschmälert, mit stumpfen hleinen Sägezähnen; Deckblätter länglich-Janzettlich, länger als die Blïthe; Blu. menkrone auf der Oberfläche an Rande kurz-lchaart, Oberlippe etwas zusammengedrïckt, abgestutzt, so lan: als die Staubge/üsse; Staubbcutcl an der Spitze etwas 
zollig. $\odot$. Wiesen, Triften, feuchte Afcker gemrin. Juni - Herbst. E. verna B ellard. Oduntites rubra Pers. Bartsia Odontites $\mathbf{S} \mathrm{m}$ ith. Blume meist hell. purpurroth. Höhe $1 / 2-1 \frac{1}{2}$ '

E. se rotina I, a m. nit lanzettlichen, zugespitzten, an Grunde etwas verschmälerten Blättern und kiirzeren Weckblättern ist zwal inmerhalb der Grenze dos Grbie. tes noch nicht aufyefunden, aber gewiss vorhanden.

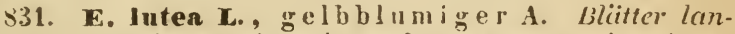
zctlich-linealisch, schwach-entfernt-gesägt, die oberen lincalisch, ganzrandig, alle nebst dem strngel wherwärts und dem Kelche von angedrückten, gekräuselten, drüsenlosen Haaren weichhaarig; Blumenkrone lärtiggewimpert; Oberlippe zusammengedrürkt, abgestutzt, kiirzer als die Stanbgefässe; Staubbcutel laht. ๑. Dürre Iriften und Hurel, besonders an Kalkbergen, stellenweise. An Kalkbergen bei Bennstedt his Kölme und I augenbongen hin, an Berge zwischen Wansleben und Rullsdorf, fohlt östlich und südlich von Halle bis Weissenfels; bei Naumburg am Ausgange des Mordthales nach Flemmingen zu, in den Weinbergen hei Freiburg sparsam, a川 Buchberge des Zipgelröder Furstes, bei Aschersleben an den Bergen "ach Nehringru zu, bei Sandersleben am Schiessherge, an Kalkbergen bei Bernburg, fehlt im nordöstlichen Gebiete ganz. Ang. Sept. Odontites lutea Rchb. Blume dottergelb. Höle $1 / 2-1^{\prime}$.

\section{Familie. Labiaten Juss. Lippen- blüthler.}

1. Gruppe. Ilenthoideen Benth. Ninzengewächse. Blumenkrone fast glockig oder trichterförmig, mit 4-5spaltigen Saume und fast gleichen Lappen; Staulgefässe von einander entfernt, gerade, Staubbeutelfächer gleichlaufend, selten auseinanderweichend, in einer Längslinie aufspringend.

329. Mentha K. Minze (nicht Münze) (Pflanzenname bei Plinius).

A. Menthae genuinae. Aechte II inzen. Kelchschlund nackt.

a. Blüthenquirle endstäudig, ährenartig verlängert.

832. M. rotundifolia L., rundblätterige M. Blc̈itter sitzend, rundlich, eiförmig, gekerbt-gesägt; 
Aehren linealisch-walzenförmig; Deckblïtter lanzettlich, kurz, Kelch schwach-gerieft, zur. Fruchtzeit fast kugelförmig - bauchig, mit lanzettlich - pfriemlichen, zulTetzt zusammenneigenden Zühiven. 24. Grähen und Sïmpfe sehr selten. An Gräben der Wiesen bei Burg Liebenau; bei Reideburg und Bischdorf zwar schon von $K n a u t h$ und $B u x b$. angegeben, aber jetzt äusserst sparsam. Juli. Aug. M. macrustachya 'T e nor. M. rugrosa Lan. I. suaveolens Ehrh. Blume sehr klein, hellviolett oder lila, wie an den folgenden. Die Blätter sind oberseits runzelig, "eich-behaart, unterseits zwischen den Adern weiss-filzig. Der steif - aufrechte Stengel ist $1-2^{\prime}$ hoch.

833. M. silvestris L., Wald - M. H a y e Arzneigew. XI, 34. Bliitter fast sitzend, eiförmig oder lan. zettlich, gezähnt - gesägt; Achre linealisch-walzenför $r$ mig ; Decliblätter linealisch - p friemlich; Kelch schwach gerieft, zur Frnchtzeit bauchio, oberwärts eingeschniirt, mit linealisch-pfriemlichen, zuletzt 'ein wenig zusimmenneigenden Zähnen. 24. Griben, Ufer, feuchte Hecken stellenweise. Fehlt in der Nähe von Halle; findet sich in Gräben der Anenwiesen bei Burg Liebenau nach Merseburg 'zu, an der Geissel zwischen Merseburg und Mücheln, an der kleinen Saale bei Naumburg, häıfig an Bächen bei Bihra nach Saubach und Steinbach zı; bei Dessau und Oranienbaum stellenweise. Juli. Aug. Aendert ab:

a) vulgaris Koch: Blätter filzig, flach oder nur wenig wellenförmig und zwar

1) Blätter unterseits locker-, fast zottig-filzig. M. silvestris Willd. M. hybrida Scheich.

2) Blätter unterseits angedrückt - weisslich - filzig. M. nemorosa Willd. M. serotina Tenor.

b) glabra Koch: Blätter kahl oder unterseits auf den Nerven zerstreut - behaart, Stengel kahl oder etwas behaart. M. viridis der deutschen Autoren und wahrscheinlich auch 1. Diese Form ist sehr selten, sie wird ron Spreng. hal. ed. 2. p. 261 in Sümpfen der Elsteraue, hinter Schkenditz angegeben.

c) crispata Schrader: Blätter kahl, blasenförmig-runzelig, eingeschnitten-gesägt. M. hercynica Röhl., so an Gräben bei Bibra nach Saubach zu.

834. M. nepetoìdes Lej., dickährige M. Blättcr sestielt, eiförmig, gesägt; Aehren länglich-wualzen- 
förmig; die oberen Deckblätter linealisch-pfriemlich; Zähne des Kelches linealisch-borstenförmig, an den fruchttragenden gerade vorgestreckt, Röhre gerieft. 4. Gräben, Ufer sehr selten. Bisher nur an Grïben bei Bibra gefunden. Juli. Aug. Blätter der M. aquatica und Aehren der M. siliestris, aber dicker. Die Blättel sind gewöhnlich behaart. Die Pflanze ändert aber ab:

b) hirta Willd.: Blätter unterseits sparsamer und besunders nur auf ten Adern behaart.

b. Biüthenquirle endständig und kopfartig gedrängt oder hattwinkelstcudig und entfernt-steliend.

835. M. aquatica L., W a s s er-M. Blätter gestielt, eiförmig, gesägt; Bliitlien in einem endstïndigen, rundlichen Bliithenkopfe, unter dem keine oder ein Paar entfernte Blïthenquirle stehen; Kelchzähneaus 3eckigem Grunde pfriemlich, zur Fruchtzeit gerade vorgestreckt; Kelchröhre gefurcht. 24. Ufer, Gräben, Sümpfe gemein z. B. an Gräben vor Reidehurg und Bischdorf, an der Reide zwischen Dieskan und Osendorf sehr hänfig u. s. w. Juli. Aug. M. palustris Mill. Der einfache wder ästigre Stengel ist $1-3^{\prime}$ hoch. Die Staubgefässe sind bald eingeschlossen, bald ragen sie hervor. Aendert ferner ab:

b) hirsuta L. : dicht rauhhaarig-zottig, Blätter öfter's hïrzer gestielt. M. dubia Vill.

c) citrata Ehrh.: kahl, blos die Kelche gewinuert. M. odurata Sule. M. adspersa Moench.

d) sativa $I_{\text {..: }}$ behart oder fast kahl; Blüthen in blattwinkelständigen, entfernt stehenden Quirlen; Kelchzähne 3eckig-lanzettlich, zugespitzt.

836. M. arvensis L., Fe/A-M. Blätter gestielt, eiförmig oder elliptisch, gesägt; Blïthen in blattwinkelständigen, entfernt stelıenden Quirlen; Kelchzähne Beckiglanzettlich oder eiförmig, geralde vorgestreckt; Kelchröhre glockenförmig. 24. Ufer, Gräben, feuchte Aekker gemein. Juli. Aug. Stengel und Blätter sind meist kurzhaarig, Blïthenstiele und Kelche kahl oder zottig. Die Pflanze ändert aber ab:

b) gentilis L.: Stengel, Blätter und Blütheustiele fast kahl; Kelchzähne zugespitzt. M. pratensis Sole. M. rubra Huds. Diese Furm ist etwas sel. tener. An Gräben vor Reideburg und Bischdorf, bei Burg Liebenau, Zöschen, Möritzsch, bei Naumburg auf Saalkies, häufig an Bächen bei Bibra, 
all der Wipper in der Nähe von Aschersleben, hei Dessau.

B. Pulegium Mill. Kelchschlund durch ein Haarkränz. chen geschlossen.

837. M. Pulegium L., Pulei-M. Hayne Arzneigew. XI, 3!. Blätter gestielt, plliptisch, stumpt, schwach-gezähnt; Blïthon in Llattwinlielständigen, hiugelförmigen, entfernt stehenden Ouirlen; Kelch röhrenförmig, die 3 oberen Kelchzähne zurückgekrümmt, 3eckig-lanzettlich, die 2 unteren pfriemlich, Kelchschlund nach dem Terbliihen durch einen IIaarring geschlossen. 4. Ufer, überschwemmt gewesene Plätze sehr zerstreut. In der Aue hei Canena, Schkopau und Collenhey häufig, an überschwemmt gewesemen stellen bei Dessau gipichfalls hüufig. Juli. dug. Pulegium vulware Mill. Der unten kriechende, dann anfsteigende Stengel ist $1 / 2-1$ ' hoch. OFF. herba Pulegii.

330. Lýcopare F. Wulfstrapp (ein aus iixos, Wolf, und tors, Fuss, gebildeter l'flauzenname bei 'Tournefurt).

x3s. L. curopacus L., ge mein er W. Blätter ge. stielt, eiförmig-länglich, grub-eingeschnitten-gezähut, an Grunde mehr oder weniger fiederspaltig-eingeschnitten; Kelchzähne pfrimmlich - zugespitzt; Staubgefässe meist 2; Früchte schmal-keilig-verkehrt-eiförmig. 4. Gräben, l'ejche, Büche gemein z. B. an Gräben zwischen Kröllwitz und Gimritz, an Gräben zwischen Halle und Nietleben. Juli. Ang. Blume klein, weiss, inwendig mit purpurrothen P'unkten. Höhe $1-3$ '.

Elsholtia cristata Willd. ist bei Wettin einmal verwildert gefunden.

2. Gruppe. Monardeen benth. Monardengewächse. Blume 2lippig. Zwei fruchtbare, unter der Oberflảche der Blume gleichlaufende Staubgefässe.

331. Salvia L. Salve i (Pflanzenuane bei Plinius).

839. S. pratensis L., Wiesen-S. Hayne Arzneigew. VI, 2. Stengel lirautartig, oberwärts nelost den Deckblätcrn, Kelchen und Blumen lilebrig-behaart; Blätter eiförnig oder länglich, doppelt-gekerbt, ungetheilt oder 3lappig, runcelig, unterseits weichhaarig, dic wurzelständigen an Grunde herzförnig, gestielt, die wheren viel Kleiner, stengelumfassend; Deckblätter 
eiförmigr, zugespitzt, hürzer als der Kelch, krautartig; Oberlippe des Kelches kurz-3zähuiğ, Unterlippe 2spaltig. 4. Trockene Wiesen, Rain , Weinberge im Gebiete meist häufig $z$. B. auf II iesen an der Gersdorfer wüsten Feldmark, auf Kalkbergen bei Bennstedt, Weinberge bei Rullsdorf u. s. "., nur in nurdöstlichen Gebiete seltener. Mai. Juni. Blume dunkelblau, hellblau, rusenroth, weiss. Höhe '2'.

840. L. silvestris L., W a I $-S$. Stengel krautartig, reichblätterig und nebst den Blättern unterseits und dem Kelche grau-weichhaarig; untere Blätter gestielt, doppelt-gekerbt, an Grunde herzförmign, obere allmählig an Grösse abnehmend, kirzer-gestielt und sitzend, meist rinfach geherbt, am Grunde ei- nder herzförmig; Decklliitler eiföınig, zugespitzt, gefürlt, kürzer als die Bliithen; Oberlippe des Kelches kurz-3zähnig, Unterlippe 2spaltig. 7. Wegränder, Raine, unbebaute Orte stellenweise. An Chausseegraben und an Abhängen zwischen Langenbugen und Rullsdorf, an breiten Kainen zwischen den Dömeken und Wansleben, bei Unterriesdurf unweit Eisleben und sparsan an der Hüne. burg, an den Seelöchern bei Zabenstedt unweit Gerbstedt, an Ackerrändern unmittelbar in der Nähe von Aderstedt unweit Bernburg. Juli. Ang. Blume violett und ruseuroth. Höhe $1-2$ '.

3. Gruppe. Satureje en Benth. Köllengewächse. Blume 2lippig; Staubgefässe 4, von einander entfernt und entweder oberwärts auseinanderfahrend oder unter der Oherlippe der Blume zusaramenneigend; Staubbeutel 2fächerig, Făcher von einander getrennt, an das quer-verbreiterte Connectiv beiderseits schief-angewachsen.

332. Driganum I. Dost (ein aus ügos, Berg, und $\gamma(\dot{c} \nu o s$, Zierde, Schönheit, gebildeter Pflanzenname bei Diuscoricles).

841. O. vulgare L., gemeiner. D. Hayne Arz. neigew. VIII, ४. Stengel aufrecht, weichharig; Blätter gestielt . eiförmig, oberseits dunkelgrïn, unterseits bleicher; Deckbliitter auf der inneren Seite oder völlig driisenlos; Kelch mit 5 glcich grossen Zähnen; Aehren an der Spitze des Stengels und der Aeste abgerundet. 4. Waldränder, Raine, truckene Anhöhen häufig z. B. in der Dölauer Heide, in Weinbergen von Röglitz u. s. w. Juli. Aug. Blume purpurroth oder weiss. Höhe $1-1 \frac{1}{2}$. OFF. herba et flores Origani vulgaris. 
842. O. Majorana L., Majoran-D., Meyran. II a y u Arzneigew. VIII, 9. Stengel aufrecht, fast kahl: Blätter gestielt, elliptisch, stumpf, ganzrandig, beiderseits grau-filzig; Deckblätter gefurcht, sehr dicht dachziegelig, oft drüsig-punktirt; Kelch an der inneren Scite fast bis anf den Grund gespalten; Aehren an der Spitze der Aeste meist zu 3 stehend, oval. $\odot$ und 4. Stanıt aus Nordafrika, wird jetzt zum Küchengebrauche hä口fig gebaut. Juli. Aug. Blume röthlich-weiss. Höhe 1 - 1 1 1 12 . OFF. herba Majorànae s. Sampsuchi.

333. Thymers L. Quendel (Pflanzenname bei 'Theophrast).

843. Th. Serpyllum L., Feld-Q. Hayne Arzneigew. XI, 1. Stengel niederliegend uder aufsteigend; Blätter linealisch oder elliptisch, stumpf, an Grunde in einen kurzen Blattstiel zusanmengezogen, ganzrandig, flach, drusig-punktirt, kahl oder rauhhaarig, am hinteren Rande „ewimpert; Blüthenquirle kopfartig oder traubenförmig; Oberlippe der Blume ausgerandet, eiförmig, fast 4eckig. Ђ: Hügel, Triften, Waldränder, Heiden gemein. Juli - Sept. Stauhgefässe vorragend uder eingeschlossen. Blume purpurroth oder weiss. OFF. herba Serpylli. Aendert vielfach ab:

a) Chamaedrys Fries (Sturm Heft 5): Stengel zweireihig - behaart. 'I'. Se'pyllum $\beta$. L. Diese Form kommit anch rauhhaarig vor nnd zwar mit beiderseits rauhhaarigen Blättern und rauhhaarigen Stengel, an welchem aber 2 Seiten kahl oder weniger rauhhaarig sind. 'T. lanuginosus Schk. 'T. Serpyllum $\gamma$. L.

b) angustifolius Pers. (Sturm Heft 70): Stengel ringsum gleichmässig-behaart. 'T. Serpyllum Fries. Sind die Blätter linealisch-länglich, elliptisch oder verkehrt-eiförmig, s" hejsst diese Form I. Serpyllum R c h b. 'T. reflexus I, p j. und mit rauhhaarigen Blättern T. lanuginosus Link.

334. Saturéja K. Kölle (Pfefferkraut) (Pflanzenname bei Culumella; das Wort Kölle ist aus dem früheren lateinischen Namen dieser Pflanze cunila gebildet).

844. S. hortensis L., Garten-K. Sturm Heft 5. Stengel aufrecht, sehr ästig, krautartig; Blätter linealisch-lanzettlich, spitz, driisig-puntitirt; Ebensträuss- 
chen blattwinkelständig, meist 5blïthig. $\odot$. Stammt aus Südeuropa, wird jetzt zum Küchengebrauche häufig gebaut. Juli-Octub. Blume lila oder weiss, in Schlunde roth - getiipfelt. Höhe $1 / 2-1^{\prime}$.

335. Calamintha Mil unch. Cal am in the (ein aus xcìos, schön, und $\mu i v \vartheta \eta$, Minze, gebildeter Pflanzenname).

845. C. Ácinos Clairville, Feld-C. Sturm Heft 70. Stengel aufsteigend oder aufrecht, an Grunde mit aufstrebenden Aesten; Blätter eiförmigg, gesägt; Blüthenquirle 6blüthig; Blütheustiele ungetheilt; Kelch 2lappig, an Grunde bauchig, die Zähne zur Fruchtzeit zusammengedrängt und den Schlund fast schliessend. $\odot$. 'Triften, Berge, trockene Acker - und Wegränder nicht gerade selten z. B. an Kalkbergen bei Bennstedt, Kölnıe, Langenbogen, an Ackerrainen iı der Nähe des Mittelholzes, in Bienitz u. s. w. Juni-Aug. Thymus Acinos L. Acinos thymoides Nönch. Melissa Acinos Benth. Blume hellviolett. Höhe $1 / 2-1 \frac{1}{2}{ }^{1}$. Stengel und Blätter sind bald kahl, bald behaart.

336. Clinopodium I. Wirbeldost (nach Dioscorides von xiivn, Bett, und nov̌s, Fuss, wegen der von einer Hülle dicht umgebenen Blüthen).

846. C. vulgare L., gemeiner IV. Stengel aufrecht, zottig; Blätter kurz-gestielt, eiförmig oder länglich - eiförnig, entfernt - schwach - gekerbt; Blïthenquirle vielbliithig, von zahlreichen, borstenförmigen Deckblättern umgeben; Kelche nebst den gleichlangen Deckblättern zottig - rauhhaarig. 24. Wälder, Zäune, Anhöhen nicht selten z. B. in der Dölauer Heide, in Mit. telholze, bei Röglitz, Ermlitz u. s. w. Juli. Aug. Blume purpurroth. Höhe 1-2'. Meist sind mehrere Blü. thenquirle vorhanden, seltener nur ein einziger kopfförmiger, an der Spitze des Stengels stehender.

4. Gruppc. M ellissineen Benth. Melissengewächse. Blume 2lippig. Staubgefässe 4 , von einander entfernt und entweder oberwärts auseinandertretend oder unter der oberlippe zusammenneigend. Staubbeutelfächer an der Spitze zusammengewachsen, am Grunde aber später auseinanderfahrend oder von Anfang an bcide in einer Linie tast wagrecht aufliegend und beide mit einer gemeinschaftlichen Ritze aufspringend. 


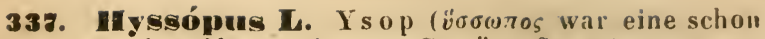
den Ilten bekannte Gew ïrpflanze).

847. H. officinalis L., ge bräuchlicher Y. Ha y n e Arzneigew. VI, 18 . Stengel aufrecht; Blätter lanzettlich oder linealisch-lanzettlich, ganzrandig; Blïthen quirlig - traubenförmig, einseitswendig; Kelchzähne aufrecht, ziemlich gleich. 24. Stanmt aus siiddeutschland, jetzt auf Mauern, an Bergen, im Steingerölle bisweilen verwildert, so auf der Stailtmaner in Halle sehr häufig, bei Naumburg an Pfortuberge nach der Windliiche zu in Steingeröle. Juli. Aug. Blume dun. kelblau. Höhe $1-1 \frac{1}{2}$ '. OFF'. herba s. summitates Hyssopi.

5. Gruppe. Nepeteen Bentb. Katzenkrautgewächse. Blume 2lippig. Staubgefüsse unter der Oberlippe gleichlaufend, genähert, nach dem Verblühen bisweilen zur Seite hinabgebogen, die oberen länger. Zähne des Fruchtkelches etwas abstehend oder zusammenneigend.

338. Népeta K. Katzentraut (Pflanzenname bei Plinius).

848. N. Catriria L., ge me ines K. Ha yne Arz. neigew. IV, 8. Stengel aufrecht; Blätter gestielt, eiförmig, spitz, tief gekerbt-gesägt, am Grunde herzförmig, unterseits graufilzig; Ebenstrüusschen gestielt, gellungen, reichblüthig; Deckblätter ungefäh! so lang als die Kelchröhre; Kelrhzähne aus lanzettlichen Gıunde pfriemlich-stachelspitzig; Nïsse glatt und kahl. 4. Schutt, Zäune, unbebaute Stellen an Dölfern nicht sel. ten z. B. in Zäunen bei Giebichenstein, Dieskau u. s. w. Juni - Aug. Blume "eiss wder etwas röthlich, mit roth-punktirter Unterlipue. Höhe 2-4'. Die Blüthen haben einen angenehmen, bisweilen citrumenartigen Geruch.

N. nuda L. uder N. pannonica Jacq. wird von Spreng. hal.ed. 2 . p. 266 nach $13 u k$ anf der Hiineburg bei Eisleben unter Prumus spinusa angegeben, ist aber daselbst seit vielen Jahren vergehlirh gesucht.

339. Clechóma L. Gundelrebe (ein aus dem bei Theophrast vorkonmenden $\gamma \lambda_{i}{ }^{\prime}(\omega \nu$, wiruntel Mentha Pulegium L. verstanden werden soll, gebildeter Pflanzenname).

849. G. hederacea L., e pheuartige G. Hayne 
Arzneigew. II, 8. Stengel kriechend; Blätter gekerbt, nierenförmig, dir oberen fast herzförnig; Blïthenquirle tblüthig; Kelchzähne eiförnigg uder lanzettlich, in eine Granme zugespitzt, 3mal kürzer als die Röhre. 4. Grasplätze, Züune, Wiesen, schattige Wäldro, feuchte Gebuische übrrall gemein. April - Juni. Nepeta Glechoma Benth. Calamintha hederacea Scop. Blume hellinlett, am Schlumbe und auf der Unterlippe mit lunkelvioletten Flecken. Stengel 1/2 - 2' lang. OFF. herba Hederae terrestris, aber jetzt nur wenig im Gebrambh. Iendert mit grösseren und kleineren Blättern und Bliithen ab.

340. Tracocéphaluma L. Drache ntopf (ein

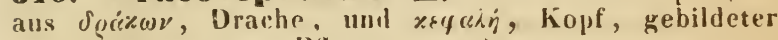
Pflanzenname).

850. 1). Rayschiana L., sehwediseher. D. Sturm Heft 90. Stengel aufrecht, kahl; Blattel linealisch-lanzettlich, ungetheilt, ganzrandig; Bliithen in einer kurzen, endstïndgen, fast kupförmigen tehre. $\div$. In Wädern sphr selten, nur bei Oranipnbaum an trocke. nen Stellen in: Nichrim und am Ellerborn nach Raguhn zil. Juni - Aug. Blume viulett. Höhe 1-2'.

6. Gruppe. Stacliydeen Benth. Ziestgewächse. Blume 2lippig. Staubgefässe unter der Oberlippe gleichlaufend, genähert, nach dem Verblühen bisweilen zur seite hinabgelıgen, die unteren länger.

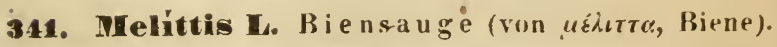

851. M. Melissophýllum L., melissenblät té rige B. Sturn lleft 90 . Stengel aufrecht, eiufach, rauhharig: Blätter herz-eifömig, die wheren eiförmig-länglich, stumpf-gesägt; Blüthen einzeln oder zu 2 und 3 in den Blattwinteln zientich lang-gestielt; Kelch weit - gluckentörmig. 4. Bergige Laubuäller sehr selten, "ur bei Ialle im Mittelhulze und in ler Abbatissina bei Kitten. Mai. Juni. M. grandiflura Sm. Blume gelblich-weiss odor weiss. Der Vittellappen an der Unterlippe purpurroth. Höhe $3 / 2_{-2}$. Die Furm. mit einfarbig-weissen Blüthen kunnt im Gebiete nicht vor.

342. Cŕmium T. Ta ub nessel (Pflanzenname bei Plinius; der deutsche Name Taubuessel steht im Gegensatz zur Brenunessel). 
A. Lamiopsis Dumort. Röhre der Blume gerade.

852. L. amplexicaule L., st e ng elumfas s e nde

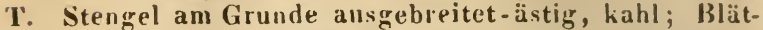
ter ungleich-stumpf-gekerbt, die unteren herz-eiförmig oder rundlich, gestielt, die oberen sitzend, stengel. unfassend, etwas gelappt; Röhre der Blume gerade, inwendig nackt; Kelch siline vor und nach dem Bliihen zuscommenschliessend; Staubbeutel bärtig. $\odot$. Bebauter Boden, decker nicht selten. Blüht fast das ganze Jahr hindurch. Blume purpurroth. Stengel 6-12" lang. Im Frühlinge entwickelt sich die Blumenkrone meist nicht vollständig, sondern bleibt in Kelche.

B. Lamiotypus Dumort. Röhre der Blıme über dem Grunde gekriimmt, unter der Krümmung schnïler und enger (nur bei $\mathrm{L}$. purpurem ist die Röhre bisweilen gerade), inwendig nit einer Haarleiste hesetzt.

853. L. purpureum L., purpurrothe T. Stengel aıI Grunde ausgebreitet-ästign; Blättęr herz-eiförmig, ungleich-gekerbt-gesägt, gestielt; Röhre der Blume gerade oder meist ïber dem Grunde gekrümmt, unter der Krïmmung enger, an der Einschnirung inwendig mit einer Haarleiste; Schlund der Blume beiderseits mit 2 Zähnchen, von denen das obere pfriemlich; Kelchzähne nach dem Verblïhen abstehend; Staubbeutel bär. tig. $\odot$. Bebauter Boden gemein. März-Octub. Blune purpurroth. Höhe $4-8$ ". Hat einen widrigen Geruch.

854. L. maculatum L., gefleck te $T$. Stengel aufsteigend oder aufrecht; Blätter herz-eiförmig, zugespitzt, ungleich gesägt; Röhre der Blume gekriimmt, iiber dem Grunde bauchig-erweitert, unter der Erveciterung quer zusammenpeschniirt und inwendig mit einer querlaufenden Haarleiste; Rand des Schlundes abgerundet, mit einem pfriemlichen 'Zahne bezeichnet; Staubbeutel bärtig. 24. Schattige Wälder, feuchte Gebiusche nicht selten, z. B. in Gebüsche am schwalchloche hinter liröllwitz, im Wörnlitzer Hölzchen, in Gebüsch an den 'Teichen bei Dieskau u. s. w. April. Mai. Juli. Sept. L albun $\beta$. Pollich. I. rubrum Wallr. I. rugosum Ait. Blüthen purpurroth, Unterlippe lila, roth gefleckt. Höhe $1-3^{\prime}$. Die Pflanze kommit im Gebiete meist mit ungefleckten Blättern vor.

855. L. album L., we is se T. Hayne Arzneigew. V1, 41. Stengel aufsteigend; Blätter herz-eiförmig, zu- 
gespitzt, ungleich-gesägt; Röhre der Blume gekrïmmt, iiber den Grumle mit einer schiefen Kerbe erweitert. unter der Kerbe zusammengeschniirt und inwendig nit einer schicfen Haarleiste; Schlund des Blume mit 3 kleinen und einen längeren, pfriemlichen Zähnchen; Staubbeutel bärtig. ㅇ. Züune, Wrge, Grasplütze, in Dörfern gemein z. B. in Giebichenstein, Kröllwitz u. s. w. April. Mai. Aug. Sept. Blume weiss, Lippen gelb. lich mit grünlichen Flecken an Grunde der Unterlippe. Höhe $1-2^{\prime}$. OFF. flores lamii albi s. Galeopsidis s. Urticae mortuae.

343. Conleólodolon Huds. Golduessel (von gadín, Wiesel, und $\beta \delta o ́ \lambda o s$, Gestank, auf den unangenehmen Geruch der Pflanze himdentend).

856. G. Iuteum Huds., g e I b b I umige G. Stengel anfsteigend, an Grunce mit "eit hriechenden Ausläufer'n; Blätter eiförmig oder eiförmigr-länglich, doppeltgekerbt-gesiigt, die unteren etwas herzförmig, die oberen öfters spitz; Blüthen in meist 6blïthignn Quirlen sitzend. 2. Feuchte I älder, Hecken meist nicht selten. Fehlt in del Nähe von Halle (vielleicht ist es im Amtsrarten in Giebichenstein), in der Brenau bei Wettin, im Gemeindeholze bej Zöschen, im Walde zwischen Schkeuditz und Kl. Dölzig, im Walde bei Leislingen, in Wällern bei Naumburg, Freiburg, Ziegelrude, Lodersleben, Allstedt, Eisleben, Sandersleben, Lingenau und Törten unweit Dessau, bei Oranienbaum in Nirhrim häufig. Mai. Juni. Galeopsis Galeobrolon I. Isamium Galeublolon Crantz. Pollichia Galeobdolon Willd. Len. nurus Galeobdolon scop. Blume gelb, des mittlere Lappen der Unterlippe überall und die seitenständigen an Grunde dottergelb mit bräunlichen Flecken. Höhe $1 / 2-1 \frac{1}{2}$.

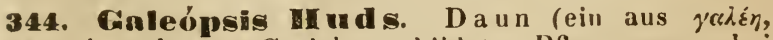
Wiesel, und öııs, Gesicht, gebildeter Pflanzenname bei Dioscurides).

S57. G. Ládanum L., A cker-D. Sturm Heft 62. Stengel mit abwürts angedrückten, weichen Haaren be. setzit, unter len Gelenken nicht verdiclit; Blätter lan. zettlich oder linealisch-lanzettlich, gesägt oder fast ganzrandig; Oberlippe der Blume schwach-gezähnelt. $\odot$. Auf Aeckern, besonders nach der Ernte, häufig. Juli. Aug. Blune purpurroth, nit einem gelblich-weissen, 
purpurn-geflechten Hofe am Gruncte der Unterlippe. Höhe $1 / 2-1 \frac{1}{2}$. Aendert ab:

a) Iatifolia $1 /$ off $n$.: Blätter eifürmig wier länglich-lanzettlich, entfernt-stumpf-gesigt; Stengel uberwärts nebst den Kelchen drüsenhaarign; Blumen gross; diese Furm ist bei Halle seltener als die folgende.

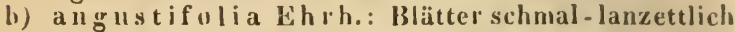
oder linealisch-lanzettlich, entfernt wenig-gesägt uder auch ganzrandig. Diese form besonders an Kalkbergen, aber auch an deckern häufig.

858. G. ochroleuca $L$ m., gelblichweisspr D. Sturm Heft 62 . Stengel init abwärts angeriickten, weichen Ilaaren besctzt, unter den Gelenken nicht verdickt; Blätter gesügt, die stengelstiindigen eiförmig, die astständigen eiförmig-lanzettlich; Oberlippe der Blume eingeschnitten-gezähnelt. $\odot$. Auf Aeckern sehr selten. Mit Sicherheit nur hei Nanmburg auf derkern am Spechtsar und in der Nähe eires Steinbruches in Kroppen. thale zwischen Schönburg und Wetau selten. Juli. Jug. G. cannabina Pollich. G. villosa $H$ uds. G. grandiflora $\mathrm{Roth}$. Blume gelblich-weiss, mit einem schwefelgelben Hofe am Grunde der Unterlippe. Höhe 4-10'.

Diese Pflanze wird von Spreng. hal. ed. 2, p. 264 auf sandigen Aeckern un Reinsdurf und Karsdorf an den Ufern der Unstrut, von $\mid 1$ a III. sched. $\mu .203$ auf sandigen Aeckern bei Rossleben und Nebra als selten angegeben, an welchen Orten der Verfasser sie nicht gefunden hat.

859. G. Tetrahit L., g e me i $u$ e r D. S turm $H+f t$ 62. Stengel steifhaari.,, unter denGelenken verdickt; Blätter länglich - eiförmig, gesą̈t, zugespitzt; Rührc ler Blume so lang oder liir zer als der Kelch; Mittellap. pen der Unterlippe fast 4cchig, flach, kleingekertst, stumpf oder schwach-ausgerandet. $\odot$. 'Zämme, (irbii. sche, Wege, Aecker gemein z. B. aut Aeckern vor der Dölauer Heide, in der Heide u.s.w. Juli. Aug. Blume hell-purpurroth wder weiss, mit einem schwelelgelben, purpurn-gefleckten Hofe an Grunde der Unterlippe. Höhe $1-2$ '. Aendert mit grösseren und kleineren Bluthen $a b$.

860. Ct. bifida Woenningh., a usgerandeter D. Sturm Heft 62. Stengel steifhaarig, unter den Gelenken verdickt: Blütter lünılich-eiförmig, zugespitzt: Rühre der Blume nicht so lang als der Kelch; Mittel. 
lappen der Unterlippe schmal, liinglich, an der Spitze ausgerandet, spïter am Rande zuriickgerollt. $\odot$. Aekker, Gräben, Gebüsch, I eqe. Anf Aeckern bei Röglitz, an Bienitz und gewiss weiter rerbreitet. Juli. Aug. Blume hlein, blass fleischroth, mit 2 gelblichen Flecken au Schlnude, der Vittellappen der Unterlippe violettbraunroth, mit weisslichem Rande. Die untersten Deck. blätter der Blïthenquirle sind meistens blattartig.

Dipse Planze ist dr vorhergehenden Art, besonders der hlein - und hellblïthigen Furm von G. Tetrahit sehr ähnlich, unterscheidet sich aber ausser den angegebenen lerkmalen durch eine stärkere furche auf den Rücken zuische" der Krunröhre und der Oberlippe, durch einen blassgriinen, nicht ruthbraunen Kelch, durch weniger steife, etwas brejtere und hürzese lielchzähne und durch hleinere Samen.

861. Cr. versicolor Curt., bunter D. Siturm Heft 62. Stengel steifhaarig, unter den Gelentien verdirkt; Blatter länglich-eiförmign, zugespitzt; Röhre der Blume doppelt so lang als der Kelch: Mittellappen der Unterlippe rundlich - 5cclig, flach, kleingekerbt, stumpf oder ausgerandet. $\odot$. Züune, Gräben, fuchte Wälder Ind Gebuische, Bäche im rehiete nicht häufig. In feuchten IIaldern bei Schkeuditz nach Kl. Dölzig zu, bei Märtendorf unweit Naunburg, ebeuso zuischen Gipkau und röbitz, bei Freiburg in einem Wäldchen an der Ziegelscheune, häufiger im uordöstlichen Gebiete. Juli. Aug. G. cannabina Roth, nicht Pollich. G. 'Tetrahit 3. I. Höhe bis $\jmath^{\prime}$. Blune gross, schwefelgelb, Unterlippe an Grunde citrunengelb, die sejtenständigen Zipfel ion der Mitte all weiss, der mittlere violett, mit weisslichem Kande.

Galeopsis pubescens Bess., bej welcher ler Stengel nit kürzeren, weichen, abwärts angedrückten Haalen bedeckt, unter den Gelenken aber mit längeren, horstenförmigen Haaren und daselbst etwas verdiclit ist, wächst gewiss auch innerhalb der Grenzen des Gebietes.

345. Stachys T. Zi est (Pflanzenname bei Dioscu-

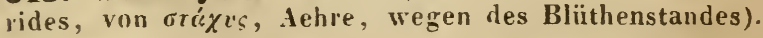

A. Eriostachỵs Beuth. Quirle reichblüthig; Dechblättchen halb so lang wder so lang wie der Kelch.

862. St. germanica C., deutscher Z. Sturm Heft 83. Stengel aufrecht, vun einfachen Haaren dicht- 
wollig-zottig; Blitter gestielt, herz-eiförnig-gekerbt, wollig-filzig, die obcren sitzend, schnäler, lanzetllich; Quirle reichbliithig; Kelche eiförmig, stachelspitzig, stechend. $\odot$. Wege, sonnige Inhöhen, unbebaute Stel. len, an dell Dörfern zerstreut. An den Weinbergen zwischen Gimritz und Kiröllwitz, in den Schluchten der Berge zwischen Benustedt und der Einuehnerwohnung, an der Kapelle bei Landsberg, an Anhöhen bei Keusch. berg, in Markranstedt, bei Mücheln, bei Naumburg zerstrent z. B. an l'fortenberge, bei Allstedt ziemlich häufig z. B. an der Fohlenwiese, am Kloster Naundorf, bei Wurnsleben unweit Eisleben, hei Sandersleben, in nordöstlichen Gebiete sehr selten. Juli. Aug. Blume hell-purpurroth. Höhe $2-4^{\prime}$.

B. Stachyotypus Benth. Quirle meist wenigbliithig; Deckblatter sehr klein; Bliithen roth.

863. St. silvatica L., Wa I $d-Z$. H a y n Alzneigew. IV, 11. Sturm Heft 84. Unterirdische Auslänfer an der Spitze gleich dick; Stengel aufrecht, steifhaarig. nit abwärts gerichteten Haaren, obcruäirts ästig und driisig-bchaart; Blätter lang-gestielt, breit-herz-ciförmig, zlocspitzt, gesägt, rauhharig; Quirle 6blüthig; Kelchzähne aus 3echigem Grunde pfriemlich, stachelspitzigr; Blume doppelt so lang als der Kelch. 24. Feuchte Wälder und Gehüsche häufig z. B. in Sebenschen Busche, bei Lieskau u. s. w. Juni-Aug. Blume braunoder purpurroth. Höhe $1-2^{\prime}$.

864. St. palustris L., Sumpf-Z. Ha yne Arzneigew. III, 40. Stul m Heft 18. Unterirdische Auslïufer an der Spitze lieulenfürmig-verdiclt: Stengel aufrecht, einfach, kurz-steiflıarigy, mit abwärts gerichteten Haaren; Blätter aus herzförmigem Grunde lanzettlich, spitz, gekerbt-gesügt, weichhaarig, die unteren kurz-gestielt, die oberen sitzend, hallstengelumfassend; Quirle 6-12blüthig; Kelchzảne aus 3eckigem Giunde pfriemlich, stachelspitzig; Blume doppelt so lang als der Kelch. 24. Ufer, Gräben, feuchte Aekker gemein. Juli. Aug. Blumen purpurroth. Höhe 1-3'.

Stachys ambigua $\mathrm{Smith}$ nit gestielten, aus herzförnigem Grunde lanzettlichen, zugespitzten Blättern, 6bluthigen Quirlen und an der Spitze keulenförmig-verdickten, unterirdischen Ausläufern hat der Verfasser noch njcht in Gebiete gefunden, obgleich dieselbe von Wallr. an Sebenschen Busche angegeben wird. 
865. St. nrrensis L., Feld-Z. Sturm Heft 84. Stengel ziemlich rauhhaarig, einfach oder am Grunde mit aufsteigenden Aesten; Blïtter gestielt, herz-eiförmig, stumpf, gekerbt, zerstreut-behaart, die blüthenständigen sitzend, eiförmig-länglich, begrannt; Quirle 6hlïthig; Kelch fast so lang als die Blume, Zähne lan. zettlich, stachelspitzig. $\odot$. Auf Aeckern sehr zerstrent. Fehlt in der Nähe von Halle; findet sich auf Aeckern zwischen dem Bienitz und Rückmarsdorf, zwischen Kötschau und Dürrenberge, fehlt bei Naumburg; auf Aeckern bei Rossleben nach Ziegelrode zu, bei Lodersleben, bei Landerafrode und auf Aeckern an der Hube umweit Vuigtstedt, bei Opphausen unweit Querfurt, auf der Grenze zwischen Leimbach und Greifenhagen bis nach Bräunrode hin häufig, ebenso auf Aeckern bei Willerode und Harkerode und in dieser ganzen Gegend nirht selten, bei Bernburg und Dessau sparsam, zwischen Zöckeritz und Neuhäusel. Juli-Octob. Blume klem, blassroth. Höhe 4-9".

c. Pseudo-Sideritis. Quirle meist armblüthig; Deckblätter sehr klein; Bluthen blassgelb.

866. St. annua L., e injährig*r Z. Sturm Heft 84. Stengel aufrecht, von Grunde his zur Spitze ästig, wberwärts weichhaarig; Blätter kahl, gestielt, gekerbtgesägt, die unteren cval-länglich, die bliithenständigen lanzettlich, zugespitzt, ganzrandig, liurz-stachelspitzig; Quirle 4-6blüthig; Kelch zottig, Zähne kürzer als die Köhre der Blume, lanzettlich, stachelspitzig-pfriemlich, Stachelspitze fast bis an das Ende weichhaurig. $\odot$. Aecker, Ackerränder. Weinberge, besunders auf Kalkund Lehmboden, stellenweise. An Kalkbergen bei Benmstedt bis nach Kölne hin, auf Aeckern zwischen dem Bienitz und Möritzsch, auf Aeckern bei Hohenmölsen, bei Naunburg in deu Rossbacher Weinhergen zerstreut und auf Aeckern am Eingange des Mordthales nach Flem. mingen zu, an Bergen zwischen Rossleben und Bottendorf häıfig, auf deckern zwischen Rathmannsdorf und Hohenerxleben nördlich von Aschersleben, bei Bernburg, Dessau und Oranienbaum zerstreut. Juli-Octob. Blune gross, ochergelb, mit roth punktirter Unterlippe. Höhe $1 / 2-1$ '.

867. St. recta L., g e rad er Z. H a y n e Arzneigew. IV, 12. Sturm Heft 48. Stengel aufrecht oder aufsteigend, nebst den Blättern kurzhaarig; Blätter läng- 
lich oder lanzettlich, gekerbt-gesägt, nach drm Grunde verschmälert, die unteren gestielt, die oberen bliithen-

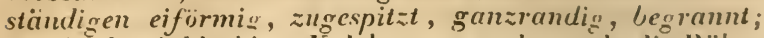
Quirle 6-10blüthig; Kelch etwa so lang als die Röhre der. Blume, rauhhaurig, Zähne 3eckig..zugespitzt, mit ciner liahlen Stachelspitze endigend. 24. Sonnige Anhöhen, Felsen, Raine, Wegränder in grössten Theile des Gebietes häufig z. B. au Galgeuberge, an Felsen bei Kröllwitz sehr verbreitet, an den Weinbergen bei Rörlitz, bei Dïrrenberge u. s. "., "ur im nordöstlichen Gebiete seltener. Juni-Herbst. St. Betunica Scop. St. procumbens Lam. Blume gelblich-weiss, mit einigen violetten sitreifen nud Punkten auf der Unterlippe. llöhe $1-3^{\prime}$. OFF. herba Sideritidis.

346. Betónica E. B etouje (sull nach Plinius eigentlich Vetonica hejssen, weil dip Vettonen in Spanien diese Pflanze ziferst als Heilmittel gebrauchten).

868. H. officinalis L., gebräuchliche B. Hayne Arzneigew. IV, I0. Stengel aufrecht, einfarh; Blätter aus herzförmigem Grunde eiförmig-länglich oder eiförmig, gekerbt, rauhhaarig odel kahl; Bliithenquirlc in einer länglich-walzenförmigen, am Grunde oft "11terbrochenen Aehre; Kelch aderlus; Blume auswendig dicht - weichharig, lippen auseiuanderstehend, dip "beren länglich-eiförnig, zuletzt zurïckgeschlagen; Staubgefässe kïrzer als die halbe Oberlippe. 4 . II äl. der, Waldränder, Wiesen häufig z. B. in der Dölaneı Heide, in Mittelholze u. s. w. Juni. Aug. Blume purpurroth. Höhe $2^{\prime}$ und darüber. OFF. rad. et herb. Betonicae. Aendert ab:

a) hirta Leyss.: Stengel hurzharig; Kelch rauhhaarig. Dies ist die gewöhulichste Form.

b) gla brata Koch: Sitengel nebst dem Kelche hahl. B. officinalis Leyss., so auf torfhaltigen Wiesen z. B. bei Kl. Dölzig, am Bienitz.

Die Abart B. stricta Ait., welche grösser, rauhhaariger ist und weit breitere Blätter besitzt, hat der Verfasser noch nicht im Gebiete berbachtet.

Sideritis montana $I_{\text {. }}$. wird zuerst ron $L_{\text {A e ys. }}$ hal. ed. 1. p. 107 an Bergen in der Heide als häufig, in der 2. Auflage S. 141 an demselben Standorte als selten und zuletzt run spreng. hal. ed. 1. p. 170 an den ihm mitgetheiltell Standorten, in Bergwäldern 
hei Hornburg und Ebersrodes als $s \in \mathrm{hr}$ selten angegeben. Diese letzten Standorte sind von Ko ch Synops. ed. 2. p. 656 und 'laschenb. d. Deutsch. Flora S. 413 und in der Fl. sax. ed. 1. und 2. p. 204 von Rchb., welcher jedoch irrthïmlicher. Weise glaubt, dass Wa IIr. diese Pflanze gefunden hate, wieder aufgenomnen. Da aber $S p r e n g$. die Angabe jener standorte nur einem Freunde verdankte und die Planze nicht selbst gesehen und in der 2. Aufl. del Flora ganz unerwähnt gelassen hat, dieselbe auch in neuerer Zeit nicht wieder aufgefuuden ist, also seit 1806 vergeblich gesucht wird, so erscheint das Weglassen derselben gewiss hinreichend gerechtfertigt.

348. Than a úbiom E. Andorn (ein bei Columella vurkommender Pflanzenname, welcher nach einer Stadt des alten Latiums, wo diese Pflanze häufig wuchs, be. llant sein sull).

869. Mr. peregrinum L., f r e m de r A. Stengel selu. iistig, Aeste spreizend; Blättes gran-filzig, unterseits netzaderig, die untersten eiförnig, stumpf, geherbt, die uberen länglich-lanzettlich, gekerbt-gesägt, hinten ganzrandig; Quirle 6-melirbliithig, fast gleich hoch; Kelche 5-10zähnig, Zällne nebst den Deckblättern pfriemlich, filzig. 24. Unbebaute Orte, Wege, Kirchhöfe sehr selten. Juli. Aug. Blume weiss, wie bei den folgenden. Höhe $1-3^{\prime}$. Aendert $a b$ :

a) latifolium Koch (R chb.pl. crit. IIl. Abb. 473): Blätter breiter, Filz ein wenig lockerer, Stachelspitze der Kelchzähne weiter nach dem Grunde kah!. an den meisten Kelchen zwischen den grösseren Zühnen kleinere. M. peregrinum $\alpha$. L. M. panicu. latum Dess. M. pannonicum Rchb. Die Kelche an den wberen Quirlen sind fast immer 5- und nicht 10zähnig. - Ob diese run $B u x b$. bis $S p r e n g$. angegebene Abart nuch bei Erdeburn wächst, kann der Verfasser nicht behaupten.

b) angustifolium Koch (Rchh. pl. crit. IYI. Abh. 461): Blätter an dem uberen Theile des Stengels und der Aeste weit schmäler, spitzer, entferntergesägt, Filz dichter, an den Zähnen weiter hinaufgehend oder sie ganz bedeckend. M. peregrinum $\beta$. J. M. peregrinum Jac q. M. creticum Mill., so auf dem Erdeborner Kirchhofe.

Garcke, Flora. 
870. M. vulgare L., ge me ine I. A. II a y n e A'z. neigew. XI, 40. Stengel weissfilzig, an Grunde ästig, mit aufsteigenden, cinfachen Aesten; Blätter eiförmiğ, in den Blattstiel hinablaufend, ungleich-gekerbt, filzig, runzelig, unterseits netzig-grubig, die unteren herzförmig-rundlich; Quirle reichbliithig, fast kugelförmig; Kelch LUzähnig, Zähne nebst den Deckblättern pfriem. lich, zottig, von der Nitte an kahl, an der Spitze halenförmig-suriickgerollt. 24. Wege, Mauern, Schutt, in Dörfern gremein. Juli. Jugg. Höhe 1-2'.

348. Eüallóta C. Gottesvergess (Pflanzenuame bei Dioscurides).

871. B. nigra L., s chwarzer G. Stengel ästig, vierkantig mit küszeren oder längeren, abstehenden oder abwärts gerichteten Haaren; Blätter eiförmig, gekerbt; Quirle vielblüthig; Kelch 5zähnig, Zühne eiförmig, stachelspitzig. 24. Wege, Zäune, Schutt, unbelaute Plätze gemem z. B. in Zäunen in Giebichenstein, Böllberg n. s. w. Jurni-Aug. Blume bläulich-purpurroth. Höhe $2-4^{\prime}$. Das Kraut hat einen widrigen Geruch. OFF. herba Ballotae s. Marrubii nigri s. foetidi. Aendert $\mathrm{ab}$ :

a) ruderalis Fries: Kelchzähne aufrecht, ans eiförinigem Grunde lanzettlich, zugespitzt, pfriemlich-stachelspitzig. B. vulgaris $L i n k$, dies die gewöhulichste Furm.

b) foetida Laum.: Kelchzähne abstehend, breit-eiförmig, abgerundet, mit äusserst hurzer Stachel. spitze. H. borealis $5 \mathrm{chweigg.,} \mathrm{sehr} \mathrm{selten,} \mathrm{von}$ Wallr. einmal in Zäunen bei Russleben gefunden.

Nach Koch's Synops. ed. 2. p. 657 soll bei B. foetila Lam. die Stachelspitze so lang oder kïrzer sein als der Kelchzahn, bei B. ruderalis Fries aber länges als der Kelchrahn. Da nun bei der überall gemeinsten Furm die Stachelspitze uur so lang oder anch etwas kïrzer als der liejchzahn ist, so hat jene Diagnose bei kuch einige namhafte Butaniker zu dem Irrthume ver. leitet, dass die gemeinste Furm B. foptida Lam. zu nennen sei und wird ron ihnen auch so bezeichnet. Die Länge der Stachelspitze lässt sich daher mit jener der Kelchzähne und der Blumenröhre nicht vergleichen, dia dieselbe wenigstens bei der geneinen Form sehr ieränderlich ist. 
349. 耳eomaniras W. Herzgespann (der zuerst bei Breyn vorkummende Name ist aus $\lambda \varepsilon \dot{\varepsilon} \omega \nu$, Löwe, und ov̉ó, Schwanz, zusammengesetzt, von den vielen sich in einer langen Aehre entwickelnden Blüthenquirlen so benannt; im Deutschen heisst die Pflanze Herzgespann, weil sie als Mittel gegen die gleichnamige lirankheit angewendet wurde).

872. L. Cardiaca L., geme ines H. H a yne Arz. neigew. III, 41. Stengel aufrecht, ästig; untere Blätter handförnig - 5spaltig, eingeschnitten - gezähnt, obere ganzrandig, 3lappiy, am Grunde keilförniy; Quille vielblüthig, sehr dicht stehend; Kelch fast kahl, starr, stechend; Unterlippe der Blume in einen länglichen Zipfel zusammengerullt. 4. Züune, Wege, unbebaute Plätze, in Dörfern häufig z. B. an 'Zäunen unmittelbar vor den Ieipziger 'Thore, in Giebichenstein u. s. w. Juli. Aug. Blune hlein, blass-röthlich, Unterlippe in der Mitte gelb, roth gefleckt. Höhe $1-3$ '.

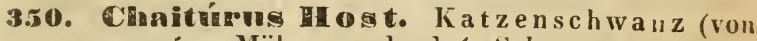

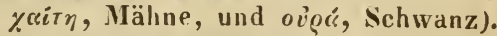

873. Ch. Marrubiastrum Rehb., andolnartiger K. Sturm Heft 84 . Stengel aufrecht, weichhaarig; Blätter fein-weichhaarig, unterseits' mit zahlreichen weissen Drüsen besetzt, die unteren rundlich-eiförmig, grob-gekerbt, die oberen lanzettlich, beiderseits verschmälert, nit wenigen Sägezähnen; Quirle vielblüthig, dicht stehend; Kelch weichharig, mit eiföımigen, stachelspitzigen Zühnen; Blumenkrone kaum länger als der Kelch. $\odot$. Schutt, Wege äusserst selten. Nur auf der Grenze bei Wahren und Stahmoln unweit Schlieuditz, an der nordöstlichen Grenze in Vockerode und in Pödnitz zwischen Dessau und Oranienbaum. Juli. Aug. Leonurus Marrubiastrum L. Blume klein, hell-rosenivth, am Schlunde purpurroth. Höhe 1-4'.

Sprengel gribt (hal. ed. 2. p. 268) für diese seltene Pflanze ausser dem botanischen Garten in Halle gar keinen Standort an.

7. Gruppe. Scutellarineen Benth. Schildträgerge wä chse. Blume 2lippig; Staubgelässe unter der Oberlippe der Blume gleichlaufend, genähert. Kelch 2lippig, nach der Blüthe durch Zusammenneigung der Lippen platt-geschlossen, die Oberlippe ungetheilt oder kurz-3zähnig, die Unterlippe ganzrandig oder 2zähnig. 
351. Seutelláno L. S childtrager (der zuerst bei J. Bauhin rorkomnende Name ist vun scutun, Schild, abgeleitet und die Pflanze "egen der Gestalt des liel. ches so benannt).

874. Sc. galericulata L., geme ine $\mathrm{I}_{\mathrm{s}} \mathrm{h}$. H a y. ne Arzneigew. III, 36. Stengel aufrecht oder am Grunde niederliegend, scharfkantig und an den Kanten behaart; Blätter aus herzförnigem Grunde länglich-lanzettlich. entfernt-stumpf-gelierlot-gesïgt; Bliithen blattwinkelständig, einseitswendig; Kelche meist kahl; Rö̌re der blume am Grunde fast reclitwinkelig - gckriimmt, vielnal länger als der Kelch. 24. Gräben, Bäche, Ufer, feuchte Gebiische nicht selten $\boldsymbol{z}$. B. in Gräben hei Passendorf, Dieskan, sehr häufig am salzigen See bei Ober Röblingen, ebenso in der Aue bei Burg liebenau 'u. s. w. Juli. Ang. Bluṇe hellviolett. Höhe $1 / 2-11 / 4 \%$ Dic l'flanze andert mit "eichharigen, aber drüsenlusen Kelchen ab.

875. Sc. Jastifolia L., spiessblät eriger Sch. Stengel anfstejgend, scharfliantig, weichharig; Blätler länglich-lanzettlich, am Grundc durch 1-2 Zülnze auf jeder Seite ctrvas spiessförmig, die untersten eiförnig, die ubersten lanzettlich, am Grunde fast herzföınig ; Blüthen blattwinkelständig, einseitswendig, trauhenförmig genähert; Kelch driisig - weichhaarig; Rülıre der Blume am Grunde fast rechtwinticlig-gcliviimmt, vielmal länger als der Kelch. 24. Fenchte Wiesen, Gräben sel. tener als die vorhergehende Art. An Waldrande bei Kl. Liebenau bis nach Kl. Dölzig hin, anf Wiesen un. ter Rauschen's Hölzchen bei Nerseburg, an Gräben zwischen Balgstedt und Jaucha in der Nähe der $U_{n-}$ strut, anf Wiesen zwischen der Steinklippe und Memleben, auf der Grenze hei Hecklingen unweit Stassfurt, bei Dessau hänfig. Juli. Aug. Blıne riolett, grössel als bei der vorhergetsenden und nachfulgenden Art. Höhe $\mathbf{1}^{\prime}$.

876. Sc. minor L., $\mathrm{kl}$ e iner $\mathrm{Sch}$. Stengel aufsteigend oder aufrecht, schwach-behaart; Hlïtter länglich lanzettlich, am Grunde durch 1-2 Züline auf jeder Scite ctwas spiessförmig, die untersten eiförmig, die obersten lanzettlich; Blithen meist einzeln, blattwin. helständig, einseitswendig; Kelch von drüsenlosen Haa. ren kurzhaarig; Röhre der Blume gerade, am Grunde etwas bruchig, mur 3-4mal länger als der Kelch. 4. sumpfige lliesen, Muorboden sehr selten. Nur bei 
Oranienbaum am Göttertsbrueh und in der Scheitlache zwischen Gremin und Zschiesewitz. Juli. Aug. Blume klein, blassblau. Der sehr schwache stengel ist $4-$ 8 " huch.

352. Prumélla C. Brunelle (der lateinische Name ist von Tragus aus dem Deutschen gebildet; die Pflanze wurde alier nicht als Nittel gegen die Bräme so benannt, wie C. Bauhin meint, sondern erhielt ihren Namen von der braunen Farbe der abgeblühten Kelche).

877. P. vulgaris $\mathbf{L}$., gemeine B. Il a yne Alzneigew. VI, 10. Stengel aufsteigend, einfach oder wberwärts ästig; Blätter gestielt, läuglich - eiförmig, ganzrandig, gezahnt oder fipderspaltig; Blüthenquirle an der Spitze des Stengels in einer liopförmigen, rundlichen uder eiförmigen Aehre, am Grunde meist ron 2 Blättern gestiitzt; Zähne der Oberlippe des Kelches sehr kurz, abgestutzt, stachelspitzig, die der Cuterlippe eiförmig - lanzettlich, stachelspitzig, schwach - gewimpert; die lüngeren Staubgefässe an der Spitze mit einem geraden, dornfümigen Zahne versehen. 4. Wiesen, Triften, Raine. Waldränder hänfig. Juli. Aug. Blume violett oder röthlich, selten "eiss. Höhe $1 / 3-1$ '. Die Blïthen sind bisweilen doppelt so laug, balı kaum läıger als der Kelch.

578. P. orandiflora Jacq., grossblumige B. Stengel aufsteigend, meist einfach; Blättel gestielt, länglich - eiförmig, ganzrandig, gezähnt oder fiederspaltig; Blüthenquirle an der Spitze des Stengels in einer kopfförmigen, rundlichen Aehre, am Grunde meist whne Blätter; Zähne der Oberlippe des Kelches breit-eiförmig, crannenartig-zugespitzt, die der Unterlippe lanzettlich, grannenartig-zugespitzt, gewimpert; dic langeren Staubgefässe an der Spitze mit einem Kleinen Höcker versehen, ohne Zahn. 24. 'Trockene Wiesen, Raine, Anhöhen, besonders an Kalkbergeni. seltener als die vorhergehende Art. An Donnersberge hinter Kröllwitz, auf dem Vugelsberge bei Benustedt häufig, einzeln an Anhöhen bei Röglitz, Ermlitz, häufig auf Wiesen bej Kl. Dölzig und an Bienitz, an hreiten Rainen zwischen vïcheln und Oehlitz, hei Nammburer und Fieiburg anf Kalkburen lïufig, an Kalkbergen zwischen Rossleben und Bottendorf, bei Allstedt am nordwestlichen Rande des Rathsholzes, bei Eisleben, in Hitz. genthale zwischen Sandersleben und Hettstedt, an Kalk. 
bergen bei Bernburg, fehlt im nordöstlichen Gebiete. Juli. Aug. P. vulgaris $\beta$. grandiflora L. Blume violett, doppelt so 'gross als an der vorhergehenden. Höhe $1 / 3-3 / 4$.

R. Gruppe. Ajugoideen Benth. Günselgewächse. Blumenkrone 2lippig. Oberlippe sehr kurz, Unterlippe verlăngert; Staubbeutel mit einander verschmolzen; Nüsse etwas netzförmig-runzelig.

353. juga L. Gïnsel (soll nach Einigen rou ahigere, abtreihen, herkommen und wird mit dem von Plinius 24, 6 erwähnten Ahiga in Verbindung gesetzt, welche Ableitnng jedoch unwahrscheinlich ist; der deutsche Name Günsel ist aus Consolida, dem älteren Namen der Pflanze elltstellt).

1. Bugula Tournef. Bliithenquirle reichblïthig; Haarleiste in der Röhre der Blumenkrone nicht unterbrochen, von der Einfügnng der Staubgefüsse entfernt.

879. A. reptans L., kriechender G. Hayne Arzneigew. IX, 17. Stengel fast kahl oder 2reihig- hehaart, am Grunde mit kriechenden Auslïufern ; Blätter ausgeschweift - oder undentlich-gekerbt; Bliithen quirlig; Deckblätter länglich, ganzrandig uder' schwach - gekerbt, die oheren meist kürzer als die Bliithenquirle. 24. Wiesen, 'Triften, Grasplätze, feuchte Wülder gemein z. B. auf Wiesen an den Pulverweiden, im Sebener Busche und auf den benachbarten Wiesen u. s. W. Mai. Juni. Blume blau, seltener fleischroth oder weiss. Höhe $1 / 2-1$. Die Ausläufer sind an Pflanzen, welche auf trockenem Boden stehen, oft sehr kurz.

880. genevensis L., b e ha a r te r, eigentlich ge 11 fer G. Hayne Arzneigew. IX, 18. Stengel zottig, olıne Ausläufer; Blätter ausgeschweift-gekerbt, die wurzelständigen gestielt, die stengelständigen sitzend; Blïthen quirlig; die unteren Deckblätter 3lappig, gezähnt oder ganzrandig, die oberen kiirzer oder kaum so lang als die Bliithenquirle. 4. 'Truckene Wälder, Waldrä̉nder, Hügel, Wegränder häufig z. B. in der Dölaner Heide, im Mittelholze u. s. w. Mai-Juli. A. alpina L. mant. A. montana Rchb. Blume schön blau, seltener blassroth. Höhe $1 / 2-1^{\prime}$. Aendert mit ganz kleinen und schr grossen Wurzel- und unteren Stengel- 
blättern und mit 3lappigen, gezähuten oder eiförmigen und ganzrandigen uberen Deckblättern ab.

881. A. pyramidalis L., p y ramidaler G. Hay. ne Arzneigew. IX, 19. Stengel aufrecht, zottig, ohne Auslïufer ; Blätter ausgeschweift-gekerbt, dic vurzelständigen gehïuft, kaum gestielt, meist sehr gross; Blüthen quirlig; Deckblätter ausgeschweift-gekerht, die oberen doppelt so lang als die Bliithenquirle. 24. Waldränder, sehr selten. Nur an nördlichen Rande der Dölauer IIeide Lettin gegenüber sparsam. Mai. Juni. Blume klein, blassblau. Höhe $1 / 3-1^{\prime}$.

Ist der vorigen Art, besonders der Form mit grossen Wurzelblättern sehr ähnlich und vielfach mit ihr verwechselt worden, unterscheidet sich aber durch die zahlreicheren, gehäufteren Wurzelblätter, durch die einander sehr genäherten Blïthenquirle, welche schon am unteren 'Theile des Stengels beginnen, durch die weit kleineren, hellblauen Blïthen, welche von den oft braun oder bläulich angelaufenen Deckblättern weit überragt werden.

Wallr. tadelt mit Recht die Vereinigung dieser und der vorhergehenden Art mit A. reptans L. bei Spreng. hal. ed. 2. p. 259 und bemerkt dabei, dass die ächte A. pyramidalis schwerlich bei Halle vorkommen möchte. Wenn auch der Verfasser nach der allerdings sehr düftigen Diagnose und der Allgemeinheit des Standortes (in Wälderı und an Waldrändern) bei Spreng. a. a. O. iiberzengt ist, dass derselhe die $A$. pyramidalis nicht gefunden und nur formen von $A$. genevensis dafür gehilten hat, so kann doch jetzt das Vurkommen der ächten A. pyramidalis I. nicht mehr bezweifelt werden.

B. Chamaepitys Tournef. (von quecri, am Boden, niedrig, und mitvs, Fichte, eigentlich kleine Fichte, wegen der Gestalt der Neste und Bläter). Blüthen in den Blattwinkeln einzeln, gegenïberstehend; Haarleiste in der Röhre der Blumenkrone an die Einfügung der Staubgefüsse gestellt, aus unterbrochenen Haarbüschelchen zusammengesetzt.

882. A. Chomaépitys Schreb., g ellblumiger G. H a yn e Arzneigew. VIII, 1. Stengel ausgebreitet, aufsteigend, zottig; Blätter 3spaltig, mit linealischen Zipfeln; Bliithen einzeln, blattwinkelständig, kürzes 
als das stützende Blatt; Röhre der Blunie doppelt so lang als der Kelch. $\odot$. Aecker, trnckene Abhänge, geru auf Kalk, stellenweise. An den Kalkbergen zwi. schen Bennstelt und Kölme, fehlt in südlichen Gehıete bis Weissenfels; bei Naumburg in den Weinbergen zerstreut, bei Sandersleben nicht selten z. H. auf dens Schiessberge, im P'regel u. s. w., an Kalhbergen bei Beruburg. Juli - Sept. 'Tencrium Chamaepitys L. Röhre der Blumenkrone weisslich, Uuterlippe citronengelb, au Grunde braun punktirt. Höhe 2-6". Das klebrige und stark riechende Krant ist hin und wieder als Herba Chaemaepityos s. Ivae arthriticae officinell.

354. Teucrimm I. Gamander (ein bei Dioscorides vorkonmender Pflanzenname. Welcher nach 'Teucer, dem Könige vou 'Troja benamnt sein soll).

A. Scorodonia Adans. Kelch 2lippig, Oberlippe aus einem breiten 'Lahne, Unterlippe aus 4 .Zähnen bestehend.

S83. T. Scorodonia L., salbe iblät teriger G. Stengel meist steif - aufrecht, ästig; Bläter yestielt, herz-eiföınig ơlır lierzförnig-länglich, gekerbt-gesägt, runzelig, weichharig; Blütlıen in end- und blattwinkelständiger, verlängerter, Jockerer 'Iraube; Kclch mit eiförmiger, ungetheilter Oberlippe. 24. Heiden, Waldränder, trockene, sandige Abhängre sehr selten. Nach spreng. bei Gutenberg, "o es bisher vergelich gesucht ist; von Schwabe fl. anh. bej Lingenall angegeben; anf der Grenze an rothen IIause zwischen Eilenhurg und Dïben und an anderen Stellen der Dïbener Heide, vielleicht auch bei Bitterfeld, welchen standort s preng. citirt. Juli. Aug. Blume grïnlich-weiss. Höhe $1^{\prime}$.

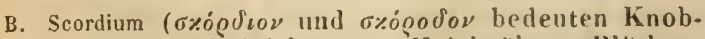
lanch). Fünf uleich grosse Kelchzähne. Blüthenquirle 2 - 6blüthig, blattwinkelständig, von einander entferut; die hlüthenständigen Blätter den stengelständigen gleichgestaltet.

834. T. Botrys L., 'I'r a uben-G. Stengel anfrecht, pinfach oder ästiy, zottig und zugleich drüsig-klebrig; Blätter gestielt, doppelt-fiederspaltig-geschlitzt, die blüthenständigen gleich gestaltet; Blüthenquirle 2-6bliithig, blattwinkelständig. $\odot$. Sonnige Abhänge, Kalkberge zwischen Gebïsch selten. Fehlt bei Halle, Mersehurg und Weissenfels; findet sich bei Naumburg und Freiburg 
häufig, in den Schmonschen Bergen, bei Schraplau nach s preng., an Kalkbergen bei Bernburg. Juli - Herbst. Blume röthlich, der Mittellappen der Unterlippe blass. gelb, mit bräunlichen Punkten. Höhe $3-10^{\prime \prime}$.

885. T. Scordium L., knoblauchduftender G. II a y ne Arzneigew. VIII, 3. Stengel zottig, aufrecht uder aufsteigend, am Grunde meist mit kriecheuden lusläufern; Blätter sitzend, läinglich, grob-und stmmpfgekerbt-gesägt, meist weichhaarig, die unteren am Grunde abgerundet, die oberen am Grunde verschmïlert, die blüthenständigen gleichgestaltet; Blüthenquirle 2 - 4 blüthig, blattwinkelständig. 24. Grüben, fenchte Wiesen, keineswegs selten, wie Wallr. sched. p. 295 meint. An Gräben zwischen Halle, Reideburg und Bischdorf häntig, an Wiesengräben zwischen Pfitzenburg und Kochstedt, auf feuchten Wiesen bei Planena, Neukirchen, Corbetha, bei Merseburg auf Wiesen nach der Fasanerie zu, auf Wiesen zwischen Wesmal und Ermlitz, bei Naumburg besonders in der Aue und an des alten Saale, bei Freiburg auf Wiesen an der Unstrut nach Scheiplitz zu, auf Wiesen bei Allstedt, bei Aschersleben und Dessan häufig, bei Laus hinter Delitzsch. Juli - Sept. Blume purpurroth. Höhe $1 / 2-1 \frac{1}{2}$ ' Die etwas geriebenen Blätter riechen nach Knoblauch. OFF. herba Scurdii.

c. Chaemaedrys Dillen. (von zceuci, am Boden, klein, und $\delta o \ddot{s}$, Eiche, eigentlich kleine Eiche, wegen einiger Aehnlichkeit der Blätter). Fünf gleich grosse Kelchzähne; Blüthenquirle 2 - 6blüthig, in eine endständige Traube zusammengrestellt, die oberen oder alle blüthenständigen Blätter decliblattartig.

886. T. Chamaedrys L., gemeiner. G. Il ayne Arzneigew. VIII, 4. Stengel zottig, anfsteigend, am Grunde ästig; Bliitler gestielt, eifürmig oder länglich, licilfürmig in den Blattsticl zulaufend, eingeschnittengekerbt; Bliithenquirle meist 6bliithig, in endstïndiger. Traube. 21. Sonnige Anhöhen, besonders auf Kalkboden, stellenweise. An den Kalkbergen bei Bemnstedt; fehlt im ganzen östlichen und im südlichen Gebiete bis Weissenfels; bei Nammburg an Kalkbergen häufiy, ebenso bei Freihurg z. 13. am Schlifter, an den Schlagbergen 1. s. w., am Felsen bei Weudelstein, an den Kalkbergen bei Buttendorf, ebenso bei Bernburg. Juli- 
Sept. Blume hell-purpurroth. Kéche und Dechblätter meist rothbraun. Ilöhe meist $1 \%$.

D. Polium Benth. Fïnf gleich grosse Kelchzähne; Bliithenquirle in endständige Köpfchen zusammengedrüngt.

887. T. montanum L., Be irg - G. Stengel niedergestreckt, ausgebreitet, halbstrauchartig; Blcittcr linealisch.lanzellich, ganzrandig, am Rande etwas ungerbugen, unterscits grau-filzig; Blithenquirle in cin endständiges Köpfchen zusammengedrüngt. 24. Sunnige Kalkberge sehr zerstrent. Am Vogelsberge und an den Kalkhergen bei Bennstedt nach. Kölme hin häufig, bei Wettin auf Zechstein selten, bei Naunburg an Kalkbergen häufig, ebenso bei Vitzenburg unweit Nebra und bei Bottendorf. Jumi-Aug. Blume blassgelb. Stengel 5-9" lang. 'T. supinum L. ist eine schmalblätterige Furm.

\section{Familie. Verbenceen J Is s. Ei -} sen hart些wächse.

355. Verhéna L. Eise nhalt (Pfianzennane bei Plinius; in Deutschen heisst die Pflanze Eisenhart, weil sie nach altem Wahne unverletzlich und hart wie Eisen oder hart gegen Eisen machen sollte).

8s8. v. officinalis L., g e bräuchlicher E. H ay ne Arzneigew. V, 42. Stengel aufsteicend oder aufrecht, ästig; Blätter gegenständig, eiförnnig-länglich, tief-3spaltig, geschlitzt und gekerbt, in den breiten Blattstiel zusanmengezogen; Blïthen i॥ fadenförmigen, rispigen Aehren; Kelch klein, 5zähni w. $\odot$. Weg-und tclierränder, Gräben, Schutt, in Dörfern häufig z. B. am Wege von der Eisenbahn nach Reideburg sehr häufig, in Giebichenstein u. s. w. Juli - Sept. Blume klein, blassblau. Höhe 1-1\%'.

\section{I.XXV. Familie. Lentibularieen Richard. Wasserhel mewächse.}

356. Utricularia L. W a s s erh e I m (von utriculus, Schlauch, wegen der mit Schläuchen besetzten Blätter).

859. U. vulgaris L., gemeiner W. Sturm Heft 
13. Hliitter nach allen Seiten hin abstehend, gefiedertvieltheilig, im Umrisse eiförmig, Zip/el haarfein, entfernt-feinstachelig-gevimperl; Blüthen an der Spitze des Schaftes; Sporn kegelförmig; Oberlippe von der Länge des Gaumens. 24. Sümpfe, 'Teiche, überhaupt stehende Gewässer, stellenweise. In Sïmpfen und Gräben zwischen Passendorf und der Irrenanstalt, daselbst aber nicht blühend, in einem 'Teiche bei Kaschwitz un" Weit Wettin, in alten Braunkohlengruben zwischen Weglitz und Zöschen, hei Weissenfels, fehlt bei Naunbury; in deı Lehmgrube zwischen Ziegelrude und dem Klapperborn, bei Allstedt im Rathsteiche und in der Entenpfütze, im Aschersleber See hänfig, bei Dessau auf dem Gruss Kühnauer See urd im 'Thiergarten, früher auch bei Benndorf beobachtet. Juni - Aug. Blume dottergelh. Schaft $1 / 2-L^{\prime}$ hoch. Die meist untergetauchten, wurzelfaserähnlichen Blätter sind mit Luftblasen besetzt.

Koch gibt Synops. ed. 2. p. 665 als charaliteristisches Merkmal für diese Art die zusammengewuachsenen Staubbeutel an, welche bei U. neglecta Lehm. frei sind. Sie sind jeduch auch bei U. rulgaris I. nicht zusammengewachsen, sondern kleben uur bisweilen aneinander, werden aber ebenso oft, ja öfters frei gefunden.

890. U. minor L., kleiner. W. Sturm Heft 17. Blïter nach allen seiten hin abstehend, gabelspaltigvieltheilig, im Umrisse kurz-eiförmig, Zip/el borstenförmig, kahl; Spurı sehr kurz, kegelförmig; Oberlippe ausuerandet, von der Länge des Gaumens; die fruchttragenden Blïthenstiple zurücligebogen. 4. In Sümpfen besunders anf Turf- und Moorbuden sehr selten. Ist bei Weissenfels, in der 'Torfstecherei bei Möst unweit Dessau und in der 'Torfstecherei an der Benndurfer Vühle gefunden worden. Juni - Aug. ,Blume blassgelb. Scháft weit kleiner, als an der vorigen drt, meist inir $2-4^{\prime \prime}$ hoch.

\section{Familie. Primulaceen Vent. Him -} melschliis selgewächse.

35\%. Trientalis E. Siebenstern (nach der gewöhnlichen, aber sehr unwahrscheinlichen Erklärung stammit der'latemische Name ron triens, trientalis, ein Drittheil, weil die Pflanze nur die Höhe des dritten 
Theiles eines Fusses erreiche; dies ist jeduch geradezu unrichtig; etwas wahrscheinlicher ist wenigstens die Erklärung, nach welcher die l'flanze Jen Namen Drittheil erhielt, weil der 'Theil, an welchem die Blätter und Blüthenstiele sich befinden, bis zur spitze wirklich den dritten 'Theil del ganzen P'lanze ausmacht).

891. T. curopaea L., e u rupäis cher $S$. Sturm Heft 17. Wurzelstoch hriechend; Stengel aufrecht, unten mi $1-3$ schuppenförmigen Blättern, oben mit 5-7 grösseren, elliptischen, kahlen, in einen Quirl gestellten Blättern; Blüthen lang-gestielt; Staubgefüsse 5-9, mit purpurrothen Staubbeuteln. 24. Auf lockerem Boden in Wäldern. An den tiefer gelegenen Theilen des Lindberges und Zorgs, anf Heidebuden an Bächen bei Osterfeld nach Meinweh zu. Mai. Juni. Blume weiss, oft mit röthlichem Anfluge. Der dünne Stengel ist $4-8$ " hoch.

358. Cysinachia L. Friedlos (der von Diosco-

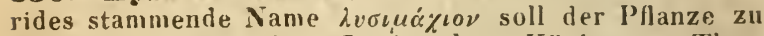
Ehren ihres Entdecters Lysimachus, Königs von Thracien gegeben sein; der Trivialname Nummularia kumnt von nummus, Geldstiick, her, und ist der Pflanze wecen der runden Blätter beigelegt).

1. Naumburgia II ö $\mathrm{n}$ h. Blïthen in gedrungenen, blattwinkelständigen'Trauben. Ein kleiner Zahn zwischen den Blumeuzipfeln.

892. L. thyrsiflora L., strauss blüthiger F. Stengel aufrecht, meist einfach; Blïtter gegenständig oder zu 3 oder 4 quirlförmig, lanzettlich, braunrothpunktirt; Traube blathwinlielstïindig, gestielt, gedrungen, walzenförmig, kürzer als das stiitzende Blatt; Staubgefässe nur am Grunde nit einander verwachsen. $\rightarrow$. Sümpfe, Gräben äusserst selten. Nur am Loberbache bei Benndorf und bei Dessau hin und Wieder. Juni. Juli. Blume klein, gelb. Höhe 1-2'.

B. Lysimastrum Dub. Blïthen rispig oder blattwinkelständig; Buchten zwischen den Blumenzipfeln zahnlos.

a. Staubgefásse 5, unterseits oder his zur Mitte zusammengewachsen, den liruchtinoten bedeckend.

893. L. vulgaris L., gemeiner. F. Hayne Arzneigew. II, 59 . Stengel aufrecht; Blätter gegenständig 
uder zu 3 - 5 quirlförmig, kurz - gestielt, länglich - lanzettlich oder eifornig, wberseits fast kahl, unterseits rtwas zottig; Bliithen an der Spitze des Stengels in einer rispenartigen Traube; Blïthenstiele aufrecht; Zipfel der Blume piförmig, am Rande kahl; Stanbgefässe 5, von dem Grunde bis zus Mitte zusammengewachsen. 24. Sumpfige Stellen, Grähen, Flussufer gemein z. B. auf der Rabeninsel, in Gebiisch an der stillen Elster zwischen Radewell und Osendorf u. s. w. Juni. Juli. Blume goldgelb. Höhe 2-4'. Aendert in Schlanme mit langen Ausläufern (L. paluiosa $B$ a u $\mathrm{m} g \mathrm{~g}$.) ab.

b. Stanhgefasse frei oler unterwarts kurz zusamnengewabsen, den Frocitkuot, n nicht berbeckend.

394. L. Nummularia L., rundblät te riger F. Il ay $\|$ e Irzneigew. III, 16 . Stengel niederliegend, kriechend; Blätter gegenständigr, herzförmig-rundlich; Blithenstiele blattwinkrlstüulig, einzeln, kürzer als das Blatt; Kelchzipfel her förmig. 4. An feuchten Stellen auf Wiesen, in Wälderı, an Gräben gemein z. B. sthon im Chaussegraben ror dem Geisthore. Juni. Juli. Blume ziemlich gross, eitronengelb. Stengel bis $1^{\prime}$ lang. Die Blïthenstiele sind bisweilen länger als die Blätter. Fiüher als Pfennigkraut (Herba Nummulariae) offi. cinell.

895. L. némorum C., II a in-F. Sturm Heft 1. Stengel niederliegend, am Ende anfsteigend; Blätter gegenständig, eiförmig urler etwas herzföruig, spitz, kahl; Bliithenstiele blattwinkelständig, einzeln, länger als das Blatt; Kelchzipfel lincalisch-pfiremlich. 4. Feuchte Haine und Wälder änsserst selten Im Jodersleber Forste sehr selten; ron $\$ p r e n g$. wird auch die Kl. Eichstedter Wüste angegeben, "o die Pflanze noch jetzt rorkommen mag, wenn auch nur selten, weniger. zurerlässig ist der andere vun ihm angegebene Standort hinter Schkeuditz an der Luppe, bei Zweymen. Juni. Juli. Blune klein, citronengelb. Stengel $6-10$ "lang.

359. Amagallis T. Ga u $\mathrm{ch}$ heil (Pflanzenname bei Dioscorides; der deutsche Name Gauchheil stamnt ron Gauch, Narr, wegen der vermeinten Heilkraft gegen Geisteskrankheiten uder wegen seiner die Diebe (Gauche) abhaltenden Kraft).

896. A. arvensis K., A ck e r - G. H a y n e Arzneigew. 11, 45. 46. Stengel meist ausgebreitet; Blätter gegenständig oder zu 3 quirlständig, sitzend, eiförmig; Blï- 
thenstiel su lang oler länger als die Blätter; Zipfel der Blume klein-gekerbt, feill-drüsigr-gewimpert, ein wenig länger als uer lich. ऍ. Aecker, Weinberge, Schutt gemein z. B. auf Aechern vor Giebichenstein, zwischen Halle und Niptleben, hei l'assendurf u. s. w. Juni-Herbst. A. phuenicea Ja m. lilume mennigruth, am Grunde blutroth-geflerkt, spltener fleischfarben nnd dann zuweilen an Grunde mit violetten Flecken. Höhe $3-6$ " hoch. Aendrert ab:

b) coerulea Schreh.: Blune blai, am Rande meist völligr drüsenlos. Diese Form liebt mehr Kalhbudeu, hummt jeduch, obwohl seltener, mit Her Hanptalt zugleich vor, so zwischen Halle und Nietleben, häufiger hej Bellnstedt, Wettin, sehr häufig auf kallhaltigem Bulen bei Freiburg.

360. Ceatémadus L. Kleinling (ein von Pli. nius aus cento, läppchen, gebildeter Name, mit Bezug auf die Kleinheit des Plänzchens).

S97. C. minimus L., Ackel-K. Sturm Heft 30. Stengel anfrecht oder liegend, zuweilen ästig; Blätter wechselständig, eiförmig; Bliithen einzelu in den Blattwinkelı sizzend. $\odot$. Feuchte, sandige Stellen der Aeckel' und 'Iriften stellenweise. In alten Falugleisen zwischen Kiöllwitz und lattin und anf Aechern am nord. östlichen Rande der Dölaner Ileide, auf Aerkeru au Dölauer Kirchhulze, auf saudigen Aeckern am Bienitz, bei Naumburg anf sandigen Aeckern bei der Henne und bei Flemmingen, bei Bibra hänfig, fehlt bei Aschersleben, bei Dessan an den Ufern der Mulde und Elbe. Juni. Juli. Blume klein, weiss uder röthlich. Nur 1-4" hoch.

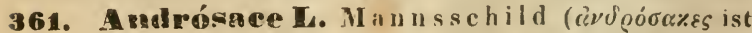

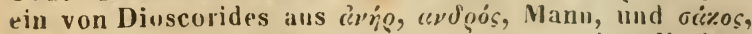
Schild, gebildeter Pflanzenname, worunter aber die Acetabularia integra $\mathrm{L}$ a $\mathrm{m}$. zu verstehen ist).

898. A. elongata L., verläng erter M. Blätter grundständig, rosettenarig, Janzettlich, gezähnt, am Rande nebst den Schafte und den Blüthenstielen mit sehr kurzen, feinsternigen Haren besetzt; Blüthenstielchen viel länger als die Iüllblättchen, zuletzt fast su lang als der Sichaft; Kelch länger als die Blume. (-). Sounige, etwas grasige Anhöhen, sandige Brachäcker sehr zerstreut. An grasigen Stellen des Gartens zur 
litintraube, an Felsen an der Saale hinter der Kröllwitzer Papiermühle sehr sparsam, am Schwalchloche nicht häufig, früher auch anf sandigen deckern zwischen Schkeuditz und Neuscherbitz gefunden, fehlt in ganzen südlichen und "estlichen Gebiete; bei Aschersleben friiher an den Westerbergen, später nur an den Ochsenbergen beobachtet, fehlt dann wjeder im ganzen nurdöstlichen Gebiete. Mai, auf Aeckern oft erst nach der Erute. Blume weiss, mit gelblichem schlunde. Schaft nur $1-3^{\prime \prime}$ hoch.

362. Fúnala E. H imm elschlïssel (Prinula (veris), Erstling des Frühlings, bezicht sich auf das frühzeitige Blïhen dieser Pflanzen).

899. P. elatior a cq., hoher H. Hayne Arzneigew. III, 3j. Schaft aufrecht; Blïtter eiförmig-länglich oder eiförmig, in den geflügelten, gezähnten Blatt. stiel herablaufend, runzelig, wellenförmig - geherbt, untcrseits nebst dem Schafte und der Dolde kur:aharig; Harre des Blïthenstielchens so lang als der Querdurch. messer des Blüthenstielchens; Dolde mehrblüthig; Zähne des geschärft-kantigen lielches eiförmig, lang zugespitzt; Blume trichterförnig, Zipfel des Sammes flach. 24. Fruchte, schattige Wälder, Gebüsche, li iesen sehr zerstrent. Fehlt in der Nähe von Halle; findet sich in den Wäldern der Aue bei Schkenditz, Kl. Liebenau u. s. w. häufig, bei Naumburg häufig, bei Lingenau und Oranienbaum stellenweise. März. April. P. veris $\beta$. elatior J. Blume geruchlos, schwefelgelb, an Grunde mit ejutm Jottergelben Ringe oder ohne denselben, in Gärten in fast allen Farben. Ilöhe $1 / 2-1^{\prime}$. Aendert wie die folgende mit einer lang - und kurzgriffeligen Furm ab.

900. P. officinalis J cq., gebräuchlicher H. II a y e Arzneigew. III, 34. Schaft aufrecht; Blcitter eiförmig oder etwas herzförnig, in den geflügelten, gezähnten Blattstiel herablaufend, runzelig, wellenförnig. gekerbt, unterscits nebst dem Schafic und der Doldc sammetartig; Dolde reichblüthig; 'Zähne des geschärftkantigen, anfgeblasenen Kelches eiförmig, sehr kurz zugespitzt; Saum der Llume glockenförmig-vertieft. $\stackrel{3}{4}$ Wälder, Wiesen häufig z. B. in Lindberge, in der bölauer Heide u. s. w. April. Mai. P. veris «. officinalis I. Blume wohlriechend, hochgelb, an Schlunde mit 5 safraufarbenen Flecken. IÖh $4-9 "$. Bei der langgriffeligen Form stehen die Staubgefässe in der Mitte 
der Röhre, bei der kurzgriffeligen sind sie dem Schlunde eingefügt.

Die ächte P. ac a ulis Jacq., welche Spreug. fral. ed. 2. p. 1118 in feuchten Wäldem bei Burg- und hl. Liebenat angibt, ist gewiss nie in Gebiete gefunden warden, sondern dies ist "hne $Z$ weifel nur die bisweilen rorkummenle stengellose Furm ron P. elatior sewesen, wie auch aus der sprengel'schen Diagnose herrorrugehen scheint.

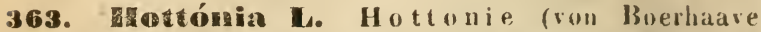
nach seinem Vurgänger in der l'rofessmr der Butanik zu Leiden, Peter Hotton, genannt, weil er dessen stelle (erhielt).

901. H. palustris L., S $\mathbf{L}$ m f-H. Blätter hammförnig-fiederspaltig, mit schmalen, linealisch-pfrienlichen Zipfelı; Blüthen gestielt, in endständigen, quirlförmigen 'Trauben, die Blïthenquirle der 'Traube gleichweit abstehend; Blume viel länger als der Keleh. 4. Gräben, Sümpfe stellenweise. In Gräben der Aue bei Osendorf, Collerbey, löpitz, Burg Liebenau, im Gemeindehulze bei 'ö̈schen, am Bienitz, sehr häufig an Wiesengräben an der Fuhne bei Zörbig, Löbersdorf, Radegist, fehlt im gauzen südlichen, westlichen und nordwestlichen Gebiete, findet sich hei Dessan häufig, bei Oranienbaum nach der Kapenmülı zu nicht selten, in Gräben bei Crina östlich von Bitterfeld, im Bruche zwischen sandersdurf und Bitterfeld, in Gräben der Gotsche zwischen Paupitzsch und Niemegk und bei De. litzsch. Mai. Juni. Blume weiss oder hellrusenruth. Schaft $1^{\prime}$ hoch. Aendert mit langem und kurzem Grî́fel ab.

364. Sáazolars. Bunge (nicht Pungen) (Plianzenname bei Plinius).

962. S. Walerandi L., S a I z. B. Stengel anfecht, oberwärts - ästig; Blätter verkehrt-eiförmig vder länglich, stumpf, die grundständigen rusettenartig, die oberen sitzend; Traube zuletzt verlïngert; Deckblättchen linealisch-lanzettlich, mitten auf dem Blüthenstielchen stehend; Kapsel fast kugelförmig. 24. Nasse Wiesen nud Gräben, besunders auf salzhaltigem Buden, stellenweise. Bei Halle nicht selten z. B. an Gräben zwischen Halle und Reideburg, an den 'Teichen bei Diestan, an Wiesengräben unmittelbar an und hintel den Gärten bei Nietleben links ron der Chanssee, an Gräbell zwischen 
Trotha und der Lerche, an Gräben zwischen Kölme und Langenbogen, am Rande des salzigen Sees bei Rollsrlorf, an Gräben bei Zöschen und bei Kl. Dölzig sparsam, häufiger auf salzhaltigem Boden bei Kötschau und Ieuditz; fehlt bei Naumburg und im ganzen westlichen Gebiete, tritt bei Stassfurt, an der Fuhne bei Leau und zwischen Löbersdorf und Radegast wieder auf und fehlt dann bei Dessan, Oranienbaum und überhaupt im ganzen nordöstlichen Gebiete. Juni-Sept. Blume weiss. Höhe $1 / 2-1$ '.

365. Clnux L. Milchkraut (Pflanzenuame bei Dioscurides).

903. G. maritima L., Meerstrands-M. Stengel niederliegend oder aufstrebend, ästig; Blätter sehr dicht stehend, dicklich, etwas fleischig, meist sitzend, linealisch-lanzettlich, die unteren gegen-, die oberen wechselständig; Blüthen pinzeln, in den Blattwinkeln fast sitzend; Kapsel kugelförmig. 4. Nasse, salzhaltige Orte stellenweise. An den 'Teichen bei Dieskan häufig, auf Salzboden bei Kölme und Langenbogen, sehr häufig am salzigen See bei Rollsdorf, am Gotthardsteiche bei Zscherben unweit Merseburg, einzeln an Wegen bei Zöschen, sehı häufig auf salzhaltigem Buden um Kötschau und Teuditz, fehlt bei Naumburg, Freiburg und im ganzen westlichen Gebiete mit Ausnahme der Grenze bei Artern; findet sich bei Ascherslehen an dem Salzkoth nach Mehringen zu, an den Seelöchern bei Zabenstedt unweit Gerbstedt, bei Stassfurt und Leau, fehlt im nordöstlichen und östlichen Gebiete. Mai - Juli. Rlüthenhülle klein, blass - rosenroth, Staubfäden purpurroth, Staubbeutel schmutzig - violett. Höhe nur $2-5^{\prime \prime}$.

\section{Familie. Globutarieen D C. Ku- gelblumengewächse.}

366. Globularia K. Kugelblume (ein von Clusius aus globulus, kleine Kugel, gebildeter Pflanzenname).

904. A. vulgaris L., gemeine K. Sturm Heft 27. Wurzel vielköpfig; Wurzelblätter verkehrt-eifölnig, spatelförmig, ausgerandet oder kurz - 3zähnig, Stengelblätter sitzend, lanzettlich, spitz; Blüthen in einem endständigen Köpfchen. 24. An sonnigen Kalkbergen

Garcke, Flora. 
sehr selten. An Kalkbergen zwischen Bennstedt und Kölne, anı südlichen Kande der neuen Giehle bei Freiburg. Mai. Juni. Blume blau. Höhe 3-y".

\section{Familie. Plumbrgineen $\mathrm{J}$ ॥s s.} Bleiwurzgewächse.

367. Arméria Willd. Grasnelke (der Name ist nach Clusius Umbildung des französischen Volksnamens Armoiries, "elcher für verschiedene Nelhen gebraucht wurde).

905. A. vulgaris willd., geme ine G. Sturm Heft 1. Schaft an der Spitze einen mit einer Hïlle versehenen Bliithenkopf tragend; Blätter sämutlich grundständig, linealisch, spitzlich, 1nervig, gewimpert; die äusserstell Hüllblättchen haarspitziy, die inneren sehr stumpf, durch den auslaufenden Nerven stachelspitzig; Blüthenstielchen so lang als die Röhre des zottig - gerieften Kelches; Blumenblätter ungetheilt, klein-ge. kerbt, oder ein wenig ausgerandet. 24. Sonnige Anhöhen, Raine. trockene Grasplätze häufig z. B. an Bergen bei 'Trutha, am Schwalchloche hinter Kröllwitz u. s. w., fehlt bei Allstedt. Mai - Herbst. Statice Armeria L. St. elongata $H$ of $\mathrm{m}$. Blume rosenroth. Die Blätter grasartig. Schaft $1 / 2-1^{\prime}$ hoch.

\section{Familie. Plantagineen Juss. We- gerichgewächse.}

368. Plantáå L. W e g e ri c h, We g e bre it (Pflanzenname bei Plinius).

a. Samenträger 2 flügelig, heiderseits 2-4samig̣. Rühre der Blume kahl.

906. P. major L., grosser W. Hayne Arzneigew. V, 13. Schaft aufstrebend, stielrund, schwachgerieft, ungefüihr so lang als die Bliitter; Bläitter gestielt, eiförmig oder elliplisch, etwas gezähnt, kahl oder zerstrent - weichhaarig, 5-9nervig; Aehre linealischwalzenförmig, verlängert; Deckbläitter eiförmig, stumpflich, gehielt, am Rande häutig. ungefähr so lang als der Kelch; Kapsel 8sanig. 24. Wege, Grasplätze, Triften, Aecker sehr häufig. Juli-Octob. Blume blass bräunlich, Staubbeutel blass - violett. Höhe $1 / 2-1^{\prime}$. Aendert $a b$ : 
b) min im a DC.: Schaft sehr klein, nur $1 / 2-1$ " lang, Aehre 3 -10blüthig, so an sandigen fenchten $\mathrm{Or}^{\circ}$ ten z. B. auf Aeckern bei Dölau.

b. Samenträger beiderseits 1samig; Röhre der Blume kahl.

907. P. media L., mittlere IV. Hayne Arzneigew. V, 14. Schaft stielvund, schwach-gefurcht; Blätter elliptisch, etwas gezähnt, 7-9nervig, beiderseits kurzhaarig, in einen lur:en, breiten Blattstiel verschmä. lert; Aehre länglich - walzenförmig, gedrungen; Deckblätter eiförmigg, spitzlich, kahl, anı Rande häutig; Röhre der Blume kahl; Kapsel 2samig. 24. Wiesen, Wegränder, Triften häufig. Mai. Juni. Blume wohlriechend, Kronblätchen weisslich-durchscheinend, Staubfäden lang-hervorragend, weisslich oder schwach-viulett. Schaft bis $1 \frac{1}{2} 2^{\prime}$, viel länger als die Blätter.

908. P. lanceolata $\mathrm{C}$., la nze t tb lät terige $r$ IV. Hay" e Arzneigew. I, 15. Schaft 5furchig; Blätter lanzettlich, nach beiden Enden verschmälert, etwas gezähnelt, 3-6nervig, kahl oder rauhhaarig; Aehre ejförmig oder länglich-walzenförmig, gedrungen; Deckblätter eiförnig, verschmälert - zugespitzt, trockenhäutig, lahl; die seitenständigen Kelchzipfel kahnförmig, etwas zugespitzt, am Rande kahl, auf dem Rïcken mit gewimperten oder kahlem Kiele; Kapsel 2samig. 4. Wiesen, Triften, Wege überall gemein. April-Herbst. Kronblättchen durchsichtig, Staubfäden gelblich - weiss. Höhe bis $1 \frac{1}{2}$.

Bei dieser Art finden sich, wie bei anderen dieser Gattın:, monströse Exemplare mit mehren Aehren oder mit beblätterten Aehren, so zwischen Rothenschirnbach und Horuburg.

c. Samenträger 2flägelig, beiılerseits 2samig. Rühre der Plume behaart voler weichhaarig.

909. P. maritima $L$., Me erstrands. W. Sturm Heft 88. Schaft stielrund; Blïtter linealisch oder lanzettlich-linealisch, nach beiden Enden verschmälert, ganzrandig oder gezähnt, an Rande kahl oder feinborstıg-gewimpert, fleisclig, 3nervig; Athre linealisch, verlängert; Deckblätter eiförmig, spitzlich, anı Rande häutig, ungefähr so lang als der Kelch; die vorderen Kelchzipfel am lande häutig, die hinteren hrautig-gekielt, mit spitzem Kiele; Röhre der Blume etwas zottig. 4. In Gräben und an Wiesen auf salzhaltigem Boden stellenweise. In Chausseegraben an Krukenberg's Gar. 
ten sparsam, weit hänfiger an den Teichen bei Dieskau und auf Wiesen zw ischen der Dieskauer Mühle und Osendorf, anf Wiesen zwischen Pfitzenburg und Wanslebell, besonders hänfig an den Dömeken, dem salzigen und süssen See bis nach Wormsleben, an der Salzke zwischen Rollsdurf und Langenbogen, an den Salinen von Kötschau und Teuditz, fehlt bei Naumburg, an dev Grenze in der Nähe der Saline bei Artern, an den Seelöchern bei Zabenstedt unweit Gerbstedt, bei Stassfurt und Leau häufig; fehlt im nordösthchen Gebiete ganz. Juni-Octub. Höhe meist $\frac{1}{2}$ '

Littorella lacustris L. wird ron Schwabe fl. anh. am Kühnauer See bei Dessau angegeben.

IV. Unterclasse. Monochlamydeen. Ei nh üllblïthige.

Blüthenhülle einfach, da die Blumenblätter entwe. der fehlen oder mit den Kelche verwachsen sind.

\section{Familie. Amarantaceen Juss.}

A marantgewächse.

369. Amarántus L. A marant (ein aus dem

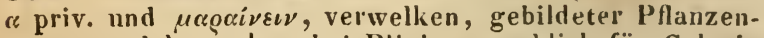
nanie, welcher schon bei Plinius angeblich für Celosia cristata L. vorkonnit; der Name ist nach dieser Ableitung ohne h zu schreiben).

910. A. Blitum L., g e me iner A. Stengel ausge. breitet, aufstrebend, kahl; Blätter eiförnigg, fast rauteriförmig, sehr stumpf oder an der Spitze ausgerandet; die blattwinkelständigen Blïthenknäuel rundlich, die endständigen in eine nackte Aehre zusanımengereihet; Deckblätter kiïzer als die Blitthen; die männlichen Blii. then 3 Staubgefässe enthaltend; Kapsel rundlich-eiförmig. $\odot$. Auf bebautem Boden, ausgeworfener Gartellerde, an Wegen in den Dörfern nicht häufig und meist unbeständig. Ist in Döllnitz, bei Wahren und Stahmeln unweit Schkeuditz, an der Saale bei Naumburg, an Wegen bei Bibra gefunden. Juli. Aug. A. adscendens Loisl. A. viridis Pollich. Albersia Blitum Kunth. Blüthen grïn. Stengel $1 / 2-1$ ' lang. Die Blätter sind gefleckt und ungefleckt. 
911. A. retrofiexus L., rauhhaariger A. Sten. gel aufrecht, kurzhaarig; Blätter eiförnig, zugespitzt, an der Spitze selbst stumpf; Blüthenknäuel Aehren bildend, die endständige Aehre zusammengesetzt; Deckhlätter doppelt so lang als die Bliithenhiille, fast dornig-stachelspitzig; die männlichen Blïthen 5 Staubgefässe enthaltend; die Zipfel der Blüthenhülle linealisch läuglich, stumpf oder abgestutzt und mit einem Stachelspitzchen. $\odot$. Auf bebautem Buden, Schutt selten, aber meist beständig. An hohen Ufer der Saale in der Nähe von Rauschens Hölzchen sparsam und anf Feldern sïdlich von Nerseburg, häufiger bei Naumburg z. B. an Wege und an Ackerrändern nach Almerich und Grochlitz hin, in Grochlitz selbst. Juli-Sept. A. spicatus Lam. Blïthen grün. Höhe $1 / 2-3^{\prime}$.

\section{Familie. Chenopodeen Vent. Gän-} s efussgew ï chs e.

3zo. Schobéria C. A. Meyer. Schoberie (nach dem russischen Botaniker Schuber benannt).

912. Sch. maritima C. A. Me yer, Me erstrandsSch. Stengel krautaltig, kahl, meist ausgebreitet, ästigr ; Blätter halbwalzenförmig, spitz; Blüthen meist zu 3, blattwinkelständig, mit gekielten Zipfeln; Samen fein-punktirt. $\odot$. Salzhaltige Orte, Salinen sehr zerstreut. In den Dömeken zwischen Pfitzenburg und Wansleben, an den Lachen in der Nähe des salzigen Sees zwischen Wnusleben und Rollsdorf, an der Salzke zwischen Langenbogen und Rollstorf, auf der Grenze bei Artern un! Stassfurt. Aug. Sept. Chenopodium naritimun I. Suacda chenopodioides Pall. S. maritima $H_{\| q}$ "i $\|$. T'and. Die Stengel sind $1 / 2-\mathcal{L}^{\prime}$ lang, entweder aufrecht mit aufrechten $Z$ weigen oder liegend mit aufsteigenden ' $L$ weigen.

371. Salicomia I. G I a s s chmalz (ein in Mittelalter gebildeter Pflanzenname).

913. S. herbacen L., krautartiges G. Stengel krautartig, ästiz, geglierlert; Blïthen fleischige Aehren bildend, die Glieder der Aehren beiderseits 3hlüthig; Blüthenhüllen in ein Dreieck gestellt, in einer Ritze sich öffnend, aus welcher 1-2 Staubgefässe hervortreten; Samen glatt, weichhaarig. $\odot$. Salzhaltige Orte, 
Salinen stellenweise. An Salzstellen in der Nihe der Teiche bei Dieskau, sehr häufig auf Salzboden an den Dömeken zwischen P'fitzeuburg und Wansleben, ebenso zwischen Langenbogen und Rullsdorf, am salzigen See bei Erdeborn und zwischen Wansleben und Rollsdorf, auf salzhaltigem Boden zwischen dem Schlosse zu Seeburg und den Weinbergen, auf Salzboden in der Nähe der Salinen von Kötschau und l'euditz und auf Salzwiesen bei Schladebach, fehlt bei Naumburg, Freibur, und Bibra: findet sich auf der Grenze bei Artern häufig, an den Seelöchern bei Zabenstedt unweit Gerbstedt sparsam, auf Salzbuden bei Stassfurt und Leau. Aug. Sept. Der fleischige, blattlose, meist roth angelaufene Stengel ist sowohl niederliegend, als aufrecht und dann $1 / 2^{\prime}$ hoch.

3ซ2. Polycnémum L. K norpelkraut (ein aus nohvs, viel, und $\% \nu \eta_{1} u \eta$, Schienbein, gehildeter Pflanzenuanie).

914. P. arvense L., Acker-K. Sturm Heft 44. Blätter sitzend, zienlich steif, 3kantig-pfrienlich, stachelspitzig: Blüthen in den Blattwinkelu sitzend; Deckblättchen kaum halb so lang als die Bliithenhiille; Samen klein. $\odot$. Sandige Aeckn nicht gerade selten z. B. am Donnersberge hinter Kröllwitz, am Dölaner Kirchholze bei Lieskau, zwischen der Dirskauer Mïhle und Döllnitz, sandige Aecker am Bienitz, ebensu bei Eulau unweit Naumburg. Juni - Aug. Der meist aus. gebreitete, oder aufrechte, üstige Stengel ist unr 2-6" lang.

915. P. majug Alex. Rraun, grösseres K. Blätter sitzend, steif, 3kantig-pfriemlich, stachelspitzig; Blüthen in den Blattwinkeln sitzend, Dechbliittchen liinger als die Blïthenhiille; Samen gross. $\odot$. duf Aeckeru sehr selten. Bisher nur auf Aeckern zwischen Zscherben und Pfitzenburg und bei Grohlitz unweit Naumburg gefunden. Juli. Aug. Die Früchte sind doppelt su gross als an der vorigen; die ganze Pflanze ist weit stärker, straffer, oft bis 1 " hoch und hat dip Tracht von Salsola Kali. Der Verfasser hat sie nach li 1 ch als Art angenommen, ub sie jedoch wirklich specitisch von der vo. rigen unterschieden ist, müssen "eitere Untersuchungen lehren.

Kochia scoparia Schrad. ist früher auf Salzboden zwischen den Dömeken und Wansleben in der Nähe 
des salzigen Sees gefunden worden und der Verfasser hat Exemplate, welche in Jahre 1820 an diesem Standurte gesanımelt warelı, bei Prof. Kunze selbst gese. hen. In neuerer Zeit ist sie dort nicht wieder beub. achtet.

373. Chenopodium $\mathbf{~}$. Gï ns e fuss (chenopus ist ein bei Plinius vorkommender, aus $\chi \dot{\eta} \nu$, Gans, und $\pi \circ \tilde{s} s$,

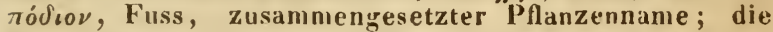
3eckigen Blätter einiger Arten wurden nänlich mit dem Plattfusse der Gänse verglichen).

a. Blitier tief-huclitig-eckig, mit zugespiłzten Ecken.

916. Ch. hýbridum L., B a stard-G. Sturm Heft 75. Blätter lang-zugespitzt, am herzförmigen Grunde ganz:andig, an den Seiten tief-buchtig-echig, mit zugespitzten Ecken; Blüthen in rispenartigen rrugdolden; Samen grubig-punktirt. $\odot$. Bebauter Buden, Schutt sehr häufig z. B. auf dem Pfännerholzplatz, auf Schutt und an Wegrändern zwischen Halle und Nietleben u. s. w. Juli. Ang. Ilöhe 1-3'. Die oberseits glänzenden Blätter siml denen des Stechapfels ähnlich.

\section{h. Blätter ungleich - gezähnt.}

1. Blatter glanzend.

917. Ch. úrbicum L., ste if e r G. Sturm Heft 75. Blätter glïnzend, 3eckig, am Grunde in den Blattstiel rorgezogen, buchtig oder ausgeschweift-gezähnt; Achren zusammengestrzt, steif - au/recht, dem Stengel angelehnt, fast blattlos; Samen stumpfkielig, glänzend, braunschwarz, glatt, nur bei stärkerer Vergrösserung sehr fein punktirt. $\odot$. Mauern, Zäune, Schutt in Dörfern stellenweise. Bei Halle besonders auf salzhaltigen Orten hin und wieder, bei Kötschau häufig, fehlt bei Naumburg, Freiburg und Bibra; anf der Grenze bei Artern, zwischen Oerner und Hettstedt und sonst zerstreut vorkummend. Aug. Sept. Höhe 1-21. A endert ab:

a) vulgare: Blätter kürzer-gezähnt, mit 3eckigen, spitzen Zähnen. C. melanuspermum W allr.

b) interm edium M. u. K.: Blätter buchtig-gezühnt, mit 3eckig-lanzettlichen, zugespitzten Zähnen. C. rhumbifolium Müh lénb.

918. Ch. murale L., Ma u e r-G. St u l' m Heft 75. Blïtter rautenförmig-eirund, oberseits glänzend, schmal buchtig-gezähnt, mit rurwälts gerichteten, spitzen Zähnen; Trugdolden ausgespreizt; Samen rauh, schwarz, 
glanzlos, ziemlich breit. und scharfhielig-berandet. $\odot$. Schutt, unbebaute Plätze, Wege, in Dörfern überall gemein. Juli - Sept. Höhe $1 / 2-1 \frac{1}{2}$ '.

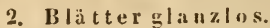

919. Ch. album L., gemeiner G. Sturm Heft 75. Blc̈itter rautenförmig-eirund, klein-gezïhnt, "lanzlos, die oberen länglich-lanzettlich, ganzrindig; 'lrug. dolden fast blattlos; Samen glänzend, schwarz, glatt, nur bei sehr starker Vergrö ssernng schwach-punkitirt. $\odot$. Schutt, Aecker, Mauer'n üherall gemein. Juli-Sept. Höhe $1 / 2-2$. Aendert mit fast ganzrandigen Blätter'u ab und:

a) spicatum Koch : Blüthenknäule ährenförnig. Ch. album I.

b) cymínrum Koch: Bliithenknäule trugdoldig. Ch. viride L.

920. Ch. opulifolium Schrad., s chne eballb lätteriger G. S tur'ul IIPft 75. Blätter kurz, rundlich-rautenförmig, fast 3lappig, sehr stumpf, ausgebissen-gezöhnt, die obersten elliptisch-lanzettlich; Trugdulde fast blattlos; Samen schwarz, glänzend, glatt, nur unter starker Vergrösserung schwach-punhtirt. $\odot$. Schutt, Wege, Zäune, in Dörfern zerstrent. Bei Halle an der Gottesackermaner, an Zäunen auf dem Pfännerholzplatze, bei Naumbury stellenweise, bei Aschersleben nicht selten, bei Dessau zerstreut. Juli-Sept. Höhe $1-2^{\prime}$.

921. Ch. ficifolium $\mathbf{s}$., f eige nblät teriger G. Sturm Heft 75. Untere Blïtter fast spiessförmig-3lappig, gezähnt, nach Hem Grunde verschmälert, der mittleve Lappen verlïngert, lïnglich lanzettlich-stumpf, wbere. Blätter linealisch.lanzettlich, ganzrandig; 'Irugdolden fast blattlos; Samen glänzend schwarz, fein-einge. driickt-punktirt. $\odot$. Schutt, Wege, selten und meist unbeständig. Einmal in der Nähe des Pfänuerholzplatzes gefunden, bei Aschers'eben sehr sparsam: Juli. Aug. Höhe 1-2\%. Die Punktirung des Samens ist schon ohne Vergrösserung zu bemerken.

\section{c. Blätter ganzrandig.}

922. Ch. polyspermum $\mathrm{X}$., vi $\mathrm{l}$ s a mige r G. Sturm Heft 75. İläitter eiförmig oder lainglich-eiförmig, ganzrandig, ganz kahl; 'Trauben blattlos; Blüthenhiille zur Fruchtzeit abstehend; Samen glänzend, schwarz, sehr fein punktirt. $\odot$. Bebauter Boden, Schutt, besonders 
an etwas feuchten Orten, häufig z. B unter dem Felsen bei líröllwit, links von der Fïhre, in Giebichenstein, in feuchten Gebüschen zwischen Kadewell und Osendorf. Aug. Sept. Höle $1 / 2-2$. Aendert mit schmäleren und breiteren, spitzen und stumpflichen Blättern ab und ferner:

a) cymosu-racemosum kuch: 'Trauben aus 'Trngdolden zusammengesetzt: C. pulyspermum der Autoreil.

b) spicatu-racemosum Koch: 'Trauben aus kleinell Aehrel zusammengesetzt: C. acutifuliun Kit.

923. Ch. olidum Curt., st inkender. G. Sturm Heft 75. Blätter rautenförmig-eirund. ganzrandig, mehlig-graugriin; Traube blattlos; Samen glänzend, sehr fein punktirt. $\odot$. Wege, Mauern, Schutt nicht selten z. B. an der Stadtmauer in Halle, an Mauern in Giebichenstein u. s. w. Juli. Aug. Clı. Vulvaria L. Ch. fuetidum I, a m. Der niederliegende Stengel ist $1 / 2-1^{\prime}$ lang. Hat einen äusserst widrigen Geruch.

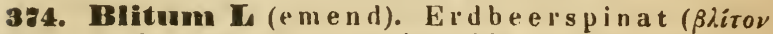
ist der Name für ein unschmackhaftes Gewächs bei 'Iheophrast).

a. Blüthenhülle zur Fruchtzeit heerenartig.

924. R. virgatum L., a c h se l b liit higer E. St u r m Heft 74. Blätter länglich-3eckig, fast spiessförmig, tief-gezähnt; Bliithenknäuel sämmtlich blattwinkelständig; Bliithenhiille sur lruchtzeit leerenartig; Samen schwarz, mit stumpfen auf der einen seite rinnigem Rande. $\odot$. Eine auZäunen und Nauern bisweilen veruilderte Gartenpflanze, "elche in siiddeutschland und Oberitalien einheinisch ist. Sie ist an Mauern in Zö. schen, bei Naumburg am Spechtsar und sonst hin und wieder beubachtet. Juni-Ang. Höhe $1 / 2-2$. Früchte dunkelruth.

h. Blüthenhülle zur Fruchitzeit s:ftlıs oder wenig saftig, aher nicht beerenartig.

925. F. Bonus Henricus C. A. Meyer, a us dauernder. E., guter Heinrich. Sturm Heft 74 . Blätter 3echig-spiessförnig, ganzrandig; Blïthenknäuel in end- und blattwinkelständigen, zusammengesetzten Aehren, die endständige Aehre eine verlängert-kegel. förmige, blattlose Aehre bildend; Bliithenhiille zur Fruchtzeit sa/tlos; Samen sämmtlich aufrecht. 24. Wiiste Plätze, Mauern, Schutt, iı Dörfern gemein. Mai-Aug. 
Chenopodium Bonus Henricus L. Agatophytum Bonus Henricus M oquin-'Tand. Höhe $1 / 2-2$ '.

926. T. rubrum $\mathbf{R}$ hb. (fl. excurs.), rother E. Stur m Heft 74. Blïter glänzend, rautenfürmig-3eckig, fast spiessförmig-3lappig, buchtig-geziihnt, mit lanzettlichen Zähnen; Blüthen in end. und blattwinkel. ständigen, zusammengesetzten, beblätterten Aehren; Bliithenhiille zur Frnchtzeit saftlos, die der Seitenblïthen 3theilig, nit 1-2 Staubgefässen, die der Endblüthe des Kuäuels 5thrilig, mit 5 Staubgefässen; Samen glatt, aufrecht, die der eudständigen Blüthen an den Knäueln wagrecht. $\odot$. Schutt, Wege, Mauern, in Dörfern häufig z. B. anf dem Pfännerholzplatze, an Wiesenrändern zwischen Pfitzenburg und Wansleben, in Oberthau, Kötschau, Dürrenberge u. s. w. Juli-Sept. Chenopodium rubrum L. Agatophytum rubıum R chb. fl. sax. Der aufrechte, etwas saftige $1-2$ ' hohe Stengel ist meist roth angelaufen.

927. R. glaucum Koch., me ergrün er E. S t u rm Heft 75. Bliittar liin_lich oder eiförmig-länglich, stumpf, entfernt-gezälınt, unterseits meeroriin, mehlig; Blïthen in end- und blattwinkelständigen, blattlosen Aehren; Bliithenhiille 4spaltig, zur Fruchtzeit saftlos; Samen glatt, aufrecht und wagrecht. $\odot$. Fenchte Stellen, in Dörfern, oft in Menge beisammen. An Pfännerholzplatze bei Halle, an den Dömeken bei Wansleben häufig, .tm salzigen See sehr häufig u. s. w. Juli-Sept. Chenupudium glaucum L. Stengel aufrecht oder aufsteigend, $3 / 4-11 / 2$ ' huch.

\section{az5. Beta I. Mangold, Runkelrübe (Pflanzen- namie bei Varro).}

928. T. vulgaris L., gemeiner M. Wurzel einstengelig; Sten'yel aufrecht; Wurzelblätter eiföımig, stumuf, etw is herzförnig, Stengelblatter rautenförmigeirund; Blüthen sitzend, zu $2-3$ gekıäuelt und ver"arhseu, in langen, bebätterten Aphren; Narben eiförmig. $\odot$ und $\odot$. . Eine eurupäische Seestrandpflanze, weiche häıfig auf Aeckern gebaut wird. Juli-Sept. Höhe 2-4'. Aendert ab :

a) Cicla L.: Wurzel durch Kinltur sehr vergrössert und fetter, aber immer weit dünner als an der folgenden thart; "risse Runkelrübe B. vulgaris Cicla l. var. ?. $\eta$. B. horteusis Mill.

b) rapacea Kuch: Wurzel dick, fleischig: B. rul. 
garis L. mit Ausschluss der Var. ל. und $\eta$. Von dieser werden wiederum viele Spielarten gebaut.

376. Spimacia K. Sp in a t von spina, Dorn, wegen des stacheligen Samens; der Name findet sich zuerst bei Petr. de Crescentiis).

929. Sp. oleracen L., G e m üs e-Sp. Blätter eiförmig-länglich oder spiessförmig: Blüthen geknäuelt, in den Blattwinkeln sitzend; Blïthenhülle griin, an den weiblichen Blüthen 2-3spaltig, an den männlichen 4theilig. $\odot$ und $\odot$. Wird zum Kïchengebrauche allgemein gebaut, stammt aus dem Oriente. Mai. Juni. Aendert $a b$ :

a) spinusa Mönch, Winter-Sp. Zipfel der Blüthenhiille zur Fruchtzeit yergrössert, hornartig-verhärtet; Blätter am Grunde beiderseits spiessförmigzähnig.

b) inermis Mönch, Summer-Sp. Zipfel der Blïthenhïlle zur Fruchtzeit kleiı, "ehrlus; Blätter stumpf-3eckig oder länglich-eiförmig.

877. Hálimas WTI1r. Keilmelde (Pflanzen. name bei $C$. Bauhin).

930. F. pedunculatus walir.. stielf rï chtige K. Sturm Heft 80. Stengel krautartig, aufrecht, geschlängelt, ästign; Blätter ganzrandig, stunıpf, am Grunde verschmälert; Blïthen in eul - und blattwinkelständigen Aehren; Blüthenhulle zur Fruchtzeit lang-gestielt, umsekehrt-3eckig, ansgerandet 2lappig, mit einen dazwischen befindlichen Zähnchen. $\odot$. Salzhaltige Orte sehr zerstreut. Anf salzhaltigen Wiesen zwischen Stassfurt und Bermburg und bei Herklingen, ebenso bei Leau und auf der Grenze des Gebietes hei Artern, besunders in der Nähe des Sonlgrabens häıfig. Sept. October. Atriplex pedunculata L. Dintis atriplicuides M. B. Obione pedinculata Mo qu in. Ta nd. Höhe $1 / 2-1$ '.

378. Átriplex I. Me Id e (P’lanzenname bei Culumella; das Wort ist ïbrigens in Lateinischen meist säch. lichen Geschlechts).

A. Euatriplex C. A. Il e yer. Bliithen vielehig; weibliche Blüthenhülle bei der Reife liratartig oder häutig, nur an Grunde zusammengewachsen.

931. A. hortensis L., Garten-M. is urm Heft 79. Stengel krautartig, aufrecht, mit aufrecht-abste- 
henden Aesten; untere Blïtter herzförnig-3eckig, gezähnt; beiderseits griin, glanzlos, wbert länglich, 3eckig, fast spiessförmig; Blithenhiille zur Fruchtzeit rundlichciförmig, lurz-zugespitzt, netzaderig, ganzrandi auf den Grund getheilt $\odot$. Wird gebaut und verwildert nioht selten auf deckern, an Zäunen, so an und auf Mauern in Giebichenstein, häufiger anf Aeckern bei Böllberg, einzeln bei Köglitz, zahlreich bei Kötschau, Dürrenberg u. s. w. Juli. Aug. Höhe meist 2-4', dagegen an Felsen, wo sie scheinbar pinheimisch ist, wit kleiner, oft nur $1 / 2-3 /{ }^{\prime}$. Die ganze Pflanze ist zuweilen blutruth gefärbt.

932. A. nitens Reb ent., gl änzende M. S turm Heft 79. Stengel krautartig, aufrecht, mit aufrecht-abstehenden Aesten; untere Blätler herzförmig - 3eckig, buchtig-gezähnt, oberseits glänzend, untcrscits silberweiss - schiilferig, wbere aus 3eckigem, buchtig-gezähntem Grunde lang-zugespitzt, ganzrandig: Bliithenhiille zur Fruchtzeit eiförmig, zugespitzt, netzaderig, ganzrandig, bis auf den Grund getheilt. $\odot$. Wüste Plätze, Wege, Manern, Weinberge stellenweise. Bei Halle selten an Zäunen zwischen Böllberg und dem Wörmlitzer Hölzchen, weit häıfiger in und an den Weinbergen vun Röglitz, an Wegen bei Rollsulorf, bei Weissenfels und Nammburg, bei Eisleben vur dem Freihstrassenthore, auf Maue'n beiHettstedt, zwischen Aschersleben und Mehringen. Juli. Aug. A. acuminata W. K. Höhe 2-4'.

\section{B. Schizotheca G. A. Meyer. Blüthen einhäusigg.}

a. Weihliche Blütlıeuhïlle hei der leife lirautartig oder häutig, nur an Grunde zusammengewachsen.

933. A. tatárica L., länglichblätterige M. Sturm Heft 79 . Sitengel krautartig. anfrecht, mit aufrecht-abstehenden Aesten; untere Blïtter eiförmig-lanzettlich, etwas spiessförmig, gezähnt oder ganzrandig, obere lanzettlich, ganzrandig; fruchtragende Aehren locker, an der Spitze überlı̈̈ngend; Bliithenhiilte zur Fruchtzeit eiförmig, etwas rautenförmig. ganzrandig, bis auf den Grund setheilt. $\odot$. 'Irocicene Hïgel, Mauern, Hecken, Wege selten. Bri Halle sehr sparsam, bei Nietleben, bei Diirrenberge, bei Aschersleben un die Stadt häufig. Juli. Aug. A. tatarica sch k. A. ublongifulia W. K. Höhe 1-3'. Eine Furn mit schmalen, fast zahnlosen Blättern ist: $A$. campestris $K 0 \mathrm{ch} \mathbf{u} . \mathrm{Ziz}$. 
934. A. patula L., a usgebreitete M. Sturm Heft 79. Stengel krautartig, langästig, untere Aeste spreizend; die unteren Blïlter eiförmig-lanzettlich, fast spiessförmig, gezähnt uder gansandiy, die oberen lanzettlich, die wbersten linealisch; fruchttragende Aehren steif - aufrecht; Bliithenhiille zur Irruchtzcit spiessfürmigrautenförmig, bis auf den Grund "etheilt.

$\odot$. Hege, schutt, Griasplätze uherall gemein. Juli. Aug. A. patula Pollich. A. angustifulia s'mith. Aendert mit aufrechtem und niederliegendem, ausgebreitetem stengel und noit lanter lanzettlich-linealischen Blattern ab und ferner:

b) nicrocarpa Koch: Blithenhiille zur Fruchtzeit kaum grösser als der Samen, deswegen gewölbt; Stengel steif-aufrecht: 1 . erecta $s$ mith.

935. A. Iatifolia wa hle $n$ b g., b r e i t b lät terige M. Sturm Ieft 79. Stengel krautartig, ästig; die unteren Aeste spreizenul dic mnteren blätler 3eckigspiessförmig, gezühnt, die oberen spiessfürmig-lanzettlich, die ubersten lanzettlich, ganzrandig; bliithenhiille zur. Fruchtzeit 3ecki,r, ganzrandig uder gezihnelt, bis auf den Grund getheilt. $\odot$. Wege, Vüune, Schutt, Aecker mcht selten. Juni - Aug. A. patula Smith. A. hastati Pullich., S $\cdot$ h k. und vieler Aut. Der Stengel ausgebreitet oder aufrecht. Nie Blüthenhïlle überragt den Samen neist un Vieles; die Pflanze ändert aber ab:

b) nicrospermis W. K. : Blïtsenhiille zur Fruchtzeit kaum grösser als der Samen und gewölbt: 1 . ruderalis Wall 1 .

c) sali na W all r.: Blätter schiilferig - grau: A. oppositifulia DC. und wenn die Bläter ganzrandig oder nur wenigg gezähnt sind: A. Sisckii Rustk. u. Schm., so auf salzhaitigen Buden bei Kölme, Langenbugen, Wansleben, Kötschau, 'Tenditz hüıfig.

h. Weihliche Blüthenhïlle hei der Reife vom Grunde his zur Nitte knorpelig-hart, weisslich und ungefalir bis zur Mitte zusammengewaclisen.

936. A. Iaciniata L., ge lappte M. Sturm Heft 80. Stengel krautartig; Blätter tief-buchtig-gezähnt, fast spiessförmig, silberweiss - schülferig, die unteren 3eckig-rautenföınig, die oberen spiessförnig-länglich; Aehren meist nur endständig, blattlos, nur am Grunde beblättert; Bliithenhiille zur Fruchtzcit rautenförnig, fast 3lappig-gezähnt oder fast ganzrandig, vom Grunde 
bis zur Mitte wcisslich - Knorpelig und bis dahin zusam. mengewachsen. $\odot$. Wird von L,eyss. und Spreng. an der Salzke und am salzigen See angegeben. Aug. Sept. Der Stengel niederliegend oder aufsteigend.

937. A. rosea L., rosenartige M. Sturm Heft 80. Stengel krautartig, ausgespreizt - ästig; Blätter buchtig - gezähnt, silherweiss - schülferig, die unteren rautenförmig, die oberen eiförmig; Aehren end-und blattwinkelständig, unterbrochen, beblättert; Blïthenhiille zur Fruchtzeit 3eckig - rautenförnig, spitz, gezähnelt, vom Grunde bis zur Mitte weisslich-knorpelig und bis dahin zusammengezvachsen. $\odot$. Schutt, Wege, unbebaute Orte, in Dörfer'n meist nicht selten, so am Guttesacker bei Trutha, ror und in Passendorf, in Teutschenthal, am salzigen sre bei Amsdorf, bei Rög. litz, Kötschau, Dïrrenberge u. s. w. Aug. Sept. Hốhe $1-3^{\prime}$.

\section{Familie. Polygoneen J us s. K nö- terichgewächse.}

379. Rumex L. A mpfer (Pflanzenname bei Plinius; der deutsche Name Ampfer hängt mit dem holländischen amper, sauer, zusammen, daher ist die gewöhnliche Benennung Sauerampfer eine Tautologie).

A. Lapathum Tournef. Blüthen zwitterig oder viel. ehig. Griflel frei. Blätter an Grunce verschmälert, abgerundet oder herzförmig, aber weder spiess - nuch pfeilförmig.

a. Die 3 imeren Zipfel der fruchttrageuden Blitthenhülle auf dem Rükkell alle oder nur einer vou ilinen eine schwicle tragend.

1. Blüthenquirlesämutlich mit blättern gestützt.

938. R. maritimus L., goldgelber A Sturm Heft 73. Blätter lanzettlich-linealisch, in den Blattstiel verschmälert; Blïthenquirle mit pinem Blatte gestïtzt, die oberen zusammenfliessend; die inneren Zipfel der fruchttragenden J:liithenliille fast rautenförmig, beiderseits borstenfürmig - 2zïhnig, an der lanzettlich-vorgezogenen Spitze ganzrandig, alle schwielentragend, die borstenfürmigen Züilne von der Länge des Lüngendurchmesser's des Zipféls. (-). Teiche, Sümpfe, Flussufer häufig z. B. an der Saale bei Giebichenstein in der Nähe der Fähre, an 'Teichen zwischen der Kreuzschäferei und 
der Dölauer Heide, an den 'Teichen bei Dieskau u.s.w. Juli. Aug. Stengel steif - aufrecht, sehr ästig, $1 / 2-2$ ' hoch. Blüthenhuille und Blätter mehr ins Gelbliche zithend als bei R. palustris.

939. R. palustris $\mathbf{s}$ ith, grüngelber A. S $t$ urm Heft 73. Blätter lanzettlich-linealisch oder verlängert lanzettlich, in den Blattstiel verschmälert; Bliithenquirlc mit einen Blatte gestützt, zienulich entferıt; die inne. ren Zipfel der fruchttragenden Bliithenhiille eiförnig. länglich, beiderseits borstenförmig-2zähnig, an der lanzettlich - vorgezogenen spitze ganzrandig, sämmtlich schwielentragend, die borstenförmigen Zìhne eiförmig länglich, kiirzer uls die Zipfel der Etiilhenhiille. @. Sumpfige Stellen, 'Teiche sehr selten; bisher nur aut der Grenze bei Leutzsch beobachtet, aher gewiss weiter verbreitet. Juli. Aug. Ilöhe $1-1 \frac{1}{2}$ '.

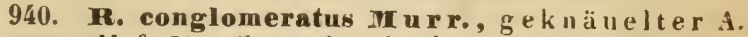
Sturm Heft 73 . Stengel aufrecht, mit wpit-abstehen. den, aufstrebenden Aesten; die untersten Blätter herz. förmig oder eiförmig-länglich, stumpf oder spitz, die mittleren herzförmig - lanzettlich, zugespitzt; Lliithenquirle entfernt, mit cinem Blatte gestiitzt, nur die obersten blattlos; die inneren Zipfel der firuchttragenden Bliithenhiille linealisch-länglich, stumpf, ganzrandig, sämmtlich schwielentragend. 4. Gräben, 'leiche, sünıpfe gemein. Juli. Aug. R. glomeratus Schreb. R. Nemulapathum Ehrh. R. acutus $\mathbf{S}$. Höhe $1-\mathbf{3}^{\prime}$.

2. Blïthenquirle blattlos oder nur die untersten mit eille in Blatte gestutzt.

941. R. sanguineus K., Wald - A. Sturm Heft 73. Stengel anfrecht, nit geraden, aufrecht-abstehenden Aesten; die untersten Blätter herzfürmig-länglich oder über den Grunde etwas zusammengezogen und fast geigenförmig, stumpf oder spitz, die mittleren herzförnig lanzettlich, zugespitzt; Bliithenquirle scimmtlich blatt. los wder nur die untersten nit einem Blatte gestützt; die inneren Zipfel der fruchttragenden Bliithemhiille linealisch-länglich, stumpf, ganzrandig, ein einziger schwielentragend, 24. Feuchte Wälder, Haine und Gebüsche z. B. bei Seben, Radewell, in den Wäldern der Aue bei Burg Liebenau u. s. w. Juli. Aug. Höhe $2-3^{\prime}$. Aendert ab :

a) viridis Koch: Stengel und Blattadeın nicht farbig. B. sanguineus $\beta$. viridis $\mathbf{S m}$. R. nemorosus Schrad., dies die gewöhnlichste Form. 
b) genuinus Koch: Stengel und Blattadern blutroth. R. sanguineus I. Gaud. und die eigentliche Lin né ische Pflanze, diese Furm wird nut gebaut und erscheint hin und wieder auf Kuhläckern verwildert.

Nach dem Vurgange von $S$ mith, Gaudin und Koch ist der Linnéische Name vorangestellt, obgleich er nur eine Abart bezeichnet.

942. R. obtusifolius L., stump fblät terige $\mathrm{l}^{\mathrm{A}} \mathrm{A}$. Ha y ne Arzneigew. XIII, 1. Sturm Heft 73. Stengel aufrecht; untcre Bliitter herz-ci/örmig, stumpf ower spitzlich, die mittleren herzförmig-länglich, spitz, die obersten lanzettlich; Blüthenquirle blattlos, ziemliclı entfernt vun einander; die inneren Zipfel der firuchtra. genden Bliithenhiille eiförmig-3eckig, hinten gezïhnt, in eine längliche, stumpfe, gauzrandige Spitze vorgezogen, sämmtlich schwielentragend, die Zühne der Zipfel zeckig, zugespitzt oder pfriemlich. 24. Wiesen, Flussufer, feuchte Wälder, un die Dörfer nicht selten. Juli. Aug. R. divaricatus I, nach Fries. Höhe $2-3$ '. OFF. radix Lapathi acuti. Aendert ab:

b) purpureus Poir.: Stengel, Blattstiel, Blattaderu oder die ganzen Blätter und Trauben blutroth, so in Gärten.

c) silvestris Wallr: die ganze Pflanze grün; Blüthenhiille halb so gross als bei der gewöhnlichen Form, spärlicher gezähnt. R. obtusifolius L. nach Fries. R. arutus 'T a us e h.

943. R. pratensis Mert. $u$. Koch, Wi e s e n-A. Hayne Arzneigew. XIII, 2. Sturm Heft 73. Wurzelständige und untere stengelstündige Blätter herzförmig-länglich, spitz, die obersten lanzettlich; Bliithenquirle blattlos, einander genähert; die inneren Zip/el der fruchttragenden Iiliithenhiille eiförmig, am Grunde etwas herzförmig. stumpf, nach hinten stark-gezühnt, an der Spitze ganzrandis, sämmtlich oller nur einer schwielentragend, die Zähne der Zipfel 3eckig, zugespitzt oder pfrienlich. 24. Wird von W allr. an Zä̀nen und im Weidengebüsch bei Wendelstein, Osterhausen und Erdeburn, von Spreng. bei Lettin, Seben und Radewell angegeben. Juli. Aug. K. acutus L. nach Koch. R. cristatus und Oxylapathum Wallr. Höhe $2-4^{\prime}$.

944. I. crispus I., krauser A. Ha yne Arzneigew. XIII, 3. Sturm Heft 73. Blätter lanzettlich, spitz, ivel. 
wellenförmis, hraus; Blüthenquirle blattlos, einander genähert; die inneren Zipfel der fruchtragenden Bliithenhiille rundlich, fast her fürmig, ganzrandig oder nur am Grunde klein-gezähnelt, sämmtlich oder nur Piner schwielentragend. 24. Aecker, Wege, Schutt, Mauern, Wiesen überall gemein. Juli. Aug. Höhe 2-3'.

Rumex Patientia L. aus Unteröstereich stammend wird bisweilen in Gärten zum Kïchengebrauche gebaut, ob auch im Gebiete?

945. R. Hydrolápathum H u ds., R i e s e u-A. If ayne Arzneigew. XIII. 4. Sturm Heft 73. Llätter lanzettlich, züespitzt, nach dem Grunde verschmälert, flach, am Rind " wellenförmig - kleingekerbt, Llattsticle obcrseits flach; Bluthenquirle blattlos, einander genühert; die inneren Zipfel der fruchttranenden Eliithenhiille cifürmi . 3cclit:, oganzrandig oder hinten gezähnelt, alle schwimlentragend. 24. Sümpfe, 'Teiche, Flussufer nicht gerade selten. An den Teichen bei Dieskau, an den Lachen bei Benustedt und Wansleben, zwischen Wendelstein und Rossleben, bei Aschersleben, Dessau. Juli. Aug. Höhe bis 6'.

b. Die 3 inneren Zipfel der fruchttragenden Bläthenhülle sämmtlich whe schivielen.

946. R. aquaticus L., Wasser-A. H a yne Arzneigew. XIII, 4. Stul u Heft 74. Wurzclblitter herzciförmig, spitz, am Grunde verbreitert, Blattstiele zusammengczogen-rinnenförmig; Blüthenquirle blattlos, einander genähert; die inneren Zipfel der fruchtrascnden Bliithenhiille eiförmig oder etwas herzförmig, hïiutig, ganzrandig oder etwas gezähnelt, ohne Schwielen. 24. Gräben. Teiche, Flnssufer. An den Ufern der Saale z. B. zwischen Kröllwitz und Lettin, an deu Ufern der Unstrut u. s. w. häıfig. Juli. Aug. K. Hydrolapathum $\beta$. Fries. Höhe $3-5^{\prime}$. Die Wurzelblätter sind bei dieser und der vorhergehenden Art oft $1-2$ ' lang.

B. Acctosa Tournef. Bliithen 2häusig oder vielehig. Die Griffel oberwärts mit den Kanten des Fruchtknotens verwachsen. Blätter spiess - oder pfeilförmig.

a. Bläthen vielehig.

947. R. scutatus L., schildblätteriger A. Sturm Heft 74. Blïter meist rundlich-spiessförmig oder herzspiessförmig; Blüthen in armblüthigen, entfernten, blattlosen Halbquirlen; die inneren Zipfel der fruchttragen.

Garcke, Flora. 
den Blïthenhiille rundlich-herzförmig, ganzrandig, häutig, ohne Schwiele, die äusseren dem unteren Rande der inneren anliegend. 24. Wird hin und wieder als Gemiïsepflanze in Gärten 'und auf Aeckerı gebaut, su schun zu Buxbaun's 'Zeit (cf. hal. p. 4), verwildert bisweilen und hält sich oft lange Zeit, Z. B. an den Ruinen des Palastes der Ottonen in Memleben und zwar nach W a IIr. (ann. bot. p. 56 und schedl. p. 181), welcher diese Pflanze mit Unrecht für ejuheimissh hält, früher nicht selten, jetzt sparsam. Juli. Aug. Der anfsteigende Stengel ist $3 / 4-11 / z^{\prime}$ hoch. Die Blätter sind graugrün. Aendert ab :

a) hastifolius M. B.: Blätter beiderseits mit einep tiefen und schmalen Bucht, der Endlappen eiförmig, fast breiter als lang; dies die gewöhulichste Form.

b) hastilis Koch: Blätter 3erkig, spitz, durch den beiderseits verlängerten Zahn des Grundes spiessförmig; die untersten Blätter oft wie bei der vorigen Abart.

b. Blüthen zweihäusig.

948. R. Acetosa L., geme iner A. H a yne Arzneigew. XIII, 6. St tur III Heft 74 . Blitter pfeil-oder spiessförmig, aderig, Tuten geschlitzt - gezähnt; Blüthenrispe blattlos; die inneren Zipfel der fruchttragen. den Bliithenhiille rundlich - herzförmig, häntig, ganzrandig, am Grunde mit einem kurzen, herabgebogenen, schuppenartigen Anhängsel, die ïusseren abstehend, nach der Blüthe zurïckgeschlagen. 24. Wiesen, Grasplätze, Wälder gemein, ausserdem als Genüsepflanze bisweilen gebaut. Nai. Jun. und in Herbst oft wieder. Der aufrechte Stengel ist $1-2^{\prime}$ hoch. OFF. ladix et herba Acetosae. Aendert ab:

a) vulgaris Koch: Blätter pfeilförmig, die unteren eiförmig, stumpf, die oberen spitz.

b) a uriculatus W a I r.: Blätter spiess - pfeilförmig, die untersten länglich, die uberen verlängert-lanzettlich, wellenförmig, die obersten sehr schmal, oder die untersten Blätter auch lang-linealisch. lanzettlich, die ıberen linealisrh, lang-ierschmälert.

c) fissus Koch: die Oehrehen am Grunde der Blätter 2-3spaltig. R. Acetosa $\%$. L., aber nicht $\mathrm{K}$. intermedius DC.

949. R. Acetosélla L., kleiner A. Sturn Heft 74. Blätter spiessförmig, laniettlich oder linealisch; 
Blütlienrispen blattlos; die inneren Zipfel der fruchttra. genden Bliitlienhiille rundlich-herzförmig, häutig, netzaderig. ganzrandig, am Grunde ohne Anhängsel, die äusseren auch nach der Blüthe aufrecht-angedrückt. 4. Sandfelder, sonnige Hügel, Triften gemein. Mai Jul. und in Herbste wieder. Stengel $3-10^{\prime \prime}$ hoch. Aendert ab:

a) vulgaris Koch: Blätter lanzettlich, pfeilförmig.

b) angustifulius Koch: Blätter linealisch oder schmal-lanzettlich, meist nur mit einem, seltener ganz uhne Oehrchen.

c) multifidus Koch: grösser, Oehrchen am Grunde der Blätter 2-3spaltig. R. Acetosella J. L. und R. multifidus $\mathbf{I}$.

380. Polyogonm F. Knöt erich (ein in Betreff der vielen Gelenhe aus roiv́, viel, und yóvv, Knie, gebildeter Pflanzenuame bei Dioscorides).

A. Bistorta Tournef. Eine einzige Aehre an der Spitze des einfachen Stengels. Griffel 3theilig. Narbe sehr klein I.

950. P. Bistorta L., Wi es e n-K. - Hayne Arzneigew. V, 19. Stengel ganz einfach, an der Spitze eine wialzenförmige, gedrungene Aehre tragend; Blätter länglich-eiförmig, fast herzförmig, wellenförmig, Blattstiele der wuurzelständigen Blïtter breit-gefliigelt. 4. Feuchte Wiesen häufig z. B. auf Wir'sen am Sebener Busche, bei Gutenberg u. s. w. Juni. Juli. Blumen röthlich - "eiss. Höhe $1-3^{\prime}$. Die Wurzel ist hart, etwas knullenförnig. OFF. rad. Bistortae.

B. Persicaria Tournef. Stengel ästig, jeder Ast mit piner Aehre endigend; Griffel 3spaltig; Narbe gross, kopfartig.

a. Aehren dicht, gedrungen, walzenfürmig.

951. P. amphibium L., ortwechselnder K. Wurzelstock kriechend: Blätter länglich - lanzettlich, an Grunde etwas herzförnig oder abgerundet; Aehren meist einzeln, sedrunsen, walzenförnig. an den ungetheilten Aesten endständig; Blüthen 5männig. 24. Stehende und fliessende Gewässer nicht selten z. B. an der Reide bei Bischdorf häufig u. s. w. Juni. Juli. Blüthen purpurroth. Stengel $1-3^{\prime}$ lang. Aendert ab:

a) natans $\mathbf{M}$ önch: Blätter schwimmend, lang - gestielt, kahl, nur am Rande scharf. 
b) coenosum Koch: Stengel nebst den Blättern auf sumpfigem, ausgetruckirtem Boden niederliegend, wurzelnd, an der Spitze aufstrebend und daselbst mit schmäleren, beiderseits kurzharig-scharfen Blättern.

c) terrestre Leers: Stengel aufrecht; Blätter kurz-gestielt , schmäler, kurzhaarig - scharf, so an Gräben, feuchten Wiesen.

952. P. Iapathifolium C., a mp ferblät teriger K. Rchb. pl. crit. V. Abb. 688 . Stengel aufrecht uder hingestreckt, ästig; Blätter eiförmig, elliptisch oder lanzettlich, Tuten kahl oder etwas wollig, liurz- und sehr fein-gewimpert; Achren länglich-walzcnfürmig, gedrungen, aufrecht urles etwas nickend; Blüthen 6männig, Bliithenstiele nebst dem Kelche driisig-rauh. $\odot$. Gräben, Sümpte, Ufer, feuchtesAecker gemein. Juli Herbst. Stengel 1-2' hoch, nebst den Biüthen grün oder roth wder der Stengel ruth gefleckt, die Gelenke bisweilen sehr verdickt: P. nodosum Pers. Die Blätter sind entweder schwarz gefleckt oder ungefleckt. Aendert $\mathrm{ab}$ :

b) inc anum Schmidt: Blätter unterseits wolligfilzig.

953. P. Persicaria $\mathbf{L}_{\text {. }}$ (var. $\varkappa_{\text {. }}$ ), g e meine $\mathbf{r}$ K. II a y e Arzneigew. $V, 22$. Stengel aufrecht oder niederliegend. ästig; Blätter eiförmig, elliptisch oder lanzettlich, Tuten rauhhaarig, lang-gewimpert; Achren länglich-walzenfürmig, gedrungen, aufrecht oder etwas nickend; Bluthen 6männig, Bliitlienstiele nebst den Kelchen driisenlos. $\odot$. Gräben, We'ge, unbebaute Plätze mit der vorigen Art gemein. Juli-Herbst. Blüthen weisslich oder purpurruth. Blätter gefleckt oder ungefleckt.

\section{b. Achren locker, dünn, fadenförmig.}

954. P. mite schrank, milder K. Rchb. pl. crit. V. Abb. 686 . Blätter lanzettïch oder länglich-lanzettlich, nach beiden Enden verschmälert, Tuten rauhhaarig, lang-gezvimpert; Aehren fadenförmig, locker, iiberhaingend, fast gestielt; Bliithen $6 \mathrm{männiy,} \mathrm{drüsenlos.}$ ○. Gräben, Pfützen, feuchte Stellen, in Dörfern. An einer quelligen Stelle zwischen Kröllwitz und dem Donnersberge, häufig bei Naumburg z. B. an feuchten Wegen im Buchholze, an Gräben in der Aue, bei Schulpforte und gewiss weiter verbreitet Juli-Octob. P. laxiflorum Weihe. P. dubium Stein. P. Braunii Bl. 
u. Fing. Blüthen anfangs weisslich, dann grünlich und purpurroth. Blätter nicht scharf schmeckend. Höhe $3 / 4-11 / 2^{1}$.

955. P. minus Fuds., $k \mathrm{l}$ e iner K. Hayne Arzneigew. $\mathrm{V}, 21$. Stengel meist aufrecht, schlank; Blätter aus abgerundetem Grunde fast gleich-Ureit, vorne allmählig verschmälert, lanzettlich-linealisch, Tuten angedrückt - behaart, lang-gewvimpert; Aehren fadenförmig, locker, meist aufrecht; Blïthen 5männig, drüsenlos. $\odot$. Feuchte Stellen, Gräben, Teiche nicht gar häufig. In feuchten Gebüschen in der Näłe der Teiche bei Dieskan, bei Radewell, Döllnitz, bei Naumburg sparsam, nur an Wiesenrändern bei Russbach. Juli Herbst. P. Persicaria $\beta$. angustifolium L. P. pusillum L a m. P strictum A II. Bluithen purpurroth oder weiss, nur halb so gross als bei der vorhergehenden und nach. folgenden Ait. Die Blätter an den Aesten sind anı Grunde bisweilen etwas spitzer als die des Hauptstengels. Ins Ilerbste ist die ganze Pflanze oft roth.

956. P. Hydrópiper L., p f e f ferartiger K. W a s serpfeffer. II a y aufiecht; Bliitter lanzettlich oder elliptisch, nach beiden Enden verschmälert, Tuten fast kahl, kurz-gewvimpert, die blüthenständigen fast wimperlos; Aehren fadenförmig, locker, iiberhäingend, unterwärts unterbrochen; Blüthen 6männig, drïsig-punktirt. $\odot$. Feuchte Stellen, Gräben. Teiche, Pfützen gemein. Juli-Herbst. Blüthen grün, an Rande purpurroth oder weisslich, seltener ganz purpurroth. Die Blätter oft mit schwarzem Flecke. Höhe $1-1 \frac{1}{2}$. Hat einen pfefferartig beissenden Geschmack.

C. Avicularia Me isn. Blïthen in den Blattwinkeln büschelig oder lurch Verkleinerung der Blätter an der Spitze der Aeste in unterbruchenen Aehren. Griffel 3, kurz, frei; Narben sehr klein.

957. P. aviculare $L_{0}, \mathrm{~V}$ og el-K. Ha yne Arzneigew. V, 23. Stengel niederliegend, anfstrebend odes aufrecht, die Aeste bis zur Spitze beblättert; Blätter lanzettlich oder elliptisch, flach, 'Tuten meist 6nervig,

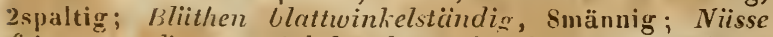
fein-runzelir-gestrichelt, fast glanzlos. $\odot$. Wege, Aecker, Triften, Mauern überall ganz gemein. JuliHerbst. Blïthen grün, am Rande purpurroth oder weiss. Stengel $1 / 2-1 \frac{1}{2}$ ' lang. 
D. Helxine Koch. Hlüthen in den Blattwinkeln gebüschelt. Griffel 1. kurz, mit einer einzıgen, 3lappigen Narbe. Stengel windend.

958. P. Convólvulus L., windenartiger $\mathbf{K}$. Stengel windend, kantig-gerieft; Blätter herz-pfeilförnig; Bliithen 8männig; die 3 inneren Zipfel derfruchtragenden Bliithenhiille anf dem Riicken stumpf: gekiclt, ohne Fliigel; Nüsse 3 kantig glanzlos. $\odot$. Aecker, bebauter Buden gemein. Juli-Herbst. Blüthen griin, am Rande und inwendig weiss. Der Stengel 1/2-3' lang.

959. P. dumetorum L., Hecken-K. Stengel windend, kantig-gerieft; Blätter herz-pfeilförmig; Blüthen Smännig; die 3 ïusseren Zipfel der fruchtragenden Bliithenhiille mit einem ziemlich brciten, häutigen Fliigel; Nïsse 3kantig, glänzend. $\odot$. Zänue, Hecken, Gebiische häufig, ubgleich sparsaner als die vurige Art z. IB. im Gebüsche zwischen dem schwalchloche und Lettin. Juli-Sept. Blüthen griin, anı Rande und inwendig weiss. Der stengel klettert bis $8^{\prime}$ huch.

E. Fagopyrum Tournef. Bliithen traubenförmig, Trauben rispig oder ebensträussig; Frucht länger als die Blüthenhïlle. Griffel 3 .

960. P. Fngopýrum L., B u $\mathrm{ch}$ w e iz e $n-K$. H a yne Arzneigew. V, 21. Stengel aufrecht; Jilïter pfeilher-förmiğ, zugespitzt; Trauben blattwinkelständi fach, die endstïndigen ebenstrï̈ussig; Nïsse zugespitzt, 3kantig, Kanten ganzrandig. $\odot$. Wird hin und wieder, besonders in unfruchtharen Heidegegenden im Grossen gebaut. Juli. Ang. Blüthen rosenroth vder weiss, am Grunde grün. Höhe $1-2$ '.

961. P. tataricum L., $t$ it $t$ a $\mathrm{r}$ s che $\mathbf{r}$. Stengel aufrecht: Illïter pfeil-herzförmig, zugespitzt; Trauben blattwinkelständig, einfach, die endstïndigen ebenströussio; Nüsse spitz, Jkantior, Kanten aus»eschueift. gezähnt. $\odot$. Auf Aeckrru unter der vorigen Art oft sehr häufig. Juli. Aug. Blüthen grün. Höhe 1-2'.

\section{Familie. Thymelaeen Jus s. Se i- delbas tge $\underset{\text { ä }}{\mathrm{c}}$ lı se.}

381. Passering K.-(nach Wickström's Verbess.) Spatzenzunge (nach Bock, dem Entdecker dieser Pflanze, wurde sie ron Einigen Lingua passerina und 
seithem in Deutschen Spatzenzunge genannt; es hat daher der italienische Dichter Valentinus Passerini, von welchem Andere diesen Namen ableiten, nichts mit der Pflanze genieii).

962. P. annua Wickst., e injährige Sp. Stengel steif-aufrecht, einfach uder astig, kahl; Blätter zerstreut, linealisch, spitz, aufrecht-abstehend; Blïthen blattwinkelstänoig, zu 5, 3 oder nur einzeln, weichharig; Zipfel der Blïthenhülle nach dem Verblühen zusanmenueigend. $\odot$. Sonnige, trockene Anhöhen, Aecker, liebt Kalkboden, selten. An Kalkberven hinter Benustedt rechts von der Chaussee, an Weinbergen bei Langenhogen, auf steinigen, sonnigen Aerkern zwischen

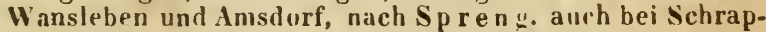
lau, nach Schw ib e auf truckenen Feldern bei Bernburg, überall nul sparsam. Ang. Sept. Stellera Passerina L. Blüthen grün. Höhe $1 / 3-11$.

382. Wnphne L. Zeiland ( $A$ i $i \psi \nu \eta$ ist bei Dioscorides der Name des Lorbeerbaums; der in der Schriftsprache jetzt gebräuchliche Nume Seidelbast ist aus Zeiland d. h. Bienenblume oder nach einem anderen Dialekte Zeidel und nicht aus Seide entstanden).

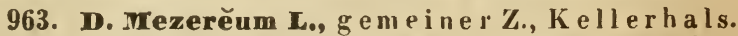
H a y " Arzneigew. 111, 43. Blätter nach den Blïthen erscheinend, lanzettlich, am Grunde keilförmig-verschmälert, kahl; Blüthen meist zu 3 buschelfölmig an den Seiten der Aestchen sitzend; Blüthenhülle 4spaltig, weichhanrig, mit eiförmigen, spitzen Zipfeln. 24. Gebirgswälder, Haine stellenweise. Fehlt bei Halle und Merseburg; in den Wäldern bei Nammburg, Freiburg, Lodersleben, Allstedt, Eisleben, Mannsfeld und Hettstedt häufig; fehlt im nordöstlichen Gebiete. Febr. März. Blïthen rosenruth. Frïchte erbsengross, roth. Ein $2-$ 4' hoher Strauch, mit abstehenden, aschgrauen, glatten Aesten. Giftig. OFF. curtex Mezerei vel Laureolae.

\section{Familie. Santalaceen R. Br. S antelgewäch se.}

383. Thesium T. V e rme inkraut (Pflanzenname

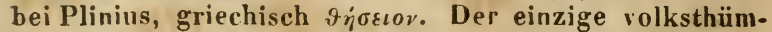
liche dentsche Name Vermeinkraut bedeutet so viel als Zauberkraut, von den oberdeutschen Vermainen, fälschen, zaubern). 
A. Tribracteata. Dreideckblätterige. Stengel oberwärts rispig oder traubig. Rispe vder 'Traube bis an den Gipfel mit Bliithen besetzt. Deck. blätter 3 unter jeder Blïthe.

964. Th. montanum $\mathbf{E} \mathbf{r} \mathbf{h}$, Belg-V. R ch b. pl. crit. V. Abb. 647. Wurzel hinabsteigend, ästig, zuletzt vielstengelig; Stengel aufrecht, "berwärts rispigr, Rispte pyramidenförmig, mit abstehenden Aesten; Blïtler lan. zettlich oder linealisch.lanzettlich, lang-zugespitzt, 3-5nervig; Deckblätter zu 3; Frucht rundlich-eiförmig, gestielt; der Saum der Bliithenhülle nach dem Verblühen eingerollt, 3 mal kürzer als die Frucht. 4. An Rande von Bergwäldern, huchgelegenen Waldwiesen selten, nur in den Wälderu bei Naumburg, Freiburg, Laucha, Bihra, aber daselhst verbreitet.' Juni. Juli. Blüthen grün, inwendig "eiss. Blätter breiter als bei der fulgenden Art. Höhe $1-2 \frac{1}{2}$ '.

965. Th. intermedium schrad., mittleres V. Richb. pl. crit. V. Abb. 645. Wurzel ausläufertreibend; Stengel aufrecht oder aufsteigend, oberwärts rispig; Rispe pyramidenförmig mit abstehenden Aesten; Blcitter linealisch-lanzettlich oder liıealisch, spitz, undeutlich3nervig; Deckblätter zu 3; Frucht oval wder länglich, gestielt; der Saum der Blüthenhiille nach dem Verblïhen eingerollt, 3mal kürzer als die Frucht. 24. Berywiesen, Waldränder, zwischen Gebüsch zerstreut. Am Dunnersberge hinter Kröllwitz, auf breiten Grasrinen zwischen dem Kröllwitz-Dölaner Wege und dem Schwalchloche, im Mittelholze selır häufig, auf den II iesen bei Kl. Dölzig und am wextlichen Raude des Bienitz häufig, bei Naumburg weniger verbreitet als die vorige Art, nur an Rainen und grasigen Ahhängen bei Goseck und an Bergabhängen uber den Sathäusern, am siidlichen Rande der neuen Giphle bei Freiburg, bei Aschersleben zerstreut. Juni. Juli. Blüthen grün, inwendig weiss. Die Blätter sind nur $1-1 \frac{1}{2}$ Linien breit. Höhe $1 / 2-1^{\prime}$.

Thesium pratense Ehrh. wird zuerst von Wallr. sched. p. 102 als Abart von 'Th. Linophyllum L., wozu auch Th. intermedium Schrad. und Th. montanum Ehr h. gerechnetwerden, an sonnigen Hügeln bei Kröllwitz nnd Rossleben angegeben und später von Spreng. hal. ed. 2. p. 125 mit Angabe der richtigen Abbildung als im Mittelhulze und in Bienitz vorkommend erwähnt. Aber schon Rchb. weis't in der Fl. 
sax. ed. 1 1. 2. p. 110 nach, dass an den von Spreng. citirten Orten wur 'Th. iutermedium "achse und ebensu verhält es sich mit den von Wall r. angeführten Stellen. Beite haben also das ächte 'l'h. pratense Ehrh., welches bis jetzt in Gebiete vergeblich gesucht ist, mit I'h. intermedium Schrad. verwechselt.

The sinm alpinum L. mit linealischen, Inervigen Blätte:n, anfrecht-abstehenden Aesten und röhrenförmiger, an der Spitze eingerullter Blüthenhülle, welche so Jang oder länger als die Frucht ist, wird von Schw a be fl. anh. bei Desian vor dem Akenschen Thurhanse und bei Oranienbium als häıfig angenehen. Der Standort hei Seeburg in Rehb. fl. sax. ed. 1 11. 2 p. 109 ist ganz unrichtig, wie dies $\mathrm{Rchb}$. anch selbst andeutet.

B. Unibracteata. Eindeckblätterige. Der fruchtbare Stengel an der spitze durch unfruchtbare Deckblätter schupflörnig. Ein einziges Deckblatt unter jeder Bliithe.

966. Th. ebracteatum Y a yne, na cktblüthiges V. Rchb. pl. crit. V. Abb. 649. Wurzel kriechend; Stengel aufrecht, mit einfacher Traube, die fruchttragende Traube durch unfruchtlare Deckblätter an der Spitze schopfförmig; Bliithen 1deckblätterig; Früchte oval, gestielt, lederig, 3mal kïızer als die röhrenförmige, an der Spitze eingerollte fruchttragende Blüthen. hiille. 4. 'Truckene, grasige Orte, Waldränder sehr selten; nur bei Allstedt an somigen, grasigen Stellen des siidwestlichen und südlichen Kandes des Allstedter Theilholzes, aher daselbst häufig und von Schwabe fl. anh. bei Gr. Kühnau angegeben. Juni. Juli. Blïthen grün, inwendig weiss. Höhe 6-9".

Hierher gehört auch 'I'h. comosum Roth, welcher Name jeduch nicht anzunehmen ist, wie dies Einige gethan haben. Hayne hat nämlich sein Th. ebracteatum in demselben Jahre, in welchem $R 0 t h$ sein $T h$. comosum aufstellte, bekannt gemacht, und zwar in Schrader's Jumrn. 1800 Heft 1 p. 33, während Roth Catal. bot. p. 29 vom Jahre 1800, wo Th. comusum zuerst erwähnt wird, ausdrïcklich bemerkt, dass er die Planze von $H$ ay" e erhalten habe. Ihm, als dem Entdecker der Pflanze, gebiihrt also das Vorrecht und sein Name Th. ebracteatum ist anzunehmen. 


\section{Familie. Aristolochicen Jus .}

\section{Osterluzeigewächse.}

384. A ristolochia L. Osterluz e i (ein aus ṛ̌ıros $(\eta)$, der beste, und hoyic, Cieburt, zusamnengesetztel Pflanzenname bei Dioscorides).

967. A. Clematitis L., gemeine O. Haye Arzneigew. IX, 24. Wurzel kriechend; Stengel aufrecht, einfach, etwas gebogen; Blätter eiförmig, stumpflich, am Grunde tief-herzförmig, gestielt, kahl; Blüthen in den Blattwinkeln büschelförmig. 24. Yäume, Maueru, Weinberge z. B. in den Weinbergen von Röglitz, in Zämmen hei Göhren, hei Merseburg an Ufer der Saale in der Nähe vun Kanschen's Hölzchen; ursprïnglich wohl nicht einheimisch, sondern nur verwildert und jetzt eingebürgert. Mai. Juni. Die röhrenföıniøe, an Grunde bauchige, an der Spitze einlippige Blüthenhïlle ist gelb. Höhe 1-2'. OFF. rad. et herba Aristolochiae vulgaris.

Die Befruchtun dieser Pflanze geschieht vorzüglich durch ein kleines Insekt, lim 'Tipula pennicurus, welches dnrch die Röhre bis zu den Befruchtungswerkzengen hinablifiecht, nun aber durch die riickwärts gekehrten Hare am Hinauskriechen rerhimlert ist, "las jeduch möglich wird, wemn diese Haare in Fulge der Befrmchtung sich hrummen und zusammenschrumpfen.

385. Álsarum T. H is $s$ I w $\mathrm{r} z$ (Pflanzenname bei Diuscorides).

965. A. europaeum L., e ur op ä ische H. Hayne Arntigew. 1, 44. Wnzelstuck kriechend; Stengel sehr hurz, anfsteigenil, am sulle zwei gestiplte Blätter tragend, nebst ilen Blatícielen zottig: Blatter nierenförmig, ahgerundet-stumpf, glïuzend; Blüthen einzeln, kurz-gestielt, zwischen den beiden Blättern stehend. 24. Brigwälder unter Gebüsch stellenweise. Fehlt bei Halle; findet sich in der Brenan hei Wettin, im Walde zwischen L,pislingen und Srhönburg und in, den Wäldern bei Naumburg, Freiburg, I, dersleben, Schmon, Allstedt, Eisleben, zwischen Gehüsch bei Ascherslehen, in Wäldern bei Sandersleben, ïberall nicht selten: fehlt im ganzen östlichen und nordöstlichen Gebirte. März-Mai. Bluthen auswendig grïnlich-braun, inwendig dunkelblutroth. Der Stengel ist nur wenige '/ull huch. OFF. radix Asari. 


\section{Familie. Euphorbiaceen Juss.} Wolf sullchgewächse.

386. Euphórbin $\begin{gathered}\text { L. Wulfs milch (Pflanzenname } \\ \text { beinius). }\end{gathered}$

A. Tithymalus. Drüsen der Blüthenhülle rundlich oder quel wval, ganzrandig, weder halbnıondförmig, noch 2 hörnig.

a. Simen grubig - punktirt.

969. F. helioscopia L., s on ne nw en di ge W. Abb. 4754. Blätter verkehrt-eiförmig, vurne gesägt; Hiillblättchen verhehrt - eiförmig oder fast elliptisch, vorne gesägt; Dolde 5spaltig, Strahlen 3gabelig, mit gabelspaltigen Aestchen; Drüsen ganzrandig: Kapsel glatt; Samen grubig-punktirt. $\odot$ Bebanter Boden, Schutt, Ackerränder überall häufig. Juli-Sept. Drüsen gelblich. Stengel $1 / 2-1$ ' huch.

b. Simen glatt. Kapsel nit Warzen besetzt.

970. E. platyphýllos $L_{0}$, breitblätterige W. Abb. 4758. liliitter lanzettlich orler länglich, vorne etwas breiter, spitz, von der Mitte an ungleich-kleingesägt, mit her :fürmigem Grunde sitzend, die untersten verkehrt-piförmig, sehr stumpf, in den Blattstiel verschmälert; Hüllblättchen fast 3echig - eiförmig, stachelspitzig, kleingesägt; Dolden 3-5spaltig, Strahlen 3 gahelig, mit gabelspaltigen Aestchen; Driisen ganzrandig; Kapsel warzig, Warzen zerstreut, stumpf, fast halbkugelig; Samen rundlich, glatt. $\odot$. Atecker, Arkerränder, Gräben, Wege nicht gerade häufig. Im Chausseegraben in Trotha, auf Aeckern an der Reide bei Bischdorf und Reideburg, auf Aeckern bei Du' 'su, Kötzschlitz, Kötschau und T'euditz, bei Naumburg zerstreut z. B. an Ner Saale, an Arkerrändern bei Russbach u. s. w., bei Sandersleben, bei Rathmannsdorf zwischen Stassfurt und Beruburg. Juli-Sept. Drüsen gelb. Höhe 1-2'. Aendert ab:

b) literata Jacq.: Blätter unterseits und an Rande zottig, so bei Kötschau und 'Teuditz.

971. K. dulcis $\mathbf{I}$ c cq., s üsse W. Abb. 4759. Stengel stieliund, nur getrocknet fein-gerieft; Blïtter lanzettlich-länglich, stumpf, nach dem Grunde verschmälert, ganzrandig oder vorne kleingesägt, sehr kurz gestielt; Hüllblätter lanzettlich, Hüllblättchen an Grunde 
abgeschnitten, 3eckig-eiförmig, kleingesägt; Strahlen der 3-5spaltigen Dulde einmal 2spaltig; Drüsen ganzrandig: liapsel Warzig, Warzen zerstrent, ungleich, stumpf. 4. Sohattige liaubwäler, besmblers in feuchten Thälern, stellenweise. In Gebïsche an den Teichen bei Dieskau nirht häufig, wahrscheinlich auch an einigen anderen Stellen der Ane, dis die Planze bei Schkeuditz in verschlussenen Hulze und bei Lentzsih sich wiederfindet, bei Naumburg iu Buchholze und den angrenzendt'n Waldungen bei Jinisrode häufig, hei Dessau und Oranienbaum, in der Gutsche zwischen Paupitzsch und Niemegk. April. Mai. F. solisequa Relıb. 'Tithymalus dulcis Scup. Drïsen aufangs grünlich, später schwarz-purpurroth. Höhe $3 / 4-1 \frac{1}{2}$. Aendert ab :

b) purpurata Thuill.: Kapsel warziy, aber ohne Haare.

Die E. dulcis 1. wird von versehiedenen Autoren verschieden gedeutet.

972. E. palustris L., Sumpf-W. Hayne Arzneigew. II, 23. $\mathrm{Kchb}$. Abb. 4781. Blätter sitzend, lan. zettlich, ganzrandig oder etwas gezihnet, kahl; Hiillblättchen elliptisıh, stumpf, am Grunde verschmälert, sitzend; Strahlen der vielspaltigen Dolde 3spaltig und noch einmal 2spaltig; Drüsen ganzrandig; Kínsel warzig, Wurzen läıglich, kurz walzenförmi:; Samen glatt. 4. Feuchte Wiesen, Gräben, unter Weilengebüsch, meist häufig im Gebiete. Auf der grossen Hiese bei Passendurf, an Görz bei Wörnılitz, in der Aue rerbreitet z. B. zwischen Ammendurf und Silhopal, bei Döllnitz, Burg Liebrnau, Röglitz, Wesmar, bei Weissenfels zwischen Beuditz und Leislingen, auch nach Markwerben und Eulau hin u. s. w. Mai. Juni. Drüsen braungell. Der aufrechts, ästige $3-4^{\prime}$ hohe Stengel hat nebst den Blätter" die 'lratht einer kleinen Weide.

c. Samen glatt. Kapsel glatt oder nur puuktirt.

973. E. Gerardiana Jacq., Gerard's IV. Abb. 4794. Wurzel vielköpfig, hinibsteigend; Stengel aufrecht, blänlich-grüı; Blätter blïulich-griin, lanzettlichlinealisch oder linealisch, zugespitzt-stichelspitzig, ganzrandig, ganz kahl; Hüllblätchen 3eckig, eiförmig, quer-breiter, begranut-stachelspitzig, am Grunde abgeschnitten oder herzförmig: Strahlen der vielspaltigen Dolde wiederholt-2spaltig; Drüsen ganzrandig; Kapsel glatt oder sehr fein-punktirt-rauh; Samen glatt. 24. 
Anhöhen, Wegränder, besonders gern auf Kalkboden, zerstreut. Am Vogelsberge und an den Kalkbergen zwischen Bennstedt und Kölme hänfig, zwischen Langenbogen und Rollsdorf, bej Wettin an Bergen zwischen Kloschwitz und Runipin sparsam, an Kalkbergen bei Unterfarnstedt; an Berge" und IV egrändern zwischen Seeburg und Wormsleben bis nach Unterriesdorf hin, ebenso am Hutberge und an Bergen zwischen dem Volkstedter Grunde und Siersleben unweit Eisleben, an Bergen bei Gerbstedt, Sandersleben, Alsleben; fehlt in ganzen östlichen, nordöstlıchen, sudlichen und südwestlichen Gebiete. Juni. Juli. E. Cajogala Ehrh. E. linariaefolia I, am. E. Esula Pollich. Drüsen gelb. Höhe $1 / 2-\mathbf{1}^{\prime}$.

B. Esula Roeper. Drüsen der Blüthenhülle halbmondförmig oder 2hörnig.

a. Samen glatt. Hüllblättchen frei (nicht zusammengewachsen).

974. E. Cyparissias L., Cypressen-W. Hayne Arzneigew. 11, 22. R chb. Abb. 4793. Wuzel kriechend; Stengel anfrecht; Bliitter genau schmal-linealisch oder nach dem Grunde ein wenig verschmälert, ganzrandig, kahl, die astständigen sehr schmal; Ilüllblättchen rautenförmig oder 3eckig-eiförmig, breiter als lang, kurzzugespitzt, ganzrandig; Strahlen der vielspaltig* Dolde wiederholt-2spaltig; Drüsen 2hörnig; Kapsel fein-punktirt, rauh; Samcn glatl. 24. 'Truchene Anhöhen, Triften, Wegränder, fast im ganzen Gebiete gemein. April. Mai und oft im Herbste wieder. Drüsen wachsgelb. Höhe $1 / 3-1^{\prime}$.

Die Blätter dieser Pfianze sind oft mit einem sogenannten Blattpilze ( Necidium Euphorhiae P ers.) besetzt, wodurch sie kürzer, aber breiter werden, die Stengel verkrïppe!n und die ganze Pflanze keine Bliithen treibt.

975. E. Esüla L., ge me ine W. H a yne Arzneigew. II, 21. Rchb. Abb. 4791. Wurzel krierhend; Blätter lanzcttlich uder linealisch-lanzettlich, nach dem Grunde verschmälert, kahl, am Rande nach derSpitze zu etwas rauh, die unteren kurz-gestielt, die astständigen etwas schmäler; Hüllblättchen rautenförmig oder 3eckig-eiförmig, breiter als lang, stumpf, stachelspitzig oder kurz-zugespitzt; Atrahlen der vielspaltigen Dolde wiederholt-2spaltig; Drüsen 2 hörnig; Kapsel fein-punktirtrauh; Samen glatt. 24. Sandige 'Triften, Wegründer, Gräben, unter Weiciengebüsch zerstreut. Bei Halle nicht selten z. B. auf sandigen Triften am Schwalchloche, 
ebenso zwischen Trotha und Lettin, an Wegen zwischen Halle und Ammendorf bis nach Schkopau hin, bei Burg Liebenau, bei Narkrölitz und am Luftschiffe, fehlt bei Naumburg; bei Eisleben am Hutberge und soust nicht gerade selten. Juni-Aug. Drüsen wachsgelb. Der aufsteigende oder aufrechte, etwas schlaffe Stengel ist $1-2^{\prime}$ hoch. Die Blätter sind meist dunkler grün als an der vorigen Art, oft fast braungrïn.

b. Samen runzelig oder grubig.

976. E. Peplus L., Garte n- W. Abb. 4773. Blätter gestielt, verkchrt-ciförmig, sehr stumpf, in den Blattstiel vorgezogen, ganzrandig, die untersten fast kreisrundlich, Hüllhlättchen eiförniig; Aeste der 3spaltigen Dolde wiederhult-2spaltig; Drüsen 2hörnig; Kapscl cuf dem Riicken 2 kiclig, mit etwas gefliggelten Kielen; Samen auf der inneren Seite der Länge nach 2 fur. chig, auf den anderen grubig - punktirt, die 2 Riickenlinien aus 4 Griibchen bestehend. $\odot$. Anf bebautem Boden, auf Felder'n häufig (in Gärten oft ein lästiges Unkraut). Jnli - Herbst. Drüsen gelblich. Stengel aufrecht, 4-9" hoch.

977. E. exigun L., kl e in e W. Abb. 4777. Blätter schmal - linealisch oder schmal-linealisch-keilförmig, spitz oder stumpf mit pinell Stachelspitzchen oder ab. gestutzt, kahl; Hüllblättchen aus fast herzförmigem Grunde linealisch, spitz; Aeste der meist 3spaltigen Dolde wiederhult-2spaltig; Drüsen 2hörnig; Kapseln glatt; Samen knotiw-runzelig. $\odot$. Auf Aeckern unter der Saat häufig z. B3. bei Passendurf, zwischen Halle und Nietleben, auf Aechern an derDölaner Heide n. s. w. Juni - Ortob. Drüsen gelb. Stengel einfach oder ästig, $3-8$ " huch.

Euphorbia Iáthyris I.., welrhe in Süddeutsch. land einheimisch ist, "ird häufig in Gärten angepflanzt und verwildert bisweilen in deren unmittelbaren Nähe.

38\%. Mercurialis L. Bingelk raut (Pflanzen. name bei Plinins).

978. M. annua L., einjähriges B. Hayne Arzneigew. V, 11. Kchb. Abb. 4801. Stengel ästiy; Blätter gestielt, eiförnig-lanzettlich oder elförniy, entfernt-gesägt; männliche Blüthen geknäuelt, in dunnen, schlanken Aehren, weibliche fast sitzend. $\odot$. Bebauter Boden, Schutt iı Dörfern nicht gerade selten, 
aber weit häufiger in Gärten. Juni - Herbst. Höhe $3 / 4-11 / 2^{\prime}$.

979. M. perennis I., a usdaue rndes B. Hayne Arzneigew. V, 10. Rehb. Abb. 4804. Stengel einfach; Blätter gestielt, eiförmig - länglich orler lanzettlich, dicht-gesä̊t; männliche Blüthen gehnäuelt, in dïnnen, schlanken Aehren, weibliche lang-gestielt. 24. In Bergwäldern unter Gebiisch stellenweise. Im lindberge, Zorgs, Bàdendorfer Holze zwischen Seeburg und Neehausen, in der Brenan bei Nettin, bei Weissenfels an Abhängen zwischen Beuditz und Leislingen, bei Naumburg an Pfortenherge, in der alten Giehle zwischen Freiburg und Pödelist, in Ilackenholze bej Branderode, an den Gruckstedter Bergen, hei Allstedt im Hagen häufig. April. Mai. M. Cynocrambe scop. Höhe $1 / 2-1^{\prime}$.

LXXXVII. Familie. Urticeen Juss. Nesselgew ächse.

1. Gruppe. Urticeac genuinae. Aechte Nesselgewä chse. Fruchtknoten 1fächerig. Samen aufrecht, eiweisshaltig. Samenkeim gerade.

388. Urtícr L. Nessel (ein von urere, brennen, abgeleiteter Pflanzenname bei Plinius).

980. U. urens L., brennende N. Blätter gegenständig, oval, spitz, eingeschuitten-gezähnt; Rispe blattwinkelständig, kiir zer als der Blattstiel: Bliithen einhäusig. $\odot$. Bebauter Boden, Schutt, Wege, Mauern iiberall gemein. Juli - Sept. Stengel $1 / 2-1 \frac{1}{2} 2^{\prime}$ hoch. Kraut heftig brennend.

981. U. dioica I., $z$ weihäusige N. Blätter gegenständig, läıglich-herzförmig, zugespitzt, grob-gesägt: Rispe blattwinkelständio, lïnncr als dcr Blattstiel, hängend; Blüthen 2häusig. भे. IÏ̈lder, feuchte Zäune, unbebaute Orte gemein. Juli - Sept. Stengel 2-4', in schattigen Wäldern bis 7 ' hoch. Kraut heftig brennend.

982. U. pilulifern L., pill e n tra ge ende N. Blätter gegenständig, eiförnig, zugespitzt, eingeschnitten gesägt; je eine männliche lockcre, diinne und eine klei. nere, kugelförmig - zusammengedrängte weibliche Aehre aus demsclben Blattwinkel kommend. $\odot$. Unbebaute Orte sehr selten, nur in Hofe und in Gräben des 
Schlosses Mannsfeld sparsam. Juli-Sept. Der rundliche, bereifte Stengel ist 1-2' hoch. Kraut brennend.

389. Parietária T. Glaskraut (von paries, Wand, Mauer, wegen des Vorkommens der P'flanze).

983. P. erecta M. u. K., a uf rechtes G. II ay. ne Arzneigew. V, 12. Stengel aufrecht, einfach; Blätter wechselständi g, gestielt, länglich - eiförmig, anı Grunde und an ler Spitze zugespitzt, ganzrandig, durchscheinend - punktirt, kurzhaarig; Blithenkuäuél blattwinkelständig; Bliithenstiele wiederholt-gabelspaltig; Deckblätter sitzend, kurzer als die Blüthen; Blii. theuhïlle gluckenförmig, an den Staubgefässblüthen so lang als die Staubgefässe. 4. Mauern, Zäune, Schutt sehr zerstreut. Bei Halle sehr selten, von Leyss. an der Moritzhurg angegeben; hei Naumburg im Startgraben an Mauern vor dew Marienthore und unter Weiden in den Othmarwiesen, am Schlosse in Querfurt, an Schlosse hei seeburg, an Nanern der Reitbahn in Eisleben. Juli - Sept. 'P. officinalis Willd. Höhe $1-3^{\prime}$. Blätter glänzend, heim Drucke der Finger etwas allhängend. Die Stauhgefüsse sind anfangrs einwärts gekrïmnt, springen aber bei schwacher Berührung der Blïthenhülle elastisch hervul.

Parietaria diffusa M. u. K. mit gestreckten, ausgebreitetem, ästigem Stengel, eiförmigen, weit kleineren Blättern unl zuletzt verlängerten, die Staubyefässe un das Doppelte überragenden Blüthenhiillen, findet sich nur auf der Grenze an alten Mauern des Schlosses zn Eilenburg.

2. Gruppe. Cannabineen. H anfgewächse. Fruehtknoten 1eiig, mit hängenden Eiern; Eiweiss fehlend; Samenteim gekrümmt oder schraubenförmíg, mit aufeinanderliegenden Keimblättern.

390. Cámmabis T. Ha $\mathrm{n}$ (Pflanzenname bei Varro).

984. C. sativa L., g e me in er II. H a y ne Arznei. gew. VIII, 35. Stengel anfrecht, rauh; Blätter gefingert, gestielt. Blättchen schmal-Janzettlich, an beiden Enden zugespitzt, spitz-gesägt; Blüthen 2 häusior, die männlichen traubenförmig-rispig, die weiblichen in den Blattwinkeln gekıäuelt. $\odot$. Stammt aus Indien, wird jetzt hin und wieder in Grossen gebaut, im Gebiete nur in der Gegend von Wiehe. Juli. Aug. Höhe 1-3'. OFF. sem. Cannabis. 
391. Hón vinulus L. Hopfen (Pflanzenname bei Dorst.).

985. H. Lúpulus L., gem e iner H. Ha yne Arzneigew. VIIl, 36 . Stengel windend, rauh; Blätter gegenständig, gestielt, 3 -5lappig, an Grunde herzförmig, grob-gesägt, oberseits seh॰ rauh; Blüthen 2häusig, die männliches in blattwinkelständigen Rispen, die "eiblichen in kurzen, endlich zapfenähnlichen Aehren, mit grossen häutigen Deckblättern. 4. Zäune, Gebüsche, Flussufer gemein z. B. in Kessel bei Diemnitz, zwischen Gebïsch am Schwalchloche hintel Kröllwitz u. s. w., bisweilen auch im Grossen gebaut. Juli. Ang. Die uberen. Blätter sind meist ungetheilt. Die besonders zum Bierbrauen gebrauchten Fruchtähren sind auch als Strobuli Lupuli oflicinell.

3. Gruppe. Artocarpeen D G, Brotfruchtgewächse. Fruchtknoten 1-oder 2fächerig; Samen hängend, ciweisshaltig; Samenkeim gekrummt, mit aneinderliegenden Keimblätteru.

392. N⿴囗十 bei Virgil).

986. Nr. alba L., w e is s e r M. Blätter herzförmig, am Grunde ungleich, eiförmig, ungetheilt oder gelappt, gesägt: die "eiblichen Kätzchen ungefähr so lang als der Blïthenstiel; Bliithenhiille am Rande kahl; Narben kahl, mit kurzen Papillen. ち. Stammt aus Asien, jetzt bisweilen an Wegen angepflanzt und der Seidenzucht wegen öfters im Grossen angebaut. Mai. Ein Baum von $20^{\prime}$ Höhe; wird jedoch öfters strauchartig gezogen. scheinbeeren weiss, wie bei der folgenden Art durch die fleischig gewordene Blüthenhülle gebildet.

98\%. M. nigra L., s chwarzer M. Blätter herzförmig, am Grunde ziemlich gleich, ungetheilt oder gelappt, gesägt; die weiblichen Kätzchen fast sitzend, vielnal länger als der Blüthenstiel; Narben nebst dem Rande der Bliithenhïlle rauhhaarig. ち. Stannt aus Asien, wird jetzt der Früchte wegen bisweilen in Gärten angepflanzt. Mai. Scheinbeere schwarz. Höhe 20'. OFF. fructus Mori.

4. Gruppe. Ulmaceen Mirb. Ulmengewächse. Fruchtknoten 2fächerig; Sámen hängend, olıne Eiweiss; Samenkeime gerade, mit flachen Keimblättern.

Garche, Flora. 
393. Ulmus L. Ulme, Rüster (Pflanzenname bei Cato).

988. U. campestris L., Feld - U. H a y ne Arzneigew. III, 15. Blätter doppelt-gesägt, zugespitzt, am Grunde ungleich; Blüthen fast sitzend, 5männig, vor den Blättern erscheinend; Friichte geflügelt, auch am Rande kahl. Ђ. In Wälder'n, an Dörfern hüufig. März. April. Ein 50-100' hoher Baum. OFF. cortex Ulmi interior. Aendert ab:

a) nuda Koch: Rinde der Aeste glatt (nicht horkartig); dabei sind die Blätter entweder rauh und die Frïchte länglich (U. camprstris $\mathbf{S m}$. U. nuda Ehrh.), oder die Blätter sind rauh und die Früchte kreisrund (U. montana $\mathbf{S m}$. U. excelsa Borkh. U. campestris $\%$ latifulia M ey er chlor. han.), oder die Blätter sind kahl und die Früchte verkehrt-eiförmig (U. glabra Mill. U. campestris $\beta$. carpinifulia II e y. I. I.)

b) suberosa Kuch: Rinde der Aeste mehr oder weniger korkartig-geflügelt; dabei sind die Blätter entweder grösser und die Friichte verkehrt-eiförnig (U. major's m. U. hollandica Nill.), oder die Blätter sind kleiner und die Früchte kreisrund U. suberosa Eh rh. U. tetrandra $\mathbf{s} \mathrm{chk}$.).

989. U. effusa Willd., langgestiel te U. Hay. n e Arzneigew. III, 17. Blätter doppelt -gesägt, zugespitzt, an Grunde ungleich, unter'seits weichhaarig; Blüthen gestielt, hängend, 6-8männig, vor den Blättern erscheinend; Friichte gefliigelt, am Rande zottig gewimpert, viel kürzer als ihr Stiel. th. In Dörfern z. B. in Giebichenstein, Kröllwitz (häufiger als Strauch in Zäunen). März. April. U. ciliata Ehrh. U. octandra Schk. Ein $50-100^{\prime}$ hoher Baum. OFF. cortex Ulmi iuterior.

LXXXVIII. Familie. Juglandeen DC. Wallnus sgewächse.

394. Jaginans E. Wallnuss (Pflanzenname bei Plinius).

990. J. regia c., geneine W. Hayne Arzneigew. Xil, 17. Blätter unpaarig-gefiedert, mit 7 oder 9 ovalen, etwas gesägten, am Grunde fast gleichen, in 
der Jugend weichhaarigen, später kahlen Blättchen; Blïthen einhäısig, dif männlichen in hängenden, dich. ten liätzchell, die weihlichen einzeln oder 2 und 3 bei sanmen stehend; Frü̈hte hugelförmi:. ち. Stamnt aus Asien, jetzt häufig angepflanzt. Mai. Bliithen grüls. Höhe bis $80 \%$. Davon die Kerne als Nuces Juglandis maturae et immaturae und die grüne Schale als Cortex viridis nucis Juglandis officinell.

\section{Familie. Cupuliferen Rich.} Näpfchenfrüchtier.

395. Fayng E. Buche (Pflanzenname bei Plinius).

991. Filvatica L., gemeine B., Rothbuche. Blätter kahl, eiförmig, undeutlich-gezähnt, gläızend, am Rande zottig - gewimpert, kahl und nur in der Jugend etwas zottig ; Blüthen einhäusig, die männlichen in einem fast kugelförmigen, lang - gestielten Kätzchen, die weiblichen zu 2 , von einer Hülle ungeben. t. In Wäldern bei Naunıbrg, Freiburg. Lodersleben, 'Ziegelrode, Allstedt u. s. w. nicht selten. Mai. Ein Baum von $80-100$ 'Höhe.

Castanea vulgaris Lam. oder Fagus Casta. ne a l. ist hin und :vieder in Gärten und Anlagen angepflanzt.

396. Quercus I. Eiche (Pflanzenname bei Plinius).

992. R. sessiliflora $5 \mathrm{~m}$., sitzblüthige oder Win ter-E. H a yne Arzneigew. V1, 35. Blätter lang - gestielt, verkehrt-eiförmi in den Blattstiel vorgezogen, buchtig, nur in der Jugend sparsam behaart, späterhin völlig kahl, mit abgerundet-stumpfen Lappen, ohne Stachelspitze; weibliche Bliithen schr kurz-gestielt oder fast sitzend, ihr Bliithen. stiel so lang oder kïrzer als der Blattstiel; Friichte kurzgesticlt. ћ. Höher gelegene Wälder. Mai. Q. Robur $\beta$. L. fl. suec. Q. sessilis $\mathrm{E} h \mathbf{r}$. nach $\mathbf{S m}$. OFF. cortex et glandes Quercus.

993. Q. pedunculata $\mathbf{E} \mathbf{r h}$, stielblüthige oder So momer-E. Hayne Arzneigew. VI, 36. Blätter kurz-gestielt oder fast sitzend, länglich - verkehrt - eiförmig, an Grunde tief-ausgerandet, nur in der Ju. gend sparsans behaart, späterhin völlig kahl, buchtig 
oder fiederspaitig, mit abgerundet-stumpfen lappen, ohne Stachelspitze; weibliche Blithen lang-gesticlt, ihr Bliithenstiel vielmal lïnocr als der Llatistiel; Irviichte

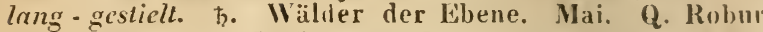
$S$ m. Robur \%. I. fl. suec. Q. racemusa Lam. OFF. cortex et glandes Quercus.

397. Córolang I. H a sel (Pflanzenname bei Virgil).

994. C. Avellána L., gemeine II. Blätter fast rundlich, herzförmig, zugespitzt; männliche Blïthe॥ in langen, hängenden Kätzchen, weibliche in Kuospen, mit rothen, fadenförmigen, hervorrawenden Nirben; fiuchttragende Hülldecke \#lockenförmig, an der Spitze etwas abstehend, zerrissen-gezähnt. †. Wälder, Gubüsche. Febr. März:

398. Carpinnes T. Ha inhuche (Pflanzenname bei Plinius).

995. C. Hétulus L., ge mi in e H., Weis buche. Blätter eiförmig, zugespitzt, faltig, doppelt - gesägt; männliche Blïthen in langen Kätzchen, weibliche zu zweien und traubenförmig; die sichuppen der weiblichen Blüthen zur Fruchtzeit 3theilig, mit lanzettlichen Zipfeln, von denen der mittlere verlängert, gesägt oder ganzrandig ist. $\hbar$. In Laubwäldern bei Halle selten, bei Naumburg, Freiburg, Wendelstein, Allstedt us. s. w. verbreitet, bisweilen auch in Dörfern und an Hecken angepflanzt. April. Mai.

XC. Familie. Salicineen Rich. Weidengew ächse.

399. Salix L. Weide (Pflanzenname bei Plinius).

A. Fragiles. Knackweiden. Kätzchenschuppen gelblich-grün, gleichfarbig, vor der Fruchtreife ab. fallend. Kätzchen seitenständig, meist nach entwickelten Blüttern blühend.

996. S. pentandra L., fünfmännige W. Hayne Arzneigew. XIII, 40. Blätter eiförmig-elliptisch uder eiförmig - lanzettlich, zugespitzt, dicht-kleingesägt, ganz kahl, glänzend; Nebcnblätter eiförmig-länglich, gleichseitig, gerade, Blattstiel oberwärts sehr drusig; Bliithen füinf-:-chnmünnig; Kätzchen gestielt, der Stiel beblüt- 
tert: Schuppen glcichfarbig, hinfällig; Kapselı aus eiförnigem Grunde verschuälert, hahl, kurz-gestielt, Stielchen doppelt so lang als die Honigdrüse; Griffel mittelmässig; Narben ziemlich dick, 2spaltig. †. Flussufer, Gräben, Teiche, Torfwiesen sehr selten. Wird ron $\mathrm{Spreng.} \mathrm{in} \mathrm{Wäldern} \mathrm{bei} \mathrm{Lodersleben,} \mathrm{Holzzelle}$ und Bitterfeld als selten, von Schwabe fl. anh. bei Dessau und Oranienbaum angegeben. Mai. Juni. \$. polyandra S chrank. OFF. cortex Salicis.

997. S. fragilis L., Bruch- W. Ha y e Arzneigew. X1II, 41. Blütter lanzettlich, zugespitzt, ganz kahl ocler die juinneren etwas scidenhaarig, -icmlich stark gesägt, mit einwärts gebogenen S̈̈gezähnen; Nebenbläter halb-herzförmig; Bliithen zwcimainnig; Kätzchen grestielt, Stiel beblättert; Schuppen jicichfarbig, abfïllig; Kapseln aus eiförmigem Grunde Panzettlich, kahl, gestielt, Sticlchen 2. Lis 4 mal so lanær als die Honigdriise; Griffel mittelmässig; Narben ziemich dick, 2spaltig. †. Ufer, Gräben, nasse Stellen der Wiesen, in Dörfern nicht selten. April. Mai. Ein Baum von 20-3(1) Höhe, aber auch strauchartig. OFF. cortex Salicis. Aendert $a b$ :

a) decipiens $H_{0}$ ffm. : die Rinde der Aestchen ledergelb, die Knospen schwarz-braun, die untersten Blätter der Aestchen breiteiförmig, sehr stumpf.

b) vulgaris koch: Aestchen rothbraun, die untersten Blätter der Aestchen länglich-verkehrt-eiförmig. S. fragilis $\mathbf{S}$. S. excelsa 'T a us ch.

998. s. alba L., we is s $\mathbf{W}$. Hay ne Arzneigew. X111, 42. Bliitter lanzettlich, zugespitzt, Klcingesä̊t, beiderscits scidenhadrig ; Nebenblätter lanzettlich; Bliithen zueimännig; Kätzchen gestielt, Stiel beblättert; Schuppen gleichfarbig, abfïlig; Kapselı aus eiförmivem Grunde verschnïlert, stumpf, kahl, zuletzt etwas gestielt, Sticlchen kaum so lang als die schr kurze Honiodriise; Gritfel kurz; Narben ziemlich dick, ausgerandet. \%. An firäben, Teichen, in Dörfern gemein. April. Mai. Höhe bis 40 '. Aendert ab:

b) coerulea $\mathrm{Snı}$ : die älteren Blätter kahl werilend, nur die jüngeren seidenhadrig.

c) vitéllina L.: Aestchen dottergelb oder lebhaftmennigroth; so an Teiche an der Strafanstait, in Kröllwitz u. s. W. 
13. Amyglalinae. Mandelweiden. Kätzchenschuppen gleichfarbig, gelblich.grün, bleibend. Kätzcheu wie bei der vurigen Abtheilung.

999. S. Amygdálina C., ni udelbläterige W. Hayne Arzneigew. XIII, 39. Blätter lanzettlich nder länglich, zugespitzt, gesägt, ganz kahl; Nebenblätter halbherzförnig; Bliitheı dreimännig; Kätzchen yestielt, der Stiel beblättert; Schuppen bleibend, nlcichfarbig, an der Spitze liahl; Kapseln ei-kegelförmig, ziemlich stumpf, kahl, gestielt, Sticlchen $2-3 m a l$ so lang als die Ilonigdriise; Griffel sehr kurz; Narben warrechtauseinanderfahrend, ausgerandet. t. Ufer, Gräben, feuchte Wiesen gemein. April. Mai. tendert ab:

a) discolor $K u c h$ : Blitter unterseits blüulich-grïi. S. amygulalina $\mathrm{L}$.

b) concolor Koch: Blütter unterseits grasgriin uder nur ein wenig bläulich-grün. S. triandra I. nach sins.

C Purpureac. Purpurweiden. Kätzchenschuppen an der Spitze verschipdenfarbir; Kätzchen seitenständig, sitzend, vor den Biättern blühend; Stanbbeutel purpurroth, nach den Verbliihen schwarz.

1000. S. purpurea L., Purpur- IV. Sturm Heft 25. Bliittcr lanzettlich, nach vorne hreiter, zurespitzt, øeschürft-lileingesägt, lahl, Jlach; Hliithen einmiinnis, durch zusammengewachsene Sitabfäden; Kätzchen sizzend, am Grunde mit Deckblättern; Kapselı eiförnig, sitzend, filzig; Honisdriise iiher den Grund des Fruchi. linotens linaufreichend; Giriffel kurz; Narben eiförmig t Ufer, Grähen. Wiresen hänfig $\%$. B. in den Ufern der Saale. März. April. Aendert in Furm der Blätter und der Kätzchen vielfach ab.

1001. S. rubra Huds., rothe W. Bliitter verlängert - linzettlich, zugespitzt, ausgeschwcift-nezcihnelt, am Rande etwas zuriickgerollt, weichhaarig, die iilteren lahl; Nebenblätter linealisch; Bliithen einbriiderig; Kätzchen sitzend, am Grunde mit Deckblüttern gestüt/t; Kapseln eiförnig, sitzend, filzig; Iloniodrïse iiber den Grund des Fruchtknotens hinauficichend; Griffel verliingcert: Narben länglich, linealisch oder fadenförmig. t. Ufer, Büche, Gräbeı selten. An den Ufern der buppe zwischen Zöschen und Zweymen einzeln; von Spreng. an Waldbächen bei Emselohe und Annerude angegeben. März. April. 
D. Viminales. Korbweiden. Kätzchenschuppen an der Spitze verschiedenfarbig; Kät/chen seitenständig, sitzend, vor der Entwickelung der Blätter blühend oder fast gleichzeitig; Staubbeutel nach dem Verblühen gelb.

1002. 5. mollissima $\mathbf{E} \mathbf{r h}$., weichha arige IV. lilïtier verlänsert-lanzettlich, zugespitzt, entfernt-ausgeschweift-gezähnelt, die jiingeren unterseits fein-filzig; Nebenblätter eiförmis, spitz; Kätzchen sitzend oler kurz-gestielt, am Grunde mit Dechblättern gestützt; Kapseln ei-kegeltörnig. filzig, sitzend; Honigdriise iiber den Grund des Irruchthnotens hinan/reichend; Griffel verlängert; Narben linealisch, 2spaltig, so lang als die Hare der Schuppen. $\hbar$. Ufer sehr selten. Wird von sijeng. an den Ufern der Saale zwischen Kröllwity und Lettin angegeben. April. Schupuen der Kät/cheu gelblich-rustbrau, Haare derselben schmutzig-weiss.

1003. S. viminalis L. K K rb- 1 . Stu $\mathrm{l}^{\circ}$ Heft 25. lilïtter verlüingert-lanzcttlich, zugespitzt, ganzrandig, etwas ausgeschweift, unterseits seidenlicarig und gläinzend; Nebenblaitter lanzettlich. linealisch, liînger als der Jlattsticl; Kätzchen sitzend, am Grunde mit Derkblättern gestützt; Kapseln aus eiförmigen Grunde lanzettlich, filzig, sitzend: Monigdriise ïber den Grund des Fruchtknotens hinauficichend; Griffel verlängert; Narben fadenförmig, ungetheilt; Haare der Schuppen külzer als Her Griffel. ち. Ufer, Grüben gemein. März. April. sichuppen ler Kätzchen schwarzbraun, Haare derselben schneeweiss.

E. Capreae. Sahlweiden. Kätzchenschuppen an der Spitze vers hiedenfarbig; Kätzchen seitenständig, dit blïhenden sitzend, die fruchttragenden mehr vder weniger gestielt, der Stiel mit Deckblättern urler mit grösseren und wirklichen Blättern bekleidet; Staubbentel nach dem Verbliihen gelb.

1004. 5. Cáprea L., Sa h I- W. H a y u Arzneigew. XIII, 43. l3lïtter eiförmig wder elliptisch, flach, zugespitzt, mit zuriickgekriimmter Spitze, schnvach-vocllenförmig-gekerl,t, obcrscits kalil, unterseits bläulich-griin, filiig; Nebenblätter nierenförmig; Knospen lacill; Kätzchen sitzend, alis Grunde mit hleinen Deckblättern gestützt; Kapseln aus eiförmigem Grunde verlüngert-lanzettlich, filzig, gestielt, Stielchen 4-6mal so lang als die Honigdriise; Griffel sehr kurz; Narben eiförmig, 
Ispaltig. ち. Wïlder, llaine, Gebüsche, Zäune, Grähen häufiz. März. April. S. tomentusa sering. Höhe bis 20 '.

1005. S. cinerea L, graue W. Blïtter clliptischoder lanzettlich-verkehrt-eiförmig, kurz-zugespitzt, Mach, wellenförmig-gesägt, „raunriin, oberscits weichhaarig, unterseits filzis-liur-hcrarig; Nehenbläter nierenförmig; Knospen srau; Kätzchen sitzend, am Grunde mit Deckblättern gestiitzt; Kapseln aus eiförmigem Grunde verlängert-linzettlich, filzig, gestielt; Stielchen $4 \mathrm{mal}$ so lan" als die ILoniodriise; Griffel sehr kurz; Varben eiformig, 2spaltig. †. Gräben, feuchte IVallund Wiesenränder, Hecken gemein. März. April. S'. acuminata $H$ off $\mathrm{m}$., nicht $\mathbf{s}$. Höhe bis $12^{\prime}$.

1006. S. aurita L., geöhrte W. Blatter verlichrt. ciförmig ocler liinglich-verkchrt-eiförmig, zuriickge kriimmt-bespitzt, wellenfürmig-gesiigt, runzelig, wberwärts weichhaarig, unterseits blïulicheriin, filzig-kur:haarig; Nebenblätter nierenförmig; Knospen lahl; Kätzchen sitzend, die fruchttragenden gestielt, an Grunde ptuas bebiättert; Kapseln ans eiförmigen Grunde verlängert-lanzettlich, filzig, gestielt, Stielchen $3-4 \mathrm{mal}$ so lang als dic ILoniglriise; Griffel sehr kurz, Narben eiförmig, ausgerandet. Ђ. Feuchte Wiesen und Wälder. Gräben, Gebiische z. B. bei Lieshill häufig. April. Mai. S. rugosa sering. S. uliginusa $W$ illd. Höhe 4-S'.

1007. S. repens L., krie chende W. Blätter oval, plliptisch oder lanzettlich, mit riickwärts-gckrïmmter Stacliclspilze, an Rande etwas herabgebugen, ganzrandig oder entfernt-drïsig-gezähnelt, glänzend, unlerseits scidenhaarig; Nebenbliitter lanzettlich, spitz; Kätzchen sitzend, die fruchttragenden ovil-walzenförmig, kurzgestielt, der Stiel beblättert; Kapselı ans eiförmigem Grunde lanzettlich, filziy wder kahl, lang-gestielt, Stielchen 2-3mal längcr als die IIonigdriise; Girffel mittelmässig; Narben eiförmig, 2spaltig. h. Nasse Wiesen, Brüche, auf Munboden mad feurhtem Sande z. B. hei Dölau, Lieskau u. s. w. April. Ein sehr wiedriger, bis $1^{\prime}$ hoher Strauch. Aendert ab:

a) vulgaris Kuch: Blätter lanzettlich; Kapseln filzig: S. repens $\mathrm{S}$ m.

b) fusca Sm.: Blätter läıglich-oval; Kapseln filzig.

100. Pópunas L. Pappel (Pflanzenname bei Plinius). 
A. Lence D u b. Die jungen Zweige filzig oder, wenigstens bei jungen P'flanzen, kurzharig. Staubgefässe 8 . Kätzchenschuppen gewimpert.

1008. P. alba L., Silber-P. Blïtter rundlich-eiförmig, "inkelig - grezähnt, unterscits nebst den Zweigen schnecueiss-filigig, an den endstïndigen Zweigen hier:förmig -5lappig; Srhuppen der weiblichen Kätzchen lanzettlich, an der Spitze gekerbt, gewimpert. 5. Hin nnd wieder an IIesenrändern, in Dörfern angepflanzt. Värz. April. P. nivea Willd. Knospen filzig, nicht klebrig. Ein Baum ron 40' Höhe.

1009. P. canexcens $\$ \mathrm{~m}$, gr raue P. Elïtter rundliıh-eiförmig, winkelig-gezähnt, nnterscits nebst den 'Wweigen gran-filzig, an den endständigen Zweigen her-cifürmig, ungelappt; Schuppen der weiblichen kützrhen an der Spitze gespalten, am Rande wewimpert. 5. In feuchten Wäldmrn und Dörfern z. B. im Bienitz. März. April. P.alba Willd. Kuospen graulich weichhaarig, nicht klehrig.

1010. P. tremula L., Zitter-P. Aspe oder Espe. blïter fast kreistund, gezähnt, beiderseits nebst len Zweigen kahl, die der wurzelständigen Triebe und der jïngeren Pflanzen hurzhaarig, eiförmig und spitz; Kätzchenschuppen finıerförmig-eingeschnitten, dicht-zottiggewimpert. 万. Wäller, Gebiische. När».. April. Kumspenkahl, klebrig. Aendert mit beiderseits angedrücktwolligen Blättern ab: P. villosa L, ang, so im Bienitz, öter in Dörfern angepflanzt.

B. Jigeiros Dub. Die Kweige nebst den wurzelständigen Trieben kahl. Staubgefässe 12-30. Kätzchenschuppen kahl. Knospen klebrig.

1011. F. pyramidalis Rozier, Py ramiden-l'. liläter rautenfürmig, zugespit/t, gesägt, am Rande lahl; Aeste aufrechi. ち. Soll aus dem Oriente stammen, jetzt an den Chausseen häutig angepflanzt, aber nur der ilännliche Baum. Mär\%. April. P. fastigiata Puir. P. dilatata $A$ it.

1012. P. nigra L., Schwarz-P. Hayne Arzneigew. XI11, 47. Jilätler 3echig-eiförmig, zugespitzt, gesägt, am Rande lathl, am Grunde abgeschnitten und g*sägt, Blattstiele in der Jugend oberseits weichharig; deste abstchend. $h^{2}$. An Uferu, auf 'Triften und in Dörfern häufig angepflanzt. April. 
1013. monilifera At., Rusenhran\%. P. Jiliiter 3cchig-eiförmig̈, zugespitzt, gesägt, an Grunde eingeschnitten uder fast gatl\%andig, am Rande veichlianrig: Blattstiele an der Suitze an Blattgrunde meist 2driisig; weibliche Kätzchen perlschnurförnig. ち. Stammt aus Nurdamerika, jetzt an Strassen und in Dörfern oft angepflanzt. April.

\section{Familie. Betulineen Rich. Birken- gen}

101. Esétrala L. Birke (Pflanzenname bei Plinius).

1014. H. verrucosa $\mathbf{E h ~} \mathbf{r h . ,}$ wa r\%ige B. Jjlitter rautenförmig-3eckig, laug-zugespitzt, cloppelt-gesiggt, langestielt, kahl; die fruchttragenten kätzchen langgrestitlt, hängenl, Schuppen 3lappir, der Nittellappen lurz-3eckig, die Seitenlappen zuriickgebugen, langgestielt, laum merklich gevimpert; Samen elliptisch, der riiggel cloppelt so breit als der Same sellixt und his zur spitze der Narhen hinaufreichend. ち. In Wäldern häufig. April. Maj.

Diece Art ist schon in ersten Jahre ihrer Entstehungr aus Samen durch eine dünne, kurze, aber steife Behaarung an dem Stämmchen und an den Blättern, welche abel in ziveiten Jahre fast ganz ' ('schwindet, und durch. die immer stärker hervortrotenden, Betulin führenden, Würzchen leicht zı erkennen.

1015. H3. odorata echst., Ri echbirke. riciitcr eiförmig, spitz, stumpf, gcziihnt, gestielt, an Rande mit wenigen Härchen und in den Aderwinkeln bärtig: die fruchttragenden Kätzchen langgestielt, hängend, Schuppen 3lappig, der Mittellappen kurz-3eckig, die Seitenlappen abgerundet, gestirlt, rauhlıacurig; Sanın länglich verkehrt-eiförmig, dcr Flïgel etwas breiter als der Same sellst, nur wenim iiber dessen spitze hinatreichend. ち. In Sümpfen bei Lieskan. April. Mai. Hierzil wird gewöhnlich die seltene B. pubescens $\mathbf{E} h \boldsymbol{r} h$. gezugen, welche aher nach Henze's genauen Untersuchungen (s. Butanisclie Zeitung Jahrg. 1848 S. 73 ff.) specifisch verschieden ist. Ob B. alha L. zu B. odurata Bechst., wit Fries jetzt meint, oder zu B. verrucosa îh r. gehört, ist nuch nicht entschieden.

Die aus Samen erzogenen P'flanzen dieser Art sind in ersten Jahre mit langen, weichen Haaren stark be- 
setzt, welche an den Stïmmchen und an den Blattstielen wayrecht abstehen, auf heiden Blattflächen aber anliegen ; an den Stänmchen furlen sich gelhlich-weisse kleine Flecken, aber keine Ifärzchen. Die Beharung jist im zweiten Jahre an der ganzen Pnanze nuch stärker und vermindert sich erst in fünften und sechsten Jahre.

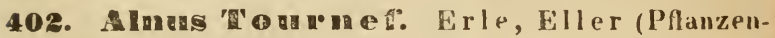
name bei Plinius).

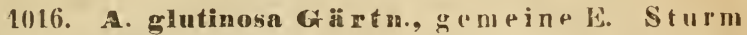
Heft 29. Blättel rundlich, sehr stumpf, abostutzt, am Grunde keilförnig, ungleioh doppelt-gesägt, hahl, unterseits in den Ailprwinkeln bärtig; Sampu ohne häutigen Flugel. ち. Fenchte Wälste mol Wiesen, Brüche, Siimpfe hänfig. Febr. März. Betula Aluus «. glutinosis L. Jendelt in Gärten mit eingeschnittenen und fiederspaltigen Blättern ab.

\section{Familie. Coniferen Juss. Zapfen- friichtir.}

403. Enniperess E. W a chholder (Pflanzenname bei Plinius; nach $C$. Bauhin ist ler Name alss juniora, jïngere, unıl pariu, jch gehäre, zusammengesetzt, weil sich schon wieder junge Früchte ansetzen, ehe die altell reif sind).

1017. J. communis L., gem ei ne 1W. Strauchaltig, aufrerht, zuletzt bammartig; Blätter zu dreien, weit-abstehend, linealisch-pfrienlich, in eine Stachelspitze zugespitzt, oberseits schwach-rinnenförnig, unterseits stunipf-gehielt, mit einer den stiel durchziehenden, eingedrürkten Linie; Beeren eiförmig, bereift, 2. oder 3 mall kürzer als die Blätter. ћ. Dürre, sandige stellen, Heiden z. B. zwischen dem Lindherge und Aer Dölaner Heide sehr häutig. April. Mai. Beeren schwarz, blau-bereift, erst im zweiten Jahre reifend. Höhe meist $3-4^{\prime}$. Die bamnartige Form hisweilen in Parkanlagen angepflanzt.

404. Pinus T. Kiefer, Fichte (Pflanzenname bei Plinius).

A. Pinaster. Kiefer. Hlïgel der Samen abfällig.

1018. P. silvestris L., ge me in e K. Blätter zu zweien, lanchgrün; Zapfen olıne Glanz, die jungen auf 
cinem halicnfürmig-herabgelogenen Sticle, von der Lï̈„ce des Zapfens selust, die reifen kegelförmig; der schilit der schuppen gewölbe oder an den unteren stumpf-geschnäbelt, mit kurzem, zuriichgebogenem Schnabel; der Flügel 3 mal läuger als der Same. $\hbar$. Bildet in sandiuen, trockenen Gegenden grosse Waldungen. Mai. Ein schlanker, bis $120^{\circ}$ hoher Baum.

B. Abies Link. Fichte. Flügel der Samen nicht abfällig; Schuppen der Zaipfen bleibend; Dechblätter bald rerschwindend.

1019. Ries $\mathbf{L}$. gemeine $\mathrm{F}$., auch Roth. unil se hw a rzt a n ne genaunt. Bliitter cinzeln, zuscinnmengedriiclt, fast 4kantig, stachelspitzig ; Zapfen walzenförnig, hängend, schuppen ausgebissen-yezühnelt. †. ln Wablern seltener als die vorhergehende. Mai. P'icea vulgaris link. Abies excelsa P'oir.

c. Larix Tournef. Lärche. Flügel der Samen nicht abfällig; Schuppen der Zapfen bleibend; Deck. blätter bleibend.

1020. P. Larix L., Lärehe. Blätter biischelig, Rach, etwas rinuenförmig, abfällig; Zapfen eiförmig, aufrecht, Schuppen sehr stumpf, an der Spitze loclier. ћ. Stammit aus süddeutschland, jetzt häufig in Anlagen, bisweilen auch in Wäldern angepflanzt. Ipril. II ai. Larix europaca DC. Abies Larix Lam.

\section{Classe. Phanerogamische Eu- dogenen, Monocolylen.}

Der Stamm, sowohl ohne mittelpunktständiges Mark und ohne Narkstrahlen, als anch who Rinde, bestelit aus zerstrenten, durch das Kellgewebe laufenden Fasern. In den Blüthentheilen herrsilat die Dreizahl ror. Samenkeim nit werhselständigen Keimblättern.

\section{Familie. Hydrocharideen I) C. Froschbissgew ächse.}

105. Suratiótes L. Krebsscheere fotoctutitns, Krieger, von den schwertförnigen Blättern genannt; bei Dioseurides bezeichnet dieser Name die in Acgryten einheimische Pistia Stratiotes L.). 
1021. St. aloides.L., a l o e b lätterige K. Abb. 111. Wurzel im Schlamme kriechend, ausläufertreibend; Blätter schwertföınig, 3kantì̆, stachelig-gesägt; Blüthen 2häusig; Blüthenseheide am Rande scharf-gesägt. 2. stehende Gewässer änsserst selten, nur bei Dessau, aber daselbst sehr häufig (bei Oranienbaum schon ausserhalb. der Grenze in allen kleinen Seen bei Riesigk, Rehsen, Wörlitz n. s. w.) Juli. Aug. Blune weiss. Die Blätter sind denen einiger Aloe-Arten sehr ähnlich.

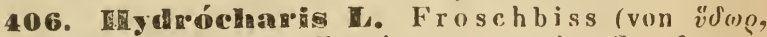
Wasser, und zúos, Freude, wegen des Standortes; der bei 'Taberuirmontanus vorkommende Name Morsus ranae bezieht sich auf die Gestalt der Blätter, als wären sie vun Froschen angebissen).

1022. H. Iorsus ranae $\mathrm{C}$., gem e in er F. Abb. 112. 13lätter schwinmend, gestielt, kreisiund, am Grunde tief-herzförmig; Blüthen 2häusig. 24. Strhende Gewässer, Gräben sehr zerstreut. In der stillen Elster bei Osendorf und in Gräben zwischen Döllnitz und Osendorf häıfig, in einem 'Teiche am Gemeindeholze bei Zöschen, fehlt bei Naumburg und im ganzen westlichen Gebiete; findet sich bei Freckleben unweit Sandersleben, bei Dessau, Oranienbaum und im nordöstlichen Gebiete überhaupt häufig. Juli. Aug. Blume weiss.

\section{Familie. Alismaceen Juss. Frosch- löflelgeü̈chse.}

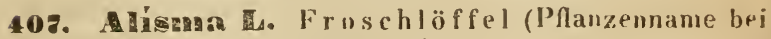
iiuscurides).

1123. A. Hentago L., ge me in er F. Abb. 100102. Schaft quirlförmig-rispig; Blätter sämmtlich grundständig, herzförmig, eiförnig oder lanzettlich; Fruchtknoten inwendig iiber dem Grunde den Griffel tragend; Fiüchtchen an der Spitze abgrerundet-stumpf, grannenlos, auf dem Rïrken 1-2furhig, eine stumpf-3eckige Frucht bildend. 24. Gräben, stehende Gewässer gemein, die Abarten weit seltener. Juli. Aum. Blume weiss oder röthlich. Höhe $1 / 2-3^{\prime}$. Aendert ab:

b) Ianceolatum IVith.: Blätter lanzettlich, nach dem Grunde verschmälert, nur 1" breit. A. Plantingo $\beta$. W illd.

c) graminifolium Ehrh.: Blätter sämmtlich gras- 
artig, linealisch, schwimmend, nur das eine orler das andere mit schmal- Janzettlicher Blattläche ïber das Wasser hervortretend. A. Plantago $\gamma$. gramini. folia Wahlenb. A. natans Pollich, nicht I., so in Gotthardsteiche bei Merseburg.

108. Sagitútria I. Pfeilkraut (von sagitta, Pfeil, wegen der pfeilförmigen Blätter).

1024. s. sagittaefolia L., ge me ines Pf, Abb. 94. Schaft einfach; Blätter sämmtlich grundständig, lang. restielt, tiff-pfeilförmig, lie untergetauchten lanzettjich; Blithen gestielt, in 3blïthigen Quirlen, von de. nen die unteren weiblich, die oberen männlich sind. 7 . Stehende Gewässer, Flussufer zerstrent. An der Sale zwischen der Steinmühle und Giebichenstein, sehr häufig in der'stillen Lister bei Osendorf, bei Naumburg häufig z. B. in der Aue und der alten saale, fehlt mit Ausnahme von Kalbsrieth im ganzen Riethe bei Allstedt, fehlt bei Aschersleben; bei Dessan, Oranienbaum und im ganzen nordöstlichen Gebiete häufig. Juni. Juli. Blume weiss, am Nagel purpurruth. Höhe $1-3^{\prime}$.

XCV. Familie. Butomeen Rich. Schwain enblumengewächse.

409. Frátomags I. Schwanenblume, Was serliesch (Pflanzenname bei 'Theophrast).

1025. B5. umbellatus L., doldenbliithige Sch. Abb. 103. Schaft stielrund, an der Spitze eine einfache, mit einer Hiille versehene Dolde tragend; Blätter sämmtlich grundständig, lang-linealisch, rinnenförmig-3sei. tig. 24. Gräben, simpfe, 'ieiche hänfig z. l3. in Ialchen an der Elisabethbrücke, an der Irrenanstalt, bei Passendorf u. s. w. Juni - Aug. Blüthen rosenroth. Höhe $4^{\prime}$ und darüber. Aendert in 'Zuhl der Fruchtinnten und Staubgefässe sehr ab.

XCVI. Familie. Juncagineen Rich. Blumenbinsengew ächse.

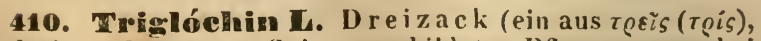
drei, und $\gamma \lambda \omega \chi i \nu$, Spitze, gebildeter Pflanzenname bei Dalechamp, die Gestalt der reifen Frncht einiger Arten bezeichnend). 
1026. T. maritimum L., Meerstrands-D. Abb. 92. 93. Schaft in eine lange, vielblüthige Traube endend; Blätter sämmtlich grundständig, schmal-linealisch, halb-stielrund; Friichte ciförmig, kantig, unter der Narbe eingeschniirt, in 6 Kapseln zerfallend. 4. Sumpfwiesen, besonders auf Salzboden, ziemlich verbreitet. Im Chausseegbiben an Krukenberg's Garten, an den 'Jeichen bei Dieskau sehr häufig, am Gotthardsteiche bei Merseburg, hei Kl. Dölzigr, sehr häufig un die Salinen von Kötschau und 'leuditz, bei Naumburg sehr sparsam. Juni. Juli. Blüthen griinlich. 'Schaft $1 / 2-1 \frac{1}{2} \%$ hoch.

1027. T. palustre E., Sum $p$ f - D. Abb. 90.91. Schaft in eine lange, vielbliithige 'Traube entend; Blätter sämmtlich giundstäıdig, schmal-linealisch, halb-stielrund; Friichte linealisch, kantig, nach dem Grunde verschmailert, an die spindel angedrïckt, in 3 Kapseln zerfallend. 24. Simmpfige Wiesen, feuchte Triften verbrejtet z. B. bei Dölau, Lieskan, Gutenberg n. s. w., nur bei Naumburgy sparsäm. Juni. Juli. Blüthen grïnlich. Höhe $1 / 2-1^{\prime}$.

Scheuchzeria palustris I. wird von Schwabe fl. anh. in Torfsümpfen bei Radegast angegeben.

XCVII. Familie. Potameen Juss. Samkrautgewächse.

41. Rotanzogéton L. Samkraut, I, aichkraut (der Name Potamogeton, welcher bei Plinius $(26,8,29$ )

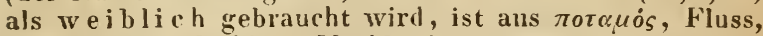

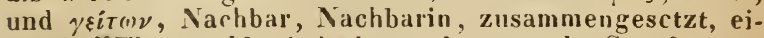
gentlich Flussnachbarin bedeutend, wegen des Standortes).

1. Heterophylli. Verschied en blätt erige. Blätter wechselständig, nur die blüthenständigen gegenständig, die ubersten meist schwimnend, von den untergetauchten unteren verschieden.

a. Wie hï̈ther.scändigen Blitter sämmtlich lederartig und schvimmend.

1028. P. natans $L$. , s chwimmendes S. Abb. 89. Stengel einfach; Blätter sämmtlich lang-gestielt, die jüngeren untergetauchten schmäler, lanzettlich oder länglich, die schwimmenden lederartig. am Grunde etwas herzförmi, oval oder länglich; Blattstiele auf der uberen Seitt etwas rinnenförmig, die untergetauchten 
zur Blüthezeit zuweilen schon völlig zerstört; Blüthenstiele gleichdick; die firischen firiichte zusammengedrücht, am Rande stumpf. 4. 'I'eiche, Jachen, Grïben meist häufig z. B. in den Teichen bei Bruckilorf und Dieskau häufig u. s. W., fehlt in der Nähe von Aschersleben, "w er sich nur' in den 'Teichen bei Wall. beck findet. Juli. Aug.

Potamogeton fluitans Ruth ist gewiss auch innerhalb der Grenzen des Gebietes, obgleich noch nicht gefunder.

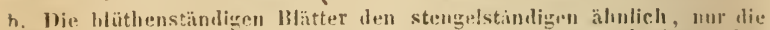
spateren schwimmend, lederartiog; öfter fohlen die schwimmenden Blatter wathz.

1029. P. rufescens s chrad., röthlirhes S. Abh. 56. Stengel einfinch; die untergetanchten Bliiller sitzend, häutig, durchscheinend, lanzettlich, am Grunde und an der Spitze verschmälert, ziemlich stumpf, am liande slatt, die schwimmenden lederartiv, verkehrt piförmig, stumpf, in den Blattsticl, welcher liirzer als das Blatt ist, verschmiilert; Blïthenstiele gleichdick; die frischen Früchte linsenförmig - zusammengedrückt, nit einem spitzen Rande versehen. 4. Stehende und langsam fliessende Gewässer sehr selten. Soll nach $\mathrm{Spreng.}$ in den Fischtejchen bei Bruckilorf wachsen, ist vom Ferfasser jedoch nicht gefunden; wird ansserdem vun it allr. sched. p. 66 in pinem langsam fliessenden liache auf dem Rossleber licthe, von Schwabefl. anh. bei Dessau in Jandgraben anf den Kochstedter Wiesen angegeben. Juli. Aug. Die Blätter sind oft schon an der frischen Pllanze röthlich-griin, beim 'Trochnen wer. den sie braumoth.

B. Homophṛlli. Gleichbläterige. Die ganzœ Pflanze untergetaucht, nur die Aehren während der Bliithezejt über das Wasser hervortretend. Die Blättel wechselständig, die blüthenständigen gegenüberstehend, alle häutig.

1030. T. Incens L., spiegeJndes S. Abb. 64. stengel ästig; Blïtter siimmtlich untcrgetaucht, hïiutig, durchscheinend, gestielt, oval oder lanzettlich, stachelspitzig, am Rande feingesägt-rauh; Blüthenstiele uberwäts verdickt; die frischen Früchte zusammengedrückt, am Rande stumpf, schwach-gekielt. 24. Strhende und langsam fliessende Gewässer zerstreut. In den Teichen bei Dieskau sehr häufig, in Teichen bei Ködgen zwi. schen 
schen Brehna und Delitzsch, in dell Teichen bei Wallbeck unweit Hettstedt, bei Bernbury und Sandersleben zerstreut, bei Dessau selten. Juli. Aug.

1031. Perfoliatus L., durchwachsenes $S$. Abb. 53. 54. Stengel etwas ästig; Blïtter sïmmtlich untergetaucht, durchscheinend, aus her zförminem, sten. selumifassendem Grunde eiförmig oder ciförmig-lanzett. lich, am Rande ctwas rauh; Blüthenstiele gleichdick; die frischen Früchte zusammengedı̈ickt, anı Rande stumpf. 24. Stehende und fliessende Gewässer nicht gerade selten z. B. in der Saale zwischen Halle und der Rabeninsel, in Iachen bei Passendorf, läufig im salzigen See bei Rollsdorf u. s. w. Juli. Aug.

1032. P. crispus L., hrauses S. Abb. 50. Stengel ästig, zusammengedrückt; lilïter sämmtlich untergetaucht, häutig, durchscheinend, sitzend, linealischlänglich, ziemlich stunpf, kurz - zugespitzt, klein-gesägt, wollenfürmi $\underline{n}$ - lrous; Blüthenstiele glejchdick; Früchte zusammengedrücht, geschnäbelt. 4. Stehende und fliessende Gewässer häufig z. B. in Lachen an der Kreuzschäferei bei Kröllwił̧, in den 'Ieichen bei Dieskau u. s. W. Juni - Aug.

C. Chloëphylli. Grasblätterige. Die ganze Pflanze untergetaucht, nur die Achren während der Blüthezeit ïber das Wasser hervortretend. Blätter grasartig, genau-linealisch, alle gleichgestaltet, sitzend, wechselständig, nur die blïthenständigen gegenüber.

1033. P. compressus $\mathrm{L}$. nach Fries, flachstengeliges s. Abb. 45. Stengel ästig, gefliggelt.zusammengedrückt; Licïter sämmtlich untelgrotaucht, häutig, durchscheinend, sitzend, genau-linealisch, stumpf, hurzstachelspitzig, vielnervig, mit $3-5$ stïrliren Nerven; Achren vualzen/örmig, $10-156$ liithig. 24. In Lachen in der Aue nach Merseburg zu, von Wallr. ann. bot. p. 27 (cf. sched. p. 67) auch in langsam fliessendēn Ge. wässern bei Russleben, in Lossgraben u. s. w. angegeben. Juli. Aug. P. zosterafofius S chnnacher. P. complanatus $11 \mathrm{ill} d$.

1034. P. acutifolius $\mathrm{L}$ in $\mathrm{k}$, s p it $\mathrm{z}$ b lät t e riges $\mathrm{S}$. Abb. 44. Stengel sthr ästig, geflïgelt-zusammengedrückt; Blätter sämmllich untergetaucht, häutig, durchscheinend, sitzend, genau-linealisch, am Ende haarspitzig, vielnervig, mit $3-5$ stärkeren Nerven; Achren Garclie, Flora. 
4-6bliithig, die fruchttragenden rumdlich. 4. Stehende und fliessende Gewässer. Bisher nur auf der Grenze in der Helme bei Katharinenrieth unweit All. stedt gefunden. Juli. Aug.

1035. P. obtusifolius M. U. Koch, stumpfblä . teriges $S$. Abb. 43. Stengel sehr ästig, zusanmengedrückt, an den Ründern abgerundet; Bläitter sämmt. lich untergetaucht, häutig, durchscheinend, sitzend, genau-linealisch, stumpf, kurz-stachelspitzig, 3-5nervig; Bliithenstiele so lang als die 6-8bliithige ununterbrochene Aelre. 4. In Lachen zwischen Burg Lie. benau und Wallendorf. Juli. Aug. P. gramineum $\mathbf{S}$. P. compressum Roth.

1036. P. pusillus $\mathrm{K} ., \mathrm{k} l$ e ine $\mathrm{S}$ S. Abb. 38. Stengel sehr ästig, stielrund-zusammengedrüickt; Bläitter siimmtlich untergetaucht, häutig, durchscheinend, sitzend, genau-lineatisch, ziemlich spitz, kurz-stachelspitzig, 3-5nervig; Bliithenstiele 2-3mal so lang als die 4Sbliithige, oft unterbrochene Achre; Friichte schief-elliptisch. 24. Stehende Gewässer und Lachen meist nicht selten z. B. in Gräben zwischen der Irrenanstalt und der Eisleber Chaussee. Juli. Aug. Aendert ab:

a) major Fries: Blätter breiter, fast 1 Linie breit: P. compressus $M$. und $\mathrm{Koch}$.

b) vulgaris Fries: Blätter ungefähr $1 / 2$ Linie breit.

c) ten nissimus M. u. Ko ch. Blätter sehr schmal, bisweilen kaum $1 / 4$ oder $1 / 3$ Linie breit.

D. Coleophỵlli. Scheidenblätterige. Die ganze Pflanze untergetaucht, nur die Aehren während der Rlüthezeit über das Wasser hervortretend. Die Bläter grasartig, genau-linealisch, alle gleichgestaltet, wechselständig, am Grunde scheidenförmig, die Scheide an die Blatthäutchen angewachsen.

1037. pectinatus $C$., fadenblät terige S. Abb. 30. 31. Llätter sïmmtlich untergetaucht, häntig, durchscheinend, am Grunde scheidenförmig, linealisch oder linealisch-borsten/örmig, spitz, lnervig, quer-aderig, Adern ziemilich dick; Aehren langoestielt; Friichte schief. verkchrt-eiförmig, halbkreisrundlich, zusammengedrückt, im getruckneten Zustande auf den Rücken gekielt. 4. Stehende und fliessende Gewässer nicht selten $z$. B. in Lachen zwischen der Eisleber Chaussee und ier Irren- 
anstalt, in der Reide bei Osendorf, bej Röglitz u. s. w. Juli. Aug. Aendert ab:

b) scuparius Wallr.: Blätter linealisch-borstenförmi:, an den oberen Aesten dicht büschelförmig. hesenartig stehend, so in Lachen zwischen Warsleben und Rollsdorf, in salzigen See.

E. Enantiophylli. Gegenblätlerige. Die ganze Pflanze untergetaucht, nur die Aehren während der Blüthezeit ïber das Wasser hervortretend; Bläfter durchscheinend, sämmitlich gegenständig.

1038. Pensus $\mathbf{L}$, dickblätteriges S. Abb. 46-49. Blïtler sämmtlich gegenständig, untergetaucht, häutig, durchscheinend, sitzend, stengelumfassend, elliptisch, lanzettlich oder linealisch-lanzettlich; Aehren gabelständig, kurzgestielt, nach den Verblühen zurückgebogen; die getruckneten Früchte zusammengedrückt, breitgekielt, geschuäbelt. 24. Stehende und fliessende Gewässer sehr selten. In der Luppe bei Kl. Liebenau, in der Elster bei Schkeuditz. Juli. Aug.

412. Ruppia T. Ruppje (zur Ehre Heinr. Bernh. Rupp's, des Verfassers einer Flora von Jena benaunt).

1039. R. rostellata Koch, s chuabelf r üchtige R. Abb. 25. Stengel fadenförmig, schwimmend; Blätter sehr schmal-linealisch; Säckichen der Staubbeutel fast kugelförnıg: Früchte langgestielt, schief - geschnäbelt, fast halbmond-eiförmig, aus stumpfem Grunde aufstrebend. 24. In salzigen Lachen bei Amsdorf und Röblingen, nach S p reng., weit häufiger auf der Grenze im Soolgraben bei Artern; sparsam auch bei Stassfurt. Aug. Sept.

Hierher gehört R. maritima bei Spreng. ed. 2.

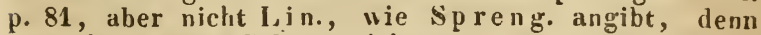
diese kommt im Gebiete nicht vur.

413. Zannichéllia K. Za nnichellie (zum Anden. ken an Joh. Hieronym. Zannichelli, Apotheker und Verfasser der ersten Flura ron Venedig).

1040. Z. palustris L., kurzgestielte $Z$. Abb. 20. 24. Stengel fadenförmig, fluthend oder kriechend und wurzelnd; Blätter sehr schnal-linealisch; Friichte kurzgestielt oder fast sitzend, Griffel halb so lang als die Friichte. 4. Stehende und fliessende Gewässer, Gräben stellenweise. An Gräben hinter den Gärten bei 
Nietleben, aber nur in nassen Jahren, in Gräben zwischen Iieshau und lem Zorgs, in der Salzke in der Nähe des salzigen Sees, in Jachen zwischen Amsdurt und Röblingen, in Gräben bei Kl. Dölzig, auf der Grenze in Gräben zuische⿰ Artern und Kahstedt. Juli - Sept. Aendert mit Früchten ab, welche auf dem Rüchen kanm geflïgelt, daselbst gefliigelt und geherbt oder auf bei den Seiten geflügelt sind; bei ausgewitterten Flüguln bleiben dic Zähne als Dörnchen, und ferner:

b) " a jur Bön ingh.: der Stengel in tiefem Was. ser verlängrit, aber am Grunde nicht kriechend.

c) repens liönningh: der Stengel in nicht hohem Wasser an den Gelenken wurzelnd.

1041. Z. pedicellata Fies, I anggesticlte Z. Abb. 21. 22. Sitengel fadenförnig, fluthend; Blättor sehr schmal-linealisch; Friichte deutlich und ziemlich langgestielt, Griffel schlauk, so lang oder fast so lang als die Friichle. 24. Jachen, 'leiche, Bäche seltener als vorige drt, wonspreng. vor dem ehemaligen Forsthause angegelien. Juli-Sept. Z. palustris $\beta$. pedicellata II ahlenbg. Aendert gleichfalls mit hreiten Rïckenkiele ( $\%$. peduneulata R c hb.) und mit beiderseits geflïgeltem Kiele ( $\boldsymbol{Z}$. gribherosa R chb.) ab.

\section{Familie. Najadeen Link. Nis - krautgewächse.}

414. Najas L. Nixkraut (die Pflanze erhielt diesen Namen von Limné des Standortes wegen).

1042. N. major Roth, grösseres N. Sturm Heft 41. Stengel gabelspaltig; Blätter linealisch, ausgeschweift-gezähnt, Blattscheiden ganzrandig: Blïthen 2häusig. $\odot$. Landseen, 'Teiche äusserst selten. Im salzigen See in der Nähe von Rollsdorf und im Gross. Kühnauer See bei Dessau, aber an beiden stellen hänfig. Aug. Sept. N. marina $\alpha .1$. N. fluviatilis I. a m. Ittuera Naids Guel. fl. had. Der unter der Oberfläche des Wassers stehende Stengel ist bis $1^{\prime}$ hoch, bei der männlichen Pflanse mit "Ienigen, bei der weiblichen mit zahlreichen Weichstacheln besetzc

Najas minor All. uder Caulinia fragilis Willd. mit fein-wimperig-gezähnelten B!attscheiden und eishäusigen Bliithen wild von Schwabe fl, anh. in Iachen bei Oranienbaum angegeben. 
XCIX. Familie. Lemnaceen Link. Was serlinsengewächse.

15. Hemma L. Wasserlinse (Pflanzenname bei Theophrast).

1043. L. minor L., $\mathrm{kleine} \mathrm{W.} \mathrm{Abb.} \mathrm{15.} \mathrm{Jeder}$ blattörmig - verbreiterte, verkehrt-eiförmigc, leider. scits flache Stengel unterseits mit einer einzigen Wurzelfaser besetzt, Stengelglieder aneinander sitzend; Frucht 1samig. $\odot$. Auf stehenden Gewässern schwimmend, gemein. Ilai. Juni.

1044. L. gibba L., buckelige W. Abb. 16. Jeder blattförmig - verbreiterte, verkehrt-eiförmige, unterseits schwammig-gewöllbte Stengel unterseits mit einer cinzigen Wurzelfaser besetzt, Stengelglieder aneinander sitzend; Frucht 2 - oder mehrsamig. $\odot$. Auf stehenden Gewässern schwimmend, weit seltener als die rorige Art. In Iachen unnittelbar bei Dölau in der Nähe des Wirthshauses, in Lachen bei Kölme, an beiden Orten in Mai auch blühend yefunden. 'Telmatuphace gibba Schleid.

1045. L. polyrrhiza L., vielwurzelige W. Abb. 17. Jeder blattförmig-verbreiterte, rundlich-verkehrtciförmige, beiderseits flache Stengel unterseits mit mehren biischelförmigen - Wurzelfasern besetzt, Stengelglieder aneinander sitzend; Frucht 2samig. $\odot$. Auf stehenden Gewässern schwimmend, nicht so häufig als $L$. minor. Am Hospitalgarten in der Saale, in Lachen an der Klause bei Merseburg. Mai. Spirodela polyrrhiza Schleid.

1046. L. trisulca L., dreifurchige W. Abb. 19. Jeder blattförnig-verbreiterte, lanzeltiche, beiderseits flache Stengel unterseits mit piner einzigen Wurzelfaser besetzt, Stengelglieder zuletzt gestielt, kreuzweise stehend. $\odot$. In stehenden Gewässern untergetaucht und schwimmend. In Teichen bei Bruckdorf und Dieskau und in Lachen der Aue überhaupt häufig, in Lachen an der Klause bei Merseburg. Mai. Staurogeton Rchb.

\section{Familie. Typhaceen Juss. Kolben- rohrgewäc hse.}

116. Typha L. Kolbenrohr, Rohrkolbe (Pfanzenname bei Theophrast). 
1047. T. Intifolia L., breitblät eriges K. Abb. 747. 748. Blätler breit-linealisch, flach, länger als der blüthentragende Stengel; die weibliche Achre unmittelbar unter der münnlichen stehend. 24. Stehende Gewässer, Flussufer zienslich verbreitet. An den Teichen bei Dieskau häufig, bei Naumburg in der Aue,häufig, bei Allstedt an einem 'Teiche unter' Kloster Naundorf, häufig an salzigen See u. s. w. Juli. Aug. Athren walzen. förmig, bedeutend dicker als an der folgenden Art. Der einfache, aufrechte Stengel ist $3-6^{\prime}$ hoch.

1048. T. angustifolia $\mathbf{L}$., s c h malblät eriges K. Abb. 745. Blitter schmal-linealisch, unterseits fast rinnenförmig, länger als der blüthentragende Sten. gel; männliche Achre von der weiblichen entfernt. 4. sümpfe, Teiche, Gräben weit seltener als dip vorher. gehende Art. An den 'Teichen bei Diekau. Juli. Aug. Aehren walzenförmig, nur etwas dicker als eine Federspule. Der Abstaud zwischen beiden Achren beträgt $1-1^{1 / 2}{ }^{\prime \prime}$. Der einfache, aufrechte Stengel ist $3-6^{\prime}$ hoch.

118. Spargánium L. Igelskolbe (Pflanzenname bei Dioscorides).

1049. Sp. ramosum Huds., ästige I. Abb. 751. Stengel oberwärts cinen cistigen Blithenstand tragend; Blätter an Grunde 3 kantig, an den Seitell vertieft; Narben linealisch. 24. Gräben, Teiche, Bäche häufig. Juli. Aug. Sp. erectum $r$. L. Höhe bis 2 '.

1050. Sp. simplex H uds. mit Ausschluss der Var. B., einfache I. Abb. 750. Stengel oberwärts einen cinfachen, traubenartigen Bliithenstand tragend; Blätter am Grunde 3kantig, an den Seiten flach; Narben linealisch. 24. Gräben, Teiche, Jachen häufig. Juli. Aug. Sp. erectum $\beta$. L. Höhe $1-11^{1 / 2}$.

1051. Sp. natans L., s $\mathrm{ch}$ w immende I. Abb. 749. Stengel einen cinfachen Bliithenstand tragend; Blätter niederliegend oder schwimmend, flach; Narben lïnglich; an des. Spitze des Blüthenstandes meist nur eine uännliche Aehre. 24. Teiche, Sïnpfe selten. Im Lossgraben bei Rossleben nach Wallr. sched p. 483 , in der Entenpfütze im Allstedter Theilholze, in der 'I'orfstecherei bei 'Iörten südlich von Dessau, bei Oranienbaum in der Scheitlache zwischen Gremin und '/schiesewitz und in ler Rehlache südwestlich von Oranienbaun, wach Spreng. auch im Loberbache bei Paupitzsch, wo der Verfasser jedoch vergeblich gesucht hat. Juli. Aug. Der schwache Sten. 
gel ist in Wasser bis 1' lang, am Rande der Lachen und Pfützen jedoch schmächtiger und nur 4-6" lang.

\section{Familie. Aroideen Juss. Aronge- wächse.}

1. Gruppe. Aroideae verac R. Br. Aechte Arongewächse. Blüthen ohne Blüthenhülle.

418. Arrmin Aron ( ${ }^{*} A \rho \circ \nu$ bei Theophrast ist Arum Culucasia L., dessen Wurzel noch jetzt in degypten als Nahrung benutzt wird).

1052. A. maculatum L., gefle ckter A. Hayne Arzneigew. Xlll, 32. $\mathrm{Kehb}$. Ahb. 8. Schaft an der Spitze einen Blüthenkolben tragend, welcher von einer grossen, unten zusammengeruliten Bliithenscheide umgeben ist; Blätter sämmtlich grundständig, spiess - pfeilförmig, gleichfarbig - grün uder braun-gefleckt; Kolben gerade, kürzer als die Blïthenscheide, an der Spitze keulenförmig, Keule 3mal so lang als der übrige 'íheil der Blüthenspindel. 2. Schattige, feuchte Laubwälder, im ganzen Gebiete verbreitet. Auf der Rabeninsel bei Böllberg, in den Wäldern der Aue sehr häufig z. B. bei Schkeuditz, Dölkau, Zöschen, zwischen Möritzsch und Kötzschlitz, bei Naumburg verbreitet z. B. am Pfortenberge, an der Steinklippe nach dem Wangener Grunde zu, bei Eisleben im Helftaer Holze und im Badendorfer Holze zwischen Seebury und Neehausen, bei Aschersleben häufig, bei Dessau sparsamer, bei Oranienbaum in Nichrim, in der Gutsche zwischen Paupitzsch und Niemegk nördlich von Delitzsch. Mai. Die Blätter sind nur selten gefleckt. Höhe bis $1^{\prime}$. Giftig. OFF. radix Ari.

419. Calla I. Schweinkraut (Pflanzeuname bei Plinius).

1053. C. palustris L., $\mathrm{S}$ in $\mathrm{p}$ f - S ch. H a y neigew. 1, 15. Rchb. Abb. 13. Schaft an der Spitze eintrn kleinen Blüthenkolben tragend, welcher von einer flachen, aussen grïnen, innen weissen Blüthenscheide unıgeben ist; Blätter sämmitlich grundständig, herzförmig. 24. Sünpfe, Torfbrüche selten. Wird zwischen Döllnitz und Burg Liebenau, bei Dölkau und Schkeuditz angegeben; fehlt in ganzen südlichen, westlichen und nördlichen Gebiete, im nordöstlichen aber ziemlich 
1erbreitet z. B. Lei Sichierau, bei Oranienbaum im Göttertabruch und in der Nähe der Scheitlache zwischen Gremin und 'Lschicsewitz, an Abhängen des Muldenthales zwischen Rösa und Pouch östlich von Bitterfell, bei Delitzsch in Poetengange nach Gertitz zı. Mai-Juli. Höhe $1 / 2-1 \frac{1}{2}$, . Giftig.

2. Gruppe. Orontiaceen R. Br. Orontiengewächse. Blüthen mit einer Blüthenhülle.

120. Áŏzees C. Kalmus (Pflanzenname bej Dioscorides, rom a priv. und xó oos, Sättigung, Ueberdruss, wril die Wurzel gegen Appetitlusigkeit yebrancht wurde).

1054. A. Cálamus L., gemeiner h. Hayne Arz. neigew. Vi, 31. Schaft blattartig, zusammengedrïckt, mit einer scharfen und einer rinnenförmigen Kante, in der Mitte an der rinnenförmigen Kante einen kegelig. walzenförnigen, sehr dichten, grünlichen Kolben tragend und darüber in eine sehr lange, blattartige, flache Spitze enclend; Blätter sämmtlich grundständig, lang. schwertförmig. 24. Ursprünglich aus Asien stammend, jetzt an Siimpfen. Gräben, Teichen eingebiirgert, obgleich im Gebiete nicht sehr verbreitet. Bei Passendorf sparsam, häufiger zuvischen Danmendorf und Quetz sïdlich von Zörbig, bei Dessau häufig. †. Juni. Juli. Höhe $3-4^{\prime}$. OfF'. radix Calami arumatici.

\section{Familie. Orchideen Juss. Knaben-} krautgewächse.

1. Gruppe. Ophrydineen. Frauenthrănengewächse. Staubbeutel ganz angewachsen; Staubmassen kleiulappig, elastisch - zusammenhängend.

121. Drelnis L. Ku a be n kraut (Pflanzenname bei Dioscorides, von ě $६ \iota s$, Hode, wegen der Wurzelkul. len so benannt).

a. Deckblätter Inervig. Wurzelkuollen ungetheilt.

1. Lippe 3 theilig, der mittlere Zipfel vorne verhreitert. 2spaltig, meist mit einem Zähuclou in der. Ausrandung der auseiluandertretenden Zipfei.

1055. O. fusca Ja cq., b r a un bliithiges K. Sturm Heft 41. Wurzelknollen ungetheilt; Blätter länglich; Lippe pinselförmig - punktirt, 3theilig, die seitenständigen Zipfel linealisch, der mitllere vom Grunde an allmählig 
verbreitert, verkehrt-eiförmig, 'meist mit einem dazwischen liegenden borstenförmigen Zahne, Lappen eiförmig, fast abgeschnitten, ausgehissen-gekerbt, Sporn kürzer als die IIälfte des Fruchtknotens, Zipfel der Blüthenhülle in einen eiförnigen Helm zusammenschliessend, unterwärts zusammengewachsen; Deckblütter häutig, 1nervig, vielmal kiirzer als der Fruchtknoten. 4. In Bergwäldern, unter Gebüsch sonniger Hügel, besonders auf Kalk, selten, nur in Thüringen, zwar immer eiuzeln aber daselbst ziemlich verbreitet. Bei Naumburg nicht gerade selten z. B. am Pfortenberge, bei Freiburg in der alten Giehle nach Pödelist zu, an der Steinklippe bei Wendelstein einzeln, bei Rossleben in der Nähe des Mühlthales häufig, an den Schnonschen Bergen. Mai. Juni. O. militaris $\beta$. und $\gamma$. L. HeIm schwarz-purpurroth uder grünlich nit schwarzpurpurrothen Punkten, Lippe aveiss oder hell-rusenroth purpurn-rauhharig - punktırt. Höhe $2-3$ '.

1056. O. militaris L., helmartiges K. Wurzelknollen ungetheilt; Blätter länglich; Lippe pinselförmigpunktirt, 3theilig, die seitenständigen Zipfel lincalisch, der mittlere linealisch, an der Spitze verbreitert, 2spaltig, mit einem dazwischen liegenden burstenförmigen Zahne, Lappen länglich, spreizend, an der Spitze feingekerbt, Spurn kürzer als die Hälfte des Fruchtkuntens, Zipfel der Blüthenhïlle in einen piförmig-lanzettlichen Helm zusammenschliessend, unterwärts zusaminıngeuachsen; Deckblätter häıtig, 1nervig, vielmal kiirzer als der Fruchtknoten. 4. Nourwiesen, sonnige Kalkberge stellenweise. Nach Sprengel in Bergü̈ldern hei Gutenberg, wo sie in neuerer heit vergeblich gesucht ist, häufig auf den Wiesen bei Kl. Liebenau, Möritzsch, Kötzschlitz, Gross und KI. Dölzig, am Bienitz, an dell Quellen zwischen den Bienitz und Rürkmàrsdorf, bei Weissenfels am Kruge, bei Naumburg, Freiburg und Bibra sehr verbreitet, bei Lodersleben einzeln, am Burhberge bei Rossleben in nererer Zeit niclit wieler gefunden, bei Allstedt sehr selten, nur im Hagen in der Nähe des Schlosses, bei Aschersleben selten, fehlt in 1 ordöstlichen Gebiete, bei Delitzsch in der Sprödaer Heide. Mai. Juni. Heln aschgrau oder hell-purpurroth, I,ippe blass - purpurroth, in der Mitte weisslich, mit purpurrothen Punkten bemalt. Höhe bis $1^{\prime}$.

1057. O. variegata All., buntes K. Flora v. 'Thüring. 1. Heft 2. Wurzelknollen ungetheilt; Blätter läng- 
lich; lippe punktirt, kahl, 3theilig, die seitenstiindigen Zipfel länglich, der mittlere breit-verhehrt-eifürmig, meist mit einer dazwischen liegenden Starhelspitze, alle spitz-gezähnt, sporn halb so lang als der Fruchtino. ten oder etwas länger, Zipfel der Bliithenhiille in einen Helı zusammenschliessend, sämmtlich verschmälert. spitz, die 2 innersten nur ein wenig kürzer als der rückenständige; Deckblätter häutig, 1ncrvin, halb so lang als der Fruchthnoten oder länger. 24. 'Trockene Iriften, Waldränder, Weinberge stellenweise. Findet sich an Apullosberge bei IIestewitz, welchen Ort Spreng. angibt, nicht mehr; aber an nördlichen Rande des Mittelholzes, einzeln am Altrinnstedter Kirchhofe, bei Leislingen unweit Weissenfels, bei Naumburg und Freiburg sehr verbreitet, bei Allsterlt an nurdwestlichen Rande des Rathshulzes, auf den Kirchbofe zu Querfurt, an Bergen bei Niederfarnstedt. Mai. O. tridentata Scop. O. Simia Vill. nach Haller's Syn.. nicht L a m. Blüthen hellpurpurroth, Lippen purpurroth. punktirt. Höhe meist $1 / 2^{\prime}$.

1058. O. ustulata K., $\mathrm{k}$ le in blü thiges K. S t u r m Heft 12. Wurzelknollen ungetheilt; Blätter länglichlanzettlich; Lippe sammetartig-punktirt, 3theilig, die seitenständigen Zipfel länglich-linealisch, an der Śpitze etwas gelierkt, der mittlere 2spaltig, meist nit einem dazwischen liegenden Zähnchen, Lappen länglich-linealisch, etwas gekerbt, Sporn 3mal kürzer als der Fruchtknoten; Zipfel der Blïthenhülle kugelförnig helmartig - zusammenschliessend, eiförmig, frei, die iuneren fast spatelförmig, stumpf; Decklicitter häutig. 1nervig, halb so lang als der Fruchtlinoten. 24. Trokkene Bergabhänge sehr selten. Findet sich am Apollosberge bei Westewitz nicht mehr; aber bei Freiburg an einem Abhange des Miihlholzes Balgstedt gegeniiber, einzeln auch an südlichen Rinde der neuen Giehle und an der Steinklippe bei Wendelstein; wird von Spreng. und $\mathrm{Schwabe}$ auch bei Rothenburg, Alsleben, Bern. burg und Sandersleben angegeben. Mai. Juni. Blüthen klein. Heln dunkel-schwarz-purpurruth, Lippe weiss, mit dunkel-purpurrothen Punkten. Höhe $4-8$ ".

2. Lippe tief-3spaltig, der Mittellappen Iänglich, ungetheilt oder abgestutzt-ausgerandet.

1159. O. corióphora L., Wa nzen - K. Wurzelknollen ungetheilt; Blätter Iinealisch - lanzettlich; Lippe hall. 3spaltig, herabhängend, Zipfel fast gleich, der mittlere 
länglich, ungetheilt, die spitenständigen fast rautenförmig, kürzer, Sporn kegelförmig, gekrünmt, hinabsteigend, 2-3mal kïrzer als der Fruchtknoten, Zipfel der Blüthenhülle helmartig - zusammenschliessend, zugespitzt; Deckblätter häutig, lnervig, so lang oder länger als der Fruchtknoten. 24. Feuchte und trockene Wiesen ziemlich verbreitet. Auf einer Wiese zwischen Dölau und der Heide sehr sparsam, häufig anf Wiesen bei Zöschen, Kl. Dölzig und am Bienitz, gleichfalls häufig auf Wiesen zwischen Kösen und der Rudelsburg, einzeln am Rande der neuen Giehle bei Freiburg, auf einer Wiese zwischen Lodersleben und dem Scheierhulze, bei Dessan auf Wiesen in der Nähe von Alten und Mnsigkau, auf Wiesen an der Benndorfer Mühle, Mai. Juni. Helm schmutzig-rostbraun, Lippe in der Mitte hell-röthlich mit dunkel-purpurrothen Punkten, Zipfel grïn mit röthlichem Rande. Höhe bis 1'. Hat einen wanzenähnlichen Geruch, daher auch der Name coriophora (ron

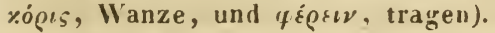

\section{Lippe 3 lappig, Lappen hreit, kurz.}

1060. O. Morio L., gemeines K. Wurzelknollen ungetheilt; Blätter länglich-lanzettlich; Lippe 3lappig, Lappen breit, der mittlere abgestutzt - ausgerandet, Spurn walzen- oder fast keulenförmig, wagrecht oder aufsteigend, ungefähr so lang als der Fruchtknoten, Zipfel der Bliithenhiille stumpf, sämmtlich helmartigzusammenschliessend; Deckblätter 1nervig, die untersten meist 3nervig, su lang als der Fruchtknoten. 4. Trokkene Wiesen, 'Triften, Raine, Hügel meist häufig z. B. auf breiten Rainen und kurz-begrasten Hügeln am Schwalchloche und überhaupt zwischen dem Donnersberge und der Dölauer Heide hinter Kröllwitz nicht selten, ebenso auf Rainen zwischen dem Lindberge und der Eisleber Chaussee, auf Wiesen bei Döla", an Bienitz und sunst nicht gerade selten. April. Mai. Blïthen purpurroth, mit mriinen, starken Adern auf den Zipfeln der Blüthenhülle. Höhe $4-8^{\prime \prime}$. Aendert mit ganz weissen Blüthen ab, so an Schwalchloche hinter Köllwitz, am Bienitz, bei Allstedt an den Pulvertannen beobachtet.

1061. D. pallens L., b lasses K. Flora v. Thüringen 1. Heft 11. Wurzelknollen ungetheilt; Blätter verkehrt-eiförmig, länglich, stumpf; Lippe schwach-3lappig, ganzrandig oder kaum fein-gekerbt, am Grunde sammetartig, Sporn walzenförnig, wagreoht oder auf- 
steigend, ungefähr so lang als der Fruchtknuten, Zip el der Bliithenhiille eiförmig, stumpf, die 3 inneren fast gleich, die 2 seitenständigen zuletzt zuriickgebogen; Deckblïtler Inervig, so lang als der Fruchtknoten, die entwickelte Aehre eiförmig. 24. Bergwiesen, in lichten Laubwälderu, meist anf Kalk, selten. Nur in südlichen Febiete, aber daselbst verbreitet, so in Wäldern bei der Schönburg, in Buchholze, auf denı Pfortenberge, in Wäldern bei Rossbach, bei Freiburg besonders in Schatholze unweit Nismitz und an Abhängen des Mühl. holzes Balgstedt gegeniiber, einzeln auch am Schlifter; vereinzelt und sehr selten in westlichen Gehiete an der Steinklippe links von dem Wendelstein-Nebraer Wege und an den Schmonschen Bergen. April. Mai, friihel als die meisten anderen Knabenkrautarten. Blütlen gelblich - weiss. Höhe $1^{\prime}$.

1062. O. mascula L, männliches K. Flora v. Thüring. I. Heft 2 . Wurzelknollen ungetheilt; Blättel länglich oder lanzettlich; Lippe ticf-3lappig, am Grunde kurzhaarig; Lappen breit, gezïhnt, der mittlere ausgerandet nit einem dazwischen liegenden Zahne, Spurn walzenförnig. wayrecht oder aufsteigend, ungeführ so lang als der Fruchtknoten, Zipfel der Bliithenhiille eiförnig, stumpf, spitz oder zugespitzt, die 2 innersten kürzer als der rüchenständige. die 2 seilenständigen $z u$ let:t zuriickgeschlagen; Decliblätter inervig, su lang als der Fruchtknoten, die entwickelte Aehre verlängert, lokker. 24. An feuchten Stellen in Wäldern und auf Bergwiesen stellenweise. In den Wäldern der Aue nicht selten z. B. bei Kl. I,iebenau, Horbur", Schkeudit, auf Wiesen bei KI. Dölzig sparsamer, bei Naumburg und Freiburg verbreitet, bei Lingenau und Dessau. Mai. Juni. Aendert mit stumpfen, spilzen oder kurzzugespitzten Zipfeln der Blüthenhïlle ah und:

b) specinsa Host: Zipfel der Blïtheuhülle langzugespitzt, so auf Bergwiesen bei Freiburg.

Den Namen männliches Knabenkraut (O. mascula I. oder O. morio mas C. Bauh.) erhielt diese Art von C. B a uhin, weil er eine andere, die O. Morio I. weibliches K. (O. morio fenina) nannte; den ersten Namen hat I,inné beibehalten, den letzten aber nicht angenommen.

h. Deckhlätter 3 - his mehrnervig und entweder die untersten oder alle zugleich netzaderig; Wurzelknollen ungetheilt oder (bei O. sambucina) an der Spitze kurz - blappie.

1063. O. Iaxiflora Lam., lockerbliithigges K. 
Wurzelknollen ungetheilt; Blätter lanzettlich-linealisch; Lippe 3lappig, die seitenständigen Lappen vorne abgerundet, der mittlere tief-ausgerandet, breiter, kürzer oder ein wenig länger als die seitenständigen; Spurn walzenförmig, wagrecht oder aufsteigend, kürzer als der Fruchtknoten, Zipfel der Blïthenhülle länglich, stumpf, die seitenständigen zurückgeschlagen; Deckblätter $3-5 n e r v i g$, die unteren zugleich aderig; Aehre verlängert, locker. 4. Torfhaltige, sumpfige Wiesen stellenweise. Auf Wiesen zwischen der Nietleber Wind. mühle und dem. Dorfe, aber nur in nassen Jahren, anf Wiesen vor Bennstedt häufig, auf Wiesen zwischen Pfitzenburg und Wausleben, auf Wiesen zwischen del Dieskauer Mühle und Döllnitz, bei Kl. Dölzig, fehlt bei Weissenfels, Naumburg, in ganzen westlichen Ge. biete sehr selten, bei Aschersleben sehr häufig, bri Stassfurt, auf Wiesen an der Benndorfer Mishle. Juni. Juli. Blüthen purpurroth. Höhe 1-11/2. Aendert ab:

a) Tabernaemontani Gmel. fl. had.: der Mittel. lappen der Lippe deutlich kïrzer als die Seitenlappen.

b) palustris Jacq.: der Mittellappen der Lippe so lang oder ein wenig länger als die Seitenlappen.

1064. O. sambúcinn L., holunderduftiges K. Wurzelknollen länglich, ungetheilt oder an der Spitze kurz-2-3lappig; Stengel 4-6blätterig; Blätter lanzettlich, vorne etwas breiter; Lippe kurz-3lappig, Sporn kegel-walzenförmig, hinabsteigend, so lang als des Fruchtknoten, die seitenständigen Zipfel der Bliithenhülle abstehend; Deckllutter sämmtlich mahrnervig, länger als die Bliithen. 24. Bergwiesen, zwischen Gebüsch sehr zerstreut, in Nittelholze selten, am Bienitz in newerer Zeit nicht "ieder gefunden, bei Naumburg in Wäldern über der Henne, bei Freiburg verbreitet, be. sonders in den Wäldern an Rödel, bei Allstedt in Theilholze häufig, bei Eisleben in Bischofsröder Holze und in Katharinenholze, fehlt im nördlichen Gebiete ganz. Mai, blüht kurze Zeit nach der O. pallens. Höhe 6-9". Bliithen nur schwach nach Holunder riechend, gelblich-weiss, Lippe hellgelb, an Grunde mit purpurrothen Pünktchen. Aendert aber mit purpurrothen Blüthen $a b$ : 0 . incarnata Willd. und der deutschen Autoren, nicht Lin. Beide Formen wachsen an den angegebenen Stellen meist beisammen. 
e. Deckblätter 3 - his mehrnervig und entweder die untersten oder alle zugleich netzalerig. II urzelknollen handförnig.

1065. O. maculata L., geflecktes K. Wurzclknollen handfürmig; Stengel nicht hohl, meist 10blätlerig, die oberen Bliitler verkleinert, deckblatlfürmig, das oberste von der Achre weit entfernt, die mittleren lanzettlich, nach beiden Enden verschmälert, die untersten länglich; Lippe 3lappig, Spurn kegel-walzenförmig, hinabsteigend, kürzer als der Fruchtknoten, die seitenständigen Yipfel der Blïthenhülle abstehend; Deckläitter 3nervig und aderig, die nittleren so lang als der Fruchtknoten, die untersten länger als derselbe. 4. Wälder, lichte Waldstellen, Wiesen häufig. Juni. Juli. Blüthen hell-lila oder fast weiss, mit purpurrothen Flecken und Linien. Höhe 1-2'. Die Blätter sind meist braun gefleckt.

1066. O. Iatifolia L., bre itblätteriges K. Wurzelknollen handförmig; Stengel röhrenförmig, 4-6bliithig; Blätler abstehend, die unteren oval oder lïnnlich, stumpf, die oberen kleincr, lanzettlich, zngespitzt; Lippe 3lappig, Sporn kegel-walzenförnig, hinabsteigend, kïrzer als der Fruchtkngten, die seitenständigen Zipfel der Blïthenhiille anfwärts - zurïckgeschlagen; untere und nittlere Deckblätter länger als die Bliithen, alle 3nervig und aderig. 24. Nasse und sumpfige Wiesen gemein z. B. bei Dölau, Nietleben, Bennstedt u. s. w. Mai. Juni. O. latifulia Fries Novit. ed. 2. mant. 1. o. majalis $R \mathrm{chb}$. Blüthen purpurroth; Blätter meist braun gefleckt. Höhe $3 / 4-1^{\prime}$. Die Pflanze hat einen schlaffen Wuchs.

1067. O. incarnata L., nach Fries, fle ischfar. benes K. Wurzellnollen handförmig; Stenoel röhrenförmig, 4-6bliitterig; Blïtter aufrecht, mit dem Stengel glcichlaufend, verlïngert.lunzettlich, nach oben verschmälert, an der Spitze miitzenförmig-zusammen. gezogen, das oberste den Grund der Aehre überragend, das unterste kürzer, ahstehend; Lippe 3lappig, Sporn kegel - walzenförmig, hinabsteigend, kürzer als der Fruchtknoten, die seitenständigen Zipfel der Bliithenhülle abstehend, später aufwïrts-zurückgeschlagen; Deckblätter sämmilich länger als die Bliithen, 3nervig und adcrig. 24. 'I'orfhaltige, Sumpfige Wiesen nicht allgemein verbreitet. Auf Wiesen zwischen Dölau und der Heide, auf torfhaltigen Wiesen zwischen Lieskau und dem Zorgs, auf Sumpfwiesen unter dem Tannen- 
berge bei Gutenberg, auf Wiesén zwischen der Dies. kauer Mühle und Döllnitz, auf Wiesen hinter dem Schlossgarten bei Zörbig, ebenso bei Kl. Dölzig, bei Naumburg in der Aue, bei Schulpforte und auf der Gröbitzer Wiese. Juni, fängt erst an zu blïhen, wenn die vorhergehende bereits verbliiht ist. 0 . angustifolia Wimm. u. Grab. O. Jatifolia Rchb. Blüthen fleischfarben bis purpurroth. Blätter meist ungeflecht. Höhe $3 / 4-11 / t^{\prime}$. Die Pflanze hat einen kräftigeren und steiferen Wuchs.

422. AmReamptis te

1068. A. pyramidalis Richard, pyramiden förmige H. Wurzelkuollen ungetheilt; Blätter lanzettlich-linealisch; Lippe halb-3spaltig, am Grunde mit 2 seitlichen Plättchen, die Lappen länglich, stumpf, gleich, ganzrandig, Sporn fadenförmig, so lang oder länger a!s der Fruchtknoten, Zipfel der Blüthenhülle eiförmig-lanzettlich, ziemlich spitz, die-seitenständigen abstehend; Dechblätter am Grunde 3nervig; Aehre gedrungen. 24. Bewaldete Bergabhänge anf Kalk und buntem Sandstein, sehr selten. An einigen Stellen der Steinklippe bei Wendelstein, an Abhängen des Buch. berges bei Rossleben, an den Bergen bei Bibra, erscheint aber nur in nassen Jahren in grösserer Anzahl (früher. auch am Pfortenberge bei Naumburg gefunden). Juni. Juli. Orchis pyramidalis $L$. Bliithen purpurroth. Höhe $1 \frac{1}{2}-2$.

423. Cymmadéaia R. H 10. H öswurz (ron $\eta^{\prime} v$ uvós, nacht, und čơn', Drïse, eigentlich Nacktdrüse, "eil die Fächer des staubbeutels am Grunde ohne Beutelchen sind; der Tririalname conopsea ist aus xivery', Nïicke, Fliege, gebildet).

1069. G. conópsea R. B r., fliegenaltige H. Wurzelhnollen handförnig; Blätter verlängert-lanzettlich; Lippe 3spaltig, Lappen eiförnig, stumpf, Sporn fadenfürmis, fast doppelt so lang als der Fruchthno. ten, die ̈̈iusseren Zipfel der Blïthenhiille weit abstehend; Dechblätter 3nervig, so lang oder länger als der Fruchtknuten: Aehre walzenförmig, verlängert. 24. Trockene und nasse, torthaltige Wiesen, Kalkhaltige Rergabhänge. Auf nassen Wiesen hei hil. liebenau, zuischen Göhren und Kodden, bei Kl. Dölzig, am Bienitz häufig, bei 
Naumburg und Freiburg, häufig auf Kalk z. B3. am P'urtenberge und nach dem Murdthale zu, am Srhaafholze unweit Nismitz, im Mühlholze u. s. w., an den Bergen bei Bibra, an den Schmonschen Bergen, bei Dessau auf den Wiesen bei Alten, auf Iorfwiestn bei Crina östlich von Bitterfeld und anf Wiesen am Bruche zwischen Sandersdorf und Bitterfeld. Juni. Juli. Orchis conopsea L. Blüthen purpurruth. Höbe 1-2'. Aen. dert bisweilen mit kiirzeren, dem Fruchtknoten kaum gleichlangen sporue ab, unterscheidet sich dann aber durch die grösseren Blithen und den nur schwachen Germch von der foigenden Art.

1070. G. odoratissima re ichard, Wohl riechell. de H. Wurzelknollen handförmig; Blätter linealisch. Ianzettlich und linealisch; Lippe 3spaltig, Lappen eiförmig, stumpf, sporn fadenförmig, ungefïlor so lang als der Fruchtlinoten, die äusseren Zipfel der Bliithenhiille weit abstehend; Deckblätter 3nerijg, so lang oder län„er als der Fruchtknoten; Aehre walzenförnig, verlängert. 24. Feuchte Wiesen sehr selten, nur auf Wiesen bei Kl. Liebenau und Kl. Dölzig. Juni. Juli. Orchis odoratissina $I$. Blüthen kleiner als an der vorigen Art, wohlriechend, meist purpurroth.

424. Himantoglossum Spe $\mathrm{mg}$. Ri emen-

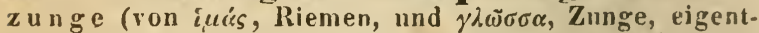
lich Riemenzunge, weil bei $\mathbf{H}$. hircinum der Mittellappen der Lippe riemenartig verlängert ist).

1071. H. Hícinum R $\mathrm{i}$ h., Bucks-R. Flura s. Thüring. I. Heft 11. Wurzelknollen ungetheilt; Blätter elförmig-lanzettlich; Lippe 3theilig, 'Lipfel linealisch, der mittlere sehr lang, an der Spitze 2spaltig, etwas gedreht, die seitenständigen viel lürzer, wellenförnig. kraus, Zipfel der Blüthenhiille helmartig-zusammen. schliessend; Sporn sehr kurz, kaum $1 / 3$ so lang als der Fruchtknoten; Deckblätter länger als der Fruchtknoten. 4. Waldränder, buschige Hiigel, Weinberge gern auf Kalk, sehr selten. Einzeln auf dem Pfortenberge bei Naunburg, häufiger bei Rossbach, in den Weinbergen bei Zengfeld unweit Freiburg, einzeln und sehr selten am Schlifter bei Freiburg. Mai. Juni. Satyrium hircinum L. Loroglossum hircinum Rich. Orchis bircina Swartz. Heln weiss, inwendig purpurroth und griin gestreift; Iippe weisslich-grün, rötblich-punktirt. Höhe $2^{\prime}$ und darüber. 
Von Schwabe fl. anh. wird diese seltene Pflanze auclı bei Sandersleben an der Freckleber Kalkhütte angegeben.

425. Platanthéra Fich. Kuckucksblume

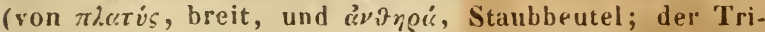

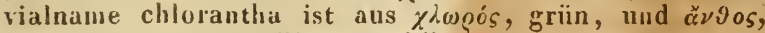
Blume gebildet).

1072. Pl. bifolia IR ich., $z w e$ iblätterige K. Wurzelknollen geschwänzt; Stengel ïber dem Grunde mit 2 gegenständigeu, rerkehrt-eiförmigen oder ovalen Blättern; lippe ungetheilt, linealisch, Sporn $1 \frac{1}{2}$ - bis Imal so lang als der Fruchtknoten, faden örmig; Deckblätter fast so lang oder länzer als der Fruchtinoten; Staubbcutelfächer gleichlaufend. \&े. Wälder und Wiesen häufigr z. B. in der Dölauer Heide, im Nittelholze u. s. W. Juni. Juti. Orchis bifolia L. 0 . bifulia $\beta$. brachyglossa Wa $\mid l$ r. Habenaria bifolia R. B r. Blüthen veiss, mit hellgrïner Lippenspitze und Sporn. Höhe 1'.

Vom Volke wird diese Pflanze im Gebiete auch Nachtschatten genant und von Solanmm Dulcamara l., " Nelches gleichfalls und zwar in weiteren Kreisen Nachtschatten heisst, durch den Kusatz wohlrie. che ud ex. $\mathbf{N}$. unterschieden.

Eine de! Pl. hifulia Ri ch. nahestehende Pflanze ist die in neuerer Zeit als Ait unterschiedene Pl. pervia l'eterm., welche, nach dem standorte zu schliessen, von Rchb. ก. sax. ed. 1 и. 2 p. 89 zu Pl. Wankelii G. Rchb. gezogen wird, wozu sie jedoch nicht gehören kanı. Sie unterscheidet sich vun Pl. bifolia $\mathrm{Rich}$. durch folgende Merkmale: Schlund der Blïthe ganz oflen, weit, rundlich. innenseits am Grunde whne Driisenhöcker; Staubbeutelfächer parallel-aufiecht; Aehre kurz, dichter, Lippe ganz griin, Spuru dicker, fleischiger; sie wächst auf feuchten Torfwiesen bei Kl. Dölzig und am Bienitz, blüht in Juni und Juli, aber später als PI. bifolia. Weitere Untersuchungen werden bald ein sicheres Resultat liefern.

1073. P1. chlorantha Castor, grünblü thige K. Lippe ungetheilt, linealisch; Sporn doppelt so lang als der Fruchthuoten, fadenförmig, nach hinten fast keulenförmig: Staubbeutelfächer mit der Spitze an einander stossend, zntervärts weit aus, einander gehend. 4. Schattige Wälder sehr selten. Bei Naumburg in Sperlingsholze, häufiger an Abtrüngen bei J,engefeld, auf frarcke, Flora. 
Wiesen am Schaafholze bei Nismitz unweit Freiburg, an Kalkbergen bei Bibra. Juni. Juli. Orchis bifulia $\alpha$. macroglossa Wallr. O. virescens Zollik of. Bliithen grün. Höhe bis 2'.

426. Dphrys L. Frauenth lä ne (von òy gís, Allgenbraune, Stulz, vielleicht wegen der schönen Blïthen).

1074. O. muscifera Huds., Fliegen-F. Flora v. 'Thüring. I. Heft 11. Wurzelknollen ungetheilt; Blätter glänzend, länglich-lanzettlich, zugespitzt, am Grunde des Stengels stehend; lippe länglich, sammetartig, in der Mlitte mit einem fast 4eckigen, kahlen Flecken, doppelt so lang als die Blüthenhiille, 3spaltig, die seitenständigen Lappen lanzettlich, der mittlere doppelt so lang, an der Spitze tief 2 lappig, olme Anhäingsel, die zwei inneren Zipfel der Blïthenhülle zottig, linealisch, zusammengerollt und fadenförmig. 24. Kurz begraste, trockene 'Triften, sonnige Stellen in Laubwälder'n, am läutigsten an Kilkberge'l, im Gebiete stellenweise. Bei Naumburg sehr häufig z. B. bei Almerich, Schulpforte, jum Murdthale, bei Kösen u. s. w., bei Freiburg besonders an den Schlagbergen und an kurz begrasten $\mathrm{Ab}$ hängen des Niilıhulzes, an dell Kalkbergen bei Bibra häufig, bei Oranienbaun im Nichrim; nach s $\mathrm{ch}$ wabe anch hei Bernburg und Alsleben. Mai. Juni. O. myodes swartz. 0 . insectifera ${ }^{\circ}$ myodes L. Lippe dunkel. rothbraun, in der Nitte mit einem grau-bläulichen Flecke. Bliithenhiille grün. Höhe $1 / 2-1$ '.

1075. O. aranifera Hud so, s' $p$ in n e n - F. Wurzelknullen ungetheiłt; Blätter lanzettlich; Lippe länglich. verkehrt-eiförnig, ungetheilt, gewölbt, gedunsen, am Rande zuriikgrebugen, an der Spitze stump/ oder schuach. ausgerandet, ohne Anliängsel, behaart, in der Mitte mit $2-4$ am Grumde quer-verbundenen Kahlen Längslinien, die änsseren Zipfel der Blïthenhülle ungefähr sol lang als die Lippe, die imeren kiirzer, kahl. 24. Sonnige Wiesen, Wülder. Bergabhänge äusserst selten; nur einzeln an Pfurtenberge bei Naumburg. Mai. Juni. Lippe mit einem stumpfen kleinen 'Zahne beiderseits in der Mitte des Randes, aber nicht 4lappig, purpurbraun oder gegen den Rand hin gelblich, die, kahlen Linien trüb. gelb. Blüthenhülle grün. Höhe bis $1 / 2-1$ '.

1076. O. apifera $\mathrm{H}$ ud s., B i enen.F. Wurzelknullen ungetheilt; Blätter lanzettlich; Lippe rundlich-verkehrt-eiförmig, gewölbt, geclunsen, samnietartig, ge- 
scheckt, 5 spaltig, die 2 inneren Jappen eiförnig, etwas abstehend, am Grunde mit einem rauhhaarigen Höcker versehen, die 3 anderen zuriickgekrïmmt, unterseits zusammenneigend, der mittlere in ein kahles Anhängsel endigend, die inneren Zipfel der Blüthenhülle kurz, kurzhaarig. 24. Trockene, sonnige Wiesen, Weinberge sehr selten; nur bei Naumburg in Weinbergen am Kruppenthale zwischen Schönburg und Wetau, an . Ibhange des Pfortenberges nach der Windlücke $\mathrm{zu}$, bei Kösen, besonders häufic an Abhängen des Berges jenseit Lengefeld. Juni. Juli. N. insectifera t. l. Lippe braun, mit „elblichen Zeichnungen. Höhe bis $\mathbf{1}^{\prime}$.

Aceras anthropophora R. Br. oder Ophrys a "thropophura $L_{\text {. }}$ ist von Wallr. (cf. ann: bot. p. 104) vor 1815 an begrasten Hügeln im Mühlthale links vom Rossleben-Ziegr.Jröler Wege gefunden, wird aber seit jener Zeit daselbst vergeblich gesucht.

\section{Herminimun F. Fr. Rag w urz (von £̨uiv,} Stütze, Pfahl, wegen des einfachen Stengels).

1077. H. Monorchis R. B r., einknollige R. Flura v. Thïring 1. Heft 11. Stengel an Grunde meist mit 2 linealisrhen Blättern: Zipfel der Blüthenhïlle 3lappig, der Mittellappen verlängert, Lippe tiefer 3spaltig, 'Zipfel linealisch, die seitenständigen fast spiessföruigabstehend, der mittlere Zipfel duppelt so lang. 4. Feuchte und trockene Wiesen, Triften, begraste Bergabhänge selten. Auf Wiesen zwischen Kl. Dölzig und dem Bienitz, aber jetzt weit seltener als früher, bei Naumburg an Abhängen des Pfortenberges in der Nähe von Almerich, bei Freiburg an grasigen Abhängen des Mühlhulzes Balgstedt gegenüber. Mai. Juni. Ophrys Monorchis I. Blüthen klein, gelblich-grün. Höhe 4- ${ }^{\prime}$. An Grund des Stengels befindet sich ein einziger, sundlicher Knollen, "elcher aber an einem langen Stiele einen netuen, entfernt stehenden treibt.

2. Gruppe. Li modoreen. Dingelgewächse. Staubbeutel frei. Blüthenstaubmassen aus zahlreichen, kantigen, elastischzusammenhängenden Läppchen zusammengesetzt oder mehlig, oft mit ihrem Grunde an ein€r nackten Drüse änhăngend.

428. Cephalanthéra Fi elh. W a I dvögle in

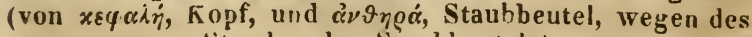
Stiandes des Staubbentels).

1078. C. pallens Rich., blasses W. Flora v. 
'Thiiring. 1. Heft 11. Blcitter eifürmir oder eifürmiglänglich, zugespitzt; Fruclitknoten hahl; Platte der Lippe herz-eiförnig; breiter als Jang, alle Zipfel der Blüthenliülle stunuf; Decliblätter liinger als der Fruchtfnoten. 4. Bergwälder, besonilers auf Kalkbudell, selten. Bei Naumburg in allen Waldungen häufig, bei Freiburg im Schaafholze unweit Nismitz, in der neuen Giehle und sonst verbreitet, einzeln an Buchberge bei Russleben, an den Schnonschen Bergen. Juni. Epipactis pallens $\mathbf{S}$ w. Serapias graudillora Scop. S. Iongifolia Huds. Blüthen weiss mit schwach-gelblichem Anfluge, Lippe mit gelben Linien. Möhe $3 / 4-11 / 2^{\prime}$.

1079. C. ensifolia ich., schwertblätteriges W. blätter lanzettlich, die oberen linealisch lanzettlich, verschmälert-spitz; Fruchtinoten liahl; Platte der lippe sehr stumpf, breiter als lang, die äusseren Zipfel der Bluthenhiille spitz; Decliblïtler vielmal liirzer als der Fucliknoten, die untersten bisweilen su lang als derselbe. 24. Iaub- und Nadelwälder stellemweise. Bei Naumburg in allen Waldungen, aber etwas seltener als die vorige Art, bei Freiburg am Rande der neuen Giehle. und im Schaatholze unweit Nismitz, fehlt jetzt am Buchlerge bei Rossleben, wo sie einst Wallr. fand, findet sich in den Schmonschen Bergen, bei Unterfarnstedt nördlich vou Querfurt, in feuchten, schattigen Wäldern bei Lingenau und Dessau. Juni. Serapias ensifulia S m. Epipactis ensifolia swartz. Bliithen weiss, mit einem gelben Flecke an der Spitze der Lippe. Höhe $3 / 4-11 \%$ '

1080. C. rubra Rich., rothes W. Blcitter lan. zettlich oder linealisch-lanzettlich, zugespitzt: Frvuchtknoten weichhaarig; ' $Z$ ipfel ller Blüthenhülle alle zugespitzt, Platte der Lippe eiförmig, zugespitzt, su lang als die inneren 'Zipfel. 24. Wälder, buschige Hügel, gern anf Kalk, selten. Bei Naumburg, bei Freiburg in der alten und neucu Giehle, an den Schmonschen und Grockstedter Bergen. Juni. Juli. Serapias rubra L. Epipactis rubra A Il. Bliithen schön purpurroth, lippen mit vielen ge!ben Streifen. Höhe $1-2$ '.

429. Epipactis Tient. Sumpfwurz (Pflanzenname bei Plinius).

1081. F. Iatifolia A 11., bre it blät terige S. Bluitter eiförnig, an Rande und auf den Nerven weichhaarig-rauh, länger als die Stengelglieder; Blüthenhülle zuletzt weit-abstehend, die Zipfel derselben alle kahl, 
Platte der Lippe zugespitzt, an der Spitze zurückgebogen, die Höcker am Grunde derselben glatt. 4. Schattige, feuchte Wälder und Gebüsche stellenweise und fast immer einzeln. In der Pröse bei Glessina nördlich von Schkeuditz, im Bienitz, in schattigen Wäldern bei Naumburg häufig z. B. nach dem Mordthale $z u$, bei Rossbach, ebenso bei Freiburg in Schaafholze unweit Nismitz und an Abhängen des Nühlholzes, in schattigen Wäldern bei Ziegelrode, bei Allstedt im Bornthale und in der Hube unweit Voigtstedt, bei Dessau in Georgengarten, Entenfang, an quelligen Stellen des Muldenthales zwischen Pouch und Rösa östlich von Bitterfeld. Juli. Aug. Blüthen grünlich oder grunlich nit röthlichem Antluge. Höhe $1-2$ '.

1082. E. rubiginosa Ga ud., b ra un rothe S. Blät. ter eiförmig, an Rande und auf den Nerven weichhaarig-rauh, lïnger als die Stengelglieder; Blüthenhülle gluckenförmig - offen, die 3 äusseren Zipfel etwas weichhaarig. Platte der Lippe zugespitzt, an der Spitze zurücligekrümmt, die Höclier am Grunde derselben faltighraus. 24. Uníruchtbare Hügel, auf Kalkboden, nicht sehr verbreitet, aber gesellig. Bei Naumburg und Freiburg sehr verbreitet, an den Bergen bei Bibra häufig, ebenso an den Bergen bei Schmon. Juni E. latifolia $\beta$. rubiginosa Gaud. Serapias latifolia atrorubens $\mathrm{H}$ of $\mathrm{fm}$. Blüthen kleiner als an der vorigen Art, dun. kel-braunroth "der schmutzig-violett. Höhe $1-1 \frac{1}{2} 2^{\prime}$.

1083. E. microphylla Ehrh., kleinblät terige S. Blätter ei-lanzettlich oder lanzettlich, am Rande weichhaarig-rauh, auf den Nerven kahl, die mittleren und oberen kürzer oder so lang als die Stengelglieder; Blüthenhülle glockenförmig, die Zipfel an der Spitze gerade vorgestreckt, die 3 äusseren weichhaarig, Platte zugespitzt, an der Spitze zurückgekrümmt, die Höcker am Grunde faltig-kraus. 4 . Berguälder, buschige Hïgel sehr seltell, nur bei Naumburg zwischen der Kuhlenstrasse und dem Mordthale, am Ahhange des Berges, an den Schmonschen Bergen äusserst selten. Juni. Juli. Blüthen grün, am Rande röthlich, Lippe am Rande weisslich. Höhe bis '1'.

1084. E. palustris Crantz, gemeines S. Sturm Heft 13. Blïtter lanzettlich, am Rande kaum etwas rauh, auf den Nerven kahl: Platte der Lippe rundlichstumpf, so lang als die Zipfel der Blüthenhülle. 24. Sumpfige, besonders torfhaltige Wiesen stellenweise, 
keinesweges gemein, wie Spreng. angibt. Sumpfwiesen vor Bennstedt, zwischen Kölme und Langenl. bogen, Wiesen zwischen Göhren und Rodden, beı Kl. Dölzig, am Bienitz, bei Osterfeld, auf Wiesen bei Balgstedt unweit Freiburg, auf Sumpfwiesen zwischen dem Walde Namens Mish und Bibra, bei Eisleben anf sumpfigen Wiesen in der Glume, bei Lingenau, Oranien. haum, an der Benndorfer Mühle, bei Delitzsch. Juni. Juli. Serapias palustris S'cop. S. longifolia L. Bliithen grau-grünlich, inwendig am Grunde röthlich, Lippe weiss, roth-gestreift. Höhe $1-1 \% 4^{\prime}$.

430. Listérn R. Br. Z weiblatt (zu Ehren des englischen Naturforschers Mart. Jister genannt).

1085. L. ovata R. B r., e iblät teriges Z. Flora v. Thüring. 1. Heft 11. Stengel mit 2 gegenstindigen, eiförmigen, rundlichen oder "valen Blätter" besetzt; Zipfel der Blüthenhülle helmartig-zusammenschliessend, Lippe linealisch, tief-2spaltig. 24. Wälder, Gebüsche, feuchte Wiesen häufig z. B. in Sebener Busche, in Gebüschen vor Gutenherg sehr zahlreich, ebenso bei Dieskau und sonst verbreitet. Mai. Juni. Ophrys ovata L. Epipactis ovata All. Neottia latifulia Rich. Blüthen grïnlichgelb. Höhe $1-1 \frac{1}{2}$.

431. Neottin L. Vuge Inest (von veotrix, Nest, die nestartig sich in einander schlingenden Wurzeln bezeichnend).

1086. N. Nidus avis $\mathrm{R} i \mathrm{ch}$., gem e ill es $\mathrm{V}$. Strngel hlattlos, nit Scheiden besetzt; Lippe verkehrt-herzförnig, undeutlich 3lappig, Deckblätter län. yer als die Bluthenstiele. 24. In schattigen Wäldern auf Baumwurzeln schmarutzend. In der Nähe von Halle sehr selten, einzeln im Lindberge und bei Gutenberg, häufig in den Wäldern bei Freiburg und besonders im l,udersleber und Ziegelroder Forste, in den Schnouschen Bergen einzeln, bei Allstedt in Rathsholze in der Nähe der Pulvertanuen hänfig, in Küchenberge bei Holzzelle unweit Eisleben, in Wäldern bei Lingenau, bei Oranienbaum in Nichrim. Mai. Juni. Ophrys Nidus aris L. Epipactis Nidus aris A.II. Die ganze Pflanze gelb, endlich bräunlich. Höhe bis $\mathbf{1}^{\prime}$.

432. Goodyéra R. H r. G o odyere (zum Andenken an den englischen Naturforscher Goodyer benannt).

1087. G. repens R. Br., kriechende G. Flora 
r. Thüring. I. Heft 11. Stengel mit Scheiden versehen, oberwärts nebst dell Blättern hehaalt; Wurzelblätter eiförmig, gestielt, netzaderig; Deckblätter so lang als der Fruchthnoten. 2. Zwischen Mous und abgefallenen Nadeln in Nadelwäldern sehr selten, nur in der Lingenauer Heide bei Dessan. Juli. Aug. Satyrium repens L. Neottia repens $\mathbf{S}$. Blüthen klein, weiss. Höhe $1 / 2-3 / 4$.

433. Spiranthes Fö in. Wendelorche (von

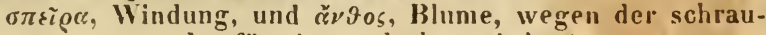
benförmig - gedrehten Aehre).

1088. Sp. antumnalis Reh., Herbst- W. Wurzelknullen länglich-walzenförmig; Stengel blattlos, mit scheidenförmigen Schuppen besetzt; Wurzelblatter eiförmig uder eiförmig-länglich, in den Blattstipl vorgezogen, neben dem Stengel stehend; Aehre schraubenförmig-gedreht; lippe verkehrt-eiförnig, ausgerandet. 4. Truckene, huchuelegene-'Iriften sehr selten. Mit Sicherheit nur bei Allstedt in der Nähe der 'Iannen und dem Rathsteiche und nach Laudgrafrude zu. Aug.Octob. Ophrys spiralis I. Neottia spiralis Sw. Bliithen klein, weisslich. Höhe bis $\mathrm{S}^{\prime \prime}$.

In der Nähe der Lehmgrube in Buchthale unweit Rossleben, wo diese Pflanze IV allr. einst fand, ist sie in neverer Zeit nicht wieder beobachtet, dagegen ist sie bei Weissenfols auf Wiesen wach Jangeudurf zu einmal gefunden; von Spreng. Werden noch Wulferode und Gräfenstuhl unweit Mannsfeld als Standurte angegeben.

3. Gruppe. Malaxideen. Weichkrautgewächse. Staubbeutel frei; Blüthenstaub wachsartig oder aus Körnchen bestehend, welche zuletzt in eine wachsartige Masse zusamınenfliessen.

434. Comallorrlíza Th a!. Kuralle nwurz (von roguidicov, Koralle, und gi ç. Wurzel, wegen des korallenartigen Wurzelstockes).

1089. C. innata r. Fr., e ingewachsene $K$. Flora v. Thïring. I. Heft 2. Verzweigungen des korallenartigen Wurzelstockes ineinandergewachsen; Stengel blattlos, mit scheidenförmigen Schuppen besetzt; Aehre armblüthig, Zipfel der Bluithenhiille spitz, die unteren herabgebogen, lippe länglich, stumpf, beiderseits stumpf 1zähnig, das Mittelfeld der Länge nach 2schwielig. 4. 
Schattige Lauh - und Nadelwälder, auf Baumwurzeln schmarotzend sehr selten. Juni-Aug. Ophrys corallorrhiza I. Cymbidium corallorrhiza Swartz. Bliithen grünlich-weiss. Höhe $6-9 "$.

Diese äusserst seltene Pflanze wird von Spreng. hal. ed. 1. p. 253 in sumpfigen Wäldern bei Lodersleben und Ziegelrude als sehr selten angegeben und in der 2. Aufl. der Flora ganz unerwähnt gelassen. In nenerer Zeit ist sie in jener Gegend wiederum gefunden, abes nur sehr selten.

435. Sturmia Rehb. Sturnie (nach den Botaniker Jacob Sturm benannt).

1090. St. Loeselii It chb., I, ösel's St. Schaft 3 kantig, an Grunde 2blätterig; Blätter elliptisch-lanzettlich, glänzend; Aehre 3-sbliithig; Lippe eiförmig, stumpf, fein-grkerbt, von der Länge der Zipfel der Blütheuhülle. 24. Auf morrigen Wiesen sehr selten und meist nur in sehr nassen Jahren. Früher in 'Torfstichen an der Benndorfer Mühle, daselbst aber seit Jängerer Zeit vergeblich gesucht; auch auf der Grenze anf Sumpfwiesen bei Hecklingen unweit Stassfurt einst gesammelt, in newester Zeit nu auf Wiesen zwischen Querfurt und Nemsiorf gefunden und zwar nur sehr sparsam. Juni - Aug. Ophrys Loeselii L. Liparis Lueselii Rich. Blüthen grïnlich - gelb. Höhe 4-8". Ein eiruniter, mit einer Scheide versehener Knollen steht an der Seite des Stengels.

4. Gruppe. Cypripedieen. Frauenschuhgewächse. Blüthen 2männig.

436. Cypripedium L. Frauenschuh (von Kiv$\pi \varrho \iota s$, Venus, und $\pi i \delta\llcorner o v$, Fuss, Schuh).

1091. C. Calcéolus L., gemeiner F. Florar. Thüring. l. Ileft 11. Stengel beblättert; Blätter elliptisch, zngespitzt; Lappen der einwärts gekrümmten Befruchtungssäule herabgebogen, eiförmig, stumpf; Lippe etwas zusanmengedrückt, kürzer als die Zipfel der Bliithenhülle. 2ł. Laubwälder, buschige Bergabhänge, besonder's auf Kalkboden, selten, nur in Thüringen. Bei Naumburg in den Laasen, im Sperlingsholze, auch nach Schulpforte zu pinzeln, bei Freibury am Schlifter einzeln, hänfiger im Schaaf - und Mühlholze, in Weinbergen bei Laucha, an Kalkbergen bei Bibra häufig, da- 
„egen hei Erdeborn nach Ausrodung der Wälder längst verschwunden. Mai. Juni. Biuthenhüllblätter purpurbraun, lippe gelb. Höhe 1'.

CIII. Familie. Irideen Juss. Schwerte Igewäclise.

437. GIaliolus L. S i e g w u r z (von gladius, Schwert. wegen der schwertförmigen Blätter).

1092. C. palustris Ga ud., Sumpf - S. Sturm Heft 83 Fasernetz der Wurzelknollen stark, mit riuden und eiförmigen Maschen; Blätter an Grunde dek stengels linealisch-schwertförmig; die uberen seitlichen Zipfel der Bluitheuhülle rauten.eiförmig, die Staubhentel hürzer als die 'Träger; die 'Zipfel der Narbe anf. wärts allmählig verbreitert und fast ron ihrem Grunde an mit Papillen bewimpert; die Kapsel länglich-verkehrt-eiförmig, gleichmässig 6furchig, an der Spitze abgerundet, nicht eingedriickt. 24. Sumpfige Wiesen sehr zerstrent. Auf lWiesen bei KI. Dölzig, auf des Sauerwiese zwischen Göhren und Rodden, auf Wiesen bei Mosigkau unweit Dessau, bei Oranienbaun auf der grossen Luchwiese in der Nähe der Briickmülıle, am 'Torfstiche bei der Benndorfer Mühle. Juni. Juli. G. Buncheanus Schlecht. G. pratensis Alb. Dietrich. Blïthen purpurroth mit einem weissen, dunkel-purpurrothen, eingefassten Streifen auf den drei unteren Zip. felı der Blïthenhülle. Höhe 1-2'.

Hierher gehört anch G. imbricatus bei Spreng. hal. ed. 2. p. 30, aber nicht Lin., wofïr spreng. diese Pflanze ausgibt. Der von ihm angefuhrte Stand. ort „auf Waldwiesen bei Löbejün“ hat seit der gänzlichen Ansrodung der Wälder daselbst natürlich keine Giltigkeit mehr.

438. Iris L. Schwertel. Schwertlilie (Pfanzennane bei Theophrast, von iovs, Regenbogen, wegen der Mannigfaltigkeit der Blüthenfarben dieser Pflanzen).

A. Bärtige. Die üusseren Zipfel der Blïthenhülle am Grunde inwendig mit einen Streifen dicht-gestellter Haare besetzt.

1093. I. germanica L., d e u ts cher Sch. Abb. 765. Bärtig; Blätter schwertförnig, Stengel mehrbliithig, 
länger als die Blïtter; Bliithenscheiden während des Aufblihens vom Grunde bis zur Milte krautartig; innere. Zipfel der Blüthenhïlle so lang als die äısseręn, hreit. verkehrt-eiförmig, plötzlich in den Nagel vorgezogen; Staubbeutel so lang als der Träger; Zipfel der Narbe. länglich, an ler Spitze hreiter, die Lappen eiförnig, ausgespreizt. 24. Auf Lehmmanern in Dörfern hin und wieder angepflanzt z. B. in Kl. Dölzig, Kötschau u. s. w., sonst häufig in Gärten gezowen. Mai. Blüthen geruchlos, dunkel-violett, Nägel gelblich-weiss, mit braunen Aderin. Höhe $1-2^{\prime}$.

1094. I. squalens $\mathrm{L}$., s $\mathrm{c}$ h m u tziger $\mathrm{S} \mathrm{ch.} \mathrm{Abb.} 763$. Bärtig; Blätter schwertförmig; Stengel mehrbliithig, länger als die Blätter; Bliithenscheiden während des Aufblühens vom Grunde bis zur Mitte krautartig; äussere 'Zipfel der Blüthenhulle verkehrt-eiförmig, innere su lang als die äusseren, oval, an der Spitze ganz oder schwach-ausgerandet, plötzlich in den Nagel zusallmengezogen; Träger anderthalbmal so lang als der Staubbeutel; Zipfel der Narbe länglich, in der Mitte ein wenig breiter, die Lappen eiförmig, vorgestreclit, auseinanderfahrend. 24. Auf Lehmmauern angepflanzt z. B. in Querfurt, ansserden häufig in Gärten. Juni. Aeussere Zipfel der Blüthenhülle violett, hinten weisslich, mit dunkleren Adern bemalt, die inneren blassschmutzig - gelb. Höhe $1-2$ '.

1095. I. sambúcina L., holundelduftiger Sch. Abb. 762. Bärtig; Blätter schwertförmig; Stengel mehrblüthig, länger als die Blätter; Bliithenscheiden während des Aufbliihens von Grunde bis zur Mitte krautartig; äussere Zipfel der Blïthenhïlle verkehrt-eiförmig, innere so lang als die iusseren, oval, mit einer spitzen und deutlichen Kerbe ausgerandet, plötzlich in den Nagel zusammengezogen; Träger anderthalbmal so lang als der Staubbeutel; Zipfel der Narbe länglich, in der Mitte ein wenig breiter, die Lappen eiförmig, mit ih. rem inneren Rande zusammenschliessend. 24. Felsen, hochgelegene Waldwiesen sehr selten, nur auf Berg. wiesen in Mordthale bei Naumburg. Mai. Juni. Blüthen stark nach Holunder riechend; äussere Zipfel der Blüthenhülle violett, hinten weisslich, wie bei I. squalens, aber mit stärker ausgedrückten Adern, die inneren Zipfel grau-bläulich. Höhe $1 \frac{1}{2}-21$.

1096. I. bohemica $\mathrm{schmidt,böh} \mathrm{mischer} \mathrm{Sch}$. Abb. 758. Bärtig; Blätter schwertförmig; Stengel mehr- 
blüthig, zur Zeit der Blüthen ungefähr su lang als die Blätter, der unterste Blüthenstiel unter der Mitte des Stengels oder fast auf der Wurzel entspringend; Bliithenscheiden zur Zeit der Bliithen überall frisch, nirht oberwärts trockenhäıtig; die inneren Zipfel der Bliithenhiille so lang wie die äusseren, "val, plötzlich in cinen Nagel zusammengezogen; die Zip/el der Narbe länglich-kcilförmig, in ihre Oberlippe allmählig verbreitert, mit geraden Rändern; der Fruchtknoten ziemlich stielrund, beinahe gleichförmig-6furchig. 2. Bergige Laubwälder, Waldblössen stellenweise. In Lindherge, Mittelholze, fehlt südlich bis Weissenfels; bei Naumburg in den Weinbergen mit Kalkunterlage häufiy z. B. an der Henne, bei Russharh, bei Freiburg an südlichen Rande der neuen Giehle und in den Weinbergen daselhst häıfig, an der Steinhlippe hei Wendelstein selten. Mai. I. nudicaulis $S$ ch a u er. Blïthenhïlle violett. Höhe $3 / 4-11 / 4$.

1097. I. pumiln L., niedriger Sch. Abb. 752. Bärtig; Blätter schwertförmig, länger als der sehr kurze, 1bliithige Stengel; Röhre der Bliithenhiille iiber die Bliithenscheide hervortretend, Zipfel länglich-verkehrt-eiförnig. 24. Auf Jehmmauern in Dörfern häufig angepflanzt. April. Mai. Blüthen violett, selten hellblau oder weiss. Höhe $3-4^{\prime \prime}$.

B. Bartlose. Die äusseren Zipfel der Blüthenhülle bartlos.

1098. I. Poeud - Ácorus L., W a sser-Sch. Abb. 771. Bartlus; Blätter schwertförmig, lanzettlich-linealisch, ungrefähr sol lang als der sticlrunde, mehrblüthige Stengel; die äusseren Zipfel der Blüthenhülle eiförmig, breit-genagelt, die inneren linealisch, schmäler und kiir:zer als dic Zipfel der Narbe. 24. Teiche, Gräben, Sumpfwiesen meist häufig z. B. bei Dieskau an den Teichen, in Gräben der Aue bei Collenbey, Döllnitz, Bug Liebenau u. s. w. Mai. Juni. Blüthen gelb. Höhe $2-3$ '.

1099. I. sibirica L., sibirischer Sch. Abb. 768. Bartlos; Blätter schwertförnig, linealisch, kürzer als der stielrunde, röhrenförni@e, meist 2blüthige Stengel; die äusseren Zipfel der Bliithenhiille verkehrt.eiförmig, in einen kurzen Nagel verschmälert; Fruchtknoten 3seitig; Kapsel kurz-bespitzt. 24. Sumpfwiesen stellenweise. Auf einer. Wiese zwischen Dölau und der Heide 
häufig, pjuzeln auf Wiesen zwischen der Gersdorfer wüsten Feldmark und dem Kröllwitz. Jeettiner Wege, sehır häufig in der Aue zwischen Döllnitz und Cullenbey und nach Burg Liebenau zu, anf Wiesen bei Wesnar, zwischen Göhren und Rodden, häufig hei Kl. Dölzig, am Bienitz, hinter dem Schlossgirten hei Zörbig nach Prussendurf zu, auf Wiesen zwischen Weissenfels und Markwerben, fehlt in westlichen und nördlichen Gebiete, findet sich auf Wiesen hei Mosigkau unweit Dessau, ebenso hei Oranienbaum, auf Wiesen zwischen Seelhausen und Löbbnitz nordöstlich von Delitzsch. Juni. Aeussere Zipfel der Blïthenhülle hellblau, ron violetten Adern netzaderig, innere violett. IIöhe 1-2'.

\section{Familie. Amaryllideen R. Br. Ama- r yllisgewäch se.}

139. Leucójum L. Knotenblume (ein aus $i \varepsilon v$ xos, weiss, und yov, Veilchen, gebildeter Pflanzenname hei 'Theophrast).

1100. L. vernum $L_{\text {. }}, F r$ ii $h l i n g s-K ., W$ ald - oder grosses Schneeglöckchen. Flora v. Thiiring. I. Heft 10. Schaft an der Spitze eine Iblüthige Blüthenscheide tragend; Blätter grundständig, linealisch, grasgrün, Griffel keulenförmig. 24. Schattige Laubwälder, Gebiische, Waldbäche stellenweise. Fehlt in der Nähto von Halle; findet sich in Walde bei Schkeuditz an der Iuppe einzeln und sehr häufig links rom Wege nach Kl. Dölzig, bei Leislingen nnd Schönburg zwischen Weissenfels und Naumburg häufig, bei freiburg an feuchten Waldstellen zwischen der Querfurter Chaussee und der Giehle, in Nihlthale zwischen Ziegelrode und Rossleben, an rothen Brunnen in Scheierholze bei Lodersleben, an fenchten Stellen des Mulkenbrunnen. thales bei Allstedt, in Helftaer Holze bei Eisleben, in Wäldern und an Bächen bei Freckleben, Welbsleben, Sandersleben und Dessau häıfig, in der Gutsche zwischen Paupitzsch und Niemegk, in Schenkenberger Busche bei Delitzsch. März. April. Blïthenhüille weiss, die Zipfel an der Spitze verdicht und vor der Spitze mit einem grünen oder gelben Flecke. Schaft 3-8" hoch, zur Fruchtzeit jednch oft 11/2' lang. Aendert bisweilen mit 2- oder 3 bliithiger Blüthenscheide ab.

Das gemeine Schueeglöckchen, Galanthus 
nivalis L., bei welchem die 3 äusseren 'zipfel abstehen, die 3 inmeren aufrecht, bedeutend kïrzer und ausgerandet sind, kann nicht als einheimische Pflanze angesehen werden, da es nur in Gärten gefunden wird und nicht einmal verwildert.

\section{Familie. Asparageen Juss. Spargel- gewächse.}

440. Asprégug H. Spal'gel (Pflanzenname bei

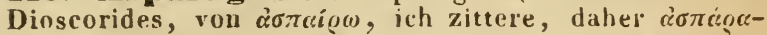
yos, zarter Stengel bedeutend).

1101. A. officinalis L. ( $\mathrm{val} . \%$ nit Ausschluss des Var. $c_{\text {. und }} \beta_{\text {.) }}$ ge bräuchlicher Sp. Hayne Arzneigew. VIII, 29. Situngel krantartig, stielrund, anfrecht; Blätter büschellörmig, burstenförmig, stielrund und nebst den Zweigen ganz kahl unil glatt; Blüthen meist 2häusig; Röhre der Blutheuliille fadenförmig, halb so lang als der Saunı; Staubäden der männlicheu Blüthen von der Länge des länglichen Staubbentels. 24: Wiesen, Triften, Waldränder, Weinbergge meist einzeln, aber fast nirgends fehlend. In Lindberge, in Gebüsche an der Saale hinter den Schwalchloche, im Frenzelholze bei Lieskau, bei Röglitz, Kötschau, in Weinbergen bei Nanmburg zerstreut u. s. w. und ansserden in grosser Menge gebaut. Juni. Juli. Blüthen grünlichweiss. Höhe $2-4$ '.

441. Pais E. Einbeere (ein bei Fuchs vorkummender Pflanzennanie, welcher von par, gleich, herkommen sull, wegen der Vierzahl des Blätter und Blüthentheile).

1102. P. quadrifolia L., vierblät terige L. Hayne Arzneigew. III, 7. Kch b. Abb. 857. 858. Stengel ganz einfach, oberwärts tinen Quirl von 4 Blättern und an der Spitze eine einzelne, gestielte Blüthe tragend; Blüthenhülle Stheilig, die äusseren Zipfel lanzettlich, breiter und länger als die inneren; Staubbeutel in der Mitte der Staubfäden stehend. 4 . Schattige Wälder und Gebüsch stellenweise. In Walde bei KI. Dölzig, bei Naumburg zwischen Goseck und Eulau einzeln, im Lodersleber Forste, bei Allstedt in Hagen im Thiergartenhuhlwegre und in Bornthale, bei Eisleben im Helftaer und Bischofsiöder Holze nicht häufig, fehlt bei 
Aschersleben (und findet sich erst ausserhalb der Grenze in der Nähe des Harzesı, bei Dessau häufig, bei Oranienbaum im Nichrim, an Abhängen des Muldenthales zwischen Pouch und Rösa östlich von Bitterfeld. Mai. Blüthen grün; Frnchtkuoten und Narben schwarz-roth. Beeren dunkelblau. Höhe $1 / 3-11$. Aendert mit 3 und 5 quirlständigen Blättern ab. Die ganze Pfanze ist $\mathrm{g}$ if . tig, besonders aber die Beeren.

442. Comvallania I. Ma iblume (Convallaria ist aus dem älteren Namen dieser Pflanze Lilium convallium, Lilie der 'Thäler, gebildet).

A. Polygonatum Tournef. Blüthell blattwinkelständig; Bliithenhïlle röhrig - walzenförmig, weiss, an der Spitze grïn.

1103. C. Polygónatum L., we is sw urzelige M. 11 a y e Arzneigew. III, 19. K chb. Abb. 864. Stengel lantig; Blïlter stengelumfassend, werhselständig, eiförmig-länglich oder elliptisch, ziemlich stumpf, kahl; Blüthenstiele blattwinkelständig, 1- oder seltener 2blüthig und nebst den Staubgefässen kalıl. 24. Wälder, buschige Berge verbreitet, wbgleich seltener als die beiden vurigen Arten. In der Dölawer Heide, auf einer Wiese zwischen Dölau und der Heide sparsan, im Mittelholze, im Frenzelholze bei Liestau, in Lupholze bei Schochwitz, im Bienitz, sehr häufig an den Sichlagbergen bei Freiburg und an den Schmonschen Bergen u. s. w. Mai. Juni. Der Wurzelstock ist gegliedert, "eiss, aber etwas dïnnel als an der folgenden Art. Beeren schwarzviolett, "ie bei der folgenden, Stengel $1-1 \frac{1}{2^{\prime}}$ hoch, uberhängend.

1104. C. muItiflora L., vie l blüthige M. Hay Arzneigew. III, 20. $\mathrm{Kchb}$. Abb. $861-863$. Stengel stielrund; Blälter stengelumfassend, wechselständig, eiförmig-länglich uder elliptisch, ziemlich stumif, kahl; Blattstiele blattwinkelstandig, 3-5blüthig, kahl; Staub. Jäden behaart. 4. Fenchte Laubwälder nicht gerade selten z. B. in der Dölaner Heide, im Sebener Busche, an einigen Stellen der Aue z. B. bei Dölkau u. s. w. Mai. Juni. Blïthen um die Hälfte schmäler als bei der vorhergehenden. Stengel $1-3^{\prime}$ hoch, überhängend.

B. Coelocrinon. Lilium convallium Tournef. Blüthen in einer endständigen, einseitswendigen 'Traube: Blüthenhülle glockenförmig, ganz weiss. 
1105. C. majalis L., wohlriechende M. Hayne Arzneigew. III, 18. Rchb. Abb. 860. Schaft blattlos, halbstielrund; Blätter 2, grundständig, neben ilem Schafte stehend, elliptisch-gestielt; Bliithen traubenförmig, überhängend. 4. In allen Wäldern häufig z. B. in Lindberge, in der Dölaner Heide u. s. w. Mai. Beeren roth. Höhe $1 / 2-3 / 4$. OFF. flores Liliorum Convallium.

443. Majómthemumn WViğg. Einblatt (nicht Kweiblatt, wie erst neuere Botaniher es nennen; aus

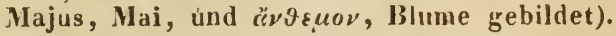

1106. M. bifolium DC., $z w$ w blät eriges E. Abb. 967. Stengel meist 2 wechselständige, ge'stielte, herzförmige Bl̈̈ter und all der Spitze pine Blüthentraube tragend: Blïthenhiille 4theilig, wagrecht-ausgebreitet; Staubgefässe 4. 4. Schattige IVäldel häufig. Mai. Juni. Cunvallaria bifolia $I$. Bliithen weiss. Beeren anfangs weiss, mit rothen Punkten, später ganz roth. Höhe $3-6^{\prime \prime}$.

\section{Familie. Liliaceen DC. Lilienge-}

wäc hse.

1. Gruppe. Tulipeen. Tulpengewächse. Blüthenhülle 6blätterig; Kapselfächer vielsamig; Samen flach, reihenweise dicht über einander liegend; Samenbaut immer blejch oder braun, nicht krustig und schwarz.

44t. Túlipa I. 'T'ulpe (der zuerst bei C. Gesner' vorkommende Name soll das ursprünglich orientalische llort Tulipan, Turpan sein, weil die Blume nit der Furm eines orientalischen Turbans verglichen wurde).

1117. T. silvestris L., Wald-'I'. Abb. 983. Stengel Iblüthig, hahl; Blätter linealisth-lanzettlich; Blüthenknospen nickend, die 3 äısseren Blïthenhüllblätter schmäler, lanzettlich, die 3 inueren breiter, elliptisch, nebst den Staubgefassen an Grunde bärtıg. 24. In Weinhergen oft in glosser Auzahl beisammen, so in deu Weiubergen bei Nanmburg z. B. an der Henne, an Bürgergarten 11. s. w., ausserdem bisweilen in Baumgärteń verwildert z. B. in Waisenhausgarten, hinter dem Schlossyarten hei Zörbig, bei Aschersleben, Dessau. April. Mai. Blume gelb, wohlriechend. Höhe $1-1 \frac{1}{2}{ }^{\prime}$. 
445. Eiliam I. Lilie (Pflanzenname bei Plinius).

1108. L. Mairtagon L., 'T úrhe n bu nd-I. H a yne Arzneigew. VIII, 29 . Stengel einfach, steif - aufrerht, etwas rauh; untere Blätter quirlförmig, elliptisch-lanzettlich, uberste gegenständig oder zerstrcut; Bliitheu ïberhängend; Blüthenhüllblütter stark zurrickgerollt. 4. Bergü̈lder, Gebiische stellenweise. In der Dölaner Heide, im Frenzelholze bei Lieskau, in Mittelholze, im Bienitz, bei Naumburg am Pfortenberge, bei freiburg häufig z. B. im Srhatholze, Mühlholze II. s. w., in den schmonschen Bergen, bei Allstedt häufig z. B. im Hayen, Rathsholze, bei Eisleben an der Hïnehura, in Kiatharinenhulze, bei Sanderslebell. Juni. Juli. Blume blass-braunroth mit dunkleren Flecken. Ilöhe 2-3'.

2. Cruppe. Asphodeleen. Affodillgew ïchse. Blüthenliülle 6blätterig; Kapselfücher wenigsamig; Samen ron mannigfacher Gestalt, oft mit einer schwarzen Samenhaut versehen.

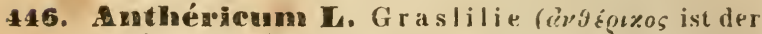
bei Theophrast vorkommende Pflanzenname fïr Aspho. delus luteus $\left.\mathrm{I}_{\text {.. }}\right)$

1109. Liliágo C., a stlose G. Schaft einfach, an der Spitze eine cinfache Blüthentranbe tragend; Blatter grundständig, linealisch, etwas rinnenförmig, aufrecht, kürzer als der Schaft; Griffel abwärts geneigl. 4. Trockene Anhöhen, Weinberge, hochgelegene Wäl. der und Wiesen stellenweise. An Bergen zwischen Kröllwitz und der Kreuzschäferei, lüufig an den Kalkbergen hei Bennstedt, auf Wiesen hei KI. Dölzig, in Bienitz, bei Weissenfels in den Weinbergen bei Goseck, hei Naumburg in den Weinhergen iiber der Henne, bei freiburg am sïllichen Rande der nenen Giehle, an der steinklippe bei IIculelstein, an Bergen bei Bibra, fehlt bei Aschersleben. Nai. Juni. Phalangium Liliagn S chrad. Blumen weiss, über " im Durchmesser. Höhe 1-2".

Zuweilen hat zwar A. Liliago einen Stengel, welcher eine mit $1-2$ desten versehene Bliithentraube trägt, ist dann aber durch die doppelt so yrossell Blüthen, die gebogenen Griffel und die frühere Blüthezeit an gleichen Standorten von A. ramosum zunterscheiden.

1110. A. ramosum L., ästige G. Flora v. Thüring. II. Heft 22. Schaft an der Spitze eine rispig-verästelte 
iistclte Blütlentranbe traqend; Blätter grundständig, linealisch, rinnenförmig, kürzer als der Stengel; Griffel gerade. 4. Truchene Anhöhen, Weinberge, sumige Waldiänder etwas seltener als die vorige Art. Am Tannenherge bei Gutenberg, ạn Kalkbergen bei Bennstedt, in Bienitz einzeln, bei Naumburg häıfig, an Kalkberyen hei Bottendorf, bei Allstedt im Hagen und im Rathsholze, bei Sandersleben häufig. Juni. Juli. Phalangun ranosum Lam. Blume "eiss, nur halb so gross als an der vorigen Art. Höhe $1-2^{\prime}$.

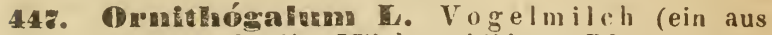
óovıs, Vugel, und g'élu, Nilch, gebildeter Pfanzenname bei Diuscurides).

1111. O. umbellatum L., ebensträussige $V$. Zwiebel rundlich; Blätter grundständig, schmal-linealisch, kahl, mit einem veissen Längsstreifen; Blithenstiele eluenstrïussiy, die mineren fruchttragenden wag. recht-abstehend, länger als die Deckbläiter, Frucht aufstrebend; Blüthenhïllblätter länglich, stumpf; Staub. fäden ungezähnt. 4. Grasige Higel selten. An der sürllichen Seite des Galgenberges, an Bergen an 'Trothater Kirchhofe, bei Naumburg selten, nur in der Aue nach Grochlitz hin, ausserdem an Grasplätzen, Arkerrainen hin und wieder verwildert $z$. B. hinter den Schlussgarten bei Zörbig. Nai. Blume weiss, mit grünen Rüchenstreifen. Höhe 4-6", in Gärten oft fusshoch.

1112. o. nutans L., nickende $r$. Zwiebel eiförnig; Blätter glundständig, breit-linealisch, kahl, mit einem weissen Längsstreifen; Bliithenstand locker-tranbig, schon zur Blüthezeit einseitswendig und überhängend; Bliithenstiele gleich lang, kürzer als die Deckblätter; Bliithenhiillbliitter slockenförmig, offen, lanzettlich, stumpf; Staubgefässe alle 3zähnig, abwechselnd um die Hälfte kürzer, die Seitenzähne der längeren ïber den Staubbentel hiuausragend. 24. In Weinhergen an der Henne bei Naumburg, in Weinbergen bei Freibury, ausserdem in Grasgärten und Parkanlagen und deren unmittelbarer Nühe öfters verwildert z. B. in Schlossgarten ron Weissenfels, hinter dem Schlossgarten bei Zörbig. Mai. Blume "Neiss, mit grünen Riuclien. streifen. Höhe ${ }^{3} / 4-1 \frac{1}{4}$ '

448. Gager Salisls. Guldstern (uach dem Eug. länder Thomas Gage benannt). 
A. Wurzeln aus 3 wagrechten, nackten und von keiner geneinschaftlichen Haut eingeschlossenen Zwiebeln zusammengesetzt, von welchen die zwei diesjährigen blattlos, die einjährige dritte aber ein einzelnes Blatt und einen blüthentragenden Schaft treibt.

1113. A. stenopétala R chb., s chmalblätteri ger G. S'turm Heft 3 . Zwicbcln 3, wagrecht, die leiden jährigen keulenförmig, gesticlt; das Wurzelblatt einzeln, linealisch, nach dem Grunde und der Spitze verschmälert, flach, geschärft - gekielt, blüthenständige Blätter 2, gegenständig; Bliithensticle kahl, eiıfach, nach dem Terbliihen nach allen Seitcn abstehend. 4. Aecher, Dïmme, Hecken nicht gerade selten. Am Felsen der Gärten vor Giebichenstein, bei Gimritz sparsan, am Rande des Zorgs, anf Aeckern zwischen Böll. berg und dem Wörmlitzer Hölzchen, an der Elsterbrücke bei Ammendorf und im Chansseegraben his zur Einnehmerwohnung, am hohen Saalufer unmittelbar an Rauschens Hölzchen bei Nerseburg, an Wiesenrändern zwischen Wesmar und Zöschen, auf Aeckern bei Naumburg nicht selten u. s. w. April. Mai. Ornithogalum stenopetalum Fries. $O$. luteum $\mathbf{H}$ of $\mathrm{fm}$. und vieler Autoren. Blume innen gelb, ausserhalb grünlich, wie bei den folgenden Aiten. Höhe $4-6^{\prime \prime}$. Aendert mit $2-3$ Wurzelblättern ab und ausserdem :

b) pratensis Koch: das untere blüthenständige Blatt scheidenförmig die Blüthenstiele umfassend, Blüthenstiele nach dem Verbliihen einseitswendig, die beiden jährigen Zwiebeln eiförmigr, sitzend, so nit der gewöhnlichen Form an der Elsterbrïcke bei Ammendorf.

B. Wurzel aus 2 aufrechten, ron einer gemeinschaftlichen Haut eingeschlossenen Zwiebeln gebildet, zwischen welchen der Schaft herworsprosst. Nur die eine grössere $Z$ wiebel nit Wurcelfasern versehen.

1114. G. arvensis $5 \mathrm{chnlt}$., A cher-G. Florav. Thüring. 11. Heft 19. Zwicbeln rundlich; zwei linealische, Jinmenförmige, stumpf - gekielte, oben zurückgekrïnmte Wurzelblätter, Stengelblätter fehlend, die 2 bliithenständigen Blütter gegenstüindig; Blïthenstiele isstig, ebensträussig, zottig; Bliithenliiillblicitter lanzeltlich, spitz. 24. decher, Dämme, 'Zi iune etwas seltener 
als die vorhergehende Art. Auf Aeckern und an Zäunen zwischen Böllberg und den Wörmlitzer Hölzchen, an der Elsterbrïcke bei Ammendorf, am hohen Ufer der Saale bei Rauschens IIölzchen vor Merseburg, auf Aeckern und in Weinbergen zwischen Rollstorf und Seeburg nicht selten. März. April. Ornithogalum arvense Pers. O. minimum Roth. O. villosum M. B. Höhe 4-6".

1115. G. saxatilis Koch, Felsen-G. Flora v. Thüring. 11. Heft 20. Zwiebel rundlich; zwei fadenförmige, rinnenförmige, zuruckgebogene Wurzelblätter, Stengelblätter wechselständig, lanzettlich, zugespitzt oder mit verlängert-fadenförmiger Spitze endigend; Blüthen endständig, meist einzeln; Bliithenhiillblïtler länglichlanzettlich, stumpf, an Grunde nebst dem Stengel und lem Blattrande zuttig; Fruchtknoten länglich-verkehrteifürmig. 4. An feuchten Felsen, besonders auf Porphyr, stellenweise. Am Felsen zwischen Giebichenstein und Trutha nicht selten, einzeln am Galgenberge, an Felsen an' der Saale in der Nähe der Papiermühle bei Kröllwitz, an Felsen bei Hohenthurn und I,andsberg, bei Wettin nicht selten, bei Aschersleben nach Westorf und Welislehen zu. März, blüht früher als alle andeJen dieses Gattung. Ornithogalum bohemicum Gau d., nicht Z Z uschner. Höhe $1-3^{\prime \prime}$. Aeudert in Zahl der Blüthenhüllblätter, Fruchtknoten und Griffel vielfach ab.

Zuweilen kummt G. arvensis mit einblüthigem Schafte vor, unterscheidet sich dann aber von der ähnlichen G. saxatilis durch den kahlen Scliaft, durch die gegenständigen blüthenständigen Blätter und dem Mangel der Stengelblätter, durch die $3-4 \mathrm{mal}$ längeren Blüthenstiele, die linealisch-lanzettlichen, spitzen Blïthenhïllblätter und den tiefer ausgerandeten Fruchtknoten.

1116. O. spathacea $\$$ chult., scheidenförmi . ger G. Sturm Heft 27. Zwiebcl cifürmig; zwei aufrechte, fadenförmige, halbstielrunde, oben flache oder schwach - rinnenförmige Wurzelblätter, bliithenstïndiges Blatt einzeln, lanzettlich, scheidenförmig-zusammengerollt, von der gestielten, $2-5$ blithigen, kahlen Dolde entfernt; die besonderen Blibthenstiele einfach, kahl; Bliithenhiillblätter länglich-lanzettlich, stumpf; Fruchtknoten verkehrt-eiförmig. 2. Wird von Spreng. hal. ed. 2. p. 156 in schattigen Wäldern bei Schkenditz und Freibury als selten angegeben. Der Verfasser hat sie innerhalb der Grenzen des Gebietes noch nicht gefun- 
den, da jeduch die Wälder bei Srhheuditz grosse AehoJichheit mit denen vun Kumewit\% bei Leipzig haben, wo diese Jflanze wächst, so ist die Möglichktit des Vorkonmens nicht zu bestreiten. Anders verhilt es sich mit den II äldern hei lireiburg. April. Mai. Ornithogralum spathacem Hi $y$ ic. Höhe $4-6$ -

1117. G. minima shult., kle iner G. Sturm Heft 23. Zuvicluel ciförnig; Wurzelblatt piuzeln, auf. recht, linealisch, wbrr - tind unterseits flach oder nur schwach - rinneuförmig, bliillicnstïndiges Blatt einzeln. schcidenformig, lanzettlich, am Grumde den gemeinschaftlichen Bhüthenstiel der 2-5blüthigen Dolde einschliessend; die besunderen Blüthenstiele einfach oder istig, hahl; Bliithenfiilll, lätler lisealisch-lanzettlich, zugespitzt: Fruchtknuten länglich. 24. Haine, Gebüsche stellenweise. Auf dem Irothaschen Werler, im Wörmlitzer Hölzchen nicht selten, in einem Wäldchen an det lindenschlurht bei Sechurg ziemlich zahlruch, etwas seltener in Badendorfer Holze zwischen Seeburg und Veehausen, bei Weissenfels im Puetenholye und zwischen Beuditz und Jacislingen, boi schönburg, in Ilechen am Spechtsar bei Naumburg, in Hagen bei Esperstedt, im Ziegelroder Furste, bei Mllstedt in Hagen an der Ilagenecke, in sugenannten Busche bei Aschersleben und unter dem Arustein bei Harkerude. April. Nai. Ornithogalum minimum L. 0 . Sterubergii 11 op p Höhe $3-6 "$. Ist durch den zarten und schmächtigen Wuclis schom aus ier Ferne zu erkenmen.

Nach Spreng. hal. ed. 2. p. 156 soll diese Pllanze auch bei Vechteritz unweit Weissenfels vorkummen, welche Angabe jedoch unriohtig ist; nach $R \mathrm{chb}$. sax. el. 1 4. 2. \%. 73 soll sie B eneken daselbst gefunden haben, was gleichfalls ganz unwahr ist.

C. Wurzw aus einer festen, aufrechten Zwiebel gebilitet, welche am Grunde den Schaft ungibt und ein einzelnes Blatt trägt.

1118. 6t. Intes sehult., Wald-G. Flora v. Thüring. II. Heft 20. Zwichal eiförmig, cinzeln; Wurzelblall cinzsh, aufrecht, brcit-linealisch-lanzetlich. flach, plötzlich mützenfürmig-zugespitzt, sibharf-gekielt: bliithenstaindige Blitter 2, fast gegeniibersteliend: die besonderen biüthenstiele einfarh. duldenförnig, kiahl; Blüthenhillblïtter länglich, sehr stumpf. 4. Haine, Baumgärten, Hechen, Wiesen, durch das ganze Gebiet häll. 
fig. April. Mai. Ornithogalum luteum $\beta$. L. O. silvalicum Pers. O. Personii Hoppe. Höhe $1 / 2-\mathbf{1}^{\prime}$.

449. Scilla M. Meerzwiebel (Pflanzenname bei Hipporiates).

1119. Sc. amoena L., schön e M. Stengel kantig, meist 4 blätterig; Blätter aufrecht, breit-linealisch, ziemlich flach, an der Spitze fast miitzenförmig-stumpf; Blïthenstiele aufrecht; Declbliitter am Grunde der Bliithensticle hiiutig, selr klein, abgestutzt ouler gezïlunt; Traube endständig, 2-4blüthig. 24. In Walde bei Wallbeck unweit Ilettstedt nach 1 a mpe wirklich wild, sonst oft in Gärten als 'iieruflanze und in Banmgärten verwildert. April. Mai. Blume blau, grösser als an ler folgenden Art. IIöhe $6-9$ ".

1120. sc. bifolia L., $z$ we $\mathrm{b} b \mathrm{a}$ t terige M. Stenrel stielrund, 2-, selten 3blätterig; Blätter abstehend wder zurïchgekrüısmt, lanzettlich-linealisch, rinnenförmig, in eine stielrunde Spitze zusammengerollt; Blüthenstiele anfrecht; Deckbliitter fehlend; Traube endständig, 3-10blüthig. 24. Fenchte Wälder und Gebiische sehr selten, nur bei Weissenfels in Walde mnmittelbar hinter L, eislingen links rom Wewe nach Schönburg. März, nicht Mai, wie Spreng. angibt, ist eine der ersten Fühlingspflanzen. Blume blau. Höhe $4-8$ ".

450. Allium I. I, a u ch (Pflanzenname bei Plinius).

A. Blätter flach oder oberseits etwas rinnenförmig, aber nicht röhrenförmig.

a. Sitrngel hlattlus. Staubgefisse sämuntlich zalinlos (d. I. olıne Velenstauhfolen).

1121. A. ursinum C., Bäle $\|$ - I. Sturm Heft 41. Stengel blattlos, stumpf-3kintig; Bliitter lang-gestielt, brcit elliptisch-lanzettlich; Bliithenscheide $1 \mathrm{klappig,} \mathrm{beim}$ Anfblülen 2-3spaltig; Dolde kapseltragend, gleich hoch, lorker; Staubgefüsse zahnlos, lïrzer als die Blïthenhülle. 4 . Schattige, feuchte Wälder selten. In feuchten Waldungen der Aue, aber daselbst oft in zahlloser Menge z. B. bei Burg Liebenau, zwischen Schkenditz unil Kl. Dölzig, bei Horburg, in Bärgrunde bei Kötzschlitz, bei Naumburg anf der Giekauer und Gröbitzer Wiese in der Nälse des Baches, in der Gotsche zwischen Paupitzsch und Niemegk nördlich von Delitzsch. April. Mai. Blume schneeweiss, stark nach Knoblauch riechend. Iöhe $3 / 4-1$ '. 
1122. A. fallax Don., tr ü gli cher J. Zwiebel auf einem wagrechten Wurzelstock sitzend, mit ganzen Häuten bedeckt; Stcngel blattlos, obcrwärts scharfkan. tig; Blätter ungestielt, schmal-linealisch, ungefähr von der Breite des Schaftes, unterseits schwachnervig, kiellos; Blüthenstheide 1klappig, beim Aufblïhen 2-3spaltig; Dolde kapseltragend; Staubge/ässe zahnlos, laingcr als die Bliithenhiille. 24. Hügel, Felsen stets auf Kalk stellenweise. Auf Anhöhen bei Röglitz, in Bienitz, auf Bertram's Berge bei Wettin, bei Naumburg auf Kalkhügeln, besonders an Pfortenberge häufig, an den Schmonschen Bergen. Juli. Aug. A. angulosum J a c q. A. acutangulum $\beta$. montanum und $\gamma$. calcareum Nert. u. Koch. A. montanum Schmidt. Blume rosenroth. Höhe 1'. Blätter $1-2$ Linien. breit, getrocknet durchscheinend, mit stärkeren und schwächeren Nerven durch. zogen, der mittlere aber nicht dicker.

1123. A. acutángulum schxad., scharfkanti. ger I. Zwiebel auf einen wagrechten Wurzelstock sitzend, mit ganzen Häuten bedecht; Stengel blattlos, oberwärts scharfkantig; Bläter ungestielt, schmal-linealisch, ungefähr von der Breite des schaftes, unterseits 5nervig und durch den hervortretenden Mittelnerven scharf-gekielt; Blüthenscheide 1klappig, beim Aufblühen 2-3spaltig; Dolde fast gleich hnch, kapseltragend; Staubgefässe zahnlos, so lang als die Blïthenhiille. 24. Nasse Wiesen häufig z. B. auf der grossen Wiese zwischen Halle und Beuchlitz, auf Wiesen zwischen Halle und Nietleben, einzeln an Schwalchloche hinter Kröllwitz, oft in zahlloser Menge beisammen, so in Riethe zwischen Artern und Nikolausrieth. Juni - Aug. A. angulosum Pollich und der meisten Autoren. Blume rosenroth. Höhe $\mathbf{1}^{\prime}$. Ist der vorigen Art sehr ähnlich, aber ausser den angegebenen Merkmalen durch den verdickten Mittelnerv der Blätter unterschieden.

h. Stengel unten oder bis zur Mitte mit Blättern besetzt.

1. Staubgefisse sämmtlich zahnlos, üher dem Grunde der Blütlıenhüllblätter eingefügt.

1124. A. oleraceum $\mathbf{L}$., G e mï s e-L. S turm Heft 34. Stengel stielrund, bis zur Nitte mit Blättern besetzt; Blätter linealisch, rinnenförnig, nach der Spitze zu flach, unterseits vielriefig; Blüthenscheide 2 klappig, die eine Klappe sehr lan?-geschnäbelt; Dolde zuiebeltragend; Staubgefässe zahnlos, nngefähr so lang als die Bliithenhiulle; Blätter der Blüthenhülle stumpf, nit 
einem Spitzchen. 24. Gebusche, Waldränder, Hecken nicht gerare selten. In Frenzelhol,e bei Lieskau, im Lindberge, zwischen Gebüsch am Schwalchloche hinter Kröllwitz, in Weinbergen vor Röglitz, an Bienitz, häufig bei Naumburg und Freiburg, im Hagen bei Esperstedt u. s. w. Juni. Juli. Blıme griunlich-weiss oder röthlich mit einem grünen orler purpurrothen Rückenstreifen. Höhe $1-2^{\prime}$. Aendert bisweilen mit hohlen Blättern ab und ferner:

a) angustifolium Koch: Blätter sehr schmal, $1-1 \frac{1}{2}$ Linien breit und daher mehr rinnenförmig.

b) latif oliu "Kuch: Blätterflach, 3 Linien breit; A. carinatum Pollich. A. oleraceum $\beta$. complanatum Fries.

Hierher gehört auch $A$. carinatum bei Spre ng. hal. ed. 1. und Wallr. sched. $\mu$. 132, nicht Lin., wie Wallr. fälschlich citirt, demn dieses kummt im Gebiete nicht vor.

2. Staubgefasse hriderseits. am Grunde miteinem kurzen, stumpfen $Z$ a line verseh ell.

1125. A. strictum $\mathrm{s}$ ch rad., ste if b lät teriger $\mathrm{L}$. Rchb. pl. crit. V. Abb. 591. Zwiebelhäute zuletzt nez. zig-faserig; Stengrel stielrund, am Grunde mit Blättern besetzt; Blätter linealisch, oberseits rinnenförmig, nach der Spitze zu flach: unterseits fast halbstielrund, glatt, schwach-nervig; Blüthenscheille 2 klappig; Dolde fast kugelförmiu, kapseltragend; Staubgefässe abwechselnd am Grunde beiderseits 1zïhnig, Zähne viel kürzer als der Staubfaden. 24 Wird ron Spreng. hal. ed. 2. p. 158 an Bergen hei Nebra als selten angegeben; ob diese Bestimmung richtig ist, kann der Verfasser nicht behaupten, fast möchte er mit IV a llr. daran zweifeln. Juli. A. reticulatum Presl. A. volhynicum Bess. A. suaveotens Gaud. Blume hellroth. Höhe 1'.

1126. A. sativum E., Knoblau ch. Zwiebel aus vielen, eiförmig-länglichen, kleinen Zuvicbelchen zusanmenosetzt und von einer gemeinschaftlichen Haut eingeschlossen; Stengel stielrund, bis zur Mitte mit Blättern besetzt; Blätler breit-linealisch, flach, schwachrinnenförmig; Blüthenscheide 1klappig, sehr lang-geschnäbelt, hinfällig; Dolde zviebeltragend; Staubgefïsse abuechselnd am Grunde beiderseits 1 zähnig, Zäline viel kürzer als der Staubfaden. 24. Wird zun Küchengebrauche häufig gebaut. Juli. Aug. Blume schnutzig" eiss. Höhe 2' und darüber. OFF. radix Allii. 
1127. A. Ophioscórodon Don, Pe rl-I., Perl. zwiebel. Zuviebel ans vielen rundlich-eiförmigen, kleinen Zwiebelchen zusimmengesetzt; stengel stielrund, bis zul Mitte beblättert; Blätler breit-linealisch, /lach; Blüthenscheile 1 klappig, sehr lang-geschnäbelt, hinfäl. lig; Dolde zwiebeliragend; Staubogäisse abwechselnd an Grunde beiderseits Izïhnig, Zühne viel kurzer als der Staubfarlen. 4. Wird zum Küchengebrauche auch unter dem Namen Ruckenbulle, Rocambule bisweilen gebaut. Juli. Aug. Ist vielleicht nur Abart der vorigen Art.

3. Porrum Tournef, thubgefäse abwechselnd 3 fachhatrpitzig, die mittlere Hat arspitae den staubeutet tragend, dieseitenstindigen ladenfürmig, oftgedreht.

1128. A. Porrum L., gr e me iuer Is., Porrei oder Porree. Stengel stielrund, bis zur Mitte mit Blättern besetzt; Blätter flach; Dolde kapsellragend, kugelförmig; Blüthenhiillblätter am Kiele rauh; Staubgefässe etwas länger als die Blüthenhiillblätter, die 3 inneren 3fach-haarspitzig, die mittlere Haarspitze den Staul. beutel tragend, halb so lang als der Staubfaden selbst. (.) und 24. Wird zum Küchengebrauche häufig gebaut. Juni. Jali. Blume blass - purpurroth. Höhe 1-2'.

1129. A. rotundum L., runder L. Zwiebel aus zahlreichen, von einer Haut eingeschlussenen Zwiebelchen gebildet; Stengel stielrund, bis zur Mitte mit Blättern besetzt; Bliitter flach; Doide liapseltragend, kugelförmigg; die seitrinständigen Blüthenstiele viel kürzer; BliithenhiillWütter am Kiele rauh, länger als die Staubgefïsse; die 3 inneren Staubgefässe 3fach-haarspitzig, die mittlere Haarspitze den Staubbeutel tragend, fast $3 \mathrm{mal}$ kïrzer als del Staubfarlen selbst. 24. Dïrre Abhänge, Weinberge selten. Bei Naumburg in Weinbergen zerstreut $z$. B. an del Henne, selten in den Weinbergen hei Freiburg, au der Steinklippe bei Wendelstein selten, ebenso an den Bergen bei Schmon; soll nach Schwabe fl. anh. auch bei Bernburg und Sandersleben vurkummen. Juli. Aug. Blume purpurroth. Höhe $1-2^{\prime}$.

1130. A. sphaerocéphalnm L., rundköpfiger L. $Z$ wiebel aus Zahlreichen, von einer Haut eingeschlosse. uen Zwiehelchen gebildet; Stengel bis zur Mitte mit Blättern besetzt; Blïtter halbstielrund, oberseits tiefrinnenförmig; Dolde kapseltragend, kugelförmig; Blii. thenhiillbliitter am Kiele glatt, kiirzer als die Staubge- 
/iisse; die 3 inneren Staubgefässe 3 fach-haarspitzig, die nittlere Haarspitze den Staubbeutel tragend, halb su lang als der Staubfaden selbst. 24. Auf Aeckern unter den Getreide selten. Bei Sandersleben über dem Pre. gel am Wege nach Arnstedt, hänfiger zwischen Alsleben und den Vurverk Zeitz, von Sohwabe auch bei Dessau an Koruhause angegeben. Juni. Juli. Blume purpurioth. Höhe $1-22^{\prime}$. Die Blätter sind zuweilen an Grunde hohl.

1131. A. Scorodóprasum L., mit Ausschluss der Var. $\beta$., Schlangen-1.. Stengel bis zur Mitte mit Blättern besetzt; Blïtter fach, am Rande rauh; Bliithenscheide 2-3klappiy, Klappen sich sugleich in eine lange, dick - stielrunde Spitze verschmälernd; Dolde zwiebeltragend; Staubgefässe hürzer als die Blüthenthiille, die 3 inneren 3 fach-haarspitzig, die mittlere Haarspitze den staubbeutel tragend, halb su lang als der Staubfaden selbst. 4. Zwischen Gebïsch, in Wäldern, an Waldrändern häufig $z$. B. im Lindberge, in der Dölauer Heide, im Gebüsch am Schwalchloche hinter Kröllwitz

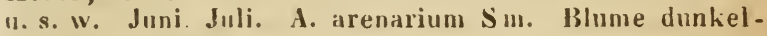
purpurroth. Höhe $2-3^{\prime}$.

1132. A. vineale L., Weinbergs - L. Stengel bis zur Mitte nit Blättern besetzt; Bläitter sticlrund, oberseits schmal-rinnenförmig, inwendig hohl; Blüthenscheide 2klappig, Klappen aus breitem Grunde sich in pine pfriemliche Spitze verschmälernd; Dolde zuiebeltragend; Staubgefuisse länger als die Bliithenhiillblätter, die 3 inneren 3 fach - harspitzig, die mittlere Haarspitze den Staubbeutel tragend, länger als der Staubfaden selbst. 24. Aecker, Weinberge, auf Sandboden. Bei Halle auf Aeckern hin und wieder. Juni. Juli. A. arenarium L. fl. suec. nach Fries. Blunie purpurroth. Stengel dünner und schlanker, 1-1 1/2' hoch. Das Köpfchen ist klein, oft blus zwiebeltragend.

B Blätter stielrund oder halbstielrund, vollkommen röhrenförmig.

1133. A. Schoenóprasum L., Schnitt lauch. Stengel blattlos oder an Grunde wenigblätterig, stielrund; Bläitter linealisch, pfriemlich, gleichförmig - stielrund oder nur pin wenig zusammengedrückt, vollkommen röhrenförmig, so lang oder fast so lang als der Stengel; Blïthenscheide 2klappig, fast so lang als die Dul. de; Dolde kapseltragend, fast kugrelförmig, Bliithenhiill- 
blätter lanzettlich, spitz, läinger als die zahnlosen Staub. gefässe. 2. Wird zun Küchengehrauche häufig gebaut. Juni. Juli. Blume hellpurpurroth. Iöhe $1 / 2-1$.

1134. A. Ascalónicum L., Schalotte. Stengel gleichförmig-stielrund, am Grunde beblättert; Bliitter pfriemlich, gleichförmig - sticlrund, vollkommen rülirenförmig; Blüthenscheide 2 klappig, hürzer als die kispseluder zwiebeltragende, kugelförmige Dulde; Staubgefässe ein wenig länger als die Bliithenhiillblätter, dic inneren am Grunde beiderseits kurz-1zïhnig. 24. Wird zum Küchengebrauche hin und wieder gebaut. Juni. Juli. Blume bläulich, kommit jedoch nur selten zur Blüthe. Höhe $1 / 2-3 / 4$ '.

1134. A. Cepa L., gemeine $\mathrm{Z} w$ iebel. Stengel am Grunde heblättert, unter der Mitte bauchig-aufgeblasen; Blätter vollkommen röhrenförnig, stielrund, bauchig, kürzer als der Stengel; Blïthenscheiden kürzer als die kapseltragende, kugelförmige Dolde; Staubgefässe läinger als dic Bliithenhiilllblätter, abwechselnd am Grunde beiderseits kurz-1zähnig. 24. Zum Küchengebrauche überall gehaut. Juni. Juli. Blume weisslich. Höhe 2-3'. OFF. radix Cepae.

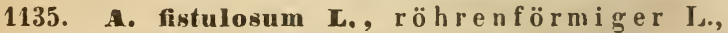
Winterzwiehel. Stengel am Grunde beblättert, in der Mitte aufgeblasen; Blïtter vollkommen röhrenförmig, stielrund, bauchig; Blïthenscheide länger als die kapseltragende, kugelförmige Dolde; Staubgefüsse zahnlos, länger als die Bliithenhiillblätter. 24. Zum Küichengebrauche gebaut. Juni. Juli. Blume weisslich mit grünlichem Kiele. Höhe 1-1 $\frac{1}{2}$ '. Die Blüthenstiefe sind nur 2-3mal so lang als die Bliithe, während sie dieselbe bei der vorigen $A$ rt um das $6-8$ fache an Länge iibertreffen.

3. Gruppe. Ilemerocallideen R. Br. Tagblumengewächse. Blüthenhülle 1blätterig, getheilt; Kapsclfächer wenigsamig; Samen von maninigfacher Gestalt, bei den einheimischen mit einer schwarzen Samenhaut.。

451. Núncari 'Tomer. Bis amby cinthe (Pflanzennanie bei Clusius).

1136. M. comosum Mill., schopfblithige B. Blätter linealisch, rinnenförmig, kürzer als der Schaft; Bliithen kantig - walzenförmig, die unteren entfernt, wagrecht-abstchend, die oberen länger-gestielt, aufrecht, 
genähert, schopfförmig, unfruchtbar. 24. Bergwälder, Haine, Weinberge, sehr zerstreut. Bei Halle nicht selten z. B. in der Dölauer Heide an Bischufsberge, im Frenzelholze bei Lieskau, im Lindberge, Zorgs, im Mittelholze, fehlt im ganzen östlichen und südlichen Gebiete bis Weissenfels und findet sich auch bei Naumburg nur sparsam an Weinbergen dem Fischhause gegenïber, in Wäldern bei Miicheln, bei Allstedt im Hagen gleich hinter dem Bürgerhause häufig, bei Hettstedt. Mai. Juni. Hyacinthus comosus L. Blume blälllich, am Grunde und der Spitze olivengrïn, die oberen unfruchttaren nebst den Blüthenstielen und der Spitze des Schaftes violett orler lebhaft blaı. Höhe 1-1 $1 \frac{1}{2}$.

1137. M. botryoídes Rill., 'Trauben-B. Sturm Heft 7. Blätter lanzettlich-linealisch, rinnenförmig, nach dem Grunde etwas verschmälert, cufrecht-abstehond, länger oder kürzer als der Srhaft; Blüthen fast rundlich-eiförmig, iiberhängend, zuletzt mässig entfernt, die obersten aufrecht, unfruchtbar. 24. In II einbergen sehr selten, nur bei lleissenfels und Namburg in den Weinbergen bei Burgwerben, Eulan, an der Henne, aber daselbst zahlreich. April. Mai. Hyacinthus botryoides L. Blume schön blau, mit weisslichen Zähnen. Höhe 4-6".

Spreng. gibt hal. ed. 2. p. 160 für diese seltene Pflanze gar keinen besonderen standort an und in Folge dessen findet sich bei Rchb. sax. ed. 1 1. 2. p. 79 die Mittheilung, dass sie bei Halle nicht selten sei, während sie doch in einem grossen Umkreise ron Halle gar nicht vorkommt.

Muscari racemosum Mill. wird ron Spreng. hal. ed. 2. p. 160 in Weinbergen bei Seeburg als selten angegeben. Da jedoch seit langer Zeit stets vergeblich nach dieser Pflanze gesucht ist, so kann sie nicht wieder aufgenommen werden.

\section{Familie. Colchicaceen DC. Zeit- losengewächse.}

452. Cólchicum L. Z e itlose (Pflanzenname bei Dioscorides).

1138. C. autumnale L., Herbst - Z. Hayne Arzneigew. V, 45. Kchb. Abb. 849. 850. Zwiebel mehr- 
blüthig; Blätter sich nach den Blüthen entwichelnd, breit-lanzettlich, spitz, steif; Röhre der Blüthenhülle 5- vder bimal so lang als der Saum, Zipfel lanzettlich, mit wellenförnigen Nerven, die äusseren verkehrt-eiförmig - lanzettlich; Stauhgefässe wechselweise länger und höher eingefügt. 24. Iuf feuchten Wiesen und Triftell gemein z. B. auf Wiesen vor und hinter Nietlebell, zwischen Dölau und der Heide, auf Wiesen im Görz bei Wörmlitz und mit Ausnahme des nordöstlichen Gebietes nicht selten. Blüht ron Ang. - Octob., die Blätter und Frucht aber erst im folgenden Frühiahre erscheinend. Blume fleischfarben. Höhe 6". OFF. radix, flores et semen Colchici.

453. Tofieldia Hud s. Tofieldie (nach dem Engländer Tofield benannt; der Name ist daher viersylbig anszusprechen).

1139. T. calyculata wahlenb., kelchblüthige T. Abb. 930. 931. Stengel aufrecht, am Grunde beblättert, oberwärts kahl oder nit einigen kleinen Blättern besetzt, an der Spitze eine Aehre tragend; grundständige Blätter schmal-linealisch-schwertförmig, verschmälert - zugespitzt, vielnervig; Blïthenstielchen sehr kurz, am Grunde mit einer länglichen, und unter der Blüthe mit einem kelchförmigen, 3lappigen Deckblatte besetzt. 24. Sumpfige, besonders torthaltige Wiesen, selten. Auf sumpfigen Wiesen bei Rückmarsdorf in der Nähe der Chaussee zahlreich, auf Wiesen $z$ wischen Nemsdorf und Querfurt, an der Benndorfer Mühle nördlich von Delitzsch, von Schwabe auch bei Radegast angegeben. Juli. Aug. 'T. palustris $\mathbf{H}$ op pe und st te rnb. Anthericum calyculatun var. «. L. Blüthen gelblich. Höhe $1 / 2-3 / 4$ '.

\section{Familie. Juncaceen Bart ling. B in-} sengewächse.

454. Juncus L. B ins e (Pflausenname bei Plinius).

A. Nichtblühende Halme pfriemlich und nebst den blühenden knotenlus, an Grunde von blattlosen uder blättertragenden Scheiden eingeschlussen; Samen uhne Anhängsel; Spirre eigentlich endständig, aber wegen des unteren, aufrechten, eine Fortsetzung des Halmes darstellenden Hüllblattes oft seitenständig erscheinend. 
1140. J. conglomeratus L., gekn äuel te B. Abb. 912. 913. IIalm blattlos, fein-gerillt, mit ununterbrochenem Marke angefiillt; wurzelständige Scheiden blattlos: Spirre scitenstiindig, doppelt-zusammengesetzt, gedrungen; Blätter der Bliithenhülle lanzettlich, sehr spitz; Griffel fast fehlend; Kapsel verkehrt-cifürmig, gestutzt, mit dem auf einem erhabenen Buckel sitzenden Grunde des Griffels endigend. 24. Sümpfe, Gräben, feuchte Plätze häufig z. B. zwischen Kröllwitz und der Dölauer Heide, bei Nietleben n. s. w. Mai. Juni, blïht früher als die folgende Art. Scheiden am Grunde des Halmes gelbbraun. Höhe 1-2'. Aendert mit Jockerer, etwas ausgebreiteter Spirre ab.

1141. J. effusus L., f I a t t e rig e B. Abh. 920. Hlalm blattlos, ganz glatt, getrockuet fein-gerillt, mit ununterbrochenem Marke angefültt; wurzelständige Scheiden blattlus; Spirre seitenständig, doppelt-zusammengeset zt, gedıungen; Blätter der Blüthenhiille lanzettlich, sehr spitz; Griffel fast fehlend; Kapsel verkehrt-cifürmig, cingedriickt. gestutzt, mit dem liurzen, in einem Grübchen sitzenden Grunde des Griffels endigend. 4. Siimpfe, Gräben, feuchte Stellen gemein. Jnni. Juli. Scheiden am Grunde des Halmes gelbbramn; Blïthen wie bei der vorigen Art 3 mäunig. Höhe $1-2$ '. Aendert mit geknäuelter Spirre ab.

1142. J. glaucus Ehrh., me erg rüne h. Abb. 922. Halm blattlos, tief - gerillt, mit füicherförmig-mnterbrochenem Marlie angefiillt; wurzelständige Scheiden blattlos; Spirre seitenstüindig, doppelt zisammengesetzt, gedrungen; Blätter der Blüthenhülle lanzettlich, sehr spitz; Griffel bemerklich; Kapsel lïnolich-elliptisch, stumpf, stachelspitzig. 4. Gräben, fenchte 'Triften häufig z. B. an Wegrändern vor der Dölauer Heide, vor Seben u. s. w. Juni-Aug. Scheiden am Grunde des Halmes schwarz-purpurroth; Halme meergrün; Blüthen 6 männig. Höhe $1-2$ '.

1143. J. flliformis L., fa de $\mathrm{n}$ örmig e B. Abb. 919. IIalm blattlos, fadenförmig, überhängend, glatt, getrocknet fein-gerillt; wurzelständige Scheiden blattlos; Spirre scitenständig, meist 7bliuthig; Blätter der Bliithenhülle lanzettlich, spitz; Griffel fast fehlend; Kapsel rundlich, sehr stumpf, kurz-stachelspitzig. 24. Nasse, sumpfige, hesonders etwas torfhaltige Wiesen und dïrrer Sandboden sehr zerstreut. Fehlt in der Nähe von Halle, im ganzen südöstlichen, südlichen und west- 
lichen Gebiete mit Ausnahme der Grenze bei Wiehe nach Wallr. und bei Ober Schmon unweit Querfurt nach Spreng., im nordöstlichen Gebiete dagegen häufig z. B. bei Dessau, in Walde zwischen Pouch und Crina östlich von Bitterfeld, auf Wiesen an der Benndorfer Mühle, bei Paupitzsch häufig. Juni. Juli. Höhe bis $1^{\prime}$.

B. Nichtbluhende Halme fehlend und statt dieser nichtbluhende Blätterbüschel; Blïthen in Köpfchen, die Köpfchen an der Spitze des Halmes einzeln, oder zu zweien, eines über dem ande. ren oder viele in einer Rispe; Samen ohne An. hängsel.

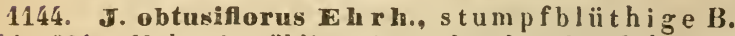
1bb. 901. Haln 2l-3blätterig und nebst den Scheiden und Blüttern stielrund, letztere fächerförmig-röhrig; Spirre endstiindig, doppelt - zusammengesetzt, spreizend; die stengelstündigen Aestchen zurïckgebrorhen; Bliitter der Bliithenhiille gleich, abgerundet-stumpf, ungefähr so lang als die eiförnige, spitze Kapsel. 24. Gräben, Quellen, 'Teiche sehr zerstreut. In einem Sumpfe zwischen Halle und Nietleben links von der Chaussee sparsam, auf Sumpfwiesen vor Bennstedt, an den Quellen zwischen Rückmarsdorf und dem Bienitz häufig, fehlt bei Weissenfels und Naumburg; findet sich auf Sumpfwiesen zwischen Bibra und dem Walde Namens Hahn, in Gräben zwischen Querfurt und Weidenbach häıfig. Juli. Aug. J. bifolius Hop pe. J. divergens Ko $\mathrm{ch}$ und Zi z. Bliithenhiillblätter fast silberweiss. Höhe $1 \frac{1}{2}-3^{\prime}$.

1145. J. lamprocarpus Ehrh., glänzendfrüchtige B. Abb. 902-964. Halm 2-3blätterigr, nebst den Scheiden und Blittern rundlich-zusammengedriickt; Blätter fächerförmig - röhrig, mit starken, äusserlich bemerkbaren, knotenförmigen Querwänden, die Glieder getrocknet glatt oder sehr schwach-gerillt; Spirve endständig, doppelt-zusammenoesetzt, abstehend oder spreizend; Blitter der Bliithenhiille slcichlang, gerade, an der Spitze kurz-stachelspitzig, die äusseren spitz, die inneren stumpf, alle kürzer als die eiförmig-lanzettliche, stachelspitzige Kapsel. 24. Gräben, 'Teiche, Bäche, feuchte Wiesen gemein. Juli. Aug. J. aquaticus Roth. J. articulatus $a_{\text {. }}$ und $\beta$. L. Die Blüthen und Blïthenköpfchen sind meist grösser als an der folgenden Art. Höhe $1-3^{\prime}$. Aendert mit strohgelben und 
schwälzlichen Blüthenköpfchen und mit niederliegendem und wurzelndem oder fluthendem Stengel ab.

1146. J. silvaticus Reichard, spitzblïthige B. Abb. 910. Halm 2-3blätterig, nebst dell Scheiden und lilätern rundlich zusammengedriickt; Blätter fächerförmig - röhrig, nit starken, aussen deutlichen Querwänden, die Glieder glatt oder getrocknet sehr fein gerillt; Spire endstäindig, doppelt-zusammengesetzt, gespreizt; bliitter der Jilithentiille zugespitzt-begrannt, die inneren liinver, an der Spitze zurückgebogen, alle kürzer als die eiförmire, zugespitzt-geschnäbelte Kap. sel. 2. Feuchte Wiesen, Gräben, Wïller seltener als die vorige Art. Juli. Aug. J. acutiflorus Ehrh. J. subnodulosus Schrank. Höhe 1-2'. Aendert ab:

b) brevilostris Nees: Blüthentöpfchen doppelt so gross, weniger zahlreich, auch die Blüthen grösser; Kapsel ron der Lünge der Blüthenhülle.

1147. J. atratus Focker, schwarzblüthige B. Abb. 909.910. Halm 2-3blätterig, nebst den Scheiden und Elättern rundlich-zusammengedriickt; Blätter fächerförmig-röhrig, mit schwachen, aussen undeutlichen Querwänden, die Gitieder getrocknet tief-gerillt; Spirre endstiindig, doppelt-zusammengeset $t$, abstehend; Bliitter der L'liithenhiille zugespitzt-legrannt, die inneren liinøer, an der Spitze etwas zurückgebogen, ungefähr von der Länge der eiförmigen, zugespitzt-geschnäbelten Kapsel. 24. Bisher nur auf der Grenze an der Ziegelscheune von Gundorf und an feuchten Stellen der IValdwiesen bei Lentzsch beobachtet, aber gewiss weiter verbreitet. Juli. Aug. J. melananthos Rchb. J. septangulus P etern. Malme $2-3^{\prime}$ lioch, anfsteigend, Blätter ;kantig, stärker und dicker als bei J. silvaticus; Blüthen glänzend, schwarz, fast doppelt so gross als au der vurigen Art.

1148. J. supinus M ̈̈ n ch, Sum p f - B. Abb. $882-$ 886. Halm fadenförmig; Blitter fict borstenförmig, oberscits schmal - rinnen/örmig, unterseits gewölbt; Aeste der endstïndigen Spirve verlüngert, fast einfach; Blüthenköpfchen entfernt; Blätter der Blüthenhülle lanzettlich, lï̈zer als die lüngliche, stump $f$, stachelspitzige Kapsel, die äusseren spitz, die inneren stumpf; Staub¿e/üsse so lang als der Staubbeutel. 4. Gräben, torfhaltige Wiesen, Noräste, wenig betretene Waldwege stellenweise. In dén Sümpfen bei Lieskan häufig, fehlt bei Naumburg; an 'Triften bei Bibra häufig, bei Des. 
sau, in der Sprodaer Heide bei Delitzsch. Juli. Aug.

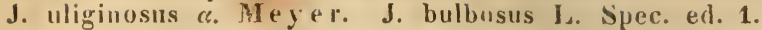
J. subverticillatus Wulf. J. verticillatus Pers. Halme 1/3 - 1' lang. Aendert mit liegendem, wurzelnden und verlängertem, im Wasser fluthendem Halue ab.

1149. J, capitatus eigel, $k$ opf blüthige B. Abb. 862. IIalm hlattlos; Wurzelblätter borstenförmig, am Grunde rinnenförmig; Blïthenküpfchen endständign, einzeln oder ein zweites und drittes gestıeltes; Bliitler der lilithenhiille eiförmig-lanzettlich, zugespitzt-haarspitzig, langer als die eifürmige, stumpfe Kapsel. 4. Sandige, feuchte Aecker, übersihwenmt gewesene, kiesige Flussufer sehr selten, nur bei Dessau an den Ufern der Mulde und Elbe. Juni-Aug. Höhe nur 2-4".

c. Nichtblïhende Halme fehlend, statt dieser Blät. terbiischel; B!üthen einzeln, entfernt uder ebensträussig und eine endständige Rispe bildend; samen whne Anhängsel.

1150. I. senarroses llalm etwas kantig, Llattlos, an Grunde mic Blattschei. den umgeben; Elïtter linealisch, rinnenförmig, abstehend, starr; Spirre endständig, zusammengesetzt, mit ebensträussigen Aesten; Blätter der Blïthenhülle eiförmig-lanzettlich, spitz oder etwas stumpf, su lang a's die verkehrt-eiförmige, stumpfe, stachelspitzige Kapsel; Staubjäiden 4 mal kiirzer als der Stanbbeutel. 2!. Iorfboden, Torfwiesen, feuchte, turfhaltige II älder sehr zerstreut. Auf torfhaltigem Boden zwischen der Krenzschäferei und der Dölaner Heide, thensu zwischeu Kröllwitz und der Dölauer Heide rechts vum Kröllwitz. Dölauer Wege, fuhlt in ganzen südlichen und südwest. lichen Gebiete; findet sich auf der Wüste bei Ziegelrude in der Nähe der Querfurt-irternschen Chaussee, zwischen Puuch und Crina östlich von Bitterfeld, bei Benn. dorf. Juli. Ang. Höhe bis $\mathbf{1}^{\prime}$.

1151. J. compressus J a cq., $z$ us a m m eng e drü ckte B. Abb. $890-892$. Halm zusammengedrückt, in der Mitte 1blätterig; die Wurzelblätter und das stengelständige Blatt linealisch, rinnenförmig; Spirre endständig, zusammengesetzt; Aeste aufrecht; Aestchen ebenstränssig; Blätter der lliithenhiille eiförmig-länglich, sehr stumpf, fast um die Häilfte kürzer als die fast kugelförmige Kapsel; Griffel halb su lang als der Fruchtknoten. 24. Feuchte Grasplätze, Wiesen, 'Irif- 
ten häufig z. B. an der Mühle in Trotha, am Wege zwischen 'Trutha und Seben, auf einer Wiese zwischen Dölau und der Heide u. s. w. Juli. Aug. J. bulbosus L. Spec. ed. 2. nach $\mathbf{S} \mathbf{m}$. und der meisten Autoren. Höhe $1 / 2-1^{\prime}$. Blüthenhüllblätter gelbbrann, auf denı Rürken mit einem breiten grünen Streifen, breit weisslich berandet; Narben hell-fleischroth.

1152. J. Gerardi Lo is 1., Gerard's B. Abb. 888. 889. Halm fast stielrund, in der Mitte lliütterig; Wurzelblätter und das stengelstündige Blatt linealisch, rinnenförmig; Spirre endständig, zusammengesetzt; Aeste anfrecht, Aestchen ebensträussig; Blätter dcr Bliithenhiille eiförmig-länglich, sehr stumpf, fast so lang als die lïnglich-ovale, etwas 3seitige Kapsel; Griffel su lang als der Fruchtkuoten. 4. Feuchte, besonders salzhaltige Wiesen und 'Triften stellenweise. Auf einer Wiese zwischen Dölau und der Heide, häufig bei Dieskau, sehr häufig am salzigen See zwischen Wiusleben und Röblingen, zwische" Langenbogen und Rollsdorf, auf salzhaltigen 'lriften bei Kötschau, fehlt bei Nauniburg; bei Bibra anf einer Sumpfwiese am Wege narh Burkersiode, bei Aschersleben zerstreut. Jnli. Aur. J. bottnicus $W$ ahlenh. Höhe $1 / 2-1^{\prime}$. Bliithenhiillblätter dunkler als an der vorigen Art, kastanienbraun, auf dem Rücken grïn, schmal weisslich berandet; Narben dunkelroth.

1153. J. Tenageia Ehrh., zarte B. Abb. 923. 924. IIalm 1-2blätterig; Blätter borstenförmig, am Grunde rinnenförmig; Aeste der Spirre verläıgert, 2spaltig, abstehend; Bliithen einzeln, entfernt; Blätter der Blüthenhülle eiförmig-lanzettlich, spitz und stachelspitzig, su lang oder ein wenig länger als die rundliche, sehr stumpfe Kapsel $\odot$. Ueberschwemmt gewesene Stellen, veraltete, nasse Wiesenwege, feuchter Sandboden sehr zerstreut. In der Aue bei Döllnitz und Burg Liebenau, auf ïberschwemuten Wiesen bei Wansleben, von Schwa b e bei Alt-Jesnitz angegeben. Juni Aug. J. Vaillantii Thuill. J. gracilis Lej. Höhe $3-S^{\prime \prime}$.

1154. J. bufonius L., Kröten-B. Abb. 8 i2- -876 . Halm beblättert; Blätter borstenförmig, am Grunde rin nenförmig; Aeste der Spirre verlängert, 2 spaltig, anf: recht; Blithen einzcln, cntfernt; Blätter der Blïthenhülle lanzettlich, zugespitzt, benerhlich länger als die iingliche, stumpfe Kapsel. $\odot$. Gräben, Weg- mid

Garcke, Flora. 
Wiesenränder, feuchte Aecker überall ganz gemein. Juli. Aug. Höhe 2-9". Bliithenhüllblätter weiss be. randet.

455. Luzula DC. Marbel (ein von DC. zuerst gebrauchter Nanie, welcher nach Flor. franç. III. $\mu$. $158 \mathrm{sq}$. aus dem angeblich bei J. Bauhin vorkummenden Gramen luzulae gebildet ist).

1155. L. pilosa willd., be ha a rter M. Abb. 848. 849. Wurzelblätter lanzettlich, anI Rande langhaarig, Stengelblätter weit hleiner; IBliithen in einfacher, ebenstriiussiger Spirre, cinzeln stehend, lang-gesticlt; Spirrenäste I-3bliithig, anfrecht, die oberen nach dam Vcrbliihen zurïcligelorochen; Samen an der Spitze nit einem grossen. sichelförmigen Anhängrel. 24. Bergwälder meist nicht selten, nur bei Halle sparsam. Im Bergholze, in Bienitz, in den Wäldern bei Naumburg, Freiburg, Ludersleben, Allstedt, Eisleben häufig. April. Mai. L. vernalis DC. Juncus vernalis Ehrh. J. pilusıs a. L. Bluthenhüllblätter braun, breit weisslich berandet. Höhe $1_{2}-1^{\prime}$.

1156. L. albida DC., we is slicher M. Abb. 854. Wurzel-und Stengelblätter lang-linealisch, an Rande langhaarig; Bliithen in mehrfach-zusammengesetzter Spirre, an der Spitze der Spirrenüstchen meist zu 4 bei. sammenstehend, sehr hurz-gestielt; das unterste oder die untersten Hüllblättchen meist länger als die Spirıe; Blätter der Blüthenhülle spitz, länger als die Kapsel; Staubleutel fast sitzend; Samen ohne Anhängsel. 24. In höher gelegenen Wäldern hänfig. Juni. Juli. Juncus

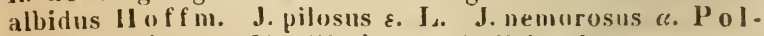
lich. Höhe $2-3^{\prime}$. Hlüthen weisslich oder:

b) rubella Hoppe: Blüthen söthlich oder kupfer. farbe'll.

1157. L. campestris DC., genciner M. Abb. 831-833. Wurzelstock schief, liurz lriechend; Blätter linealisch, am Ramle lang behaart, zuletzt kahl werdend; Bliithen in kur:en, rundlich-eiförmigen Achren, die endständige Aehre gauz kurz, die seitlichen lang gestielt und etwas nichend; Blätter der Blütlienhülle zugespitzt, länger als die rundliche, stumpfe, stachelspitzige Kapsel; die cntleerten Staubbeutel $3 \mathrm{mal}$ läinger als ihr Staubfaden; Samen an Grunde mit einem kegelförmigen Anhängsel. 24. Heiden, Iriften, Gras. plätze, Kaine, Anhöhen überall gemein. März-Mai. 
Juncus campestris L. J. nemorosus Hust. Blïthen heller oder dunkler braun. Die an Grunde aufsteigenden Halne sind 4-10" hoch.

1158. L. multiflora Lejeune, vie l b lii th i ger N1. Abb. 838. Wur ₹elstock biischelförmig; Blätter linealisch, am Rande lang behart, zuletyt kahl werdend; Eliithen in rundlich-eiförmigen Aehren; die endständigen Aehren hurz, die seitenständigen lang und steif grestielt; Blätter der Blüthenhülle zugespitzt, stachel. spitzir, liunger als die l'undliche, stumpfe, stachelspizzige Kinpsel; die entleerten Staubbeutel kaum etwas länger als ihr Staubfaden; Samen am Grunde mit einem hegelförmigen Anhängsel. 7. Heiden, Triften, trockene Waldstellen hänfig. Nai, fängt erst "n blühen an, wenn die vorhergehende $A$ rt verbliiht ist. J. multiflorus $\mathrm{Eh} \mathrm{rh}$. J. erectus Pers. Die ánfrechten Halme 1-2' hoch. Scheint von der vorigen Art wirklich sperifisch verschieden zu sein.

\section{Familic. Cyperaceen Juss. Cyper- grasgewächse.}

1. Gruppe. Cypereen. Lechte Cypergrasgewächse. Blüthen zwitterig; Bälge 2reihig.

456. Cypérus L. Cypergras (Pflanzenname bei Theophrast).

1159. C. flavescens $\mathrm{L}$. , $\mathrm{g}$ e / b lich e s C. Abb. 662-664. Wurzel faserig; Halm stumpf-3kantig, am Grunde von Blattscheiden umgeben; Spirre zusammengeselzt, meist gedrängt, mit buschelförmigen Aehrchen; Hülle meist 3blätterig, länger als die Dolde; Aehrchen lanzettlich, zusammengedrückt-flach; Bälge länglich-eiförmig, dicht dachziegelförmig; Narben 2; Niisschen rundlich-eiförmig, zusammengedri:ckt. $\odot$. Feuchte 'Triften und Wiesen, auf nassem Sand -, Lehm - und Torfboden sehr zerstrent. Auf der grossen Wiese nach $\mathbf{S p r e n g . , ~ a u f ~}$ Wiesen bei Döllnitz, Ermlitz, am Bienitz, bei Dessau zerstreut, bei Oranienbaum an der Scholicker Lache unweit Jüdenberg. Inli. Ang. Bälge gelblich, mit grünen, ror der Spitze verschwindendem Rückenstreife. Höhe $2-6^{\prime \prime}$.

1160. C. Cuscus L., schwarzbraunes C. Abb. 667. Wurzel faserig; Halm spitz-3kantig, an Grunde 
von Blattscheiden umgeben; Spirre fast doppelt-zusammengeset $=l$, mit büschelförmigen Aehrchen; Hülle neist 3blätterig, länger als die Oolde; Aehrciten linealisch, zusamnengedruckt-llach; Bälge länglich-eifürmig, zuletzt etwas abstehend nnd etwas entfernt; Narben 3; Niisschen elliptisch, nach beiden Enden verschmälert, scharf-3kantig. $\odot$. Gräbrn, 'Teichränder, feuchte Wiesen, torfhaltige Orte stellenweise. An Gräben auf der Wiese an der Steinmühle, in der Aue bei Döllnitz, am Bienitz, an Wiesengräben bei Giekau unweit Naum. burg selten, weit häufiger im norlöstlichen Gebiete bei Dessau und Oranienbaum. Juli. Aug. Pycreus flavescens $P$. B. Bälge schwarzbraun, mit schmalem, grïnem. in die Spitze aushaufendem Rückenstreife. Höhe $3-6^{\prime}$.

457. Selnoemus I. Kopfriet (von oyoiros. Strich, weil aus einer Simsenart dieses Namens Stricke verfer. tigt wurden).

1161. Sch. ferrugineus L., ros tbra un $K$. Abb. 676. Halm stielrund, blattlos; Blätter yrundständig, pfriemlich, viel kürzer als der Halm; Köpfchen aus 2 -3 Aehrchen bestehend, an der Spitze des Halnies seitenständig; das äussere Hiillblatt steif -aufrecht; unterständige Borsten 3-5. 24. Mourboden, 'l'urfsumpfe sehr selten; nur an der Benndorfer Mühle nördlich von Delitzsch und nach $\mathbf{S} \mathrm{ch}$ w a bei Radegast. Mai. Juni. Aehrchen schwarzbraun. Höhe bis $\mathbf{1}^{\prime}$.

Schoenus nigricans J., bei welchem die Köpf chen aus 5-10 Aehrchen zusammengesetzt und endständig sind, wird ron $\mathrm{Sch}$ w a b in 'Turfsümpfen bei Radegast angegeben.

2. Gruppe. Scirpeen. Simsengewäehse. Blüthen zwitterıg; Bälge von allen Seiten her dachziegelig-aufeinanderliegend.

458. Hhynchóspora Va I. Mo orsimse (àus

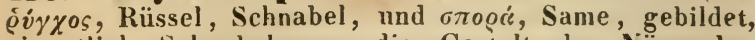
eigentlich Schuabelsame, die Gestalt der Niisse bezeichnend).

1162. Kh. alba Wahl, we is s M. Abb. 678. Wur. iel faserig; Halm 3seitig-beblättert; Blätter schmallinealisch; Aehrchen fast ebensträussig-geknäuelt, Biischel ungefähr so lang als dic Hïlle; unterständige Borsten 10, von derlänge der Nuss. 24. Sumpfige, torfhaltige Orte sehr zerstreut. In der Dölauer He ide nach 
Dölau und Lieskau zu, an Teichrändern zwischen Osterfeld und Meinweh, häufiger bei Dessau, bei Benndorf. Juli. Aug. Schoenus albus L. Aehrchen während der Bliithezeit "eiss. Höhe $1 / 2-1^{\prime}$.

1193. R. fusca Rom. u. Schult., braune $M$. Abb. 677. Wurzelstock kriechend; Halm 3seitig, beblättert; Blätter borstenförnig; Aehrchen kopfförmiggeknäuelt; Biischel vielmal kiirzer als die Hiille; unterständige Borsten 3, doppelt so lang als die Nuss. 4. 'Torfsümpfe sehr selten, nur in der Heide und den Sümpfen bei Lieshau. Juni. Juli. Schvenus fuscus L. Aehrchen während der Blüthezeit braun. Höhe $1 / 2$.

459. Hele ichanto He. Er. Riet (von čios, Sumpf, und záoıs, Anmuth, ejgentlich Sumıfzierde oder Freundin des Sunipfes).

1164. H. palustris R. F r., Sump f-R. Abb. 704. Wurzelstock kriechend; Halm stielrund, etwas zusammengedrückt; Aehrchcn endständig, einzeln, länglich; Bälge ziemlich spitz, der unterste nicht über die folgenden hinausragend, das halbe Achrchen umfassend; Narben 2 ; Nuss verkehrt-eiförmig, zusamnengedrückt, glatt, an den Rändern abgerundet-stumpf. $\leftarrow$ - Sümpfe, Gräben, Teiche, stehende Gewässer gemein. Juni-Aug. Scirpus palustris I. Nüsse bräunlich. Höhe $1 / 2-1 \frac{1}{2}$.

1165. H. uniglumis Link, breitschuppiges R. Abb. 703. Wurzelstock kriechend; Halnı stielrund; Aehrchen endständig, einzeln, länglich; Bälge ziemlich spitz, der unterste nicht über die folgenden hinausragend, rundlich, das Achrchen ganz umfassend; Narben 2; Nuss verkehrt-eiföımig, zusammengedrückt, glatt, an den Rändern abserundet-siumpf. 24. Nasse, torfhaltige Wiesen etwas seltener als die vorige Art. Bei Dieskau, Kı. Dölzig, am Bienitz, Kötschau u. s. w. Juni-Aug. Scirpus tenuis S chreb. Nüsse bräunlich. Höhe $12^{\prime}$. Ist vielleicht nur Abart der vorigen Art.

1166. H. ovata R. I r., e iförmiges R. Abb. 700. 701. Wurzel faserig; Halm stielrund, getrocknet feingerillt; Aehrchen endständig, einzeln, rundlich oder breit-eiförmig; Bälge breit-eiförmig, abgerundet-stumpf, der unterste nicht iiber die folgenden hinausragend, das halbe Aehrchen umfassend; Narben 2; Nuss verkehrt-eiförmig, zusammengedriickt, glatt, scharf-bcrandet; Borsten anderthalbmal so lang als die Nuss. Im Rande stehender Gewässer, an überschwenmt ge- 
wesenen Plätzen sehr selten; nur bei Leutzsch und bei Dessau, früher auch bei Passendorf yefunden. Juli. Aug. Scirpus ovatus $R 0 t h$. S. capitatum Schreb. S. multicaulis Gaud. Niisse strohgelb. Höhe $1 / 2$.

1167. H. acicularis $\mathbf{R}$. H r., na d e lförmiges $R$. Abh. 695. Wurzel kriechend; Halm dün borstentörmig, gefurcht-4seitig; Aehrchen endständıg, einzeln, eiförmig; Bälge eiförnig, stumpf, der unterste nicht über die folgenden hinausragend; Narben 3 ; Nuss länglich, fein-vielrippig. $\odot$. Sumpfige Orte, am Rande stehender Gewässel nicht gerade selten. Auf der Wiese an der Steinmühle sparsam, häutiger in Iachen zwischen Ammendorf und Schkopau, zwischen Döllnitz und Burg Liebenau, hei Naumbur ä an der Saale und in Lachen der Aue 11. s. W. Juni - Aug. Scirpus acicularis I. Linunochloa acicularis Rchb. Höhe $1-4^{\prime \prime}$.

460. Sevipus T. Simse (Pflanzenname bei Plinius).

A. Aehrchen endständig, einzeln am Ende des Halmes oder der Halmäste, aber die Aeste nicht rispig.

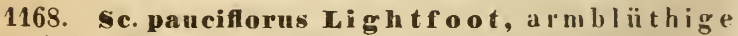
S. Abb. 707. 705. Halm stielrund, an Grunde mit blattlosen Scheiden; Aehrchen endständig, einzeln, eiförmig; Büloce stumpf, orannenlos, der unterste grösser, das Aehrchen ganz unfassend, mit einem vor der Spitze verschwindenden Nerven durchzogen; Narben 3; Nuss 3seitig, glatt; Borsten cin wenig hiirzer als die Nuss. 4. Sumpfige, besonders torfhaltige Wiesen zerstrent. Auf einer torfhaltigen Wiese zwischen der Kreuzschäferei und der Heide, häufiner in den sümpfen bei Lieskan, an salzigen See zwischen Wansleben und Rollsdorf, bei Aschersleben stellenweise, hei Dessau und Oranienbaum häufig, ebenso in 'I'orfstiche an der Benn. dorfer Mühle. Juni. Juli. Sc. Baeothryon Elilh. Höhe $2-6 \cdot$

1169. Sc. parvulus Roem. u. Schult., kle ine s. Ahb. 706. Halm stielrund, inwendig querwandig; Scheiden sehr diinnhïutig, blattlos: Aehrcheu endständig, einzeln, eiförmig-länglich; Bälge stumpf, srannenlos; Narben 3: Nuss 3seitig, glatt; Borsten lïneer als dic Nuss. $\odot$. Ueberschwemnt gewesene Stellen am Rande von Seen sehr selten, uur am salzigen See und zwar an dem sugenannten Binnensee bei Rollsdurf, einzeln auch am nördlichen Rande des salzigen Sees zwi- 
schen Erdeborn und Rullsdorf und am süssen See. Sc. nanus Spreng. Sc. humilis Wallr. Nur -2" hoch.

Die Pflänzchen hängen durch einen unterirdischen haarfeinen Wurzelstock zusammen und senden nach allen Seiten ähnliche haarfeine, einfache Ausläufer, welche mit einer kleinen, fast knollenartigen, etwas sichel. förmig-gekrïmmten, zugespitzten Kinuspe endigen. Nur äusserst selten tragen sie reife Frïchte.

B. Spirre trugsejtenstänlig, indem das grössere Hiillhlatt sich aufrichtet und eme Fortsetzung des Halmes darstellt; Aehrchen einzeln uder mehre in einem Büschel oder viele einzelı am Ende der Rispenäste oder daselbst büschelförmig-gehäuft: Blätter der Hülle und wenu sip vorhanden siud, les Halmes halbstielrund odel 3 kantig - rinnenförmig.

a. Bälge an der splize ganz, stachelspitzig.

1180. Sc. setrceus L., horstenfö rmigr e S. Abb. 711. 712. Halm fadenförmig, dünn, stielrund; Achrchen einzeln, zu zweien oder dreicn, trug-seitenständig; das Hüllblatt vielmal kiirzer als der Halm, aufrecht, zuletzt etwas zurïckgebogen; Bälge stumpf, mit einem Stachelspitzchen; Narben 3; Vuss zusammengedrückt, längs. rippig; Bursten meist fohlend. $\odot$. Ueberschwemmite Plüt\%e, 'Teichränder, Wiesen, besonders auf feuchtem Sandbuden stellenweise. Zwischen der Irrenanstalt und der Dölaner Heide, zwischen Kröllwitz und Lettin, auf sandigen 'Iriften bei Bibra, bei Dissau stellenweise. Juli. Aug. Isulepis setacea R. B r. Höhe 1-4". dendert $a b$ :

b) clathratus $\mathrm{Kchb.} \mathrm{Abb.} \mathrm{713.:} \mathrm{Aehrchen} \mathrm{einzeln,}$ meist längej als das sehr kurze Hüllblatt, Nuss schwach querwellig gegittert, so sehr selten, nur an der Saale bei Naumburg. Die Abart hat ganz die 'lracht von Sc. Savii Sebast. und Ma ur.

2171. Sc. supinus L., $1 \mathrm{i}$ egende S. Abb. 715. Halm stielrund; Aelirchen biischelförmig, sitzend, trug-seitenständig; das Hüllblatt aufrecht, ungefähr su lang als der Halm; Bälge stumpf, fein stachelspitzig; Narben 3; Nuss 3seitigr, quer-runzelig; Borsten fehlend. $\odot$. Ueberschwenmite Plätze sehr selten. Mit Sicherheit nur bei Aschersleben an den Teichen nach Hecklin. gen zu; hei Kattau und Werdershausen zwischen Löbejün und Gröbzig jetzt zweifelhaft. Juli. Ang. Halme 
$4-6$ "lang, die mittleren aufrecht, die seitlichen aus. gebreitet.

b. Bälge ausgerandet, mit einer Stachelspitze in der Bucht.

1172. Sc. Iacustris L., Se e-S. Abb. 722. Halm stielrund; Spire zusammengesetzt, trug-seitenständig; das grössere Hüllblatt aufrecht; Aehrchen hiischelförmiggehäuft, Büschel gestielt und sitzend, Jälge glatt, frall. sig, ausgerandet, mit einer Stachelspitze in der Bucht; Narben 3; Nuss 3seitig, glatt; unterständige Bursten rückwärts feinstachelig. 4. Stehende und langsam fliessende Gewässer gemein z. B. bei Dieskau sehr häufig. Juni. Juli. Höhe $4-S^{\prime}$.

1173. Sc. Tabernaemontani Gmel., Tabernä. montans-s. Abb. 723. Halm stielrund; Spirre zusammengesetzt, trug-seitenständig; łas grössere Hüllblatt aufrecht; Aehrchen büschelförnig-gehäuft; Büschel gestielt und sitzend; liälge puntirt.rauh, fransig, ausgerandet, mit einer Stachelspitze in der Bucht; Narben 2; Nuss fast 3seitig-gewölbt, glatt; urterstän. dige Borsten rückwärts fein stachelspitzig. 4. An und in Teichen, Gräben verbreitet, obglejch etwas seltener als vorigre Art. An den Teichen bei Diestial, in Gräben vor Bennstedt, an den Dömeken bei Wansleben, in Gräben bei Kl. Dölzig und neben der Chaussee zwischen Dölzig und Rürkmar'sdorf, bei Kötschau, Schladebach, in Sümpfen des Ziegelroder und Lodersleber Forstes, bei Artern u. s. w. Juni. Juli. Sc. glaucus Sm. Der meergrïne Halm ist meist $3-5^{\prime}$ hoch.

C. Spire endständig, zusammengesetzt. Blätter des Halmes und der Hiille grasartig.

1174. Sc. maritimus L., Meerstrands-S. Abb. 726. Halm 3kantig, beblätert; Spire zusammengeset: Aehrchen büschelförmig; Büschel gestielt und sitzend; Hiille flachblätterig; fieilge an der Spitze stachelspitzig und 2spaltig; läppchen spitz, gezähnelt; Narben 3; unterständige Borsten rückwärts steifharig. 24. Seen, 'Teiche, Lachen besondes auf salzhaltigem Boden nicht selten. Einzeln an einem kleinen 'Teiche vor' dem Geistthore rechts ron der Chaussee, an Gräben zwisehen Halle und Nietleben und vor Bennstedt, an den Teichen in Schkopau, hei Röglitz, Möritzsch, Kl. Liebenau, Kl. Dölzig, Kötschan, in der Aue bei Naumburg, bei Artern, sehr häufig am salzigen und süssen See u. s. w. Juli. Ang. Hohe $1-3^{\prime}$. Aendert ab: 
b) compactus Kruck. Abb. 727. : Aehrchen alle sitzend, geknäuelt, su an salzigen See bei Wansleben.

1175. Sc. silvaticus $\mathrm{C}$, W W Id-S. Abb. 731. Halm 3 kantig, beblättert; Spirre ebenstriussig, mehrfach-zusammengesetzt; Aehrchen büschelförmig; Büschel gestielt und sitzend; Hiille flachblitterig; Bälge stumpf, feinstachelspitzig; Narben 3; unterständige Borsten gerade, rückwärts-steithadrig. 24. Feuchte Wiesen, Sümpfe, Grüben häufiy z. B. bei Seben, in Gebüsch vor Gutenberg, zwischen Döllnitz und Burg Liebenau und bei Naumburg an der kleinen Saale, bei Bibra auf sumpfigen Wiesen häufiğ u. s. w. Juni. Juli. Höhe 1-3'.

1176. Sc. radicans schkuhr, wurzelnde S. Abb. 732. Haln 3kantig, beblättert; Spirre ebensträussig, mehrfach-zusammengesetzt; Aehrchen alle gestielt; Hiille flachblätterig; Bülge stumpf, ohne Stachelspit:chen; Narben 3; unterständige Borsten zusammeng areht, glatt. 24. Flussufer, sumpfige Wiesen sthr zerstreut. An der stillen Elster bei Osendurf sparsam, an der Elster zwischen Döllnitz und Burg Liebenau, zwischen dem Bienitz und Rïckmarsdorf, bei Dessau häu. figer z. B. im 'Thiergarten, Georgengarten. Juli. Aug. Höhe 2 - 4'. Es entspringen stets mehre Halme aus einem Punkte, von denen die unfruchtbaren nach der Bluthezeit sich verlängeru, 2-4' lang werden und in einem Bugen heribgekrümmt an ihrer Spitze wurzeln; die Aehrchen sind länger und spitzer als bei Sc. silvaticus.

D. Aehrchen in einer zusammengedrückten, 2zeiligen, endständigen Aehre.

1177. Sc. compressus Pers., zus amme $\mathrm{ng}$ e drückte S. Abb. 693. Haln undeutlich-3seitig, beblättert; Blätter unterseits - gekielt; Achre 2zcilig; Aehrchen 6-8blïthig; unterstiindige Borsten riickwairtsstachelig. 24. Nasse, besunders moorige Wiesen, Gräbell. Auf einer Wiese unnittelbar hinter den Gärten bei Nietleben, bei Jieskau, Gutenberğ, sehr häufig zwischen Wansleben und Röblingen, bei Kl. und Gross Dölzig, an den Quellen zwischen Rückmarsdorf und dem Bienitz, bei Kötschau häıfig, fehlt bei Naumburg, auf sumpfigen Wiesen bei Bibra, an einem Bache жwischen Oberschmon und dem Walde häufig, bei Sandersleben auf einer Wiese am sogenannten Stall, bei Mosigkau unweit Dessau. Juni- Aug. Sc. Carjcis Retz. Sc. 
caricinus Schrad. Schoenus compressus L. Carex uli. ginosat L. Blysmus compressus $\mathrm{P}$ anzer. Halm 4-10" lang.

1178. Sc. rufus Schrad., braunrothe S. Abb. 694. Halm stielrund; Blätter kiellos; Achre 2zeilig; Aehrchen 2-5bliithig; liorsten aufrecht-weichtiaarig oder fehlend. 24. Salzhaltige Wiesen sehr selten. Auf Nalzwiesen bei Dieskan, Wansleben, am süssen See bei Seeburg, bei Hecklingen und Stassfurt. Juni. Juli. Schoenus rufus Huds. Blysmus rufus Link. Höhe 4-9" hoch. Gewöhnlich hat die Pllanze ein einzigess Hüllblatt, welches so lang als die Aehre ist, sie ändert aber ab:

b) hifolius Wallr.: Aehren von einem doppelten Hiillblatte gestiitzt, so mit der gew öhnlichen Form bei Wansleben und Stassfurt.

461. Erióplnorum I. Wollgras (ein bei Thenphrast vorkummender Pflanzenname, welcher ans źgıo", Wolle, und pégı, tragen, zusammengesetzt ist, wegen der unterstündigen, nach dem Verblïhen verlängerte" Burste").

11\%9. E. vaginatum L., scheidenförmiges W. Abb. 686. Wurzel faserig; Ilalm blattlos, vom Grunde bis zur Nitte mit 2-3 gedunsenen Scheiden besetzt, uberwärts 3seitig; Błätter grundständig, fadenförmìr, an Rande rauh; Aehrchen cinzcln an der Spitze des Halmes, länglich-eiförnig; unterständige Borsten zahlreich, nach dem Verbluihen verlängert und eine lange "eisse Wolle bildend. 4. Auf Mour. und 'Torfborlen sehr selten. In 'Torfsümpfen bei Schierau südlich von Dessau, bei Oranienbaun an mehreren Stellen z. B. all der Kolonie Gnadicke, an der Jurhwiese in der Nähe der Brücknühle, zwischen Pouch und Crina östlich von Bitterfeld, nach speeng. auch bei Oberschmın. April. Mai.

1180. E. latifolium Yoppe, bre itblät teriges W. Abb. 691.692. Halm stumpf - 3seitig; Blätter ziemlich breit-lineilisch, flach, an der Spitze 3kantig, an Rande rauh; mehre Achrchen an der Spitze des Halmes; Pliithenstiele riiclizuairts stachelig; unterständige Bursten nach dem Verblïhen verlängert und eine lange weisse Wulle bildend. 24. Sumpfige, besonders twifhaltige Wiesen, nicht allgemein verbreitet. Auf Sumpfwiesen bei Dölau, bei Gutenberg unter dem T'annen- 
herye, zwischen Pfitzenhurg und Wansleben, auf torfhaltigen Wiesen bri Möritzssh, Kl. Dölzig, am Bienitz, bei Kötschau; fphlt bei Nammburg und im Riethe bei Allstedt digegen im nurlöstlichen Gebiete häufig. April. Mai. E. polystachyum $\beta$. L. E. pubescens S m. Höhe 1-2'.

1181. E. angustifolium reth, schmalblät te riges W. Abb. 689. 690. Halm ziemlich stielrund; Blätter schmal-linealisch, oberseits rinnenfürmig, an der Spitze 3kantig, am Rande fast glatt; melre Aehrchen an der Spitze des Halmes; Bliithensticle slatt; u1terständige Bursten zahlreich, nach dem Verblühen verlängert und rine lange weisse Wolle bildend. 4 . Sum. pfige Wiesen häufiger als die vorige I't z. B. auf Sumpf. wiesen bei Dölau, Bennstedt, Gutenberg, schon unmittelbar vor der Stadt an der sugenannten faulen Wiese u. s. w. April. Mai. E. polystachyun «. L. Höhe $1 / 2-1 \frac{1}{2}{ }^{\prime}$.

1182. E. gracile Koch, schlankes W. Abb. 687. 68s. Halme undeutlıch-3seitig; Blïtler 3 kantig, am Rande towas rauh; mehre Achichen an der Spitze des Halmes; Bliithensticle filzig-raulı; unterständige Burteu zahlreich, nach den Verblühen verlängert uud eine lange wrisse Wolle billend. 24. Torfsumpfe sehr selten. Wird von Wallr. zwischen Leimbach und Ziegelrode und ron Spreng. zwischen Ruthenschirmbach und Hornburg angegeben; der Verfasser hat es im Gebiete nuch nicht gefunden. Mai. Juni. E. triquetrum H op e. Höhe 1'.

3. Gruppe. Cariceen. S eggengewächse. Blüthen eingeschlechtlich.

462. Carex L. Segge (Pflanzenname hei Virgil).

A. Psyllophorae Loisl. Flohseggen. Aehrchen einzeln auf der Spitze des Halmes. Granne an dem Fruchtyrunde fehlend.

a. Narben 2; Aehrchen thäusig.

1183. C. dioica L., $z$ we ihäusigge S. Abb. 522. Wurzel ausliiufertreibend; Blïtter und Halme lahl; das Achrchen endstïndig. einzeln, 2hïusig; Narben 2; Früchte ziemlich aufrecht, eiförmig, vielnrrvig, oberwärts am Rande rauh. 24. Sumpfige, schwammige, torfhaltige Wiesen sehr selten. Auf Wiesen zwischen Gross Dölzig und Möritzsch, an den Quellen zwischen dem Bie- 
nitz und Rïckmarsdorf, sparsam auf der torfhaltigen Wiese an der Benndorfer Mühle. Blüht im April. Mar, aber erst Ende Juni mit reifen Frïchten. C. Linnaeana Host. Höhe nur 3-6".

Für diese seltene Pflanze gibt Spreng. el. 2. p. 402 zwar die sumpfigen Wiesen bei Seben und Gutenberg als Standorte an, alier laselbst findet sich nur $\mathrm{C}$. Davalliana $\mathrm{S}$. und $\mathrm{W}$ all $\mathrm{r}$. hat Sched. p. 491 nachgewiesen, dass Sprenuel die C. divica immer verkannt und eine Form des C. Davalliana Sm. für die C. dicioa gehalten habe.

1184. C. Davalliana Sm., Daval'sche $\mathbf{S}$. Abb. 523. Wurzel faserig; Blitter am Rande nebst den Halmen rauh; das Achrchen endstïndig, einzeln, 2hüinsig; Narben 2; Früchte zurückgekrümmt-abstehend, länglich-lanzettlich, fein-vielnervig, oberwärts an Rande etwas rauh. 24. Sumpfige, torfhaltige Wiesen selten. Auf Wiesen vur dem Sebenschen Busche sparsam, weit häufiger auf den sumpfigen Wiesen bei Gutenherg unter dem Tannenberge, bei Möritzsch, bei Gr. Nölzig, zwischen Wl. Dölzig und dem Bienitz, auf torfhaltigen Wiesen an der Benndurfer Mühle, fehlt in ganzen siidlichen, westlichen und nördlichen Gebiete. April. Mai.

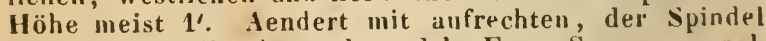
angedrücliten Früchten ab, welche Form S'preng. nach W allr. für C. dioicu L. ausgegeben hat.

h. Narhen 2; Aehrchun mannweibig.

1185. C. pulicaris L., flohs a mige S. Abb. 524. Wurzel ansläufertreibend; Blätter borstenförmig; das Aelwchen endstïndiw, einzeln, mannweibi=, oberwäirts männlich; Narben 2; Iriichte entfernt, liinolich, nach beiden Enden verschmälert, nervenlos, zurïckgebogen; Bälge abfallend. 24. 'Turfhaltige Wiesen sehr selten, bisher nur zwischen Pouch und Crina östlich von Bitterfeld gefunden. Mai. Juni. C. psyllophura L. Höhe meist $6 "$.

\section{c. Narben 3.}

1186. C. obtusata Liljeblad, ährige S. Abb. 528. 529. Wurzel ausläufertreibend; Blätter linealisch, flach, grasgrün; das, tehrchen endständig, cinzeln, linealisch, mannweibig, oberwärts männlich; Narben 3 ; Friichte länger als der Balg, eiförmig oder elliptisch, gedunsen, glänzend, in einen stielrunden, glatten, an 
der Spitze weissen und durchscheinenden zweispaltigen Schnabel zugespitzt. 2;. Auf trockenem, feinsandigem Buden im Bienitz, besonders an der Sïlwestseite häıfig. Mai. C. spicata Schkuhr. Höhe 6".

Diese äusserst seltene Pflanze wird zuerst run W o hlleben (supplem. ad l.eyss. flor. hal. p. 3s) unter dem Namen C. Jeucoglochin erwähnt und als Standort die sumpfigen Wiesen bei Gutenberg dem Tamnenberge ge. gen ïber angegeben. Von Wohlleben erhielt darauf Schkuhr (Beschreibung und Abbildung der Riedgräser p. 11) ein Exemplar dieser Pflanze durch den Apothekel Kohl in Halle, bildete es in seiner Cariculogie ab, konnte aher keine Exemplare mit reifen Früchten erhalten. Dies schkuhr'sche Exemplar befindet sich nuch jetzt in seiner zu Halle aufbewahiten Sammlung der Seggengräser. Sprengel gibt in der Flora hal. ed. 1. p. 258 als Standort für diese Pflanze die schwam. mige Wiese bei Gutenberg unter dem lannenberge an und in der 2. Aufl. S. 402 fiigt er als zweiten Standurt den Bienitz bei Kl. Dölzig hinzu. An dem ersten Standurte, der schwammigen Wiese bei Gutenberg wächst aber nur C. Daralliana S $\mathbf{S}$., welche bisweilen mit mannweibigen Aehren vorkommt und eine sulche Form liegt im Sprengel'schen Herbario unter der Bezeichnung: ,C. spicata Schk. Gutenberg d. 23. Mai 18:9"“; anch hat Prof. Kunze nur diese Furm der C. Davalliana S m. für C. spicata Schkuhr aus Sprengel's Händen empfangen. Sprengel hat also die ächte C. spicatia Schk. nie bei Halle gefunden und immer mit C. Davalliana $\mathrm{Sm}$. verwechselt, was um su begreiflicher ist, da er sogar eine andere Furm der C. Davalliana Sm. für die ganz bekannte C. dioica L. halten konnte, wie dies oben nachgewiesen ist; er hat alsu aus der einen Segge, der C. Davalliana Sm. drei Arten construirt!! Was nun aber die Angabe bei Wohlleben betrifft, so muss der Verfasser annehmen, dass eine Verwechselnng des Standortes stattgefunden habe, da C. spicata Schk. nur auf lockerem, feinsandigem Boden, aber nicht auf sumpfigen Wiesen vorknmmt. Wenn endlich auch Wallr. sched. p. 492 diese Pflanze fïr die Flora von Halle, zwar ohne bestimmten Standort angibt, indem er sagt: "gramen agro halensi et lipsiensi fursan proprium “ und darunter etwa die schwammige Wiese bej Gutenberg verstanden wissen will, so muss sich auch bei ihm ein Irthum eingeschlichen haben. 
B. Vigneac. Vigneen. Aehrchen mannweibig, in einer unuterbrohenen oder unterbruchenen Aehre, mit e.jnem Deckblatte gestützt, von denen das unte:ste oft in ein Blüthenblatt übergeht.

a. Narben 2; Aehrchen wherwärts männlich.

1. Wurzel lange dusläufer treibell.

1187. C. arenaria L., Sand - S Hayne Arzneigew. V, 7. R b. Abb. 551 . I nrzel lange Ausläufes treibend; Halnı uberwärts auf den Kanten rauh; Aelire doppelt-zusummengesetzt, länglich oder fast eiförmig, gedrungen und unterwärts unterbrochen, die obercn Achrchen mainnlich, die unter'n weiblich, die mittleren an der Spitze mänulich; Narhen 2; Friichte eilörmig, flach-gewölbt, 7-9nervig, von der Vitte an mit cincm verbreiterten, feingesägt-rauhen, an dem 2spaltigen Schnabel hinaufziehenden Fliigel eingefasst; Bälge zugespitzt, su lang als die Frucht. 2. Auf Sandboden, besunders Flug. sand sehr seiten, nur bei Dessau, aher daselbst häufig. Mai. Juni. Höhe $1 / 2-1$ '. OFF. radix Caricis arenariae, Sarsapariliae germinicae s. Graminis majuris.

1185. C. disticha H ads., zweize ilige S. Abb. 552. Wurzel auslänfertreibenil; Halm an den Kanten rauh; Aehre doppelt-zusammengesetzt, länglich, gedrungen oder unterwärts unterbruchen; die olsersten und untersten Aehrchen weiblich, die mittleren münnlich; Varben 2; Friichtc eiförmig, flach-gewölbt, 9-11ner. vig, mit cinem schmalen, feingesägt-rauhen liande umgebcu, in einen 2zähnigen Schnabel, länger als der Balg; Bälge spitz, mit einem vur der Spitze verschwindenden Nerven. 24. Feuchte Wiesen, Gräben nicht selten z. B. auf der Wiese am Dunnersberge hinter Kröllwitz, sehr häufig auf II iesen zwischen Langenbogen und Rollsdorf u. s. w. Mai. Juni. C. internedia Good. C. arenaria l, e e rs. Höhe $1^{\prime}$ und darüber.

2. Wurzel einen dichten Rasen von blätern und Halnen, aber keincoder sebrkurze $A$ uslaufer treibend.

1189. C. valpina L., fuchsbraune S. Abb. 564. Wurzel faserig; Halnı an den Kanten sehr rauh; Aehren doppelt - zusammengesetzt, eiförmig - länglich, und gedrungen oder verlängert und unterbruchen; Aehrchen uberwärts männlich; Narben 2; Friichte sparrig-abstehend, eiförmig, flach-gewüllt, in einen 2 spaltigen, an Rande dicht-feingesägt-rauhe'n Schnabel zugespitzt, 6-7nervig; Bälge stachelspitzig, kürzer als die Frucht. 4. Gräben, Teiche, Sümpfe nicht selten z. B. schon 
im Chausseegraben zwischen Halle und Trotha, bei Seben u. s. w. Mai. Juni. Malm 1-2' hoch. Aendert ab:

b) ne un orusa IV illd.: Bailge ausser ejnem grünen Rückenstreifen weisslich, anı Rande bräunlich, dies ist C. nemorosa Willd. und Rebentisch, aber nicht Lum uitzer, so meist an bewaldeten, schattigen Stellen.

1190. C. muricata L., nach Sm. und Wahlenb., spar rf iichtige S. Ahb. 561.562. Wurzelstock dicht. rasenfürmig, ohne Ausliuifer; IValn an den Kanten oberwärts rauh; Achren zusanmengesetzt, lïnglich, gedrungen oder an Grunde unterbruchen; Aehrchen ober. "ärts männlich; Narben 2 ; Friichte sparrig, die unteren fast wagrecht - abstehend, lanzettlich - eiförmig, flach-gewöllbt, in einen am Rande dirht-feingesägt. ranhen sirhnabel zugespitzt, nervenlos oder undentlich nervig; Bälge stachelspitzig, kürzer als die Frncht. 2. Wälder, Wiesen häufig. Mai. Juni. C. canesceus Leers. C. spicata Huds. C. cuntigua Hoppe. Die sparrigen, endlich niedergebogenen Halme sind bis 11/2' lang. Aenlert ab:

b) virens I, am.: Halme steif-aufrecht; Deckblätter blattartig; Aehren gewöhulich mehr verlängert und unterbruchen: Bälge hlässer; Frïchte grïn und oft ein wenig grösser: C. nemorosa Lumitzer. C. muricata Hoppe, so in Hainen und Gebüschen.

1191, C. teretiuscula Good., stielrundliche S. Abb. 572. Wurzelstock schief, ein wenig kriechend; Halm oberwärts rauh, Jkantig, die Seiten ziemlich gewölbt; Achren zusammengesetzt oder meist doppelt - zusammengesetzt, gedrungen-gehäuft; Aehrchen uber. wärts männlich; Narben 2 ; Frïchte eiförmig, löckerig ¿elvölbt, glänzend, nervenlos, glatt, auf dem Rücken an Grunde etwas rillig, in einen 2zähnigen, am Rande feingesägt-rauhen Sihnibel verschmälert; Balge unge゙fähr su lang als die Frucht. 24. Sumpfige, torflialtige Wiesen sehr sriten. An den Quellen zwischen deu Bienitz und Rüclimarstorf, von Spreng. hal. ed. 2. $\mu$. 4115 auch auf den sumpfigen Wiesen am Ioberbache bei Benndurf angegeben, wo dre Verf. bisher nur C. paradoxa gefunden hat; von S chwabe bei Uranienbaum an. gezeigt. Mai. Juni. C. diandra $R(1)$ h. C. paniculata B. Pullich. Höhe $3 / 4-11 / 2^{\prime}$.

1192. C. paniculata J., rispige S. Abb. 574. Wuriel faserig, dicht-rasenfürmig; Halm oberwärts sehr 
rauh, 3hantig, die Seiten flach; dehren rispig; Achrchen oberwärts männlich; Narben 2; Friichte eiförmig, höcherig - gewölbt, nervenlos, glatt, an dem Rïcken an Grunde etwas rillig, in einen 2zähnigen, am Rande teingesägt - ranhen Schnabel zugespitzt; Bälge breit, silberweiss-berandet, ungefähr so lang als die Frucht. 4. Sumpfige, schwammige, etwas torfige Wiesen, Gräben, Bärhe stellenweise. An schattigen, sumpfigen stellen in der Nähe der 'I'eiche bei Dieskau, an Wiesen. rä̈ndern bei Kl. Dölzig, an den Quellen zwischen dem Bienitz und Riickmarsdorf; fehlt im südlichen und westlichen Gebiete; findet sich hei Aschersleben im see häufig, bei Dessall und Oranienbaum. Mai. Juni. Höhe 1 - $3^{\prime}$. Ist durch die breiten, silberweiss beran. deten, glänzenden Bälge sugleich von der vorhergehenden und nachfolgenden Art zu untrrscheiden.

1193. C. paxadoxa Willd., a b weichende S. Abb. 573. Wurzel faserig, dicht-rascnfürmig; Halme oberwärts sehr rauh, 3 kantig, die Seiten etwas gewölbt; Aehren rispig, Aehrchen uberwärts männlich; Narben 2; Friichte eiförmig, höckerig-gewöllt, auf beiden Seiten nervig-gerillt, in einen 2zähnigen, am Rande feingesägt-rauhen schnabel zugespitzt; Bälge so lang als die Frucht. 24. 'Tortige Wiesen sehr selten. An pinem Bache auf den sumpfwiesen bei Gutenberg, bei Möritzsch, bei Kl. Dölzig, an den Quellen zwischen dem Bienitz und Rüchmarsiorf, bei Naumburg auf der Gröbitzer Wiese, am Loberhache bei der Benndorfer Mühle nördlich von Delitzsch, bei Allstedt in Bornthale, nach Spreng. auch in Sumpfe bei Lieskau, wo der Verf. bisher vergeblich gesucht hat. Mai. Juni. Bälge schmäler als an der vorigen Art, schmal weiss. lich berandet oder ganz unberandet. Höhe 1-2'.

b. Nirbe 2; Aehrchen am Grunde: mämlich, in einer einfichen sehre wechselstiudiv.

1. Wurzel weit kriechend.

1194. C. Schreberi schrank., Schreber's $S$. Abb. 549. Wurzelstock weit kriechend; Aehre zusammengesetzt; Aelrchen meist 5, wechselständig, gedrungen, gerade, eiförmig - länglich, unterwärts männlich; Narben 2; Friichte aufrecht, so lang als der Balg, läng. lich-eiförmig, flach-gewölbt, fast vom Grunde an à Rande feingesägt-wimperig, in einen 2spaltigen Sschnabel zugespitzt. 24. Sonnige Anhöhen, trockene Grasplätze, Kaine, Wiesen, Wegränder sehr häufig z. B. 
an den Pulverweiden, an der Bergschenhe bei Kröll. witz und sunst gemein. April. Mai. C. praecox Schreb. A ehrchen dunkelbraun. Blätter meist schmäler als an der folgenden Art. Höhe meist $12^{\prime}$, an schattigen Stellen aber bis über 1' huch. Aendert ab:

b) pallida Lang: Bälge heller gefärbt, aber imı̨er noch dunkler als die dehrchen von C. brizoides, so in der Brenau bei Wettin.

1195. C. brizoides L., zittergrasartige S. Abb. 548. Wurzelstock weit kriechend; Aehre zusammengesetzt, fast 2zeilig; Achrchen meist 5, wechselständig, senähert, gekriimmt, lïnglich-lanzettlich, alle mannweibig, unterwärts männlich; Narben 2, Frïchte aufrecht, so lang oder meist länger als der balg, lanzettlich, flach-gewölbt, glatt, geschuäbelt-verschmälert, am Rande vom Grunde an jeingesägt-vimperig; Sehnabel 2spaltig. 4. Feuchte Wäldrr, schattige Stellen sehr zerstreut, aber meist zahlreich beisammen stehend (in anderen Gegenden grosse Plätze überziehend). In den Wäldern ier Aue nicht selten z. B. zwischen Döll. nitz und Burg Liebenau, zwischen Sichkeuditz und Kl. Dölzig, bei Naumburg im Mühlholze zwischen Schö». bug und Wetau, weit häufiger in nordöstlichen Gebiete z. h. bei Dessau, Oranienbaunı, zwischen Sollnitz und Kleutsch, zwischen Pouch und Rösa östlich von Bitterfeld. Mai. Juni. A ehreh en strohgelb. Blätter gelblich - grün. Der schlauke, dünne, schwankende Halm 1-1 1 $\frac{1}{2}$ hoch. Nach Lang sind auch die vollkonmen reifen Früchte inmer taub.

2. Wurzel einen dichten Rasen ron Blätern und Halmen, iber keine oder nur sehr kurzedusliufer treibend.

1196. C. remota L., entferntährige s. Abb. 556. 557. Wurzelstock dichtrasentreibend und schief, etwas kriechend; Halm schlank und schwach in einem Bugen überhäıgend; Aehre zusammengesetzt, Aehrchen wechselständig, unterwärts mäınlich, die $3-4$ unteren entfernt, mit einem iiber den Halm hinausragenden Dechliatte gestiitzt, alle einfach oder selten das unter'ste zusammengesetzt; Narben 2; Frïchte aufrecht, flachzusammengedrückt, in einen 2zähnigen, feingesägt-rauhen Schnabel zugespitzt, länger als der Balg. 24. Fipuchte, schattige Laubwälder, besonders an Bächen, nicht gerade selten. Im Sebener Busche; in Wörmlitzer Hölzchen einzeln, hüufiger auf der Rabeninsel, sehr häufigr in der Aue z. B. bei Burg Liebenau, bei Naumburg a:ı

Garcke, Flora. 
sumpfigen Stellen z. B. in der Nähe der alten Saale zwischen Almerich und Schulpforte, bei Eisleben in Helftaer Holze am Bache, bei Dessan, Musigkau, Kochstedt, Oranienbaum, Bitterfeld, an der Benudorfer Mühle nicht selten. Mai. Juni. Höhe $1^{\prime}$ und darïber.

Nach Koch (Synops. ed. 2. p. 869) soll der Wurzelstuck bei dieser drt keine Ausläufer haben und $\mathrm{R} \mathrm{chb}$. hat (Dentschlands Flura Nr. 556 и. 557) zwei dbbildungen mit der Bezeichnung C. remota L. und C. remota repens Britting. gegeben, welche letztere Pflanze er als eigene Art anfstellen nöchte. Lang hat indessen nachgewiesen, dass C. remota $\mathrm{C}$. immer einen fast wag. vechten, nur wenig schiefen Wurzelstuck habe, wenn man sich nur die Nühe geben wolle, ihn vollständig auszugraben.

Carex axillaris Good. ist schon ausserhalb der Grenze bei Eilenburg beobachtet.

1197. C. stellulata Good., sternförnigg C. s. Abb. 560. Wurzel rasentreibend; Haln glatt oder an der Spitze seltener rauh; Aehre zusammengesetzt; Aehrchen meist 4 , zienılich entfernt, unterwärts nuännlich; Narben 2; Friichte sparrig-ahstehend, flach-gewölbt, eiförmig, in einen 2zïhnigen, feingesägt - rauhen Schnabel zugespitzt, zart-nervig-gerillt; Deckblätter kürzer als die Aehrchen. 24. Feuchte Wiesen, Wälder, Gräben häufig z. B. bei Dölan, Seeben, Gutenberg u. s. w. Mai. Juni. C. echinata Murray. C. muricata Pollich. Höhe $1 / 2-1$ '.

1198. C. leporina L., Has e up foten-S. Abb. 554. Wurzel rasentreibend; Halm oberwärts rauh oder glatt; Aehre znsammengesetzt; Aehrchen meist 6, wechselständig, genähert, rundlich-elliptisch, unterwärts männlich; Narben 2; Friichte aufrecht, flach-gewölbt, eiförmig, in einen 2 zähnigen Sirhnabel zugespitzt, nerviggevillt und mit einem gefligelten, feingesägt-lauhen, in Cie Spitze des Schnabels auslaufenden Rande umzogen. 4. Wiesen, Wä der, Grasplätze häufig z. B. in der Dölaner Heide u. s. w. Juni. Juli. C. ovalis Good. Bälge braun oder grau-braun. Höhe $1 / 2-1^{\prime}$.

1199. C. elongata L., ve rlängerte S. Abb. $\mathbf{5 6 5 .}$ Wurzel dichte Rasen treibend; Halm rauh; Aehre zu. sammengesetzt; Aehrchen wechselständig, genähert, walzenförmig, unterwärts männlich; Narben 2; Friichte aljstehend-lanzettlich, zusanmengedrïckt, auf dem Rük- 
ken ziemlich gewölbt, beiderseits nervig-viclrillig, in einen fast ganzen, an Rande etwas rauhen Schnabel verschmälert, länger als der eiförmige Balg, etwas zusammengekrümmt. 24. Sumpfige Wiesen, Gräben stellenweise. Bei Döllnitz, häufiger zwischen Schkeuditz und Wehlitz, am Bienitz, häufig bei Dessau, an der Benndurfer Miihle sparsam. Mai. Juni. C. multiculmis Ehrh. Höhe $1-2^{\prime}$.

1200. C. canescens $L$., we is g ra ue S. Abb. 546. Wurzel rasenförmig und kurze Ausläufer treibend; Aehre zusammengesetzt; Achrchen 5-6, eiförmig, länglich, etwas entfernt, unterwärts männlich, das endständige am Grunde lang verschmälert; Narben 2; Friichte eiförnig, fein gerie/t, zusammengedrückt, auf den Rücken zienlich gewölbt, in einen kurzen, ausoerandeten, iibrigens ungetheilten, an Rande etwas rauhen Schnabel zugespitzt, länger als der Balg. 24. Sumptige Wiesen, Gräben, Lachen. Bei Dölau, besunders an den Sïmpfen bei Lieskau, bei Kĺ. Dölziğ, fehlt bei Naumburg. Mai. Juni. C. curta Guod. C. cinerea Poll. C. elongata Leers. Bälge meist weisslich, selten gelblich. Höhe bis $\mathbf{1}^{\prime}$.

C. Legitimae. Aechte Seggen. Die endständige Aehre manulich, die seitenständigen weiblich; seltener die endständige an der Spitze weiblich oder der münnlichen mehr als eine.

s. Narhen 2; Früchte schnabellos oder mit einem selır kurzen, stielrunden, gestutzten oder schief-abgeschuittenen wer auch 'zaihnizen schmahel endigend.

1201. C. stricta Good., steife S. Abb. 583. Wurzel dichte Kasen bildend, ohne Ausläufer; Halm steif-aufrecht, scharfkantig, rauh; Llattscheiden saimmtlich netzartig-gespalten; männliche Aehre 1 oder 2, weibliche $2-3$, anfrecht, verlängert - walzenförnig, sitzend oder die unteren gestielt; Deckblätter am Grunde beiderseits geöhrelt, whne Scheide, das untere blattartig; Narben 2; Friichte elliptisch, flach, nervig, kahl, sehr kurz geschnäbelt, schnäbelchen stielrund, ungetheilt. 4. Sumpfiger, schwammiger Boden, in Gräben dichte und grosse Rasen bildend, sehr selten; bisher nur in Grähen auf den Wiesen zwischen Kl. Dölzig und dem Bienitz beobachtet, aber daselbst sehr zahlreich. April. Mai. Frïchte sogleich mit der Reife abfallend. Höhe $1 \frac{1}{2}-2^{\prime}$. 
1202. C. vulgaris ries, gemeine S. Ahb. 57y581. Wurzel lucker rasenförmig und auslïufertreibend; Halm steif-aufrecht, scharfliantig, rauh; Blattscheilen nicht netzartig-gespalten; männliche Achre 1, selten 2, weibliche $2-3$, selten 4 , aufrecht, länglich-walzenförmig, sitzend uder.gestielt; Deckblätter am Grunde beiderseits sehr kurz geöhrelt, ohne Scheide, das untere blattartig, kürzer, selten so lang oder länger als der Halm; Narben 2; Friichte kahl, elliptisch, vorne flach, auf dem Riicken ein venig gevölbt und vielnervig, sehr kurz geschnäbelt, Schnäbelchen stielrund, unwetheilt. 4. Fenchte Wiesen, Gräben, Teiche überall gemein. April-Juni. C. acuta \%. nigra I. C. cespitosa Good. und aller Autoren bis auf die neneste Zeit, aber nicht Lin. Höhe $1 / 4-1^{\prime}$. Aendert vielfach ab, besonders ist die Form gynobasis bemerkenswerth, bei welcher die oberen weiblichen Aehren genähert, die unterste aber fast wurzelständig, sehr lang gestielt ist, su bei Dölau.

Die ächte C. cespitosa L. oder C. pac ific a Drej. oder C. Drejeri O. F. La llg. oder C. Iteglecta Peterm., ber welcher die unteren Blattscheiden netzartig-gespalten und die Früchte nervenlos sind, ist bis jetzt noch nicht innerhalb der Grenzen des Gebietes gefunden, da die von Rchb. sax. ed. 1 u. 2. $\mu$. 45 angegebenen Standorte am Bienitz an den Schambertsquellen und an Gräben auf Wiesen bei Kl.Dölzig sich nicht bestätigen.

1203. C. acuta L., spitzkantige S. Abb. 584. 585. Wurzel ausläufertreibend; Halm steif-aufrecht, scharfkantig, rauh; Blattscheiden nicht netzartig - gespalten; männliche Aehren $2-3$, weibliche $3-4$, verlängert-walzenförmigr, die bliihenden nickend, die unterste länger oder kürzer gestielt: Dechblätter blattartig, an Grunde beiderseits sehr kurz-geöhrelt, ohne Scheide, das unterste länger als der Halm; Narben 2; Friichte kahl, elliptisch, zusammengedrückt, etwas aufgeblasen, auf beiden Seiten ziemlich gervöllt, undeutlich nervig, kurz und diinn geschnäbelt, Schnäbelchen stielrund, ungetheilt. 7. Teirhe, Grüben, Sümpfe, Flüsse gemein z. B. an der Saale bei Kröllwitz, an Teichen in der. Nähe der Kreuzschäferei, an den Teichen bei Dieskan u. s. w. Mai. C. acuta $\beta$. ruffa L. C. grapilis Curt. Die reifen Früchte fallen früher ab als an C. rulgaris Fries. Höhe $2-3^{\prime}$. 
h. Narhen 3. Die endständige Aehre männlich oder mannweibig. Trïchte schnahellos oder mit einem stielrunden, am Fnde gestutzten oder schiefahgeschnittenen oder zzahnigen Schnabel endigend.

1. Deckhlatter nicht scheidenförmig oder nur selı. kurz-scheidenfürmig. Früclite kahl.

1204. C. Huxbaumii Wahlenb., Buxbaum's . S. Abb. 589. Blattscheiden netzartig-gespalten; die endständige Aehre mannueibig, verkehrt-eiförmig, unternuärts männlich, weibliche meist 3 , die unterste kurz gestielt, entfernter, mit einem am Grunde beiderseits geöhrelten oder sehr kurz-scheidenförnıgen Deckblatte; Narben 3; Früchte kahl, elliptisch, 3kantig, stunıf, sehr kurz geschnäbelt, Schnäbelchen stielrund, kleinzzähnig; Bälge haarspitzig. 24. Sumpfige, besonders etwas torfhaltige Wiesen sehr selten, nur auf der Wiese zwischen Dölau und der Heide und auf Wiesen rechts vom Kröllwitz - Dölauer Wege, sehr sparsan auch am Rande ausgetrockneter Pfutzen an der siidseite der Dölauer Heide. April. Mai. C. polygama Schk. C. subu. lata Sch uma ch. Höhe $\mathbf{L}^{\prime}$ und darüber.

Carex limos a L. wird von Spreng. hal. ed. 1. p. 263 in Siinufen bei Lieskau und Schmon als selten angegeben, ist aber schon in der 2. Aufl. der Flora hal. ganz unerwähnt gelassen und auch in neuerer Zeit nicht wieder bewbachtet.

1205. C. supina Wahlenb., niedrige S. Abb. 631. Wurzelstock kriechend; Halm 3seitig, rauh; männliche Aehre einzeln, linealisch-lanzettlich, weibliche 1-2, genähert, halb so lang, rundlich, sitzend, Deckblätter häutig, stengelumfassend, das unterste haarspitzig, oft blattartig; Narben 3; Friichte kugelförmig-elliptisch, stumpf-3seitig, oliinzend, ganz kahl, in einen an der Spitze truckenhäutigen und 2lappigen Schnabel zugespitzt. 4. Sonnige, kurzbegras'te Hügel selten, nur bei Halle verbreitet, obgleich $\mathbf{S}$ preng. keinen Standort in der Nähe von Halle angibt. An der Bergschenke bei Kröllwitz, am Donnersberge und in der Nähe des Schwalchloches hinter Kröllwitz, einzeln am Bischofslerge in der Dölauer Heide, an mehren Stellen des Lindberges, auf Grasrainen zwischen Guteuberg und dem Mittelholze, auf den Schweizerling bei Wettin, bei Goseck in der Nähe der Weinberge zwischen Weissenfels und Naumburg (der von Spreng. angegebene Standort bei Marküölitz ist dagegen jetzt sehr zweifel. haft und der von Rchb. bei Naumburg citirte ganz un- 
richtig), bei Welbsleben unweit Aschersleben, fehlt inı ganzen östlichen und nurdöstlichen Gebiete. April. Mai. Höhe 3-6".

2. Deckhlätter nicht scheidenfürmig oder sehr kurz scheidenförmig; Früchte weichhaarig oder filzig.

1206. C. pilulifera L., $p$ illentragende S. Abb. 632. Wurzel faserig; die fruchttragenden Halme auswärts nach der Erde gekrümmt; männliche Aehre einzeln, weibliche meist 3 , genähert, rundlich, sitzend, das untere Deckblatt linealisch - pfrienılich, nicht scheidenförmig, @änzlich blattartig, aufrecht-abstehend; Narben 3; Friichte kugelig-verkehrt-eiförnig, 3seitig, kurz-geschnäbelt, am Munde etwas ausgerandet, weichhaarig; Bälge durch den auslaufenden Nerven kurz. stachelspitzig. 24. In Wäldern, besonders Nadelwäldern, Heiden stellenweise. Bei Halle nicht selten z. B. an Abhängen zwischen dem Donnersberge und der Heide, in und an der Dölauer Heide häufig, in Bienitz, fehlt bei Naumburg; bei Dessau und Oranienbaum häufig. April. Mai. C. decumbens Ehrh. Der schlaffe Halm oft bis $1^{\prime}$ lang.

1207. C. tomentosa L., filzige S. Abb. 638. Wur. zel ausläufertreibend; Halme steif-aufrecht; männliche Aehre einzeln, weibliche $1-2$, fast sitzend, walzenförmig, stumpf, das untere Deckblatt blattartig, sehr kurz-scheidenförmig, wagrecht-abstchend; Narben 3; Friichte kugelig-verkehrt-eiförmig, 3seitig, kurz-geschnäbelt, am Munde etwas ausgerandet, kurzhacrigfilzig; Bälge spitz, mit einem in die spitze auslaufenden Nerven. 24. Feuchte Wiesen stellenweise und meist nur sparsan beisammen. Auf der grossen Wiese uach Beuchlitz zu, auf der Wiese zwischen Dölau und der Heide, auf den Wiesen bei Gutenberg unter dem 'Iannenberge, in Gehüsch zwischen Döllnitz und Burg Liebenau und zwischen Collenbey und Burg Liebenau, auf feuchten Wiesen bei Kl. Dölzig und am Bienitz, hei Naumburg auf Wiesen und an waldigen Plätzen nicht selten z. B. über der Henue, auf den Pfortenwiesen u. s. w., bei Eisleben auf Wiesen nach Oberriesdorf zu, bei Aschersleben, Dessau und Oranienbaum stellenweise. Mai. Juni. C. sphaerocarpa Ehrh. Höhe 1 ' und darüber. Aendert ab:

b) thuringiara Schk.: weibliche Aehren an der Spitze männliche Blüthen tragend.

1208. C. montana L., B erg-S. Abb. 633. Wur- 
zel faserig, sedrungen-rasenförmin; männliche Aehre einzeln, weibliche $1-2$, dicht genühert, eifölmig; Deckblätler g̈̈nzlich häutig, stengelumfassend, begrannt oder mit einer blattartigen Spitze versehen; Narbe 3 ; Friichte länglich - verkehrt - eiförmig, 3seitig, kurz - geschnäbelt, an Munde ausgerandet, kurz-wcichhaarig : Bälge stumpf oder gestutzt, stachelspitzig. 24. Schattige Wälder meist häufig z. B. in der Dölauer Heide, im Lindherge, Mittel- mnd Bergholze, im Bienitz, bei Naumburg, Freiburg, Allstedt, Eisleben, Hettstedt in allen Wäldern. April. Mai. C. collina Willd. Bälge schwarzbraun; Blattscheiden purpurroth. Höhe 4-9".

1209. C. ericetorum Polli ch, H e ide-S. Abb. 636. Wurzel auslïnfertreibend; männliche Aehren einzeln, weibliche 1-2, genähert, eiförnig; Deckblätler hïutig, stengelumfassend, spitz uder begrannt; Narben 3; Friichte verkehrt-eiförmig, 3seitig, sehr kurz-geschnäbelt, am Munde abgeschnitten, weichhaarig; Läilge verkehrt-ciförmig, liurz-gewvimpert, sehr stumpf, mit einem vor der Spitze verschwindenden Nerven. 4. Truckene, sandige Stellen, besonders auf Heidebuden, keineswegs häıfig, wie Spreng. angibt. Bei Halle auf truckenen Hiigelı zwischen dem Dunnersberge und der Dölauer Heide, im Bienitz nicht selten, bei Naun. burg seltel, nur auf horhgelegenen Heiden nach Goseck zu, bei Dessau in den Rüster - Bergen. April. Mai. C. ciliata Willd. Bälge weisslich berandet. Hölse 4-9".

1210. C. praecox Jacq., frühzeitige $\mathrm{S}$. Abb. 634. Wurzel cuslïufertreibend; Halme aufrecht oder etwas gekrümut; nünnliche Aehre einzeln, weibliche $1-3$, genähert, länglich-eiförmig, die untersten uft gestielt; Deckblütter an Rande häutig, stenuelumfassend oder das unterste scheidenförnig; Narben 3 ; Frïchte verkehrt-eiförmig, 3seitig, kurz-geschnäbelt, am Munde etwas ausgerandet, weichhaarig; Bälge durch den auslaufenden Nerven stachelspitzig. 24. Trockene, sonnigre Hügel, Ackerraine, Wälder grmein. März. April. C. muntana Poll. C. filiformis Le ers. C. stulonifera Ehrh. Auf trockenen Hügelı nur $3-6^{\prime \prime}$ horh, in IIäldern meist ïber 1' hoch. Diese Waldform ist jedoch nicht die Abart C. umbrosa 11 ost, welche ausser dem verlängerten Halme auch lange Aehren und oft auffallend lange Scheiden hat, welche mit einem langen blattartigen Decliblatte rersehen sind; diese Form hat der Verfasser im Gebiete noch nicht bemerkt. 
1211. C. polyrhiza Wa 11 r. (sched. p. 492. 1822), vielwurzelige s. Abb. 639. Wurzel fuserig, dicht. rasenförmig; Halm aufrecht oder etwas gekrimmt; mäınliche Nehre einzeln, weibliche $1-3$, genähert, länglich-eiförmig, die unterste etwas gestielt; Deckbliitter am Runde lïutig, stengelumfassend, das unter. ste scheidenförmig; Narben 3; Früchte verkehrt-eiförmig. 3seitig, knrz-geschnäbelt, am Munde etwas ansgerandet, weichhaarig; Bälıre durch den auslaufenden Nerien starhelspitzig. 4. Feuchte und truckene, abes schattige Wälder nicht allgemein verbreitet. Bei Halle sehr selten, bisher nur in pinem kleinen, feuchten Wäld. chen vor Gutenberg gefunden, im Birnitz, häufiger bei Weissenfels nach Leislingen $z u$ und besonders in den Wäldern bei Naumburg z. B. im Buchlulze. Sperlingsholze, über der Henur, anch bei Freiburg nicht selten z. B. in Mïhlhulze, in Ziegelruder Forste, in deu Wäldern hei Eisleben und Sandersleben. Mai. C. Inngifulia liost, nicht R Br. C. umbrosa Hup pe bei Sturn lleft 57. 1831; dagegen ist C umbrosa Host eine Abast von C. pripcox Jacq. Blätter sehr lang, oft ïber ' ' lang. Höhe I' und darübel.

3. Deckbläter scheidenförmig; Früchte weichliarig.

1212. C. humilis Leyss., niedrige S. Abb. 595. Wurzel faserig, rasenförmig; Blätter rinnenförmig, länger als der Halm; männliche Aphre einzeln, gestielt, weibliche 2-3, entfernt, meist 3 bliithig, alle gestielt; Bliithenstiele von cinem hïutigen, scheidenförmigen, blattlosen Deckblatte eingeschlossen; Narben 3 ; Friichte verkehrt - eiförnig. 3seitig, sehr kurz-geschnäbelt, an der Miindung abgeschnitten, an der Spitze vecichhaarig. 4. Sonnige, kurz-begraste Anhöhen, besonders auf Kalkboden, stellenweise. An den Kalkbergen bei Bennstedt bis "larh Iangenhugen hiı häufig, bei Wettin, im Bienitz, bei Naumburg und Freiburg sehr häufig, bei Aschersleben, Sandersleben und Bernburg. März. April. C. clandestina Guod. Nur 2-4" huch, der Halm und die Aehren sind von den Blättern ganz eingeschlossen.

1213. C. digitata L., gefinge rte S. Abb. 599. Wurzel faserig, lasenförmig: Halm zusammengedrulit, unten mit kleinen Blättern hesetzt; männliche Aehre einzeln, sitzend, weibliche meist 3 , schwach-linealisch, etwas entfernt, gesticlt, die fruchttragenden lockerblüthig; Bliithenstiele von einem häntigen, scheidenförmigen, schief - abgeschnittenen Deckblatte eingeschlossen; 
Narben 3; Friichte verkehrt-eiförmig, 3seitig, sehr kurz- Neschnäbelt, an der Nündung etwas ausgerandet, weichhaarig, so lang als der ausgerandete, sezühnelte Balg. 4. 'Truckene, schattige Wülder zerstreut; fehlt bei Halle; im Bienitz selten, in den Wäldern bei Naum. burg, Freihurg, Lodersleben, Allstedt, Eisleben, Sandersleben häufig, fehlt in ganzen östlichen und nordöstlichen Gebiete. April. Mai. Höhe 3-9".

1214. C. ornithipoda Willd., vougelfuss för. mige S. Abb.59s. Wurzel faserig, rasenförmig; Halm rundlich, unten mit kleinen Blätter" besetzt; männliche Aehre einzeln, sitzend, weibliche meist 3, schmal-linealisch, dicht-zusammengestellt, gesticlt, die fruchttragenden luckerblüthig; Bliithensticle vun einem häuti„en, sclieidcnförmigen schief - abgeschnittenen Deckblatte eingeschlossen; Narben 3; Friichte verkehrt - eiförmig, 3seitig, sehr liurz-geschnähelt, an der Nündung etwas ausgerandet, weichhaarig, länger als der etwoas ansgerandete, nicht geziihnelte Balg. 4. Lichte Stellen dev Laubwälder sehr selten. Bisher nur bei Naumburg an beiden Seiten des Pfortenberges in der Nähe der Koh. Irustrasse beobachtet. April. Nai, Uöhe 3-5". Aehren kleiner als an der vorigen Art, mit finem Vogelfusse verglichen, daher der Name ornithopoda, von

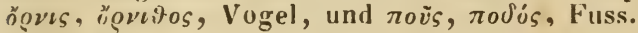

4. Jeckhlatter scheideuförmig; Frächtekahl.

1215. C. panicea Lo, hirsenartige S. Abb. 6117 . Wurzel ausläufertreibend; Halm glatt, an Grunde be. blättert; Blätter linealisch, kahl, am Randle lauh; männliche Achre einzeln, gestielt, immer aufirecht, wribliche meist 2, entfernt, aufrecht, lockerbliithig, die unterste heraustretend-gestielt; Deckbläitter blattartig, scherdenförmig: Nirben 3: Friichte fast lingelig - eiförmig, kurz geschnübelt, kahl, Schnabel sticliund, abgestut:t. 24. Nasse Wiesen meist häıfig. In den Sümpfen bei Lieskan, nuf der Wiese zwischen Dölan und der Heide, anf deh Sumpfiwiesen bei Gutenberg, auf Wiesen an Birnitz, bei Naumburg selten, nur auf Sumpfwiesen bei Gr. Jena, auf Wiesen bei Lodersleben, bei Dessan hälfig. Mai. Juni. Höhe 1'.

1216. C. glauca Scop., meergrïne S. Abb. 648 . 649. Wurzel ausläufertreibend; Halm glatt; Blätter an Rande rauh; münnliche Aehren meist 2, weibliche 2-3, entfernt, walzenförmig, gedrungenbliithig, lang-gestielt, 
zuletit hängend; Dechblätter blattartig, dic untersten kurz-scheidenförmig; Narben 3 ; Friichte elliptisch, stumpf und mit einem sehr kurzen, etwas ausgerindeten Schnäbelchen bespitzt, zusammengedrückt-gewölbt, cir wenig rauh, nervenlos. 24. Sumpfige Wiesen, Jaubwälder auf Torf-, I,ehm. und Kalkbuden zerstreut. Bei Halle häufig z. B. in den Sïmpfen bei Lieskau, auf sumpfigen Wiesen bei Dölan, Gutenberg, bei Röglitz, Möritzsch, bei Kl. Dölzig, an Bienitz, weit seltener bei Naumburg, einzeln in Wäldern bei Freiburg, bei Dessau sparsam, an der Benndorfer Mühle nördlich vou Delitzsch zahlreich. April. Mai. C. recurva Huds. C. flacca Schreb. Höhe $\mathbf{1}^{\prime}$ und darüber. Aendert ab:

b) erythrostachys Huppe: Aehren aufrecht, kürzer gestielt, Bälgye länger als die liapsel.

1217. C. pallescens L., blasse S. Ahb. 617.618. Wurzel faserig, rasenförmig; $\mathrm{Halm}_{\mathrm{m}}$ aufrecht, kahl oder nur unterwärts behaart; Blätter und die unteren Scheiden behaarl; männliche Aehre einzelı, weibliche 2-3. genähert, nickend, lïnglich-eiförmig, gedrungenblüthig, heraustretend - gestielt; Dechblätter blattartig, scheidenförmign; Narhen 3; Friichte elliptisch-länglich, stumpf, schnabellos, beiderseits gewölbt, etwas zusammengedrückt, schwach-nervig, kahl, die kleine Mündung abgestutzt. 24. In allen Laubwäldern häufig. Mai. Höhe 1\%. Die Deckblätter sind unte॥ oft quergefaltet, wellenförmig, dies ist C. undulata Kunze.

c. Narhen 3; mäunliehe Aehro einzeln, hisweilen an der Spitze weib lich, seltener 2 minnliche dehrun; Frïchte guschuabelt; der Schuabel herandet, auf dem Rücken ziemlich gewölbt, auf der vorileren Seite flach, in der Spitze 2spaltig, mit geraile vorgestreckten Zähnen, selte ner fast ungetheilt.

1218. C. flava L., gelbe S. Abh. 653. 654. Wur. zel gedrungen-lasenförmig, faserig; Halı kahl; männliche Aehre einzeln, weibliche $2-3$, ziemlich genähert, rundlich-eiförmig, die oberen fast sitzend, die unterste meist eingeschlossen-gestielt; Decliblätter blattartio, kurz-scheidenförmig, zuletzt weit abstehend oder zuriickgebrochen; Narben 3 ; Friichte eiförnig, aufgeblasen, nervig, kahl, in einen zuriickgelirimmten, auf der vorderen Seite flachen, an Rande feingescigt-rauhen, 2zähnigen Schnabel zugespitzt. 4. Sumpfige, besonders turfige Wiesen zerstreut. Bei Halle auf sumpfigen Wiesen nicht gerade selten z. B. bei Dölau, Liestian, Gutenberg, Kl. Liebenau, Kl. Dölzig, am Bienitz, spar- 
samer bei Naumburg, nur auf der Gıöbitzer Wiese, bei Aschersleben, bei Dessaul häufig, an der Benndorfer Mühle nicht selten. Mai. Juni. Höhe $1 / 2-1$ '. Aendert $a b$ :

b) lepidocarpa 'Tausch: Früchte kleiner, kurzgeschnäbelt, der Schnabel etwa halb so lang als die Frucht selbst, so auf turfigen Wiesen bei Halle und an Bienitz häufig.

Dass C. lepiducarpa 'I' a us $\mathrm{ch}$ von C. flava L. nicht specifisch verschieden ist, haben jetzt auch die bedeutendsten Caricologen anerkannt.

1219. C. Oedéri Ehrh., Oeder's S. Abb. 652. Wurzel faserign, raseuförmig; Halm kahl; männliche Aehre einzeln, weibliche 2-3, genähert, rundlich-eiförnig, die uberen fast sitzend, die wherste eingeschlossen-gestielt, oft entfernt; Deckbläter lslattartig, zuletzt weit abstehend oder zuriichgebrochen, kurz-scheidenförmis oder das unterste ent/ernt und verläingertscheidenförmig; Narben 3 ; Friichte rundlich; aufgeblasen, nervig, kahl, in einen kurzen, geraden, auf der vorderen Seite flachen, am Rande feingesägt-rauhen, 2zähnigen Schnabel zugespitzt. 24. Sumpfige, torfige Stellen, Gräben. In den Sümpfen hei Lieskau, auf der Wiese zwischen Dölau und der Heide, bei Kl. Dölzig, an der Benndorfer Mühle. Mai. Juni. Höhe 2-6". Die Friuchte sind weit hleiner als bei C. flava L.

1220. C. fulva God., gelbbraune \$. Abb. 620. 621. Wurzel Rasen und kurze Ausläufer treibend; Halm kahl wder rauh; Blatthäutchen blattgegenständig, eiförmig, kurz, abgestutzt; männliche dehre einzeln, weibliche $\mathbf{2}$, die unteren entfernt, hervortretend-gestielt oder 3 und dic 2 oberen cinander genïhert, alle aufrecht, eiförnig - länglich, gedrungenblüthig; Deckblïtter langscheidenförmig, das unterste blattartig, die männliche Achre erreichend oder iiberragend; Naiben 3; Friichte eiförmig, etwas aufgeblasen, beiderseits gewölbt, nervig, kahi, in einen 2spaltigen, geraden, auf der vorderen Seite flachen, am Kande feingesägt-rauhen Schnabel zugespitzt, weit-, die unteren o/t wagrecht - abstehend; Bälge spitz. 24. Nasse, turfige Wiesen sehr zerstreut. Auf nassen Wiesen bei Gruss und KI. Dölzig, bei Dessau auf den Wiesen bei Kochstedt und Törten, an der Beundorfer Mühle. Mai. Juni. Höhe 1-2'. Diese Pflanze findet sich in piner fruchtbaren und unfruchtbaren Form. Die erstere ist bläulich-grun und 
lie allmählig zugespitzten, griunen oder uberhalb etwas bräunlichen Früchte sind von der ausgebildeten Nuss fast ganz ausgefüllt. Dies ist C. binervis $c$. sterilis $F$. W. Schultz C. Hostiana s c h k. C. Hornschuchiana Hoppe. Die letztere, unfuchtbare Form ist gelblich. grüi, hat einen rauheren $\mathrm{Halm}_{\mathrm{m}}$, dichter stehende, melir aufgeblasene, längel' geschnäbette, am unteren 'Theile der Aehre abstehende und bei verkïmmerter Nuss meist ganz hohle Früchte; die Blätter sind in diesen Zustande meist länger. Dies ist C. binervis $\beta$. fertilis F. W. Schultz. C. fulva A t or., vielleicht nicht Good., weshalb zur Bezeichnung dieser Art ein anderer Name gew ählt werden sullte.

1221. C. distans L., e n t f e n tährige S. Abb. 622. Wurzel rusenförmig, ohne Ausliufer; Halı kahl; Blatthäutchen blattgegenständig, länglich; männliche Aehre einzeln, weibliche meist 3 , aufrecht, eiförnig länglich, gedrungenhlïthig, dic unterste weit entfernt, hervortretend-gestielt; Deckbiätter lang-scheidenförmis, die untersten blattartig, liinger als die Achre; Narben 3 ; Frïchte eiförmig, 3seitic, etwas anfgeblasen, auf der vorderen Seite ziemlich flach, in einen 2spaltigen, ge. raden, am Rande feingesägt-rauhen Schnabel zugespitzt, kahl, nervig, die seitenstïndigen Verven ein wenig mehr hervorspringend; Bälge eifồrmig, stumpf, nit einer rauhen Stachelspitze endigend. 24. Feuchte Wiesen häufig z. B. Dölau, Gutenberg u. s. w. Höhe 1-2'. Die innere Seite der-Zähne der Fruchtschnäbel ist mit kleinen $Z$ ähnchen besetzt, wodurch sich C. distans von der vorigen Art unterscheidet.

Die Abait C. distans ? $\beta$. Hampeana Rchb., bei welcher die männliche Aehre verlängert, die weiblichen walzenförmig, gedrungenhliithig, die ubere manuweibig, die unteren oft zusammengesetzt sind, ist keineswegs eine Bastalolform von C. distans L. und C. ampullacea Good., wie dies schon O. F. I, ang hinreichend nachgewiesen hat; sie wächst an der Benndurfer Mühle.

1222. C. silvatica $\mathrm{H} u \mathrm{ds}$., Wa / $\mathrm{d}$-S. Abb. $6(1)$. Halm glatt; Blätter hreit-linealisch; männliche Aehre einzeln, selten 2, weibliche 4, entfernt, lang-gestielt, hängend, linealisch, lockerbliithig; Deckblätter blattartig, verlängert-scheidenförnig; Narben 3; Friichte clliptisch, 3seitig, kahl, ganz glatt, in einen linealischen, berandeten, 2spaltigen, am Rande lahlen Schnabel zugespit:t. 24. Feuchte Jaubwälder nicht selten z. B. 
im Sebener Busche, in der Aue bei Dieskau u. s. w. Juni. C. Drymeia lihsh. C, resicaria $\beta$. I. C. capil-

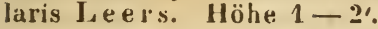

1. Narbell 3; mäunliche Aehren meist melırc; Früchte geschinäbelt, der schnabel sti.lrund oder zusimmengedrickt und herandet, duppelthatarspiczig, die Haarspitzen auseinauder-stelend.

1. Weckbläternichtoderkurz-scheidenfürmig; Früchte $k$ a ! I.

1223. C. Pseudo Cypérus C., fals che Cypergras-S. Abb. 657. Halm scharfkantig, mit rauhen Kanten; männliche Aehre einzeln, weibliche 4-6. langgestielt, hängend, Walzenförmig, gedrungen-blïthig; Deckblätter blattartig, die unteren kurz-, seltener länger scheidenförmig; Narben 3; Früchte eiförmig-lanzettlich, in einen doppelt-haarspitzigen Schnabel verschnälert, "ervig, kahl; Bälge linealisch-pfriemlich, rauh. 7. Sumpfige Stellen, Jeiche, Graben. Bei Bruckdurf, Dieskau, an der stillen Elster bei Osendurf, bei Kl. Dölziğ, hei Naunburg in Sümpfen zwischen Almerich und Sichulpfurte. Juni. Aehren blass-gelb. Höhe 1-2'.

1224. C. ampullacea God., Flaschen-S. Abb. 659. IIalm stumpfiantig, „latt; mäunliche Aehren $1-3$, weibliche $2-3$, entfernt, walzenförmig, kurzgestielt, aufrecht, gedrungenblüthig; Dechblätter blattartig, scheidenlos; Narben 3 ; Friichte sehr weit-abstehend, fast kugelförmig, auføcblasen, kahl, auf dem Riicken meist 7ncrvig; Schnabel linealisch, zusammengedrückt, doppelt-haarspitzig. 24. Sumpfige Stellen. An torfigen Stellen der Dölauer Hejde nach Dölau zu, bei Dieskau, bei Döllnitz, in Gräben auf den Wiesen an Bienitz, an den Quellen zwischen dem Bienitz und Rückmarsduri, bei Naumburg stellenweist, an salzi. gen See zwischen Ober-Röblingen und Erdeborn, hei Dessall in der'l'orfstecherei bei 'lörten und Möst häufig, an der Benndorfer Mühle. Mai. Juni. C. obtusangula Eh rh. C. vesicaria $\mathbf{H}$ uds. C. vesicaria $\beta$. L. Blätter meergrün. Höhe 2'.

1225. C. vesicaria $\mathrm{L}$., B lasen-S. Abb. 658. Halm scharfkantig, mit rauhen Kanten; männliche Aehren $1-3$, weibliche $2-3$, entfernt, länglich-walzenförmig, sitzend oder kurz-gestielt, anfrecht, gedrungenbliithig; Deckbläter blattartig, scheidenlus; Narben 3; Frïchte schief-abstehend, ei-kcgeljörmig, aufgeblasen, in einen zusimmengedruckten, doppelt-haarspitzigen 
Schnabel verschmälert, kahl, auf dem Riicken meist 7nervig. 24. Sumpfige Stellen, Flussufer, Gräben nicht grerade selten. Bei Dölau, Diestian, an der stillen Elster bei Osendurf, bei Naumburg stellenweise u. $s$. w. Mai. Juni. C. inflata Huds. C. vesicaria $\%$ L. Blätter grasgriin, Aehren grïnlich - weiss. Höhe 1-3'.

1226. C. paludosa Good., S n n pf-S. Abb. 644. Halm scharflantig, mit rauhcn Kanten; männliche Aehren 2-3, die unteren Bälge stunipf, weibliche 2-3, "alzenförmig, aufrecht, gedrungenbluthig, sitzend oder gestielt; Dechblätter blattartig, scheidenlos; Narben 3; Friichte eifürmig oder lïnglich-ciförmig, zusammen. gedriickt, etwas 3 seitig, nervig, in einen kurzen, 2zähiigen Schnabel zugespitzt, kahl. 4. Sumpfige Stellen, Gräben, 'Teiche. Bei Passendorf, Bruckdorf, Gross und Kl.Dölzig, an den Quellen zwischen den Bienitz und Rückmarsdorf, bei Naumburg gemein u. s. qv. Mai. Höhe 1 $1 \frac{1}{2}-3$ '. Aendert ab:

b) Kuchiana DC. Abb. 651: Früchte länglich; Bälge begrannt-zugespitzt.

1227. C. riparia Curt., U fer-S. Abb. 647. IIalm sclicurfkantig, mit rauhen Kanten; mäunliclıe Aehren 3-5, mit haarspitzigen Bälgen, weihliche $3-4$, walzenförmig, aufrecht, gedrungeublüthig, sitzend oder gestielt, mit haarspitzen Bälgen; Deckblätter blattartig, scheidenlos; Narben 3;. Friichte ci-kegelfürmig, am Rande abgerundet, beiderseits genvölbt, vielnervig, in einen kurzen, spitz-2zähnigen schnabel übergehend, kahl. 2. Sümpfe, Gräben, Flussufer und Teiche gemein z. B. in den Sïmpfen bei Lieskau, an der stillen Elster bei Osendorf u s. W. Mai. Juni. C. crassa E hrh. Höhe $2-4^{\prime}$. Die reife Frucht ist 3 mal grösser als bei der vorhergehenden Art und hat einen fast runden Querdurchschnitt, während derselbe bei C. paludosa Good. auf der eiıen Seite flach, also nur halb. rund erscheint.

2. Deckhlätter nichtscheidenfürmig oder das unterste kurz-scheidenförmig; Früclite kurzhaarig.

1228. C. filiformis C., fadenförmige S. Abb. 643. Wurzelstock kriechend; Halm stumpfkantig, glatt oder an der Spitze ein wenig rauh; Blätter rinnenförmig, kaum breiter als der Halm; männliche Aehren $1-2$, weibliche $2-3$; entfernt, länglich oder eiförmig, aufrecht, gedrungenblïthig, sitzend oder die unterste gestielt; Deckblätter blattartig, das unterste kurz-schei. 
denförmig; Narben 3; Friichte länglich-eiförmig, gedunsen, kurz-weichhaarig, in einen kurzen, doppelthaarspitzigen Schnabel übergehend; Bälge stachel- vder haarspitzig. 24. Stehende Gewässer, tiefe Sümpfe, wasserreiche Gräben sehr selten. Bei Dessau in der 'Törtenschen 'Turfstecherei zahlreich, von spreng. hal. ed. 2. p. 411 in Sümpfen bei Jieskau und Schmon als selien angegeben, an welchen Orten der Verfasser aber rergeblich gesucht hat. Nai. Juni. C. splendirla Willd. C: lasiucarpa Ehrh. Höhe 2-3'.

3. Deckblatterlang-scheidenförmig; Fräclıtekurzlaarig.

1229. C. hirta L., kurzharige S. Abb. 628. II urzelstuck kriechend; Halm glatt; Blätter und Scheiden behaart; männliche dehren 2, weibliche 2-3, aufrecht, länglich-nalzenförmig, die unteren gestielt, die unterste fast sitzend; Deckblätter hlattartig, das unterste lang-scheidenförmig; Narben 3; Friichte eiförmig, in einen duppelt - häarspitzigen schnabel zugespitzt, kurzhaarig; Bälge begrannt. 24. Sandige, feuchte IV iesen, Flussufer, - Wegränder häufig z. B. au sandigen, fenchten Stellen zwischen. Halle und Böllberg, häufig in der Dölauer Heide zwischen Nietleben und der Fasanerie u. s. w. Mai. Juni. Höhe $1 / 2-2^{\prime}$.

\section{Familie. Gramineen Juss. Gräser.}

1. Gruppe. Olyreen Nees. Blickenartige Gräser. Blüthen 1hăusig; die männlichen den weiblichen nicht ähnlich.

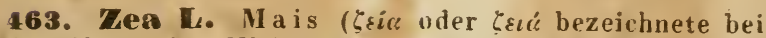
den Alten eine Weizenart (Triticum Zea Host); erst rin Linne für die vorliegende Gattung gebraucht).

1230. Z. Mays L., gew öhnlicher M. Wurzel fa. serig; Halm steif aufrecht, dick, kahl; Blätter sehr hreit, mit starkem Mitteluerven; weibliche Aehren in den unteren Blattwiuheln von Scheiden umbuillt, Griffel fadenförmig, fein gewimpert, sehr lang und als lange Fadenbïschel aus der spitze der Blattscheiden herab. häıgend; männliche Bliithen auf der Spitz des Halnes in einer ausgebreiteten Rispe; Friichte glatt, nach aussen abgerundet, nach iunen etıas keilförmig verschmälert. $\odot$. Stammt aus Siidamerika, wird jetzt zum ökononischen Gebrauche gehaut. Juni. Juli. Frïchte guldgelb, purpurroth oder weiss. Höhe $3-6^{\prime}$. 
2. Gruppe. Andropogoneen Kunth. Bartgrasartige Gräser. Aehrchen vom Rücken her zusammengedrückt, 1blüthig, mut einem spelzigen Ansatz einer unteren Blütle oder mit einer unteren männlichen Blüthe. Achrehen an den Gelenken einer Aelire oder Rispe zu 2, die endständigen zu 3, von denen die 2 seitenständigen gestielt, das mittlere sitzend erscheint.

464. Andropógon L. Bartg ras (von civio, iev. Sois, Mann, und $\pi \omega \dot{\gamma} \omega \nu$, Bart; der 'Trivialname ischite-

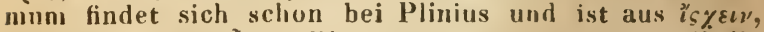
hemnen, und ciuce, Blut, zusammengesetzt, "seil die damals mit diesem Namen bezeichete Pflanze zum Blutstille" gebraucht wurde).

1231. A. Hschaemum L., ge me ines B. Abb. 461 . Blätter linealisch-rimnenförmig, behaart, Blatthäutchen lang gewinpert; Aehren 5-10, fingerartig an der Spitze des Halmes stehend; Bälge gerillt; die untere Klappe des zwitterigen Aehrchens rom Grunde bis fast zur Nitte behaiart, die des männlichell Aehrchens kahl; Spindel und Blüthenstielchen behart. 7. Trockene, sunnige Anhöhen, Wegrändẹr nicht selten. Am Felsen $\mathrm{z}$ wischen Giebichenstein und Trotha, an Bergen bei Seben und Gutenbery, am Chausseegraben vor Bennstedt, hei Dürrenberge, Tenditz, Weissenfels, Naumburg häufig, bei Eisleben, Aschersleben, Sandersleben, Bernburg auf trockenen Anhöhen verbreitet, fehlt aber im östlichen und nurdöstlichen Gebiete, suwie bei Allstedt. Julisept. A. angustifolius $S \mathrm{~m}$. Höhe 1'.

3. Gruppe. Paniceen Kunth. Hirsenartige Gräser. Achrchen vom Rücken her zusammengedrückt, 1 blüılıig oder Iblüthig mit einem Ansatze einer unteren Blüthe, welche ein: dritte Klappe darstellt. Untere Klappe sehr klein, an die flache oder ziemlich flache Seite des Aelirchens angedruckt.

465. Pánicum L. Hirse (Pflanzenname bei Plinius; von panis, Brot, weil von einigen Arten Brot gebacken wurde).

A. Digitaria Scop. Syntherisma Schrad. Aehrchen in einfachen, fast fingerförmigen Athren stehend, zu 2, das eine länger gestielt.

1232. P. sanguinale L., B I ut - H. Abb. 507. Halme zuerst liegend, dann aufsteigend; Blätter und Blattscheiden mehr oder minder behaart, selten kahl; Ach- 
ren meist zu 5, finger fürmig, aufrecht-abstehend, Aehrchen länglich-lanzettlich; die Spelze der geschlechtslosen Bliithc kahl, am Rande weichhaarig, auff dem äussersten seitennerven ohue Wimpern, die ubere Klappe halb so kurz und breit als die untere Spelze der Z $\mathbf{\text { witterblüthe. }}$ $\odot$. Sandige Aecker und Wege, bebauter Buden nicht selten z. B. auf Aeckern an Donnersberge hinter Kröll. witz, am Wege zwischen Halle und Seben u. s. w. fuli-Herbst. Digitaria sanguinalis Scop. Syutherisma vulgare Schrad. Halm $1-1 \frac{1}{2}{ }^{\prime}$ lang.

1233. P. glabrum Ga ud., kahle H. Abb. 506. Halme meist ganz liegend; Blätter und Blattscheiden kahl; Achren meist zu 3, fingerfürmig; Aehrchen elliptisch, weichhaarig, auf don Nerven kahl; die obere Klappe so langr nol hreit als die untere Spelze der Zwitterblüthe. $\odot$. Bebauter, besunders sandiger Boden nicht gerade selten z. B. anf sandigen Aeckern bei Lieskan, an Dreierhause bei Radewell, bei Kl. Dölzig, am Bienitz u.s. ". Juli-Herbst. P. Ischaemum Schreb. P. humifusum Kunth. Digitaria filifurmis Koel. Halnı bis $1 \frac{1}{2}$ ' lang. Der Blattgrund und der obere 'Theil des Randes der Blattscheiden ist bisweilen mit einigen we. nigen Haaren besetzt.

B. Echinochloa P. B. Aehrchen rispig; die Rispe aus einseitigen, zusammengesetzten Aehren gebildet; Klappen in eine Stachelspitze oder rauhe Granne verschmälert.

1234. P. Crus - galli to., Hühner-H. Abb. 515. 516. Halm aufsteigend; Blätter an Rande sehr ranh, Blattscheiden kahl; Achren wechsel-und gegenständig, zusammengesetzt, linealisch; Achrchen genähert, be. grannt; Spindel an Grunde 5kantig. $\odot$. Aecker, Scliutt, unbebaute Stellen ziemlich verbreitet z. B. auf Aeckern zwischen Halle und Giebichenstein, bei Rög. litz, Schkeuditz, anı Bienitz u. s. w. Juli. Aug. Echinochloa Crus-galli P. B. Höhe 2-4'. Aendert mit hurzer und langer Granne ab.

c. Mitium. Aehrchen rispig; die Rispe ausgebreitet oder geknäuelt. Die Klappen in eine kurze Granne zugespitzt oder grannenlos.

1235. P. miliaceum L., gente ine H. Abb. 519. Blätter lanzettlich und nebst den Blattscheiden dicht rauhhaarig; Rispen weitschweifig, aus gebreitet, iiber.

Garcke, Flora. 
hängend; Klappen zugespitzt - stachelspitzig. $\odot$. Stanmit aus Asien, wird jetzt häufig gebaut und verwildert nicht selten. Juli. Aug. P. Nilium Per's. Höhe 11/2-3'.

466. Setária P. F. Fennich (von seta, Borste, wegen der langen, borstenförnigen Hüllen).

1236. S. verticillata P. R., quirlblüthiger F. Abb. 511. Rispe ährenförmig, gedrungell, an Grunde oft unterbrochen; borstenfürmige Iliillen durch riick. wäirts gekehrte Zïhnchen rauh; Spelzen der Zwitterblïthe ziemlich glatt. $\odot$. Bebaute Orte, Züme, in Dörfern verbreitet z. B. auf Aeckern bei Giebichenstein, Röglitz, Merseburg, Kötschau u. s. w. Juli. Aug. Pianicum rerticillatun $\mathrm{L}$. Höhe bis $1 \frac{1}{2}$ '.

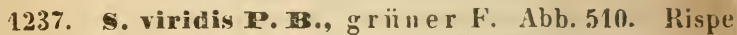
ähı enförmig, walzenförmig; borstenförmige Hïllen durch vorvü̈rts gerichtete Zähnchen rauh; Spelzen der Zwitterbliithe ziemlich glatt, die untere so lang als die obere Klappe. $\odot$. Bebauter Boden, sandige, unfruchtbare Stellen nicht selten z. B. auf Aeckern am Donnersberge hintel Kröllwitz, bej Nietleben, Bennstedt u. s. w. Juli. Aug. Panicum viride L. Burstenförmige Hüllen grün oder schmutzig - purpurroth. Haln $1 / 2-2$ lang.

1238. 5. glauca P. B., gelbhaariger F. Abb. 509. Rispe ährenförmig, walzenförmig; Corstenförmige Hiillen durch vorwärts gerichtete Zähnchen rauh; Spelzen der Zwitterbliithe quer-runzelis, doppelt so lang als die obere Klappe. $\odot$. Bebauter Buden, besonders auf Stoppelfeldern häufig. Juli. Ang. Panirum glaucum L. Borstenförmige Hüllen rustbraun-gelb. Halm $1 / 2-2$ lang, niederliegend und aufrecht.

Das Längenverhältniss der Spelzen der Zwitterblüthen zu jenen der geschlechtslosen Blüthen ist bei dieser Art in Koch's Synups. ed. 2. p. 893 nicht richtig angegeben, wie dies ' $\mathrm{I} h$. I $\mathrm{rm}$ isch in einer surgfältigen Abhandlung über die ganze Gruppe der Paniceen uachgewiesen hat. Vgl. Butanische Zeitung Jahrg. 1847. S. $929 \mathrm{ff}$.

4. Gruppe. Phalarilleen Kunth. Glanzgrasartige Gräser. Aehrchen von der Seite her zusammengedrückt, Iblüthig, mit einem spelzenartigen Ansatze zu einer zweiten oder dritten unteren Blüthe, oder mit einer oder zwei unteren männlichen BIüthen; Griffel lang; Xarben fadenförmig oder fast sprengwedelformig, aus der Spitze des Aehrchens herrortretend. 
Phalaris.

Gramineen.

467. Phalńris L. G lanzgras (Pflanzenname bei Diuscorides, von y rīēós, glänzend, wegen der weiss. glïnzenden Samen).

1239. Ph. arundinacea L., roh rartiges G. Abb. 493. Halm und Blattscheiden glatt; Rispe abstehend; Arhrchen bischelförmig - zusammengestellt; Klappen flügellos; die $/ /$ witterbliithe kahl, die unfruchtbaren behaaıt. 4. Hlıssufer, 'Teichränder, Bäche häufig z. B. an den Ufern der Saale in der Nähe der Egge II. s. I. Juni. Juli. Baldingera arundinacea $\mathrm{Keh} b$. Höhe $3-6^{\prime}$. Eine oft in Gïrten gezogene Abart ist das Band gras, Ph. picta L., bei welchem die Blätter grïı und weiss gestreift sind.

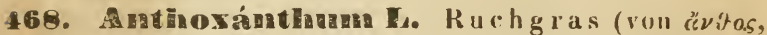

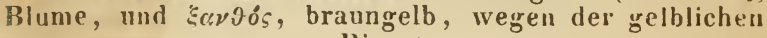
Rispe).

1240. A. odoratum L., gem e ines K. Abb. $495-$ 498. Halm glatt; Rispe ährenförmig, Jänglich, ziemlich locher; dit untere Klappe halb so lang als das Aehrehen, spitz; spelzenartige Ansätze zu 2 unteren Blüthen angedriicht-behaart, abgerundet-stumpf, halb si) lang als die innere Klappe; Staubgefässe 2. 4 . In Wäldern und auf Wiesen überall gemein. Mai. Juni. Höhe $1-1 \frac{1}{2}$ '. Die J'flanze hat besonders in trockenen Zustande einen eigenthümlichen Geruch. Aendert ab:

b) villosum I, isl.: Stielchen der Aehrchen und diese selbst behaart. Mit der Hauptform nicht selten.

5. Gruppe. Alopecuroideell. Fuchsschwanzartige Gräser. Aehrchen von der Seite her zusammengedrückt, 1 blüthig oder 1blüthig mit einem Ansatze zu einer oberen Blüthe, rispig oder in einer einfachen Traube wechsclständig. Klappen so lang oder länger als die Blüthe. Griffel lang; Yarben verlängert, fadenförınig, behaart, aus der Spitze des Aehrehens hervortretend.

169. Alopecínus L. Fuchsschwanz (von cỉci$\pi \eta \xi$, Fuchs, und ovọ́, Schwanz, wegen der Gestalt der Rispen).

1241. A. pratensis L., Wiese $\mathbf{n}-\mathrm{F}$. Abb. 478. Wur. zelstock schief, kurz oder hurz-ausliuuferartigy ; Halm aufrecht, kahl; Rispe ährenförmig, walzenförmig, stumpf ; Aeste der Rispe 4-6 Aehrchen tragend; Klappen spit;, 
unterhall der Mitle zusammengewachsen, zottig-genvimpert. 24. Auf Wiesen und Grasplätzen genein. Mai. Juni. Der Wurzelstock auf Sandboden etwas hriechend: Granne bald eingeschlossen, bald hervortretend. dehrchen narh den Verblïhen verblasst, stoltener am Grunde schwärzlich. Höhe $2-3$ '.

1242. A. nigricans I or nem., sch wärzlicher $\mathbf{f}$. Abb. 47\%. Wurzelstock weitumherkriechende Ausläufer treibend; Ilalm aufrecht, hahl; Rispe ährentöımig, wal. zenförmig, stumpf; Aeste der Rispe 4-6 Aehrchen tragend: Klappen spitz, unterhalb der Mitte zusammengewachsen, zottig-gewimpert. 4. Auf Wiesen, feuchten grasieichen Plätzen zwischen Döllnitz und Burg Lipbenau. Mai. Juni. A. repens M. B. Aehrchen nach dem Verblïhen schwarz. Höhe $2-4^{\prime}$. Weitere Untérsuchungen werden ergeben, ob dies eine coistante, gute Art ist.

1243. A. agrestis L., Acker-F. Abb. 473. Halm aufrecht, uberwärts ein wenig rauh; Rispe ährenför. mig. walzenförmig, beiderseits verschmälert; Aeste der Rispe 1-2 Aehrchen tragend; Klappen lis zur Nlitte zusammengenuachsen, zugespitzt, an Kiele schmal-geflügelt, selı kur-genvimpcrt. $\odot$. Aecher, Weiuberge. Wird vou Spreng. hal. ed. 2. p. 37 in Weinbergen und an Ackerrändern im Freiburgischen und Mannsfeldischen als selten, von $\mathbf{S c h w a b e}$ fl. anh. bei Bernhurg und Sandersleben angegeben. In nellerer Zeit ist dieses Gras nicht im Gebiete gefunden und es ist, wenn überhaupt noch vorhanden, jedenfalis änsserst selten. Juni. Juli. Höhe $1-1 \frac{1}{2}$.

1244. A. geniculatus L., geknieter F. Abb. 472. Halm aus liegendem Grunde aufsteigend, kahl; Rispe ährenförmig, walzenförnig; Aehrchen ciförmig-länglich; Klappen stumpf. gewimpert, nur am Grunde zusammengewachsen; Spelze unter der Mitte begrannt. ○. Gräben, Sümpfe, feuchte Stellen sehr häıfig z. B. auf del Wiese am Donnersberge hinter Kröllwitz u. s. w. Mai - Aug. Staubbeutel gelblich - weiss, nach dem Verblühen braun. Granne fast doppelt so lang als ihre spelze. Höhe bis $1^{\prime}$.

1245. A. fulvus $\$ \mathrm{~m} ., \mathrm{r}$ oth gelber $F$. Abb. 476. Ha!m aus liegendem Grunde aufsteigend, kahl; Rispe ährenförmig, walzenförmig; Achrchen elliptisch; Klap. pen stumpf, gewimpert, nur am Grunde zusammenoe. uachsen; Spclze aus der Mitte begrannt. $\odot$. Ueber- 
schwemnt gewesene Stellen, feuchte Plätze. An den Teichen bei Dieskau, an feuchten Waldplätzen zwischen Schleuditz und Kl: Dölzig, bei Naumburg in der Aue auf sumptigen Stellen häufig. Mai-Aug. A. paludosus P. B. Blattscheiden hechtblau; Staubbeutel jothgelb. Granne kaum längel als der Balg. Höhe $1 / 2-1^{\prime}$.

470. PInléum I. I, is che, Lieschgras (qhéws von ץ $\lambda \dot{\varepsilon} \omega$, ich fliesse, ist bei Theophrast das Poterium spinosum L., weil es bei fliessenden Ohren angewandt wurde).

1246. Ph. Boehmeri wibe l, Böhmer's L. Abb. 487. Wurzel einen Rasen von fruchtbaren, aufrechten Halmen und unfruchtbaren Blüthenbiischeln treibend; Rispe ährenförnıig, walzenförmig; Klappen linealischlänglich, schief - abgestutzt, zugespitzt - stachelspitzigr, zul sanmengedriickt, auf dem Rücken steifhaarig-gewimpert vder rauh. 24. Dürre Hügel, lirasraine stellenweise. An Bergen bei Gutenberg nicht selten, bei Röglitz häufig, I weit sparsanıer in Bienitz, dagegen a॥ den sogenannten Weinbergen bei Keuschberg und Godula wieder zahlreich, bei Naumburg an Holzränderı und Rainen häufig, an der Steinklippe bei Werdelstein, bei Eisleben, Bernburg. Juni. Jnli. Phalaris phlevides L. Chilochloa Buehmeri P. B. Höhe 1-11/2 .

1247. Ph. asperum vill., rauhe I. Abb. 486. Halm aufrecht; Rispe ährenförnig, walzenförmig; Klappen keilförmig, abgestutzt, an der Spitze aufgeblasen-kantig, stachelspitzig, rauh. $\odot$. Aecker, Weinberge sehr selten. Ist von Wallr. (nach sched. p. 29) auf Aeckern und Ackerrainen bei Lodersleben gefunden und wird von Spreng. allch in Weinbergen bei Freiburg angegeben. Der Verfasser hat ungeachtet des eifrigsten Suchens dieses äusserst seltene Gras noch nicht in Gebiete gesehen. Mai. Juni. P. viride All. Phalaris aspera $\mathrm{Retz}$. Chilochloa aspera $\mathrm{P}$. B. Höhe $1 / 2-1^{\prime}$.

1245. Ph. pratense L., Wie sen-L. Abb. 482.483. Haln an Grunde gekniet; Rispe ährenförmig, walzenförnig; Klappen länglich, quer-abgestutzt, in eine Granne plötzlich zugespitzt, am Kiele steifhaarig-ge wimpert; Granne 3mal kiirzer als der Balg. 24. Wiesen, Wegränder häufig. Juni. Juli. Höhe $1-3{ }^{\prime}$. Iendert $\mathbf{a b}$ : 
b) nodosum I.: Halm niedrig, der Grund dessel. ben ziriebelartig-verdickt, Rispe meist külzer. Ph. hulbusum Host, so an trockenen Rainen, Waldrändern z. B. am nördlichen Rande der Dölaucr Heide.

i. Gruppe. Oryzeen Kunth. Re isartige Gräser. Aehrchen von der Seite her zusammengedrückt; Klappen fehlend oder sehr klein.

471. Leergia Solamaler. Leersie (dem Anden. ken des als Apotheker zu Herburn gesturbenen J. Daniel Leers, Verfasser der Flura herbornensis geweiht).

1249. L. oryzoides Swartz, reisartige L. 1hb. 494. Halu glatt, nur an den Knoten mit abwiilts gerichteten Haalen besetzt; Blätter sehr rauh; Rispe isbstehend; Aeste schlängelig; Athrchen 3 müınig, halb"val, gewimpert. 4. Gräben, Ufer, am lande von Iachen sehi selten. Bei Naumburg an der Saale in der Nähe des Einflusses der kleinen saale und an Lachen in der Aue nach Rossbach zu, hei Dessau an Flussuferu. Aug. Sept. Phalaris oryzoides Ls: Ehrharta clandestiun Wiggers. Höhe $3-5^{\prime}$. Die Rispe tritt nur selten alls den ubersten Scheiden.

7. Gruppe. Agrostideen Kunth. Straussgasartigo Gräser. Aehrchen von der Seite her mehr oder weniger zusammengedrückt, 1blüthig oder 1blüthig mit einem Ansatze zu einer oberen Blüthe. Deckspelzen 2. Griffel fehlend oder kurz. Narbe federig, am Grunde des Achrchens heraustretend. Karyopse mit den häutigen Spelzen bedeckt.

472. Agróstis L. Strauss gras (ein aus cíyoús. Acker, gebildeter Pflanzemume bei Dinseurides).

A. Vilfa P. B. Blätter alle flach; where Spelze vor. handen.

1250. A. Vulgaris withering, genieines St. thb. 130-132. Blätter alle linealisch, flach; Blatthäutchen kurz, abgestutzt; Rispe im Umrissc länglicheiförnig, während und nach der Blïthezeit weit abstehend, Aestchen gespreizt, nach allen Seiten hin gerichtet, etwas rauh. 4. Wiesen, Triften, Grasplätze, Wälder gemein. Juni. Juli. A. stolonifera Pollich. A. hispida Willd. Rispe meist purpurbraun, seltener blassgelblich. Aendert ab: 
b) stolon if era «. L.: Ausläufer lang, weit umherkriechend, so an sandigen Stellen.

c) vivípara Koch: Aehrchen in längliche Knospen auswachsend. A. silvatica Pollich, so bei Schenkenberg unweit Delitzsch, bei Benndorf.

1251. A. stolonifera L. var. $\beta$., a usläufertreibeudes st. Abb. 133 - 137. 139. Blïtter alle linerlisch, flach; Blatthïutchen länglich; die blüthentragende Rispe länglich-kegrelförmig, Aeste wayrecht-abstehend, Aestchen gegen die Seiten der Aeste und ab. wärts gerichtet, die fruchttragende Rispe schmal-zusanmengezıgen. 24. Wiesen, unbebaute Orte, Wälder uicht selten. Juni. Juli. A. alba Schrad. A. capillaris Pollich. Rispe grün und purpurroth oder ganz purpurroth und violett oder endlich gelblich-weiss (A. alba 1.). Aehren grannenlos, selten begrannt. Höhe 1-2'.

lendert $a b$ :

b) gi g in tea Gaud.: Halı grösser, stärker, bis 4' huch, Rispe sehr reichbliithig. Sind bei dieser Abart die meisten Aehrchen begrannt, so heisst die Form: A. gigantea Ruth. A. compressa Willd. A. varia Hust., so in Gräben z. B. zwischen Langenbogen und Rullsdurf, bei Kl. Dölzig, bei Naumhurg auf Wiesen in der Aue häufig, bei Benndurf.

B. Trichodium Michaux. Wurzelblätter zusammengefaltet-borstenförmig; die obere Spelze meist fehlend.

1252. A. canina L., Hunds-St. Abb. 128. 129. Wur zelblätter zusammengefaltet-borstenförmig; Blatthäutchen län:lich; Rispe ansgehreitet, eiförnig; Aeste rauh, "ährend der Blüthezeit auseinanderfahrend, nach dem Verblïhen zusanmengezogen; untere Spelze unter der Mitte des Riickens begrannt, an der Spitze fein-gekerbt, obere fehlend wder sehr klıin. 24. Feuchte und trockene Grasplätze, Waldı̈nder etwas seltener als die vorhergehenden Arten. Am nörllichen Rande der Döl. auer Heide, bei Naumburg auf feuchten Stellen im Walde ïber der Henne, bei Dessan stellenweise. Juni - Aug. T'richodium caninumsch rad. Rispe grün und purpurbraun oder ganz viulett purpurbraun. Die Granne meist verlängert, gedreht und gekniet, seltener kürzer und gerade. Höhe bis 2'. Kleinere, oft nur $1 / 2^{\prime}$ hohe Exemplare mit einer verkümmerten Rispe bilden die $A$. alpina Leyss. fl. hal. 
473. A péro A al a. Heauv. Wind ha I m

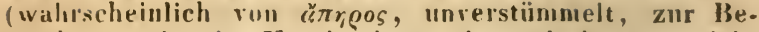
zeichnnng der in Vergleich mit Agrustis langen, nicht verstümmelten Granne).

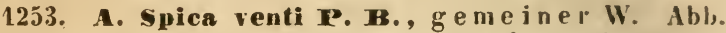
124. 125. Halm aufrecht; Blätter flach, lauh; Blatthäutchen länglich, zugespitzt, an der Spitze ein wenig gespalten; Rispe weitschweifig; Blüthen unter der Spitze begrannt, Grinne gerade oder etwas geschlängelt, 3 oder 4 mal so lang als ihre Spelze; Staubhentel linealisch-länglich. $\odot$. Aecker, Dämme, Sandplätze ge. mein. Juni. Juli. Agrostis Spica renti $I$. Rispe grïn und braun witer röthlich gefïrbt. Höhe $1-3$ '.

474. Calamagrostis Feth. Schilf (ein aus xáicusos, Ruhr, und ǎyoortıs, Ackergras, gebildeter Pllanzenname bei Dioscorides; der I'rivialname epigeios sollte, obgleich von k̇iysıos, auf der Erde befindlich, herkommend, epigeos, gebildet sein).

A. Epigeios. Spelzen häutig, durchscheinend-weiss. Ansatz zu einer zweiten Blüthe fehlend.

1254. C. Inceolata Roth, lanzet tliches Sch. Abb. 151. Rispe abstehenl, Aeste nach oben etwas geschlängelt; Klappen schnal-lanzettlich, zugespitzt, länger als die Blüthe; Hare am Grunde der Blïthe länger als die Spelzen; Granne endständig, scrade, aus einer sehr kurzen Ausrindung hervortiptend und kaun länger als diese. 2. Auf feuchten Wiesen, an Gräben unter Gebüsch sehr selten. Bisher blos an Giräben iu der Nähe des grösseren Weinberges bei Röglitz und bei KI. Dölzig beobachtet, von Spreng. mant. 2. 1\% 8 auch in Wäldern bei Lodersleben als von Wallr. gefunden angegeben, in der 2. Aufl. aber nicht wieller erwähnt. Juli. Aug. Arundo Calimagrostis L. C. ramosa Host. Rispe mehr oder minder violettroth vder ganz blassgriin. Höhe 2-4'.

1255. C. epigeios reth, Land-Sch. Abb. 154. Rispe steif - aufrecht, geknïuelt -lappig; Klappen lanzettlich, in eine pfriemliche, zusammengedruckte Spitze endigend; Haare am Grunde der Blüthe länger als die Spelzeı; Granne aus der Mitte des Rïckens hervortre. tend, gerade. 24. Flnssufer, trockene Wälder, sandige Felder und Hïgel häufig z. B. an der Saale in der.Nähe der Egge, in der Dölauer Heide u. s. w. Juli. Aug. 
Arindo epigeios L. A. Calamagrostis M. B. Rispe griin oder grün und violett - gefleckt oder ganz violett-braunroth. Höhe $3-5$ '.

B. Depeuxia P. B. Ansatz zu einer zweiten Blïthe in einem behaarten, aus dem Grunde der oberen Spelze hervortretenden Stielchen bestehend.

1256. C. silvatica DC., W a Id.Sch. Abb. 143.144. Rispe zur Blüthezeit mit abstehenden Aesten, später zusanmengezogen; Klappen lanzettlich, zugespitzt; Haare am Grunde der Bliithe $4 \mathrm{mal}$ kiirzer als die Spelzen: Granne riickenstiindig, gekniet, über die Klappen hinausragend. 4. 'Trockene und feuchte Wälder nicht selten z. B. in der Dölauer Heide, in Zurgs, Mittelholze u. s. w. Juli. Aug, C. arundinacea Roth. C. pyramidalis Host. Agrostis arundinacea L. Deyeuxia silvatica $K u n t h$. Höhe $2-4^{\prime}$.

1257. C. montana Host, Berg-S ch. Abb. 146. Rispe zur Bliithezeit mit abstehenden Aesten, später zusammengezogen; Klappen zugespitzt; Haare am Grunde der Bliithe meist so lang, seltener nur halh so lang als die Spelzen; Granne riickenständig, olnniel, kaum über die Klappen - hinausragend. 4. Bergwälder sehr selten. Wird zuerst von W allr ann. bot. p. 14 in Ziegelroder Forste und an kalhigen Felsen bei Wendelstein angegeben und von $S p r e n g$. hal. ed. 2. p. 42 die Felsen an den Ufern der Unstrut bei Nebra als Stand"rte hinz"gefiigt. Der Verfasser hat dieses seltene Gras nuch nicht in Gebiete gefunden. Juli. Aug. Arundo montana Gaud. A. varia Schrad. Deyeuxia varia Kunth. Höhe 1-3'.

Calamagrostis acutifiora DC. mit schmalesen, pfriemlichen Klappen wird jetzt gewöhnlich als Abart von C. nontana Ifost angesehen. Für das Gebiet wird sie zuerst von Spreng. mant. 2. p. 7 als ron Wallr. in Lodersleber Forste gefunden erwähnt. W allr. hat jedoch ann. but. p. 15 nachgewiesen, dass die einst für C. acutiflora DC. gehaltene Pflanze nur mit C. epigeios Roth verwechselt war und in Folge dessen hat sie Spreng. in der 2. Aufl. der Flora auch unerwähnt geliassen. Kchb. hätte daher sax. ed. 1 u. 2. p. 11 Lodersleben nicht wieder als Standort für dieses Gras citiren sollen.

Calamagrostis stricta Spreng. wird von 
Schwabe auf sumpfigen Wiesen bei Radegast angegeben.

8. Gruppe. Stypaceen hunth. Pfriemengrasartig: fräser. Aehrchen gewölbt, rom Rücken her ein wenig zusammengedrücht oder stielrund, 1blüthig; untere Klappe grösser. Griffel fehlend oder kurz. Narben federig, an den Seiten des Aelireliens heraustretend. Karyopse von den erhärteten, knorpeligen oder papicrartigen Spelzen dicht-eingewickelt.

475. Milium I. Flattergras (Linué ïbertrug den altrömischen Namen der Hirse (Milium) auf dieses ihr ähniiche Gras).

1258. M. effusum L., gemeines F. Abb. 159. Halm glatt, kahl; Blätter lanzettlich-linealisch; Blatthäutchen lang; Rispe weit ausgebreitet, mit wagrechtabstehenden, zuletzt herabgebugenrn Aesten; Aehrchen eiförmig, granuenlos; Spe!zen spitz. 2. Feuchte, schattige Laubwälder stellenveise. In der Nälıe von Halle selten, nur in den Wäldern der Aue z. B. zwischen Schkeuditz und Kil. Dölzig, bei Naumburg in Buchholze und Sperlingsholze häufig, in Mühlthale zwischen Ziegelrode und Rossleben, in den Wäldern bei Holzzelle und im Helftaer Holze unwejt Eisleben, sparsamer bei Ischersleben, häufiger in schattigen Wäldern bei Dessau. Mai-Juli. Höhe $2-3^{\prime}$.

Spreng. gibt hal. ed. 2. p. 42 fül dieses besonilers bei Halle keineswegs häufige Gras gar keinen bestimm. ten Standurt all.

476. Stypa I. Pfriemengras (von otún $\eta$, Werg, mit welchem Linné die langen, oft ineinander gedrehten Grannen verglich; es ist daher nicht Stipa zn schreiber).

1259. St. capillata L., ha a rförmiges Pf. Abb. 166. Wurzel büschelförmi treibend; Blätter rinnig - fadenförmig; Kispe an Grunde von der Blattscheide eiugeschlossen; Grannen sehr lang, gekniet, $k a h l$; untere Spelze unterwiirts nit 5 seidenhaarigen Iinien bezeichnet. 4 . Dïrre, sonnige Hiigel, auf Kalk - und Sandboden, an Porphyrfelsen stellenweise. Bei Halle nicht selten z. B. zivischen Halle und Giebichenstein, bei Trotha, an sonnigen Anhöhen bei Dürrenberge, Keuschberg, bei Nammburg auf Sandbuden häufig, bei Allstedt am nördlichen Rande des 
Rathsholzes, bei Eisleben am Hutberge, bei Ascherslehen nach Mehringen zu und $z$ wischen Mehringen und sicharkstedt, an truchenen Anhöhen bei Alsleben und Beruburg. Juni. Juli. Höhe $2-3^{\prime}$.

1261. St. pennata c., federartiges Pf. Abb. 165. Wurzel büschelförmig, rasenartig - stehende Halme treibend; Blätter borstenförnig; Rispe au Grunde von der Blattschride pingeschlossen; Grannen schr lano, gekniet, federig, an Grunde bis zu dem vierten Theile ihrer länge kahl; untere Spelze unterwärts mit 5 seidenharigen linien bezeichnet. 24. Trockene, sunnige Hïgel, trockene Raine, liebt Kalkboden, seltener als die vorige Art. Bei Halle am Lindberge, bei Naumburg und Freiburg auf Kalkhügeln häufig, an der Steinklippe bei Wendelstein, bei Dessau. Mai. Juni. Höhe bis $2^{\prime}$.

9. Gruppe. Arundinaceen Kunth. Pfahlrohrartige Gräse r. Achrchen 2-bis reichblüthig; Griffel verlängert; Narben sprengwcdelförmig, aus der Hitte oder über der Mitte der Blüthe hervortretend.

457. Phragnites $\mathrm{Tr}$ inius. Rohr (Pflanzenname bei Dioscorides, von q.@́yuc, Zaun, weil die Griechen, wie nuch jetzt die Venetianer, ihre Gärten mit Rohr, Schilf einfassten).

1261. Ph. communis $T \mathbf{r}$ in., ge me ines $R$. Abb. 502. Blätter lanzettlich, in eine lange, dünne Spitze auslaufend; Blatthäutchen lang, anfangs am oberen Rande gewimpert, später ganz in Wimpern aufgelöst; Rispe zur Bliithezeit abstehend-ausgebreitet; Aehrchen 4-5blüthig. 2. Flussufer, an Rande stehender Gewässer gemein. Ang. Sept. Arundo Phragmites L. Rispe rothbraun. Höhe bis $8^{\prime}$.

10. Gruppe. Sesleriaceen. Seslerienartige Gräser. Aehrchen 2- bis reichblüthig; Balg gross, fast die Blüthen bedeckend; Griffel fehlend oder sehr kurz; Narben fadenförmig, aus der Spitze der Blüthe hervortretend, gezähnelt oder kurz - behaart.

478. Sesleria A roluino. Seslerie (nach dem venetianischen Arzte Leonhard Sesier benannt).

1262. S. coerulea $\mathbf{r}$ d ino, b l a u e S. Abb. 444. Wurzel rasenförnig, whıe Ausläufer; Blätter linealisch, flach, an der spitze plötzlich in eine rauhe Stachel- 
spitze zusammengezogen; Scheide ungetheilt, zuletzt am Rande gespalten; Aehre oval-länglich, meist einseitswendig, dehrchen $2-3$ blïthig, untere Spelzen in 2-4 Borsten und eine Granne aus der Mitte endigend; Borsten und Granne nicht halb su lang als die Spelzen. 4. Sunnige Anhöhen, besonders an Kalkbergen, stellenweise. Auf dem Vugelsberge und an den Kalkbergen zwischen Bennstedt und Kölme, an Bergen bei Mïcheln, bei Naumbırg auf Kalk häufig z. B. am I'fol'tenberge, bei Freiburg nicht selten z. B. am Sichlifter, an den Schmonschen Bergen, fehlt bei Aschersleben; in Kalkbergen bei Sandersleben, Bernburg, bei Alsleben, fehlt im östlichen und nordöstlichen Gebiete. April. Mai. Cynosurus coeruleus L. Höhe 2-12".

11. Gruppe. Arenaceen Kunth. Il aferartige Gräser. Aehrchen 2-bis vielblüthig, die endständige Blüthe oft verkümmert; Balg gross, fast das ganze Aehrchen urngebend; Griffel sehr kurz oder fehlend; Narben federig, aus dem Grunde der Blüthe beiderseits hervortretend.

4a9. Koeleria Pers. Kölèrie (zum Andenken an G. L. Koeler, Verfasser der Descriptio graminum in Gallia et Germania nascentium).

1263. K. cristata Pers., kammförmige $\mathbf{k}$. Abb. 174. 176. Blätter flach, die unteren gewimpert; die vertruchneten Blattscheiden ungetheilt; Rispe ährenförmig, am Grunde unterbrochen; Aehrchen 2-4blüthig; untere Spelze zugespitzt, grannenlos oder starhel. spitzig. 24. Grasige Hügel, trockene Wiesen häufig. Juni. Juli. Aira cristata L. Spec. pl. Pua cristata I. Syst. nat. Meist $\mathbf{A}^{\prime}$ hoch. Aendert ab:

b) g I a u c a D C.: Blätter bläulich-grïn; untere Spelze stumpflich, grannenlos oder nit einen, der stum. pfen Spitze aufgesetzten Stachelspitzchen. P. glauca Schk., so auf dürrem Sandboden z. B. bei Hohen. thurm, Landsberg, Rollsdorf, Naumburg u. s. w.

480. Aira I. Schmele (Pflanzenname bei Diuscurides).

A. Deschampsia P. B. Granne nur ein wenig einwälts gebogen und am Grunde kaum gedreht.

1264. A. cespitosa L., rasenförmige Sch. Abb. 185-189. Wurzel dicht-rasenfürmig; Blätter flach, oberseits sehr rauh; Blatthäutchen verläingerl, lïnglich; 
Rispe weitschweifig, breit-pyramidenförmig; Blühenstielchen rauh; Granne horstenförmig, meist so lang als die Spelze. 24. Feuchte Wiesen, Gräben, feuchte Wälder iiberall häufig. Juni. Juli. Deschampsia cespitosa P. B. Höhe bis $4^{\prime}$. Aendert ab:

b) pallida Koch: Klappen gelblich-weiss, auf dem Rücken grün; Spelzen grün-gelblich, an der Spitze weiss. Aira altissima Lam., so in feuchten Gebüschen.

c) vivipara: dehrchen in längliche Knospen auswachsend, so an feuchten Stellen der Dölauer Heide.

B. Avenellá. Granne deutlicher in ein Knie gebogen und an Grunde gedreht.

1265. A. flexuosa L., ges chlängelte s ch. Abb. 182. Blätter sehr schmal, fast borstenförmig, stielrund fadenförnigg, nicht ausgehöhlt; Blutthïutchen ziemlich kurz, abgestutzt; Rispe zur Blüthezeit abstehend, schlaff, überhäıgend, nach denı Verblühen zusammengezogen, mit dïnnen, etwas gefliigelten Aesten; Blüthen kaum länger als der Balg, über dem Grunde tegrannt; Stielchen der zweiten Blüthe 4 nal kürzer als die Blïthe selbst. 24. Trockene Wälder, Heiden. In den Wäldern bei Halle sparsamer, in Bientz, bei Naumburg, Freiburg, Eislebe॥ n. s. w. läufig. Juni-Aug. Höhe $1-2^{\prime}$.

481. Corynéphorus P. B. Silbergras (ron

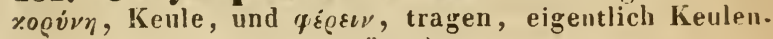
träger).

1266. C. camescens P. B., graues S. Abb. 178 . Dicht rasenförmig ; Bläiter zusammengefaltet - bor'stenförmig, graugriun ; Blattscheiden rauh; Blatthäntchen verlängert, stumpf; Rispe zur Bliithezeit mit abstehenden Aesten, ror und nach der Blïthezeit ährenförmig zusammengezogen. 4. Trockene, sandige Stellen meist häufig. Auf dürrem Sandbodén zwischen Nietleben und der Fasanerie sehr häufig, zwischen Gutenberg und denı Petersberge, an Bienitz und bei Rückmarsdorf in grosser Anzahi, fehlt bei Naunburg; dagegen bei Bibra auf sandigen Triften häufig. Juli. Aug. Äira canescens L. Rispe silberfarbig - grau. Staubbeutel dunkel-violett. Höhe bis $\mathbf{1}^{\prime}$.

482. Holeus L. Honiggras (unter óxós sollen die Alten die Mäusegerste, Hurdeum murinum L., ver. standen haben; von Anderen anders erklärt). 
1267. H. Ianatus L., wolliges H. Abb. 190. Wur. zel faserig; Blätter beiderseits weichhaarig; Blattscheiden mit weichen Haaren dicht besetzt; Rispe abstehend; Granne ler männlichen Blüthe im Balge cingeschlossen, zulctzt hakenförmig - zuriickgebogen. 24. Wiesen, Raine, Wäller gensein z. B. in der Völauer Heide häufig, auf Grasplätzen bei Nietleben u. s. w. JuniAug. Höhe $1-1 \frac{1}{2}$.

1268. H. mollis L., we iches H. Abb. 191. Wur. zelstock weit liricchend; obere Blätter und Blattscheiden kahl, die nntersten Blattscheirlen meist dicht weichhadr.jg; Rispe abstehend; Granne der männlichen Blïthe yeknict, iiber den Balow weit hinausragend. 24. Wälder, weit seltener als vorige A't. Am südlichen Rande der Dölauer Heide sparsan, im Bienitz, bei Naumburg im Mühlholze am Koroppenthale zwischen Schönburg und Wetal, bei Bibra in der Aue nicht selten, im Lodersleber Furste in der Nähe des rothen Brunnens, im Burnthale bei Landgrafiude, bei Allstedt häufig z. B. im Rathsholze, in Allstedter und Winkelschen 'Theilholze, bei Eisleben am Katharinenhulze, bei Neuhänsel nördlich von Delitzsch und in nordöstlichen Gebiete überhaupt verbreiteter. Juli. Aug. Höhe $1 \frac{1}{2}-3^{\prime}$.

483. Arrinenathérum P. F. Wiesenhafer

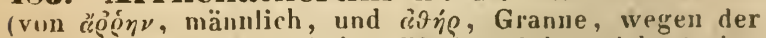
stets begrannten münnlichen Blüthe, daher nicht Arrhenáthèrumı zu sprechen).

1269. A. elatius Mr. u. Foch, hoher W. Abb. 192. 193. Blätter flach, lanzettlich-linealisch; Blatthäutchen kurz; Rispe zur Blüthezeit ausgebreitet; die untere Blütlie männlich, auf dem Rücken mit einel geknjeten, hervorragenden Granne, die obere Blïthe grannenlos nder unter der Spitze begrannt. 24. Auf allen Wiesen, 'Triften, an Wegen und Waldrändern gemein z. B3. auf der Wiese am Dunnersberge hinter. Kröllwitz. Juni. Juli. A. avenaceum P. I3. Avena elatior. J. Hol. cus avenaceus scop. Höhe $3-4^{\prime}$. Zuweilen ist auch die obere Blüthe mit einer langen, hervorragenden, geknieten, aber unter der Spitze und nicht auf dem Rükken eingefügten Granne versehen; ändert ferner $a b$ :

b) bulbosum Schlecht.: Halm am Grunde in $2-3$ iibereinanderliegende Knollen verdickt, so auf dürrem Buden. 
484. Nema L. Hafer (Pflanzenname bei Virgil).

A. Avenae genuinae. Aechte Haferarten. Aehrchen wenigstens nach dem Verblühen hängend; Klappen 5-9nervig; Fruchtknuten an der Spitze behaart. Wurzel jährig; nichtblïhende Blätterbüschel fehlend.

1270. A. sativa L., gemeiner H. Rispe gleichmässig nach allen Seiten ausgebreitet, nit wagrecht abstehenden Aesten; Bälge meist 2blüthig, länger als die Blüthen; obere Klappen 9nervig; Bliithen kahl, lanzettlich, nach der Spitze verschmalert, an der Spitze 2spaltig nud gazihnelt, die obere Blüthe grannenlos; Achse kahl, am Grunde der untersten Blüthe kurz-büschelförnig-behaart. $\odot$. Wird überall gebant. Juli. Aug.

1271. A. orientalis schreb., tii $\mathbf{r k i s c h e r}$ oder Fahnen-H. Rispe zusammengezogen, einseitswendig, nit aufrechten desten; Bälge meist 2 blïthig, Jänger als die Blüthen; olere Klappen 9nervig; Blïthen kahl, lanzettlich, nach der Spitze verschmälert, an der Spitze 2spaltig oder gezihnelt, die obere grannenlos; Achse kahl, am Grunde der untersten Blüthe kurz-büschelförmig - behaart. $\odot$. Wird hin und wieder gebaut und findet sich bisweilen auch unter dem gemeinen Hafer. Juli: Aug.

1272. A. strigosa Schreb., Rauh-oder Sand-H. Abb. 217. Rispe ziemlich zusammengezogen und fast einseitsuendig; Bälge meist 2blüthig, so lang als die Bluthen, obere Klappe 7-9nervig; Blitthen kahl, lan. zettlich, nach der Spitze verschnälert, auf dem Rücken begrannt, mit greknieter Granne, an der Spitze 2spaltig, mit begrannten Zipfeln und geraden Grannen; Achse kihl, an Grunde der oberen Blüthe mit einem kurzen Haarbüschel. $\odot$. Unter der Saat, besonders unter den gemeinen Hafer nicht selten. Juli. Aug.

1273. A. fatua L., Flug- oder $\mathbf{W}$ ind-H. Abb. 218. Rispe gleichmüissig nach allen Seiten ausocbreitet, uit wagrecht-abstehenden Aesten; Bälge meist 3hliithig; obere Klappe 9nervig; Bliithen lanzettlich, an der Spitze gezihht-2spaltig, auf dem Rïrken begrannt, rum Grunde bis zur Nitte borstig-behaart; Achse rauhhaarig. ○. Auf Aeckern unter der Saat häufig. Juli. Ang. Die Hare der Schwiele an Grunde der Blüthen weit länger als die Schwiele; die untere Spelze durch zahlreiche erhabene Punkte rauh. Aendert ab: 
b) glabrata Peterm.: Blüthen ganz kishl oder hier und da nit einem einzelnen langen Hare besetzt, auf dem Rürken gelbbraun oder blass, so auf Aeckern bei llalle sehr häufig. Diese Ahart ist in Koch's Synops. ed. 2. p. Yir irrthïmlich als Arena hybrida Peterm. beschrieben.

1274. A. hýbrida ete rm. (Flor. d. Bien. No. 80), B astard-H. Rispe etwas zusammengezogen; Bälge meist 2blüthig; Klappen an der Spitze ziemlich breit, die untere 9-, die obere 11nervis; Bliithen kahl; die Haare der Schwiele am Grunde der Blüthen nur so lang als die Schwiele, untere spelze an der Spitze breitabgestutzt und kurz-4zähnig. ( ) Unter der Saat anf Feldern bei Dölzig und Rückmaısturf. Juli. Aug.

P. Arenastrum. "Aehrchen nicht hängend; Klappen 1 - 3nervig; Fruchtknuten an der spitze behaart; Wurzel ausiauerud, nichtblühende Blätterbüschel und blïhende llalme treibend.

1275. A. pubescens L., we i chha a riger H. Abb. 213. Blätter linealisch, flach, auf beiden Sciten nebst den unteren Scheiden zottig; Rispe nach allen Seiten gleichnässig ansgebreitet, mit aufrechten, 1-5 Aehrchen tragenden Aesten, Aehrchen 2-3hlüthig; dic untere Bliithe in der Mitle des Riickens begrannt, nach der. Spitze zu silberig-trockenhäutig; Klappen 1nervig, an der spitze weiss-trockenhäutig, die obere su lang als das Aehrchen oder etwas kürzer. 24. Wiesen, Triften, Waldränder häufig $z$. B. auf Wiesen vor dem Sebener Busche, auf Wiesen unter dem Tannenberge bei Gutenberg u. s. w. Mai. Juni. Höhe $1-3$ '.

1276. A. pratensis L., Wiesen-H. Abb. 207. Blätter linealisch, oberseits schr rauh, nebst den stielrunden Blattscheiden kahl; Rispe zusamnengezogen, traubiy, die unteren Aeste zu zweien, die oberen einzeln, alle in ein einzelnes Aehrchen oder die längeren von den untersten deren 2 tragend; Aehrchen 4-5bliithig, auf dem Riicken in der Mitte begrannt; obere Klappe 3nervig; Achse behaart, die obersten Haare der Glieder 3 mal su lang als die Schwiele. 4. Trockene Wiesen, dürre Abhänge nicht gerade selten. Auf Wiesen vor dem Sebener Busche, an Apullosberge bei Westewitz, an Vogelsberge bei Bennstedt, auf Wie. sen bei Kl. Dölzig, in und am Bienitz u. s. w. Juni. Juli. Höhe $1-2^{\prime}$. 
c. Ventenata $\mathrm{K} 0 \in \mathrm{l}$. Untere Blüthe all der Spitze und nicht auf dem Rürken begrannt; Klappen 7 Inervig; Fruchthuten kahl.

127\%. A. tenuis Roench, zartel H. Abb. 197. Wurzel faserig; Bläter flach, wersejts rauh; Rispe nach allen Seiten gleichmässig ansgebreitet; Aehrchen meist 3blüthig; Klappen 7-sintrvig, untere Bliithe an der Spitzc in cine Granne zngespitzt, auf dem Riiclicn niclit begrannt, die folgenden an der Spitze haarspitzig 2grannig und auf dem kücken mit einel gekniet-einwärtsqebugenen Granne versehen. $\odot$. Irockene Hugel. Wird von Spreug. nach Bok im Katharinenhulze bei Eisleben am trorkenen, fast kahlen Abhange nach Wimmelburg zu, "o Kreisfeld zur Rerhten ist, angeureben. Der Verf. hat sit dort vergehlich gesucht. Juni. A. dubia Leers. A. triaristata Vill. Ventenata bromoides und arenacea linel. Hohe bis $1 \frac{1}{2}$.

Ii. Trisetum Persoon. Granns aus der Mitte der Bliithe oder uberhalb der Mitte herrurtretend. Klappen 1-3norvig. Blätter linealisch, flach. Fruchtknoten hahl.

1278. A. flavescens L., g elblicher H. Abb. $204-$ 206. Blätter flach; Kispe narh allen Seiten gleichmässig ausgebreitet, die längeren Arste 5-8 Aehrchen tragend; Aelırchen 3bliithig; wbere klappe 3nervig, länglich-lanzettlich, oberhalh uer Mitte zugespitzt; Fruchthnoten lahl; Achsc bchaart, Haare viel kiirzer als die Blïthe; untere Spelze durh 2 kurze Borstchen doppelt-haarspitzig. 24. Wiesen, Grasplätze häufig z. B. an Rainen zwischen der Irrenanstalt und der Dölaues Heide, in der Heide 11 . s. w. Juni. Juli. Trisetum flavescens P. B. Höhe $1-\mathbf{2}^{\prime}$.

¿. Caryophrllea. Granue unterhalb der Mitte der Blii. the hervortretend; Klappen 1-3nervig; Frucht. knoten kahl; Blätter znsammengerulli-borstenförnig.

1279. A. caryophýllea wigg., nelkeuduftiger 11. A bb. 181. islitter borstenförmig; Rispe abstehiend, 3 gabelig; Aelrelien 2blïthig, an der Spitze der Aestchen etwas gedrcingt: Blüthenstielchen of hurzer als die Achrchen; Balg länger als die Blizthen; mutere Spelze an der Spitze doppelt-haalspitzig, an beiden Blütlen unter der Nitte des Rüchens begrannt. $\odot$. Sandfelder,

Garcke, Flora. 
Heiden, trockene, sandige Waldstellen nicht gerade selten z. B. an Bergen zwischen Kröllwitz und del DöJaver Heide sehr hänfig, ebensu zwischen Nietleben und der Fasanerie, an Bienitz, bei Rïckmarsdurf, bei Nanmburg in Wäldern über der Henne, in Buchhulze, bei Allstedt anf leo Wiiste u. s. W. Juni. Juli. Iila caryopliyllea L. Nir $2-6 "$ horh.

12S0. A. praceox T. H., frühzejtiger H. Abb. 179. Blitter borstenfürmig; Rispe läinglich, cihren/ürmig-gedrungen; Aehrehen 2bluthig; Balg länger als die Blïthen; untere Spelze an der Spizze doppelt-haarspitzig, an beiden Bliithen unter der Mitte des Rïckens hegramnt. $\odot$. Diirre, sandige Anhöhen, Meiden nicht gerade selten $z$. B. an Bergen zwischen Kröllwitz und der Dölauer Heide, in der Dölauer Heide selbst, am Bienitz, bei Naumburg über der Heune und in Buch. holze, bei Allstedt auf der Wiiste u. s. W. April. Mai.

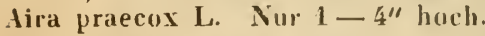

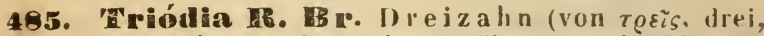
nnd ỏovis, Zahn, sollte daher 'Triödon, nicht 'Triudia heissen; ein dentscher Volksname fehlt bei dieser, wie bei mehren anderen Grasgattungen).

1231. T. decumbens P. A. liegende D. Abb. 433. Halme niederliegend oder wihrend der Blüthezeit aufsteigend; Blätter flach und nebst den Scheiden behaart; Rispe traubenförmig; Aeste einfach, ein einzelnes Aestchen oder die unteren $2-3$ derselben tragend; Aohrchen länglich.piförmig, 3-5blüthig. 24. 'Trockene IValdränder, Wiesen, Triften meist nirht selten z. B. in der Dölaner Heide, in Bienitz, in den II älderu bei Naumburg, bei Allstedt selten, Inr auf del II iiste. duni. Juli. Festura decumbens I. Pua derumbens Scop. Danthonia decumbens DC. Halm l' lang.

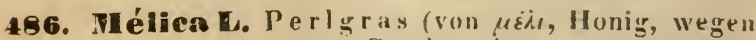
des süssen fieschmackes).

1282. IX. ciliata L., gefranstes P. Abb. 435. Rispe ahrenförmig, wleichmässig nach allen Seiten ausupreilet: nutere Spelze am Rande vom Grunde bis zur spitze dicht gewimpert-zottiw; gesshlerhtsluse Blithe linglich. 24. Steinige, felsige Orte. Bei Kröllwitz und Solzmünde nach Spreng., inden Weinbergen bei Rullsdorf, hei Naumburg unil Freiburg nicht selten, hei All. stedt in den wüsten Bergen, bei Bernburg, fehlt bei 
Aschersleben und in ganzen östlichen und nordöstlichen Gebiete. Mai. Juni. Höhe 2-4'.

1283. M. uniftora Retz., einblüthiges P. Abb. 436. Blätter flach; Blatthäutchen blattgegenständig, zugespitzt, fast krautartig; Rispe sehr Jocker, einseitswendig; Aeste etwas abstehend, die unteren meist 2 Aehrchen tragend: Aehrchen aulrecht, eiförnig; Bliithen bartlos, nut cine einzige vollkommen auswebildet. 7. Schattige, hochgeve gene Wälder selten. Fehlt bei Halle. II schattigen Wiäldern bei Weisserfels, bei Naumburg nicht gerade selten z. B. im Pfurtenholze, bei Kösen, bei Nöllern, bei Freibury im Nühtholze, im Ziegelrorler Furste, im Bischofsroder Holze, bei Sandervlehen in Freckleber Holze, häufig an Abhängen des Muldenthales zwischen Panch und Kösa östlich ron Bitterfeli. Juni. Juli. M. Lobelii Vill. M. nutans '?"llich. Halı übeshängend, 1-2' lang.

1284. TI. nutans L., nickendes P. Abb. 437. Blätter flish; Blatthäutchen sehr kurz, abgestutzt; Rispe in eine einfachn, einseitswendige, luckere Tranbe zusammengezogen; Aehrchen hängend, eiförnig; Bliithen bartlos, zwei vollkommen ausgebildet. 24. Schattige Wälder, Gebüsche hänfig. Mai. Juni. Höhe 1'.

12. Gruppe. Festucace en $\mathrm{K} u n t h$. S chwingelartige Gräs e r. Aehrchen 2 - vielblüthig, mit einer oft verkümmerten, endständigen Blüthe, gestielt. Klappen kürzer als die nächste Blüthe; Griffel sehr kurz oder fehlend; Narben aus dem Grunde der Blüthen beiderseits heraustretend.

497. Broiza L. Zittergras ( $\beta \varrho i \zeta \alpha$ vun $\beta \rho i \zeta(u$, ich nicke, schlummere, bei Theophrast ein Getreile, dessen Genuss schläfrig machte, von Linné auf diese Gattung wegen ihrel nickenden dehrchen übertragen).

1285. T. media L., ge me ines Z. Abb. 429. Blatt scheiden glatt oder rauh, die oberste sehr verlängert; Blatthäutchen sehr kuiz, abgestutzt; Rispe aufrechtabstehend, Stielchen der Aehrchen sehr diunn, geschlänyelt; Aehrchen fast herz-eiförmig, von der Seite zusammengedriickt, grannenlos, 5-9blüthig; Blüthen dicht-dachziegelförmig. 7. Wiesen, Triften, Kaine üherall häufig. Juni. Juli. Höhe 1-2'.

488. Ermgrostis I. IB. Liebesgras (ron ěce),

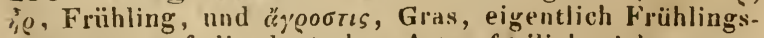
gras, was auf die deutschen Arten freilich nicht passt). 
12S6. E. pilosa P. H. be ha a ries B. Bhh. 424. Wurcel faserig; Blattscheiden an des Nündung hairtig; dic untersten Kispenäste halb-quirlfürmis, $\approx n 4$ oder 5 Aehrclien linealisch, 5-12blüthig; Blïtsen zientirlı spitz, mit einem schwachen, scitenständigen Nirven durchzogen. $\odot$. Nur an Felsen zwischen Girbichenstein und Trotha der.Papiermühle schräg gegeniiher, aber daselhst häufig. Juli-Sept. Poa pilosa J. Halme $4-10$ " lang.

1287. E. poncoidex P. M., lispengras ähnliches I. Abb. 427. Wurzel faserig; Blattscheidell an der Miindung bärtig; Rispcnäste cinzeln oder zu zueicn : Aeluchen lanzetllich-linealisch, 8-2(nhlithig; Bliithen stumpf, mit einen seitenständigen, starken Nerven durh. zugen. $\odot$. Auf Sandboden, sandigen Wegen und Aekkern nur mit fremdem Samen eingefiihrt wnd daher selten und unbeständig. Ist ron Wallr. nach ann. but. p. 18 einmal an sandigen Wegen zwischen Srhmon und Leimbach gefunden. Juli. Aug. E. minor Hust. Li. poaeformis 1,i nk. Poa Erigrostis $J$. Höhe 1-2'.

489. Poa. Rispengras (tóre war bei den Griechen allgemeiner Name für Gras, Unhraut).

A. Catapodium Link. Aehrchen anf sehr kurzen, dicken Blïthenstielchen in einer einfachen, einseitigen Aehre oder in piner aus einfachen, einsejtigen Aehren gebildeten Rispe stehend; Achrenspindel zusammengedrïckt, geschlängelt, starr. Bälge und Speizen lederartig.

1288. P. dura Scop., hartes R. Albb. 368 . Wurzel faserig; Rispe cifürmig, cinseitswendig, gedrun:cn, starr, ans hurzen, 3-6 Achrchen tragenden Achren zuscrmmengeset:t; Aehrchen sehr kurz gestielt, Jänglich; untere Spelze linpalisch-Jänglich, nervig, stumpf oder ausgerandet, meist kurz-staclielspitzig. $\odot$. Triften, Wegränder, besonders auf Lehmbuden, stellenweise. Ist seit vielen Jahren an den vill spreng. hal. ed. 2. p. 57 angegebenen Orten, nämlich auf dem Pfännerholzplatz an der Saale und anf der Eselswiese bei Querfurt vergeblich gesucht, auch hat der Verfasser diese Pflanze an den von $\mathrm{R} c h$ h. sax. ed. 1 u. 2. p. 31 citirten Standorten, bei Bennstedt und an der Kilause bei Merseburg" nie gefunden; dagegen hat er sie jährlich und zwar meist in grosser Anzahl an folgenden ()rten heob. achtet: am Fusswege zwischen Sephurg und Wormsleben 
in der Nähe des süssen Sees, bei Wansleben am Wege nach Anisdorf und bei Ober-Köblingen in der Nähe des salzigen Sees, sparsamer in Rullsclerf in der Nähe des Wirthshauses und der Mühle, bei Wettin in der Nähe von Miicheln und an Wege nach Dubis, gleichfalls sparsam auf betretenen Wegen an der Südseite von Naumbirg und unmittelbar bei Schönburg am Wege nach Leislinge॥, häufiger dagegen an Wege zwischen Nismitz und KI. Jena unweit Freiburg und bei Bibra, einzeIn an Wirthshause in Wendelstein und vor den Lederberger Thore bei Querfurt, " o sie einst schon W a IIr. fand, in Esperstedt und 'I'entschenthal, bei Aschersleben sehr häufig, bei Dessau selten; ausserdem werden als zurerlässige Standurte angegeben: Geusa unweit Merseburg, Varkramstedt an Ien Windmühlen, Iluhenmöl. sen und Delitzsch. Mai, Juni. Cynosurus durus L. Eleusine dura L a m. Sclerochloa dura P. B. Die ganze Pflanze blassgrün, nur $2-6^{\prime \prime}$ lang, meist dem Boden anliegend.

B. Poae genuinae. A echte Rispengräser. Aehrchen gestielt, zerstreut in einer. Rispe; Blïthen frei odel mit wolligen Haaren zusammenhängend, stunıpflich, spitz oder zugespitzt.

a. Wurzel faserig, lange Ausläufer felılend.

1. Rispenaste einzeln oder zuzweien; B Iüthen ausser der Wolle, wodureh sie bisweilenverhuuden sind, kahl,

1289. P. annua L., eînjähriges R. Abb. 387. 388. Wurzel faserig; Halm zusammengedriickt, an Grunde hisweilen wurzelnd und kurze Ausläufer treibend; Rispe neist einseitswendig, spreizend; Aestc kahl, einzeln oder zu zweien, zuletzt herabgebogen; Aehrchen lünglich-eiförmig, 3-7blïthig; Bliithen kahl, die oberen Blatthäıtchen länglich. $\odot$. Ueberall anf bebautem und unbebautem Buden, auf Lehnmauern, an Wegen. Blïht fast das ganze Jahr hindurch. Halm $2-10 "$ laug.

2. Rispenäte einzeln und znzweien; Blïthen ausser der wolle, mit welcher sie bisweilen verbunden sind, auf dem liáckennerven und beiderseits auf dem Randnerven mit einer dicht-seidenharigen liniebesetzt.

1290. T. bulbosa L., $\mathrm{z}$ wiebeliges R. Abb. 385. 386. Wurzel faserig, rasenförmio; Halm am Grunde oft zwiebelförmig-verdiclit; Blätter schmal-linealisch, Blatthäutchen sämmtlich länglich, spitz; Rispe aufrecht- 
abstehend; Aeste zu zueien oder auch cinzcln, rauh; Aehrchen an der Spitze der Aestchen gedrungen, eiförmig, 4-6blüthig; loliithen lïnglich-lanzettlich, an Rande und auf dem Rücken dicht-weichhaarig, mit zahlreicher, langer Wolle zusammenhüngend. 24. Sonnige, unbebaute Orte stellenweise. An Felsen bei Giebichen. stein und Kröllwitz nicht selten, an Bergen unmittelbar bei Schkopau an Fahrwege nach Merseburg, fehlt bei Weissenfels, Naumburg und Freiburg, beil Dessau häufig, bei Benndorf. Mai. Juni. Höhe 1'. Aendert ab:

h) vivípara S chrad.: Aehrchen in blattartige Knospen auswachsend. P. bulbosia $\beta$. I. Diese Form ist weit häufiger als die normale.

1291. P. alpina L., Alpen-R. Abb. $390-393$. Blätter ziemlich breit-linealisch, plötzlich in ein spitzes Ende zusammengezogen, die untcren Blatthïutchen kurz, abgestutzat. die obercn länglich, spitz; Blätterbïschel am Grunde nebst dem bliihenden Ilalme von gemeinschaftlichen Scheiden eingeschlossen : Rispe aufrecht, weihrend der Blïthezeit weitabstehend; Aeste zu zweien, glatt oder rauh; Aehrchen eiförnig, 4-10blüthig: Bliithen eiförmig-lanzettlich, am Rande und auf lem Rücken dicht-weichharig, frei uder durch spärliche Haare zusammenhängend. 24. Kalkberge. Mai. Juni. Von dieser Art findet sich in Gebiete nur die Abart:

b) badensis Haenke: Blitter kurz, breit, steif, bläulichgrïn, mit einen weissen, kıorpeligen Rande umzogen. P. collina Host. P. trivialis Poll. P. brizoides Wohlleben, so an Vugelsberge bei Bennstedt und an den Kalkbergen zwischen Bennstedt und Kölme, an der Steinklippe bei Wende\}stein, am Galgenberge zwischen Querfurt und Lodersleben, sehr häufig an den Srlinunschen Bergen.

3. Die unteren Rispenäte zu 5 , un hei mageren Fxem plaren 2-3; Blithen schwach-5nervig, a usserder Wolle, welclie sie zuweilen verbindet, mit einerseidentrarigen Linie auf den Rückennrrven und beiderseits: a d em lianduerven.

1292. P. nemoralis L., $H$ a in. $R$. Ahb. $403-409$. Wurzel rasenförnig und kurze Ausläufer treibend; Halm stielrund oder halbstielrund; Blatthïutchen sehr kirz, fast fehlend; Halmknoten nubedeckt; Scheiden kiirzer als die Halmglieder, die oberste kiirzer als ihr Blatt; Rispe abstehend; Aeste rauh, die unteren 2 bis 5 ; Aehrchen eiförmig-lanzettlich, 2-5blïthig; Bliithen schwach- 
mprvig, am Raude unil auf dem Rücken weichhaarig. †. Wälder, Gebüsche häıfig. Juni. Juli. Höhe 1-3'. Aendert ab:

a) Vu Igaris Koch: grasgrïn; Halmedünn, schwach, mit der luckeren Rispe überhängend; Aehrchen 2blüthig oder zuweilen nur 1bliithig.

b) fímula Kuch: grasgriin; Halme steif; Blattscheiden glatt; Rispe aufrecht oder an der Spitze überhängend; Aehrchen $3-5$ blüthig, so in Weidengebüsch der Wiesen, an Waldrändern; oder mit abstehender Rispe: P. nemoralis firmula (ia ud., oder mit zusammengezogener Rispe: P. nemoralis coarctata Gaud., su auf Mauern.

Alle Formell sind durch das äusserst schmale und sehr lange, meist wayrecht-abstehende oberste Blitt ausgezeichnet.

1293. P. fértilis Host, vielblïthiges R. Ahb. 410-412. Wurzel faserin, rasenförmig: Halme nelost den Blattscheiden glatt; Blatthïutchen liinglich, spitz; Rispe, ausgehreitet, abstehend; Aeste rauh, die unteren meist $\approx u 5$; Aehrchen eiförmig-lanzettlich, 2-5blïthig : Blïthen schwach-nervig, an Rande nach dem Grunde und auf dem Rïcken mit einer schmalen, weichharigen Linie bezeichuet. 4. Feuchte Wiesen, Gräben, Bäche, sïmpfe häufig. Juni. Juli. P. serotina Gaud. P. paIustris Roth. P. angustifolia L. wach Fries und Wahle $\|$ b., aber gegen die Diagnose in der Fl. suec. Höhe $1-2$.

4. Die unteren lispenäste halhquirlig, zu 5. Die Blïthen init 5 starkeu, an der getrockneten foflauze heselders hemerklichen jervell versehen, hahl oder unterwäts

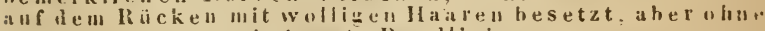
beliat ate la andlinie,

1294. P. sudetica ra enke, Sudeten-R. Abb. 421-423. Blätter lanzettlich-linealisch, an der Spitze plützlich angespitzt und miitzenfürmig-zusammengezogen ; Blattscheiden 2schneidig; Blatthäutchen liurz; unfinchtbare Blailtcrliischel 2zeilig, flach-zusammenıcdriickt; Rispe ausgrbreitet; Aeste muh, die unteren' zu 5; Aehrehen eiförmig-länglich, 3-5blüthig; Blättcr crhahen-5nervig, ganz kahl uder am Rande mit wolligen Haarell spärlich besttzt. 4. Wälder sehr seltell. Im Lodersleber Furste, besunders in der Nähe des Sandthales. Juni. Juli. P' quadripedalis Ehrh. P. silvatica Vill. P. trinervata DC. Höhe $2-4^{\prime}$. 
1295. IP. trivialis L., g( me ines R. Abh. 418-420. Wurzel faserig; IIalm nebst den etwas zusanmengeIrückten liluttscheiden rauh; Blatticiutchen der oberen Scheiden vorgezogen, länglich, spitz; Rispe abstehend; leste rauh, die unteren zu 5 ; Athrchen eiförmig, meist 3bliithig; Bliithen erlaben-5nervig, kahl, am Grunde schwach-behaart. 4. Nasse Wiesen, Gräben, feuchte Stellen häufigr z. B an Grähen und auf Wiesen in ter Nähe der 'Peiche bei Dieskau sehr hänfig u. s. w. Juni. Inli. P. duhia L,eers. P. scabra Ehrf. E. pratensis PıIl. IIöhe $1-3$ '.

1. Wurzel mit verlingerten . Iusliufern weit und hreit umher kriechenu.

1296. P. pratensis L., Wi tos e n-R. Abb. $413-417$. Wurael mit verlüngerlen Auslüufern hricchend; Halm nebst den Blattscheiden hahl, dip uberste Scheide viel länger als ihr Blatt; Blatthüutchen kurz, abgestutzt; Rispe abstehend; Arste rauh, die unteren meist zu j; tehrchen eiförmig. 3-5blïthig; Blüthen auf dem Rükken und am Rande dicht- "eichhaarig und durch eine lange Wolle verbunden, 5nervig, Nerven hervortretend. 4. Wiesen, Tritten, Grasplatze überall gemein. Nai. Juni. P. glabra Ehrh. P. angustifolia Pollich. Iöhe $1 / 2-3^{\prime}$. Kummt auf fruchtbaren Wiessn nit lebhaft grünel Farbe und verlängerten, zwar schmäleren, aber nicht burstenförmig - zusammengefalteten Wurzelblättern vor und dies ist die gewöhnlichste Furn im Gebiete. lendert aber ab:

b) I at ifolia Koch: Wurzelblätter hürzer und breiter unl wie die ganze Pflanze von blänlich-grüur oder hechthlauer Farbe. P. humilis Eh $\mathrm{rh}$. P. depressa Presl., so an sandigen, dürren Hügeln.

c) angustifolia Koch: Wurzelhläter zusammengefaltet oder zusammengerullt-borstenlörmig. P. angustifulia $I_{2}$. nach $S_{\text {m. }}$, su an truckenen, unfruchtbaren Orten.

1297. P. compressa C., zus a m m engedrü ckte R. Abb. 401. 402. Wurzel mil verliingerten Auslïufern kriechend; Halme 2schneidig - zusammengedriickt, anı Grunde liegend; Rispe abstehend, meist einseitswendig; Aeste rauh, die unteren meist zu 2 , seltener zu 5; Aehrchen eiförmig - länglich, 5-9blüthig: I3lüthen auf dem Riicken und am Runde nach den Grunde zu weich. haarig, frei oder mit spärlicher Wolle zusammenhängend, schwachnerrig. 4. 'Triften, truckene Plätze, 
besonders häufig auf Lehmmauprn, so schom in Halle und namentlich in Dörfern. Juni. Juli. Höhe meist $1 / 2-3 / 1$. Aendert ab:

b) J,angeana Rehb.: Halm etwa 2' hoch, Rispe schlaff, sehr rejch mit tehrchen besetzt. P. compressa $\beta$. effusa Ta us ch.

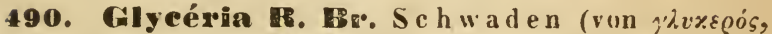
siiss, die siissen als Mannagriitze bekannten Samen der G. fluitans R. Bir. bezeichuend).

1298. Gl. spectábilis Mert. u. Koch, ansehn. liche Sch. Abb. 379. Wurzelstock kriechend; Rispe nach allen Seiten gleichmaissig aus..chreitet, weitschueifig, sehr ästig; Aehrchen 5-9blüthig; Bliithen stumpf, 7nervi., Verven stark, hervortretend. 4. An Rande stehender und fliessender Gewässer, in Sïmpfen häufig. Juli. Augr. G. aquatica Wahlenb. Poa aquatica l. Halm 4-6', dick, rohrialtig

12.j9. Gl. fluitans R. R r., fluthende Sch. Abb. 350. Wurzelstuck kriechend; die jungen Blätter zusammengefaltet; Rispe einseitswendio; 1este während der Blïthezeit rechtwinkeliø-abstehend, die unteren meist zu 2; Achrchen 7-11bliithig, an die Aeste angedriickt; Bliithen lanzettlich-länglich, ziemlich spitz, oft schwach 3kerbig, 7nevvig, Verven stark, hervortretend. 24. siimpfe, Grüben, nasse Wiesen häufig z. B. in Gräben an Jer Irrenanstalt, in der Dölaner Heide u. s. w. JuniSept. Festuca fluitans L. Poa fluitans Scop. Der fast bis zur Rispe. von Blattscheiden eingeschlossente Halm ist $1-2^{\prime}$ lang.

1300. GI. distang wahlenb., a bstehende Sch. tbb. 375. Wurzel faserig; Kispe anfänglich zusammengezogen, später nach allen Seiten gleichmässig-abstehend; die unteren Aeste meist zu 5, die fruchttragenden herabgeschlagen; Aehrchen 4-6bliithior; Bliithen ciförmig - länglich, abgestutzt-stumpf, schuach-5nervig. 4. Fenchte Orte, Gräben, besunders anf Salzboren, stellenweise. Bei Halle häufig z. B. auf dem Pfännerholzplatz und an der Saline, an den Teichen bei Dieskau, bei Bennstedt und Kölme, am salzigen See, bei Kl. Dölzig, Kötschau, bei Naunburg und Kösen, Artern, Eisleben, an den Seelöchern bei Zabenstedt unweit Gerbstedt, bei Aschersleben, Stassfurt, Lean. Mai - Sept. Poa distans L. P. salina Pullich. Gras meist grau. grün oder auch gefärbt. Höhe $1 / 2-1^{\prime}$. 
1304. G1. aquatica Pesl, Wasser-Sch. Abb. 374. Wurzel hrierhende Ausläufer treibend; Rispe nach illen Seiten gleichmässig - ausgehreitet: Aeste diinn-fadenförmig; Aehrchen limealisch, meist 2blüthig; Blïhen länglich, stumpf, 3nervig, Verven hervorlielend 24. Stehenle Gen üsser, Gräben, sandige, "asse Pläze sehr zerstreut. In Gräben beim Dreierhause, an der Salzke und an ler Fuhne nach sipreng., in Gräben bei Kil. Liebenau, Möritzsch und Kíl. Dölzig ziemlich häufig, ebenso bei Kötschau, in siidlichen und westlichen Gebiete nuch wicht bewhichtet; im dschersleber See und nach Hecklingen zu häufig, nach $S \mathrm{~S}: \mathrm{h}$ w a $\boldsymbol{H}^{*}$ auch bet Werdershausen, Giöbzig, Salzfurt. Juli. Aug. Aira aquatica 1. Catabrosa aquation P. B. Poa airoides Koel. Hydrochloa airoides Hartm. Aehrchen meist violett angelaufen. Höhe $1-2$ '.

491. Molimia Seln ratr. Molinie (nach dem Jesuiten Giov. Igrnatio Mulina, einem Missionär in Chili, benannt).

1302. N. coerulea Moench, blaut M. Abb. 372. Halns steif-aufrerht, am Grunde gleich über der Wurzel mit 1-2 dicht über einanler stehenden Knoten, sonst ganz knotenlos, nur am Grunde heblätert; Rispe etwas zusanınengezogen; Aehrchen aufrecht, granninlus, meist 3blïthig; Blüthen 3nervig. 24. Sumpfige Wiesen, Gräben, Waldsümpfe, Wialder nicht selten z. B. in der Dölauer Heide, in den Sümpfen bei Lieskau, in Bienitz, bei Naumburg auf der Sumpfwiese bei Gipkau häufig und sonst hin und wieder. Aug. Sept. M. vari. abilis Wil. Aira cuerulea L. Spec. pl. Melisa coerulea L. Mant. 2. Enudium coeruleum $G$ aud. Die Sumpform ist $1 / 2-1^{\prime}$ hoch. Das Gras ändert aber ab :

b) altissima Link: Halm $3-6^{\prime}$ huch; Aehrohen an den Rispenästen entfernter, locker gestellt; Wurzelblätter $1-2$ ' lang; M. arundinacea Sc hı a $n k$, so iı Wäldern.

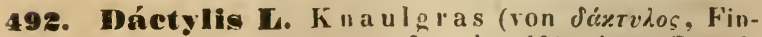
ger, wegen der gelappten, fast handförmigen Gestalt. der Rispe).

1303. D. glomerata L., gemeiues K. Abb. 364 . Wurzel rasenförmig, whne Auslüufer; Rispe aufrecht, Aaste einzeln stehend, die unteren am Grunde weithin whe Aehrchen; . Iehrchen dicht-büschelförmig-geknäuelt; 
untere Spelze 5nervig. ㄱ. Wiesen, Gräben, Grasplätze, Wälder, Wrgränder üherall gemein. Juni. Juli. Festura glomerata All. Bromus glomeratus S cop. Höhe $1-4^{\prime}$.

493. Cynosínus L. K a m m g ras (von $\nsim \dot{w} \omega \nu$, Hund, und ov̉ó,. Schwanz, eigentlich llundeschwanz, wegen der struppigen Rispe).

1304. C. cristatus L., g e me i n es K. Abb. 366. Halm steif-änfrecht; Blatthäutchen kurz; Rispe ährenförmig, gedrungen, linealisch, gerade; jedes Aehrcien an Grunde mit einen fiedertheiligen Deckblatte gestiitzt; Bälge der Deckblitter in eine Stachelspitze verschmälert. 7 . Wiesen, Triften, Grasplätze häufič z. B. zwischen der Irrenanstalt und der Dölaner Heide. häufig bei Gutenberg u. s. w. Juni. Juli. Jhleum cristatum seop. Höhe 1-2'.

494. Festúca I. Schwingel (Festuca, eigentlich Halm, Struhhalm iiberhaupt bezeichiend, erst vou den Neueru als Gattungsname angew endet; der Trivialname Pseudo-myurus ist aus $\psi \varepsilon \tilde{v} J^{\prime} \circ \varsigma$, Lüge, Trllg, $\mu \tilde{v} \varsigma$, Maus, und ov̧œ́, Schwanz, zusammengesetzt und vegen des schmalen Blüthenstandes su benannt).

A. Vulpia Gmel. Mrgalurus Link. Rispenästchen ziemılich dick oder auch nach der spitze bemerklich verdickt und fast heulenförmig; Blüthen lanzettlich-pfriemlich, lang-begrannt, bei mehren Imännig. Wurzel klein, faseriø; nichtblühende Blätterbïschel fehlend.

1305. F. Psendo-myurus soyer-wille m., falscher Mäuseschwauz-Schw. Abb. 290 . Wurzel faserig; Halm bis zur Rispe mit Blattscheiden bedeckt oder etwas aus der obersten Blattscheide hervorragend; Blatthäutchen 2öhrig; Rispe einseitswendig, zusanımengrzıgen, fast ährenförmig, meist bogenfürmignicliend; where Klappe spitz, untere 2- odel mehrmal hürzer; Bliithen lanzettlich, pfriemlich-verschmälert, lang - begrannt, kïrzer als die Granne, ranh. $\odot$. Dürre Hiigel, Sandfelder, sandige 'Triften stpllenweise. In Galgenberge, vor der Dölauer Heide, am Dölauer Kirchholze bei Lieskan, am Bienitz, bei Ninmburg über der Henne und an der Strasse nach Freiburg hin, anf den unbewaldeten Stellen der Wüste bei Allstedt, bei Freckleben unweit Sandersleben und bei Aschersleben nach 
Welbsleben zu, bei Dessau häufiğ. Mai. Juni. F.uy̆urus Ehrh. und der meisten Autoren. Vulpia myurus Gnel. V. P'sendo-myurus Rchb. F. bromoides bei spreng. hal. edl. 2. p. 56. Das Gras blassgriü, bald strohgelh werdend; Blattscheiden weit länger als ihr Blatt. Halme $3-8^{\prime \prime}$ lang.

Festuca sciuroides Roth oder F. bromoides der meisten Auturen, welche pine aufrechte Rispe und einen wherwärts nicht mit Blattscheiden besetzten Halm hat, grössel wird (bis 1' huch) und "eit läıger griin hleibt, wird vun Schwabe bei Dessall angegeben: vielleicht findet sie sich auch an anderen Stellen de.s Gebietes.

B. Festucae genuinae. Aechte Schwingel. Blïthen. stielchen der Rispe fadenförmig, unter den Bliithen mur mässig dicker; Bluthen lanzettlich, spitz, grannenlus oder begrannt; Blätter alle zusim. mengefaltet-faileuförmig oder die halmständigen flach; Wurzel ausdanernd: nichtbliihende Blätterbüschel stets vwrhanden.

1306. Fovina $\mathrm{L}$., S $\mathrm{cha}$ a $\mathrm{f}-\mathrm{Schw}$. Abb. 294. Wurzel faserig; Bliitter siimmtlich zusammengefaltct-borstenförmig; Blatthäitchen 2öhrig; Rispe während der Blüthezeit abstehend; Aehrchen $4-8$ blütlig: Bliithen lanzettlich, grannenlus uder begrannt; Granme kurz oder halb so lang als die Bliithe; untere spelze schwach. 5nervig, obeve länglich-lanzettlich, an der. Spitze 2zïhnig. 24. Wiesen, 'I'riften, trockene Wälder häufig. Mái. Juni. Höhe 1-2'. Aendert ab:

a) vulgaris Kuch: Blätter grasgrün oder nur etwas lauchgrün, sehr dünn, mehr uder weniger ranh; Aehrchen kleiner, orannenlos: F. tenuifulia sibth. (Abb. 2!6), so selteu, bei Naumburg in Pfurtenholze nicht weit von der Kohlenstrasse, oder mit sehr dïnnen, verläsgerten Blättern und kurz-begrannten Aehrchen: $r$. capillata $L$ a m., so in schattigen Wälılern häufig.

b) valesíaca Schleich. (Abb. 311): Halm höher; Aehrchen grösser; Blätter verlängert, äusserst dünn, sehr rauh, hechtblau, seltener, in Wäldern bei Weissenfels und Naumburg.

c) duriús cula L. Sp. pl., nicht Syst. nat. (Abb. 303): Halm höher; Aehrchen grösser; Blätter grasgrün oder bläulich-grün, meist dicker, steif oder zı- 
rüchgekrümnt: F. ovina Schrad., so häufig in Wäldern.

1) glauca Schrad. (Abb. 307): Blätter bläulich. grün, steif, sunst wie die vurige Abart, selten. Bei Kröllwitz, in den Wäldern bei Naumburgr stellenweise, bei Delitzsch unweit des Gesundbrunneus.

1307. F. heterophýlla cam., verschiedenblät teriger Schw. Abb. 323. Wurzcl faserig; Wurzelblätter zusammengefaltct - borstenförmig, halmständige Blütler Hach; Blatthïutchen 2öhrig; Rispe während der Blüthezeit abstehend; Achrchen 4-5hlüthig; Blüthe begrannt, lanzettlich; Granme kurz oder fast su lang als die Blüthe. 24. Truckene Wälder häufig z. B. iu der Dölaner Heide, in Frenzelhulze bei Jieskau u. s. W. Mai. Juni. F'. heterophylla Haenke. F. duriuscula J. Syst. nat., nicht spec. plant. F. nemorum Jeyss. Höhe 1-3'.

1308. rubra L., rother Schw. Abb. 321. Wurzel auslïufertreibend mud lockere Rasen bildend; Bliitter zusammengefaltet - horstenfürmig, die halmständigen Alıch; Blattliüutchen 2ührig; Rispe während der Blüthezeit abstehend; Achrchen meist 5blüthig; Bluthen lanzettlich, begrannt; Granne kurz oder fast so lang als die Blüthr. 2. Waldränder, Ackerraine, sandige Plätze nicht gerade selten z. B. bei Seben nach Guteuberg zu. Mai. Juni. Höhe $1 \frac{1}{2}-3^{\prime}$. Aehrchen oft roth angelau. fen. Aendert ah:

b) villosa $K$ uch: Achrchen mit kuren, weichen Haalen besetzt: $F$. dumetorum $\mathrm{I}_{4}$, so an schattigen Plätzen der Wälder zerstreut, häufiger in den Wäldern bei Naumburg.

c. Schedonori. Blüthenstielchen der Rispe, Aelırchen und Blïthen wie bei der vorigen Abtheilung, aber dit Blatthäutchen nicht 2öhrig; Blätter meist flach.

1309. Fo silvatica vill., Wald-Schw. Abb. 326. Wurzel faserig; Blïtter lamzettlich-linealisch, oberseits blïulich-griin, unterscits lebhaft-griin, am Rande rauh; Blatthäntchen länglich, stumpf; Blätterbüschel unterwärts mit blattlosen, allmählig in Blätter iibergehenden Schuppen hedeckt; Rispe aufrecht, ausgebreitet, sehr ästig; Aeste rauh, die unteren zu 2, 3 oder 4; Achrchen meist 5!lïthig; Achse ein wenig rauh; where Spelze rerschnälert, sehr spitz, grannenlus, feinpunktirt-rauh; 
fast 5nervig, 3 Nerven stärker hervortretend; Fruchtknoten an cler Spitze behaart. 24. Schattige Gebirgs. wälder. Wird ron spreng. in den Wäldern hei Lodersleben, Ilornburg und Helfta angegeben. Juni. Juli. F. calamaria S m. Poa trinervata S chrad. Bromus triflorus Ehrh. IIöhe 2-4'.

1310. F. gigantea vill., Riesen-Schw. Abb. 358. Blïter breit-linealisch, flach, kahl; Blattläutchen schr hurz, abostutzt; Rispe weit abstehend; Aeste an der Spitze schlaff - iiberhängend; Aehrchen 5-sulüthig; Blïthen unter der Spitze hegrannt; Grannen gefliigelt, doppelt so lang als die Spelze; Fruchthnoten lang. 24. Fenchte, schattige Laubuälder und Gebüsche häufir z. B. in Sebener Busche, in der Ane sehr verbreitet. Juni. Juli. Bromus giganteus 1 . Höhe 2-5'.

1311. F. arundinacea shreb., ruhrartiger Schw. Abb. 33.4. Blätter flach, lanzettlich-linealisch: Blatthäutchen sehr kurz; Rispe ausgehreitet, iiherhängend; Aeste rauh, zu ziveien, ver zweigt, 5-15 Aelirchen tragend; Aeluchen eiförmig - lanzettlirh, 4-5bliithig, untere Spelze unter der Syitze stachelspitzig oder anch granneulos; Fruchtinoten kahl. 24. Fenchte Wiesen, Weidengebiisch, Gräben wicht selten z. B. auf Wie. sen an den Teichen bei Dieskan, auf Wiesen vor und hinter Bennstedt, bei Kl. Dölzig, am Bienitz u. s w. Juni. Juli. F. elatior $\mathbf{S}$ m. Bromus armndinaceus $\mathbf{R}$ oth. B. elatior Spreng. Höhe $2-5^{\%}$.

1312. F. elatior L., hoher Schw. Abh. 330-333. Blätter flach, lanzettlich - linealisch; Blalthïulchen schr kurz; Rispe einseitswendig, zusamnengezogen, während der Blüthezeit abstehend; Aeste rauh, zu sweien, der eine dann sehr kurz und meist 1 Aehrchen, der zueite traubenförmig und 3-4 Achrchen tragend; Aehrchen linealisch, 5-10bliithig; Klappen stumpf, untere Spelze 5nervig, an der Spitze gezahuelt, grannenlus oder unter der Spitze stachelspitzig; Fruchthnoten kalll. 4. Anf allen Wiesen und Grasplätzen häufig. Juni. Juli. F. pratensis Huds. Bromus elatior Ko el. Höhe 1-3'. Aendert mit Rispenästen ab, v'nn denen der eine $2-5$, der andere 3-8 Aehrchen trägt; die Rispenäste sind jednch meist nicht wieder verïstelt.

495. Hrachypédium P. B. Z Z w e nke (von f $\varrho$ ce$\chi \dot{v} s$, kurz, und ródiov, kleiner Fuss, wegen der kirzen Aehrchenstiele). 
1313. D. silvaticum Re m. 11. Schult., Wald Z. Abb 277-279. Wurzel faserig; Blätter flach, lanzettlich-linealisch, schlaff; untere Blattscheiden meist von abstehenden Haaren zuttig; Aehre 2zeilig, ïherhäıgend; Achrchen zahlveich, begrannt; Grannen der oberen Bliithen länger als die Spelze. 4. Schattige, feuchte Laubwälder nicht selten z. B. hei Seben, Gutenberg, Ermlitz u. s. w. Juli. Aug. Festuca silvatica Huls. Bromus pinnatus $\beta$. L. B. gracilis Weigel. 'Triticum silvaticum Mönch. Höhe $2-3$ '.

1314. B. pinnatum P. H., gefiederte Z. Abb. 230 - 232. Wnrzel kriechend; Blätter flach, linealisch oder lanzettlich-linealisch, ziemlich strif; Aehre 2zeilig, aufrecht oder ein wenig überhäugend; Achrchen zahlreich, begramnt; Grannen kiirzer als die Spelze. 4. Grasige Hügel, Iaidränder, Gebüsche häufig z. B. an Waldrändern hei Gutenberg, an Bergen bei Röglitz, hei Ermlitz, bei Ki. Dölzig, im Bienitz u. s. w. Juni. Juli. Bromus pinnatus I. Festnca pinnata Mö neh meth. Triticum pinnismm Mönch hass. Der steif aufrechte Halm ist $3-4^{\prime}$ hoch. Blătter wie die ganze Pflanze gelbyriin. Aendert ab:

a) vulyart $K$ uch: Aehrchen rauh oder zottig, gerade uder gekriimmit, so am häufigsten.

b) rupestre Koch: Aehrchen kahl, nicht selten verlängert und sichelföımig. Bromus rupestris $\mathrm{H}$ os t. B. corniculatus La m., su an truckene'n Kalkhügeln.

496. Mremus I. Trespe (von pocisuc, Nahrung, Futter; wal bei den Griechen Name des Hafers).

A. Bromi sccalini. Aeluchen aurh nach dem Verbliihen narh der Spitze: zu schmäler; untere Klappe 3 -5nervig, obere 5 - bis vielnervig; wbere Spel. ze mit ziemlich steifen Bursien entfernt kammförmig - gewimpert.

1315. R. secáliuus L., Ruggen-'T. Abb. 353. Blattscheiden kahl; Rispe abstehend, narh den Verblühen ïberhängend; Aehrohen länglich; Bläthen breit-elliptisch, die fiuclittragenden am Rande zusummengeiogen, sticlrund, sich nicht deckend; unterc Spelze 7 nerig, an Rande abgerundet, so lang als die obere; Granne hervorgestreckt, geschlängelt oder ziemlich gerade. (.). Anf Aeckeru besonders unter Ruggen nebst den Abarten nicht gerade selten z. B. anf Aeckern zwismen Nietleben und der Fasaneric häufigg, zwischen Dölau 
und bettin u. S. W. Juni-Aug. Höhe 1-3'. Aendelt $\mathrm{ab}$ :

a) glossus Koeh: Aehrchen sehr gruss, ungefahr bis 16blithig, kahl oder rauh: B. grossus p. Ga ild.

b) velutinus Koch: Aehrchen sehr gruss, kurzhaarig-sammetartig: $B$. grossus c. Gaud. su seltener, 111 bej Naumburg beobachtet.

c) vulgaris Koch: Aehrehen hleiner. Wenigerblii. thig, kahl oder rauh, Granuen verlängert: B. secalimus Schrad., fehlen dagegen die Grannen oder ist nur an der einen oder anderen Blüthe ein klejnes Spitzohen, su heisst diese Furm B. submuticus Rehb.

1316. B. commutatus sehrad., verwe chsplte 'T. Abb. 347. Untere Blatlscheiden behadrl; Rispe al.. stehrend, zulctzt iiberliängend; Achrchen länglich-lanzettlich, kahl; Blüthen elliptisch-länglich, die fruchttragenden au Rande sich dachziegelförmig-deckend; mntere spelze Inervig, am Rande obcrhall der Mitte in eincn stumpfen Winticl hervortretend, bemprhbrh läıger als die ubere, Granne gerade he:vorgestreckt, fast ron der Iänge ihrer Spelze. (-). Auf Aeckern unter der Saat, auf' Iriften, an Wegen selten. Bei Namulurg an Wegen in der Nähe der Saalhäuser, bei Bibra auf deckern, bei Aschersleben besunders auf Esparsettächern häufiger, bei Sandersleben und Dessau. Mai. Juni. Höhe $1-2$ '. B. simplex $G$ a $u d$.

Unterscheidet sich ron B. secalinus durch die fiuchttragenden, sich mit dem Rande darhziegelförmig-deche॥den Blithen, die untere Spelze, welche bemerklich länger, als die ubere ist, durch dïmere Blïthenstiele und zuttige untere Blattscheiden; ron B. racemosus durch die längere, länglich-eiförmige untere und die linealisch-längliche, nur am Grunde rerschmälerte obere Spelze, durch den wherhall, seiner Mitte in einen stumpfen Winkel herrortretenden Rand der unteren Spelze, furch die entfernter von der Spitze eingefïgten Granuf:n und die feineren Blïthenstiele.

1317. F. racemosus L., traubenförmige R. Abh. 349. Untere Blattscheiden behaart: Rispe abstehend, aufrecht uder ctwas üherhängend, nach dem Terbliihen zusammengezogen; Achrehen eiförmig-länglich, kahl; Bliuthen breit-elliptisch, die fruchttragenden am Rande sich dachziegelförmig derkend; untere Spelze 7nervig, am Rande abgermulet, benerhlich länger als die obere; 
Granne gerade hervorgestreclit, fast rou der Läuge ih. rer Spelze. (-) Wiesen, 'Triften, Brachäcker stellenweise. Bei Halle nicht gerale häufig. Auf der Wiese zwischen den Vugelsberge und der Chaussee bei Bennstedt, auf Wiesen bei Kl. Liebenau, bei Kl. Dölzig, anf den Wiesen am Bienitz, an den Quellen zwisclien dem Bienitz und Rückmarsdorf, bei Körschau, bei Naumburg in der Aue ziemlich verbreitet, auf Wiesen an der Unstrut zwischen Balgstedt und Jaucha, auf Wiesen unter der Steinklippe zwischen Kl. Wangen und Wendelstein, bei Russleben, Lodersleben, Eisleben, bei Aschersleben und Dessau häufig, bei Benndorf. Mai. Juni. B. pratensis Ehrh. B. multiflorus Roth. Höhe 1' und daruber.

1318. B. mollis L., " $\mathrm{e} \mathrm{ch}$ h a a r ige 'T. Abb. 345 . 346. Blattscheiden uid Blätter behaart; Rispe aufrecht, nach dem I'erbliihen zusammengezogen; Aehrchen eiförmig-länglich, weich-behaart, seltener fast kahl; Blüthen breit-elliptisch, die fruchttragenden am Rande dachziegelförmig sich deckend; untere Spelie inervig, an Rande oberlialb der Nitle in cincm stumpfen Winfiel hervortretend, bemerklich länger als die obere; Granne gerade hervorgestreckt, fast von der Länge ihrer Spelze. (-). Wiesen, Triften, Ackerründer, Kaine, Wege überall gemein. Mai. Juni. Höhe $1 / 3-11 / 2^{\prime}$. lendert mit grösserer, ausgebreiteterer und kleinerer, mehr zusammengedrängter Rispe und fast kahlen, nur auf den Nerven mit kurzen Haaren besetzten Aehrchen ab.

1319. R. brachystachys Kornung, kurzährige T. Untere Blattscheiden behaart; Rispe aufiecht-abstehend, nach dem Verbliihen unverändert; Aehrchen eiförnig - länglich oder linealisch - lanzettlich; Blïthen fast rautenfürmig, bei der Fruchtreife an Rande dachziegelformig sich deckend; untere Spelze 7ıervig, am Rande uberhalb der Mitte in einem stumpfen Winkel herrortretend, die obere fast so lang als dic unterc, Granne yerade hervorgestreckt, halt so ling als die Blïthe. (.) Ackerraine sehr selten. Ist an dem vom Autor zu. erst aufgefundenen Standorte an Acherrainen hei Mehringen unweit Aschersleben später durch Umpflügen rerschwunden, findet sich aber auf dem Aschersleber Gottesacker und nach $\$ \mathrm{ch}$ wabe an duhöhen bei Saudersleben und Bernburg. Juni. Höhe 1-1⁄2.

Unterscheidet sich ron dem nahestehenden B. arGürcke, Flora. 
vensis $L$. durch die zweijährige Wurzel, die steifere Rispe, die stärkeren Aeste, die kürzeren und breiteren Blïthen, die weit kürzeren Grannen, die verkehrt-eiförmig-längliche Karyopse, welche ein wenig länger ist als die Spelzen, während diese bei B. arvensis linealisch und um den vierten 'Theil kürzer ist als dic Spelzen. Die an den zuerst aufgefundenen Exemplaren beobachteten kïrzeren Aehren dagegen haben sich bei der Aussat nicht als constant gezeigt, sie besitzen vielmehr die Form von B. arvensis.

1320. H. arvensis C., A cker- T. Abb. 343. Blattscheiden und Blätter behaart; Rispe abstehend, aufrecht, bei der Fruchtreife chwas iiberhängend; Aehrchen linealisch-lanzettlich; Bliithen elliptisch-lanzeltich, die fruchttragenden am Rande dachziegelförmig sich deckend; untere Spelze Inervig, an Rande oberhalb der Nitte in einem stumpfen Winkel hervortretend, die obere ungefähr so lang als die untere; Granne gerade hervorgestreckt, fast von der Länge der Spelze, im trocke. nen Zustande bisweilen auswärts gebogen. $\odot$. Aecker, Ackerüunder. Fehlt bei IIalle ginz; auf Aeckern bei Namburg nicht gerade selten, auf Aeckern bei Lodersleben und Allstedt ziemlich hänfig, bei Eisleben zwischen Helfta und dem Walde und häufiger an Ackerjändern nach Helbra zu, bei Leimbach, Maunsfeld, Aschersleben und im ganzen nordwestlichen Gebiete häufig, im östlichen und nordöstlichen dagegen wieder fehlend. Juni. Juli. B. versicolor Poll. B. multiflorus W e ig. Höhe $1^{\prime}$ und darüber.

B. Bromi festucacei Bertol. Aehrchen auch nach der Blüthe nach der Spitze hin schmäler; untere Klappe 1-, obere 3nervig; obere Spelze am Rande sehr kurz - weichharig.

1321. B. asper II r r., rauhharige T. Abb. 357. Untere Blattscheiden nebst den Blättern kurz-steifhaarig, obere kahl; Rispe ästig, schlaff-iiberhänoend; Aeste der unteren Halbquirle zu $3-6$; Aehrchen linealisch-lanzettlich, spitz; untere Spelze aus sehr kurz2zähniger Suitze begrannt und länger als die Granne, 5nervig, die 2 mittleren Nerven schwach-ausgedrüclit, die obere Spelze am Rande fein-ueichhaarig-genvimpert. 4. Bergige Laubwälder stellenweise. Bei Halle selten, in Mittelholze, in den Wäldern bei Naumburg häufig, ebenso in Lodersleber Forste, bei Allstedt z. B. im 
Hagen, in der Hube unwejt Vingtstedt, bei Eisleben in Helftaer Holze, in Wäldern bei Freckleben unweit San. dersleben, bei Dessall und Oranienbaum. Juni. Juli. B. ramosus M urr. B. hirsutus C u l't. Höhe 2-4'.

Unterscheidet sich von dem B. serotinus Beneken durch die frühere Blïthezeit (an gleichen Standorten um 2 - 3 Wochen), durch die stärkere Behaarung der Blätter, durch die kahlen oberen Blattscheiden, durch die kleinere Rispe, deren untere Aeste genähert, zu 3-6 gestellt sind, ron welchen einige imner nur 1 Aehr. chen tragen und durch die längs den Șeitemnerven mit Wimperhaaren besetzten uberen Klappen, welche nach der spitze schmal zulaufen.

1322. Herótinus Beneken, (Botanische Zeit. Jahrg. 1845. S. 724), s pätb l üh en lle 'T. Unterte Blattscheiden lurz-steifhaarig, obcre ranhharrig, Rispe ästig, loclier, an der Spitze iiberliängend; Aeste der unteren Halbquirle $\approx u$ zueien, auseinanderfahrend; Aehrchen linealisch-lanzettlich, 5-9bliithig, schwarh glänzend; Klappen Kahl; Blüthen lanzettlich-linealisch, spitz; untere Spelze unter der zweizähnigen spitze begrannt, länger als die Granne, obere spelze am Rande sehr kurz-gewimpert; Staubleutel violett. 24. Bergige Laubwälder, Waldschluchten selten. Bei Naumburg im Buch. holze, Sperlingsholze, bei Bibra an buschigen Kalkbergen, bei Allstedt im Hagen und zwar im Thiergarten. Blüht Ende Juli und Aug. Höhe $4^{\prime}$ und darüber.

1323. Fis. erectus H u ds., a u frech te '1. Abb. 360. Wurzelbläter sehr schmal, am Rande gevimpert, Blatt. scheiden behaart oder kahl; Rispe nach allen Seiten oleichmässio ausgebreitet, aufrecht; untere Aeste zu $3-6^{\prime}$; Aehrchen linealisch-lanzettlich; Blïthen lanzettlich; untere Spelze an der Spitze sehr kurz-2zähnig, aus der schwachen Ausrandung begrannt und länger als die Granne, 5-7nervig, olere Spelze am Rande fein-weichhaarig-gewimpert. 24. Sonnige, besonders kalkige Ilügel, unbebaute Orte sehr zerstreut. Iuf und unter dem Vogelsberge bei Bennstedt, bei Naumburg auf dém Bürgergarten, an Kalkbergen bei Querfurt, Karsdorf und Burg Scheidungen, bei Allstedt im Hagen am Wege nach der Hagenecke, nach $\mathrm{Schwabe}$ an Kalkbergen bei Sandersleben und Bernbur. Juni. Juli. B. agrestis All. B. perennis Vill. Festuca montana $\mathbf{S}$ avi. Höhe 1-2'.

1324. B. inermis Leyss., (n. hal. ed. 1. p. 16 , 1761), grannenlose 'T. Abb. 335. 336. Blätter und 
Blattscheiden liahl; Rispe nach allen Seiten gleichmässi” ausgebreitet, aufrecht; untrre Aeste zu $3-6$; Aehr. chen linealisch-lanzettlich; Blütlien lanzettlich; untere Spelze an der Spitze sehr kurz 2zähnig, grannenlus uder ans der schwachen Iusrandung lurz-begrannt, 5-7nervig, obcre Spclic am Rande fein-neichliariggewimperl. 2. Wald- und Wiesenränder, Wege, Acker. raine häufig z. B. an Rande des Frenzelholzes bei l,ies kau, auf Wiesen unter dem Vogelsberye bei Bennstedt und in Chansseegräben und an Wegen bei Halle sehr häufig. Juni. Juli. Bromus inermis L. mant. alter. p. 186. 1771. Festuca inermis DC. F. speciosa S chreh. Höhe $1 / 2-3^{\prime}$.

c. Bromi genuini. Aehrihen nach der Spitze hin breiter; untere Klappe 1-, obere 3nervig; obere Spelze mit starren Borsten hanınförmig-gewinpert.

1325. H. stérilis $\mathrm{L}$., $\mathrm{t}$ a $u$ be R. Abb. 339. IIalm ganz kahl; Blätter usd Blattscheiden etwas behaart oder rauh; Rispe locker, zuletzt überhängend; Aeste verliingert, an der Spitze iiberhüngend; Aehrchen länglich, nach der Spilse hin breiter; Blüthen linealisch-pfrienlich; untere Spelze ans 2theiliger Spitze hegrant, Granne gerade, länger als die Spelze, ubere Spelz: kammförmig - gewimpert. $\odot$. Wege. Züune, Mauern, Schutt, Ackerraine häufig. Mai - Aug. Isange schön griin bleibend. Höhe $1 \frac{1}{2}=2^{\prime}$.

1326. R. tectorum L., Dach.R. Abb. 340. Halm obervärts weichharig; Blätter und Blattscheiden weichhanrig; Rispe-iiberliaingend, fast einseitswendig; Achrchen linealisch, zuletzt nach der Spitze hin ureiter; Blüthen lanzettlich-pfrienlich, untere Spelze ans 2 theiliger Spitze begrannt, Granue gerade su lang als die Spelze; obere spelze hamniörmig-gewimpert. $\odot$. Wegränder, besunders auf Dächeru und Lehmmauern in grosser Menge. Nai - Aug. Das Gras bald ausblühend und gell " werdend. Höhe meist 1'. Aendert mit kahlen Aehrchell und fast kahlen Halmen ab. Die Blätter und Blattscheiden siud jedoch meist stärker und weicher behaart, als bei der vorigen Art.

13. Gruppe. Il ordeaceen Kuntli. Gerstenartige Gräser. Aelireben 2 - vielblüthig, un den Aussclinitten der Spindel sitzend; Blüthensticlchen fehlend; die endständige Blüllie oft rerliümment; Griffel sehr kurz oder fehlend; Narben federis, aus ılem Grunde der Blüthen hervortretend. 
497. Tríticum L. W e izen (Pflanzennane bei Plinius, eigentlich Dreschfrucht bedeutend, von triturare, dreschen).

A. Cerealia. Getreide. Aehrchen mehr oder weniger bauchig-gedunsen; Klappen eiförmig oder länglich.

1327. T. vulgare vill., gemeiner W. Aehre 4scitig, dachziegelföı'nig; Blïthenspindel zälıe; Aehr. chen meist 4bliithig; Klappen bauchig, eiförmig, abgestutzt, stachelspitzig, unter der Spitze zusammengcdriickt, auf dem Rücken abgerundet-gewölbt, mit einer wenig hervortretenden stumpfen Rückenkante; Früchte frei. $\odot$ und $\odot$.) Ueberall auf Aeckern gebaut. Juni. Juli. Aendert ab :

a) aestivun L. Sommerweizen: Aehre lang begramnt, kahl oder sanınietartig-weichhaarig, bei der Reife gelblich weiss, brüulich oder schwarz.

b) hibernum L., Winterweizen: Aehre grannenlos, kahl oder sammetartig-weichharig, bei der Reife gelblich- "eiss oder bräunlich.

B. Agropyrum. Aehrchen nicht bauchig-gedunsen; Klappen lan ettlich; oder linealisch-länglich, an der spitze gerade und nicht auswärtsgebogen.

1328. T. repens L., Quecken-W. Abb. 256-261. Wurzel kriechend: Blïtter oberseits von spitzen, einzelnen Piinktchen mehr oder weniger rauh; Aehre 2zeilig: Aehrchen meist 5blüthig; Klappen lanzettlich, 5nervig, zugespitzt; Blüthen zugespitzt oder stumpflich, grannenlus uder begrannt; Bliithenspindel meist buh. 24. Felder, Zäıne, Wege, Grasplätze überall gemein. Juni. suli. Höhe 2- $4^{\prime}$. OFF. radix graminis. Aendert mit spitzen und stumpfen, begrannten und grannenlosen Bliithen und mit grasgriinen und meergriunen Blättern ab.

1329. T. caninum sheb., Hunds-W. Abb. 254. Wurzel faserig; Blätter beiderseits rauh; tehre 2zeilig; Aehrchen meist 5blüthig; Klappen lanzettlich, 4-7nervig, zugespitzt; Blüthen zugespitzt, begrannt, Granne länger als die Bliithe; Blüthenspindel fein borstenförnig-rauh. 24. Waldründer, Gebüsche, Zäune, Bäche nicht selten z. B. im Gebüsch an Schwalchloche hinter Kröllwitz, bei Gutenberg, im Hagen bei Esperstedt u, s. w. Juni. Juli. Elymus caninus L. Höhe $3-5^{\prime \prime}$. 
498. Secríle T. Rog gr e n (Pflanzenname bei Plinius, von secare, schneiden, weil der Roggen in suidlichen Gegenden gewöhnlich ror der Reife als Viehfutter geschnitten wird).

1330. S. cereále L., gemeiner R. A ehre zur Fruchtzeit riemlich 4seitig; Klappen sehr schmal, hïutig, pfriemlich, kürzer als die Blïthen; Blüthen aus der Spitze lang begrannt; Blïthenspindel zähe. $\odot$ und (.). Wird uberall gebaut. Mai. Juni.

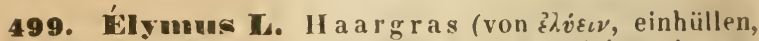
bei Dioscorides Panicum italicum I. bezeichnend, wegen seiner in Grauneu eingehüllten Körner).

1331. E. europaeus L., e uropä ischer H. Abb. 246. Blätter flach, kahl; Blattscheiden behaart; Aehre aufrecht; Aehrchen 2blüthig "der 1blüthig mit dem Ansatze zu einer zweiten Bliithe, in der Nitte der Aehre zu 3; Klappen gerade, limealisch-pfriemlich, begrannt: untere Spelze lauh, begrannt, die Granne 2 mal länger als die spelze. 2. Laubw älder sehr selten, nur in schattigen Wäldern bei Naumburg zwischen der Kuhlenstrasse und dem Murdthale und früher einmal von W a IIr. in bergigen Buchenwäldern bei Wendelstein gefunden. Juni. Juli. 'Triticum silvaticum Salis b. Hordeum muntanum Schrank. Höhe $2-5^{\prime}$.

500. IIónodeum K. Gerste (Pfanzenname bei Plinius, von horrere, starren, wegen der straffen Gramen).

1. Ilordea sativa. Gebaute Gerste. Blüthen sämmtlich zwitterig oder die seitenstäudigen männlich und diese inmer granuenlus.

1332. H. vulgare L., g e m e ine G. Aehrchen sämmtlich zwitterig, Iruchtbar, begrannt, die fruchttragenden 6reihig geordnct, 2 Reihen auf beiden Seiten mehr hervorspringend. $\odot$ und $\odot$. Auf Aeckern gebaut. Juni. Juli.

1333. H. distichum L., z w eizeilige G. Aehre 2zeilig; scitliche Achrchen ron den zu 3 beisammen stehenden Aehrchen männlich, unfiuchtbar, grannenlos, das miltlere Achrchen zwitterig, fruchtbar, mit auf: rechter, langer Granne; Granne der Klappen von der Länge der Aehrchen. $\odot$. Wird überall gebaut. Juni. Juli. 
B. Hordea murına. Măus egerste. Die seitenständigen Blüthen männlich oder geschlechtslos; alle begrannt.

1334. H. murínum L., M äus e gerste. Abb. 249. Halm meist nur wenig uber die oberste, etwas gedunsene Blattscheide vorragend; Aehrchen alle begrannt; Klappen des mittleren Aehrchens linealisch-lanzettlich, bevvimpert, die der seitenständigen Aehrchen borstenförmig, rauh, die nach innen befindlichen auf der einen Seite bewimpert. $\odot$ Wege, Mauern, Schutt überall gemein. Juli. Aug. Höhe $1 / 2-1^{\prime}$.

1335. H. secálinum s chreb., roggenartige G. Abb. 251. Halm weit über die oberste, anliegende Blattscheide rorragend: iehrchen alle begrannt, Klap. pen aller Aehrchen borstenförmig und rauh. 24. Wiesen stellenweise. Bei Halle nicht selten z. B. schon auf der Würfelwiese am Fürstenthale, auf Wiesen zwischen Pfitzenburg und Wansleben, auf Wiesen bei Dieskau häufig, auf der Wiese zwischen Corbetha und der Chaussee, bei Schkopau und in der Aue überhaupt häufig, ebenso bei Kl. Dölzig und anı Bienitz, bei Naumburg in der Ane und bei Gross-Jena, auf den Wiesen unter der Steinklippe bei Wendelstein, bei Dessau und Oranienbaum. Juni. Juli. H. pratense Huds. H. nodosum M. B. und der meisten Autoren, aber wahrscheinlich nicht Lin. Höhe $1 \frac{1}{2}-3^{\prime}$.

Unterscheidet sich von der vorhergehenden Art ausser den angegebenen Merkmalen durch die kleineren Aehren und die un die Hälfte kürzeren Grannen.

501. Tólium L. Lolch (Pflanzenname bei Virgil; der deutsche Name ist das verdorbene lateinische Wort).

1336. L. perenne L., a us d a u e rnd e r I. Abb. 235. Wurzel etwas zusammengedriicht, bliihende Halme und nichtbliihende Blätterbiischel treibend, die jungen Blätter einfach-zusammengefaltet; A ehrchen länger als die Klappe: Blïthen lanzettlich, unbegranut oder kurz - stachelspitzig. 24. Wiesen, 'Triften, Wegränder überall gemein. Juni - Herbst. Höhe $1-3{ }^{\prime}$. Aendert mit 7 yblüthigen und mit nur 3-4blithigen Aehrchen ab; zu der letzteren Form gehört L. tenue L. nach $\mathbf{S}$ m. Die Abart I. festucaceum Link hat der Verfasser noch nicht in Gebiete beobachtet.

1337. L. linícola Sond., leinliebender $I$. 
1hb. 226-223. Vichlbliihende Bliillerbiischel fehlend; Halm steif - aufrecht, stielrund; Klappe fast so lang oder hiir:zer als das Aelirclien; Aehrchen länglich wle eiförmig; Blüthen kurz-begrannt oder unbegrannt, bei ter Fruchtreife elliptisch. $\odot$. Auf Aecheru nur unter dem Lein und daher selten. Juni. Juli. I. arvense Schrad. und der meisten Autoren, aber nirht Wither., welches Gras eine Abart von I. temulentum ist. Höhe $1-2$ '.

1338. L. temulentum L., 'T' a $u \mathrm{mel}$. L. Abb. 231 233. Vichubliihende Bliitterbiischel fehlend; Halm steif anfrecht; Klappen läinger als das Achrchen; Aehrchen länglich; Blütlıen kïrzer - odes läıger-begranut, bei der Fruchtrcife clliptisch. $\odot$. Auf Aeckern unter der Saat meist nicht selten. Juni. Juli. Höhe $2-3^{\prime}$. Ist das einzige bekannte narkotisch "irkende Gras.

14. Gruppe. Nardoideen. Borstengrasartige Gräser. Aehrchen in den Aushöhlungen einer Aehrenspindel sitzend; Tarben fadenförmig, weichhaarig, aus der Spitze der Blüthe heraustretend.

502. Nardus I. B orstengras (Nardus war eine im Alterthume berïhmte, schon in Hohenliede 11, 13.14. unter diesem Namen erwahnte, wohlriechende, gewürzhafte Giaswirzel, welche nach I,nureiro wirklich von Nardus indica I. kam).

1339. N. stricta L., steifes B. Abb. 450 . Wurzel einen dichten Rasen unfruchtbare. Blätterhüschel und blühende lialme treibend; Blätter burstenförnig, zusammengerullt; Halme dï̈n, burstenförmiğ; Aphre einseitig, Aehrehen 1 blüthig, pfriemlich; Klappen fehlend; Griffel 1. 24. Mourige, turfige Wiesen, sandige, feuchte 'Triften stellenweise. Bei Halle zwischen liröllwitz und cer Dölater Heide häufig, auf sumpfinen Wiesen am Bienitz, bei Naumburg selten, auf sandigen, feuchten Triften bei Bibra häufig, bei Allstedt auf der Wüste an dell Iannen, an unfruchtbarell Bergen zwischen dem Rödge" und Greifenhagen nördlich von Mannsfeld, bei Dessau häıfig, an der Benndorfer Mühle häufig. Mai. Juni. Höhe $1 / 2-1^{\prime}$. 


$$
\text { Peg is ter. }
$$

Alle Zahlen beziehen sich auf die Seiten. Die erste Zahl hinter den Gattungs - und Familiennamen zeigt die Seite der Anorinung der Gattungen und der tabellarischen Vebersicht der Familien an. Die Jamen ohue Stern sind Synonyma.

Abbiss 224.

Abies excrlsa Poir. 428.

Alsinthimm rulgare $\mathrm{G}$ ä r tn. 240.

Acerineen D C. 92.88 . Acer L. 3s. 88.

* campestre L. 88.

* platanuides I. 88 .

* Pseudoplatanus L. 88.

Aceras anthropophora R. B r. 451 .

Ichillea 1.69. 243.

- Millefolium L. 243.

* nobilis L. 244.

* Ptarmica L. 243. setacea II. K. 244.

I chyrophurus Scop. 63.278.

* maculatus Scup. 278. radicatus S S c p. 278.

Acinus thymoides M c h. 359. Aconitum L. 47. 17.

Bernhardianum Wallr. 17.

Canimarum Jaeq. 17.

* Lycoctunum L. 17. Thelyphonum R e h b. 18. + variegatum L. 17. A c orus L. 37.440.

* Calanus L. 440. A cta ea I. 47.18. * spicata L. 18. Adunis I. 48. 7. * aestivalis L. 7. anomala Wallr. 8.

* autumnalis I. 7.
Adonis flammea Jac q. 8 . miniata J a c q. 8 .

* vernalis I. 8.

Ad oxa L. 40. 209.

* Moschatellina L. 209.

A e gupodium L. 26.184.

* Podagraria L. 184.

Aesculus L. siehe Ésculus.

A thusa L. 28. 190.

* Cynapiun I. 190.

Agatophytum Bonus Henricus Mo q. 'T'and. 394.

A grimonia L. 44. 148.

* Eupatoria L. 148.

* odorata Ait. 148. procera Wallr. 148.

Igrostem ma L. 43.67.

* Githago L. 67.

Agrostis I. 14.518. alba Schrad. 519. arundinacea I. 521 .

* canina L. 519. capillaris Pollich. 519. hispida Willd. 518. Spica venti L. 520.

* stolonifera L. var. $\beta .519$. stolonifera Pullich. 518.

* vulgaris Wither. 518. Ahorn 88.

A i r a L. 15. 524. aquatica L. 538. canescens L. 525. caryophyllea L. 530.

* cespitosa L. 524 . coerulea L. 538. 
Aira cristata L. Spec. pl. 524.

* flexuosa L. 525. praecux L. 530 .

A jug a L. 50. 374. alpina L. mant. 374 .

* Chamaepitys s chreh. 375.

* genevensis I. 374 . montana $R \mathrm{chb} .374$.

* pyramidalis L. 375 .

* reptans L. 374.

Albersia Blitum Kunth 388.

Al chemilla J. 18.154. Aphanes Leers 15.5 .

* arvensis S cop. 155. montana Willd. 155.

* vulgaris L. 154.

Alectoroluphus Hall. 53. 351 .

grandiflorus Wallr. 351. hirsutus All. R chb. 351 .

* major Rehb. 351 .

* minor W im m. u. G rab 351.

parvillorus Wallr. 351. Alismaceen Juss. 118. 429.

A I i s m a J. 3๙. 429 . natans Pollich. 430.

* Plantago L. 429.

Alliaria officinalis Andrz. 34.

A $11 \mathrm{inm} \mathrm{L.} \mathrm{36.} 469$.

* acutangulum s chrad. 470.

angulosum J ac q. 470 . angulosum Pollich.

470.

arenarium 1. 473. arenariun S m. 473.

* Ascalonicurir L. 474. calcareum M ert. und K n ch $\mathbf{4 7 0}$. carinatum Poll. 471.

* Cepa L. 474.
Allimm fallax Do n. $\mathbf{4 7 0}$.

* fistulosum 1. 474 . montanum Schmidt 47() .

* oleraceum L. 470.

* Ophioscurudon Don. 472.

* Purrum I. 472. reticulatum Pres I. 471.

* rotundum L. 472.

* satirum L. 471.

* Schoenoprasum I. 473.

* Scorodoprasum L. 473.

* sphaerocephalun L. 472.

* strictum s ch l'a d. 471 . suaveolens Gaud. $\mathbf{4 7 1}$.

* ursinum L. 469.

* vineale L. 473. volhynicum 13 ess. 471. A Inus 'lournef. 73.427. * glutinosa Gärtn. 427.

A l o pecurus L. 13. 515.

* agrestis L. 516.

* fulvus S m. 516.

* geniculatus L. 516 .

* nigricans H or n e m. 516. paludosus P. B. 517.

* pratensis L. 515. repens M. B. 516.

Alsineen D C. 86.68 .

A Is ine Wahlenbg. 42.71 . cespitusa $\mathrm{Ehrh}$. 71 . marginata schreb. 70 . media I. 74.

* tenuifolia WhJbg. 72.

* verna Bartl. 71.

Al th a e a L. 58.84.

* officinalis $\mathrm{L}$. 84 .

Alyssum I.. 55.40.

* calycinum ${ }^{\circ}$. 41 . campestre Leyss. Spr. 41. incanum L. 41.

* nontanum L. 40.

Amarantaceen J u s s. 115. 388. 
A un a r antus L. 74. 388. ardscendens $L_{0}$ is 1.388 .

* Blitum L. 358.

* vetroflexus L. 389. spicatus L a m. 389. viridis $\mathrm{Polli} \mathrm{ch} .388$. Amaryllideen R. Br. 121. 460 .

Anıbusiaceen L, k. 101. 295. Ampelideen $\mathrm{H}$ b. $\mathrm{B}$ p I. K th. 93. 89.

Ampelopsis Michaux 23. 89.

* hederacea M chx. 89. Ampfer 398.

Amygdaleen Jus s. 87. 132. Anygdalus Persica L. 132. Anacamptis Rich. 70 . 447.

* pyramidalis Rich. 447. All agallis I. 21.381.

* arvensis $\mathrm{L}$. 381 . coerulea S chiceb. 382. phuenicea La n. 382.

A n c husa L. 20.317. arvensis MI. B. 317.

* officinalis L. 317 . Andorn 369 .

Andropogon L. 12.512. angustifulius $\mathrm{S}$ m. $\mathbf{5 1 2}$.

* Ischaemum L. 512.

Androsace L. 20.382.

* elongata L. 382 .

Anem one L. 48. 5.

* Hepatica L. 5.

* nenorosa L. 7.

* pratensis I. 6 .

- Pulsatilla L. 5.

* ranunculoides L. 7.

* silvestris I. 6.

* verualis L. 6 .

Anethum L. Hoff m. '30. 198.

Foeniculum I. 191.

* graveolens L. 198.

Angelica L. 28. 194.
Angelica Carvifolia Spr. 194.

pratensis M. 13. 194.

* silvestris L. 194.

Anisum vulgare G är tn. 186 . Antennaria dioica D C. Gärtn. 239.

Anthemis L. 69.244.

agrestis Wa 11 r. 245.

* arrensis L. 245. arvensis Wallr. 245.

* Cotula L. 245. nobilis L. 246.

* tinctoria L. 244.

A nthericum L. 36.464.

* Liliago 1. 464. calyculatum rar. «. I. 476.

* ramosun 464.

Anthoxanthum L. 13. 515.

* odoratum L. 515.

Anthriscus $H$ of $\mathrm{fm}$. 31 . 203.

* Cerefoliun H of f m. 204.

* silvestris $\mathrm{H}$ o f f m. 203.

* vulgaris P ers. 204.

Anthyllis L. 60. 102.

* Vuineraria L. 102.

Antirrhineen Jus s. 106.321.

An tirrhinum L. 53. 332. arvense $九$. L. 335.

Cymbalaria L. 333.

Elatine L. 334.

Linaria L. 335.

- majus I. 332. minus L. 334.

* Orontium L. 333. spurium L. 334.

Aparyia alutumnalis Willd. 272.

Apera Adans. P. B. 14. 520.

* Spica venti P. B. 520. Aphanes arvensis I. 155. A pium L. 26. 182. 
Apiun graveolens L. 182. Apricyneen R.B r. 110.308. Aprikose 132.

Iquilegia I. 47. 16.

* vulgaris L. 16.

A rabis I. 57. 28.

* auriculata L, a m. ^29.

- brassicaeformis Wallr. 28.

* Halleri I. 30.

* hirsuta S c up. 29. patula Wallr. 29.

Thaliana I. 34.

Araliaceell J uss. 98. 207.

Arctium Bardana Willd. 264.

Liappa L. 264.

minus s shk. 264.

tumentosum S c h k. :264.

Arenalia I. 42.72. marina Roth 71 . media L. 71. rubra var. L. 70.

* serpyllifulia L. 72. trinervia I. 72.

Aristolochieen Juss. 111. 410.

Aristolochia J. 72.410.

* Clematilis I. 410.

Armeria Willd. 386.

* vulgaris Willd. 386 .

A'moracia rusticana Fl.

Wett. 42.

Arnica J. 68.248.

+ montana L. 248.

Arnoseris Gtn. 65. $2700^{\circ}$ * pusilla Gärtn. 270.

Aruideen Jus s. 123.439.

Aron 439.

Arrhenatherum P. B.

15. 526 .

arenaceun P. B. 526.

* elatius M. Ko ch 526.

Artemisia L. 68. 239.

* Absinthirm L. 240.

* campestris I. 241.
Artemisia laciniata Willd. 240.

* maritima L. 242.

Nertellsiana Wa II r. 241.

* pontica I. 241 .

* rupestris I.. 240. salina Willd. 242. sericea Fries 242.

* vulgaris L. 242.

Aru ni L. 72. $43 \%$.

* maculatum I. 439.

Arundo Calamagrostis $\mathrm{L}$. 520.

montana G a ॥ d. 521 .

Phragmites I. 523. varia Schral. 521.

As a r III I. 43.411 .

* europaeun l. 411 .

Asclepiadeen R. Br. 110.3117.

Asclepias Vincetwxicum I. 308.

Asparageen J uss. 122. 461. As paragus L. 36.461 .

* officinalis L. 461 .

Asperugo L. 19. 314.

* procumbens I. 314.

Asperula L. 18. 212.

* cynanchica L. 212.

* galioides M. B. 213.

* udurata L. 212.

* tillctoria 1. 212.

Astel. L. 67. 228.

* Amellis L. 228. annuirs I. 230.

* Leucanthemus De sf. 229. pannonicus Jacq. 229.

* salicifulius Scholl 229.

* salignus Willd. 229.

* 'Íripolium I. 228.

Astränze 181.

Astragalus J.6 60.117.

* Cicer. L. 117. danicus Retz. 117.

* exscapus L. 118.

* glycyphyllus L. 117. 
Astragalus Hypoglottis I. 117.

microphyllus IV illd. 117. pilosus L. 116.

Astrantia L. 26. 181.

* major L. 181.

Athamanta Cervaria L. 196. Libanotis I. 192. Oreoselinum I. 196.

Atriplex L. 74. 395. acuminata W. K. 396. angustifolia Sm ith 397 . campestris $\mathrm{Koch}$ und Z i z 396. erecta $\mathrm{Smith} 397$. hastata Pollch. Schk. 397.

* hortensis I. 395.

* laciniata L. 397.

* latifulia Wahlenbg. 397.

* nitens Rebent 396 . ublongifolia II. K. 396.

* patula L. 397. patula Pollich. 397.

pedunculata L. 395 .

* rosea I. 398.

* tatarica L. 396. tatarica Schk. 396.

Itrupa L. 22. 326.

* Belladonna L. 326.

Augentrost 352.

Aurikel 289.

Avena L. 15. 527.

* caryophyllealli g g. 529 . dubia Leers 529. elatior L. 526.

* fatua L. 527 .

* flavescens L. 529.

- hybrida Peterm. 528.

* vientalis Schreb. 527.

* praecox P. B. 530.

* pratensis I. 528.

* pubescens L. 528 .
Avena sativa L. 52\%.

* strigosa Schreb. 527.

* tenuis M önch 529. triaristata Vill. 529.

ERachburgel 168.

Bärenklau 198.

Bärenschote 117.

Baldgreis 249.

Baldingera ar undinacea R ch b. 515.

Baldrian 219.

Ballota L. 50. 370 .

borealis Schweigg. 370.

fuetila I, am. 370.

* nigra 370. ruderalis Fries 370 . vulgaris Link 371 . Balsamineen A. Ri ch.91.96. Ba rb a ra e R. Br. 57. 27.

* arcuata Rchb. 27.

* stricta Andrz. 28.

* vulgaris R. B r. 27.

Bartgras 512.

Bartsia Odontites Snith 353.

Bauernsenf 45.

Beifuss 239.

Belli s L. 68. 230.

* perennis L. 230.

Berberideen V'ent. 81. 18.

B e r beris L. 35. 18.

* vulgaris L. 18.

Berberize 18.

Berteroa incana D) C. 41.

Berula Koch 27. 186.

* angustifolia Ko ch 186 . Bessera azurea schult. 320.

Beta I. 25. 394.

* vulgaris I. 394 .

Betonica L. 51. 368. hirta Leyss. 368 .

* officinalis I. 368 . stricta Ait. 368 . 
Betonie 368.

Betula L. 76.426. alba L. 426 .

* odorata B echst. 426 . pubescens Eihrh. $\mathbf{4 2 6}$.

* verrucosa Eh I.h. 426 .

Betulineen Rich. 116.426. Biberklee 308.

Bibernelle 155.

B i d e 11 s I. 69. 235.

* cernua L. 236. minima I. 236.

* tripartita I. 235.

Biensauge 361 .

Bilsenkiaut 327.

Bingelkraut 414.

Binse 476 .

Birke 426 .

Bisanihyacinthe $\mathbf{4 7 4}$.

Bisankraut 209.

$\mathrm{Hiscute} I \mathrm{I}$ L L. 54. 45.

* laevigata L. 45.

Bitterich 273.

Blasenstrauch 116.

B I i t u m I. 25.393.

* Bonus Henricus C. A. M e yer 393.

* glaucum Koch 394 .

* rubrum Rchb. 394.

* virgatum L. 393.

Blumenkohl 37.

Blutauge 143.

Blysmus compressus $\mathrm{Pan}$. z e r 490.

rufus Link 490.

Bockshorn 105.

Borage 316 .

Boragineen D e s v. 103.314.

B or ago L. 19.316.

* officinalis L. 316.

Borstengras 552.

B rachypodium P. B. 16. 542.

* pinnatum P. B. 543.

* silvaticum Roem. und Schult. 543.
Brassica I. 57.36 . alpina L. $_{2} 29$. campestris I. 38.

* Napus L. 38.

* nigrir Ko ch 39.

* oleracea I. 36. orientalis L. 36.

* Rapa I. 38.

Braunkohl 37.

Braumw urz 331.

Brennsaat 192.

Brignule 134.

Brillenschote 45 .

Briza L. 16.531 .

* media L. 531.

Bronibeere 138.

Bromus L. 16.543. agrestis All. 547 . arundinaceus Roth $\mathbf{5} 42$.

* arvensis I. 546.

* asper Murr 546.

* brachystachys Horn 11 n 545 .

* commutatus Schrad. 544 .

elatior $\mathrm{K} 0 \mathrm{e}$ l. 542.

* erectus Huds. 547. gigauteus L.. 542 . glomeratus Scop. 539. gracilis 11 e igel 543. hirsutus C u r t. 547.

* inermis Leys s. 548.

* mollis L. 545 . multiflorus Roth $\mathbf{5 4 5}$. multiflurus We i g. 546. perennis $V^{\top} i l l .547$. pratensis Ehrh. $\mathbf{5 4 5}$.

* racemosus L. 544. ramosus M urr. 547.

* secalinus L. 543.

* serotinus Ben ek en 547.

* sterilis L. 548 .

* tectorum 1. 548. triflorus Eh rh. 542.

* versicolor Pollich 546 . 
Brunelle 373.

Brunnenkresse 25.

Brustwurz 194.

Bryonia I. 76. 169.

* alba L. 169. divica L. 170.

Buffbohne 124.

Bunge 384.

Bupleurum L. 26. 187.

* falcatum L. 188. junceum 187.

* longifolium L. 188. perfoliatum L a m.- 189.

* rotundifolium I. 159.

* tenuissimum L. $18 \%$.

Butomeen Rich. 118. 430.

B ut o mus L. 40.430 .

* umbellatus 430 .

Calamagrostis Roth 14. 520 .

acutiflora D C. 521. arundinacea $I_{\text {A. }} 521$.

* epigeios Roth 520 .

* lanceulata lioth $\mathbf{5 2 0 .}$

* montana Hust 521. pyramidalis Host 521 . ramosa $H_{0}$ s t 520 .

* silvatica DC. 521. stricta S preng. 521.

Calamintha Mönch 52 . 359.

* Acinos Cla irv. 359 . hederacea Scop. 361 .

Cal endula \&. 70. 255.

* arvensis L. 255.

* ufficinalis L. 255.

$\mathrm{C}$ all a I. 72. 439.

* palustris L. 439.

Callitricheen L.k. 112. 166. Callitriche 1. 72.166.

* hamulata K ütz. 167.

* platycarpa Kütz. 166 .

* stagnalis Scop. 166.

* vernalis Kütz. 166.

Callun a Salis b. 39. 302.
Calluna vulgaris Salis b. 302.

Calt ha I. 48.15.

$\therefore$ palustris L. 15.

Camelina Crantz 55. 42.

* dentata Pers. 43. microcarpa Andrz. 43.

* sativa Crantz 42.

Campanulaceen Jus s. 99. 296.

C a mpanula L. 22. 297.

* bononiensis L. 298:

Cervicaria L. 300.

* glomerata L. 300.

* patula L. 299.

* persicifolia L. 299.

* rapunculoides L. 298.

* Rapunculus L. 299.

* rotundifolia L. 297. ruthenica M. B. 298.

* Thaliana Wallr. 298.

* Trachelium L. 298.

$\mathrm{C}$ a nn abis L. 77. 416.

* sativa L. 416.

Caprifoliaceen Juss. 102. 208.

Capsella Med. 55. 47.

* Bursa pastoris M c h. 47 .

* procumbens Fries 48.

Card a mo ine L. 56. 30 .

* anara $\mathrm{L}$. 31.

* inpatiens L. 30.

* pratensis L. 31.

* silvatica l,k. 30 .

Cardaria Draba Desv. 46. Carduus L. 66. 262. acanthifolius $\mathrm{I}$, a m. 258.

* acanthoide's' L. 262.

* crispus I. 262. crispus Huds. 262. eriophorus I. 257. lanceolatus L. 256.

* nutans L. 263. palustris L. 257. polyacanthos schreb. 
Carduns tuberusus l'oll. 258.

tuberosus var. $\beta$. I. 258.

Carex L. 73. 491.

acuta L. 500.

acuta var. nigra L. 500. acuta $\beta$. ruffia L. 500 .

* ampullacea G o od. 509.

* arenaria I. 494 . arenaria $J$, e e r's 494. axillaris Good. 498 .

* Brizoides I. 497.

* Buxbaunii Wh lbg. 501. canescens I. 499. canescens L e ers 495. capillaris $\mathrm{J}_{1}$ e e is 509.

* cespitusa Go od. 500. ciliata Willd. 503. rinerea Pollich 499. clandestina Good. 504. collina Willd. 503. contigua $\mathrm{Hop}$ o e 495. crassa Ehrh. 510. curta Good. 499.

* Davalliana S m. 492. decumbens Ehrh. 502. diandra Roth 495 .

* digitata L. 504.

* distans L. 5118.

* disticha Huds. 494.

* divica I. 491.

Drejeri O. F. J,ang. 500.

Drymeia Ehrh. 509. echinata Murray 498.

* elongata I. 498. elongata Jeers 499.

* ericetorum Poll. 503.

* filiforńis L. 510 . filiformis Leers 503 . flacca S chreb. 506.

* flara L. 506.

* fulva Good. 50 \%

* glanca S cop. 505. gracilis $\mathrm{Cu} \mathrm{r}^{\circ} \mathrm{t} .500$.

* hirta L. 511.
Cares humblis Leyss. jo4. inflata $\mathrm{H}$ u ils. 510. intermedia Good. 494. lasiocarpa Ehrh. 511.

* lepurina L. 498.

limosa L. 501.

Linnaeana $\mathrm{H}$ ost 492. Jongifolia Hos t 504 .

* montana I. 502. montana P') 11. 503. multiculmis Eh $\mathrm{I}^{\circ} \mathrm{h} .499$.

* muricata L. 495.

muricata Poll. 498. neglecta Pe term. 500 . obtusangula Eh rh. jug.

* obtusata L/ jb. 492.

* Oederi Ehrh. 507.

* ornithopoda 11 illd. 505. ovalis Guod. 498 . pacifica D r ej. 500.

* pallescens L. 506.

* paludusa Guod. 510.

* panicea I. 505.

* paniculata L. 495. paniculata $\beta$. Poll. 495.

* paraluxa ll illa 496 .

* pilulifera L. 502.

polygama s chk. 501.

* polyrrhiza IV allr. 504.

* praecox Jacq. 503.

praecox Schreb. 497 .

* Pseuilo-Cyperus I. 509.

psyllophora L. 492 .

* pulicaris L. 492 . recurva Huds. 506.

* remuta J. 497.

* riparia Curt. 510.

* Schreberi Schrk. 496.

* silratica $\mathbf{~ I l ~ u ~ d ~ s . ~} \mathbf{5 0 8}$. sphaerocarpa E h r h. 502 . spicata $\mathrm{Huds}$. 495. spicata Schkuhr 493. splendida Willd. 511.

* stellulata Go od. 498 . stolonifera Ehrh. 503. 
Carex stricta Goo d. 499. subulata Schumach. 501.

* supina IV a h len b. 501.

* teretinscula Good. 495 .

* turientosa L. 502. uliginosa L. 490 . umbrosa Hop pe 504. resicaria $\mathrm{Huds}$ s. 509.

* vesicaria 1. 509. vesicaria $\beta$. L. 509.

* vulgaris Fries 500.

* vulpina L. 494.

C a l lina 1. 66.265.

* acaulis 1. 265. alpina $J$ a c $q .265$. caulescens Lam. 265. subacaulis DC. 265 .

* vulgaris L. 265.

C. arpinus L. 75.420.

* Betulus I. 420.

C a ru m L. 27.184.

* Carvi L. 184.

Castanea vulgaris La m. 419. Catabrosa aquatica P. I3. 53 s.

Cathartulinum pratense Rehb. 81).

C a calis $\mathrm{H}$ of $\mathrm{fm} .30 .201$.

* daucoides I. 201. helvetica $J$ a c q. 203. latifolia L. 202.

Caulinia fragilis $\mathrm{Will}$. 436.

Celastrincen R. B r. 93. 99.

Centaure al l. 09, 266.

* Calcitrapar L. 269.

* Cyanus L. 268.

* Jacea I. 267.

* maculosa La nı. 268. montana L. 269. paniculata Ja c q. 269.

* phrygia L. 267.

* Scabiosa I. 268.

* solstitialis L. 269.

Centunculus I. 17. 382.

Gareke, Flora.
Centunculus minimusI.362. Cephalanthera Rich. 71: 451 .

* ensifulia Rich. 452.

* pallens $\mathrm{Ri} \mathrm{ch.} 451$.

* rubra Rich. 452.

Cerastium I. 43.76.

aquaticum L. 76 .

* arvense I. ig.

* brachypetalum D e s p.77.

* glomeratum '1 h u i l 1:76.

* glutinosum Fries 78. ovale Pers. 76. pellucidum Cha $\mathrm{Cb}$. $7 \%$. pumilum M. K. 78.

* semidecandrum 1. 77. semidecandrum Pers. 78.

strigusum Fuies 77.

* triviale Link 78 . viscidun Link 77. viscosum Fies 77. viscosum Pers. 77. viscosum Poll. 77. vulgatum $\mathrm{I}$. $\mathrm{s} \mathrm{m} .76$. rulgatum Wahlenbg. 79.

Ceratophylleen Gray 115. 167.

Ceratophy 11 um I. 74. 167.

* demersunir I. 167.

* submersum L. 167.

Cerefolium sativum B ess. 204.

Cha erophyllum l. 31 . 204.

* bulligsum I. 205.

* hirsutum I. 205. silvestre L. 204.

* teniulum L. 205.

Chaiturus Host 51.371. * Marrubiastrum Rehb. 371.

Chamanerion obscurun Schreb. 162. 
Cheiranthus DC. 57.25.

* Cheiri I. 25. silvestris $\mathrm{L}$ a m. 34 .

Chelidonium J. 46. 22. corniculatum L. 22.

Glaucium L. 21. laciniatum Mill. 22.

* majus L. 22.

Chemopodeen Vent. 114. 389.

Chenopodium L. 25. 391.

* album I. 392. Bonus Henricus 394.

* ficifolium S m. 392 . foetidum Lam. 393.

* hybridum L. 391. melanospermum IV allr. 391.

* murale I. 391.

* olidum C u rt 393.

* opulifolinm Schrad. 392.

* polysuernum L. 392. rhombifulium M üh . le $\mathrm{n}$ l. 391.

* urbicum L. 391. Vulvaria L. 393.

Chilochloa Boehmeri P.B. 517.

Chimaphila umbellata Nutt. 305.

Chironia Gerardi S $\mathrm{ch}$ m i d t 312.

Chondrilla I. 64.280. * juncea I. 280. rigens $R$ ch b. 280.

Christinclienkraut 234.

Christophskraut 18.

Chrysanthe mum L. 69. 246.

* corymbosum I. 247.

* inodorum L. 248.

* Leucanthemum L. 246.

* Parthenium Pers. 247.

* segetunı I. 248.
Chrysocoma Linosyris I. 228.

Chrysosplenium I. 39. 179.

* alternifolium L. 179.

* oppositifolium L. 179.

Cicerbita nuralis Wallr.282.

Cichori um, L. 64. 271. Endivia J. 271.

* Intybus L. 271.

Cicuta L.27. 182.

* virosa L. 182.

Cineraria campestris $R$ e $\mathbf{t z}$. 250.

integrifolia W a 11 r. 249. palustris I.. 250. spathulaefolia Gmel.249.

C i r c a e a I. 8. 163.

* alpina I. 163. interniedia Ehrh. 164.

* Iitetiána L. 163.

Cirsium Tournef. 66. 256.

* acaule All. 258.

* arvense Scop. 259.

* bulboso-acaule Naeg. 261.

* bulboso - oleraceum

Na e g. 259.

* bulbosum D C. 258. caulescens Pers. 258. Chailleti Gaud. 257.

* eriophorum Sc op. 256. Kocheanum I, öh 262.

* lanceulatum Scu p. 256. mediun All. 261.

* oleraceo-acaule $\mathbf{N}$ a e g. 260.

* oleraceo - bulbosum

Na eg. 260.

* oleraceum Scop. 257.

* palustre Sc op. 257.

* palustri - bulbusum

Na eg. 261. semidecurrens $\mathrm{Richt}$. 262. 
Cirsium tuberusun 1 \1. 258. Zizianum koch 261. Cissus yuinquefolia Pers. 89.

Cistiueen Dunal 86.51. Cistus canus $\mathrm{J}$ a $\mathrm{c} q$. 51 .

Helianthemm I. 52. marifolius sin: 51. vinealis $\mathbf{W i} / \mathrm{l} .51$.

Cle m a $\mathrm{t}$ is 1.49 .2$.

* Vitalba I. 2.

Clinopo dium !. 52.359.

* vulgare L. 359.

Cuicus acauli - tuberosus

Schied. 261.

acaulis 11 illd. 258.

dubius IV ill d. 258.

eriophorus $R$ oth 257.

lanceulatus $\mathbf{W}$ illd. 256. oleraceus L. 258.

palustris Willd. 257.

Cnidium Cussun 29.192.

* venosum Koch 192.

Cochlearia L. 56.42.

* Armoracia L. 42.

Corunopus I. $4 \mathrm{~S}$

Draba I. 46.

rusticana $\mathrm{I}$ a m. 42.

Colchicaceen D C. 119.475.

Colchicum L. 37.475.

* antumnale 1. 475.

Colute a I. 61.116.

* arborescens L. $\mathbf{2 1 6}$.

* cruenta Ait. 116.

C o m a r u m. I. 46.143.

* palustre I. 143.

Compositen Adans. 100. 226.

Coniferen Juss. 117. 427.

Coninm L. 31.206.

* maculatum I. 206.

Conringia 'Thaliana $\mathrm{R} \mathrm{ch}$ b. 34.

Convallaria L. 35.462. bifolia I. 463.

* majalis J. 463.
Cunvallaria multifloral. 462.

* Polygonatum L. 462.

Cunvoliulaceen $\mathrm{J}$ us s. 108. 313.

Convolvulus L. 21.313.

* arvensis L. 313.

* sepirim I. 313.

Soldanella I. 313.

Conyza squarrosa I. 234.

Corallolrhiza II all.

71. 455 .

* innata R. Br. 455.

Coriandrum L. 31. 206.

* satirum L. 206.

Curneen 1) C. 98. 207.

Coruelhirsche $20 \%$.

Cornelle 207.

Cornus L. 18. 207.

* mas L. 207.

* sanguinea L. 207.

Cor"w illa L. 62. 11 s. curonata L. 119. minima Ja c q. 119.

* montana Scop. 119.

* vaginalis $\mathrm{L}$ a m. 118 .

* varia L. 119.

Coronopus Ruellii All. 48 .

Corrigiola L. 34. 171.

* littoralis 1. 171.

Corydalis DC. 59. 22.

* cara 5 c h weigg. und li ört. 22.

digitata Pers. 24.

* fabacea Pers. 23.

Lubelii 'Tausch 23.

* puinila Hos t 23. tuberosa D C. 22.

Corylus L. 75. 420.

* Arellana L. 420.

Corynephorus P. H.

15. 525 .

* canescens P. B. 525.

Cotuneaster Medic.

45. 157.

* vulgaris Lindl. 157.

Crassulacee॥ DC. 82.173. 
Cral to e 14. 1. 45. 156.

* monogyona Jar ce. 156

* Oxyacaisha I. 156. turuminalis J. 15:).

Crepis 1..64.25\%.

* biennis 1. 286.

* fuetida 1. 285. hiplacioides $\mathbf{1 1}$. K. $2 \times 8$.

* paludusa Mön a h $28 \%$. pinnatifida $\mid I$ illd. 28 i. polymurpha II a II 1.2x6.

* pracmursa'l a usch 283.

* succisafulia Tausch 298.

* terturum I. esti.

* vireus Vill. 287.

Critamus agrestis Bess. 184.

Cruciferen Inss. S4. 25.

Cuculsalus 1. 42.64.

* bacriferus 1. 64 .

Behen 1. fij.

Otites 1. 63.

Cucumis J. 76. 169.

* sativus I. 169.

Cucurbitaceen . uss.99.1(i9.

Cucurbita J. 76. 169.

* Pejol I. 169.

Cupuliferen $\mathrm{Ki}$ ch. 116.419. Cuscuta 1. 25.313.

* Evilinum Weile 31 .

* Epithymum 1. 314.

* europaea 1. 313. major Koch. Ziz. 314. ulgaris Pers. 314.

Cuscutina hassiaca ' $f(e$ iff. 314.

Cydonia Iournef. 45. 158.

* vulgaris J'ers. 158.

Cymbalaria muralis Fl. 1 .

Wett. 333 .

Crmbidim rorallor rha

sw. 456.

Cynanch um 1. 25. 307.

* Viucendicum R. Br. 30 \%.
C y 1 0gु I Diosenridis Vill. 31 li. lapjula Scop. 31.).

* motanum 1, al m. 31ti.

* officinale I. 315. silvaticum 11 a e nke 316 .

Cynusurus 1. 16. 539. durus 1. 53:3. cuerulews 1. 524.

* rristatus 1. 539.

Cyperaceen duss. 124. $4 \times 3$.

Cypergras 483.

Cyperus J. 10. 453.

* flavescens 1.. 483.

* fuscus J. 493.

Cypripedium I. 71. 4.9.6. Calcrulus 1,. 45 (6.

Cytis us 1. 5y. 101.

* sagittalis Kuch (1)l.

Dactylis 1. 15. 53s.

* glumerata L. 533.

Danthonia decumbens De. 530.

Da h he 1. 39. 4117.

* Jezerruin 1. 407.

Daturia 1. 21. 327.

* Stramoniuni L. 32\%.

D а ис иs. I. 30. 200 .

* Caruta l. 200.

D) aun 363 .

Dе।phіиіun 1. 47. 16.

* Cumsulida L. 16.

I) 11 iaria 1. 56. 32.

* bulbifera 1. 32.

Deschampsia cespitusa i". B. .25 .

Deyeuxia silvatica lin i21.

Di a thus L. 41. (i). arenarius Leyss. 63.

* Armeria J. 6.j.

* Carthusianorum L. 62.

* deltuides 1. 63. diminutus 1. 62

* prulifer l. (il. 
Dianthus Seguierii silvaticus ll op pe 63 .

* superbus I. 63.

I) ictitu nus f.. 40.98. albus I. 98.

* Fraxinella Pers. 98.

Digitalis I. 53. 332.

* grindiflura I a m. 332. wehrolencar Jacq. 332.

l)igrituria filifurmis $k$ öl. 5il3.

sallguinalis Scop. 513.

Niotis atriplicoides . I. B. $39 \%$.

Diplutaxis DC. 57. $\frac{40}{4}$.

* ienuifolia D C. 40.

Dipsareen D C. 103. 223.

Dipsacus I. 17.223.

* Fullonum Vill. 224.

* pilosis 1. 224.

* silvestris I. 223.

Distel 262 .

Dutterblume 15.

(1) i a b a 1. 56.4 l.

* muralis 1. 41.

* verna I. 42.

Bracheukupf 361 .

Dracucepha! um I. 5l. 3itil.

* Ruyschiana I. 361 .

Dreizahn 530 .

Dinseraceen 5.5 .

i) rusera I. 35. jx. anglica Huds. 58. intermedia ll a yne 58.

* Invgifolia L. 5í.

* rutundifolia I. 58.

Diirrwur\% 231.

Ả:beresche 159 .

Eberwurz 265.

Exhinuchloa Crus galli P. B. 513.

Lit chinops I. 70.256.

* sphaerocephalus L. 256 .
Eะ hiแแ

19. 315.

* Lappula I. e h m. 315. squarrusum Rehb. 315.

Lich i m I.20. 319.

* vulgare 1.. 319.

Ehrenpreiss 335.

Ehrlarta clandestina $11 \mathrm{i}$. ge rs 518.

Eibisch 84.

Eiche 419.

Einbeere 461.

Eimblatt 463.

lisemhart 378.

lisenhut 17.

Elatineen $\mathrm{C}$ a m bes. 91.79.

Elatine I. 40.79 .

* Ilsinastrum I. 80 .

* Hydropiper 1. 79.

Eleusine dura la a m. 533.

Eller $42 \%$

Bistobere 159.

Elsholtia cristata Hilld. 356.

E I $\mathrm{y} \mathrm{m}$ us I. 12. 550 . caniuus L. 549 .

* eurupaeus I. 550 .

Buphet 207.

E) Eilobium L. 3太. 16 औ.

* angustifolium 1. 160 .

* hirsutinm I. 160 . hirsutum 3. L. 161. molle $\downarrow$ a m. 161 .

* montanum I. 161.

* palustre I. 161.

* parvillorum Sch reber 161. pubescens $R$ ith 161 .

* roseum Sirheb. 162.

* tetragonum 1. 162.

E p ipactis Rich. 71.452 ensifolia s w. 452 .

* latifulia A11. 452.

* nicrophylla Ehrh. 453. vidus avis $A 11$. 4.54 . wata 111. 454. 
Epipactis pallens Sw. 452. * palustris Crantz 453 .

* rubiginosa G a u d. 453 .

Eppich 209.

Eragrostis P. B. 16. 531 . minor Host 532 .

* pilusa P. B3. 532. poaeformis Link 532 .

* poicuiles P. B. 532.

Erbse 127.

Erdbeere 142.

Erilbeerspinat 393.

Erdkohlrabi 39.

r.rdnuss 128.

Eiric a I. 39. 302.

* Tetralir l. 3112 .

vulgaris L. 302.

Ericincen Dess. 110. 302.

Erigeron I. 67. 231.

* acris J. 231.

* canadensis L. 231.

Eriophorum I. 11.490.

* angustifolimu Roth 491 .

* wracile Kuch 491 .

* latifoliun Hope 490. polystachyum L. 491 . pubescens $\mathrm{S}$ m. 491. triquetrum Н о p pe 491. * Vaginatum Is. 490.

Erie 427.

Erodi um L'H erit. 58.95.

* cicutarium L'H e rit. 95. Erophila vulgaris DC. 42. Frucastrum Schimp. und $S$ p. 57. 40 . inodorum Rehb. 40.

* Pollichii Schimp. und sip. 40.

Errum I. 61. 124.

* cassubicum Petern. 105.

* gracile D C. 126.

* hirsutum I. 125. Lens I. 12s.

* monanthos 1. 126.

* pisifurme P'e term. 124.
Ervum silvaticum [' e f é l' rir.

125.

* tetraspermum L. 12 i.

E ry ng i u m 26. 182.

* campestre I. 182.

E rysi m u m J. 57.34.

Alliaria 1. 34.

Barbarea I. 27. canesceus Roth 35.

* cheiranthuides I. 34.

* crepidifolinm R ch b. 35. diffusum E hrh. 36. hieracifolium $\mathrm{H}$ erb. Li in. 35. hieracifolium L. fl suee. 35.

odoratum Ehrh. 36 . officinale 1. 32.

* urientale R. B r. 36. pallens Pers. 35.

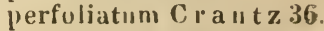

* strictum FI. IV ett. 35. repandum I. 36. virgatum D C. 35.

Erythraea Ren. Rich. 21. 312 . angustifolia IV a II 1 . 313.

* Centaurium P'e rs. 312. compressa $\mathrm{H}$ a y ne 313. inaperta S chlch t. 312 .

* linariaefolia Pers. 312 . littoralis Fries 313 .

* pulchella Fries 312 ramusissima Pers. $3 ! 2$.

Esche $30 \%$.

Es culus I. 3s. 89.

* Ilippocastimum ]. 89.

Esparsette 120.

E u v a $t$ or i u m I. 65. 226.

* Caunalinum I. 226.

Euphorbiaceen Juss. 112. 411.

Enphorbia L. 72. 411. Cajogala Ehrh. 413.

* Crparissias I. 413.

* dizlcis $\mathrm{J}$ a cq. $41 \mathrm{~L}$. 
Euphorbia Esula I. 413. Esula Pollich. 413.

* exigua L. 414.

* Gerardiana J a c q. 412.

* helioscopia L. 411. linariaefolia I, a m. 413 .

* palustris L. 412.

* Peplus 1. 414.

* platyphyllos I. 411. solisequa $\mathrm{Rchb}$. 12 .

Euphra sia L. 53.352.

* lutea L. 353. nemorosa Pers. 352.

* Odontites L. 352. officinalis Hay ne 352 .

* officinalis I. 352 . pratensis Fivies 352 . Rostkoviana Hayne 352.

serotina L a m. 353. stricta Host 352 . verna Bellard. 353.

liv o n y m us I.. 23.98. * europaens I. 99.

Fagus L. 75.419. Castanea I. 419. * silvatica L. 419.

Fahnwicke $\mathbf{1 1 6 .}$

Falcaria $H_{\text {os t }} 27.184$.

* Rivini Host 184.

Fal'setia R. Br. 55. 41.

* incanil R. B r. 41.

Faulbaum 99.

Fenchel 191.

Fennich 514.

Ferkelkraut 277.

Festuca I. 16.539.

* arundinacea Schreb. 542.

bromoides Aut. 540. calamaria S n. 542. decumbens 1. 530 . duriuscula L. Sp. plant. 540.
Festuca duritscula L. Syst. nat. 541.

* elatiur S nı. 542. fluitans L. 537. glauca S ch rad. 541.

* gigantea Vill. 542.

glomerata A 1l. 539.

* heterophylla I, a m. 541. inermis D C. 548.

montana S avi 547. niyurus Ehrh. 540. nemorum I, eyss. 541.

* ovina L. 540 . pratensis Huds. 542.

* Pseudo-myurus S oyer. W ill e m. 539.

* rubra I. 541. sciuroides Ruth 540 . silvatica $H$ u d s. 543.

* silvatica Vill. 541 . speciosa Schreb. 548 . tenuifolia Sibth. 540 . valesiaca $\mathrm{S}$ c h I ch. 540 .

Fetthenne 173.

Fenerbohne 132.

Ficaria ranunculoides

Mö n ch 11. verna 11 uds. 11.

Fichte $42 \%$.

Filago L. 67. 236.

* arvensis L. 237. arvensis Wa hle $n$ b. 237 . gallica l. 237.

* germanica L. 236.

* minima Fries 237. montana L. 237. montanaW a h I e $\|$ b. 237. Fingerhut 332 .

Flachsseide 313.

Flattergras 522.

Flieder 307.

Foeniculum $\|$ of $\mathrm{fm}$.

28. 191.

* officinale A I1. 191.

F r a g a ria J. 46.142.

* collina Ehrh. 142. 
Fragaria elatior Eh rh. 142. sterilis L. 147.

* rescia L. 142.

Frangula vulgaris Rchb. 110.

Franenflachs 333 . Frauenschuh 456 .

Franenspiegel 300.

Frauenthrüue 450.

Fraxinus J.8. 8. 307.

* excelsiur L. 307.

Friedlos 380.

Frosclibiss 429 .

Froschlöffel 429.

Fuchsschwanz 515.

Fumariaceen D C. 84. 22.

Fum aria I. 59. 24.

hulbosa $\lessdot$ I. 23.

bulhosa $\beta$. L. 23.

cava $M$ ill. 22.

fabacea Retz. 23.

intermedia Fihrh. 23.

* officinalis I. 24.

* Vaillantii I, (uisl. 24.

* Wirtgeni Koch 24 .

Cränsefuss 391 .

Gänsekresse 28.

Gänserich 143.

Gage a Salis b. 36. 465 .

* arensis schult. 466.

* Intea schult. 46 .

* minima Schult. 468 .

* saxatilis Koch 467 .

* spathacea Schult. $46 \%$.

* stenopetala Rehb. $\mathbf{4 6 6}$.

Gale obdol on 11 uds. 50. 363.

* luteum II u ds. 363 .

Galleosis Huds. 49. 363 . angustifolia Ehrh. 364 .

* bifida B o e nn ingh. 364 . cannabina Roth 365 . cannabina Poll. 364. Galeobdolon L. 363. grandiflura Roth $36 x$.
Galeopsis Iadinnm I. 363. latifulia 11 of $\mathrm{f}$ แ⿰ 364 .

* ochruleuca I, a III. 36í. pubescens Bess. 365.

* Tetralit L. 364 .

* versicolor Curt. 365. villusa $H$ uds. 364.

Galins og a Ru izu. l'av. 69.235.

* parviflora Cavauilles 235.

Gamander 376.

Gali I m L. 18. 213.

* Aparine 1. 215.

* bureale 1. 216.

campanulatum Vill. 213.

* Cruciata Seu p. 213. ghlaus:um L. 213.

hercynicum Weig. 218.

* Mullugo I. 217.

* palustre L. 216.

* parisiense L. 216. rotundifulium 1. 217.

* saccharatum A11. 214.

* saxatile L. 218.

* silvaticum I. 218.

* silvestre Pull. 218.

* tricorne With. 214 .

* uliginosum I. 215. Valantia 11 igg. 215. verrucosum S Im. 214.

* veruin 1., 217.

Garbe 243.

Gartenkerbel 204.

Gartenkresse 47.

Gaspeldorn 100.

Gauchheil 381.

Geisbart 136.

Geisklee 101.

Genista L. 59. 10l.

* germanica L. 101.

* pilusa I. 101. sagittalis I.. 102.

* tincturiar L. 101.

Gentiana L. 25.309.

* acaulis I. 310 . 
Gentiana Amarella Poll. 311.

* callpestris I. 310. Centaurium L. 312.

* ciliata 311 .

* cruciata I. 309. elliptica Kl. u. Richt. 310.

* germanica IV illd. 311.

* Pucunionantie 1. 311.

Gentianeen Juss. 10.9. 308. Genziane 309.

Geraniaceen D C. 90.90.

Gera川ium I. 58. 90. cicutalium I. 96.

* columbinum L. 93.

* dissectum 1. 93.

* lucidum L. 95.

* molle J. 94.

* palustre 1. 91.

* pratense I. 90.

* pusillum J. 93.

* pyrenaicum L. 92.

* Robertianum 1. 95.

* roturdifulinm 1. 94. rotundifo'ium Pollich. Fries 93.

* sanguineum J. 92.

* silvatieum 1. 90. viscidulum Fries 94. (ierseh 184.

Gerste 5.50).

G e u m L. 46.137.

* intermedium Eh rh. 137.

* rivale I. 137.

* urbanum 137.

Giersch 184.

Githago segetum D e sf. 67. GIa di 01 us I.. 10. 457.

Boucheanus Schlecht. 4.57.

imbricatus $\mathrm{S} p$ re $\mathrm{ng.457}$.

* palustris Gaud. $45 \%$. pratensis $A l b . D$ iet $r$. 457.

Glanzgras $\mathbf{5 1 5 .}$
Glaskirsche 135.

Glaskraut $\mathbf{4 1 6}$.

Glasschmalz 389.

Gla ucium 'Tournef. 46. 21 .

* corniculatum Curt. 21.

* luteum Scop. 21. phoeniceum Gärtı. 22. triculor Bernh. 22.

G I a u L. 24. $3 \times 5$.

* maritima I. 385.

G I e ch o III a 1. 51.360 .

* hederacea I. 360 .

Gleisse 190.

Glubularieen D C. 104. 385.

Gi i b u I a I i a L. 17. 385 .

* vulgaris I. 385 .

Gluckenblunie 297.

Glyceria R. B 1. 16. 537.

* aquatica Presb. 538. aquatica ll ah I e l b.537.

* distaus II ali lenl. 537.

* fluitans R. Rr. 537.

* spectabilis Mert. lích 537.

Ginalenhraut 331 .

Guaph a li um I. 67. 237. arenarium I. 239.

* divicum 1.. 239.

* luteo-album I. 23s. rectum Sm. 238.

+ silvaticum L. 238.

* uliginusun I. 238.

Goldlack 25.

Guldnessel 363.

Goldiuthe 231.

Guldstern 465.

Goudyeral R. Br. 7.1. 454.

* repens R. Br. 454.

Gottesiergess $3 ; 0$.

Gramineen Juss. 125. 511.

Graslilie 464.

Grasnellie 386.

Giatiola L. 8. 331 .

* officinalis L. 331 .

Grossularieen D C. 94. 176. 
Grundfeste 285.

Grundheil 196.

Gïnsel 374.

Gundelrebe 360 .

Gurtie 169.

Gymnadenia R. B r. 70. 447.

* conopsea R. Br. 447.

* odoratissina Rich. 448.

Gypshraitt 61.

Gypsophila I. 41.61.

* inuralis L. 61. serotina Hayne 61 . Vaccaria s n. 64.

Haargras 550.

Haarstrang 195.

Hahenaria bifolia R.Br. 449.

Habichtskraut 288.

Hachelkopf 278.

Haferschlehe 133.

Haferwurz 274.

Haftdolde 201.

Hahnenfuss 9.

Hainbuche 420 .

Halimus Wallr. 74. 395. * pedunculatus W a 11 r.395. Halorageen R. B r. 97. 164. Hanf 416 .

Hartheu 85.

Hartriegel 306.

Hasel 420.

Haselwurz 410.

Hasenlattich 280.

Hasenöhrchen 187.

Hauhechel 102.

Hauslaub 176.

Hauslauch 176 .

Heckensame 100.

H edera I. 24. 207.

* Helix I. 207. quinquefolia L. 89.

Hederich 39.50.

Hedrsarum Onubrychis L. 121.

Heide 302.
Ileidelberere 301.

Hele ocharis R. Br. 11 . 48.5 .

* acicularis R. Br. 486 .

* ovatir R. B r. 485.

- palustris R. 13 r. 495.

* miglumis l,ink 485 .

II elianthemum 'T'our. nef. DC. 47.51 .

* Fumana Mill. 51.

* oelandicum IV h Ib g. 51 . vulgare D C. 52.

* vulgare Gärtn. 52. vulgare Gaud. 52.

Helianthus I. 69. 236.

* annuus L. 236.

Helichrysum Gärtn. 67. 239.

* arenarium I) C. 239.

Helminthia Juss. 63 . 273.

* echioides Gärtn. 273.

II elosciadium Koch 26. 183.

* repens Koc h 183.

Hepatica triloba 5.

H er a cle u m L. 29. 198.

* Sphondylium L. 198.

Herm in i m R. Br. 71.451.

* Monorchis R. B r. 451.

H e rniaria J. 24.172.

* glabra K. 172.

Herzgespann 371.

Hexenkrant 163.

Hiel"a cium L. 65. 288. affine 'T' a us ch 295.

* Auricula I. 289.

* bifurcum M. B. 289.

* bureale Fries 294. collinum Gochn. 292. crmusum L. 292. dubium S $\mathrm{m} .290$.

* echivides W. K. 291. fallax D C. 292. integrifolium Hоppe 288. 
Hieracium Lactucella

IV a IIr. 290.

laevigatum Koch 295. lanceolatum Vill. u. T'a us ch 295.

* murorum L. 293.

* Nestleri Vill. 292. aleraceum Scop. 283.

* Pilosella L. 289.

* praealtum Ko ch 290. praealtum var. 292.

* pratense 'l a us ch 292.

* rigidum Ha rtm. 294. sabaudum Lin. 294.

* Schmidtii Tausch 293. silvaticum L. 294. silvestre 'T'a 1 s ch 294. 'raraxaci 1. 272.

* Inmbellatum L. 295.

* rulgatum K o ch 293.

Himantoglossum Spreng. 70.443.

* hircimum Rich. 448 .

Himbeere 138.

Hinmelschlïssel 383.

Hippocistaneen DC. 92. 89.

Hippocrepis I. 62. 120.

* cumosa I. 120.

Hippurideen Link 111.165.

Hippuris L. 7. 165.

* rulgaris I. 165.

Hirschwurz 192.

Hirse 512.

Hirtentäschel 47.

Höswuı'z 447.

Holcus L. 15.525. avenaceus S c op. 525.

* lanatus 1. 526.

* mollis L. 526.

Hulosteum L. 42.73.

* unbellatum L. 73.

Holunder 209.

Huniggras 525.

Hupfen 417.

Horde um L. 11.550).

*listichum L. 550 ().
Hordeum montanum Schrank 530.

* murinum L. 551. nodusum M. B. 551. pratense Huds. 551.

* secalinum s chreb. 551.

* vilgare L. 550 .

Hornklee 114.

Hornkraut 76 .

Hot tonia I.. 21.384.

* palustris L. 384 .

llühuerbiss 64.

Huftrisenklee 120.

Huflattich 226.

H u mulus L. 77. 417.

* Iupulus L. 417.

Hundsgleisse 190.

Hundskamille 245.

Hundpetersilje 190.

Hundswurz 447.

Huniszunge 315 .

Hungerblume 41.

H u t c h i is s a R. Br. 55. 47.

* petraea R. Br. 47.

Hyarinthus comosus I. 475. botryuides l. 475.

HydrocharideenDC.120.428.

$11 \mathrm{ydruch}$ a $\mathrm{r}$ is L. 78.429.

Morsus ranae L. 429.

Hydrochlua airoides

H a r t m. 538.

Hydrucutyle L. 26. 180.

* vulgaris L. 180.

Hyos cy am us L. 21. 327.

agrestis Kil. 327.

* niger L. 327.

Hyuseris minima L. 270. Hypericineen DC. 91. 85.

H y e ricum L. 62. 85 . delphinense Vill. 86 . dubium Le eis 86.

* elegans Steph. 87.

* hirsutum L. 88.

* humifusum L. 86. Liottardi Vill. 87.

* montanum I. 87. 
IIypericum perforatum I. S5. pulchrum I.. 87. quadrangulare $\mathbf{S}$ il. $\$ \mathbf{5 6}$.

- quadrangulum I. 86.

* tetrapterum Firies S6.

Hуроch oе ris I. 63. 277. Balbisii Koch. I, uisl. 278.

* glabra L. 278. maculata J. 278.

* radicata 1. 278.

If y s s U [ us I.. 51 . 360 .

* officinalis L. 360 .

Iasione 1.2 22.296.

* montana 1. 296.

* perennis la a m. 296.

Ib er is L. 55. 45.

* imara I. 45. nudicaulis $\mathbf{J}$. 45.

Jelänger, jelieber 211.

lgellock 167.

lgelskilbe 438 .

11 ecebrum I. 24.172.

* verticillatum I. 172.

Inmerschöı 239.

I m patieas L. 23.96.

* Noli tangere 1. 96.

Imperatoria 1.. 30. 197.

* Ostrutiun L. 197. palustris Bess. 194.

Intybus praemorsus fries $2 \leqslant 6$.

In uI a I. 67. 232.

* Britanica I. 234.

* Cunyza DC. 233. dysenterica L. 23j.

* germanica I.. 232.

* hirta L. 233. media M. B. 232. Pulicaria L. 234.

* salicina I. 232.

Johannisbeere 176. Juhanniskraut 85 .

Irideen Juss. 121. $45 \%$.

Iris 1. 10.45\%.
Iris bohemica sehmidt 458.

* germanica I. $45 \%$. mudicaulis sehauer 459.

* Pseud-Acorus I. 4ig.

* pumila 1. 459.

* sambucina l. 458.

* sibirica I.. 459.

* squaleus J. 458.

Is a tis I. 54.49 .

* tincturia I. 49.

Isolepis setacea R. B r. 4RT. Ittrera Najas Gmel. 436. Judenkirsche 326 . Juglander.u DC. $115.41 \%$. Juglans 1. 74. 418 .

* regia 1. 418.

Juncaceen B a r tl. 122. 476 . Juncagineen R ich. 118.430. Ju ucus L. 37.476 . acutiflorus Ehrh. 479. albidus $1 \mathrm{I}$ of $\mathrm{f}$ m. 482 . afjuaticus $R$ oth 478 . articulatus $\%$. $\beta .1 .47 \mathrm{~s}$.

* atratus kirucke 48 !). bifolius 110 p pe 478 . bottnicus Whlbg. 4 h.

* bufomins 1. 481. hubosus 1. 480.451 . campestris I. 453 .

* capitatus Weigel śu.

* compressus Ja c q. 480.

* conglumeratus 1. 477. divergens Koch u. \%i\% $4 ; 8$.

* effinsus 1. 477. erectus Pers. 493.

* filifurmis I. 477.

* Gerardi Lais J. 45l.

* glaucus Ehrh. 477. gracilis $\mathrm{l}, \mathrm{ej}$. 481.

* lamprocarpus Eh rh.478. melananthos R c h b. 479 . multiflorus Ehrh. 483. nemorosus Host 48 ?. 
Juscus nrmatrusus a. P o 11. 452.

* obtusiflurus ithrh. 4is. pilusiss «. I. $4 \times 2$. septangulus Petellu. 479.

* silviticus Reic:h. 479.

* squarrosus I. 480 . subnodulosus Sc hr. 479. subverticillacus Wulf. 480.

* supinus Mönch 479.

* 'Tenagria Ehrh. 481 . uliginosus $M$ e yer 480. Vaillantii Thuill. 481 . vernalis Ehrh. 482. vertirillatus Pers. 4s().

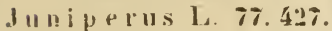

* communis L. 427.

Juvinea Cass. 66. 266 .

- ranuides Rchb. 266.

Kälberkropf 204.

liäsehwhl 37.

Kïasepappel 81.

lialnus 440 .

liamille 246.

Kammgras 539.

liarde 223.

Karthäusernelke 62.

Katzenhraut 360 .

latzenschwanz. 371

Kieilmelde 395.

kierbel 203.

liefer 427.

Kirsche 132.

Kirschpflaume 134.

Klapper 351.

Kilauenschote 119.

Klre 107.

Kleinling 382.

Klette 263.

Klettenkerbel 202.

Knabenkiaut 441 .

Knachelbeere 142.

Knauel 173.
Killaulgras 538.

Knautia Coult. 17. 224 .

* arvensis C 11 ult. 224 .

Knoblauch 471.

kilöterich 403 .

Knorpelkirsche 134.

Knorpelkraut 172. 390.

Knoteublume 460 .

Kuchia scoparia sehrad. 390.

Köleria Pers. 45.524.

* cristirta Pers. 524.

kölle 358 . glaura DC. 524.

Königsherze 32র.

Kinhl 36 .

Kiolilrabi 37.

Kiohliübe 39.

kinlbencohr 437.

Kopfluhl 37.

liopfriet 434 .

Korallenwurz 455.

Koriander 206.

Kormblume $26 \mathrm{~s}$.

Kranichschnabel 90.

Kratzbeere 140.

Kratzdistel $\mathbf{2 5 6}$.

hirebsdistel 263.

lirebsscheere 425 .

liresse 46 .

Kreuzblume 59.

Kreuzdorn 99.

Kriechen 133.

lirouwicke $11 \%$

Krümling 280.

Kuckuclisblume 449 .

Küchenschelle 5.6.

Kïmmel 184.

Kürbis 169.

Kugelblume $3 \times 5$.

Kugeldistel 256.

Kuhblume 279.

Kuhschelle 5.6.

Kunigundenkraut 226.

Tabiaten Jus S. 104. 353. 
Iabkraut 213.

Iack 25.

I, a c tuca I. 64. 281.

* nuralis Fresen iu s 282.

* perennis 1. 283. quercilla Willd. 282.

* saligna I. 282.

* sativa L. 281.

* Scariula Is. 281.

* stricti W. K. 282.

* virosa 1.. 281.

lärche 428.

Läuchel 33.

Laichkraut 431.

I. a m i u m L. 50. 361 .

* album L. 362 .

* amplexicaule I. 362 . Galeobdolon Crantz 363.

* maculatum I. 362 .

* purpureum L. 362. rubrum Wallı. 362. rugosum A it. 362 .

Lammkraut 270.

I, a m p s a a I. 65. 270 .

* conmunis Gärtn. 270.

J, а р ра ' ' o u rnef. 66.263.

* major Gärtn. 264.

* miner D C. 264.

* tomentosa La m. 264.

Jappula Myusotis Mö n ch 315.

Lapsana pusilla Wi Il d.270. Larbrea aquatica $\mathbf{S t}$. Hil. 75.

Larix europaea D C. 425. Laserkraut 199.

J, aserpitium I. 30. 199.

* latifolium L. 199.

* pruthenicum I. 200.

I, a thrae a L. 52.348.

* Squamaria L. 348.

Lathyus 61. 128.

* Aphaca L. 128.

* Lens Peterm. 128.
I athyrus macrorrhizus

wim m. 131 .

* montanus Be rnh. 131.

* niger IV i nı m. 131.

* Nissolia I. 128.

* palustris I. 130).

* platyphyllos Retz. 1311.

* pratensis l. 129.

* sativus I. 129.

* silvestris I. 129.

* tuherosis 1. 128.

* vermus $B$ e rnh. 130 .

Listich 281.

lauch 469 .

1 sinchhederich 33.

J, a v a te r a I. 58.84 .

* thuringiaca L. 84 .

Iseberhlume 5 .

Le d um L. 41. 303.

- pilustre L. 303.

l. e ésia Solander L3. 518.

* oryzoides Sw. 518.

I,eindotter 42.

Leinkraut 228.

Lemnaceen I, ink 124. 437 .

L. e m n a I. 8. 437 .

* gibba I. 437.

* ininor I. 437.

* polyrrhiza L. 437.

* trisulca I. 437.

l.entibularieen $\mathrm{Richal}$ 105. 378.

Le ontodon I. 63.272.

* autumnalis I. 272.

* hastilis L. 272.

I, e o n u $\mathrm{r}$ แ s I. 50. 371 .

* Cardiaca I. 371.

Galeubdolon S co p. 363.

Marrubiastrum L. 371.

I. e pidi 1 II L. 55.46.

* campestre R. Br. 46.

* Draba L. 46. petraeum L. 47.

* ruderale I. 47.

* satirum L. 47. 
Lepigonum Wahlberg 42. 70.

* marginatum li och 71 . marinuni Wahlbg. 71 .

* medium IV ah l b g. 70.

* rubruir IV a h J b g. 70. L e u c o ju m I. 35.460 .

* vernum I. 460.

I, evisticum Koch 28. 193.

* officinale k o ch 193.

l, ibanotis Crantz 29. 192.

* montana All. 192.

Lichtnelke 66.

Lit:bäugel 317.

Liebesgras 531.

Liebstöckel 193.

Lieschgras 517.

Ligustrum L. 8. 306 .

* vulgare I. 306

Iigusticum Levisticun L. 193.

Liliaceen DC. 121. 463.

Lilium L. 36. 464.

* Martagon L. 464.

Lim os ella L. 53. 344.

* aquatica L. 344.

l, inaria 'Iournef. 53. 333.

* arvensis Des f. 334 .

* Cynubalaria Mill. 333.

* Elatine Mill. 333.

* minor Desf. 334 .

* spuria Mill. 334.

* vulgaris Mill. 335 .

I inde 85.

Lineen D C. 90. 80.

Linosyris D C. 65. 228.

* vulgaris Cass. 228.

Linse 128.

L in u m L. 35.80.

* catharticunı L. 80 . Radiola L. 81. tenuifolium L. 81 .

* usitatissimum L. 80 .
Liparis Löselii Rich. 456 . L, is tera R. B r. 71. 454 .

* ovata R. B r. 454.

Li thospermum L.. 20. 320.

* arvense L. 320.

* officinale L. 320.

* purpureo-coeruleum L. 320.

Littorella lacustris L. 388 . Iische 517.

Löffelkraut 42.

löwenmaul 332.

Iöwenzahn 272.

Lolium L. 11.551. arvense Schrad: $\mathbf{5 5 2}$.

* linicola Sond. 551.

* perenne L. 55 1.

* temulentum 552.

L, (1) i cer a L. 23. 211.

Caprifolium L. 211.

Periclymenum L. 211.

* Xylosteum L. 211.

Lonitzere 211.

Loranthaceen D 0 n. 94. 208.

Loroglossum hircinum

$\mathrm{Rich} .448$.

L, ot us L. 60. 114.

* cosniculatus L. 114. major S m. 115. maritinus L. 115. siliquosus L. 115.

* uliginosus Schkuhr 115.

Lungenkraut 319 .

Iuzerne 103.

I, $u z u$ I a D C. 37.452 .

* albila D C. 482.

* campestris D C. 482.

* multiflora Lej. 483.

* pilosa Willd. 482 . vernalis D C. 482 .

Jychuanthus scandens G m e l. 64 .

L. y chnis DC. 43.66 . dioica 4. L. 67. 
I.y.huis disica $\beta .1 . .67$.

* diurina Sibch.67.

* Flus cuculi l.. (ifi. pratensis Sp I. 67. siliestris II 10 pe 67.

* vespertina Sibih. 67.

* Viscaria J. 66.

I. y c i IIII I. 22.324.

* barbarum I. 324.

1. yous is L. 20.317.

* arvensis 1.. 317. pulla J. 318.

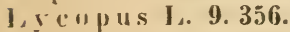

* europaeus J. 356.

1. rsimachia J.. 21.390.

* " неmuruir L. 381.

* Aimmularia l. 331.

* Clisersiflura L. 3so.

* viigaris $\mathrm{I}_{\text {. }} 3801$.

Lrtharieen Juss. 88. 168.

i. نthim L. 163.

* liyssopifulia I. 16s.

* Silicaria L. 16.5.

Männertrene 182.

Värzblismehen 5 .

Väusegerste 551 .

Mäuseschwanz 9 .

Maja nthemum II igg. 18. 463 .

* bifulium D C. 463 .

Naiblume $\mathbf{4 6 2}$.

VIal achium fries 43.76 .

* arquaticum Fries 76 .

Malva I. 58.81.

* Alcea I. 81 .

* borealis II a II ma mauritiana L. 83.

* moschata L. 82. pusilla Wither. 83 . rotundifolia L. 83.

* silvestris I. 82.

* vulgaris Fries 83.

Malvaceen R. B r. 89.81 .

Mannsschild 382 .

Vlarbel 482.
Maricndistel 262.

Ma I I h i แ แ l. 49. 369. angustifulium $\mathrm{K}$ o $\mathrm{cl}$ 369 .

cretirum Nill. 369. latifolium lio ch 369. paniculatum Dess. 369 . panivulatum R $\mathrm{ch}$ b. 369 . peregrinum I a c q. 369 .

* peregrinum 1. 369 .

* vulgare I. 370.

Maruta Cutula D C. 24.7.

Massholder 88 .

Massliebe 230.

Matricaria J. 6 x. 246.

- Chamomilla I. 246. incodora I. 248.

P'arthenium I. 247.

Manerpfeffer 174.

Maulbeerhaum 417.

Nedirago I. 61. 103.

* dentirinlata Willd. 104.

* fislcata I. 103.

* lupulina L. 103.

* minima I. 104.

* sativa J. 103.

Neerrettig 42.

Meerzwiebel 469 .

Meier 212.

Meisterwurz 197.

N I l a m p yr u m I. 53. 349.

* arrense I. 349.

* cristatum L. 349.

* nemorosum I. 349.

* pratense 1. 350 .

Nelde 395.

Melica I. 15. 530.

* ciliata I. 530. I,obelii Vill. 531.

* nutans J. 531. nutans Poll. 531.

* uniflura Retz. 531 .

Melilotus 'Tournef.

L a n. 60. 105.

* alba Desi. 107. arvensis Wallr. $10 \%$. 
Melilotus dentata Per.s. 105.

* macrorrhiza Pers. 106.

* officinalis Des r. 106. Petitpierieana $\mathrm{Rch}$ b. 107. vulgaris IFilld. $10 \%$.

Melissa Acinos B e n th. 359. Nelit tis L. 51. 361 .

* Melissophyllum L. 361. Menth a L. 51.353. adspersa Mönch 355 .

* aquatica I. 355 .

* arvensis L. 355. crispata sichrad. 354. dubia Vill. 355. gentilis L. 355.

hybrida S c h l eich. 354. macrostachya 'I e n 0 r. 354.

* nepetoides I, ej. 354. palustris Mill. 355.

* Pulegium L. 356.

* rotundifolia L. 353. ruyosa La m. 354 . serotina Tenor. 354.

* silvestris I. 354. suaveolens Ehrh. 354. viridis Aut. 354 .

II nyanthes I. 21. 308.

* trifuliata L. 309.

Mercurialis L. 78. 414 .

* annua L. 414. Cynocrambe S co p. 415.

* perennis L. 415.

Mespilus L. $45.15 \%$. Cotoneaster J. 157.

* germanica L. 157. Uxyacantha G ärtn.156. Meyran 358.

Milche 270.

Milchkraut 385.

Mili un I. 13.522.

* effusum I. 522.

Milzkiaut 179.

Mistel 208.

Ga r cke, Flora.
Minze 353.

Mo ehringia I. 42.72.

* trinervia Clairv. 72.

Moenchia Ehrh. 42.75. erecta FI. d. Wett. 75. * quateruella Eh rh. 76. Möre 200.

Molinia Schr. 16.538. * cuerulea Mön ch 538. variabilis $\mathbf{W}$ i b. 538 .

Muneses grandiflora $\mathbf{S}$ a $1 \mathrm{i}$ s b. 305 .

Monotrupa I. 41.305 . Hypophegea Wallr. 306.

Hypopitys IVallr. 306.

* Hypopitys I. 305.

Monotropeen Nutt. 93.305.

No nt i a L. 10. 170.

* minor G mel. 170. rivularis $\mathrm{Gm}$ el. 171.

Moorkönig 350 .

Muorsimse 484 .

I o r us L. 73. 417 .

* alba J. 447.

* nigra I. 417.

Mottenkrant 303.

Nulgedium alpinum Bess. 283.

Nummel 19.

Muscari 'T'ournef. 36 . 474.

* botryoides Mill. 475 .

* comosum Mill. 474. racemosum Mill. 475 .

Mutterkraut 247.

Mutterwurz 194.

Myagrum dentatum Willd. 43.

paniculatum L. 49. perenne I. 50. sativum $\gamma$. I. 43.

Mycelis muralis R chb. 282. Mylinum Carvifulia Ga ud. 194. 
Myopteron incanum Spr. 41.

Myosotis L. 20.321 . arenaria s chrad. 323. arvensis $\mathrm{Sehrad} .323$. arvensis $\beta$. Pers. 322.

* caespitosa Srhultz 321 . collina $R \mathrm{chb} .323$.

* intermedia Link 322.

* hispida Schle cht. 323. Lappula L. 315.

lingulata $R o$ em. und Schult. 322.

* palustris With. 321 . scorpioides Willd. 321. silvatica $\mathrm{Ehr}$. 322 .

* silvatica $\mathrm{H}$ o f f m. 322 .

* sparsiflora Mikan 324.

* stricta Link 323.

* versicolor Pers. 323.

My os urus I. 48. 9.

* minimus 1.3.

Myriophyllum l. 74. 164.

* spicatum L. 165.

* verticillatum I. 164.

Myrisis bulbosa Spr. 205. hirsuta s p r. 206. temula Sp r. 205.

Nachtkerze 162.

Nachtschatten 324.

Nadelkerbel 203.

Najadeen link 123. 436.

$\mathrm{Naj}$ a L L. 72.436 . fluviatilis La m. 436 .

* major Roth 436. marina L. 436. minor All. 436.

Nardus I. 11552.

* stricta I. 552.

Nasturtium R. Br. 56.25.

: amphibium R. Br. 26. anceps $\mathrm{D} \mathrm{C.} 27$. aquaticum Wallr. 26.

* officinale R. Br. 25.
Nasturtiun palustre I)C. 27. riparium Wallr. 26.

* silvestre R. B r. 26. terrestre R. Br. 27.

Natterkopf 319.

Nelkentwirz 137.

Neottia I. 71.454. latifulia Rich. 454.

* Nidus avis $\mathrm{Kich} .454$. repens S $\$$ w. 455 . spiralis $\mathrm{Sw} .455$.

Nepeta L. 50.360.

* Cataria L. 360.

Glechoma Benth. 361 . nuda 1 . 360 . pannonica J a c q. 360.

Neslea Desv. 54.49.

* paniculata Desv. 49.

Nessel 54. 415.

Neunkraft 227.

Nicotiana L. 21.327.

* latissima Mill. 327. macrophylla Spr. 327.

* justica L. 327.

* 'Tabacum L. 327.

Nigella L. 48. 15.

* arrensis L. 15.

* sativa L. 16.

Nixblume 19.

Nixkiaut $\mathbf{4 3 6}$.

Nonnea Med. 20.317.

- * pulla D C. 317.

Nuphar Smith 47. 19.

* luteum Smith 19.

Nymphaeacern DC. 84. 19.

Nymphaea L. Smith 47. 19.

* alba I. 19.

lutea I. 19.

Dherkohlrabi 37.

Obione pedunculata Mo qu in-I and. 395.

Ochsenzunge 317.

Odermennig 148.

Odontites rubra P e r s. 353 . 
Gelsenich 196.

O) en anthe 1.2.29. 189.

* fistulusa L. 189.

Phellandrium I. a m. 190.

Tabernaemontani G m. 194.

Oenothera I. 35. 162.

* biennis 1. 162.

Ohublatt 305 .

Oleaceen Lindl. 107. 306. Omphaludes scorpiuides

$\mathrm{I}, \mathrm{e} \mathrm{h} \mathrm{m.} 316$.

Unagrarie. "Juss. 95. 159.

Onobrychis 'ournef.

61.120

* sativa Itat 11.120.

Ononis $\mathrm{J}_{\text {. }}$ 59. 102.

procurrens $\mathrm{W}$ a $/ 1 \mathrm{r} .102$.

* repens L. 102.

* suinosa I. 1112.

Onupordun I. 65. 263.

* Arantium L. 263.

Ophrys L. 71.450. anthropophora L. 451 .

* apifera ll uds. 450.

* aranifera 11 u ds. $\mathbf{4 5 0}$. corallorrhiza I. $\mathbf{4 5 6}$. insectifera $\iota$. I. 451. insectifera $a$. I. 450.

Löselii I. 456.

Monorchis I. 451 .

* muscifera II uds. 450 . myodes S w artz 45 ().

Nidus aris L. 454.

ovata L. 454.

spiralis 1. $\mathbf{4 5 5}$.

Oporina autumalis $1 / 0 \mathrm{n}$. 272.

Orchideen 119. 440.

Orchis 1. 70.440.

angustifolia $\mathrm{W}$ im m. Is.

G r a b. 447.

bifolia I. 449 .

conopsea I.. 448 .

* curiophora I. 442.

* fusca Ja c (. 440.
Orchis hirciua Sw. 448 .

: incarnata L. $\mathbf{4 4 6 .}$

incarnata Willd. 445 . latifolia Fries $\mathbf{4 4 6}$.

* latifolia L. 446 . latifulia Rch b. $44 \%$

* laxiflura 1, am. 444.

* maculata L. 446 . majalis Rehb. 446 .

* mascula 1. 444.

* militaris L. $4 \frac{1}{4}$ l. militaris $\beta . \%$ I. 441 .

* Morio Is. 443.

- odoratissima I. 448.

* palleas I. 443. palustris Jace 445 . pyramidalis L. 447.

* sambucina I. 445. Simia Vill. 442. Taberuaemontani

- Gimel. 445 tridentati Scol. 441 .

* ustulata L. 442 .

* variegata A11. 441. virescens $Z$ ulliliof. 450.

Oreosclinum legitimum M. B. 196.

Or ig a n u m L. 52.357.

* Majorana L. 358.

* rulgare J. 357.

Orlaya grandiflora $I$ of $\mathrm{m}$. 260.

O in it ho gal um L. 36.465. arvense $P$ e rs. 467.

buhemicum $\mathbf{G}$ a u d. 467 . luteum $\mathrm{H}$ of $\mathrm{fm} .466$. luteum $\beta$. I. $\$ 69$. minimun L. 468 . miniuum Roth 467 .

* nutans I. 465.

Personii Hoppe 469 . silvaticum Pers. 469 . spathaceum II a y n e 46 . stenopetalum F ries 466 . Sternbergii II o p p e 4 fis. 
Ornithugalum umbellatum I. 465.

villosum M. B. 467.

Ornithupus 1.62. 119.

* perpusillus J. 119.

Orobancheen Juss. 106.344.

Orobanche 1. 52.344 .

* arenalia $B$ ol khausen 347.

Artemisiae campestris

Ga 11 d. 346 .

Buckiana Ko ch 347.

Buekii Dietrich 346 . caryophyllacea $S$ m. 346. coerulea Vill. 347.

platiur Kuch. $Z$ iz $34 f$ fi. elatior Sclileich. 347. elatior Sutton 345.

* Epithymum DC. 345.

*Galii () 11 b r 345 .

* luricata Relib. 346 .

* majur I. 344.

* minor Sutt. 347. Medicaginis Scluultz 346.

purpurea Ia c q. 347. ranosa $\mathrm{L}$. 348 .

* rubens II allr. 346 . rubra $S$ mith 345 . sparsiflora Wall r. 345. stigmatodes $\mathbf{W}$ i m m. 345.). strubiligena $\mathrm{R}$ c h b. 346 . vulgaris D C. K o c h 346.

Orobus niger I. 131. tuberosus I. 131. vermis I,. 131.

Ostericum Hoffm. 27. 194.

* palustre Bess. 194. pratense $H$ of $\mathrm{m}$. 194.

O xalideen i) C. 90.96.

O) $\mathrm{xali}$ s L. 43.96 .

* Acetosella I. 96.

* corniculata I. 97. curniculata J. eyss. 97. corniculata St. 97.
Oxalis stricta 1. 97.

Oxytropis DC. 61). 116. montina Spreng. 117.

* pilosa DC. 116.

Panicum I. 12.512.

Crus -galli L. 513.

* glabrum G a ud. 513. glancum L. 514. humifusum $K \|$ h Ischaemums ch re b.5 13.

* miliaceum I. 513 Milium P'ers. 514.

sanguinale J. 512. verticillatum L, 514. viride 1. 514.

Papavel 1. 47. 19.

* Argemune J. 20.

* lubium L. 20.

* hybrilum l.. 20.

* lihoeas I. 20.

sumniferum L. 21. trilobum II a IIr. 21.

Papaveraceen DC. 83. 19.

Papilionaceen L. 83.100.

Parietaria 1. 18. 416 . diffusa M. u. K. 416 .

* erecta M. 11. K. 416. officinalis Willd. 416 .

J'a i'is 1. 40. 461 .

* quadrifolia L. 461.

Pal nassia 1. 34. 59.

palustris 1. 59.

Paronychieen St. 11 il. 87. 171.

1'asserina J. 39. 406.

* anmua II ickst. $\$ 07$.

Pustinara I. 30. 198.

* sativa L. 198.

Pediculatis I. 52.350.

* palustris L. 350 .

* silratira L. 350.

Peplis L. 35. 168 .

* Purtula L. 168

Perlgras 5:30. 
Persica Tourlif. 44. 132.

* vulgaris Mill. 132.

Pestwurz 227.

Petasites Gärt11.67.227.

* officinalis Mönch 227. spurius Rch b. 227. vulgaris D esf. 227.

Petersilje 183.

Petroselinum Hoffm. 26. 183.

* sativum Hoff $\mathrm{m} .183$.

I' e ucedan um L. 30. 195. alsaticum L. 196.

* Cervaria I. a p. 195.

* officinale J. 195.

* Oreoselinum Möneh 196.

Silaus I. 193.

silvestre DC. 197.

Pfaffenkäppchen 98.

Pfefferkrant 46. 358 .

Pfeilkraut 430).

Pfennighraut 43 .

Pferdesaat 189.

P'firsiche 132.

Plaume 132.

Pfriemen 100.

Pfriemengras 522.

Phalangium Liliago

Schiad. 464.

ramosum La m. 465.

'halaris I. 13.515.

* arundinacéa I. 515 . aspera $R$ etz. 517 . oryzuides I. 518. phlevides 1. 517.

I'haseolus L. 62. 132.

* multiflorus WVilld. 132.

* vulgaris L. 132.

Phellaudrium aquaticum $\mathrm{L}$. 190.

Phleum L. 13. 517.

* asperum Vill. 517.

* Boehmeri Wibel $51 \%$. cristatum Scop. 539.
Phleum pratense 1. 517. viride A11. 517.

Phragmites 'Trinius 14. 523.

* communis Trin. 523.

Physalis L. 22. 326.

* Alkekengi I. 326.

Phyt eum a L. 22. 297.

* orbiculare L. 297.

* spicatum L. 297.

Picea vulgaris $L i ı k 428$.

Picris L. 63. 273. echioides I. 274.

$\therefore$ hieracioides I. 273.

Pimpinella L. 27. 185.

Allisum L. 186.

* magnil L. 185. uigra Willd. 186.

* Saxifraga I. 185.

f i $\mathrm{i} 11 \mathrm{~s}$ J. 72.427.

* Abies I. 428.

* Larix L. 428.

* silvestris L. 427.

f'i s แ 61 . 127.

* arvense I. 127.

* sativu*n 1. 127.

Plantagineen J us s. 105.356.

Plantago 1.. 17. 386.

* lanceulata L. 387.

* major I. 386.

* maritina L. 387.

* media L. 387.

Platanthera Rich. 70. 449.

* bifolia Rich. 449.

* chlorantha Cust. 449 .

Platterbse 128.

Plumbagineen Juss. 104. 386.

Po a 16. 532. airoides $\mathrm{Ko}$ el. 538 .

* alpina L. 534. angustifolia L. 535 . angustifolia Poll. 536.

* annua L. 533. aquatica L. 537. 
Poa brizuides 534 .

* hulbosir I. 533. collina Ho st 534.

- compressa 1. 536. cristata I, 524. decumbens sicop. 530 . depressa Presl. 536. distans 1. 537. dubia Leers 536 .

* dura Scop. 532. Eragrostis L. 532.

* fertilis Host 535 . fluitans s cop. 537. glabra Ehrh. 536. humilis Ehrh. 536 .

* Iscomoralis L. 534. palustris $\mathrm{R}$ oth 535. pilosa I. 532.

* pratensis I. 536. pratensis $P_{0} 11.536$. quadripedalis E hr h.535. salina Poll. $53 \%$. scabra Ehrh. 536. serotina Gaud. 535. silvatica Vill. 535.

* sudeticia Ha enk e 535 . trinervata D C. 535 .

* trivialis 1. 536 . trivialis $\mathrm{P}$ ull. 534.

Poduspermum DC. 63. 278.

* laciniatum D C. 277.

Po] yси с m um I. 10.390.

* ariense L. 390.

* majus A lex. Braun 390.

Polrgala L. 59.59.

* anıara I. 60. austriaca Kuch 60. austriaca $R \cdot h b$. 60).

- comosir Sehk. 60. (1)yptera Rchb. 60. nligiunsa lichb. (jo.

* rulgaris I. 59.

Pulygaleen Juss. 107.59. l'olygneen duss. 112.398.
Polygu 1 แ แ I. 39. 40\%.

* amphibium I. 403 .

* aviculare I. 405.

* Bisturtar I. 403. Bramii B1.u. Fing.41)4.

* Convolvulus I. 405. dubim Stein 404.

* dumetorum L. 406.

* Fagopyrum I. 40)(i.

* Hydrupiper L. 405.

* lapathifulium I. 404. laxiflorum Weihe 404.

* minus H nds. 405 .

* mite schrank 404.

* Persicaria I. 404. Persicaria p. I. 405. pusillum I, a n). 405. strictmm a 11.405.

* tataricumi I. 406.

Pomaceen Lindl. 98. 156.

') ори1 us I. 78. 424.

* alba I. 425.

* canescens Sim. 425. dilatata $A$ it. 425. fastigiata Poir. 425.

* monilifera A it. 426.

- nigra L. 425. nivea IVillo. 425.

* pyramidalisko zi er 425.

- tremula I. 425.

Porst 303.

Portul il ca L. 44. 171.

* oleracea I. 170.

* sativa 11 a w. 170.

Portulaceen Juss. 87. 170. Potameen Jus s. 119. 431. Potamogeton I. 19.431.

* acutifulius Link 433. complanatns IV ill d. 433 . compressum Roth 434.

* compressus I. 433.

* crispur I. 433.

* densis 1. 435. fluitans $\mathrm{Roth} 432$. gramineum Sn. 434

* Fucens 1. 432. 
Putamogeton natans 1. 431 .

* ubtusifolius M. u. K o c h 434.

* pectinatus L. 434 .

* perfoliatus L. 433.

* pusillus I. 434.

* rufescens Schrad. 432. zosteraefulius $\mathrm{S} \mathrm{chum}$. 433.

l'otentilla L. 46.143.

* alba 1. 147.

* Anserina L. 144.

* argentea I. 144. Fragaria S m. 147.

* Fragariastrum Ehrh. 147.

nemoralis Nestl. 145.

* opaca J. 146.

* procumbens S ibth. 145 .

* reptans I. 145.

* rupestris L. 144.

* supina I. 143.

* Turmentilla Sibth. 145.

* verna l. 146.

poterium 1. 74. 155.

* Sanguisorba I. 155.

l' l'e unthes 1. 64. 280. mulalis L. 282.

* purpurea I. 280.

P'rimula 1. 21).383. acaulis $J$ a $\mathbf{c} q$. 384.

* elatior J a c q. 383.

* officinalis $\mathbf{J}$ a c q. 383 . veris L. 383 .

Prinulaceen Vent. 105.378. Prismatocarpus Speculun

L'Herit. 301 .

l'ruluella L. 49. 373.

* grandiflura J a c q. 373 .

* vulgaris L. 373.

') ' II I u s I. 45. 132.

* Armeniaca I. 133.

* arium I. 134.

* Chamaecerasus Ja cq. 135.

* Cerasus I. 134.
Prunus domestica T. 133. fruticans We ihe 133 .

* insititia L. 133.

* Padus L. 135.

* spinosa L. 133.

Pulegium vulgare Mill.356. P'ulicariaGärtn. 67.234. bellidiflura Wrall r. 230.

* dysenterica G är tw.234.

* vulgaris G ärtn. 234.

PuImon aria I.. 20. 319. angustifulia Schrank 321 .

* azurea l3esse 319.

* "fficinalis L. $31 \%$.

Pulsatilla pratensis Mill. 6. vulgaris Mill. 5.

Pycreus flavescens P.B. 484. Pyrethrum corymbosum

Will 247.

Parthenium sim. 247.

Pyrula 1. 41.303.

* chlorantha Siv. 304. media Hayne. S w. 304.

* media Sw. 304.

* minur L. 304.

* rotundifolia I. 303.

* serunda L. 304.

* umbellata I. 305.

* uniflora I. 305. virens $\mathbf{S c h w}$ igg. "I. Körte 304 .

Pyrolaceen I, ind1.92. 303. P'y l' S I. 45.148. acerba Merat 158. ancuparia G ärtı. 159.

* communis I. 158. Cydonia L. 158.

* Malus L. 158. Pollveria Lej. 158. Surbus Gärtn. 15.9.

Qutendel 358 .

Quercus L. 75.419 .

* pedunculata Ehrh. 419 . racemosa $\mathrm{L}$ a m. 420 . 
Quercus Rubur S n. 420. Rubur $\beta$. I. fl. suec. 419.

* sessiliflora S m. 419 . sessilis Eh $\mathrm{rh}$. $\mathrm{S}$ แ1. $\$ 19$. Quitte 148.

Rade 67.

Radieschen 51.

Radiola Gmel. 19.81.

* linoides G m el. 81 .

Millegrana S m. 81 .

Ragwurz 451.

Rampe 40 .

Raninculaceen Juss. 82. 1. Ra un u $\operatorname{lus~L.~} 48.9$.

* acris $\mathrm{I}$. 12.

* aquatilis I. 9.

* arvensis L. 14.

* auricomns L. 12.

* bulbosus L. 13. eassubicus $\mathrm{St}$. 12. circinatus Sibth. 10.

* divariratus S ch rk. 10.

* Ficaria I. 11.

* Flanınula $\mathrm{H} .11$.

* fluitans I a m. 10. fluviatilis $\mathbf{W i g} \mathrm{g} .10$. heterophyllus il i g g. 9. hirsutus $\mathrm{C}$ y $\mathrm{rt}$. 14.

* illyricus I. 11.

* lanuginosirs I. 12.

* Lingua I. 11. pantothrix $\%$. D C. 10.

* paucistamineus 'l'a us ch 10.

peucedanifolius A 11. 10.

* Philumotis Ehrh. 13.

* polyanthemos L. 13. polymorphus All. 12.

+ repens I. 13. rigidus $H$ of $f \mathrm{~m} .10$. sardous C rantz 14.

* sceleratus I. 14. stagnatilis Wallr. 10.

Raphanistrum arvense R chb. 50.
Raphanus I. 56.50 . Raphanistrum I. 50.

* sativus I. 50 .

Rapistsum Hoerh. DC. 54. 49.

* perenne A II. 49. Raps 38.

Rapüzchen 221.

Rapunculus orbicularis S c o p. 297.

spicatus S c o p. 297.

Raukensenf 32.

Reinfarn 242.

Reiherschnabel 95 .

Rempe 4).

Resedaceen D C. 85. 57.

Resta L. 44.57.

* Intea I. 57.

* Luteola L. 57.

Rettich 50.

Rhammeen R. B r. 88.99.

Rhamnus l.. 23.99.

* cathartica L. 99.

* Frangula L. 99.

Rhinanthaceen DC. 107.349. Rhinanthus Crista galli I. 351.

Rhynchospora Vahl. 11.484 .

* alba Vahl. 484 .

* fusca Roem.u.Schult. 485.

Ribes L. 24.176.

* alpinum L. 177.

* Grossularia L. 176.

* nigrum L. 177. reclinatın L. 177.

* rubrum L. 178. Ura crispa I. 177.

Riechbirke 426.

Riemenzunge 448 .

Riet 485 .

Rindsauge 244.

Ringelblume 255.

Rispengras 532.

Roggen 550. 
Kohr 523.

Rohrkolbe 437.

Rusaceell Juss. 82. 136.

Ros a I. 46. 148. austriaca Crantz 154 . campanulata Ehrh. 150.

* canina L. 150.

* cinnamumea I. 150. Eglanteria I. 149. Eglanteria Mill. 152. francofurtana $M$ ü n $\mathrm{ch}$ h. 150.

* gallica L. L, indl. 153.

* lutea Mill. 149. marginatalW a ll r. K o ch 153.

+ pimpinellifolia DC. 149.

* pomifera Herman n 153.

* rubiginusa $I_{\text {. }} 152$. sllavifolia Lightf. 152.

* tumentosa S Im. 152.

* turbinata A it. 150.

Russkastanie 89.

Rosspappel 82.

Rothbuche 419 .

$R$ u bus L. 46. 138. affinis Weihe U. N. 13y.

* caesins L. 140. candicans W e ihe 139.

* corylifolius $\mathrm{S}$ m. 141. fruticosus L. Fi i e s $\mathbf{1 3 8 .}$

* fruticosus Weihe u. N. 139.

* Idaeus L. 141.

* plicatus W e i h e u.N.138.

* saxatilis L. 141.

* vulgaris IV e i h. U.N. 139.

Ruchgras 515.

Rübsen 38.

Ruhrkraut 237.

R un ex L. 37. 398 .

* Acetusa L. 402.

* Acetosella I. 402. acutus S m. 399 . acutus ' $\mathrm{I}$ a us ch 400 .

* aquaticus L. 401 .

* conglomeratus Murr. 399.
Rumex crispus L. 400. cristatus $\mathbf{W}$ a $11 \mathrm{r} . \mathbf{4 0 0}$. divaricatus 1. Fries 400. glomeratus S c h r e b.399. Ilydrolapathum $\beta$. Fries 401.

* Hydrolapathum Huds. 401 .

* maritimus l. 398. Nemolapathum Ehrh. 399.

* obtusifulius L. 400 . Oxylapathum Wallr. 400 .

* palustris $\mathrm{Sm} .399$. Patientia L. 401.

- pratensis Mert. Koch 400.

purpureus l'oir 400.

* sanguineus L. 399.

* scutatus L. 401 . silvestris Wa $11 \mathrm{l}$. 400 .

Ruppia L. T. 435.

* rostellata Ko e h 435 . miritina L. 435.

Ruprechtskraut 95.

Rutaceen Juss. 93. 9s.

Rut a L. 39.98.

* graveolens L. 98.

Sabulina cespitosa Rchb.71.

$S$ ä i in a I . 43. 68 .

* apetala L. 68.

* nodosa Torrey und Gray 69.

* procumbens I. 68 .

Sagittaria L. 74. 430 ). sagittaefolia $I, 430$.

Salicurnia I. 7.389.

* herbacea L. 389.

Salicineen Rich. 117. 420.

Salix L. 76.420. acuminata $\mathrm{H}$ of $\mathrm{fm} .424$

* alba L. 421.

* aniygdalina I. 422.

* anrita L. 424.

* Caprea L. 423. 
Salix cinerea 1. 424.

* frigilis J.421.

* mollissima Ehrh. 423.

* pentandra L. 420. polyandra schr. 421.

* purpurea Is. 422.

* repens 1. 424.

* rubra H u ds. 422. rugosa sering. 424. tomentosa Sering. 424. triandria L. S in. 422. uliginosa Willd. 424.

* viminalis L. 423. vitellina I. 121.

Sulvei 356.

Sialvia 1.9. 956.

* pratensis 356 .

* silvestris I. 357.

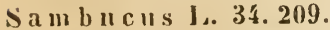

* Ebulus I. 209.

* nigra J. 210.

* raremosa I. 210.

Simkraut 431.

Sa mulus I. 22.384.

* Valerandi I. 384 .

Sandkraut 72.

Sanguisorbeen I,i n 11.113. 154.

sa II

* ufficinalis L. 155.

Sani cula I. 28.181. * europaca I. 181.

Sanikel 181.

Santalareen R. Br. 111. 407. Saponaria 1. 41.64.

* Vaccaria L. 64.

* ufficinalis 1. 64.

isarotham inus IV inm. 59. 100.

* vulgaris IV i nim. 100.

Siat ureja l. 52.358.

* hurtensis 1. 358.

Satyrimm hircinum 1. 448. repens L. 455.

Saulistel 283.

Sauerdurn 18.
Sallerkirsche 134.

Samerklee 96.

Savuyerkuhl 37.

Sinxitrageen Vent. 95. 178.

Sa $\mathrm{x}$ if $\mathrm{r}$ a a I. 4L. 178. exilis P' 11 . 179.

* gramulata I. 178.

* tridactylites I. 178.

Sc abiosa Roem. Ind Schult. 17. 225. arvensis I. 224.

* Columbaria 1. 225. ochroleuca l. 225.

* suiveulens Desf. 225. Succisa 1. 225.

Scandix 1. 31. 203. Anthriscus I. 204. Cerefoimm I. 204. infesta 1.. 203.

* Pecten Veneris I. 203.

Schaafgarbe 243.

Schachtiohl 73.

Sichalotte 474.

Siliarbock 11.

Scharte 266.

Schaumliraut 30 .

Schriberich 183.

Schellkraut 22.

Schellwurz 22.

Schiprling 206.

Schil:Iträger 372.

Schilf 520.

Schimmelkrant 236.

Schlammling 344 .

Sclilangenäuglein 314 .

sichleifenblume 45.

Selilinge 210.

Schminkbohne 132.

Schueckenklee 103.

Schneeball 2 ll.

Schnittlauch 473.

Schuberia C. A. Me yer 25.389.

* maritima C. A. M e y e 389.

Schöllkraut 22. 
sich enus I. 10.494. albus 1. 485. compressus I.. 490.

* ferrugineus I. 484. fuscus $L_{\text {. }} 485$. nigricans I. 484 . rufus $H$ uds. 490 ). Schollera Oxycoccus Roth 302.

Schotenweiderich 160. sehuppenwurz 348. schwalbenwurz $30 \%$. Schwanenblume 430 . schwarzwurz 275. silliweinkraut 439 . Sichwertlilie 457. sicilla J. 37.469 .

* amisena J. 469.

* bifulia 1. 469.

sicirpus I. 11.496 acicularis I. 4:6.

Baeothryon Ehrh. 4>6. capitatus schreb. 486. caricims Schrad. 490. Caricis $R$ etz. 489 .

* compressus Pers. 459. glaucus $\mathrm{S}$ nı. 488. humilis Wallr. 487.

* lacustris I. 488.

* maritimus L. 498. multicaulis Gau». 486 . nanus sipreng. 487. watus Ruth 486 . palustris 1. $48 j$.

* parvilus Roe mi. und schult. 486 .

+ pauciflurus Lght. 486 .

* padicans selihuhr 489 .

* rufus Sclirad. 490.

* seticeus I. 487.

* silvaticus L. 4:9.

* supinus I. 487.

* Talernaemontani Gmel. 458.

tenuis Sิcreh. 485 .

siclerantheen Lh. 114. 173.
- Sclerauthus I. 41.173.

* anmuus I. 173.

* perennis 1. 173.

Nilerochloa dura P. B. 533. Scurzun tיa J.63. 275 . allgustifolia Wigg. 276. asphubleloides IV allr. 276.

glastifolia IV allr. 276 .

* hisparica I. 276.

* humilis I. 275. laciniata L. 277. laniti sehrank 276. wetangularis $W$ ill d.277. plantaginea Schleich $2 ; 6$.

* purpurea L. 277.

Scruphularia L. 53.331. aquatica Aut. 331 .

* Ehrharti Stev. 331 .

* nudosa I. 331.

Scutellaria L. 51. 372.

* galericulata I. 372.

* hastifulia J. 372.

* ninor L. 372.

Secale I. 12. 550.

* cereale I. 550 .

Se dum L. 43. 173.

* albumi L. 174.

* acre L. 174.

* maximum Su t. 173.

* purpurascens K o c h 174.

* reflexum I. 175. rupestre L. 175.

* sexangularc J. 175. 'Telephium d.u. $\varepsilon$. L. 174. Seelilie 19.

seerose 19.

Segge 491.

Seide 313 .

Siejenkraut 64.

Selin um I. 28. 193.

* Carvifolia L. 193. Cervaria Crantz 196. palustre I. 197. silvestre Crantz 194. 
Selinum siliestre I. 192.

Sellerie 182.

Sempervivum I. 44.176. hirtum Liı. 176.

* soboliferun Sims $\mathbf{1 7 6 .}$

* tecturum I. 176.

Senebiera Pers. 54. 43.

* Coronopus Poir. 45.

Senecio I. 68. 249. alpinus Scop. 252.

* aquaticus H IIds. 252.

* campestris DC. 249.

* erucifulius I. 251. fluviatilis Wallr. 254.

* Fuchsii Gmel. 253. germanieus Wallı. 25.3.

* Jacubaea I. 252.

* nemorensis I. 253.

* paludosus I. 254.

* palustris DC. 250 .

* saracenirus I. 254.

* silvaticus I. 251.

* spathulaefolius DC. 249 . tenuifulius Jacq. S m. 251.

* viscusus J. 250.

* vulgaris I. 250.

Serapias ensifolia S m. 452. grandiflora Sc"p. 452. latifulia atrorubens $H$ o f $f$ il. 453. longifolia $\mathrm{J}_{\text {. }} 454$. longifulia $\mathrm{H}$ ud s. 452. palustris Scop. 454 . rubra $\mathrm{L} .452$.

Sprratula L. 66. 266. arvensis L. 259.

Pollichii Korh 266.

* tinctoria L. 266.

Seseli I. 29.191.

* coloratum Ehrh. 191.

* Hipponarathrum I. 191. velusuni $H$ of $\mathrm{fm} .192$.

Sesleria $\mathrm{Ardui}$ il. $\mathbf{1 4 . 5 2 3 .}$

* coerulea Arduino 523 . Setarià P. B. 13.514.
Setaria glauca P'. B. 514 .

* verticillata P. B3. 514.

* viridis P. 13. 514.

Sherardia I. 18. 211 .

* arvensis I. 211.

Sichelmöre 184.

Siderites montana J. 36 s.

Siebensterı 379 .

Siegwurz 457.

Sigmarsw urz 81.

Silaus Bess. 29. 193.

* pratensis B ess. 193.

Silbergras 525.

Silene I. 42.65.

* Armeria I. 66. baccifera Roth 64 .

* inflatir 5 m. 65.

* noctiflora I. 65.

* nutans J. 65.

* Otites Sm. 65.

Silereen DC. 86.61.

Silje 193.

Si i ybu m Gärtı. 66. 262.

* marianum 262.

Simse 496.

Sinapis L. 57. 39.

* alba I. 39.

* arvensis L. 39. nigra I. 39.

Sinau 154.

Singrïı 308.

Sisou Podagraria S p re 184.

Sis y m brium I. 57. 32 .

* Alliaria Scop. 33. amphibium L. 26.

* austriacum Ja c 4.32. eckartsbergense if illd. 33.

Eincastrum Poll. 40.

* Joeselii L. 33 . multisiliquosum Huffu. 33.

Nasturtiunı L. 26.

* officinale Scop. 32.

* Sophia I. 33. 
Sisymbrium tenuifolium I. 40.

* 'Thalianum G a u d. 34 .

Si um I. 27.187.

angustifolium L. 187.

Falraria L. 184.

* Iatifulium L. 187.

longifolium Mert. u.

Kuch 187.

Sulaneen Jus s. 109. 324.

Sula $\| 13$ L. 22.324.

* Dulcamara L. 325.

* miniatum B ernh. 325.

* nigrum L. 325.

* tuberosuni I. 326.

* villesum l, a nt. 325 .

solidago L. 63. 231 .

* Virga anrea L. 231.

Sommerrajs 32 .

Sunmerribsen 38.

Summerweizen 549 .

Sommerwurz 344.

Sonchus L. 64.283.

alpinus L. 283.

* arvensis 1. 284.

* asper Vill. 284. laevis Vill. 283.

* werareus I. 283.

* palustris L. 284.

Sounengïnsel 51.

Sumenröschen 51 .

sumenruse 236 .

Sonnenthau 58.

Sorbus L. 45.159.

* ancuparia I. 159.

* domestica I. 159.

* torminalis Cra ut $\mathrm{t} 159$.

spal'ganium L. 73.433.

erectum $\%$. L. 438.

erectum $\beta$. L. 438.

* Hatans 438.

* ramosunı 11 nds. 438.

* simplex H

spargel 461.

Spargelbuhne 115.

spargelkohl 38.
Spartium scopariun L. 101. Spatzenzunge 406.

Specularia Heist. 23. 300.

* Sueculum Al ph. DC. 300. $\mathrm{Speergula} \mathrm{I.} 43.69$.

* arvensis L. 69.

maxina IV eihe 69. nudosa L. 69.

* pentandra L 69. sativa Boe 1 ningh. 69. vulgaris Bue nn gh. 69 . Spergularia salina Presl. 71 . Spilling 134.

Spiuacia J. 77. 395. jnermis Mönch 395.

* oleracéa L. 395. spinosa Mönch 395. Spinat 395.

sipiraea L. 45. 136.

* Aruncus I. 136.

* Filipendula L. 136.

* Uluaria L. 136.

spiranthes Rich. 71.455.

* autumualis Rich. 455 .

Spirodela polyribia

Sclileid. 43i.

spitzklette 295.

Springkraut 96.

Sitachelbeere 176.

Sitarliy's J. 50.365 . ambigua 5 mith 366 .

* anmila L. 367.

* arvensis 1. 3667. Betunica Scup. 368.

* germanica I. 365 .

* palustris I. 366 .

procumbens La

* recta l. 367 .

* silvatica I. 366.

Statice 1. 35.386 . Armeria L. 386. elougata H iff $\mathrm{m} .386$. Staurogetun Rchb. 437. stechapfe] 327. 
Steclirübe 39.

steinbrech 178.

Steinklee 105.

Seinpeterlein 185.

Steinsame 320.

Stellaria 1. 42.73.

Msine Reichard 75.

Dilienianil l, eers 75 .

* glauca II ither. 74.

* graminea I. 74. graminea $\beta$. I. 74.

graminea $\%$. I. 75.

* Holostea J. 74.

* media Vill. 73.

* nemorum L. 73. palustris Retz. 74 .

* uliginosa M uray. 75 .

Stellaten I. 101. 211.

Stellera Passerina J. 407.

stena ctis Cassin. 63 .

230.

annua $\mathrm{N}$ e e s-230.

* bellidiflura Alex.

Brau $\mathrm{r} 230$.

Stiefmütterche॥ 57.

Stielsame 277.

Stipa siehe Stypa.

Stramonium foetidum

Gärtn. 328.

Strandling 171.

Stratiotes 1. 78. 428.

* aluides L. 429.

Strausgras 518.

Strenze 181.

Sturmhut 17.

Sturmia Rchb. 71.456.

* Lueselii Rchb. 456.

Stypa L. 14. 522.

* capillata I. 522.

* pennata L. 523.

Suaeda chenopodioides

Pall. 389.

maritima Moquin.

'r and. 389.

Succis a M. K. 17.224.

* pratensis $\mathbf{M}$ ö nch 224 .
SumpfwแIz 452.

Symphytum l. 20.318.

* officinale I. 318.

Synanthereen Rich.100.226.

Syntherisma vulgare

Schrad. 513.

Sy ringa 1.8. 807.

* rulgaris L. 307.

'E'ahak 327.

'Timuel 79 .

'Tischelkraut 47.

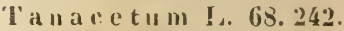

* vulgitre I. 243.

'lannwedel 165.

'T a r a x a c u m J u s s. 64.279.

* officinale Higg. 279.

Taubenkrupf 65.

'Taubnessel 361 .

'Tausendblatt 164.

'Tausend giildenkraut 312.

'Tausendkorn 172.

'I' e e s d a I e a R. Br. 55. 44.

lberis D C. 45.

* nudicaulis R. B r. 44.

'lelmatophace gribba

Schleid. 437.

Tetragonolobus Scop. 60.115 .

* siliquosus Ruth 115 .

'Te ucium L. 50. 376.

* Botrys I. äfo.

* Chamaediys 1.. 377.

* Chamaepitys 1. 376.

* montanum L. $37 \%$.

* Scordiun 1. 377.

* Scorodunia I. 376.

'Teufelskrallen 297.

'Teufelszwirn 324.

'Ihalictrum J. 49. 2.

* angutifoliun J ac q. 4 . angustifolium L. 4. (anonymon) Wallr. 5.

* aquilegifolium L. 2.

Bauhinianum W all 1 . 4 . collimum Wallr. 3 . 
'Jhalictrum flavun I. 4.

* flexuosum $B$ e rnh. 3 . Jacquinianum Ko ch 3 . minus L. 3.

montanum If allr. 3. nigricaus $G$ a ud. 4 . nigricans $\mathbf{J}$ a $\mathbf{c} q .5$.

'The si u II I. 24.407. alpiıun I. 409 . comosum Roth 409 .

* ebracteatun H a y 11.409 .

* intermediun schrad. 408 .

linophyllum l. 409 .

* montãnum Ehrh. 408. pratense Ehrh. 408.

Thlaspi 1. 5.5. 43.

* alpestre I. 44 .

* arrense I. 43.

Bursa pastoris I. 47. caterulescens Presl. 44. campestre J. 46 .

* montinum L. 44. montanum Poll. 44.

* perfoliatum J. 43.

'Thrincia Roth 63.271.

* hirta Roth 271.

Leysseri II allr. 272.

Thurmkraut 28.

Thymelaeell J I s s. 114. 406.

Thy m s I. 52.358.

Aicinos L. 359.

augustifulius Pers. $35 \mathrm{~s}$.

Chamaedrys iries 358.

lanuginosus J ink 358 .

* Serpyllum 1. 3.58.

'Thyselinum 11 offm. 30. 196.

* palustre $110 \mathrm{ffm}$. 196.

I'ilia 1. 47. 85.

europitea $\beta . \delta$. $\varepsilon$. I. S5.

* grandifolia Ehrh. 85 . oxycarpa Reli h. 85.

* parvifulia Eh $\mathrm{th}$. $\$ 5$. pauciflora 11 a y ue 8.5 . plat ypliyllos s c o p. 85 . ulmifolia Sc op. 85.
Tiliaceen J us s. S8. 8.5. Tithymalus duleis Scop. 412.

'lofieldia Huds. 37.476.

* calyculata Wh $\mathbf{l}$ b g. 476 . palustris Hoppe und Sce hieb. 476 .

Tollkirsche 326.

'Iorlylium I.. 29. 199.

Anthriscus I. 202.

latifulium L. 202.

* maximum L. 199.

'Torilis Ada 11 s. 30. 202. Anthriscus Gärtn. 204.

* Anthriscus Gmel. $2(1)$.

* helvetica G mel. 202.

'Trago $\mu_{0} 0 \mathrm{~g} 0 \mathrm{n} \mathrm{L}_{\text {. }} 63.274$.

* majur Ja c q. 274. vrientalis L. 275.

* porrifulius L. 274.

* pratensis L. 275.

'I'rapa L. 1x. 164.

* nataus 1. 164.

'Traubenlirsche 135.

'rrichodium caninum

Schrad. 519.

'l'ientalis I. 38.37!.

* europaea 1. 380.

'Trifolium I. (60) $10 \%$.

* agrarium I. 113.

* alpestre I. 108.

* arvense İ. 10s. allreum Pull. 113. campestre G mi el. 113 . lentatum W. K. 106.

* filifurme I. 113. flexuosum Jac q. 110.

* fragiferum $\mathrm{J}$. 111 .

* hylitidum I. 112. Kuchianum 11 ay ue 106.

* medium 1. 109. Melilotus uff. $\%$ I. 106. minus $S$ m. 114.

* montanuni L. 111 .

* parviflurum Ehrh. 111 .

* pratense L. 107.

* procumbens I. 11. 
'Trifolium procumbens P')I1. 114.

* repens L. 112.

* rubens 1. 110. scabrum J. 109 spadiceum J. 114.

* striatum L. 108. strictum Schreb. 112.

Irigloch in I. 37.430 .

* maritimum L. 431 .

* palustre I. 431.

'I r i gon ell a L. 61. 105.

* Furnum graecuni I. 105.

Triodia R. Bs. 15. 531 .

* decumbens P'. B. 530.

Tripleurospermum inodo-

rum C. H. Schultz 248.

Tripmadam 175.

Tripulium vulgare Nees 229.

Trivetum flavescens P. B. 529.

Jriticum 1. 12.549.

* caninum Schre b. 549. pinnatum $\mathbf{M}$ ön $\mathrm{ch} 543$.

* repens J. 549. silvaticum Möneh 543 . silvaticuu s a lis b. $\mathbf{5 5 0}$.

* vulgale Vill. 549.

Trullius J.48. 15.

* europatus I. 15.

Türtentund I. 464.

I ulipa L. 36. 463 .

* siliestris I. 463.

liulpe 463 .

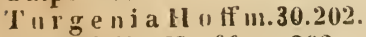

* latifolia H of $\mathrm{m} .202$.

Tiritis l. 56.28.

* elibira I. 2 .

hirstita 1.. 30.

I' us ilago I. 68.226.

* Farfara L. 227. hybrida 1. 227. Petasites Is. 227.

'I' y pha I. 73. 437. angustifulia L. 438 .
'Typha latifolia I. 43.

'Pyphacerll Jus s. 123.437.

Ul ex I. 59. 100.

* europacus I. 100.

UImus I. 25418.

* campestris 1. 418 . ciliata Elirh. 418.

* effusa Willd. 418. excelsa 13 orkh. 418. montana Sm. 418. nuda Ehrh. 418. octandra sichk. 418. suberosa Ehrh. 418. tetralidra s chk. 418 .

Umbelliferen J uss. 96. 180. Urticeen Juss. 113. 415.

Urtica 1. 73.415.

* divira L. 415.

* pilulifera I. 415.

* urens L. 415.

Ut i cularia l. 8.378.

* ninor L. 378.

* vulgaris I. 378 .

Vaccaria pyramiduta Fl. Wett. 64.

Vaccineen D C. 100.301.

$V$ a c c in i u m39.301.

* Myrtillus L. 301.

* Oxycoccos 1. 302. palustris Pers. 302 .

* Vitis illiea 1. 301.

Valantia Aparine L. 214. Aparine Poll. 215.

Cruciata 1. 214.

Va le riand I. 9. 219. altissima $H$ or 1 e 11.221 .

* divica I. 221.

* exaltata Mik. 220. multiceps Wallr. 221.

* officinalis L. 219.

* sambucifolia Mik. 220.

Valerianeen DC. 102. 219.

Valerianella Poll. I. 221.

* Auricula D C. 222. 
Valerianella carinata Loisl. 221.

* Morisonii D C. 222.

* ulitoria Vönch 221.

Veilchen 52.

rentenata avenacea $\mathrm{Koch}$ 529.

bromoides koel. 529.

Verbasceen 13 art1. 108.328.

Verba s cum I. 21.328.

* Blattaria 1. 330.

* I,yclonitis 1. 329.

* nierum 1. 330 .

* phlomoidles I. 329.

* phoniceum I. 330. rugulosum II illal. 329.

* Scliralleri Me yer 328.

* thapsifurme Schrad. $32 x$.

Thapus I. Fries. Sm. 329 .

Thapsis sichrad. 329.

Thapsus Weyer 328 .

Verbena 1. 54. 378 .

* officinalis I. 378 .

Verbenaceen Juss. 107.378.

Veroniua l. 9. 335.

* agrestis I. 342.

a)ternifulia $\mathrm{l}, \mathrm{ej}$. fl. squa. 34 ().

* Inagaliis 1. 336 .

* arvensis 1. 34 1).

* Beccabunga f. 336.

* Buxbaumii 'l' enule 342 .

* Chamaedrys 1. 336. didyua leurerek h 343.

filiformis I) C. S 11.342 .

* hederaefuliar 1. 343. hospita lineli 342. lancifulia Kuch 340.

+ latifulia 1. 333. laxiflura l,oj. 33.

* Iongifolia L.. 339. maritima sehra 1 . 3.39 . media 1, $\mathrm{j}$. r.r. 340.

dareke, Flaro.
Veronica montana 1. 337. neglecta Sch midt 340 .

* officinalis L. 33\%.

* opaca Fries 343. persica Poir. 342. pilosa $S c h m i d t 336$.

* polita Fries 343.

* praecox .111. 341 .

* prostrata L. 337.

Pseudochamaedry t a c q. 338 .

pulchella Bast. Ciuss. 343.

romana Scup. 341.

* scutellatia 1. 335.

* seruyllifulia J. 340 .

* spicata 1. 339.

* spuria l. 338 . tenella All. 340.

louruefurtio Gm el. 342.

* triphyllos I. 341.

* verna I. 340 .

riburnum 1. 34. 211).

* Iantana 1.. 2 ll.

* Opulis 1. 210.

$V$ icia I. 61. 121.

* angustifulia Roth 123 . articulata li illd. 127.

* Cracca I. 121.

* dunietorim I. 121.

* Faba I. 124. gracilis Lois 1. 126.

* lathyruides I. 123. multiflura Poll. 125. pisiformis L. 125.

* sativa L. 123.

* sepium I. 122.

* tenuifolia Ruth 122.

Viıra I. $21.3 ! 8$.

* miner l. Зus.

$\mathrm{Viotal}$ L. 23. 52. alba Autur. 53. alenaria ID C. 54. ralcarea Rehh. 54.

* camina I. 54. elatior fries ij. 
Viula flavicornis S m. 54 .

* hirta L. 53.

lactea $\$$ m. 55.

lancifulia 'Thore 55.

* mirabilis I, 5 ti. nemoralis $K$ ii $\mathbf{t z} .55$.

* odorata I. 53.

^ palustris 1. 52.

persicifulia Schk. 55. pratensis V. K. 56.

* rectia G cke. 55. Piplacea Krock 56. Riviniana Rchb. 54 . Ruppii A II. 55.

* silvestris 1. a m. 53. stagnina Kit a i b 56 . stricta Hor 1 . 55.

* tricolor i. 57.

* uliginosa Schra 1. 53.

Violarieen D C. 85. 52.

Viscum 1.. 7\%. 208.

* albuill I. 20 ?.

Vitis I. 23. 89.

* vinifera L. 89. hederacea Willd. 89.

Vogelkirsche 134.

Vogelkraut 73.

Vogelleim 208.

Vogelmilch 465 .

Vogelnest 454 .

Vulpia myurus G me I. 540. Pseudo- IIyurus Rehb. 540.

\section{8 achholder 427.}

IV achtelweizen 345 .

IValdneier 212.

Waldmeister 212.

IValdrebe 2.

Walilvögleiı 451 .

Wallnuss 418.

Wallwurz 318.

Wasserdost 23.5.

Wasserhelm 378.

Wasserliesch 430 .

Nasserlinse: 437.
IVassernabel 180.

Wassernuss 164.

Wasserschierling 182

Wasserstern $\mathbf{1 6 6 .}$

Wau 57.

Weberkarde 224.

Wegebreit 386 .

Wegerich 386 .

Wegwarte 271.

Weichkirsche 134.

IVeichling 76 .

IVeichsel 134.

Weide 420.

Weiderich 16 s.

Weimebe 8?.

Weimrose 152.

Weinschlehe 134.

Weisshuche $\mathbf{4 2 0}$.

Weissdurn 156.

Weisskraut 37.

Veizen 549.

Welschlohl 37.

Wendelorche 455 .

Wiborgia Acmella Roth 235.

Wicke 121.

Wiesenhafer 526.

Wiesenknopf 15.5.

Wiesenrate 2.

Winde 313.

Windhalm 520.

Windröschen 5.

Windsbock 49 .

Wintergriin 303.

Winterhiesse 27.

Winteriaps 38.

Minterriliste 38 .

Winterweizen 549.

II irbeldust 359 .

Wirsing 37.

Wolfsmileh 411 .

II ulfstrapp 356.

Wollgras 490 .

Wollkraut 328.

Wulverlei 248.

Huchesblume 246. 
Wüherig 182.

Wundhlee 102.

Wurmkraut 273.

Xanthium L. 75. 295.

* strumarium I. 295.

Ysop $36 \%$.

Zanuichellia I. 72.435.

gibberosa Rchb. 436 .

* palustris I.. 435. palustris $\beta$. Wh l b g. 436 .

* pedicellata Fries 436 .
Zamichellia pedmeulata $\mathrm{Rchb.} \mathbf{4 3 6}$.

Zaunrebe 89.

'Linunrübe 169 .

$Z$ e a 1. 73.511 .

* Vays 511.

Zeitlose 475 .

Ziest $\mathbf{3 6 5}$.

Zimmetrose 150 .

Zimnensaat 27.

Zirmet 199.

Zittergras 531.

Zweiblatt 454.

'Wwetsche 133.

Zwiebel 474 . 


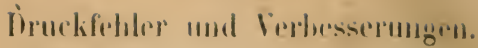

Silie 7 K. 2 ron unten lir's Gallumgs - slall drten.

- 127\%. J6 ron mulen lirs Marschall stall Marselaal.

- 4 \%. 21 von olien lies heteropligllum statt heterophtyllmu.

- 21 \%. 7 von 'unten lies 8 ' statt 8 '.

- 39 Z. 20 von unten fehlt hinter dem Worle Sishoten: $\odot$.

- 42 \%. 2 von unten lies Chamaelina statt Chamelina.

- $49 \%$. 8 von unten lies Borrhave stalt Boerhave.

- $57 \%$ \% vou mulen sirciche: $\odot$ uns.

- S0 \%. 14 von unten felult ror dem Worte Wiesun: C.

- $85 \%$ \% 6 von minten fehlt linter Ilypericuns - I.

- 137 \%. 6 van olsen fohlt hinter Dryadengewächse: Früchtoben ?

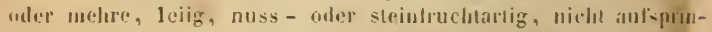
gend, auf eimrm trockenen oder feischigen Fruchthoden sitzens. Der fruchttragende lieleh liraulartig ouler verhärtel.

- 110 \%. 8 von oben stelit 4 stalt t.

- 148 Z. 3 ron miten fulilt ror Rosa: 3. Grupje. Rusecu [1.. Früchtchen melse, Jeiig, unssartig, nicht anfspriugend, rou der fleischigen nud bei der Reile saftigen Rohre des lielehi. ringeselıbrsicen.

- 153 Z. 2 vou mulen stels 4 stalt t.

- $224 \%$. 21 von mnten lirss Kuatut statt Knaull.

- 235 7. 20 von unten fohlen Iribter Galinsoge die Worle: narb

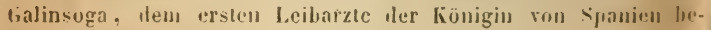
แลกn!.

- $305 \%$. 19 von oben lir's umbellata statl umbellitum.

- $332 \%$ \% 10 von oben setze vor lligitalis lic Worle: Verbarecur

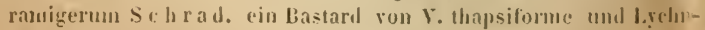
is findet sirh an litrgen bei Wellin.

- 357 7. 9 von ohen lies S. -ilvestris statl 1. silventric.

- 361 \%. 16 vou when Jies Ruỵschiana stalt Raysehiana.

- $386 \%$ ti von oben setze slall Amneria Willl. - Salıe .. Imil \%. 10 slatt A. vulgaris 1 ill l. - s. elongata II oll:., la die ron Willd. auligeslellte liattung Armeria sich IIII duh I

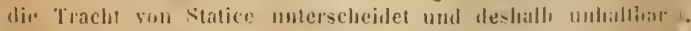

- 422\%. 18 von uben setze hiuzu: 999b. Salix undulata Ehr..

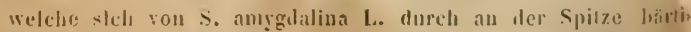
seluppen und-lanzettiche, lang zugespilzte, weichhantige, z. letzt liahle blattre unterscheidet, lindel sich an Zinmen in Be derses: unwest Weltin.

- 451 \%. 11 von oben lies 0 . inscetifura statt $\mathrm{x}$. insectifiril.

- 5ot) streiclse 7. 24-28 von oben und setze dafiut: fimder auf den Schambertwiesen nur solu selten. dagegen aut den Wi. sen am Bienitz. hinlig.

(Druck von Ed. He gnemann in II a II ..) 




\section{New York Botanical Garden Library}

314.G288 T.1

Garcke, August/Flora von Halle, mit nahe

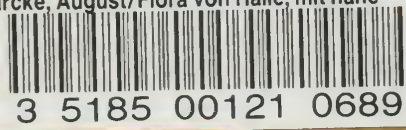


